O, E Bitris Mskar chlot 


\section{Digitized by the Internet Archive in 2008 with funding from Microsoft Corporation}





\title{
DISEASES OF THE HEART
}

\author{
AND

\section{ARTERIAL SYSTEM}

\author{
DESIGNED TO BE A PRACTLCAL PRESENTATION ()F \\ THE SUBJECT FOR THE USE OF STUDENTS \\ AND PRACTITIONERS OF MEDICINE
}

\section{BY}

ROBERT H. BABCOCK, A.M., M.i).

Former Professor of Clinical Medicine and Diseases of the Chest, (i)llewe of Physician ame sur

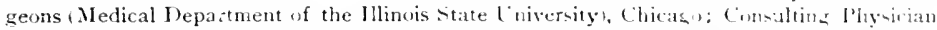

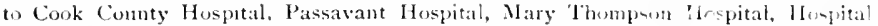

of St Antbony de Padua, and of Marion-Sime Sanitarimm: Memh.r of the Association of American Ihysicians, Imerican Climatutogical Anoma-

tion, American Nedical Assuciation. National Asseriation fur the Study and Prevention of Tuberculsis; Corresponding Menber if Nedico-Chirurgical suriety of Folinburgl, etc.

WITH THREE COLOURED PLATES AND

ONE HUNDRED AND THIRTY-NINE ILLUSTRATIONS

TIIRI) EDITION, REITSEI)

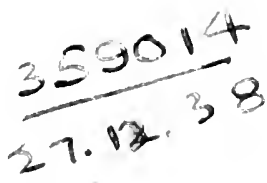

NEW YORK ANI) LONDON

D. APPLETON AND COMPANY 


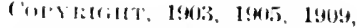

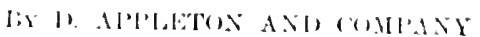

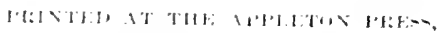

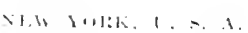




\section{PREFACE 'TO 'THE 'TIIRD EITITON}

Tine changes in this third exlition are not numerons, but are such as were needed to bring entatin portions of this work up to

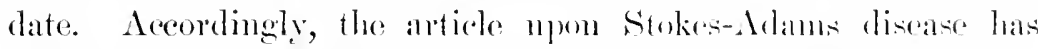
been entirely rewritten so as to conform with our recently aequiped knowledge concerning hearthlock and its redation to the StokesAdams sindrome. An addition has berem matere aloo to the original contribution by Dr. Otto Schunidt upou Gacrtuer's tomemeter and its use in clinical medieine. These additional palace will be fomd under the caption of The Splyomomanometer', since instruments known by this generie appellation have supplanted the tememeter of Gaertner and the instrument of vom Baselt in the Fuited States. Finally, a few fort-motes and enrections have beren mads which it is believed increatere the value of the text.

R. II. B. 


\section{PREFACE TO TIE SECONI) EUITION}

The dhanges made in this second edition while not numerous

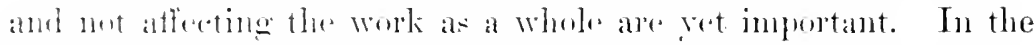

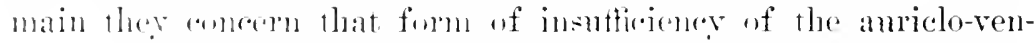

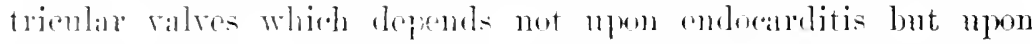
alderation of the myocardium, and in the former edition was regarded as always relative. In this one the anthor believes he

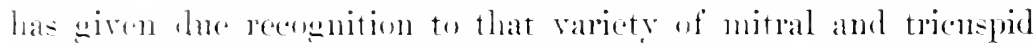
incompretenes temed muscular. Ilemere a portion of Chapter XXlI has heen cotiorely rewritten, while allusions to muscular insutticieney have been intrenlued luere and there in other chapters. The work hat been enlaneed in value thereby and has leen brought strictly up to date.

R. II. B. 


\section{PREFACE}

Is the preparation of this work the antlow hat endearomed to present the subject in a simple, pratetical fashim that would suit the need of the stmelent and puratitionere of medicine. Ther ories and speculations hare been omited al given but seanty consideration, in the belief that they tend to confune the sturlent. The anatomy and physiology of the cirenlatery organs have re eeved only such notice as was thomght necestary to a bedter understanding of the mattere in hand, sinee an extended consileration of them wats beliered ont of place in a work devoted to discilsed conditions. Althomgh alwale that phesical signs are properely a

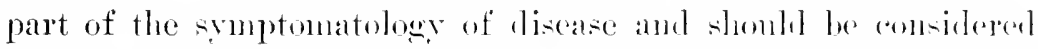

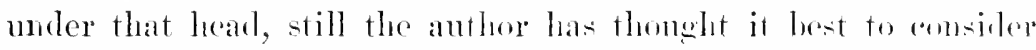
them separately, for the sake of facilitating the knowlerlge of that

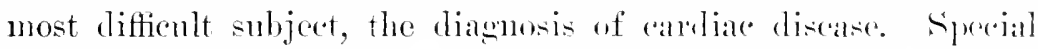
attention has been paid to treatment, and this part of the sulpject

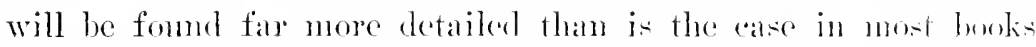

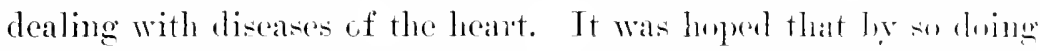
the work might be given a more pratedical value to the germerat practitioner, although of course the anthor realized that he womld lay himself open to adrerse criticimin, and eould to lut little more than lạy down principles for management. The phrascology has been kept sinple and fiee from needless technicalities, while in the terminology an attempt has heem matle to employ the terms which are in most familian no amome American and English physicians. To claim is laid to originality, as is appalrent from 


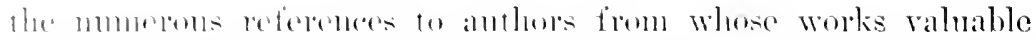

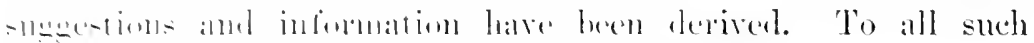

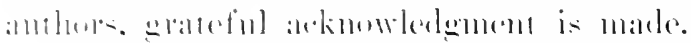

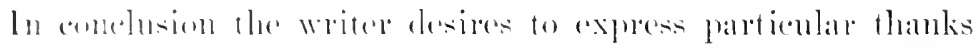

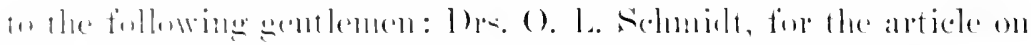

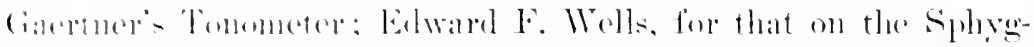

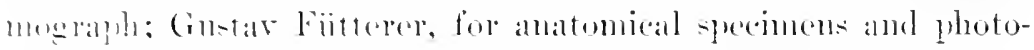

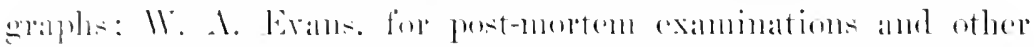
alis : and Milton W. Tall, for preparing the illustrations. Finally,

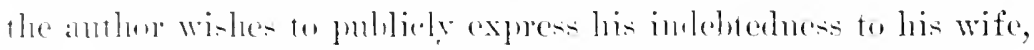

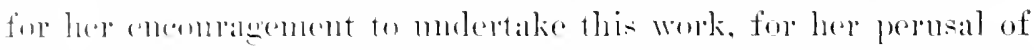
lis mammerelipt. and sugegestions, without which many passages niglit have lxen whenre, and for her invaluable ain in the revisione uf proet.

Robrite H. Babcock.

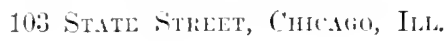




\section{CONTE N'T S}

GENERAL CONAIDERATIONS PERTAINA TO TIL ANATOHY, PHYSIOLOGY, AND EXAMIXATION OF TIE HEART

Introductory

Location of the heart .

The relations of the heart to the anterior thoracie wall

Pusition of the wrout ressels and valves . . . . . . . . . 3

Cardiac perension . . . . . . . . . . . . . 5

Auscultutoriy or stethosenic pereussion . . . . . . . . . . s

Pelpatory perenssion . . . . . . . . . . . . 10

Anscuitation of the heart . . . . . . . . . . . 12

Formal leart-somuls . . . . . . . . . . . . 1:

Reduplication of the heert-sonduls . . . . . . . . . . . 16j

Reduptication of the first sombl. . . . . . . . . . . 1s

Grellop or canter rhythm . . . . . . . . . . . . . 18

Hurmurs . . . . . . . . . . . . . . . . $\$ 1$

Endocurlial murmus of organic origin . . . . . . . . . . \$1

Cardica areas . . . . . . . . . . . . . 5.j

Accidentul murmurs . . . . . . . . . . . . . . . . 20

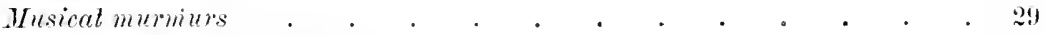

Accidental mesicat mumurs . . . . . . . . . . . . . 8:2

The differential diagnosis of accidental heart murmur . . . . . . . it

Exocurdiat murmurs . . . . . . . . . . . . . . . 36

\section{SECTION I}

\section{DISEASES OF TIIE PERIC.IRDIUM}

\section{('IlAPTER I}

ACLTE PIRICARDITIS

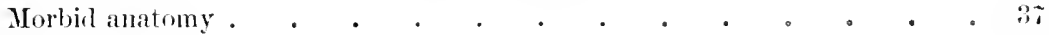

Etiology

DRY PFRIT'ARUITIS

Srmptoms . . . . . . . . . . . . . 48

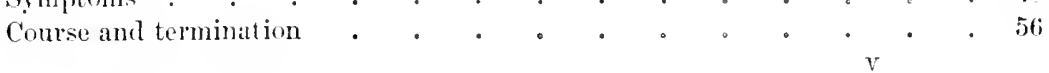




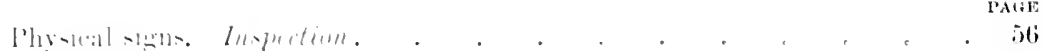

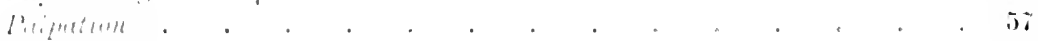

Prensien . . . . . . . . . . 5 . 58

1werltation . . . . . . . . 5 . 5

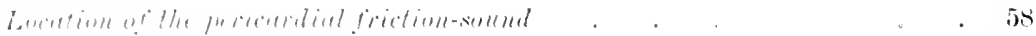

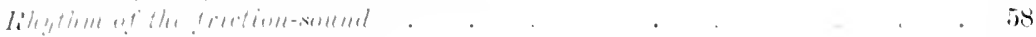

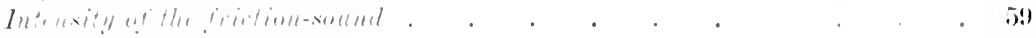

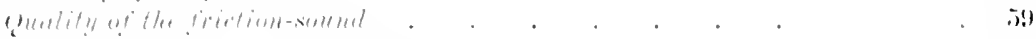

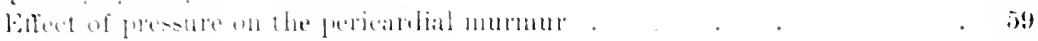

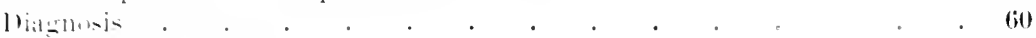

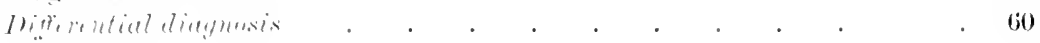

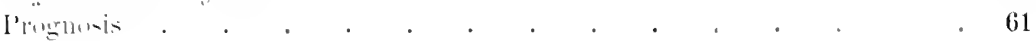

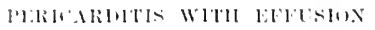

Srmptomi

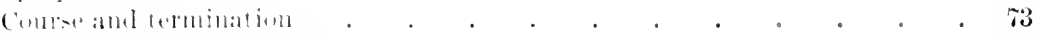

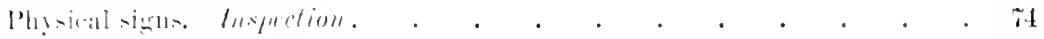

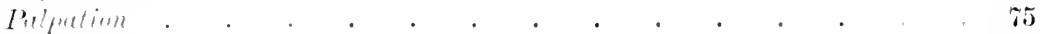

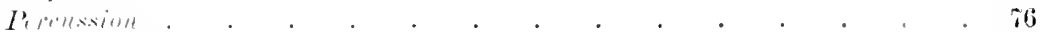

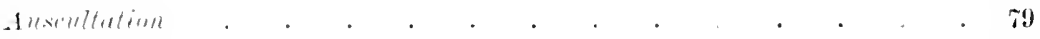

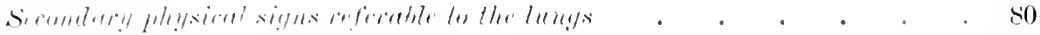

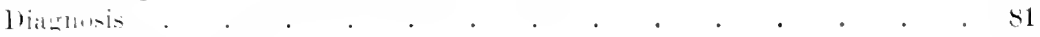

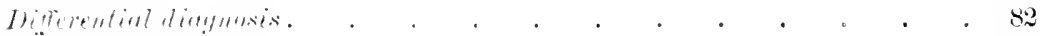

Proumeris . . . . . . . . . . . . . . . 84

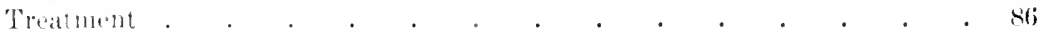

Treatment in the sage of edrusion . . . . . . . . . 90

\section{('ILAL'TER II}

('HRONH PERHARHTHS

Morbirilatumy .

Eitoleng

simpunsin:

Corren and termination

Phy-inal signs. Intyetion.

l'elputionet

I', relswions

Atweroltatien

biatume-is

Pownus is

Treatuent

$$
\begin{aligned}
& 100 \\
& 103 \\
& 104 \\
& 117 \\
& 118 \\
& 120 \\
& 121 \\
& 121 \\
& 122 \\
& 123 \\
& 124
\end{aligned}
$$

\section{CIIAPTER III}

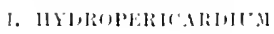

Inthid atlitomy

Eitilesey

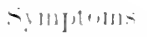

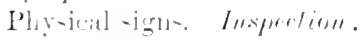

I'llpertion

1. 
I'ercusion

Alusertation

I) iatgumis

Progruosis

Treatment

II. HEMOPELICALI)I',

Morbid anatomy.

Etiology

Symptems

Pliysical sigus

Diagnosis

Prognosis

Treatnent

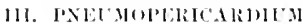

Morbir anatomy

Etiologry

Symptoms

Plysical signs. Inspetion.

Percussion.

duscultation

Diagnosis

Prognosis

13.5

Treatment

Morbid anatomy

Etiology

Symptoms

Physical sigus

biagnosis

Prognosis

Treatment

V. SYPIILIS OF TIL PERICARLUU

Morbid anatomy

Etiology

Symptoms

Physical signs

Diagnosis

Prognosis

Treatment

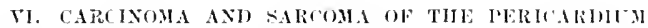

Morbid anatoms

Etiology

Symptoms

Plirsical signs

Diagnosis

Prognosis and treatment 


\section{SECTION II}

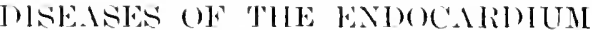

\section{('HATPIER IN}

Jorhid allatomy

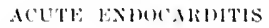

Btiolong.

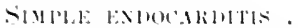

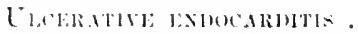

simptoms.

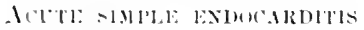

1)iantumis.

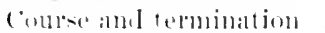

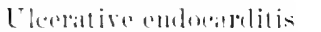

collt:and termination

Physicial signis. Inspection.

I'dlpulion.

Prepusion

dissmllution

Iniannowis .

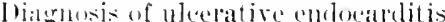

$\circ+0^{\circ} \cdot 0^{\circ} \cdot 0^{\circ}$.

Treatment . . . . . . . . . . 。 . . 187

Treatment of acute nlcerative endorarditis . . . . . . . . 191

('HAPTili $\mathrm{V}$

Monlicl anatomy.

(IIROXI" bXUOC'ARUITIS

Etiolory

Symutoms

(IITH'THE VI

MITRAL REGLRAITATON

Morbivi anatomy.

Etiulougy

simproms

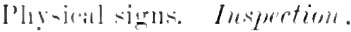

linfertione

Irerenswion.

1escultertion

Ditrinter

Promerno-

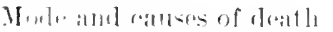

rIIAPTER VII

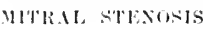

Yorbil anatomy.

Eatiolregy 
Symptoms

Physical signs. Inxpection.

Palpation

I'ercussion.

Auscultation

Diagnosis

Prognosis

Mode and canses of death.

\section{(NADPTER VHI}

AORTIE REGIRGITATION

Morbid anatomy .

Etiology

Symptoms

Physical sirns. Inspuction.

Pulpation

Percussion

Diaguosls

Prognosis

Ilode and canses of death

\section{CIIAPTEL IX}

\section{AORTIC STENOSIS}

Morbid anatomy .

\section{Etiology}

Symptoms

Physical signs. Inspertion .

\section{Palpation}

Percussion

\section{Auscultation}

Diagnosis

Progliosis

. Mode and causes of death

\section{CHAPTER X}

\section{TRICLSPID REgURGITATION}

Morbid anatomy .

Etiology

Symptoms

Physical signs. Inspertimn.

Palpation

Percussion

Diagnosis

Prognosis

Mode and canses of death.

\section{CIIMP'ER XI}

Morbid anatomy 


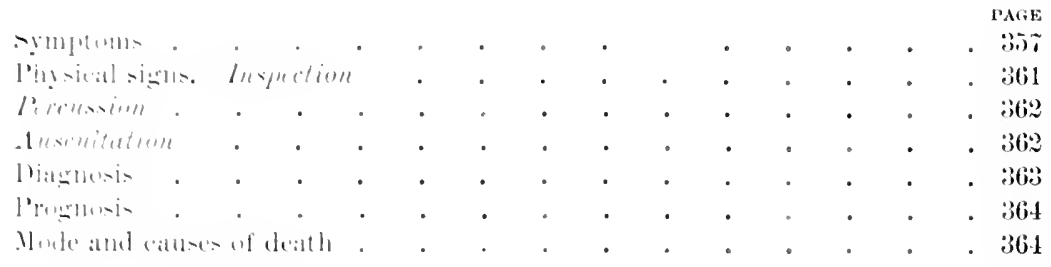

('lliplitis Nil

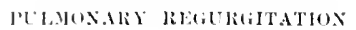

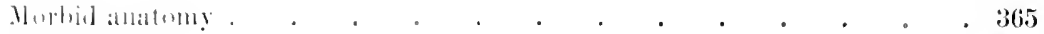

litiolugy . . . . . . . . . . . . . . 360

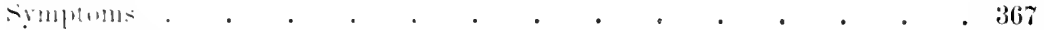

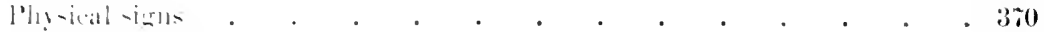

linpection . . . . . . . . . . . . . . 3 371

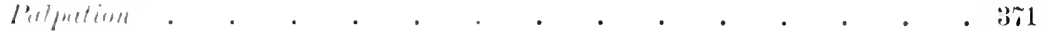

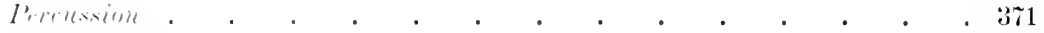

-11\%schltution . . . . . . . . . . . . . 322

biatmosis. . . . . . . . . . . . . . 373

Promein . . . . . . . . . . . . . . 354

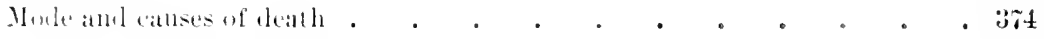

\section{CHAPTER Xill}

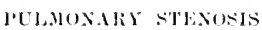

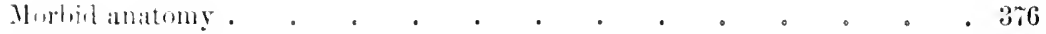

litinley. . . . . . . . . . . . . . . 380

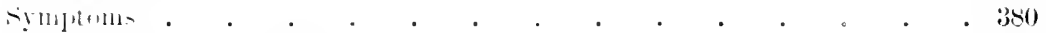

Physical signs, Inspertime . . . . . . . . . . 385

linlpution . . . . . . . . . . . . . . 386

I'prescion . . . . . . . . . . . . . . 386

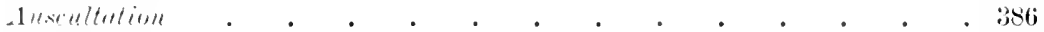

Jiatmo-is . . . . . . . . . . . . . . 387

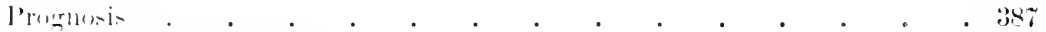

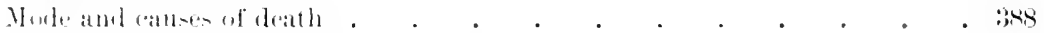

Summary of physical signs of valve lesions of the right heart. . . . 389

\section{CIIAPTIR NIV}

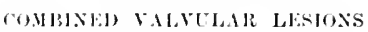

Combined mitral stomu-is atul regurgitation . . . 。 • • . 390

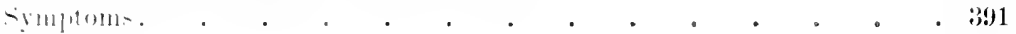

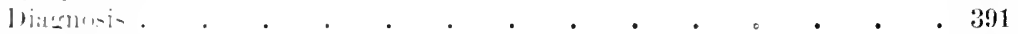

prome-in. . . . . . . . . . 892

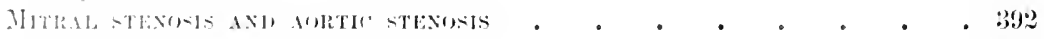

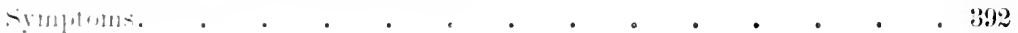

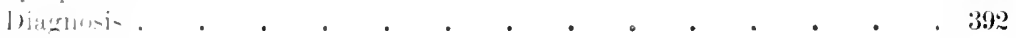

lougruts. . . . . . . . . . . . . . 393 


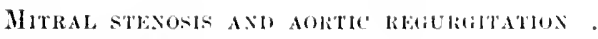

sympioms.

:3:3

Diagnosis .

$: ; y: ;$

Inspection

:i9.1

l'ulpution.

$: 3(1, j$

39.5

Iercussion . . . . . . . . . . . . . . . . . . . . . .

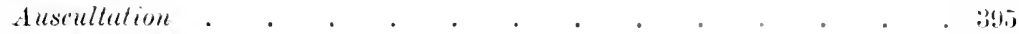

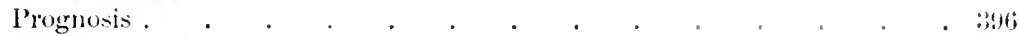

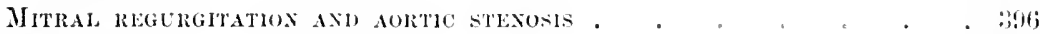

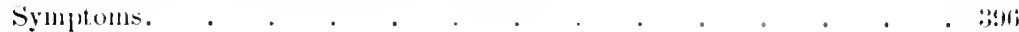

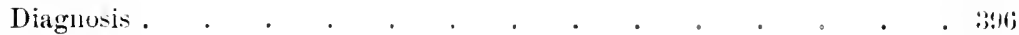

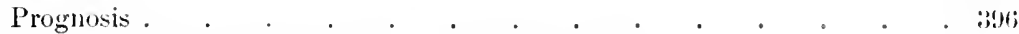

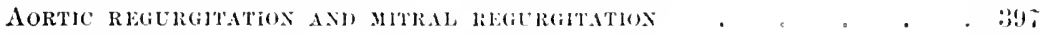

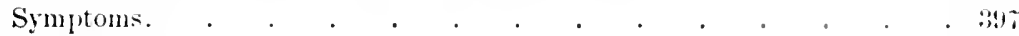

Diagnosis . . . . . . . . . . . . . . . . . . . . . . . . . . . . . .

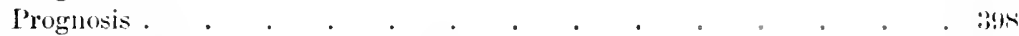

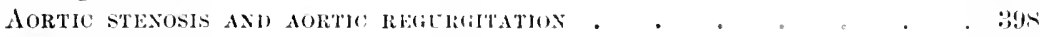

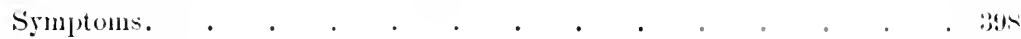

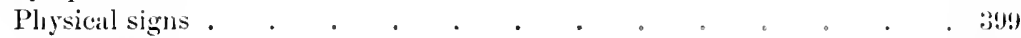

Diagnosis . . . . . . . . . . . . . . . . . . . . . . . . . . . . .

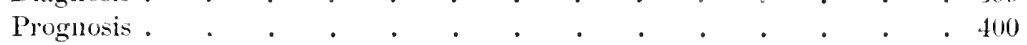

C'IIAT'TEli AT

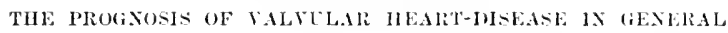

Complications . . . . . . . . . . . . . $4(1,5$

Rheumatic diathesis . . . . . . . . . . . . 406

Digestive and bronchial disorders . . . . . . . . . 40\%

Age . . . . . . . . . . . . . . 40\%

Temperament . . . . . . . . . . . . . 40s

$\operatorname{Sex} . \quad . \quad . \quad . \quad . \quad . \quad . \quad . \quad . \quad 409$

Oecupation . . . . . . . . . . . . . . . 409)

Ilabits . . . . . . . . . . . . . . . 410

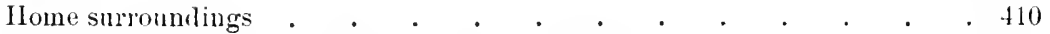

Tine probable effect on the patient of the linowledge of his lesion . . . +11

The effect of digitalis on the patient . . . . . . . . . . +11

The relation of prognosis to life insurance . . . . . . . . 412

\section{CHAPTER XTI}

THE TREATMENT OF VALVLAR IIEART-DISEASE

I. Compensation being still perfect . . . . . . . . . 414

Exercise . . . . . . . . . . . 414

Occupation . . . . . . . . . . . . 119

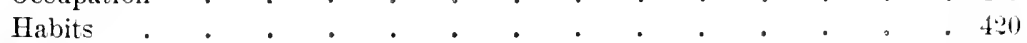

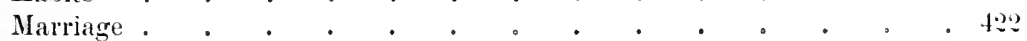

Clothing . . . . . . . . . . . . 4:5

Baths . . . . . . . . . . 4 4 4

Food. . . . . . . . . . . . 4 . . . .

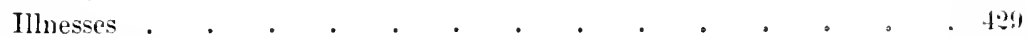

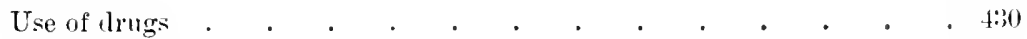

Change of elimate, with special reference to high altitnde . . . . 4:30 
('IIAP'THL NTH

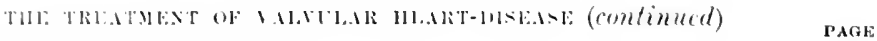

11. Complensition buing imperfert

Mellitinal atents

livine

liverion

lineistanecentereise.

Ninderim hathe.

lient.

clothings. habits, occupation

\section{('Il. Priti Xill}

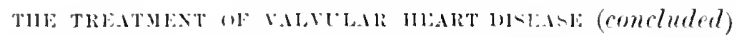

11!. Compensation lo-

The treatment of dropsy.

Galhation.

The use of dieritalis.

Accenery beatrt tonies

Ilypunirs

liest .

Fisereise

liatlis

Ruteiving visilurs

lriut.

\section{SEC'TION IJI \\ DISEASES OF THE IIOCARDIUH \\ GHAPER NIX \\ ACETE MYOCARDITIS}

Mrrilid anatoms .

Eivingy

Sivmpitoms

Plysiral signs. Inspection

Pelpation

Itrensiom

Alscultetion

1) iacureis

l'roerurais

l'reatnent

\section{CALP'TER XX}

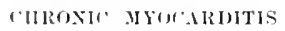

Mrorbil anatemy. 
Symptoms

Physical signs. Inspection.

Petpetom

I'rectession . . . . . . . . . . . . . . 5th

Aluscultetion . . . . . . . . . . . . . . . . . . . . . .

Diaguosis . . . . . . . . . . . . . . . . . . . . .

Prognosis . . . . . . . . . . . . . . 5.1!

Treatment . . . . . . . . . . . . . . 5is

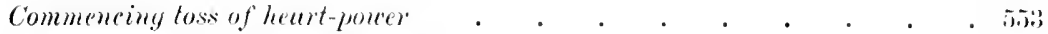

Cardiae incompeteney pronouned . . . . . . . . . . . 55j

\section{('II.MP'PAR XXI}

WYPETROPHY OF THE HEART

Morbid anatomy . . . . . . . . . . . . . . 56.j

Etiology . . . . . . . . . . . . . . . 5tis

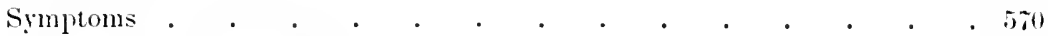

Physical signs, Inspeetion . . . . . . . . . . 5il

Palpation . . . . . . . . . . . . . . . . . . . 501

Percussion . . . . . . . . . . . . . . . 5 . . . . .

Auscultation . . . . . . . . . . . . . 5.2

Jiagnosis . . . . . . . . . . . . . . 520

Prognosis . . . . . . . . . . . . . . . 5 . . . . . .

Treatment . . . . . . . . . . . . . . . 505

\section{CIIAPTER XXII}

DILATATION OF THE HEART-REJATHE ANU MUSCULAR MITRAL INSUFFIELNCY

I. DILATATION OF THE IILART

Morbid anatomy .

Etiology

Symptoms

Physical signs. Inspection

Paipation

Percussion.

Auscultation

Diagnosis

Prognosis

Treatment

(1) Bloodletting .

(2) Nauheim baths

(3) Resistance exercises

11. RELATIVE AND MUSCULAR Mitral INSUFFiCiENCY

Pathology

Etiology

Symptoms

Physical signs

Diagnosis

Prognosis

Treatment

\begin{tabular}{|c|c|c|c|c|c|c|c|c|}
\hline • & • & - & - & - & - & - & . & . 576 \\
\hline • & $\bullet$ & - & - & • & - & • & - & .57 \\
\hline - & - & • & - & - & - & • & 。 & . 580 \\
\hline • & • & c & • & - & - & - & . & - 585 \\
\hline - & • & 。 & • & • & - & 。 & - & . $\quad 585$ \\
\hline • & • & , & 。 & • & 。 & - & • & . 585 \\
\hline • & • & - & . & 。 & 。 & - & - & - 586 \\
\hline - & - & - & 。 & 。 & ' & 。 & - & - 586 \\
\hline - & • & • & • & - & - & - & . & - $58 \pi$ \\
\hline - & - & - & • & - & 。 & 。 & - & - 590 \\
\hline • & • & - & 。 & - & • & - & - & - $5: 41$ \\
\hline - & • & • & - & • & 。 & • & 。 & - $\quad 592$ \\
\hline . & . & . & & & & & . & 592 \\
\hline
\end{tabular}




\section{('Il.1Pliti XXIII}

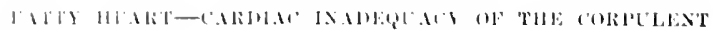

Yurbial anatumy

l'ililuilang

lininlus?

- Im11101115

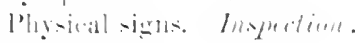

\section{('ildelia XXI}

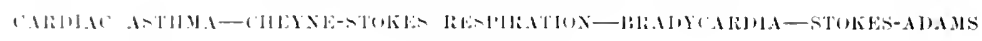
SYXILOME

I. Cardiac asthma

II. (heyerne-stolies rejpirat ion

. P . . .

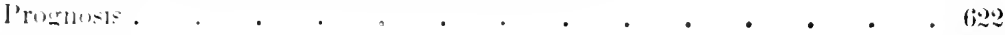

Treitmint . . . . . . . . . . . . . $60 \% 3$

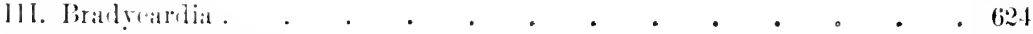

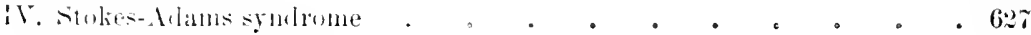

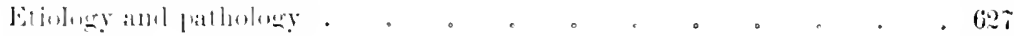

simptoms . . . . . . . . . . . . . 60!

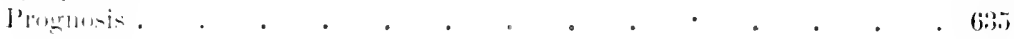

Treatment . . . . . . . . . . . . . 635

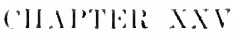

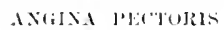

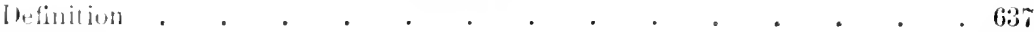

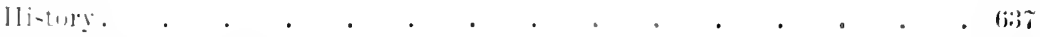

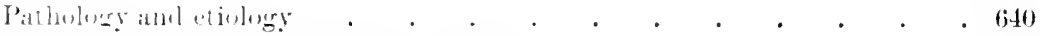

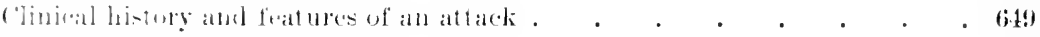

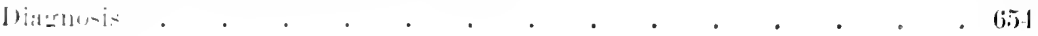

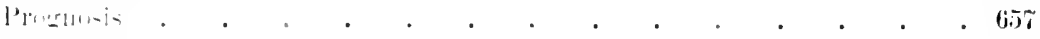

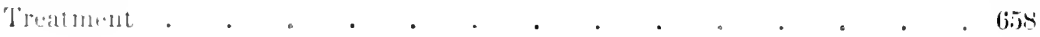

\section{('HATPLR XIVT}

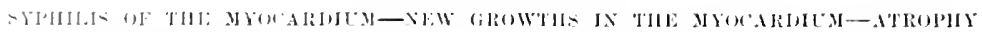

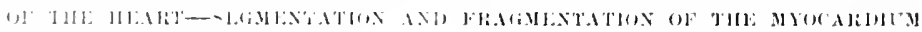

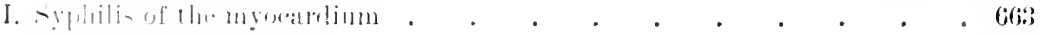

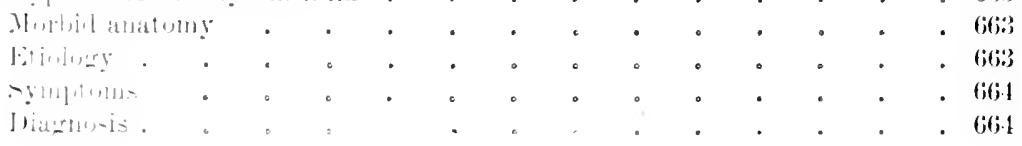


P'rognosis .

'Treatment

I1. New growths in the myocardium .

III. Atrophy of the heart

Morbid anatomy

Etiology .

Symptoms.

Diagnosis .

Prognosis .

Treatment

IV. Segmentation and fragmentation of the myocardium

lifiji

(ibi)

$666 ;$

itis

$60 \%$

$66 \%$

668

(j6)

bis

665

668

\section{CIIAPTER XXTH}

PEDCNCULATED ANJ BALL TIIROMBI OF THE HEART

Pathogenesis and etiology .

Symptoms

Diagnosis

Prognosis

T'reatment

Bibliography of cases of ball thrombi

\section{CHAPTER XXVIII}

\section{DEXTROCARDIA}

Congenital dextrocardi:

Symptoms.

Diagnosis .

Acquired dextrocirdia

Morbid anatomy

Etiology .

Symptoms.

Diagnosis .

Inspection and palpretion

Pereussion

Auscultation

Prognosis .

Treatment

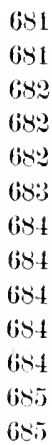

\section{CIIAPTER XXIX}

CONGENITAL, ULEASES OF TIIE IIEAR'

Morbid anatomy .

Etiology

Symptoms

Physical signs. Inspection.

Palpation

Percussion

Diagnosis

Prognosis

Treatment 


\section{SECTION IV}

\section{C'ARDLAC NELROSES}

six. Fonetional lisurdes of the Meurt

('II P'I'ER XXX

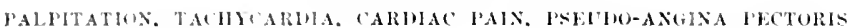

l'athology

PAGE

sinptems

Palpitation

Tachycaralia.

Cariliac Jain

Peomlo-allerina prectoris

Ftiolons

Diagnosis

Progrosis

Treat ment

Treatment of the attack

lielpitation.

The attack of puin

\section{CHAP'TER XXXl}

ESOENTAL PAROSYSMAL TARHCARLIA

Yatholog! . . . . . . . . . . . . . . . . . . . . . 731

Etiology . . . . . . . . . . . . . . . . . . . . . . . . . . . . . . .

Feitures of the paroxysm . . . . . . . . . . . . . . . . . . . . . . . .

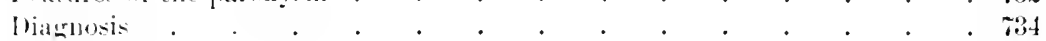

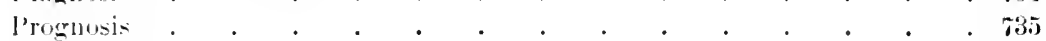

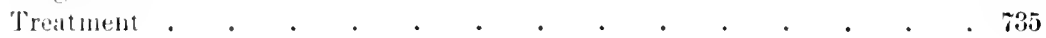

\section{SEC'TION $\mathrm{V}$}

DISEASES OF THE ARTERIAL SYSTEM

\section{('HAPTER XXXI}

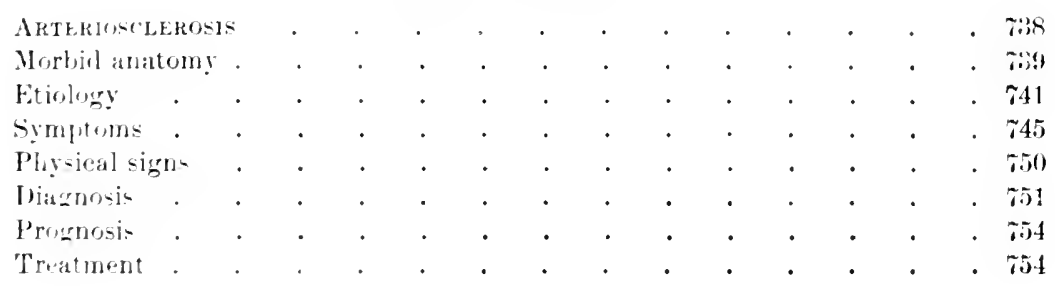


CHAP'TER XXXHI

ACUTE AORTITIS - ACUTE ARTLRITIS - SYIHLITIC ARTERITIS - ENDARTERITIS OBLITLRANS-PERIARTERITIS NOLOSA-STENOSIS OF THL AORTA ANI PULNONARY ARTERY-CONGENITAL SMALLNESS OF THE ARTERILS

I. ACLTE AOR'TITIS

Morbid anatom: .

PARE

Etiology

Symptoms

Physical signs

Inspection

I"alpation

Perenssion

Auscultation

Diagnosis

Prognosis

Treatment

11. ACUTE ARTERITIS

Morbid anatomy . . . . . . . . . . . . . . 752

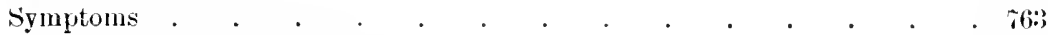

Physical signs. Inspection-I'alpetion . . . . . . . . . 763

Diagnosis . . . . . . . . . . . . . . $76 ;$

Prognosis . . . . . . . . . . . . . . . . . . . . . . . . . . . . . . . . .

Treatment $. \quad . \quad . \quad . \quad . \quad . \quad . \quad . \quad . \quad . \quad . \quad . \quad .764$

111. SYPHILITIC ARTERITIS

Morbid anatomy . . . . . . . . . . . . . 764

Etiology . . . . . . . . . . . . . . 760

Symptoms . . . . . . . . . . . . . . . . . . .

Diagnosis . . . . . . . . . . . . . . . . 766

Prognosis . . . . . . . . . . . . . . 7660

Treatment . . . . . . . . . . . . . . . 766

IV. ENHARTERITIS OBLITERANS

Morbid anatomy . . . . . . . . . . . . . . . . 766

Etiology . . . . . . . . . . . . . . . . 566

Symptoms . . . . . . . . . . . . . . . . . . . 6 . 6 .

Diagnosis . . . . . . . . . . . . . . . 768

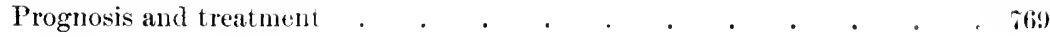

Morbid anatomy .

Sirn.: Comgenital Aneurysm

Etiology

symptoms

Diagnosis

Prognosis and treatment

. . . . . . . . . 769 


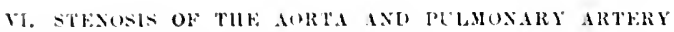

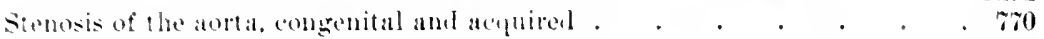

crmptoms . . . . . . . . . . .

Jiannesin. . . . . . . . . . . . . . .

Prognosicalld tratment. . . . . . . . . . 782

stemesis of the pulmoniny artery . . . . . . . . . Fas

simptom- . . . . . . . . . . 7\%

liagnosis. . . . . . . . . . . . . 672

I'roglosis and tratment. . . . . . . . . . . . 783

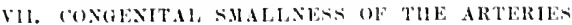

Srmptoms . . . . . . . . . . . . . . 773

liagnosis. . . . . . . . . . . . . . . . . . . . . . .

Prognosis and treatment. . . . . . . . . Fit

\section{CHAPTER XXXIV}

AXEURYSM H THE THURATH AORTA

Morbid anatomy.

Etiology

simptoms

liein

Iy:spmone

('ongle .

Erreclorution

P'hrical simns. Insprection. . . . . . . . . . 800

l'slputions . . . . . . . . . . . . 801

Proussion . . . . . . . . 802

Alescultation . . . . . . . 802

D) iatglosis . . . . . . . $80 t$

l'remuetio . . . . . . . . . . 808

Youles and atuses of ileath. . . . . . . . . 808

Treatmont . . . . . . . . . . . . 809

\section{APPENIIX}

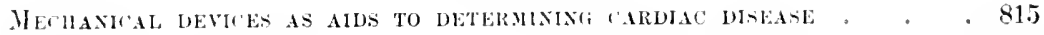

The X-ray . . . . . . . . . 81.5

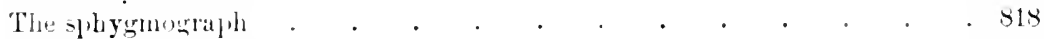

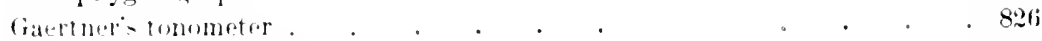

The sphymmanometer . . . . . . . . . . . $8: 31$ 


\section{LIST OF PLATES AND ILLUSTRATIONS}

PLATE

I. Anatomical relations of thoracic and abolominal viscera .

11. Aortic regurgitation with calcified vegetation that swung in blood current, causing atherona of endocarlinm and of intima of anrta . . 2is

III. Exterior of heart of Fig. 42, showing hypertrophy and dilatation of both ventricles

Cardiac valve areas, shouing where sounds are most distinctly heard . PAGE

Normal deep-seated cardiac dulness . . . . . . . . . . 6

Auscultatory percussion . . . . . . . . . . . . . . 9

Hein's palpatory pereussion . . . . . . . . . . . 10.11

Ebstein's palpatory percussion . . . . . . . . . . . 11

Maguire's palpatory percussion . . . . . . . . . . . 12

Normal cardiac cycle . . . . . . . . . . . . 14

Cardiac valve areas, indicating sounds produced at earious valves. . . 25

Interior of left ventricle, showing fibrous band connecting aortic cusps and responsible for musical murmur. . . . . . . . . . 31

Heart of a buffalo calf, showing aberant chorda tondina in left centricle . 33

Cor villosum of acute plastic pericarditis . . . . . . . . . . . 39

Usual location of pericardial friction sound and fremitus . . . . . is

Absolute dulness in case of acute pericarditis . . . . . . . . . . $\quad .63$

Case of pericarditis in which the sac contained $3 \frac{1}{2}$ pounds of fluid (Bramwell) 6i)

Absolute dulness in case of pericarditis with effusion . . . . . . . . i1

Rotch's sign of beginning effusion . . . . . . . . . .

Pins and Ewart's signs of pericardial effusion . . . . . . . . $\quad$. 80

Apex-beat and area of cardiac dulness in case of pericarditis with effusion $\quad . \quad 93$

The various sites for puncture in paracentesis pericardii . . . . . . 94

Cardiac dulness and location of border of liver in special cases . . 10s.115

Verrucose endocarditis of aortic and mitral valves . . . . . . . 145

Verrucose endocarditis . . . . . . . . . . . . . 146

Malignant verrucose endocarditis of mitral ralve . . . . . . 147

Malignant verrucose endocarditis of aortic valve, with perforation of a cusp. 149

A pex-beat and relative dulness in case of acute endocarditis . . . . . 159

A pex-beat and absolute dulness later in same case . . . . . . . . 161

Apex-beat and relative cardiac dulness: special case _. . . . . . 165

Area of maximum audibility and transmission of nurmur ; speciul case . 165

Chart I. Temperature in case of acute endocarditis . . . . . 167

Chart II. Temperature in case of acute endocarditis . . . . . . 173

Diminntion of relative cardiac.dulness in one week under treatment . . 1 1 - 6

Relative dulness in case of chronic endocarditis . . . . . . . 203

Condition of mitral valve causing regurgitation and obstruction . . . $\quad 21 \%$ 
Diarram showing effects of a mit lial leak on the eirenlation . . . 2:20

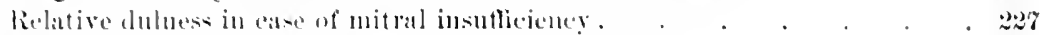

Alex-beat and relative duluess ju mitral regurgitation . . . . . . 2:30

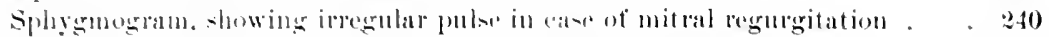

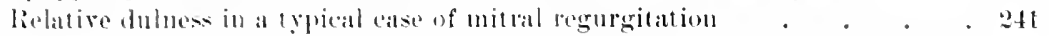

Point of maximm andibility and atea of tramsmission of mitral regurgitant mul'mur

Interior of heft rentriche, showine hattonhole slit . . . . . . . 250

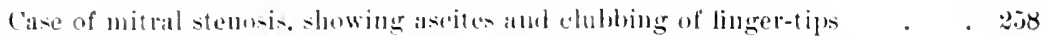

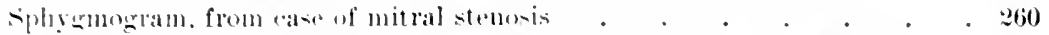

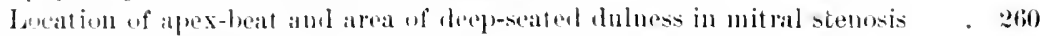

lihythm of characteristic murmur of mitral stemosis, "auricular systolic" 2061

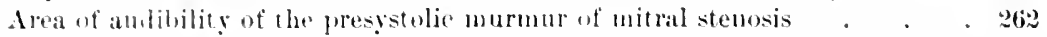

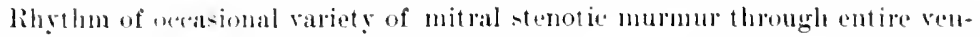

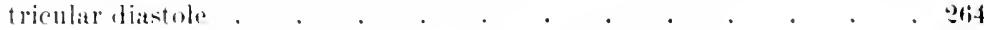

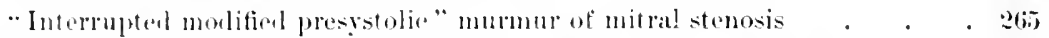

lacation of apex and relative dulursin an cate of mitral stenosis . . . 271

location of apex and relative dulnes in cate of mitral stenosis and regurgi-

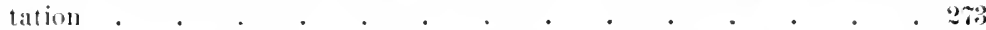

location of apes and relative duluess in ease of mitral stenosis . . . 276

Lncation of apes and rebative dubess in case of artic regurgitation . . 285

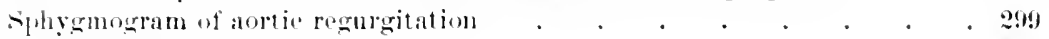

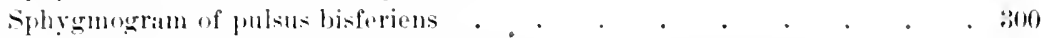

Type of relative dulness in well-comprusited aortic regurgitation . . . : \$02

lype of relative duluesin poorly compunatel antic regurgitation . . : :302

spot of maximum intensity and arat of transmision of tyjucal aortic regureritaut murum . . . . . . . . . . . . . 30;

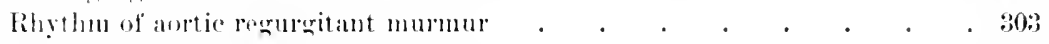

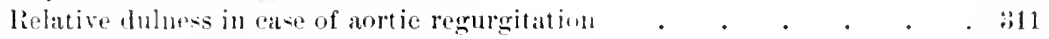

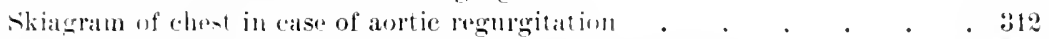

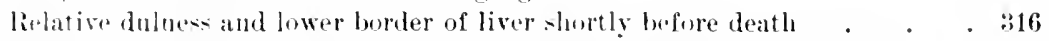

Heart of aortic stenosis with adherent cusps and also acute endocarditio . 320

Iteall of antic stenosis showing caleifiol regetations in simuses of Valsalva . 321

sphygmogram from case of aortic stenosis . . . . . . . . . 329

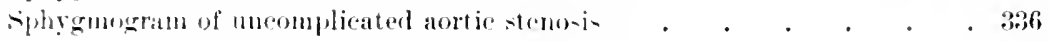

Pypical relative dulness in ease of well-rompensated aortic stenosis . . 336

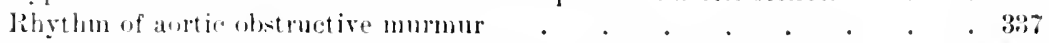

Place of maximm intensity and propagation of aortic stenotie murmur . 83:

Relativedulness in ease of primary tricuspirl regurgitation . . . . . . . 351

livative lubes in atso of trienspial regurgitation secondary to dilatation of light ventricl.

Place of maximum amblibility and area of proparation of tricuspid regrurgi-

Loreation of thrill and murmur in a typieal rase of trieuspir stenosis . . 36

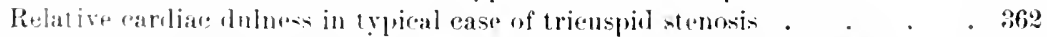

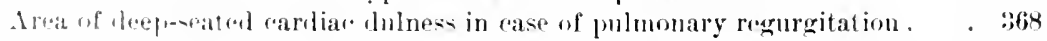

Arad of maximum intencity and of propagation of murmul in case of pul-

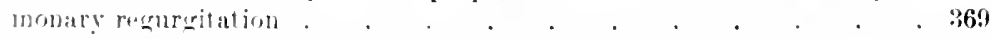

The rhythm "f murmur in typical case of pulmosary regurgitation . . 9 9

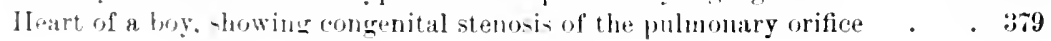


lielative cardiac dulness in cise of puhmonary stenomin . . . . . . 381

location of thrill and systolie murmur in case of puhmonaly vemosi . . . 3

lleart from case of pulmonary stenosis . . . . . . . . . 34:

same heart, left aurjole open, showing patent formen oval. . . . . . 34t

Rhythm of typieal pulmonary stenotic murnur . . . . . . . . 387

Resistance exercises . . . . . . . . 456, 45\%, 460-46;3

Shape of relative dulness in hypertrophy . . . . . . . . . . . . . . . .

Heart showing left ventricular hypertrophy . . . . . . . . . . . . . . . . . . .

Perforate interventricular silptum . . . . . . . . . . . . . 65i

Cut showing eyanosis of eongenital heart-diseast. drum-stick tinger-tips,

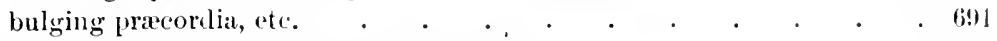

Heart showing concentric hypert rophy of left ventricle . . . . . . 699

Sphygmogram case of paroxysmal tachycardia . . . . . . . . . 73?

Skiagraph showing aneurysim of the aorta. . . . . . . . . . To

Dilatation of superficial reins secondary to pressure by anenrysm on venit

cavæ . . . . . . . . . . . . . . 786

Photograph: aortic aneurysm, showing slight bulging of anterior chest-wall. iss

Cut showing dulness and liver ontline in case of aneurysm . . . . . Fs9

Two figures showing external tunour in case of atortic anemrym . . . . 7!o

Post-mortem specimen of heart and aneurysmal sae . . . . . . . 791

Trachea, from ease of ruptured aneurysm, showing point of rupture . . 797

Opposite side of same specimen, showing interior of sac . . . . . . F ras

Skiagraph of ehest, showing tuberenlesis of right apex and tubereulom pericarditis with effusion . . . . . . . . . . . . 817

Sphygmogram of healthy man . . . . . . . . . . . . 819

Sphygmogram of womin during an at ack of paroxysual tachyearlia . . 819

From man with recurrent bradycurdial . . . . . . . . . 819

From man with acute general gonorrhoal infectimn . . . . . 820

From man with declining typhoid fever . . . . . . . . $8 \geq 0$

Hyperdicrotic pulse from woman after twelve hours recurring hamplysis . $8: 0$

From woman with moderate aortic insufficieney well compensated . . 8:1

Initial high-tension pulse from man with arterioselerosis. . . . . . $\quad \times 21$

Sustained high-tension pulse from woman with ehronie interstitial nephritis. $8: 1$

From a man with chronic interstitial nephritis . . . . . . . 8

From a woman with mild myxurlemal . . . . . . . . . 8:2

Fron a man with well-eompensated mitral iusufficiency . . . . . 892

From a woman with arteriosclerosis and fairly well-compensited mitral ineompetence . . . . . . . . . . . .

From a woman with arterioselerosis and mitral insufficiency fairly compen-

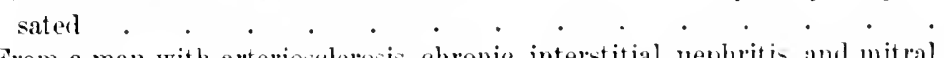

From a man with arteriosclerosis. ehronie interstitial nephritis, and mitral insuftieieney, with failing compensation, Cheyne-Stokes respiration . .

From a woman with mitril ohstrnetion and regurgitation with failing com-

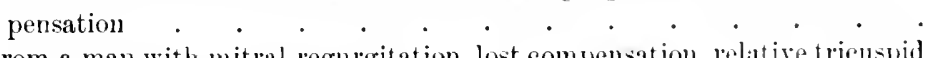

From a man with mitral regurgitation, lost compensation, relat ive trienspid insufficieney, ascites, ete.

From a woman with mitral ohstruction and insufficiency, lost compensation and relative incompetence of the tricuspic Delirium cordis . . . 824

From a boy with acute rheumatism on second day of endocarditis . $\quad 825$

From same patient, two years later, with developed aortie stenosis . . 895

Cardiogram from a girl with mit rial insufficiency . . . . . . 826 



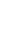




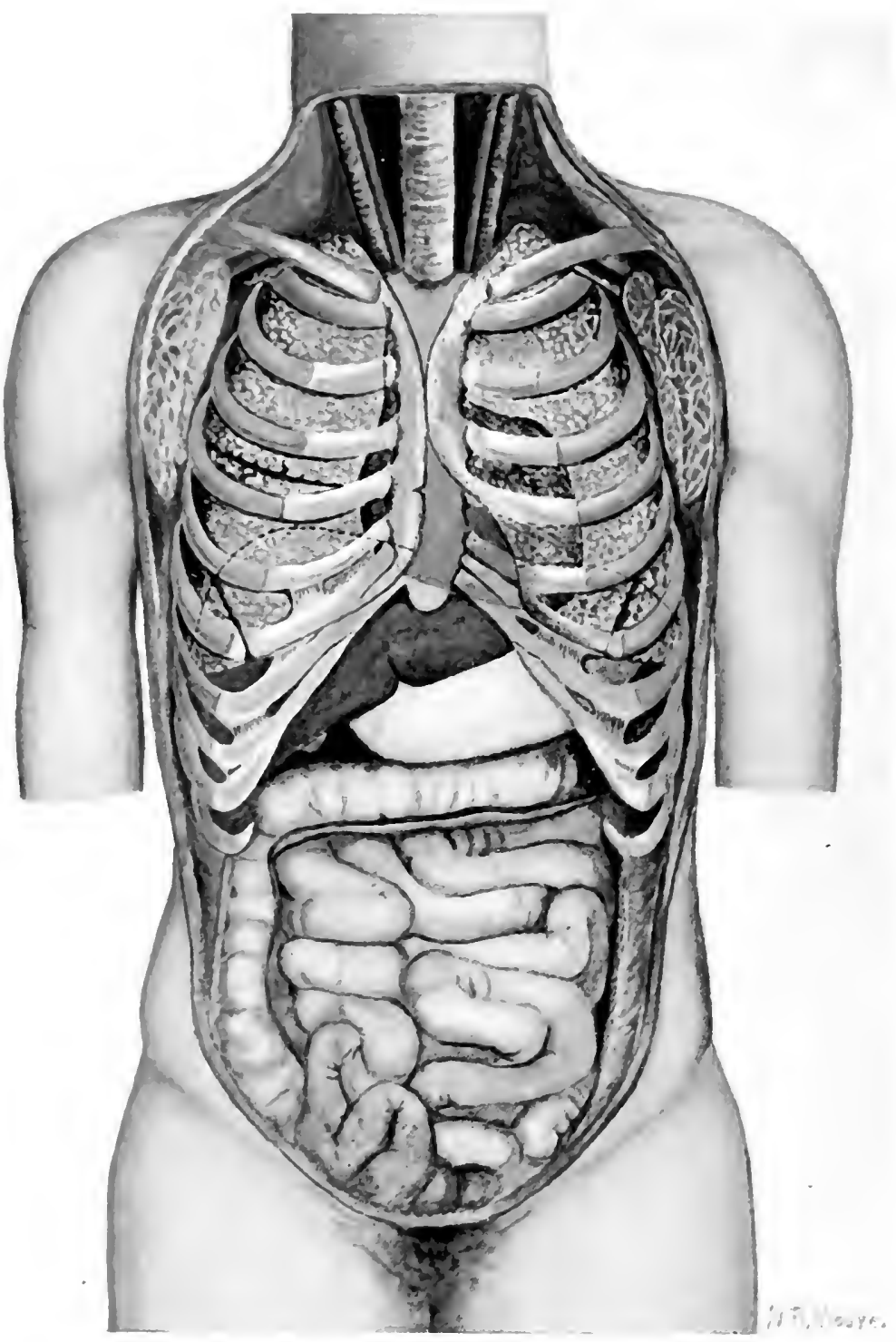




\section{DISEASES OF THE HEAR'T}

\section{GENERAL CONSIDERA'TIONS PER'TAINING TO THE ANATOMY, PHYSIOLOGY, AND EXAMINATION OF THE HEAR'T}

\section{INTRODUCTORY}

$I_{N}$ this chapter are presented certain facts which, beeanse of their bearing on the examination and the diseases of the heart, should be well understood.

Location of the Heart.-This main organ of circulation is situated in the central and lower part of the thoracic carity, resting upon the upper convex surface of the diaphragm (see frontispiece) in such a manner that its long axis forms an angle of sixty degrees with that of the body (Rosenstein). The base of the organ is directed npward, backward, and towards the right side, while its apex points downward, forward, and to the left, so as to strike against the chest-wall in the fifth left intercostal space an inch inside the nipple-line. The larger portion of the heart, therefore, lies to the left of the melian line. It is attached at its base to the great vessels and is inclosed by the pericardial sae, which invests it loosely below, being bound to the central tendon of the diaphragm beneath, to the stermm in front, to the mediastinal pleura at each sile, and behind to the anterior surface of the oesophagus, trachea, and large bronchi. In consequence of the oblique position of the heart, the pericardial sac forms a loose fold at the lower right-hand corner, so that when it becomes distended by an effusion the earliest evidence of the fluid is obtained in the fifth right interspace in what is known as the cardio-hepatic angle. Further details on this matter are contained in the chapter on Acute Pericarditis. 
The Relations of the Heart to the Anterior Thoracic Wall arr?

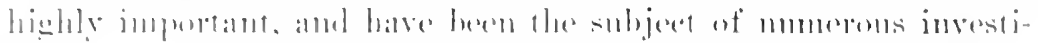

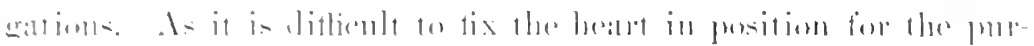

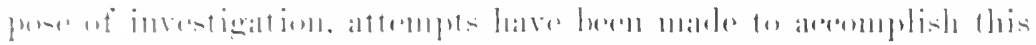

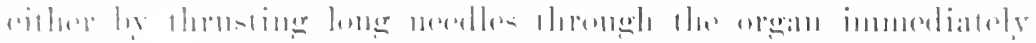

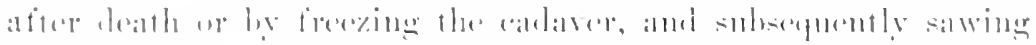

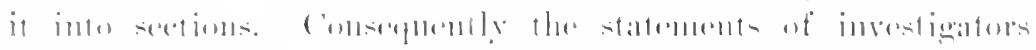

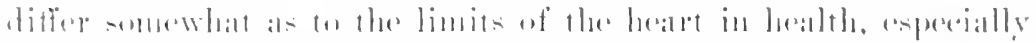

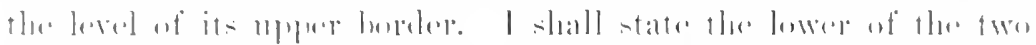

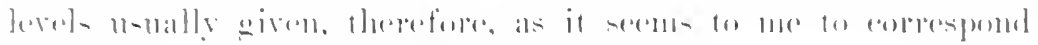

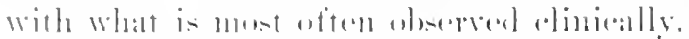

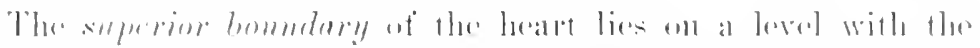

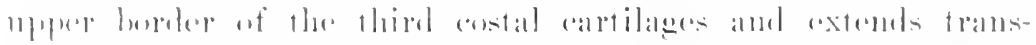

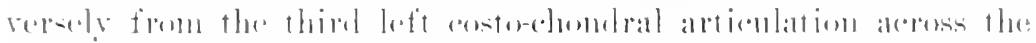

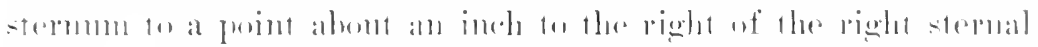
marein. The right horder of the heart, formed hy the slightly

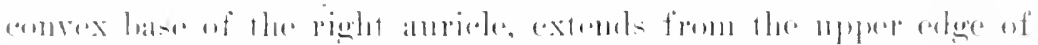

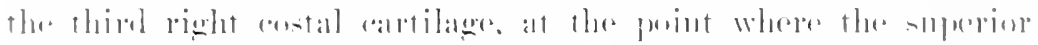

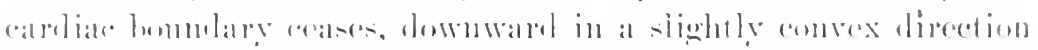

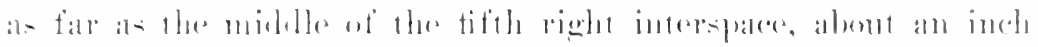

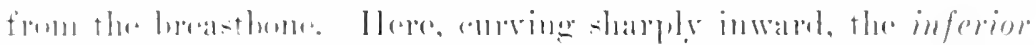

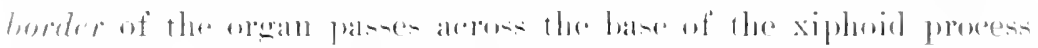

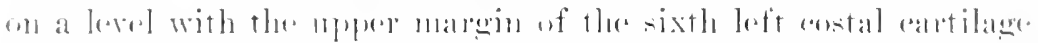

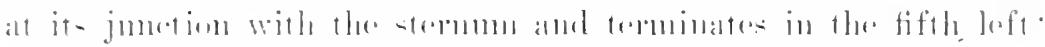

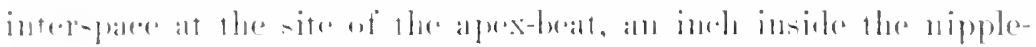

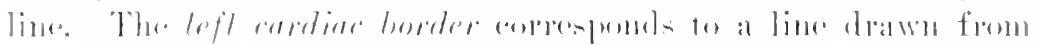

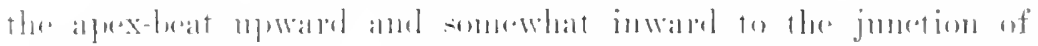

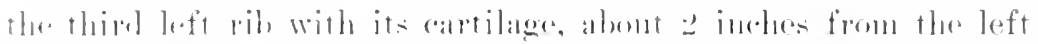

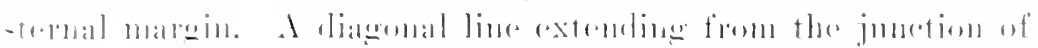

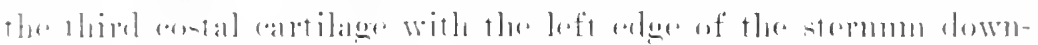

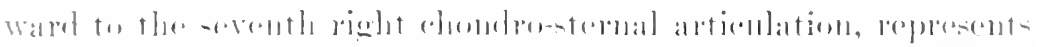

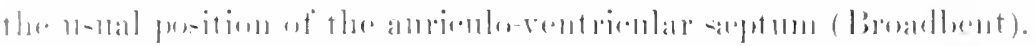

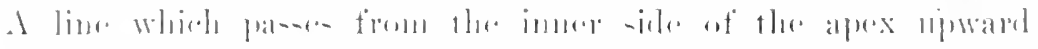

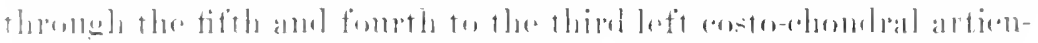

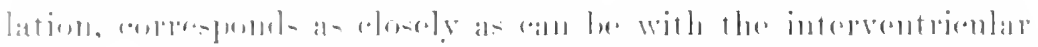

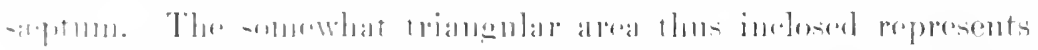

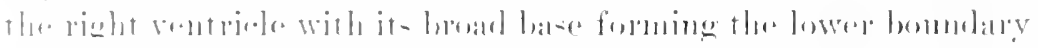

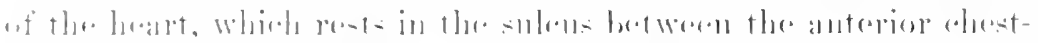

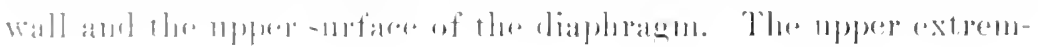


ity of this triangular area is filled by the pulmonary artery and the tip of the left anricular appendix as it curves aromed the outer border of the left ventriele to apprear in froint to and terminate near the trmik of the great artery. It is obvious, therefore, that only the upper third of the right anricle lies behind the stermun, while it lower two thirds are to the right of this bone. The left anricle is situated behind, being completely invested by the left lung and entirely obsured from view from the front. The same is the case also with the left ventriele, excepting a narrow strip which forms the left border of the heart and is visible anteriorly. It is the inferior extremity of this narrow strip which, propelled against the wall of the thorax, oceasions the alpex-beat. Consequently it is a portion of the right rentricle only which is exposed to view after removal of the breastbone and adjacent contal caltilages. The remainder of the heart, even that which lies anteriorly, is covered from view by the lungs.

The anterior lung borders are in apposition behind the midlle of the stermum from the level of the seand to that of the fourth costal cartilages. It this latter situation they diverge, the borter of the right lung passing on lownward to the level of the fifth right costal cartilage, where it turns off to the right to mnite with the inferior margin of the same lung. The anterior margin of the left lung diverges abruptly at the level of the fourth cartilage, passing outward along the lower edge of this cartilage as far as its union with its rib. It then turns downwal, and, after curving slightly inward and then ontward, mites with the inferior border at the level of the sixth costal cartilage near its point of artielllation with its rib. In consequence of this peculial arrangenent of the left lung a portion of the anterior surface of the right ventricle cones into immoliate contant with the chest-wall, and, being aneovered by lung, forms the area of superficial ratiac dulness. By many this area is eonsidered of great importance in the determination of the size of the heart by perension, as will be shown in dealing with the subject of rardiar prension.

Position of the Great Vessels and Valves.-The puhmonary artery lies about half an inch to the left of the breastbone and extends from the level of the centre of the third left interspace upward to the level of the second costal cartilage, where it divides into its two main branches. The position and course of the as- 


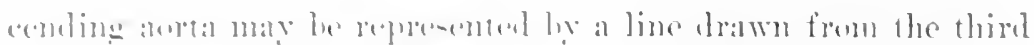

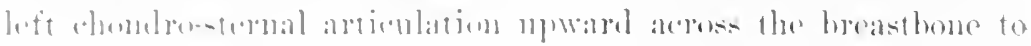

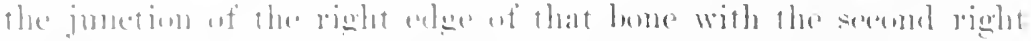

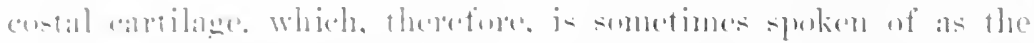

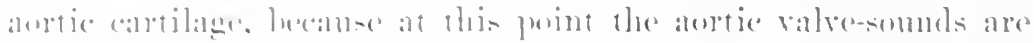

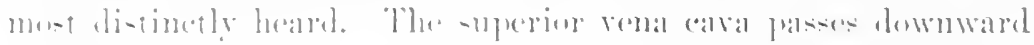

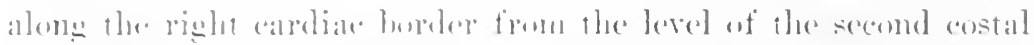

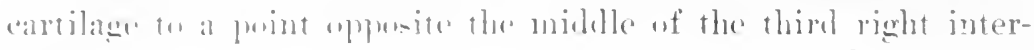
- prallor.

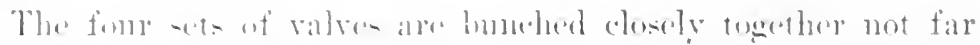

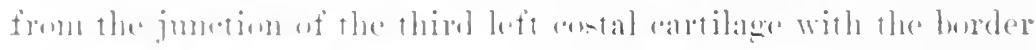

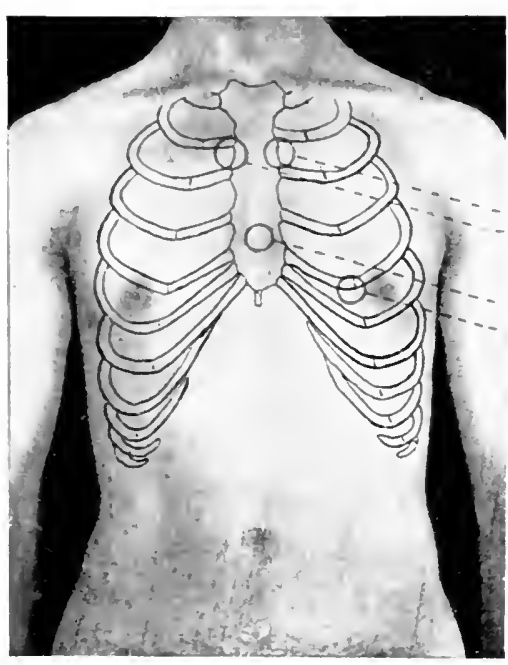

Fin, 1.-CARlHAC VALVE drelis.

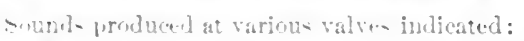
p. pulmolary : a. iortice: to trielappid: m. Initral. of the stermum, the pulmomary heing mast superficial, the miiral nest intermal, the triemspid nuret inferions, and the anortice the mot contral. There camot, therefore, lne anerultated in the rewion of their anatomic seat if ane in to lifferentiats their inclivisual somule. For this reaton we take allantage of the law soreming the comduction of their sumls and ans"ultate them in wertain areas. nanced alfier the resprective villver.

Thus the mitral area is -itmatred at the aprex-heal and inclurles: a linitul distriet inmediatery remblalkent. The

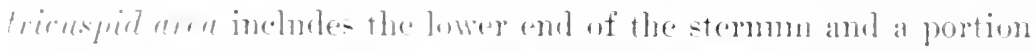

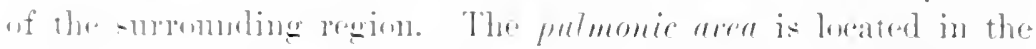

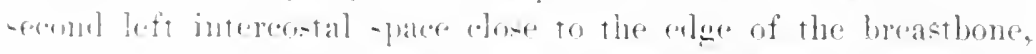

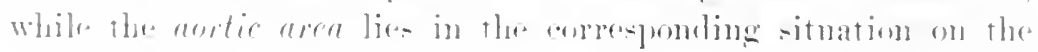

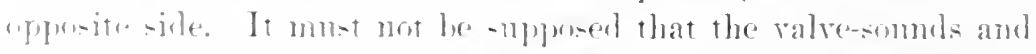
momme are heart only in these eituations-they are widely

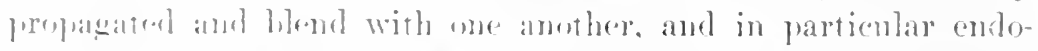

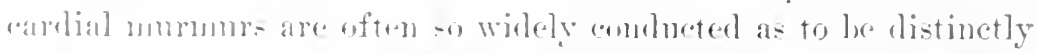
andible in where areas than thowe to which they properly loelong. 
Leaving further consideration of this subject at this time, wo now pass on to the discussion of the mothods he which the size of the heart is ascertained dming life (Fig. 1).

Cardiac Percussion.--In employing this means of examination we aim to determine, first, the boundaries of the area of superficial duhness, and second, the limits of deepresated dnhess. To accomphish the former, perension must he malde lightly, whereas the latter requires a firm, heary pereussion-stroke.

The area of superficial or absolule cardiar dulness corresponding with the portion of the right ventriele menvered by lume during inspiration, extends rertically from the mpere eder of the fourth left costal cartilage to the sixth, and tramserely from the left borler of the sternum to a point midway between the parasternal and mamillary lines. As its onter or loft hommary is irregular, and, roughly speaking, pa-ses obliquely downwarl towards the left, this area is hroader at its lower than at its mper margin. Eulargement of the heart crowds the lumg-borders aside, and hence generally inereases the dimensions of superficial dulness, especially to the right in cases of hypertroply and dilatation of the right rentricle. But a rariety of conditions ontside of the heart may inerease or diminish the extent of superticial dulness, and hence render this not always a trustwonthe indication of the actmal size of the heart. Thus the Imog-lorders may he retracted by plemitic adhesions and expose an abmormally lange portion of the right ventricle, or heing distendert by pulnomary emphysema, they nuy diminish or entirely obliterate this area.

Consequently it is preferable to rely upon deep rather than superficial percussion in endeavoming to ascertain the size of the heart, since when the limits of deep-seated or retative cardiale dulness are found increased wo know it is dne to increase in the size of the organ itself. Vierordt objerets to this latter methot because of its greater ditticulty and uncertainty, simos pulmomary resonance shades so gratually into the plative dulness overlying the heart that two observers of apparently equal skill may not agree in their results. Doubtless individual judguent depends very largely upon practice and delicacy of learing, and doubtless emphysema, inelasticity of the ribs, wreat thickness of the parietes, ete, often make it impossible to acemately determine decp eardiae limits. Nerertheless the cases in which relative dulness is possi- 


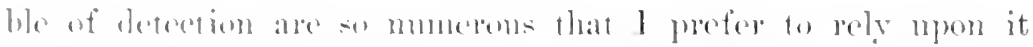

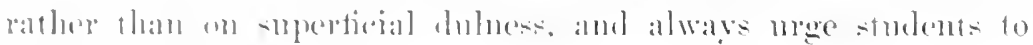
maker ma of this- methen.

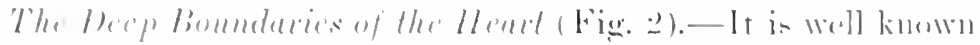

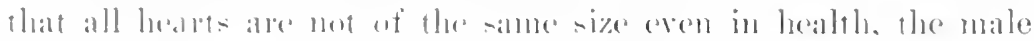

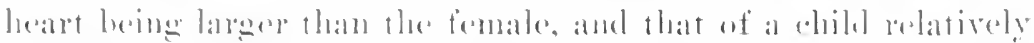

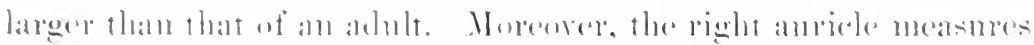

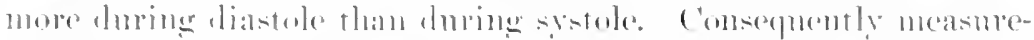

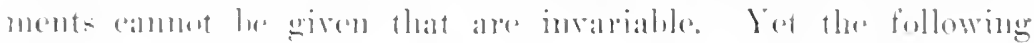

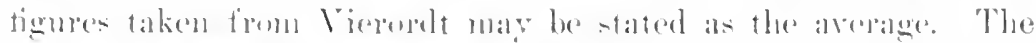

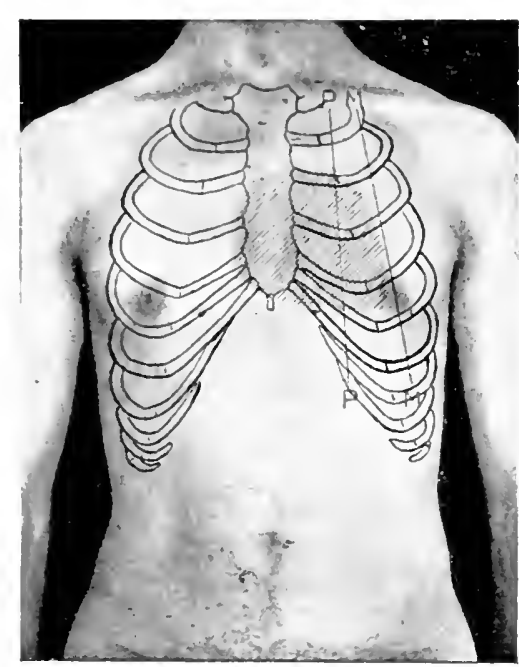

Fir, 2,-NGRMAL I) EEP-SEATEY ('ABIIA J) TLNESS.

I'P. para-ternal line; H Y. manillary line. arhlt brate "axteruls from

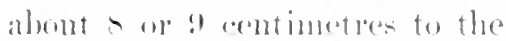
left of the median lime (alpex of

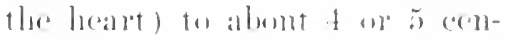
rimberles to the rielst of the salure, i. a. albont ome and a

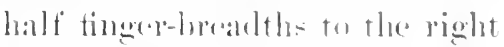
of the right lombler af the stor10131 (right aluriele)." Busse,

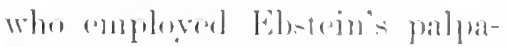
tory ferensiom, fommel the loft londere of the lealle in lacalth

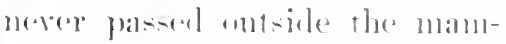
illary line, while Holnkolıl determined the arearages in arlults to be 7.2 remtimetres fiom the left sternal malroin. (On the pient side the heart ex-

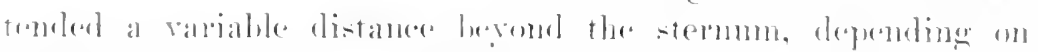

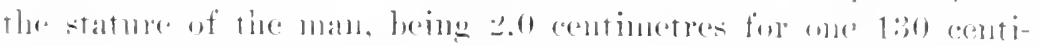

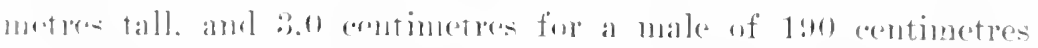
in leciglit. In woment these figures are slighty less. while in

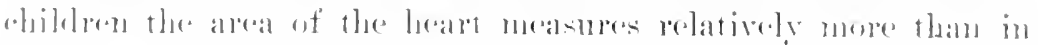

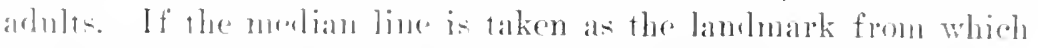

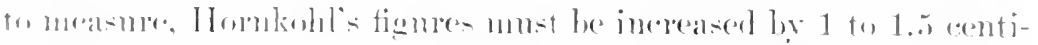

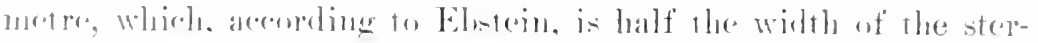

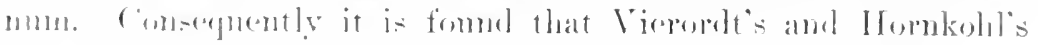

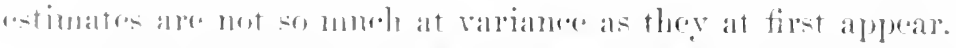

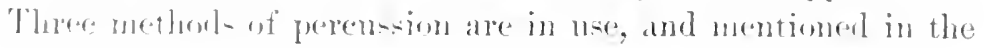


order of their popmlarity are: (1) plessinetric, (2) auscultatory, (3) palpatory perenssion. I do not propose to discuss the advantages or disadvantages of employing a plexincter and hammer, but merely to express my very positive proferenec for the nse of the fingers, for the reason that thereby one is enabled to obtain valuable information from the sense of resistance.

In ascertaining the area of absohnte duluess light strokes are essential, while the reverse is the case as regards deep-seated dulness. Moreover, in ontlining the area of relative dulness the pleximeter finger should he pressed fimly against the chest-wall, to exchde so far as posibible the vilorations of the bony structures. This is the "abgedimple" perenssion of the Germans. The finger is placed fimly at right angle to the ribs at a point well ontside the cardiac area, and perenssion is made with considerable force at erer lecreasing distances from the stermm until a slight rise in pitch and increase of resistance incieare that the airless organ (the heart) has loeen reached.

In this mamer one is to perenss from above downwarl along the left parasternal line, beginning in the first intercostaî space and ceasing when the npper borler of the liver is reached. It the sides, fercusion is to be performed first in an obligue direction from above downward and inward, and next on a transverse line from withont towals the centre. If, wherever comparative dulness is perecived, a mark is mark with a lermographic pencil, these marks can subsequently be mited, and will then represent the probable linits and shape of deep-seated cardiac dnluess. If one prefers he can, instead of placing his finger across the ribs, press it strongly into the interestal space parallel with the ribs, and if his finger is slender can thus convey his perenssion-strokes more directly to the heart withont eliciting so much viluation from the elastic structures intervening.

Sansom makes use of a narrow pleximeter, which is ot such small size as to fit well down into the intercostal space, and claims remarkably accurate results, more precise incleed than in any other way.

It may be well to here remark that, when in women accurate percussion of the heart is impossible on accomnt of the large size of the mamma, fairly trustworthy information concerning the size of the hean may be gained by careful palpation of the apes- 
beat. Since the mamillary line is not a trustworthy guide in females it is better to measure the site of the apex impulse from the mid-sternal line or from the mid-elavienlar line, it being in the tith interspales. an inch within the latter.

Two statements should also be marle regarding perenssion of the heart in whilien. In the tirst place, the area of superfieial dulness is said he Hornkohl to he somewhat more extensive than in achlts. paldicularly above, where it is asereded to reach up into the thirel interostal spaer, while its moter malegin passes somewhat finther levomel the left parasterual lime. i. e., to a point a litthe neatrer the mamillary than the parasternal line. Tn the seeond place. it is important to bear in mind the great elastieity of the ehild: chest, and henee to perens- with far mole delieacy than is andisulde in grown prople. Otherwise the note of pulmonary resonamee and the vilurations of molerlying structures will assuredly prevent accurate and trustworthy results. For these reasons it is far preferable to rely on the other modes of perenssion now to be described.

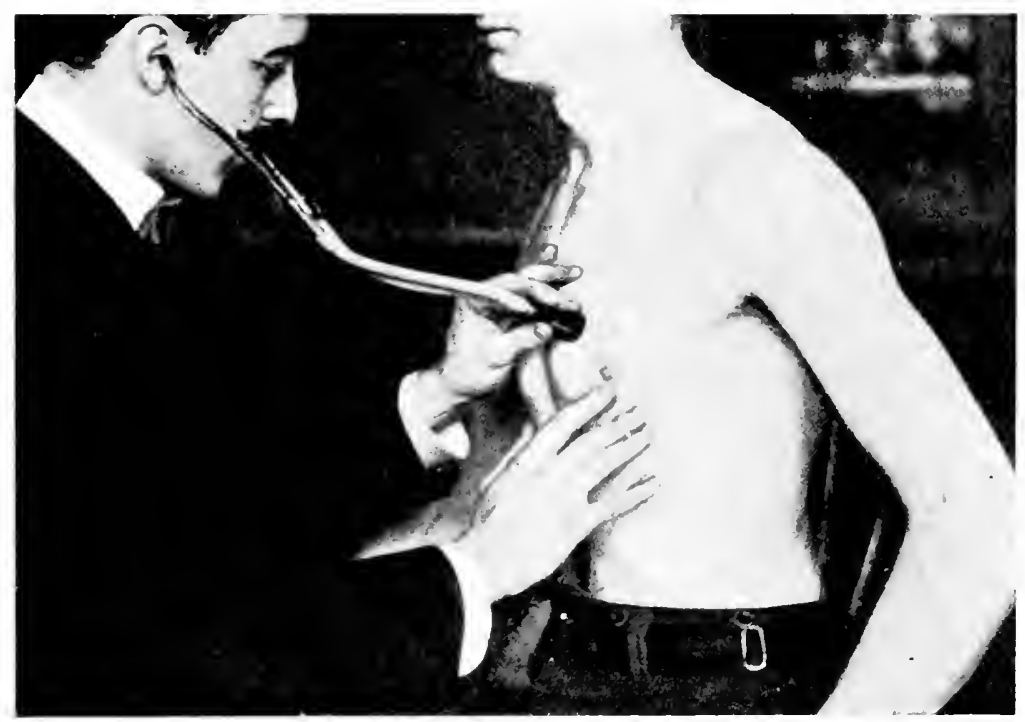

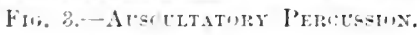

Lescultutory or Stothoserpir Percussion. - This is a combinatirn of an-conlation and pereussion, and is based on the principle that when the stroke is malle orer a solid organ its note is higher, 
sharper, and more clearly defined than when orer an air-eontaining organ. It is fomml, moreover, that there is a distinct difference in the character of the note of two visecra of similar structure. This is, of eomse, the same principle that underlies plessimetric perension, but the anseulatory method enables one to appreciate more delicate sharlings of tone and to define more precisely the deeply sitnated borders of an organ or solid thoracic tumour. It even enables one to distinguish between the dulness of pleuritic or pericardial effusion and that of a contiguous pulmonary consolidation.

It is practised in either of two ways: The examiner may with one hand hold the bell

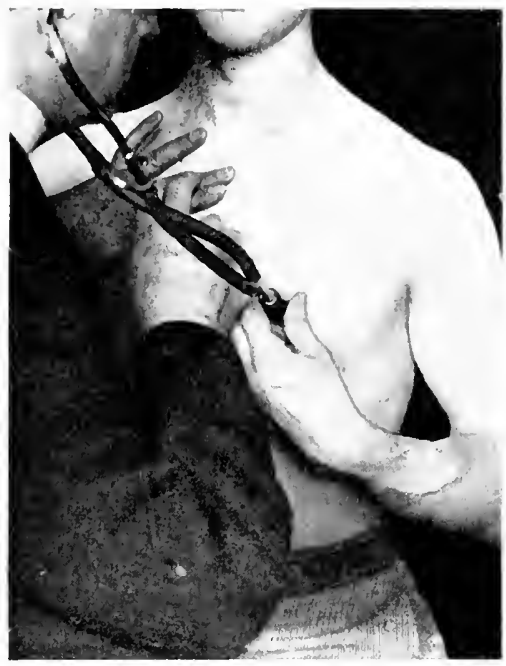

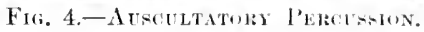
of his binamal stethoseope against the centre of the artiate area, while with the tip of a finger of the disengaged haml he taps the chest-wall lightly from withont inward and on al line with his stethoscope (Fig. :3), or he may have his instrument helk by an assistant while he perfoms pereussion in the ordinary manner (Fig. 4). The former mole is preferable, becanse more delicate. Snch astonishing and incredible acemacy is elamed for ansenltatory pereussion, notaluly by Bezly Thorne, that Broadbent and others have been led to test it, and have come to the conclusion that it possesses no advantages over plessimetric perenssion. I have employed it a great deal, and, although recognising its liability to error and its limitations, still I believe it is in certain cases with thin-walled elastic chests and when practised carefully a very accurate means of outlining the heart. I have repeatedly compared its findings with those of the two other methods, especially plessimetric, and find it satisfactory and trustworthy. One occasionally encounters cliests in which for one reason or another it is next to impossible to determine the deep limits of the heart in the ordinary fashion. It is well in such cases to 


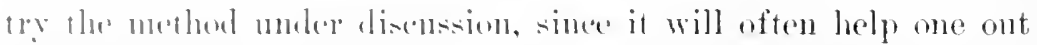

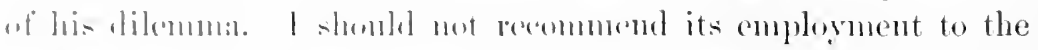

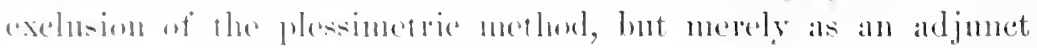
thereto.

l'alputury l'eremsion. - by this term is meant a method of nsing lonth palpation and peremsion at the same time. In other

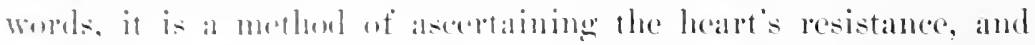
thereby of ascortining its outline and limensjons. It makes nse of the fueling of resistance rather than of the auditory perception of ditforences in somml. Anenbrugerer and latennec pereussed the Ches-wall immentiandy-that is, whllout the intervention of a plessimeter: the formur, hy striking with the tip of his finger, and the lattrel with the end of his stethoseope. It is needless to say this monl. of performing pereussion is mure or less painful to the patient. In 1 s.7 Ehsein propesed palpation of the leart and other solid viseral, as the liver, as a moans of appreciating their size by their lesistance, and at the International Medical Congress at Ronte in 1-51t he pad an elaberate paper in which he disensed

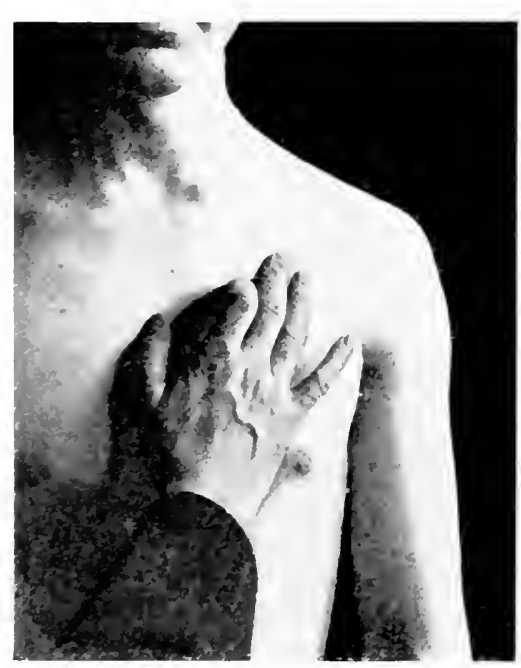

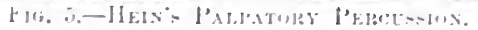
first poitiun. amel explained his method at comsiderable lemeth. In this jialere he called attention to at methond rompleged by .J. Hein, which comsists in palpating the hoart with one fingere while perersing with the other in the following manner: 'The palmar surface of the terminal phalamx of the outstretched middle finacer is placed upon the chest, while a light tap is made on the chest with the tip of the bent

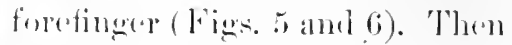
while the extremity of the first finger rests andinst the wall of thr thosax he gives a light hlow

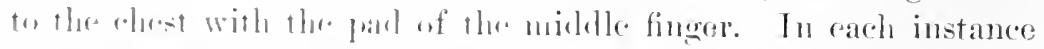

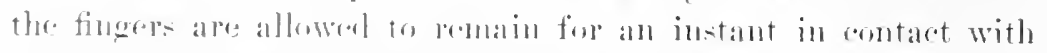

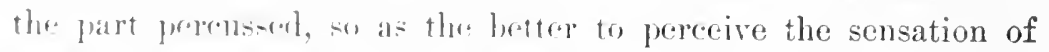

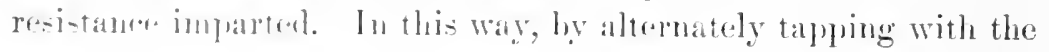


two fingers, the entire area is traversed. 'This is said to yield very acenrate results, but is ly Ebstein consilared inferior to his method, beeause not altogether devoid of pain to the patient. Ebstein, therefore, malies use of a small glass pleximeter, upon which he gives a gentle pressing stroke with the tip of one finger, which, flexed at its metacarpal articulation, is held slightly and rigidly curved as the stroke is given (Fig. 7 ). The blow is not male with a quick rebound (stacceito), but with a firm pushing movement (legalto). The stroke is given in a line perpendienlar to the surface thus perenssed and the pleximeter is held firmly in position. Ebstein's pleximeter of glass is $\frac{1}{2}$ an inch (1.3 centimetre) in width, $1 \frac{3}{5}$ inch $(4.0$ centimetres) in length, and sur-

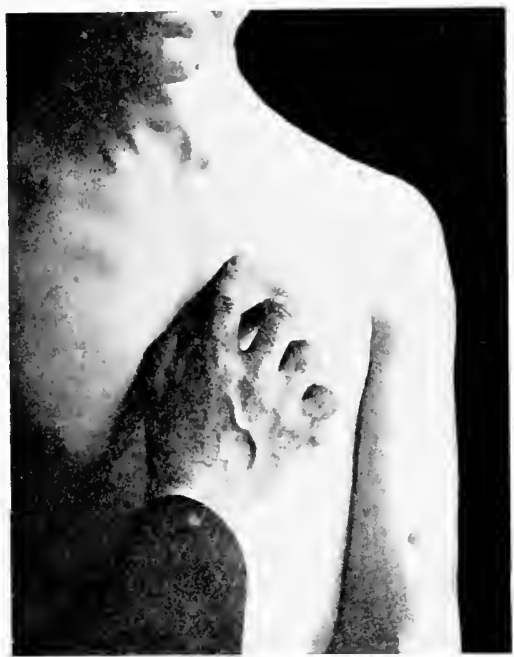

Fia. 6.-Diein's Palpatury Pertiagion. Seeond position. mounted by a small handle $\frac{3}{5}$ of an incls (1.5 centimetre) in height. With such a pleximeter Ebstein asserts the nethod is not only gratifyingly precise, as he has repeatedly proved on the caldiver by means of needles, but is easily acquired, which is an opin-

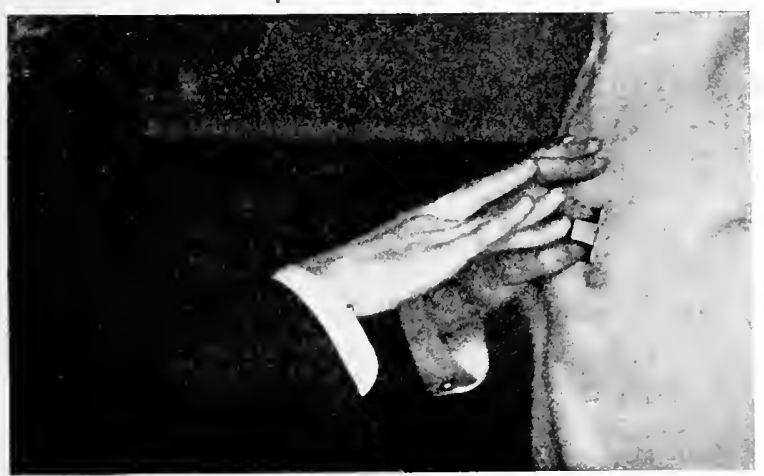

Fig. 7.-Ebstein's l'aliatory P'erclssion. ion contlaty to that expressed loy Vieroritt. Moreover, it possesses the arlitional antrantagen of enabling the examiner to arail hinnself of his pereeption of the sound and pitch of the note produced, as well as of the sense of resistance. In this way two impressions are received simultaneously which serve to control 


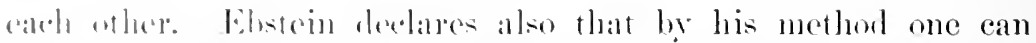

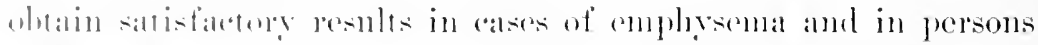
with a thick pronniculus of fat or lange mammally glands, all of

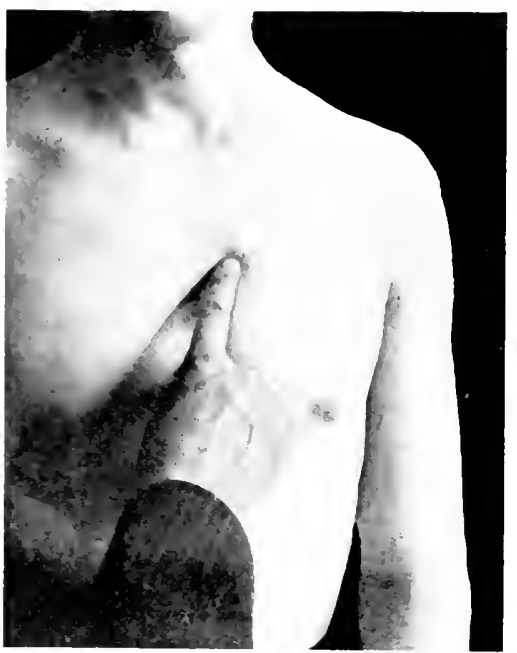

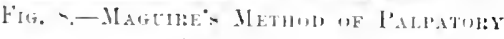

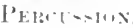

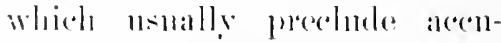
rate perension after the ordinilly method.

liobert Magnire, of England, advocites palpatory percosion ly tappling lightly with the soft palmalr chshion of the teminial phalanx of one finger, and ralins equally acenrate results (Fig. s). He expressly states that the stroke minst be not short and quick, but long and pressing, as if one were fecrling or palpating with the tingere. It is applicable, he saly, not mily to all solid organs, spleen and kidneys, as

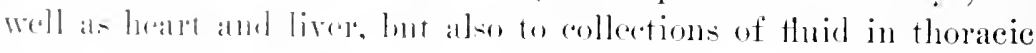
and peritoneal arvition.

In carse which alm at all obsentre it is well to verify the con-

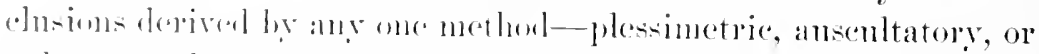

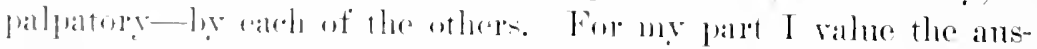
cultatury methen the leat highly, becanse so liable to error in

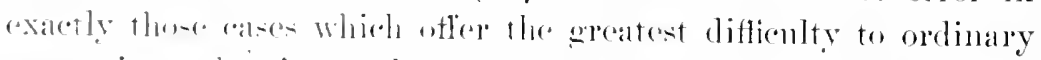

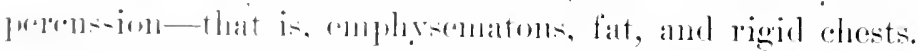

Auscultation of the Heart is another and indispensable means of uaking andiar sambintions, and by the inexperienced is apt

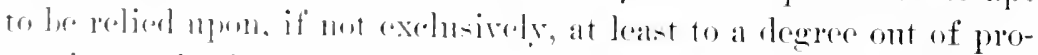

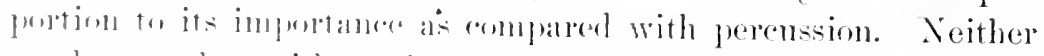

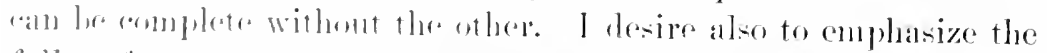

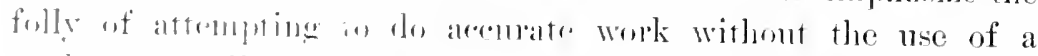

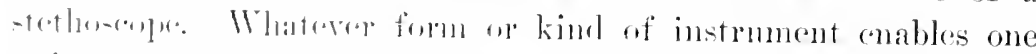

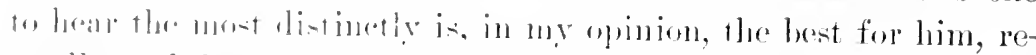

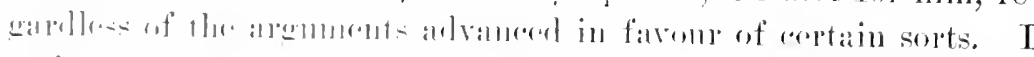

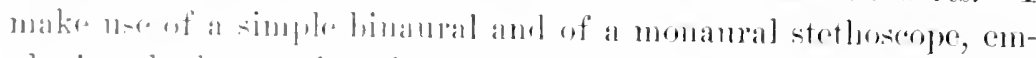

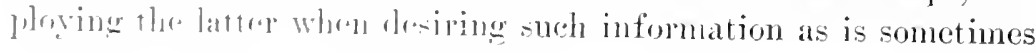


obtained from the inpulse of the hypertrophied or dilated heart

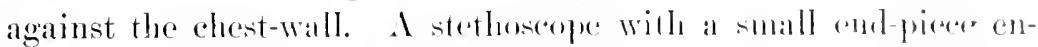
ables one to differentiate sommds and numbunts and to trate then to their somree in a way that camnot be done by the eal plated against the precordia.

Normal Heart-sounds. - The eletection of inturmul's is mot the only object of ansentation. 'The heart-sommls themselves often aftord as much, if indeed not more information than do hutuits. Therefore, if one is to correcetly interpret what he lacar's come from the heart, he must be fimiliar with the chardeters of the normal sounds of this organ. 'To this end he must know how they are produced," and keep in mind what is going on within, during the portions of the cartiale cerele, at the tine of the sommls and during the intervals of silenee.

If one listens at any point upon the eardiace area he hears two distinct sounds, known as the first and secont somm respectively. Over either of the ventricles, in the neighlomblesed of the alpex, the accent falls on the first, which is longer, of a lower pitell, and more intense-that is, more booming than the serend, which is, conversely, short, sharp, and clicking, having a valvular quality we say. Moreover, the ear detects two intervals or periods of silence, of which the shorter acens during systele between the first and suceeding second somul. The longer, known ats the pause, falls between the secomel and next ensuing first somul, during diastole. This sucession of sounds and silenees wives to the heart-sounds their peculiar rhythm, likened to the tirking of a elock. If now ansentation be mate at the base of the organ, in the second interspace at either sille of the stermme, it is pereeived that the aceent falls on the second somml, sincer this is the louder and elearer and higher pitched of the two. Their rhythm is, however, the same as at the apex. Furthermore, it is generally perceived that the secont somml is loulder on one side of the stermum

* It is common to speak of sounds, whet ler normat or abmormal, ats produced within the heart or chest. Of course such phraseology is lowere and nut in accordance with the known laws of acoustics. Sounds are the aulitury perereption of waves imparted to the air by the vibration of structures within the therax, the tissnes serving as gool condertors of these vilmations. With this understanding of the mode of production of these acoustic phenomena, I shall, for the sake of convenience and the avoilance of circumloeution, speak of sombls ats gencrated in the heart or chest. 
than on the other, the prition of greater intensity not always being miform in different individuals, depending on various conditions, ils alece. are.

What ondsins this slight dirersity between the somds at

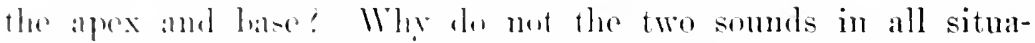
tims have the same challatede' l will answer the latter query tirs. The tirst smmel is simblomons with the apex-beat, and is therefore produecel during rentricular systole. Physiology

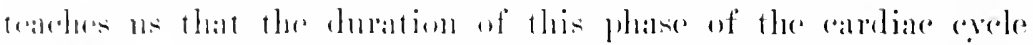

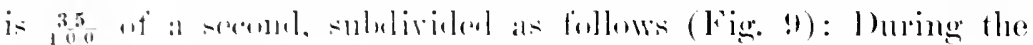

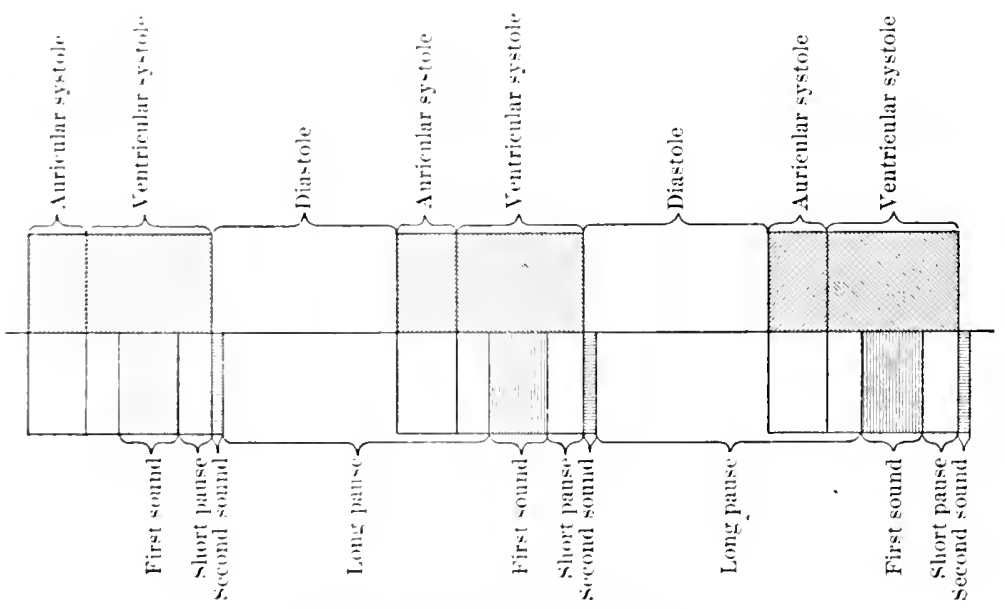

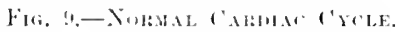

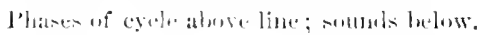

first tenth of a second the ventricle is intiating its contraction and is silent; during the following $\frac{15}{100}$ of a second its contractim reareles its maximm enerey, the amrirulo-ventricular valves

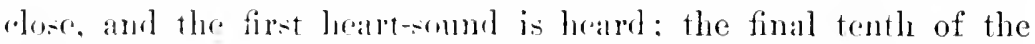
secombl, during which the rentriele still remains contracted, is atain a periont of -ikenere and terminates the phase of ventricular sy:tole.

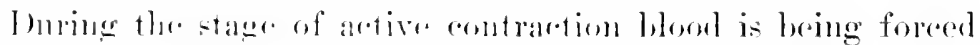
from the ventrieles inte the antal and putmonary artery. With the completion of this fromlsive stage the ventricles relax; arterial walls recoil, formeng the mass of l, toon against the sigmoid rallurs. which, thus thrown into tensiom and closed, give forth a tone, the second somml, which signals the closure of the valve and 
the commencenent of diastole. 'This somel is, therefore, liastolie,

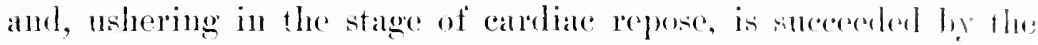
period of silence or long panse.

This brief statement of what takes place during the different phases of the cardiae cycele will help us to miderstand the mode of production of the two somuls. During the midelle portion of systole, when the first somel is audible, the ventricle is actively contracting and the auriculo-rentricular valves are closed and lad lo closely in eontact through the contraction of the papillan muscos. Experiments have shown that if either participant in this stage ean be made to act withont the other a somed is still andible, but it has lost its normal character. If in the bloodless heart the ventricles are made to contract while the andeulo-ventricular valves are looked hack, the sommel is low in piteh, prolonged, and hooming, while if the ventricle be opened and the valves elosed withont contraction of the musenlar walls, the somd producert is higher pitehed, shorter, and less intense. It is thus apparent that the first cardiac somnd is a composite one made np of two clements, a museular and a valvular.

On the other land, the second somed is due solely to the ribrations generated in the semilunar valves at the instant of their elosme and possesses no muscular element. It is consequently of higher pitch, shorter duration, and less intensity than the first somud. Tnasmuch as the first is a conposite somml, it is obvions that its two elements must synchronize exactly if the sommd is to be pure and normal. Furthermore, there are two ventricles and two sets of auriculo-ventricular valves. Comsepuently each half of the heart is responsible for its own first sound. Anscultation at the apex, however, reveals but one first somd, which is the result largely of the blending of the two someds erenerated in the two halves of the organ, hut comducted to this point. That this is the ease is proved by the clinical experience that ocoasionally over one or the other ventricle the systolic somud is heard to be of altered quality or divided into its two elements, while over the opposite half of the organ it retains its normal characters.

Inasmuch as there are two sets of semilmal valves, there are two separately produced yet synchronons second sounds. Of these, the aortic is heard most distinctly at the right edge of the sternmm in the second interspace, while the arca of greatest audibility for 


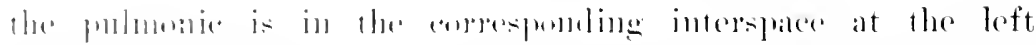

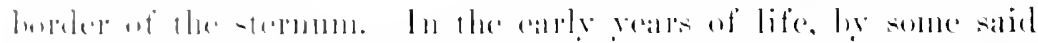

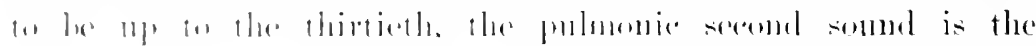

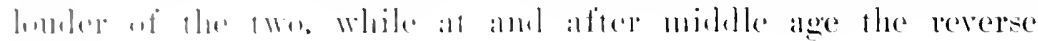
nitilin-.

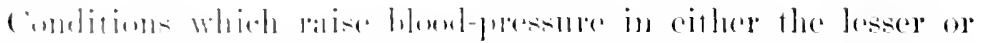

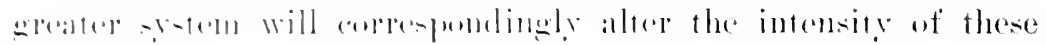

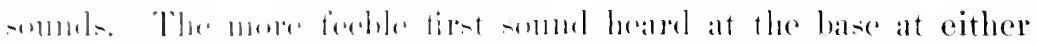

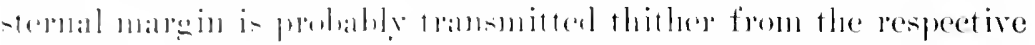

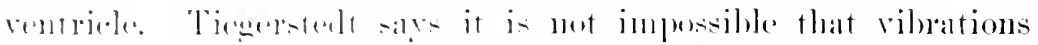

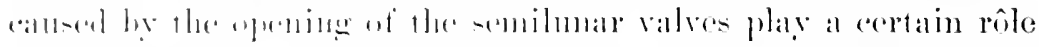

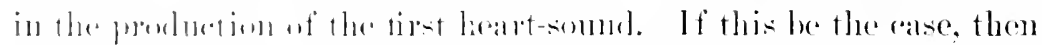

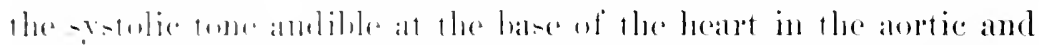

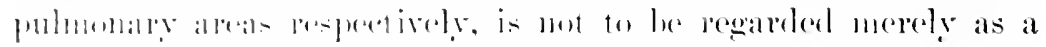

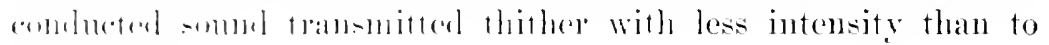
the alex.

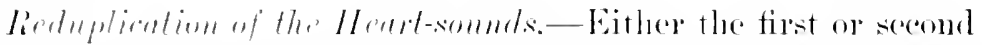

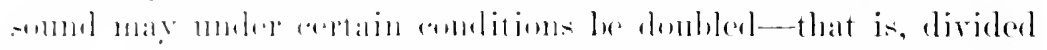

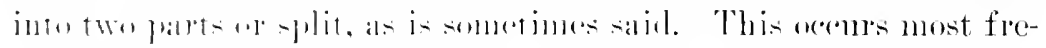

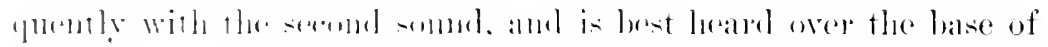

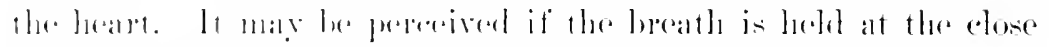

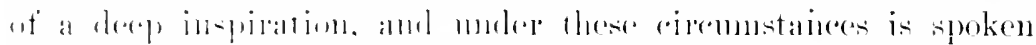

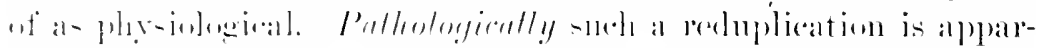

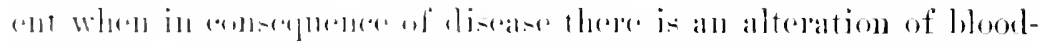

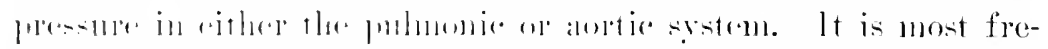

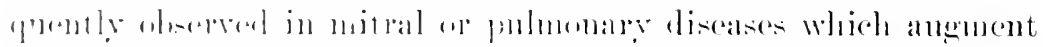

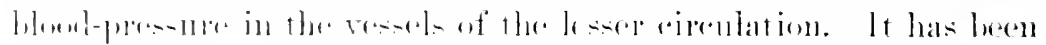

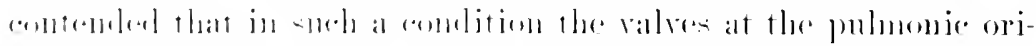

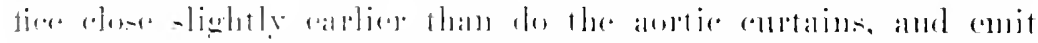

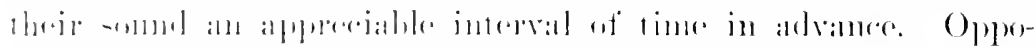

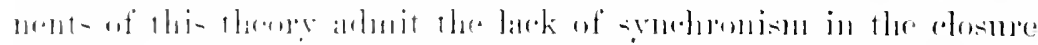

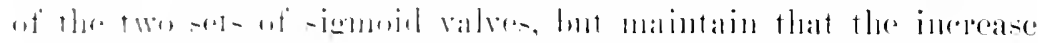

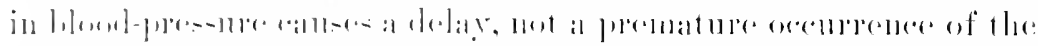

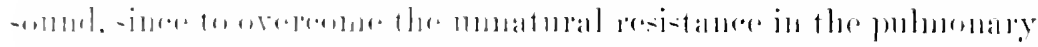

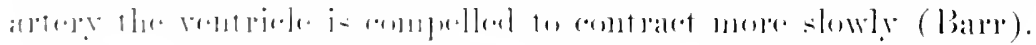

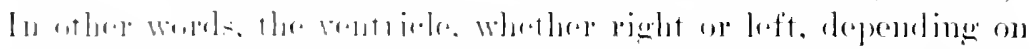

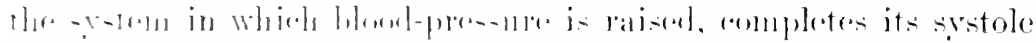

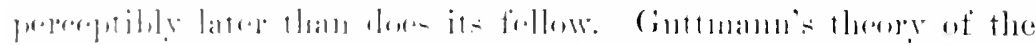

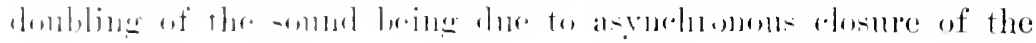


individual leaflets of a valre is reganded as fallacious. Rorduplicaltion of the second somul, therefore, is an indication of some alteration of blood-pressure in ane or the other system.

There is another form of doubling of the second somme which, among English writers, who appear to haw paid particulan attention to this anomaly of the heart-somels, is distingmisherl from the foregoing as apparent or simulated doubling. 'This varicty, it I may so term it, is heard only at or near the apes, and appears to be confined to cases of mitral disease with predominating stenosis. The phenomenon is belicred to be due to the ardition or interpolation of a third sound closely following the physiological second. The only theory regarding its morle of production that appears tenable is, so far as $I$ am able to learn, that advanced by Samsonn. ITe believes it to be a somd of tension in the altered segments of the mitral valve. Epon the oceurence of ventricular diastole the mass of blood liekl hack during systole in the left auricle and pulmonary reins rushes forcibly into the rapidly relaxed rentricle, and, streaming in the direction of least resistance, fills the space behind the thickened and displaced mitral cusps, "bellying them out," after the manner of sails filled by the wind. This sudden bulging of the discased curtains produces a sound of tension which is audible in the fore part of diastole soon after the normal second somnd, which in mitral stenosis, in Sansom's opinion, is the pulmonic second, transmitted to the apex. The artir second is, he thinks, too fecble to be heard at the apex. That this third element of sound is produced at the mitral orifice seens supported by the observation that it oceasionally becomes transformed into a diastolic murmur oceupying the same position in diastole-i. e., following the normal second somet. The rliagnostic value of this seeming doubling of the second sound at the apex will be discussert in the chapter on Mitral Stenosis.

Sewall likewise attributes this reduplication of the second sound to the tone of valve-tension, but explains it on the hypothesis that the irritable papillary muscles, stimmlated ly the inmsh of blood from the overtistended anicle, contract too soon-i. e., in the fore part of diastole. This explanation may hold for those cases in which douhling of the second sound is a transient phenomenon, as heard sometimes during states of great cardiac excitement, but not for cases of mitral stenosis. 


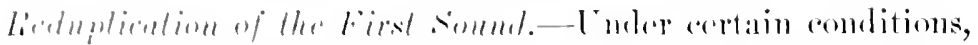
ats that of almermal blond-pressure within one on the other ventricle,

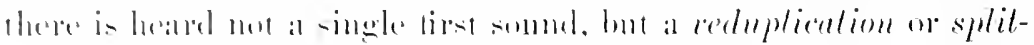
time of this somml. This almommality is less frepluently pereeded

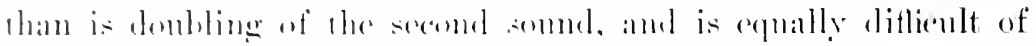

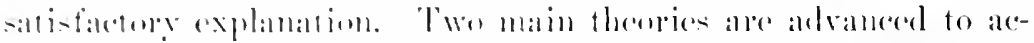

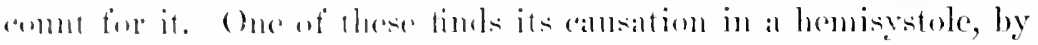

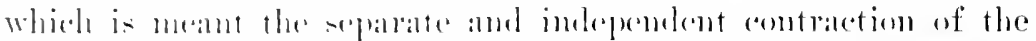

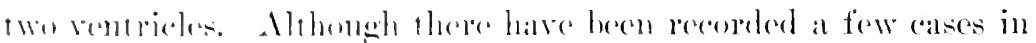

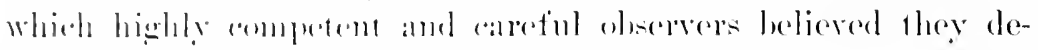

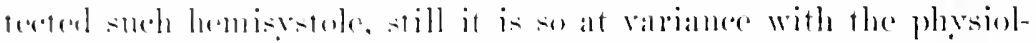

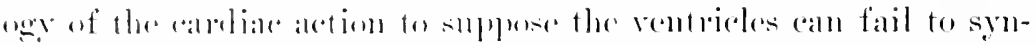

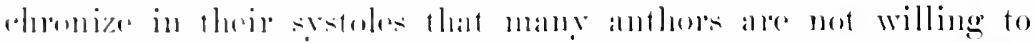

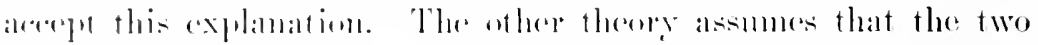

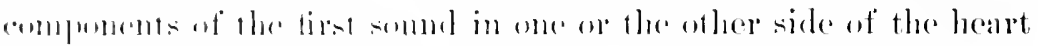

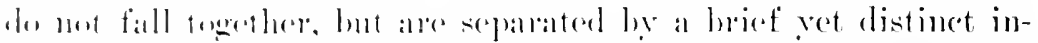

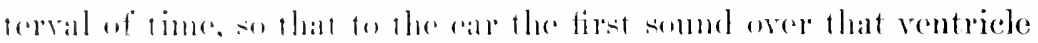

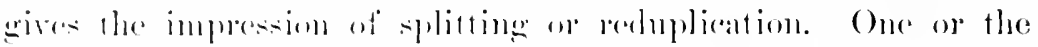

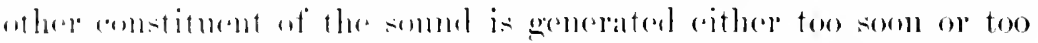

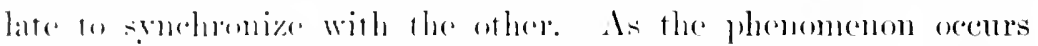

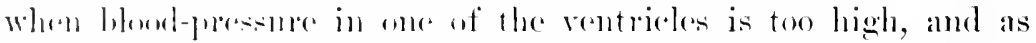

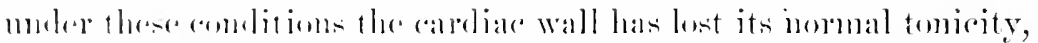
it sermes rasmald, that the tension inte which the valves are

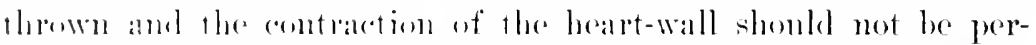

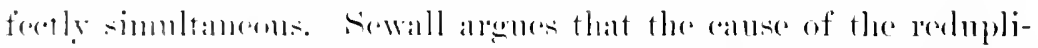
"ation lies in the falibure of the papillater muscles to contract at

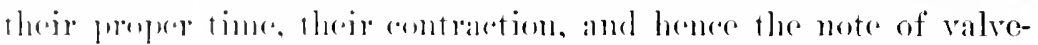

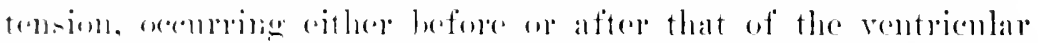
wall. Whatrerer le the true apdanation of this phenomenom, its

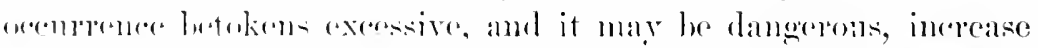

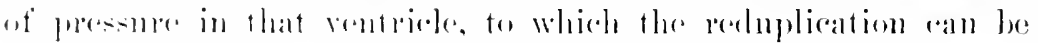

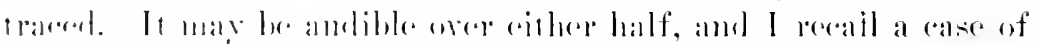

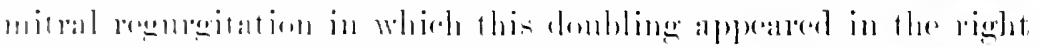

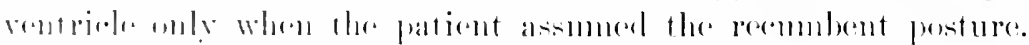

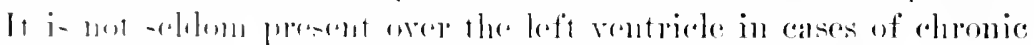

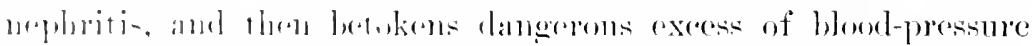

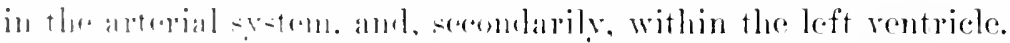

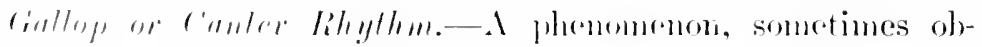

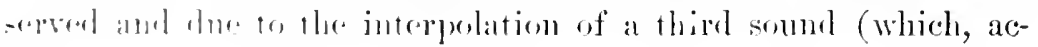


corting to its position in the diastole, produces an apprerent reduplication of either the first or sorond somel), resembles so closely. the hoof-beats of a galloping horse that it has been termed the eanter-rhythm or bruit de galop. The merit of having tirst deseribed it is accorded ly the French to Bonilland; yet to Potain, but to Barie in particular, belongs the aredit of having first lomenght it to the notice of the profession. Fracutzel hats also giren a most elear and disecrning deseription of the phenomenom hased on arenrate scientific observation. When the peenliarity under eomsiderattion is present, the anscultator heals not nerely two somuds of normal relative strength and rhythm, but theee, of which the last is an aceidental or interpolated somd ocemring in the long panse. Francois-Franck, according to Sewall, is anthority for the statement that this third sound may oceur in any one of three positions: Immediately after the normal second, in the midlde of the diastolic interval, or at the end of the long silenee shortly before the first sound. When it falls directly after the normal serond sound, it must not be confomded with the apparent doubling of the second somd already deseribed. It is distinguishalle from this latter by its peculiar tempo. Its canter rhythm is imparterl to it by the shortening. up of the long interval and by the aleeent falling on the midklle one of the three somnls-i. e., the normal second (Fraentzel). If one will imitate the somel of a stow canter liy striking his hands on his knees, he will at once appreciate the rorrectness of Fraentzel's statement.

Any*one, however, who has studied this rhyth of the heartsounds in a large number of eases will have appreciated the fact that it not infrequently possesses the characters of a rapid gallop' rather than a slow eanter. When such is the case, Fraentzel's description does not apply. The tempo and accent are now changed, as may be proved lyy again initating the sound by the hands. It will now be ohserved that the interval separating the first from the second somel is shorter than that weparating the second from the third or interpolated sound, while the areent falls most sharply sometimes on the first, sometimes on the third, lunt in every case least strongly on the mildle one of the three somuds. In still other instances the rhythm described by Fraentzel is maintained, but the accent is on the first somul, thus producing a not quite typical canter-rhythm. It is this lack of uniformity in 


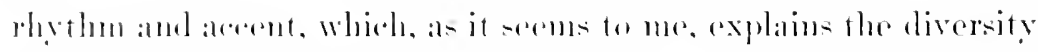

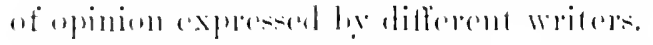

l'otalis a explanallion of the phemennenom is that it is dne to an

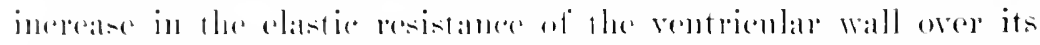

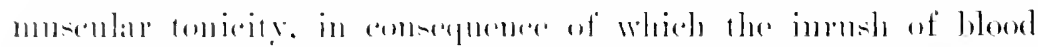

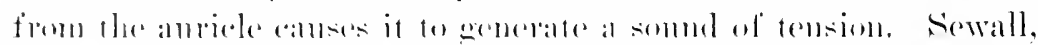

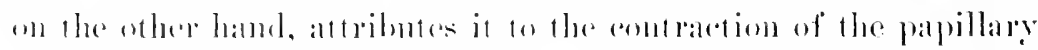

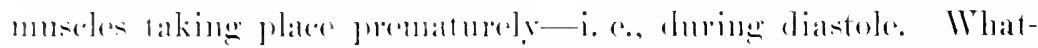

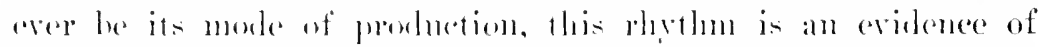

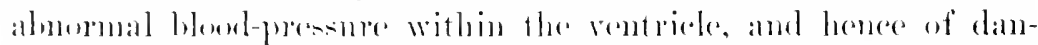

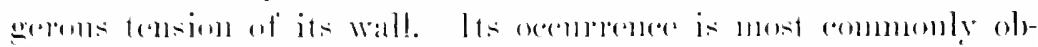

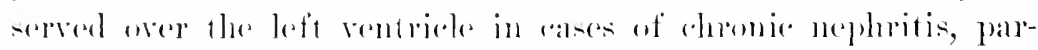

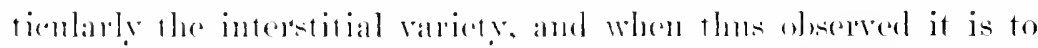

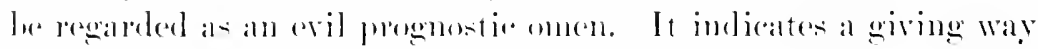
of the rentriele, which is no lomger alde to cope sllecessfully with the resistanere in the arterial system.

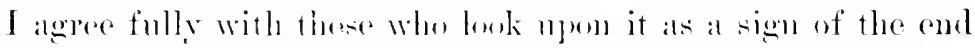

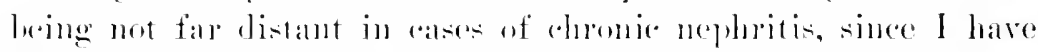
never known an individual to reowere in whom this rhythm was

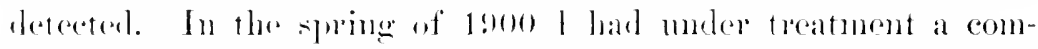

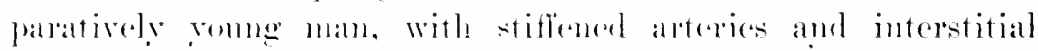

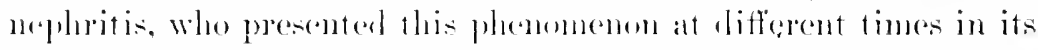

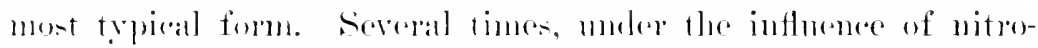

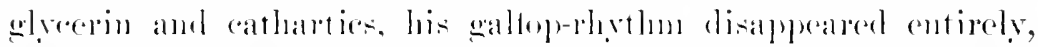

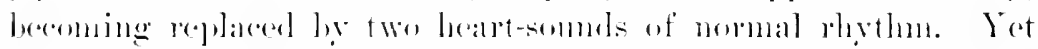

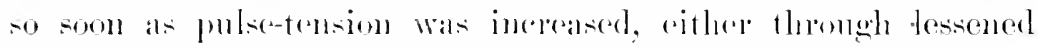

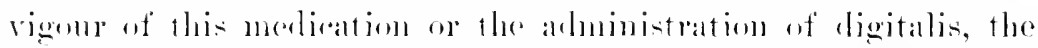

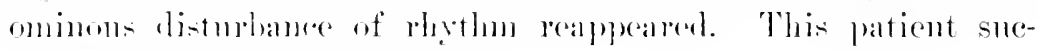
combled after alometwo montls.

This interesting ander-rluthm is never hearel at the base of

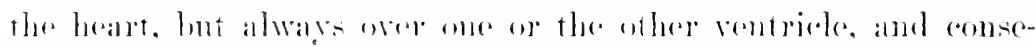

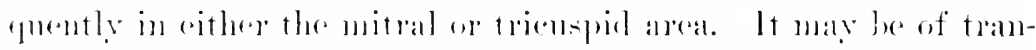

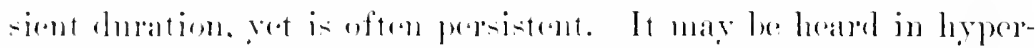

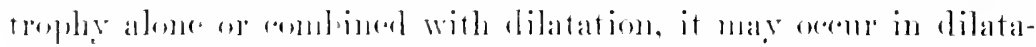

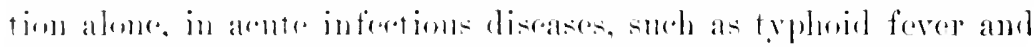

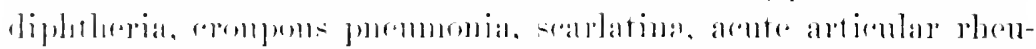

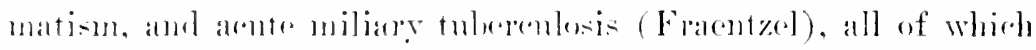

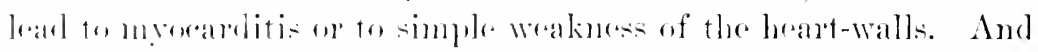

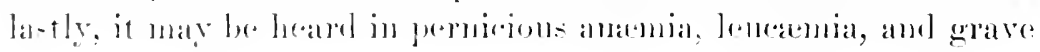


cachexia, which imhere profound cardiac asthenia and conscoutent want of tonicity.

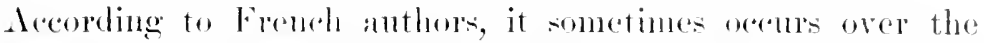
right ventricle in ares of gastric disease, and Johnson sars it maly"

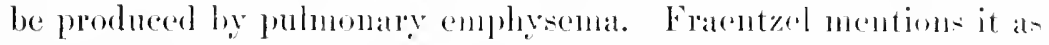
occurring in other lung affections, leading to dilatation and hepertrophy of this right diamber, with marked cachexia. I once observed a true galloprelythm in the fonth and tifth right interspaces close to the strenum, for a brief tince, during which there was very obvious oremelistention of the right arities secondary to a rhemuatic mitral reguregitation. The very numsual situation of the rhythun in this instance is only explicalule ly the supposition that in conseguenec of the enormons distention of the right rentricle the andiculorentricular sidptum had beconse pushed so far towards the right that the wall of the ventricle extended fo the fourth and fifth right interspares. It disatpleared so soon ats

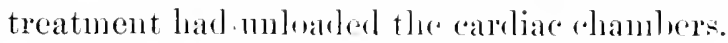

Murmurs.-This is a comprehensive term, which inchules all those adventitions aromstic phenomena comnected in some way with the heart's action and not resemloling in tome the nomal cardiac somols. They nay be primarily divirled into endordedid and exocardial. The endocordial are subdivirled into organic or structural and inorganic or aceidental, ealled also functional, anamire, hemic, and dynamie. Exomolinl are divisible into pericardial, plenropericardial, and andio-pulmonary.

By organje murnums are meant such as owe their origin for the most part to structural defect or alteration of the calreliac orifiecs or valves-in other words, to dofinite patholugical changes of the structures recognisalile after leath. decidental murmurs cannot, on the other hand, he ascribed to definite pathological lesions, and thelefore have received a variety of appellations in aceorelance with the varions theories offered in explanation of the phenomena.

Endocardial Murmurs of Organic Origin.-These were once thought to be ansed he friction of the hood in its paseage over the ronghened inner surfare of the heart. This theory was shown to be untenable as long ago as 1S47, when it was replaced by the one now generally aceepted-namely, that currents or eddies are produced in the strean of blood, the same as in any other fluid, 


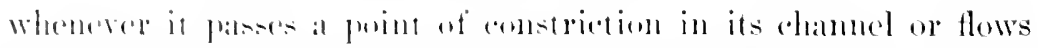

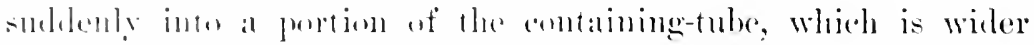
than that diberty ahore. Thase oldies and currents in their tum

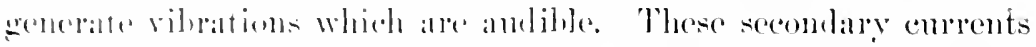

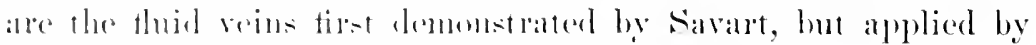

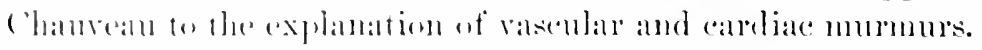

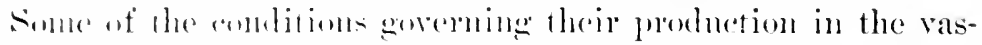

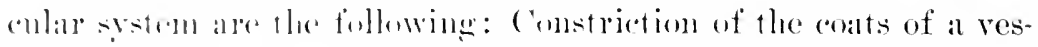

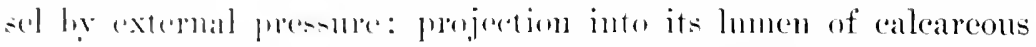

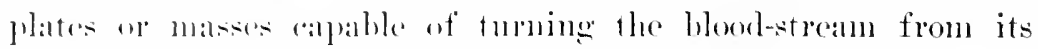

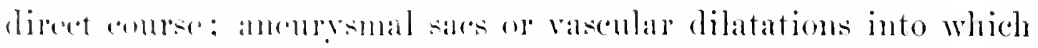

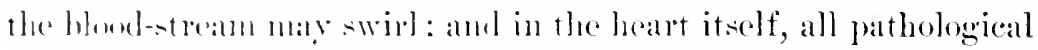

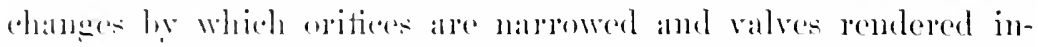

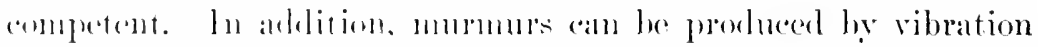
of thin membranes and hamds as the hlowt-enrent sweeps over the'in.

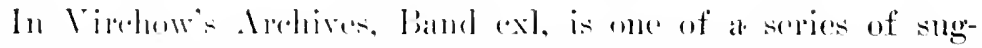

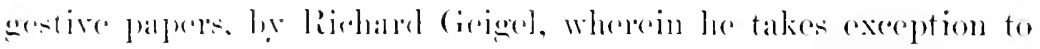

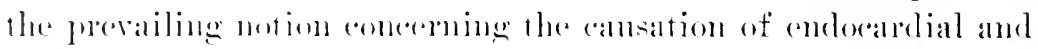

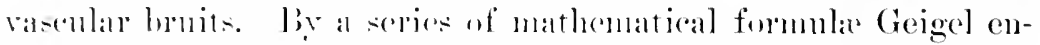

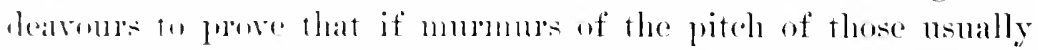

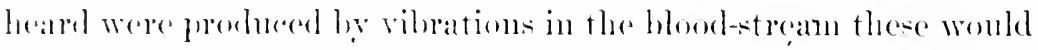
have to he of a length that would be plessically impossible within

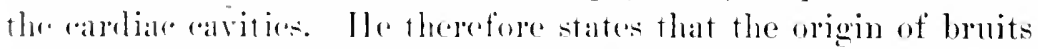

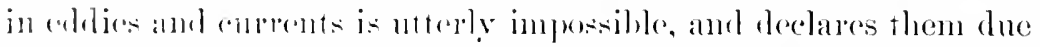
(1) transerese vilurations of lhe walls of the structures inclosing

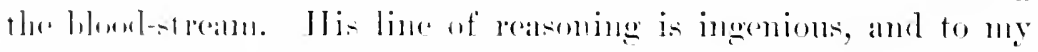

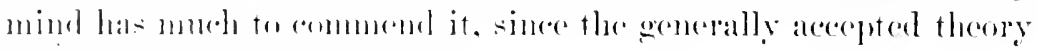
i- mot altugether sati-fartory.

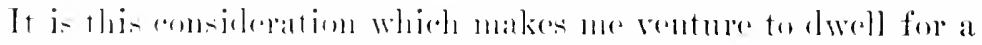

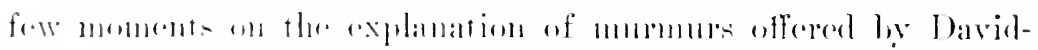

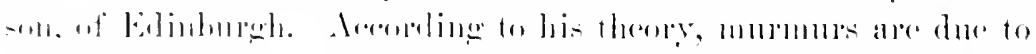

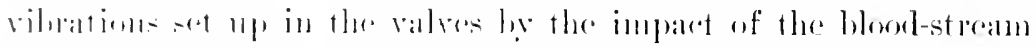

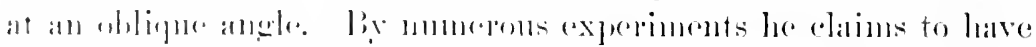

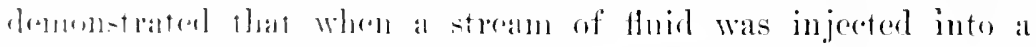

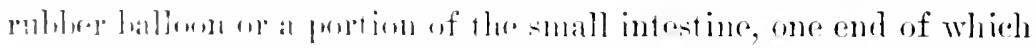

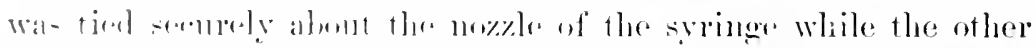
wa- tieloty ligatured, the fluid roins amb coldies thus generated

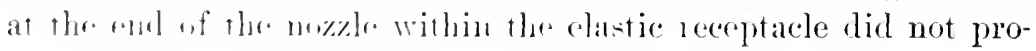


duce more than a very faint murmur, andilibe by means of a hinamral stethoseope. Whem, howerere, the fluid wats matle to strike the inner surface oblipurly a distinct clear sombl wats generaterl, the intensity of which depended npon the fores of impact. By reducing the rapidity and fores of the stream lodvidson was alble to produce murmurs of varying loudness and ronghness. By another set of experiments he was able in the same manner to generate an aortic systolic bruit.

The conditions which favour the generation of organic vascular and cardiat murmurs are multiform, and hence snch alventitions sounds rany in respect to intensity, piteh, quality, and duration. They also obey the laws of conduction and are propatgated in different dircetions, according to the seat and time of their production. Moreover, two mummers of independent rhythm may be generated at the same orifice, or two or nore mily be produced simultaneonsly at different locations. So that if one is to differentiate endocardial nummurs, and correctly interpret their significance, he must be familiar with these rarions characteristies.

The inlensily of a murmur hears al direct ratio to the amplitude of vibrations in the blond-strean, and therefore to the forre of cardiac contrations, and is not at all a criterion of the gravity of a lesion. The forcible escape of blood through a small fenestration in a valve-segment, in itself a comparatively trifling regurgitation, may be declared by a very loud murmur that is andible to the patient, or even to a bystander a mmuber of feet distant. Thus Miller and (iib)s narrate the instance of a girl who presented a murmur of such intensity that it conld be planing heard 12 feet away when the listener was in the same room and patient fully dressed, and :) feet distant when separated from the patient by a elosed door. On the other hand, a very grave valrular affection may, if eardiac power, is fecble, oceasion a scarcely andible murmur or even none at all. It is well known, for eximule, that a presystolic murmur of mitral stenosis, intense while the heart is strong, may farle away to complete inamlibility when the heart becomes feeble.

Conversely, a murmur searcely aulible dnring a period of eardiac asthenia may grow in intensity as heart-power is reganed. This is the case particularly in aortic regurgitation. In the ex- 
andination of a pationt we therefore avail ontrelose of the knowl-

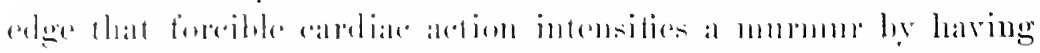

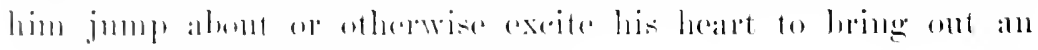

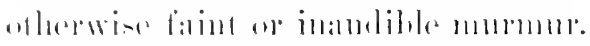

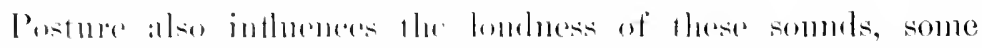

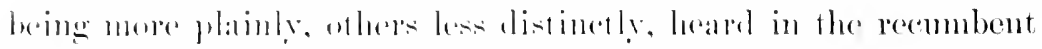

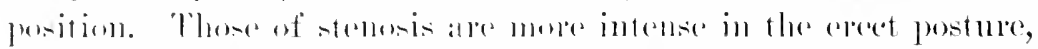

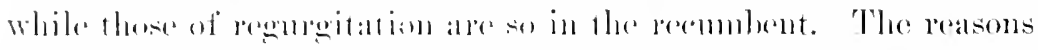
for such ratrittons in intensity ane based an the influence of the

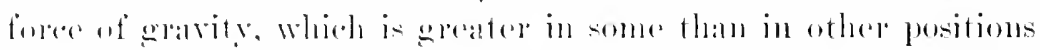

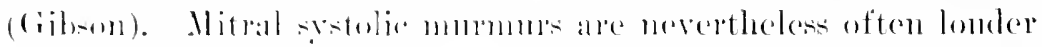

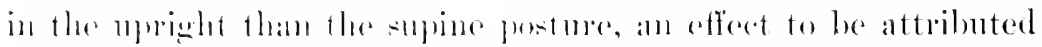

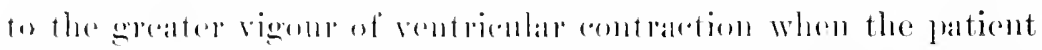

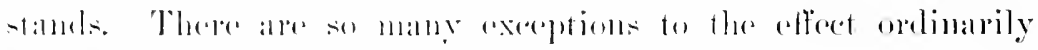
exerted hy position that a pationt shomblalway be examined

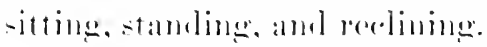

The pilde depenels upens the rapidity of the vibrations pro-

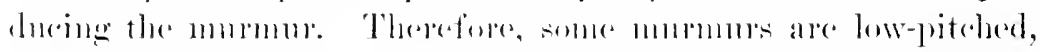
while others an high. The mion of oreptomes with the fumda-

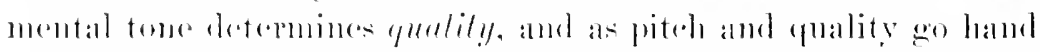

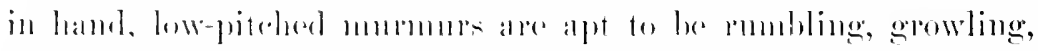

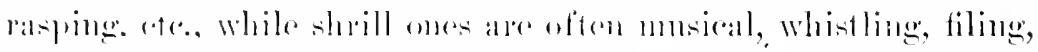
sawing, twangines, and the like.

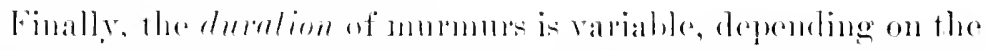

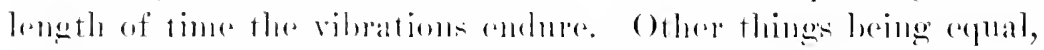

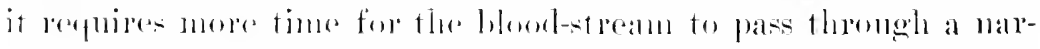

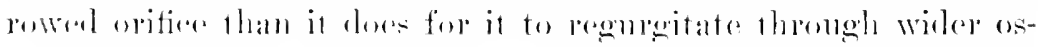

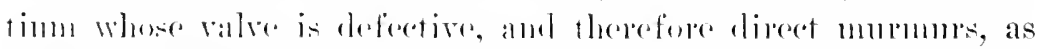

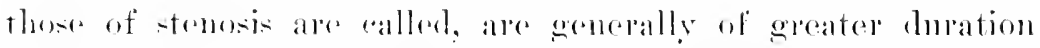

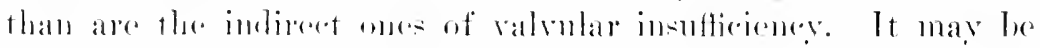

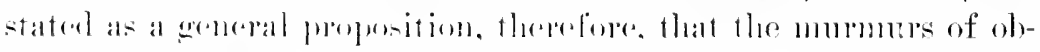

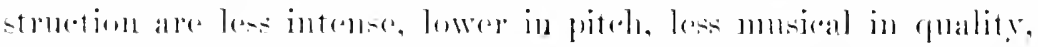

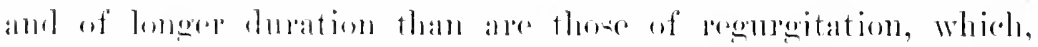

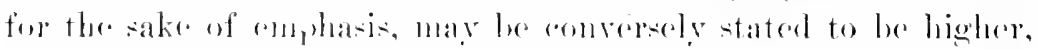

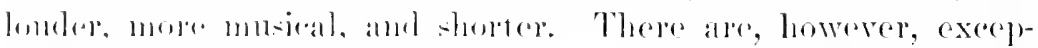

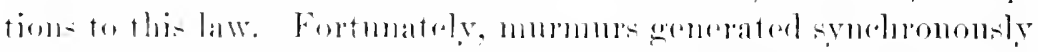
yet at different retia are nerere inlentieal in threse fom colatracter-

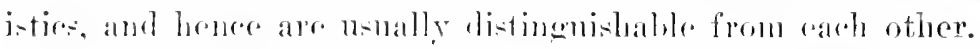

It is also of the utungst iminortanee to uotre the rhylhm of mur- 
murs, since in this way alone can be determined in what period of the cardiac eyele they are produced. They are either systolio or diastolic. Even the nurmur of mitral and tricuspid stenosio is diastolie, since it aceurs during the panse; rot. ats it is generatod. at the time of andentar contraction-that is, immediately prion to rentrienlar systole-it is eommonly dreignated at presistolie. or, as proposed by Gairdner, as ampicular systolic.

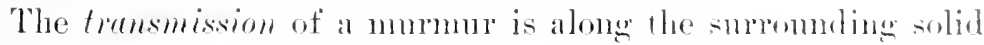
media, and in the general direction in which the strean promeroing it flows. It is also coverned laredy by the intensity of the murmur. Fortunately for diagmosis, it is this law of comblution whirh aids in the traring of a murmur to its sat of production. As already stated, the anatomical locations of the four orifices with their valves are so elosely related within a ciremuscrilied area that if the somds, of whatever nature, were not propagated to cortain regions where they can be heard with maximm intensity, throil correct interpretation would be vastly more difficult. Exery examiner of experience las realized the truth of this in the not very infiequent cases in which murmurs are widely comluredel and ret not most distinct in their. own areas.

Cardiar dreas.-These are four in number, corresponding to the ostia, and are definitely located in circmmscribed regions on the chest-wall, where the respective valve-sounds and murmurs are hearl most elearly (Fig. 10). Thus the aortic area is located at the junction of the second right interspace and corresponding costal cartilage with the border of the sternum. The

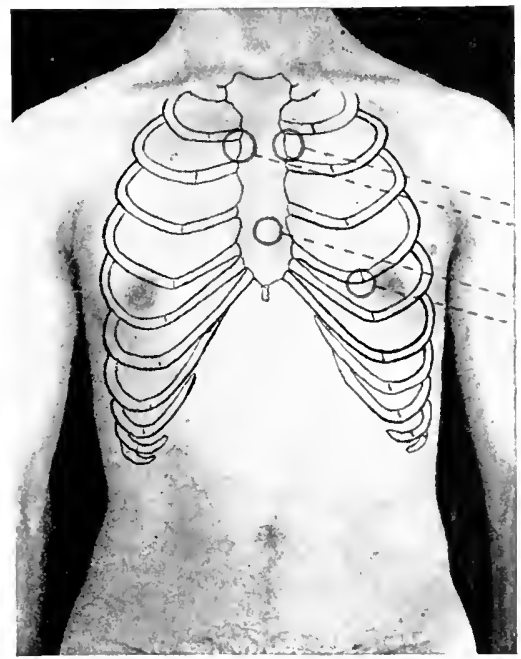

Fig, 11,-Carihae Valve drel-

Sounds produced at various valves indicated: $p$, pulnonary: a, artic: $t$, tricusinit; $m$, mitral. sounds, whether normal or adventitious, which are here the londest, are generated at the aortic opening. The pulmomary area lies in the corresponding situation at the opposite or left edge of the breastbone. The 
fuhlumbl -

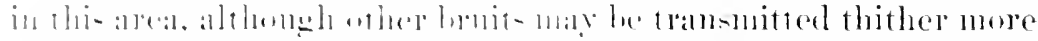

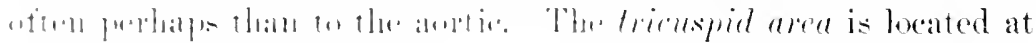

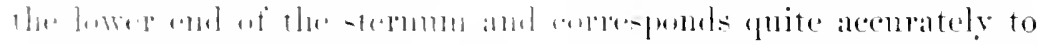

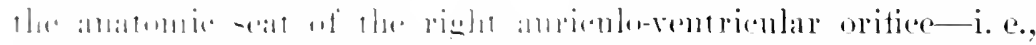

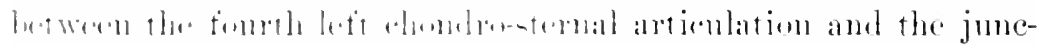

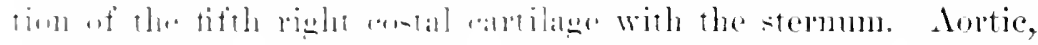

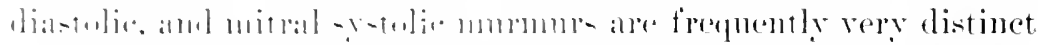

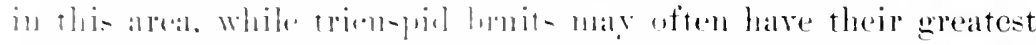

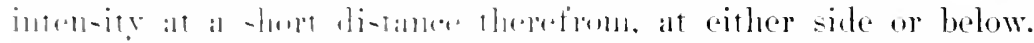

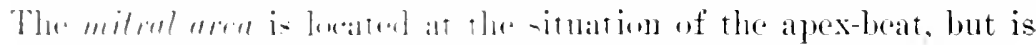

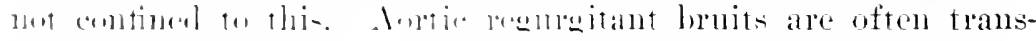

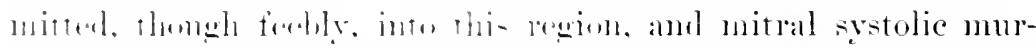

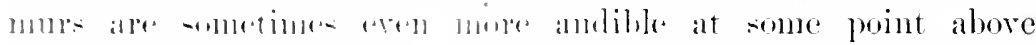

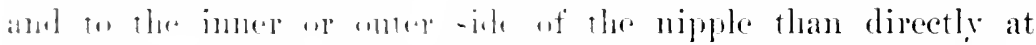

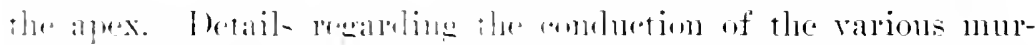

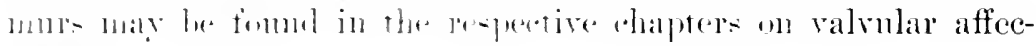
tinns.

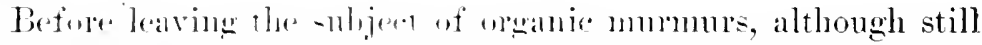

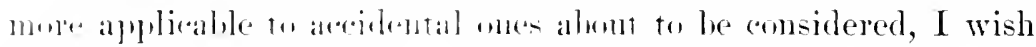

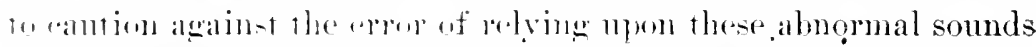

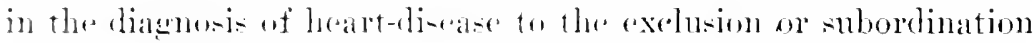

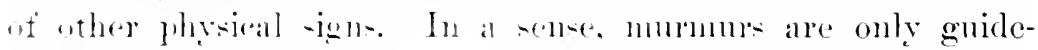
jw-t which point wht the way one is to look. They are highly valualle signe, lut the information they furnish shonld be eon-

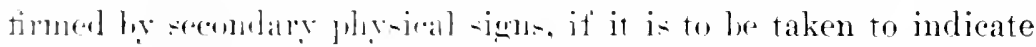
valkular tiverax. I mumm may mi-lead one becanse aecidental, and the failure to hear a bruit may of the same, but secondary

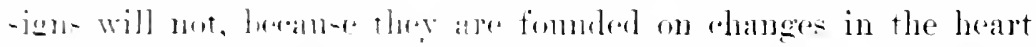

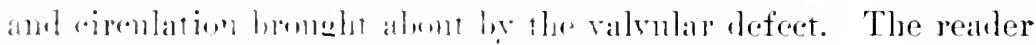

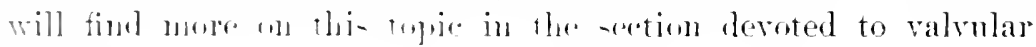
lu...inls.

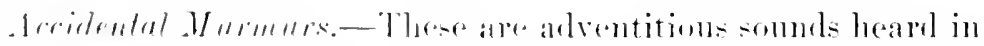

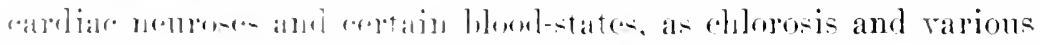
from- of anir) nial.

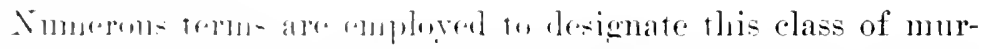

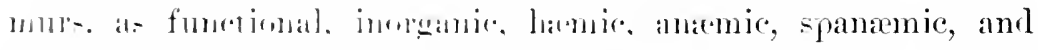
denanie. The firet two inuly that there is no structural cardiac affertion. and that the murmurs are in solue way dependent upon 
perversion of the leart's finction. II Inic, andmic, and spanatmie commit one to the proposition of an altered blond-state being responsible for the murmurs. The appelation druamic carloses with it the asimution that the arenstic phenomena depend upon vibrations set up ly powerful, perlaps irregular and faultr, action of the heart-muscle. The tem acedelental sufticiently declanes its own meaning, and implies nothing more than that the mmmm is a chance result of cardiac action.

Theories to atecomt for these mumums are many and rarions, and so long as the condition or comditions governing their production are not definitery ascertainerl there cam be no term that is not open to objection. These abmomal sommls may be heard in any situation wer the organ, but are most frequent in the pulmonic and mitral areas. Ther are systolic and have a blowing or bellows-like character. Such (onupetent and intelligent observers have advanced diverse theories in explanation of these mmmuns that it seems to me the part of wisdom to assume that no one hypothesis is applicable to all cases. May they not have their origin in a variety of conditions, some within and some without the heart? I shall describe briefiy only the more important theories.

Namyn explained the systolic mmmur heard in the pulmonary area in cases of chlorosis and other depraved hlood-states as being in reality due to mitral regurgitation, and assmed that, instead of obeving the law nsmally governing its propagation, it is conducted along the left anricular appendix to the tip, which, as we have seen, lies directly beneath the chest-wall in front, sometimes overlapping the base of the mlmomary artery. This theory was warmly supported by Balfour, but appears now to meet with general disapproval. Russell proposed two theories, of which one attributed the murmur to narrowing of the pulmomary artery by pressure upon it of the dilated left amricle. In other cases he believed a mumm of tricuspiel insufficiency was transunited into the conns arteriosus, which, in consequence of dilatation of the. right ventricle, became displaced ontward in the second left interspace. Hanford claims that the phenomenom, which is eitler heard only or intensified in the dorsal decubitus, results from the pressure upon the artery of a flabby and dilated heart. Foxwell agrees with Rnssell as regards pressure in some cascs of the dilated 


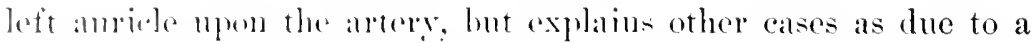

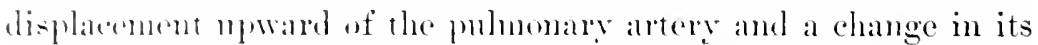
axis and that of the right rentrible, in consecquenee of which its nornal corve is increased amel it is flattened somewhat against the wall of the ehest. biamwell attributes the murnm to the

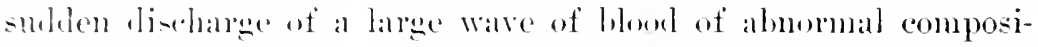
tion into the probaluly dilated artery. Sansom thinks that in a condition of right-rentricle weakness toiling to orereome increased

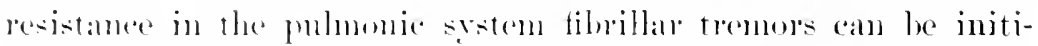
ated at the werstrained portion of the right rentricle-i. e., the

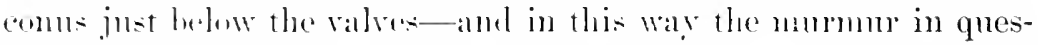

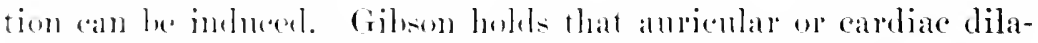

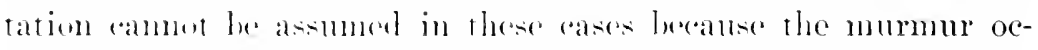

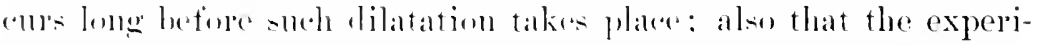
ments on whieh foxwells view is lated were finlty: also that if

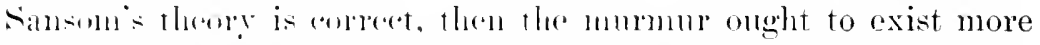

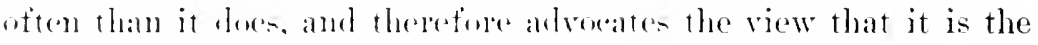

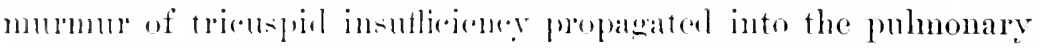

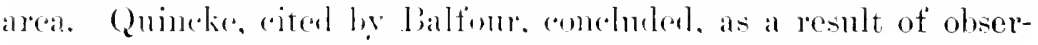

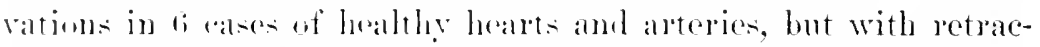
tion of the long-bonders, that a systolie hatse murmure can be prodened be presure by the heart of the puhnomaty artery against the rhest-wall.

Vierortt agrees with Sahli that in many cases renous mur-

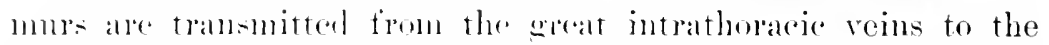
heart. Pontain ures the ardin-pulmonary origin of accidental mommers maintaining they are generated by the impulse of the heart's alpex andinst the long, an hypotheris that appears sup-

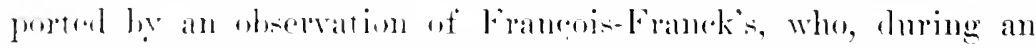
operation 11 wn a doge detected a systolic murmm in the region of the apex which disappeatred on som an the processus lingualis was lifterl away from contalet with the heart, and returned when this portion of pulnomary ti-sure wals allowerl to algan rest against the surface of the orean. Surb eardiopmlumenary origin is especially

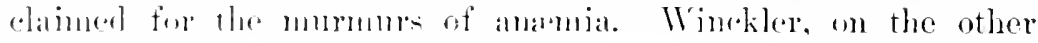
hame, lyelieves he hat diservered the origin of accidental apexbrotits in a defortive action of the papillary muscles or a fanlty insertion of the valve-1mmerese which permits of regurgitation.

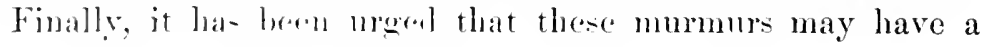


hamic origin in calece of peluicions and other glare secomblaly ancmias, while opponents of this view uree the elinical ob-ervation that in such blood-states 110 rumurs are not always presont, and, on the other hand, ocenr when anamia does not exist. Bearing on this objection are the experinents of Thalua, who found that palltial exsangunation of togs did not give rise to acedelental nunmurs. A condition of werfulness of the ressels calused ly the injection of a warn saline solution into the fenoral rain wat: followed by their appearance.

The number and diversity of the foregoing theories serve lut to emphasize the sad fact that in medieine there ale still many phenomena which have to be accepted as facts, withont at saltisfatetory explanation. In respeet to the origin of accidental murums, therefore, we can but place ourselves in a judicial attitude and a wait further proots.

Musical Murmur.-These are lere introdaced becalus. I lropose to classify them, not according to their acoustic characters or rhythm, but as organic and accidental, depending upon the anatomical conditions underlying them. First, organic musical nummurs are those not infrepucutly heard in clearly demonstrable eardiac affections, nsually valvular. In their time they may be systolic or diastolic, and in pitch and timbre they are variable. 'Thus they are described as sawing, filing, huzzing, whistling, ete. Their intensity may he such that the patient is amoged by the murmur, and it is audible sereral feet distant, or it may require close attention for its detection. Regmegitant musical mumurs are, as a rule, nore intense than direct ones. Yet I recall an elderly gentleman who presented a sestolic aortic hruit of a strikingly sawing quality so loud as to be alnost painful to the ear. In the ease of a negro observed in my dispensary service some years ago there was an aortic liastolic numur which was audible a short distance from the chest and had aromsed the womeler of its possessor. It was not constant, and when present wholly obsened a soft diastolic murmur that was appreciable when the musical one was silent. Each time the sawing sound was present it was accompanied bra thrill in the third left interspace near the stermum of such intensity that it tickled the palm of the palpating hand. This bruit disappeared some weeks prior to death, and at the autopsy no cause for its peculiar quality could be discovered 
other than the schrotic and incompretent semilunar valres. In amother man, with a lmut of almost identical characters, exeepting that it was enstant, the necrups revealed sclerotic aortic valres, one of the ensps being fencstrated, and there being two thin

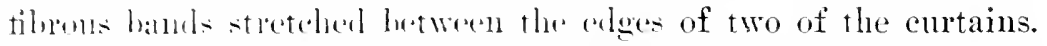
This patient Wals a palluer at the ('ouk Comnty Poorhouse, and

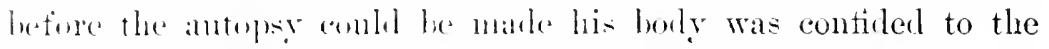

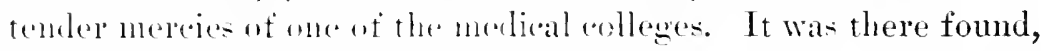
and the healt soemed after a laphe of throe weeks. The heart was injures by the presoring thid. pale and sottened, so that during the cxamination of the deticate fibroms bands they were ruptured. Before the photograph wat taken two threads of sewing ootton were passed thomgh the orlges of the valves in reprenentation of the hands. The examination and preparation of this leatr, slown in Fig. 11. were mate hy Dr. W. A. Evans. In this instance the fenestration permitterl rethe of the blood-stream

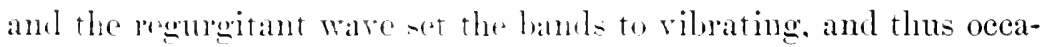

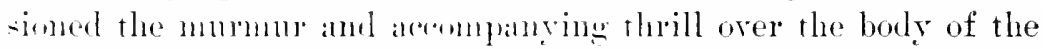
leart. Enged has reported a similar cares, in which a fibrous band wats stretelied across the arortic orifice to a pocket of one of the (11-1)s.

The Ron-ian, whe muler the name of Lewis travels from one medieal selumel to another to exhibit himselt to the students, is the

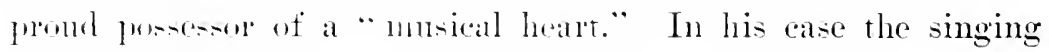
brut is systolic and of maximum intensity orer the right ventri-

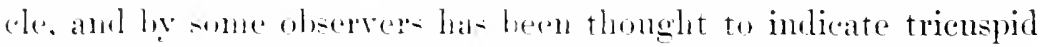

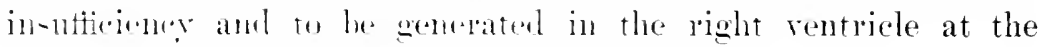

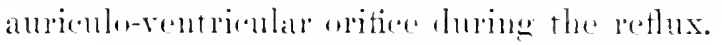

In aldition to filmons bands ar ends, some of the conditions

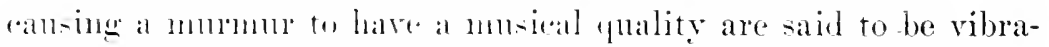
tions imparted to the thin. stiffencel adge of a cu-p or fenestration, ol to a delicate atheromatom- plaque by the blood-stream

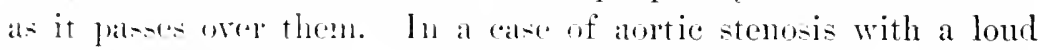
s-tolic musical numbur lemented by Marne, two fibrous bands

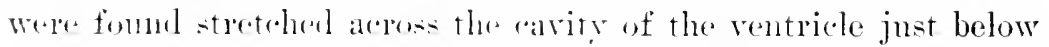
the ereatly narromed orifiee. In anotler case of mitral insutti-

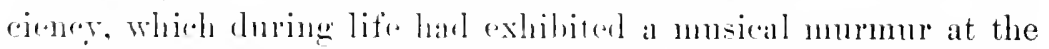
bare and a ryololic mmmm at thr apex. Potain discovered post inonten a enpl which pasied to the wall of the ventricle from the 
edge of the anterion mitral valve jut helem the artio orition.

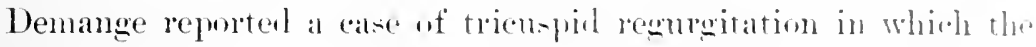

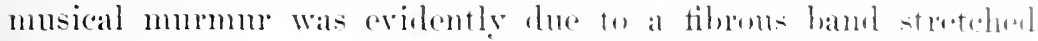
across the interior of the rentriale alue to the trioll-pid ringe.

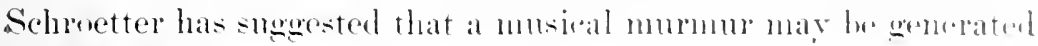

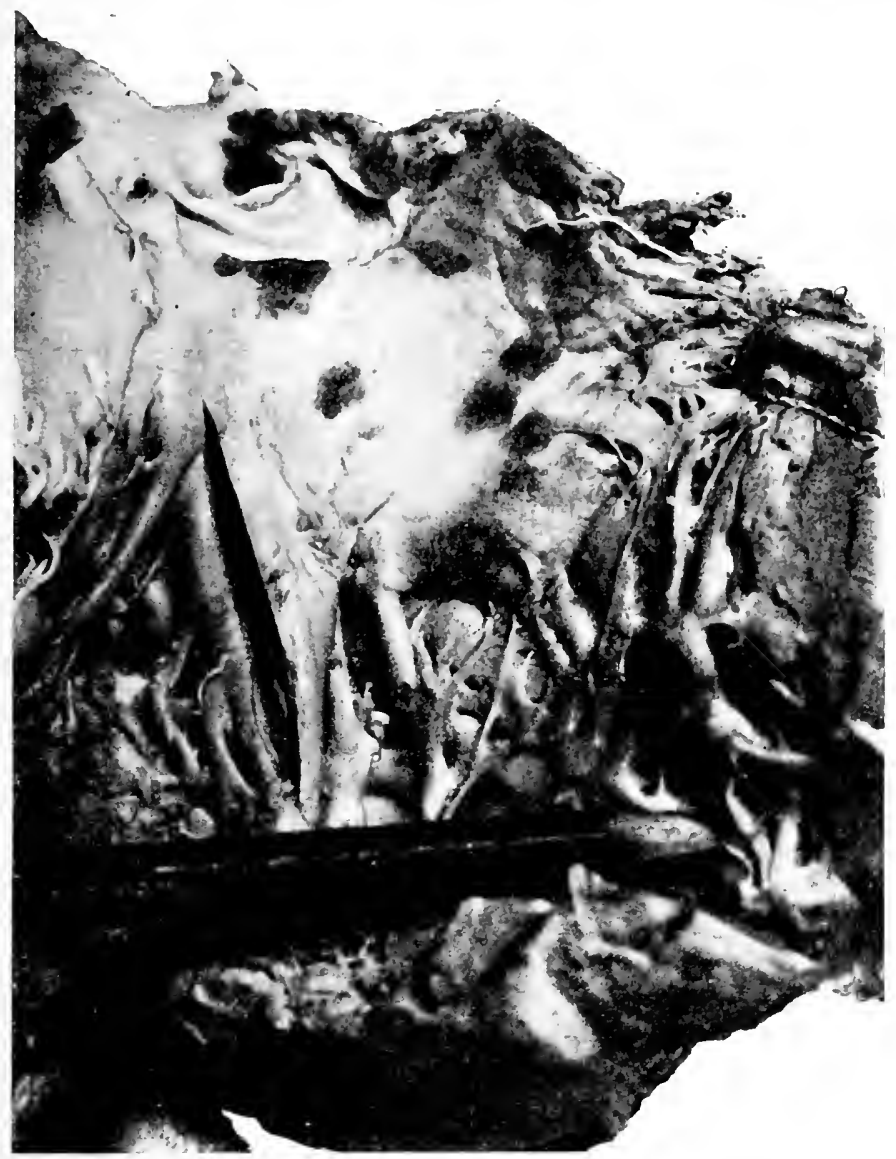

Fin. 11.-Ixteren of Laft Vexthith.

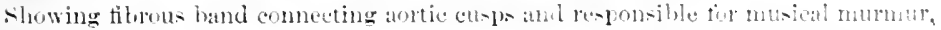

by the ribration of a temlinens cond swinging frese in the ventricte,

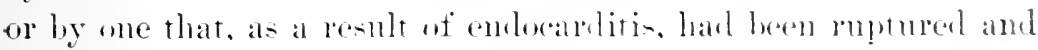
subsequently attached in an abmomal situation. It is neodless to remark that the musical quality ut these mumms possessos a pathological interest, but scancery a diagnostic significance. At the most we eammot do more than conjecture their nowe of 
cansation during life motil the true condition is revealed by the attopro:

Ieridentel musienl mumurs are rase and ret that they do

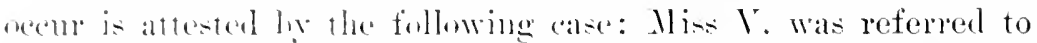

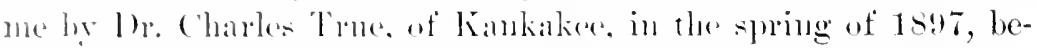

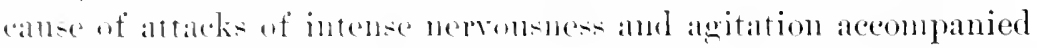
ly palpitations and priendial pain, for which no adequate canse

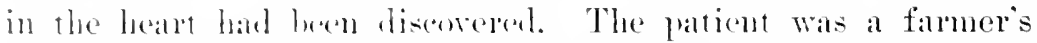
danghter, nineteent rears of age, tall and slender, and gave no histery of articular rhemuation or any other infeetion that would have led to inflammation of the ardiale struetures. Family history was also negative. The girl wat extrencly excitable and unable to give a rere hecid or intelligent drectiption of her symptoms further than that she often berame frightenerl, at what was not at all clear. apprebended some imaginatry danger to herself on family, and had rapid heating of the heart. During my exannination she was numeh anitated, and the heart aletion was greatly

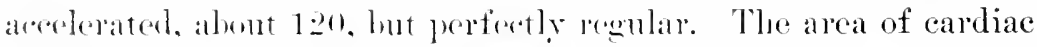
duhner. beth superticial and derp, was mot inereased, but there

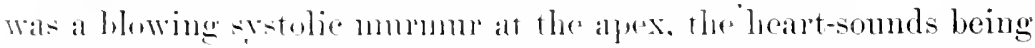
sharp and ringing. She wat melerately anemice, and there was a - light cuteropusio. A-irle from a not very tromblesome fermentative indigretion and andipation, her finctions appeared to be nomal and the urine wat neative. The ease was eonsidered one

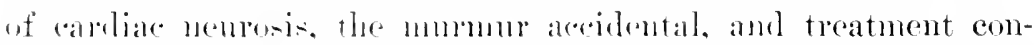

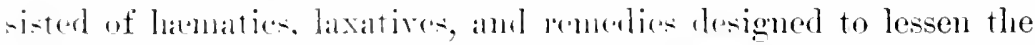

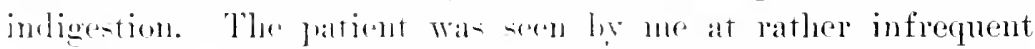

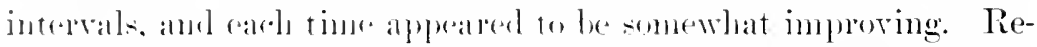
peated examination- of the lacist failed to dicit anything more

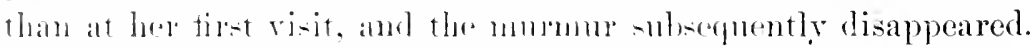

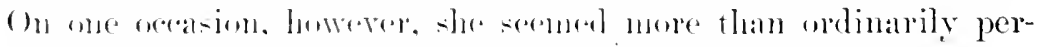

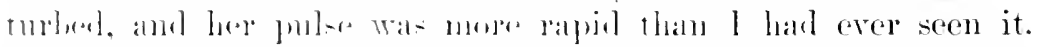

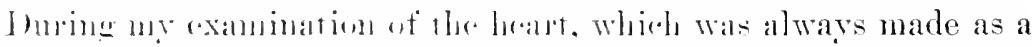
matter of pouthe. I was astomished to hear oxer the body of the right rentriele a listinct, slort, expuisitely twanging murmur of

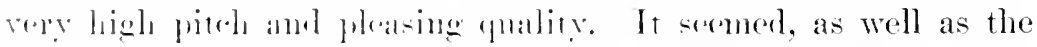

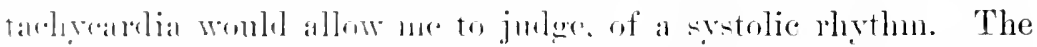
artion of the leart at the tine was extrene? rapid and violent.

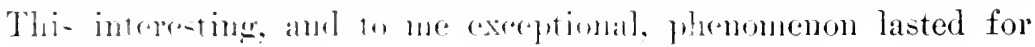


sereral minutes, indeed so long as the rapility of cardiac action endured. When at length her pulse grew more quict the musical murnur became inaulible and did not reapreatr. This patient was seen by me in septenther, 1 !no, after a lapee of more than a year from her last risit, and althongh I diligently songht for the twanging sound and any signs of cardian disease, I failed to detect any abnomality. The patient seported hereedf als in much bettere health and less excitable, bejug lout rarely annoyen by her former symptons, and indeed alpueared not the least disturbed by the examination.

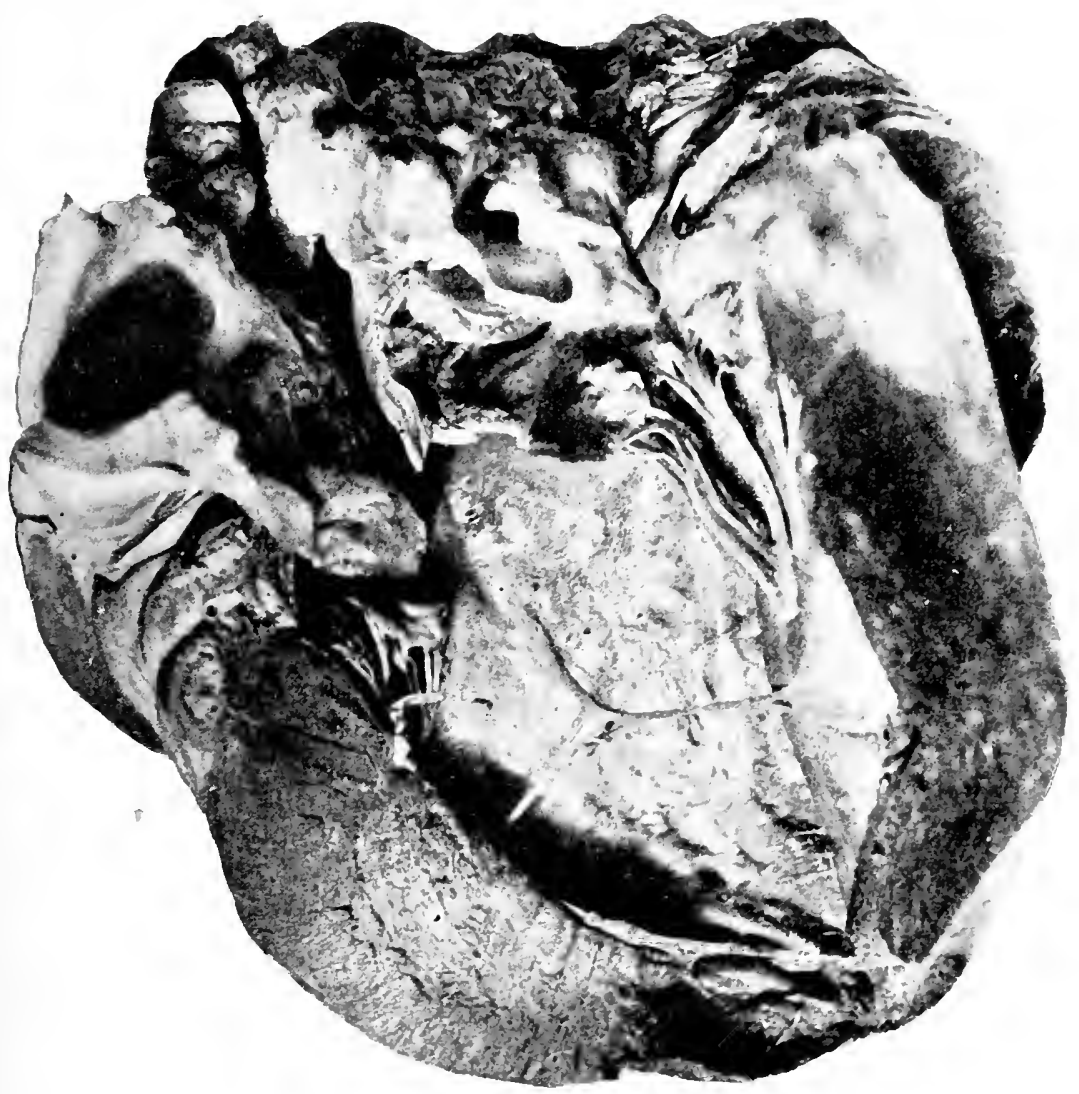

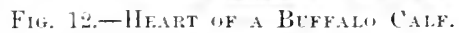

Showing aterrant chorda tendinie in ledt ventricle.

The only explanation that has seemed to alceonnt for this remarkable phenomenon is that the musial mmmur was due to the vibration of one of the so-called aberunt cords (Fig. 12) or mod- 


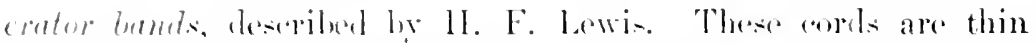

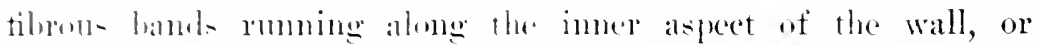
stretehed acters the mpere part of the carity, ar from a papillary

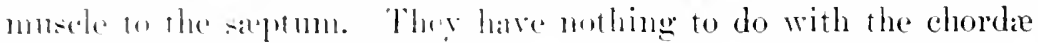

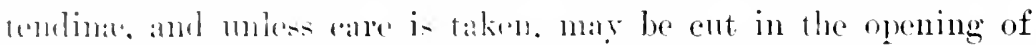

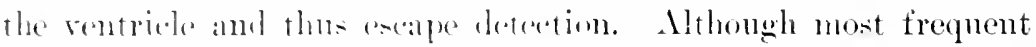
in the loft. they hase been formel in the right ventricle, and there are instances of such a hand palsing from the valve of the foramene walle inter the earity uf the left rentriele and attached to a leaf of the mitral ralle. It is suppered that the function of these moderater hamd- is to stremethen the ardiac walls in times of werstrain." In the care marrated it is assmmalle that owing to the tateherardia the cardiate chambers beeme wertilled and an allerrant cond was thens put on the streteh. In this state of ten-

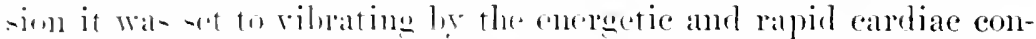
tratcions. thun enerating the twanging momm, like that of a vinlin-tring twitehed ly the finger of the musieim. Lewis says

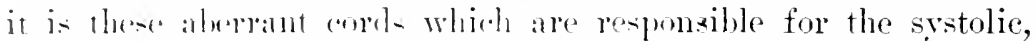

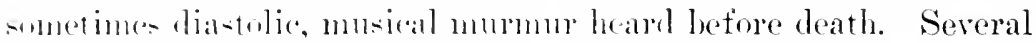

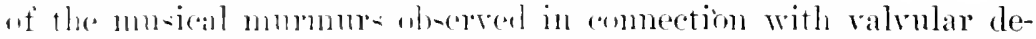

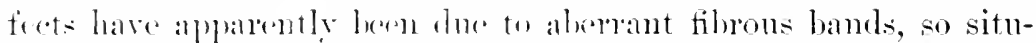

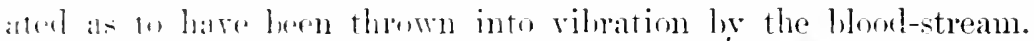

The Differential Diagnosis of Accidental Heart Murmurs.-Un-

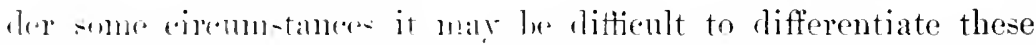

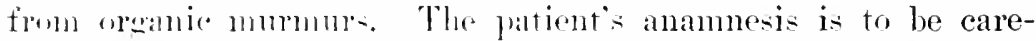

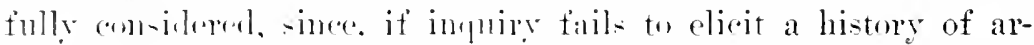
ticolar rhemation or any infortions divease likely to love set up

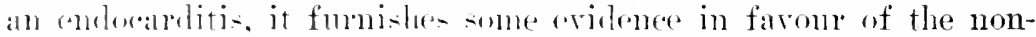
rromic natme of the mumne. This is strengthened if the pa-

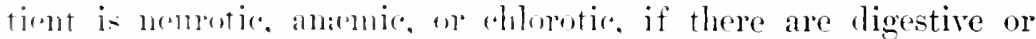

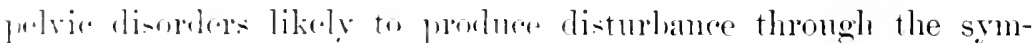

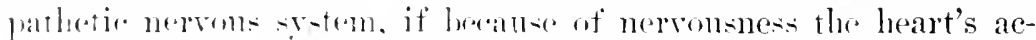
tion is rexcitent on if there is a history of carliae orerstrain. If the

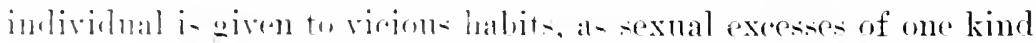

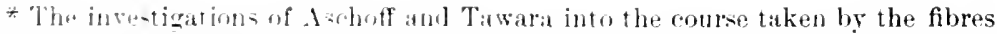

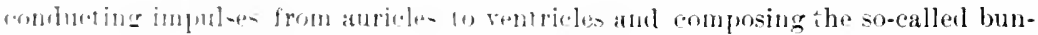
dle of Hi- have frowe that the athermal bank stretching across the interior of

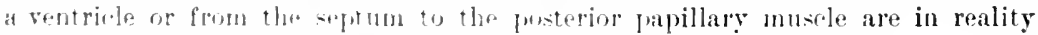
branches of the combluting -yotem which hase taken a wong direction. 
or another, particularly masturbation, or indulges ton freely in tobaceo, teal, or coffee, the presumption is strengthemed that the murmur is aceidental. Ot compe, these and mumerome nther fare. tors that are said to attord prima facie evidence of the malanly being not organic may exist in a given ease with an conderaldial murnur of ralvular disease. There must, therefore, be made a careful examination of the heart and other viscera.

It may be stated as a general proposition that aceidental murmurs are not aceompranied by sefondary ehanges in the size of the heart or by eireulatory disturbances, such as generally attend and depend upon valvular affections. The discovery ot hrpertrophy or dilatation of the heart makes strongly for the organie and against the aecidental origin of a murmur. Smalhess. frobleness, and intermittence of the pulse, ramosis, drspurea of effort, hepatic and other risceral congorgement, etco, are not usual aroompaniments of accidental murmuls. Sich signs of serions chibarrassment of the circulation faling, information may he someht for in the rhythm and other characters of the murmur itself. Areidental bruits of eardiac origin are rarely it ever diastolic. whereas organic ones may ocem during any all phases of the carliac erele. Lenbe has nerer heard such a diastolic aceidental mumur, and doubts its oecurrence. Mthomel these murumurs may ('xist in any portion of the priecordia, they are most frequent ores the hase, in or near the pulmonary area, and next in frequener at the apex in the mitral region. In transmission they are nsually rather limited, and such an apex-bruit is not propagated to the angle of the left sapula.

Organic murmurs, on the contrary, oecur with frepueney in all areas, and often have a wide extent of aulibility be-ides being propagated in definite directions and to considerable distances. In the matter of intensity, murmurs of both organic and aceidental origin are variable. Leube is of the opinion that, as a rule, the latter are the less lond of the two, but the revere occisionally obtains. The murmur of chlorosis and anamia, so often spoken of as hamic, which is heard ehiefly in the pulmoniv area, is generally intensified in the dorsal deeuhitus, while Inmmmond states correctly, I believe, that the "neurotypir" (cardio-muscular) beeomes less pronounced after rest in the recumbent postmre has slowed the heart. This latter type is most intense during exeitement and in the standing position. The same is true of the 


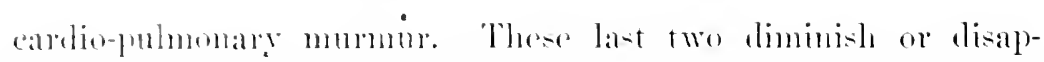
feale in the lateral deentitus. particularly when the patient lies

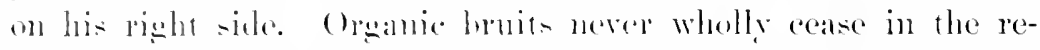

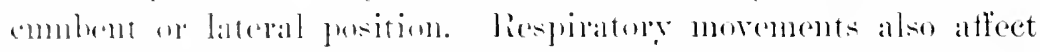

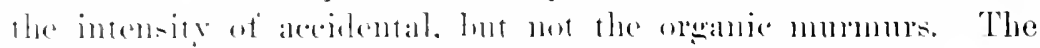

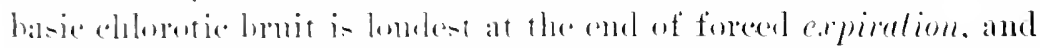

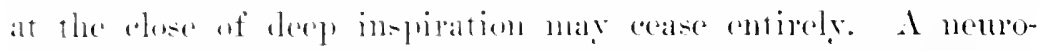

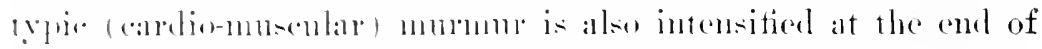
forecel expiration, and lesson aberent at the chose of a deep inspira-

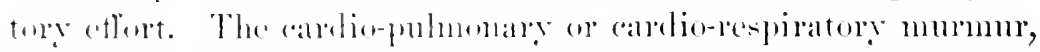
m the other hand. is intheneed conversely, lome lomelest at end of forred inspiration and weakest at end of dere expration, or

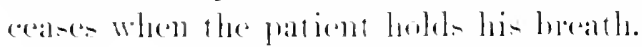

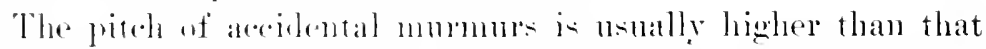

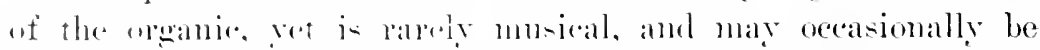
loxer. In quality the formere is apt to be softer. yet may be harsh,

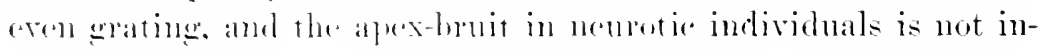

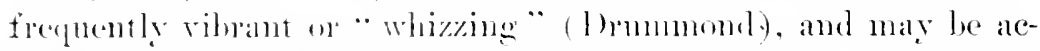

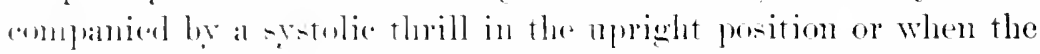
mummer is the lomelest dmping excitemente Finally, the pulnonic

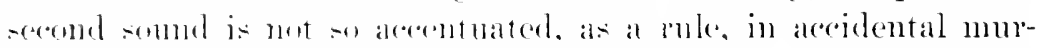

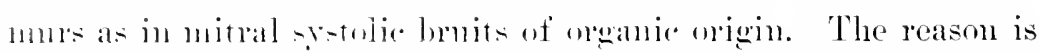
whions: in the former there is not the sume likelihood of sec-

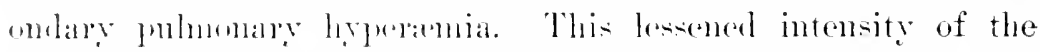

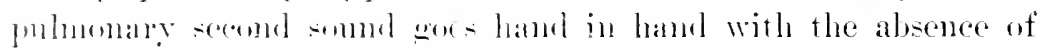

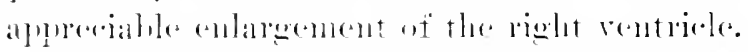

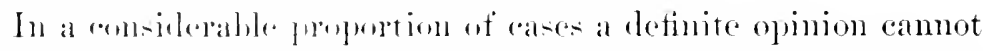

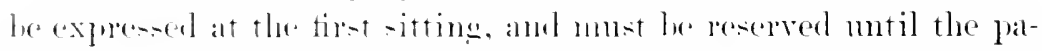
tient ha- lowene acell-temued to an cxambination or has grown less

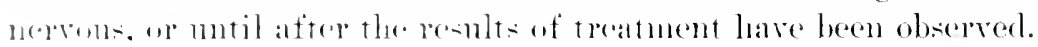

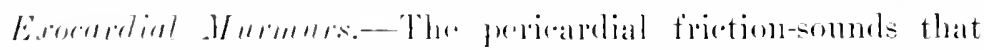

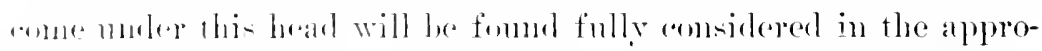

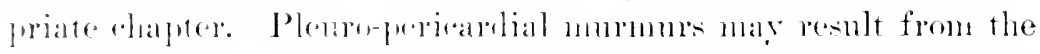

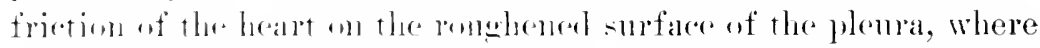

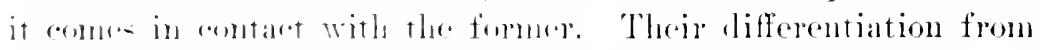

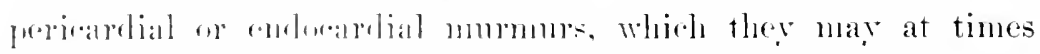

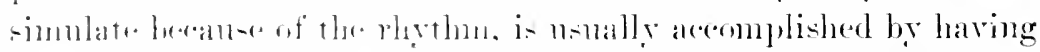
the pationt held lis herath, when the firetion-somel disappears.

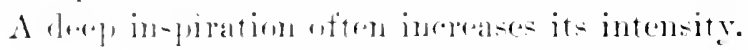




\section{SECTION I \\ DISEASES OF THE PERICARDIUN}

\section{CHAPTER I \\ ACUTE PERICARDITIS}

Morbid Anatomy. - The pericardinm is a closed sac lined with serous membrane which surrounds the heart, a risceral hyer of the serosa (the epicardium) being reflected orer the surface of that organ, and for a short distance along the roots of the great blood-ressels. The parietal layer of endothelium is re-enforced by a strong fibrous lamina, extending from the diaphragm below, to be continuous with the tibrous sheaths of the great ressels above. The pericardial sae usually eontains after death a fer drachms (10 to 15 eubic centimetres) of a clear straw-coloured fluid.

An inflammatory process of the perieardium may involve only the serosa, or may penetrate into the myocardium or into the fibrous tissue of the parietal laver. It may involve the entire surface or it mar confine itself to limited areas, single or multiple, thus giving rise to the circumecribed form of the disease. The morbid anatomical condition is the same in the two forms except in the extent of involvement, and the same description applies to both.

The first eridence of inflammation is the injeetion of the bloorvessels lying beneath the transparent serous membrane, the process nsually begimning in the parts of the sac surrounding the great vessels. This is associated with considerable desquamation of the endothelinm, which gives an appearanee that is deseribed as of having been breathed upon. Is the endothelial cells are those which lubricate the surfaces, this desquamation occasions friction between the two lavers of the sac, giring rise to the sounds that are heard during life. This is the simplest form of pericarditis, 
and the discate nay proced no firther. Usually, however, exnda-

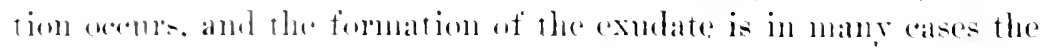
fremine fit fature of the liseare. The eharacter of the extidate ralres extremely. It may he tihrinems, serous, purnlent, or hem-

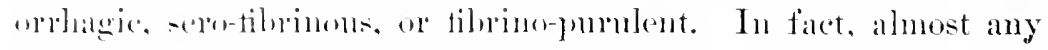
andhinattion maly arcour.

In the filninous, dry or plestie form the exmlate appears at

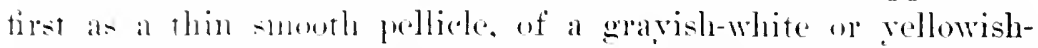
white colonr. earily betached from the injected surfice heneath. latter the exmelate becomes thicker, and is of a pasty consistence, and nut an earily detached from the mulerlying surface. The incessant motion of the leart eanses the plastic exndate to assume forms that have been varionstre described by different authors. A "ommon comdition is one resembling the appearance produced by tearing aprart two pieces of thickly buttered bread. At other times fine threals of filrin attalehed all orer the surface of the pericalrlinum give to the heart the shaggy or hairy appearance that has recerved the nanes of cor hirsutum, cor villosum, and cor tomentosem (Fig. 13). In still otleer instances the fibrin is arranged in coarser mases of the characteristic grayish-yellow eolour. Sucl an exndate, being in contact with both layers of the pericartial salc. forms between them allhesions of the kind dearibed als recent or fibrinons, in contradistinction to the old or fibrons adhewion- fomen in the chronic form. The appearances described are to sonne extent the result of the tearing apart of the two layers of the sale. thus loosely bound together. The processes learling to the repair of this lesion are those eventuating in rhronie perionditic, and ane comsidered in that connection. Acarding to ()-ler. plastic periearditis is frequently tuberenlons, but the tubereles are very asily overlooked in the presence of the fibrinous exulate.

When the exmlate into the arvity is of a fluid nature the condition is kumut a jeriearlitis with effusjon. The effusion may

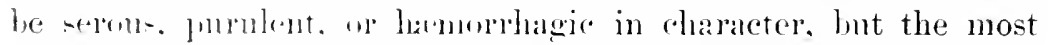

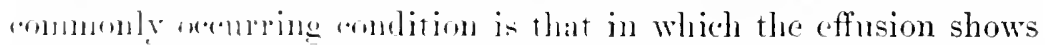
mixed "n intermediate chatracters. In the serons form there is an effurin of sermu from the intlaned surface, which may be perfect]" " lear, but more commonly contains fibrin in the form of shreds, flakes, on lareer mases, which may float in the fluid, or 





may he deposited on the walls of the sac as a ereamy layer. This is the form of the disease known as sero-fibrinous pericarditis, and is the one most commonly net with. It msmally begins as a dry predearlitis, the effusion dereloping hater, and indeed in the dry form there is aways some transurtation of fluid, although its amomnt is insignificant comprated to that of the fibrin. The fluid is often slighty turbid from the presence of lencoeytes, but in insuthedent number to entitle the effusion to be ealled purulent, or a small proportion of blond may wive to the fluid a reddish or lowwish tinge. The amount of thuid varies from a few onnces to sereral pints.

In the purulent form the effusion is rich in cells, and of a thick, eleamy comsistence, hut all degrees of variation exist betwoen this form and that presenting a serons exudate with slight turbidite from the presence of pus-cells, so that a sharp line cannot always be drawn between the two conditions. When the effusion is truly prumlent the condition is practically an abscess, and the pus may burrow and rupture externally, as, for instance, in the tirst right intersarer, or in the neck above the elavicte. The condition is a serions one, and slows lint little tendency to resorption, and yet the pus may becone inspissated and calcified.

In the hermorlengic form the effusion contains a large proportion of blood, or even, as in semry, may seem to be composed of pure blood. In cass of long standing the decomposition of the hamogholin gives the fluid a brownish rather than a red colour. Aside from the seorbutic form, hamorhagic pericarditis ocenrs most often asouciatenl with tuleremlosis of the pericardium and with malignant lisease. The effusion is usually very large, and maly take placese suddenly as to produce the symptoms of acute secomelary andemia.

Varions bareteria have been fomd in the exudates of acute fremeanditis, inchuling the varions progenic organisms, the diplorenecus pnemonia, and the bacillus tuberenlosis, but it is not alwars posible to demonstrate bacteria. 'The presenee of organisns causing putrefaction may give to the effusion a foul odour. The Jacillus acrogenes apsulatus may produce gas in the perirapdimu. This prorturtion of gas is pobably a post-mortem rhange (Osler), but arecording to ('oplin (1899) occurs during life. 
Secondary rlameses are fommd mainly in the myocardimm, which maly show inflammalory intiltration, or at fally of allmmi-

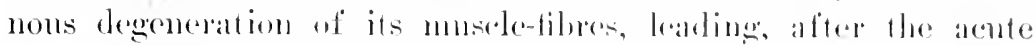
stage has passed, to an insterstitial merocalditis. 'There may be cridence of recent discase of the anderaldimm, nsually due to the same norbific agency as the periearditis. Associand disease of

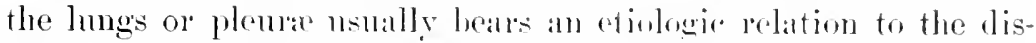
ease of the perieardimm. If there has bern high fever, the various parenchymatons organs show elondy swelling.

Etiology. - If ome compare the statements of oller anthers

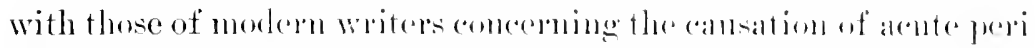
carditis, the chief ditferenere that will imprest him will be fomml

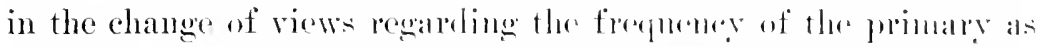
opposed to the seromelary form of this afteretion. The terme pri-

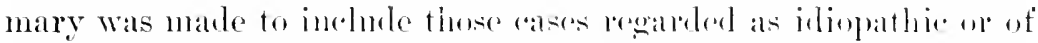
spontaneous origin. A bettre kinowledere of pathologe and otiologer, founded on the results of barteriolegional investigation, hats taught us the fallacy of a belief in spentameoms development of disease. Anthors now restriet primary intlammation of the pericardium to those cases originating in tramma, and inchlole ammon the secondary all ofluep eases mere comsidered primany or idiopathic. This is moloubtedly dore in part to a more acollate kmowledge, and therefore more frepuent reasnition, of the rhemmatice nature of many disorders whose pathologer was formerly but inclistinctly understood-as, for instance, eertain rluematic molules

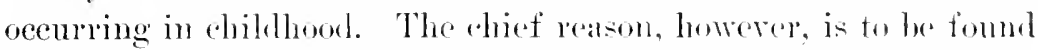
in the remarkable additions made to om knowledge during the

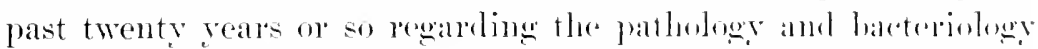
of disease, above refereed to. It present the phesiedan would be far behind the tinnes who failed to rexonise intlammation of the perieardimm as a local manifestation of a general constitutional disease or as a secomlary infection in the compe of some disease having pathogenic organisms as an etiological falcole. For instance, the primary gericarditis that was formerly thenght to follow exposure or chill was probaldy due to a rlemmatic attatek, the true nature of which esaped recognition.

Furthermore, some of the ases of preriarditis, fommerly res-

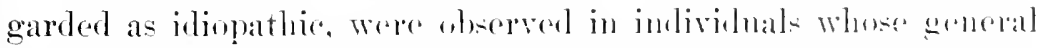
resistance had been greatly reduced by privation or chomic alco- 
holism. In wheh the perieatrial inflammation was, properly speak-

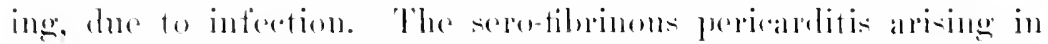
the contre of articular rhemantism is a local expression of the rhamatism, and the suppurative periearlitis sometines seen in puerperal septicanial is due to the primatry infection. Roberts goes so far at to saly: "In my onlu experience I have nerer met with an instance of acute perianditis which, when carefully investigated, could not les included a a sorondary arent in one or other of the ctiologial aronje now to be discossed." Among these, he inchules pericarditis from extension or irritation, from tramma and perforation, from ardiar and antire diseatse, and those associated with new growths, general miscellaneons diseases, and bloodstates.

In lis investigations regarling "terminal infections" in chronic discase, Flexner has made some highly interesting and inportant olvervations with reference to the etiology and bacteriology of acute pericanditis. I annot do better than to reprodnce one of his talles, which gires the frequency with which certain lacteria were foum and their point of entranes:

\begin{tabular}{|c|c|c|}
\hline Bacteria. & Frequency. & Infection Atrium. \\
\hline 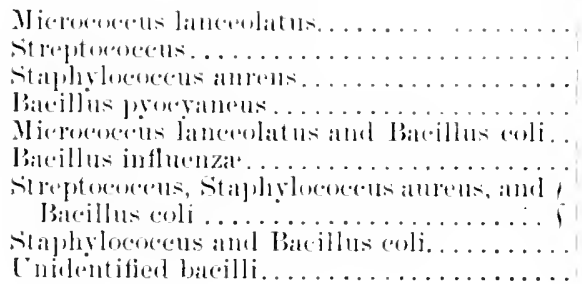 & $\begin{array}{r}11 \\
4 \\
1 \\
1 \\
1 \\
1 \\
1\end{array}$ & 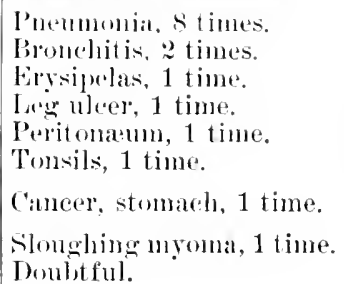 \\
\hline
\end{tabular}

Tuberele bacilli shomld be adder to this list. From the foregoning it is plain that andute periearditis may be a seeondary infection following a great ramiety of local infections processes, or it may arise in the onmso of an infections disease, and be due to the pathegenice oreanion of that discase.

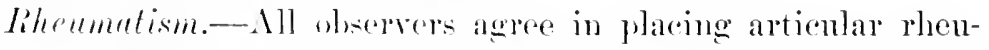
matisun first in the list of those affections which give rise to acute perienditis. The cortainty of this comnection was established by Pitcaim in 1788, althongh his views wern first widely pulblished in 1795. Writers have been in aceord concerning their cansative 
connection, get there has been ereat diversity of opinion reand

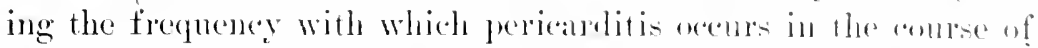

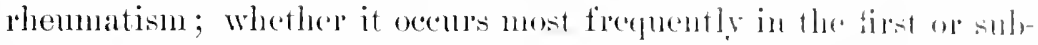
sequent attacks; whether it is most likely lo be asocriaterl with inflanmation of one or sereral joints, or any particmlar joint; whether with chronice as well as acute antienlan intlammation; and

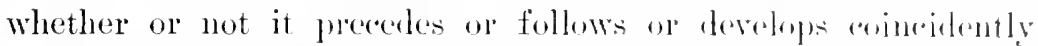
with the joint affection. Concelning the first of these puestions,

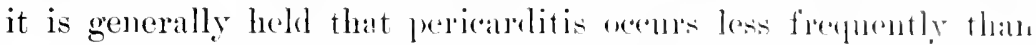
endocarditis, yet there is a ville divergener in the figures given by authors regarding its munerical relation to aftackis of rlemunal-

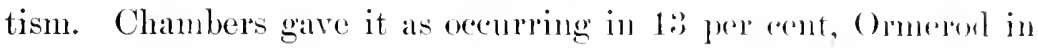
71.7 per eent, Bamberger in :30 per eent, whild baurer, althomgl believing exact figmes cammot be stated, ansidered from 16 to 200 per cent not far from the truth. Of Poynton's ling fatal cases of

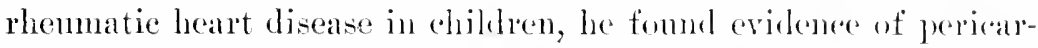
ditis in 113 cases (75 per ecut). Personally, I regald such statisties as of but small value, and consider it suttiejent to state in general terms that rhemmatism is so frepuenty complicated by arute periearditis that in every case of the former atfection the medical attendant should keep a sharp lookmit for the derelopment of pericardial inflammation. Most anthors agree, ! think, in the opinion that pericarditis is more apt to oecur in the first amd endoearditis in the subsequent attacks of articular rhemuatisul. Baner asserts that it bears no definite relation to the number of joints affected nor to the involecment of an! particular, irumt. It certainly does not ocenr nore frequently in rlemmatisus of the upper than of the lower extremities. The last-named anthor states emphatically, also, that it does not oreme in the comber of chronic rhemmatism, nor when but a single joint is afferont. The deredopment of acute pericarditis is by others thomele mone likely in the serere forms of the rhemmatic affection, and therefore when a mumber of joints becounc attackerl.

Althongh such a relationship between aroute pericarditis and serere rhemmatism was notieed by Sihwom, it was not ronstant. In children rhemuatic mamifestations are often mild, and yet the little ones do not escape pericaldial inflammatiom. In one casce coming muler my notice the perionditis followed no other evidences of rhemnatism than vague pains in the linces, with ery- 
themal acempanied by mild ferer, these stmptoms having been preceded ly tollieular tomsillitis.

There are no constent lime pelations, moreover, between an attack of rhemuatism and intlanmation of the pericardimn. The latter may aven preece the former, althongh it most commonly develops during or after the rhematism. It generally makes its appearanee from the fomplo to the sixth day of the rhematic disorder, sometimes not before the tenth or tifteenth day, and has eren been known ly siben to be portponed as long as the sixtythire day. Rhemmatic pericarditis may exeeptionally attack individuals of all ages. but is moleniahly most frequent in young adnlts who have been remleresl smiseptible to it by hard work or expentre. In England it appears to he praticularly prevalent ammog yomge servantgirls below the age of twenty-one (Sibson), and anmong peroms of both rexes thus attlicted at a later age, the majority were fomd ly the same anthor to follow more or less laborions onteloor orempations.

Its presalence anmeg children is shown hy statistics gathered from children's hospitals ly Sturese and Poynton. Yet Roberts states that, alcenting to his experience, periearditis is very much less freaguent in rhilderen of the better chasese, a fact which, he belieres, shows the predisposing inthence of hardship, not alone in the preduction of rhemuation, lont also in the development of pericalditis.

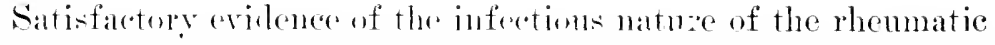
lwison has not yet heen ahlueed, althomgh many observers have expresed the betief that the pathogenie organism will yet be dis-

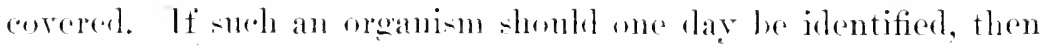

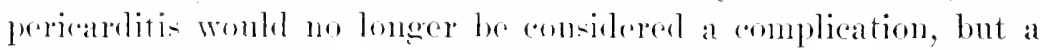
natural thongh not a neces-ary part of the pathological process of intlammatory rhemmati-n!.

Sephritis.-The improtance attalehed to renal disease in the mohution of ante perianditis is salmely appreciated, I think, ly the majority of physicians. I few writers of wide elinieal experience place nephritis a muly sereme in this regard to inflam-

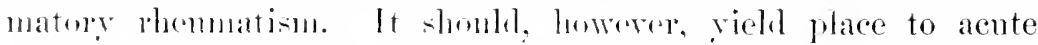

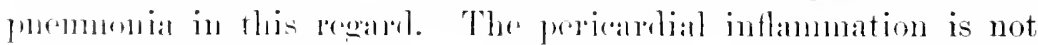

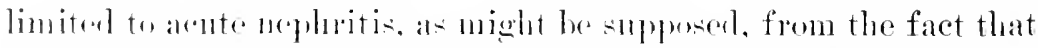
the latter is so frequently oberened in the comrse of acute infee- 


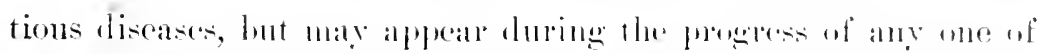

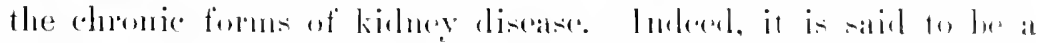

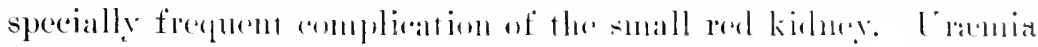

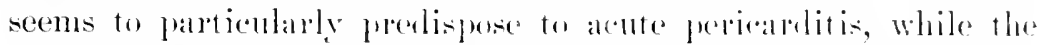

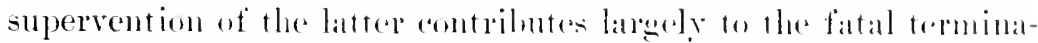

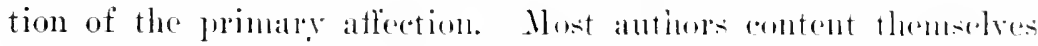
with a statement of the fact and make no attrempt to rexplain the well-known etiological connection between arute or chomic inflammation of the kidney and intlammation of the perieandimm. Two explanations may he given, howerer. By some the blood of nephritic patients is thomght to contain some noxions sulstince, possibly of chemical nature, possibly of catabolic origin, which results from renal disease, and which in conserplenere of remal inadequacy is not excreted." This noxa is an irritant, and gaining access to the pericardial carty, there sots up an irritatire inflammation. Givadinoviteh expresses the opinion that acute pericarditis in Bright's discase is of true toxic mature. It is mostly fibrinous, but may he hamorrhage and very ranely sero-fibrinons, and always oecous in an adraneel stage of the roual disease. Aceording to the other less consepative explanation, pepicarditis is a true secomblary infection. camsed by the converance to the pericardimu of erems reireulating in the blenel, and responsible for the areute or chrmic pericanditis. In cases of the small red kidney. it is assmmed that invasion of the perieardimn by bacteria takes place cithre bexamse the renal discase has impaired the germicidal action of the blowe or becanse it interferes with the proper elimination of the micro-oratuisms.

Apropos of the statement that infection freplently ocems in Bright's disease, Flexner's observatioms may again be puoted. Of 32 cases of chronic nephritis ocenrring alone, in which there was general infection, micro-oranuisus were postively identified in

* Chatin has jeporter fomr casese of pericarditis in fratents suffering from nephritis. In three cases with effusion bacteriologice axamination showed the fluid to be sterile. In these thres cases the sormm was hypertoxic. The toxic elements supposed to be responsible for the intlammation of the pericaldium have been found neither in the cireulating blood nur in the offusion: and the existenen of aseptic and amicrohic pericarditis in coptain cases of Bright's distise is well established. The pericarditis of mphritis may somedimes derolop at a remplication of an ordinary infection, and is nsually anteptic or sterile. - Revone de médecine, July $10,1900$. 
2!). It is worthy of note, howerer, that in none of these cases was fericarditis present. On the other hand, pericarditis was found a: times in ases of chomic nephritis in which there was local infection, whether the nephritis existed alone or in combination with some other chronic disease, as of the heart or liver. It would secm, therefore, that althongh a general infection maty oeeme in the eomres of ehomic nephritis, pericarditis does not take place moness there be some other local infection. In the majority of ases of pericalditis in the conrse of ehronic nephritis there was purmunomia, either croupous or lobular. It may be queried, therefore, whether the pericardial inthammation is not secomdary to the loral infertion rather than to the nepheritis itself.

Arute Preumomia.-This infection shomld certainly be given a place only subordinate to articular rhemmatism in the etiology of acute periearditis. The frequency of this association has been recognised by anthors, but has been brought out with speeial elearness by Prelile, who found periearditis in 92.4 per cent of 79 eases of fatal puemomia collected from the post-mortem records of conk comnty Inospital. Preble cane to the conclusion that the danger of pericarditis bears a clirect relation to the extent of lung involvenent, and is also relatively more frepuent in left-sided than right-sided pnemmonias. The inflammation of the perieardium may result from direct extension through the lymphaties or may oerou independently, and is due to the pnemococens, which has becon frepuently identified in the exudate.

Scarlatina.-This is sometimes complicated bs the ocenrence of acute pericarditis, and in some cases this has taken place dnring the stage of lespuanation. As the searlatinal organism has not been identified in the pericardial effusions, this latter is probably to be regarded as a mixed infection dne to streptococei or staphylonored. Banre observed a post-scarlatinal periearditis coincident with rhemmatic manifestations, and was therefore inelined to attribute it to the affection of the joints; but inasmuch as pus germs are often respousilile for the rhemmatic affection, the pericarditis, as well as the rhemmatism in that ease, may rery well have been an instance of mixed infection following the searlatina.

Other Infections.-Other discases in the comrse of which acute periearlitis has oecasionally been observed are eryipelas, smallpox, typhoid fever, measles, cholera, and even diphtheria. It 
must also be pemembered that Flexner fomml as fore of infordion

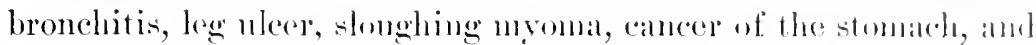

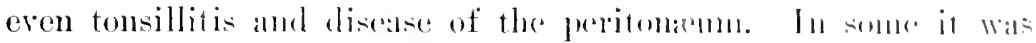

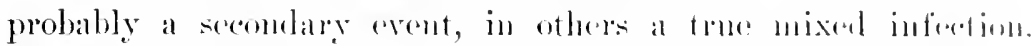

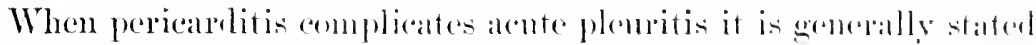
to be by extension. It is, in fart, cither a secomblaly arent due to the one and the sanne canse, or it is a mixed infectim.

Acute inflammation of the pericaldimm hat heran asterdatrel with varying diseases of neighbomring parts-c.g., colargenl glands or tmmomrs ju the mediastimm, alsers, or andes of a rib, and has resnlted from a rupture into the sac of an cmplyema, from

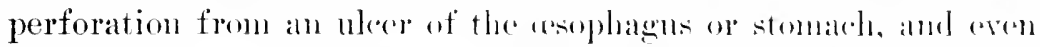
from intraperitoncal absecess. When caused by such comblitions

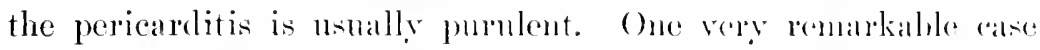
has been narrated of perforation and inflammation of the perianedium by a set of false teeth which had lecen aredelentally suallowed and hat lodged in the ersophagus, where it callsenl uleeration.

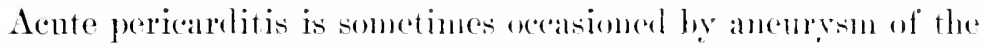
aorta and by new growths in the perieardial sale-c. s.. tubereles.

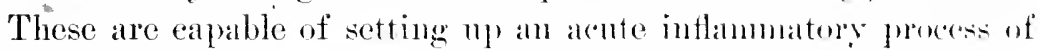
the pericardium, but as a rule the inflammation is subaroute or chronic, which probably axplains why it so frequently escapes clinical observation. It is dombtful whether gummata ever induce acute pericarditis.

Hacmorthagie pericarditis ocemrs as a secomdary infertion in the course of scurvy, purpmra hamormhagia, and himolnhilia. Some writers also assert that ancer and tuberendosis induee the halmorrhagic variety. Ebstein has reportech two coses of hamorrlatgic pericarditis, and stated that pericarditis was specially likely to be hamorthagic in the chronic or lecmoring form, and also in the aged and in the hemorrhasic diathesis. In this comblition, lae thinks, there is a toxic or inferetions anduse that creates a temeleney

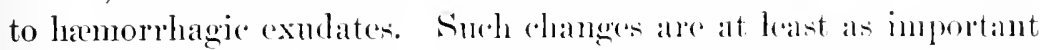
as the mechanical ones. The periearditis secomelary to seorlutus may be regarded as a tye of this chass. It may also oreme in alcoholism, which induces the hamormagic diathesis. In most cases of trammatic pericarditis the bloml fommd in the sare comes from the bleeding womd. Cases of tramatic origin in which the pericardium is not perforated are harder to muderstand. 


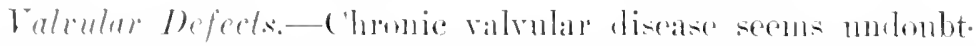

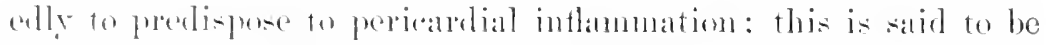

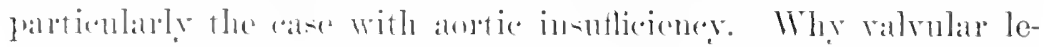

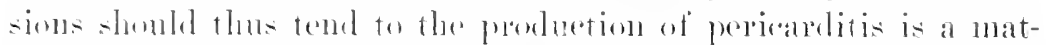

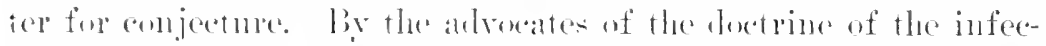

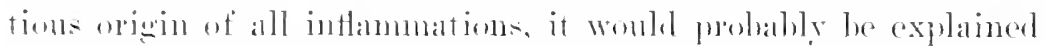
als an instance of seromdally ar mixed infertion, in comserpuenee of

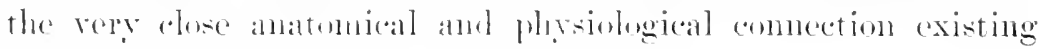

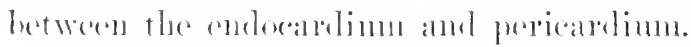

Tranme-Finally, acute pericarditis is sometimes the result

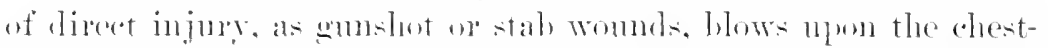

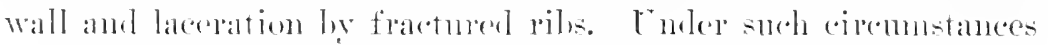

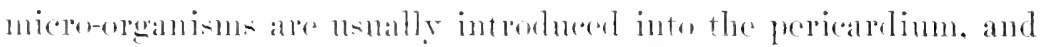

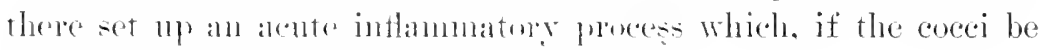
liregenic, will prose to be sulpurative.

\section{DRY PERICARDITIS}

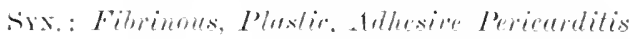

The pathologer and etioleng of this form have already been consiblereel, and therefore l hall pass at once to

Symptoms. - This disease mslally a rises during the comrse of some alrealy existing infection- pereess, and therefore its inva-

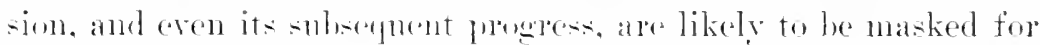
a time ly the clinical phemonena of the prinary atfeetion. Indeenl, some anthors an so tal als to state that thepe ale so fow

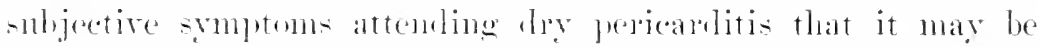
sail to bo a latent affection. In many instances this is plobably colrect. But I heliere the existane al alsence of suljective phe-

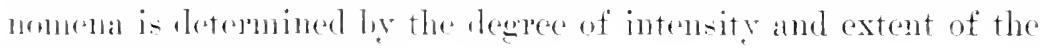
fericardial intlammation.

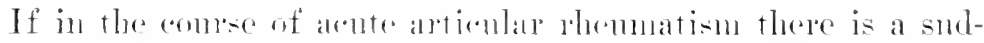
den elevation of temperature whirds ammot le explained by the

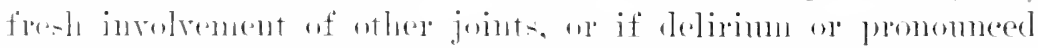

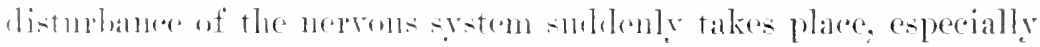

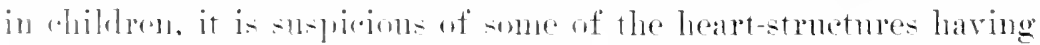

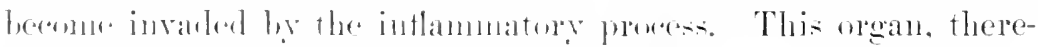
fore, shomll at once lo ralrofully examined, and if necessary repeaterlly examined, for, acoording to the fignes already proted 


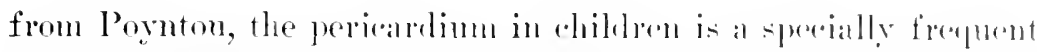
seat of inflammation. It, ats thomelat ly lioberts, the ophuion

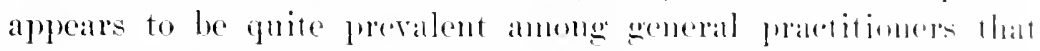

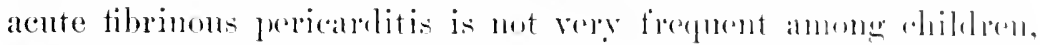

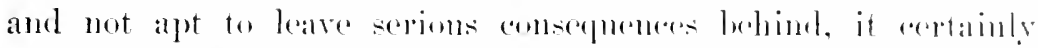

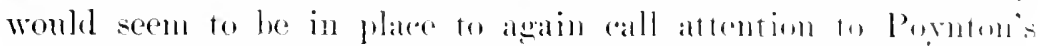

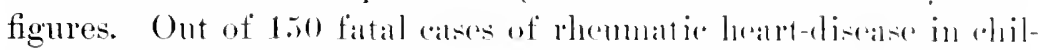

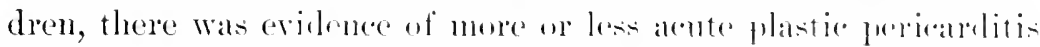

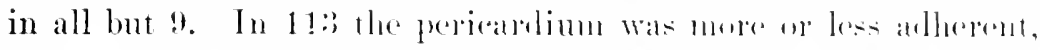

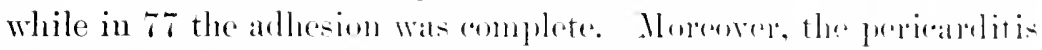
appeared to contribute more to the fatal issure than diel the endecarditis, for the reason that the inflammatory prosess extenterl from the pericartimu to the myocardimn and led to damerome dilatation.

Pain.-This is an arly and fairly anstant symptom, althlumb

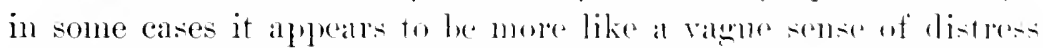
than actual pain. It is generally felt in the audiate regeron, hut may" be located in the epigastrimm, while in some "alses it ratuliates over the front or sicle of the rhest, eren atome the asured of the brachial plexus into the arm. In a rase of this kind deserilued by Sibson there was also endoearditis. Oceasionally it is experienced between the shomblers, and is then held to indioate intlammation of the posterior portion of the sale. baimuler lats described pain and sensitiveness on the sille of the laryms. In some instameses there is associated with the pain such a hyerabthesial of the skin of the pracordia as to make peremseion of the heart alnust impossible. Painful deghtition has leen frepuently repurterl, and is not difficult to molerstand when we rementere that the fereatre-

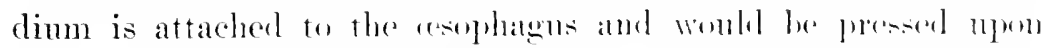
by the ingesta in their passige down the gullat. Patients have also been known to eomplanin of the heall hulting them with raleh contraction, and it maty well he that when lle corering of the

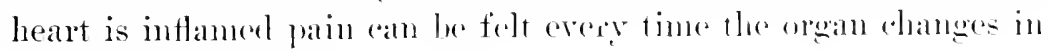
form during systole.

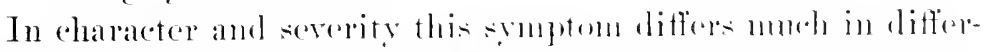
ent cases. It may he sharp and entting of alull and heary. ln a case olserved recently the pationt was only alle to deserilue his pain as a steady dull ache over the heat. Ismally the angmish is continuous, although in some cases it is intronitfent, anning and 
woing like a reritalle nembilgial. In others again it assumes a

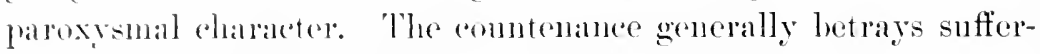
ing by an expression of pain or distress, and the patient not infrequently keress his hand upon his heart. Althongh this symptom, pain. is dombtess due, in large part at least, to the friction produed by the mbling together of the inflaned perieardial surfiaces, still its intensity depends also upon the sensitiveness of the pationt, it being well known that some persons never feel pain so acutely as do others of a less phleguatie temperament. The pain of periearditis perists so long ats the inflaned surfaces contimue to rub against carch other, and hence when these becone separated lye effued thuid this symptom abates or disappears. Therefore, if pain suddenly araes while the continuance of prexia points to contimuanee of the active inflammation, it may be taken to indicate heginning effusion into the sale.

Congl may or may not be present, hut when present is nsually dry and frequent, and when conjoined with pain may give rise to the sinpicion of plenrisy. In a fourteen-year-old girl seen not long awo and in whom the inflaned pericardimn had led to great cardiac dilatation, with consecquent pressure on the left lung, the attending physician at first miston the case for one of preumonia. This case is so instructive that I will briefly report its salient features. On a certain Friday tnis girl complained of slight pain and stiffness of one of her legs, but was not prevented therely from going to school as usual. The following Monday she felt several slight chills, which were attributed to the coldness of the room in which she was at the time. For several days following she showed signs of malaise, and in other respeets did not seem well, ret did not wive up and go to bed. Fridas night, a whele week from her initial rhemnatic attack, she spent at a friend's house, but when the next morning cane was mmistakably ill, and the family dextor was sont for. Ile fomd her with a dry

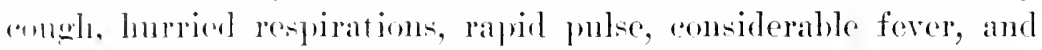
a sharp pain in the left side alowe the heart. Exalnining the lungs, and discovering sone dnluess and bronchial breatling at the left proterior lase, he pronomeed the case pnemonia-an error that entld have been aveided by a proper examination of the heart. There lays later another physician saw the patient, and at once recognised the true character of the discase. When on the ensu- 
ing afternoon I was ealled in eomsultation, the andiale dulnesis

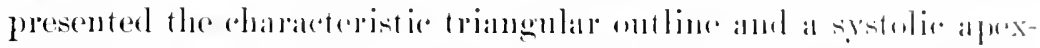

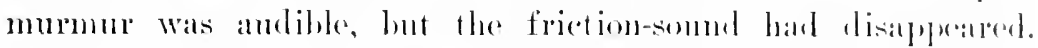
The case was one of alente perieanditis, as shown a fow days suberquently by the results of aspiration. 'The amomnt of reflusion wats small, however, and the matherl increase in the allea of andian dulness was due ehiefly to the dilatation the heart had mulerenone. It was impossible to siy whether the mitral systolic murmur indicated a ralvular lesion or was relative in romsepuenee of the dibatation. But as there was a history of some solp of illuess there years before, at which time she harl " heart tromble," it was foulded that the valves were defortive and were perhalys sharing in the present inflammation. In this ase the poriearditis had problalbly begum almost a work before she was obligeel to givo upe, so lhat it is not strange that the process shomld have indueed signs of prossure by the end of the first week. This pationt ultimately made a good recovery.

The pulse in these ases is accelerated, rmunges somotimus ats high as 130 , or even 140 to the minute, and is nstlaly andupensible and regular in the early stage bofore the myocardimu hats become much affereterl.

The respirations are nsually rapid and often slallow. oither because the patient shrinks from taking a leep brath, lest the pain be intensified, or becanse an actual sense of drepmeral is experienced.

Temperature. - An elevation of bodr-femperature probably attends most cases of acute pericarditis, but is often masked or modified by the fever dne to the prinary affection. As a rule. the degree of pyrexia is not great, averaging perhaps $10.2 \circ$ to $10: 3^{\circ} \mathrm{F}$.. and being generally continnoms or mild!y remittent. When it occurs in the compe of chronic nephritis, or when it is associaterl with ehronic myoeandial or endocardial lesions and independent of rhenuatism, the pericarditis frepuently rums its onmse withont fever, or at all erents with so slight a prexial as to be overlooked. The duration of the temperature is somewhat variable, depending on the intensity of the infeetion, lut may he sait to average two to three weeks.

Loss of appetite and other derangenents of the digestive tract, as flatulence and constipation, are usually present, the sane as in 


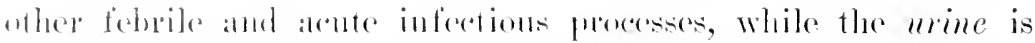

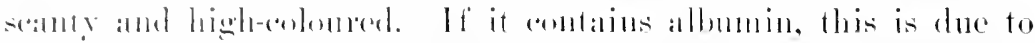

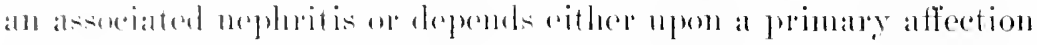

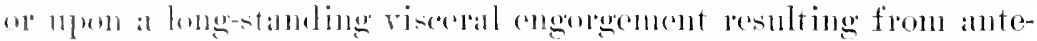

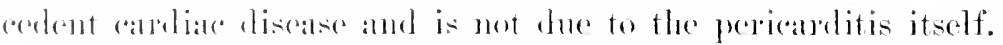

sleep is disturlued ar prevented altogether by the pain and

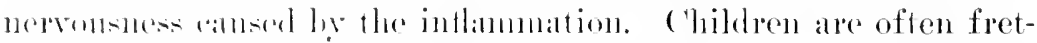
ful and restlesis. Thor comntemanee is pale and anxions or expressive of sulfering. In the spring of 1!) I treated a gentleman of fifty-firr for somptoms of falling heart, the result of ehronie nyo-

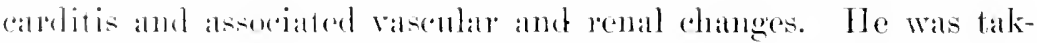
ing a conlse of Xinheim baths and seemed to be getting on very well, when I left tow for a few days. Tpon my return I re-

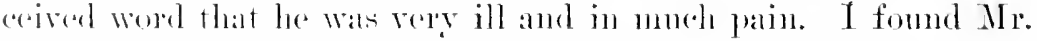
Il. sitting in a chair lowking pale and drawn, and when he spoke it was with a hollow, feolle tome of voice. This was Thursday afternown. Ilo stated that on the Tuestar morning preceding lie had heren serized with a dull, heary pain orer the heart, which had not loft him for a moment since. 1le had not slepet for two nights, :mel andel not lie down on areount of his epeat shortuess of breath. The pulse was 106, watk, inclined to be threarly, yet regular. llis breathing was not noticealbly disturbed so lomg as he was quice. lut his tomperatme in the month was 101.20 F. Suspecting pricantitis, I ret purpesely reserved my investigation of the

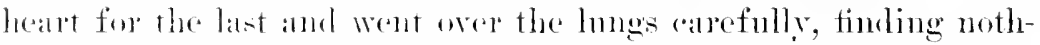
ing more than riles of hypastalic congestion at the posterior bases. (oming to the heant I combl deteret no change over what had been disoreded at my last visit, the Saturday previons, excepting that

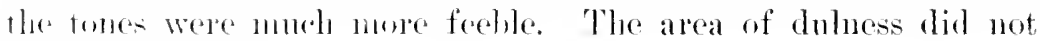

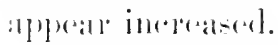

I was about to give 11$]$, in doulut of the nature of the tronble,

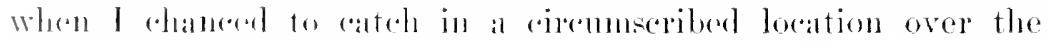
routs of the eleat resols at the left of the stermum a soft bushing nummer that had nor beren there at any of my examinations lufore. This mommu was systolic and shost, not at all like a

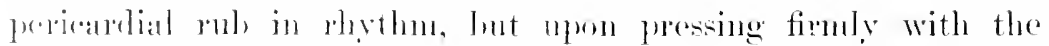

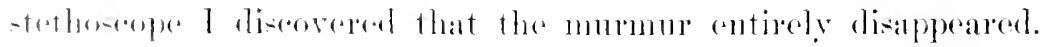
This compineded ne that the atse was one of acute pericarditis,

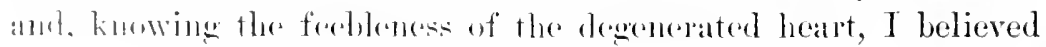




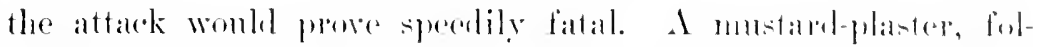

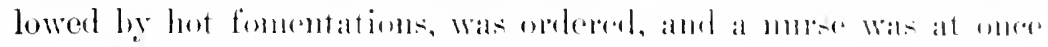
secured. At my next risit, fome lomes later, the pain was miti-

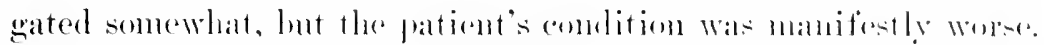

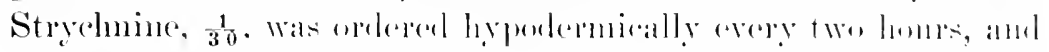

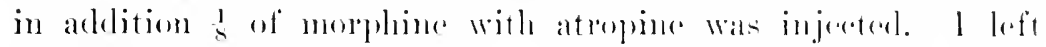

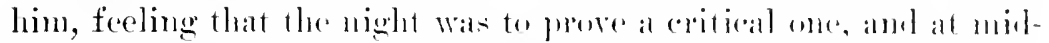
might I received a telephome nessage that Mr. II. Was failing rajpidly, his breathing being rerge labomed, and his pulse at the wist

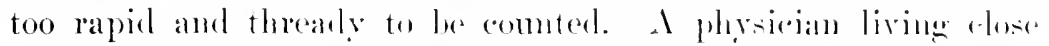
by the pationt was sent at onee and lecean the allministration of

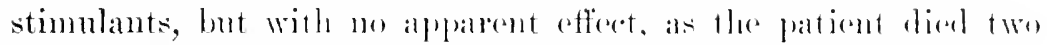
homes later. It was sulsegurently statenl to mo that als his combli-

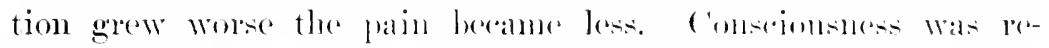

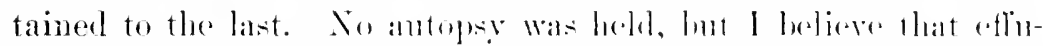
sion began to take plare, which redieved the pain hy sepalrating

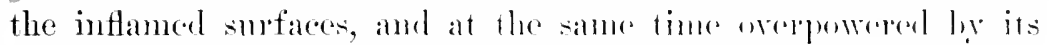
pressmre the degencrated myocatrim, which led to rapid asystolism.

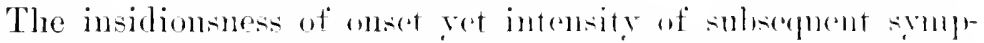

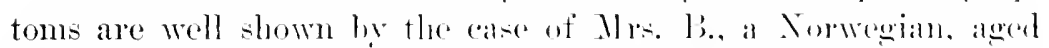
twenty-eight, who comsulted ne in April, 1s- t. " fom healt trom-

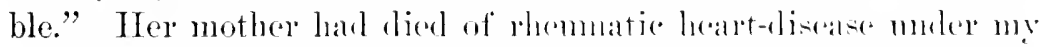

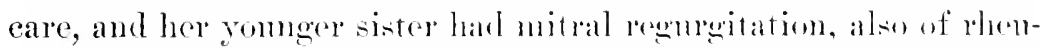

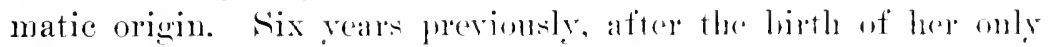
child, the patient had anticular rhemation and was aling for a year, yet had not harl symptoms of leaptedisease aftemand. In

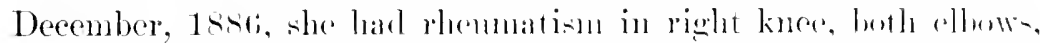

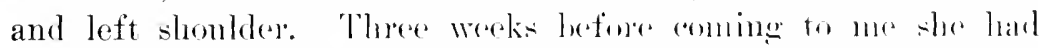

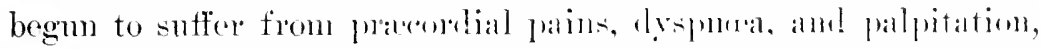

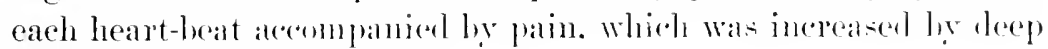
breathing and lying down.

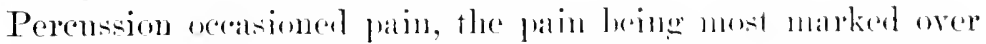

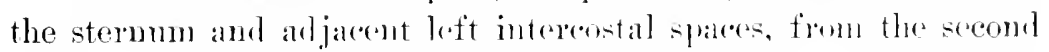
to the sixth, particularly in the thimel ame fommle. The patient's face was duskr, the eres dull, and a systolie phitsation was visible

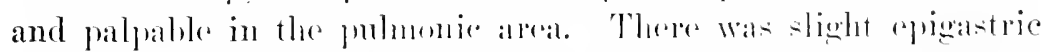

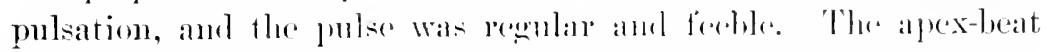
was in the fith left interspace, somewhat too far to the left, quick, 
and aecompranied by a feeble thrill. Cardiac dulness was increased in all directions, and in the mitral area there was a lond, harsh sistolic mummur tramsmitted to the back. All the sounds, especially the fmhmonic second, were sharply aceentuated, and over the hase of the heart was a triple murmur that by its rhythm and other characters was plainly a pericardial frietion-rub.

Excepting retraction of their anterior margins the lungs were negative. Iles temperature and mine were nomal. The diagnosis was mitral insufticiency of rhemmatic origin, and aeute pericarelitis, probably plastic, and also rhematic.

Patient was sent lome to bed and a blister was applied to the prevordium. It first, after rest in bed, local applications and salieglate of soda, the patient's condition improved, and she was allowed to get 1 p at the end of ten days. In a few days, however, she again took to her bed, and from this time forward her symptoms steatily grew worse. C'ough became rery troublesome, with dithiclilt mucous or muco-sanguincous expectoration, and there were anorexia and constipation. The pulse always remained at 120 , and as it failed to be slowed by digitalis, the drug was discontinued. June ed there was a sudelen attack of aente rhenmatism in the left hand and wrist with substernal pain, and temperature rose to $1020 \mathrm{~F}$. Salicylate of soda gave prompt relief to pain, and as the mine was scanty and acid, the salicyate was discontimned for the bicarbonate of potash, which was alministered until the urine becanne alkaline. June 6 th, at 2 .. x., there was a sudden exacerbation of substernal pain and listress. I perieardial frictionsound now dercloped orer the body of the right rentriele, ehietly below and to the left of the ensiform appendix. There was great cpigastric tenderness and interscapular pain. The anterior margin of the left lung hecame somewhat nore retracted, and the apexbeat now moved nearer to the left anterior axillary line. The patient complained much of pain across the front of the chest, along the lines of the diaphragm, from the right inframamillary to the left infrataxillary region. She complained bitterly of pain in the pit of the stomach, and suffered with nansea and romiting. . Jume sth fomd patient momel distressed for breath and unable to rotain food. Epigastric pain diminished, but condition of the healt very much as before. Fever was $102^{\circ}$ F. at 8 r. x. Stimnlants and food in small anounts were ordered. At 11 r. .r. there 
were sudden defervesecuee, and potuse perspiration for the lost

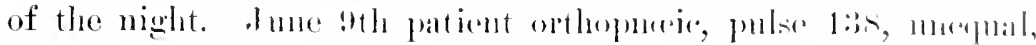
and weak; pain abated; int patient pestless. Examination l'ovealed duhness of lefi base, as high as lower angle of arapmis. Lxpectoration scanty; congh almost inpossible; passenl at rery band night; opiates given froely. June 10th, smmmoned hastily al noon to see patient. Mblonen rery distenderl with gats: Mreath very short; heart very feeble; camminatives, stimulants, anrl enemata ordered, but very little relief obtained. Doatl alt 5 .;0) r. x. Treatment throughout tonic, smpporting, sedative, and antirhemmatic.

Autopsy by Dr. Elbert Wing nineteen homes after death. The inner surface of the perieardim was eovered here and thepe with loose tibrous threach, wheh presented the appearance of cor rillosum, while upon both the anterior and posterior surfaces of the heart was an area of reeent pericarditis. Tho sac contained at small amount of serous effusion. The nuroeardimu showed changes of chronic myocarditis, probal)ly dating from the tince of the previous attack of pericarlitis. The mitral values gave evidence of chronic endocarditis that had led to their insutticiency, and showed also the efferts of recent molowalitis. There wats acute circumscribed plenritis of the left side with alout somers of sero-fibrinons offusion. In the right plental arity were old plemritic athesions. The lumgs were hypelamie and ardemattous. There was subarute diaphragnatic peritonitis, also subacute splenitis, and passive congestion of the liver. Kidneys and other organs were negative.

In some paticnts, particularly children suffering from acute artienlar rhemuatism, there maly be marked symptoms pointing to profound disturbance of the nervous systen. These are jactitations, subsultus tendinum, cerebral excitenent and restlessness, and low muttering delirimm.

It must not be supposed that all the foregoing simptoms are of a necessity present in any one case of acute fibrinoms pericarditis, or that they always lave the gravity just deseribed. In one patient pain is the chief complaint, amother may be amoyed by persistent pappitations, others may manifest no partienlar disturbance either of the lieart or nervons systen. linless the pericarditis is associated with inflammation of the endocardium, 
lyspmen is mot likely to be marked mut the aleute inflanmatory precess gives plane to extensive effusion. Respiration may be

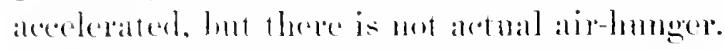

In many instances, als previons ly stated, this affection remains so latent that if the physicaln were to rely for its detection upon suljective mantestations, the discatse would smrely be overlooked. For this reatom the medieal atfendant shomleh make daily examinations of the heart ats a matter of rontine pratetice, in all cases of rhematic ferer or other infections diseases capable of lighting up lericallial intlanmintion.

Course and Termination.-If an acnte dry pericarditis is circmuscribed, the plastic exmlate not involving the whole sae, the activity of the process may speedily sulside, and all evidence of its existence disalppealy in the comrse of a few days or a week. If, on the other land, the inflammation is intense, and involves the myocardium, or if the plastic axulate is poured ont over the entire ming, the contre of the discase may extend over several weeks. In snch calses, particularly in chilluen with already existing ralrular discase, death is not mlikely, or if the patient recorers, he is likely to be left with a damiaged heart.

Acute cardiale dilatation is not infrequent, as shown by Poynton's statisties. Indeed, all clinical observers of much experience with pericarditis in children have come to look upon dilatation of the heart as a quite general result, and to regard its oceurrence with considerable apprehension. The extension of the inflammation to the myocardium is a matter of grave langer, and one that is likely to result fatally. If filmin be deposited in a thick layer orer the entire surface of the dilated organ, it may at as a mechanical hindrance to the subsequent return of the heart to normal size. This extensive fibrinoms exulation resnlts, furthermore, in an adherent pericardimm, which will be described in a subsequent chapter.

Physical Signs.-Inspection.-From the very nature of acute filminons periearlitis it is crident that no information of more than a merely negative kiml cam be derived from an ocular examination of the patient. The comtenanee may express anxiety or suffering, and insection of the chest may note some disturbance of respiration or an exaggerated and rapid heart-beat; but if there be evidence of deramged circulation this will probably 


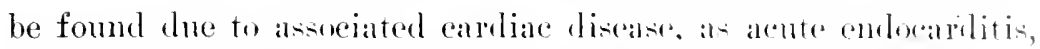

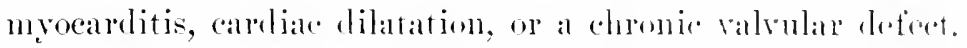

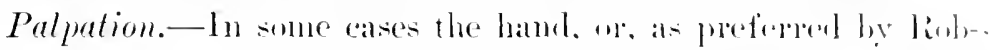

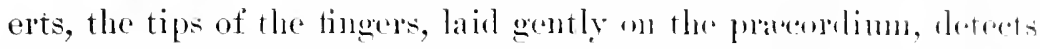
a ribration or fremitus, which is the tactile impression problued by those conditions that wive rise to the pericalrelial friction-sonme subsequently to be alescribed. If felt at all, this fincmitus is detected over the borly of the heart, usmally in the soome ou thind intercostal space, not far from the left stermal malgin. It may, howerer, in rare instances be detected at different perintis throughont the praceordimm. Infortunately this sign is net often present, but when it exists, it eonvers the impresion of a rubling or wrating of two rough surfaces, a sort of " to-aurl-for " or back-amel-forth rub, which is not strictly syuchemons with ardiac systole and diastole. It is this peenliar olding character of the frictionfremitus which realily enables one to distinguish it firom an endoeardial thrill. Presume may modify the intensity of this fremitus: moderate pressure increasing, forcible presure diminishing or obliterating it altogether.

Percussion. - In this form of pericardial inflammation the ontline of eardiac dulness may only le affected in so fal as this disease leads to dilatation of the heart; in other words. pereussion reveals nothing characteristic of phatic pericarditis, or that will be of material service in arriving at a diagnosis.

Anscultation.-In the early stage of acute poricarelitis of whatever form, and it may be thromghont the entire conrse of dry perienreditis, anscultation furnishes for the most part our only means of diagnosis. Somully, the two perieardial surfaces glide over each other withont frietion and noiselesty. But when one or both of them have become romelsened by fibrinous exmation more or less friction of morement is oreasioned, and this is declared by the so-ealled pericardial frietion-somd.

Before deseribing this in detail, it may be well to state that a perieardial frietion-somed has also been deterted independently of periearditis. It may be produced by the milk-spots matly found on the inferior surface of the right rentricle, also by concretions (Baner): hy dryness of the serous surfaces (Colliu and Walsh): and ly viscosity of the periearlimm during an attack of cholera (Pleischl). Nerertheless, such facts do not viti- 
ate the truth of the statement that in the reognition of the pericardial frietion-somul lies on bet and nsually onr only reliable mealls: of arriving at al dialsmeris.

Loention of the Pericardial Friction-mumar.- Is this exo-

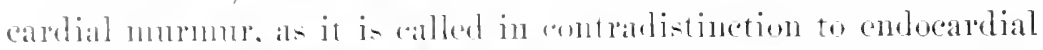

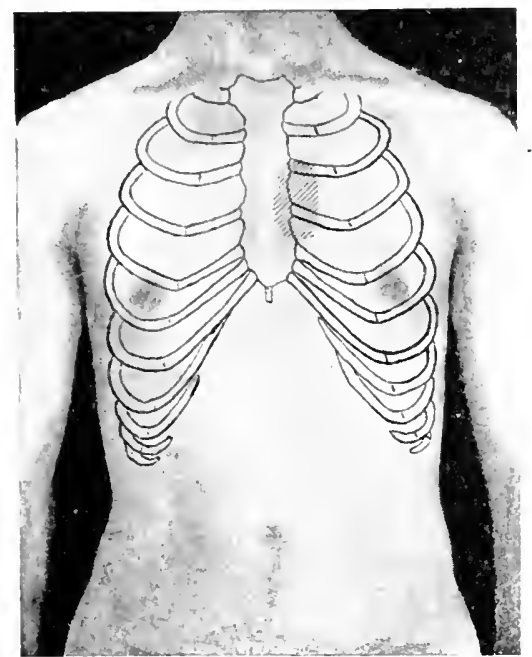

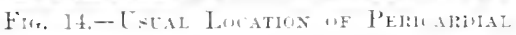

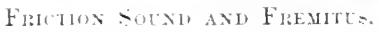
murnurs of valunlal disease, is often rery ciremmseribed, it is important to know where it is most freguently and best heard. This is generally wer the body of the heart it the origin of the great arteries upon which the periardimm is reflected, or in rme cases npom the anterior - miface of the right ventricle, very rarely at the apex of the heart. Consecpuently this friotim-somm is audible at the left of the stromm in the seeome. third, and fomrth left interectatal spaces in the same lowality is that in which friction-fremitns is commonly felt (Fig. 14). In -mme intances of extemsive pericarditis it is heard at reattered prints or themenout the praserdimn.

Phythm of the Friclion-sommt. - This is the most important

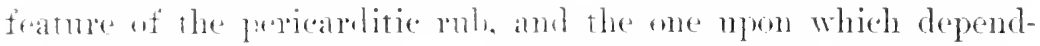
once is hicetly placed in the interperetion of its nature. It is

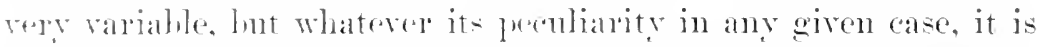

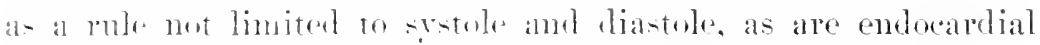

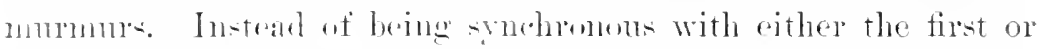
secent heart-somul. or bealring a definite relation to these tones,

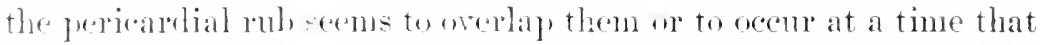
i- wholly independent if them. Thus, aceording to Skods. it may

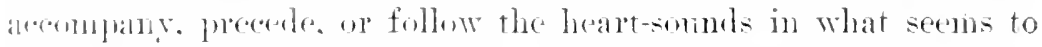

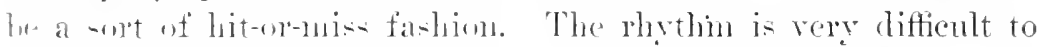

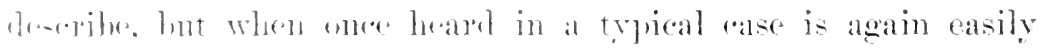
recontionl. In ment instanes the frietion-murmur is composed of either two or there parte, and when of but two, has a to-and-fro 
or back-and-forth rhythm, after the mammer of a loulde aortic bruit, but distinguishalle trom this ly its time ame guality. The variability in the rlepthm of this semed is wring to the falct that

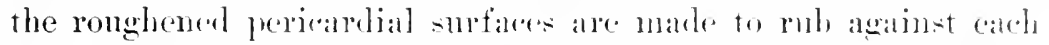

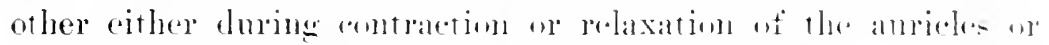
during the enderemeling phanes of the voutrieles. Therefore.

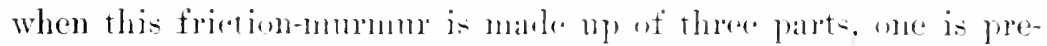

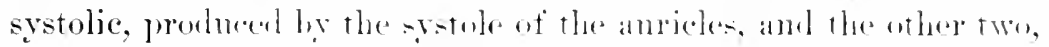

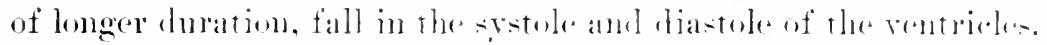

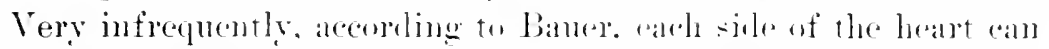
produce a swotolic and a diastolic rule of alifferent dustions, so that

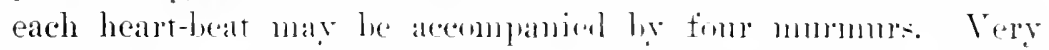

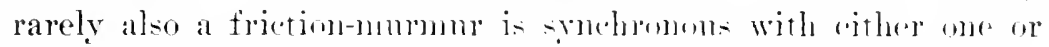
the other heart-onmels. and when this is the arse its duration is greater than that ut the tone it anommpanies, a remmotance by

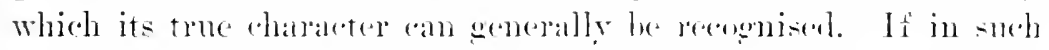

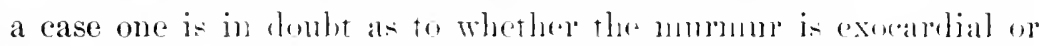
endocardial. he cam generally ascertain its natme by moting the

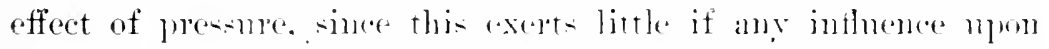
valvolar murumrs. Finally, it shomld be penembered that a friction-somed may disilpurar for homrs together and then again hecome andib]e.

Intensity of the Friction-sommt. -This depends upon two conditions: (1) the nature of the exmlate. 12) the foree of carliac

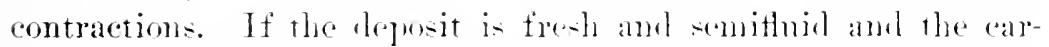
diac action feeble, the somm! of the rul, is likely to he imlistimet. If, on the other hand, the tilmin is dre and mueven and the heart is beating forcilly. the tipetion-sumel is likely to be lond.

Quatity of the Frietion-sommd. - This differs in different cates, depending pobably mon the drenes and viscosity of the fibrin. It may be grating. coraking like loatuer. erackling like parchnent or like the crumehing of dry snow beneath the heel, ete. but in my experience is nost often of a soft bushing quality rery dissimilar to the timlure of ralyular lirvits.

The Effect of Prossure on the Prricurdial Murmat.-It is usually fomd that persure with the stethoseole monlitios this friction-somel in its intensity if not its gnality. (iontle pressure by bringing the ronghened surfares closer together intensities it, while fim preseme diminisles on obliterates it entirely. It is 
sometimes fomml also that the intensity of the murmur is affected in one way or another ly the patient a position, being louder in the crect. weaker in the resmmbent posture or the reverse. In some rises also the intensity is affreted by respiration, being londer when by fored inspiration the periendial layers are brought into firmer apposition, and contratrise enfeebled when separaltad bye expiration. The perrese of this has been observed, howerer.

There is nothing in ante feriearditis per se to canse abnormal alteration of the heart-sommls. As stated hy Roberts, either

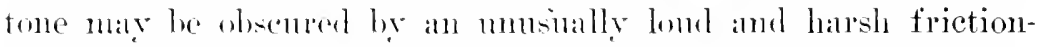
nulmur, but in eceneral they are hearl throngh the murmur in those calses in which they hilppen to be syehronons. When the intlammatery process has invarled the myocartium or has weakened it throngh dangerons dilatation, the eandiace soments are likely to become feeble, and the first at the apex may be more or less toneless, hut there is nothing in this peculiar to pericarditis. Stasis in the pulmonary srstem is evined among other things by mulne acentuation of the pulnonic second tone, while in consequence of the feethe dischatrang power of the left rentricle the abrtic second simme heeomes enfeebled.

Diagnosis. - The diagnesis of dry pericarditis is not as a rule attemled with insuperable lifficulty. In eases in which it is latent or its srmptoms are maskm by those of the primary affection it may he eatily werlooked. In most instances its presence is declared hy the history of an antecedent or associated rhemmatism, ly pracosdial pain, ote. and by the characteristic rubbing thrill and murmur. When the anammesis and symptomatology ane negative, reliance must he placed upon the anseuttatory phenomena, and these failing, a correct diagnosis is hardly posible.

Differentinl Dinguoxis. - This ancerns aeute endoearditis, plempy and pmemmia. The diagnosis of ante endoearditis is liarlly posibile unless valvular nomrmurs and other definite change in the sommls and shape of the heart and embolic phenom"nat are detected. The differentiation of endocardial from exocalrdial murmurs is based on the laws concerning the latter just describerl. and as a rule is not particularly elifficult if due attention is paild to the ir rhrothm. 
In acute pleurity reliane must he placed num the detertion

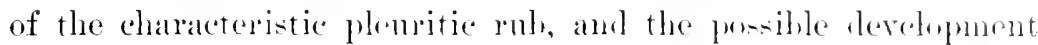
of pleuritic effusion, since the history and symptoms of a leftsided pleuritis may lo very like thuse of pericarditis. I point of prime importane is that the plenritic rub ceases when the breath is held, while that of periearditis does not.

In premunial there ale the initial ahill, the higher continnous fever, painful difticnlt congh, tenarims rusty sputum, loss of normal pulse-respiration ratio, dulness of one or more lubes cerepitant râles, and bronehial hreathing, and, lastly, the temination by erisis after five to seven diry.

One would scarecly think that aortic aneurysm wonld be mistaken for pericarditis, and reet I recall two instunes in which such was the calse. A mirldle-aged gentleman onere consulted me beeanse of pain in the uppere front ehest. The nuly aluomal sign was a faint seratehing -omel in the region of tle wreat resals not sxnchronows with either heart-somml. In the alsence of otlere findings, I pronounced in faromr of localized pericalditis, and yet four months later. I liscovered in the sane situation a wellmarked anenryem. The second instance wat that of a man in Cook County Ifospital who presented a to-ind-fro rubling murmur over the base of the heart, also met sulnehonizing with either cardiac tone, no dulners. no presine-rmptoms, and the necpopsy disclosed three small anemrymal saes smromding the base of the aorta. They were of albont the size of English walnuts, and the swish of the blood as it entered and left the sacs had evidently oceasioned the prendo-pericardial rul.

Prognosis. - This is alwats grave, lut depents upon the severity and duration of the attack. In childlen with articnlar rheumatism an acnte attack of pericarditis, even withont effirion, is so likely to set up dingerons dilatation of all the cartiar carvities that if the disease is protracted there is imminent danger of a fatal issue. Dangerons weakness on the part of the myocardium is shown by feebleness and muttling of the first somm at the apex, diminution of the aortic second somd, and ly a threarly and intemittent pulse. Great deranganent on the $i^{\text {rart }}$ of the nerrons system is also a sign of danger, even thomgln the life of the patient be not immediately threatened. The remote progmeis is unfavourable, since acute liastic pericarditis may be followed by 
offects that will greatly hamper the heart in the future. Firm adhesions at different points nay mite the two hayers of the pericardimn, which, if they do nut beeme stretehed, may ultimately lead to weakness and liiatation of the right rentricle (Broadlent), or the sace may be bembl down to the heart throughont, forming what i- known as stunechie pericurdii, the baneful effects of which will be described in a subsequent chapter. Broadbent hats relaterl a case in which the redema and other signs of persistent renows engorgement throughont the body were found due to tibrons bands which had partly constricted the right auricle and led to total obliteration of the inferior vena cava.

Althongh it is stated that the plastic exulate may sometimes be absorlend, this is a very remote contingeney, and should never be reckoned 11 mon at all likely. When the disease is complicated with endocanditis, plenrisy, or puemonia, or when it oceurs in the conrse of chronic Bright s disease, the prognosis is usually more unfarourable than when it ocenrs independently or in the course of rhematic ferer.

The mortality of fibrinons pericarditis is not generally considered very great, and yet a study of the 150 fatal cases of rhenmatic heart-discase collected by Poynton shows the erroneousness of this opinion. In : it of his cases myocarditis was present as secondiry to pericarditis and death seemed due to the effect upon the myocardiun. Even when the inflammation does not extend to the heart-musele the heart of a child is very likely to undergo a serions degree of dilatation, and when both these conditions are combined with endocarditis reenery is rery improbable. This was well show in the "ase of the ten-year-old coloured boy, from whon was whained the specincen shown in Fig. 13. When seen for the first and only time a few days prior to death, this boy was sitting up in bed on accomnt of difficulty of respiration and of pain in the heart-region. IIs illness had hegun with rhemmatism and lasted ten weeks, and he hat become strikingly emaciated and his rountenance showed marks of patient suffering. The thorax and ablomen were distended from just below the clavicles to the umbilicus, were unnaturally hroat across the loins, and thus filled ont precented a striking contrast to the thimness and smallness of the neck and extrenities. Breathing was extrenely rapid and shallow, and as evinced by the pulse the heart's action was also 
rapid and feelle. The skin wats dry and sealy and folt lwot, although as a matter of filct there wals hit slight fever.

The eardiac impulse was rely feeble, and the apex-beat cond not be clearly defined. Akolute dulness wats commonsly increased in all dianeter's, reaching as high as the second instal cartilages, and transersedy from at least 2 inchen to the right of the stepmun far heyond the left nipple almust to the anterior axillary line (Fig. 15). This gave to the duhess a pramidal shipe closely resembling the ontline of the pericardimm distented with tluid, but ditfering from it in the circumstance that the left border of dulness lin not pass outside the limits of cardiac impulse. The heartsounds were feeble, and all

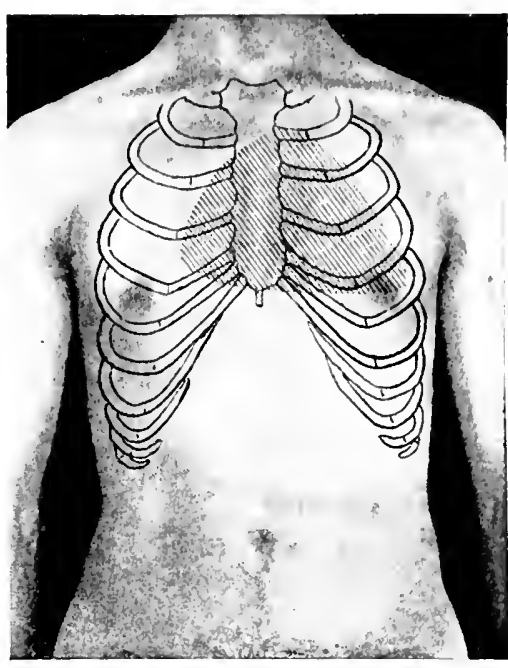

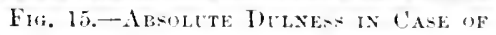
ACLTE P'ERICARIDTI.:

over the praceordium was a loud, hatris systolic mumur, having its greatest intensity in the mitral area and audily throughnot the back of the chest. To pericardial friction-rul, conlel be distinguished, but there was one sound that at first was quite misleading.

Beneath the right clavicle, and therefore in proximity to the aortic area, was a donble blowing somel, having a to-and-fro rhythm of a quality very like a harsh douhle endocindial mumm. It was so lond as to obscure the heart-tones, yet, althongh very rapid, not fast enongh to be generated in the heart, and moreover was andible orer the back. So soon als these differential points had heen noted it was concluded to he despiratory, and alerordingly was found to eease so som an the little patient hedel his breatl. The lung-margins in front were retracted by the presine of the large heart: pulmonary resonance was impairent to right and left of the heart, as well at at the posterior hase of the left lung. There was manifest engorwenent of the liver and ofler abdominal viscera, but there wals no inlema. 
In the matter of diagnosis it was not so easy to determine whether ethision was present or whether the enormons area of duhness was due to dilataltion, als it might at first seem to be. Howerer, ly arefully comparing the left lateral limit of duhese with the feeble cardiale imponlse and finding that they pretty closely angeed, it was concluded that the condition was mainly dilatation, secomlary to acute pericarditis, and probably also enderarditis, with perhates a small amomt of effusion, but rertainly not conough to watrint tapping in the hope of relieving the child's drepmat. The hopelessness of the prognosis in such a state of atfairs was justitied ly the fatal insue about a week subsequently.

The antopse disclesen acute platic pericarditis, without effusion, acute endocarditic, and fatty degeneration of the myocardimu, and death was probabiy to lue attributed to the state of the heart-muscle.

\section{PERICARDITIS WITH EFFUSION}

Sero-fibrinous.-As already stated, a sharp dividing line between fibrinons and sero-filprinons pericarditis eamnot always be drawn pathologically, becanse, althongln a pericarditis may remain dry throughont its compe, the fibrinoms exudate is generally united with an effusion of sermu, wo that a process which was plastic at first may afterward be characterized by an effusion of a large quantity of sermu within the pericalrdial sac. The two elements of fibrin and serum may be mixed in varying proportions; in one ease the former being almulant, while in another the fluid may contain lut an insignificant proportion of plastic material. The amomt of effusion in any given case varies within wide limits; there may lie 1 or 2 ounces, or the sae may be enormously distended by 1, 2, or more pints (Fig. 16i). The effusion generally takes Hace gradually, but in some instances oceurs with such rapidity that the sac becomes entirely filled in twenty-four hours from the onsect of the affection.

Purulent.-In this variety the effused fluid is eomposed ehicfly of pus with hut little fibrin, and contains pyogenie baeteria. In rare instances the micro-organisms may be of sueh a nature that the pminlent fluid becomes fortid, and the disease assumes a very grave aspect from the onset. 
Homorhagie.- This form is characterized by the effurion of blood into the pericandial sale as a result of the intensity of the process, which molermines the integrity of the pericardial bloonressels. Or al sero-tibrinoms effusion may beeome deeply bluodstained through hichorrhages from minnte vesicl.s.

These three varieties of coffusion may be lookerl upon ats different manifestations of one and the same process, having the same pathology, and differing only in the etiology and intensity of the inflammation.

Symptoms. - These are to be divided, according to the stage of the process, into (1) those that attend the onset, and which are chiefly inflanmatory in their nature; and ( 2$)$ those that result from mechanical distention of the sac, which are, therefore, simptoms of pressure on the heart and neighbouring riscera. Furthermore, the three kinds of effusion should be theoretically distinguished one from the other by the

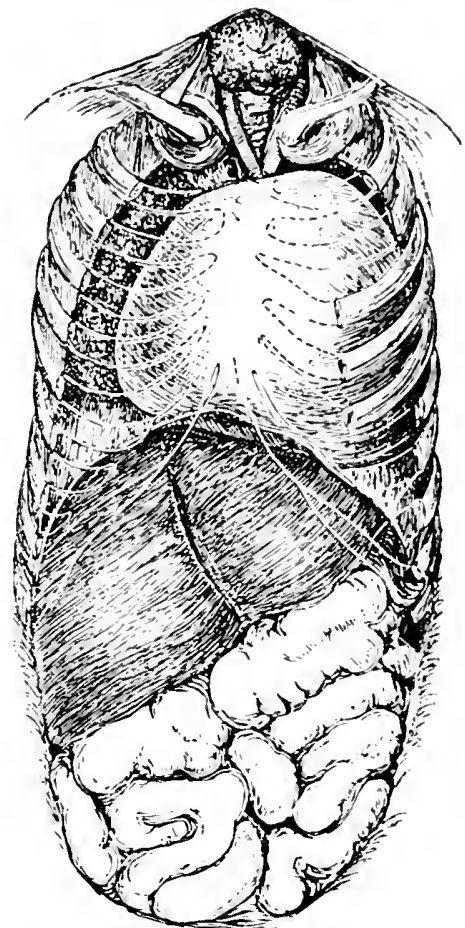

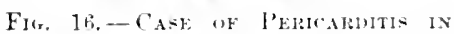

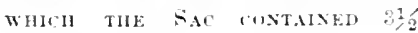
Porsis of Flodb. (Bramwell.) severity of their symptoms-that is, of their comstiturional effect:; as a matter of fact, however, there is of ten nothing in the simptomatolog $\mathrm{s}$ that declares the nature of the exulate.

The phenomena attemling the early or inflanmatery stage have been described under In Pericarlitic, and therefore we may pass at once to the consicteration of the srmptoms due to thid acemmulation in the sac.

As effusion takes place it gradually distents the sar from below upward, and, separating the roughened and inflamed pericardial surfaces, canses a cersation of the pain attending the onset of the affection. The fover of the inflammatory stage still persists, howerer, as may also the congh. With distention of the 
sate, the smptons due to active inflammation gradually merge into and alresubotinatert to these oceasioned by pressure. When the :monnt of exmelation is small, s'mptons of active inflammation may still predominate, but when it eompletely fills the sac, reaching. it maly be, one or more pints, pressure-effeets alssert them-

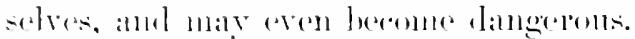

('hilden impress me as complaining less of these effects than do adults, ret, of "onrso, inlividual peenliarity langely determines the anmme of complaint nom the part of the patient. I have

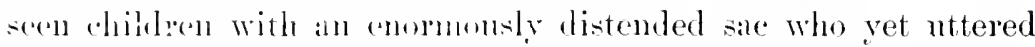
no word of amplaint amd whe silent snffering was truly pathetie. They alle nonally restless, however, and display fretfulness when disturbed. In many ases their patient fortitude as regards subjective smuptoms presents striking eontrast to the oljective evidenee of circulatory and respiratory embarrassmentl.

The face is pale and anxious, or there is congestion of the cutaneons ressels, producing a blue-white appearance, and the reins of the neck are turgid. The pulse is small, rapid, and of low tension, which gives it a degree of ahruptness that may make it somewhat resemble the suden pulse of artic incompetence. Sume writers describe the pulwe in the stage of effusion as larger and fuller than wonld be expecterl from the feebleness of the heartsommls. Markest irregnlarity, and eren intermittence, are sometimes oberved, particularly after the effusion has persisted for a consilerable time. Such arhythmia eoming on late is a sign of danger, sine it points probably to failure of the heart-musele. It shomld not he forgotten, howerer, that irregularity and intermittence of the pulse may be present from the beginning of the pericalritis. when this latter is ansociated with a valvular defeet, in which catse it is not to be attributed to the pericardial effusion or inflatmuation.

The listurbance of the "irenlation everywere evineed is a direct aresilt of presure on the heart by the abundant effusion. Not only does the heart have to sustain the weight of the superinpuest fluid, but when the effusion is great enough to distend the sate, it is confined muler high tension and forced, therefore, to prese inward on the heart. Acoording to Sibson, the thickwallerl and powerful rentricles are better able to withstand such 
pressure than are the thin-walled amrieles and reins, which ennsequently have their capacily diminished. There is actual mechanical inpedinent to the intlow of bleme inte the right heart, and likewise to passage of the stream ont of the pulmomaly reins

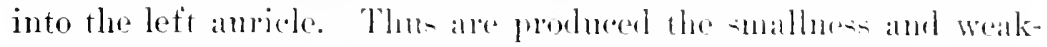
ness of the ralial pulse with tulness of the sistemie voins.

This is not all of the presone-etfects, howerer. The distended

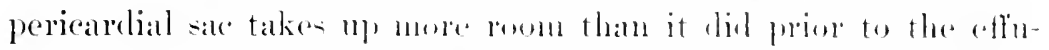

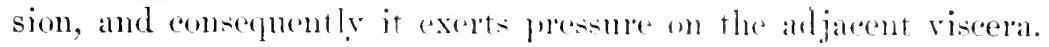
It pushes aside the elatic hump-borders: and as the heart lies more to the left than to the right of the median line. it is the left lung that feels the areater prentre. The lower lobe, therefore, is

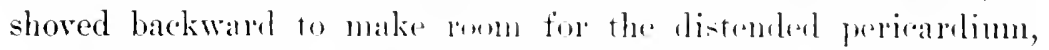
consequently the pationt sntfers fom mepilatury mubarassment

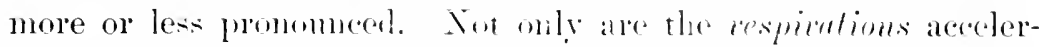
ated and shallow, lut the patient is ampellerl tes sit ul) in bed to breathe (orthopmoa). or in some instances to lean forward with his elbows on his knees. so as 10 allow of as molh gravitation of the sac away from the lumes as is pessible moler the cilemustances. No doubt that carbonir-acisl intoxication resulting from the nechanical impediment to respiration also plays a part in the production of dysmera.

Insommin is often a rery tromblesome symptom, ame secme to be due not only to passive recehral congersion, but also to the patient's dyepmera, which rembers it imposible fur him to lie down, or speedily aromses him when so fortumate als to fall into even an uncasy slcep.

There is monlly amoredin: nut whly has the pationt no appetite, but the drsponea and dysphegir render the taking of food difficult, and children often turn away from it when proffered.

The urime is seanty, the alulumen is distended lestle from retention of gas in the buwels and from congestion in the portal

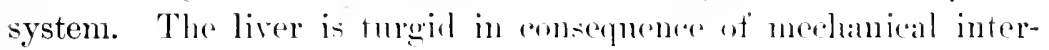
ference with corculation thromels the lmugs. and is more or less tender: there may be eomstipation or small tiepuent watery stools, because of serous transulation into the intertind from the engorged ressels within their walls. I hatre always lonked npon this diarrhea as Xatme's effort to moloud the distrumlerl ressels, and therefore as a rery raluable therapentic hint. If the disease be 
protracted, and venous congestion very marked, there mar eren be some adema of the lower extremities.

Fecer is of variable intensity and charaeter; it is likely to abate somewhat as the artive inflammatory stage passes into that of effusion, and if this latter stage persists for some weeks the temperature nsually retmins to normal, or nearly so.

The sumptoms of pressure as above described usually manifest themselves gradually, but appear suddenly in those eases in which the sac beemes rapidly tilled. The gravity of the symptoms usually bears a direct relation to the amomt of effusion. When this is small, but 2 or :3 omees, or when it takes place insidiously in the course of eacheetic diveases, simptoms may be entirely latent.

When the pericarlial effusion is purulent, the gravity of the smptoms depends both upon the anount of the exudation and the kind of miero-organi-ms concerned in the process. It is in this form that the sac often reaches its greatest degree of distention, and since the legree of mechanical interference with both cirenlation and respiration accords with the amount of effusion it requires no further comment.

Searcely had the foregoing been penned when I was asked to see 2 cases of acute rhemnatic pericarditis in children, which illustrated so well certain features of similarity, and yet of contrast, that I have decided to narrate them here. 1 girl of twelve years, seen with Dr. F. S. Johnom, wave the history of a severe attack of inflammatory rhemution five years previonsly involving several joints, but the heart was aid not to have been affected. She afterward had two mild rlemmatic attacks, of which the last was a year ago. During the past summer and fall the patient was thought by her parente to lave been remarkably well. About four weeks ago she hat an attack rharacterized by mild ferer, roated tongne, and siglet jam liee, but no distinet rhematic symptrons. Ten days ago she was allowed to attend the opera and eat freely of candy, after which the symptoms of two weeks earlier returned with greater intensity.

When Dr. Johnorm assmed charge of her ease he found the patient with mild internittent prexia, ankles and knces painful, lut not red or puffy, slight pricerdial pain, great nerrousness, restlesness, and so much entaneons hypersthesia, as well as pain, that a rery thorongh exannination of the chest was not possible. 
He found weak, rapirl, but regular pulse, 120 to 130 , and respirations of 60 ; great increase of both absolute and relative cardiace duhess, particularly noward and to the left; a lond systolic murmur throughout prareorlimu, but most intense at apex, togethri with a short presintolic murmm limited to a small area within and above the alpex-beat.

The apex-beat was in fifth space outside left nipple, heartsounds were everywhe andible, puhnonic second banging and split. A pericardial friction-sound existed at the base, orer right auricle. Left lung was compressed and the liver palpable just above the level of the mubiliens. There was no dropsy, and the urine was negative.

The ease was regarded as one of acute rhematic periearditis supervening upon a combined mitral lesion, and having led to great general dilatation of the heart. Three dars later temperature was $102^{\circ} \mathrm{F}$, pulse 120 to 130 , but regular, and respirations 60 to so. Patient was in evident distress, complaining of pain in the heart above the left nipple. She also lrad great difticulty in swallowing. $1 \frac{1}{12}$ grain of morphine gave her a fairly comfortable night, and the norning when $I$ saw her the condition was as follows: Patient lay nearly flat in bed, several joints of both lower and upper extremities anointed with a liniment containing oil of wintergreen and swathed in bandages. She was exeitable, fretful, and inelined to cry out when tonehed. There was no eyanosis, but respirations were shallow and rapid, 60 or 80 to the minute, the pulse of fair volume, but dierotic, was about 120, perfectly regular. The abdomen was distended and tympanitie, tense and painful in the region of the liver, which conld be made out extending nearly to the level of the mubilicus. The heart's apex was visible and palpable, thomgl rather weak and diffused, in the tifth left interspace ontside the nipple-line. There was no pericardial fremitus, but the cardiace impulse was diffused from apex to base and from left manillary line to the stermum.

Cardiae dulness, both superficial and deep, was increased transversely, but chietly to the left, the deep linit reaching nearly to the anterior axillary line, lut not extending outside of or below the palpable impulse of the apex. A harsh mitral systolic murmur was everywhere andible, as were also both someth, the pulmonie second being greatly intensified and split. Over the 
borly of the strmum presure with the stethosepe brought ont a soft mbing murmur. Which, from its guality and rhythm, was

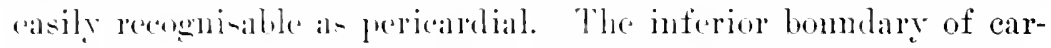

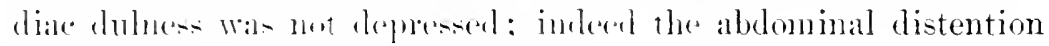
areasioned an clevation of the healst.

This high perition of the liver callsed the upper margin of hepatie dulnes- to reateh the lexel of the tifth right costal eartilage and intertered with the deternination of the precenec or absence

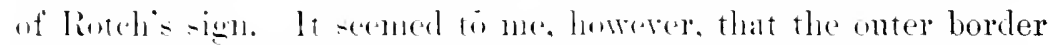
of the right anriele lareked it natural enre dewnward and inward, and that the line of chlness joined that of the liver at nearly a right angle. The pain which ohange of position cansed the little patient, remberenl examination of the hares of the chest inadrisable. The dector stated. lowerer, that the bay before he had found dulness with corre-umeling alteration in the breath-somels at the left persterior barece.

The diagnowis was acote rhemuatie perieatrditis with great cardiac dilatation and powible arote nuycarditis smpervening upon a provim-ly existing enderanditi- that had led to mitral insuffieiency. Llistinet signs of effu-ion were not obtainable, and henee it was conclnderl that the exulate was tilurinons, or if united with sermm, the profortion of the latter was not large. The extensive cilatation present was attributed in part to the mitral lesim. and in gart to the lilating influence of the pericarditis, whether as-redated with acute myorarditio or not.

The -rmptum in this care were not distinctly those of pressure: repiration was greatly acederated. to be sure, lout there was no cranowi- no downward di-glacement of the liver, and no

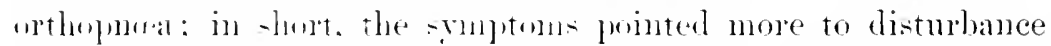
of the nervons -rotem, with consecuent rapility of breathing, than to circulatory conbaraisment. The rery considerable hepatic engerewentent comld be vere reasomally referred to the free mitral leak and the greatly arestraines right rentricle. This patient nltimately made a genel recorerer.

On the -ance day on which I an the preceding patient, Dr. Jo-

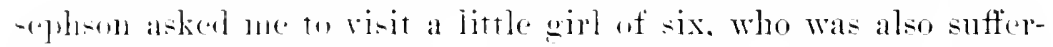
ing from acente pericarlitis. She hard passed throngh an attack of ararlatina in the only preanding. and for the past three or four weeks had been suffering from acute articular rhemmatism, which 


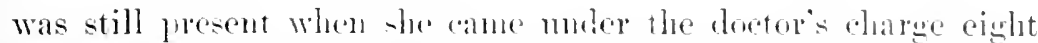
days before my risit. He hat at onee recognised an ande intlanmatory affection of the heart. ller somewhat fhetuating temperature had averaged alumt 10.2 F.

The child's comdition when I sa low was follows: she was

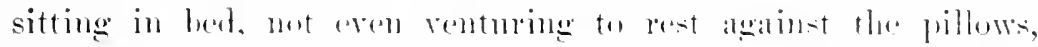

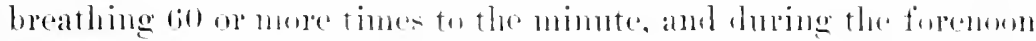

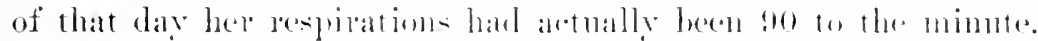

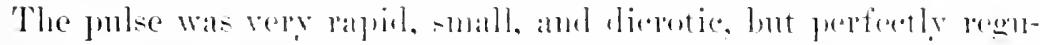

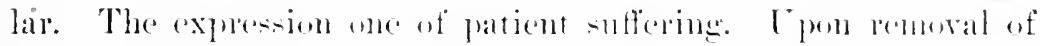

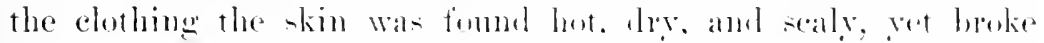

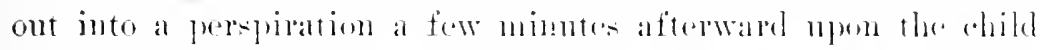

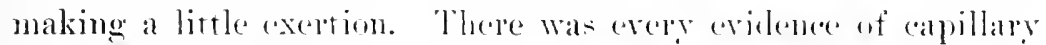
and renous comeretions. The abdomen was distemderl ansl hared, particonlanly alumt the waist-line; the thelax was eridently distended to its utumet caparity, the sutire trent of the chest bulging, and the intereostal spaces more ar less smoothed ont. The apex-licat was feebly palpahle helow and a little to the lett of the nipeple, and there wals diffinced systolic shock wer the lexty of the organ. Mlrohute cardiale flatmess (Fis. 17) bewan at the right nipple, pasiod njward to the first intersiatere. then

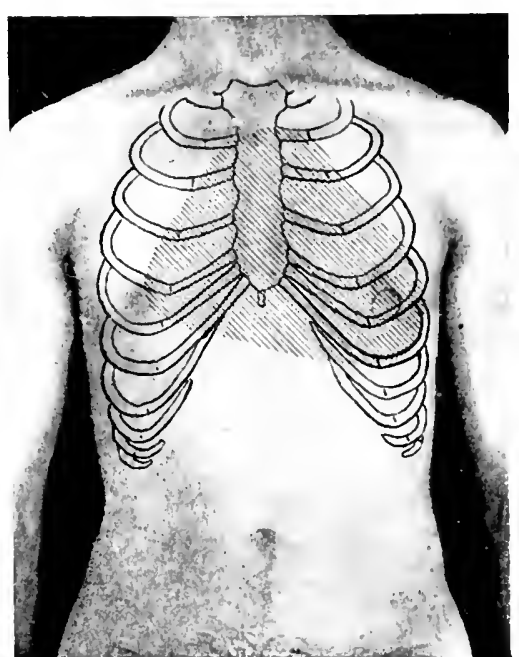

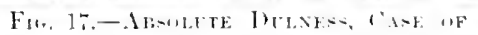

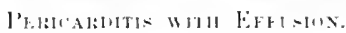

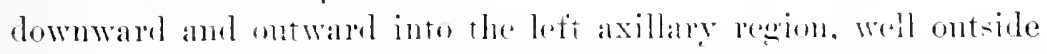

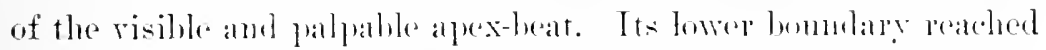

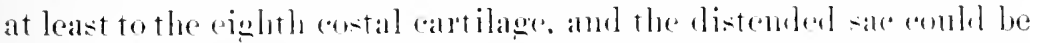

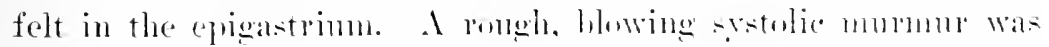

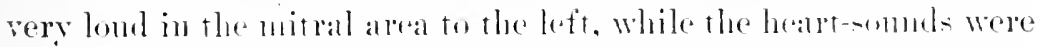

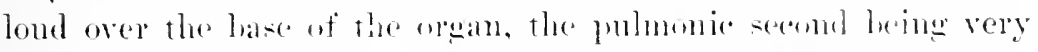
banging and sightly split. From the mislle of the stepmm downward to the encifom was a spating pericatrolial friction-somud, which had a simple to-and-fro rhrthm not syehronoms with either 
systole or liastole. It the left base, posteriorly, was a dull patch corresponding with Ewart's dull pateh in outline, but the harsh, rery hurried breath-somds were everwhere andible. In front, resonance was inpaired leneath both elavicles, and the sense of resistance imparted to the tinger upon perension of the proeordium was renarkably intense.

In this eave the diagnowis was also acute pericarditis, but, unlike the foregoing. there was a massive exudate, oecasioning rery grave presure-xigns. There was also present the same valvular lesion, mitral regurgitation, lut there was very strong suspicion of the existence of ande endocarditis, sinee from the history of searlet fever in .July. with more or less rhemmatism subsequently. with no other previous etiological factor, it was not likely that the mitral disease dated hack more than six months.

Deghtition gave this little sufferer so much distress that she would hesitate for minutes together before making up her mind to take the proffered modicine or nomishment. In this ease the urgency of the symptoms arose from pressure. Dyspncea was so great that the little thing begged to be allowed to stand up, evidently to relieve the thoracic organs, already much compressed, from still greater pressure by the abdominal viscera foreed upward against the diaphragm in the sitting position.

The eontratst presented by these two eases was most instructive. In this latter case paracentesis perieardii was atvised without delay. It would have been eruel, if not useless, to postpone the pperation mitil trial had heen made of catharties and diureties. Far better tap first, and administer these afterward.

Suppurative pericorditis generally accasions phenomena of sepsis, but chills, ferer, and sweating are sometimes said to be absent (Roberts). When present they are an indieation of sepsis, and as such may he a part of the symptomatology of the primary affection as well as of the pericarlitis. When the effusion is fotid, as rarely happens, septic simptoms are most marked, and prostration comes on early and is extreme. In some cases there is nothing in the nature of the smptoms whereby one may determine the purnlent character of the exulate.

The sumptomatologe of hormorthergic pericarditis depends upon the rapidity with which the effusion takes place, rather than upon its nature. I harmorrhagie effusion into the perieardial sae 
during the conrse of scorlutus, for example, may take place so suddenly that sympens of pressure and of anamia rapidly develop. In other cascs the effusim is slowly prodnced, and symptoms manifest themselves gradually or are cutirely absent.

In Ebstein's two ases the symptoms wele those of plessure, cyanosis, dyspnera, congh, and pain. hut in one the eomblition was thought to he extreme ardiac dilatation, and its true nature wats

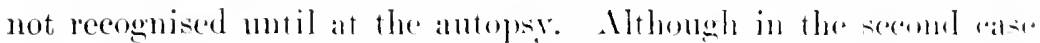
pericardial eftusion was recengised during life, there was nothing in the symptoms to point to the hammerhagere chatrater of the. exulate.

Course and Termination.-There is no mifurmity in the clinical history of pericarditis with effusion. Cases vary willy from each other in the morle of onset, in the contse they pursue, and in their mode of temination. An ordinary eate ocempring during a rhemuatic attack may be expecterl to terminate by absorption in two to four weeks this haply erent may very rapely take place within a few days, the disabe haring passed thromeh the sucecessive stages of inflammation, etfusion, and aldenplion in less than a week. In other instances the affertion manifests a strong tendency to become eitler subacoute or chronic. IVhile in others, again, the discase is eharacterized hy phases of partial absorption

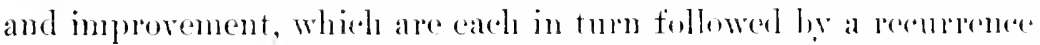
of inflammation and increased effusion ( Bance), mutil at length the patient is worn out by the persistent and obstinate natme of the disease. These variations depend, mo roubt, upon the activity of the etiological agent, and are mot at all sllprisings, for, as arery one knows, no discase presents mifomity in its olinical phonomonal.

Other conditions besides the activity of the pathenenic agent also determine the eourse and serepity of an antre periearditis. Its oecmrenes with or as a sefurel to plenrisy or pmemmonia is also likely to intluence its eomrse and termination. in aceorelanere with the intensity of these latter proeesses and the desuedo which they have undermined the patient's resistance. W'ben periearlitis is the result of chomienepheritis it is very likely to rum a slow and latent comrse.

In children with inflammatory rhemmatiom the discase is apt to prove persistent, and if it does not destroy life ly invanding the myocardim, terminates in complete or partial syedha pericardii. 
suppurative prentitis is a very serious affection, manifesting but litte temtency to -pontaneme recovery. It is stated, howsere that if the prosente bateria be not very rimlent, and if life le prolonged for a com-inderalib time bevond the stage of active

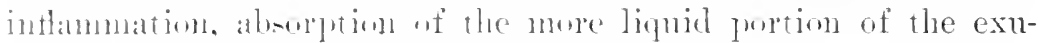

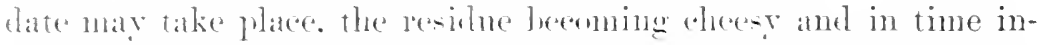
filtrated with line-alth. They are erentually trumsformed into

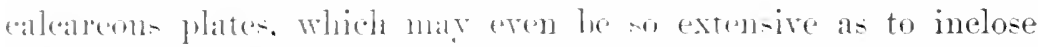
the heart in a case of lume-like halvhers. I lave observed two -nch ratses: in whe a callearesmo plate the size of a silver dollar was fomm w the anteriug surface of the left rentriele, while in

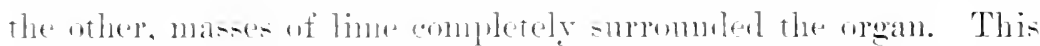

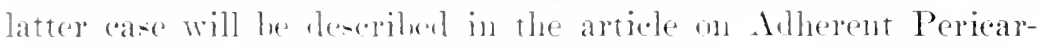

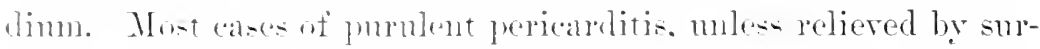
whal interference. pon-me a rapid comber and patients snecumb

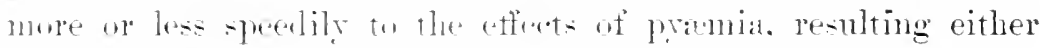
from the pericaldial or luinary affection.

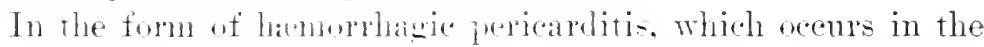

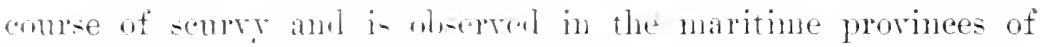
Fins-ia, the effu-ion witen takes place with oreat rapidity and destroys life in one or two dars. In thee cates death seems due in no suall measure to the rapidly induced anamia.

Finally, the course af ante perionditis with offusion is determined not alone ly the intensity of the inflammation. but by the amount of the exudation. If this is sufticient to wreatly distend

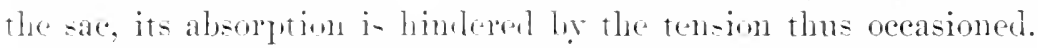
In some instanees, no lombt. a pericardial exmlation is absorbed, and no permanent ill effects lemain.

Physical Signs.-Inspetion.-The degree of information attorded hy inspection tepend- mpon the amomnt of effusion and the comlitions residing in the chest-walls. In a child of tender

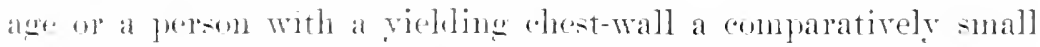
pericarlial reffusion maly areasom pereeptible prominence of the

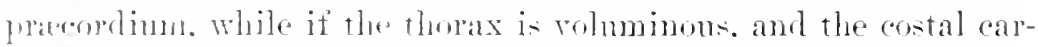

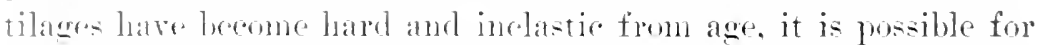

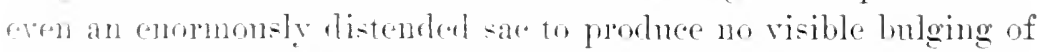

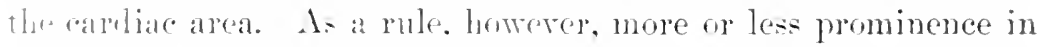
this previon is olserved, while the intereostal spaees look filled out, and the kin covering then appears tense amd shing. The apex- 
beat is not visible, on lnt faintly so, and candiac impulse is foebly diffused or wanting. The alex-leat, moneorer, if visille, may he. situated lower tham nombul when the liver is depeserel by a massive effusion, and in such a calse there may be bulging of the epigastrium.

Cyanosis and distemled reins give evilence of eimenlatory disturbance, while respiratory embatrassment is evineed hy hurred breathing and restricted mowenents of the chest. If copions effusion oceasions great presinte, and particularly if this has formed rapidly, the attitude of the paticut and the experesion of his eomtenance betray suflering and it may be oplupesion.

Inspection is an aid to diagnosis, but cammot sulely le relied upon, since procordial bulging in children may be the result of cardiac enlargencent without pericanditis.

Palpation.-In great effision the ronghenend pericaldial surfaces are removed from carll other, and henee the hand no longer

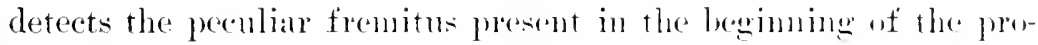
cess, when the exudate is fibrinoms and not semsoms.

Otherwise palpation serves chintly to corpoborate the result of inspection. The pracorlial a rea may impart a sense of incleased resistance from internal pressure, and the normal intereostal depressions are fomd obliterated. Rarely there is fluctution. In-

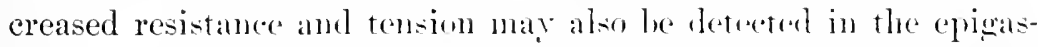
trium. Older writers wore acoustomed to attach great insportance to an elevation of the a px-beat, which they explained hy lifting of the apex of the heart ly the effused liquid. Roherts. Finart. and others regard this as erroncoms, heliering that what was thought to be the apex-heat is, in fact, the implate of the body of the heart as it is thrown against the anterior clent-wall by the collection of fluid behind, the apex of the orean lesing at the same time moved backward and to the left. In cases of extrene eftusion the depression of the diaphragn, oreasioned hy the heary sae, leads to an actual lowerine of the apex-lxat (Jianer). The prericardial fremitus present during the inflammatory stage disappears with the ocenrence of coffusions. In some cases the head of the left clavicle is said be Ewart to be clevated so that the first ril ean be felt all the way to the stermm (" tirst-rib sign").

The most striking eharacter of the pulse is its want of tension. It is rapid and may be regular or irregular, even intermittent. In 
some instances pulsus paradoxus is present. This is an inversion of what is mslally observed during the two acts of inspiration and expination. Instead of hemming stromger and fuller at the end of inspiration and the heginning of expiration the pulse becomes small and wak, or mar cren disappear during deep inspiration, becoming anain stronger and fuller tomald the end of expiration and the berinning of the next astuing inspiration. Pulsus paradoxus is inconstant and is not pathongmbonic when present, and posseses therefore only al negaltive value.

l'erension.-This method of investigation fiurnishes the only reliable sign of pericaldial ctfusion, since ly this means one is often able to determine the presence of so small an anomnt as 100 ("ubic continetres (lianer), 1.20 to 200 cubic eentimetres (Aparti and Figaldeli). 'That one may mulerstand why so much reliance is to be placed upon perension, I will consider for a few moments in what way pericardial effrision alters the normal relation of the farts and modifies the area of cardiae dulness.

The pericardinm is a closed sace. which is thrown around the heart, being wrapper abont the origin of the great ressels above, and attached to the central tendon of the diaphragm below. When fluid is effused into this alesed carity it sinks to the most depend(nt part, and then creping upward distends the sac in all direcetions, mohing aside the antering lorders of the overlapping lungs. The area of absolute ardiale dulness now becomes altered in a striking manner (Fig. 17), and to an extent commensurate with the ammunt of effusion. Some anthorities consider that this alteration of eardiac duluess eorrespmels in shape with that of the distended sac (Baner, Sibson). while others attribute it chiefly to the crowling asile of the hung-margins (Duchex, Roteh). Mr own opinion is that the contiguration of this area depends largely non the anatomical arrangenent of the lung-borders overapping the heart, sines when ther liecome retracted by adhesions and in cardiar dilatation, the shape of the resulting dulness is essentially thes sume, thomgh less rextensive, as in pericarditis with effusion. Probally lwoth factors, the thape of the sac and the arrangement of the lung-borders are responsilnd for the peenliar outline of the arra of duluess oberred. This area of absolute dulness or flatuess is rarionsly described as triangular, prranidal, pear-shaped, or perifom, that of a truneated cone, or " that of a bag of fluid 
spreading out at the batec" (Ewatr). Its broat base rests upon the diaphangm, while its rombed apex oecupies the uper sternal

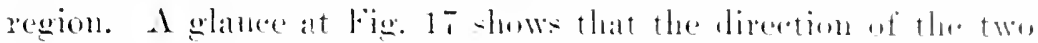
side-lines is not the sante. heing rather more verticat at the right.

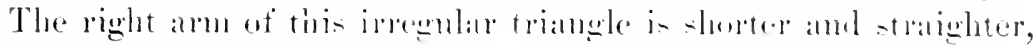

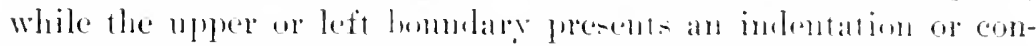
earity soon after leaving the alex, and, shping eradually downward, joins the base-line at a romeded somewhat whome angle.

The shape of this area in ly most anthors eon-idened rery characteristic, althongh shattare in of the epinion that the peenlial feature is not the forms, hut the filet that the dulness spreats ont in

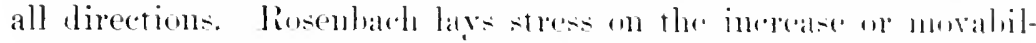
ity of dulness to the right when the pattient lies on his riglat ride.

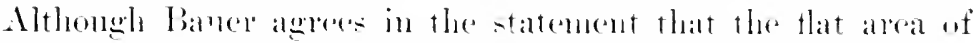

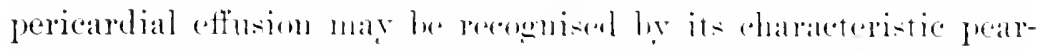
shaped ontline, he mevertheless apmesese the opinim that mere

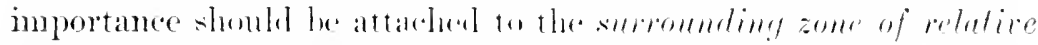

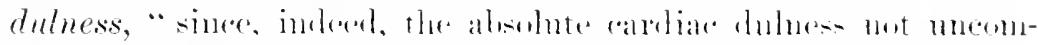

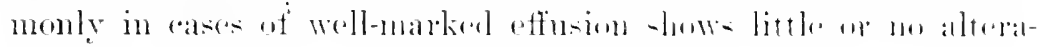
tion."

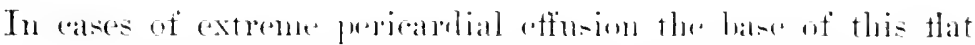

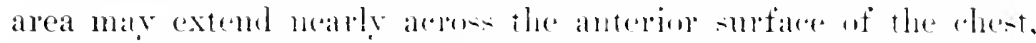
from within, or in some cates even ont-isle the right mamillary line, to a variable listanee outsile the left manillary or to the left anterior axillary line. ln anserpenese of the depereson of the left lobe of the liver camerel he the weight of the distemded sace

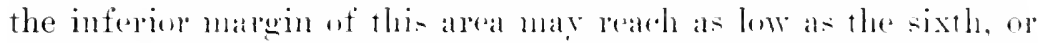

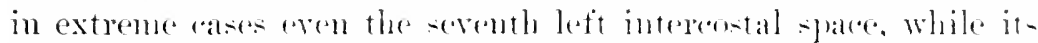

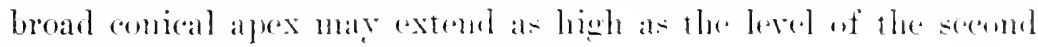
costal cartilage or the first interspare.

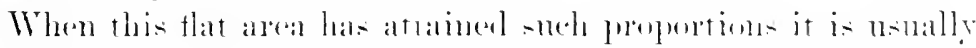
not diflicult to determine the nature of the "ater. Fot, since a

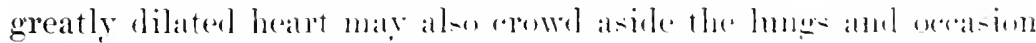
a similar extension of the area of cardiar dulues. erore cam only be avoided be attention to the following prints: 11 , When the

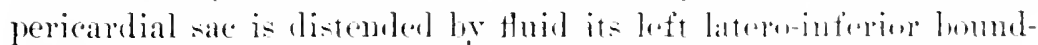
ary extends beront the -ituation of the apex-heat. and lence this latter, as determined liy anconltation, is fomd rithated within and above the extreme left lower angle of cardiate duhess. In dilata- 
tion of the leal't. on the other hatul, it is the orean itself which determines the duhess, and therefore the apex-beat corresponds with the onter and lower linit of atrdiac dulness. Lenbe lays ereat stress on thi- point in the differential diagnosis of these two

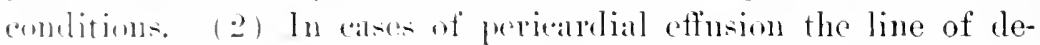
matrattion hetwern the areat of thatness and surromeling pulnonaly resmance is repre alumpt. While in cardiale dilatation the trinsition from flatness th resonaluece is much less pronouneed. bance and simam buth attaldh great importance to the abruptness of this transition in eatses of periealrelial effusion. At the same

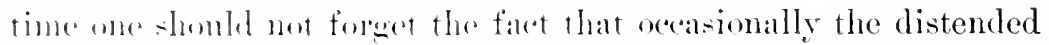
sale may be werlapped ly the lomes, and therefore alsolute dulness mate thate off throngh a suromuling zone of comparative duhness inter full pulmenary resomanere.

When pericaldial affuion takes place the first elange noticeable npun ferension is the development of a small triangular area

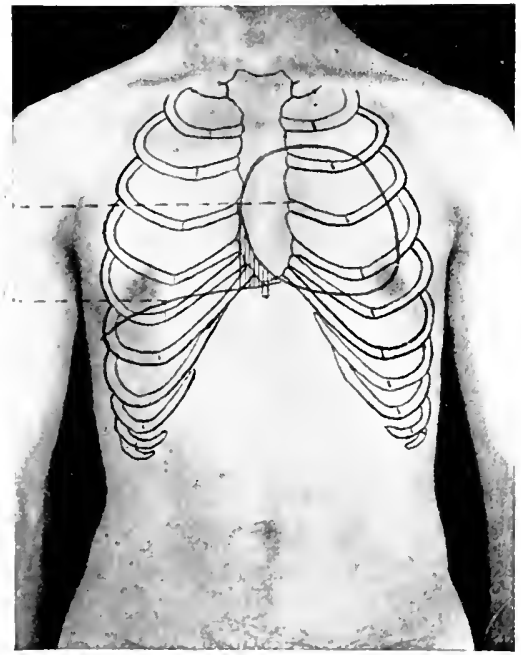

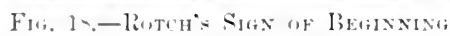

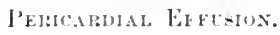

Dolness in shuled area or eardio-hepatic

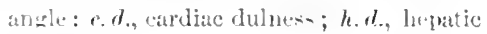
dulne.s. of dnhness in the fifth right intereartilaginons spaee, or, as the (iemuns term it, in the cordio-hepatic angle (Fig. 18). This sign, first described by Rotch, and sometimes called Rotch's sign, is due to the fact that when effusion collects it first distends the sac at its lower right cormer, oceupying the space between the curved inferior margin of the heart and the upper line of hepatic dulness immediately to the riglt of the lower end of the sternum. Ewart and Ebstein have aleo directed attention to the orenrence of this small triangular dull patch.

Normally, the outer boundary of camliar duhnes were the right auricle presents a eurved line, pat-ing from the level of the thind costal ealrtilage downward and ontwal, and, after aroming the fourth cartilage, passes in- 
ward as well as lownwald to join the inforol matrein of the right

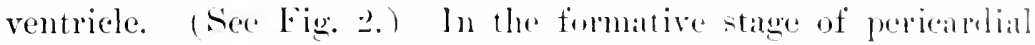

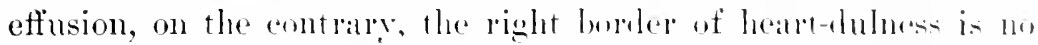
longer eurved, hut pasios directly downwald, joining liver-dulnows at an ablupt angle. Rotrh's sign is therefore of gereat value in determining the begimning of perieamlial effinsion.

One oecasionally sees statements to the effect that an alteration in the extent of carliac eluhness depending upon the patient's position makes strongly for pericanditis with effusion. This is nevertheless a very momstworthy sign, sinee, if the heart is greatly enlarged, it may fall away from the anterior chest-wall in the dorsal decubitus with consepnent dimimutom of eardiac dutness, and in the erect posture again approble the anterior parictes and oceasion a correspmeling inceace in the heart's area. No inconsiderable danger of fatal sineope sometimes attaches to the patient's change of position from the reembent to the ereet, and since the sign just alluded to is of but slight value, one is hamlly justified in thus subjecting a patient with pericarditis to the risk of sudden death.

Arscultation.-- As a rule, the periendial frietion-somnd of the first stage disapleal- with the oceurenee of effusion, to reaplear after absorption has again allowed the ronghened pericamial surfaces to conte in contalet. Xevertheless all writers agree in stating that the persistener of the frietion-somm is not incompatible with a considerable anomut of fluid, even als much as a quart (Cejka), in the periearlial sac. The explanation of the nondisappearance of the friction-sound in such cases is fomd in the presence of arthesions orer the body of the heart. which prevent the separation of the epiearelinu from the periandium, and forec the fluid to the dependent parts surromeling, or in faibure of the sac to be eompletely filled. In other intances the frictiont-somed becomes faint when not wholly inamelible.

Any alteration that takes place in the heatr-somels affects their intensity rather than their fuality, sinere they have to he transmitted to the ear form a distanee proportionate to the recession of the heart from the rhest-wall and through a layol of thint. If the effusion is massive and fills the sac to its utmost capacity the cardiac tones may be inamdible, lut this is so ram that I have never observed a case in which they were wholly absent. In most 
cases the soumds at the apex are feeble, but not wanting, while at the base they are heard more elearly. The pulmonic second sound is aceentuated and the anotic sommel is dinninishoul.

In a recently obsered cas of extensive pericardial effusion in a child the cardiac impulse. the someds, and a previously existing endocardial nummur all rematined distinct orer the body of the oram, and were attributed to the presence of adhesions that had forred the thind to the side of the sale.

sccondary Physical signs lieferable to the Lungs. - Taluable information of the existence of pericardial effusion may also be oltaned hy exanination of the lumgs. The retraction and compression of pulmenary tisine aecasions a loss of normal pulmonary reomance in the neighbomblomel of the sac. In the left infraclavicular region perens-son elicits Skodaic resonance, or if the conpuresion be rery great, impaiment of the note. Both Pins and

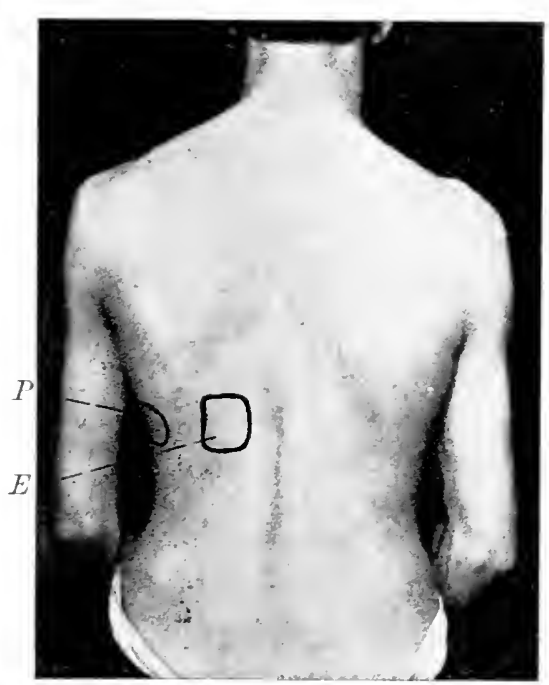

Fug. 1:-Location of Pulanonary changes

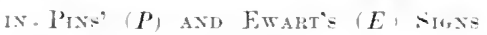
of Pericarihal EfFusios. Ewart have called attention to ertain changes discoverable by percussion and ausenltation at the posterior base of the left lung. The "Pins' sign" is duhness and bronchial breathing in the left infrascapular region, which, upon the patient leaning forward, give way to tympanitic resonance, crepitant râles, and finally resicular breatling. This dulnes and bronchial breathing can hardly he attributed to plenritic effuion, if one bears in mind the curved upper line of the dulness in this latter affection.

Exart has described a posterior patch of dulnes. in cass of extensive pericardial effusion -itnated at the hase. and which, oxtending from the spinal column ontwarl nearly or anite to a line corresponding with the internal lowder of the seapula, turns abruptly upward at a right angle, and, after reaching the level of the ninth or tenth dorsal spine, again 
turns sharply inward to reach the sile of the vertehtral column (Fig. 19). Over this patch hreath-sounds ate watuting and roice-

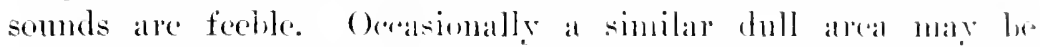
found to the right of the spine. Ewat atributes this sign to "altered dorsal relation of the liver." Immediately belnw and to the left of the tip of the left seapmla, experally in ehildren (Sansour), is a dull pateh of about 2 inches diameder, in which are bronchial breathing and bromehophony or anplone Ewart has also directed attention to a sonewhat inconstant sign monsisting of a small area of bronchial breathing in the right mamillary line, between the right nipple and the uples surface of hepatic dolness.

Diagnosis. - Is a rule it is not difficult to leterumine the existence of pericardial exudation when this is abumlant, but it is not easy nor always posible to determine its nature. If the pericarditis arises in the combse of articular rhemmatism, and signs of distention of the sale present themselves, the cxulation is probably

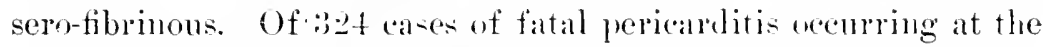
Berlin Charite hetween 1 o6ti and 1st6, and which were analyzed by Breitung (Fichlorst), scro-fibrinoms was fomml los times, a against 24 of purulent and :30 of hamorrhagic exmlation. Finthernore, the nature of the primary affection to which the pericarditis is attributable is of diannostic signifionne, since it is likely to detemine the nature of the exulate. If the inflammation oceurs in the contere of septicamia, or results from extension of empyema, or trom the perforation of a gastric uleer, from a perforating womel, ote. it is likely to be purulent. The appearance of distinct septic phenomena, rigors, and an irregular intermittent ferer, profuse perspirations, ereat and rapidly increasing prostration, a dry, coated tomenc, diarlucea, etc., warrants the diagnosis of properinalimm.

If signs of fluid listention of the sac develnp rapidly in the comrse of scorluntus or pmrpura hamorrhagica or some other dys-

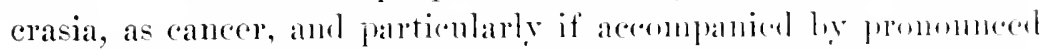
and rapidly increasing anduia, the probability is in faromr of a hamorthagie pericarditis. Inasmuch, however, as surh theoretical distinctions in the symptomatology of the thee varieties are not always clearly defined, a differential diagnosis is often only possible by means of exploratory puncture. 
Differential Diagnosis-Before considering the differentiation of thid-collection within the pericardim from eertain other comlitions with which it may be confounded, it is well to speak of the diftieulty of diagnosis arising from pulmonary emphysema and old adhesions that date from a previons attack of pericarditis. Emphysena may prevent the lung-margins from being crowded aside, and henee the eharacteristic area of cardiac flatness may not exist. In such an erent reliance must be placed on the outline of deepreated dnlness. and this failing. absolute diagnosis is hatrlly prsible: When oll athesions exist over the front of the heart they force the exmlate to accmunlate at the sides and bottom of the sale or to be pent up poteriorly: Acemmlation of fluid along the lateral and inferior margins canses increase of dulness in these sitnations, its triangular ontline being fairly well maintained. In ardition, the cardiac impulse and tones, together with the friction-ruh, remain both palpable and andible over the body of the organ.

When effurion is confined to the posterior aspeet of the sac its recognition is mont difticult, if not inpossible. In such a case one must rely mainly on the smptoms of (1) inflammation, as pain and ferer, and ( $(2)$ of a leeply situated collection of fluid and pressure on the esophagns and hronchi, drephagia, and drspnoa. The last two smptom are rery suggestive of exudation into the posterior portion of the sac. Ilasil calls this an Enersted Pericarditis with retrocarliac effusion, and ays its srmptoms are so obscure that one can do no more than diagnose the pericarditis withont being able to decide whether effusion is present or not. He thinks that dnlness at the left posterior base with mufting or absence of heart-tones in this region. together with signs of pressure on the resophagns and of artive pericardial intlammation, are strongly suggestive of a posterior effusion.

Dilatation of the heart in the condition which most often has to Iw. differentiated from pericarlial effusion. The enlargement of the organ canses retraction of the lmg-borders and an area of dulnes very like that of eftusion, and if the heart-tones and impul are very frelle, from fatty degeneration, a preeise diagnosis may muler certain cirennstances be extremely diffienlt. The main whint on which reliance is placed is not. as sometimes stated, ereater distinctness of heart-shock and sounds in dilatation as 
compared with eflusion, but is the position of the apex-beat with relation to the outer and inferion marein of hulnese (nee page

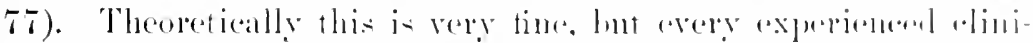
cian knows that in many ases it is impossible to sal dofinitely whether they eorrespoml or not wh aceount of the indistinctues; and diffuseness of the cardiar impulae. I one saw the late distinguished ron Ziemsicn, one of Gormany"s most skilful elinieal teachers, make a mistake in just sluch a calse. The pationt, who was in extremis. was plesented to the rass as an instance of massive pericardial exmbltion. There was a large triangular area of absolute cardiac dulness orer which impulse was wanting and

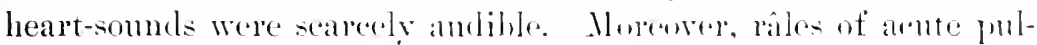

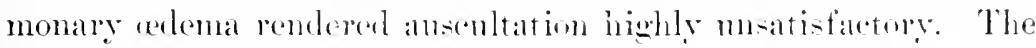
antopsy, next day, disclosed a fitty aml extremely dilated loant,

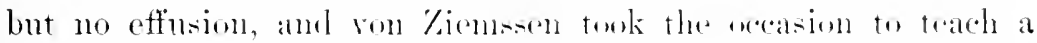
most instrletive lesson on the diffienlties of differential diagnosis.

Should it prove inposible to locate the apex-iunpuline in the reembent postme, the patient may be shely and cant ionsly lifted into the erect position in the lone of the heart aratating forwarl, and thes declaring the situation of its alpex. If hhis not entirely safe puredure tails. then aid may sometime be derived from careful stmely of the pulse, which in poricaldial etfusion is said to oceasionally he lelatively strenger than the feetheness of the heart-sommls womld lead ome to expert.

This is also a theoretionl print which I have nerel fomm to stand the test of practionl experience. When a pericardial exmdation is massire, as well as when extreme dilatation simulates effusion, the equilibrim of eirrulatim is lost, the reins ane overfilled, and the arterial sytem is empotr. so that, as a matter of faret, the pulse of extensive reftusion is small. weak, amel rapid. Shombl all attempts to arrive at a differential diagmes fail, them. as sllggested by Lenbe, we may have roumber to digitalis and other therapentic measures in the liope of eloaring up the condition. In dilatation proper treatment may revire the tagerwe heart and restore the apex-beat amb hoart-somels, while in periearlitis it may cause absorption of thuid and a reaplearance of pericardial friction.

Pleurisy with offusion may be mistaken for pericanditis, or rather a pericardial may be considered a plenritic effusion. There 
is much smilarity in the pain, ferer, and dyspmoa, as well as certain presolue-effects, lut error is aroidable by attention to the following points: (1) In plemitic ctfusion there is a curved line of flatmess which extends from the back around the side to the front, wheh line usually shifts with rhange in the patient's position. (2) I left-sile effinsion (the only one likely to lead to error) pushes the heart over to the right of the median line. (3) Breathsommds at the left base are diminished or absent, instead of exagecrated or bromehial, as in prepoarlial eftusion. (t) Dysphagia is very lanely if erer present in plenrisy. (5) In pericarditis there is usmally a history of rhemuatism or other acute infections. proeess to bad to calrdiar involvenuent. In an adult a differential diagnosis between these two affections is seldom difficult, but I have seen young ehilhren in whom it was at first not at all easy to say which was the process. owing to the great compression of the left lumg and consepuent extent of dulness laterally and behind.

The foregoing are the only two affections likely to mislead; pet the careless, and still more the inexperienced, may mistake for pericarditis a number of conditions that oreasion increase in ardiac dulness upward and to the left. These are nediastinal tmmours, which crowd the lung-margins asirle and displace the heart, and pulmonary tuluremlosis or old plemritic adhesions, which eanse pernanent retraction and fixation of the anterior border of the left lumg. Error omght to be avoided, howerer, by due attention to history, symptoms, and physical findings. The history is that of insidions commencenent and slow comse-symptoms are thone of a chronic process without ferer, exeept, of course, in the ease of pulnomary tulerendosis, when there is characteristic suntum to act as a gnide-and as regards elinical findings, the dulness lacks the distinetively trimgular shape of pericarditis with effusion. Time settles the diannosis beyond question.

Prognosis. - This lepends npon the nature of the exudate, the rapirlity of its formation, its amount, the effect, both of inflamuation and reonlting effusion mpon the myocardium, the ex-

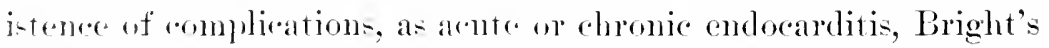
li-rare, tmberemlosis, ote., am tinally. the age and vitality of the jaticint.

Supunatire pericarditis, mules reognised and treated surgically, is rery likely to prove fatal, and yet, as previously stated, 
if of rather a benign type the thid portion of the exulate may ultimately become absorbed, learing a cheess, and at times a ealcareons, unass behind.

Pericarditis hemorhargica anta may lestroy life within a few days. When the malarly is chronie, its prognosis is essentially that of the scorluntus or wher prinam affection.

An effusion of whatever natme that forms rapjelly and to a large amomit is always serions, becanse time is not allowed for the system to adjust itself to the altered conditions. Such a ease may speedily prove fatal. If the inflammation extends to the myocardium, or if this latter hats nutereone previons degeneration, the heart-muscle will be ill prepared to sustain the pressure exerted by the fluid confined within the tense and resisting sac. Serious eirculatory and respiratory embarrasinent, or the pessibility of fatal syncope, renders the immediate pongusis most grave.

Acute endocartitis is a repions complication, and the existence of a chronic ratrular lesion ocosions a degree of grarity which might not be the case if the periearditis existed aldone. It the disease oceurs in a person with acute or ehronic nophritis, or if pulmonary tubereulosis coexists, the patient is harlly in andition to sucessfully cope with the oremrence and long huration of an exudative pericarditis. Moreser, roming on as it does toward the end of chronic nephritis, the pericarditis contributes largely to the fatal result.

Finally, emphasis has been repeatedly lad on the serions nature of periearlitis in ehilken, owing to the frequeney with which it implicates the heart-nuscle and the strong likelihood of its leading to cardiac dilatation. In children, therefore, the immediate, as well as the nltimate prognosis, is serions. In oll people and those enfeebled by some chronic malady that has hronght them to a state of eachexia there is small likelihood of the pationt surviving until tine an bring about absorption of the effusion.

In all eases, eren when death does not result direcely from the acute inflammatory or exulative proeses, there is a possibility of the heart being erippled by inflammatory damage to the myoeardium, or by partial or total obliteration of the sale. Of the 321 cases analyzed by Breitung, there were ciremseribed adhesions in 111, and complete adhesion of the periearlimm in 2:;. The remote prognosis depends upon the richness of the exulate in fibrin; in 
-mell the likelihood of allhesions is the areater. Pericardial inflammation, therefore, of whatever nature, shonld never be looked upon is a trivial complaint.

Treatment.-We poskens no means of arresting an attack of fericarditis, and therefore we nust content ourselves with endearomring to combat the rhemmatisn or other affection in the course of which pericandial inflammation owecurs, in the hope of preventing the latter. 1t. nerertheless, the sac becomes involved, we must strive to lessen the reverity of the proeess, and this failing. to relieve sumptoms and sustain the powers of life mutil the diseatie connes to a natural termination.

Inasumch as we are powerless to abruptly terminate pericarditis. and it oxemrs most often in the eonrse of articular rhemmatism, every pesible effort should be made to ent short or mitigate the intensity of the rhemmatic attack. This is no place to disenss the treatment of the latter affection, ret I wish to record my confirlence in the salieylie-acid treatment, especially in metlyylsalieylate, both locally and intemally. If this is not a speeific, we at all events poses nothing betres, and nust await the time when definite knowledge of its nature may supply ns with an efficient weapon against rhemmatism.

The importance of plyysicel rest cannot he too strongly insisted upon wheneres ferer or other rhematic symptoms make their appearance. This is particularly wise in the case of children who have an old-standing valvular lesion. Such children ought to be seen by the family doctor whenever sure throat or other suspicions symptoms arise. Physical exertion by increasing the foree and frequeney of cardiale contractions, tends not only to intensify pericarditis when it is alraty present, but may even determine its development in the same way that nse of a rluematic joint may aggravate the arthritic. If an alult is mwilling to submit to rest, he shomld be informed of the posibility of endocardial or perieardial inflammation, and thus perhaps be induced to take proper care of himself.

When periearditis onere sets in, mealsures are indieated to lessen its intensity. Tesication of the precordia was once extensively need for this pmrpoes, and there are still many physicians who lolime in the effieacy of this treatment in the initial stage. Per-mally, I am seeptical of the influenee of blisters in this regard, 


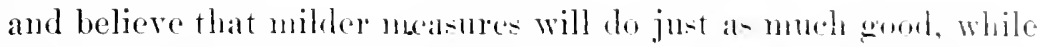
at the same time saving the patient from the pain and diacontort of a large blister. The real benefit of resication, in my opinim, is found in the rolice of pain, and therefore I think it is preforeable to adopt small blisters, a fresh we heing applied so sorm as

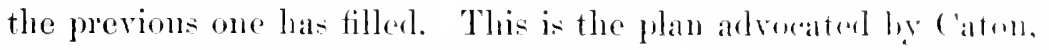

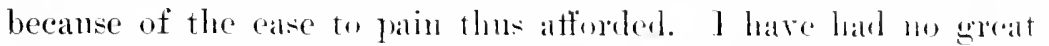
experience with this mode of treatment, becamen I prefer the application of cold to the cardiale area. I know that comnterirritation often eases the suffering encasioned by inflammation of serons membranes, and therefore alvise that if cold is not well borne and the intensity of the initial pain secms to call for some. measure of the kind, that this be a sinapiom mate of English numstard by the nurse, and that it be left on mutil the skin beenume thoroughly reddened. When the mustard-dranght is remored, it: place may be supplied hy a poultice or by hot founcutations. Noint heat to the precordimu gives great relief in sonte alses, and is much extolled. Roberts applies 2 or : lecehes over the heart in suitable cases, but as a rule finds poulticing in the early stage gives positive relief to pain.

Lees is a strong adrocate of the contimuons nse of the ice-bag, and asserts that it not only gives comfort by alleriating pain and palpitation, but tends to mitigate tle sererity of the intlammatory process. This mode of treatment has always applated to me ats rational, and in all cases in which I have seen it: use faithfully tried it has appeared to be very comforting and agreable. The ieebag must be light, so as not to oppress the patient by its weight, and should be held in place by a cord passing aromel the neck. As the sufferer is nomaly in a semi-recumbent pasture, the bag, thus suspended, rests lightly on the pracordia without danger of slipping off. Furthermore, the jee-hag must not be allowed to rest against the bare skin, as it is apt to occasion irritation, but a small piece of dry, thin cloth is to be interposed between the surface of the ehest and the bag. In this manner the bag is generally well borne, when hefore it amld not he endured. Children are sometimes measy at first, ret if the application of cold is firmly insisted upon, they not only loam to tolerate it, hut actually find it soothing. Should jeliosnerasy render an individual absolutely intolerant of cold, then it may be replaced ly poultices. IIot fo- 
mentatins aro objectionable on aceount of the liability of their weting the clothing, and of a chill when the choths are changed. In the emplovment of the poultioe due attention should be paid to the principle that to be eflicacions it must be hot, not merely warm, and must be replaced by a frosh one so soon as it grows cool. Ithen at length poultices are discontinued the surface of the ehest must he coreded by a layel of aotom ar flamel.

Treatment in the inflammatory stage is largely symptomatic, and in most cases something more than either heat or cold is requiped to allay pain and restlessness. In mild cases an anodyne liniment, as belladoma, chloroform, or one containing morphine, may suftice, and shomld be triced hefore recourse is had to internal medications.

When pain and restlessness ale severe nothing is so serviceable as opimn in some form. In the case of adults a hypodermic of morphime is the but; to children it is far better to give the remedy hy the month. Their well-known susceptibility to the drug makes it adrisable to try the effect of colleine before resorting to opium or morphine. In some cases it will be found that a combination of codeine and sodium bromile will act efficiently and render more powerful remedies nunecessary-a consideration to be always borne in mind with children.

Besides allaying pain and quieting the little sufferers, these agents tend to lessen the violence of heart-action-a desideratum of importance-and to promote slexp). Insommia is often very tronblesone, and when not orerome it contributes greatly to the patient's nerronsness and inaliblity to hear well the strain of a protracted ilhess, which, like pericarlitis, makes great demands on the pationt's powers of culurance. In oprate steadies the nerves, and if it does not too ereatly distmrb digestion and secretion I brelieve it cruel to withlold it in cases characterized by the forewoing symptoms.

('ough is an annoying foaturo in some rases, and when this is so it affords an arlditional rason for the arministration of contrine or morphine. I preferable remedr, however, is heroin, which to an alult may be given in the dose of $\frac{1}{12}$ grain, and to (rhilelen in poportionately smaller amounts. It not only allays anch officionty, lut is levoid of the mupleasant after-effects of morphine. 
Nausea and romiling may in some arses tax medieal skill to the utmost, and, as in a recontly ohereved instanee, defy all at

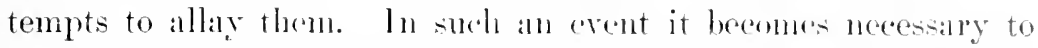
stop oral adninistration of fond and medicines, and to rely on enemata in the hope of the stomach hecoming guicet.

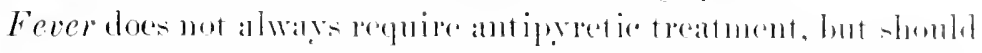

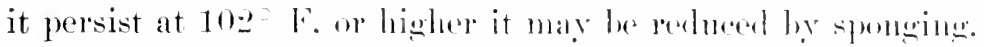

In this carly stage refped, restent artion of the heat is often

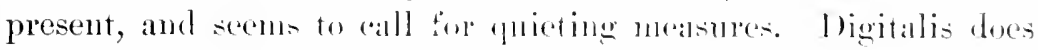
not appear to me to be indicaterl, for talchrourdial is now not at manifestation of wakness. hut of irritation, and in my experience the heart does mot bealr kindly attrunte to slow it ly digitalis. Neither shoukl aconite or veratrum be preseribed for this purpose, since they are too depressing, and the heart $j$ s likely to need all its reserve force befone the strugerle is over. I helieve no therapentic measure is more chlicient in quieting the orean than an ice-bag worn contimuonsly.

The routine administation of digilatis is objectionable in any form of eardiac disease, and in periearlitis is esperally so. The real indication for its nse in this affection is not merely rapidity of the pulse, hut feehleness, together whit rapidity. Throptore. should the unchecked tachyeandia hewin at bongth to toll on the heart, or should the organ furnish signs of dangerents dilatation with seantiness of urine and other evilenees of riscoral congestion, then it is well to proscribe digitalis. The lopolomie administration of digitalin does not seeme to mo so reliable or ceffective as the internal nse of a fat free tincture, or of the infusion

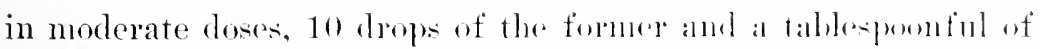
the latter to an adult, and to a child a proportionately smaller amount every four to six lomm.

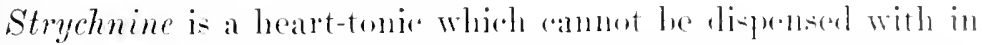
this stage. Its dose does not need to be lanere at first, perlatps fio if the patient is grown, $:$ or 4 times a day. It may lu giren hy the mouth, but muler the skin is proferible, since its action is more direct and powerful.

There is always a more ol less promommed tomelemery to eongestion in periearititis, the liver feeling tho brunt of the attack, and henee being menally palpable. ('mscumenly it is well to relieve risceral and portal congestion by a mild daily laxative, calo- 
mel or a saline aperient water. Yigorous depleting measures in the inflammatory stage are harmful, however, rather than benefieial, and should be rescrved against the time when fluid aceumulation oceasions distress.

Food must be light and nutritions, consisting largely of milk and nemrishing somps and broths, into which a raw egg has been dropped. If ferer is not high, and the patient's condition demands healrtier food, this nuly be given in the form of chicken, raw orsters, a hird, or a small piece of carefully broiled beefsteak, with toast or light bisenit. In occasional eggnog is also excellent. It is better to feed these patients often and in small amounts than to supply them witle a hearty meal only :3 times a day. Pure or slightly acidulated water should be given freely so long as ferer and thirst are present. It also promotes excretion and protects the kidneys from the injurions effects of toxins. In most calses skilful mursing is far more necestary and heneficial than medication.

Treatment in the Stage of Effusion.-With the appearance of exudation and abatenent of active inflammation, symptoms of presure supervene and demand attention. The object of management is now threefold: (1) to restrict the rapidity and amount of effusion, (2) to aid the heart in its attempt to maintain circulation, (3) to promote removal of the exulate by absorption or otherwise.

In my opinion, it is very doubtful if we possess any means of limiting the amomi of effusion, since we have no criterion by which to estimate the efficiency of measures employed in any given "are. 1 single large blister or a sncecssion of smaller ones over the pracordia is recommended ly some anthors; but what assurance have we that the withlrawal of sermm in anywise diminishes the anomnt poured out in the sar? As a matter of fact, the quantity of the exudate, and the rapidity of its formation, are determined ly the intensity of the inflammation. If, therefore, we are to leson the anount of effusion, we must restrain the activity of the inflammatory process. Nleasures to this end have already been discussed, and althongh mulombtedly they should be employed, their utility is open to dombt. I pass, therefore, to the consideration of the second object of treatment.

In some cases effusion takes place with such rapidity and in- 
duces snch megent presine-sinptoms that smrgical interforence has to be resorted to withmit delay. More often, lomerere, indiations of pressure alpeale sowly, and time is afforded for a trial of medieinal troatnent.

Absolute rest is now injerative, and the paticut, if nhl entush, must be advised of the nexesity at refinining from any suldem

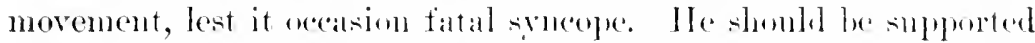

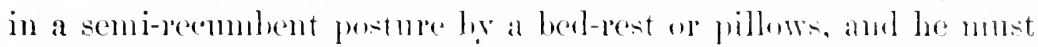

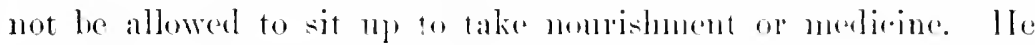
should be distmbed as little as presible for the pmrone of examining the heart.

The state of the coundation, as shown ly pulse and remons engorgement, is to be calefully watched, and so long as lhe quality and rate of the pulse romain good, stryelnine may les the only heart-tonic required. So soon, howerer, as the pmlse shows dicoro-

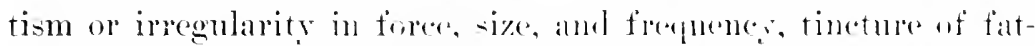
free digitalis must, he ordered in doses suitalle to the age of the patient-to an adult 10 drojs every fom to six homrs.

The daily equntity of mine shomld be accurately noted, and in these cases a pronounced falling off of its anomut is an indieation for digitalis, even thongh the pulse remains fairly goot.

Careful examination of the liver will always detort more al less engorgement of this organ. Palpation of the liver is often painful or unsatisfactory by reason of abdoninal distention, but we know hy experienee and deduction that stasis within the por-

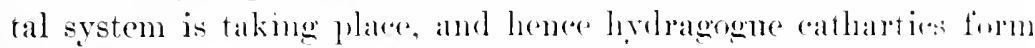
an important, nay an indispensable, part of our therapentice neasures in this stage. By depleting the portal syotem catharsis aids in maintaining the venoms circulation. Insteal of wakening the patient, it adds materially to his comfort hy lesinengepigatric pain anel relieving abdominal pressme.

Sleep should be indued ly a lypotic, for wothing will more surely tend to exhanst the novous system than insommia. I have sometimes found that the adlition of a : or $\stackrel{1}{2}$ erain of cordeine to a sulphonal powder iusures the action of the latter. At this stage morphine or a preparation of opium is to he given with rery great caution. It may he indicated by dyspmal of restlesiness, but actual danger attend the adninistration of the drug, through its depression of the respiratory eentres. If it he given to allay the 


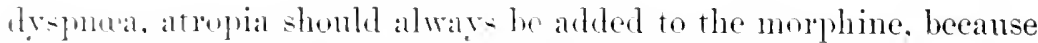
of its well-knewn effect in lexpening respiration.

The pasive congestion within the ablominal eavity inpairs digestion and lesens alisolption, ret nomrishment is imperatirely

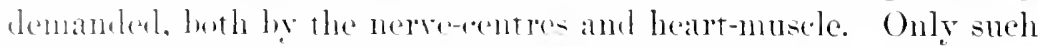
firml shomlel be given as an be easily assinilated, and as but a small anoment shomld he taken at a tine, it shonld be concentrated and highly mutritions. Sime of the prepared foots will now be fomme to be of ereat serviee.

Whes by the subidenese of the prexia. if that has existed, it is jutged that the actire intlanmatory process has ceased, or when lepeated examinations of the heart indicate that the amount of eftusiom is stationary the purery naturally arises. What means are to he emploved for its remeral! shall an attempt be made to pomote this hy absoption, or shall paracentesis perieardii be performed! This bring mp the question, is alsorption of the effusion posible! Clinical experience certainly gives an affirmative answer. Theorotically, absorption of the exudation may be hinkered or prevented by an abmelant coating of fibrin orer the surface of the perieardimu whereby the thid eamot reach the

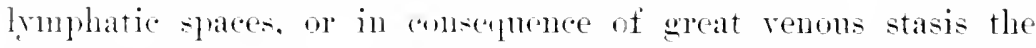

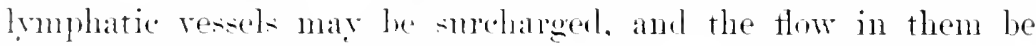
ton slugei-h to promote artive absorptim. Terertheless, partienlarly in rhemativ cases. experience affords ahmond pront of the frepurent, even rapid, alsorption of extensive perieardial attilision.

Therefore. I leliers the phrician is culpable who refuses to make the attemit at least to carry oft the fluid by a resort to dimetic and eathartic remedies. I great legree of renous stasis often nemtralizes the effect of dimretics mntil congestion within the

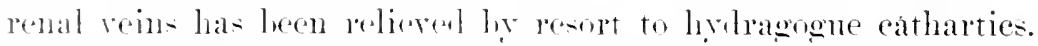
The two clases of remedies shomld be conjoinest therefore. In mar

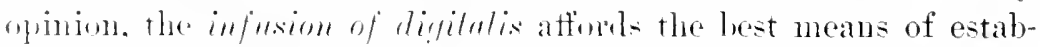
lishing fore thoresis. I tablespenful to legin with may be administered to an alnlt wery fomr homrs. While the patient also pereive latily some mirritating wathartic. rapable of indneing a number of copions watery stome. I lawe seen truly astonishing pesult- follow smeh a plan of treatmont. This is well illustrated hy the ase of a boy ut seren rears with mitral regurgitation of 
rhemmatic origin, in a state of perfect eompensation, who hand heen meler occasional abervation for a rear.

On May 9, 1s!!!, he developed what appealled to he a mill wate of follicular tomsillitis, for which he received alpleperialde treatment. Three dars later he was repolted net on well, and at my

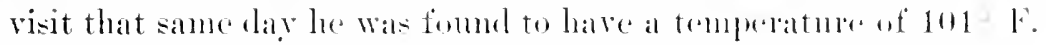
He complained of vagne pains in the linees, which were not reddened or swollen, hut showed an erythema. As the attark was m-

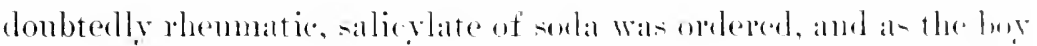

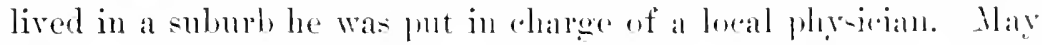

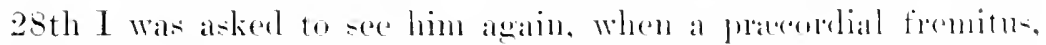

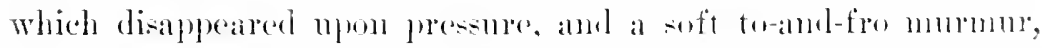

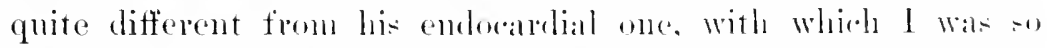

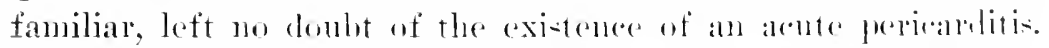
The attending physivian stated that these firetion-mummurs hard developed a few days previously. By Jume onte the aletual increase in the alea of calreliar. dulness avive arielenes of the ocempener of effin:iom, though the cardiale inpulse and tirietion-somnds still persistod orel the bodre of the orean. Pyrexia was momlerate, pulkr 120, of good quality and repirations were alcoolerated. In ice-bag land her'll worm nost of the time sines May 2-th. althongh pain harl at nu tims been a rery matied toature. From now an the exullation increased stealily in amount until, by . Jume outh, the (x-

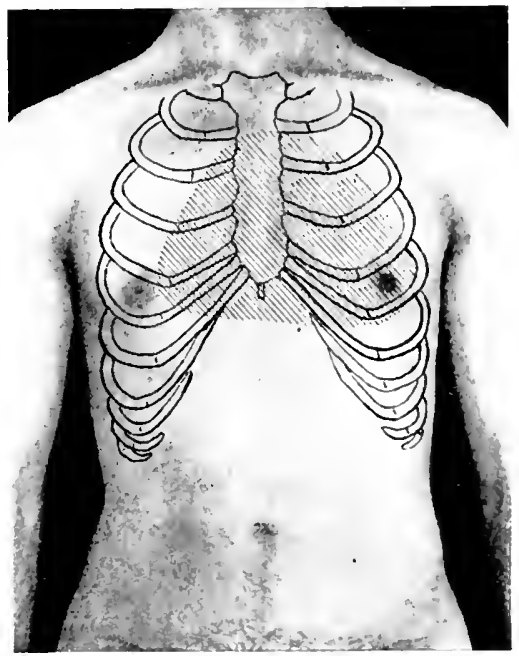

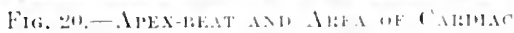

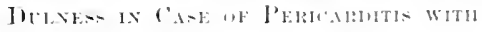

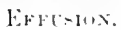
treme limits of andiale duluese rateled from just within the right nipple, quite to the left axillary line, fal ont located apex-buat (ser Fig. : 01$)$.

The persistence of the pericardial rut, somewlant less intense, to be sure, together with palpable andiale impulse wer the hody of the beart, and the distinctness of the heart-omels and of the 
mitral regureitant mumur. were thomght to inclieate the existence of alluesions on the anterion surfiace of the organ and to have prevented the offued thid from corering orer the heart. That the offu-ion was eonsiderable was erinced by the great distention of the sac laterally and downwel, hy great pressure upon the lungs, and pronomed cinculatory embarrassment. There were marked cranosis, distrution of the superticial veins, great enlargenent and tendernes of the liver, and slight ankle oedema. Respilations were to, pulse 1 th, mall, and dicrotic, but still regular. salicylate uf sola had heen discontinued upon appearance of the effusion, lest it might too greatly depress the heart, and as the scantr mine was highly acid, bicarbonate of soda and citrate of potath had been smbtituterl. A = digitalis and mild cathartics had failed to apprecially diminish the amonnt of effusion, surgical interference was decided upon.

The selection of the site of pmeture was left to me, and, believing that in consequence of arthesions orer the front of the heart the exudation could be most smely reached at some lateral

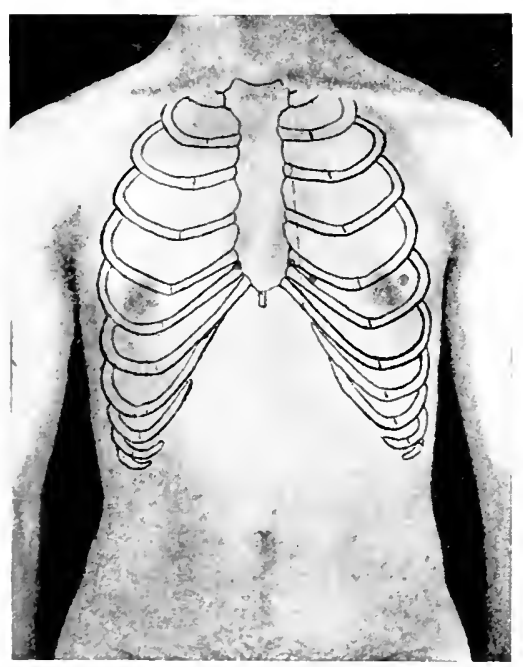

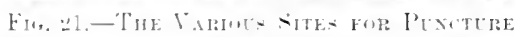

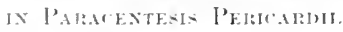

Fotted line indiates course of internal mam mary artery. point. I selected the fifth left interspace, between the apeximpulse and the onter margin of Hatness (Fig. 21). Aceordingly the surgeon introduced his trocar in that situation and obtained fluid. This was distinctly blooly in appearance and -o surprised the operator that after permitting an ounce or two to thow he withdrew his annula for the purpose of dis(n--ing the significance of the blowl. We concluderl it was a hamolrhagic effusion, and adrised a fresh tapping. This was sow oljected to by the parent: on the ground that nuce at a time was enough, and a reletition of the procelure wa- leferred. It was never lemated, homeror, and hecanse of the following eonsiderations: 
The great obstacle to absorption vas belioverl to lie in the musemons congestion within the purtal system, and the lays lis-

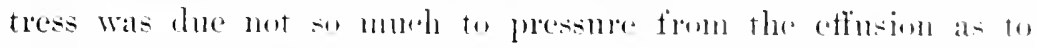

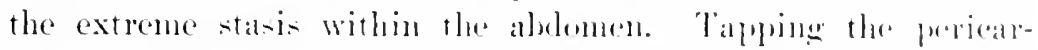
dium might relieve the heart, but with all the comblitions prose ent in the mitral regurgitation for the maintename of hepatie: engorgement it could not materially improse the state of thinges in the portal system. ('umesepuently, with the heart-musele showing no rerge theatening signs of failule, it was thenght best to make one last rigoroms molanght on the star-is within the hroutie ressels. Accordingly a drachum of the satumaterl solution of Epson salts was ordered homly until it bram to exert effect. At the same tine a drathm of the forsh infosims of digitalis

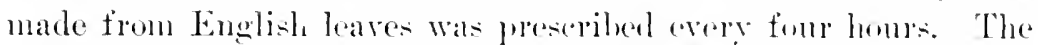
results were astonishing. Siereral doses of the matenesia snlphate were taken next moming withomt any rey malken offects upon the bowels. Int instead the kidnoys heanto to act, and in the next twenty-fomr homs limesis amomntenl to something like 8 quarts. Sot only did the patient $=$ lyspunal lesen, lut the area of eardiac lubess hegan promptly to liminish in size, the liver beeane softer and lose teuder, and the patient's improvement was clearly noticeahle exen to his parents. The salts were comtinued daily, thomgh with gualually diminishing amomnts. After two or three days sirup of spuills wats alded to the infusion of digitalis, and the prosese towards recovery entimul withomt interruption. This little patient lived nearly three rears, and then

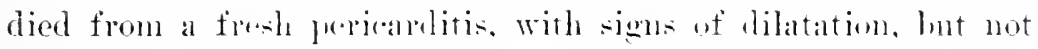
effusion.

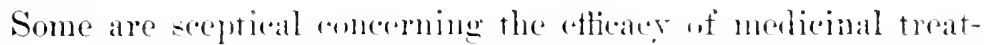
ment in promoting absuption, hasing their objections on the faet that absorption sometimes sets in spontanomsly. eren after the pericardial effu-ion hals romained statimary for sme time. Nevertheless, in this atse, the chamge for the lutter began so som after the administration of the matenesimm-alt that I heliose it can be justly regardul as an instance of propter hoc. nut post hoc. Enfortumately, the result of therapentie measures is not alwars so

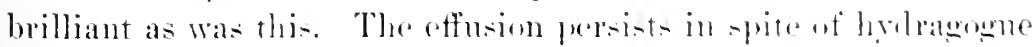
eathartice and diuretics, or the exmlation takes place so rapilly and copionsly that it thratens to overpuwer the heart before time 
is allowed for remedies to exert their effect. In either event the perieadium onglat to be tapped, and it is best not to delay. It serms to me there can le no question concerning the indication for paraleentesis in such cares, but early in the disease I see no call for surgieal interterene so long als alaming pressure-symptoms do not supervene.

Nites for Puncture.- l'mentery performerl, this operation is safe, and ats it is likely to afford prompt relief, one should always stand ready to tap whenever sneh intervention is indieated. The indications are not alway fomend in dyspmea, cyanosis, and rapidity of the pmbe: these romptoms are present in all eases of pericardial offuion of contiderable annount, but indications are present whenerer the heart show- eritence of dangerons weakness by syncopal attacks and intermittence, or when sutficient time having been given for spontaneons recovery, or for absorption through medicinal treatment, these do not take place. Paracentesis being decided an, it only remains to select a suitable point for puneture. Varions sites (see Fig. ․1) are reemmented, and all aim at rearling the fluid most readily withont fear of wounding the heart, interual mammary artery, or other struetures.

The point most nenally recommented is in the fifth left intercostal space at a safe distane from the internal mammary artery. A: this iases dewnward from $\frac{1}{1}$ to $\frac{1}{2}$ inch from the edge of the sternmm. the needle may he introhneed either very elose to the sternal fromer, so as to be hetween it and the vessel, or at the onter sille of the artery 1 incls or more from the bouse. Rotels prefers the fifth right inter-pare are to the stermum. sinee at this forint the sale is sure to be distended, even should the anomt of fluid prose maller than is anticipated. Shattuck has punetured in the fifth left spare, 1 to 2 inches outsisle the nipple-line, just within the left lateral border of earliare lulness, where, as a matter of fart. I adviced talphing in the case narrated, although at the tine I was not aware of Shattmek's recommendation. The objectim ureed against this site is the possibility of wounding the lunera at this print. This is, of course, a cogent reason, yet if the sale is greatly distended it will have puthed the border of the left hung well aside, and the perieardimm will ocenpy the region monally filled ly the lung. In my ase fluid was readily reached, ant the surecon was contislent he did not touch the pleura. An- 


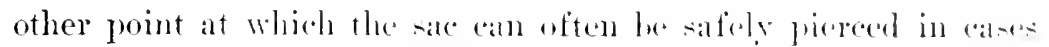
of extensive offusion is in the angle hetween the leti matrin of the siphoid cartilage and the aljacent costal callilateres. The Hoid

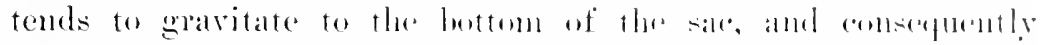

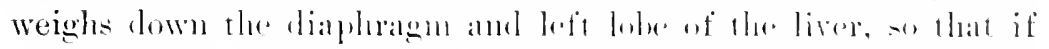

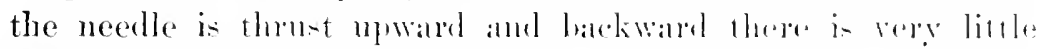

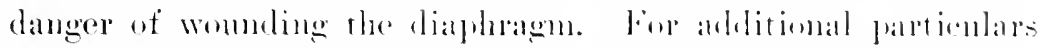

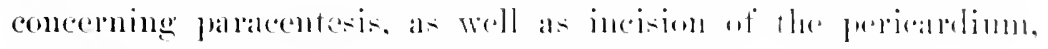
the reader is reforred to works ans surerery.

Whether all the rffusion presible is to be withellatwo ar

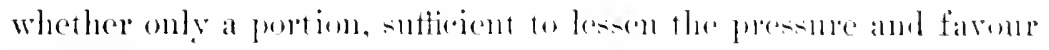
subsequent alsomption of the remainder. is a matter that must he left to the judgment of the ejerattor. Personally, I adrocalte the

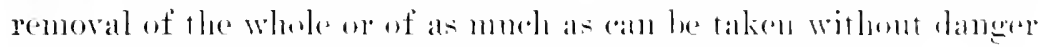
of the heart coming in contalet with rhe point of the needles.

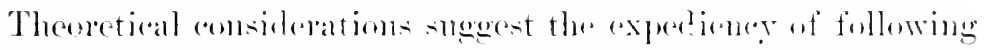

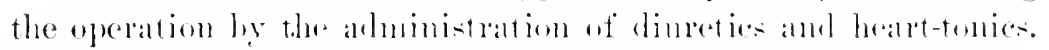

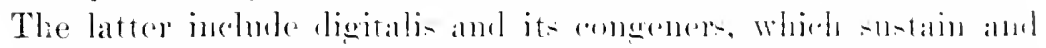
strengthen the leant-musele while at the sume time they incleater

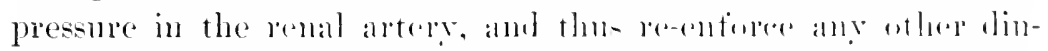

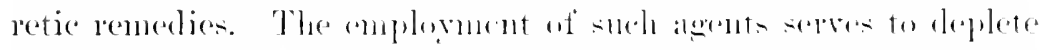

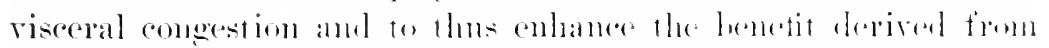

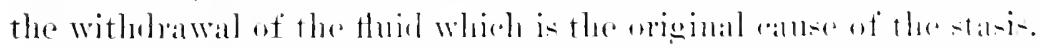

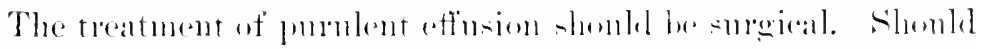

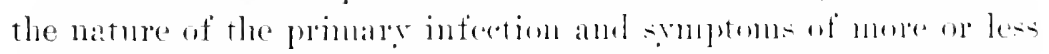

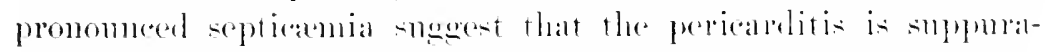

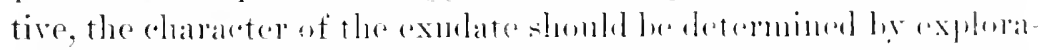

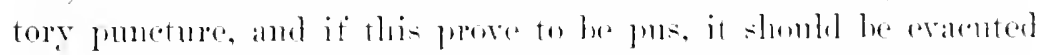

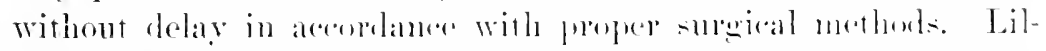

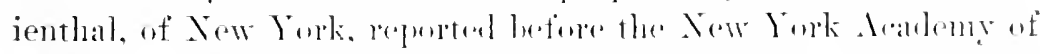

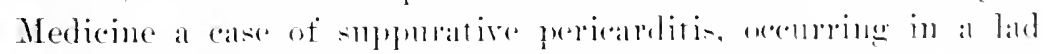

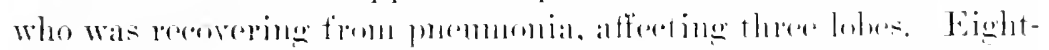

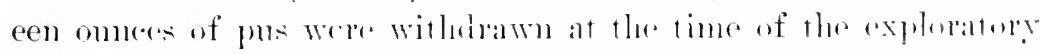

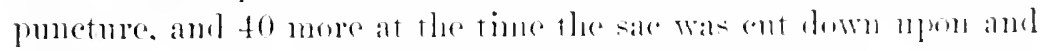

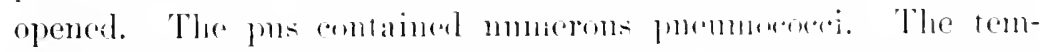

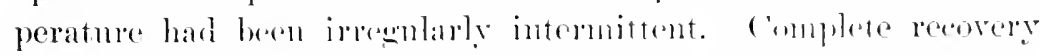
followed the operation. Fincaine was need as a lenal andesthetic.

Maniorrhagic effusion is to be managed aconding to the principles governing the treaturent of the sero-fibrincus form, no spe- 
cial indieation for treatment being presented by the bloody character of the effusion. No great effeet is to be expected, however, from either medieal or surgical treatment in those cases in which the atfection is associated with a serious blood-state or dyscrasia, and measures should be directed to the removal of these latter.

The subsequent malnagement of a patient convalescing from acute pericarditis comsists in such neasures as will rapidly restore the general health and heart-tone in the hope that the organ may not he left seriomsly damaged. We possess no means of either preventing adhesions or promoting the absorption of fibrinous deposits. 


\section{('II.MPTELIT II}

\section{CHRONIC PERICARDITIS}

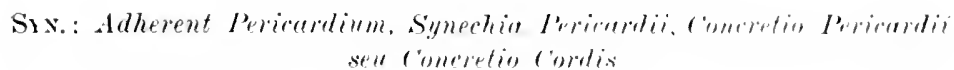

Curonic pericarditis may be divided into two great gump: (1) That in which it incolves only the two layers of the sac, proicarditis interna chemian, and (2) that in which the process involves both the pericardium and mediantinmm, periotarditis interna et externa chenien. In luth of the forms intlammation results in the formation of filmoms timene. which bimls the palts more or less closely and extensively together. There is still another much rarer form in whirh the ehronic intammation is asooeiated with serons distention of the sale alne is terment thereforn. chronic pericarditis with effusion.

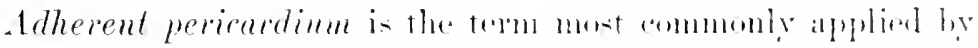
English writers to the titst form, while the areonl is kmown as

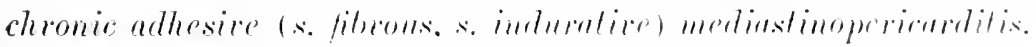

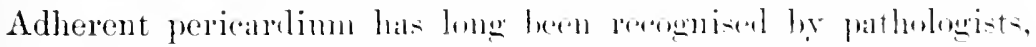

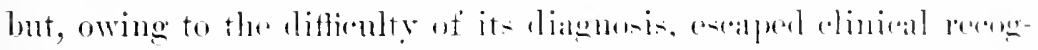
nition, althongh it is a compalratively frepuent pent-mortem find-

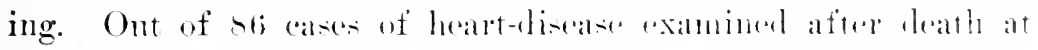

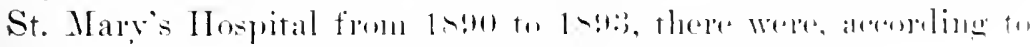

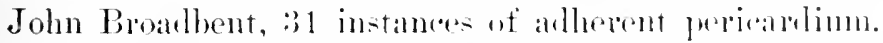

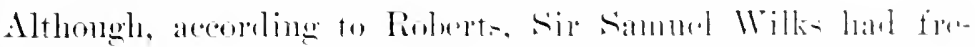

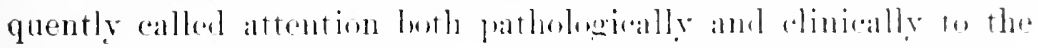
existence of chronie fibroms thiskening within the molia-tinum

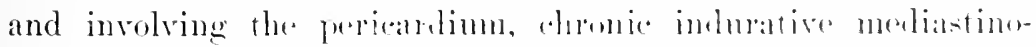

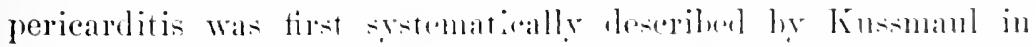

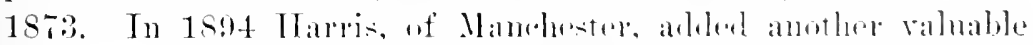
contribution to the subjert and collenterl all thr phiblished eases. For much of what will be alil in the following bates $\mathrm{i}$ wish to 
express alekumbledement to Ilamis's momograple, and to thankfully ackuowledge the stimulns derived therefom. It has enabled me to give more intelligent and discrinninating study to the rabes which have conte to my notice. I now systematically look for indications of chromide mediatinopericarditis, and discover them many times when oflerwise I should probably have overlooked them. Intortmately, ante-mortem observarions of several

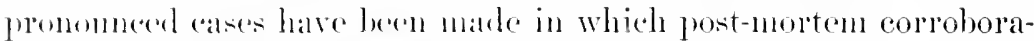
tion of the diannesis has heen denied. Several instructive and ypical instances will be narlated in these pages. I wish also to express nur indehtedness to John Broalbent's nonograph on this subject, as weil as to Friedel Pick's paper, Pericarditic Psendocirrhosis of the liver, in which is particularly discossed the effeets on the liver and the prenluction of ascites.

Morbid Anatomy.-The norbid anatomical changes found in rhomice pericalditis are almost always the result of previous acute intlammation. The more common form is the result of the oreanization of the fibrinom exulate of an ordinary plastic pericarlitis. This process may legen as early as the third or fourth day of the acute inflammation. It is crsentially a conservative process, temding to make gured the danage womght by the inflammation. This is hronght abont hy the conversion of the inflammatory exmble into a grammlation-tissue, and finally into fibrons cicaltrical tissue.

The deeper layers of the exulate are first invaded by newly

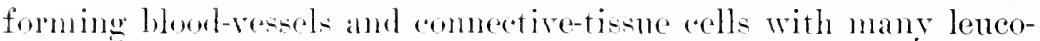
cyter, which form the grambition-tisise. This gradually grows intu and replaces the entipe exulate, and in the comse of time the development of intercellular subtance converts it into the glistening. white reatrix. If during this proeses the two lavers of the perieandima an in entatet, mion takes place and the eicatrization proluos fim arlhesim hotwern the opposing surfaces. These adhesoms mar be genclal or local, varying with the extent of the original pereess, and with the conclitions obtaining at the time of (1)

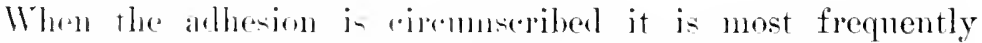
fomm in the parts of the sar. where the motion is the least, most frepuently. then, at the base of the heart, about the great vessels, Jes often at the ales or at the boderes of the orean. When adhe- 


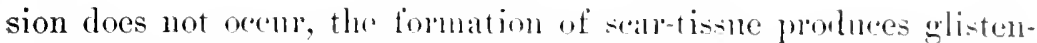
ing white areas on the sulfire of the heart, which show where the previons intlammation existed. These are the somalled millsspots or macular temdinire.

An intemediate comblition letween this and the syedhia peri-

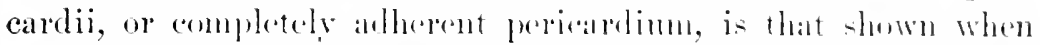
slight eiremmseribed allhesions hase heen partially or completely torn apart hy the motion of the leatr, prolueing string-like pro-

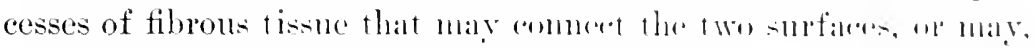
in rare cases, hang lowe in the pericandial sale. When the layers are not adherent, in ralle anses thuid is fomml in the sale.

The layers of the perieardimm may be alluenent with hut slight thickening, but it is the rule to tind consinleralule inclease in fibrous tissue, especially in the ehronic tuluerentoms form, where it may become extreme.

Caleifieation may oeror, especially following a pmolent pericarditis, the pus becoming first imspisated, and then impregnated with lime-salts. Such calleateons plates may be isolated, ol may form a complete investuent for the heart, resimbline a coat of mail (Ziegler). In this case the motion of the heart is permitted by cracks and fissmes in the calcareons mass.

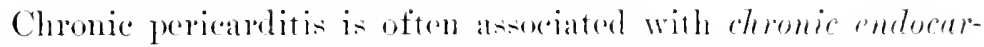
ditis, for the reason that they losth often have the same rhematic

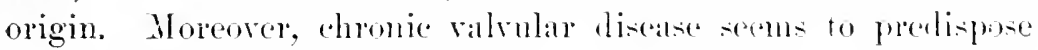
to pericardial inflammation.

Secondary to the periearlitis are msully fomme more ol less hypertrophy and dilatation of the heart, with legeneration of the myocardium, which probably are the result of the meehamical hindrance to the hearls arotion, and also of the risereral chasges that are always the result of long-standing circulatory disturbance.

Also associated with the chromice perienditis may le an imburative mediastinitis. It may exist alone, lut its mone frequent ocecurrence in combination with induration perionditis rombers it appropriate to consider it here. It amsists of a more or less extensive hyperplasia of the comneetive tissme of the menliatimum, which binds together the structures contained therein, and is often associated with allhesion of the two layers of the perieardium. This derelopment of filmons tissue results either from an extension of a chronic pericarcitis thromgh the parictal la? yer of the peri- 
cardium. or from a chronic proliferative inflammation of the mediastinmu iteelf, either alone or assoeiated with periearditis. Extensive tibroms adhesions may hind the heart-sac inseparably to the diaphragm, or the sac may be mited to the anterior ehest-wall, to the plenrar, arophlagns, spinal cohmm, or to all these structures. In some instances the contents of the mediastinum are so matted together by dense fibroms tisue that they eamot be separated withont laceration of the oreans.

When snch extensive adhesions exist they may be found to form hut a part of a chronic inflammatory or proliferative proeess which has led to extensive or general adhesions between the two larers of the plenrat, or hetween the lungs and the diaphragm.

In exceptional cases fibrons adhesions have formed only at the roots of the great ressels, and have led to partial or complete obliteration of the superior vena cava, either alone (Roberts), or in combination with involvement of the main trunk of the pulmonary artery, or the ascending aorta (Kinsmaul). At the present writing I have meder observation a female patient, in whom, to judge from physical signs, chronic mediastinopericardial adhesions have led to such retraction of the borders of the lungs that the entire anterior surface of the heart is morered. The apexleat is held immorably fixed in the serenth intereostal space, anterior axillary line. The normal exension movements of the diaphragm in front are entirely abolished, and the respiration is of purely costal type.

The secondury effects of this form of the disease are not limited to the heart, as in the simple adherent pericardium. As the disease is nsnally combined with chronic valunlar disease, it is difficult to say how much importance is to be attached to this, and how much to the fixation of the perieardimm in the production of the great hypertrophy and dilatation found in these eases. The rhanges in the lungs of chromic bronchitis and brown induration are due partly to the pasive hyperamia secondary to the cardiae Aisease, and partly to the retraction and immobility of the lungs incident to the plenro-perieardial or associated pleuritic adhesions.

Cirrhesis of the liver is generally present, and is largely responsible for the ascites of frequently observed as a terminal erent. There may be also thickening and entraction of the capsule of the liver and spleen, and more or less evidence within the abdom- 
inal earity of what appears to have heren a genelal sopesitis or pow liferative inflammation of the serons memblames.

Chronic Pericarditis will Elfusion.-This lorm of periondial

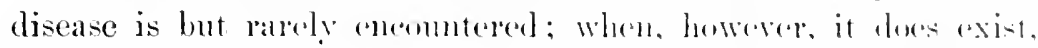
it may be considered to have originated in onc of two ways: (1)

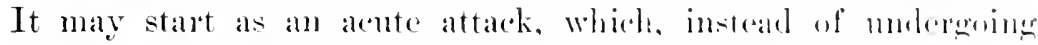
complete subsidence, suffers repeated exarerbations. and finally

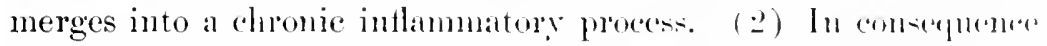
of the mildness of the infection the pericalditis asmunes a sowly progressive character from the begimning, at uo time mantesting a tendeney to molerego arrest. In the fomer elasis the exmbtim fluctuates in anome from time to time, acomeling as the intensity of the intlammation abates, and partial abonption enecurs, or alecording as fresh infection aceme the inllammatory process again rekindles. In the second chass, chronic from the ontset, effusion accumulates slowly, and either renains stationary, after having reached a eertain degree, or temds to gradualy incloase. Thi form of chronic pericarditis is said to he observed chiefly in elderly or aged individuals, and to be associated with chronic nephritis. Roberts expresses the opinion that such abes can le differentiated only with great ditlienlty form instances of hypho perieardimm, and that it is quite possilste, indeed, that the ehromice periearditis originated in a simple seroms transmdation. This. it seems to me, is quite mulikely unless the originally serous effusion becomes infected by pus-oncei, in which event it would likely be transformed into proprericardimm.

Etiology.-Chromic pericalitis is in most instances of either rheumatic or tuberenlens origin, the intammation laving been slowly progressive from the start. In other ases an acute process passes into a chronic one, whieh exhibits no tendeney to abatement, but persists for vears with repeated exacerbations of the inflammation. This is the alse particnlarly with the form which, starting in the sac, spreaks to the mediastimm, am ultimately becones a chronic fibrons mediastinoperiearditis.

In some cases a mediastimitis is timst set mp and subsepment?y invades the pericardinu. This last form may miginate as eitlop a chronic or acute mediastinitis, which is set up by disease of the bronchial or mediastinal glands, malignant tmuonrs, tuberenlosis of the lungs, pleura or glands, pnemmonia, or by tranma. 
The disease is most frequently olserved in young adults and in children. Of. 22 ases collected by Halris in which antopsy wals hehl, only a oceurred in persons past thirty, while ! were muler eighteen years of age. Sereral instances lave been reported of its post-mortem discovery in infants. Aceording to Irapris, chronie indurative mediatinopericalditis is much more frequent in males than females, o0 ont of 25 cases laaving belonged to the former sex.

Symptoms. - $l l a n y$ calses of adherent pericardimm run an absolutely latent contre, and ane only discovered on the autopsy talble. In other alses the smptoms are those of eirenlatory and respiratory embarrasment, and are attributed to dilatation or to an arsociated valvular discase. In a third series of cases the srnechia perieardii is orerloweet oning to the development of ascites and other srmptoms of hepatic cirrhosis. For the most part the last-mentioned class of eases belongs to what has been described as chronic arthesive meeliastinopericarditis.

The explanation of these clinieal differenees is not always chear, but probably depends npon sereral factors. If the perieardial adhesions are of limited extent they may produce no appreciable scoudary effects on the heart or circulation, but if they lead to total obliteration of the sac, and particularly if this latter is also bound to some of the surmomling structures, cardiac hypertrephy is likely to result, which, if slight, is not recognised elinically and does not occasion symptoms of embarrassed eirculation. If, howerer, the heart is dilated as well as hypertrophied, it is very ant to be more on less inadequate with resulting respiratorry and circulatory semptoms. The enlargement of the organ may lee recognised, but not its cantse, and the condition is perhaps considered cardiar myasthenia or eren chemic myocarditis.

Sir William Broadlent is of the opinion that perieardial adhesions learl most frepuently to anlargenent of the right heart in "on-cyuence of the relative thinness of its wall, while others maintain that the entire heart is hypertrophied. The mode of produetim of hypertrophy in cases of atherent perieardinm is difficult of sati-factery explanation, but is due in some way to the hampering of the heart's work.

In most instances conditions are present which easily account for the cardiac hypertophy. Chronic valvular disease and adher- 


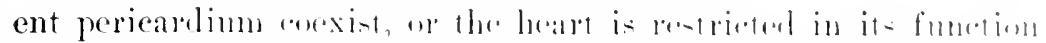

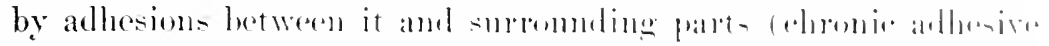

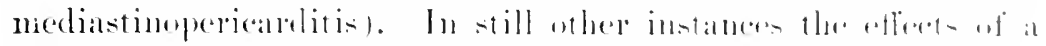

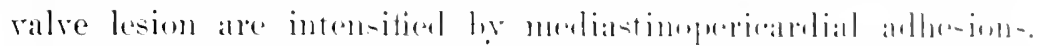

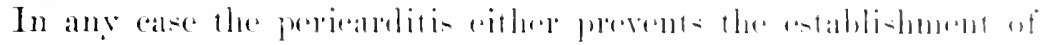

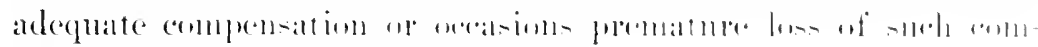
pensation as maly have hern attained.

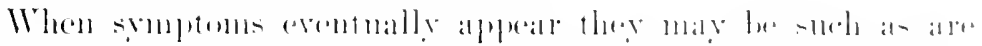

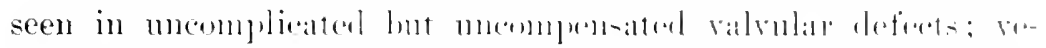

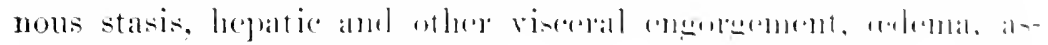

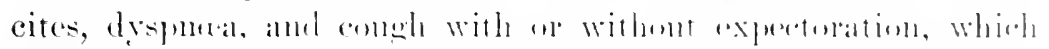

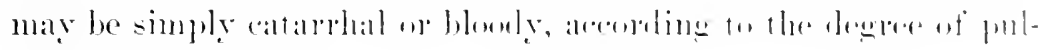
monary congestions.

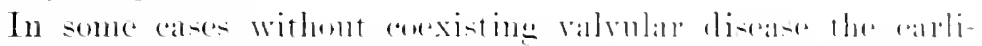

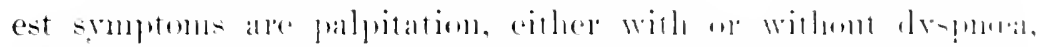

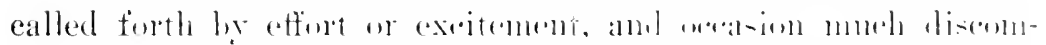

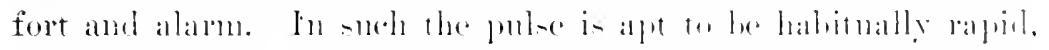

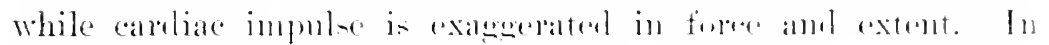

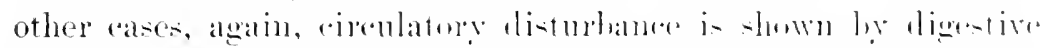

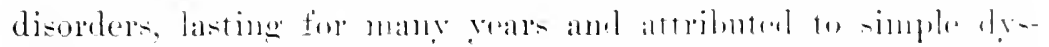

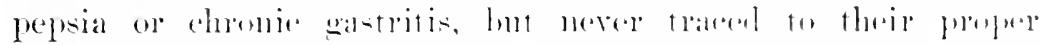

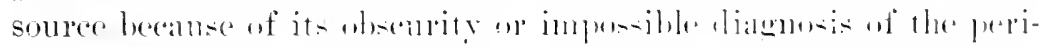

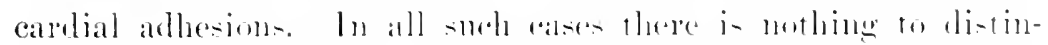

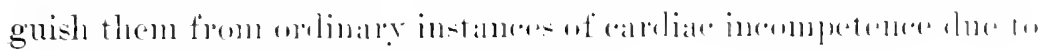
dilatation m mitral disiatse.

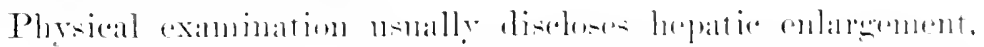

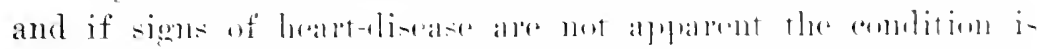

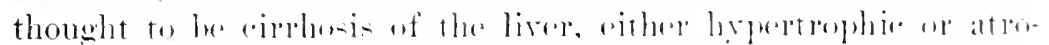

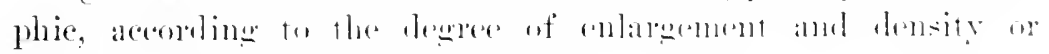
smoothleses of the "reant.

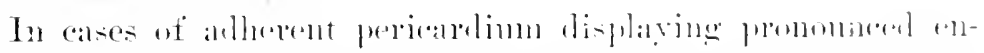

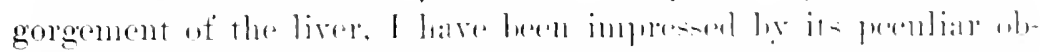

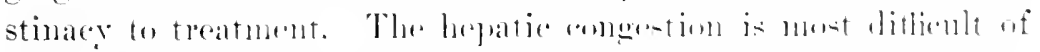

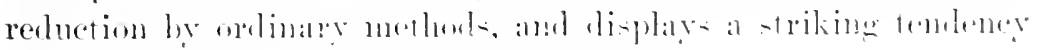

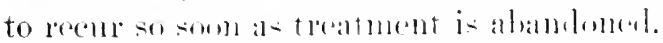

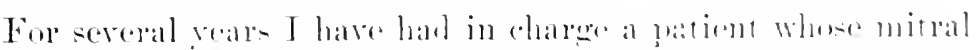

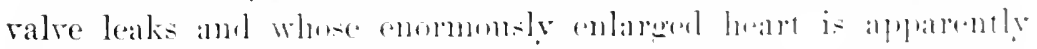

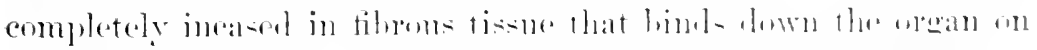

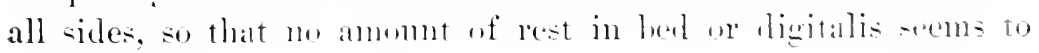


reduce its size in the least. 'The liver has always heen greatly engorged, extending for a long time nearly to the erest of the ilemm, and requiring the daily use of saline laxatives to relieve the patient from pain and disconfort. For the past year the organ has been gratually diminishing somewhat in size and incleasing in thinness and hatrhess. The patient has experienced remarkably litthe dysprea on ceffort, but is greatly amoyed by the pounding and tmumlturus action of the heart, this sensation being specially noticatile in the epigastrimm. Of late, she has had a ereat deal of comgl, difticult mucous expectoration, and upon screral oceasions slight hamoptrsis. She has to be extremely careful in her diet. and her mine and menses have become $-c: a n t r$.

Another female patient with pronomeed mitral insufticiency has pericardial alhesions that bind down the left side and base of the heart, fixing the apex-beat immovably in place, far to the left and downward, but the border of the right heart is apparently free from adhesions. Whereas the left ventricle never varies in size under any conditions, the right heart, as shown by the area of cardiac dnlness, becomes dilated with the greatest ease and rapility. The liver, which is persistently enlarged, fluctuates somewhat in size in accorlance with the state of the right heart, lut even when at its smallest alwars extends from 2 to 3 inches below the inferior costal margin, no matter how vigorons may be the onslanghts mpon it hy means of Epsom salts. This patient's symptoms are not of the digestive organs, but are those of shortness of breath and a rapid pounding action of the heart and general weakness. The mine remains fairly abundant, and the menses are too profuse and protracted. She is aiways promptly benefited by absolnte rest in hed, a milk diet, cathartics, and digitalis, althomgl this last-named agent never materially slows the heart.

The most intresting elass of eases are those whose clinical features closely recomble a case of atrophic cirrhosis of the liver. There cases, nswally of chronic fibrous mediastinopericarditis, ecuerally pursue a latent contse for many years, and often, even after sunptoms have set in, ale not recognised as adherent pericardium until they come to autopsy. Not only is there a chronic entorement of the liver, but there is a perihepatitis with increase 
of the interstitial commertive tissme. In time this filmons ti-sure,

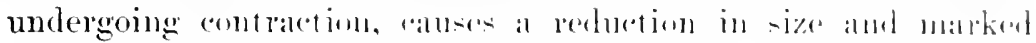

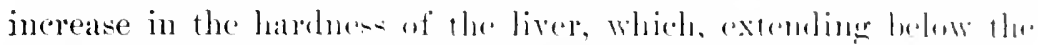

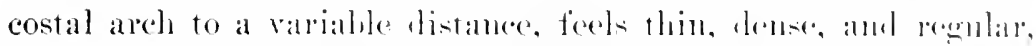

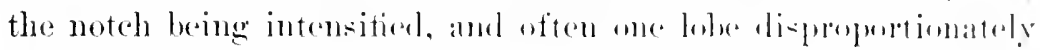
larger than the other. It is now, whene the olean hats shrumkent

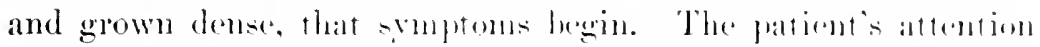
is first attracted ly an increase in the size and firment of lis

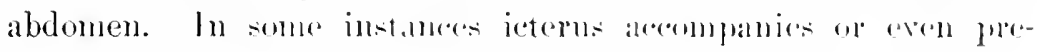
cedes this increase of girth.

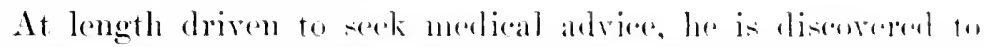

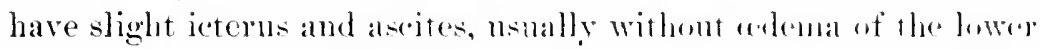
extremities. The plosicam exambues the heart and urime, drotrets no heart-disease and discovers no albumin, hut forhals some bile. The case is put dowe as one of hepatio eirhosis. The following is an illustrative (alse:

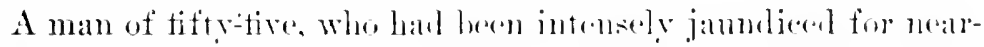
ly two years, and in August, 1900, was tapped for ascites, called me in consultation a short time ago. The ascites, which had for a

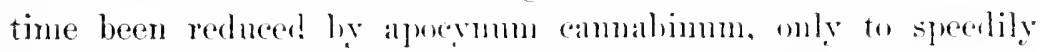
recur, had been again drawn wft the moming of the day I saw him. He had had articular mommation eightern years before, but had suffered no slortmess of breath or other discomfort since. The thin-bordered, dense, slighty gramblatefoling liver extended in the median line nearly to thr mombliens and fom one costal areh to the other, being lost lemeath the right ribs, just omside the right mamillary line. Owing we the recent palacentesis, the peritoneal cavity was fiee from thide and there was no wedema. The cardiac area was somerentat incleased to the right and downwal, the sombls were elar and strong and fiec form mompuns. The rather tapping alex-heat was in the fifth left interspale inside the vertical nipple-line, and there was a distinct though fecthe pulsattion in the epigastrinus. In the titth amb sixth interspalere, he-

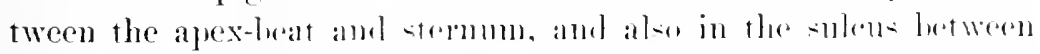

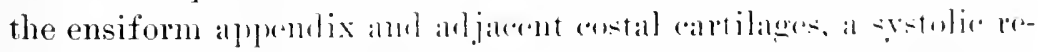
traction conld be perenved both ly palpation and inspection. Furtheruore, when the pationt was intrueted to take a shw, deep breath, the right external jugular conld he seen to bulge ont during the inspiratory effort. This distention was also palprable. P'ulsus 
paraldexus conld not be leternined. I had no hesitation in making a diagnesis of prenteratmphie cirrhosis of the liver secondary to an adherent prericardium. This patient died a few weeks later.

One of the most typical ealow, and by the way the first of the kind I ever salw, was seen in 1891 with Dr. Christophe. The fattent wats a male, aged fifty-two. had always enjoged good health until an attales of the grip in February, 1889, after which his lealth filited progrewirely. Six weeks prior to my risit he took to the hune with dropser and ascites. The former vielded to caffeine and digitalis, but the latter persisted until drawn off by tapping the diy lefure I saw him. The patient was in bed, of medimo height, considerably emateiated, and complained of dyspmea,

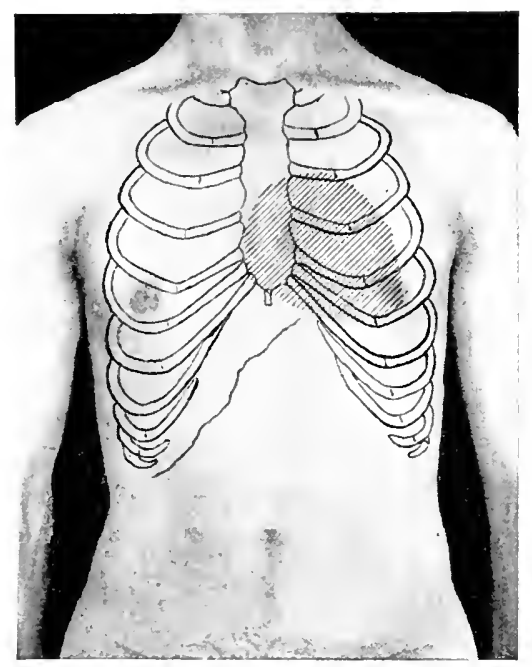

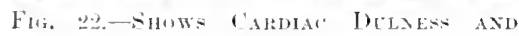
LOCATIM OF BURDER GF LIVER. dry congh, inorexia, flatulence, constipation, scanty nonallominons mine, pain in the hepatic region, and insomnia.

The lungs were negative, lout on examining the heart the apex-beat was found to be a weak tap in the fifth left inter-pace on the nipple-line and to be followed by a distinet diastolic rebound or shock, while there was in addition an ummintakalhe systolic recessim of the fifth interspace, from the border of the sternum to a point outside of the apex-inpulse. Cardiac dulnu... extended from the right sternil border to $\frac{1}{2}$ an inch ontside the left nipple, and in the mitral area was a harsh systolic murmur that was trammittent to mid-axillary line (Fig. 22). Both heart-smunts were andible, and the second at the apex was followed by at hert diatetic nurmur. The inferior hepatic border was palpable 2 inches helow the cowtal areh, and was thin, hard, and smewhat irregular. The pulse was slow, tense, and regular, and there was no icterus.

The diagnosis was plainly that of mitral regurgitation and 
adherent pericantimu with secomblary cirrhesis of the liven and aseites.

The chronicity of surh a catse is atterted her the fall that after repeated tappings and prohonged continement to the henter this

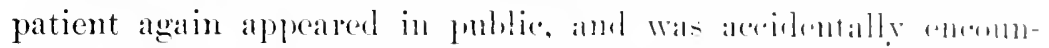
tered by me in the fall of lats. He aldutted that he wat mot repy well, and that he still haw his aseites. He diend a for month- mb-

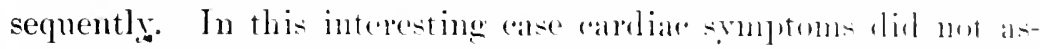
sert themselves, and the sinieal history was cesontially thalt of atrophice cirrhosis of the liver, and womld orlinarily pats for surh.

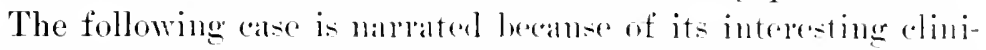

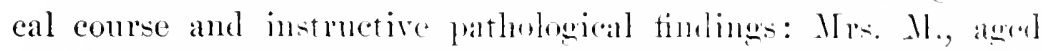
forty-five, consulted me in Felmoury, 1s:9:, becante of an olsti-

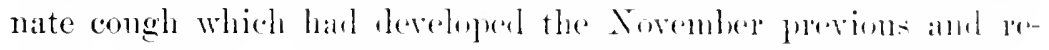
sisted treatment. She gave a hirtory of scarlatina al the age of seven, and of a pain, probably rhemantic, in the right hip alunest contimally between her tenth and thirterenth vears. She statcd. also, that at that time she suffered from shortuens of hireith upon

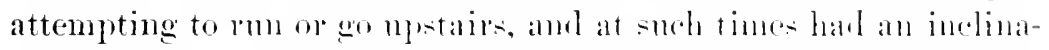
tion to faint. She thomght her pulse hat always been irregular,

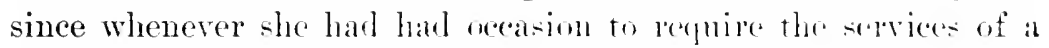
physican comment was male non it: irregulanity. She was married at the age of twenty-one, and two years later gatse birth to her only child, both the pregnancy and lathon having been moventful,

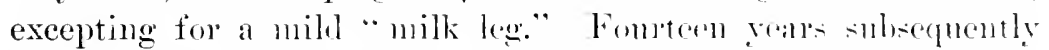

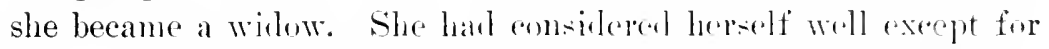
nervousness and attacks of nemrilgia. In the fall of 1 (4): wais treated for pain and swelling of right leg, letween ankle and knee, and for "fulness and tightnese" alhont the waist. In Norember had contracted a honchitis. and since llan land not been free from congh, althongh muler treatnent for same.

Her only stmptoms at the time she com-ulterl nee were firequent paroxymal cough, with santy mucons expectoration. pain across the chest, in consequenee of the congh, and mulerate shortness of breath on exertion. Digestion, lwwel nusements. and niceturition seemed normal. She lath passed the menopante several months before.

She was 5 feet 1 inch in height and weighed 14.5 pounds. The pulse was 103, somewhat irregular, not internittent, small, 
and weak. The hungs were resonint throughout, and the breathsnlmets resicnlar: no lailles exerpt tine inspiratory crepitus at the extreme right batse, close to the spinal column, and at the extreme lower linit of the left long. frem the anterior axillary to the posterior seapular line. These riles were thought to indieate old flenritic anthesions. The apexthat was in the fifth left space 2 inches from the sternum, broad, strong. and at times thumping. There wat slight epigatstric pultiation, and eardiac dulpess was increaserl solnewhat to the right.

The pulnenic secomel somm wats aceentnated. while the first at the apex was at times split am thmmping, at times preceded by al short. rongh prestotolic murmur. A sptolic apex-murmur was not rery distinct. To igns of atherent pericardim were noted at that time either becanse werlooked, or becanse the chronic mediastinitis did not derelop mit a year or two subequently. The lower borkler of the liver, firm and rounded, was palpable nearly at the level of the mulilicus. There was no wedema.

The diagnosis wat marle of mitral stenosis in a fair state of compensation, secondary hepatic engorgement, and chronie bronchitis, probably secomlary also to the mitral disase.

Ender appropriate treatment, directed mainly to relieving statio in the pulmonic and general renous systems, eough gradually disappeared, and the patient comsitered herself in fair health during the smmmer. In May it was noted that the pulse was 100, not intermittent, hut sligluty irregular in force. The following October, after I had returned from Ball Xauheim, and instituted the balneological treatment of heart-rlicease in my practice, the patient decided to try a contre of baths. Fon a time they seemed to benefit her, hut after alhout three weeks she said she began to notice increase in the size of her ablomen at its lowest part. I at once examined her, and to my smprise detected unmistakable signs of molerate ascites. The haths were discontinued in the helief that inammeh as they harl not prevented the development of ateites, there would not cause its remoral.

From that time onward ascites grarlually increased until in June, 1594, paracentesis was performed for the first time. From this time to the late of her death, a period of three years, the fluid was drawn off 32 times, the longest interval between the tappings being seren weeks and the shortest six days. In addition 


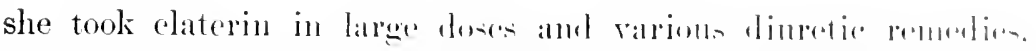

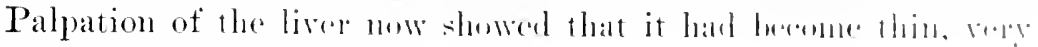
hard, and deeply motelend.

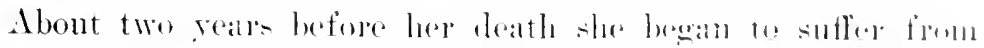

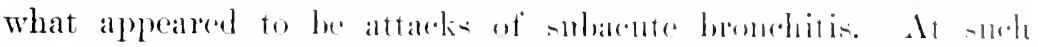

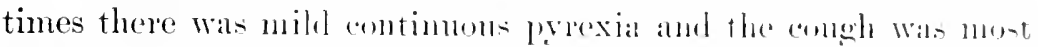

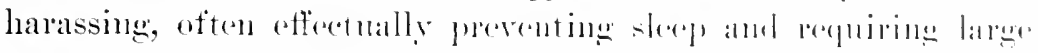
doses of eodeine phosphate. All known experentants in varions

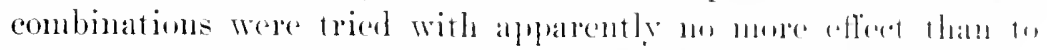
facilitate expectoration. The only tratuncolt that soment af malterial benetit was truly leroic cathatris, since the withllatwal uf

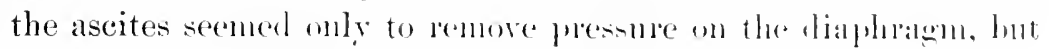
not to lessen the great renoms engoregenent.

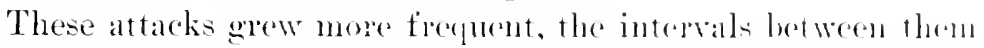

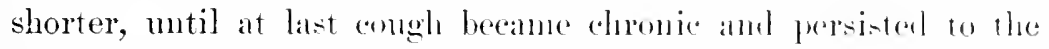

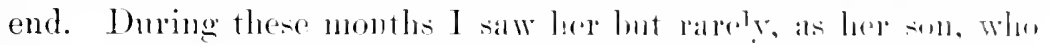
was a physician, deroted himself to her cane. At ome uf my risits, a year or more before her reath, 1 discoveresl tine raickling railes all around the base of the right lmag, particulanly in formt, which were brought ont distinctly by deap inspilatim, and were mehanged by cough. These rîles eventually sprobl so as to le heard nearly to the elaviele, while as time went wn similar crepitant sounds became andible more or less extensively at the hase of the left lung. They did not seen to have the chandeters of plenritic friction, and I was at a loss to explaiul lleme It may here he stated, however, that the antopser sulsogmonly showed them to have been due to wide-spread plemitic adho-ions.

A year before her death her son tirst deteced systolic reeession of the intereostal space, rlose to the site of the apex-heat, and pulsus puradorus. Baleilli were nevere disoovered in the sputum, and repeaterl examinations of the mine showerl nothing more than the nsual changes due to pasive comesetion. The last months of life were spent in a contimal strugele to keep within reasonable linits the evol-present and nerereonymerable venous engorgement. Exlema of the lower extrenties smpromed many weeks before the end, which finally took place in May, 1 s.9. with symptoms closely resemuling lnut not identieal with uramia.

Thanks to the intelligent study of the case by her son, the ante- 
mortem diagnosis was made of chonic indurative mediastinoperienditis. So other signs erel developed than the few mentioned above, pulsus purulorus and a visible systolic recession in immerliate proximity to the apex.

The atupey was made by II'. WI. A. Evans twenty-seren hours after death, and was briefly as follows: The abromen contained a small anomnt of fluid, and the omentum was adherent to the abdominal wall above the mubilieus and along the linea alba, adhesions being so firm that they could not be separated without tearing the onentum. The nterus was larger than normal, the right tule very firmly adlerent to rectum and posterior part of the uterus, right orary heing normal; left tube also fims y adherant to the left side of the rectum and side of pelvis and posterior wall of the uterus. completely crering the left ovary, which was alio normal. There was an exulate upon the anterior surface of the left hoad ligament. The liver was adherent to the abdominal wall orer both right and left lobes. the parietal layer of the peritonamm being thickened and its viseeral layer showing eridence of old inflammation. The orem neasured s by 5 inches, its right bobe 4 inches vertically, and its loft lobe 2 inches in its anteroposterior diameter. The smbace of the liver was markedly irregular and divided by sars into large areas, its lower border being so notched that it was practically imposible to make ont the loles. Its capsule was irregularly thickened, presenting the appearance of lace-work. The substance of the organ was firn, entting with resistance, and the lohules, rery irregular in size, stood ont prominently. and the connective tissue of the capsule condd be traced into the mulerlying liver substance-in short, it was in a state of adranced Glisonian virrhosis.

The right kidney, 5! inches long and $2 \frac{1}{2}$ wide and 2 thick, showed inclease in the thickness of its apsule, some parenchymatous legeneration and interstitial overorowth. The left kidney, 5 by 9 ly $1 \frac{3}{5}$ inclues, with eapsule firnly adherent in places and thicknod, showed other changes the same as in right kidney.

The spleen shower marked thickening and some interstitial splenitis.

The gantro-intestinal tract showed no especial changes, except that the peritoneal eorering was thickened.

The appendix was firmly bound down to the right iliae fossa 
by a solid mass of adherions behind the cancolnt, and wat les than 1 inch in length.

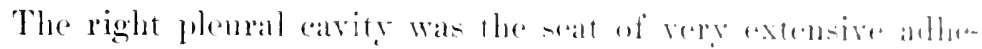
sions, which were mest firm allterionly and mure almutant at the

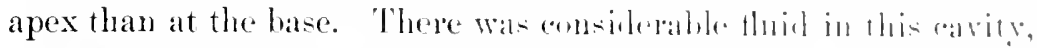

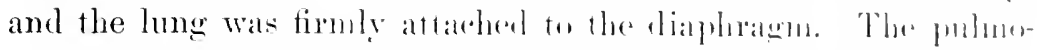
nary pleura was thickened, and on seretion the surfian af the lung

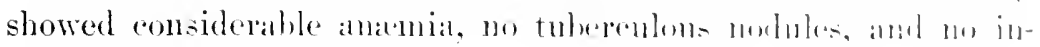
flammation.

The left lung was antherent at base anterionly and al an pu-teriorly, athesions to diaphragm being very sulil. At alex was a

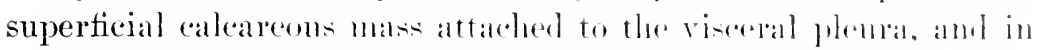

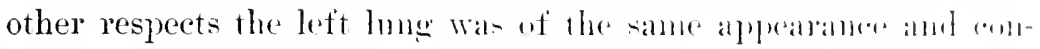
dition as the right lumg.

The pericardium was attached to the plemar and rhest-wall,

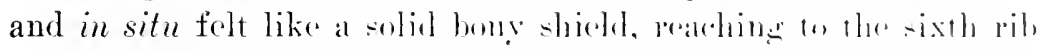
and $\frac{1}{2}$ an inch within the left mammary line. L Pon removal of

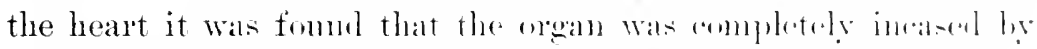
several calcareous plates, which were desely in alpweition with yet separated from each other, so that the lines of exparation hat allowed the heart to undergo comtratedion and relaxalin. Theo plates of lime mited the two periealdial layers timly. The walls of the several chambers were hipertrophied. particularly the loft auriele and right ventriele. With exeeption of the beft rentricte the earities were all molerately dilated. The halptomete had the appearance of brown atrophy. All rabes exeepting the nitral

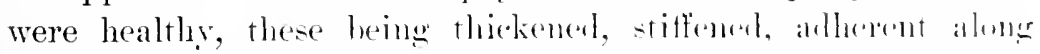
their edges, and projected inte the eavity of the ventriele like a cone or funnel. The mitral oritiee wats menlerately thickenesl with old sclerotic tissue and admitted one finger.

To me it is very interesting and quite monalsalle that the patient was never able to give any history of an attalck of pericarditis, whieh the necropsy showed num hare been rery extentive. It probably oceurred at so early a primel in chilflunel. prethaps subsequent to the scarlatima, that it falited to be impersent on her memory, or was not diseovered at the time. If it was secondary

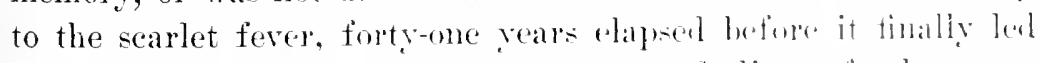
to the patient's death. The jost-mostem timlinge, furthermore, revealed in a striking mamner the extent to which chrouic pro- 
liferative inflammation may inrolve other structures, notably the liver, and may lead ultimately to the clinical features of hepatic cirrhosis with aseites. The allhesive inflammation of the pleura probably oceured at the time when the patient manifested a low sritde of ferer with congh, and fine, dry crepitus over the front and base of the right hung, and subsequently also of the left. This cale also illustrates the chronicity of some of these cases, and the fact that death is the result not so mureh of cardiac asthenia as of the effect on the srstem of the assoeiated conditions. That etiological data in such caises are frequently wanting, and that therefore the primary canse of the simptoms may be unsuspected to the ent, is shown by the following case:

Mrs. D., a physiciun's wife, aged fortr-six, was first seen by me December $24,189 t$, because of increasing symptoms of eardiac disease. IIer statements were positive that with the exception of measles and whooping-congh in childhood she had never been ill before the onset of her present tronble. She had been a sehoolteacher up to her marriage three rears before. Her husband stated that he at first noticed tachycardia shortly after marriage, but no other simptoms had been observed until May, 1894 . She then developed dyespnera on exertion, and occasionally adema of the lower extremities and face. During the summer of 1894 she took sulphite of strychnine, digitalis, strophanthus "off and on "without apparent benefit, but had recently shown some improvenent on iorlide of potash and belladomna. Her menses were absent since July: the only stmptoms complained of were slight, dry cough, a not rery marked breathlessness on exertion, a feeling of weakness, and occasional puffiness of the lower extremities.

She was of medium height and well nourished. Examination discorered signs of fluid in the right pleural eavity, reaching to the lower angle of the scapula, and some fine crackling râles at the extreme posterior left base that grew more abundant after colloh.

Otherwise the lungs were negative. The pulse was small, weak, regular, and moderately accelerated. The apex-beat was in the fifth left interspace, just ontsile the nipple-line, diffused and weak. There was no epigastric pulsation, but at the level of the fourth costal cartilage deep-seated cardiae dulness reached from 1 
inch to the right of the stemum to fully milwaly betwent the left

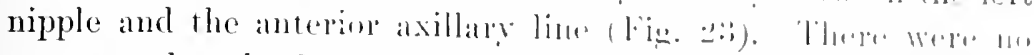

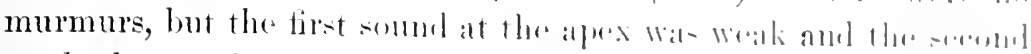

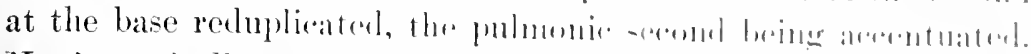

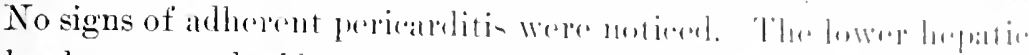
border was palpable at the level of the mubiliens, and was thin

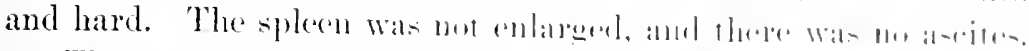

The ease was considerml one of general eatriale dilatiltion supervening upon a previous hypertrophy of the left ventricle and upon the increased pulmonary bloor-puressure oceasioned by the thinl in the right pleural carity. How much of the increalise in heart's dulness to the left was attributable to dilatation, and how much to transpowition of the organ from pressure by the intraplenral fluil, was left an open questiom. In the absence of a letinite history of plemrisy and of other signs of dropsy, the bature of

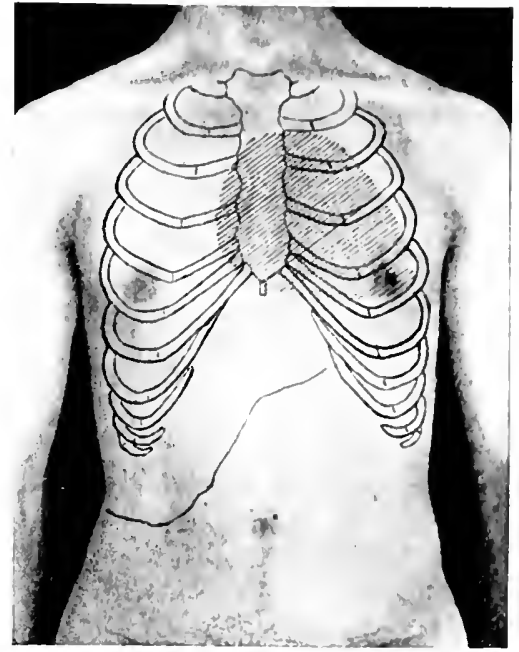

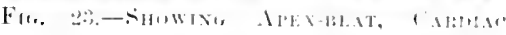

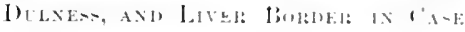
(1.) 114 ). the liquid in the pleural cavity, whether an exmlate op tran-malte.

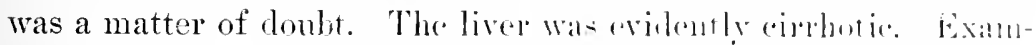
ination of the urine was negative.

In spite of physical rest, digitalis, diureties, and rathantir. the amount of intraplental this remained statimary for the mext three weeks. Paracentesis was then pertomed, and the thud rapidly reacemulating, the operation wats repeated within a wark. After the second aspiration the fluid momted to the "lpue level of the third rib and symptoms of presome increased. It was then

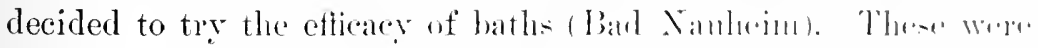
endured so badly, lowerer, that they were disentinum after four days. By February 6th the actual embarratiment hat become so pronounced that this fiat, together with the failure of paracentesis to permanently reduce the amount of plumal effusion, led the 
consulting surgeen to alvise resertion of a rib in the hope that permanent drainage would afford time and opportmity for the heant to reganin it former vigonr. The proprosal having been laid before the patient ambl her lushanl, and their consent obtained, the operation was dome the next lay. Everything seemed to progrese farourably for a fer diars. when sudelenly srmptoms of prononned tibrinous plemitis developed in that side. Temperature ruse to 10.2 F., strength waned rapilly, and the patient died ten days after the opreation. I may say here that the infection was

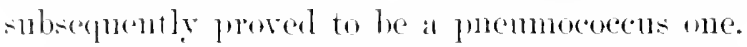

The antopsy was made hy I)r. Ilektoen twenty-four hours after leath, and the findings mat be hriefly stated to have been a totally adherent pericardium, with sereral plates of line-salts upon the surface of the ventricles, the largest lamina being about the size of a silver half lollar. The sac was also bound by adhesions to the left puluemary plenta, but not to the ehestwall. The valves and myocardinm secmed normal, there was evilence of recent rightsided plenrisy with collape of the lumg, and acute adema of the left lma with some fresh diaphragmatic pleurisy on that side.

The liver wats cirrhotie, but not atrophied. Kidneys were healthy, and there were evidenees of perihepatitis and peri-plenitis.

The necropsy sermed to make it evident that the condition within the right plemal carity had heen a hydrothorax, while the pericardial adherene explained why medical treatment had been mavaling. Ilad this patient lived, amd time been afforded for shrinkage of the lirer to take place, ascites would mudonbtedly have derolned, and the ase have presented the clinical features of what Pick terms pericarditic psendocirhosis of the liver, the same as did the whors.

In explunation of arcites in sneh cases Heideman lays down the four following proprsitions: (1) In these cases there is chronic inflammation of all the serons membranes. (2) The stagnation occasioned le degrueration of the cardiac musele leads to ascites, berante an aceomut of the chronic peritonitis the peritoneal vereds offer a locks minoris resistention. (:3) The cirrhotic prowes in the liver on often obeerved moler these circmustances is oeationed by extenion of the inflammatory irritation from the capule of the liver as well as by the chronic hyperemia. 
By the growth amb rontration of this commontive tin-me in and about the liver the stagnation and transulation in the aloleminal cavity ale incouacerl.

Course and Termination. - The antre of ahmin allsesive

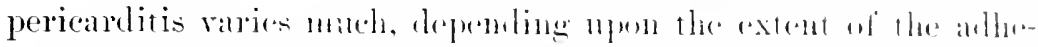

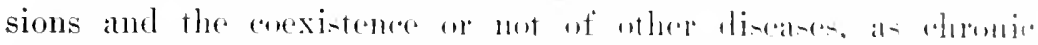

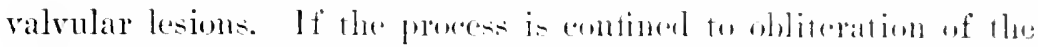

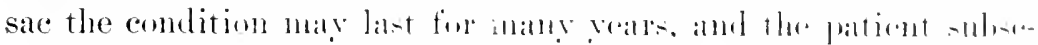
quently die from some independent affection. I'sually, howerer,

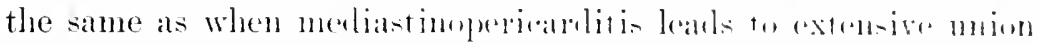

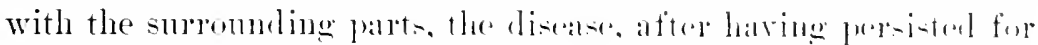
a long time withont symptoms, is likely to hring almolit those ar-

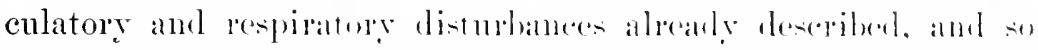

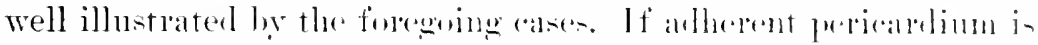

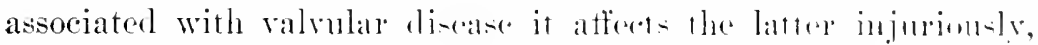

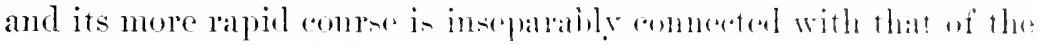

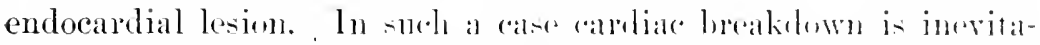

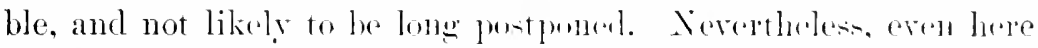
muth depends upon the troatment and upon the pationt sintelli-

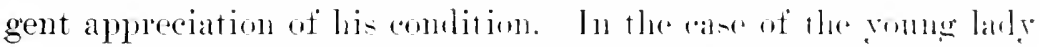

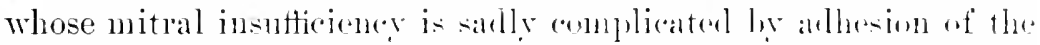

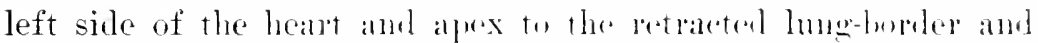

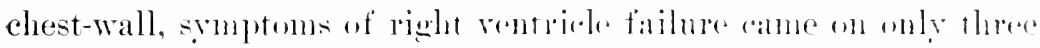
years after her first attack of rhommation, and wore molumbtedly

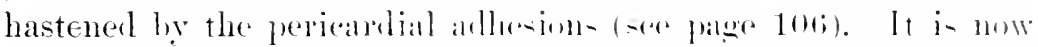

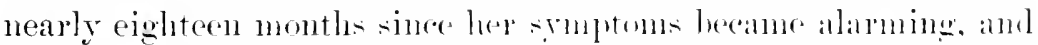
the fact that her overlumelened right rentriele is to-day antially

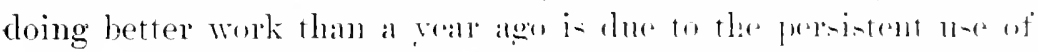
appropriate remedies and to her haring learned that su sum ats the first signal of danger is pereedved the must take to her beel mutil the right heart recorens its tome.

The mannel in wheh many eases of this attection terminate has already leen made apparent. Either the smoptoms are those of atrophic cirrhosis of the liver or they are indieative of cardiac insufficiency of mitral discase. Fither stasis in the systemic reins and riscera increases mit the pationt sucemuls to general exhanstion, or in another set of eases he is worn ont after months or rears by the erer-pecurring ascites, the heat not erinoing frecial weakness. According to Kilssmaul, pulmonary infarets are particu- 
larly frequent in eases of dnonic mediastinoperiearditis, and these mily prove the caluse of death.

Physical Signs. - Inspection.-The ease and eertainty with which allherent pericardium ran be reognised clinieally depend mpon the situition and extent of the athesions. If the sae is bouml down to the heart, lnt not to surrounding parts, the condition dere not of a neecesity prohe recognisable physical signs, and this falct explains why sinechial periearlii is so often first detected on the post-morten tahle. In the ases in which an adherent pericardimu is diagnosed there are generally adhesions between the sale and some of the surrombling structures, as the anterior thoracir wall, the pulnomary plenra on either side, and the diaphragm.

Acordingly, it is in eases of ehronic indurative mediastinopericardit is that the diagnosis is nust easily and frequently made. This. is owing to the faet that the existence of adhesions interferes with the change in form and position of the heart normally oeeasioned ly rentricular systole. During this phase in its contractions the heart becomes depressed at its lase, and assuming a more rounded -hape thrusts its point forward, upward, and towards the left, and thu- prodnces the impulse against the chest-wall known as the apex-leat.

It is evident that if allesions restrict these movements the heart will of a necessity pull on the part to which it is bound. This pulling action is exerted during ventricular systole, and eon-equently the most obvions and the most frequently observed sign of artherent pericandimn is a risible systolic recession of the ehestwall. It may be pereerved in varions situations, but most eommonly in the neighbourhom of the apex-beat. Only a very limited area may be thes drawn inward, but in most instances a rytolic sinking takes place in sereral of the interspaees near the apex and even in the "pigatrimm, the extent and location of the adherime leternining the extent and position of this sign. It is hout rherived by placing the patient in a strong light, and then lowking at the lated cheot from ahove downward or from one side to the othere.

It is well to have the patient suspend respiration for a moment while insertion in heing male, that the observer may not be deceiver or confued he sinking of the soft parts ineident to move- 


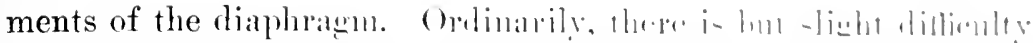

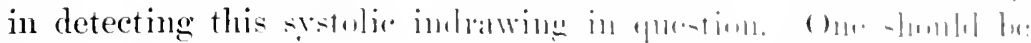

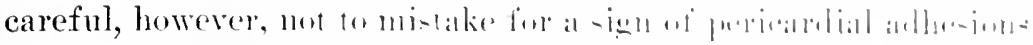

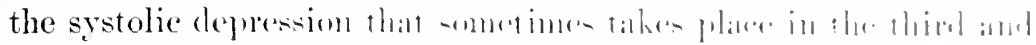

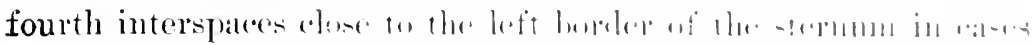

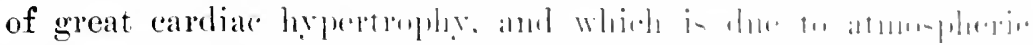

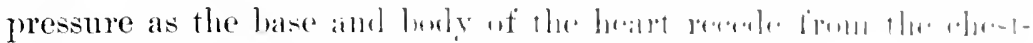
wall during systole.

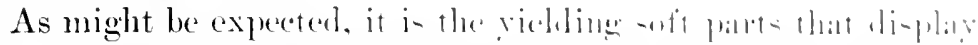

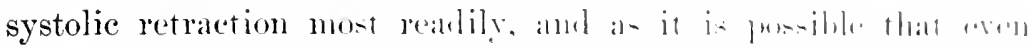

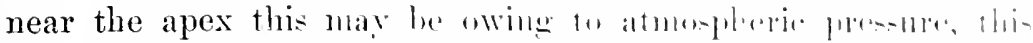

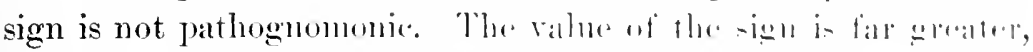

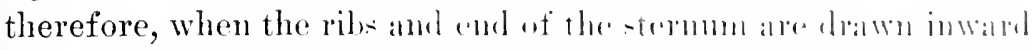

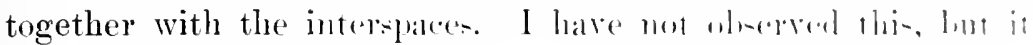
is said to sometimes ocerrr.

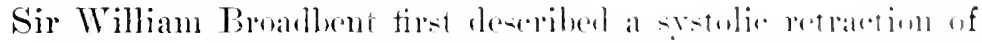

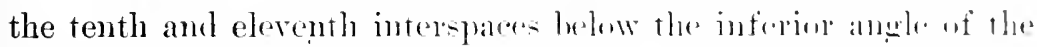

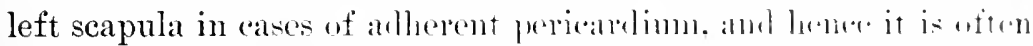

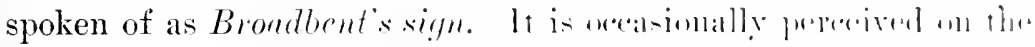
right side also. It is aseribed to the drawing on the dialphingun of

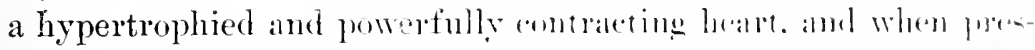

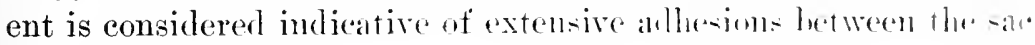
and the diaphragn.

Gibson very justly attaches ereat inportance to firation or im-

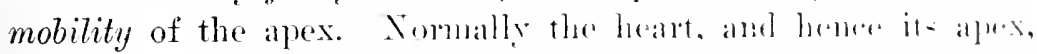
gravitates towards the dependent sild whenerele the grationt ate

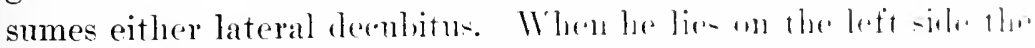

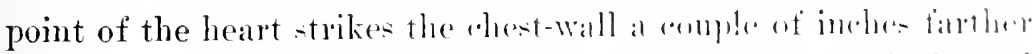
to the left than when he is on his halk. while in the right lateral

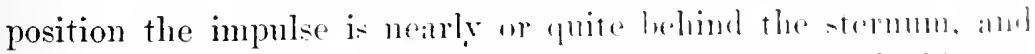
hence imperceptible. Conseducutly in any ases in which this mo-

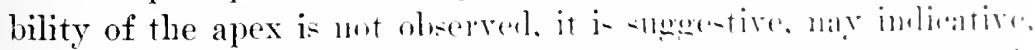

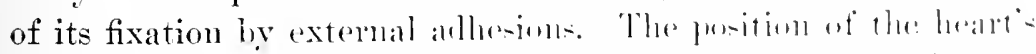

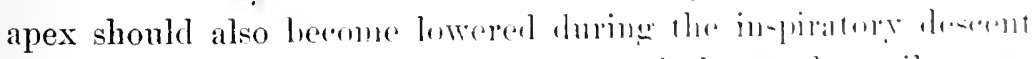

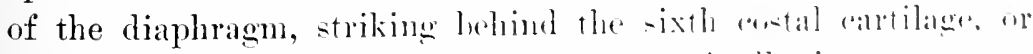
even the sixth interspate. The existrmee of allesions maly pre-

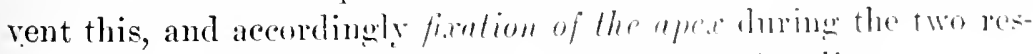
piratory acts is likewise a sign of adluerent jerpirallimm.

The other phenomena pereeived hy insportion in sume cases 
are comnecter with the external jugular reins, and are (1) inspiratory suelling of the reins. known as Kussmanl's sign, and (:) dinstolic collapse of the reins. known as Fricdreich's sign. In my experience these signs ale not as frequently met with as is the drawing inward of the interspales, and I do not recall an instance of diastolic collapue of the reins. Knssmanl's sign is present when perieardial allhesions prevent the dilatation of the right anriele that nomally takes place during inspiration. Instead of the inspiratory act exerting an aspirating effect upon the contents of the reins, and thus collapsing them, the opposite effect is produced, and the jugulars become risibly distended. Diastolic col-

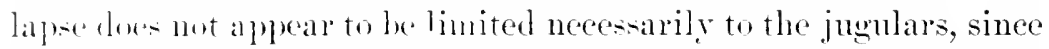
Broadbent has observed it in the superficial veins on the front of the chest, and sars it was due to traction of fibrous bands on the cont s of the internal mammary rein miting this ressel to the pericaptinu, and ansing its sudden lilatation during ventricular relaxation. In the catse of the cervical reins their diastolic collapse is probably to be explained by the aspiratory force exerted by the sulden diastolic rehound of the right an ricle, pulled upon as it is l,y athesions between it and suromding parts. Two other physieal signs that remain to be considered are best pereeired by the hand. and are therefore described under palpation.

Pelpution.--In some exceptional instances the hand laid over the apex perecives a di-tinet sudlen shock not synchronons with syotole, but with liatole. It is spoken of. therefore, as the diastolir shock or rebound. It is eansen liy the pulling of fibrous adhesion: which. put on the strotch during systole pull the heart suddenly lack against the rhentwill after srotole has ended. Such a rebound can -calrecly be aceasioned by any other condition than external perieartial adherions, and therefore by some is considered fathogmomic of the disease under discusion. I have observed it but twice, one in the patient whose case I have reported, and the otleer time in a man at cook Comnty Hospital who had, in adtition, arotic insutticiencer.

The seermet phenomenon observalue by palpation is the pulsus purtoloris. Normally the pulse leecomes fuller and stronger towind the end of inspiration, smaller and weaker towards the end of expirition. In the paraluxie pulse, on the contrary, the reverse chtalins, strong inspiration cansing a diminution in the foree 


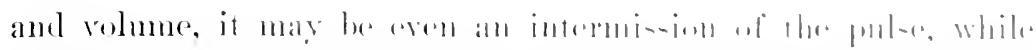

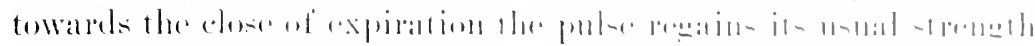

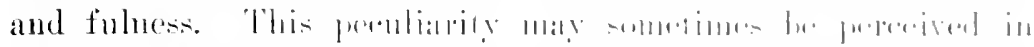

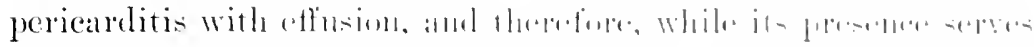

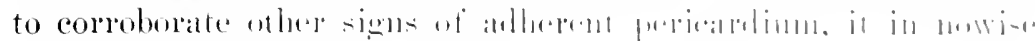

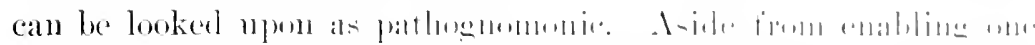

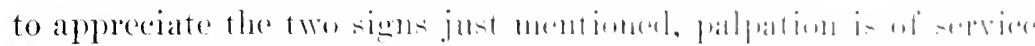

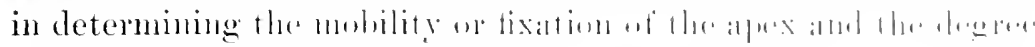

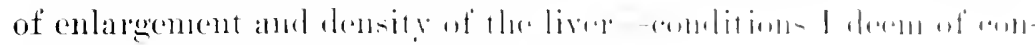
siderable importance in dombttinl wares.

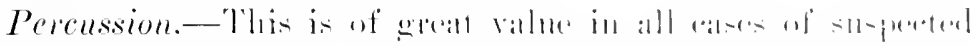

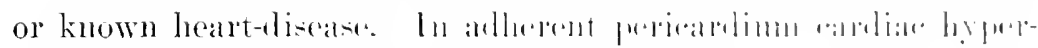

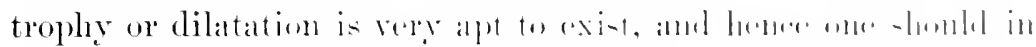

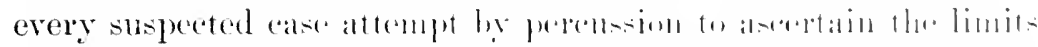

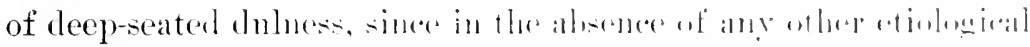

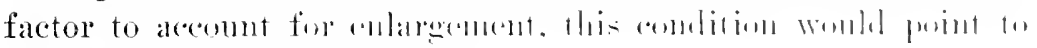
the likeliluood of allhesions.

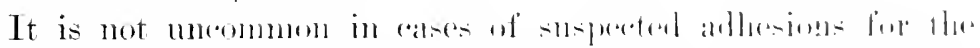

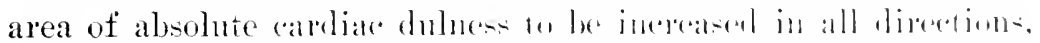

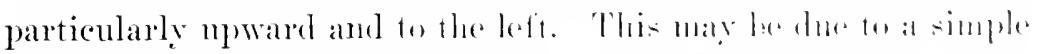

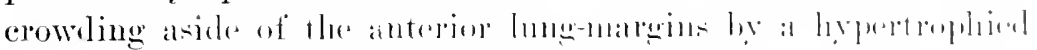

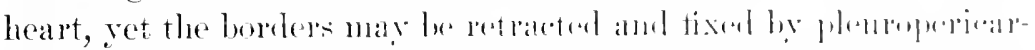

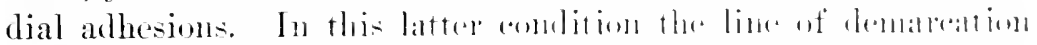

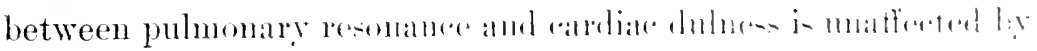

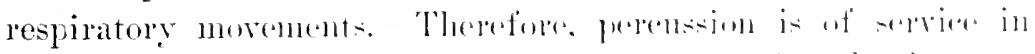

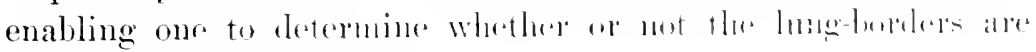
bound down by adlesions.

Auscultation.-For the most part hlis is of newation valure.

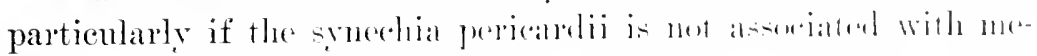

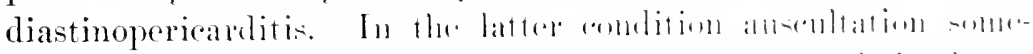

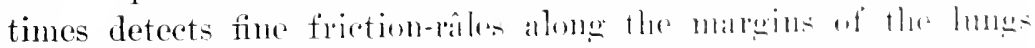

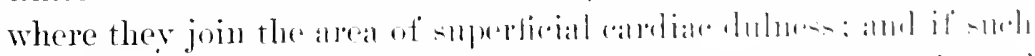

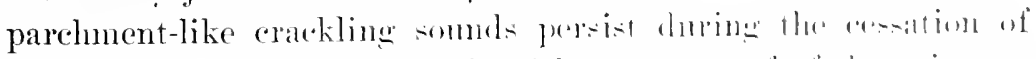

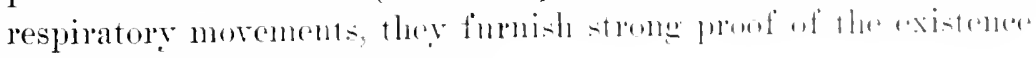
of pleuropericamilial athesions.

Roberts quotes Porez as anthority for the statement that in

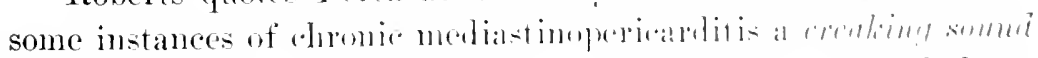
upon the body of the stemmen is andible during nl and down movements of the amis. I lave tested this in sereral of my pat- 
tients, and in no I letected this creaking friction-sound described he Pere. Is in these calses other positive signs of adherent peri"aldinn were present, this sign of Perez possessed considerable interest, if net material injortanee.

Diagnosis. - From the foregoing description of the physical signs it is apparent that in some cases the diagnosis of pericaldial athesions can be marke alnost at a glance, while in others the munt skilful diagnostician may not be able to decide whether the pericardim is adherent or not. The difticulty is found in "ares in which the two layers of the salc are mited withont allhesions to the surromding parts. In such, one must observe critically the jugular veins and the radial pulse in the hope of deterting some of the anomalies that have been described. The size of the heart shonld also be mapped out by perenssion, and the liver shonld be examined as to its size, density, and outline, since sincelial pericardii may declare itself by no other signs than by its effect on these organs.

In cases of chronic indurative mediastinopericarditis the matter of diagnosis is nsually far less difficult. Indeed there may be a conjunction of several physieal signs. Thus in one of my patients the apex is firmly fixed far below and to the left of the nipple. There is systolic retration of the soft parts between the alex and the epigastrimm, and of the intercostal spaces below the left scapula. The anterior margins of both lungs are drawn aside and inmorable, causing nearly the whole heart to be uncovered, as shww by the great area of superficial dulness. The liver extemils nearly to the iliar crest and is hard and deeply notehed, while owing to the enomons size of the heart and liver the front of the chest looks distended and smooth, and when the patient stands the abromen appears disproportionately large and pendulons. Pusus paratoxus and inspiratory swelling of the cervical veins are also present.

Lastly, one should always be suspicions of an adherent pericardimm in erery case of rhemutic valvular disease, and if in such il cate the liver resembles in thickness and density the organ in atpouhic cirrhosis, ret is not so contracted, if ascites develops withent alpurent canse, or takes place prior to or ont of proportim to anasurea, there is gool reason to suspect the complieation of an adherent pericardiun. 


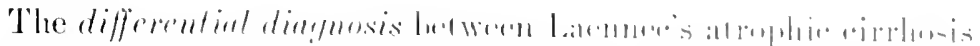

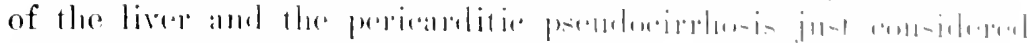

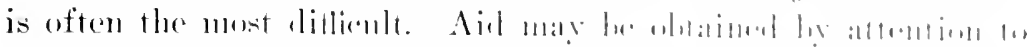

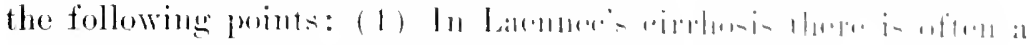

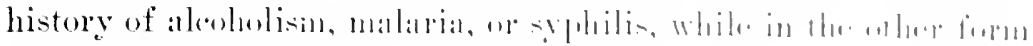

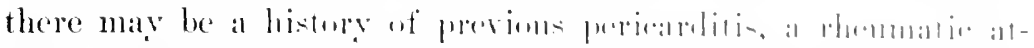

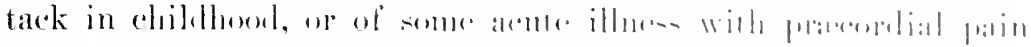

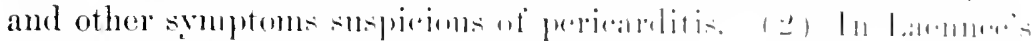

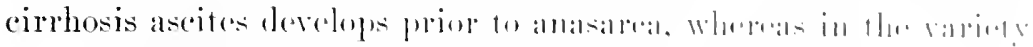

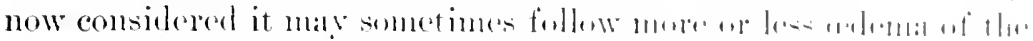

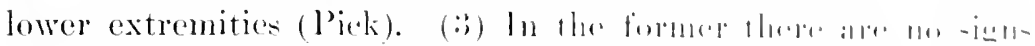

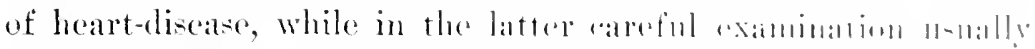

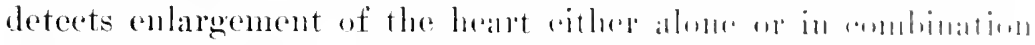

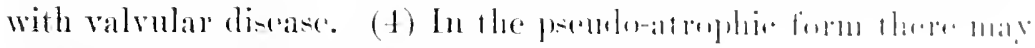
be some of the signs of allorement prelicalrelimm.

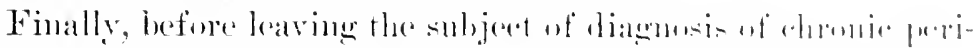

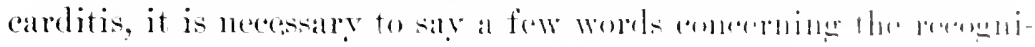

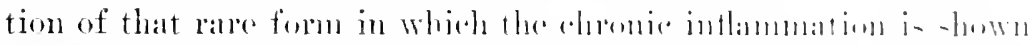

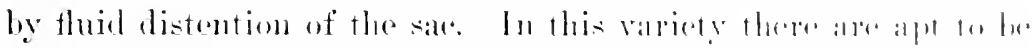

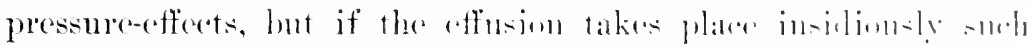
effects may not decelare themselses. In

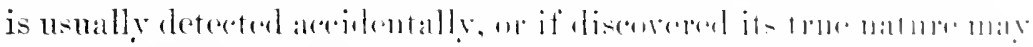

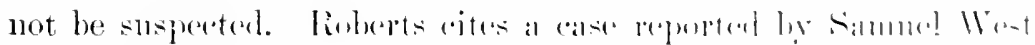

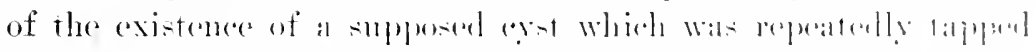

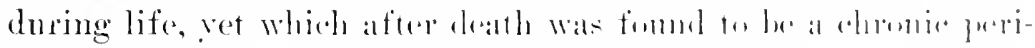

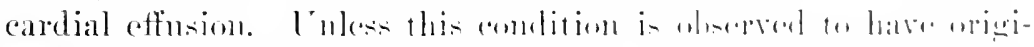

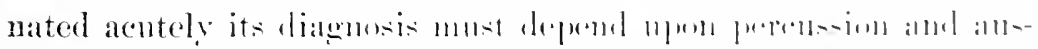

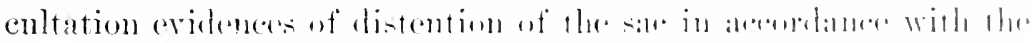

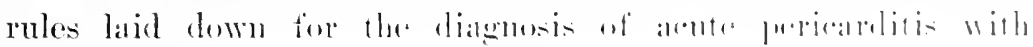
effusion.

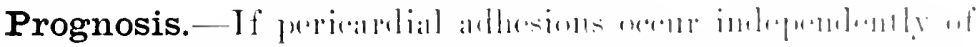

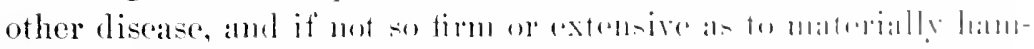

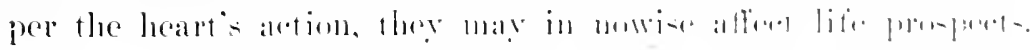

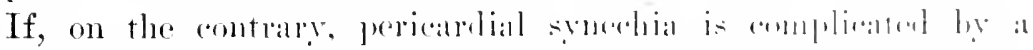

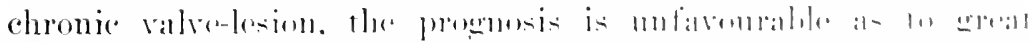

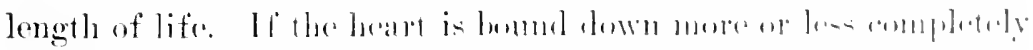

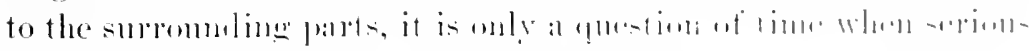

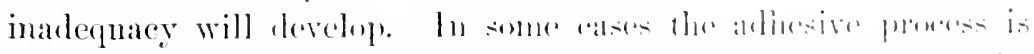

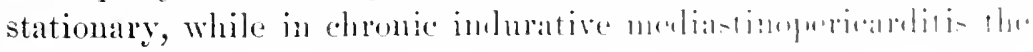


fendency to subsequent adhesive inflanmation of other serons membranes and to the sprealing of the adhesive process within the mediatimm furmishes an exerelingly grave outlook for the future. When ascites, anasarea, and other symptoms of the final lorakdown apperar there is small prespect of a restoration of rompensation. Inder such eonditions the duration of life is likely to bo homded by a few months or even a fow weeks. Althongh, as in the ases narrated, the strugegle may be extended over a number of rears, the patient is a chronic invalid at the best, and can only with ereat difficulty postpone the fatal erent. The absence of all subjective and objective srumptoms furnishes presumptive evidence that the adhesions are not extensive. If, on the contrary, symptoms of engorement within the lesser and greater circulation are nerer wholly absent, they aftord the hasis for unfarourable prognosis. The greater the secombary caldiac hypertrophy and dilatation, particularly in childron, in whom chest capacity is stall, the slighter the prospect of the long retention of adequate compensation. When the last stage of the journey is reached it is likely to be a shout one.

The prognosis of chronic pericardial effusion depends upon its etiologr and the length of tine during wheh it has existed. It also depends moon its association or not with some other disease, as chronic nephritis, and upon its amenability to treatment.

Treatment. - It goes withont saying that we possess no means of breaking up the pericardial arhesions; at the most we cam only strive to lessen their ill effects and to prevent an extension of the process. In mundeavom to acomplish the latter, any rlemmatic attack or acute illuess, no mattel how trifing, should be promptly and cherectirally combated hy appopriate means. The patient shomld be at once confined to the house, and if possible to the bed, in order to relieve the heart of any mmecessary work, and the obly if possible prevent fresh pericardial inflammafine orestrain the activity of the process, shomld the pericardium acain lecenue attarkod. Salicylates, comnter-irritants, or other milel antiphlogistic neasmeses are in ordere

The rhicf aim of management shonld be to preserve compensatory lisportrophy, and so far as possible to minimize the ill ef-

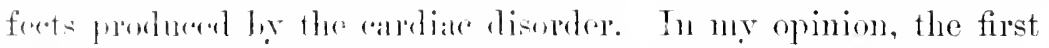
escential is that the patient be not left in absolute ignorance of 


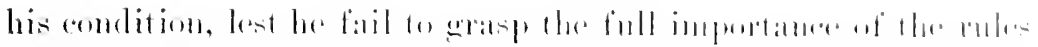

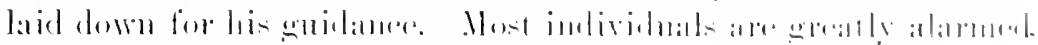

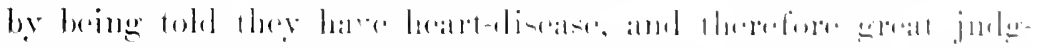

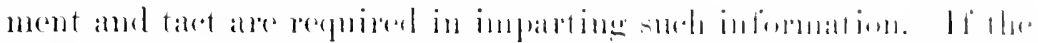

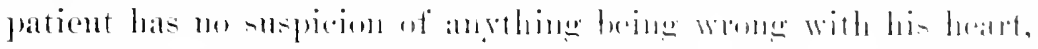

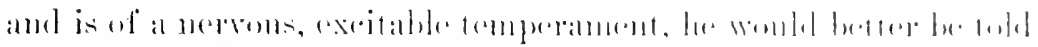

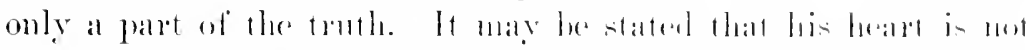

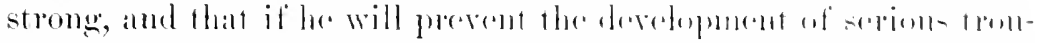

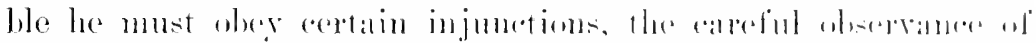

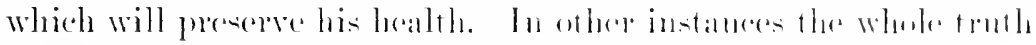

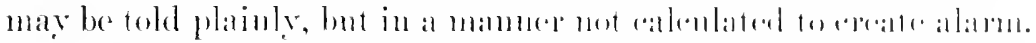

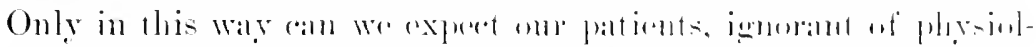

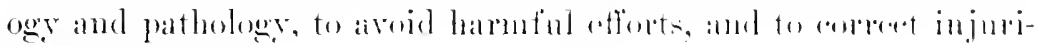
ous habits.

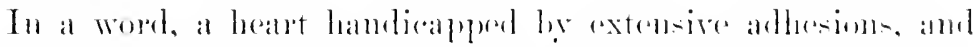

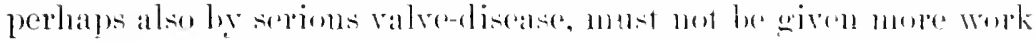

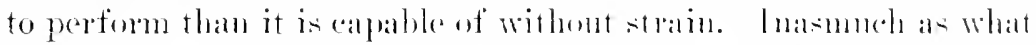

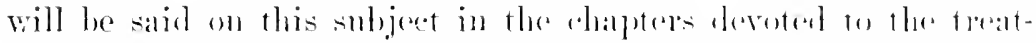

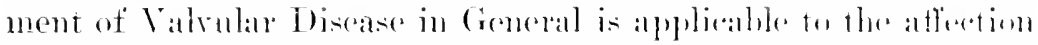

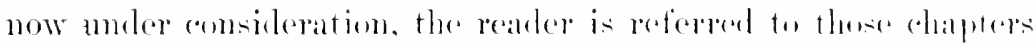
for the details of this fart of the mantagenent.

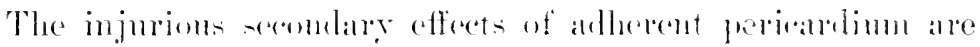

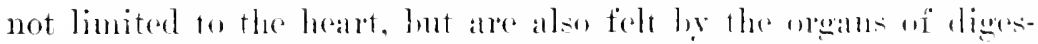

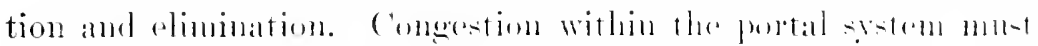

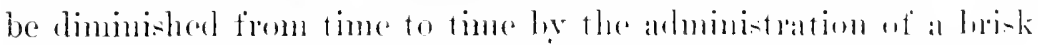

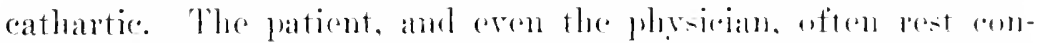

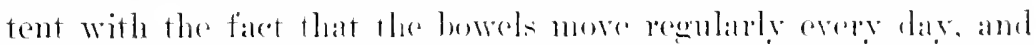

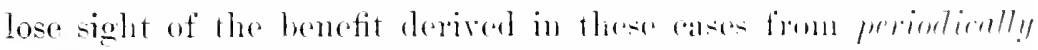
untoating the liere. Nothing is bettere to this and than a hlue pill

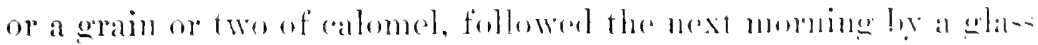

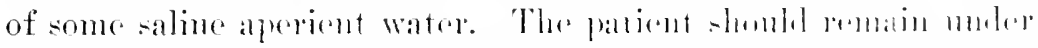

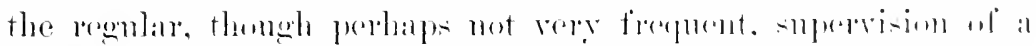

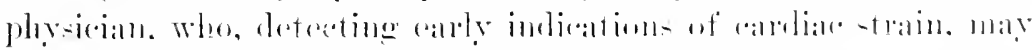

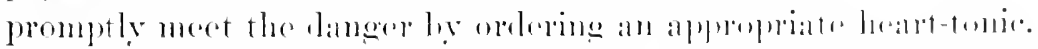

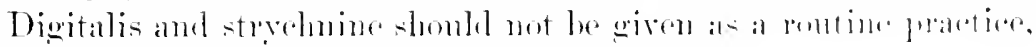

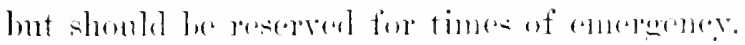

As a rule the somptoms pointing to weretrain wh the part of the heart an le allayed ley regulation of the line restrieting the amount of work or exercise, and it way be by insisting upon rest 
in the hense for a time. The food shomld be relatively rich in proteids, moderate in quantity, and taken at regular intervals. If the individual is inclined to eorpulener, or suffers from fermentative indigestim, carbohychates and fats should be allowed sparingly. Lomestraned consmption of fluids is objectionable, since it is a rery easy matter for the intake of liquids to greatly exceed the needs of the system and the eliminating power of the exeretory oreans.

When the breakdown of compensation at length comes, with all its attendant manifestations, the case is to be managed in aecordance with the principles governing the treatment of the same condition in any other form of cardiac disease. It has been my experience that one camot expect or achieve as brilliant results from the employment of digitalis in these cases as in valvular affections unfettered ly adhesions. It is not so much a question of whipping on the jaded heart as it is of relieving it of as much of its loan as possible. Physical rest must be strictly enforced therefore, and catharsis must be brisk. Digitalis must be given for the purpose of invigorating rather than greatly slowing the leart, and with a view of obtaining its diuretic effect. Dinretin and other dinretic remedies are also in order. It is now that strvelmine is of particular service, and to produce its most beneficial effects it should be administered hypodermically. Pain, congh, insomnia, and ofler distressing symptoms are to be relieved as they arise. One should not hesitate to remove ascites by aspiration whenever it accmulates to the extent of seriously embarlasing the heart and respiratory organs. If the anasarea does not fiedd to appropriate remedies, it may be drained off ly the use of Sonthey's tubes or by incising the ankles, always under striet areptic precautions. 


\section{CHAP'TER III}

\section{HYDROPERICARDIUM - HAEMOPERICARDIUM - PNEU- MOPERICARDIUM-TUBERCULOSIS OF THE PERI- CARDIUM-SYPHILIS OF THE PERICARDIUM-CAR- CINOMA AND SARCOMA OF THE PERICARDIUM}

\section{IIYUROPERI('ARIILU}

Br this term is meant a transmation of sepmon inter the pericardial sale. It is a non-inflammatery procese, and the antalegne of what takes place under similar conditions in other serons cavities. The presence in the perieardium of 1 or 2 drachlons of ecrum

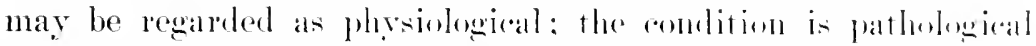
only when the transudate reaches such an anoment ats to constitute a veritable dropsy (hydrops pericarelii). Althomgh the comblition is the comberpart of transudation inte ofler sorons alvities, it does not oecur with anything like so great freplneney as hycilrothorax and ascites.

Morbid Anatomy.- dial sac is found more or less distended and thetuating, the same

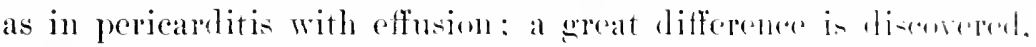
however, when the sac is opened. Instean of fibrin-misses and other evidences of inflanmation, together with a sepous exulats. the sac contains a clear, straw-eoloured fhuid, poor in allunnin, ant eontaining vere little if any fibrin. Berame of its redative hefieieney in allomin the specifie gravity of the transmate is lower than that of a scro-fibrinoms offusion, ranging fon $1.001-101.01 \%$. The pericardial tissues may look more or lese adematents: hut aside from this appealrane and being filled with sermuth. the salle

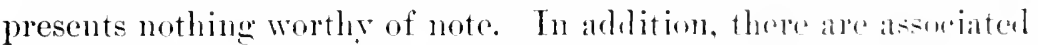
changes in other tismes and organs-such ats ardema, depemding

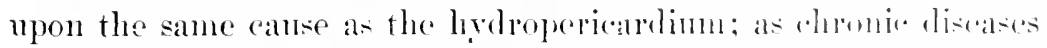
of the heart or kidners, or both, which have served to bring about 
the serons transulation into the sale. The transudation into the pericatrimu valries in almont from a few ounces to several pints.

Etiology.-Itrdroperiendim is a dropsy, and therefore is produed in the sane mamere and depends mon the same variety of callses as dropseical fhuid in other situations. The canses may be divided therefore into general and local. The general inelude chromic andiale disease, nephritis, both acute and chronic, and eachexiar. By local canses are meant those diseases, such as tumours, which, sitnated within the thorax, exert pressure on neighbouring blecel-rescols, and thus bring about stasis in the reins and eapillamies of the perieamlimm. ('hronic heart-disease leads to dropsy in the same way, but the stasis within the pericardial ressels is only al part of a genceral condition.

Symptoms. - These are likely to be overshadowed by those of dropisal acemumation in the phenral earity and general renous congestion. If by chance hydroperieardiun exists alone, a very rare event, or formes the leading pathological condition, the symptoms are those resulting from pressure, and consist of the same phenomena of circulatory and respiratory embarassment as are aborved in cases of extensive sero-tibrinons pericarditis. Dyspnera is more or less marked, and maly eren amount to orthopnoa; "Yanosis and venous congention are also present, and the pulse is small, feelle, rapirl, and it maly be irregular. The more rapidly the hatropericardinn superves the more promonnced the symptoms. As dropsical distention of the sac, when it develops in the comre of ehronic cardiace or renal disease, is one of the teminal

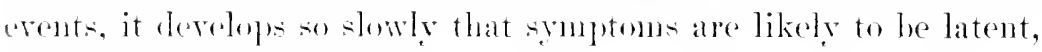
and therefore ereape motior.

Physical Signs.-Inepertion.-This affords lout little if any information, owing to the fart that in most arses distention of the

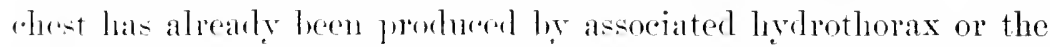
heart and humes have heen epowed upward he aseites. Should

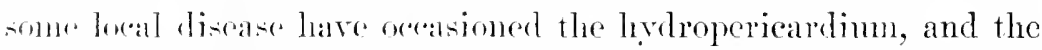

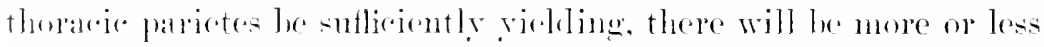
pricorrtial bulging, togetlee with absenee of cardiae impulse.

Prolpution. - What has been said regarding inspection applies alos to jalpation. The chief, and perhaps the only thing noted, is utsener of errdiue impulse, and possibly a sense of increased pre- 


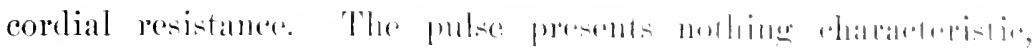

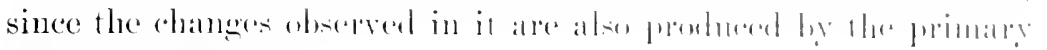
cardiale alfections.

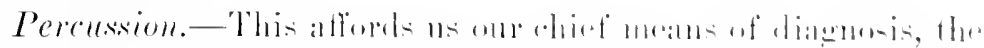

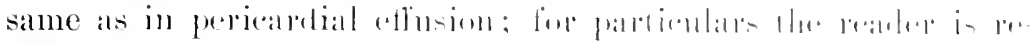

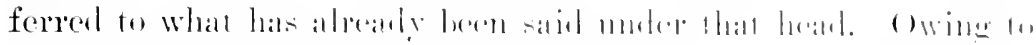

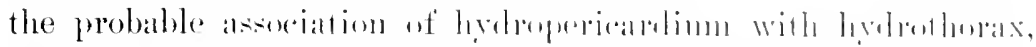

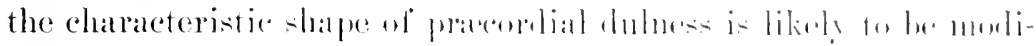

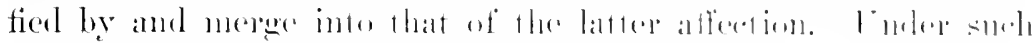

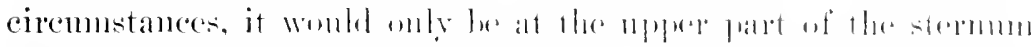

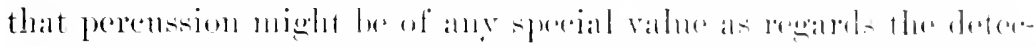

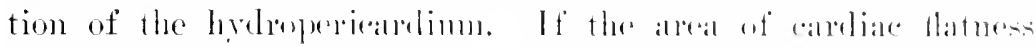

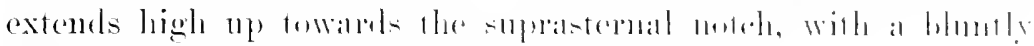

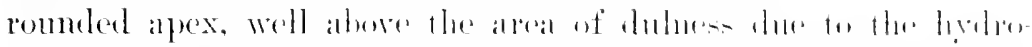

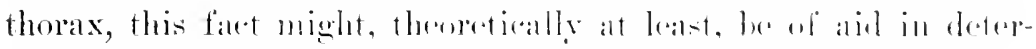

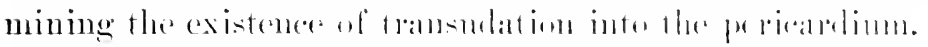

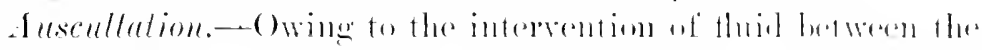

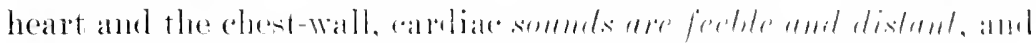

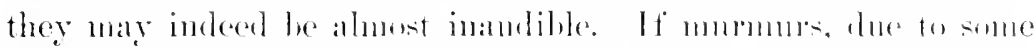

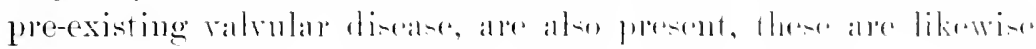
enteebled.

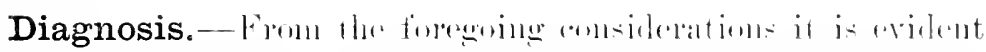

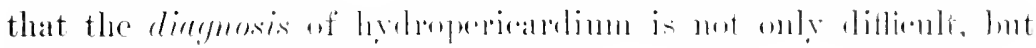
may be aretnally improsible.

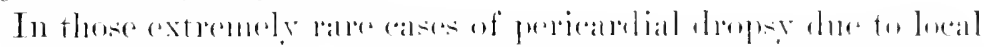

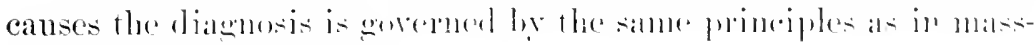
ive perieandial exmlation.

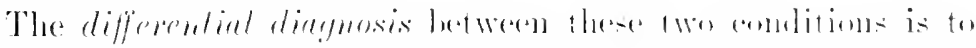

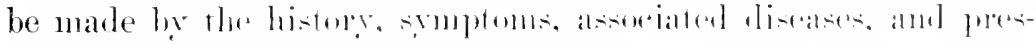

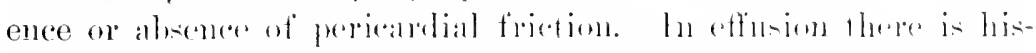

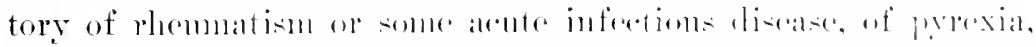

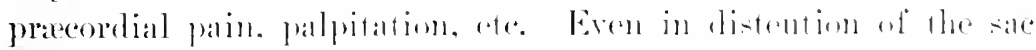

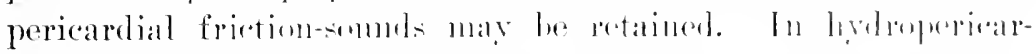

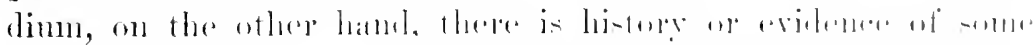

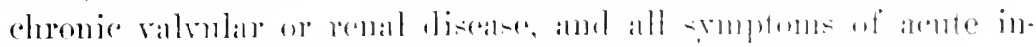

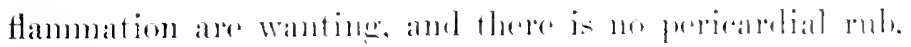

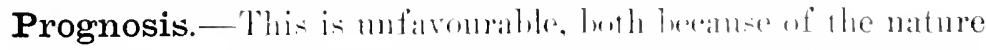

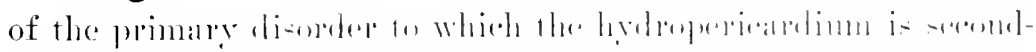

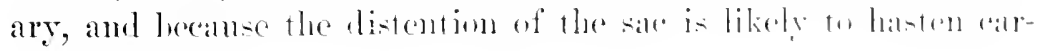


diale failure. The prognosis is also influenced by the amenability to theatment of the camse of the drops.

Treatment. - This resolves itself essentially into the treatment of the primary disorder, since with the remoral of the gen(ral dropse the fluid within the pericardimn is absorbed. Unless the simptoms be exeedingly threatening, surgical treatment, if not actually muise, affords only a very temporary relief. In wher words, the treatment of hridroperieatrdimm is mavailing unless its canse ean be remored. The mamagennent of dropsy when associated with chronic cardiac disease, will be found fully narrated in subsequent chapters.

\section{H.EMOPERICARDIUM}

by this term is not meant hemorrhagie pericanditis, but an cxtrarasition of blenel into the pericardium independent of any intlammatory process. It is fortmately a rather rare condition, and yet ocemrs many more times than it is reegnised. It requires lut very brief consideration.

Morbid Anatomy. - Is with serous transudation or effusime the excalpe of blood into the perieardium causes a distention of the sac proportionate to the amount of the extravasated blood. If the hemorlange takes place rapidly the amount discovered post mortem is msually not laree, because it has speedily occasioned the deatly of the patient. If, on the other hand, it takes place slowly, the sac mar be greatly distended. The blood may be wholly fluid or have indergone more or less coagulation. After the evacuation of the pericardial contents, careful serutiny discovers evidenee of some one of the causes of the hemorrhage.

Etiology.--Blood may be effused into the pericardium in comerpuence of external injury, as by gunshot or stab wounds, laceration of the sac by the slarp elge of a fractured rib, ete. It also follows rupture of the heart-muscle, the bursting of an aortic anemrem, or in rane instances, of one of the coronary arteries. It is stated that sacenlated anemryms of the ascending areh fre quently rupture into the perieardium. Of 953 cases of aortic ancemram analyzed by Hare and IIolder, death took place from rupture 2s: tines, and of there, T5 cases ruptured into the pericardium. Rupture of the heart oecurs from degeneration of the mroeardinm, and is fortmately a comparatively infrequent event. 


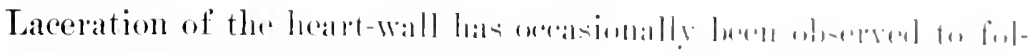
low a "rushing injury ho the rhest.

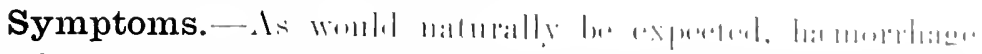

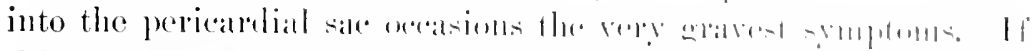

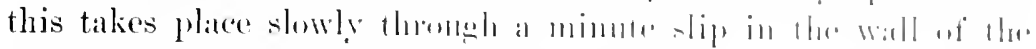

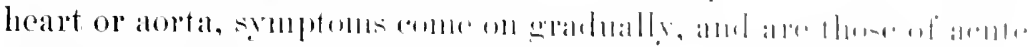

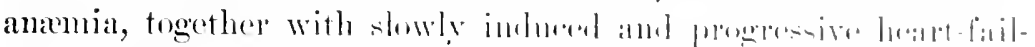

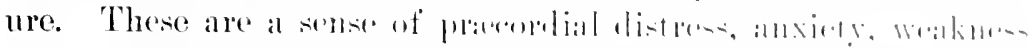

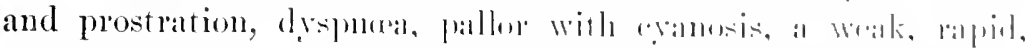

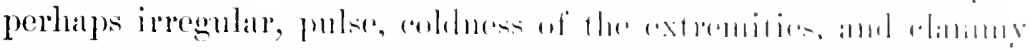

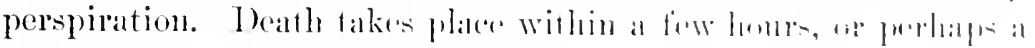
day or two.

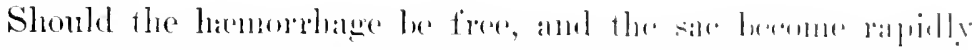

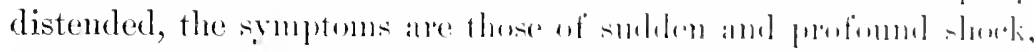

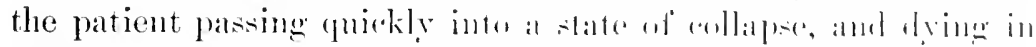

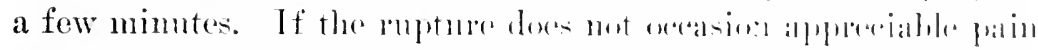
there may be mothing in the simptoms to dirent altention to the pericardinm. In most instances the comber is rapid, loulding to a speedily fatal temination.

Physical Signs.--Thes ale the signs of Hoil tistention of

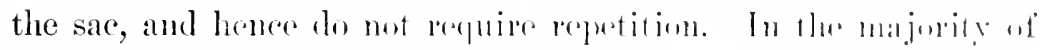
instances death is too rapielly indered an the distention of the

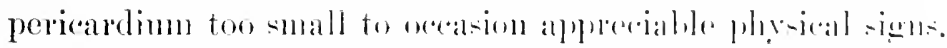

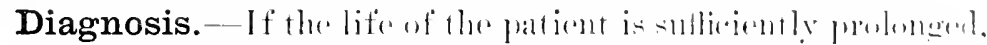

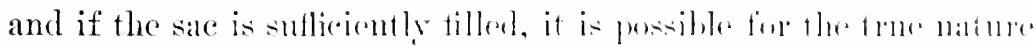

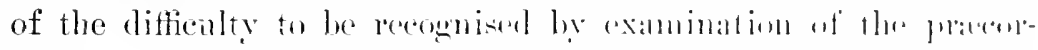
dium. If the presence of thint in the perieatrem is male nut, the

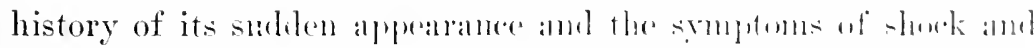

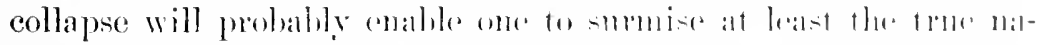

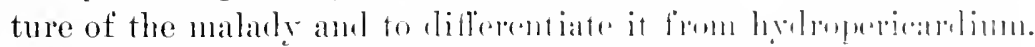

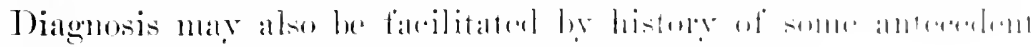

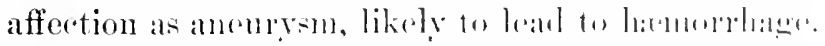

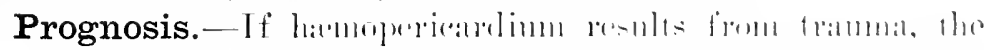

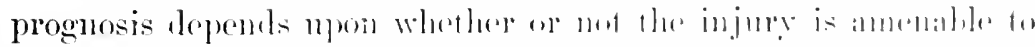

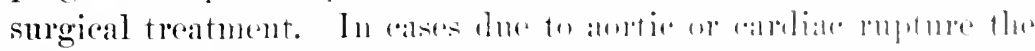

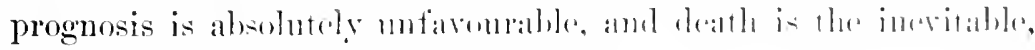
it may be tle immediate, result.

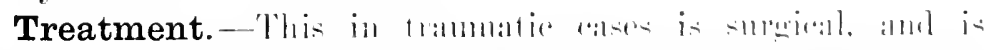

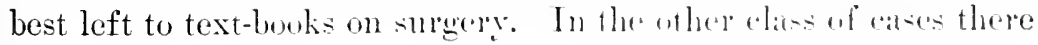


is 110 treatmont, exerpt possibly in those late instamess of tran-

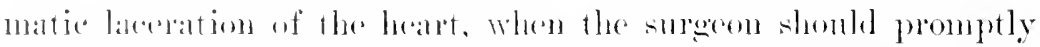

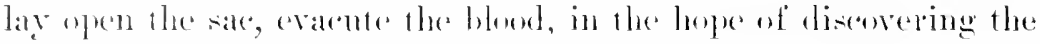

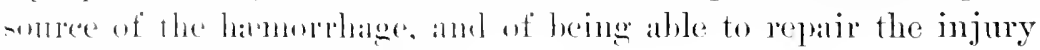

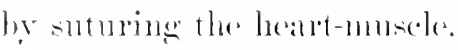

Merlicinal tratmont is limited to stimulation of the heart and an atfempt 10 suppert the powers of life. In most instances the plesician arrives on the seene too late to do more tham witness the deathestrugegle or sign the deathecertiticate.

\section{PNELMOPERICARIMLA}

This is so extremely rare an affection that but few have been so fortumate as to olserve an instance of the kind. By this term is neant a collention of air or gas within the pericardial sac, and hence it is the counterpart of the condition known as pneumothoras.

Morbid Anatomy.-Pnemmopericardimn is nsually associated with collection of thuid, most commonly of pus, within the sate. The anomet of contained air or gas is variable, but is suffirient, together with the axubation, to orasion great distention. It the gas is not abourbed, and the poricarlimn be opened post mortem, the gats ascalpes with a hissing noise and often possesses a firtid oflour. In some instances its arenue of entrance can be arsily aterertained, while in others there is m discoveralle opening into the pericardium, either becanse, if strel have existed, it has berome cloned, or becanse the gas has been generated in loro. There are usually present atso evidences of acute peri(allitis.

Etiology.-Pnemungerieardium may be produced in any one of three ways: (1) Perforation of the sac from withont may allow of the entranere of atmesplueric alr ; (2) communication may le establishen lutween the sac and some portion of the digestive tract, thus pormitting the ingress of the gases normally exist-

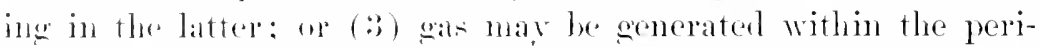
"ardium withont solution of its continuty. The entrance of

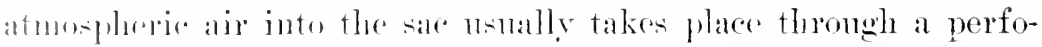
lating wombl, as fom a lullet ol some stabbing instrument. In

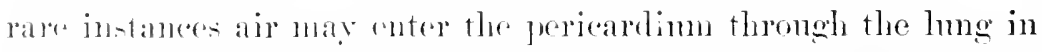

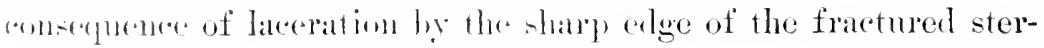




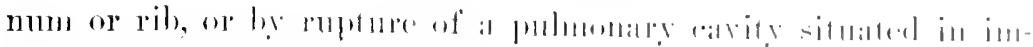
nediate contignity to the sale.

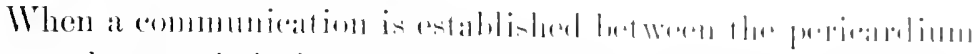

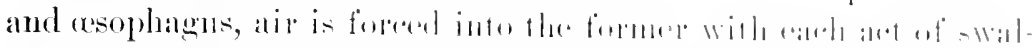

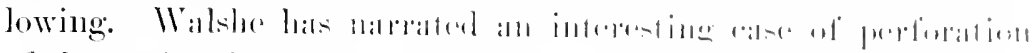

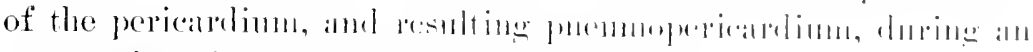

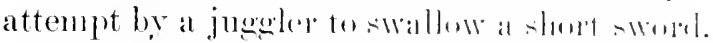

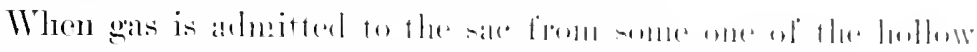

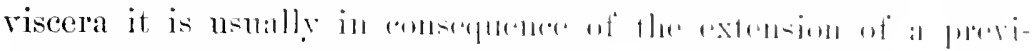

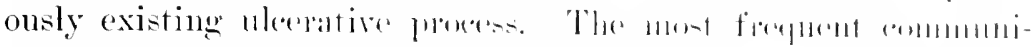

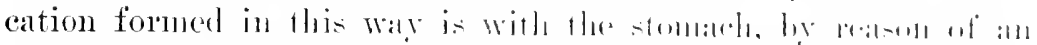

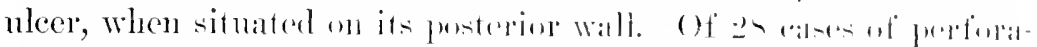

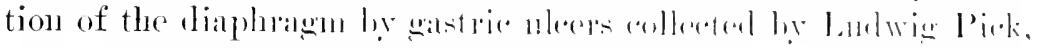

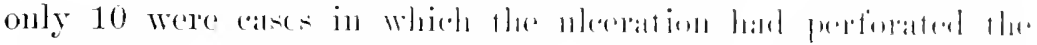

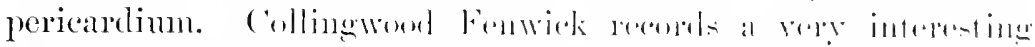

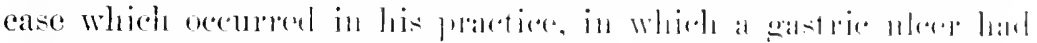

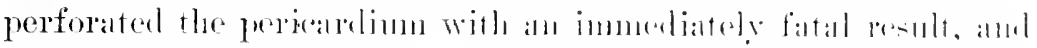

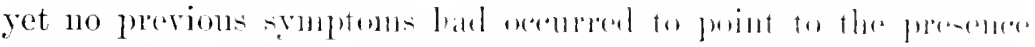

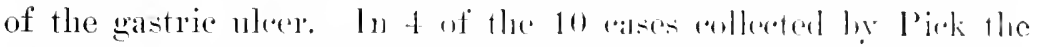

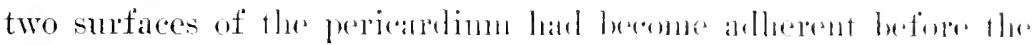

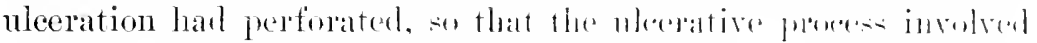

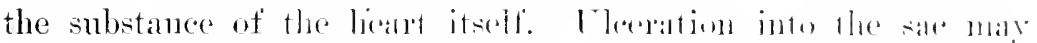

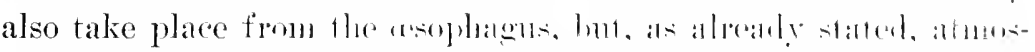

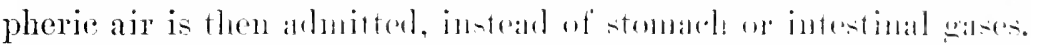

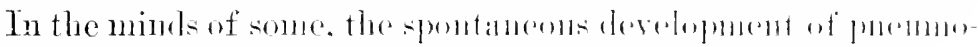

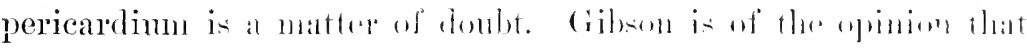

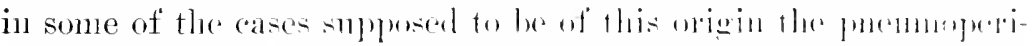
cardiom was in rality the result at an numing inte the sale.

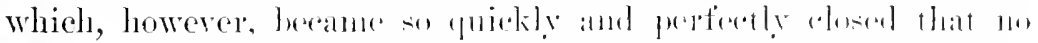

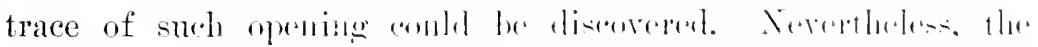

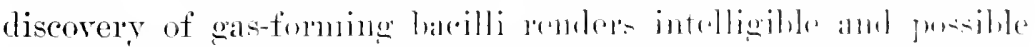

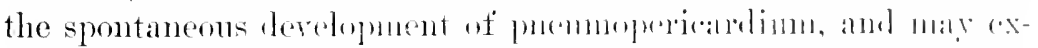

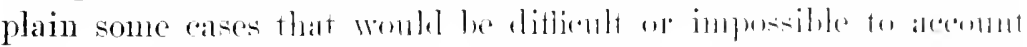

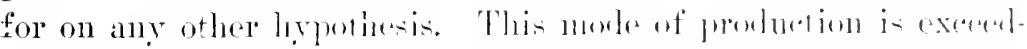

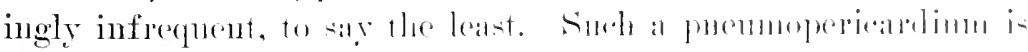

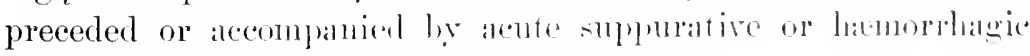
pericartitis.

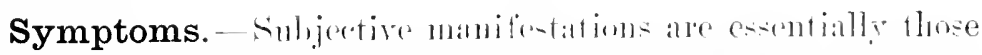
of sudden distention of the sale from any other callse. They alle 
simptomis of presine; but inasmuch als the entrance of gas takes place suddenly, syuptoms develop rapidly and are extreme. In some instances there are simptoms of shock; a weak, irregular prulse, a pale, anxions comtenance, the skin eorered with cold sweat, which, together with orthopural, produces a picture of mortal anony. The physician's attention is at once directed to the leart, the examination of which reveals a most singular group of oljeetive srmptoms.

Physical Signs.-Inspection and Palpation.-These afford evidence of perieardial clistention but not of the nature of the discale, and are of minor importance since the diagnosis is readily established by other means of exploration at our disposal.

Perenssion.-The phenomena perecired by perenssion are unique; instear of cardiac duhness, encroached upon and surromeded by pulmonary resonance, the precordinm is found to be trmpanitic, either thronghont or at its upper portion. If the pericardimu contains fluid, as well as air or gas, there is dulness over the dependent part and high-pitched tympany above. Gas being lighter than the exudate, clange in the patient's position from the recmmbent to the upright, and from side to side, causes the gas to move about, so as to be always above the level of the fluid; lience there is cliange in the location of dulness and tympany according to the posture of the patient. In the erect position dulness ocempies the bottom and tympany the apex of the sac. If the patient lies on his loft side the flnid gravitates in that direction, with corresponding dulness surmomited by tympany; and, on the other hand, the assumption of the right lateral decubitus causes a corresponding alteration in the relative position of the gas and liquid, with resulting traneposition of trmpany and dulness. Moreover, the larger the anmonnt of exulate the smaller the space allotted to the gaw, and hence the higher the piteh of the tympanitic note. Stokes claimed in one case to have detected "eracked-pot" resonance.

Auscultation.-Perhaps the most striking features are the peculiar somuts olserved on anseultation. The movements of the leart cance an agitation of the gas and liquid contents of the sae, and lience a trine surcussion-sound on splashing. This is varionsly described as churning, splathing, or like that produced by a waterwhecl. These are sometimes accompanied by that musical sound 


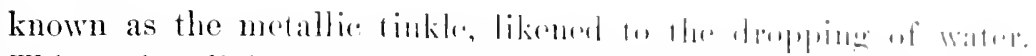

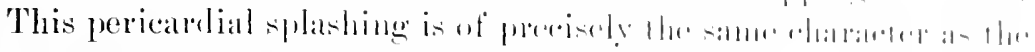

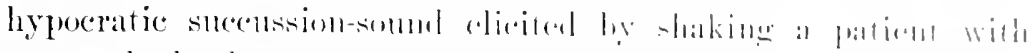

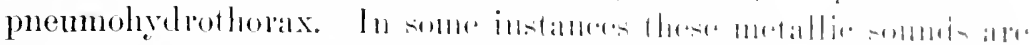

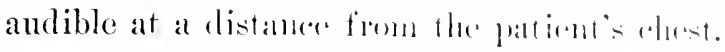

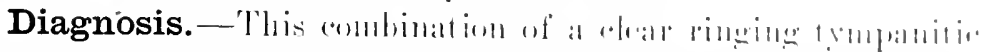

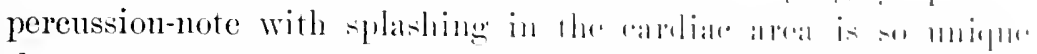

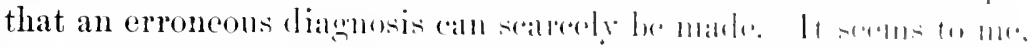

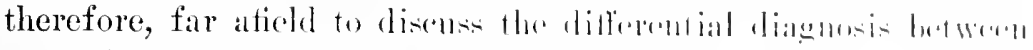

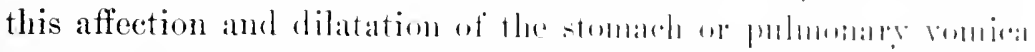

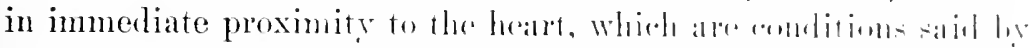
some authors to render a mistake in diannesis posilile. lainally,

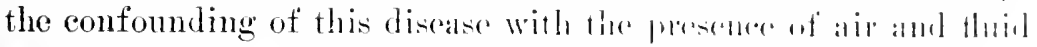
within the plenral arvity is sealrecly likely, if om will leal in

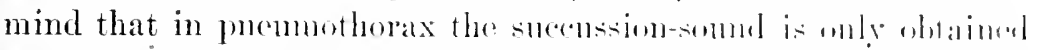
when the patient's bexly is agitated, while in the aflection muldep discussion the peculiar somed is puesent oven when the pationt is at rest.

Prognosis. - This is always sepions, yet in trammatic alice

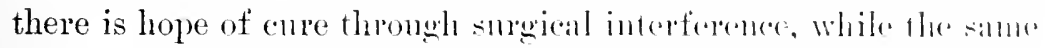
may be said regarding cases associated with pumlent gerianditis. Should gas gain entrance to the pericaldimm, and lu net followed by infection of the sac and intammation, there is a jusilility of

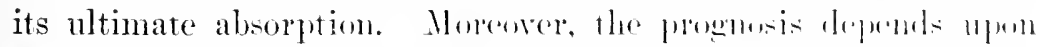

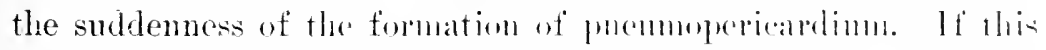
is sufficiently rapid to ocousions symptoms of shore there is struls likelihood that the pationt will sncemuls. It, on the nther lamm, the condition derelops slowly, s.mploms may mot lo very urent, and time may le allined for sureical intervention.

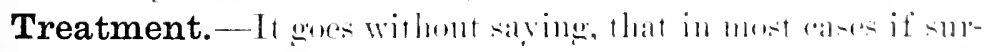

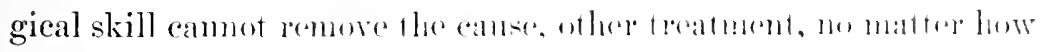
energetie, will la fomm mavaling. The same promeiples woxem

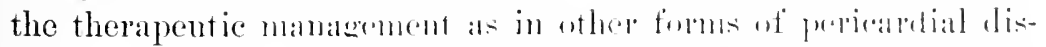

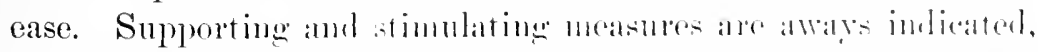
and may even enable the jationt wo rally ferm the intiat slowek.

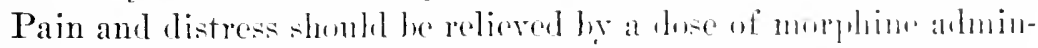

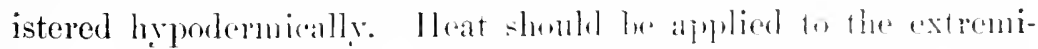

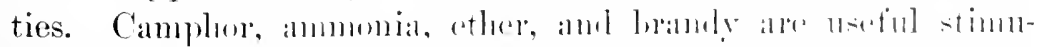
lants, and should be given ireely. The physician shomlal not form- 
wet the weat value of strichnine and digitalis in supporting the heart: the former shomld he abministered molder the skin.

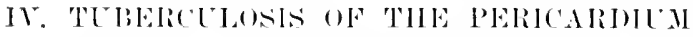

Morbid Anatomy. - Thluerenlosis prodnes in the perieardiun all of the rharaleteristic lesions to which it nlay give rise in othere regions of the bexly. The proxess may be acute or chronic in comrse, and cither exulative, productive, or destructive in niatinere.

The acute proess is not often to be distingnished from an ordinary acute pericarditis exeept by microsepic and bacteriological metlods. The exudate may be fibrinons, sero-fibrinous, or purnlent, hut tuberentoms periearditis shares with the inflammation of malignant divease the distinetion of being the most frequent cante of halmorrhagic exmlation in the perieardium. Tubercles nay not he demontrable post morten, and when fomd are often exceelingly small, even microseopic. They are nsually fornd on the parietal layer of the sac, owing to the frequeney with which the infection extends from neighlenting viseera. The mitiary tubereles may be overed by the fibrinoms exmbate, and are then to be disonered by detaching the fibrin. They may, however, he easily seen, and when eollected in groups give rise to areas of cascation. These raseons areas may invarle the myocardium, and in one instance a chees mats had perforated the wall of an anricle and projerted into its avity, being covered ly a thrombus where it was in contact with the likent.

Again, when the prohnetion of grannlation tisue is the predominating feature of the process, the two layers of the perieardimm are bemud together by a bluish translueent mass of newforned tisme. This of conrse hecomes white as it grows older, and the condition of adherent periardinm is prodnced. Only rarely is the cancoms man walcified after the cessation of the active proces-calcification luing more common in the inspissated remains of purulent exmlates.

Arute pericarditis is probably mberculons in a larger proportion of ases than has been stlphosed, and indeed camnot be consilfered a rare condition. Of 1,0th antospies on adults dead from

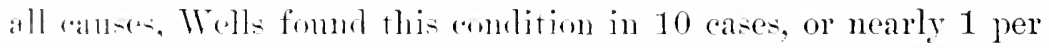
rent: and since in 125 cases the pericardium was actively involved, 
the 10 a alses a

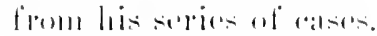

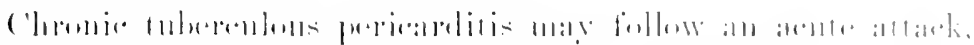

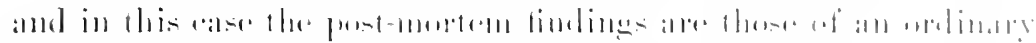

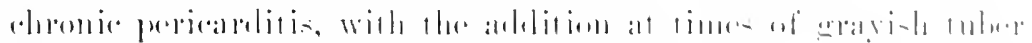

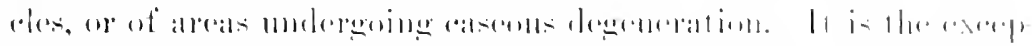

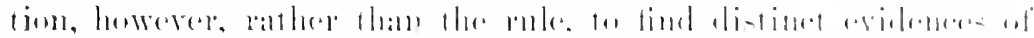

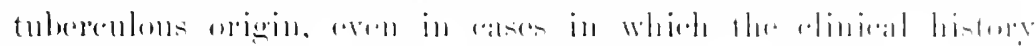

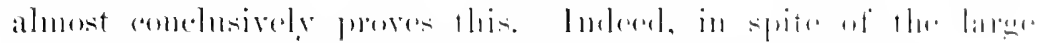

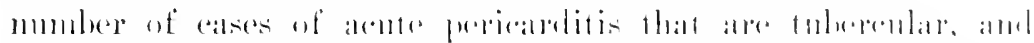

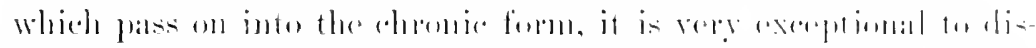

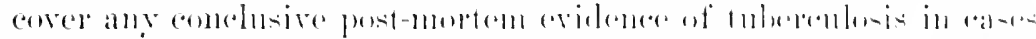

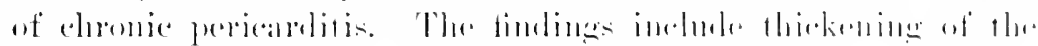

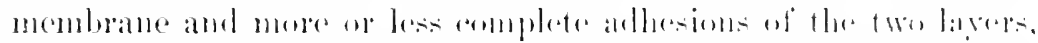

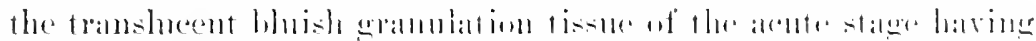

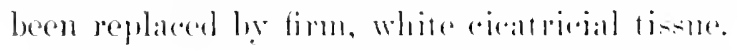

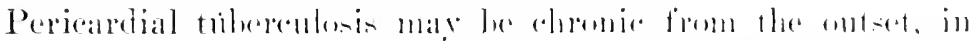

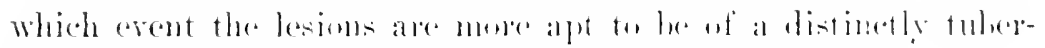

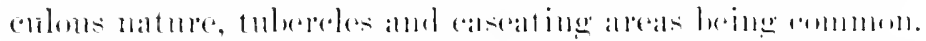

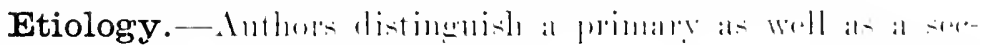

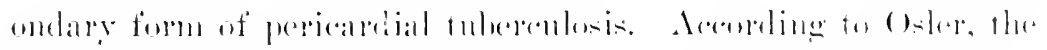

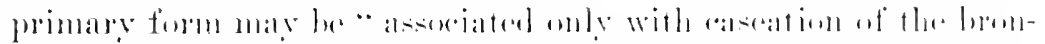

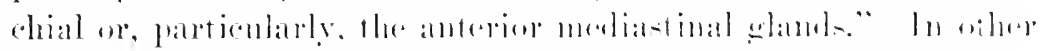

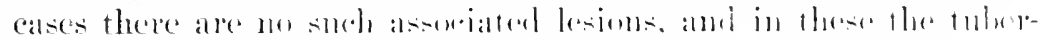

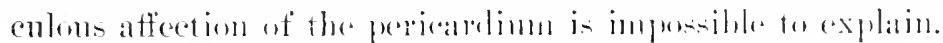

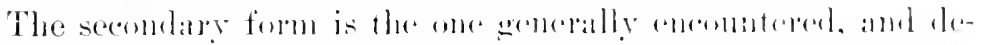

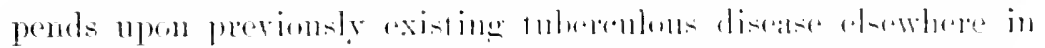

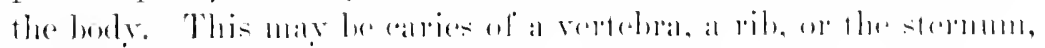

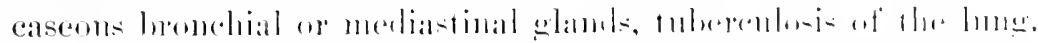

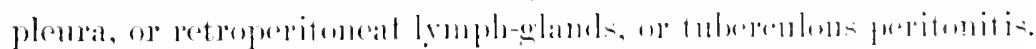

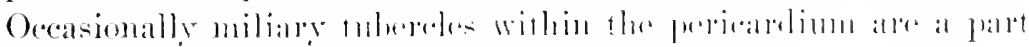
of a gemeral miliary interefime

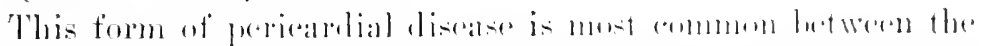

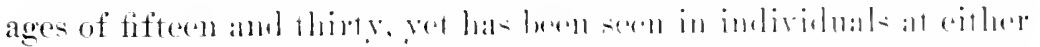

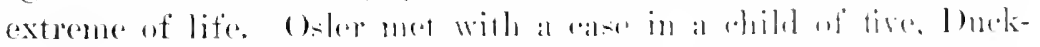

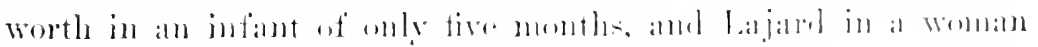

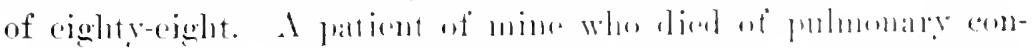

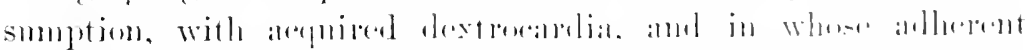

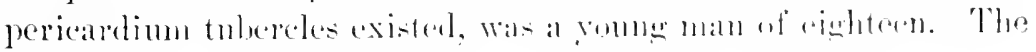


diseane affects both sexes, but for some strange reason appears to be rather more common in miles. ()ther predisposing causes are all those anditions that renter an individual susceptible to this forlu of infection.

Symptoms. - In most cases the disease is wholly latent, and is mly discovered on the antopsy table. This is due to the fact that the disease is generally subarente or ehronic, and arises insidionsly. If it gives rise to acute inflammation with effusion the symptoms are those of acute periearlitis from other causes-pain, palpitation, fever, friction-somnds, and, upon distention of the sac, the pressure-effects alreaty consilered. Even an exudative pericarditis of this origin may in some instances pursne a chronic course.

Physical Signs.-()hjective manifestations of the disease are wanting muless the affection is declared as an acute process. When such is the case there are the fremitus, pericardial frictionsound, and, with filling of the sac by exndation, the evidence of fluid distention-i. e., triangnlar area of dulness and disappearance of the cardiac impulse, ete.; in short, the signs already described in the chapter on Acute Pericarditis.

Diagnosis. - Owing to the insidions onset and latent nature of this discase it is rarely diagnosticated during life. If in the course of pulmonary tubereulesis or of pleuritis in a tubereulous subject the physical signs of pericardial involvement should make their appearance, one might with confidenee make the diagnosis of pericardial tubereulosis; but withont such favouring conditions it is not at all likely that the disease would be discovered.

Prognosis. - This is not always serions so far as it affects the duration of life, yet it muloubtedly contributes its share to the unfarourable termination of the general tuberculous disease. It: remote effects are an acherent pericardimm and cardiac insufficiency. The appearance of a tuberenlons pericardial effusion in the late stages of pulmonary tuberculosis, the patient being alrealy rachectic, would moloubtedly hasten the fatal issue.

Treatment. - This is to be conducted on the lines already laid down for the management of other forms of acute pericarditis.

\section{SYIIILIS OF TIF PERICARDIUM}

Invasion of the pericardium by syphilis is so rare an affection that most text-books on disceases of the heatrt either do not con- 


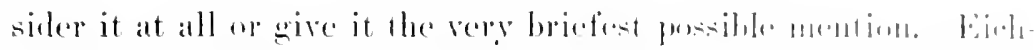

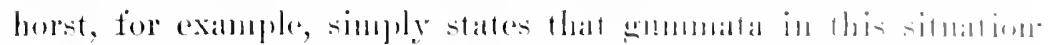

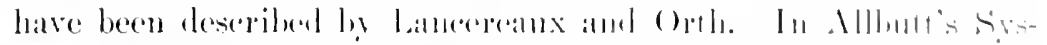

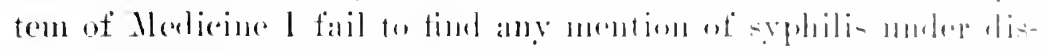

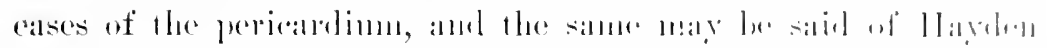

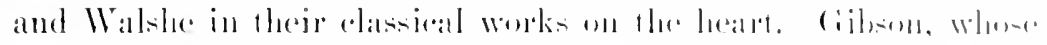

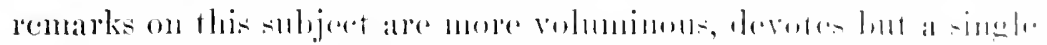

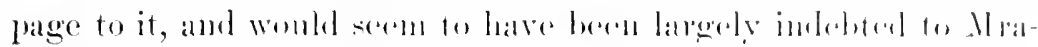

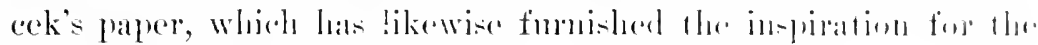
following brief eonsileration:

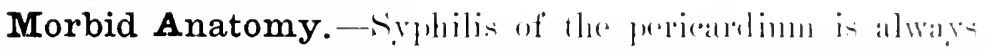
a very rare affection, and is almost nerer mot will massoniatenl

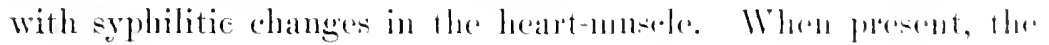
disease is limited to the riseoral lavere and manifests itself cithele

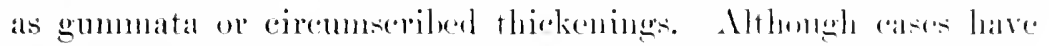

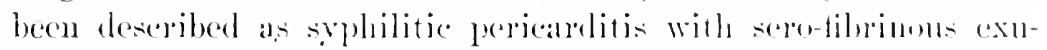

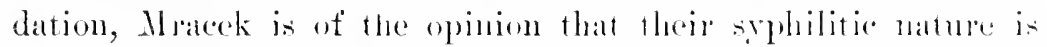
open to doubt. Of the two forms in wheh pericallial sylitis

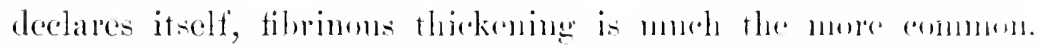

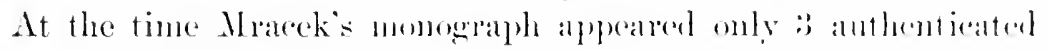

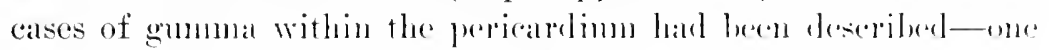
each by Lancercaux, (Orth, and Mlareok.

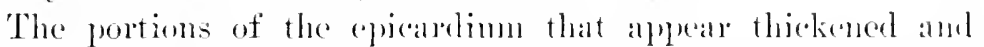

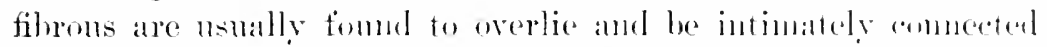

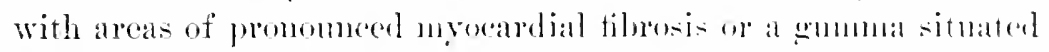

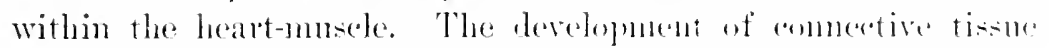

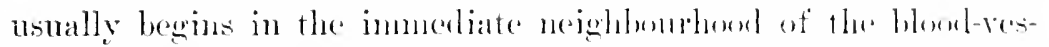

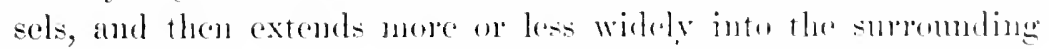
parts.

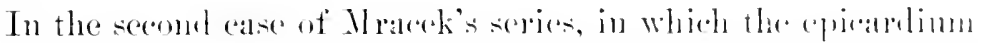

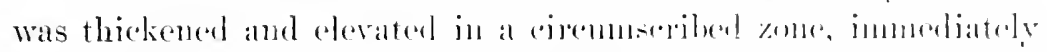

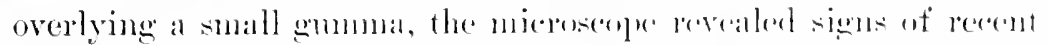
inflammation of the allipese tissue. This tisome was hlickly intil-

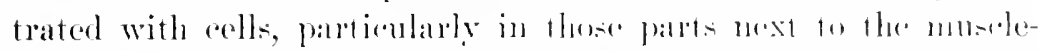

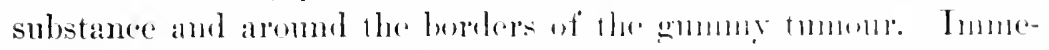

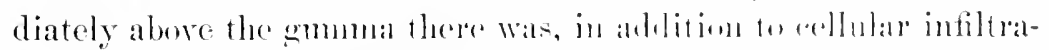

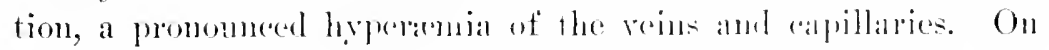
the overlyiug surface of the epicardimm the fiblous tissue was ald and firm. 
In the comber of time the blood-resseds supplying the newly

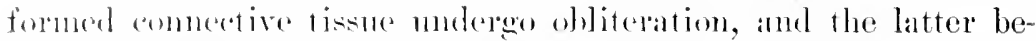
comes transformed inte tim cieatrieial tissuc. Thickening of the serous memblume is not necessirrily associated with a deposit of fihrin, and anseguenty pericardial adhesions are not always observert. In some instaness, howerere, the two layers are foumd

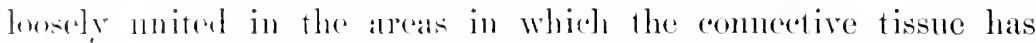
nukberane hyperplasia. 'lotal obliteration of the sace is almost

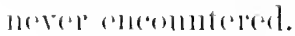

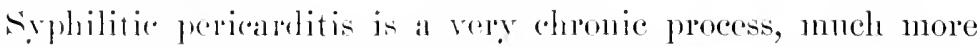

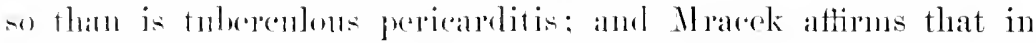
those cases in which it is difficult to determine whether the process

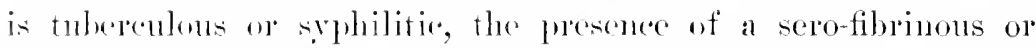
hammorhagic exudation tolls in farour of its tubereulous origin. ln arses of exuchtive prepounditis syphilis is the last thing to be thomelit of. In some instances the sac may be found to contain a small amomut of relear sermu, lut when present this is a transudation due to compression of the hood-resseds by the prodnets of sphilitic dicease. Very ranely hamogerienolimm may also be

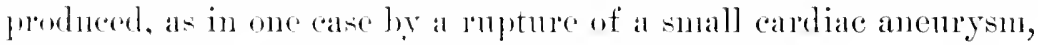
itself the result of syplititie fibrous myocalditis.

Etiology. - Syplititic discase in this situation is a late manifestation of the infection. There are no known factors which detemine its imasion of the pericardial sale, but, as it is a constitutional discase, it is only simgular that it is not more frequently present in this lonation.

Symptoms. - Srphilis of the pericardimu aither oceasions no s.mptoms, or these allo olsenened by those of syphilitic discase

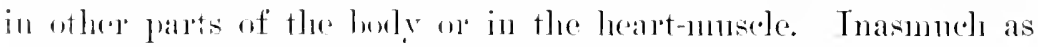

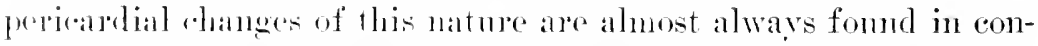
ucetion with luetic disease of the myeraldium or condocardimu, it is imposible to say how momeh, if amy of the symptomatology is to

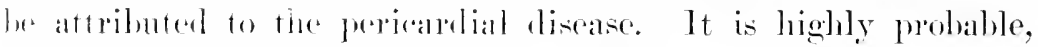
homerere, that the ahief role in this respect is played by the myo-

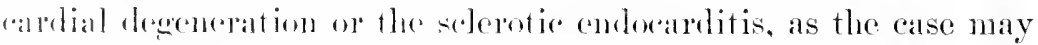
he. T'he ratriale manifustions will be fully described in the chilpter an Heant Sirplitis.

Physical Signs. - Exropt in tlor rane cases in which the jerieardial rhanges loal to the development of a friction-sound 


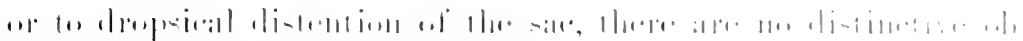

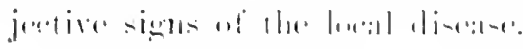

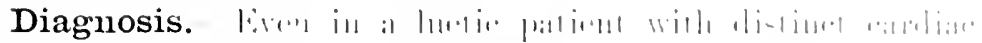

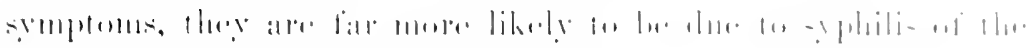

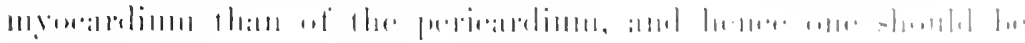

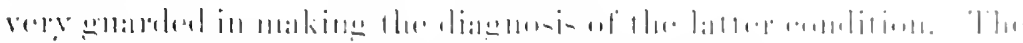

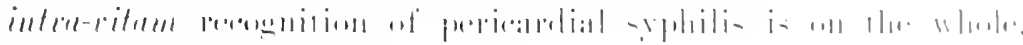
therelore, vely minlinl!.

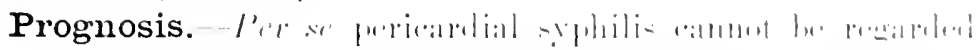

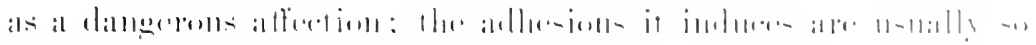

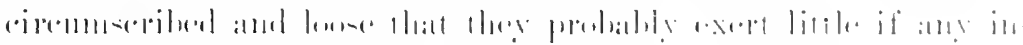

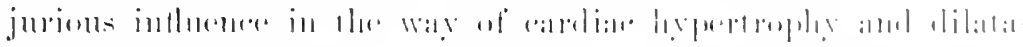

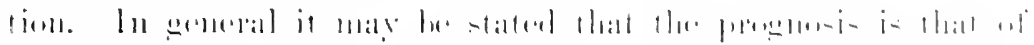

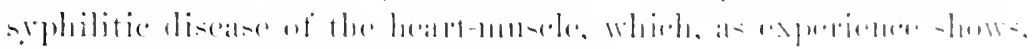

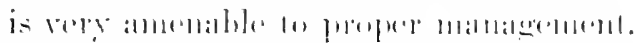

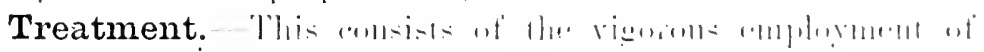

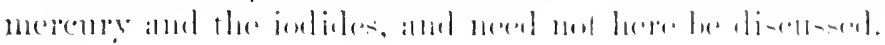

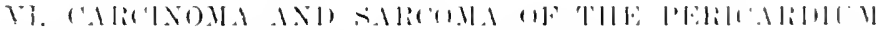

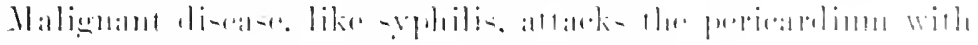

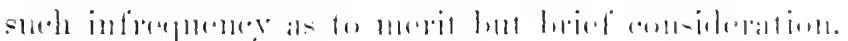

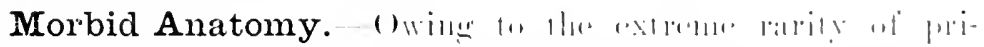

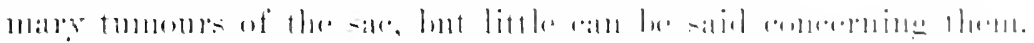

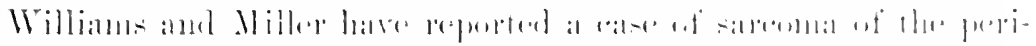

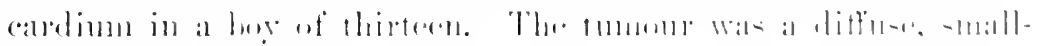

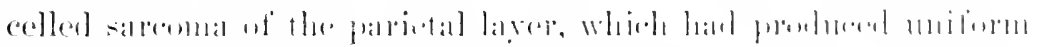

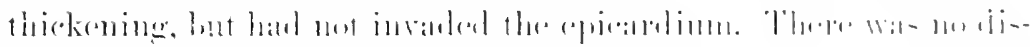

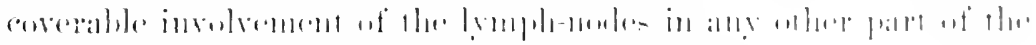

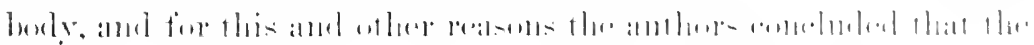

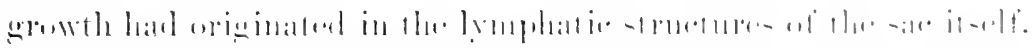

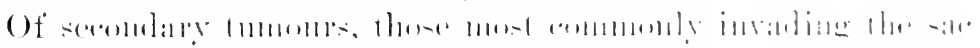

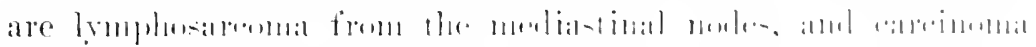

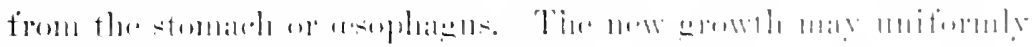

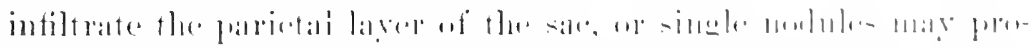

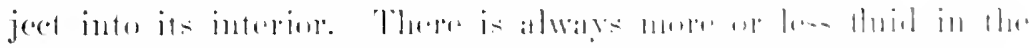

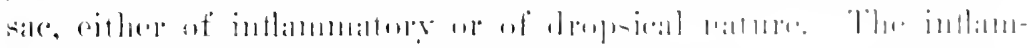

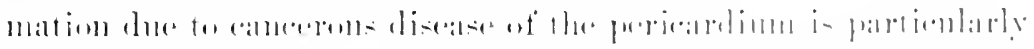

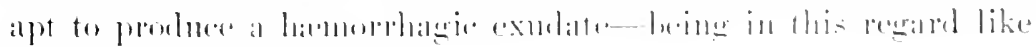
the tulererolens diserise. 
Etiology. - Primary malignant lisease of the perieardinm is so ran that, alecording to Gilsom, the only anthentic ase on record was the one observed by kocster. Sir W'illiam Broatbent has, however, reported an instance of salleonlal, which wals thought to be primary, and I have mentioned alove the ease reported by I'illians and Miller. In the vast majority of cases this affection of the sace is secondary to new growths in other sitnations, as in the asuphigus, lunge, phenra, mediastinal glands, liver, etc.

Symptoms. - Is a rule this disease of the perieardium is latent or the elinieal picture is that of the primary tmmour.

Physical Signs. - So far as known, there are no distinctive phreical signs of malignant invasion of the pericardium. If such are produced, they are those of secondary inflammation or of dropsical distention of the sace, and require no repetition.

Diagnosis. - This is rarely if erer possible, and would matnrally depend on oljectire manifestations of perieardial disease, which, as just stated, are very meertain.

Prognosis and Treatment.- The former is hopeless, since the disease is not anenable to surgieal interference, and the latter must he confined to measures ealenlated to relieve suffering aml promote enthanasia. 


\section{SECTION II}

\section{DISEASES OF THE ENI)(OARIITM}

\section{('IIAPTER IV}

\section{ACUTE ENDOCARDITIS}

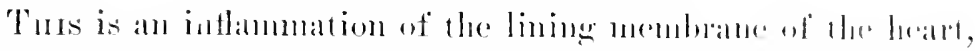
which it has long been constomaly to divide inten two forme, for reatsens apparent in the variens adjectives applied to theme 'Thus

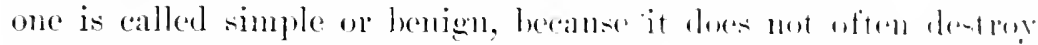

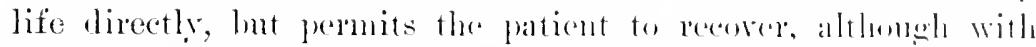

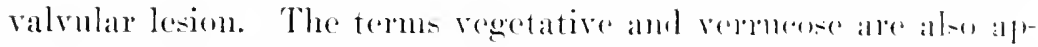
plied to this variety, particularly by the Germans, on allemml of the nature of the intlammatory changes indured. Simple and benign refer to its elinical manifestations, verronenes and regutative to its anatomial characters.

The other form, fortmately monch less firecpuent than the preceding, is spolien of ats malignant, to designate its n:mally fallal

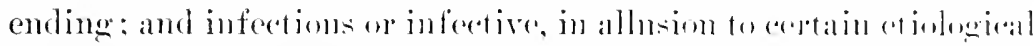

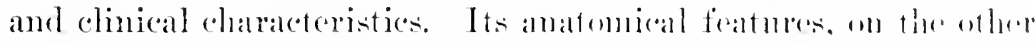
hand, are shown by its other names-nlextative, diphlaritie, myeotice. Diphtheritie was applied to it he Vireleww and morente. by Winge, who was the first to describe mierentes in the valver.

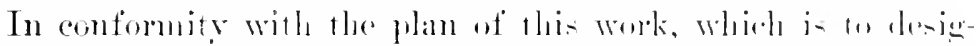

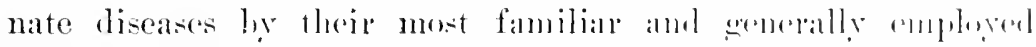
names, these two afferetions will be sumken of ats arenle simple and

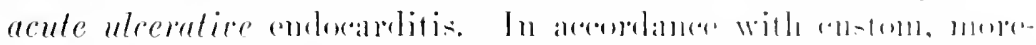

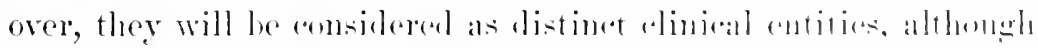

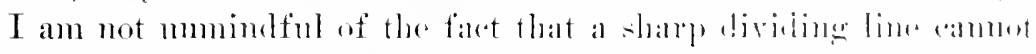

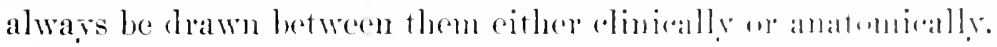

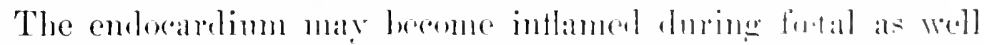

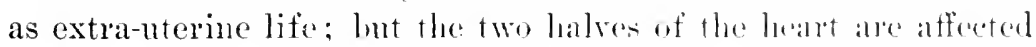


with different degrees of frequeney during these two periods of existence. After birth it is the lining membrane of the left side that is generally attacked by inthamnation, as is so well shown by Sperling's oft-cited statistics of :300 (atses at the Berlin Pathologiat lustitute. (I) these, the left side alone was fomd affected 268 times, right heart alone 31 times, both together 2 ! times. Of the calses affecting the left sirle, the nitral valves were involved 255 times, the antic but 12 ! tines.

Morbid Anatomy. - The endocardiun is the lining menlrane of the heart, and is continnoms with the intima of the bloodresects througl the rarions openings in the anricles and rentricles. It consists of two lamine-al fibrons, very thin in most portions, $f$ and an entothelial, the latter comsisting of a single layer of flattened eells, which are in eontace with the blood.

The values of the heart are folds of the endocardium, the filmons layer lieing increased to give them greater strength. The values contain no numsenlar tiswe, and alre arascular, with exeeptim of the attacherl mal wins of the mitral and trienspid leatlets, which contain a few very mall resiels. These are the only portions of the endecandinn that contain blocel-resseds, as the mural entocardimm, as well as the remaining portions of the ralves, derives its nutrinent from the bloot passing orer it. Lymphaties are, however, muneroms.

Anatomically, it is exeedingly difticult to draw any sharp distinction between the henign and malignant forms, as all intermediate granles are fomml and the differences seen to be only those of intensity of the pureess. These differences are doubtless dependent on infection by different onganisns, of which a large number have been deseribed lyy different investigators.

In the simple form the first clange visible to the unaided eye is a chomliness or opacity of the nembrane. This is probably in all cases precerted by the loxgment of nicro-organioms on the surface, which hat been rendeped vulnerable ly some previons injury. Wyoknwitch, Prudden, and others have shown by animal experiments that "ultures of pathogenine lateteria, injected into the cir"ulation, protuce the lesions of entocarditis only when the endo"ardimm has been previonsly injuled, as by passing a probe down the caroticl artery or jugular rein. This probably explains the fact that the lesions are most often found on the valvular endocar- 


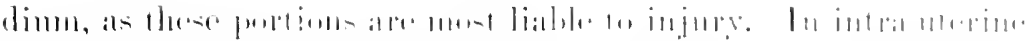

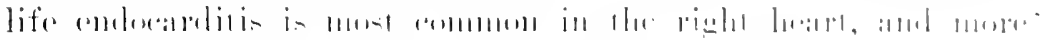

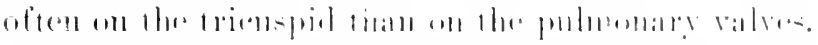

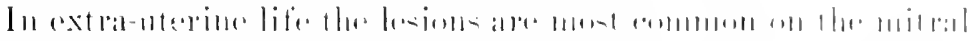

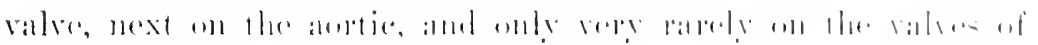

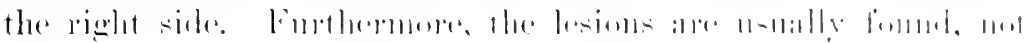

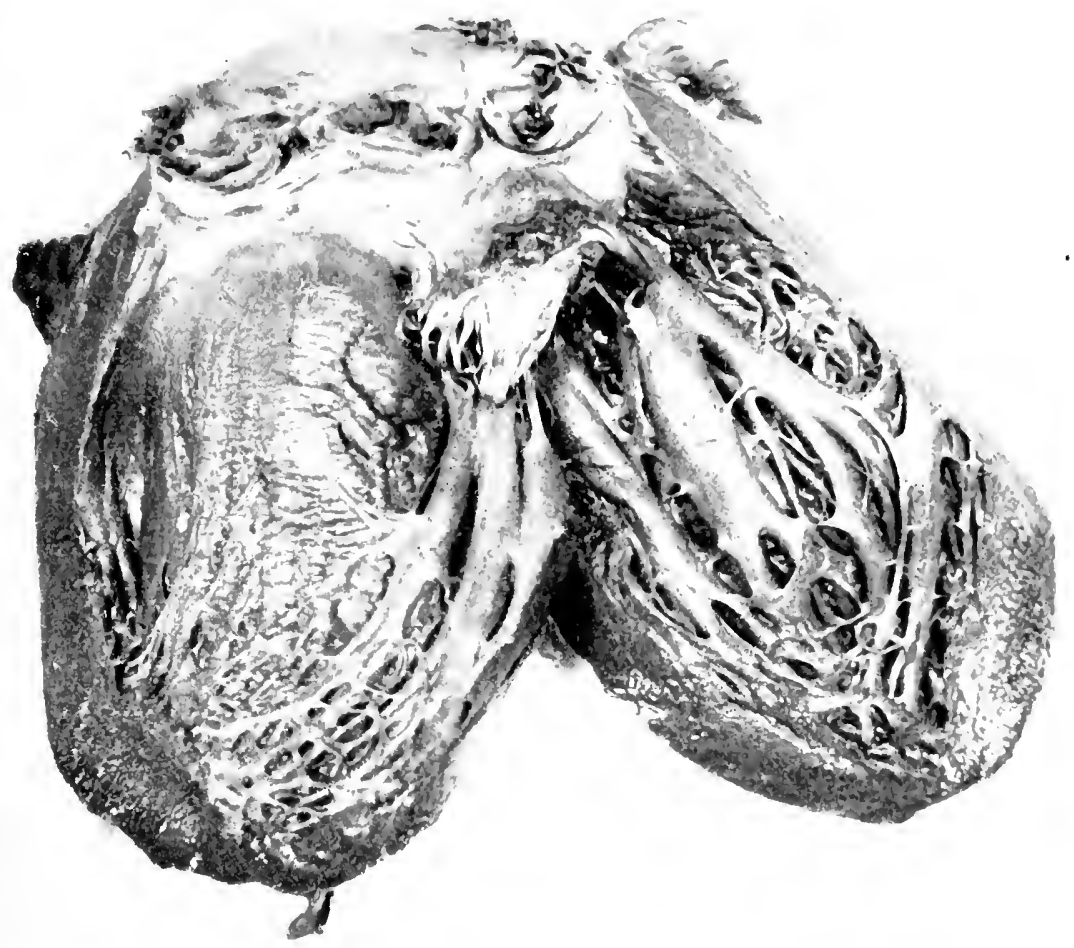

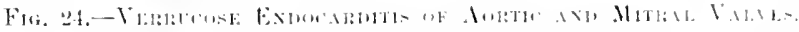

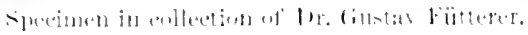

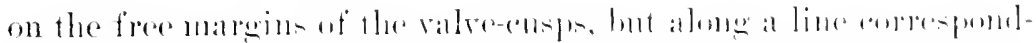

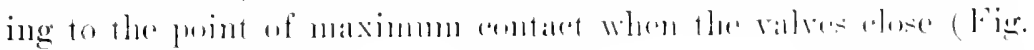

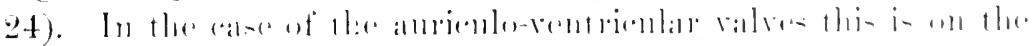

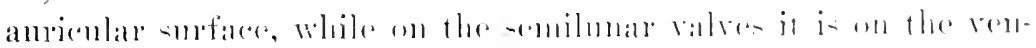

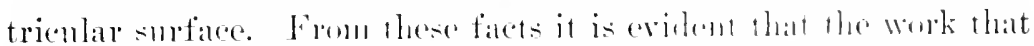

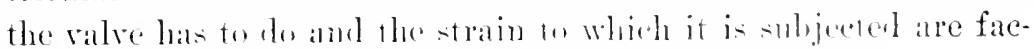
fors in the determination of the lowatinn of the process. 
Following the appearance of elowlines, the membrane becomes thickened and adematoms, while the straining and pomeding to which the segments are suljected are rery apt to produce erosions

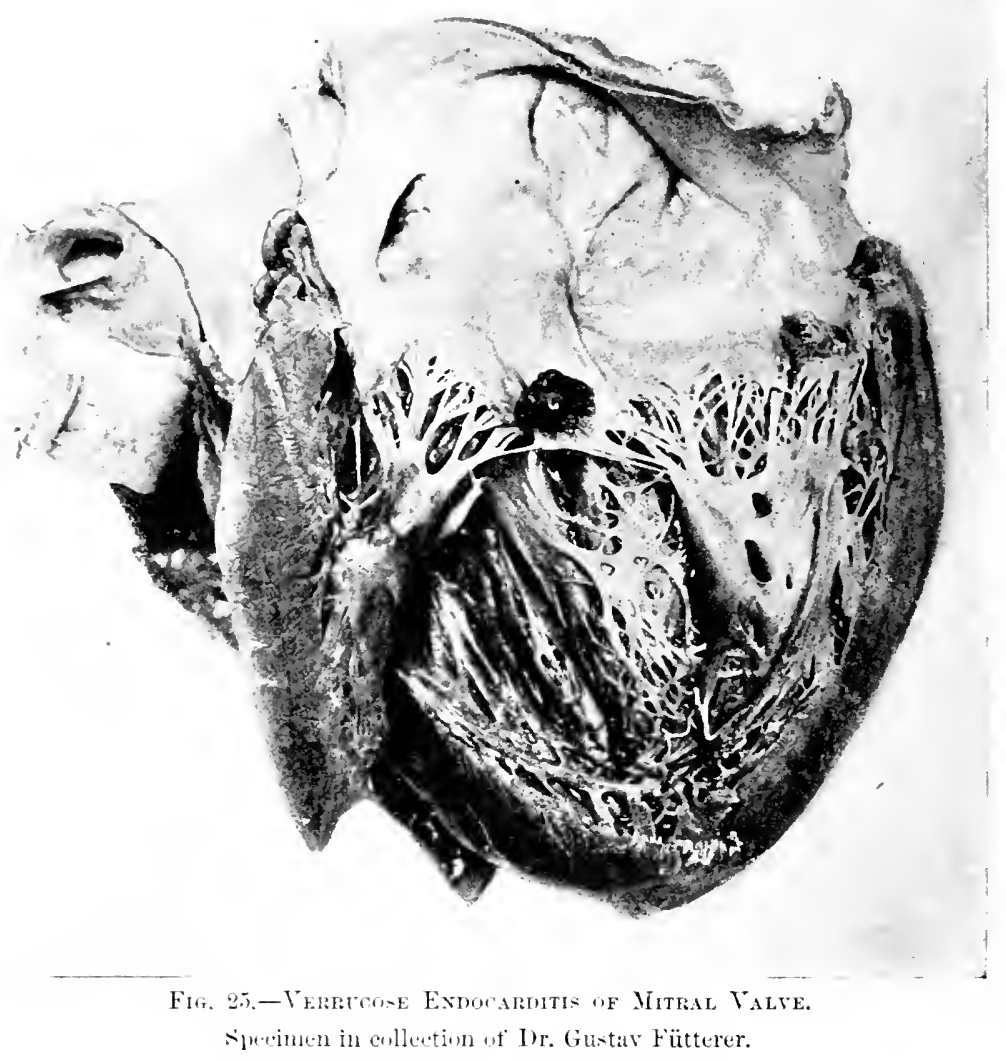

w lacerations. Thee natmally ocenr at the points weakened by the invision of miero-monims, and if the eroded surface is not at whe covered by the deponit of fibrin from the bloot, a considrable loss of substance may take place. This is far more common, lowerer, in the malignant form, although it has been observed in siuple andocarditis complicating rhemmatism. More eommonly the erorkl surface, necrotic from the action of bacteria; is at once envered hy a reposit of fibrin from the bloot. This fibrin forms a firn warty mas of a yellowish or reddish colomr, which rises above the surface of the membrame, and hence has received the name 


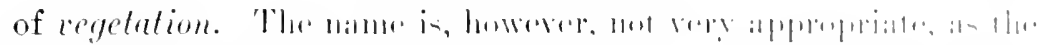

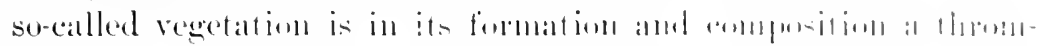

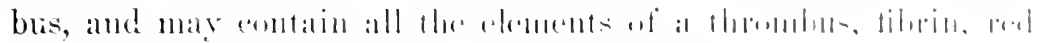

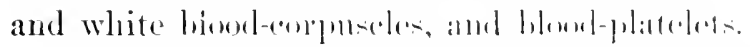

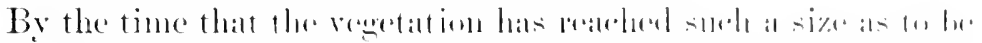

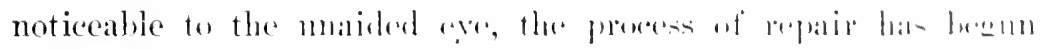

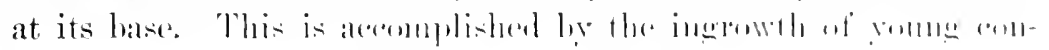

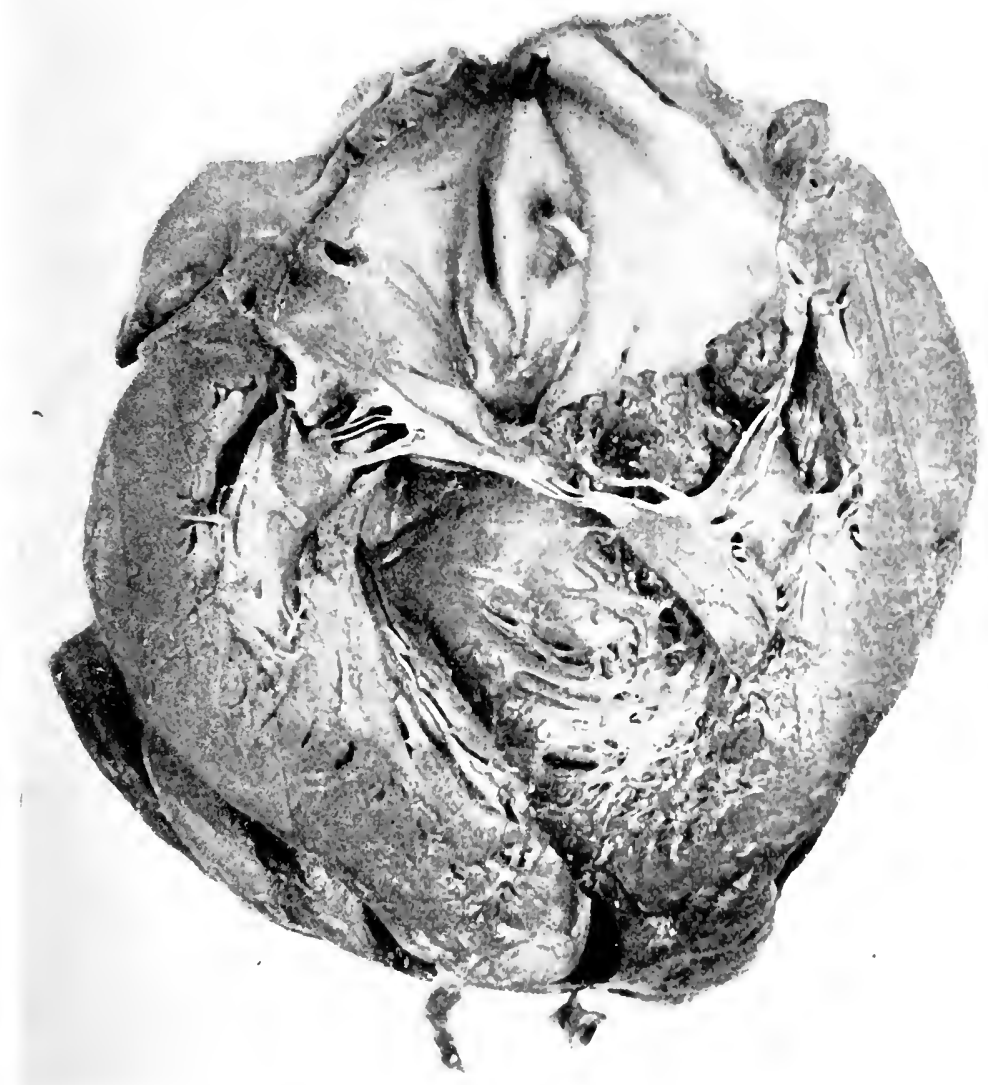

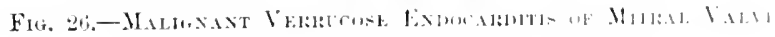

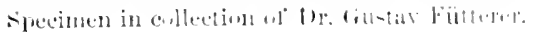

neetive-tissue cells and the formation of at eramblatim tisme

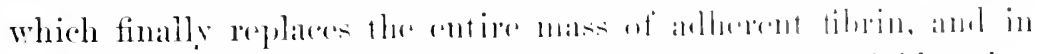

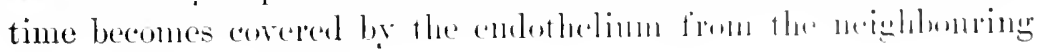




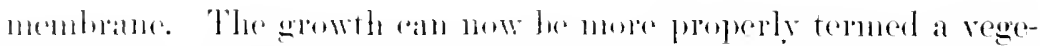
tation, as it is asentially an anterowth from the subjacent tissue, and some anthors linit the term to this form. The arcemulation of tibrin wor such an affected area may le very large, but the arerage vegetation is about : millinetres in length. When of the

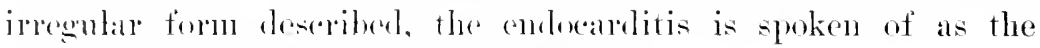

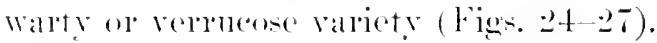

The regetation may he latre and polypoid in shape or long and string-like, attarehed at one end so as to swing in the bloodstean. The discatse is then spoken of ats of the polypoid or villous variety respectively. The regetation may be too large for complete organization, and may soften and redissolve in the hlond-streant, or poltions may break off and be carried in the bhorl nutil they loarle a resisel of too small calibre to permit their passage, when they plug the ressel and cut off the circulation of the parts supplied hy it. Thr infarets thus produced by the emboli of simple endocarlitis are nisully of a non-infective nature.

The further repair of these lesions and the changes in the ralves comsegume to them are dealt with moler the head of ('hrouic Endocarditis.

The moligmant form of the disase is mainly characterized by the intensity of the inferetion, and the fact that embolic phenomena are more common tham in the simple, and are almost always of a septic nature. The local lesions may be regetative, suppurative, or ulcerative, depending on the nature and violence of the infection. In all cases the necosos of the attected areas is mope marked than in the simple form, and nltimately leads to loss of substance,

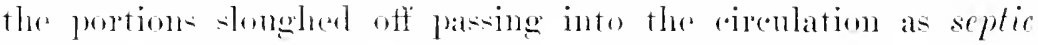
emboli.

The ralve-ens] thens mlereaterl is naturally weakened, and frequently erives way lefore the presene of the blond. forming small pouches in the valve, the sorecalled ralvular anenresus, or giving way enpletely perforate the valves. Acote valvolar insufficiency

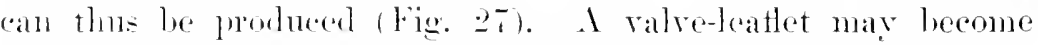
partially detached, and the fiee ond swing in the blood-strean. Fleration of the papillary museles or the chordac tendina mas porluce stretching or lupture of the cords, or a thrombus covering thre afferetod anea may mat then closely together.

Ithen the lesims are situated on the mural endocardinm, per- 


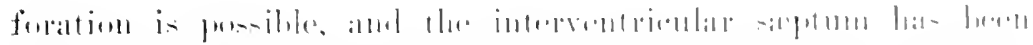

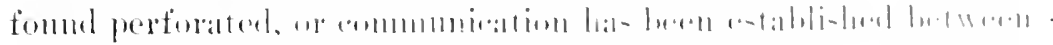

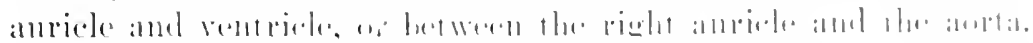

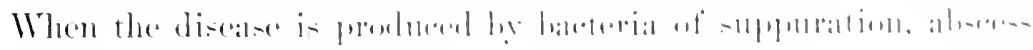

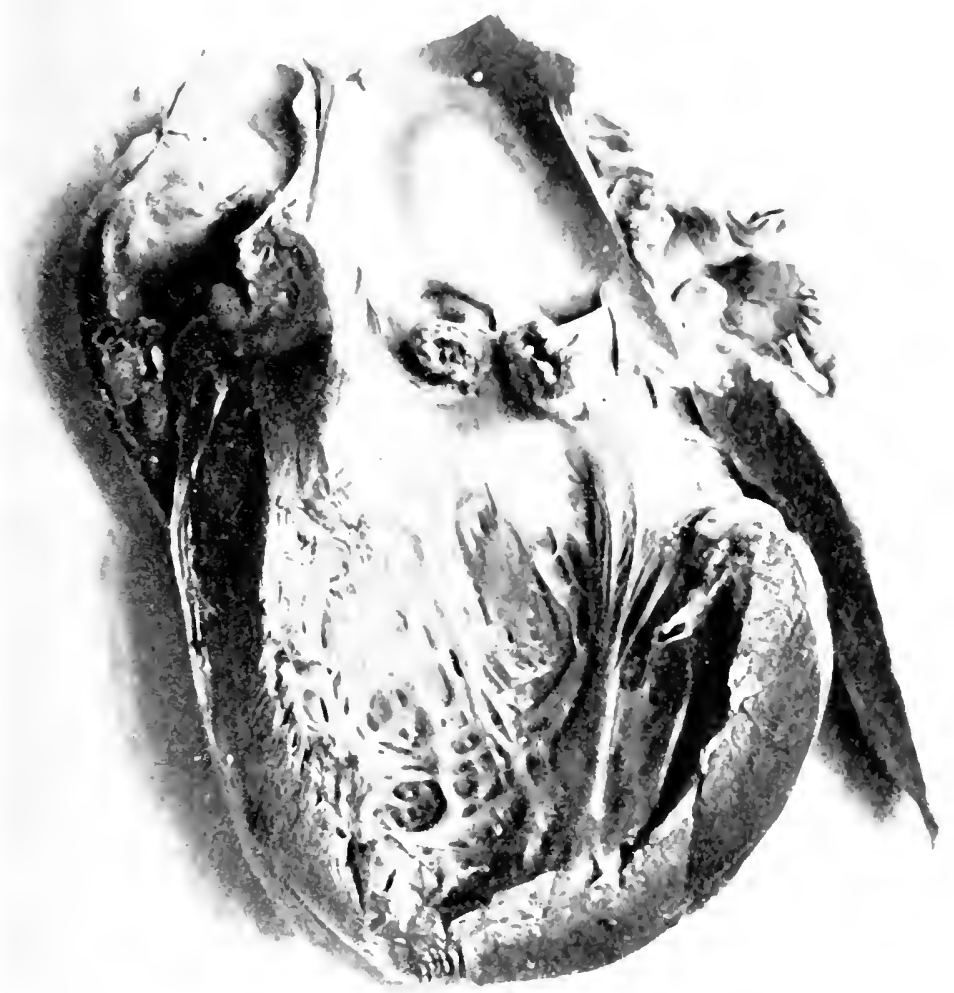

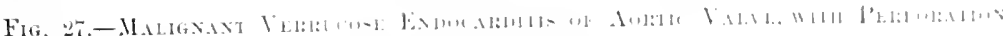
$15+11 \%$

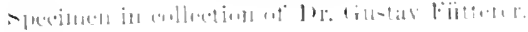

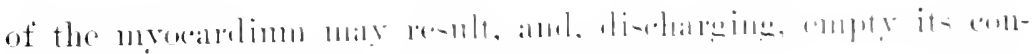
tents into the circulation. (s.eptir limbeli.)

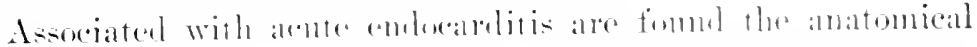

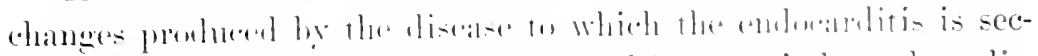

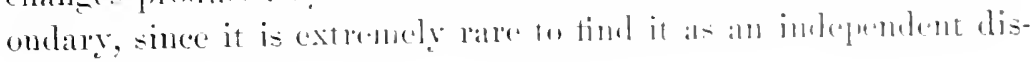


eare. It is repry often asenciated with the dhronie form of endocallititis.

The secontlary changes in the simple form are trifling, and as a rule produce no smmptoms. It is only in the course of time, when the direase palsese into the rhennic form, that serions damage is dene. Scomblary to the meliguent form, on the contrary, are cirenlatery disturbanese censequent on the ulceration or perforation of the valves, and more important still, the metastatic foed of discalse set up all orer the boly by means of septic emboli. The spleen and kidney are especially apt to suffer in this way. The infiarets so produced nuay he for, or immmerable minute foci of smpluration may be saittoped orer the whole body. It is to these eptic mululi that this form of the disease owes its malignant chatracter.

Etiology. - It may be stated as a general proposition, that the bacterial origin of acute cudocarditis, both simple and uleerative, hat been established. Heilerg's discorery in 1872 of mierocoeci in the thrombotic nuases of the malignant form has led to an mbroken series of researches and experiments by the most brilliant pathologists in Emrope and this compry, with the result that the cloud of dombt and speculation once enveloping this subject hats at length been eleared awar. Special activity in this work was displaved during the rears immediately following 1885 , and prouninently figuring in this line of investigation are the names of Virchow, Klebs, Birch-ITirschfeld, Koester, Weichselbamm, Fraenkel and Sacnger, Rosenbalch and Tetter in Germany; Gillert and Lion, (ormil and Babes, Roux, Josserant, and Dessy, in France; Dreschfeld, Cayley, Purser, in England; Osler, Flexner, and Prudelen in this comtry. It is manifestly impossible within the linits of this work to give a detailed aceount of the nature of the researehes made by these eminent workers, and it mulst suftice to state the farts that have been established.

Miero-organisure have been quite generally fonnd in eases of malignant endocnditis. some of them being the same as those fomd in other infections diseases a few being specific to endo-

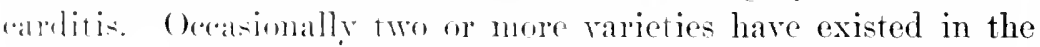

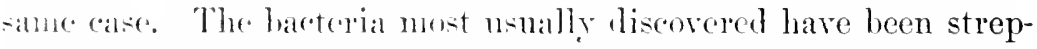
trencens progenes, particularly of erroipelas; staphyloeocens fyogenes, anrcus, and albus, and the micrococens lanceolatus. 


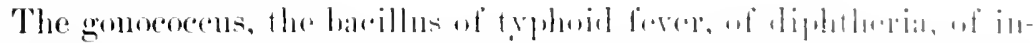

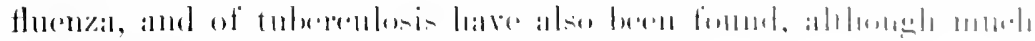
less frequintly.

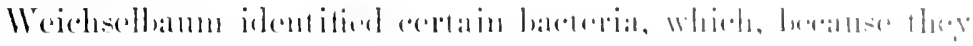

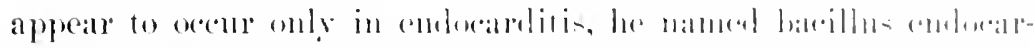

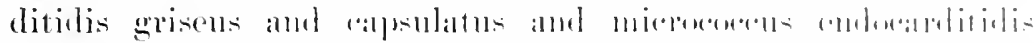

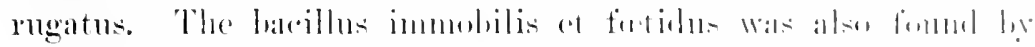

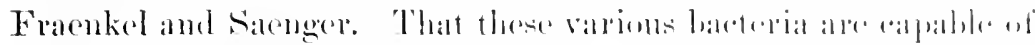

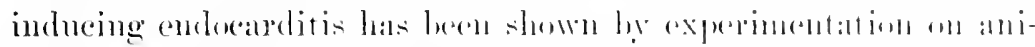

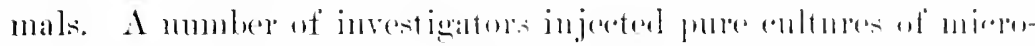

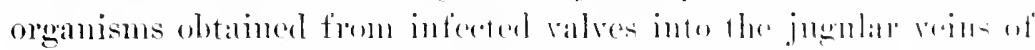

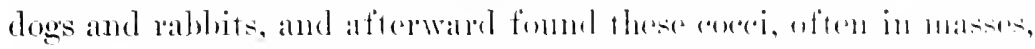
both on the surface and in the dereper lalyer's of lowth andie and

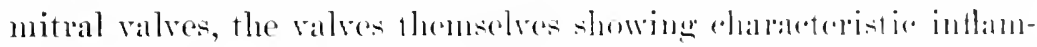
matory changes. By some experimenter's it was atserted that

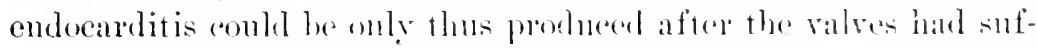

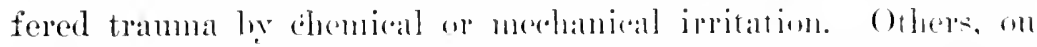
the contrary, chamed to have predued enderamelitis ly injection of microbes inte animals withom previons injiury of the entucardinm.

In numerous instanees the baterial found on the affected

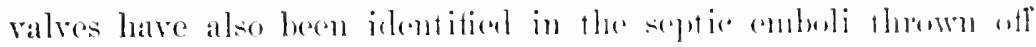
during the comre of the discalse, while in a fere instances lles blool of patients suffering from infeetive emberseditis hat lecen forme to contain septic orianisms.

The bacteria fomm in the lesions of uleerative ondocaldits

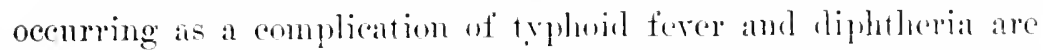

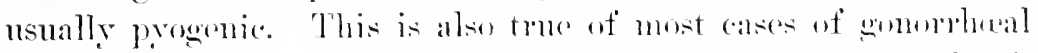

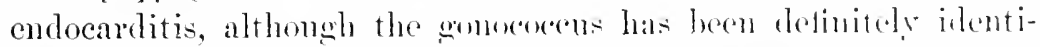
fied in the endocarditic tesions. The punemmereens of Fraenkel

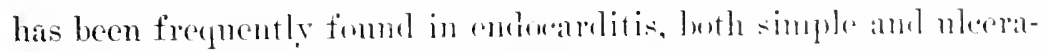
tive, but, aceording to Oslere more frecuently in the latter variety.

It appears well estaldished that a primary andocalditis of hacterial origin is occasiomally, althongh ralrely, met with. Jlest instances of endocarditis are secomdary to some weneral or locial infection.

There has been considerable speculation, and for a time there was a lieated discusion, particularly between Klobs and Koester. orer the route by which microbes are carried to the infected ralves. 


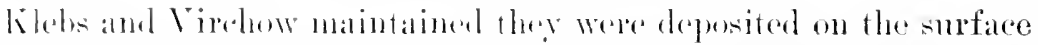

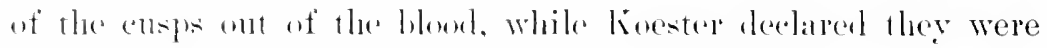
carried thither in the minute apillatries sitnated in the deeper layers of the valves. He maintained that the masses of eoeei

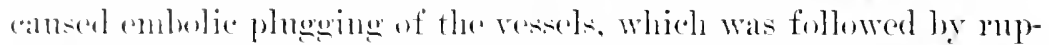
ture, thus setting free the haleterial and allowing them to reach the surfiace. Against this explanation wats urged the seareity of blood-

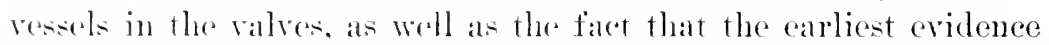
of inflammatery ehange is along the line of contact of the ensps. It is now held that looth contentions are correct, but Virchow's view is aleepted ly the majority of ohservers. The adherents of Virelow"s opinion believe that the pressure of the blood forees the nicerorganisms hetween the endothelial eells of the endoeardium -at theery that probalily alecomits for the development of endocarditis in the left heart after birth and in the right side during fortal existence. As is well known, blood-pressnre is greater in the right rentricle before and in the left rentriele after birth.

Another explanation for the localization of endecarditis is that intamuch as oxygen is needesary to the growth and activity of most

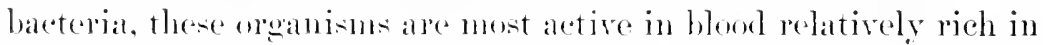
oxyen, a condition uhaning in the riglit catralia clambers in the futw: and in the left during extrit-nterine existence.

A nues interesting question relates to those conditions that determine whether the condecarditis is to be simple or nleerative, since both forms are of microlic origin, and some of the same oreanions have loen fonnd in the endecarditic regetations of both rarieties. What are the faleters that determine the malignaney or benignity of the affeetion! It has been sugerested that this depereds upon the munber of hacterial present. It is more probable, howerer, that when healthy valves are attacked the nature of the cmedorarditis depends npon the virulenee of the infecting organimms. Other fartops are of influener, lowever, aside from the nature or virulence of the balcteria, and these will now be considereerl.

Simple Endocarditis. - Articular rhennatism is the disease per

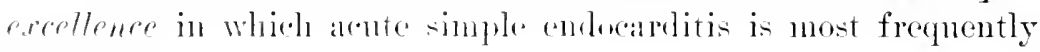
(u) isered.

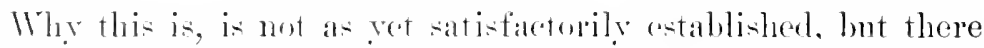
appeatrs to be al growing betief among pathologists in the bacterial 


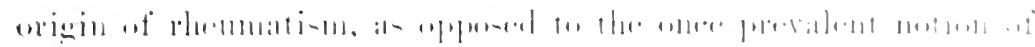

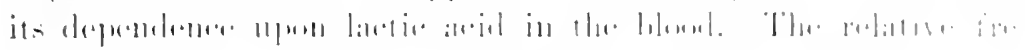

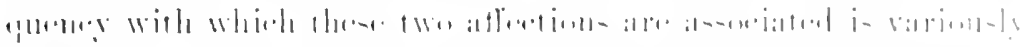

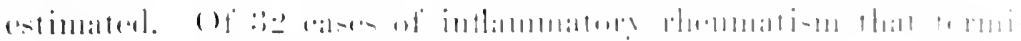

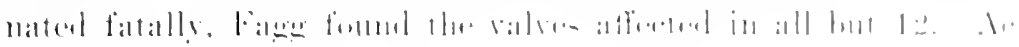

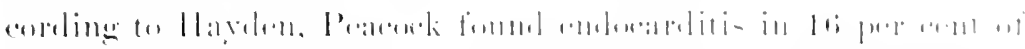

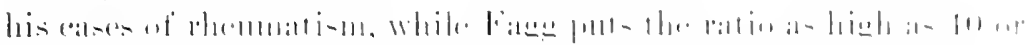

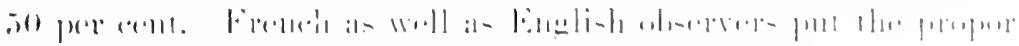

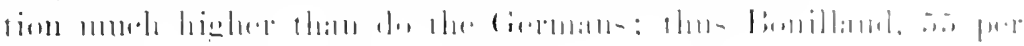

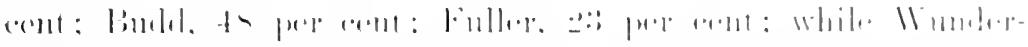

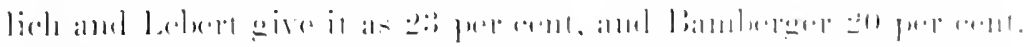

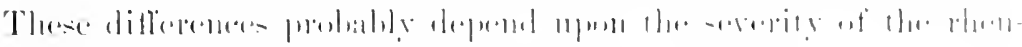

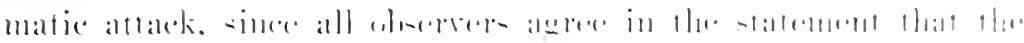

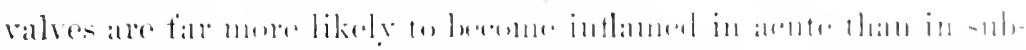

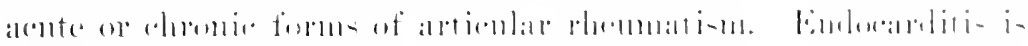

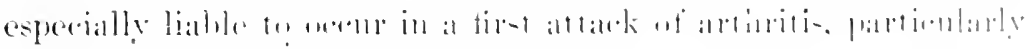

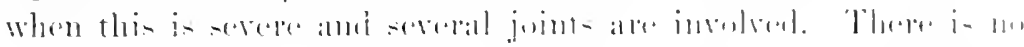

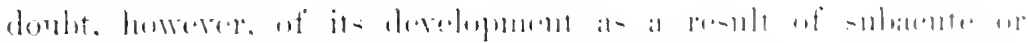

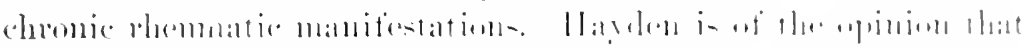

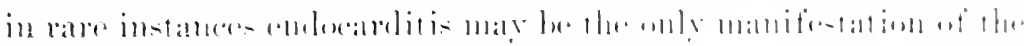

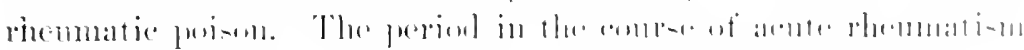

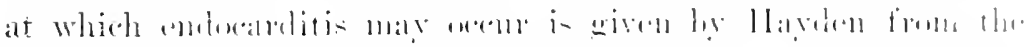

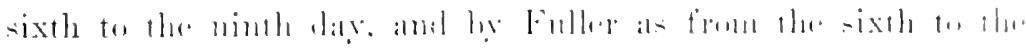

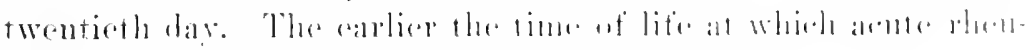

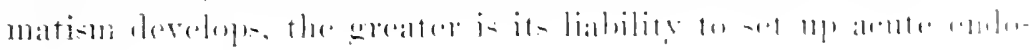
ralitis.

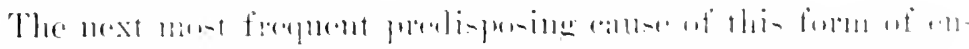

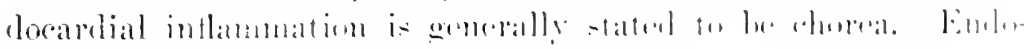

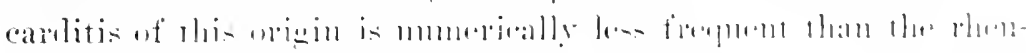

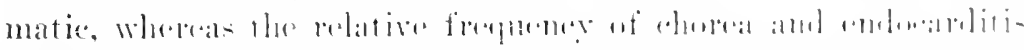

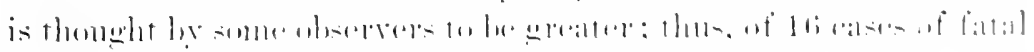

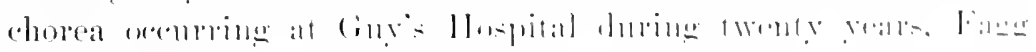

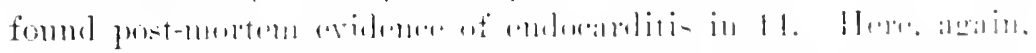

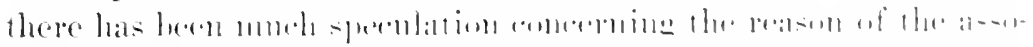

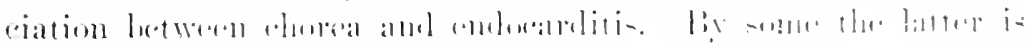

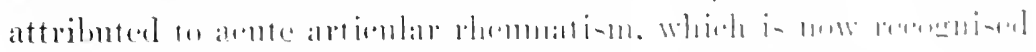

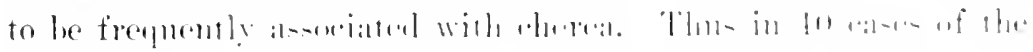

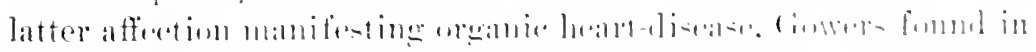

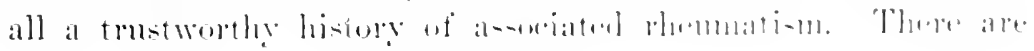


some obscrvers, on the other himel, who hold that chorea is capable of cumsing emdocarditis independently of associated or antecedent anthritis. Since girls are muleniably more subject to elorea than anc lors, endocarditis of this origin is observed more frequently in the former sex.

Scarlatina and meales are also accredited with the causation of endocardial inflammation. This may be either a secondary resnlt, or the endocarditis may be due to a mixed infection. Inasmuch, however, as sarlet fever is not infrequently followed by rhemnatic manifestations, the entocarditis is held by some to be referable to the latter and not to the former affection.

Other irruptive diseases, particularly enteric ferer and smallpox, are also capable of setting up endocarditis, bnt as subsequently stated, this is more likely to be malignant than merely simple.

Although gonorhura is more likely to canse the nlcerative form, regetative endocarditis undonbtedly ocenrs as a result of gonococens or perhaps a mixed infection, a conclusion that would seen justified by the entipe alsence of any other etiological factor in certain cases of ralyular discase.

As previonsly stated, there is both clinical and pathological evidence of the ocemrence of acute endocarditis in the course of croupons pnemmonia or in comsequence of pnemmococens infection. Althongl such an endocarditis is more likely to be nleerative, it may nevertheless be benign. In a fatal case of pmemonia, which had exhibited no cridlences of endocarditis during life, Haushalter fomnd a colony of pmemococei in the interior of one of the mitral cuspe, while the other sherwed an almost invisible swelling of the culcothelimn near the point of insertion of the valve. From this he concluded that not only is acute endocarditis a probable sequence of pnemmonia, hut also endocarditie changes of a slow sclepotic type may be ultimately set up. His conchnsions were as follows: (1) The abeence of murmurs during life or of naked eye rhanges post morten does not prove the integrity of the ralve, since during the course of the pnemmonia the pathogenic organisms may be carried into the interior of the valve, and thus prove the starting point of future valvular misehief. (2) The possilility of such an endocarditis shonld be remembered, since a latent period may exist between the primary disease and the develop- 


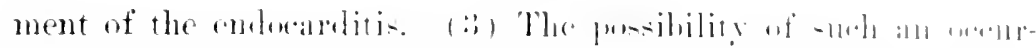

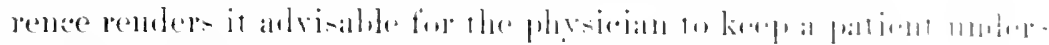

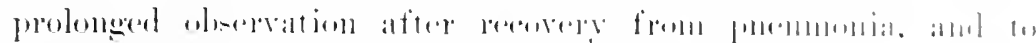

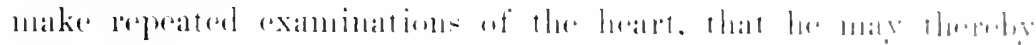

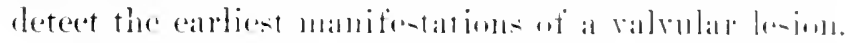

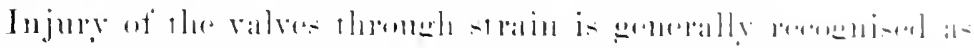

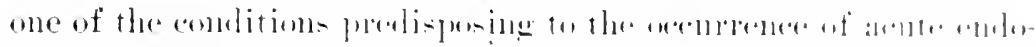

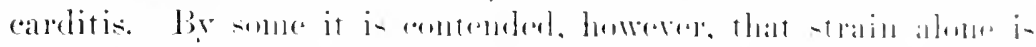

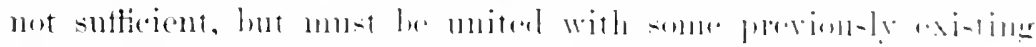

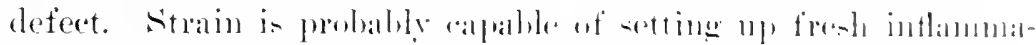

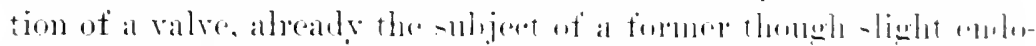

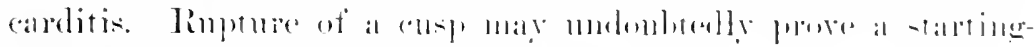

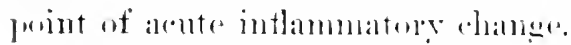

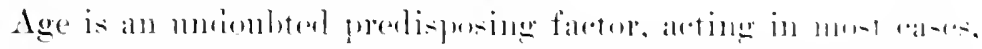

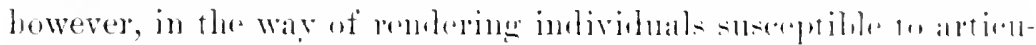

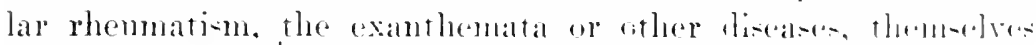

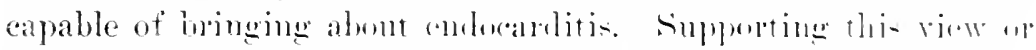

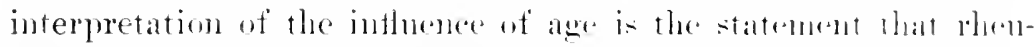

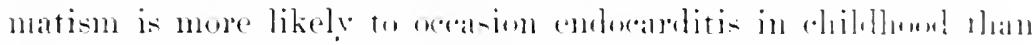

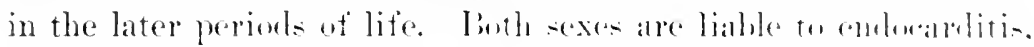

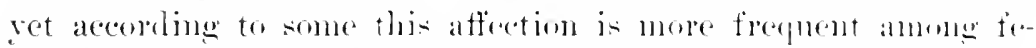

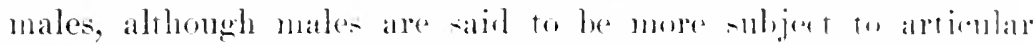
rhemuatism. To my mind there is nofling in sex. per se mendere

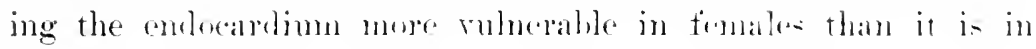
inales.

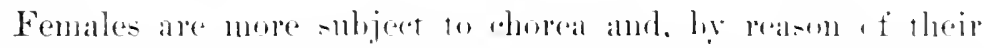

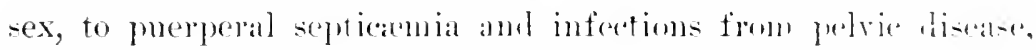

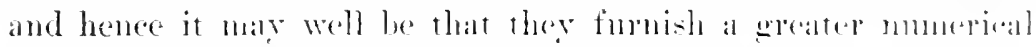

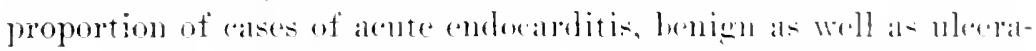
tive. With inceasing experience. I find my-elt groming in the

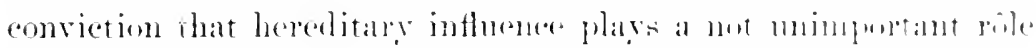

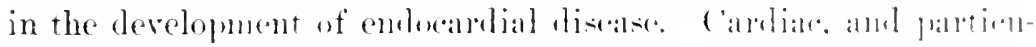

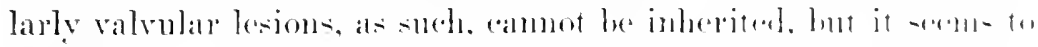

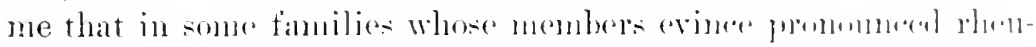

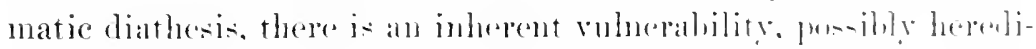

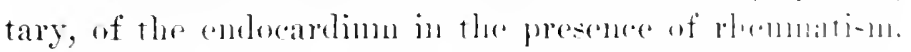

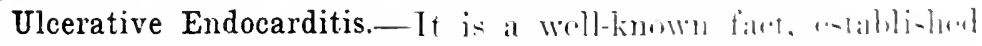
both by elinieal and fost-mustem observation. that the malignant

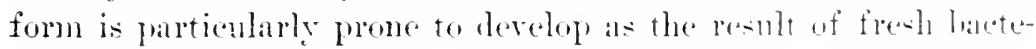


rial invalion in ralkes alrealy the seat of chronic emecarditis or scherotic change. This is particnlarly true of the aortic-valve alp palraltus.

Infections entoraditis is alwo specially liable to attack individuals suffering flom exhanting diseases or cachexia, chronic alkoholim, cirthosis of the liver, hepatic absess, cancer, ete.

Goneral infection, as pramial, pnerperal septicamia, influenza, diphtherial, variola, and lucalized septir processes or abseesses, preslipune to malignant rather than to simple endocarditis. Flex-

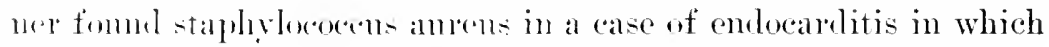
the atrimm of infection was leg ulcer: in another, staphylococens, the print of entrance being the intestine: in still another, streptococens and staphylocowns, the atrimm being hepatic abscess. This form of acute endocarditis has been particularly frequent in association with prepperal septicamial dne to infection either of the uterus or its arhexa. It has been known to follow tonsillitis, and eren so apparenty trivial a locil process as a furmele.

Croupous pmenmonin or a pmemococens meningitis has not infrequently been fonnd as the primary infection in cases of nleerative entocarlitis. Althongh the pnemococens may occasionally give rise to the simple form, it is much more frequently responsille for ulcerative inflammation of the ralves. This malignant form is also stated ly. Ireschfeld to have been associated with $t$ cascs of gall-stones "with or withont suppuration of the biliary passages." Ireschfeld thinks that the discovery of the bacterium coli commme in tiveases of the hiliary pasages may explain their connection with acute enclinarditis. In this comnection it is interesting to note that Flexner, in one ease of endoearditis associated with areinomia of the plorm, identified the bacillus coli, together with the bacillus procyanems: and Itasenfold has reported artificially prodnced entocarlitis in animals infected with the bacillus procyunen. Of furthere interest is the fact that, despite the severe infection- process, distinct hypertrophy of the heart was observed to kevelop in so short a time as a week.

Finally, this form of curtocarditis. althongh much less fregunently than the simple. may exist in commection with articular rhomation, as mentioned ly Osler and others.

Its drependence upon the diphtheria hacillus, though rare, is mdoubteal. Ifoward has reported a case in which a bacillus was 


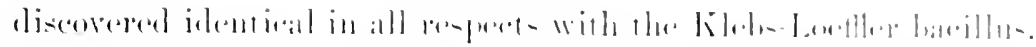

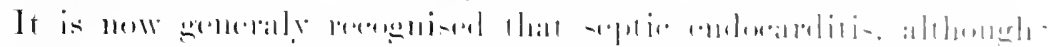

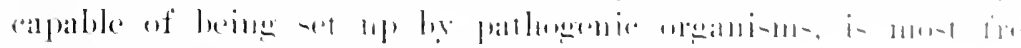

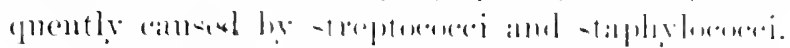

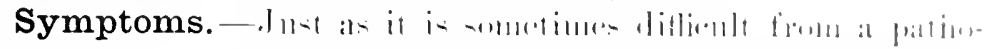

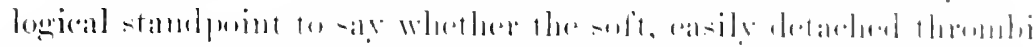

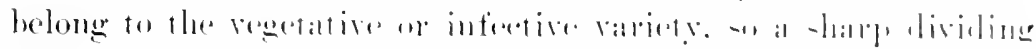

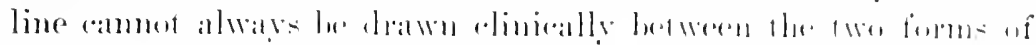

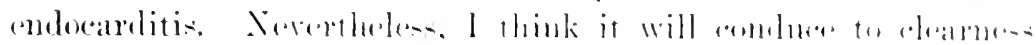

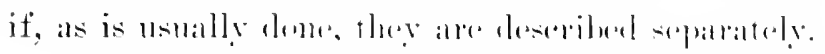

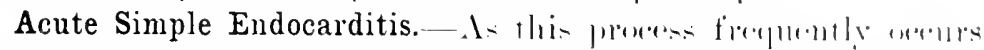

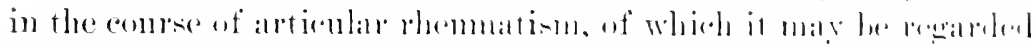

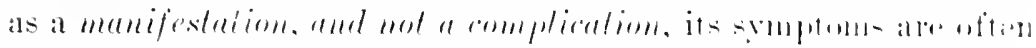

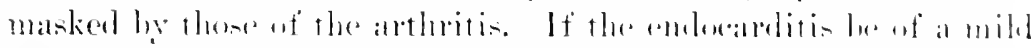

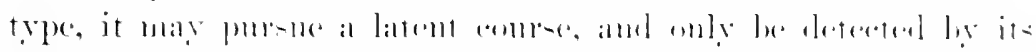

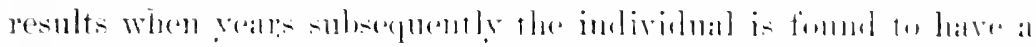

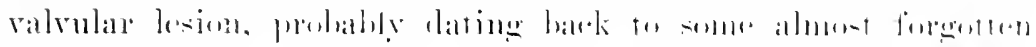

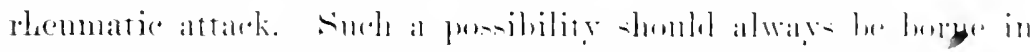

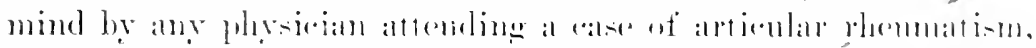
however mild, amb shomld imeite him te a daily examination of

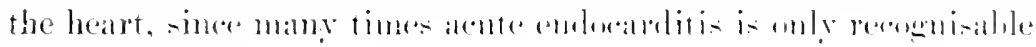
by such m11:ins.

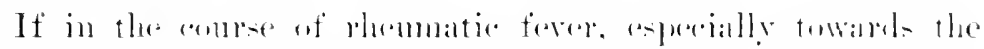

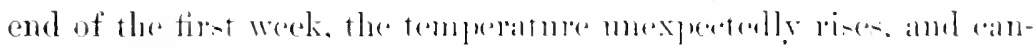

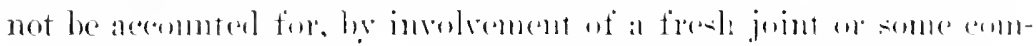

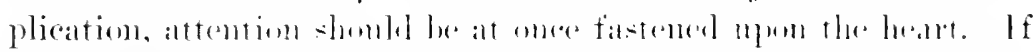

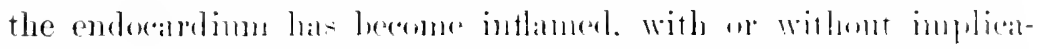

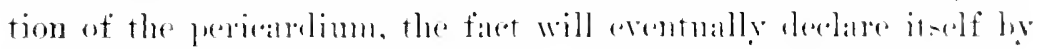

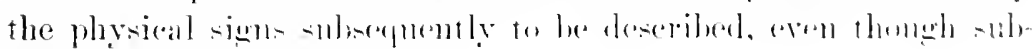
jective simpltanc ane wanting.

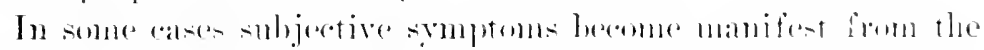

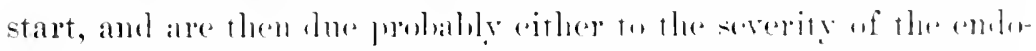

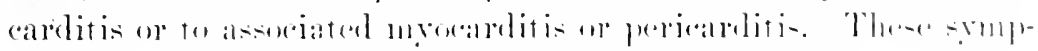

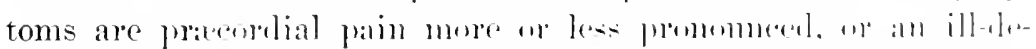

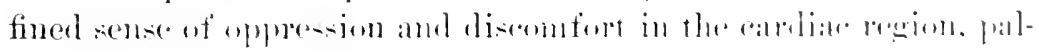

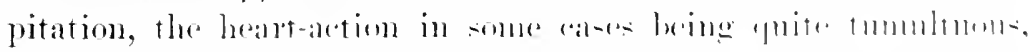

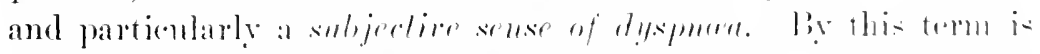

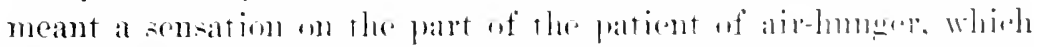
may not be evinced by lahoures or hurred respiration. hut which 
is m-nally greater than cam be aceomnted for upon examination of the elest. I eamnot now recall a single case of acute cndoearditis, recognised as suel, in which this spmptom was not present. In some in-tances this feeling of breathlessness actually amounts to

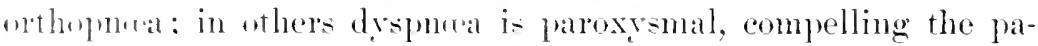
tient to-it mp in bed during the continumee of the paroxysm. In mild easus the prexia is likely to be mild, and possesses no peen-

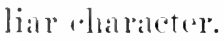

In other instances the discalne prouluees profound constitutional disturbances. with thetnating terel and profuse perspiration, plainly sngesting infection, and with a pulse so empty, irregular, and perhaps accelerated, as to at once direct the physieian's attention to the heart. These are the ases difficult, if not impossible, of differentiation from the malignant form.

Embolic phenomena are less trepuent in the benign than in the malignant form, ret when embolisms oceur the symptoms they induce are referable to mechanical interference with the cireulation, rather than to a local or eneneral septie process. The most nsual seat of infarets is in the kidner, intestines, and brain. Ther undoubtedly oceur many times withont giving lise to recognisable srmptoms; ret when such are iroduced, they are a sudden, sharp pain in the affected part ur oran, ehill more or less pronounced, and prexia. If the embolus lorlge in a kidner the mrine is likely to contain blool, alhmin, and even pus. Hemiplegia and aphasia, the result of cerebral embolism. may in rare instances furnish the first, or prerhays the conclusive. evillence of the existence of acute endorarditis. The following ate is instructive: IT. J. M., male, aged forty-eight years, height six feet, weight 176 pounds, first consulterl me Novenber 9, 14!ni, not, he said, beeanse he thought himerlf in poor health, hut herance, having some heart-trouble, a triend adviod him to get my opinion. Family history was unimportant in its bearings upon the patient s condition, but it was -tated that one sister lad died of ansmption, another of insanity, and a thimet then living. had heartrisease. Patient declared that ho had not heen ill since his twelth rear, but had had syphilis at the age of twenty. Ifter his leath, it was stated hy his wife that the lationt had known for seron years of the existence of some oret of heartdisease. Srmptoms sucli as dyspnoea and falpitations were denied. Thit the patient, when questioned 
regarding pain, sail, " Onee in a while a little, down meall the. lic:alt,"

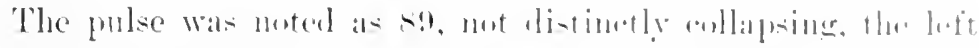

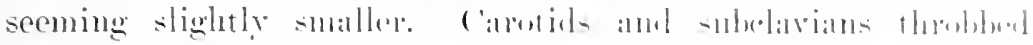

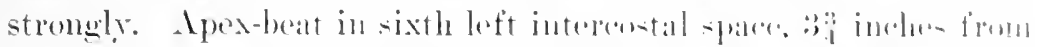

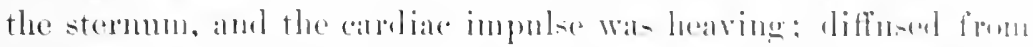

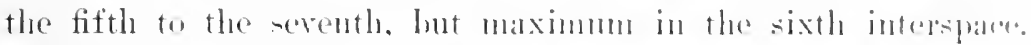
Absolute carreliare dulness was practically monmal, but the relative was increasod to the left, extending is inches to the left of the liveatsthome, downwad to the seventh rib, and but 1 incle to the right ot the sternmm (Jig. Da). The first somme at apex was muttled and the seoond was wanting: throngleme the fulacomdinum the somnd- were obsemed by murname, luotle systolic and diastolic, which were andilse orer the entire eardiare aldeal. but were of maximum intensity in the anstic area and on the berly of the stemmun. A

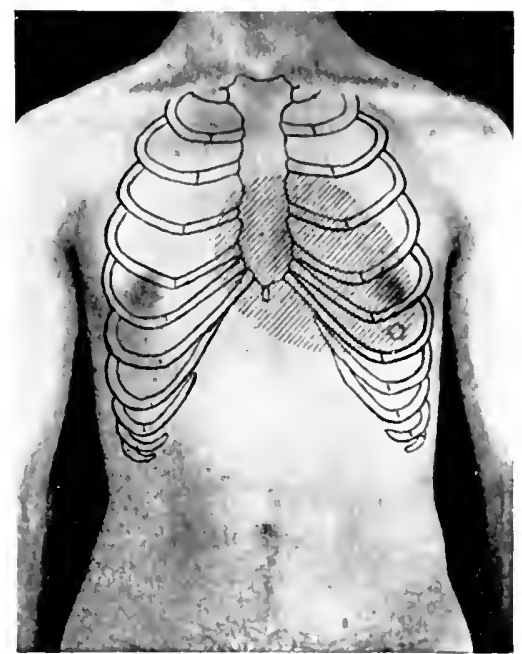

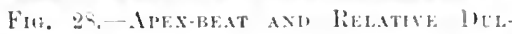

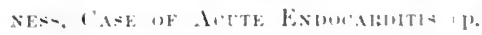
1.in

snapping systolic tone was andible in the fentoral artery. In the

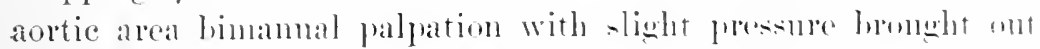
a systolic shock and thrill. Examination of alulomen and wrime was newative.

'The diagnosis las between anemrysu of the ascending andtat and insutticiency of the aortic valves. hett the lesion was sulsee-

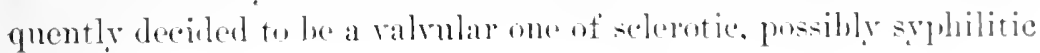
origin.

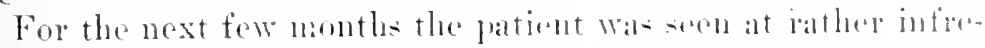
quent intervals until the last of Marels. 1-!t. In Felumaly ut

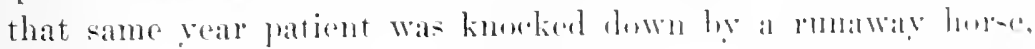

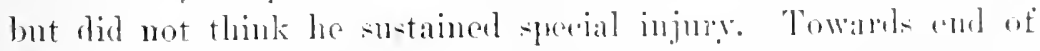
March he hegan to enmplain of insommia. eleat nerventmen. and restleseness. The heart was rapid and pumbling, and there wat 
lyspluma, eren in repose. which increased paroxysmally without canse. L'rine analysis showed pus. blood, and albumin.

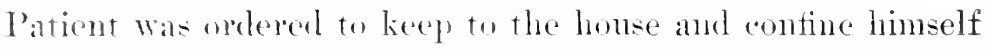
to milk diet, with potassium citrate and tincture of digitalis in small doses, with saline cathartice daile. After about two months the mine lost all traces of blood and albumin, but patient's genrat condition grew worec, and he was ordered to keep his bed. 11 call's action was still rapid amel pounding, but regular, and dyspnoa with paroxysual exareybations rerr marked. Paticnt sweated profucoly. lint the thermometer never showed fever.

One night eomplained of pain in right hypochondrim below ribs, embolism was suspectul, hut subsequently doubted. Liver leached :; fingers below costal arch, was moderately tender, firm, and with rounderl border. The condition was thonght to be passive congestion withont infarction. Mbout the last of May patient developed mental srmptoms, as shown by ngliness of temper, espe"ially towards wite: it appeared to be a mild acute mania, and the wife stated that the mother as well as a sister had died insane. Hroscine hydpobomate was ordered. supplemented subsequently by valerianate of ammonia, with improvement, the delirimm being only orasional and ngliness less.

Jume 2. 1597, examination showed the following: Radial pulse distinctly collapsing. venous pulsation in forearus, but external jugulars not tureid and withont pulsation. Ipex-beat in sixth left interspace anterior axillary line, srstolic impulse in second and thiml right interspace near stemmu, followed by diastolic thrill, also a more feeble pulsation in fourth, fifth, and sistle right intersaces. slight srotolic -lock in scomd left interspace near stermum. Alsolute duluess, patient in dorsal decubitus, reached i centinetres to right of median line, and from second to sixth cotal cartilage, the note being that, with marked resistance from second rib to fomrth interspace and slightly less dull below this moint. Dnlnes also reached 10.5 centimetres to left of median line (Fig. 20).

Ansenltation showed first somed at apes, dull and nuffled, but no, di-tinct nummur, a domble tome andible below left claricle and Jom along left axillary line: a spstolic tone and soft diastolic murnul in second left interspace and cutward $1 \frac{1}{2}$ inch from ster11mm. Thlere was also a faint -econd sound in the pulnonary area, 


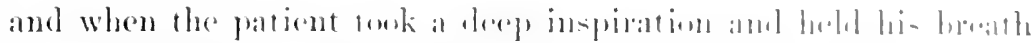

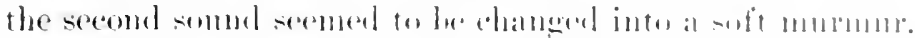

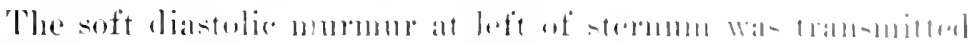

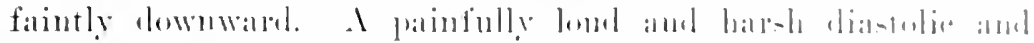

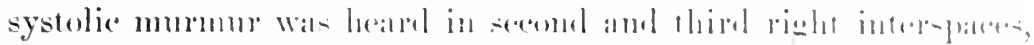

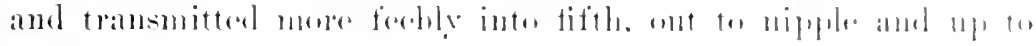
neck.

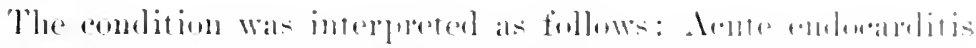

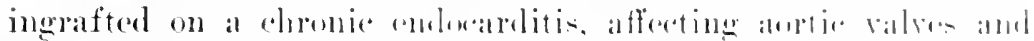

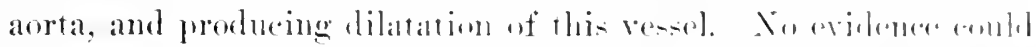

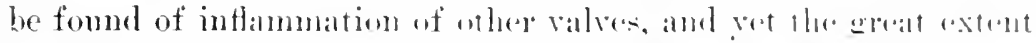

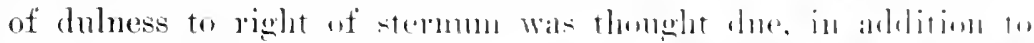
acotic dilatation, to dilaltation of the right anriele. seeondary to mitral insutliciency. Cough lias at no time il marked symptomil. excepte two or three paroxysus a tow hours before deatl, when patient seemed to have pain in left lumg. Dnring the la-t few weeks of life threse wat moderate rellena of ankles and shins, also puttines.s, lut nu pain, in lett wrist and lumm. Forty-eight to sixty lome lufore deatl pationt lexamm. comatose, with collel axtremities, very rapid. foeble. and

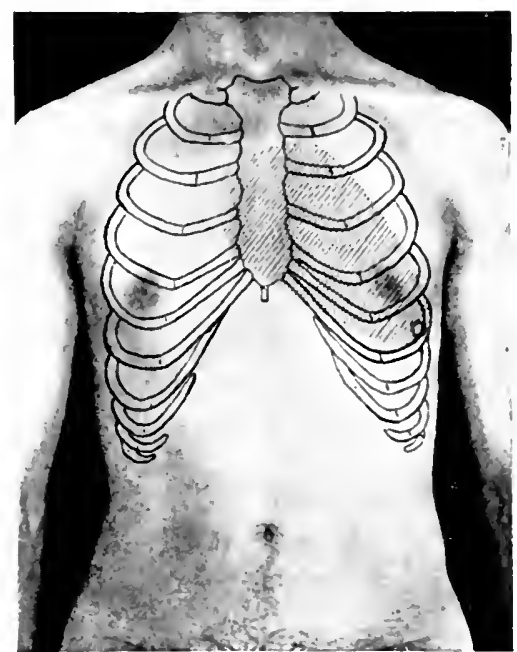

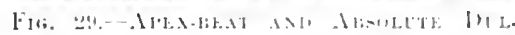

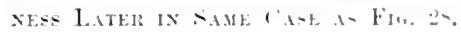

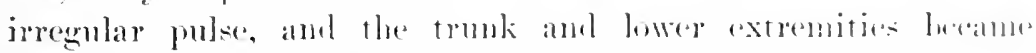

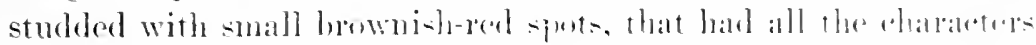

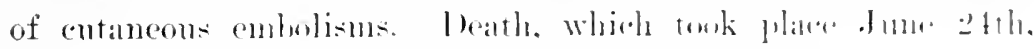

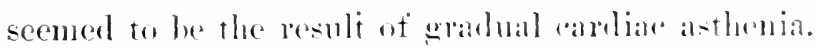

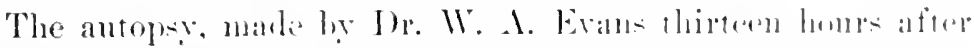

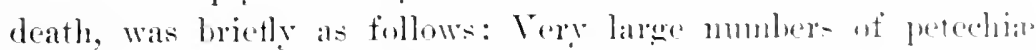
over abdomen, chest, and lege- about the size of a peat. Sinne interstitial splenitis and perisplenitis and zone nt comneetive-ti-sue

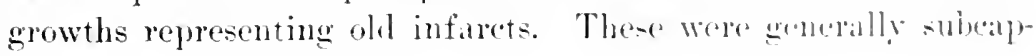
sular. 
Liecr.-Fatty infiltration-nutmeg. Lalrge numbers of small islank of connective-tissue increase, quite generally distributed in subcapsular zone. A small malss of caleareous material in lower portion of right lobe, superficial. In left lobe a small fresh infilret alkont is millimetres in dianeter.

left Kidney.-Slight parenchynatous nephritis.

light Kidney.-In the cortex an old infaret 1 eentimetre in dianneter, over this the surface of the kidney depressed. This infaret, fatty in appearance, reddish, surrounded by a reddish zone. It wats this infaret which in Malreh had oceasioned the bloody and albmuinous nuine.

Left Pleural Carity.-No fluid, no adhesions exeept to diaphrigm.

Left Lung.-Congested and sedematous. In anterior edge of inferior lobe an apoplectic focus about 1 centimetre in diameter, quite recent.

Right Pleural Cavity.-Extensive old, firm, fibrous adhesions quite general.

Right Lung.-Congested and redematons, single hamorrhagie infaret 2 centimetres in diameter.

Pericardium.- No effusion, miform athesions between pericardial layers. They strip easily, appear gelatinous or mueoid.

Aorta.-Tubular dilatation of aorta in its first portion. The lumen is somewhat oroid, measuring 9 by 8 centimetres. The aortic ostium dilated with compensatory stretching of the aortic cusps. The aortic ensps, measured along their free edge, show a length of 5 centimetres, $4 \frac{1}{2}$ centimetres, and $3 \frac{1}{2}$ centimetres respectively. All of the cusps show ridges of atheroma, with considerable thickening and stiffening. At the base of the largest eusp, a calcareous plate. Thickening, redness, and some deposit of fibrin on each of the cusps, especially towards the free edge.

The valves not competent. Aorta atheromatons. Areas of calcification, atheromatons nkeers, and some vegetations around thene loses of substance. The left ventricle enormonsly dilated, its wall :3 centimetres in thickness at its thickest portion. Myocarlium is not especially fatty. Mitral valves show multiple for $-\mathrm{i}$ of acute endocarlitis, consisting of small, romd red masses, the size of a pin-head.

Loft auricle very much dilated, right heart otherwise normal. 


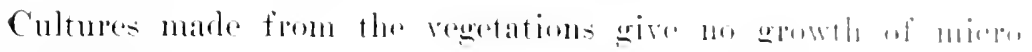
organistlis.

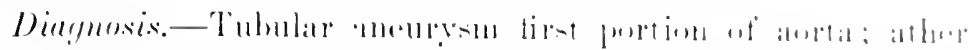

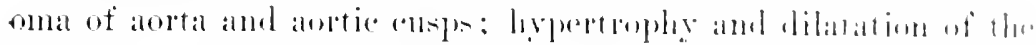

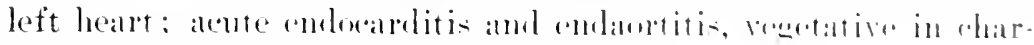
acter. Rocent intauets in liver and lumes.

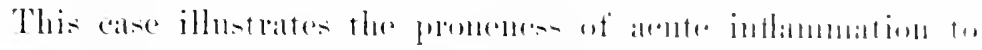

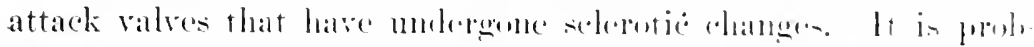

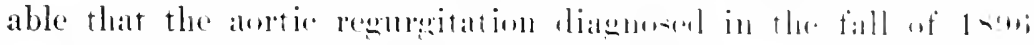

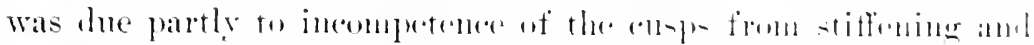

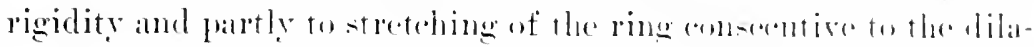

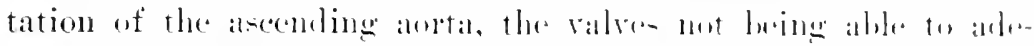

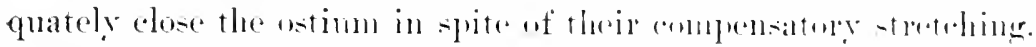

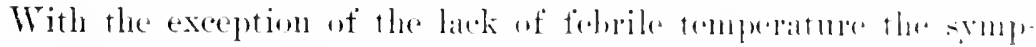

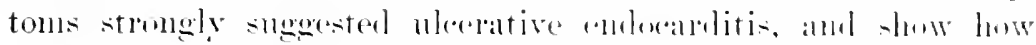

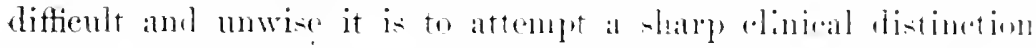

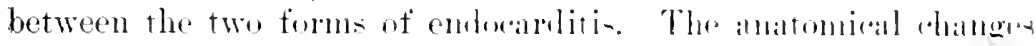

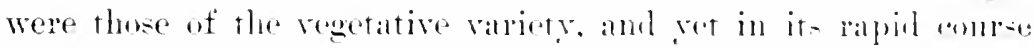
and fatal temination the process may be sail to have been matlignant.

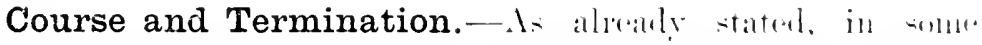

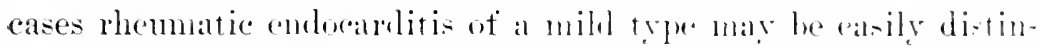

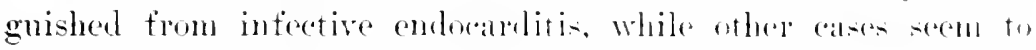
oceupy intermediate gemul, amel elindally, alt leats, ammot be classed with either one or the other trone. It is plain, therefore. that the course and termination are apually variable.

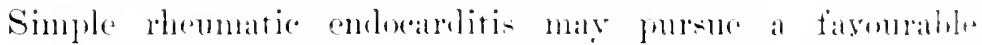
course. and teminate in the rexorery of the pattent, naly, may cren subside without serions impaiment of the attueded valve. In ib. majority of ases, howerele. the patient is usually left with at chronic valvular Iroion.

Ulcerative Endocarditis._Enler this heal allo renkmed thmar cases of inflammation of the cmlocamiom whioh manifist more or less pronomeel symptoms of general sepers. whether the ter-

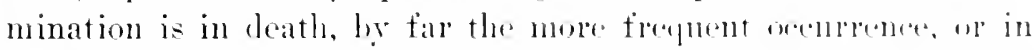
reeovery, of which instances are now and then lepeltant. As might be expected from a comsideration of the otiolegy and mor

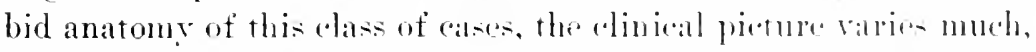
aceording as the local-that is, cardian-we the general symptoms 
pordeminate. In the majority of atses the symptoms are those of

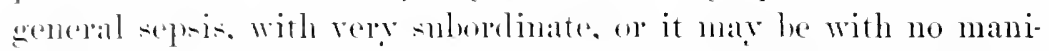
festations on the palt of the heart. In such eases the inflammatory rhange in the emblocidimin are to be regaded as merely an incident of the gemeral intertion, and therefore Rosenbach elassifies these calse as merely local manifestations of a general infeetiom. The cmelexaditis is hut nue of the mamy possible loeal ex-

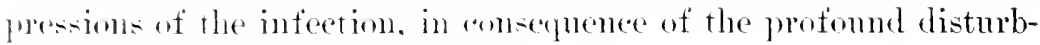
ance of mutrition there indurerel.

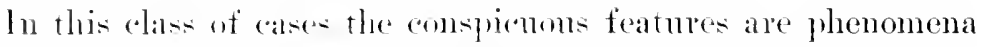
charaleteristic of pramia, an irregularly contimnons prexia, with few if any rigors. sweatings, great postration, andemia, emaciation, anorexia, diarrhera, a lry, hownish tongue, abdominal distention, stupor or low muttering delirimm, persistent dorsal decnhitus, and enlanewent of the spleen. 'The pulse is only moderately accelerated, in most instances impressing one as being ehiefly remarkable for its feebleness and want of tension, while the heart may display abolutely no evidence of disease, or may be slightly clilated, with a faint, soft systolic apes or basic mummr, the same as in typhoid ferer. Indeed, this whole condition is so like enteric ferer as to be frequently, it may he said usmally, mistaken for that divealse.

In otler ases the forer is much less typically septie, remitting or intembiting, not dropping sudenly below nomal, and acain abruptly shoting up several degrees, but ruming so mild a combe as to searcely melit the appellation of prexia.

In others, awain, the clevation of temperature is of irregular trpe, or there are dimrnal thetuations, to possibly $101.5^{\circ}$ or even $10.25 \mathrm{~F}$. The feature that mainly attracts attention in such "ases is the proglessive anamia, and the trifling ehanges diseoveperl in the heart are eommensurate with those of anamia.

The last of July, 1900). I was comsulted hy a cierman, aged fiftr-eight. Who was a merelant in the interior of Indiana. His family history was mimportant, and his personal anamesis was meacre. He had alwars combidered himself well mutil about a rat profomsly. when ho had suffered from bronchitis, for which lis had received medical treatment, at which time a heart-murmur was discovered. In Marels, 1s00, he liad been tronbled with night-streats that had resisted treatment by belladonna. Since 


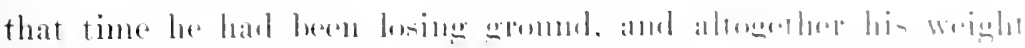

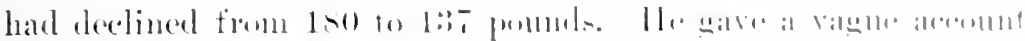

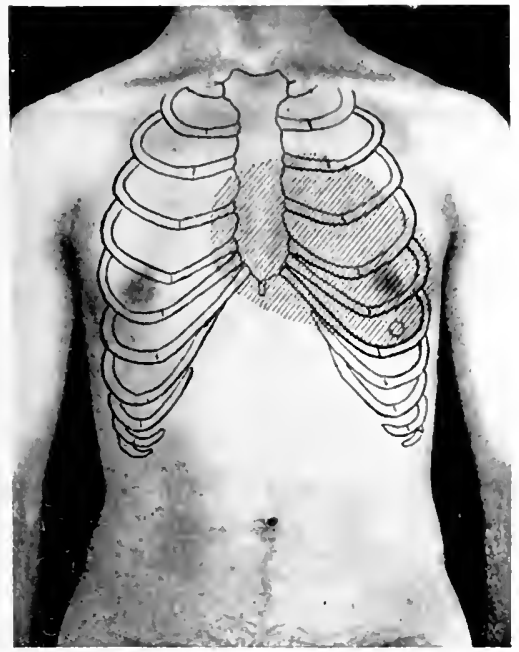

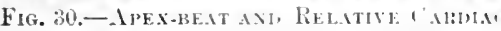
D)taEs (p. 164).

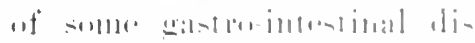

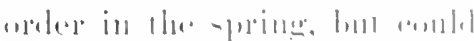

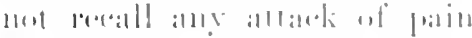

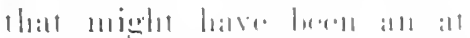

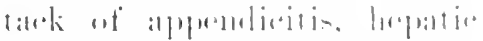

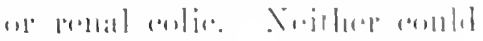

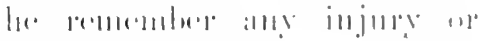

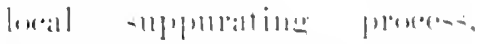

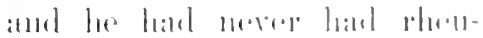

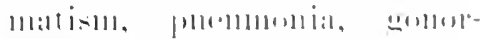
rlacat.

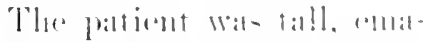

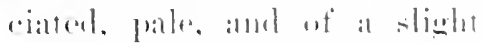

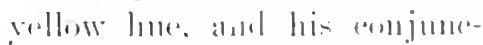

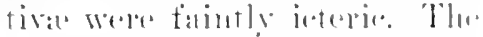
rablial aldelios ware thirk-

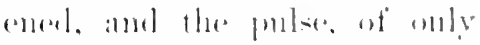

moderate temsion. Was renular and aflull. 100 to the mimute. A

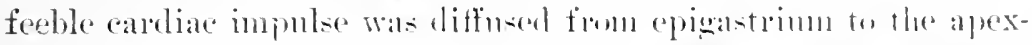

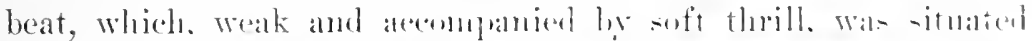
in the sixth interspace, 10 ("xntimetres to left of median line. Relative andiac dulurs: at the level of the tiftle costal eartilage extended from is exutimetres to right of the midsternal line to 14 centimetren to left of the same (Fig. : : ()). The first somd at the aluex was obsenred hy al $1101 \mathrm{~mm}$ ' and the secomel was impme. but over right rentricle luth were more distinct, while at the base both were faint. the second being scarcely andilste. the pulmonic second the limeler of the two: both arotic

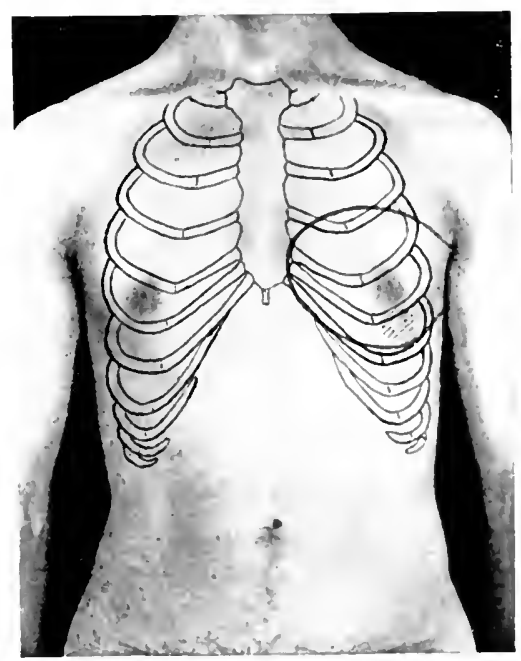

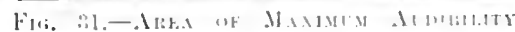

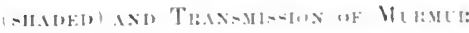
IX C.M. P. lit, 
tones were distinet, but feelle in the cervical arteries. A harsh sotolic mumberms heard at the apex, and was tramsmitted into the midelle of the axillary region and to the nedian line in fromt, ret not above the thind interspace (Fig. :31). The hung: were negative and the ahdomen was thabby, moderately tympanitie. mot temlere, while in the location of the gall blatder a soft romdish borly could be planinly male out. The mine collected wer night and analyzed next lay gare following results: Quantif tion aldid: colonr, redilish-yellow: mea, 1.4 per cent: mnein present: a slight trace of albumin: no sugar: no bile: no blood; 2 gramular and a few hraline casts: a few cylintroids and uric-acid (ristals, but no pus: not examined for preptone. The blood-examination on that day showed hemoglobin, to per cent; red cells 1er centimetre, $3,666,2,30$. pereentage of red cells. 73.8: corpusle index, 54.t, and number of lencoertes per centimetre, 13,700. HIis temperature at 11.15 . 1. x. was $98.4^{\circ} \mathrm{F}$.

As there was nothing in the examination thus far to lead to a suspicion of endocarditis, the diagnosis was male of ehronic arteriosclerosis, with chronic mvocarditis and an atheromatons mitral incompetence and a mild interstitial nephritis, ancmia. The patient was advised to go into a hospital, where he conld receive treatment le rest, appropriate diet, and medication. He lisl as advised, lut got chilled in driving to the hospital, and at my risit that sane afternoon his temperatme was found to be $101.6^{\circ}$ F.. respirations normal, and pulse only moderately aceelcrated. This febrite raction was thonght to be the result of his rhill, and fearing he might develop mamia on aceomnt of his nephritis, he was orlered to drink very freely of hot water, so as to promote elinination. The result was that ly $6 \mathrm{c}$. $\mathrm{x}$. he had fasidel 15 omees of mine, and his temperature was normal. Believing this rise of temperature to have heen but a transient flurry, I was mrpriced and disappointed to find that later that same evening his temperature again rose to $101 . t^{\circ} \mathrm{F}$. The chest was then gom orer carefully, but with negative results, and aecurate record was ke jut of the amomint and character of the urine, also without the discovery of anything of importanee.

Horing the sncoeding ix dars as shown by the annexed (hatrt ('hart I), he had a low morning temperature and a moder- 
ate afternoon $\%$ rexia with slight ferepritions, hut

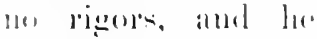
anecrted that lae folt well. As the piattient had comb from a State in which malarial is rommon, his blun! was exalumined an August 1-t for platsmodia. but with newative lowlts. Neverthelese it was deciled to test tho effect of gminime. and on Angust : 20 grains were $x-$ hibited in the aly. inorninge. On that dav he hat no fer vele, but on the next day, withont guimine, his tempreattule wont up as lusal to $101 . t^{2} \mathrm{~F}$. On Alemst the 1 i glains kept it down to $100^{\circ}$ F., and on the sth to 100. F., while on the tith, without the gemesdy, the temperiture agrain learehell $101.8^{\circ} \mathrm{F}$. and with go grains on the Tils it did not wa nrel $9 y^{\circ}$ F. On the sth,

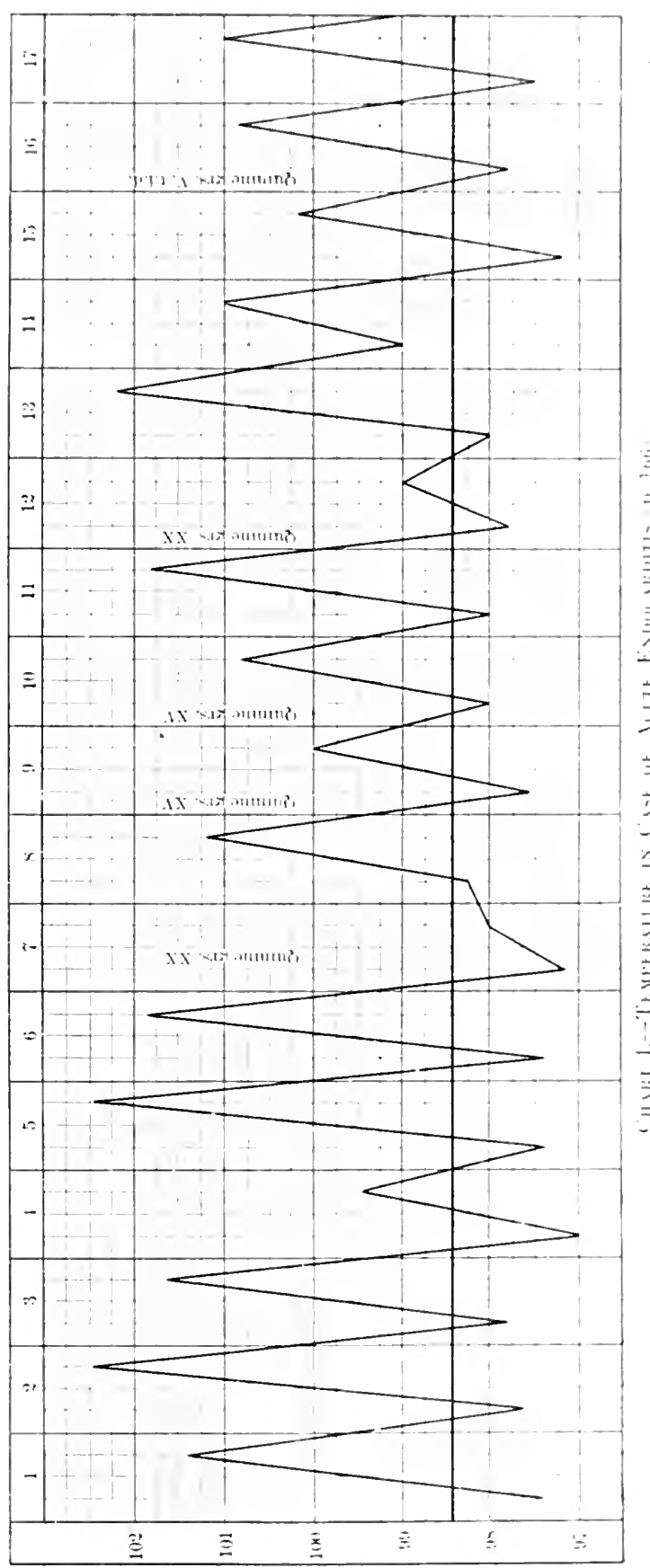


without quinine, his temperature was 102.20 F., on the 9 th a degree lower, while s grains t. i. d. on the 10th kept ferer down to $100.2 \mathrm{~F}$.

The results thus obtained convinced me that the quinine acted as an antipretic, but that, in spite of doses sufticient to exert a more lasting influence in case the srmptoms were due to malaria, the ferer reasserting itself so soom as the drug was stopped, there was some other canse at work. The mine was now tested again for peptone, and with positive results. I therefore beeame sat isfied that the ease was one of pamia. It should also be stated that the hloml had been tested for the Widal reaction, and this proved to be absent.

As the gall bladder had been fommd enlarged at the first examination, and was still palpable, it was thought highly probable that there might he an emprema of this receptacle as the source of the infection. Acoordingly the patient was seen by Dr. Bayard Holnes, who corroborated the gall-bladder enlargement and concurped in the opinion of a probahle emprema. This seemed all the more likely to le the focns of infection from the fact that no discase conld be discovered in the rectum or elsewhere. A few days subsequently Dr. Hohmes operated on the gall bladder, but although it was comononsly distended with fluid, this was not purulent, the condition heing a catarh and not an empyema.

To ill effect followed the operation, but the wound healed very slowly. For a lay or two the temperature fell somewhat, but then resumed it former characters, being down nearly or quite to normal in the early part of the day and rising in the afternoon or eroning to between $101^{\circ}$ and $102^{\circ}$ F. Rigors were never manifested, and repeated queries concerning chilly sensations always elicited a positive denial of them. Perspirations were also absent. or at the most amomuted to no more than a searcely perceptihle moistness of the skin where covered.

Week hy week the patient hist in strength and flesh, and grew more andenic in appearance, althongh his ability to take considerable nomishment persisted. He also displayed slight apathy, lying flat in hed, and changing position but seldom. Pain was not complained of, and in rain was a daily seareh kept up for signs of cmbolism. During these weeks the pulse slowly and gradually became a little more accelerated, reaching 116 or thereabout. Its 


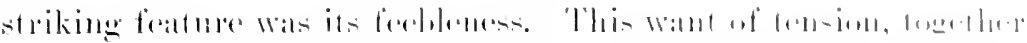

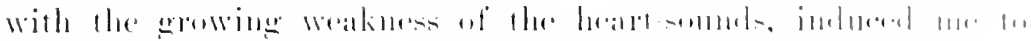

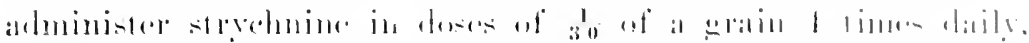

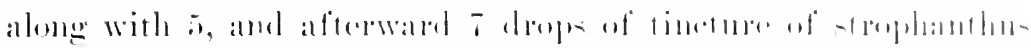

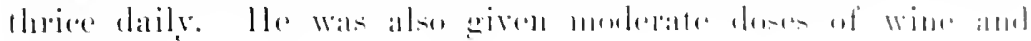
whisks.

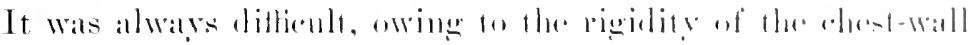

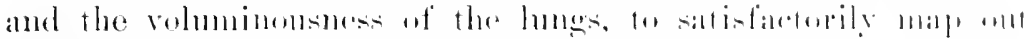

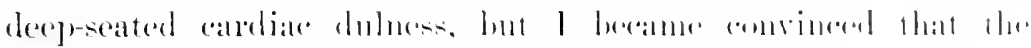

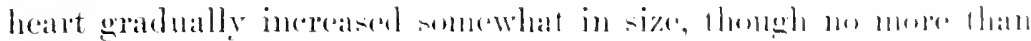

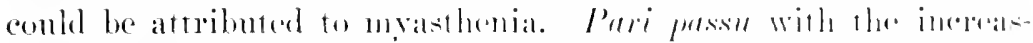

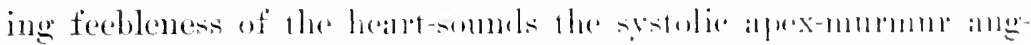
mented in intensity and retent of ambliblity moll all lemeth it

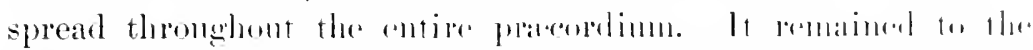

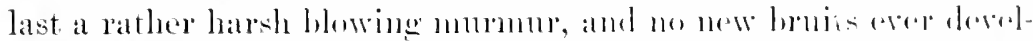

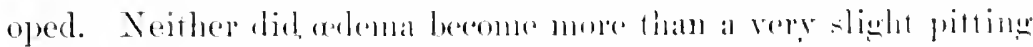
orer the tibia, and I eomld not make ont an! increase in the sime

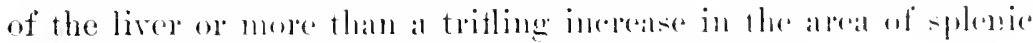

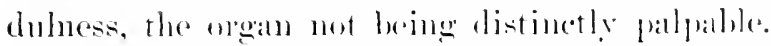

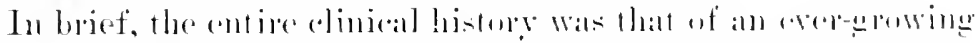

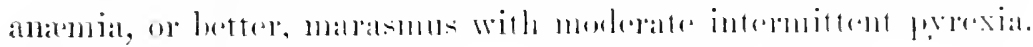

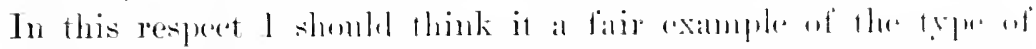

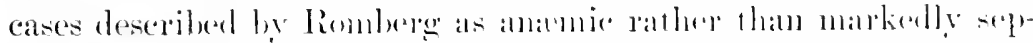

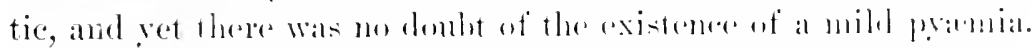

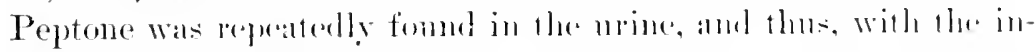

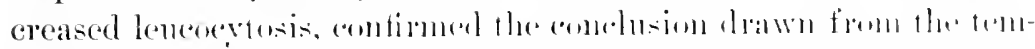

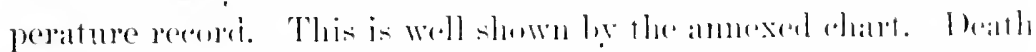

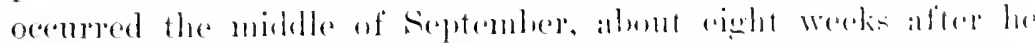

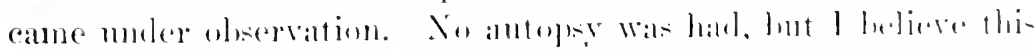

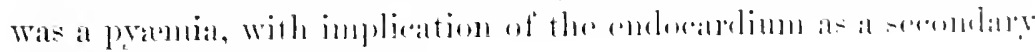
and not a primaly (ront.

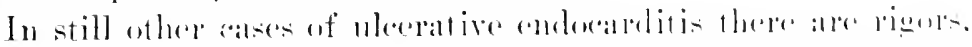

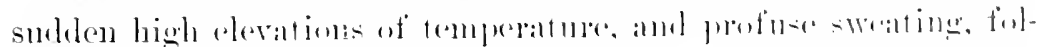

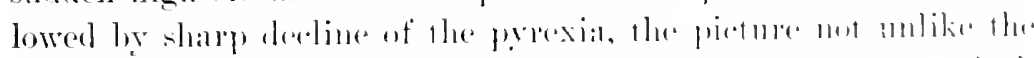

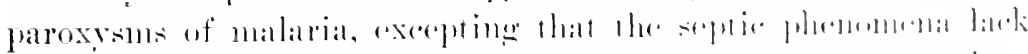

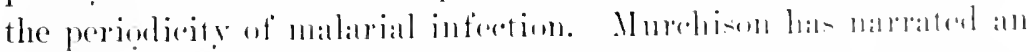

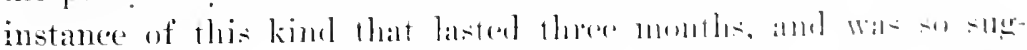

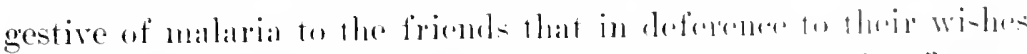

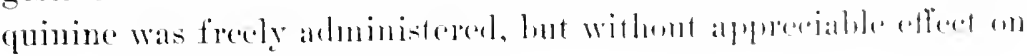


the discase. In his case, howerer, there was physical evidenee of an anetic valyular lesion.

There are other cases, again, in which the temperature pursues a still more erratic course, rising and falling abruptly for days, and then suktenly sinking to normal, or it may be to below normal. Remaining thus for day's or eren weeks, it again assumes its former irregularly intermittent trpe. During the apyrexial period the pulse still remains conspicuonsly feeble, and the patient fails to regain strength, so that by these symptoms it becomes manifest that aretual inprorement is not taking place.

Thus, whatever the varions manifestations, they are in themselves indicative of sepris, and there is nothing to show that the heart has become affected. Oecasionally, on the other hand, the involvenent of the endocardium is evinced by the appearance of cutaneons infarcts or by phenomena of embolic plugging of ressels in the intestinal organs. The lodgment of emboli in the skin is shown by the appearance on the extremities or trunk, still more rarely upon the neck and face, of reddish spots of rariable size, from that of a pin's head to a pea, or somewhat larger. These petechia mas be few and seattered irregularly, or they may come in showers and at irregular intervals. Septic infarets in the liver, spleen, kidners, ete., are productive of abseesses, which may be miliary and escape detection during life or be of recognisable size. In some instances the clinical picture is dominated by these embolic phenomena.

I recall a case in which it was the detection of a splenic abscess which secmed to justify the diagnosis of septie endocarditis. I was asked by Dr. IIaskin, of Highland Park, to see a gentleman of about sixty who had been having irregular chills, fever, and sweatings suggestive of malaria. IIis illness had begun six weeks before with malaise, and har speedily developed the symptoms of sepsis. Three days prior to my visit he had suddenly complained of sharp pain in the left hypochondrium with tenderness. I fomd him moronscion, and lying tumed to the left side, with lis thighs flexed, skin hot and moist, pulse moderately rapid, but notally weak and soft. There was a distinct blowing systolic mumur in the mitral area. Splenic dulness was greatly increased, and although palpation evidently caused pain and was resisted, a rather soft tmmonr having the form of the spleen could 
be felt extending well down below the leit ensal malmin. The

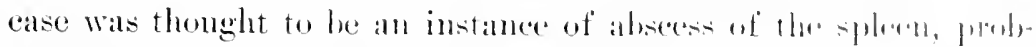

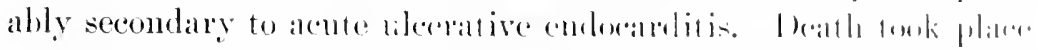

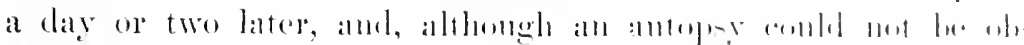

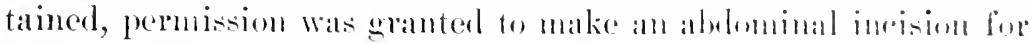

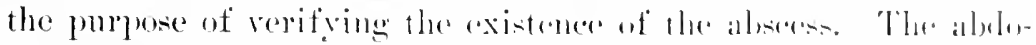

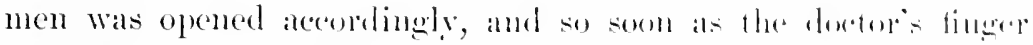

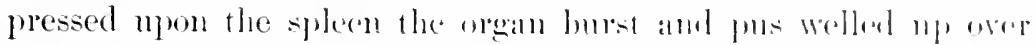

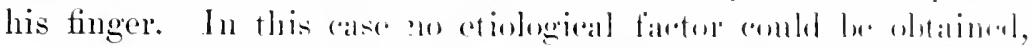

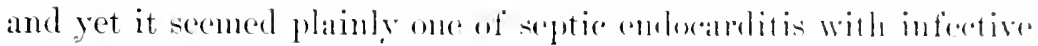
infaret in the spleen.

When emboli of this challacter lorlew in the kidhere, they are declared by allommin, pus, and hlomel, with casts in the mine.

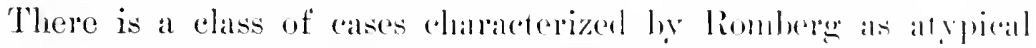

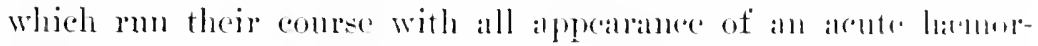

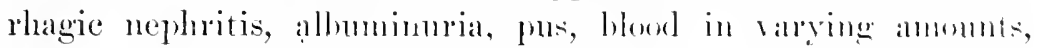
casts, renal cpithelinm, and eylindroils.

This comdition of the urine persists thomehomt, hut with re-

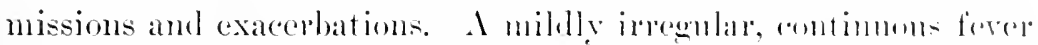
aceompanies the nephritis, and the patient displays pommunent and incereasing anamia. It is this feature, together with the pere sistent proxia out of propertion to the temperatmle nsmalls observed in nephritis, which thows lieht on the matnere of the case. The diseovery of an old-standing ralvular lesion contributes gently to the establishmont of the diagnosis.

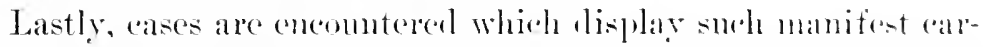
diae symptoms that by some elinicians they and elassod in a special

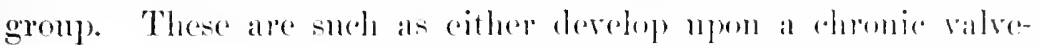
Jesion or occasion such rapid ularation and destruetion of the

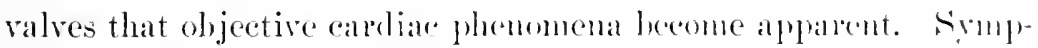
toms of general sepsis may not le malked, or it promommed, depend largely upon infertive omboli. The pulse is perulialy soft,

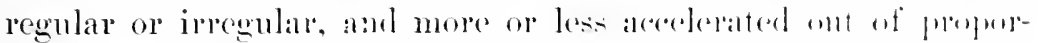

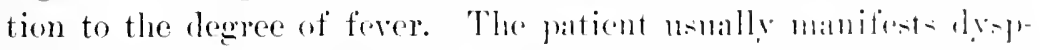

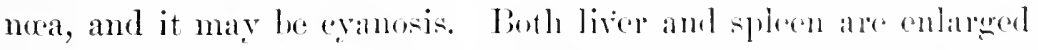

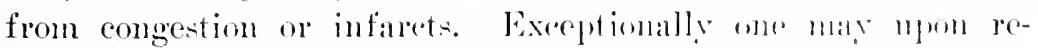
peated examinations of the heall detcet some eridemes of changes going on, sncli as increasing fardelness of impulse, sight increase in the area of dulness, and perelance a soft mumm where previ- 
onsly mone existed, or an alteration of one alleady present. More offen such examinations ane futile, and the diagnosis is largely comjortural or has to be made frem the symptom-eomplex.

Course and Termination.--The duration of acute ulcerative enderarlitis is excedingly valdiable. The disease may rom its eomles to a fatal termination within a few tars from its coning muler observation, or its combe may be dragged out over a period of weeks and eren months. Some a ases progress steadily to a fiatal issue, while others show perionls of seeming improvement, followed hy exalcelations and nore rapid decline. When death is the result it oevors either in consequence of local changes in the heart and caldiac asthemia, or as a result of acute pulmomary redema or pulmonary infarets. In other cases the patient is worn out ly prolomed sepsis, or death is directly attributable to the etfects of cmbolism in the hrain, kibneys, spleen, ete.

A gentleman of alont forty, who had a perfectly compensated mitral regurgitation of rhemutic origin, became ill in the fore part of February with what, from the history, alperars to have heen an acute follicoular tomsillitis. It subsided in a few days, but the man did not renain his acenstomed health. Ite felt weak and slightly fererish, had vague pains, dull headache, and lost appetite. Thinking his liver was at fanlt, he went to French Lick Springs, Indiana, and there drank the waters, took a conse of haths, and exereised, hut without imporement. While there he Wats amoyed by temderness and pain in the ends of his fingers, and ohorred that at such times there was a faint leddish colour of the skin immenliately alowe the roots of the mails. Ile was told it was rhemmatic.

At longth, failing to regain health, he returned home, and towards the (and of April somelit my opinion, partly on acconnt of a fropnent diy comeh that had recenty developed. I had known him in lealth, and had previonsty examined his heart. The change in his appearanco and gemeral condition shocked me. His volice was weak and tremulums, his hamels shook, his face was pale and sallow. Ilis eyes were not perfectly elear, the skin of his arus and trumk was flahly, faintly yellow, and although at first dry. Jerame bedewed with moisture upon the exertion of undress-

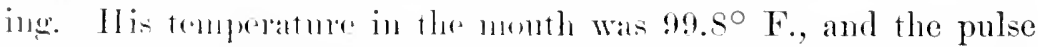
of 105 was weak and small, but regular. I was struck by the fact 
that its latte ditl lled fall

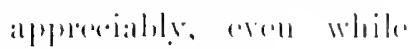
he wats lestinge an flue lomeger after nor andmination. 'The lanat elid

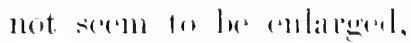
but the apex-beat was feoble amd procolad by al short, searealy perenpitble thrill.

'Thes old mitral sistolic mummm wats present, but in aldition thes first sommd hand a sllgesestion of a pressotulice bruit, and the second somud was fexhle. The lumes were negation, the liver barely palpalile, allel mline eontalined a trales at albumin with alamular and hyalime asts.

From the history of tomsillitis and l! lo symptoms, I alt ance snspertal enderarditis, and solnt hime lomes to lext. llis temperatme, which wats

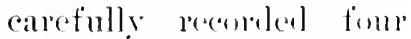
times daily, shemed al faidy antimmons byrexia, from alumt 100 F. to $101^{\circ} \mathrm{F}$. and a fialction (Chatrt II). Mlis pulse remalined persistcontly in the noighbomehoorl of 105, and the heart-fimlings were mochamged. He was givent

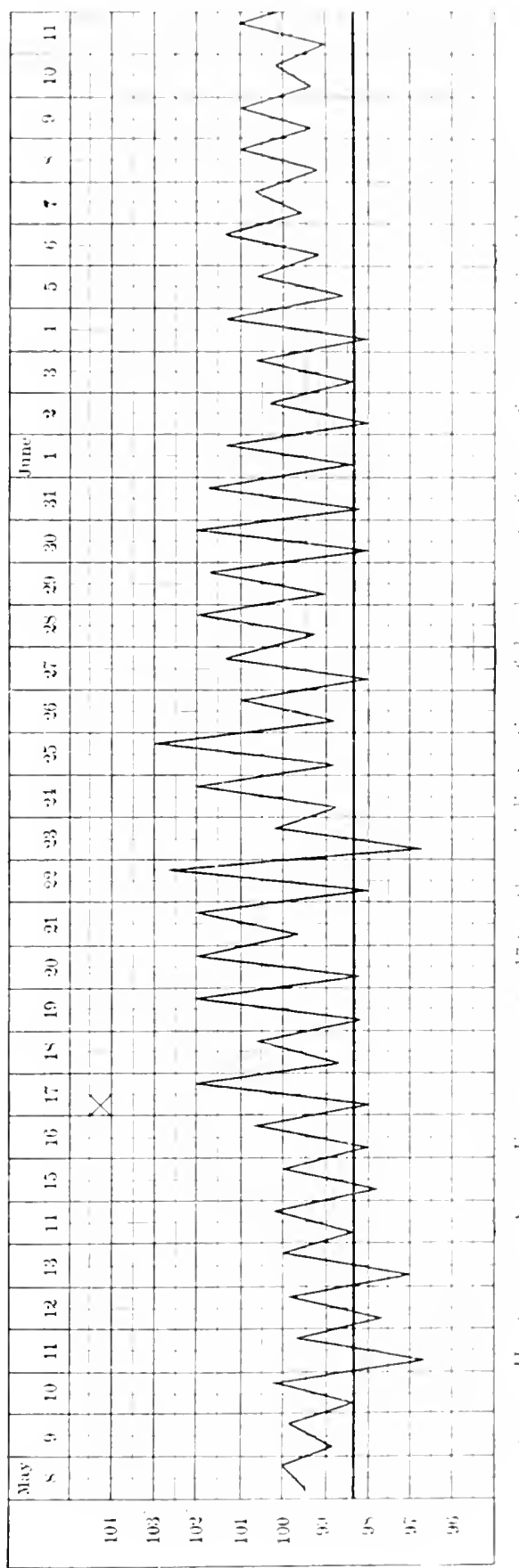


strichnine and reats-nuclein in full doses. The diet was as hearty als his fechle digestion womld permit. Ile felt so comfortable that he was kept in bed with ditticulty. Things remained in this condition for two weoks, when he one day complained of localized pain and stiffuess in the calf of the left leg, but with no objective phenomena.

Ilis comgh was so persistent that repeated examinations of the hnges were made, at first with negative results. At length I discovered moderate duhness of the right upper lobe with ill-defined hromchial breathing, but no rîles. About this same time enlargement of the spleen became demonstrable. At a loss to account for the changes at the riglst apex, I requested Dr. Arthur R. Edwards to see the patient. He agreed in the view that there was probably septicimia with endecarditis, hut conld not give a satisfactory explanation of the pathologieal condition in the lung. The pain in the left leg he thonght was due to embolism. The faint blush at the root of the nails with tenderness, pain, and moderate clubbing was also observed by him, but without special comment.

Coineidently with the appearance of distinet signs in the right apex the ferer rose a degree or two, headache was complained of. and cough withont expectoration became troublesome. This condition, which I now believe was a pnemmonia of the same bacterial origin as the general sepsis, persisted for abont two weeks, and then gradually disappeared, the lnng clearing up, and the patient's general condition retmrning to what it was before this attack.

For the next month or six weeks the elinical picture remained nearly in statu quo. Oceasionally he spoke of sudden pains in the shonlder or elsewhere, which lasted for a few days and then vanished. Once he complained of pain and tenderness of the liver, and the organ became slightly more enlarged. This condition persisterl for perhaps a week, and then disappeared slowly. All this time there was the same relentless prrexia, which at times flucthated rather more than before-lunt with exception of its becoming somewhat weaker in action and sounds, the heart showed no distinct change.

The character of the temperature is shown in the annexed "hart. Credés ointment was rubled into the skin freely for two wreks, and was then succeeded by daily injections beneath the integunnent of an old antistreptococeus serum in doses of 10 eubic 


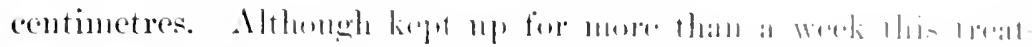

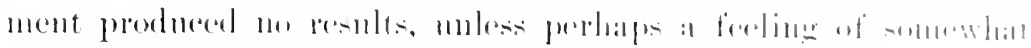

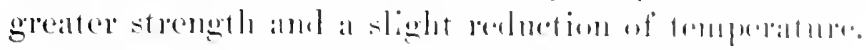

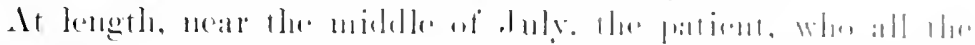

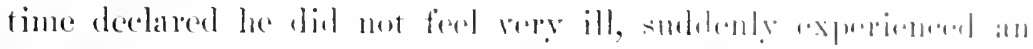

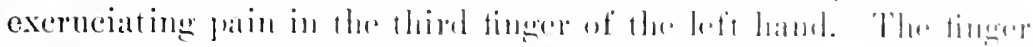

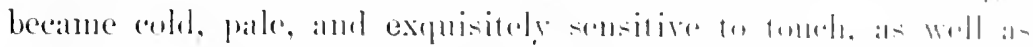

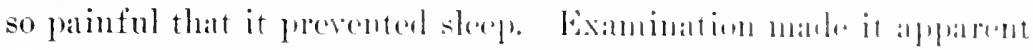

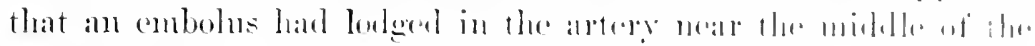

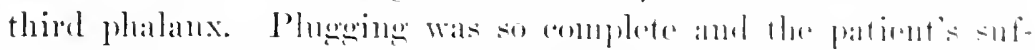

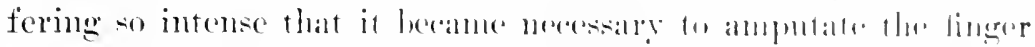

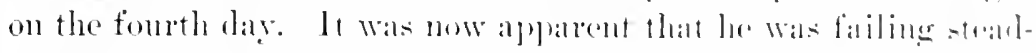

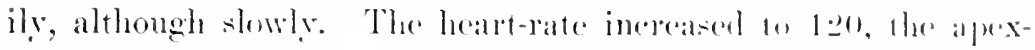

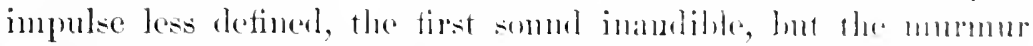

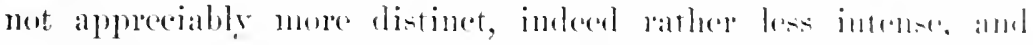

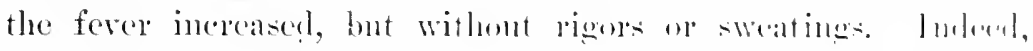

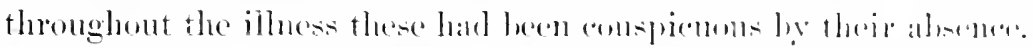

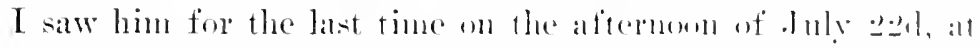

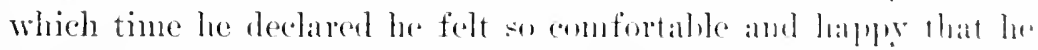

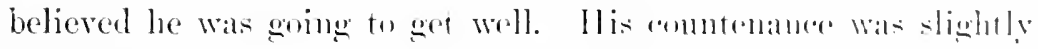
suffused, and as he harl not remaleiated gereatly. his friends and not realize how ill he in reality was. Joring the foremon of llee

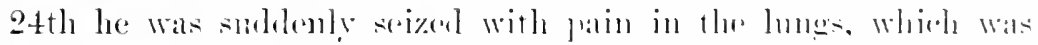

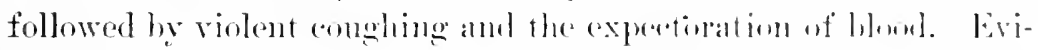

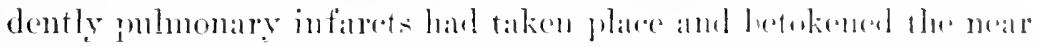

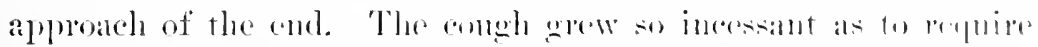

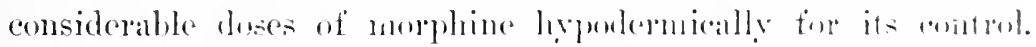

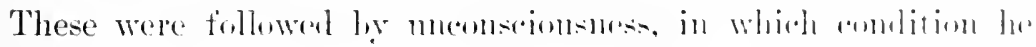

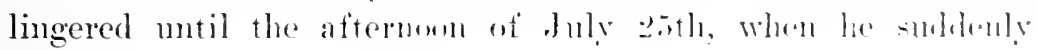
expired.

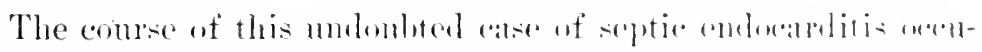
piet five montles from the attalek of tomsillitis. It was platuly and

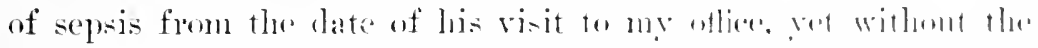

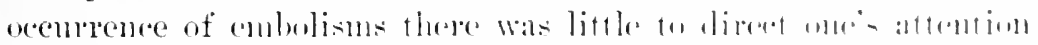

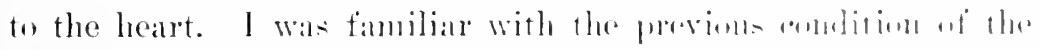

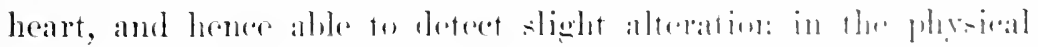

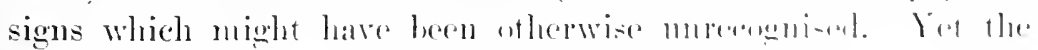

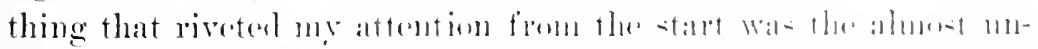
swerving persistence of the pulse at rery nearly the samberate, 
105, in fpite of rest in bed, until near the termination of the case, when it rese to 120 (1).

A highly interesting foature also was the condition of the terminal phalanges of the tingers. The fant rerlness, pain, and, it

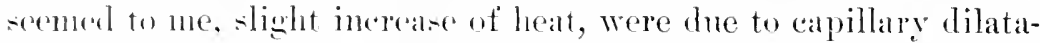
tion, which ansod the ends of the fingers to become distinctly hulbous in the conrse of a few months. During the preceding winter I had observed this sane phenomenon, only to a much more marked extent, in a romng woman who was in the ward at rook ('omnty llospital suffering trom mitral disease, and, judging from the srmptoms, from endocurditi-. She subsequently left the hospital, $\therefore$ that I camot state the cardiac condition definitely. In her case the finger-ents hecame distinctly red and mmistakahly bubnom. In hoth these instances there was pyrexia associated with cardiale disease. May not this phenomenon in the fingertips point to somothing more than mere apillary paresis, perhaps to smeh a disturbance of the cardio-vascular apparatus as may sugaest involvement of the heart as woll as general infection? It is a matter of profommd reguet that an antopse conld not be obtained in the case which has heen narrated at such length.

Physical Signs. - Inspection is of rery negative ralue, since althongh it may enable one to detect signs of cirenlatory disturbance, it dues not fimmish proof of such disturbance being dne to endoraditis. Jiesides, ralvulitis is so often masked by the symptoms and phrsical signs of the primary affection that inspection of the patient revals only such changes in the patient's appearance as belong to the rhemmatism or other original disease.

I'alpution is likewise of minor aid in the detection of acute endocarditis. It may assist in the recognition of some old-standing valvular lesom, or in loternining the presence of abnormal pulsations, rapiations in the foree, position, and extent of the ajex-heat, the possible derelopment of thrills in the course of the affection, endargencent or not of the liver, etc., all findings that lorar in cortain cases on the eondition of the heart, hut, like inspeetion, it ammot furnish diperet evidonce of the existence of acute

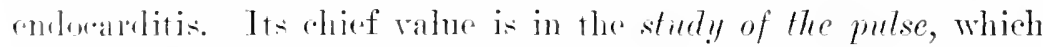
in all smejocted rases shomld he rarefully stmdied, changes in its tonsin being often of greater value than alterations of rate or rhythm. 


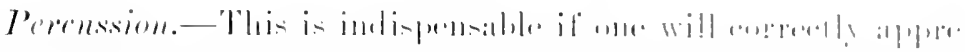

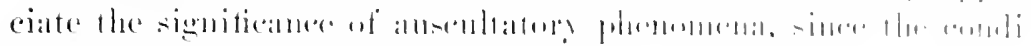

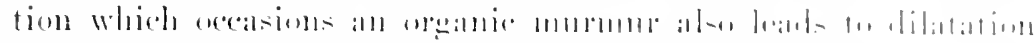

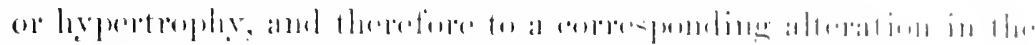

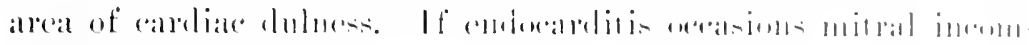

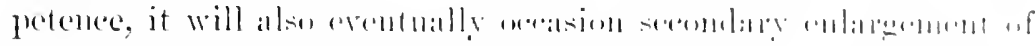

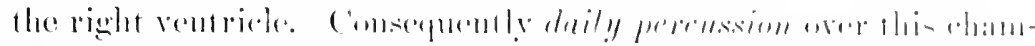

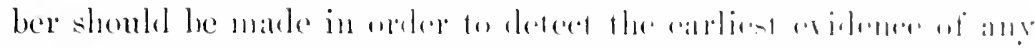

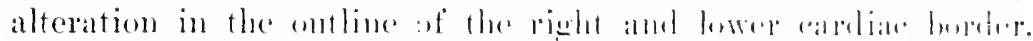

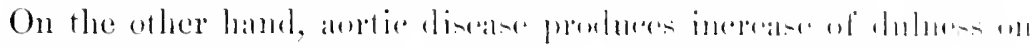

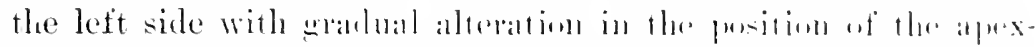

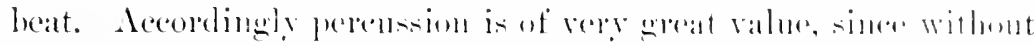

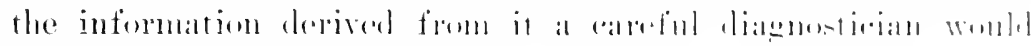

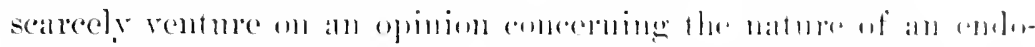

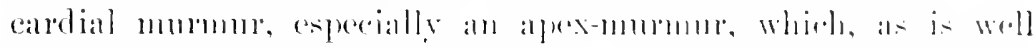

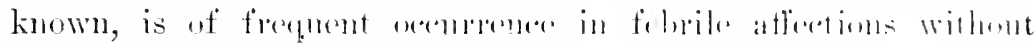
intlammater ehanges in the ralvers.

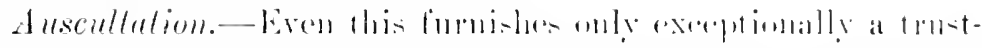

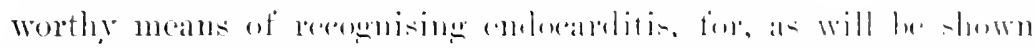

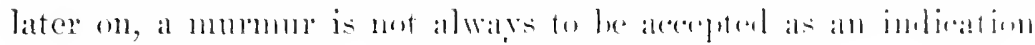
of valvulitis.

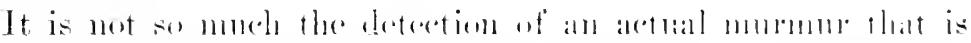

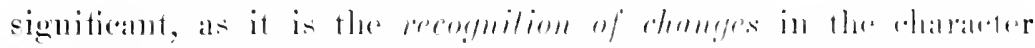

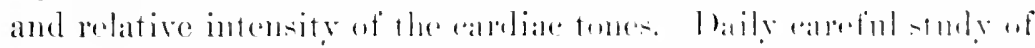

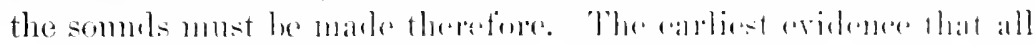
is not right at the mitral mifier (the seat of inflammation in in

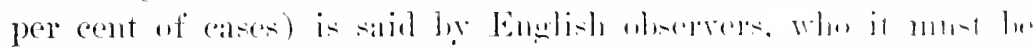

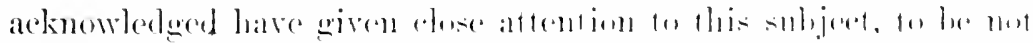

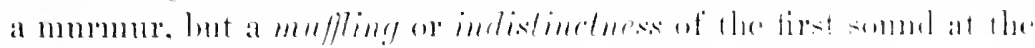

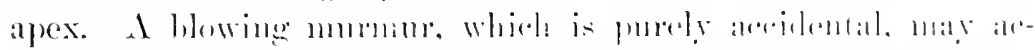

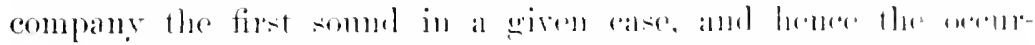

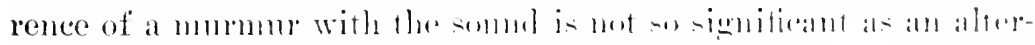

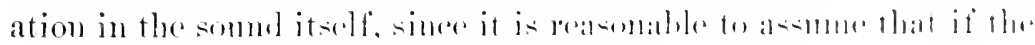
production of the sumbl is interforent with it maly lu ly intam-

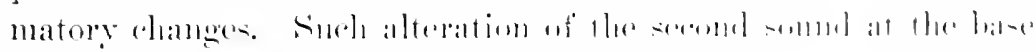

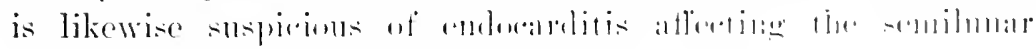
valives.

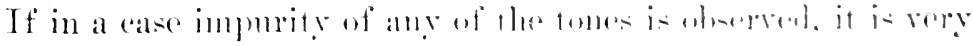

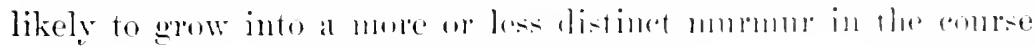


of time. While there will also develop the soromelany changes in the

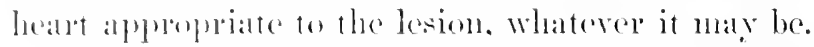

1 diestotic murmur developing in the arotic area may be set down als not aledidental, and therefore indicative of inflanmation at this astimm. If this intlammation serionsly impar the integrity of the value. it will be shown in time ly the oecmrence of the

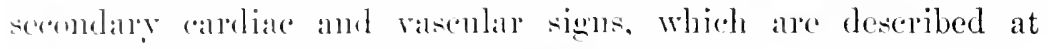
length in the chapter an sortic liegurgitation.

1 presystolir mumur rarely derelops as a result of acute endoalditis miless the process is ingrafted npon an old-standing mitral regurgitation. Intlanmation attarking previously healthy valves usually produece inemunetence of these, or this combined with a minur degree of obstrnetion. Therefore, the murmur is apt to be

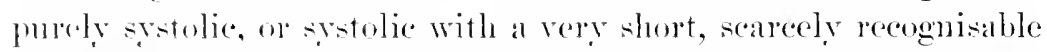
presistolic one. When, howerer, an old endocarditis affecting the mitral valve beemes rekindled, as not infrequently happens, then a presstolic bruit may derelop, and so developing it furnishes alnost indubitable proof of endocarditis being present. This eircumstance his more than onee enabled me to diagnosticate correctly the acemenes of endocarditis, as proved ly sulsequent events.

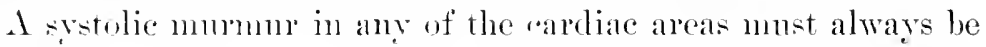
regarded with dombt mutil its true signifieance is shown by the development of secomlary physical signs. This is true of such a murnur even in the aortic notels, for experience has tanght that even here a nmmon may be aceidental. It is, however, in the cance of an apes sytolic nunmom particularly that cantion must be exereised. (1) Beceanse aceidental bruits are most often mitral, or mitral and pulmonic. (2) Becanse such a mitral systolic murmur may be the result of a previonsly existing regurgitation, and now at all due to the rhemuation in the comse of which it may halpuen to be discorered. (:) Becanse, as shown by a case reported by tanes W. Walkere of this city, an endocarditis may exi-t withont it giving rise to any mumur whatever. In his (ance the anterion and left posterior aortic ensps presented on their surface large mases of soft. friable, nombur regetations, which had filled the ostimn, and yet repeated and carreful examinations during life had ntterly failed to dretect any murmme.

Diagnosis. - These thee considerations make very plain the fallary of depending non the presence or absence of a murmur 


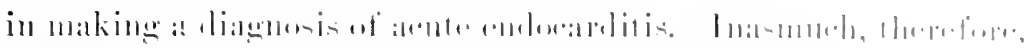

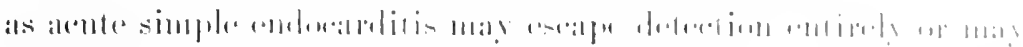

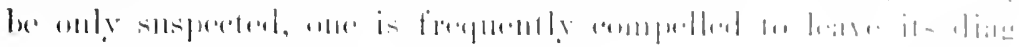

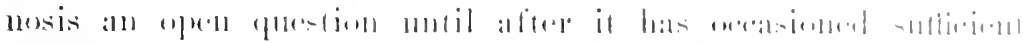

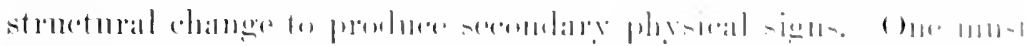

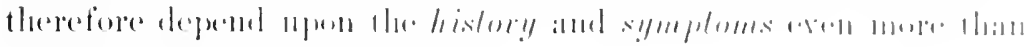
on distinctive oljeretive -igns.

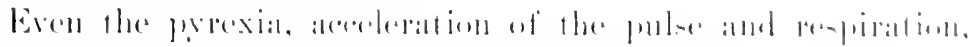

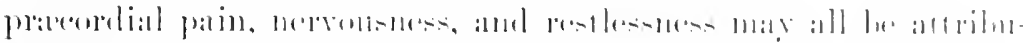

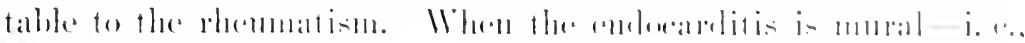

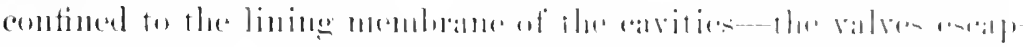

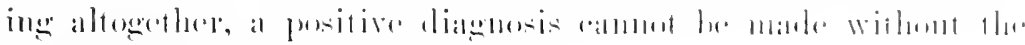

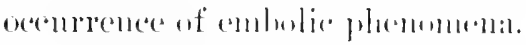

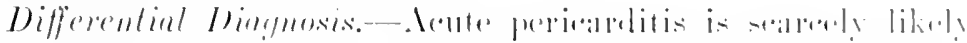

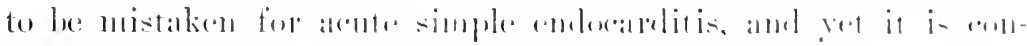

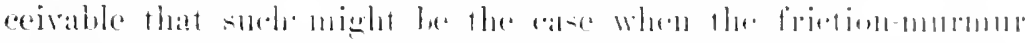

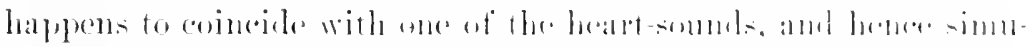

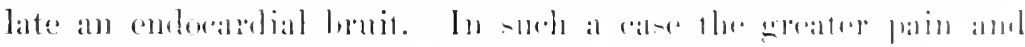

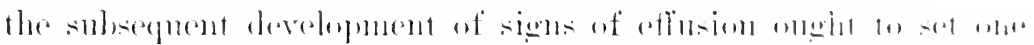

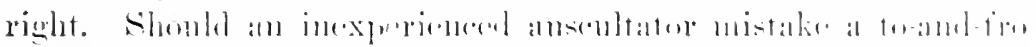

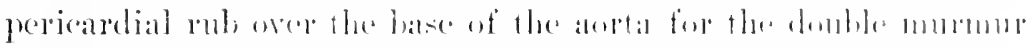

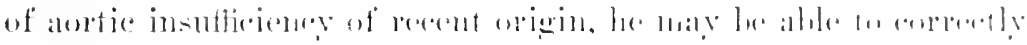

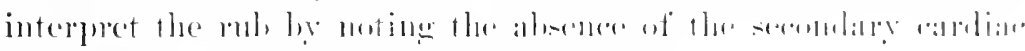

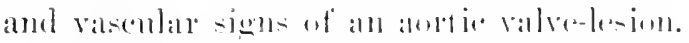

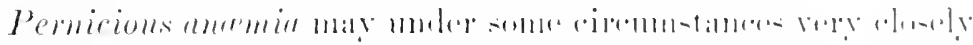

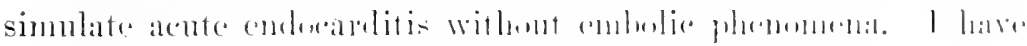

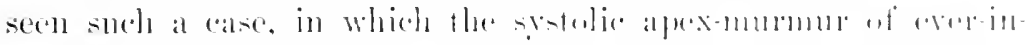

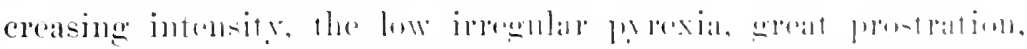

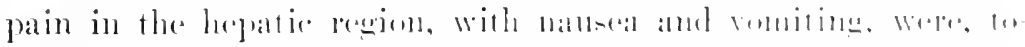

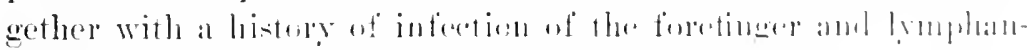

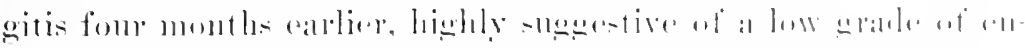

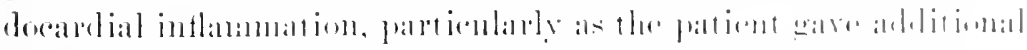

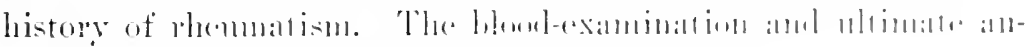

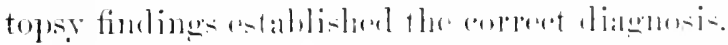

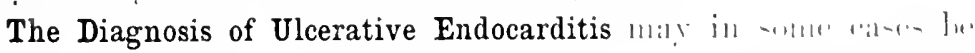

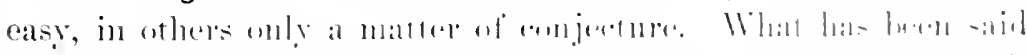

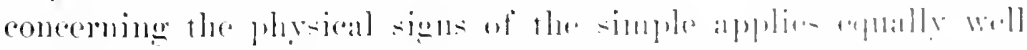

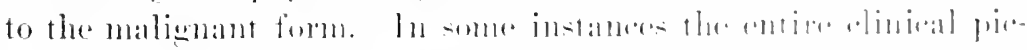

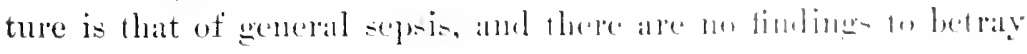




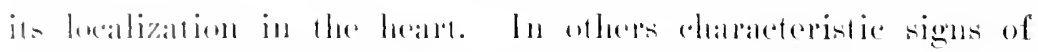

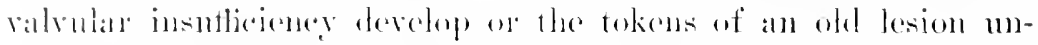

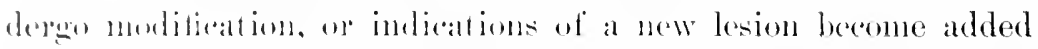

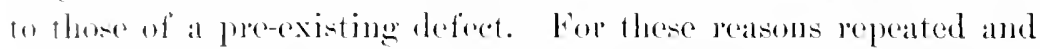

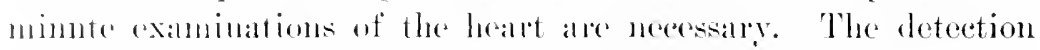
of a mmmure is in ifself of small moment somedimes, but the discoredy of changes in the rhylhm of one aleately existing, as by a presstolic lecing prefixed to a sestolic bruit, or an alteration in its

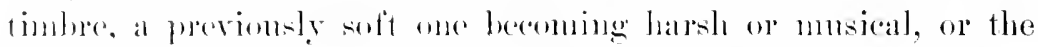
adelition of a diastolic mormun to a systolic one, all such modifica-

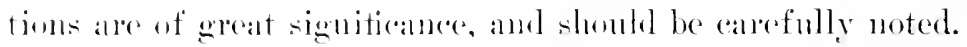

The most poliable atel in the diagnosis of malignant endoearditis is fonnd, howerer, in the history and symptoms. One must always soek for an ethoient etiological factor. For example, it was nut a great while ago that I was asked to see in consultation a Young woman who was rumbing an irregular eourse of fever, was rmaciating loming strength, and lad a carliac murmmr. It was (rident alt a glance that she wats suffering from pronomeed septieamial but the question that the physician wanted cleared up wat whether the aldiale timdings indieated septic endocarditis. There was history of an old rlemmatie mitral disease. It did not

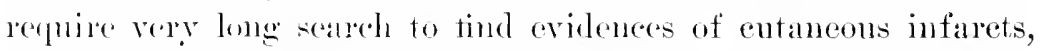
and when in response to inquiry coneerning a vaginal discharge, the morse stated that there harl lecen an extremely offensive one earlier in the illuess, and when a vaginal examination disclosed covical laceration, the chain of testimomy was complete. An abortion had lal to nterine infection, this to septicamian, and this latter to an uleceative process within the heart, which was predispured to inflammation ly its old-standing mitral lesion.

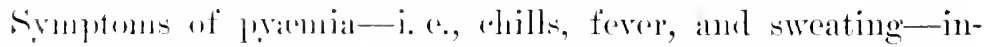

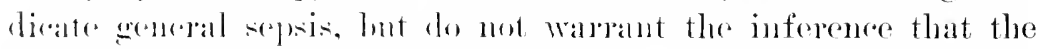
molexaldimm is involved. This am anly be assmued when embolie

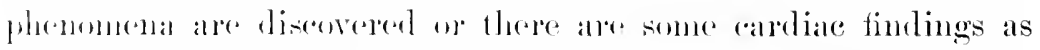

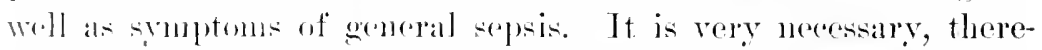
fore. to make daily exambintion of the skin, spleen, and urine for dectertiom of the changes aluandy montioned as forming an essential part of the symptomatoluge of this form of endecarditis.

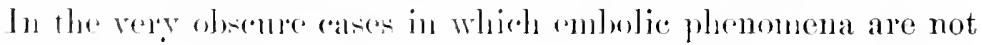
furente and there are no andiale findings to explain the pyrexia 


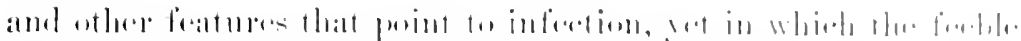

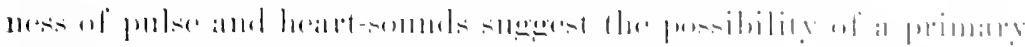

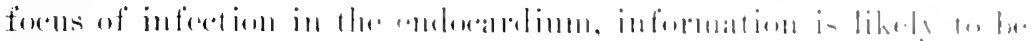

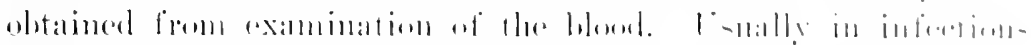

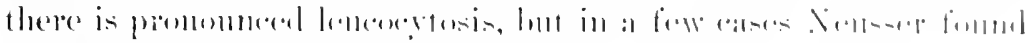

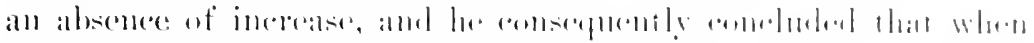

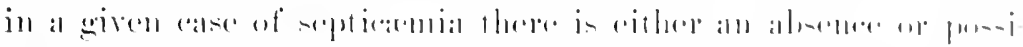

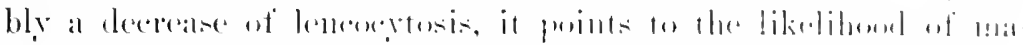

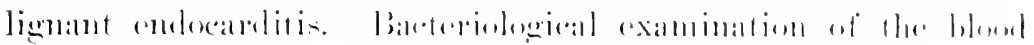

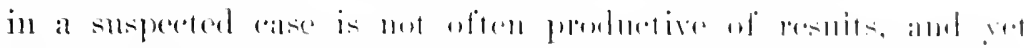

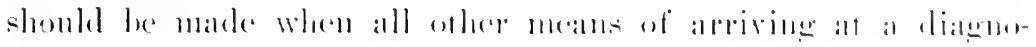
sis filil.

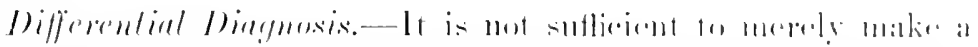

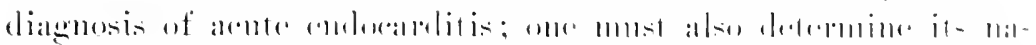

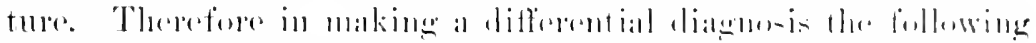

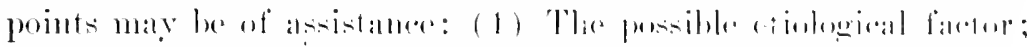

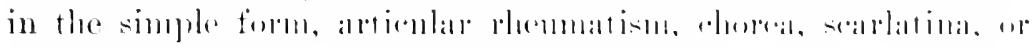

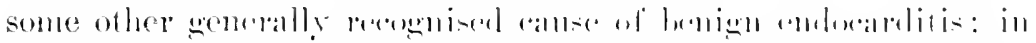

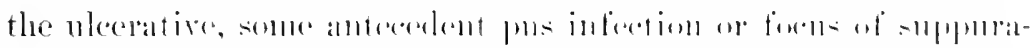

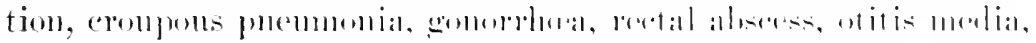

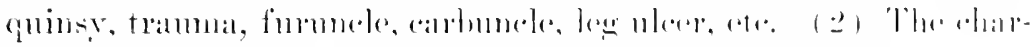

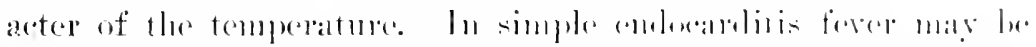

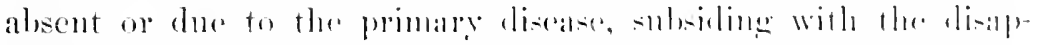

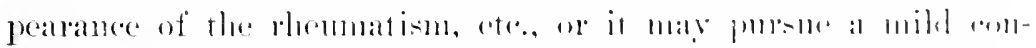

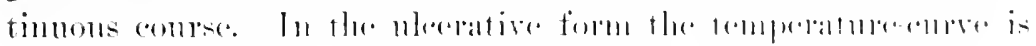

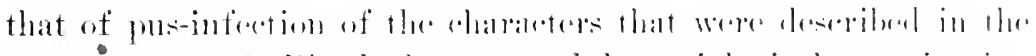

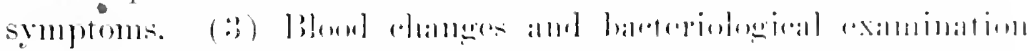

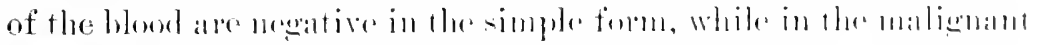

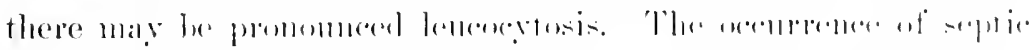

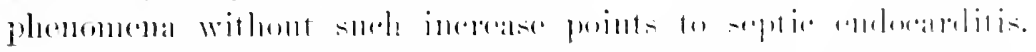

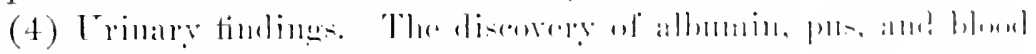

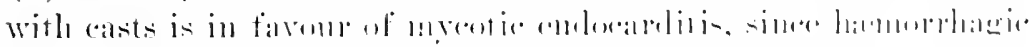

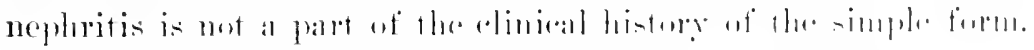

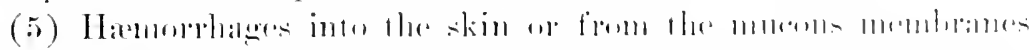

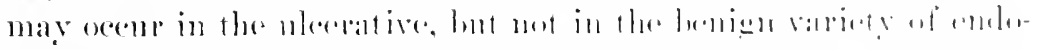

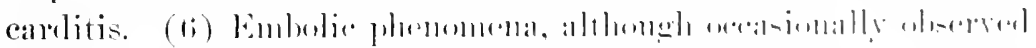

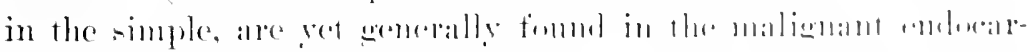

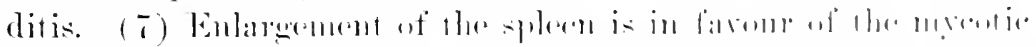

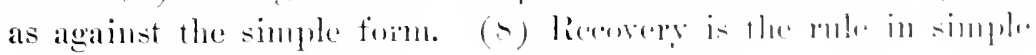


and the execption in ulcerative endoearditis, althongh its course to at faltal instue may be slow.

Typhoid ferer is the liseatse above all others for which uleerative endecalrelitis is likely to be mistaken. Is a matter of fact, most cases of the latter affertion ane diagnosed as enteric fever, and so reganded mutil in the deathonse they are found otherwise. The points of difference alre the following: (1) In typhoid fever the tempreratme is not so crratic, and in the first week often displare the characteristie gradnally asconding curve. (2) The pulse in this discase is usually slow, out of proportion to the degree of temperature. In its want of tension during the height of the malady it may be like that of cndocarditis. (3) Splenic cnlargement comes at an earlier period in enterie fever, and is more consilerable. (4) Rose-spots usually appear between the eighth and twelfth day, are apt to be in erops upon the trunk, disappear temporarily on presime, are of a nearly uniform size, and have a darker centre, fading ont towards the periphery. Cutaneous embolisms, on the contrary, appear most often upon the extremities, are irregularly distributed, of variable size, do not fade on pressure, and have a necrotic pale centre, becoming of a deeper colour towards the edge. (5) The stools of abdominal typhus are often, thongh by no means always, diarrheral, have the pea-soup appearance, and contain the Eberth bacillus. (6) Typhoid-fever yatients are very apt to manifest signs of bronchitis. ( 7 ) Excepting epistaxis early in its course and possible hamorrhage from the Inwel during the middle or latter portion, hemorrhages are not common in typhoid ferer. (S) In the Widal agghutination test we now possess a reliable means of differentiating enterie fever from malignant endocarditis, and it should invariably be made in arere doulteful case."

The value of this differential test was shown in a case under uly care a few months ago. I yomg man with extreme aortic rewnitation of rhemmatic origin was moler treatment for attacks of precordial pain, and as there were symptoms pointing to a rup-

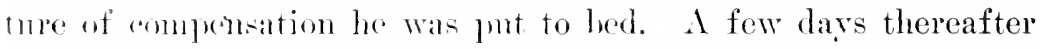
hro lewan to manifust a kow grade of irregnlar temperature, but without any other simptoms. Il is pulse remained disproportion-

* Acerrling to MacFarland, there was in 4,000 cases only 4 per cent of error. 


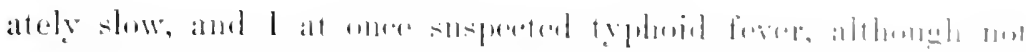

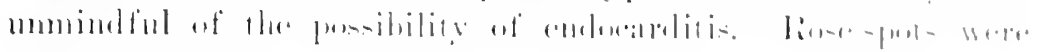

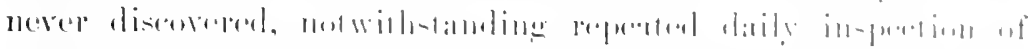

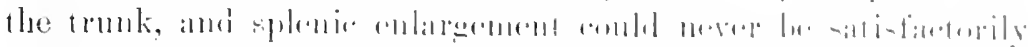

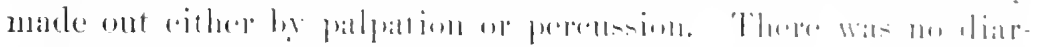

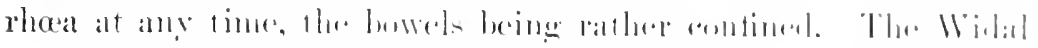

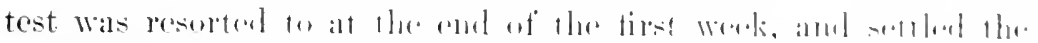

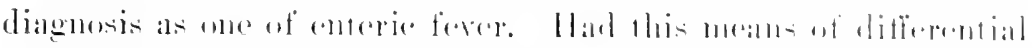

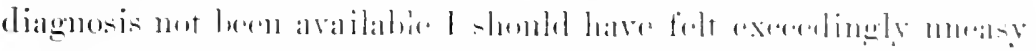

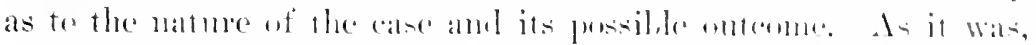

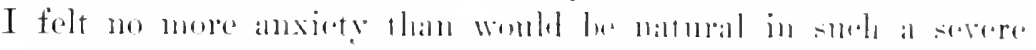

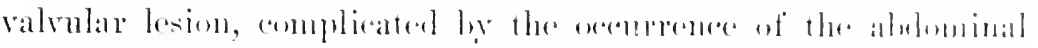

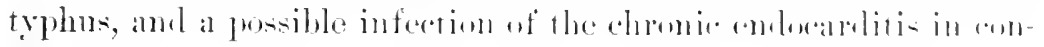
sequence.

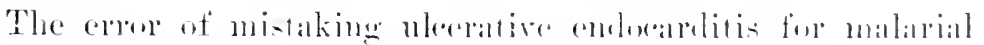

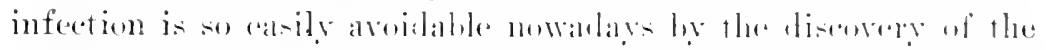

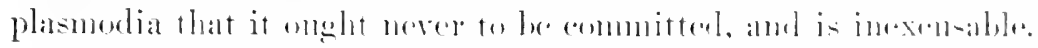

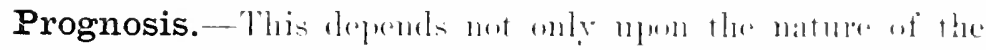

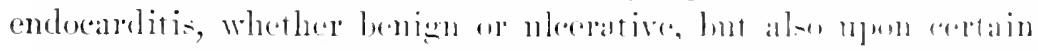
modifying conditions, as the extent and soat of the intlanmaltiom.

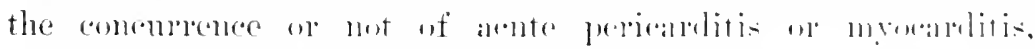

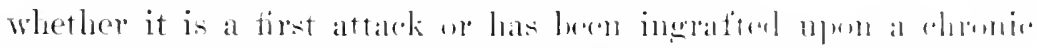

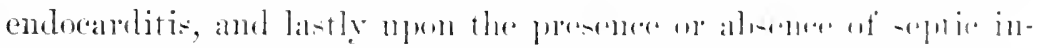

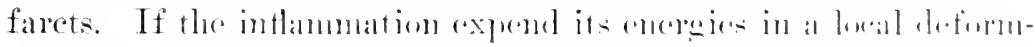

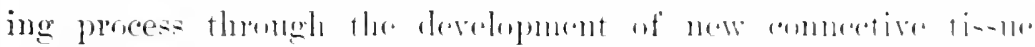

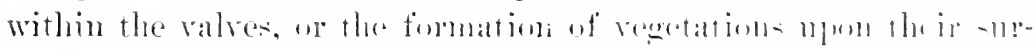

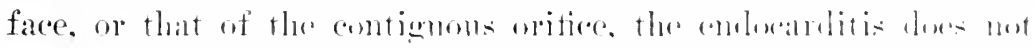

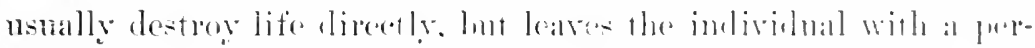

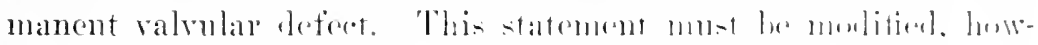
ever, in accomlanere with the salt ut the intlammation. If his is

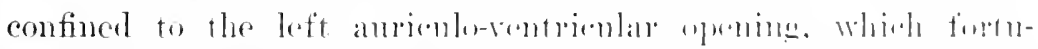

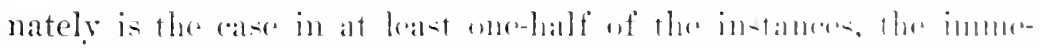

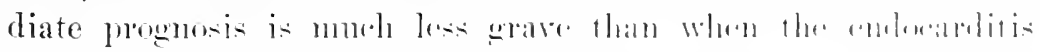

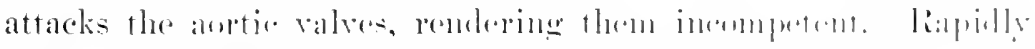

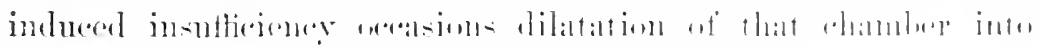

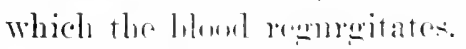

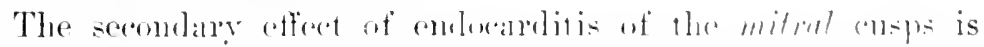

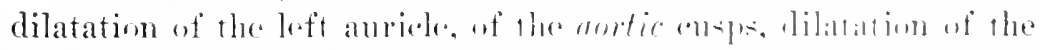
left ventricle, and there is abundant proot, both clinical and other- 
wise, that dilatation of the anricle is less dangerous to life than dilatation of the rentricle. Mloreover, in mitral regurgitation, the resistance offered by the wath of the left anricle is re-enforced by the colmun of hoor in the pulmonary ressels and by the right rentricle, while in insufticiency of the atortic valve there is not only danger of paralysis of the left rentricle from overdistention, but if in consequence of stretching of this carity and of the left anriculo-rentricular ring the mitral valves become relatively incompetent, the erits and dangers of mitral are added to those of aortic regurgitation.

If the inflammatory process extend also to the myocardium or pericardimm the prognosis becomes far more serious, since the myocarditis favonrs a rapid dilatution of the organ. Sturges directed attention to the liability in children to inflammation of all of these structures, giving it the name "acnte carditis," and pointed ont the extremely serions nature of this condition. The sravity of the proguosis in these ases is attested by the following fignres, to which reference has already been made in the chapter on Acnte Pericartitis: Of 150 eases of fatal rhematic endoearditis in children, Poynton found the pericardium healthy in only 9. while in 34 the myocardimm showed changes of one kind or another. Death was thought attributable to the condition of the myocardium rather than to that of the endocardimm.

If an acute endocarditis becones ingrafted upon the chronic process, or attacks valves alrealy the seat of selerotic changes, the prognosis becomes very donbtful, since it is a well-known fact that under snch circumstances the inflammatory process is very likely to prove septic. Noreover, even if the endocarditis should not be malignant, it is certain to intensify the changes already existing, either ly cansing still greater destruction of the valyes or by transforming a predominating insufficiency into a stenosis through the develomment of thrombi alont the edges of the opening. Thus a lecion which was compensated may be comverted into one of such gravity that compensation is never again possible.

The occurenee of embolisms renders the prognosis excedingly serious, both as to the immerliate and remote effects. Even in simple rhematic endocarditis an embolus may be carried into the brain, the left middle copetral artery beng the one most frequantly phugerl, and occasion hemiplegia. In the case of endo- 


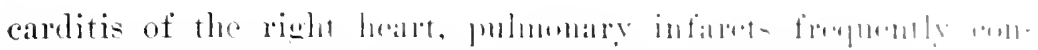

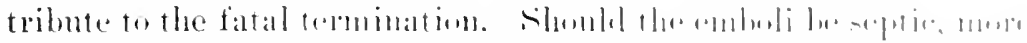

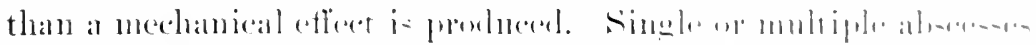

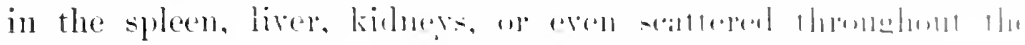

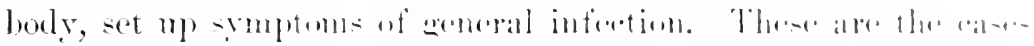

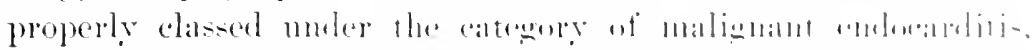

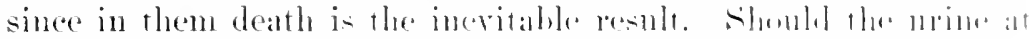

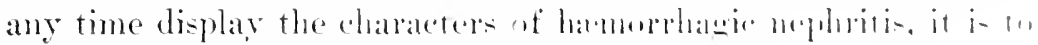
be regarded as an omen of eril import.

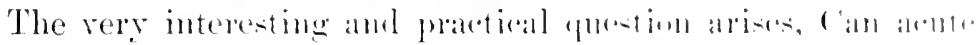

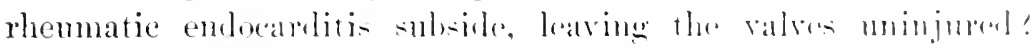
This query has beren answered in the athmative by some writer-

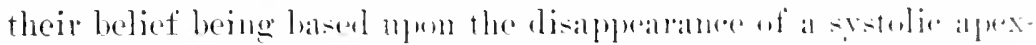

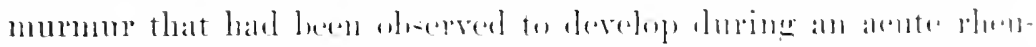
natic attack. My experienes has heen tom limited to wallalut my

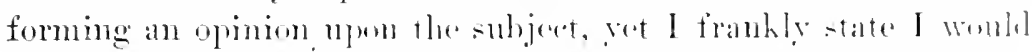

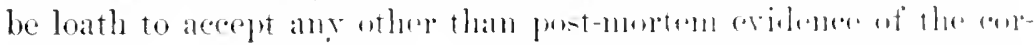

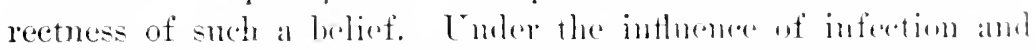

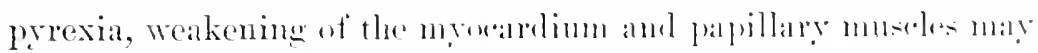
very readily oceasion dilatation, ame a sy-tolic mmsmm in the

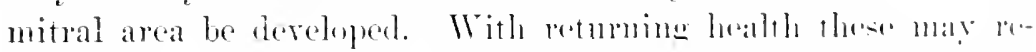
gain their tone, and the dilatation and mmrume di-alplear. Can

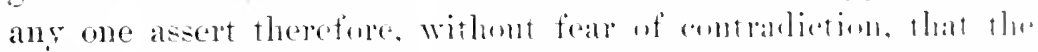

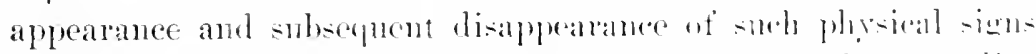

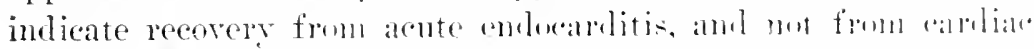

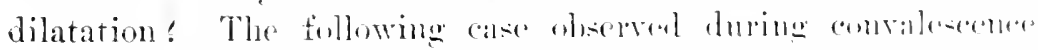

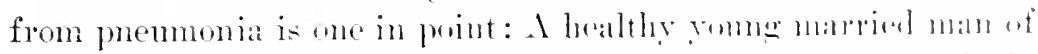

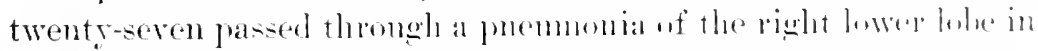

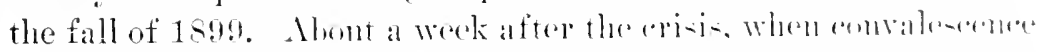

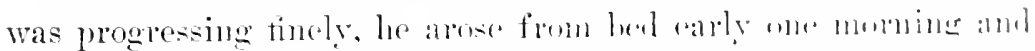

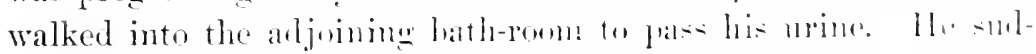

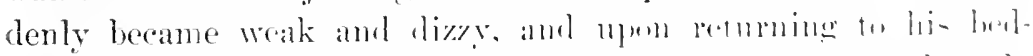

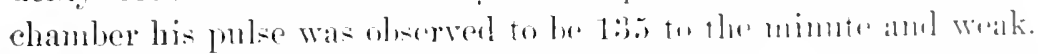

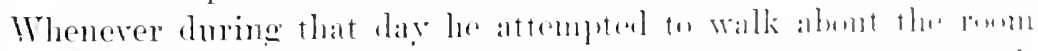

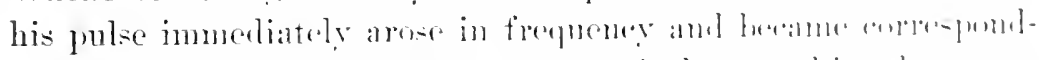

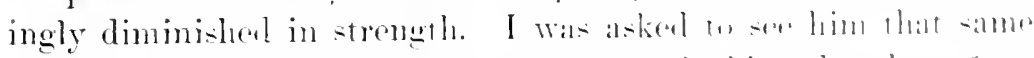

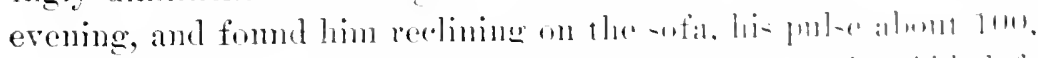

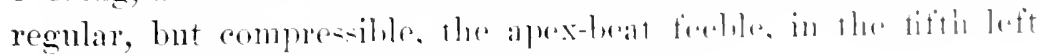
interspace slightly whicle the niplle-line. 
Relative carliace duhnes was increased transersely, partienlarly to the left, reaching 12.2 centimetres to the left of the median line. The temperature was normal, respirations tranquil, and

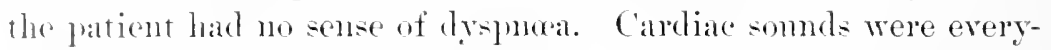
where andible, but the aortic serond wals weak, and aceompanying the first somd at the apex was a faint systolie blowing murmur. There was no histury of previous attacks of rhemmatism, and until the date of his pnemmonia the patient had indulged in much athletic excreise withont shortness of breath or palpitation. Realizing the posibility of an acute endoearditis of pnemmocoecus origin, I insisted nom absolute phrsical repose, ordered light diet, and a gentle saline aperient.

On the following day, the condition being essentially the same, $\frac{1}{40}$ of a grain of struchune sulphate three times a day was ordered. As the temperatme remained normal and the mumur hat not increated. two dars later tincture of digitalis was eau-

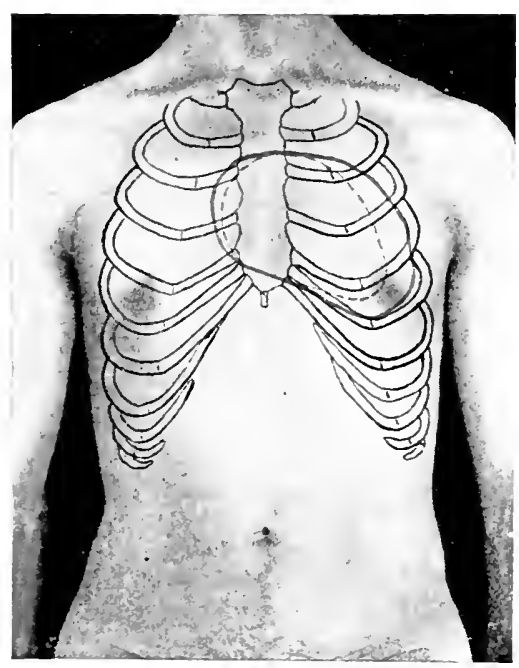

Fig. 82-Dimixtion of Relative lardiac

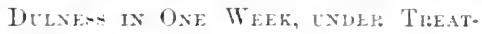
MEXT. C.IE P. 195). timsly administered. Within twenty-four hom's the left ventricle had come down 0.5 centimetres, and upon the digitalis being increased, the next twentr-fom hours witnessed a still further diminution in the extent of relative cardiae dulness to the left. In the conrse of the next week ar ten days the heart measured but 10 centimetres to the left of the merlian line, and was nomal at the right (Fig. 32).

Two months subsequently, after the patient had been withont medicine for several wreks. and had returned to his nsual mode of life, the left ventricke measurer lut ! centinetres, a restuction of more than 3 centimetres since the date of me first examination. Was this ease to be regarded as one of acute endocarditis following crompous fmemonial: Certainly not. It was one of simple acute dilata- 


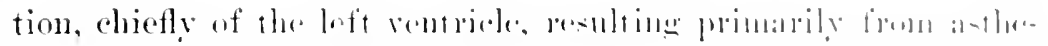

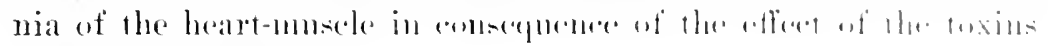

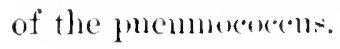

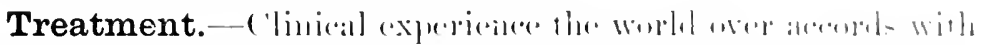

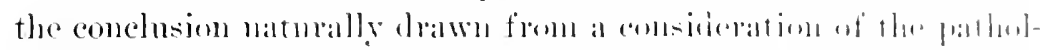
ogy and morbid anatom! of allute enderatrelitis-ri\%, llan when

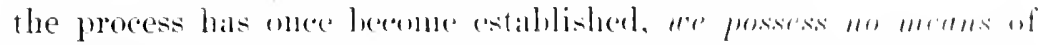

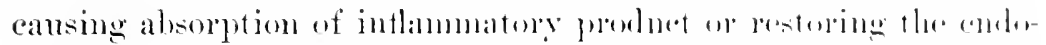

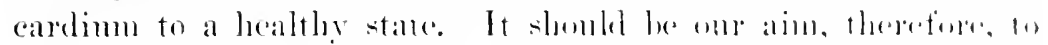
prevent where we ammot ane. Ome tirst duty is to - turly the efti-

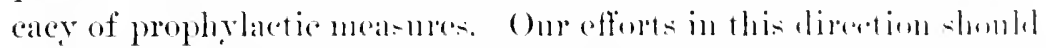

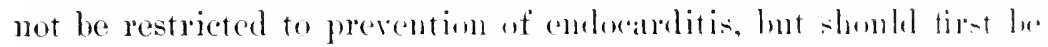

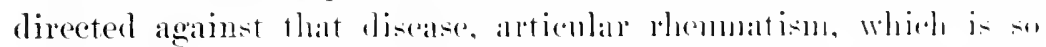

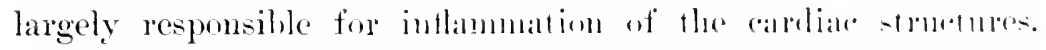
Proper sanitation and attention wo the diet, elothing, hahits, and ocempation of pationts ma! do much to this end.

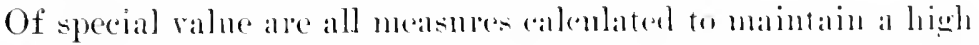

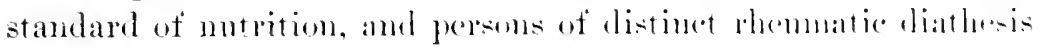

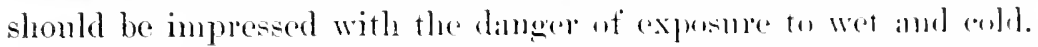

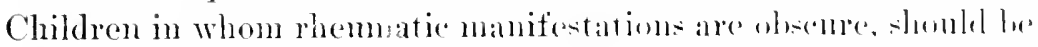

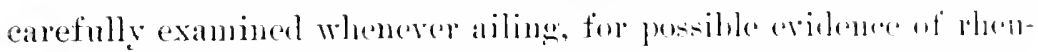

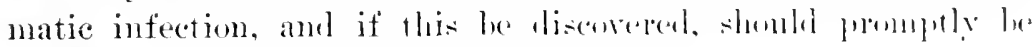
given some preparation of a salievlic ac.isl.

Much has been witten eomereming the presention of andiace involvement during rhematic attacks: and when the salieglie-

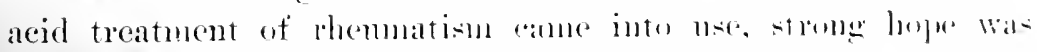

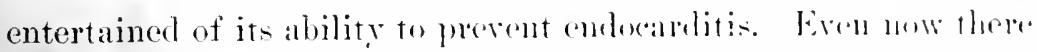

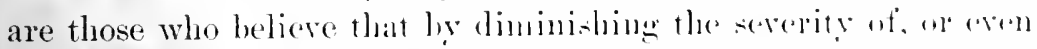
cutting short, the rhemmatic attack, this treatument lesesens the liatbility to cardiar intlammatiom. The same alse ma! lo wid wi the alkaline treatment, or of the comblinations of the alkalies and

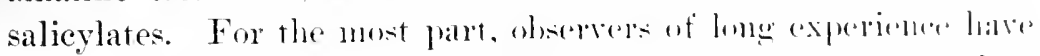
come to the conclusion that whereas the saljeylate-treatment dores

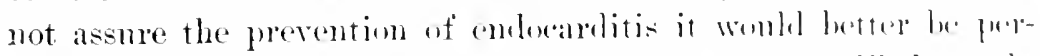
severed with, since it properly administered it is mot likely an do

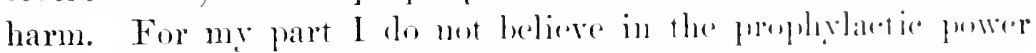

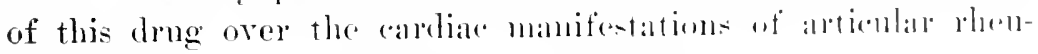
matism.

Given a case of this disalse in which salieglate ut somal is em- 


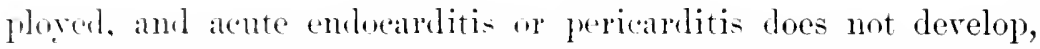
can any whe assert it would have owenred harl the remedry not been administered! Are there any -tatistics to show that endocarditis hak been less frepuent than before the nse of the salicylates! Even if one or more serins of rhematic cases treated with this rementy show a smaller pereentage of endocarditis than others not $\therefore$ treated. huw can one be sure that the lifference in results is not purely aceilental. since all rhemutic attacks do not inevitably lead to cardiace inflammation!

By all means during a rlemmatic attack resort to salicrlic acid. or one of its salts, to potaild or sorla, local applications to the affected joints, to regulation of the diet, and any other approved means of antirheumatic treatment. But do not be too confident that melocarditis will not develop. Should it not, consider yourself and the patient fortunate.

I confes to the same scepticiom concerning the efficacy of lowal treatment of the pracordimm, as leeches, blisters, and cold applications. in preventing acute endocardial intlammation. The only prophylartic measure that appeals to me as rational is the proeurement of as much rest to the heart as possible, ly keeping the patient quiet during his attack of rhemuatiom, that the ralves may not suffer trumme by rescon of stmin. Fortunately, in an acute attack of sererity the urgeney of the srmptoms compels the patient to remain at rost: hut in cases of subacnte rhenmatism, particnlarly if an old valkular defect already exists, the patient should be urged to remain at rest, so as to lesen the tension of the ralves and the pro-ibility of haring intlammation rekindled in them. Thi- is often irksmue to the patient, but if he has the reason explained to him he is likely to acquiece. althongh perhaps with no rery gow grace. Even after all the rhemmatic srmptoms have divalueared the patient should le cantioned against violent exerrire and -lwnll be kept under rather frequent observation, that the earliest evidence of embearditis, shonld sneh arise, may not be orrorlonked.

Epun the acenrence of acuste endocarditis, or of subjective or bijective rinptoms suspicions of such an inflammation, the patimt should promptly le put to bexl, if not there alreadr, and kept there as quict as porible, looth mentally and phrsically. The objeret of this is apparent: bonlily exertion as well as mental exeite- 


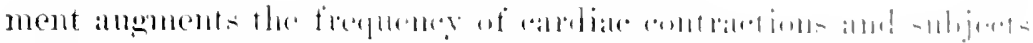

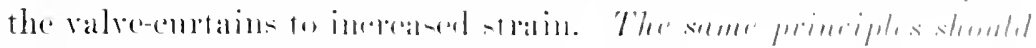

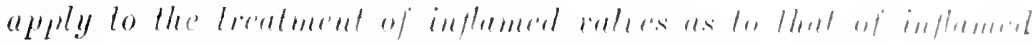

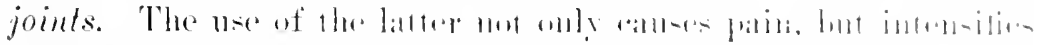

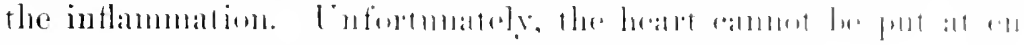

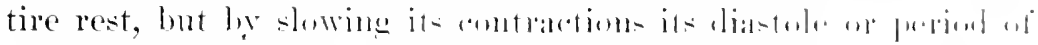

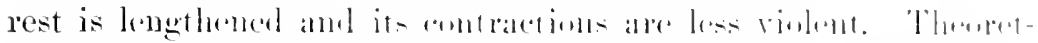

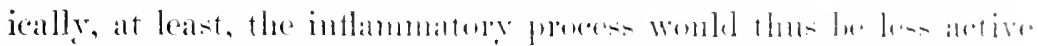

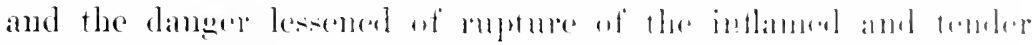

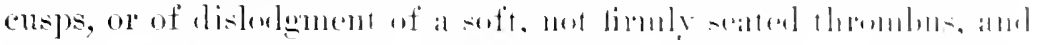

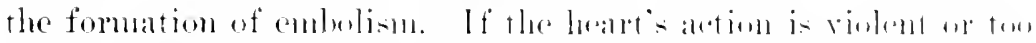

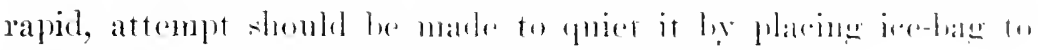

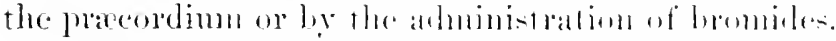

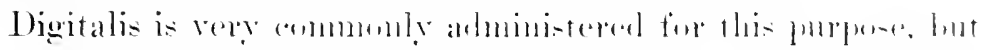

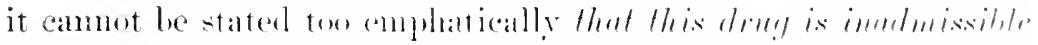

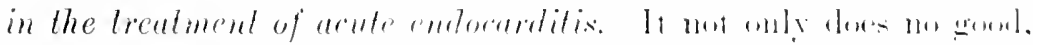

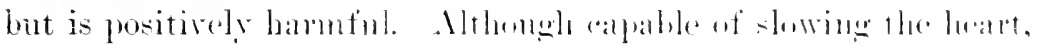

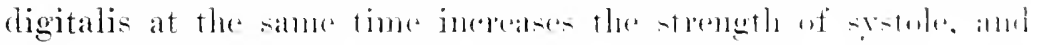

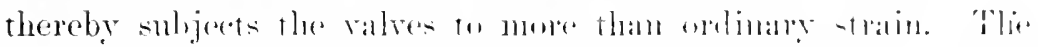

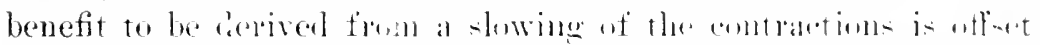

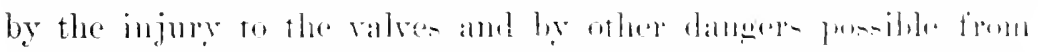

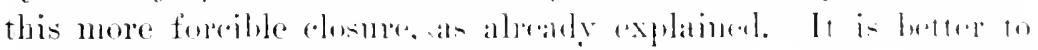

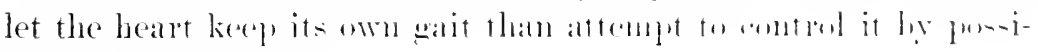
bly injurious nucaus:

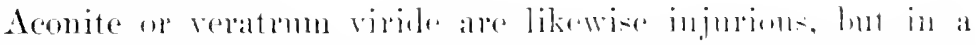

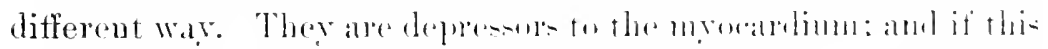

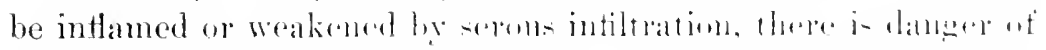

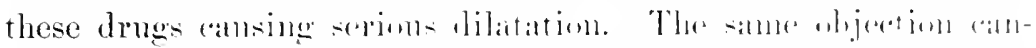

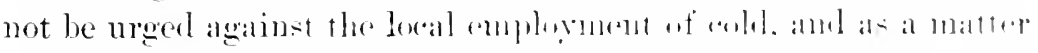

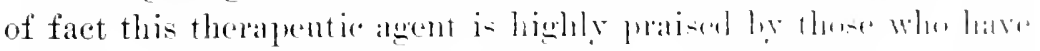

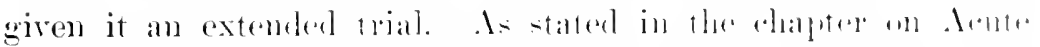

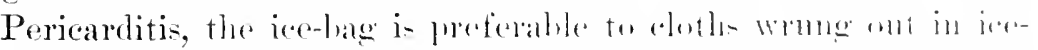

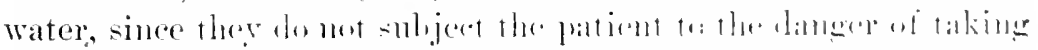

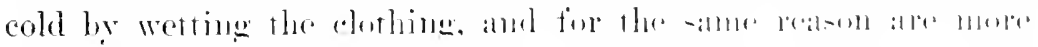

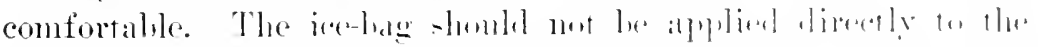

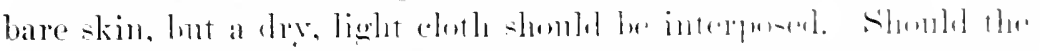

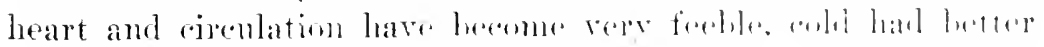

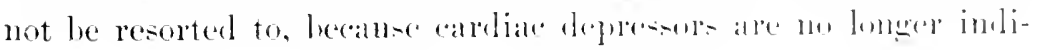
cated. 
Ilot applications to the frandium are then more serviceable on aceount of the stimulating effect they produce. Vesieation of the pracerdium. either in the form of one large blister, or of repreated small blisters, is a treaturent that once met with much faronr. but is objectionable, since it oecasions more nervons irritation than it is likely to do good. The applieation of mustard or the tincture of iodine or of a turpentine stupe are less objeetimalble beanse less serere, and are sometimes capable of alleviating pain.

Merenrials and taltar emetics are now known to exereise no restraning influence over the intlammatory process, and are therefore no longer used be the best anthorities. Moderate doses of indide of potath have been recommended, in the hope of restrieting the formation or promoting the aborption of the inflammatory products. It is, however. doubtulul if this remedy possesses any such influence in the course of acute endoearditis.

When medicines are powerless to cut short an attack, or even probably to diminish its sererity, we are left to a purely symptomatic treatment. Pain and restlessness shonld he alleviated by the use of opium, and in the ease of adults morphine hypodermically is the best mole of administration. In ehildren great care most he exereised in its we, and it is alwars well to first try the efticaler of bromiles in conjunetion with cold applications and soothing lininents. Antipurine, phenacetine, and other remedies of this class are eapahle of exerting depression. and if emploved at all shomld he in mall doses and with stryehnine or some stimulint.

The prexia of acute sinple endocarditis is msually not high, and therefore such antipuretics are not likely to be needed for the reduction of temperature. If this should become necessary, it womlil be best attempted by julleious sporring. Insomnia may he prevented by bromide, paraklehyede, sulphonal, or trional, or, best of all, hic some preparation of opimm.

So som as the endocantimm is found to be the seat of aente inflanmation the physician shomld constantly bear in mind the posilility of the heart finally surembing through weakness, if nut structural change of the mycoardium. The organ should be sn-tained, therefore, lyy that best of all heart-tonies, stryelmine. Opinm is also a heart-tonie, and while being given for the relief 


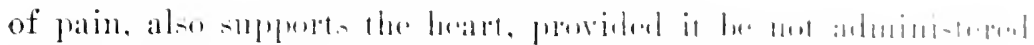

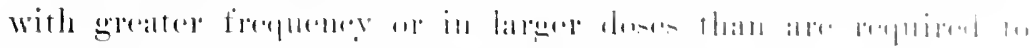

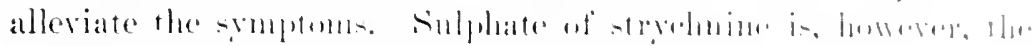

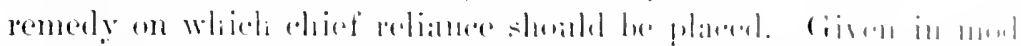

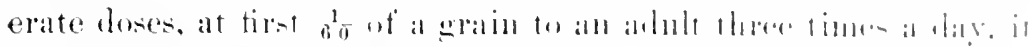

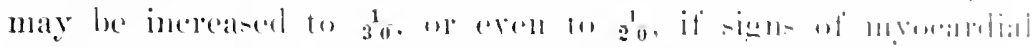

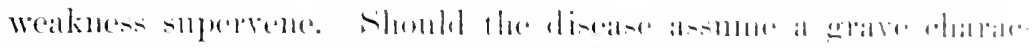

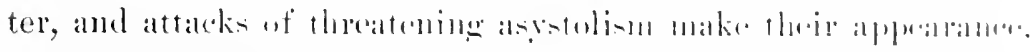

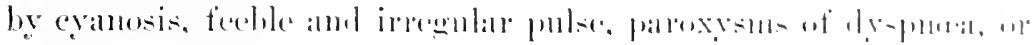

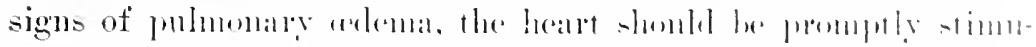

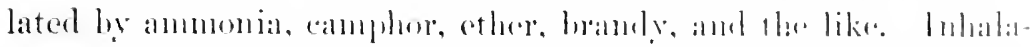

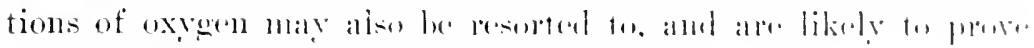
temproraly, if not permamently. hemoticial.

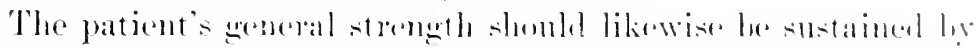

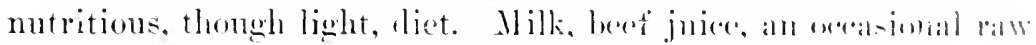

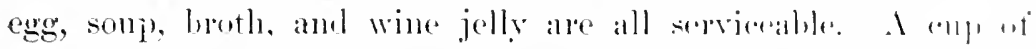

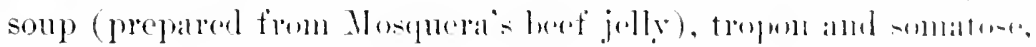

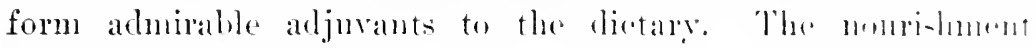

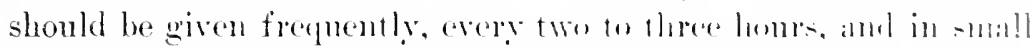

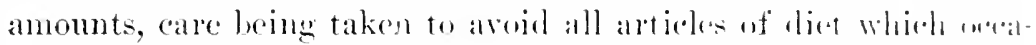
sion gaseous distention of the stomate and inte-tines. ('m-1jpattion should not be permitted, and eren if the action of the lww is regular, benefit is likely to acerme firom the oreasinal alminitration of a blue pill or small dose of ealomele followed ly a

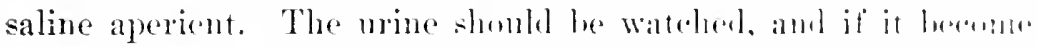

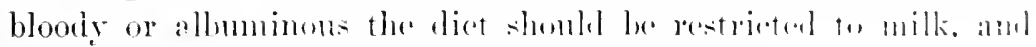
the patient mraed to drink frexly of pure water.

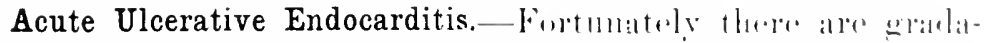
tions in the severity of this tyle of the affertion: wer. it mot -

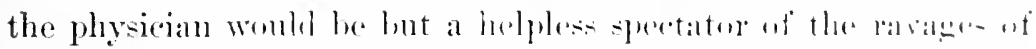

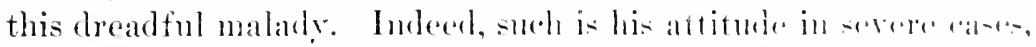

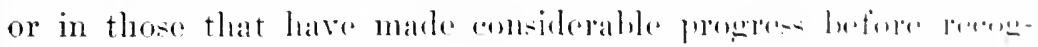

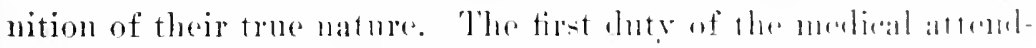

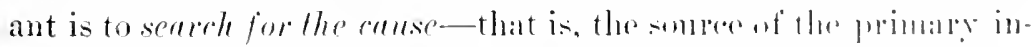

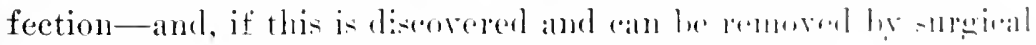
interference, to promptly resort to smele treatment. Thi-. alal-:

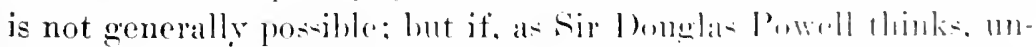

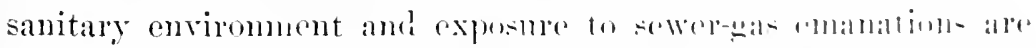

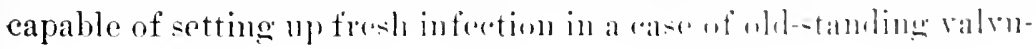


lar disease, then the jatient should be promptly removed to a lealthful loeation.

The next indication is to resort to every means which affords any hope of re-enforcing tissne resistance, as a mutritions and easily :ssimilated dict. The lines of treatment already laid down for the sustaining of the heart and protecting it against the injury resulting from mnecessaly work in the simple form are equally applicalle to the ulecrative. Inkeerl, they are still more urgently required; for not only is inflammation more destructive and likely to invade the mrocatrdim, but even when this escapes uleeration or absecss formation the heart-muscle is likely to suffer from the enfeebling effect of the toximiat.

In severe cases the prostration of the patient generally calls for the administration of small, frequently repeated doses of brandy or ammonia. The use of alcohol in conditions of sepsis is very gencrally employed, and, in the opinion of many clinicians, is highly useful. Some indeed advocate whisky in large and frequently administered anomuts. Strychnine should be given in full doses, and will yiekl the best results if administered hypodermically. Quinine was formerly exhilited in closes of 15,20 , or more grains for the control of the fever; but with a clearer knowledge of the etiology and pathology of this affection, we now know that this remedy ean exert no controlling intluence over its course. Iron and arsenic have also been employed, and Powell speaks highly of the latter, wot as a cmative agent, but simply as a cardiale and general tonic.

Attempts have heom made to introduce into the srstem antisepties in sufficient prantity to exert at least a modifying influence upon the sepsis. The one deserving special mention is sulphocarbolate of sork, which has been thought in mild cases to exert a farourable influcence. Samsom has reported one case in which during its nse such inuprovement took place that the patient left the hospital: she returned, howerer, and succumber to a fresh attack or accession at the end of ten months. "At the autopsy the diagnosis of eptic endocarditis was confirmed, the mitral, trienspirl, and aontic valves being diseased and infiltrated with nineroecoeci."

Drechfelel, in speaking of this remedy in $\frac{1}{2}$-drachm doses, mentions a case reporterl by Sansom (probably the one just quoted) 


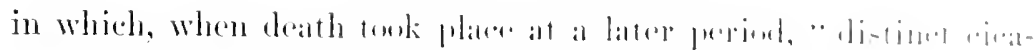

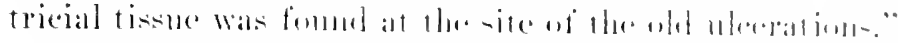

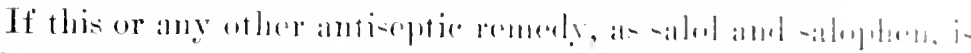

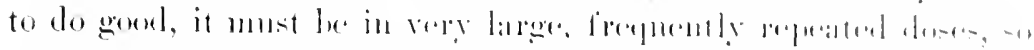

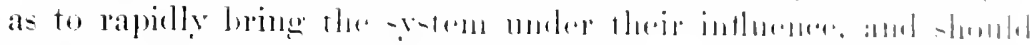

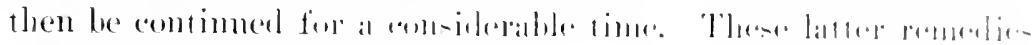

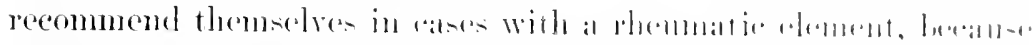

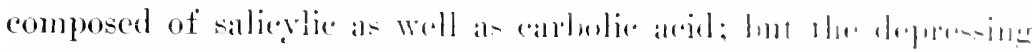

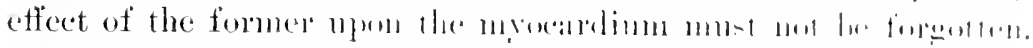

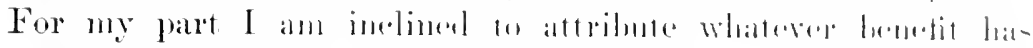

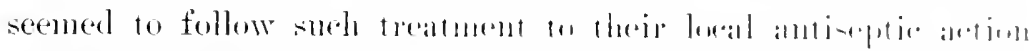

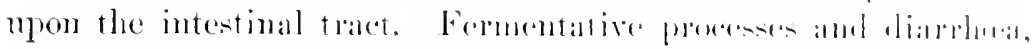

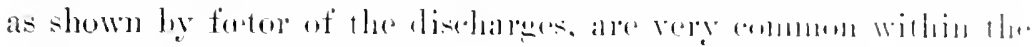

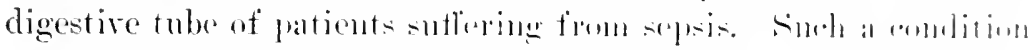

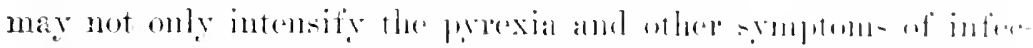

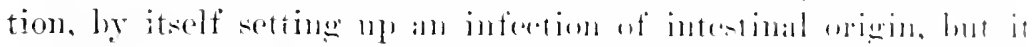
prevents the proper digertion and assinilation of monri-homent.

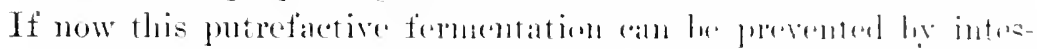

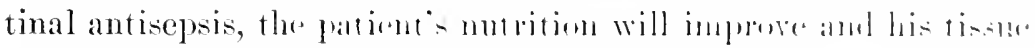

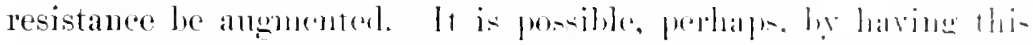

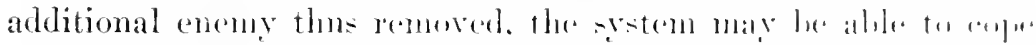

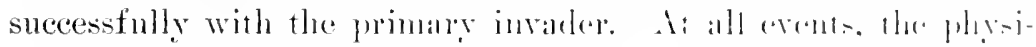

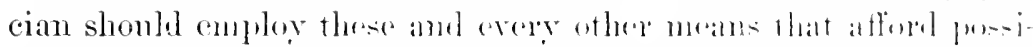

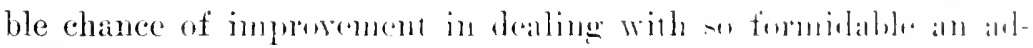
versary.

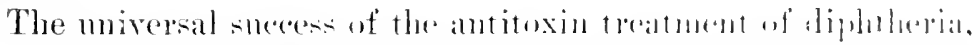

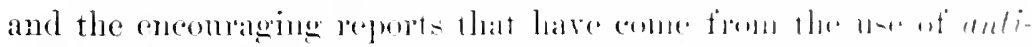

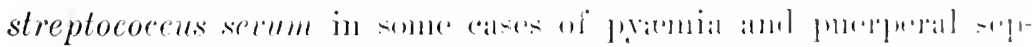

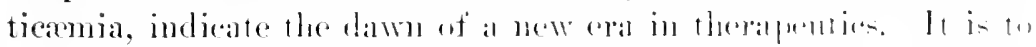

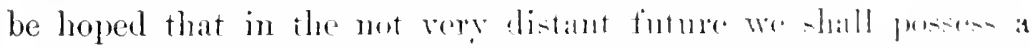

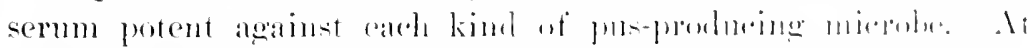

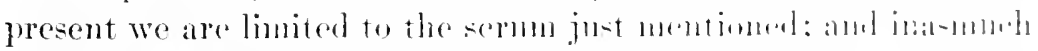

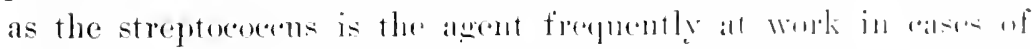

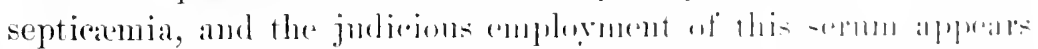

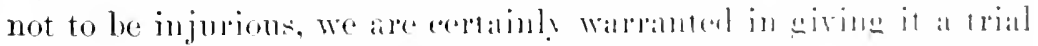

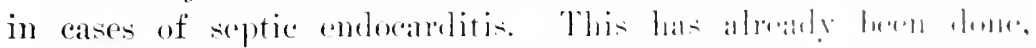

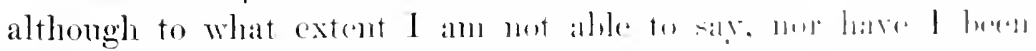

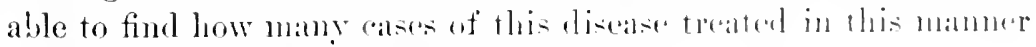
have appeared in the literature to date. 
Touglas Powell has tabulated 14 eases of ulcerative endocarditis in which antistreptoeoceus serum has been employed in London. The results are as follows: 'Three recoveries, 9 deaths, and 2 in which no favomable result ensued. Powell is of the opinion that these results appear more diseouraging than they really are, from the fact that the serm was employed in the late stages of the discase, owing to a matmeal hesitancy to try a new remedy, and after " large embolic detachments lad set up fresh centres of cultiration in many positions." He conclucles therefore: "It may be laid down as a principle, gorerning treatment by this particular sermm, that the more distinct the history of a previous endocardial lesion and a subsequent exposnre to an infection through a suppurative medim, or a sewer-gas sepsis, the more appropriate the case for the treatment. This rule would disconrage its employment in cases in which the pnemococens, gonococens, or some other microbes divergent in character from the streptococei and staphylococei were concerned; and if with the recognition of this principle, and its earlier and bolier carrying ont, more encouraging results are obtained, it will certainly follow that analogous measures will be found for the circumvention of the other forms of microlic action."

If the primary somrce of infection, an abscess for instance, be not discovered, and therefore not removed by the surgeon, or if fresh emboli laden with pus cocei repeatedly discharge into various parts of the system, to maintain the already existing sepsis or set up fresh centres of infection, then assuredly antistreptococcus sermu will prove of little or no benetit.

If, on the contrary, the patient is suffering from pyrmia, the original portal of infection having been closed, and no fresh intoxication having taken place, then this serum would be of service, even thongh the streptococens be not the only microbe concerned in the process. With this formidable streptococcus disposed of, the system omght, theoretically at least, to be able to cope successfully with the other kind of hacteria. Of course, hope of recovary or even improvement can only be entertained in comparatively mild cases, or when, as Powell says, the disease is recognised and treatment begun early. I process with a pronounced destructive tendency cannot probably be checked, but there are cases of septic endecarditis which are shown by the clinical history to be not thus 


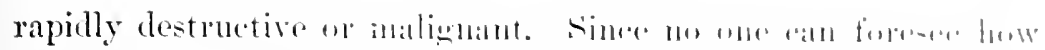

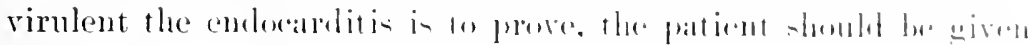

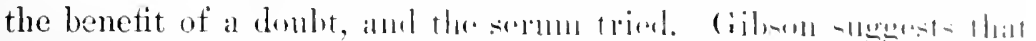

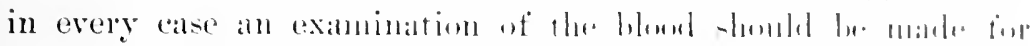

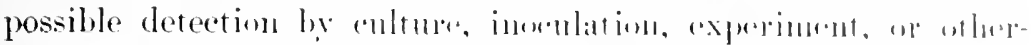

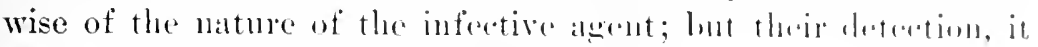
must be remenubered, is axtremely mblikely.

Endocardial inflammation tollowing pmemmmia, w in whinh

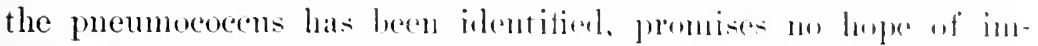
provement from this treatument. It is lo he hoped lhat wr shall

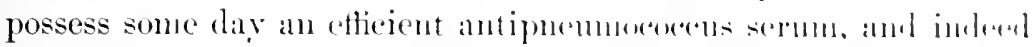
the researehes of the Klemperer houtlers and others afford sume promise of this being attained.

Personally I have had lut little experienes with antistrepton.

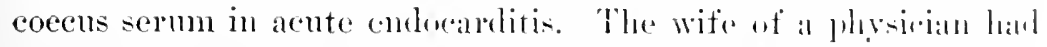

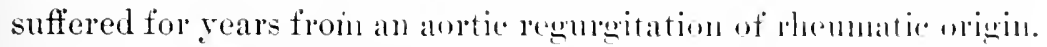
At the time I saw her she had heen ill for sereral weresis with moderate ferer of a remittent type that fhetuated hetweru abmut $100^{\circ}$ and $102^{\circ} \mathrm{F}$, or a little more. She eomplatimenl mureh of

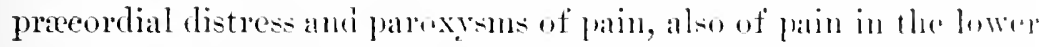
extremities about the joints, although the latter were mot appurciably swollen or tender. The nsmal antirhemuatic remerlies-sal-

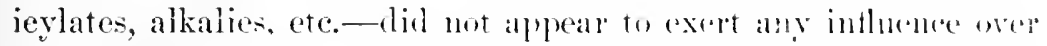

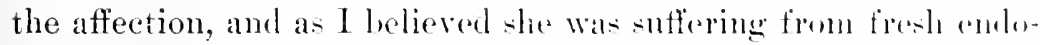
carditis, possibly ref a septic type, I alvised a trial of antistrepto-

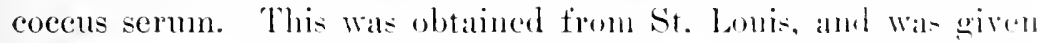

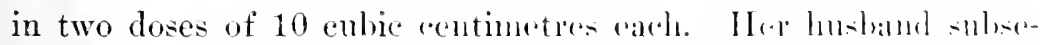
quently sent me a report, from which the folluwing lai- han extracted:

"Mrs. B. had been very sick alunt one menth when yent salw

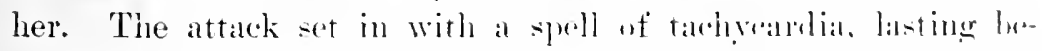

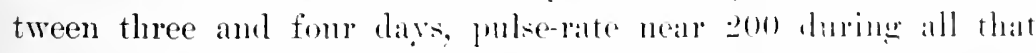

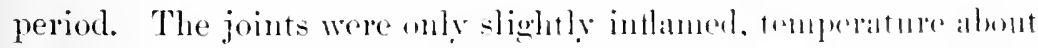

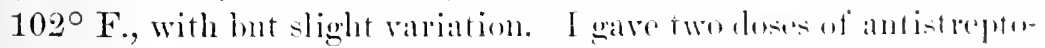
coecus sermu three days apart, as pou directed. withmut immorliate effect on temperature or symptoms. It end of two werks, lanever, temperature subsiled nearly to mormal. A very licary erythematous rash followed the nse of the sermu. Slue erminally erept from her perilous condition, hrops disuppearenl, appetite 
l'eturned with a fair degree of strength. She had a good deal of bromeditic, and was much wores aftor you saw her than she was then. Xo one whe saw her at her worst thonght she could possibly penerer,

The mature of this catse wat very doubtful, and from Dr. B.'s report the serum apreats to have been of doubteul utility. Yet I recall distinctly having suberpuently met another practitioner, who had been present at the tine of my examination, and who stated in mo mexpivenal terms that in his opinion the sermu had been of benefit.

Alout a year aw I saw in consultation with D). Lovewell a mam of alwat forty who had been ill for a mumber of weeks with an intermittent forer, rigors, and sweatings, symptoms of eardiac discalse, and listinct evidenee of an aortic valve-affection, which hat not existed hefore his ilhess. The origin of the infection could not be ascertained. There were well-marked signs of aortic insufticieney, which from the general septic phenomena and albuminuria conld not have leen other than a malignant endocarditis. As everything in the line of antisepties had been tried to no purfore, I advised the use of antistreptocoecus serum. The patient survived a number of week longer, hut died suddenly as a result ajparently of emotional exeitement. I did not see the patient again, but harl news of his condition from Dr. Lovewell, who stated more than onee that under the we of the sermm the temperature became lower. less irregular, and the other indications of sepeis lese promenneed. In falet, the general eondition inproved so much that the doretor at one time hegan to entertain the hone of his patient's nltinate recovery.

It will be rememberes that in the case reported of my patient of forty, who died of pulmomary infarrets, this sermu was likewise emploved. It failed to exert any other effect than to slightly reduce temperature and produce a feeling of somewhat greater strength. In this instance it was not used mntil late in the illness and after embelic phenomena has more than once appeared. I regret that the treatnent with the serum was not begm earlier, althomgh I an very donletfon if it would have materially affected the ultimate result. Theo expreriences are too limited to be of value in forming an estimate of the utility of the sermm, but inasumel as its ue was not attended by umpleasant effects 


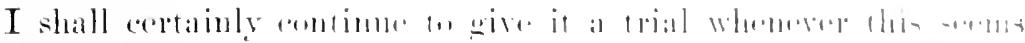
indicaterl.

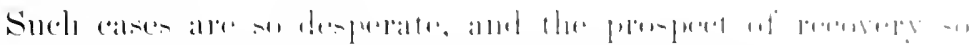

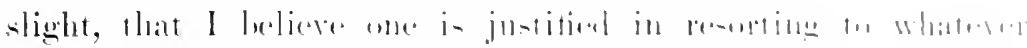

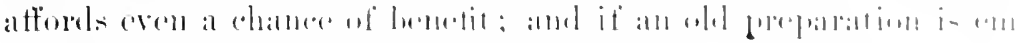

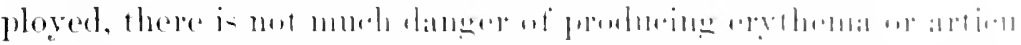

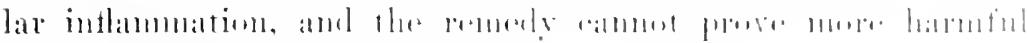
than the discate itselt, moluedient.

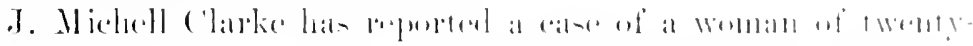

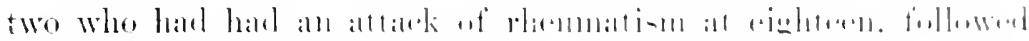

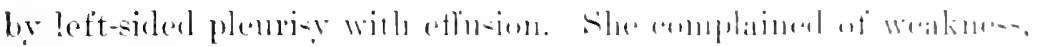

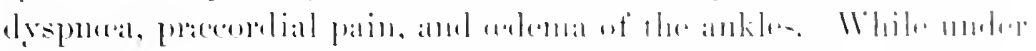

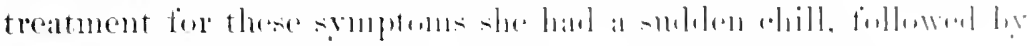

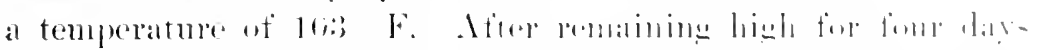

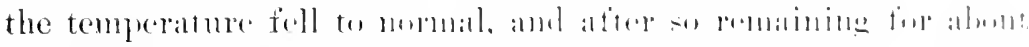

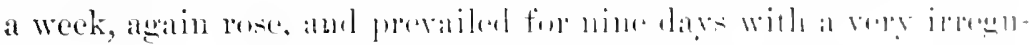

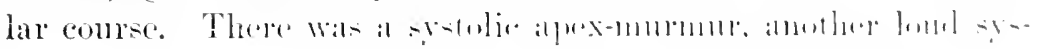

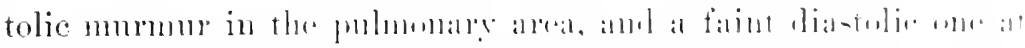

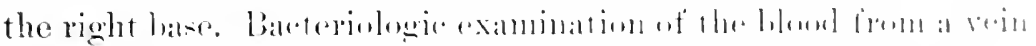

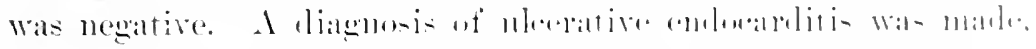

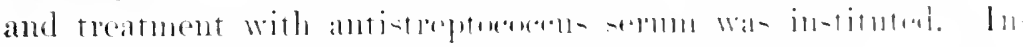
jections were viven from l)

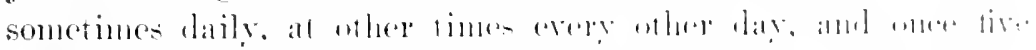

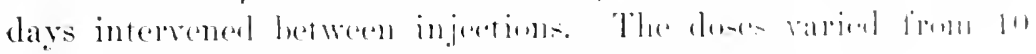

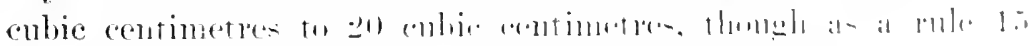

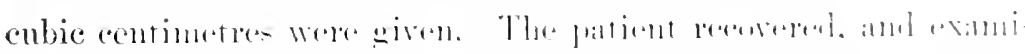

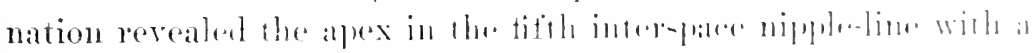

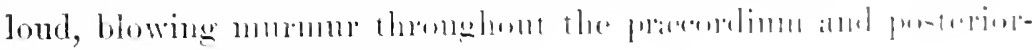

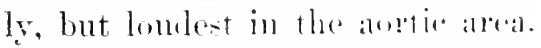

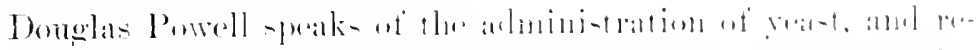

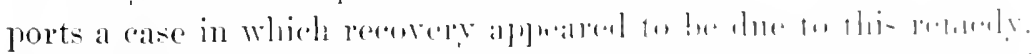

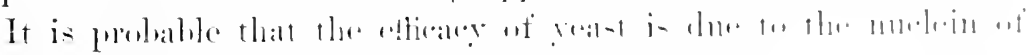

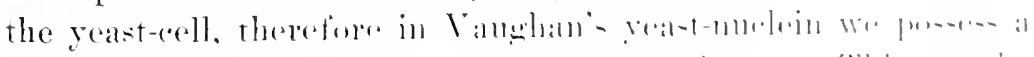

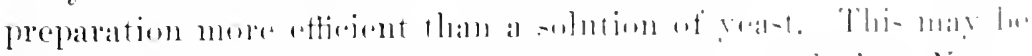

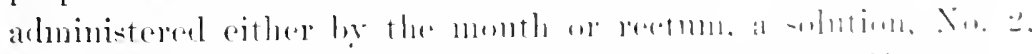

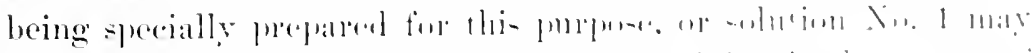

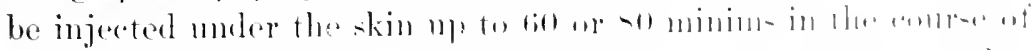

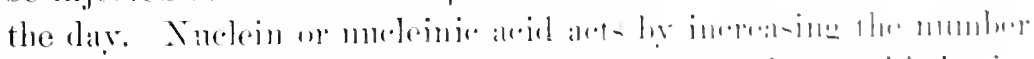

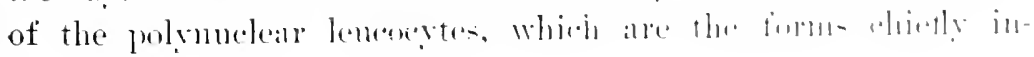


reased in the leneocytosis oberved in infection, and by the increase of which the germicidal action of the blood is angmented.

Many encouraging reports have been made of the farourable effects of reast-nuclein in cases of pus-infection and eryptogenetic infection. I employed it in we case of acute endocarditis superrening upon an old valvular lesion, which followed a follicular tonsillitis, that may have heen rhemutic, but if so was the only manifestation of rhemuatisu. The remedy was administered by the rectum, owing to the patient's dread of hypodernic injections. Ender its influence, or at least during its administration, the mild prexia which had existed for about ten days, withont showing indication of subsiding, gralually sank to normal. The patient subsequently died. From the foregoing it is evident that the most the physician can do in the treatment of acute endocarditis is to aid nature by loclping to maintain the rital powers and by remoring obstacles that lie in nature's way. 


\section{('II.MPlili r'}

\section{CHRONIC ENDOCARDITIS}

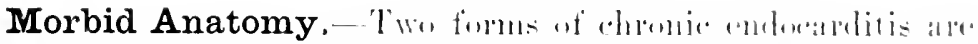

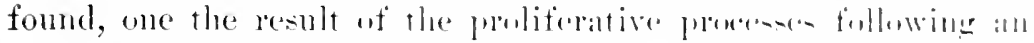

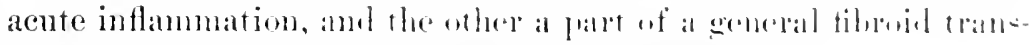

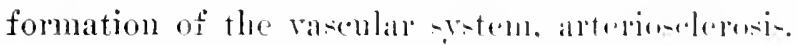

In the form following the acme discale the derelopment if fibrons tissue begins with the areanization of the renctations and thrombi that have formed in the andiep staens. I- a rule the

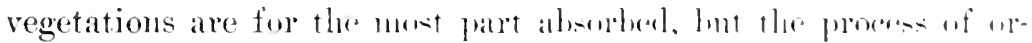

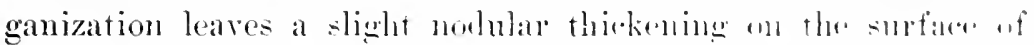

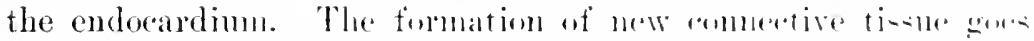
much further than the nepe repair of the allute le-ions, howerer,

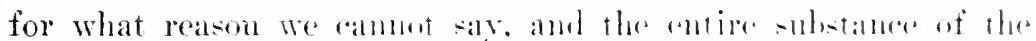

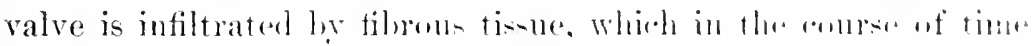

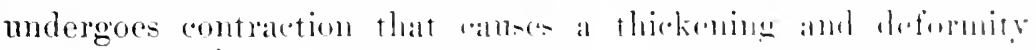

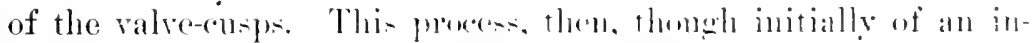
flammatory nature, erentulater in a selero-i-

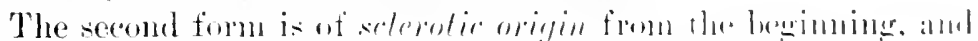

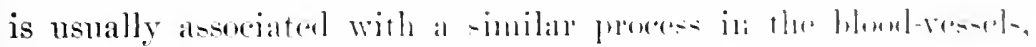

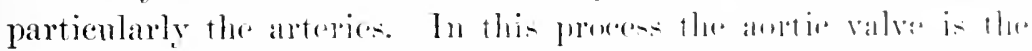

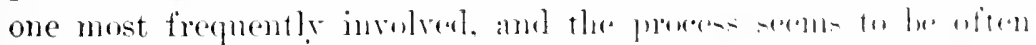

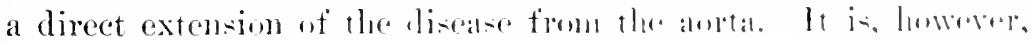

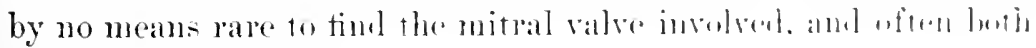
are affected togethere.

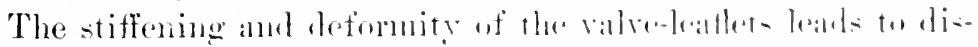

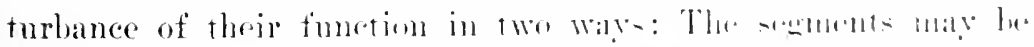

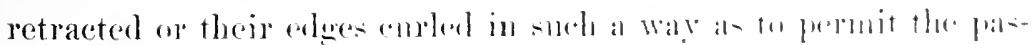

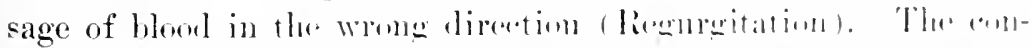

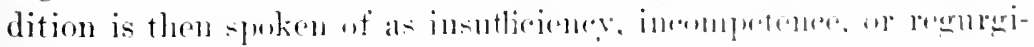

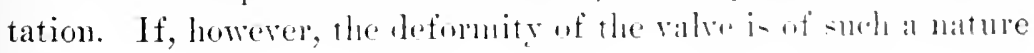


as to cause a narrowing of the orifice, the condition is known as stenosis.

stenosis may he brought ahout by thickening and rigidity of the valve-segments so that they camnot open perfectly for the passige of the blood, or the remains of regetations or thrombi, which have mulergone organization or calcification, may encroach on the opening. The special ways in which these lesions are prodneed will be considered in detail under the head of the individual valvulin discases. It should be noted here, however, that stenosis of an ostimm and incompetency of the corresponding valve are usually associated conditions, though as a rule one or the other predominates and gives its character to the lesion.

Fibroid thickening of the mural endocardimm is not uncomnon in connection with chunce valvulitis, especially of the sclerotic type. It may abo occur as a part of an interstitial myocarlitis. The membrane is thiekenes and of an opaque whitish or rellowish colonr-the latter when fatty change is prominent. Mural endocarditis is often associated with dilatation of a lieartcarity, and is then prohably due to the stretching of the membrane.

The secondery changes in chronic valvulitis are mainly those due to the circulatory disturbance oecasioned by the stenosis or incompetence, as the case may be. If a valve is incompetent it permits regurgitation into the chamber behind during its diastole, and this chamber then leceives blood from two somrees, the normal one, and through the incompetent valve. Such an oversupply of blood leads to an overdistention of the chamber, and to an increased effort in order to completely empty itself. The continuance of these conrlitions learls to a permanent increase in the capacity of the chamber, while the incleased work thrown on the mucculatme of the wall canses an increase in its strength and thickiness (Iypertrophy).

It the deforming process results in stenosis, the chamber behind the defect experiences increased diftienlty in expelling its contents, and acelops hyertrophy of the kind kmown as concentric, becanse associated with little or no dilatation. The chamber in front of a stemesed orifice, on the other hand, is apt to become atrophied and redneed in size, since it receives a liminished supply of blood, and its work is correspondingly lossoned.

The disturbances of circulation secondary to ralvular disease 


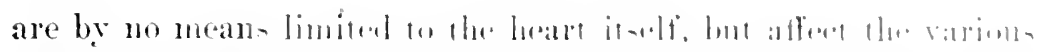

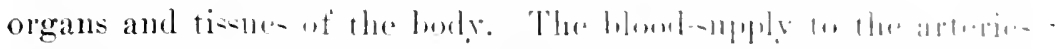

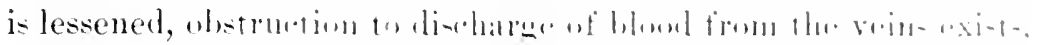

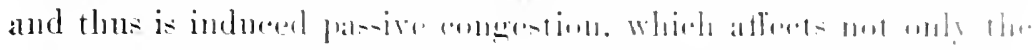

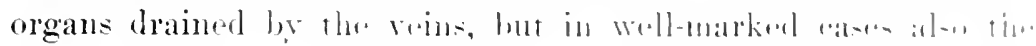

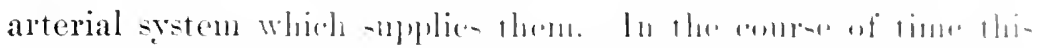

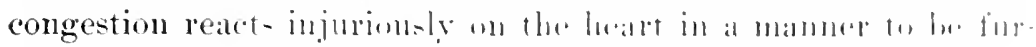

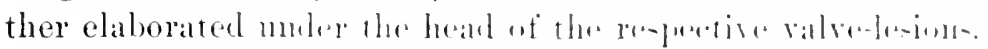

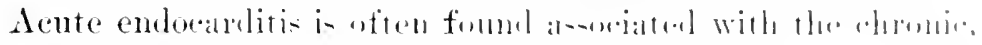

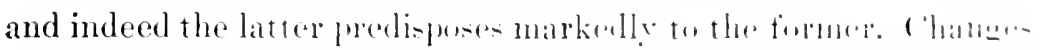

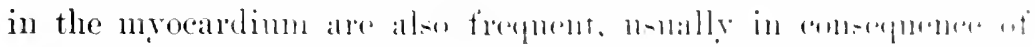

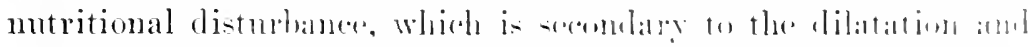

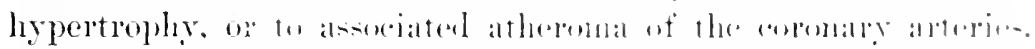

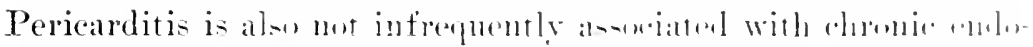

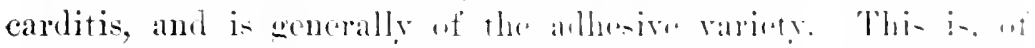
conrse, due to the two distase having hat the same munte origin.

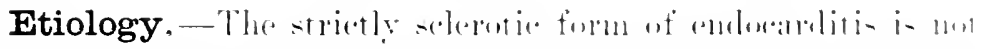
of microbic origin, hut is eithrer an experesion of mutritional

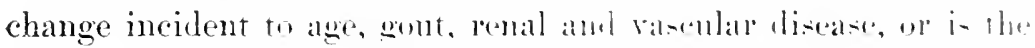
result of strain. That sume imdivilual- erince a family temdemery

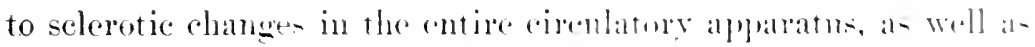

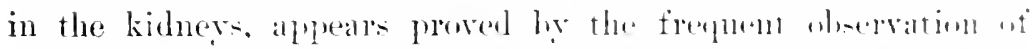
atheromatons valvular disease in two or anne nember- of the-inne family.

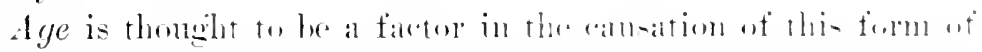

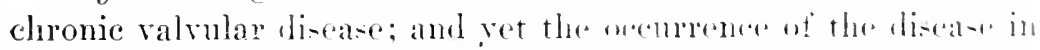

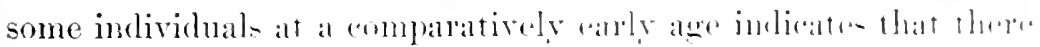
is some other inthenee at work be-ille-nenility.

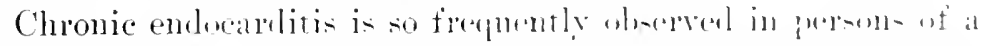

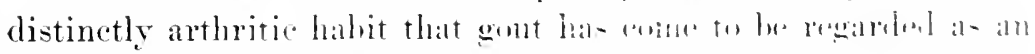

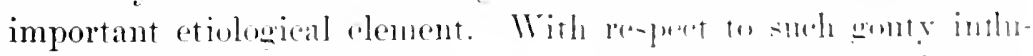
ence, it seems to me that it is rather the rutire manner at livinu

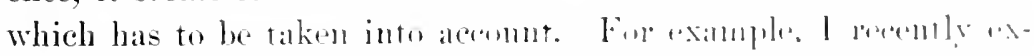

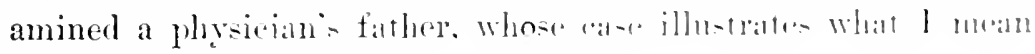
very well.

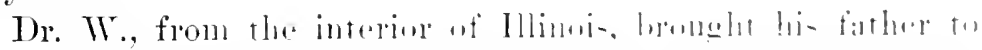
me with the following hi-tory: The fationt was a cinman, sixtr-

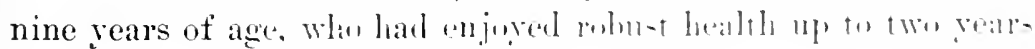


betore, at which time he developed redness and swelling, with some pain of the sreat-toe joints. This was regarded as gouty, and under appropriate therapentic and dietetic mamagement dís"lpheared. Six nonths hefore his visit to me he began to complain of hortuess of breath npon exertion, wherempon his son made an cximnination of the heart and detected a nummm. The routine treatment with digitalis, strehnine, nitroglycerine, and catharties lial failed to produce alpureciable benefit. and twice there had been expectoration of bloody sutum. During the previons two weeks he had had two noctminal attacks of dyspmos that came on in the -mall hours, while still a third took place after an evening meal. The son furthermore stated what was of special interest from an etiological standpoint-riz.. that his father had always led a sedentary life, getting exercia hy driving instead of walking, had always eaten heartily of rinh food, inlulged freely in beer and other alcoholic beverages, after the German custom, and had been a heary smoker. He had nerel had inflammatory rhematism or any other illness.

The patient was a man of powerful phrsique. and in spite of his gray hair did not look at all like an old man. His normal weicht was 207, but at date of examination was 190 pounds, while his height was of feet. Itis chest was broal and deep, his bones large and strong. the muscular system well developed, abdomen not conpulent, and subutaneons fat not excessive. The nails were moderately ridged, the radial arteries stiff but not beady, the temporal and carotid arteries not stiffened, and the subclavians did not stand ont prominently nor throb strongly, as they often do in old men. There was a pronomuced, visible, and palpable epigastric pulsation reaching at least 2 inches below the xyphoid cartilage, but the apex-beat could not be made ont. In the aortic area was a systolic tluill, palpable upon molerate pressure during expration. The thoracic parietes were so hard and resisting that pelension was difficult. lint the lungs were everywere resonant and repiratory somuls were faint and vesicular. Absolute cardiac dulness was mot increased, but by resolt to palpatory, ausenltatrery, and ordinary plessinetric perension, relative dulness was fomel greatly increased npwared, to the left, and downward, but not notably to the right. The left border reached an inch cutsirle of the left nipple, in all 5 inches from the left edge of 


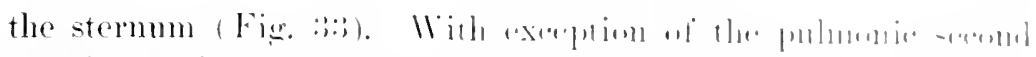

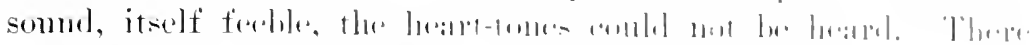

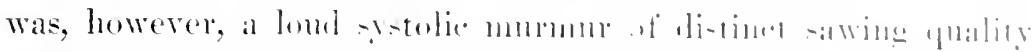

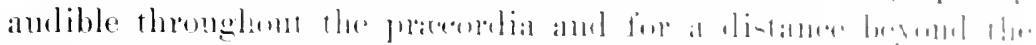

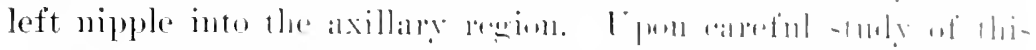

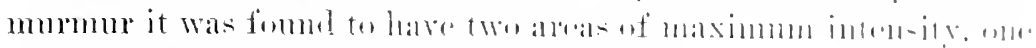

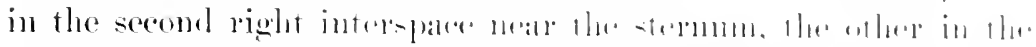

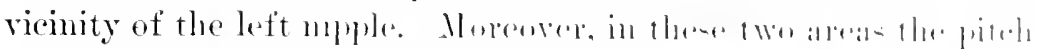

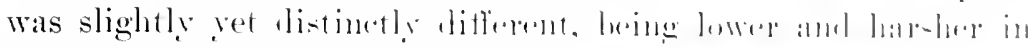
the arotic and mole mm-ical in the mitral area. The heatri rate was 90, and its rhythm regular. The liver was pialjable.

The amelible pmlmuman:y second tone and leveretreplis. dilatation of the right vempicle confirmed the evidences obtained from the mitral mmomor and established the existence of mitral remromiat tion. The antie srstolie In mit and loss of the atortic seromel sound, together with the ㄴ: tolic thrill. gave eridereo wf stiffness, and perhaps stenu-

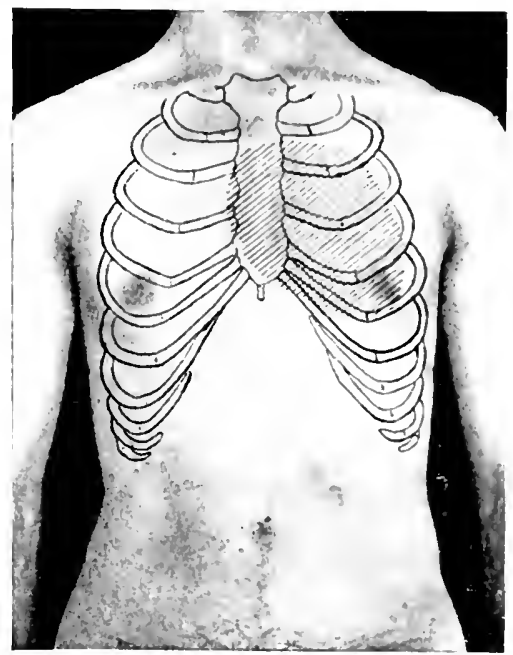

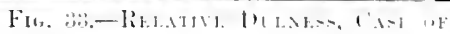

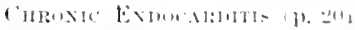

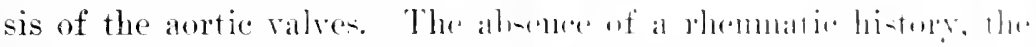

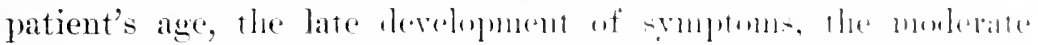

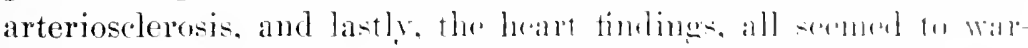

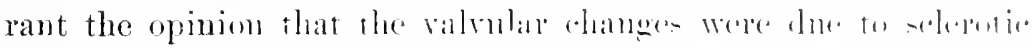
endocarditis. The condition of the kidners wat mot at-entaluml

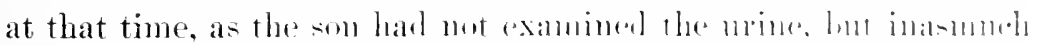

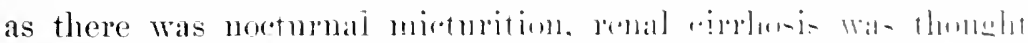

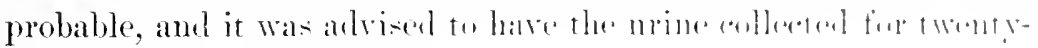
four hour's and examiner!.

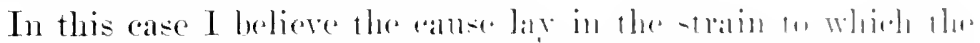

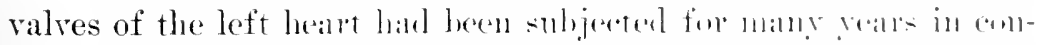

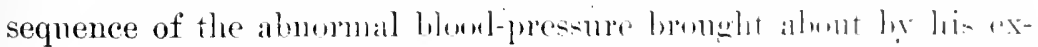

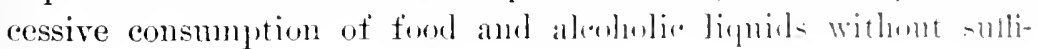


cient physical exercirc. How much, if any, influence can be attributed to tehalece and watse products I cannot say.

The intluence of strain his long been recognised in the productim of the selerutic changes now being eonsidered. High bloodpresure, lasting for rears, is a catuse of ralsular as well as of ratcular strain, but inasmuch as the individuals in whom such injurins blood-pressure is oberved generally lead inactive lives, dine well, and often suffer from indigestion and constipation, it is likely that the products of defective metaloolism circulating in the hood act as dhemical irritants. and play a not unimportant part in the tevelopment of aclerotic changes.

Discase of the aortic ralves is frequently observed in men who pursue laborions occupations, as smiths, carpenters, etc., and hence arduon: physical exertion is also accredited with the production of ralrular and vascular strain and consequent sclerosis. It is in this class of workers that rupture of an aortic cusp is most frequently observed, with its disastrous sequels. It has always seemed to me not an asy thing to correctly estimate the influence of physical strain in working people, since they are so often given to the immoderate use of alcohol and tobacco, and frequently become rictims of syphilis. We shonld probably consider that in these people all these factors are at work, and attribute their chronic endocarditis to their more of life in general, without attempting to isolate any one etiological factor. Syphilis is undonbtedly capable of setting up sclerotic deformity of the ralves, althongh endocardial changes follow luetic disease far less often than do myocardial and rascular degeneration.

Of that form of chronic endocarditis which is met with in the yomg. and which is of true inflammators origin, the one great ranee is rhemnatisn. Although these ralrular lesions may undoubtedly begin in an acute regetative cndocarditis, which merges gradually into a chronic process it is often a low grade of subante intlannuation from the beginning that luings about this form of chronic endocarditis. This inflammation may originate in an acute rhematic attack, and be recognised clinically at the tine, or it maty levelop so sowly and insidionsly as to ereate no crmptrons, and remain undetected for years. Indeed, it is not at all uncommon for valvular disease- originating in this manner to be first diagnesed after comprensation has: hegm to wane. This 


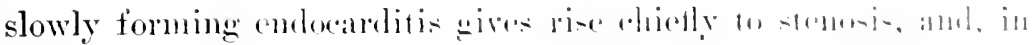

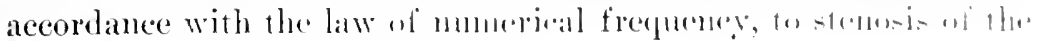
left anriculo-ventricular aritiere.

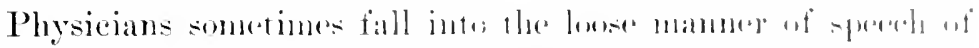

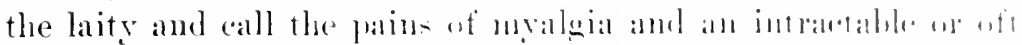

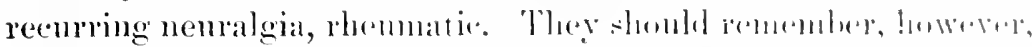
that these so-alled rhemmatic paims are etiologically amb pallu-

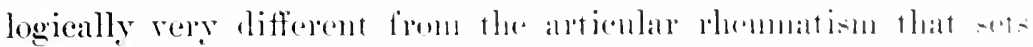

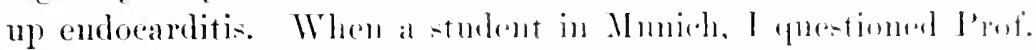

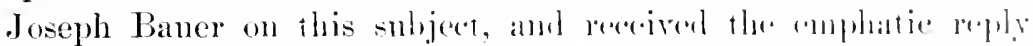

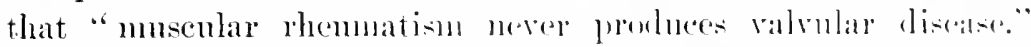

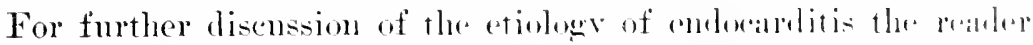

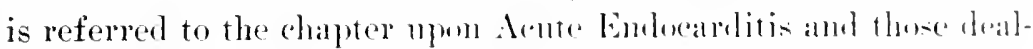
ing with the individual valve-lo-ions.

Symptoms. - The rearler of the following chapters will doubtless be impresed by the fiant that the different forme nf valvular disease present considrable similarity as rewals thowe

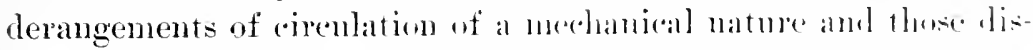
turbances of visceral function whe h give rise to smbjective sympltoms. Sueh differences as exist ale not so monch differenen in

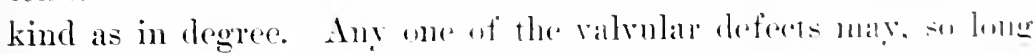

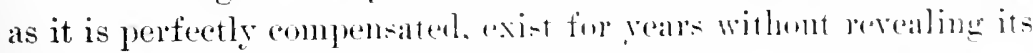

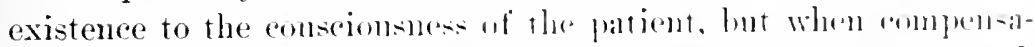
tory hypertrophy is no longer arlopulate. amelitions result which

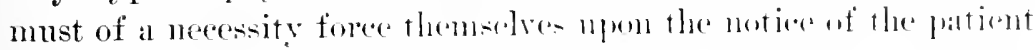
with greater or less prominenere.

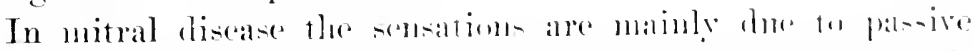
congestion, while in lexions at the antic writice ther and the losult

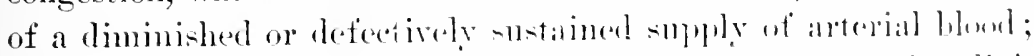

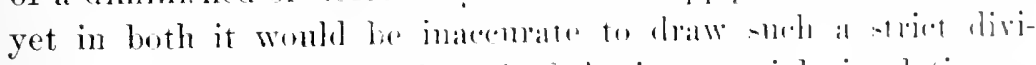

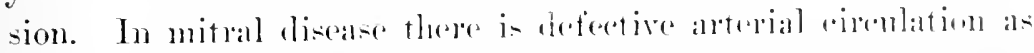

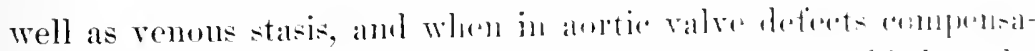

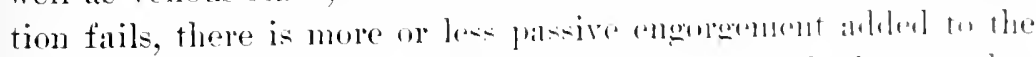

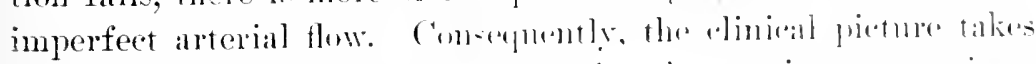

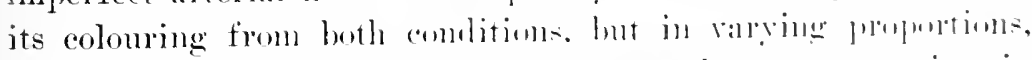

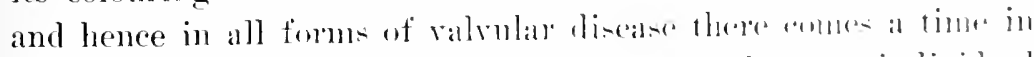

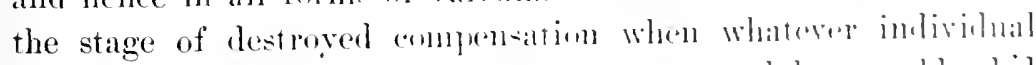

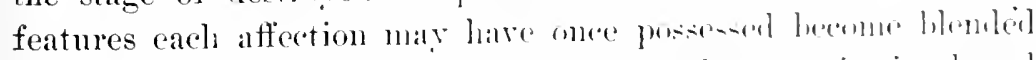

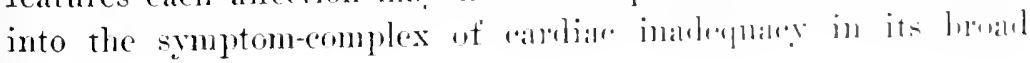


sonse. Fonde of these dharacteristirs are plainly recognised as the effocts of mechanical pressure in the renoms system, as the dull, tense pain of hepatic congestion, the scanty albmminons urine, the hamorrhodal comgestion and thuses, and, in large part at least, the sorous transmdations and the digestive disorders.

Other symptoms are probahly owing to the incomplete elimination of the normal product- of metabolism; or to the manufactmre and acemmlation in the sytem of ahmormal proulnets which lesult thom perverted finction on the part of the stomach, liver, and other chylopoietic vi-eera: or there is a combination of these

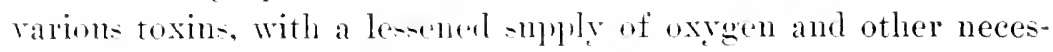
- sory montritice prineiples, that may explain some of the subjective phenomena, snch as the lnll. oppresive headache, the insomnia, nerronsness, and in some instances the low, muttering, or even active felirinu ocasionally olserved in the terminal stage.

The dyspmen of adranced healt-rlisease is probably a manifestation of both nechanical pres-me in the pulmonary ressels and upon the hmes by the dilated heart and by hydrothorax, but also of dreficient oxyenation theneh sugegish blood-flow and from bronchial obstruction ly murens and sermm. Since, then, so many factors enter into the production of the manifold symptoms complained of or manifested hy sntferer- from ralrular heart-disease, it is not posille to satisfactorily aceomt for them all or to explain why smor are plesent in one and abent in another case.

We have also to reckon with individual tondencies, neuroses, interenrent affections, romplication-, etc, all of which serve to morlify the leceitimate elinical pirture. For exampic, I recall a

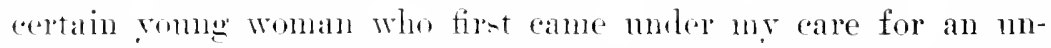
comprensated mitral regureitation of rhemmatic origin in 1893 , and who during the en-ming tive rears presented some highly interesting and puzzling phenomena.

At the lowinning hers was an omlinary case of mitral insuffireney with slight oxlema, which readily vielded to treatment, and -he wat lont sight of for two rear. She then reapleared, having -hertly before harl a recmerence of rhemmatism, and hat thereafter lexen marriel, both of which oceurlences were unfortmuate for her.

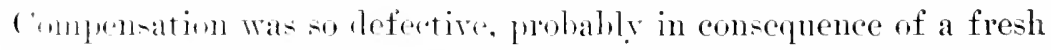
emlecambiti- which had passed heyoud its acute stage, and which

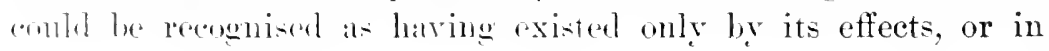




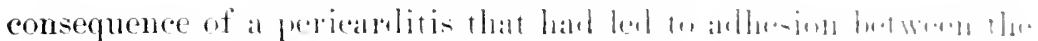

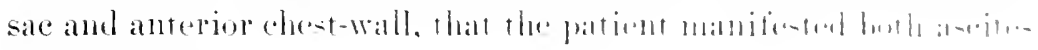
and antsille:al.

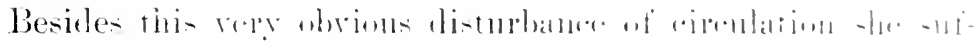

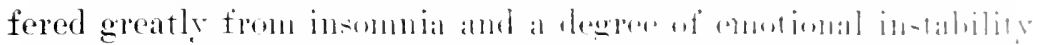

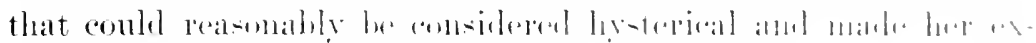

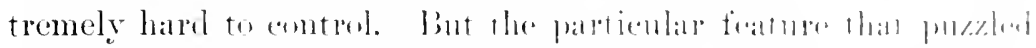

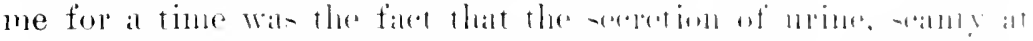

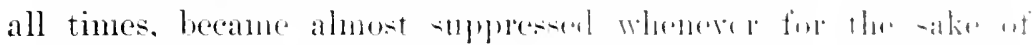

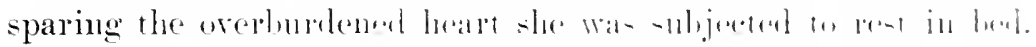

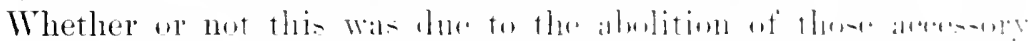

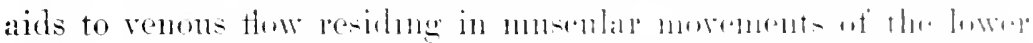

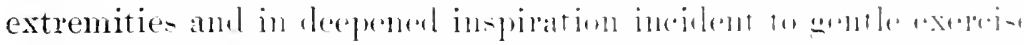

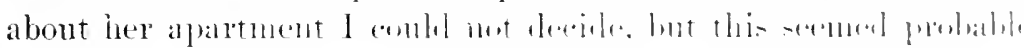

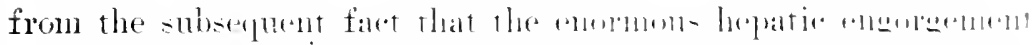

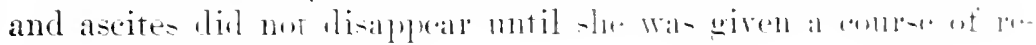
sistance exercior.

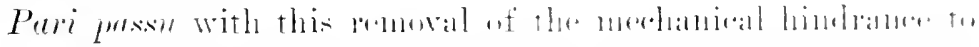

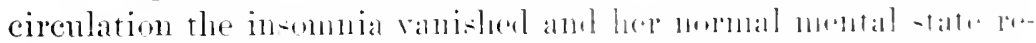

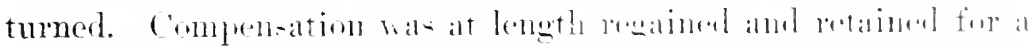

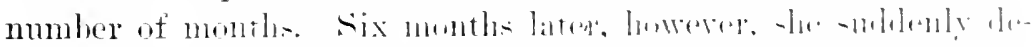
reloped an exepuciating and olstinate nemble

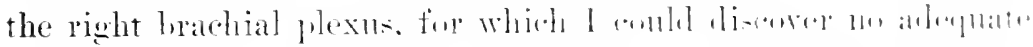

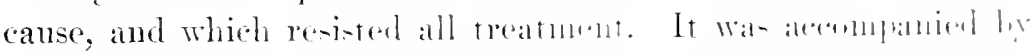

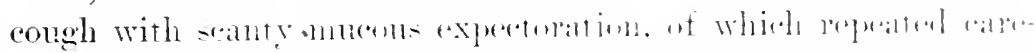

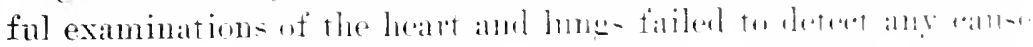

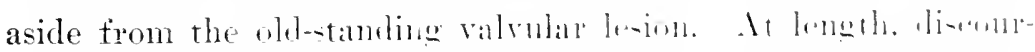

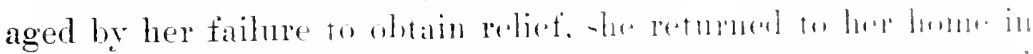

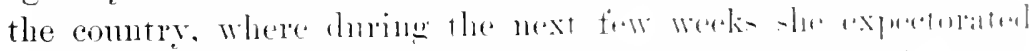

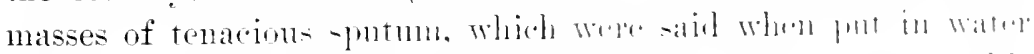

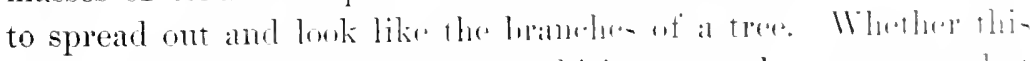

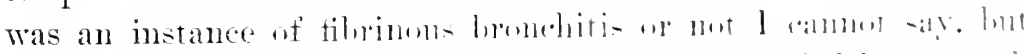

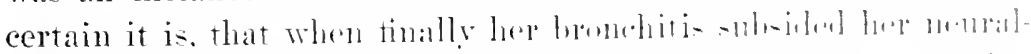

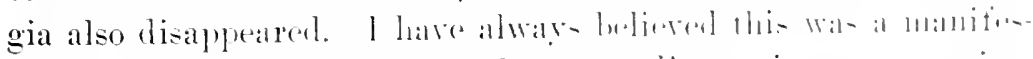

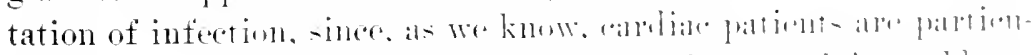

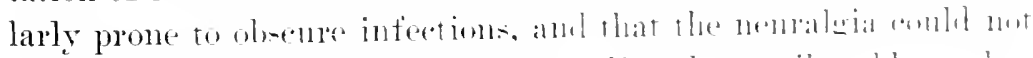

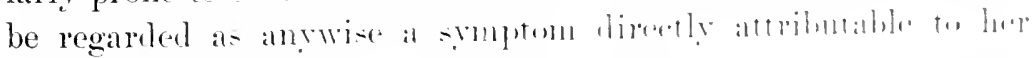
heart-disease.

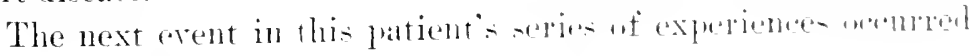


ahout a year later. She had again been suffering from rheumatism, as I was tokl, when. according to her sister's statement, she suffered one night from sorese pain in the region of the heart, for which hot cloths were being applied. Snddenly the snfferer exclaimed, "There! something has broken, and the pain has all grone." She then seement to sink away, her pulse becoming too weak and rapid to be counted, her extremities cold, and her countenance blue. Stimulants revived her, but all night she continued to have sinking spells, which necessitated the administration of restoratives.

The explanation of this attack has never been clear to me. Whether a tendinous cord napped, or a pericardial adhesion gave war, or whether the pain may not have been the to a muscular cramp, I cannot say. Curker the influence of heat the musele may have suddenly relaxed, and the cansed a sensation, which to the suffering and highly nervons apprehensive girl was naturally attributed to the heart. and threw her into a condition of mental shock which reacted on the weakened heart. At all events, the attack was fraught with no less alarm to the friends than to the patient, and an explanation was songht, which comld not be given.

Six weeks subsequently the patient was again brought to the rity in a truly deploralile condition. There were marked evilences of cardiac asthenia and consequent circulatory embarrassment, pronounced jcteris, adema of the ankles, ascites, enormous hepatic congestion, arlema of the left hut not the right arm, and in the heart signs of domble mitral disease, relative tricuspid insnfticiener, and arlherent pericardimm.

The feature of chief interest, howerer, was comnected with the dropsy of the left rupres extremity. This was strictly localized, extending from the tingers up to and ceasing with the shoulder. Palpation of the axilla disclosed that the axillary rein had heren converted by thromboris into a firm cord. To what distance the thrombosis extenderl down the arm could not be determined, but it did not involve the jugnlar reins. The "swelling," it was stated. liad made its apyearance a week earlier, but aside from the annovance did not appear to occasion paian or distress.

This highly interesting and comparatively rare condition was an instance of renous thrombosis occurring in some cases of valvular disease. It has formed the sulject of an instructive paper 


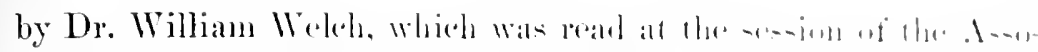

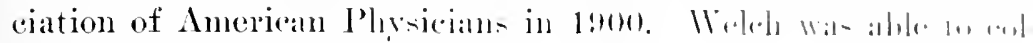

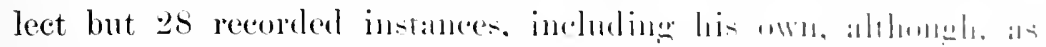

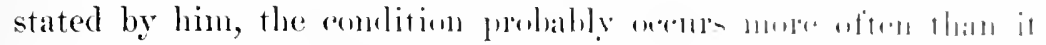

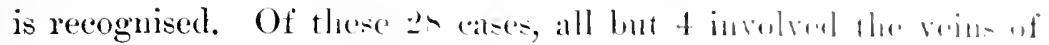

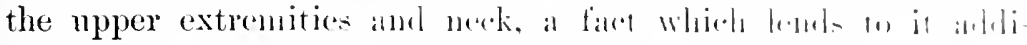

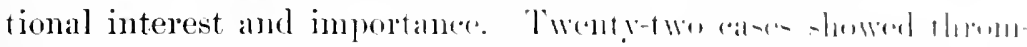

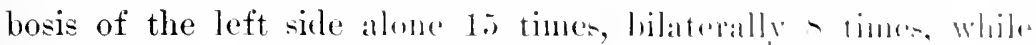

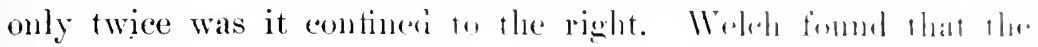
thrombosis might le linited to the reins of the allu, to ll lan of

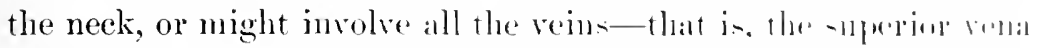
eava, the immoninate, both internal and cotolual jumblar, - bb-

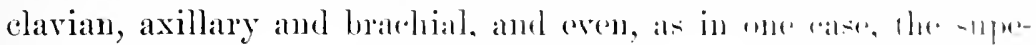
rior thyroid.

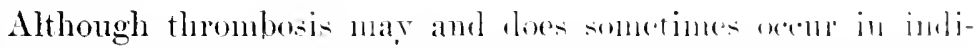

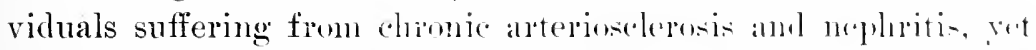
in Welch's 28 cases there was in every instance valvular disfare. as follows: Mitral regureitation! times, mitral -temesis alomedi times, mitral stenosis with iusufficieney di times, and antic lentur-

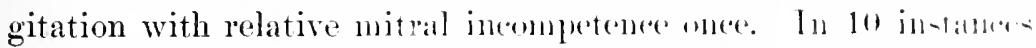
there was associated arotic and mitral discalor. The throubns

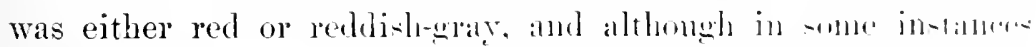
it was softened at its centre, it for the nost part was firm thromehont, and occholed the vesed exropting at its extremitios. In whe ease it was a "wall thrombur." It is also interesting to mote lial

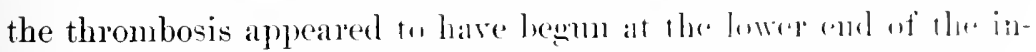

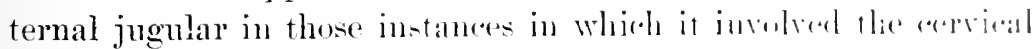
veins. This fact led Welels to eomelude that the formation at the thrombus was favoured ly the peculiar anatomuical andangement of the cervical veins on the luti sile, towethe with the anditions governing the blood-fiow in tlicm.

As pointed ont by Ilanot. the lett inmominate voin is lonene and more oblique than the right, which, together with the right-

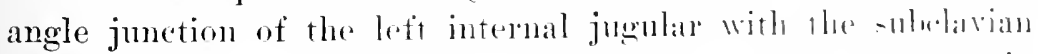
and the bulbous expansion of the internal jugular, farour- in

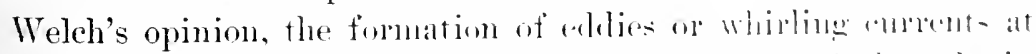
that point, and thes furthers the developunent wit thombles.s.

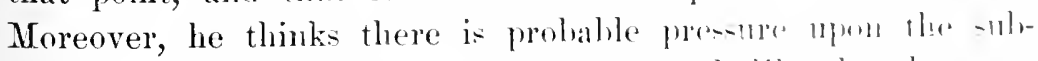
elavian vein by the dilater left andele and dilated puluonaly 
veins, so that cireulation in the eerrical and arm reins beeomes extrencly shegish, and thus provides another farouring factor. Finally, in whe of his cases Welch was able by cultures to identify the streptecoecus progenes. which, he thinks, warants the hypothesis that in these eases there is an infections origin for the thrombosis: a conchusion whirh is strengthened by recent observations going to show that in all cases of venous thrombosis there is an infertion.

ln my case there is good reason to believe that the patient was still suffering from some infection, for she had lout a few weeks earlier gone throngh with what was alled rhemmatism by her home phrsician, yet which may very well have been a streptocorens infection, which so often presents the appearances of articular rhemmatim. Moreorer, there were three small, distinctly indhrated lymphatic glands situated just above the left elavicle, near the onter border of the left sterno-cleido-mastoid muscle, while the patient displayed a slight clevation of temperature. In other resurects my ease conformed with the most of Welch's requirements -namely, she was a female, of but twenty-three years of age, and was a sufferer from mitral disease. Her symptoms too were eharacteristic in the localization of the cedema to the affected arm below the location of the thrombosis. She did not, however, suffer fain. at least not at the tine the interesting condition was detected, the oceluded rein was not tender, and I failed to diseorer any enlargenent and tenterness of the lymphaties of the arm, as is often present. If such existed, they were hidlen from obserration by the ordematous condition of the extremity. Welch states, finally, that in at least one of the cases collected by him there was mild deliriun, which was attributed to the cerebral cedema diseorered at the antops.

In the matter of the diagnosis of this form of venous thrombosis there is no difficulty, provided the thrombosed rein ean be felt, and even when not, strictly lnealized dropsy in one arm or one silc of the neek renter's the existence of thrombosis very likely. Nevertheless, according to Iranot, the greater length and obliquity of the left imominate rein may sometimes eanse milateral and cireumscribed odena even when venons thrombosis is not present.

The prognosis is unfavourable to recovery from the dropsy if the reins are extensively plugged. If the thrombosis is not com- 


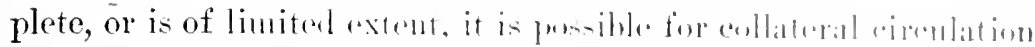

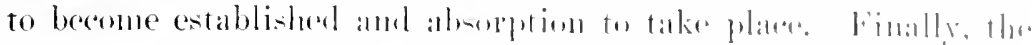

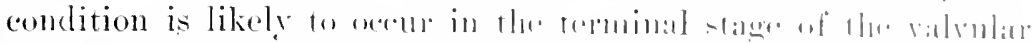

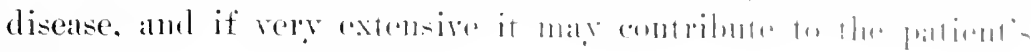
death.

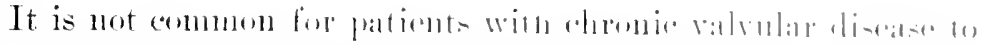

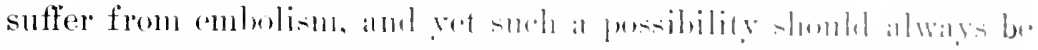

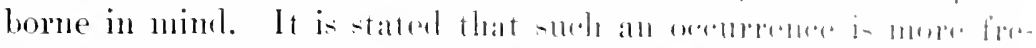

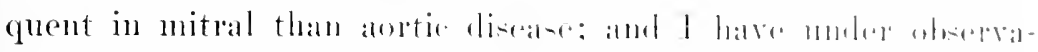

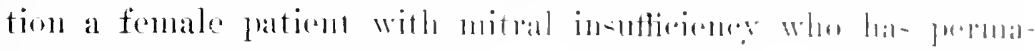

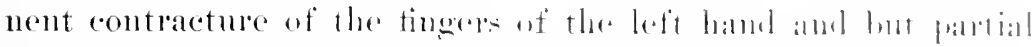

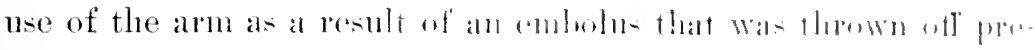

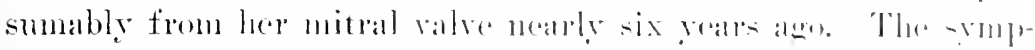

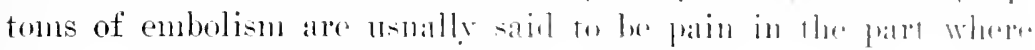

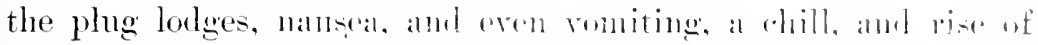

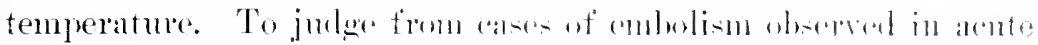

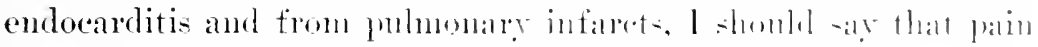
in the affected bart is the most comstant s'muptoms.

The splenic artery is a fropuent soat of enumbli-m, and it may

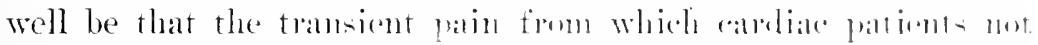

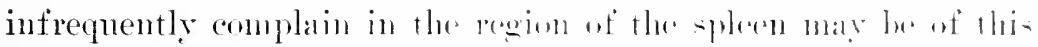

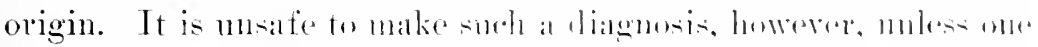

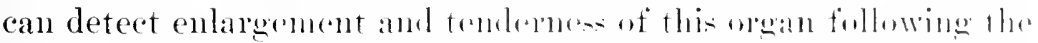

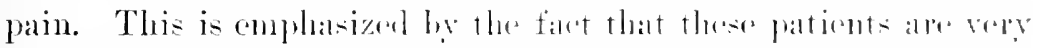

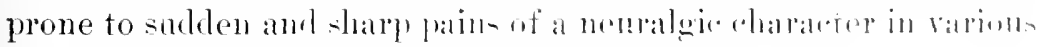
situations, particularly in the alolomen.

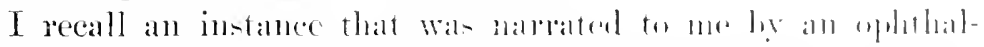

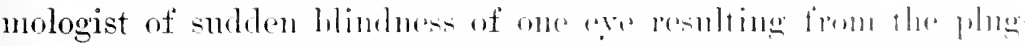

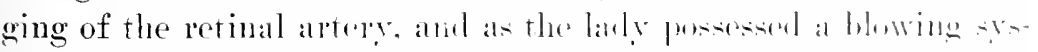

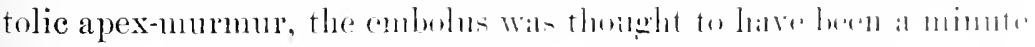

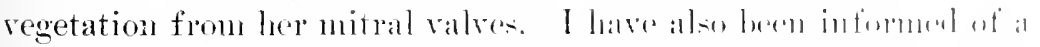

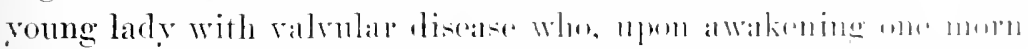

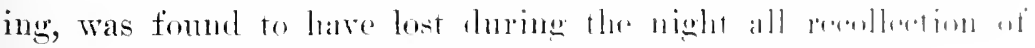

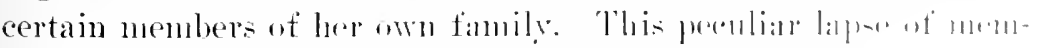

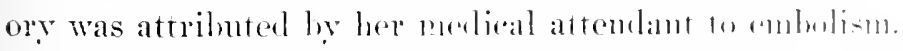

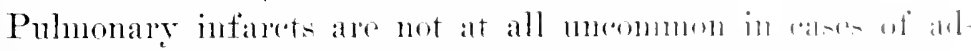

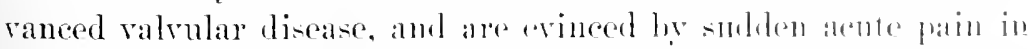

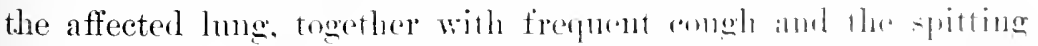
of clear blood. These cases must not be confommlon with instancen 
of hamoptysis due to smblen increase of pulnonary congestion, as not schlom acenrs in mitral patients who have overtaxed their hearts. In these cases the history of sone exertion and the absemee of mdden, shatp pain will nsmally ald in the differential dianosis. Embolism of the middle cerebral antery is attended by strele manifest symptems that there is usually but little diffienlty in determining the canse of the phemonenas.

In a single instance I have olserved the conjunetion of true epilepry with valvular direate. The patient was a man of about forty who presented well-marlied signs of mitral stenosis. His valvular lesion was of rhemmatic origin, and his convolsions antedated his cardiac disease by some years. There was every reason to conclude that the anociation of these two affections was purely accidental as regards their etiology. The fits were usually excited ly indiscretions in diet, and recpuired hromisles for their control. Althongh never assming any cansative pelation between the two, I yet believed they exerted a deleterions influence npon each other. I an very certain that the prilepsy affected his mitral disease mifaromably by serving to maintain and aggravate the dilatation of the carliac chambers. Surh cases as this are not to be regarded ats instances of cardiac epilepsy, which term has been employed to designate atacks of precolial pain aceompanied by loss of con-rionness and succereder ly twitchings of the museles of the face.

The asociation of epilepey and heart-disease in my case serves to empluasize the fact that ralvolar diveases may be eomplicated and have their clinical picture modified by other affections. I - preak of this becane inexpremeed plysicians are apt, when treating patients with valunlar disease, to attrilnte all symptoms to the rardiac complaint.

Cardinaths frequently lecome anamic and neurotic, hysteriral on nemastlenice, and then complain of all sorts of sensations, which it is clarly inpw.mible to attribute to their valvular atficetion.

The French decribe what they term "ardiac cachexia" in distinction from eardiac a-thenia, and which is analogons to the enchexias of malignant on mberenlons disease. They ascribe it to sume chenical change in the blood. It is not at all uncommon to -ee carliac patients whe, while presenting no very marked symptom- of casliac inderplarey, yet display an appearance of mal- 


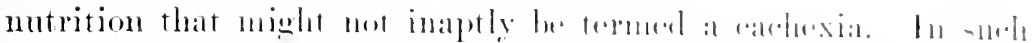

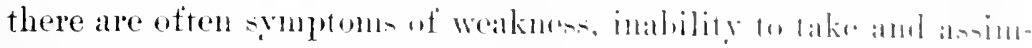

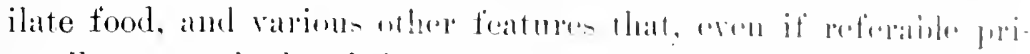

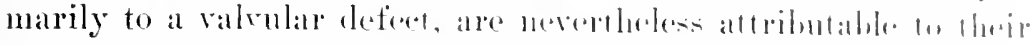

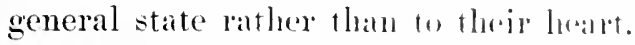

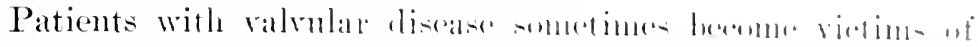

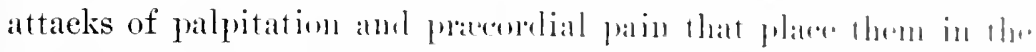

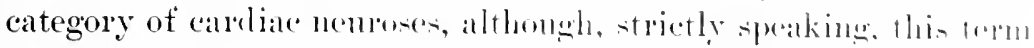
should be applied to calses in whele the attacks ane imlopentrom

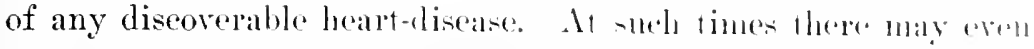
be irregularity or intermittenee of the pulse. This is maturally thought due to the eardiac lesion, and ret it may be wholly imb. pendent of the heart disonder, heing the result of some toxin pure

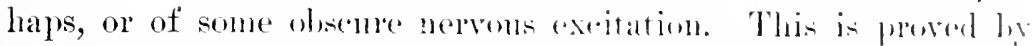
the observation that, when the attack subsiles, the heatrt's aretion returns to its former regular and tramenil state. I recall strell an instanee in a poung man with a mitral regurqutation who was sull, jeet to attacks of palpitation that invalrably threw him inte al perfect panic of fright and apprehension. Fot when his attaleksubsided he resumed his ordinaly duties without at srmptom nit his eardiae lesion.

I am in the habit of assuring such patients that theil attatekof palpitation are not indicative necessarily of a serions state nf the heart-for persons without any demon-trable cardiale li-eat-re often manifest similar disturbance-lint that lecause the lateat is not strueturally somed, it is more casily thrown ont of bildance. by indigestion or other eomlitions that womld not he notived were

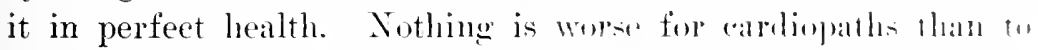
get into a state of introspection and anstant apprehomion. I have known some who were so alalmed over their valvulal defent

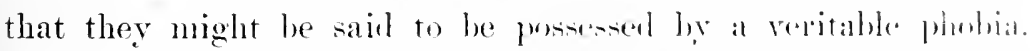
Sueh patients not only inagine all wete of symptoms that pla! wo part in the clinical histery of their particular lesion, lunt they ane afraid to venture out alone lest they acet an attack or be bumeht

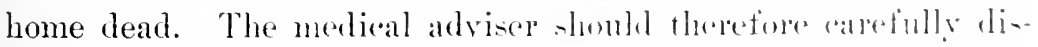

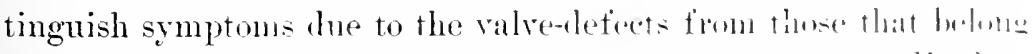
to some associated disorder, and reasure the patient andendingly:

Before completing this subject I lesile to ald a tew remarkconcerning derangements in the rhythm of the heartis action. 
lrregularity and intermittence of the pulse are common in all forms of valrular disease, yet they are by no means always observed. The regular and rhthuic contraction of the heart-muscle depends upou its receiving regular and nuiform stimulation by the presenes of the blood. Inombtless there ale many disturbing factors of which we ane ret igworant, and which nay be transient in action, such as enotional or other impulses acting through the nervous system, toxins of various kinds, ete. But aside from these there are degencrative or other alterations of the cardiac muscle itsclf that lead to arrhythmia. Such a persistent derangement of the pulse in therefore an mufivourable omen. It is quite likely to be observed in mitral disease, particularly regurgitation, it is said. Why this is, is not alear, meses it is dependent upon dilatation or degeneration of the anricles.

A mere lack of miformity in the force, volume, and frequeney of the pulse-wares, to which form of arrhythnia is applied the term irregularity is far les serions than intermittence, by which is meant a dropping out of some of the pulse-wares. This latter may be lne to actual intermissions in the cardiac contractions, or it may he cansed by the failure of all the blood-waves to reach the wrist, the heart itself beating regularly all the time, although with mequal force. Many interesting varieties of pulserhythm have been described, lut I do not know that they possess any special clinical signiticance aside from the fact of their being an indication of disordered cardiac action. Thus pulsus alternans is a term employed to describe an irregularity consisting in the appearance first of a lare and then of a small wave that follow each other in regular sncession. When the pulse-wares occur in pairs that are separated hy distinet intervals they are spoken of as pulsus bigeminus, and when in groups of three as pulsus trigeminus. Pulsus intercidens or intercurrens denotes the oceurrence or interpolation of ocrasional small waves between the regularly ocenring large waves. Pulsus tardus is a slow pulse, magmus a large pulse, partus a muill pulse, ete.

'Thror variations may exist alone and for a considerable time, or they may be blended and display their individual characters for but a few seconds; so that a pulse results that is strikingly irregular and difficult or impossible to comnt.

It has been nyy obervation that when a patient with organic 


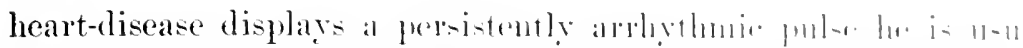

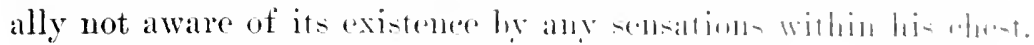

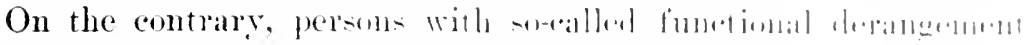

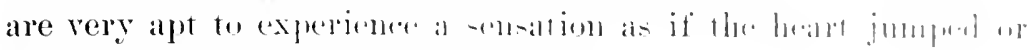
turned over whenever it intermits.

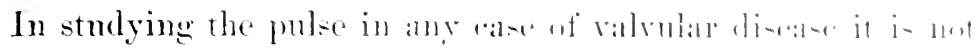

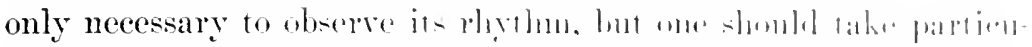

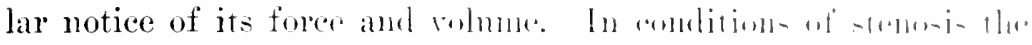

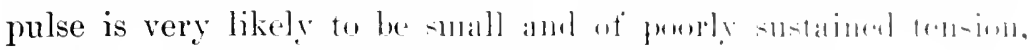

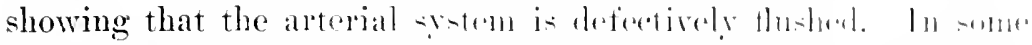

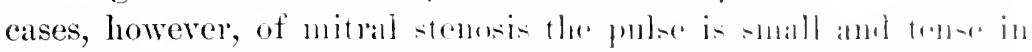

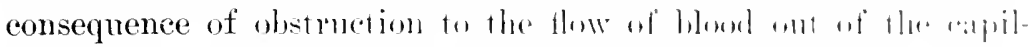

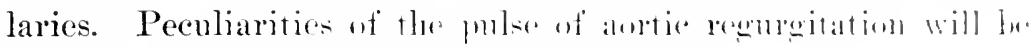
dwelt upen at some length in that -certinn. 


\section{CHAPTER TI}

\section{MITRAL REGURGITATION}

By this term is resignated an almomal escape or leakage of hlood from the cavity of the left ventricle through the left auriculo-ventricular orifice into the left amicle. Such regurgitation may be the to structural defect of the valves or to their relative incompetence from dilatation of the ventricle, or to imperfect function on the part of their muscular apparatus. In this chapter will be considered only the form due to valvular defeet. Other terms applied to this disease are mitral incompetence or insufficieney: but inamuch as the term regurgitation is more commonly employed in this comntry, this is the one that has been selected and is preferred.

Morbid Anatomy.--The structural changes of the mitral valve permitting regnegitation of the hood are mainly thiekening of the cuspe with increased rigidity that prevents perfect coaptation, or the shortening or retraction of one or both of the leaflets in such a way as to permit the reflux of blood. The segments lose their normal pinkish transparent appearance, thin delicate feel, and beeome thickened, stiff, and of an opaque whitish or grarish colonr. Contraction of the fibrous tissue may canse retraction or shortening of one or both of the cusps, or eurling of their elges in a manner to prevent effective closure of the valve. In the ralvular divate following acute endocarditis the shrivelled and often caleified remains of old regetations may be found on the anricular surface of the valve along the line of maximmm contact. When these ohl regetations are mumeroms the mitral ring is usually filmons and contracted, leading to a condition of stenosis as well as regurgitation (Fig. 34). Very commonly, also, the tendinm cords are fond more or less matted together, stiffened, and - hoptenerl, so als to still further interfore with perfect action of the ratre. The depmit of ealeareous matter is be no means limited to 


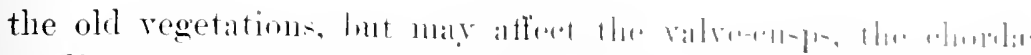

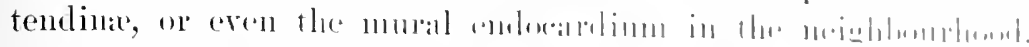

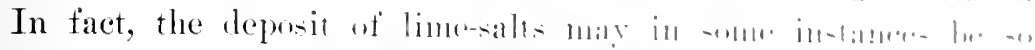

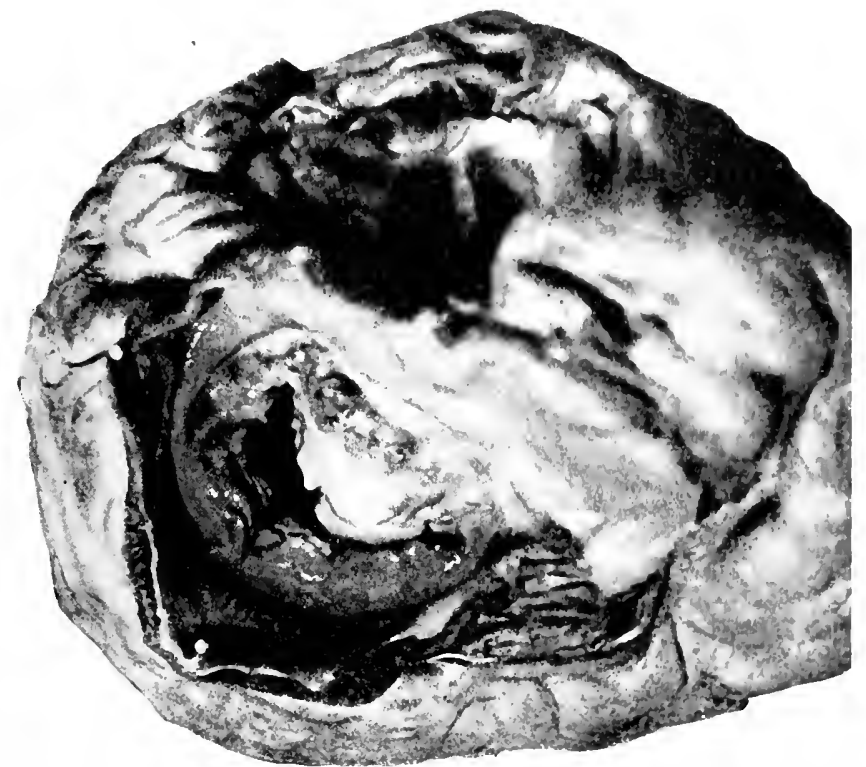

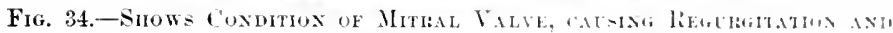

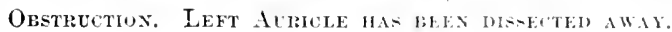

extensive as to convert the entime valunlar aplaratus into a tirm

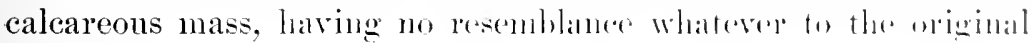
structure.

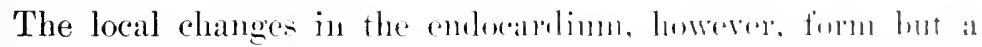
small part of the morbid changes fonmd iu a case of mitral im-ntli-

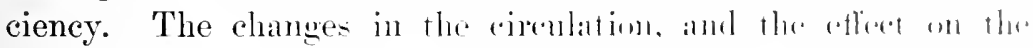

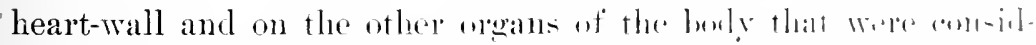

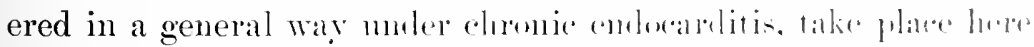

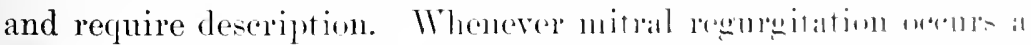

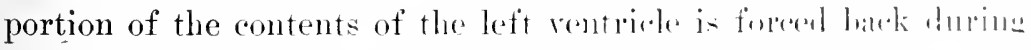
systole into the left auriele. whieh at the salme time is rexpiring

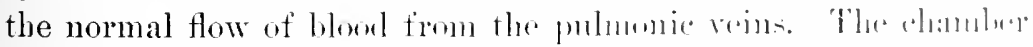

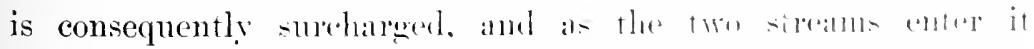

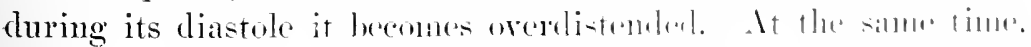

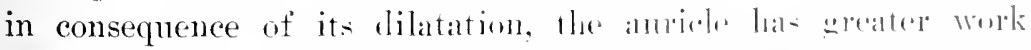
to perform in emptring itself of thi- imeromed ammont of 
blood. and in accordanece with the physiological law that an organ which has increated work to do will, so long as its nutrition is mimpaired. manifest increased power for work, the walls of the auricle at length becone thicker and stronger. In time, therefore, the anricle comes to he both hrpertrophied and dilated.

If these changes in the eireulation come on slowly, and time is afforded for compensatory changes in the heart to derelop, the nutrition of the heart-mucele, and indeed the integrity of the eirculation, may suffer nu-erions injury. Furthermore, if the auri"le is able to deliver an increased volume of blood to the ventricle, this chamber is able to clischarge into the aorta, in spite of the regurgitation, an approxinately mormal amomnt of blood, and adequate arterial circulation is maintained. So far, then, the lyppertrophy and dilatation of the auricle compensates the valvular defeet, which may conserpuently exist for a long time without produeing any ineonvenience.

If, however, the leakage is extreme, or if it becomes so with lapse of time and the anricle is malle to completely empty itself, a residue remains, which interferes with the inflow of blood from the pulmonary reins. Thus takes place an accumnlation of blood (pasive congestion) which, acting as increased peripheral resistance to the work of the right rentricle, leads to lypertrophy and dilatation of this chamber. Moreover, the stasis within the lungs induees in them the condition known as brown induration, in which the comnective-tissue elements are increased, the veins engorger, and the whole organ is of a dark-hrown colour in consequence of pigment dejonited ly the clisintegrating blood. In adranced stages there may also he pulmonary adema and hydrothorax from transulation of sermm ont of the engorged vessels. There is always more or les bronchial congestion in eonsequence of stasis within the pulmonic ressels.

When at length blowe-preseure in the pulmonary artery grows excescive, the wall of the right ventricle finds its work too great, and, viedling to the strain, permits dilatation to supersede hypertrophy. This chamber is now umalle to fully empty its contents, stasis within it grows. and at length canses trieuspid leakage either from muscular incompetence of the valve or, more often, from great dilatasion of the ventricle. In cases of long standing and extreme pressure 


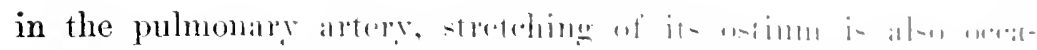

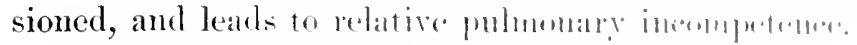

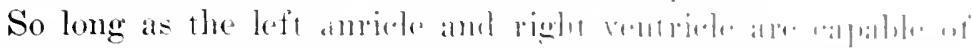

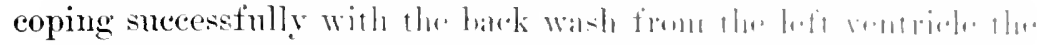

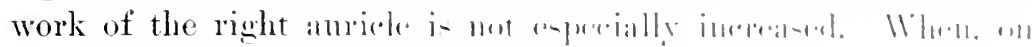

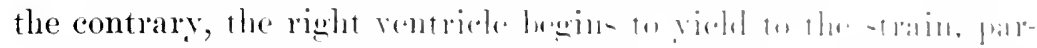

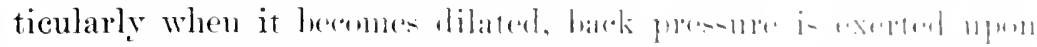

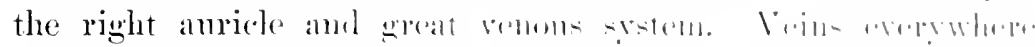

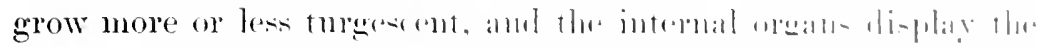

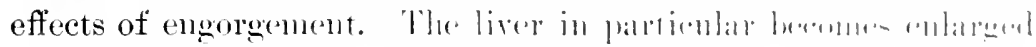

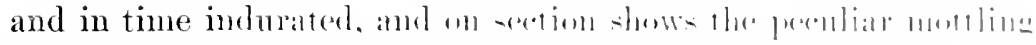

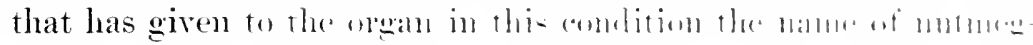
liver.

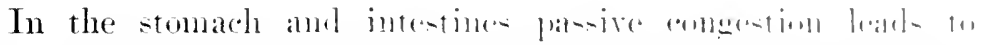

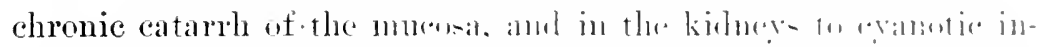
duration or even chronic nepherti- Xeme of the internal vi-nerat

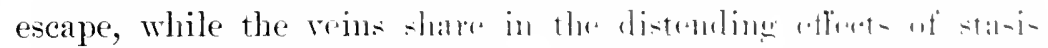

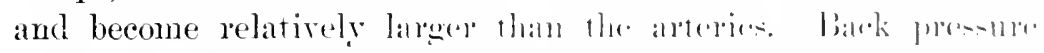
creeps downward inte the reseds of the lower extremitice. and at

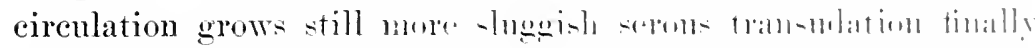

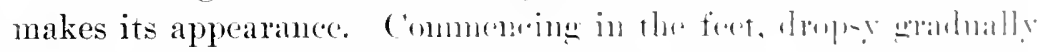

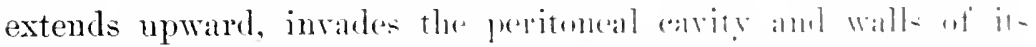

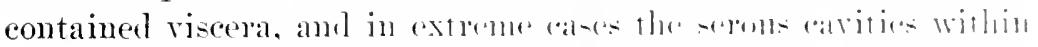

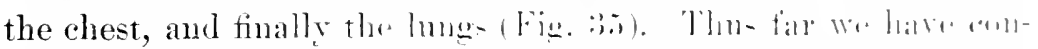

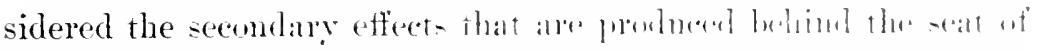

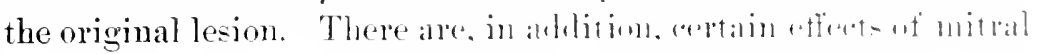

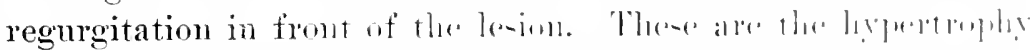

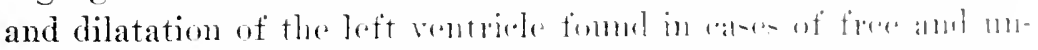

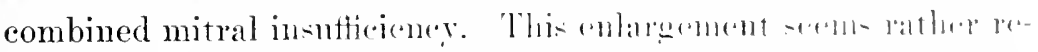

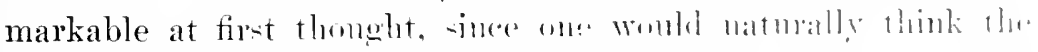

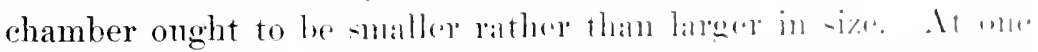

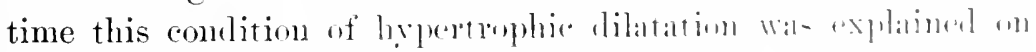

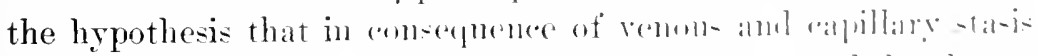

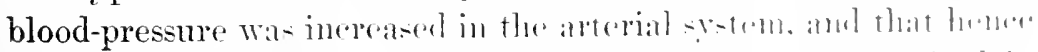

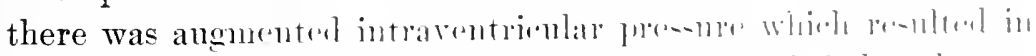

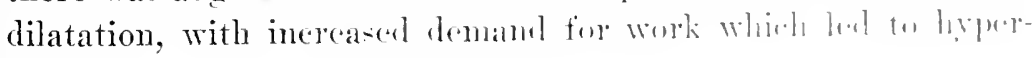
trophy.

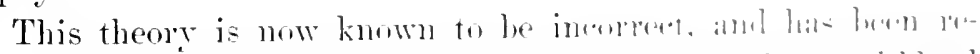

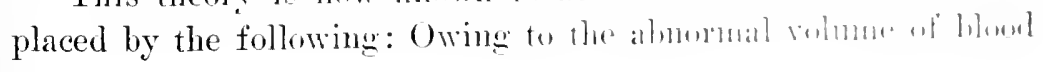


containes by the left anricle at the close of its diastole, this dhanlere, which has become hypertrophied, discharges with great force an munatural amomit of blow inte the rentriele. This

Cyanosis. and clubling of tinceres

Congertion and uelemat of liners

rongention and wdema of lower limb.

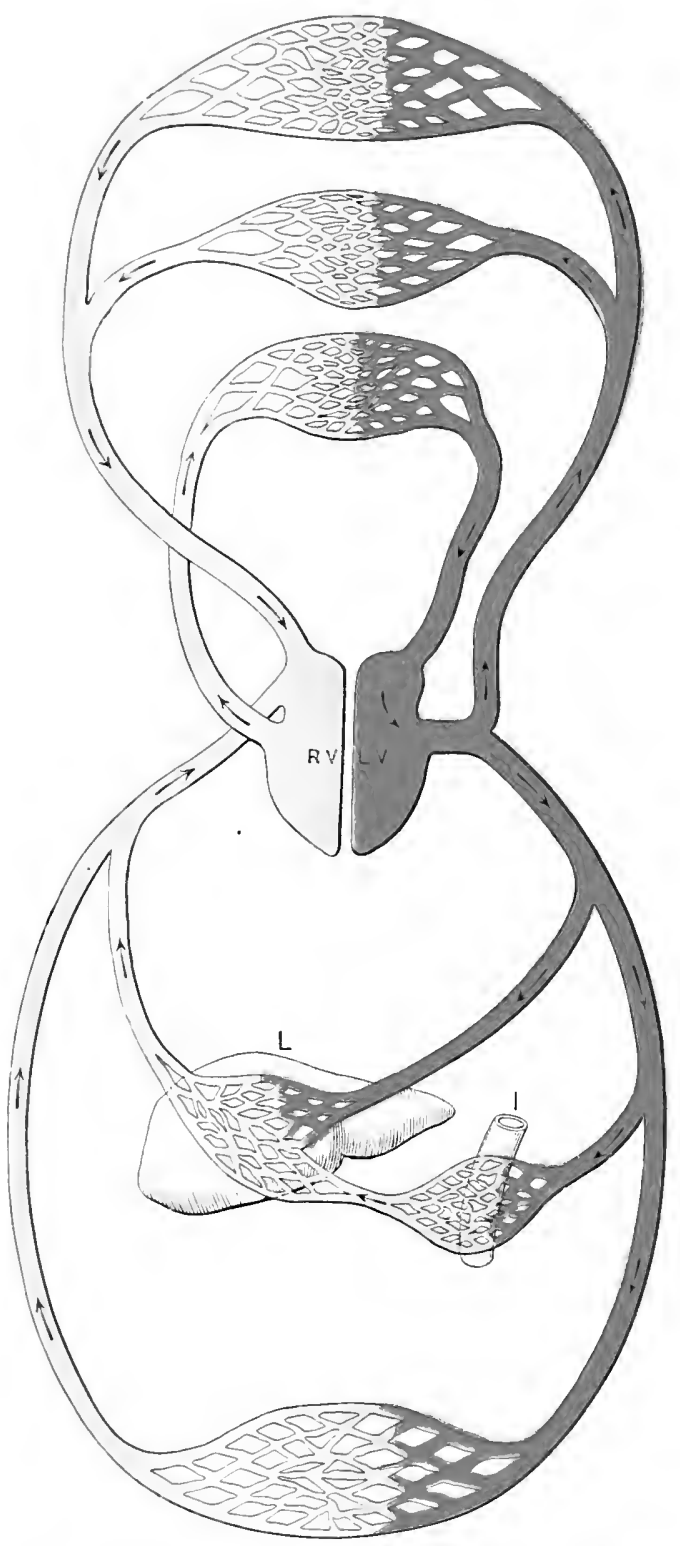

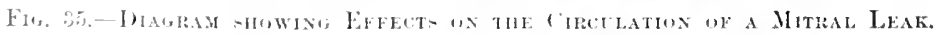




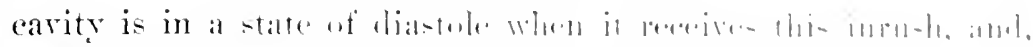

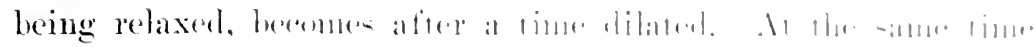

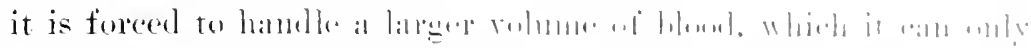

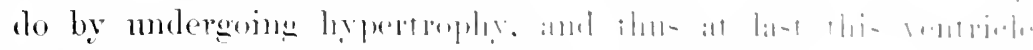

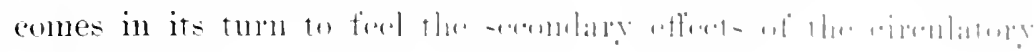
disturbance.

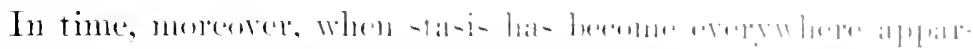

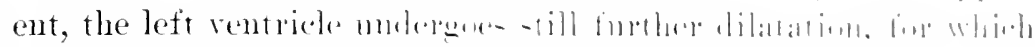

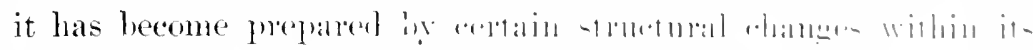

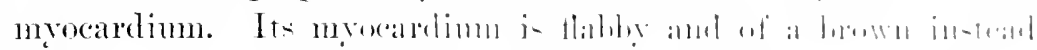

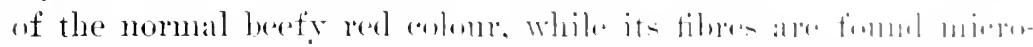

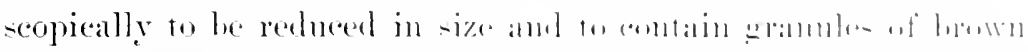

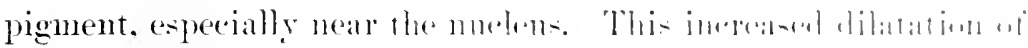

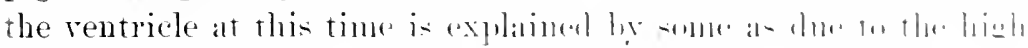

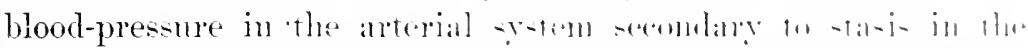

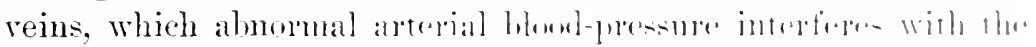

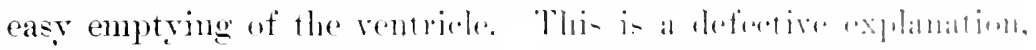

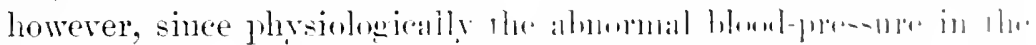

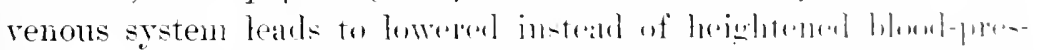

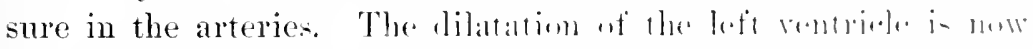

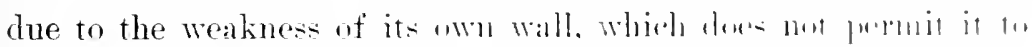

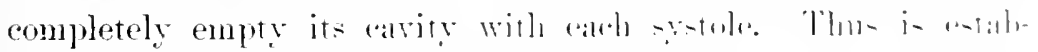

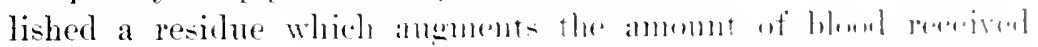
from the auricle witlo the mext diatole. while alt the -iture time it

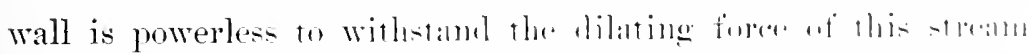

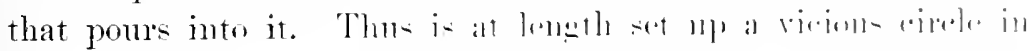

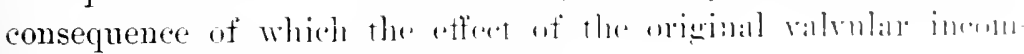
petence intensifies the rewnenitation.

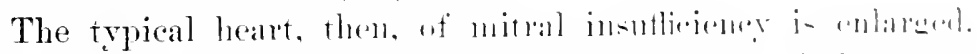

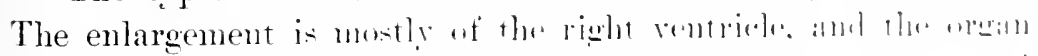

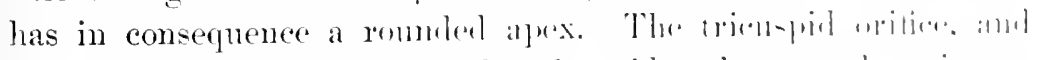

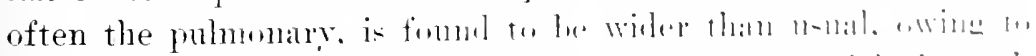

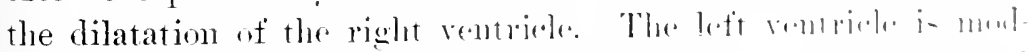

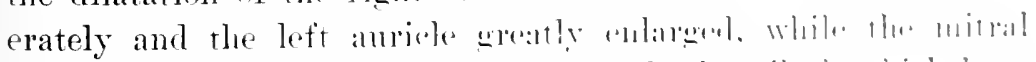

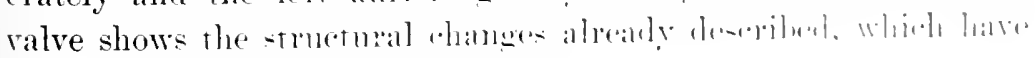
been the cause of the whole tronlibe.

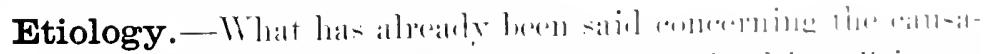

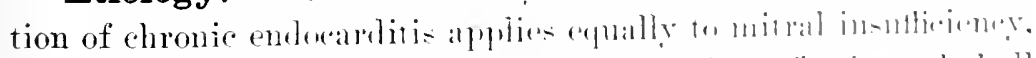

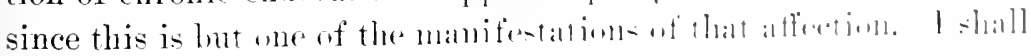


therefore only add a few weneral considerations bearing on the lexalization of the deforming proeeso at the mitral orifiece.

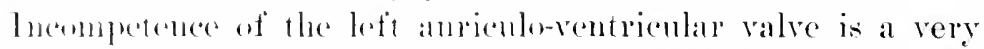
frepluent cardiale atfection-is indered the mest frequent of all vallvular defeeds. This is partienlatry the ease in children and

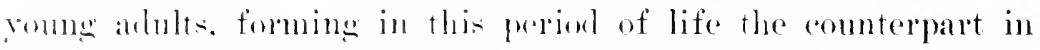
print of frepleney of the selerotic changes at the antic orifice in

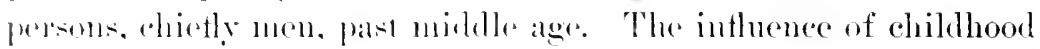
and pouth in the generation of mitral regurgitation lies doubtless, not in the fart of the age. per se, but in the prevalence in the romme of those diseases, inflammatory rhemmatism, elonea, and the examthenalta, which sot up endearditis. The greater liability of the mitral than of the arrtic ralves to suffer from endoeardiai inflammation in the artalien decades of life is probably owing to their being exposed to relatively greater strain, which their more delicate structure tits them leso well to endure.

As regalris orex, it is gemerally stated that mitral regurgitation is more frectuent among males than females. but in analyzing my ascorecords I find no predominame of either sex. After throwing ont all wase that from the history, age, or symptoms camot be saffely comsidered as arganic, there remain 126 cases in which regurgitation wats due to structural alteration of the valves. These were diviled edpully between the two sexes. Classifying

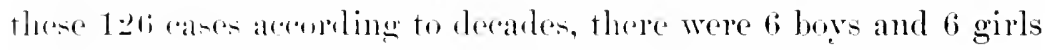
lectween one and ten realrs of age, 12 males and 16 females between ten and twenty, 1 of of ack sex between twenty and thirty, $1+$ cach betwern thisty and forter, and 1.5 males and 7 females wer forty. Examnined with referenee to rhemmatiom and other disuters, it was fomm that 32 males and 28 females gave a history of phematism alene, 4 malew and i females of searlatina alone, $\therefore$ males and $t$ fomales of measles alone, 1 female of chorea alone, while of more than we discase 1 male and ? females had har

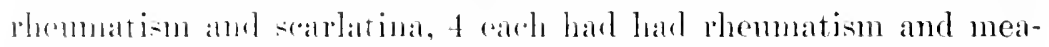

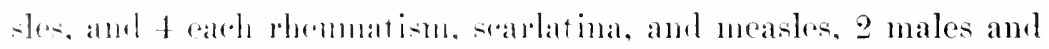
of females sarlatina and measter, 2 females meases and pertussis, and 1 female all fomr listases, 2 males and is females chorea, in andination with some of the other diseases mentioned. Two males gave al history of remereal discase. Of the remaining eases, in which un definite hi-tory of previoms discase conld be elieited, 


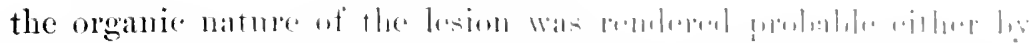

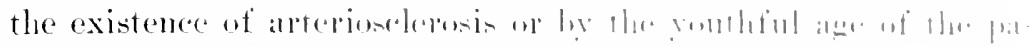

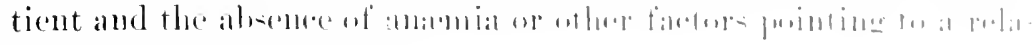
tive nitral insutticineng.

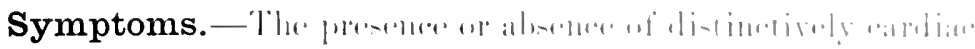

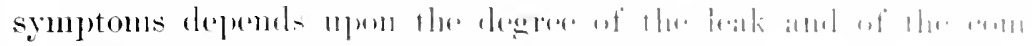

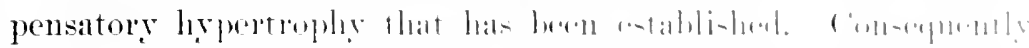

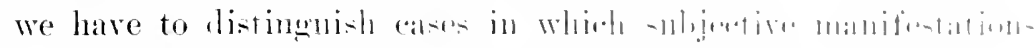

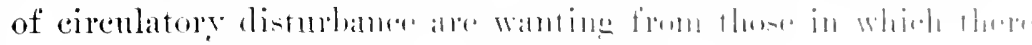

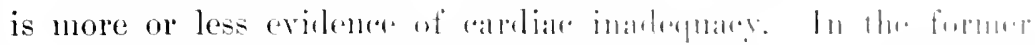

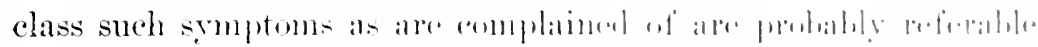

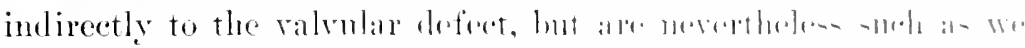

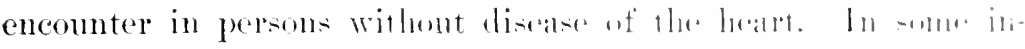

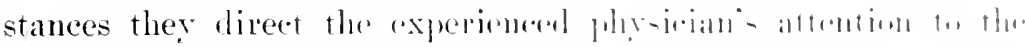

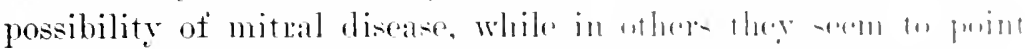

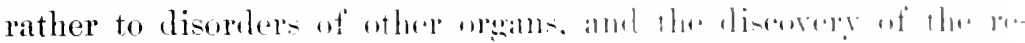

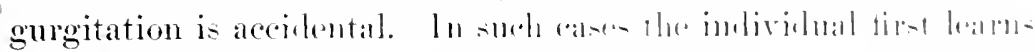

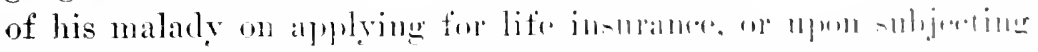

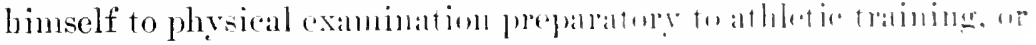

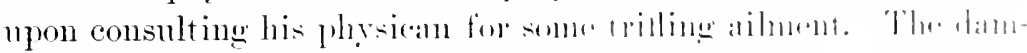

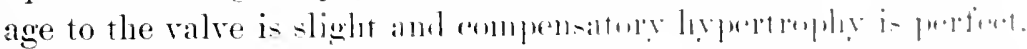

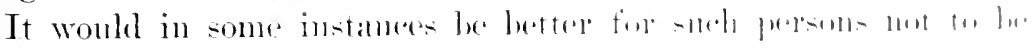

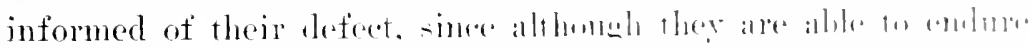

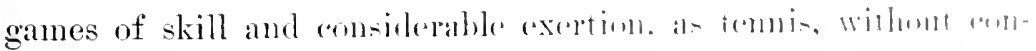

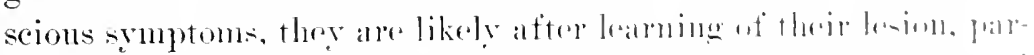

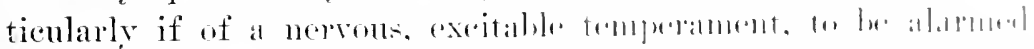

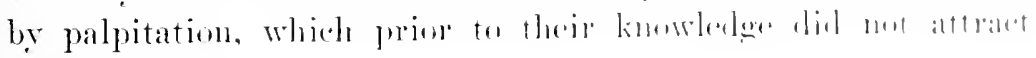
their attention.

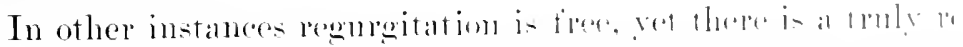

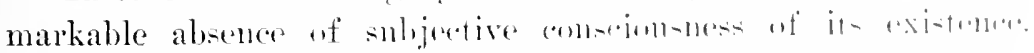

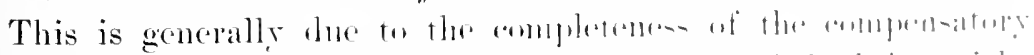

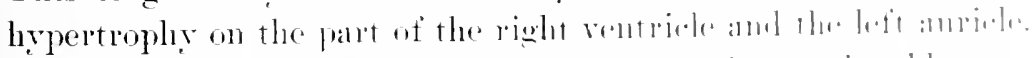

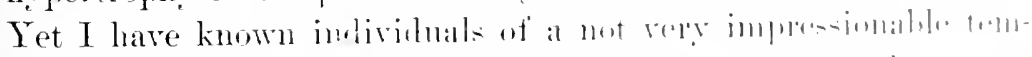

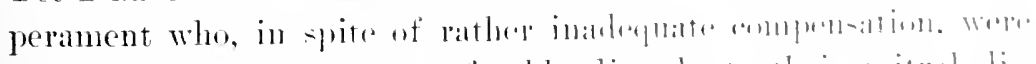

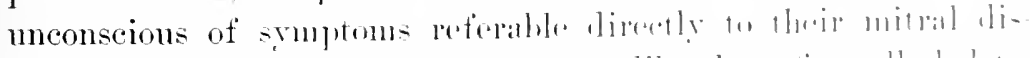

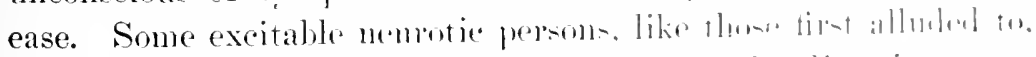

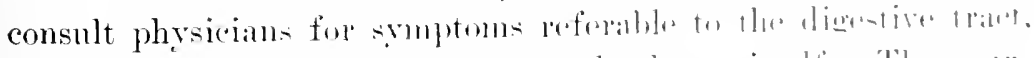

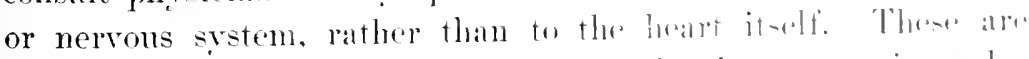
anorexia, or discomfort after foul, com-timutim, or all irregular 
state of the bowels, distresing precordial pains, which either set up or are accompranied by jalpitation. and which greatly alarm the patient and friends. In a multitule of sueh cases there is no whjeetive eridenee of lon of compensation, and the patients are able to enjog onteloor spurts " to participate in feats of enduranee witlunt subjective simplemus.

Again, ares ocerr in which the only sumptons are snch as are wenally clased muler the hear of lithernia, or the irregular manifestations of gont, and ocemring in persons of sedentary habits, are remored be regular onthor exereise.

In other cases the most that can he waid is they appear to have

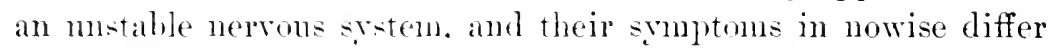
from those of other indivilnals of the same category whose hearts are healthy. In all such the valvular lesion does not appear to be directly resonsilue fur the manifestations, and ret it may well be that these can be referred to defective nutrition and elimination in consequence of the circulatory disturbance.

It is not meommon for females with organie mitral insufficiency to present evidence of simple secondary anamia or of ehlorosis withont symptoms of cardiac inadequacr. If in such eases there is shortness of breath npon unusnal exertion, it is no greater than may reasonably be attributed to the blood-state. I recall a remarkably interesting and instructive instance of this kind. In March. 1so1, a vomg married lady of twenty-four sought my opinion becanse of "a crating somm in the heart," which first attracted her notice in the fifth month of her pregnaney, and which still annoyed her at tines of muronted phrsical effort, as during rapid walking. Aside from this smptom, there was nothing that made her conscions of her heart. She admitted getting a little out of hreath, but this was so slight she had not given it any attention. Both her parents had clied of mhnomary tulserenlosis, but of her horther's and sisters, seven in all, none had shown signs of the diseare. She had had pnemumia when bnt a year old, searlatina at eight, measles and pertus-is in childhool, but nerer rheumatism, and nu to the time of lere marriage, at twenty-two rears of age, she land considered herself well. being able to romp and play like other "hilklen withont troulle. With exception of the "grating sound" montionul. her pregnaner and confinement had been meventful, and - he could not recall having suffered from more dyspnoa than 


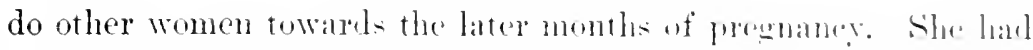

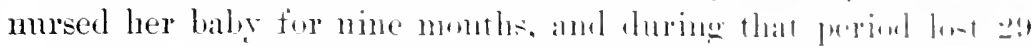

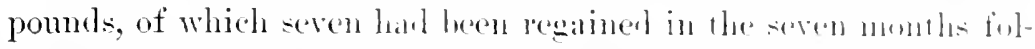

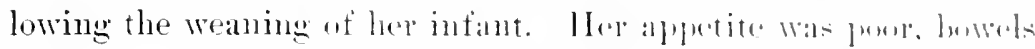

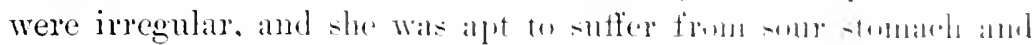
eructations. The menses were regular but seanty. Itamls and foet

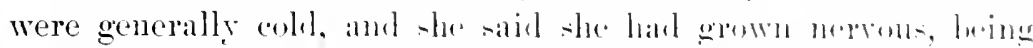
easily excited. Pain of any kind was trifling, forming a matkml eontrast to most of the cares I encomuter.

In all this history and eleseription of symptoms there wat

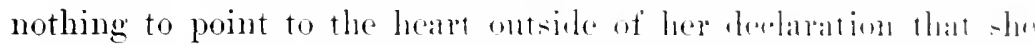
sometimes heard a pueer sommd, which she wanted to loaru the meaning of. The pulse was sit. cepual, regular. lut tem small amul weak. The broad, strong ajex-beat was in the nomal situalin, and no increase of cither superficial or decp candian dulness anll be made out. Howerei', the first soumd was partly wheroment ly at

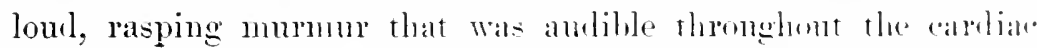
area and transmitted aromel the left side to the forme angle of

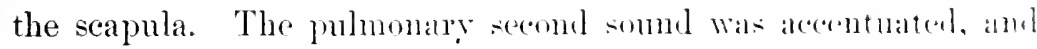
in the dorsal decubitus a softor blowing sistolic mumm be heard in the pulmonary area. Thinking this last might he a ehlorotic murmur, I had the hlowd examined, and fimml that the hemoglobin was reduced to bij per cent, led and white cell- being normal in number.

In spite of the absence of a rhemmatic history and depite chlorosis, there scemed no gond reasom to doubt the existemen at

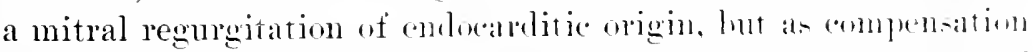

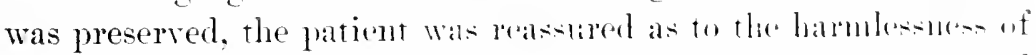
the somd she had noticed. In fiact. She was given to muleptamel that the more serions comblitions were the hlond-state and losis af weight, whicle in the light of her tamily history artainly repuired

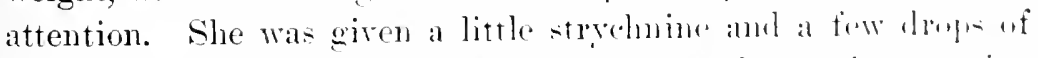

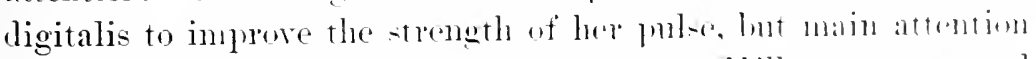
was bestowed mon the matter of mutrition. Milk, raw ang and

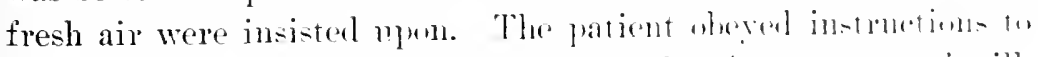
the letter, and soon was disposing admilahly of two ynats of milk

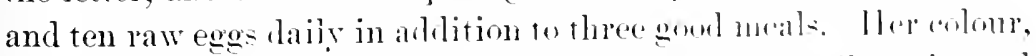
weight, and general comblition improved soalily, mut alt the emel of two months she looked the pieture of health. Sereptheles, the 
murnmer persisted, and once in a while she heard that same endo"ardial somd. It no longer worried her, however, and she never complained of any other simptoms referable to the heart or disardered circulation.

In this case it would be diffieult to say how much the mitral regurgitation wats reponsible for her condition. I believe the leak was so slight that it did not materially affect the chylopoietie and hlood-making orgams, hut that the state of her general health wats attributable to her chiluthearing and lactation, which in a woman with hereditary predisposition to pulmonary tuberenlosis proved too great a draught on her vitality. Had she been allowed to go on in her rednced condition she would in time have dereloped srmptoms either of artiac inalequacy or of tulserenlosis. $A$ it is, she is now likely to remain free from symptoms of ralvular disease for an inclefinite time.

I have note- of the case of a voung man who, because of a mitral regurgitant mumur and not sery severe symptoms of cardiace strain. Wis ordered to bed he his phrsicim, and there remanined for two vears. When I saw him he had mitral insufficiency sure enomgh, but his prolonged rest hat established perfeet compensation, the heart being not demonstrably enlarged and the liver of nomal size. Yet he dectared he conld not get up or stand, much less walk. I compelled him to get on to his legs, and little by little to walk about, with the result that he found he could exereise withont harm or srmptoms of heart-reakness. He was easily frightened about himelf for two or three rears, but did not

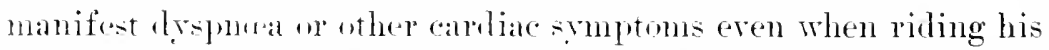
wheel orer hilly and -antly rarts. The last time he was seen by ne, now several years ago. he was as well as nine-tenths of the romag men who. like him, are -ebool-teacher's. It the most he hanl to he careful of his stomach and guard against constipation.

A medical stmlent, aged thirtr-fomr, somght nedical opinion n ancomt of attackin of palpitation. In chithood he had measles, pertur-is, and chicken-pws, and dimly recalled haring had a - wollen linere when five rear oll. At twelve or thirteen was so punc and frail that he was wiven cord-liver oil and kept in the hom-e during the winter, but after fomrteen took a start and be"arne ruged. Fonrteen rears ago he had semorrhera: had used tribaces from the age of serenteen. In 1s!:?, 1894, and 1895 he 
played football a good deal, and again two reals age, I-:1s, with-

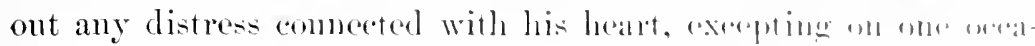

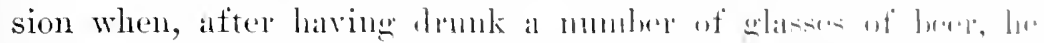

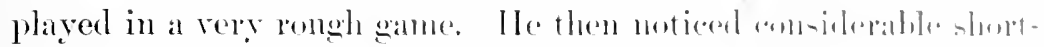

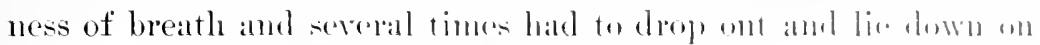

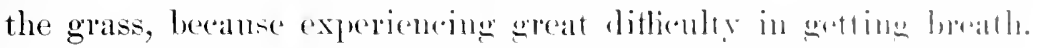

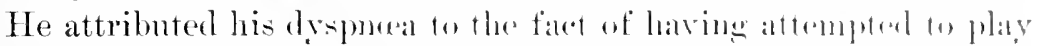

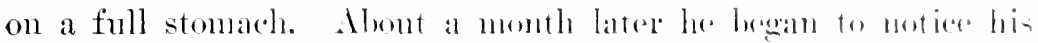

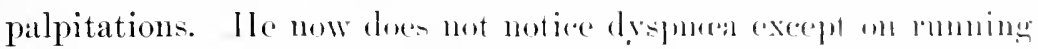
upstairs, and then no nore than he thinks andredy wombl who

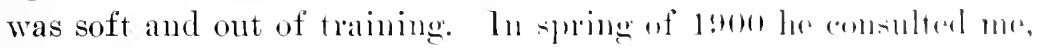
but notluing positive was discovereed to explatin his palpitationts.

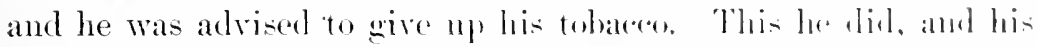
palpitations disappeared. I jom attempting to -molin aguin a fow months subsequently his symptoms potmened aml lue again abandoned his smoking pemannenty. hut his palpitations still aomtimmed.

Examination of his mine two years ago shered it to be normal. Last spring he observed for the first tine that a prolonswal and severe attack of jalpitattion was followed hy the pas:sage of a large amomnt of pale mine. His digestion is not good, he thinks, there being a "rumbling and roaring" in the bowels, some eructations. and oecasionally heart-burn. Sometimes his Hatulence ifollowed by diarrluca, lut andinarily his bowelo alle regurlar. His sleep is goom and his habits are now excellent.

The pulse varies mull in its irregularity, Jeing stealy. for twenty or thirty secomels. and then intemitting erery

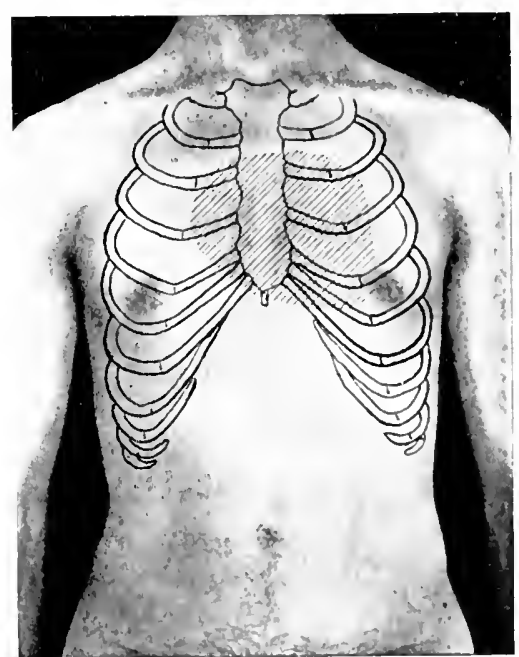

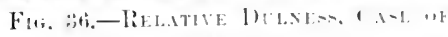

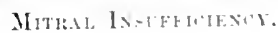

few beats; it is equal, of and rolume, and of mormal late. 'There

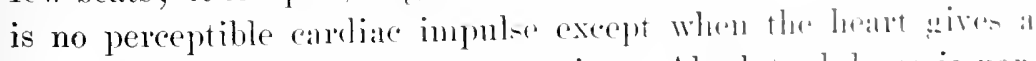
more than nsually vigorous contraction. Abolute duluess is nor- 
mal. Int ledative duhess measures $1 \frac{1}{2}$ inclues to right of the sternum and $4 \frac{1}{2}$ to the left of the median line in the thind interspace (Fig. 366). The - tomels ane distinct, lut the pulmonic second markedly acentuated. It the alpex and romed about the nipple there is a faint. ont srstolic nmmmu, which is lueard distinctly only when the heart makes a strong contraction after an intermission. In the fitth interspace, within the left nipple-line, there is a suggestiom of a very short pressistolic murmun. The systolic nmmmur is increased somewhat in the recmmbent position.

There an le no dombt of the existence of a mitral leak, but it is not puite clar whether it is of rhemmatic origin or resulted from a degree of cardiac overstrain during that game of football, and from which the leat has not recorered.

The effect of tobacen and emotional excitement on this patient is interesting. After luaving both smoked and chewed for seventeen years he has at length been compelled to abandon its use, hecause it now invariably induces an attack of palpitation, which is described as a " fluttering." He notices also that the excitement attending a gniz or examination in class will set his heart to fluttering. Also an attack is pretty sme to come on about an hour and a half after a meal, whereas if he misses a meal the palpitation does not ocem mitil the nsual length of time has elapsed after the next nueal. This individual is highly nervons, not being able to keep still, continually moving a hand or foot. It is this instability of the nervoms system that accomnts for the readiness with which his heart responds to stimmli that do not disturb cardiac action in most individnals.

In contrast iluereto is the patient's statement that even rigorons ceffort does not produce palpitation and only a moderate degree of lueathlessuess. Lastly, he is mot conscious of the luabitually intermittent action of his heart when he is at reat.

The treatment advised was a blue pill once in two weeks, to be followed by a dose of salts next morning, tincture of fat-free digitalis in 5-drop doeses, and $\frac{1}{30}$ of strychmine thrice daily, the avoidance of inmoderate plusical effort, and a dietary rich in proteids and containing a restricted amome of carbolydrates.

Intense cardiac pain of the kind to merit the term angina Jectoris is rare in mitral regurgitation, particularly in the young, or whon of endocarditic orjerin. In some, however, there are neu- 


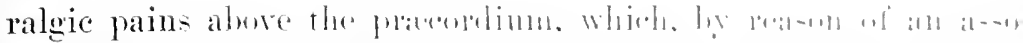

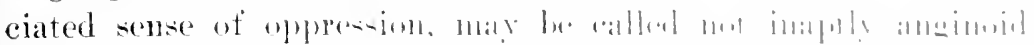

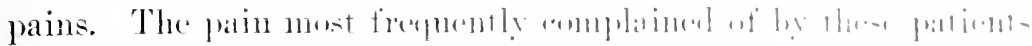

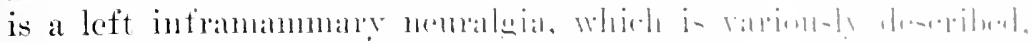

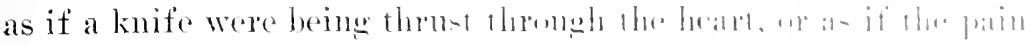

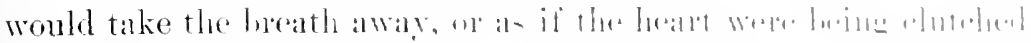

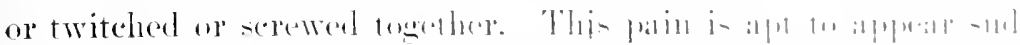

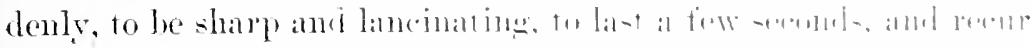

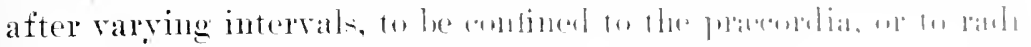

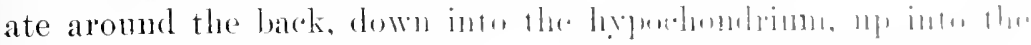

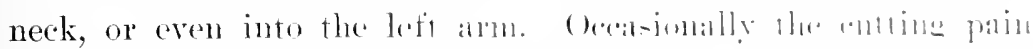

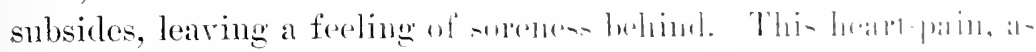

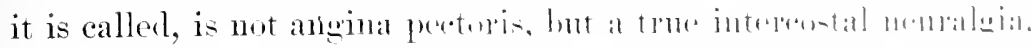

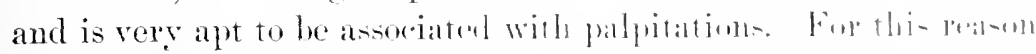

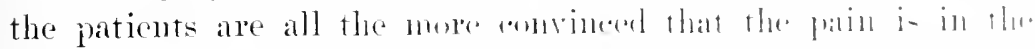

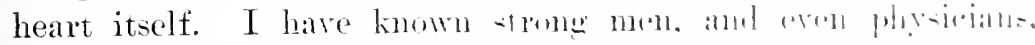

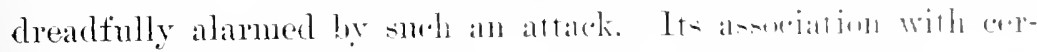

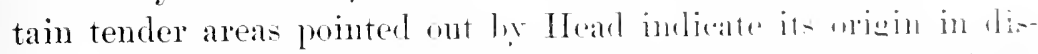

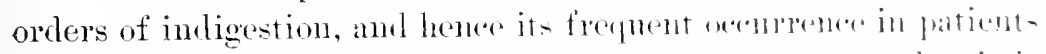

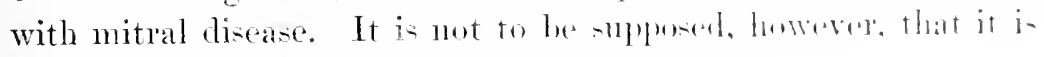
at all peenliar to this class of ear liopath-.

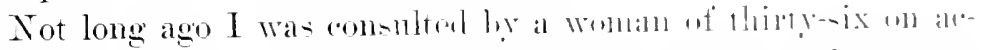
count of a sharp pain in the left sile near the heal. She gave at history of intlammatory rheumation cighterens ratu- lwefore, alt

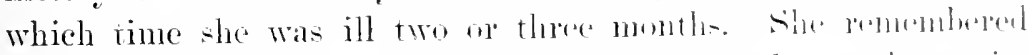

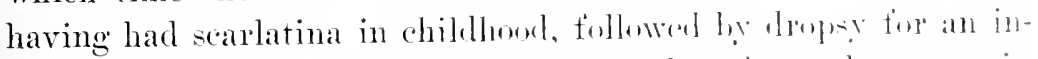

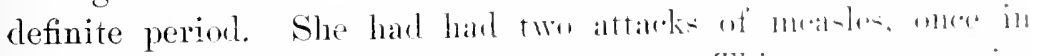

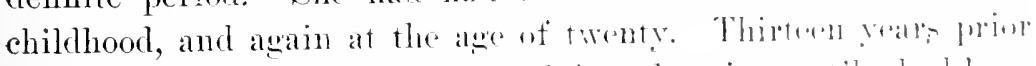

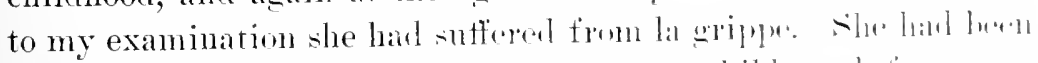

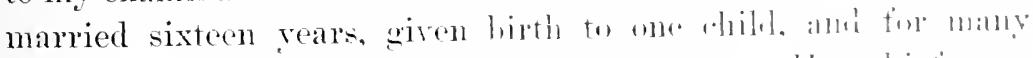

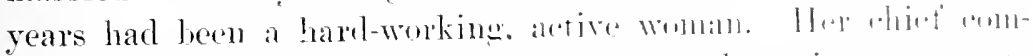

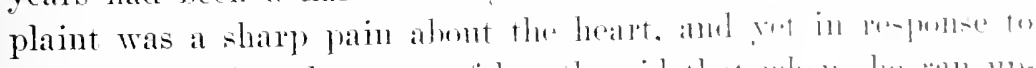

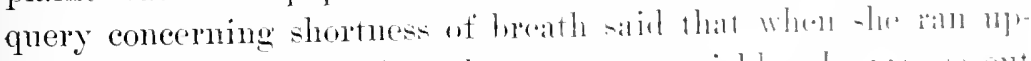

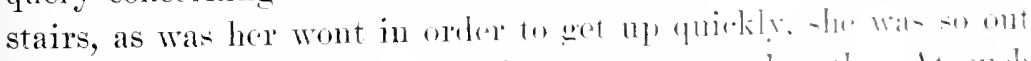

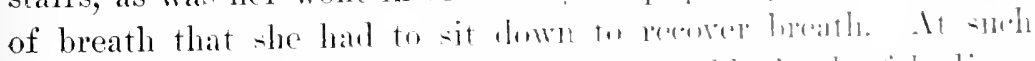

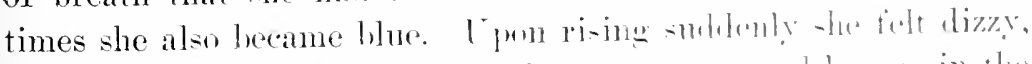

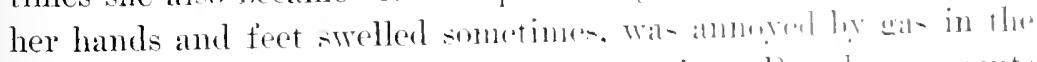

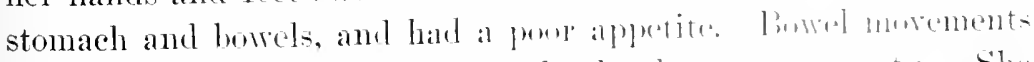
and menses were regular, thomgh the lat wore -antr. She 
sometines heard a grating noise that seened to come from the licillet.

1la pulse, while sitting, was so, small, weak, and regular. 'The aprex-beat in the fifth loft interspace, nipple-line, was weak, hut without thrill. Absolnte cardiac dnlness was nomal, but relative luluess extended to the sixtl costal cartilage below, 4 inches 10) the left of midstemmu, not increased to right (Fig. 37). The

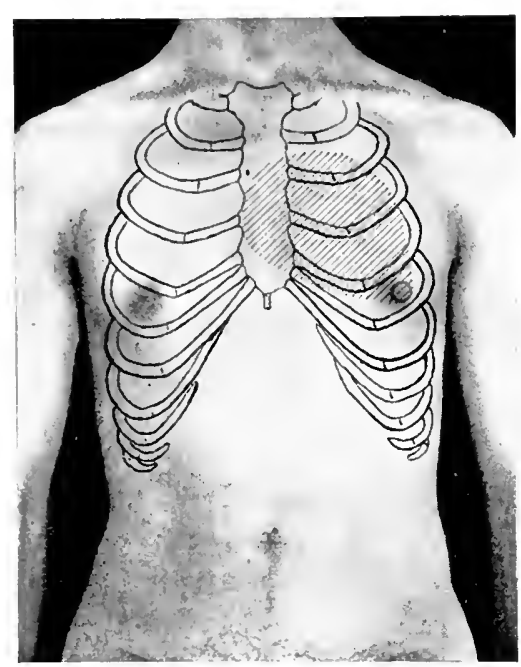

Fir. 37.-Arex-beat and Relative Delness, Case of Mitell Regurgitation (1), 22:4). first sound at the apex was feeble, being partially obscured by a murmum and snecected by a feeble second tone, while the pulmonic second was distinctly accentuated. $\quad \mathbf{1 l}$ over the cardiac area was a loud, sawing mmrmur of systolic rhythm, most distinet at the apex, and transmitted around the left side to the back. 'The liver was barely' palpable, yet tender in the region of the gall-blarlder, but in other respects the abdomen was negative. The condition was plainly a mitral regurgitation of rhemmatic origin, with innerfect eompensation heamse of the daily strain to whieh the leart was smbjected.

'This case is interesting berause of the fact that although the

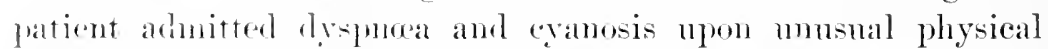
effort, she was yet chiefly distmped hy the precordial pain. This was undombtedly an interostal neuralgia that was in reality due to ber gastric and intestinal fermentation and only indirectly to the valvular bexion.

The only symptrm of which one of my male patients complains is an intemittent pulse that annoys him whenever he breaki away from his stret liet or confines himself too elosely to his office. The is always bencfited by outdoor exercise, particularly fisline, and reclan'es ly las no hortness of breath and no mucomfortalele palpitation unles his exereise is too riolent. An- 


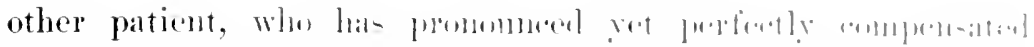

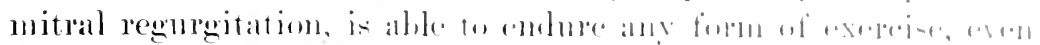

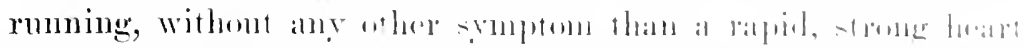

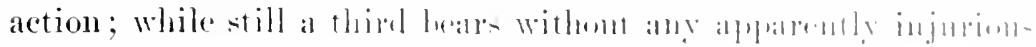
effect broadsword furatien and sparring.

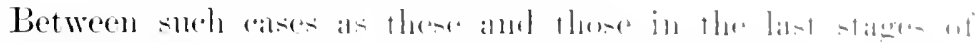

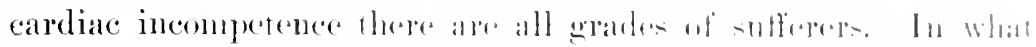

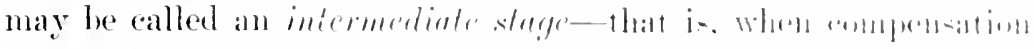

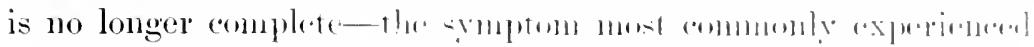

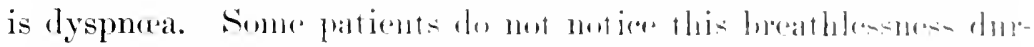

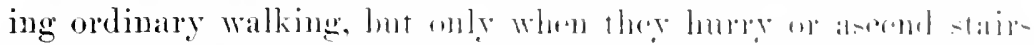

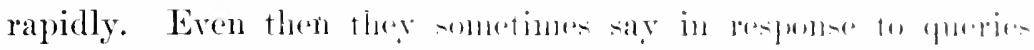

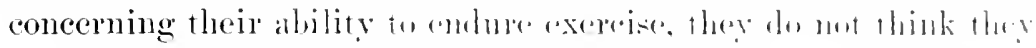

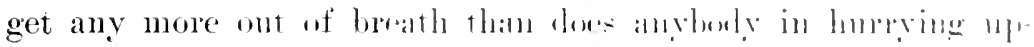

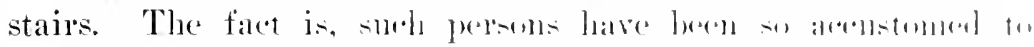

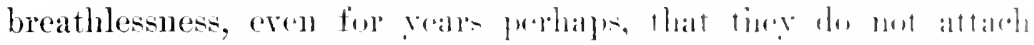

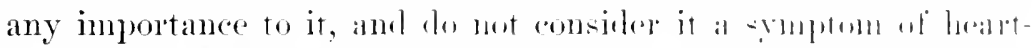

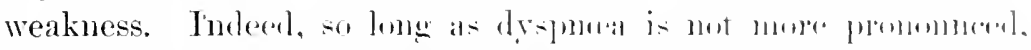

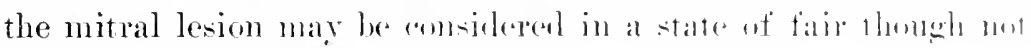
perfect conpensation.

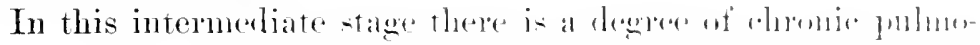

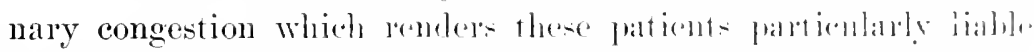

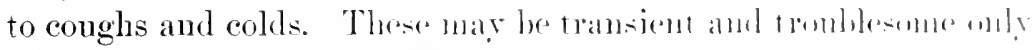

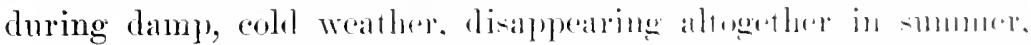

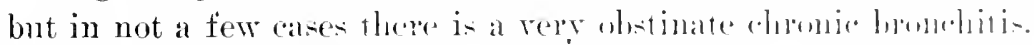

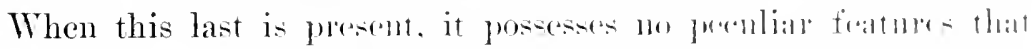

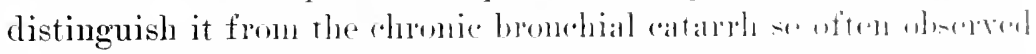

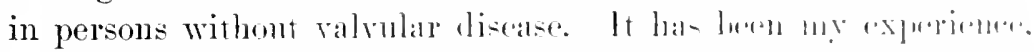

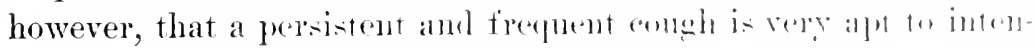

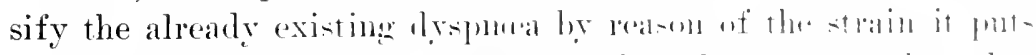

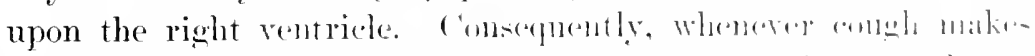

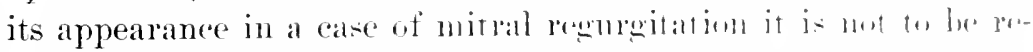
garded as of no importane ambl likely to " weall wt." It maly

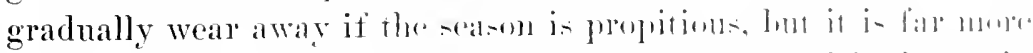

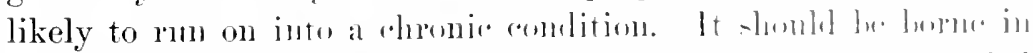

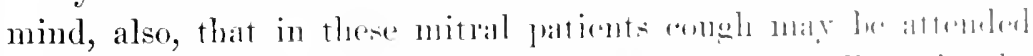

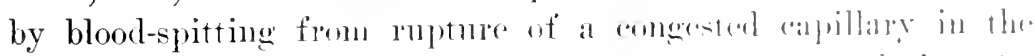

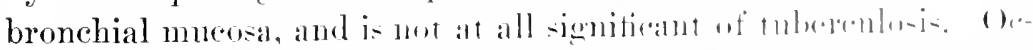
casionally congh is induced hy musnal exertim on exeitement, and 
is. of contrese whe to the irritation of excessive pulmonary hyperanlia. In two instanees coming moler my notice it was attended by a profuse sorous trothy expectoration that betokened acute unlema of the lungs. In both these cianes the attack sulsided without tratment after the patients had lrataken thenselves to absolute phreical repose. Sueh attalek are nut without danger, and often necessitate conergetic treatment.

The following case is an example of the oceurrence of hemoptrisis in mitral regurgitation. In March, 1901, a tall, slender

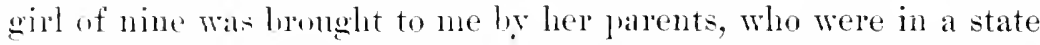
of wreat alarm heeanse of her having spit up a little blood a few dises previnusly. One of the child's maternal uncles was in Colorato on acconnt of his longs, and eonsequently it was feared the little paticnt might be developing pulmonary tuberculosis. It was ascertained that there lad been no antecedent cough, but that the himuptrsis, which had occurred more than onee, had followed upon rather more than the nsial amount of ruming. There was a history of measles, but not of scarlet fever and not of rheumatism, although the child had in earlier years suffered a good deal from pains in her legs, and been wont to cry out in her sleep from night terrors. C Jon examination I readily discovered a lond, blowing systolic apex-murmur that was propagated to the back. The heart was unmistakably enlarged and the liver was palpable. As a result of these findings and in the light of the history I had no hesitation in prononucing the case one of mitral regurgitation, probably of rhemmatic origin, and also in explaining to the parents that the smptom eansing their alarm did not denote tuberculosis. They were told that it was the result of eongestion of the lungs lronght on lyc a degree of physical effort that was too much for her damaged heart. It may le added that the knowledge of their child's ralvular lesion did not serve to allay their apprehension. This case also illustrates how remarkalily uneonscions of dyspnea children often are who have nitral insuffieiencr, for this ehild not only was fond of rmuning and playing hard, but said sneh -1wits did not make leer feel bad or get out of breath.

In cases of imperfect compensation there are likely to be symptroms of stakis within the resorels of the ahdomen as well as of the lung. l)isopders of appetitr and digestion are now quite common. Some patients lose their appetite altogether, or if they feel 


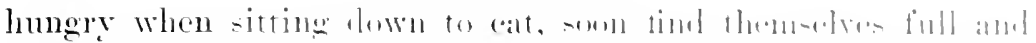

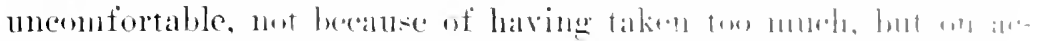

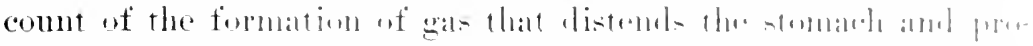

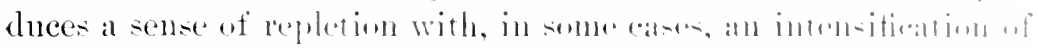

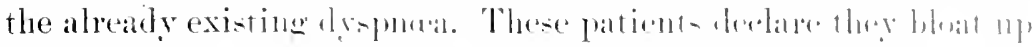

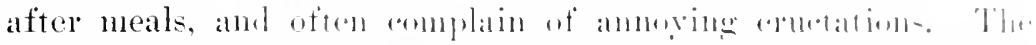

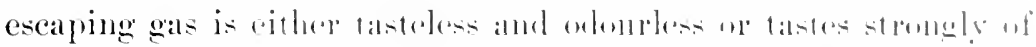

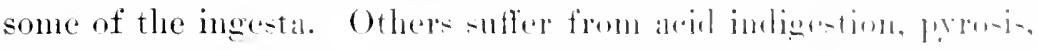

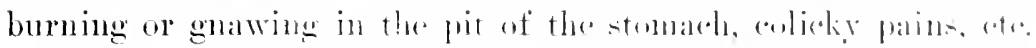
Some patients ale anstipated ame ammered ly Hatulemer, whitu.

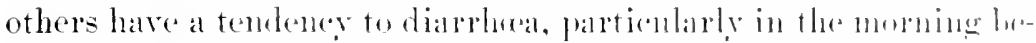
fore breakfast. In a few instances I hare known a peritalile lum-

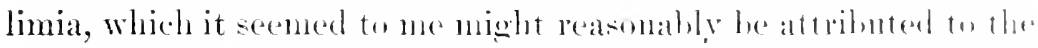

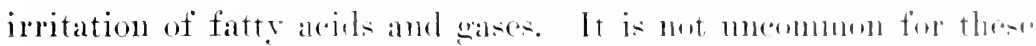

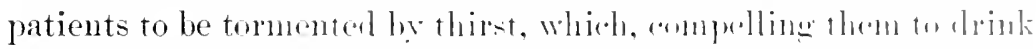

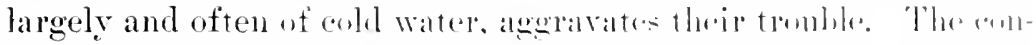

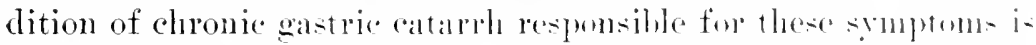

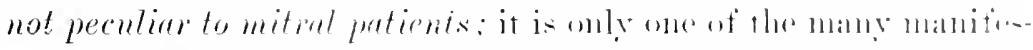

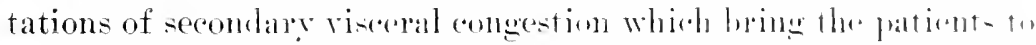
the physician. The digestive defeet is often the result of dietertid. indiscretions, ret their mitral leak predispess them to suffor form errors in diet which would not affeet then were hley leallhy.

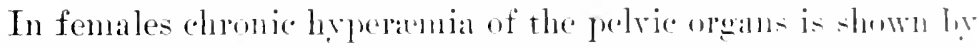
lencorrloca and menstrual derangements. In some menstruations

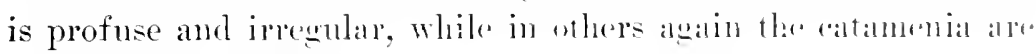
scanty or suppresiod.

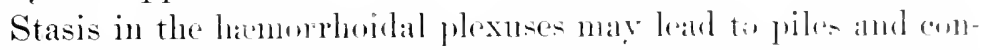
sequent constipation. Rional angestion is shown by santr, light

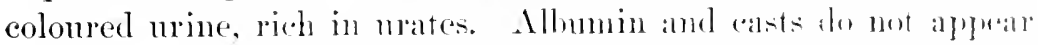
as a rule until in the latter stage of the valvular direaler, when dropsy las come on.

Examination of the liver in this intemendiate stage of the

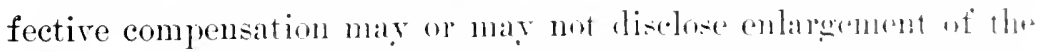
organ. In nuost instances hepatice dulness is fommd to batrle at finger's breadth or so below the inferior marein of the rihs, whil. the lower border of the orean ferels smonth, rumbled, and tirne.

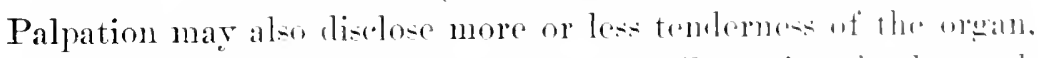
so that the patient winces and involuntarily resists finther palpation. If the congestion has affected the hilialy passigres and 
hel to their eatartat orelusion, more or less complete, this may be shown by ieterns. As a rule this is slight, and combined with anpillary conesestion prodnces a muddy lune of the falce.

In the most of these calses of partially destroped compensation there is not atetual eyanosis, but instead the lijes and cheeks present a dark-red colom that by the minitiated is very alt to be mistaken for an appealumee of rudly health. If the hands and arms are inserecterl their superficial reins are seen to stand forth too prominently, while hy night the ankles display, if not actual pitting, at last a legree of puttiness and tension which is but a little way remored from anlema and hetokens maked capillary stasis.

The patients now find their hreath nncomfortably short on hurey, and even when they walk leismely they are conseions of slight lneathlessness. In addition, they notice a feeling of fulness or tightness in the heartregiom, which if not actually painful is rery akin to pain. They tind also that they hecome fatigned more easily than formerly, and that talking requires more effort than is quite comfortahle, while if ther converse during walking they pant noticeahly. Eftorts hefore endured without conseions effect now throw them into perspiration, and make them glad to sit or perhaps lie down and rest. Such rymptoms constitute the earliest evidence of candiac inalequacy, and if not heeded will go on to srmptoms of positive loss of compensation.

In some persons in this stage there is marked tendency to drowsiness after neals or whenerer they sit quiet and strive to fix their attention on a sreaker. This is especially noticeable if the atmosphere is elow and hot. Some persons find the heat and "losenes produce a feeling of faintnes or suffocation which necescitates their seeking the open air. Sleep is heary, with frightful lleams, or there $\mathrm{i}$ - in-ommia, so that in the morning the patients are intensely weary and muefrehed. Tleadaches are not meomnon in this stage, and for the most part are dull frontal pains accompanied by a sense of mental weariness and remfusion.

A sill more adranced stage of lost compensation is shown by

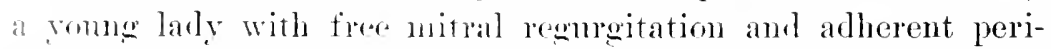
"arlium whom I have molde obsuation at this present writing. The thin along the shaft of ear.le tilia can be inclented slightly by fim preswere: the extemal jumblats stand forth as large as my little finger, are painful, and show the positive venous pulse of 


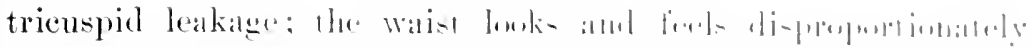

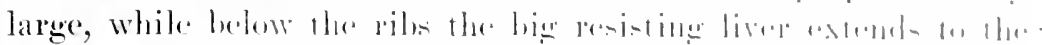

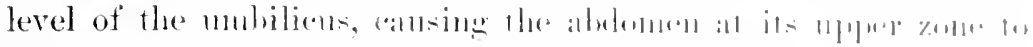

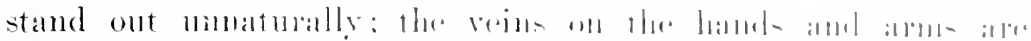

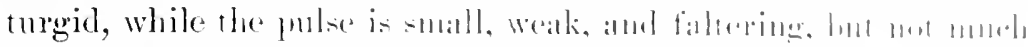

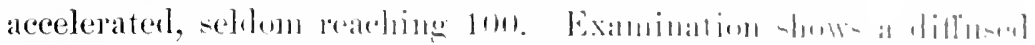

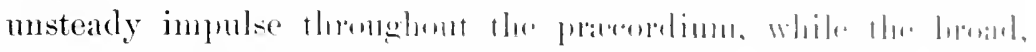

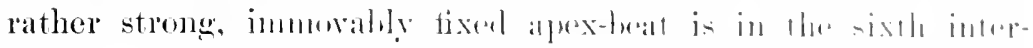
space, almost to the leti anterion axillany line: aldenlute andian

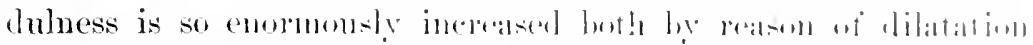

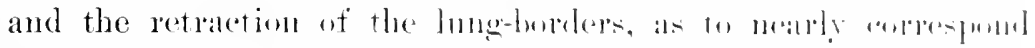

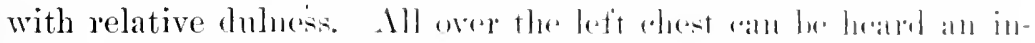

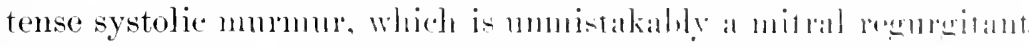
one, while to the right of the lower gurtion of the stemmon is a

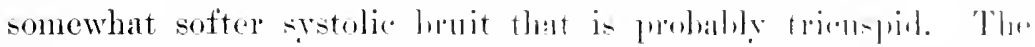

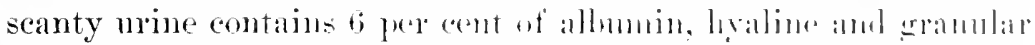
casts, while menses have been alment for the last six momtls. In the way of sulfective symptoms there are the following: Shortness of breath when walking on comversing, an oreasionlal short, dry congh, pain in the distended jugnlats, when the-e alde $11111-11-$ ally full, a sensation of fulness and tightomes in the rexion of the

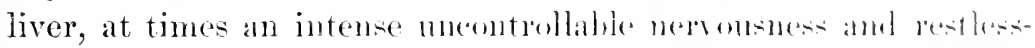

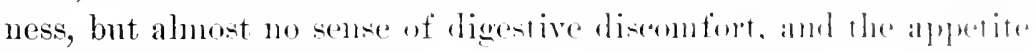
is remarkably goud.

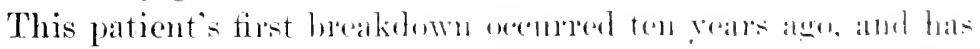

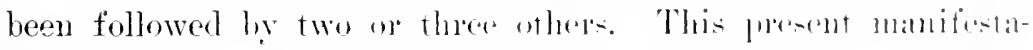

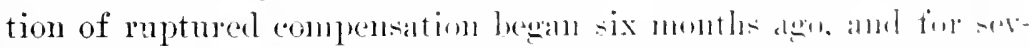
eral months was so had that she hald ascites. denpery of the ankles.

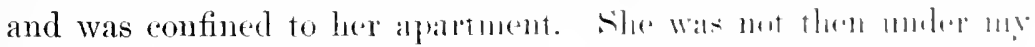
care, but was at her homle in an aljoining state. In this atore

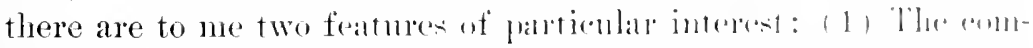

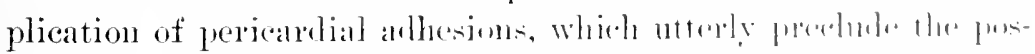

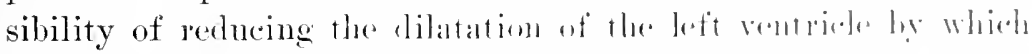

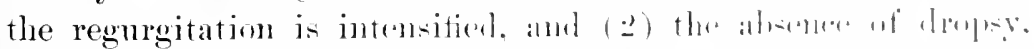

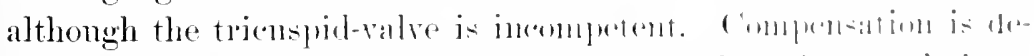

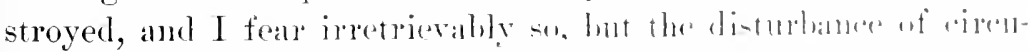

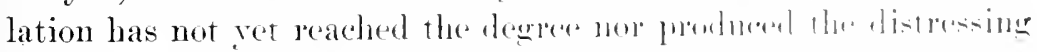

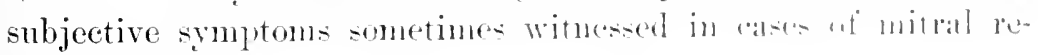
gurgitation. 
When in this disease comprensetion is wholly gone, there is a marked angraration of all the ohjectire and subjectire synptoms that have been described. There are now evidences of extreme stanis. Inopsy is generally a pronounced feature, and in many calses dominates the seene. Begimning at the ankles, it ereeps upwillel mutil it invelves the integument of the trunk, and it may he of the uppere extremities. There is also in this stage transudatim into the serons carvities, ascites, hydrothorax, and pulmonary atema. This condition leats to arthopmeal, congh, and frothy or even hlones sputum. I reeall a female who in this condition of hopeless suffering was sitting on leer beel, supporting her elbows on her knees and her face in her hands, and was conghing pure bloot. She had heen in this plight for days and had abandoned hope, having beenteld he more than we doctor that her condition was hopeless. Three month thereafter she was walking about the honse free from culcula. This car is described more fully in the chapter om Treatment. Another female patient who now visits my office was, four years ago, so dropsical that she appeared water-logged, and for six weeks had heen olliged to get what sleep she could in an easy ehair and resting her arms on a talule in front of her.

When stanis reaches such an extreme degree it has generally been preceded by dilatation of the right ventricle and signs of relative trienspis insutticiency. This condition of the right heart may and usially dres precede the dropsy, lut celema presents such differences in extent and time of appearance that something more than mere staris is required for its production. Accordingly, it is now believed that serons transulation takes place when the eapillary walls become almomally permeable or there is a state of hydramial. In sme cales donbtless the kidneys have lost their alility to edininate the sodimm chlorinle of the blood the same as in nephriti. In this erent the anlema is soft and pits far more calsily than when nechanieal interferenee with the eirenlation is the chief factor.

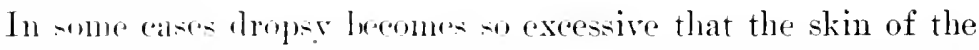
leg: beennes reel and shining, or eren forms blebs, which, bursting, permit the sermm to arze forth, and thus diminish the tension of the surmunding pallt. Fuder such ciremustances the nutrition of

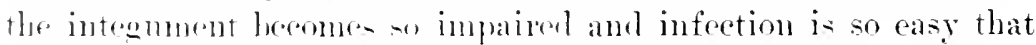
a -inple -rerateh or alurition mily - 


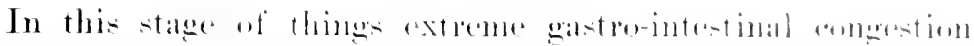

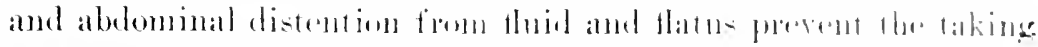

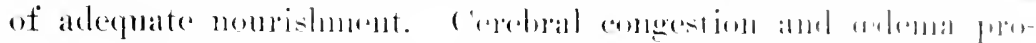

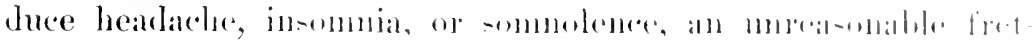

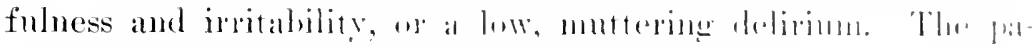

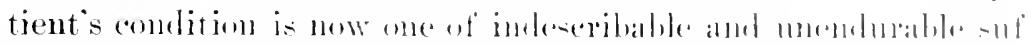

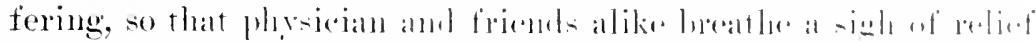

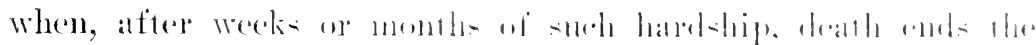
struggle.

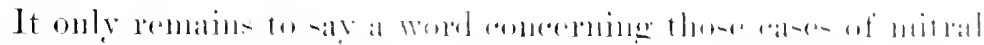

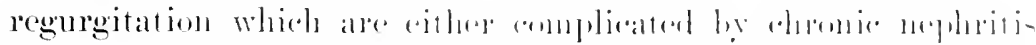

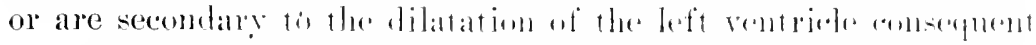

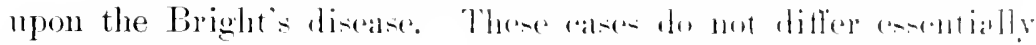

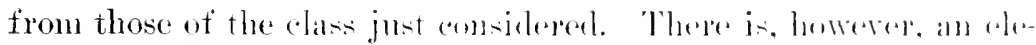

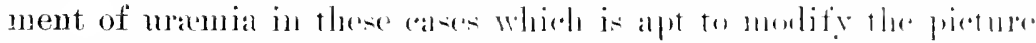

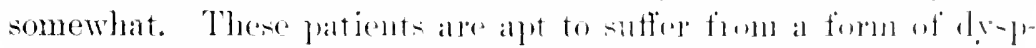

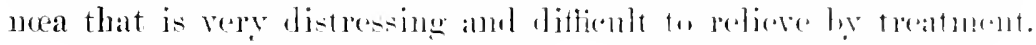

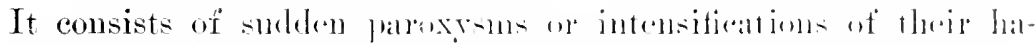

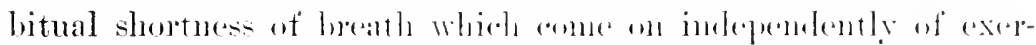

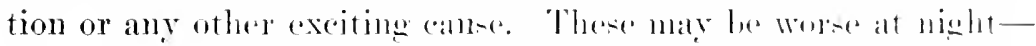

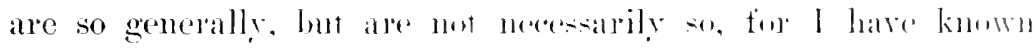

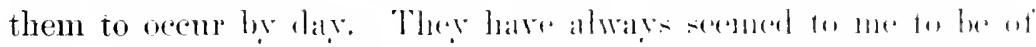

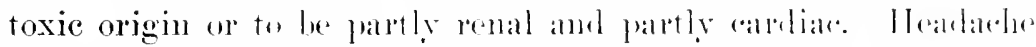
and nansea ale also likely to torment the patient. andel inllamma-

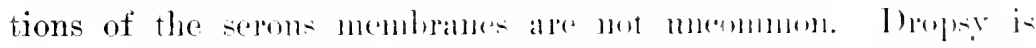

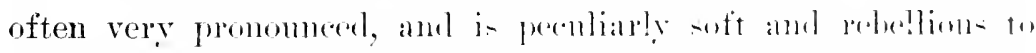

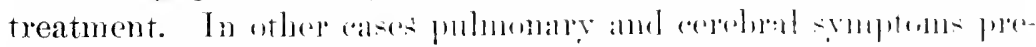

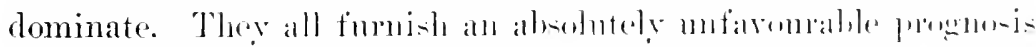

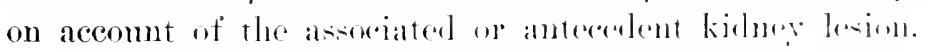

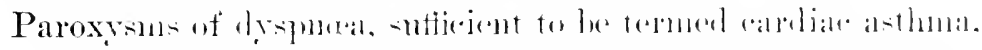

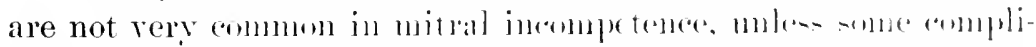

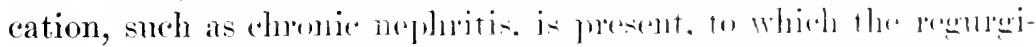

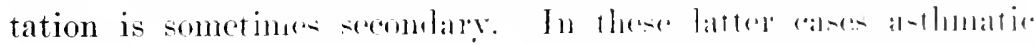

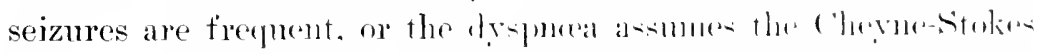

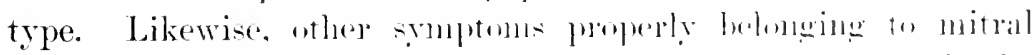

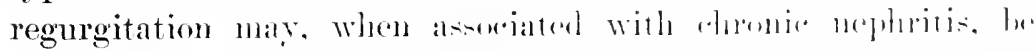
modified by manic mandestations. There mily be bery distrening nausea and romiting, and the plysician na! le al a loss to

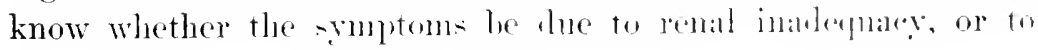


fatsive congestion of the stomath depending upon the regurgitaltiult.

It in a given case of mitral regurgitation ascites appears prior to or independent of anasureal, it is due to some compliattin, and in my exprerience this has most trequently proved to the atherent pepicaldimm. These are the cases sometimes describul as poculo-atrophice eirrhosis of the liver.

Embolism from the detachmont of a resetation is not common in mitral insulleciency muless it be complicated with acute endoanditis, yet this mutoward event may oceur, and then produces svouptoms depenting mpon the orean in which the embolus is arrested. It this be the kidney, there is likely to be bloody urine, and pet it is not mommon to discower post-mortem eridences of infarets prohlued by emboli of slleh minute size as to have escaped deteretions during life.

('orebral cubolism produees simptoms too characteristic to corape notice. As the left midelle cerebral artery is the one most (*)mmonly phoged, it is followed hy aphasia and right-sided hemiplegia. An embolus entering the hepatic artery produces acute icterus and smptoms closely rescubling acute yellow atrophy of the liver. In the ease of the spleen, the smblen, sharp pain is likely to le followed by tenderness and enlargement of the oroan. If an artery of me of the extremities is thus occheded, chatrateristic pain is followed by lose of pulsation in the artery below the seat of embolism, by weakness, numbness, coldness, and parathesia, and eren by gangrene of the limb, if the main artery happens to he plugered. L'slally, luwever, these symptoms gradnally disupurat with the establishuent of adecpuate collateral cir(•ulation. A l,y no mans meommon effect of the terminal stage of mitral regurgitation is the oecurence of pulnomary infarets she to the loulguent in the julmomary rapillaries of minute frag-

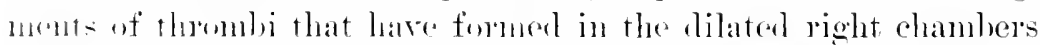
of the lieart. Pain in the affectrol lume may or may not be felt, but

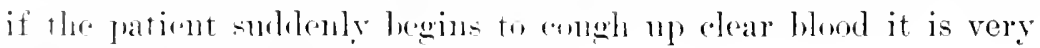
-n-pir.ious of pulumaly infaretion.

Yory exeeptionally, a mass of eomsirlerable size may be swept coff from the capliac thromlm- and ontering the pulnonary artery or one uf it- lanere branches, may produce instantaneous dyspnoea amit speorly death. 


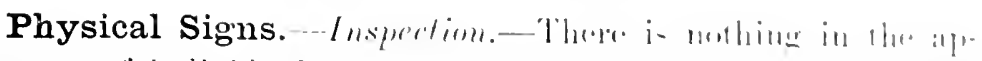

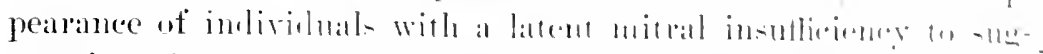

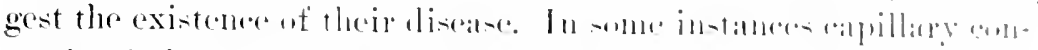

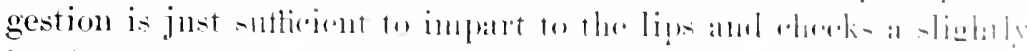

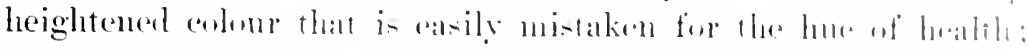

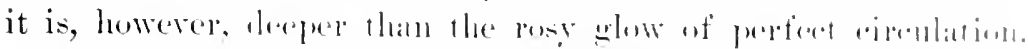

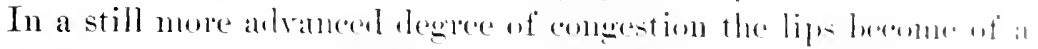
bluish or even purplish colour, the eapillatrien of the files alle in-

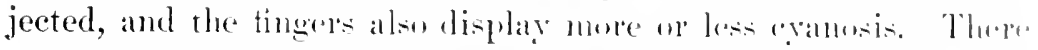
is, however, nothing in this alperature to indicate more than inpeded circulation, and henee it is not peculian to mitral renureitation.

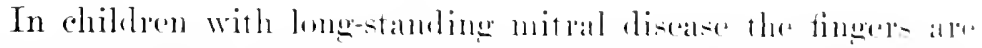
apt to be clubberl, the stature stmuted. the shomlders stompinge and

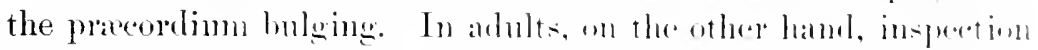
of the cardiale area reveals no alteration of the kind -ren in children.

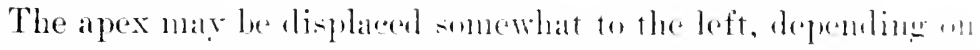
the degree of left-ventricle lyeperoply, and if serions dilatation is not present in hrealer and strenger than in health. If the right

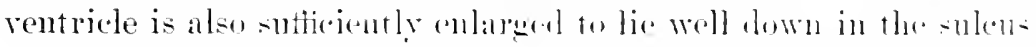

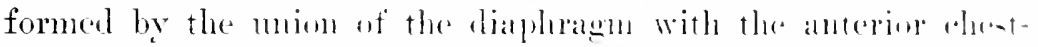

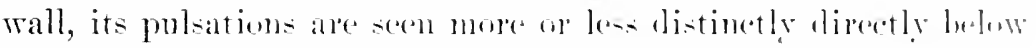
the ensiform appendix. This eprigastrir pulsution forms an im-

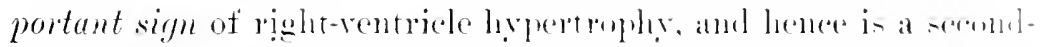

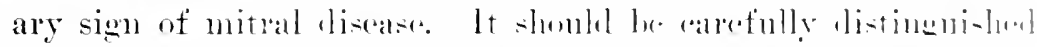

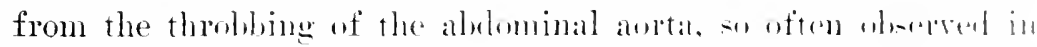
this situation in neurotic indiviluals with thin ahdoninal panteme.

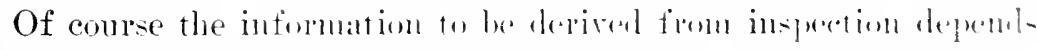

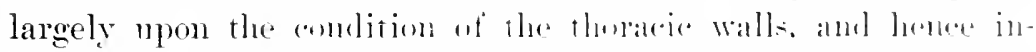

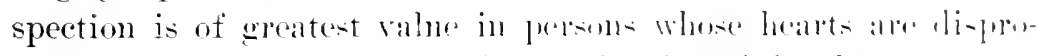
portionately larese as compared with the sime of the chest.

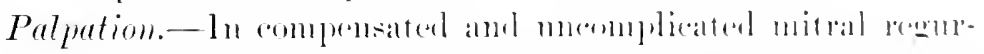

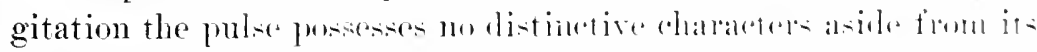

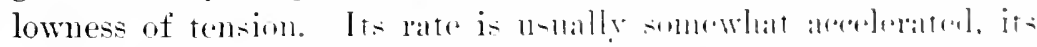

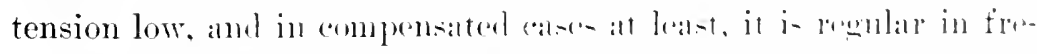

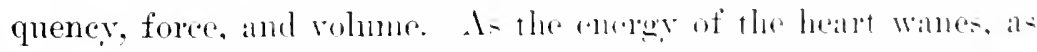

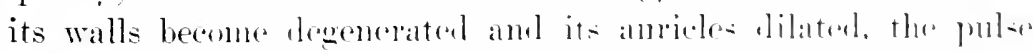
grows strikingly irregnlar and internitlent, the pul-e-wares dif- 
fering from each other in size and strength, coming at meven distances, and often dropping ont altogether even when the heartbeats are not themselves intermittent (Fig. 38). Such a pulse is exceelingly difficult to eomnt, and if subjected to a little pressure by the finger, for the purpose of laving its characters brought

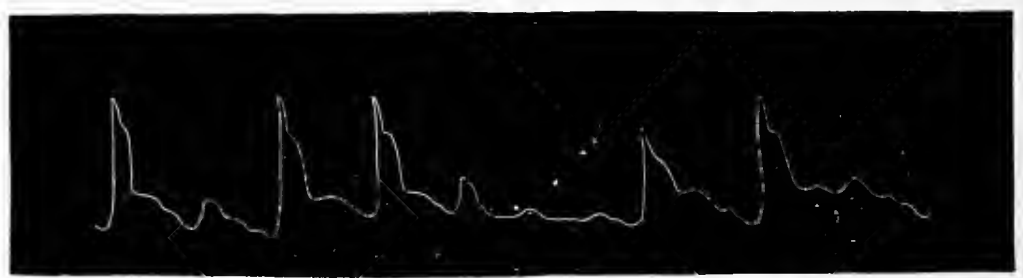

Fig. 38. - Spuygmogram of Case of Mlitral Reglrgitation, showing IRREgLlarity of P'tLse.

(Personal observation.) Enlarged.

out more distinctly, it lisappears from beneath the palpating finger in a manner that makes it very elusive. This extreme irregularity of the pulse is most frequent when regurgitation is combined with stenosis or an adherent pericardiun.

The pulse in the two wrists is generally equal, but cases have been described in which the right was distinctly smaller than the left, owing to relative tricuspid insufficiency and eonsequent pressure of the dilated right anricle on the subclavian artery. Balfour states that if the arm is elevated the peemliar characters of the pmle-i. e., its irregularity and lowness of tension-are brought out more distinetly.

Palpation of the pracordia confirms the information obtained by the ere, but in addition enables one to better appreciate the strength of cardiac contrartions. It may also deteet thrill or pulsations that cannot be pereeived by inspection. Palpation is often a valuable means of asertaining the size of the heart, particularly in females in whom exce-ive mammary development may prevent arematr perenssion. By pressing the fingers gently get firmly into the interental sace bencath the breast one can ascertain the powition of the apex-ineat, and thus julge of the size of the left rentricle.

Authorities differ as regards the existence of a thrill at the npex in cases of pure and uncomplicated mitral regurgitation. Whan, however, such a thrill is present it is systolie, and felt 
with greatest intensity at the immenliate salt of alus-impulse,

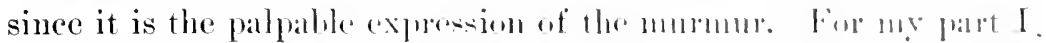

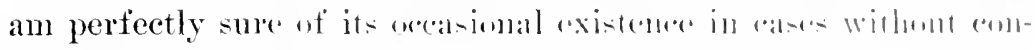
joined mitral stemosic.

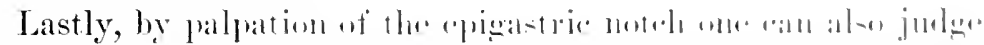

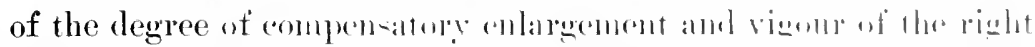

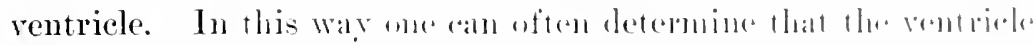

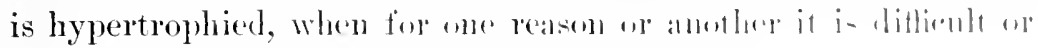

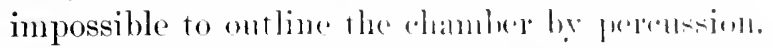

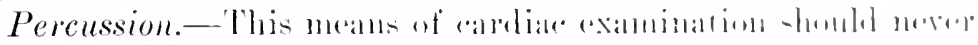

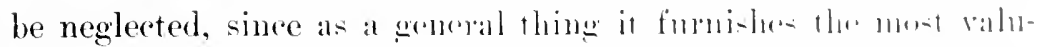

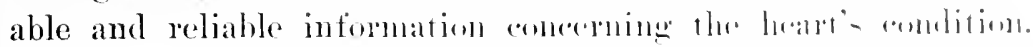

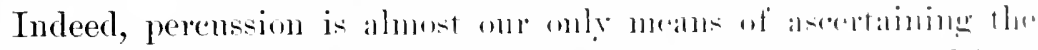
size and shape of the heart, and hemee of leandne what and how

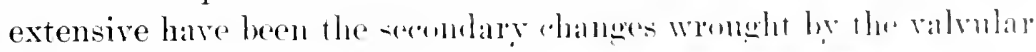
elefect. It in the lesion m. under consideration jerencsion does not detect incrence of absolnte or relative luluess to the right and downsard, the inference is warranted, even though there be an intense systolic hroit, that the leak is not free, or that heing free it has neverthelest hern perfectly compensated. In most cases of mitral reangitation, hovever, the lesion has led to enlarement of the right ventricle, and in such an event, deep-seated if $110 t+11 \mu^{m} 1-$ ficial dulness is incoratsont to

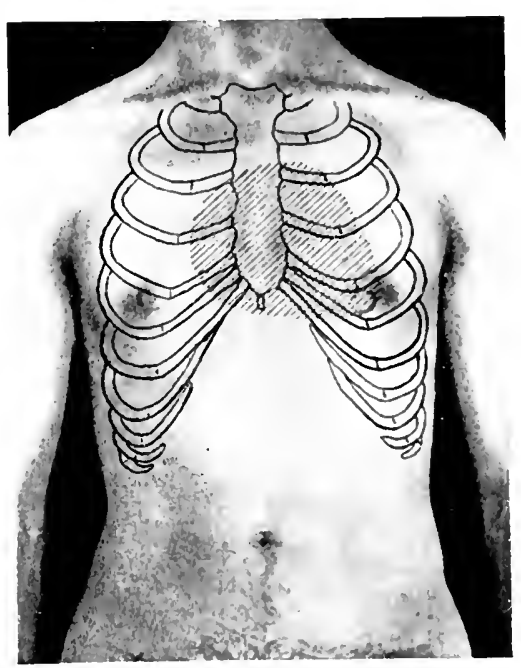

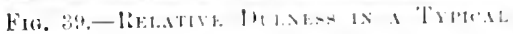

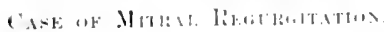

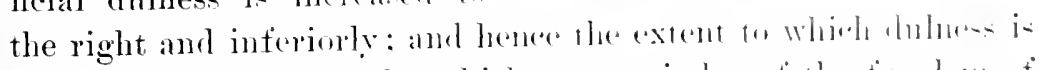

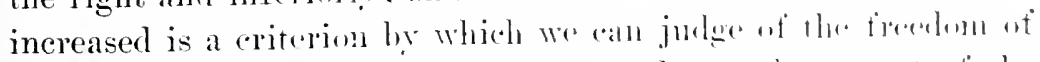

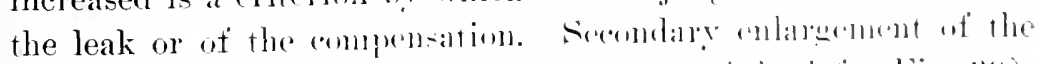

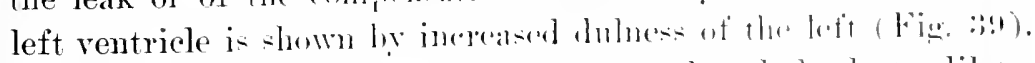

Mitral regurgitation, it will he remenubereal, loads to dilatit-

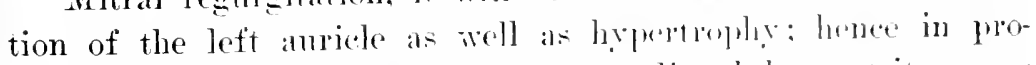
nounced eases the ontline of the dere cardias duluess at its upper 
and onter toruer, so to speak, is broal and romeled, corresponding to the enlatemenent of the ambele. It is not always easy to determine this alteration of shape ly perension; yet if tim perenssion is marle. and the chestrall is thin and rielding, it is sometimes pussible to determine the extent to which the left an icle has beren atfereded by the resurevitation.

Insentulion.-This forms a vory valuable means of cardiac examination. for withont the information thus obtained one can-

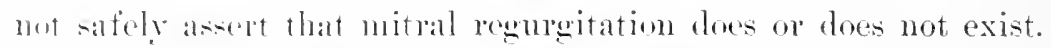
It should not be relied upom to the exclusion of other methods of investigation, howerer, for reasons that will be stated presently. The anscultatory evidence of valvular disease lies in certain aconstic phenomena which are produced hy soniferoms enrents in the blonl-stream, and are called mmrmms. It is plain that many different factors inthence the characeter of a mmmur, and that if reliable information is to be deriven from the study of a murmor

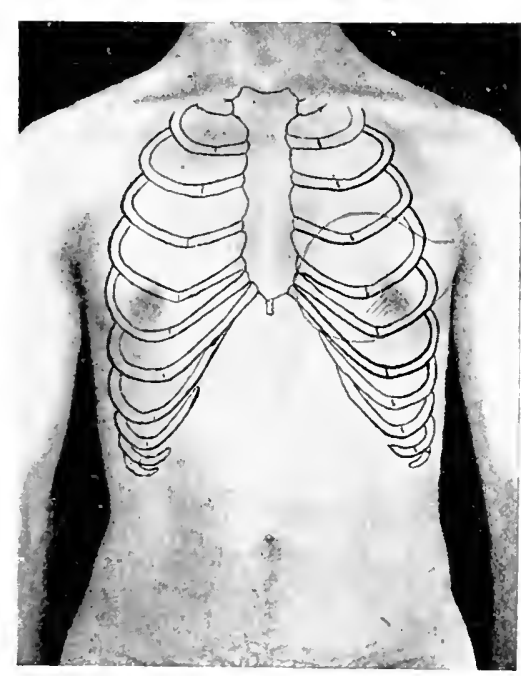

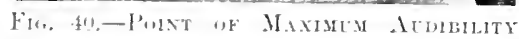

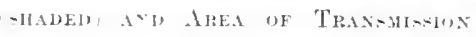
(o'thasein) of Mithal Reficmitaxt Mchisu. the characters pecoliar to each nust be inderstoon.

The anscultatory indication of mitral regurgitation, then, is a systolic mumume heard with maximmm intensity in the mitral area-i.e., at or clome to the apex-beat (Fig. 40). Such a bruit is not. howerer, an invariable sign of mitral incompetenee, simer it may be accidental, and hence there are other farot- concerning a mitral reenregitant mmomur which must lo mulerstond.

The monmur is systolic becatusc prodneed during the contratetion of the ventricles, and thepefere it is strietly synehromous with the first somul, althongle it mot infrepmently lasts a little

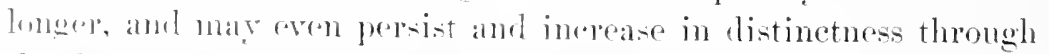

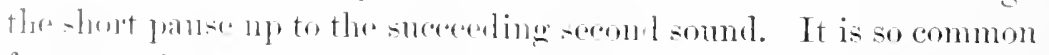
for -ende degree of obstruetion to be combined with regurgitation 


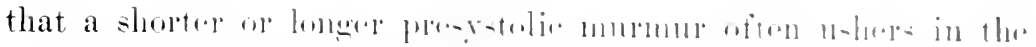

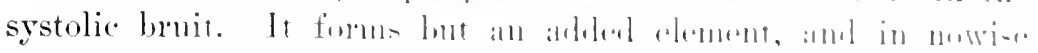

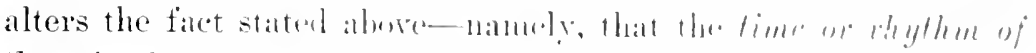

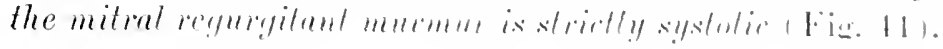

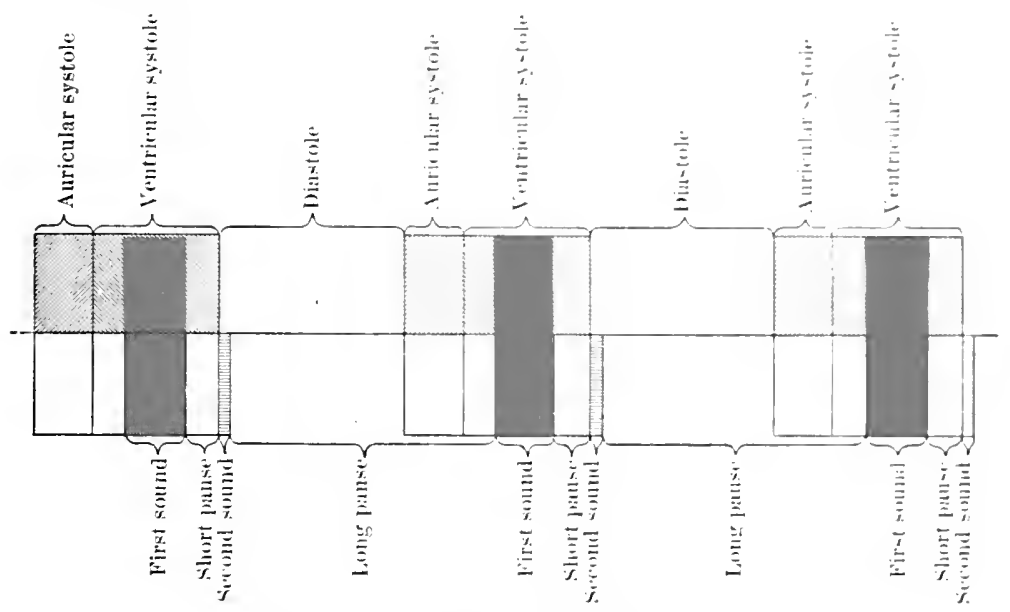

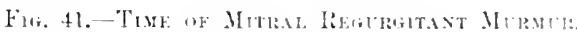

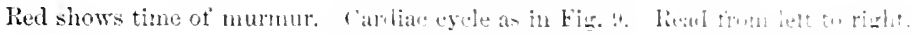

The next element of importaner is its puntion of maximum

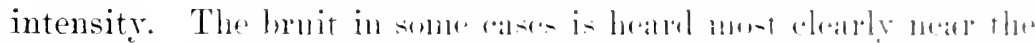
anatomic situation of the mitral ralre-i. e. alt the lorol af the

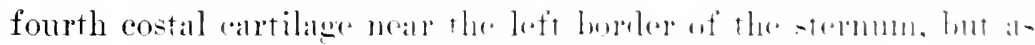

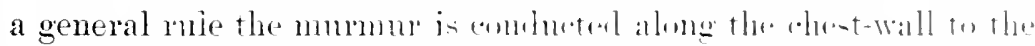

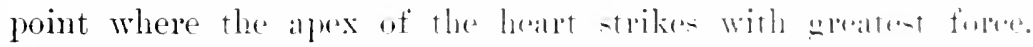

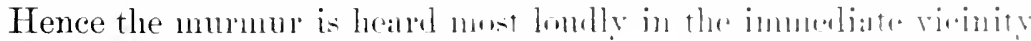

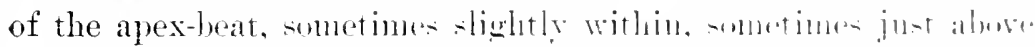

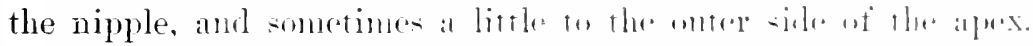

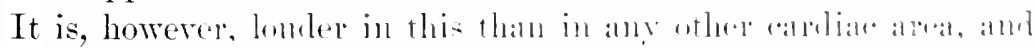

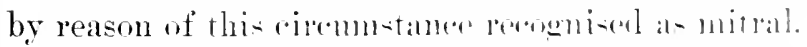

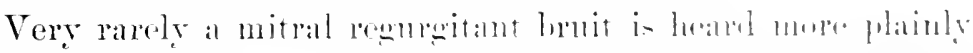

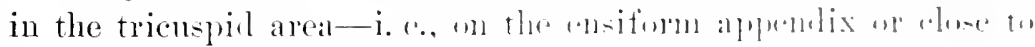
its left margin-when it is likely on he mi-laken for a trientiol bruit. I have known such a mistake to be makle in mole than onte

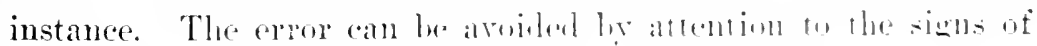

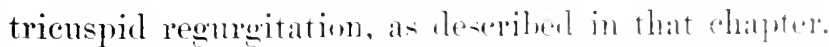

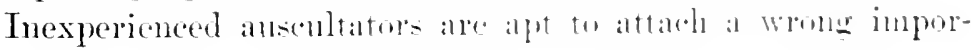


tance to the intensity and the quality of a murmur. It goes without sarving that all possible diffrences in these respeets are to be found in mitral systolic murmurs depending upon conditions governing their generation. Xeither the londness nor the quality of a hruit furnishes any evidenee per se as to the gravity of the lesions. I rery intense musical mmonm may be podnced by the blood-strean being forribly driven thromgh a small aperture, and

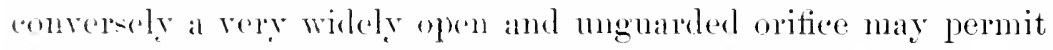
the blond to lonurgitate so easily and noiselessly that only a very soft, sancely andible mumur is generated. Hence neither intensity nor quality of a murmur is of importance in determining whether or not it is mitral; ther only facilitate the detection of the murmur, and sometimes aid us in determining the seriousness of the lesion.

Furthermore, the intensity of the murmur is governed by wher coremustances than the leak itself. The bruit of mitral remaigitation is generally lomdest during energetic action of the heart, hence during excitement and immediately after exertion. It is conseguently brought ont clearly by having the patient jump about, swing the arms violently, or do sonething else that causes the heart to beat rapidly and enerectically. By sneh a procedure it is often prosible to deteet a mitral hruit which before was inandible or $-\infty$ indefinite as to have left the examiner in doubt of its existence.

The position of the patient's body also influences the audibility of the mmmum. It is in mont ases hearel most plainly when the patient sits or stands, but I have frequently seen cases in which it came out far more distinedly in the dorsal decubitus, whieh permitted the heart to beat more forcibly becanse more slowly. Consequently, it should he an invariable rule to ausenltate a suspected casc of mitral insufficincy, and indeed any suspected case of cardiar disease, in all threr positions. It will often protect one against a serions blunder in diagnosis.

Mitral systolic mommos are nsually spoken of as blowing and soft. They are as a matter of fact softer than direct murmurs of stenosis. hut they are ly no means always soft. They may be lutrsh and rasping. or filing, grating, sawing, whistling, etc., in whirh event they are designated as musical, a character of pathologionl hut seareely diagnostic interest. 


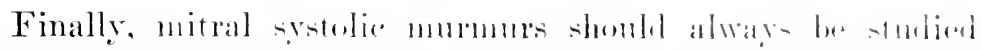

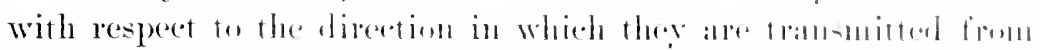

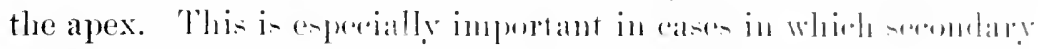

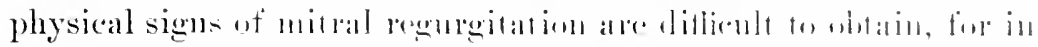

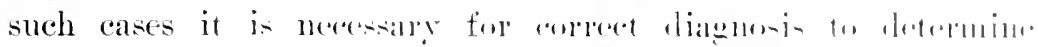
whether or not the apex sytolir brut is an aceidental nur. Sur.h

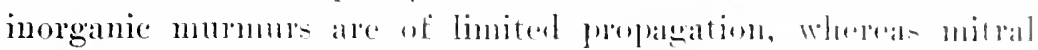

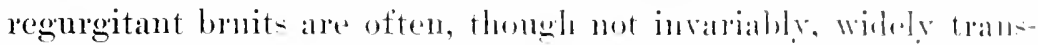

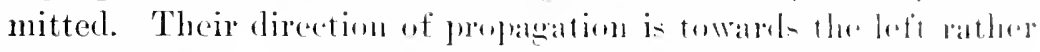

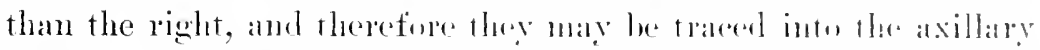
region, or, as sometines halpens, even on to the bark. It is

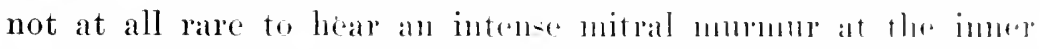

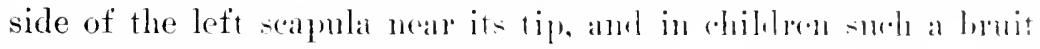

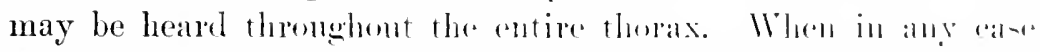

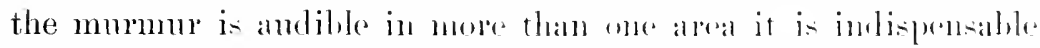

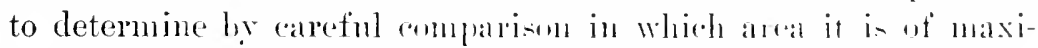

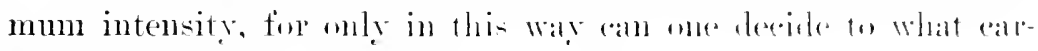
diac area the $11 m m m m$ belmos.

One is not to content himselt with stmlying only the mummur he must also corefully anscullate the sererol heort-sommels. It the

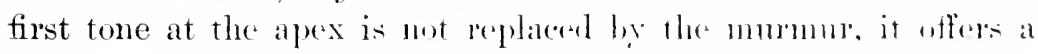

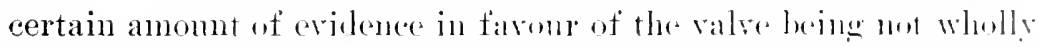
destroyed, but alble to still partially clese the orition. It, an the

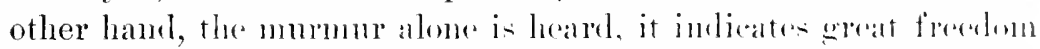
of regurgitation. Then one shomld note the deguese of aleentuation

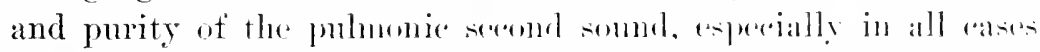

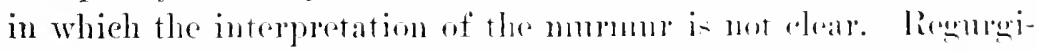

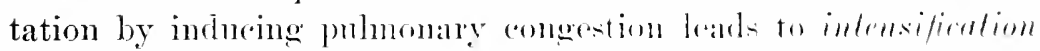

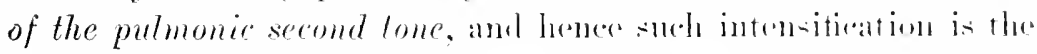
earliest recognisable secomdary plysieal sion of mitral insutti-

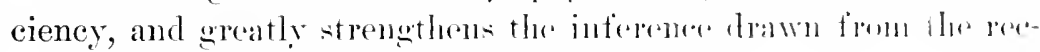
ognition of a mminme.

Diagnosis. - The diagnosis of mitual rewuroitation in mot diffi-

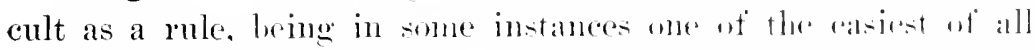
valvular lesiom to make ont. When, howerer, llw laak is slight, the murmur obscore, and the secondaty deanges in the heart and general circulation insigniticant, its diannus may be anything but easy. It is also oceasionally diffienlt when there is dropser, a rapid, tumultums aletion of the healt, extensive dilatation, and 
serons alemmulation in the plemal eavities. One may then make a diagnosis of the comelition with reservation, and wait for treatment to ceatr mp the case. Attention to the secondary physical signs will msmally lulp out amazingly mulor such eiremmstances.

The histery of the patient is also of great importance, not alone to the diagnosis of mitral insufticieney, but to the reeognition of the etiology, and therehy to the relative or organie nature of the resuresitation. Its aravity is to be letermined by the secondary effects which the heart-walls and cavitics have undergone, and by the yresence or absence of symptoms referable to the cardiac discase. Not mutil all this has been aceomplished should the physician pert satisfied, remembering that the detection of a murmur does not constitute a dingnosis.

Prognosis. - In general. it may he stated that mitral regurgitation aftords a more farommale prognosis than does any other valvular dinare, ret in this respect each case is a law unto itself. Furthermore, the prognosis of each case depends upon many different tactor: : (1) On the etiological nature of the defect, (2) its severity, (3) the degree of secomblary effects, $(t)$ the completenes of compunation, and (5) the existence or not of complications, such as cther ralrular lexions and adherent perieardium.

Insufticiency of the mitral ralve from selerosis furnishes as a rule less favourable prognosis than does that of endocarditis, becanse of the progresive temleney of the sclerotic ehange and of the age of the patient, which renders it likely that the myocardium is no longer healthy. If the regurgitation is free. if secoudary hypertophy and dilatation are extensive, if engorgement of the ereneral visecra is alparent, even thongh compensation seems adequate, the prospere of the disease remaining stationary is not suml. If mitral regurentation is mited with defects of other

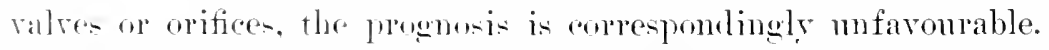
complications on the part of the pericardium and of chronic

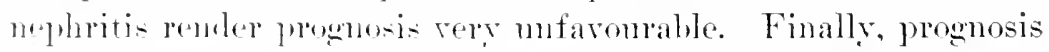
struds in divert ielation to the completeness of the compensation.

The rumbility of this lesim resulting from endocarditis has lefen murle discusifed. and. as pointed ont ly Palfom and others, sems cortainly posible. This is ennsidered particularly true aftra rohoreat.

The inthume of age, sex, orompation, environment, ete, will 


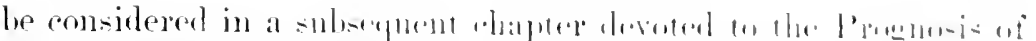
Valvular l)iscace in (indrinal.

Mode and Causes of Death.- I fillinll will munmpli-

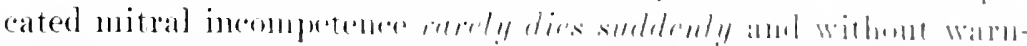

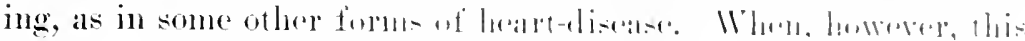

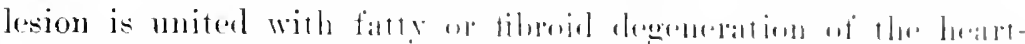

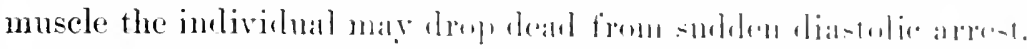

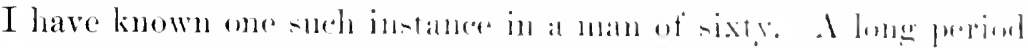

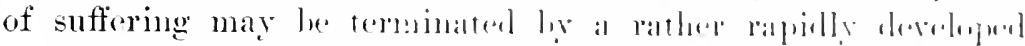

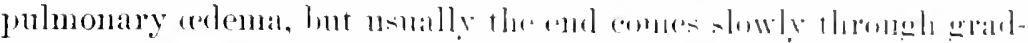

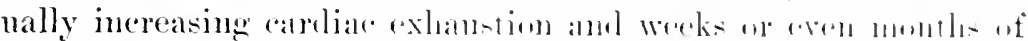
most distressing spruiptoms.

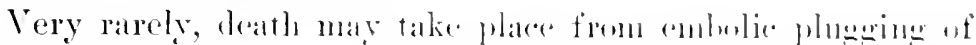

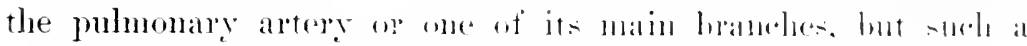

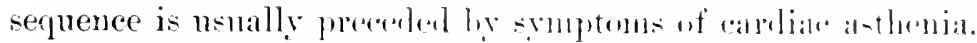

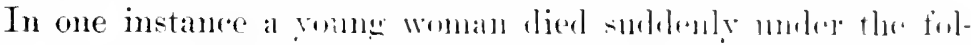

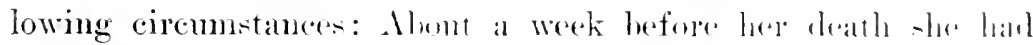

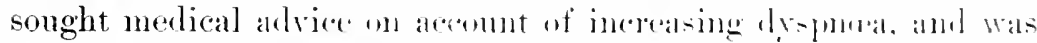

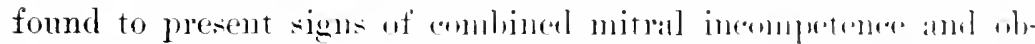

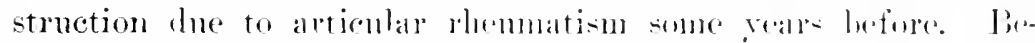

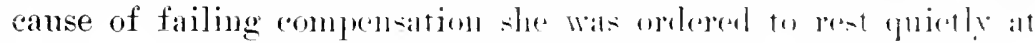

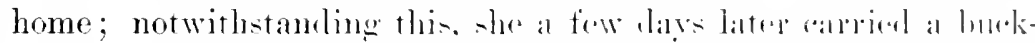

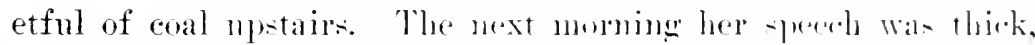

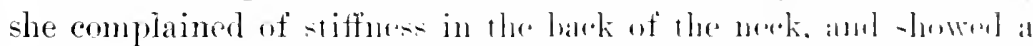

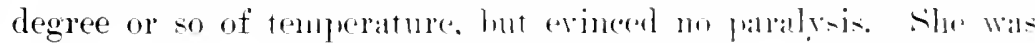

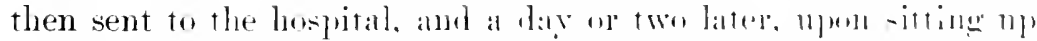

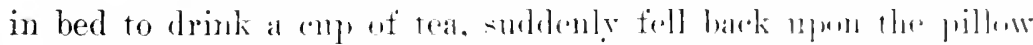

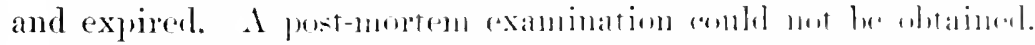

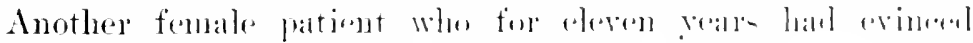

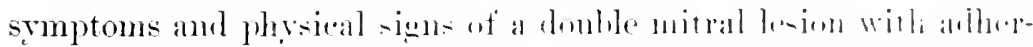

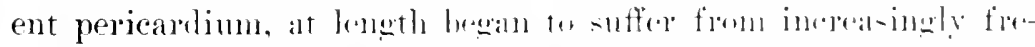

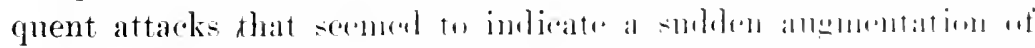

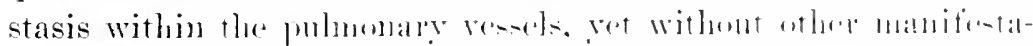

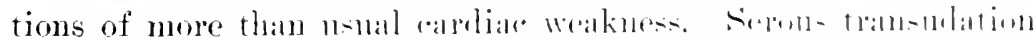

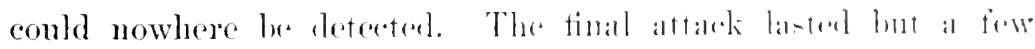

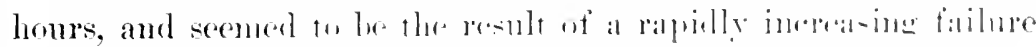

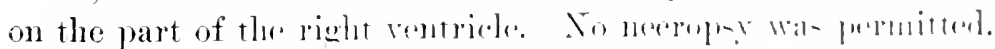

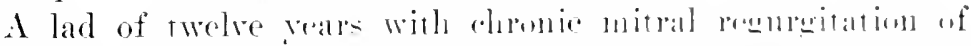

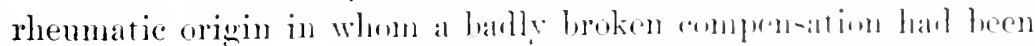


partially rentured. and whe a few weeks before death seemed to have contrateded a fresh inflammation of the mitral orifice, arose fremb bed ealy one morning to palse urine; he had scareely made the attempt when he fell on his pillow in a condition that alarmed his nure. Two henrs later I fomml him partly unconseions, and with a molerately stow and irregular pulse. He wals pronounced

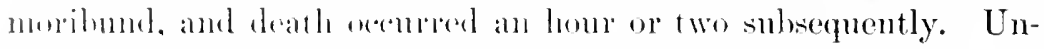

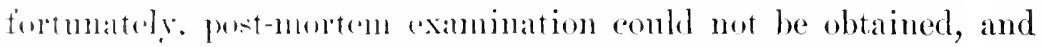

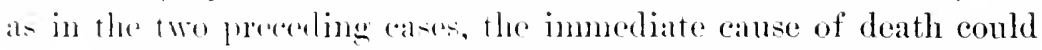
nnly he bonjectumel. It was probably due to an acute overdistention of the heart, learling to gradual patralysis.

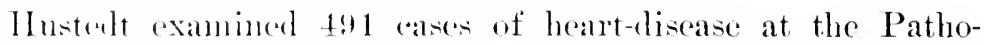
legical Institute at liel, with a view to determining the causes of keath. Of 1 is calses of mitral insufficiency, without associated earliace lesinns, le fomml the following canses of death: Cardiac

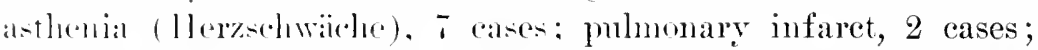
apuplexy due to cmbolism, 1 ase, while in the other 5 death was lue te some alecidental or interemrent affection, such as nephritis 1, peritonitis 2., malasmo 1, pulmonary collapse 1. 


\section{('Ildopli v'l}

\section{MITRAL STENOSIS}

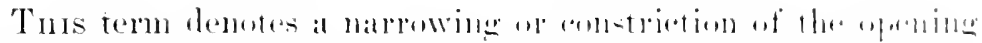

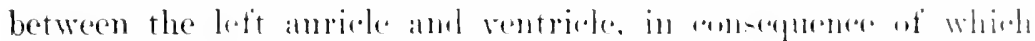
there is an obstenetion to the fires thew of hlent from the formen

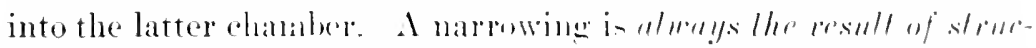

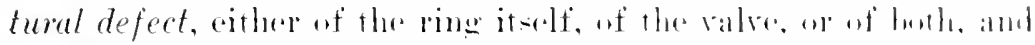

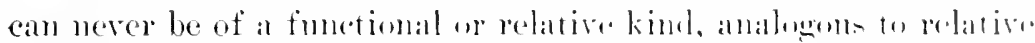

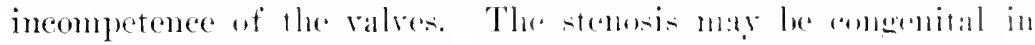

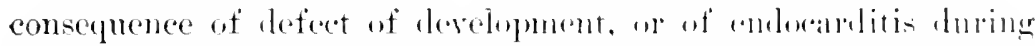

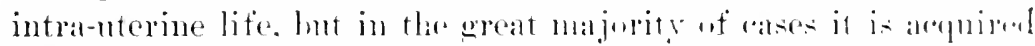

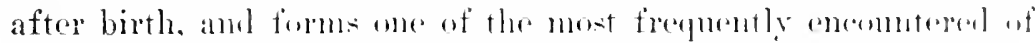
all ralvular lesions.

Morbid Anatomy. - In a well-markerl rise of mitral strono-

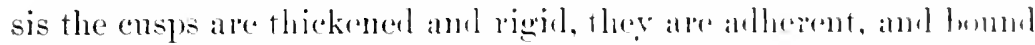

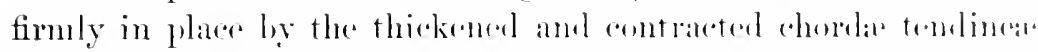

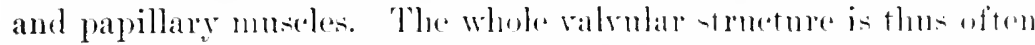

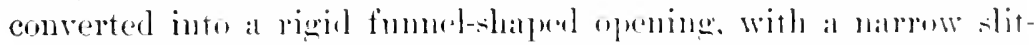
like extremity of size seareoly to anhit a small probe. This is the

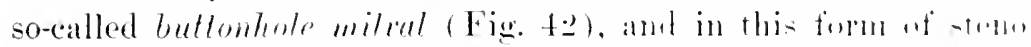

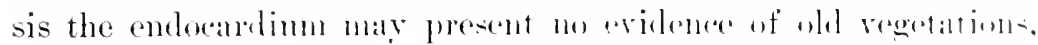

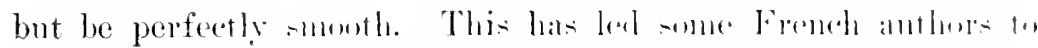

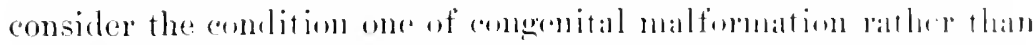
of rhematic origin. Samsom, on the wther hame, thinks it dur tw

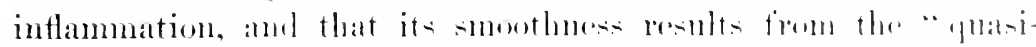

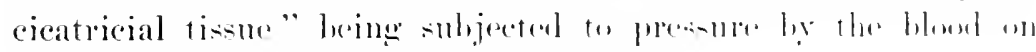
both its auricolal ams rentricular aspert.

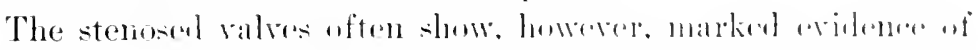

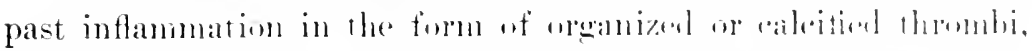

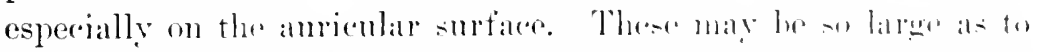

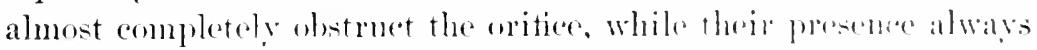
leads to shrinkige and defomity of the valse and almut alwalys 


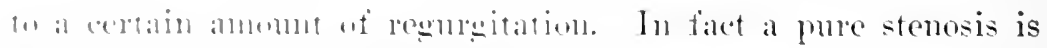

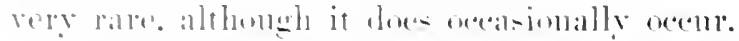

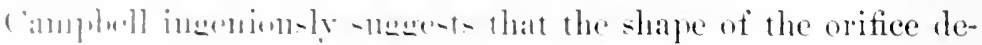

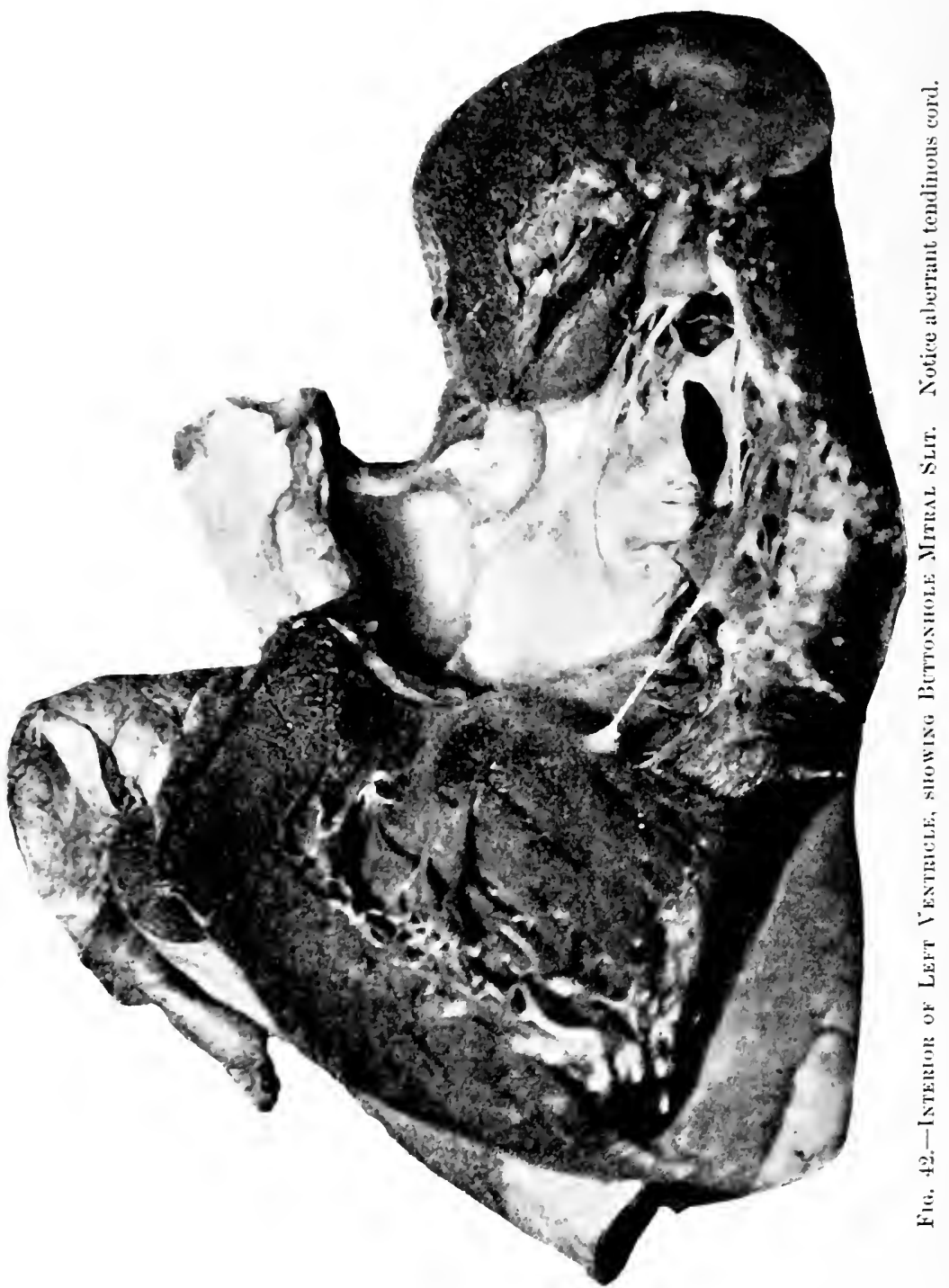

tronines the anfome of the disclatere. The shape of an orifice and the parage learling me to and away from it inflence the quantity of finid that can flas- thromeh it in a given time. "If a round 
hole be punctured in a can full of water. the eross-actiont of the fluid jet comming tion it is much less than the area uf the aperture, little more than halt' of it. The relation of one wh the of hed

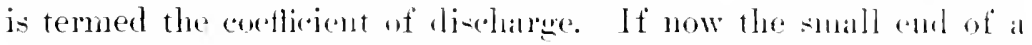
fumel be aceurately fitted tor the immer -icke of the alperture so at to initate the comdition of thing obtaining in the funnel mitmal,

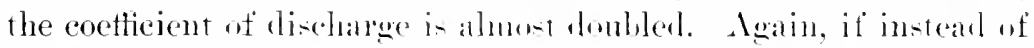
making a romel aperture in on ean we make a linear wne, so as to imitate the hutfomlole mitral. we in a similar way nearly domble the eoefficient of diseluarese. This form of the mitral oritice results

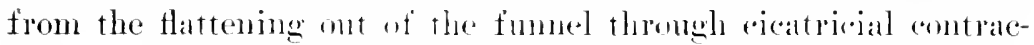
tion, so as to form a morre or las flat diaphragm, and it is indeed a remarkable fact that in this proess the romel apertme of the fumnel is invariably anverted into a slit. Fometines it will seen to be slit-shajed hefore the flattroning-ont process hegins. Ilenee it is clear that in mitral obstruetion the heart avals itself in a rery cuming way of principle- well kunwn to the engineser, so as to secure the maximm flow througl the narrowed mitral orificea brave attempt to make the best of a harl jeb."

It seems possihle, howerer, that the falet of the mithal value being conjosed of two approxinately triangular leatlets, which become adherent along their sides, and leave a small opening at their apices, where the two that cosps conne together, may have something to do with the slit-like hape of the stenosed orifiee.

The effect of namowing of the mitral orifice is to increase the diffieulty with whiel the left anricle expels its contents into the ventricle. The reaction of the musenlatme to this inereatied demand for work is hown by the prometion of hypertroplys. This is the primary effect: and lilatation. when it dues ocenr, is a later event. In mitral incompetener. on the ofler luand, dilatation

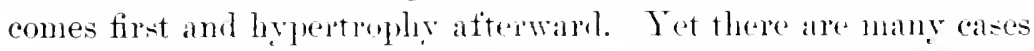
of mitral stenosis in which the andele is fomml post montem to be thin-walled and dilated. This is probably in most alses due to associated regurgitation, for in a series of eases taken from the records of Guy's Hospital, Samway- fomml that the deweres of dilattation was nearly always proportiomal to the anomnt of leakage associated with the stenosis.

The left ventricle presents a comlition in marked contrast to that found in regurgitation. The narrowed orifice allows only a 


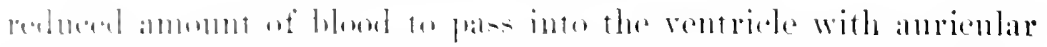

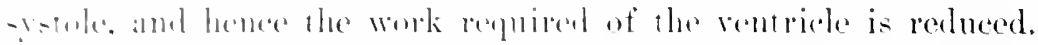

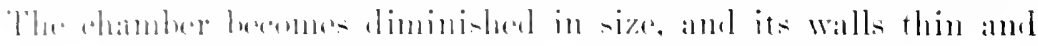

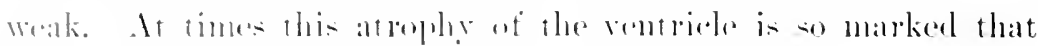

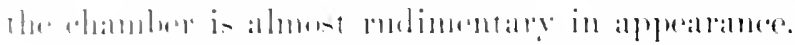

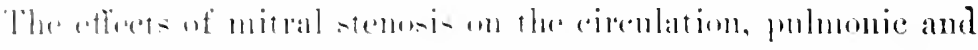

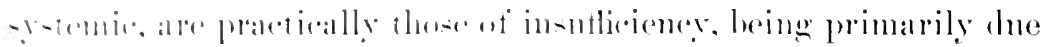

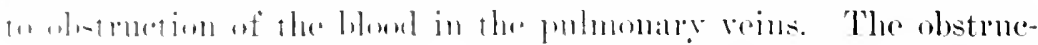

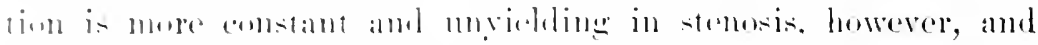

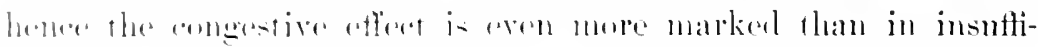
(rin)

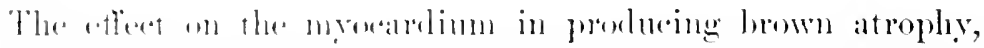

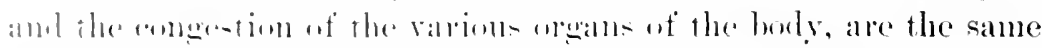
a- in mitral incompertemere and do mon all for repetition.

Etiology. Mnrh of what has been sald concerning the cansa-

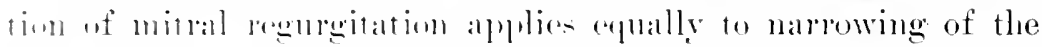
mitral ustimn. Them is me wereat differenes between the two,

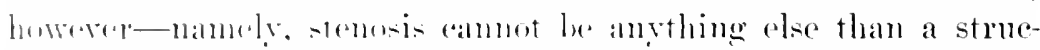

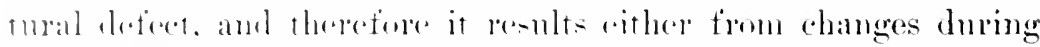
fortal existemen an from culdearditic or selerotic changes after livele. Arote inflammation n-11ally purluces elinieal phenomena

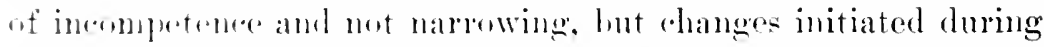
an acute attake may subequenty derelop into such as cause pronomened alstlution.

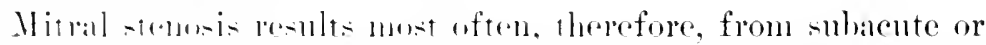

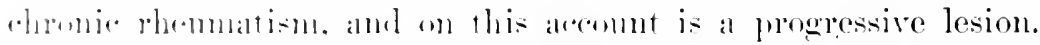

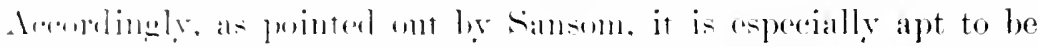

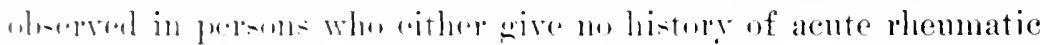

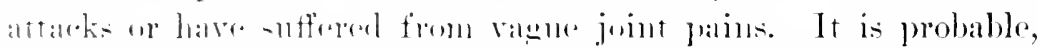
therefore. that in the majurity ut ase- mitral stemosis is of rhen-

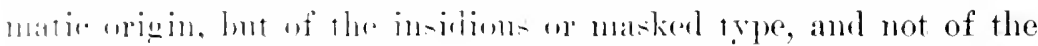

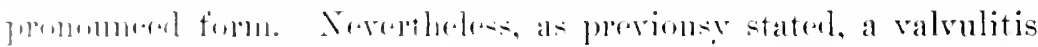

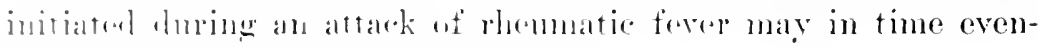

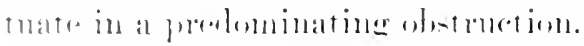

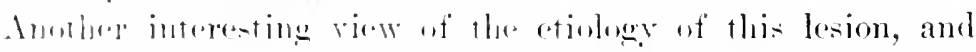

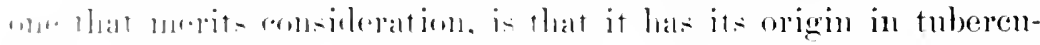

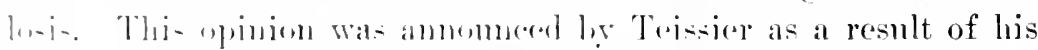

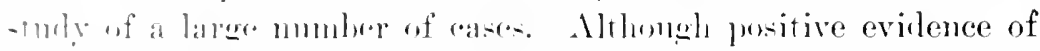

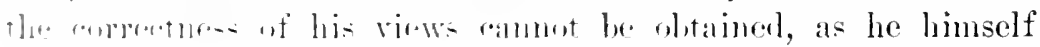


admits, he ret belieres that tuberentosis lies at the lustom of the cases of mitral stemosis which are proglessive.

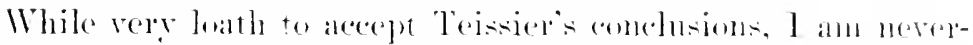
theless greatly interested in the possibility of stroh a ran-ative relationshipe for the reatom that prior to my knowlerlece of lis views I hat lecen struek with the fact that serelal times I hatel encomtered narmwing of the mitral orifier in wome women lelonging to tuberentoms fambilies. I reeall distinctly a pomme Irish

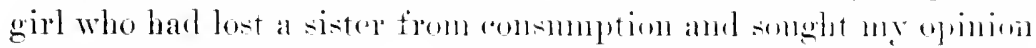

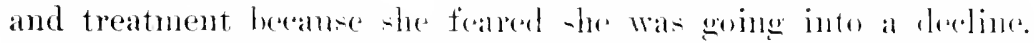
The character of the respiratory mumbur at the left apex male me very uneasy, and hesitate abont expressing an (1) inim mutil after I had kept her moler olservation tor a sufficient time to mote any changes that might take place for hetter or worte. "To my gereat surprise I at length, after rejeated examinations, disenvered signs that indicated a very slight and pungessive mitral stemosis. Atter the lapse of a number of months, luring which sle oceasionally: complained of vague leg pains without other definite indieations

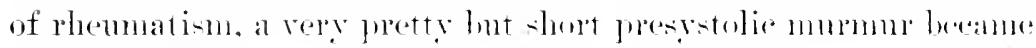
ummistakable.

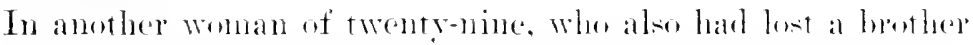
and a sister of consmmption. I fomme a rery considerable narrow-

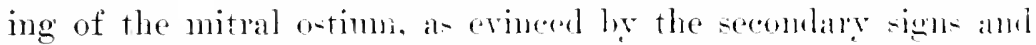

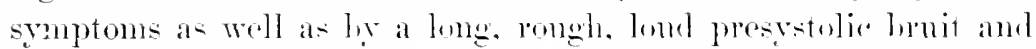
corresponding thrill. There were also imponed resmance and broncho-resicular breathing at the risht apex, which mald me verey

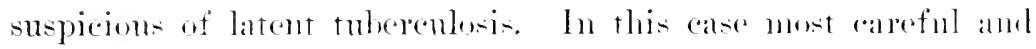
searching inguiry tailed to elicit a history of previons rlumma-

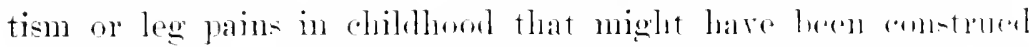

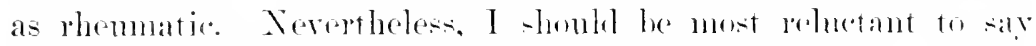
that in this one the stemosis was of tulerenlous origin. To my

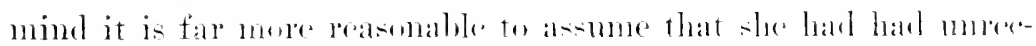

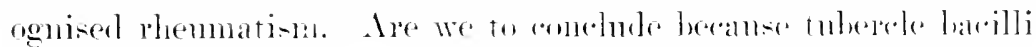

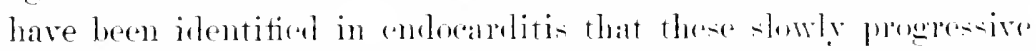

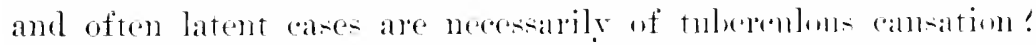
The natural delicary of andetitution in these individuals who

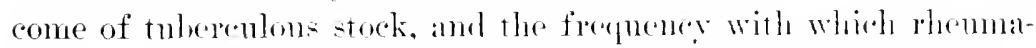

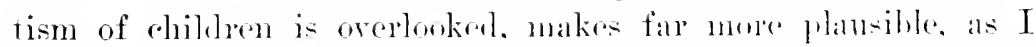
take it, the conclusion that the valvular afoect dates form early 


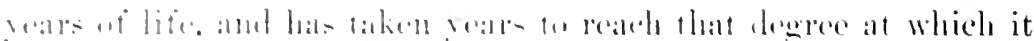

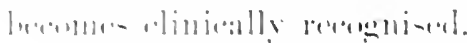

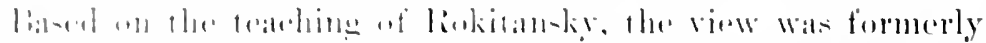

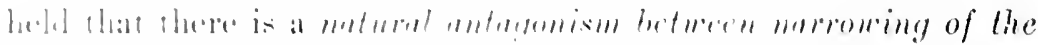

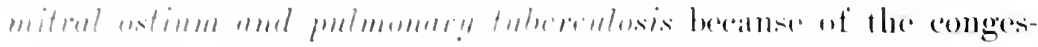

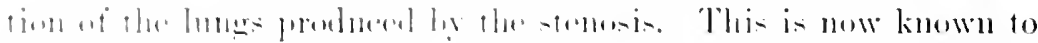

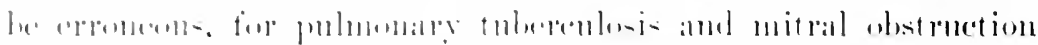

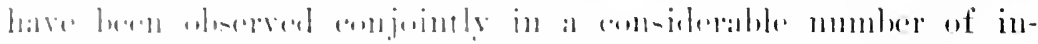

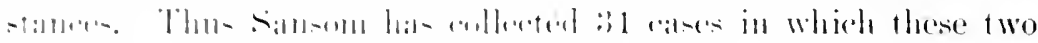

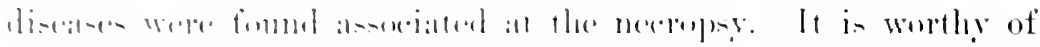

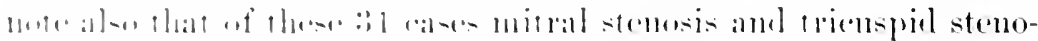

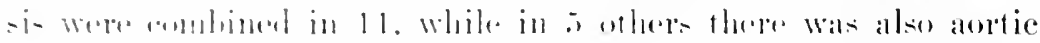

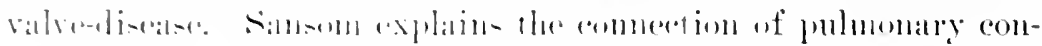
-mungion with mitral natrowing on the epomed that the latter

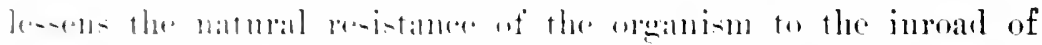

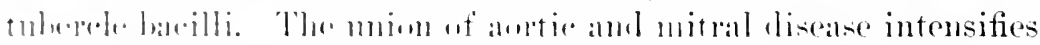

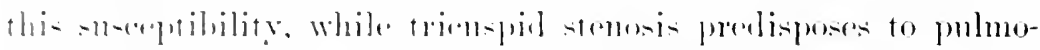

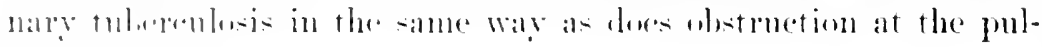

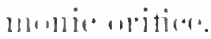

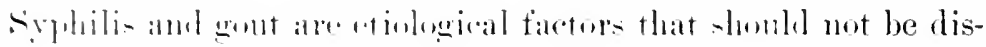

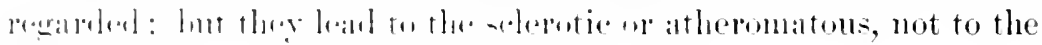

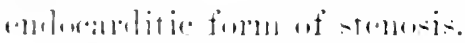

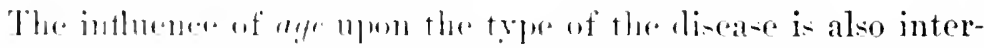

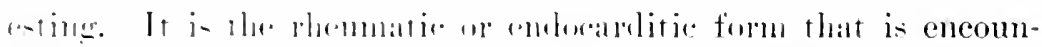

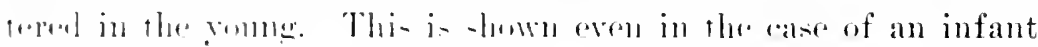

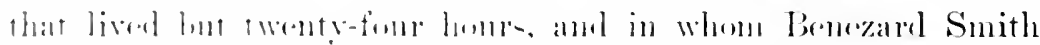

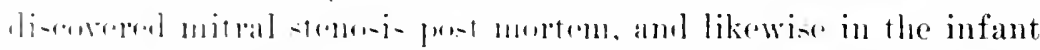

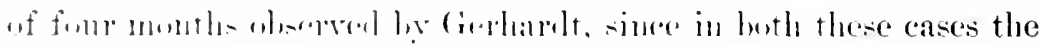

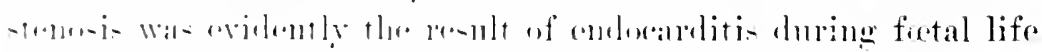

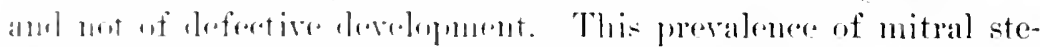

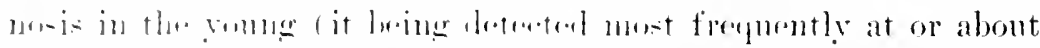

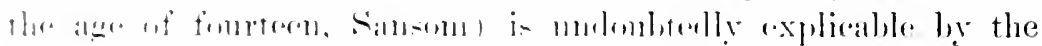

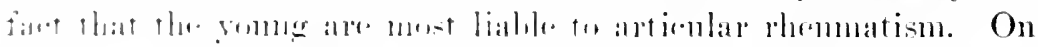

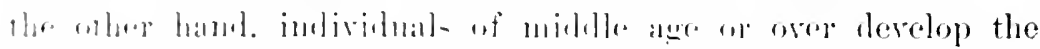
seleretir forme of this valunlar lre-ime, and in sureh it is probably

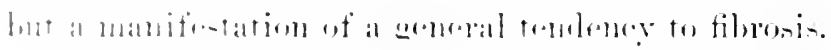

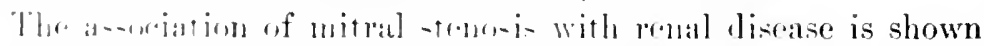

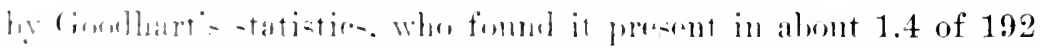

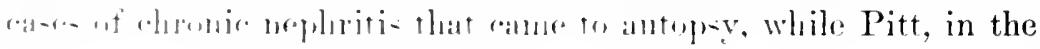


post-mortem recolds of Guy"s 110mpital, found mitral stemonis ambl gramular kidney there times as frepuently as stenosis without this form of renal discalse.

It is a striking tatet, on which all writers comment, that mitrit

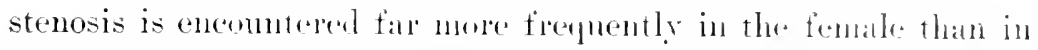
the male sex. This in especially true of thr discatoc in formons below the age of forty. in whom it is probally of intlammatory origin, while the selentic form of the lesion does not ally all ton predominate greatly in either sex. Of to care of pme mitral stenosis of which I have records, 2 ocemped in tomalo amd 1 t in males, and of the entirr mmuler hut go gare a clear history of rhemnatism. It is thus seen that of my atsos fomales numberent twice as many as males. bearing out the statenurdut that nutral obstruction is pre exepllence a rlisatec of the gerutler sex.

Symptoms.- Thasmurh as the offects of nutral regurgitation and mitral sterosis on the cireulation are practically the salne, there is a close similarity in the symptoms of the two affections. Therefore, much of what was said under the hoad of mitral regurgitation also applies to mitral stemosis. Cundombtedly this affece tion may remain latent for years, fnt it is less likely to do so tham is regurgitation. Nevertheless, hard and fast lines in this reand camnot be drawn, for the manifest reason that the degree of the effect stands in direct proportion to the glavity of the lesion. If compensation is arleguate, smptoms referable to the heart, or that call the attention of the patient to his heart, may he entirely al, sent; and yet a patient with any consinlerable degere of stenosis is not likely to he robust, or to possess much physical "moluramer.

Children are likely to be more or less stmeded in development. both mentally and bodily; while in the case of adult fenales I have been impressed by the frequeney with which they are tall and thin, with evidence of anamia. Their circulation, ats night be expected, is defective, as shown ly coldness of the hamis and teot and great sensitiveness to low temperature. Even when not suffering from srmptoms referable to pulmonary congestion, as lyspnoea, they are apt to complain of digestive and menstrual disorders, somr stomach and scanty menstruation being particularly common. They are generally constipated and their urine is diminisled in amount, of correspondingly high specific gravity, and loaded witl nrates. 
l'arients with mitral stemenis ale also rery prome to attacks

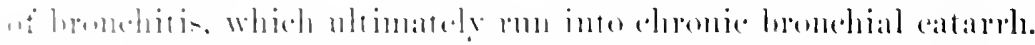

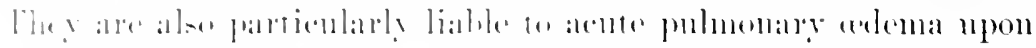

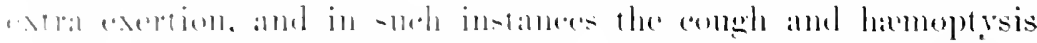

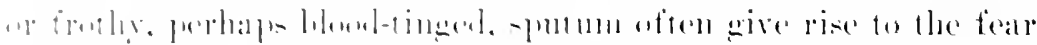

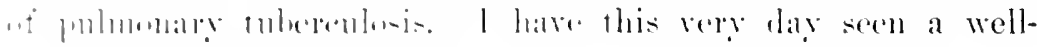
mallied instamee of the kiml.

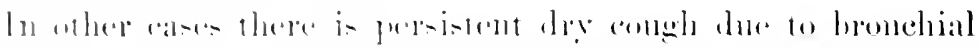

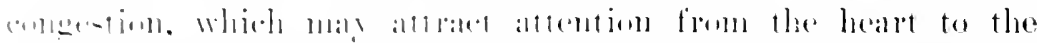

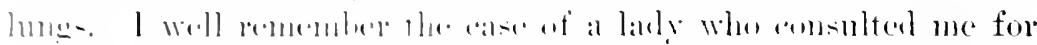

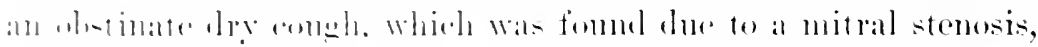

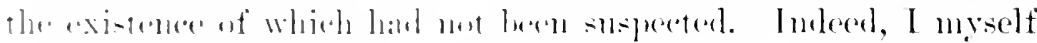

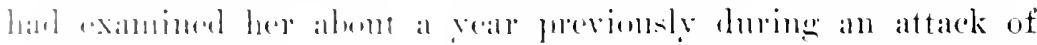

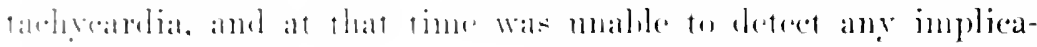
itoll of the vialse.

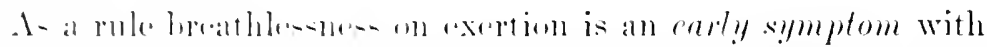

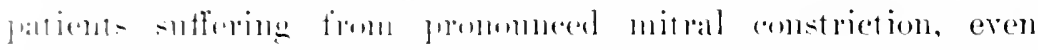

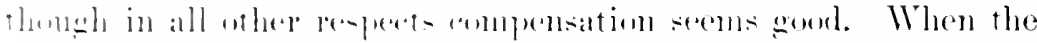

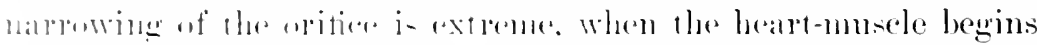

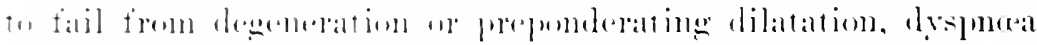

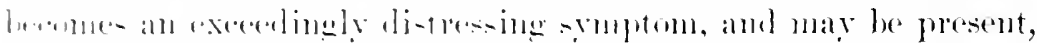

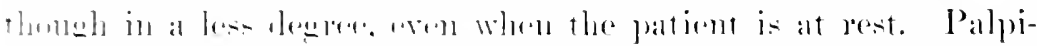

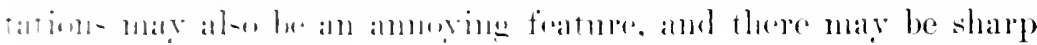

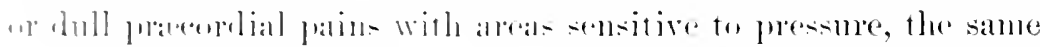

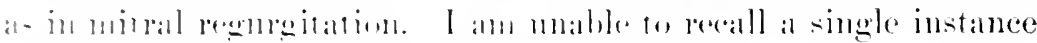

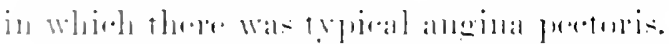

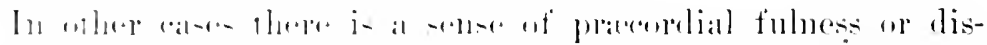

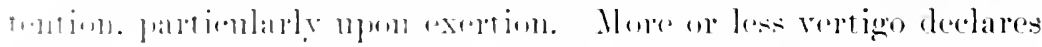

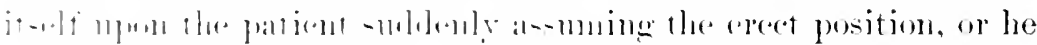

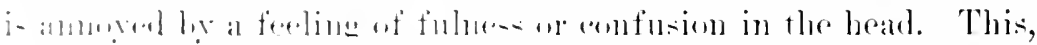

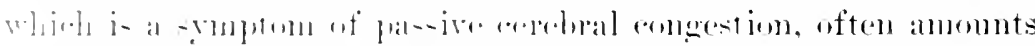

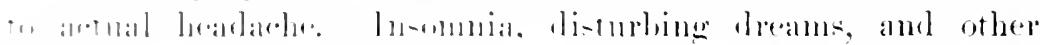

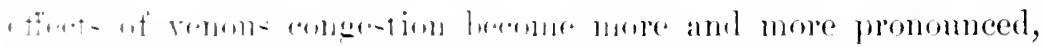

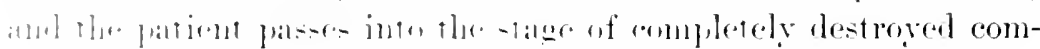

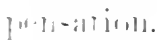

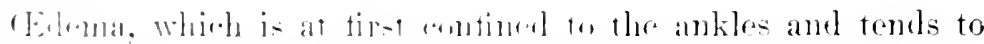

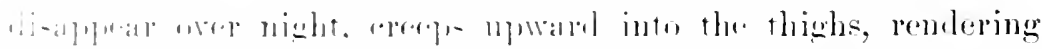

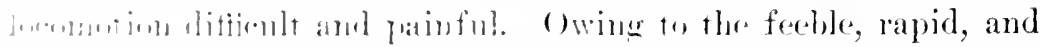

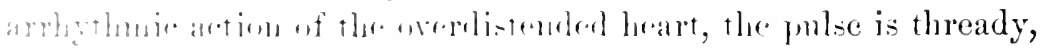


perhaps unequal in the two wriste, intermittent, and often extremely difficult to count. This intermittence may be due to. cardiac intermissions, or to such an inequality in the force of the hearts contractions that some of the blood-wares fail to reach the wrist. The hands and foreams may be cold, and the superficial reins stand ont prominently in striking contrast to the emptiness of the arteries.

Pulmonary congestion declares itself by increased dyspmera that may even amomt to orthopnea, by congh and serentucons or sero-sanguinolent sputum, duhness at the bases of the lungs, particularly behind, and by eopions, moist ribles. If the tricuspid valve gives way, permitting regurgitation into the anuicle, the turgid jugulars pulsate. The liver, aheady swollen, perhalp tender, grows still more engorged, and likewise pulsates symchronously with the epigastrie throhling of the dilated right ventricle and the so-called positive pulse in the cervical reins. The taking of food is attended with formation of gas that distends the stomach and bowels, arling greatly to the patient's distress, and rendering adequate nourishnent diftienlt. The sufferer trequently complains of dull or burning pain in the pit of the stomach, and is tormented by an intorerable thirst. Congestion of the head is shown by duskiness of the comtenance, swimming of the hearl, or headache, and insomnia. In some cases there is a condition of sommolence. and the sufferer falls into short. unrefreshing naps, which are disturbed by dreams, and from which he awakes with a start. The skin is not infrequently herlewed by a cold sweat, which about the head and neck may be so eopioms as to rum off in trickling streams.

Stasis within the renal veins leads to scantiness of the mine, which is dark in colour, loaled with nrates, and often contins albumin and easts. The action of the bowel becones irregular and constipated, or as the dropsy invales the abdominal structures the patient may be amored ly fiequent seanty, liquid stools. Congestion of the hamorrhoidal veins sonetincs gives rise to additional distress. Dieorders of the pelvie viscera are common at this time in the female; the catamenia are ant to lo scanty and irregular, and lencorrhua is not meommon. Day by day the distress of the patient increases, during his waking hours he longs for the relief of sleep at night, and by night his discomfort makes him 
long in turn for the days. Days drag on into weeks, and not infrequently weoks into months, with erer-angmenting dropsy, which at length invales the scroms carrities (Fig. 43). Aseites and tumcfaction of the abdominal walls intensify pressure upon

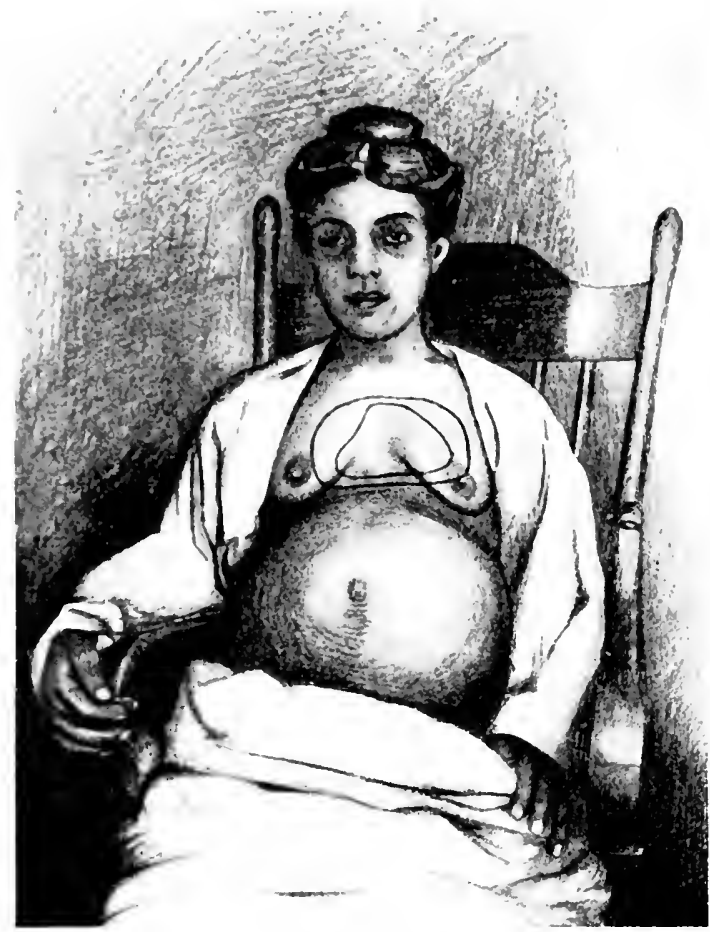

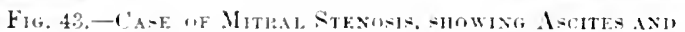

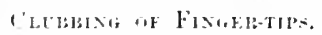

Areas of supericial and decpencated duiners are indicated. the diaphragm and abdominal ressels, rendering breathing still nore labomrer. The pressure thus oceasinned still further impedes the return How from the veins of the lower extremities, and eaures an inerease of anasarea. If hydrothorax now sets in, the patient's shortness of breath becomes extreme, and he is obliged to support his body by resting his arms on a table in front of him. I have known a sufferer from mitral disease in this

stage to remain thus for sereral weeks, not venturing to leave her "hair. Foltunately for thene patients, nature is not able long to maintain the metpual strugele, and unless treatment brings relief,

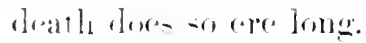

()eraminally in this extreme stage the end comes throngh sud-

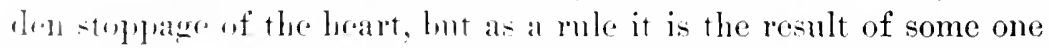
of the cance- lhat will be narrated in the part of this subject deroted tos the merle of death.

Physical Signs. - Inspertion is apt to detect more or less

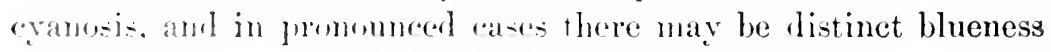


of the lips and finger-tips. Patients, partienlarly ehildren, who have had the disease for vears usually display chubing of the teminal phalanges. Often there is bulging of the pracordium, partienlarly at the lower end of the sternum, as well as risible epigastrie pulsation. If compensatory hipertrophy is great, and long-borders are retracted, the eye may discern a si-tolic pulsation over the body of the heart and a short diastolic shock in the pulmonary area the same as in regurgitation. The alpex-beat is usually feeble, and not likely to be ontside of the nipple or below its usual situation.

Palpation confirms the inpression receivel by the eye, but in addition detects a thrill at the apes, which, precoling the rentricular impulse, is known as presystolic. This thrill resembles the purring of a cat, and hence is caller " fremisement cataire." It mar be short and soft, or rongh, and extend thronghout the greater part of diastole. In some instances a shorter, feebler thrill follows the second somm, ocenpring the forepart of the diastolic period. The prestotolic thrill is found to leat up to, and terminate in a short, sharle srstolic shock or " thumping " apex-beat. This thrill is often so short as to conrey the inpresion of the apex-beat being split, the seeond of the two impulse being the sharper and stronger. A sharp stroke, imparted ly the sudden closmre of the pumonic valve, is sometimes folt distinetly in the seeond left interpare, che to the stermun. Epigastrie pulsation is generally pronounced, and gives the impresion of a powerfully contracting right rentricle.

In eompensated ease of stenosi- the pulse i- -mall, freble, and regular, and less rapid than in mitral regurgitation.

There has been much controversy, chiefly anong the English, as to whether the pulse of mitral obstrnetion or of insufticiency is the more likely to be irregnlar. This, in my opinion, is a matter of slight practical importance, and yet in my experience I have found the pulse to be more often irregular in regurgitation than in stenosis.

The annexed sphremographic tracing ( Fig. Ht) is from a ease of prononnced mitral stenosis in a female, rut shows the pulse small, of high tension, and regular. When pulse-tension is pronounced, it is due to capillary resistance amil not to the energy of left ventricular contraction. Concerning the irregularity of the 
fmles in mitral disease, it may be again stated that observations of Radizew-ky angean to pure that the chatrater of the pulse in this resecer depends mene the state uf the myerestimn of the anrickes. When this is heilthe, the pulae is regulart: when degeneratent, either filmoid or

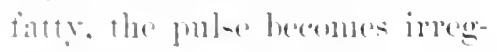

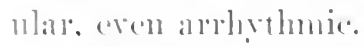

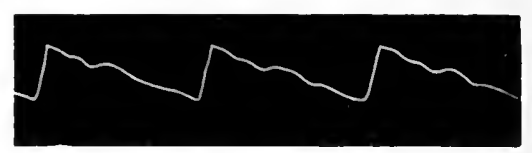

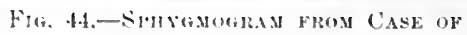
Mitura NitkNosia.

(lersomal observation.)

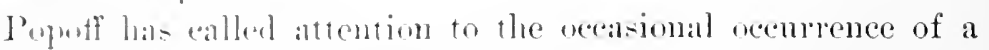
pulsus differens in thi- dierater, hy which term is meant an inequality in the two radial pulses, the left lremg the sualler. As thi- is wherved when compenstion is destroyed, and mate disappeall with restoration of calliar energy, Popoft attributes the incegnality to pres-ne of the enteatly dilated left auricle on the left onbelavian artery. Preble hat also notieed its ocenrence in some of his eares. I- pulens differens may also be produced by anen-

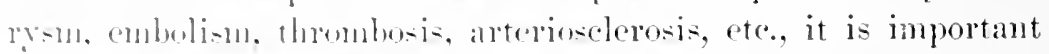

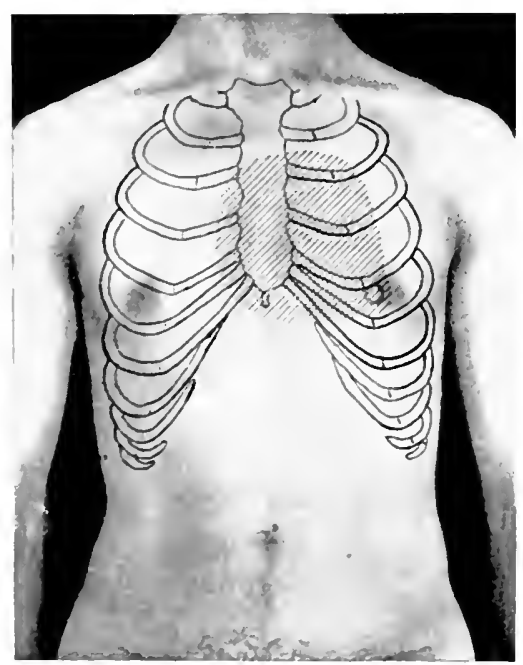

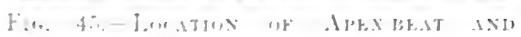

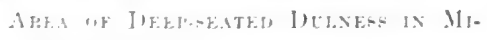

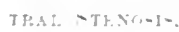
that all such aluses be exchuled before the phenomenon is attributed to extreme dilatation of the anricle, a matter that mily he of some monent in prognosis.

Percusion shows a similar change in absolute and relative cardiac dulness as deerriled in the article on mitral regmregitation-viz., an increase of entrace dulness lowards the right side and tomenerend (Fig. 45). This inerease bears a direct relation to the degree of stenosis. Acromeling to Lembe, perenssion show a more pronomeed malarenent of the right heast in thic form of mitral disease than

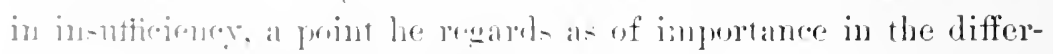
ential diagnori- between theere two affections. 
Another difference lies in the fact that, owing to atrophy instead of hypertrophy of the left ventriele, dulness is not likely to be much if at all inereased to the left.

A uscultation.-In pronounced cases of mitral stenosis, auseultation at the apex of the heart detects a murmur of snch intensity and distinctive character that it at onee fastens the attention of the examiner. In most instances it is a long-alrawn, rough bruit, which, begimning after the second somd, runs up to and termi-

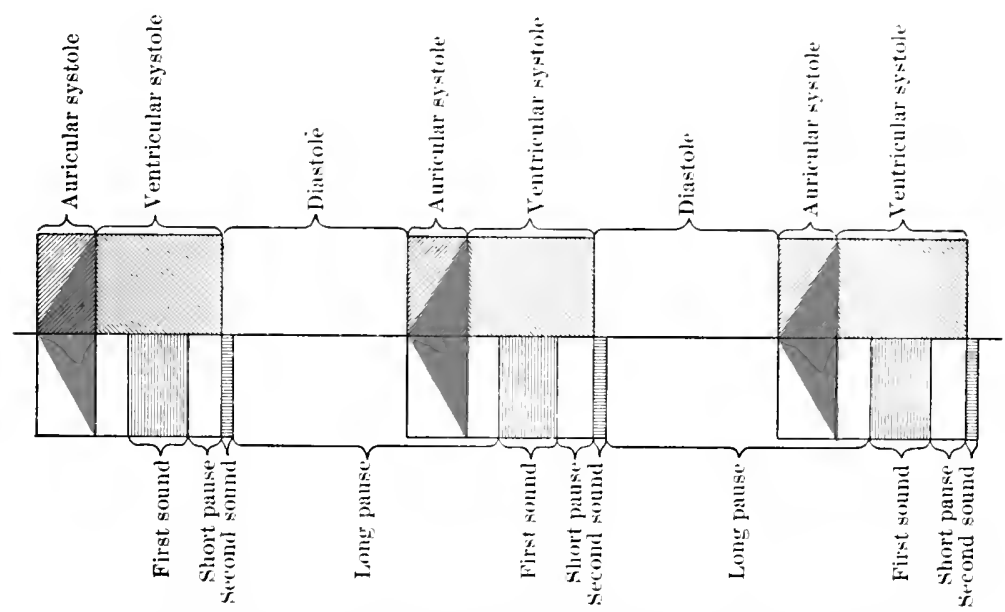

Fig. 4h.--Rhithm of Characterimte Mlematr of Mitral stexosia,

"Alricllar.Systolie."

nates abruptly in a clear, sharply accented first somel. The murmur is spoken of, therefore, as presstolic, and in this respect corresponds exactly to the thrill already deseriber. When wel! marked, this prespstolic murnur is so striking as to be almost pathognomonic of mitral obstruetion (Fig. 46).

The rhythm of this bruit, by which is meant the time of its occurrence, has been the subject of considerable controversy, for the reason that some observers have declared it to be in reality systolie and only seemingly presstolie. The generation of the first sound, say they, is delayed in consequence of the rigidity of the mitral valve, and lience, although the murmur begins with the contraction of the ventricle, its ocenrrence prior to the first tone gives it the appearance of preceling rentricular systole. The arguments in support of this opinion have never convineed me of 


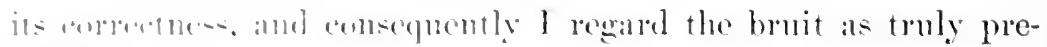
$-Y=1$ inlic.

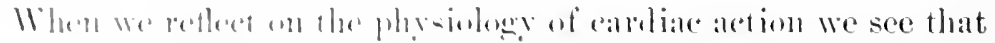

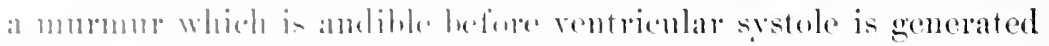

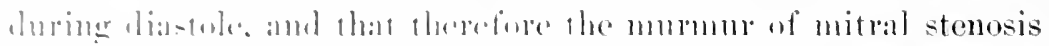

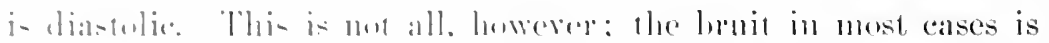

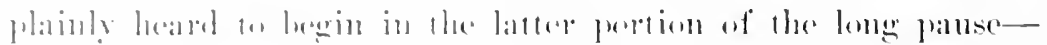

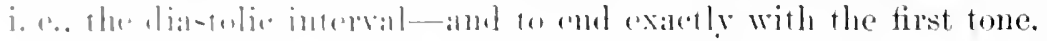

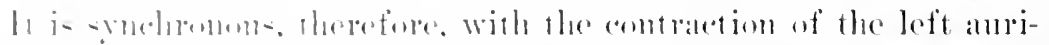

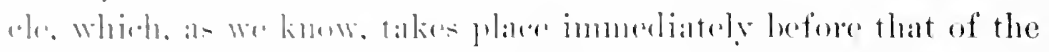

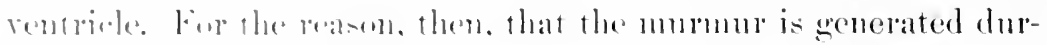

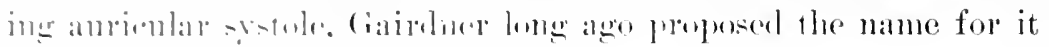

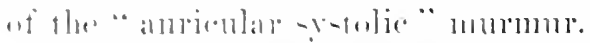

This trem is tow restrictul, howerely since, as is well known,

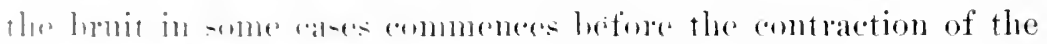

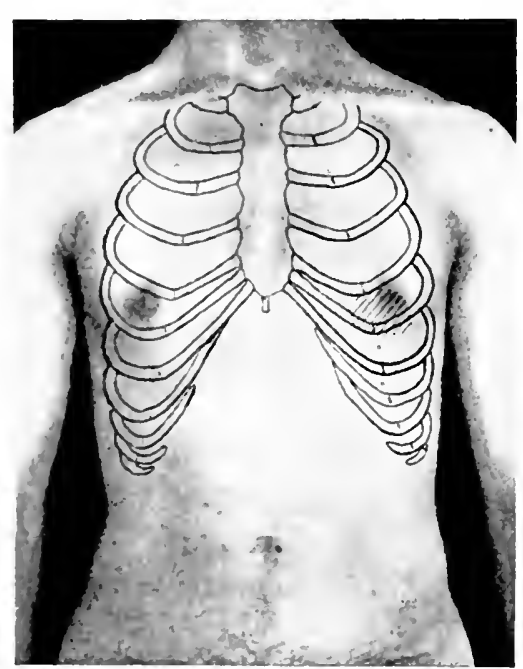

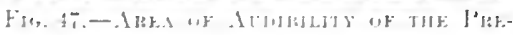

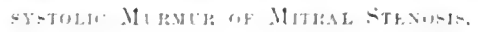

It j- ineruently limined to this ares. amrele. in faret immediately after the secomel somend, and lasts throughout the long pannse. It is consequently a diastolice and not always an auricular systolic murmur, and as smeh is in contrast to the sistolic one of mitral reemlegitation. It has also been alleel the "mitral direct" mulmum. becanse transmitted in the rivection of the blood-trame-i. e.. from the mitral neening directly to the apex of the left rentricle. Indeed, it may be stated en pressant, that all bruits of stenosis are ralled rlinect and those of re-

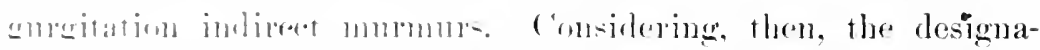

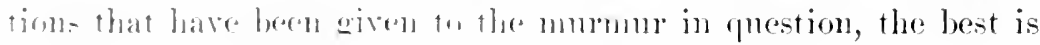

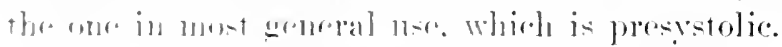

The mommone i- hearel most ristinctly close to the apex-beat,

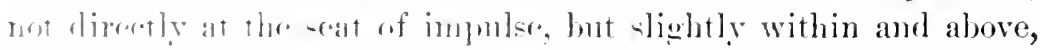
at the froint, in fart. Where the thrill is felt most plainly (Fig. 
47). Its area of amlibility is sometimes very limited, being confined to the immediate proxinity of the apex, but I have known the murmur to be anlible for a considerable distance in all directions, althongh eren then it is not tamsmitted so widely outside of as inside of and above the apex-leat.

The quality or timbre of the lonit is exeedingly rongh and harsh, so that it is frepmently described as rolling, blubbering, spluttering, etc. Balfom happily describes it in some instances as somding like $V_{-1,-0-t}$ or the somm produced by the attempt to roll out the letters R-r-b, or when still nore prolonged R-r-r-b. The final consomant of these combinations is supposert to represent the short, sharp first somnd that terminates the bruit. The murmm never possesses the soft, blowing quality of the mitral regurgitant murmme, since obstructive bruits are always rougher than those of regurgitution.

The length and intensity of a pressstolic mmrmur are influenced by posture and the rate of carrliac action. Thus a bruit, which is short and rather indistinct when the heart is beating rapidly, or when the patient is standing, is rery likely to increase appreciably in duration and to display its true character nore distinctly after the individual has lain down and the hoat's action has becone slower. In other instances the reverse obtains, the bruit being most distinet in the erect postme. One shombl anscultate in all positions and nuder varving enditions of cardiac action.

Another peculiarity of the mitral direct murmur is its changeability, by which is meant that it is not alwars the sane in distinctmess at different times. I recall vivilly a woman in whom on several occasions I felt certain of the existence of a mitral presystolic murmur. On one occasion, lowerer. after an absence from observation of several months, her heart presented no snch murmur as I had heard hefore, lut instead a feeble first somul accompanied by a faint systolic whiff. Some weeks subsepuently, after haring taken digitalis and strengthened the contractions of the left anricle, the old-time presystolic mmmur reappenred. Broadbent regards this changeability as of great significance in the differential diagnosis between stenosis and regurgitation.

The foregoing deseription applies to most cases of mitral obstruction, but not to ail, and as it is the exceptions that are crery 
mow and then encommtereal. they will now he described. In some instances the lontit is so shert that it is seatreely recognisable as

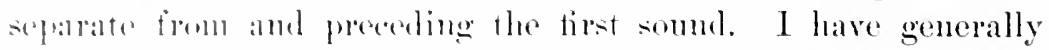
meted in slleh asos, homevere, that the first somme is short and

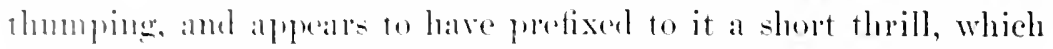

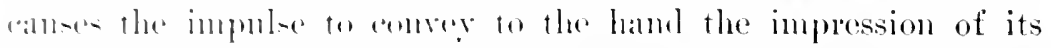

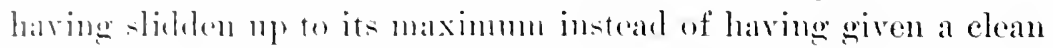
thrust, as deres the healthy heart. Hithenlt as it is to reeognise this indi-tinet or abertive murnur, it is extremely important to be able 10 de so, since it is in the detection of obseme signs of disease that the skilled phissian differs from his mokilled colleague.

The reserse at this short, satrecty recognisable bruit is the long-elawn nummur, which Tranbe first lescribed and designated

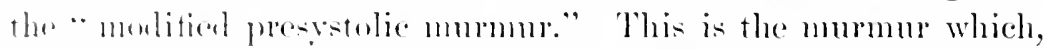
commeneing limedly at the close of spistole-i. e., immediately after the seromel somm-ratends throngh the long panse of diastole. and (ends with the next first somme (lig. 4s). $\Lambda$ not at all infequent ansultatury finding is a short murmur occurring after the soond somd and known as early diastolic, and which is

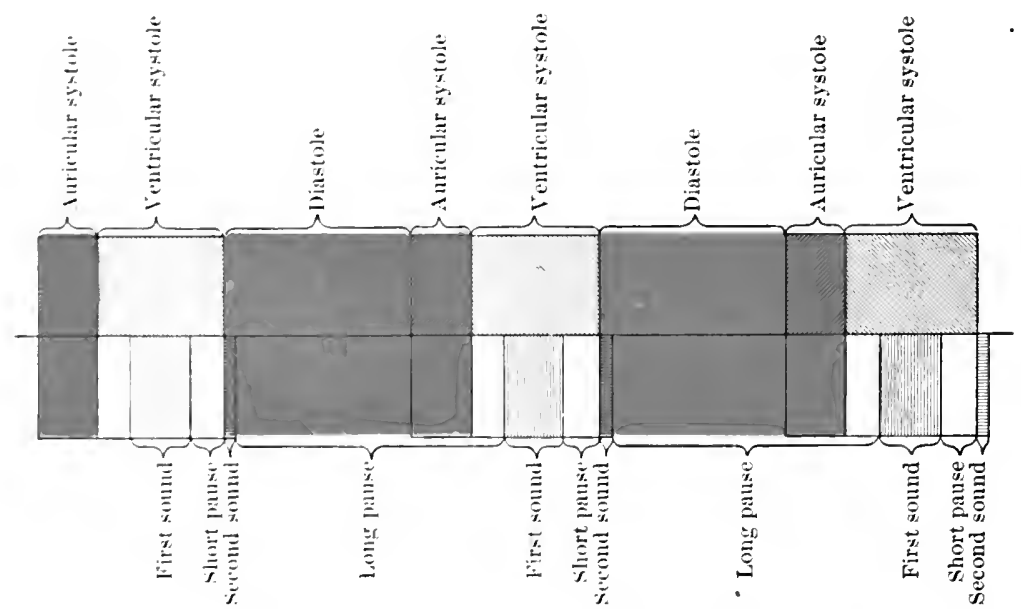

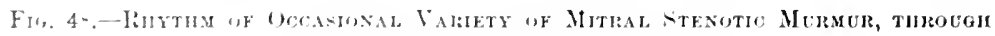

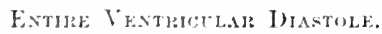

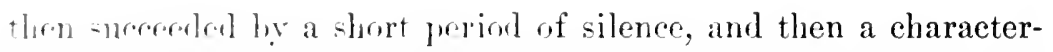
i-tic pre-rotolic mormur (Tig. 4t). This anomaly is therefore a hroking in two, as it were, of the long mumur, and by Fraentzel 
was called the "interrupted modified presystolic murmur." It is very diagnostic, hut may easily mislead an inexperienced anscultator. Should such difficulty of interpretation arise, error may be

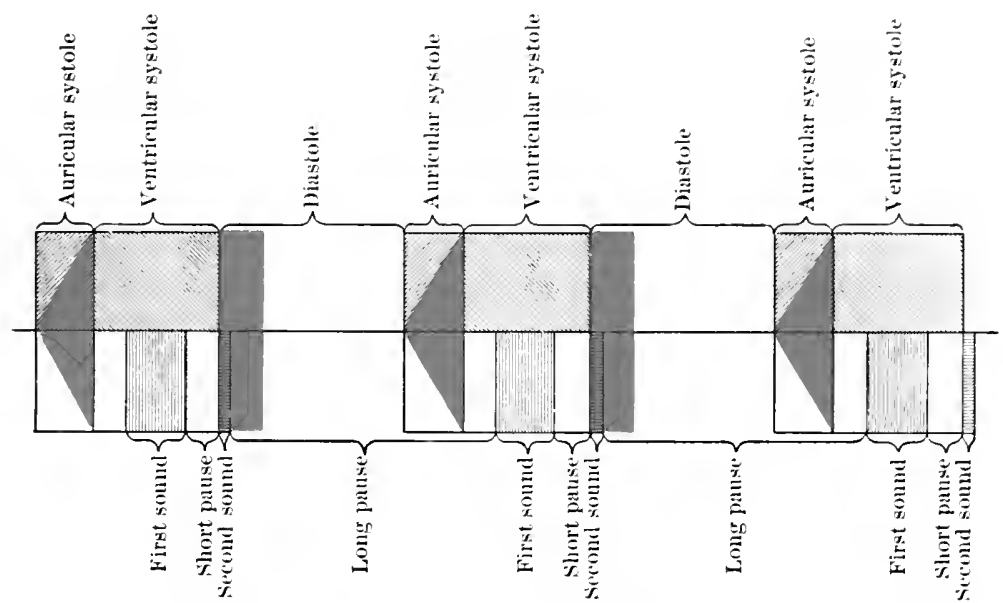

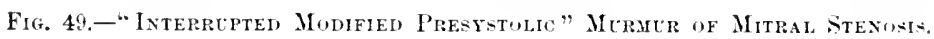

aroided by due attention to the associated secondary phrsical signs and to the modifications of the heart-sounds soon to be described.

Another departure from what is usually heard in mitral stenosis is the retention of the presstolic bruit and of the first somm] without a second sound, or of the nummr alone without either of the curdiac tones. Ittention is directed to these anomalies her Broadbent, who states that under such circmstances it is possible for the murmur to be mistaken for a systolie one followed by a second sound, or for the bruit to be considered systolic, ant to have replaced the sound altogether. Care should be taken to aroil such an error, since a ssstolic murmur means regurgitation, and for sake of prognosis as well as treatment stenosis shonld brerognised as such whenerer it exists. A mistake can probably be aroided by palpation of the carotid pulse, when it will be found that this is preceded by the murmmr.

Such comparion of the time of the murmur with that of the carotid pulse is likewise rahable when, as stated by Fraentzel, the presystolic murmur disappears in the last weeks of life, or becomes merged into a systolic one.

The various modifications in rhythm and intensity of the 19 


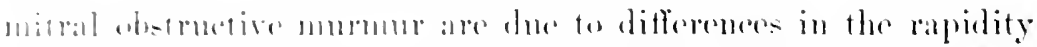

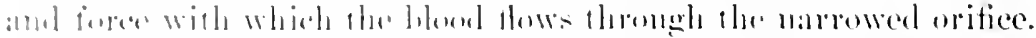

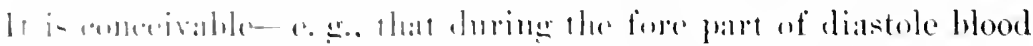

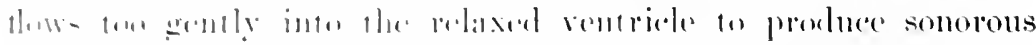

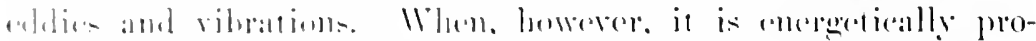

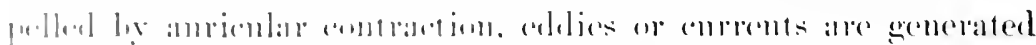

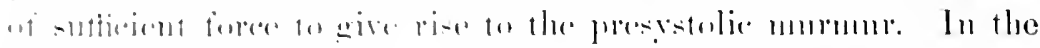

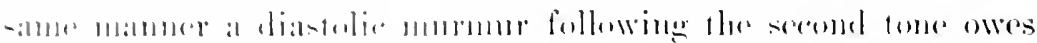

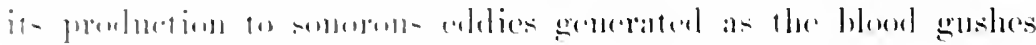

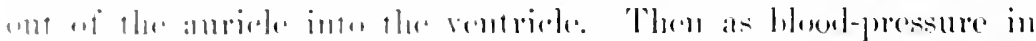

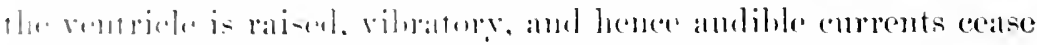

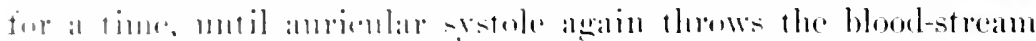

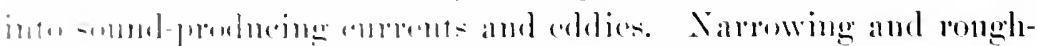

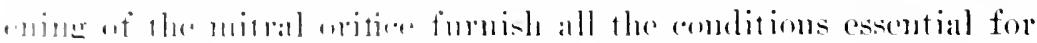

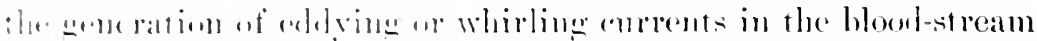

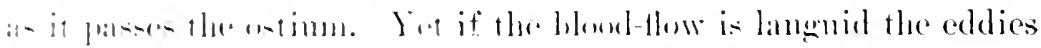
within it may fail to -ret mp vibrations of suthejent fore to be con-

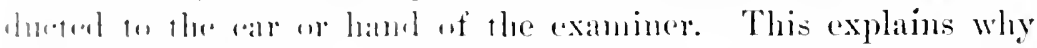

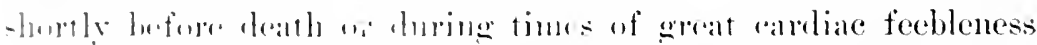

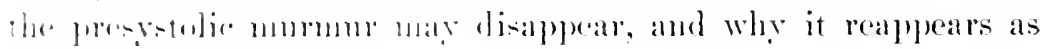

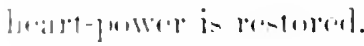

Ilent-sommls.-The renentiton of the chatacteristic mumur

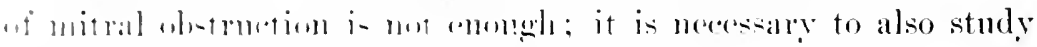

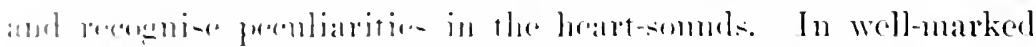

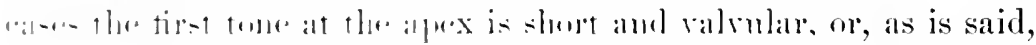
"thmmping." This plualipy is so perouliar and striking as to be

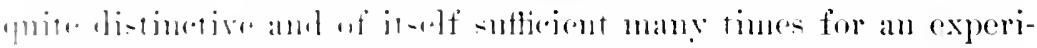

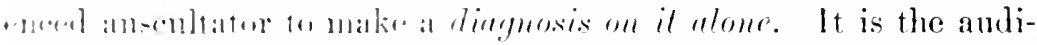

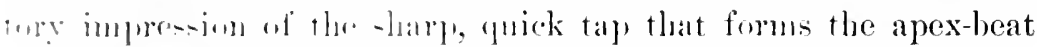

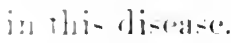

The -reondel smmed at the ajex may he distinct, but in most

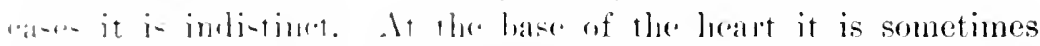

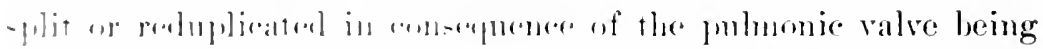

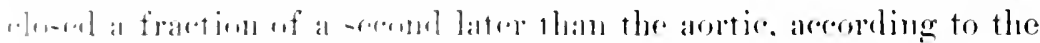

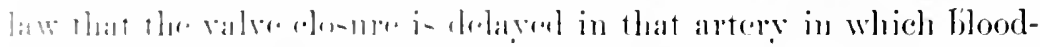

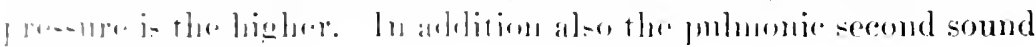
i-

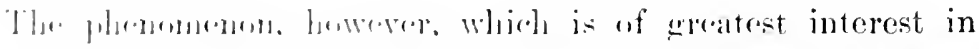

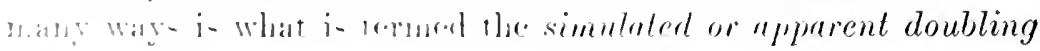


of the second sound. This is to be distinguished from the splitting of the second somnd at the base. It is limited strictly to the mitral area, sometimes to the very site of the apex-thrust, and consists in the occurrence of a third tone, which immerliately follows the normal second somd. English clinieians have given much study to this apparent donbling of the second sommd, and hare offered a variety of explanations for its ocemrence. The most reasonable theory is, as snggested by Sansom, that it is in some way a sound of valve-tension being produced as the blood gushes foreihy out of the auricle into the ventricle. This seems borne ont by the observation that this soumd sometimes becomes changed into, or replaced by an early diastolic murmmr. Sansom states also that this double sound is hearl at sonne time or other in all cases of mitral stenosis, and indeed may in some instances be the only indication of the lesion.

When this anscultatory phenomenon is present, together with a presystolic murmur, it forms a very striking assemblage of somnds that camnot possibly be mistaken for any other condition than mitral stenosis.

I have known this donbling of the second sound to be inappreciable when the heart was not strong, and to come out clearly and beautifully as treatment restored cardiac power. When the heart beats slowly and regularly it is a matter of no difficulty to differentiate the several somds and murmurs heard in mitral stenosis. When, on the contrary, the rlythm of the heart is disturbed, the impression nay be received of an indistinguishable jumble of sounds, both normal and adventitions. Thus, I have a male patient with a rhemmatic mitral narrowing combined with a slight degree of insufficiency who presents such a jumble. When, as now and then happens, his heart action is tolerably slow and regular I hear the following: A rough presystolic nummur ending in at thmmping first sound, then an exceedingly brief panse, followed by a doubled, or apparently doubled, second sound, which in its turn is suceeded by a short. early diastolic murmur and a short silence preceding the next presystolic bruit. At times a short systolic murmur accompanies the first sound, and as this heart is generally very irregular in rhythm it can letter be imagined than described what an unintelligible mixtmre is made hy its somds and murmurs. 


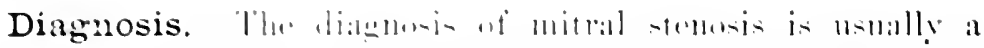

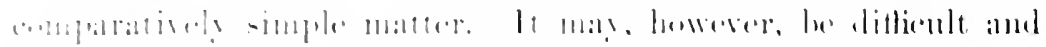

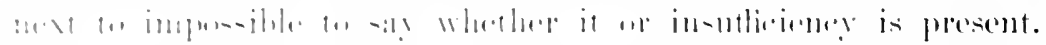

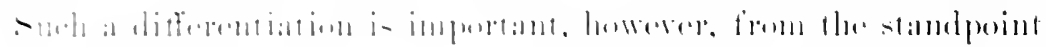

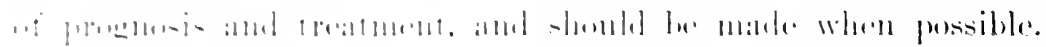

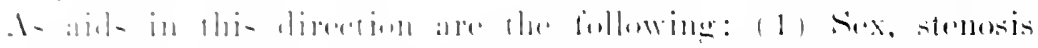

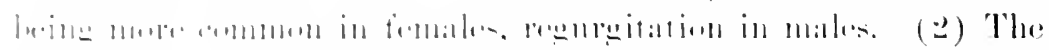

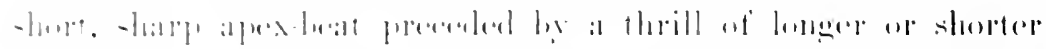

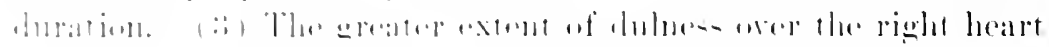

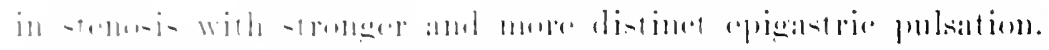

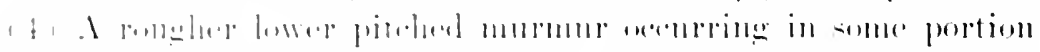

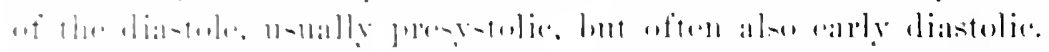

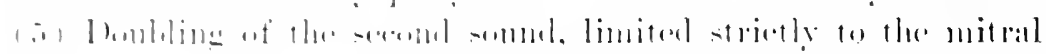

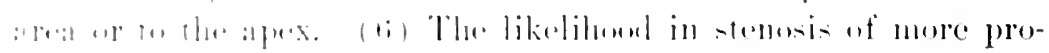

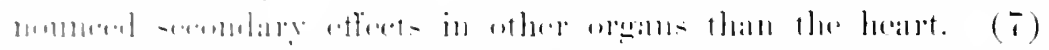

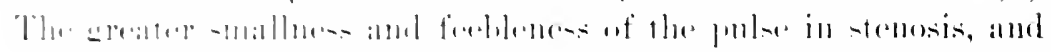

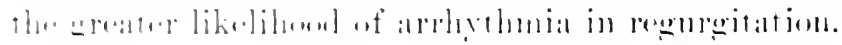

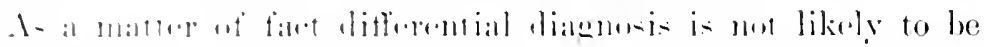

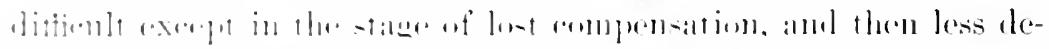

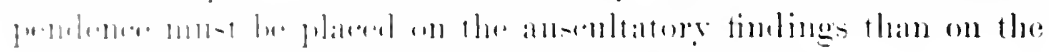

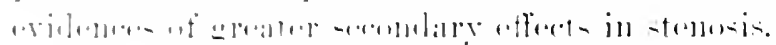

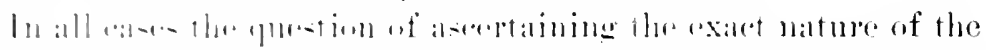

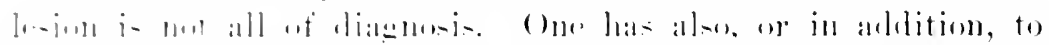

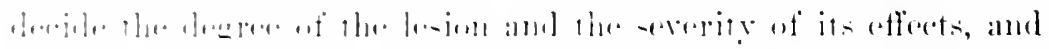

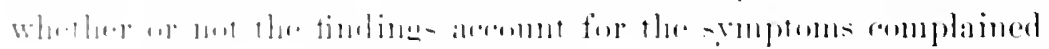

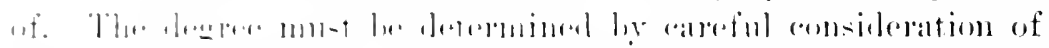

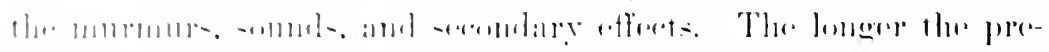

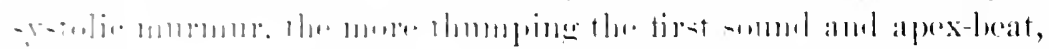

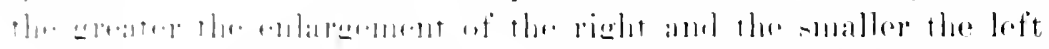

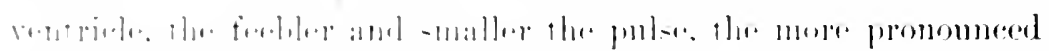

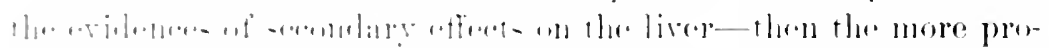

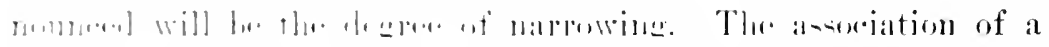

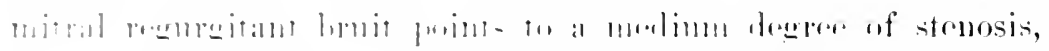

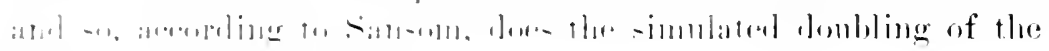
-

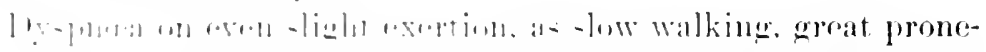

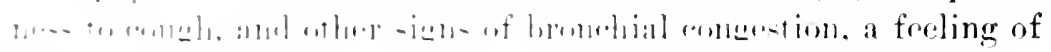

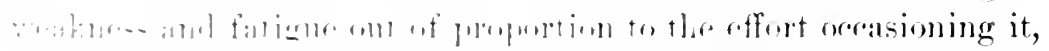

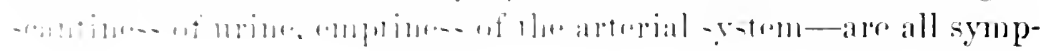


toms indicative of serions circulatory embarrassment, and attributable to the valvular disease.

On the other hand, neuralgic pains in the pracordia and a feeling of fulness or uneasines in the cardiac region, coldness and numbness of one hand and not the other. or of the hands and not the feet, headache, and prolonged rertigo, the patient being quict and the pulse not feebler than usual, a feeling of nepronsness and restlessness-may all be neurotic manifestations depending on tefective nutrition or elimination, and in such cases are apt to be out of proportion to the degree of the lesion and to srmptoms distinctive of cardiac disease.

Prognosis.-In general, this is less farourable than that of mitral ineompetence, and for two reasons: (1) Obstruction is constant and tends to greater stasis in the pulmonic ressels, in consequence of which the left anricle and right rentricle are subjectcd to greater strain. Thes are likely, therefore, to break in their compensation at an earlier period. (2) Mitral stenosis is a progressive lesion, and may under the influence of repeated attacks of subacute rheumatiom become at length so extreme that life camnot be maintained.

When the narrowing is pronounced there is but a small rolume of blood ejected into the arterial spstem, general nutrition is correspondingly poor: complications on the part of the lungs are more likely, ontdoor exereise is difficult if not impossible, normal metabolic proceses are interfered with, and general nutrition becomes very defective.

In a word, cren when uncomplicated and apparently well compensated, mitral stenosis offers an exceelingly grave prognosis. By some authorities the arerage length of life is set down as not far from ten years. It stands next to aortic regurgitation in point of grarity.

The following figures are of interest as showing the arerage age at which death took place in sereral series of cases. Of Sansom's 61 cases death oreurred at 32.7 years. In Mayden's 42 cases death took place at 37.8 rears. Of Broalbent's 53 eases it occurred at 33 years for males, and 37 to 38 for females. Samways found that at Guy Hospital during a period of ten years the average length of life for both sexes was 38.39 , rears: in less pronounced forms, 43.6 rears; more extreme cases, 33.6 years. 


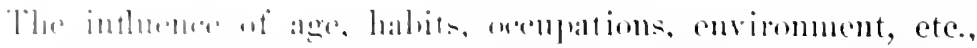

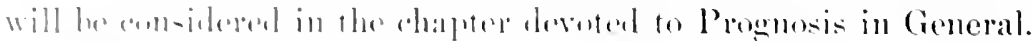

Mode and Causes of Death.-. leath in rat:en of mitral

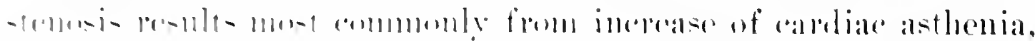

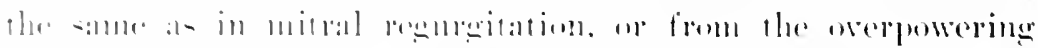

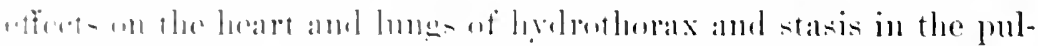

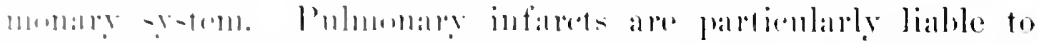

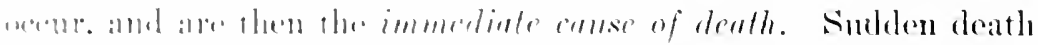

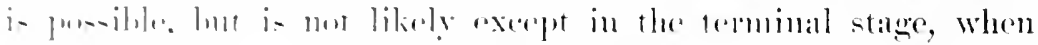

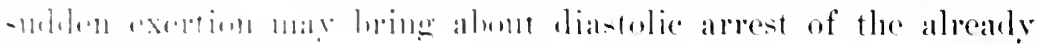

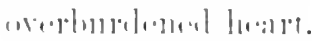

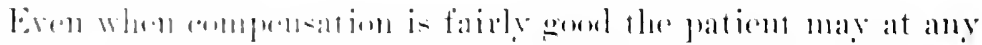

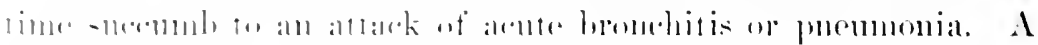

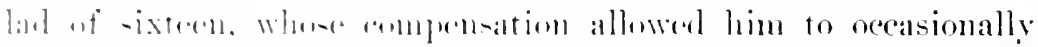

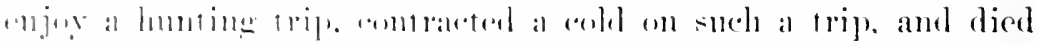

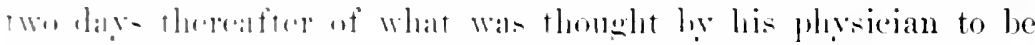
rextrome pulmumary andertion. An attack of acute pulmonary

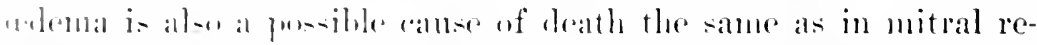
enreitation. In whe alse anning moler my knowledge obstinate rumiting antributed largely to the fatal result by preventing resention of foul and remedies. The end appeared to come as

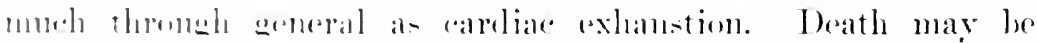

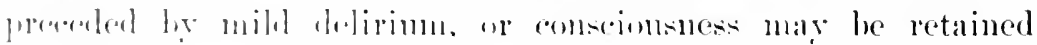
$1+1$ the $h_{a-1}$.

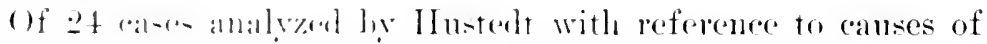

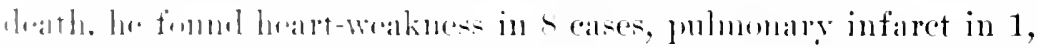

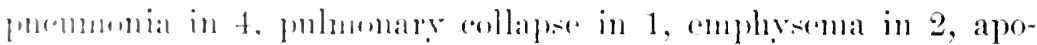

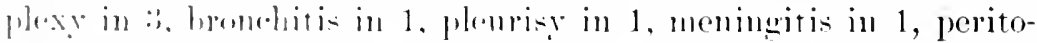
niti-in 1. and aledirimu in 1.

The following at-a - illustrate so woll mamy of the features that

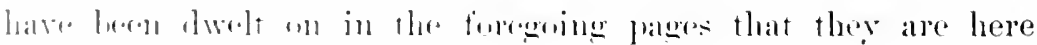

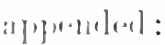

Mr-. ('., Iri-h-Amuriran, agerl thirty-fomr, was admitted to

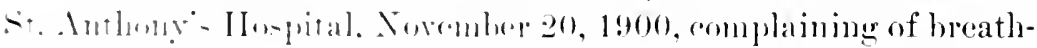

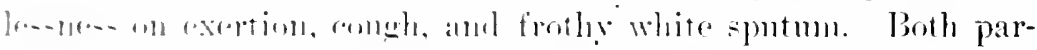

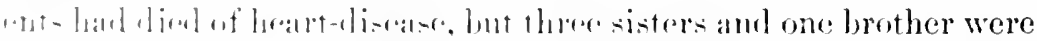
liviue and loralthe. Thre pationt harl had measles and pertussis in

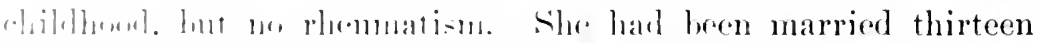

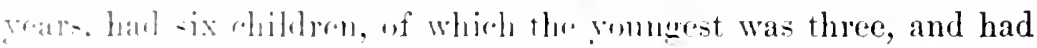


had six abortions, all of which she had herself induced, and which had not been followed by chill or ferer. During the first pregnaney she had had cedema of the left leg. pasoet no urine for two days, and had cone near "smothering." Hes physian dectaren she had "water aromd her heart," and had tapped her", but she conld not say whether water hat heen obtained wr not. She hand heen troubled with drepmera onertion for a number of years, and this had always been particularly bad during her pregnancies.

Examination showes a woman of medinn height, weighing 114 pounds, slight cranosis about lips. coll. moist extremities, and pulsation of the external jugnlars, tongue having a whitish coat and indenter hy the teeth. The pulse was 1:3t. compressible, and irregular in force and rolume, but there was no pitting of the skin orer the ankles or elsewhere. The apex-beat was in the sixth interspace, $4 \frac{1}{2}$ inches to left of the midsternal line, of the character of a faint tap in an area of diffused impulse (Fig. 50). A pressatolic thrill ram 11) to and ended with this faint, sinap tap, and there was marked epigastric pulsation. Relative duhness was in-

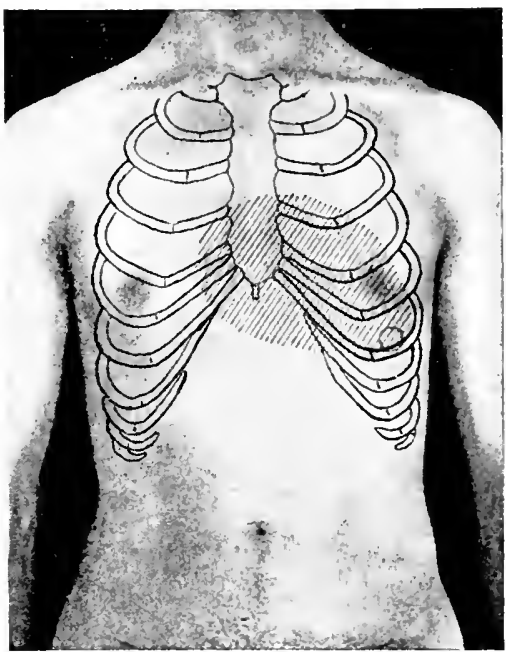

Fig. 50.-Location of Apex and Relative Deliess ix Case of Mitral stexusis (P. 270 ).

creased in all dianeters, from thipd interspace to sixth, and from 2 inches to right of median line to 5 inches to left of the same. The first sound wa- thumping, heard throughout pracordia, and followed quickly ly a scareely perceptible secont somud, the aortic second being weak and the pulmonic second markedly accentmater. A harsh murmur of greatest intensity in the mitral area began immediately after the second, ran up to and ended with the next ensuing first sound, and was not transmitted into the axillary region. The hmes revealed impaired resonance at the posterior bases, with some moist râles. The liver was palpalble two fingerbreadtls below the inferior costal margin, but the spleen was not 


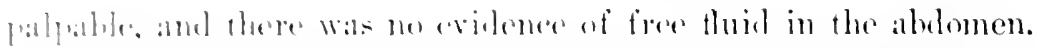

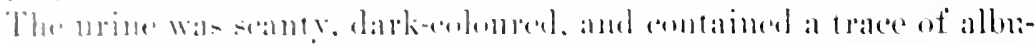

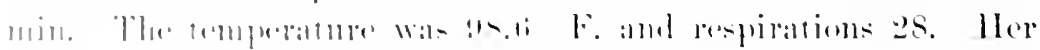

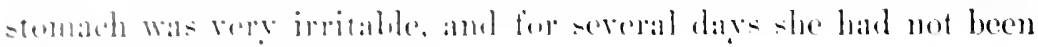

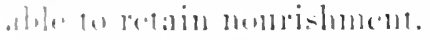

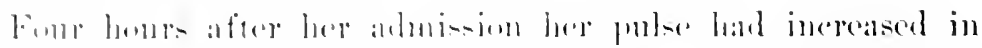

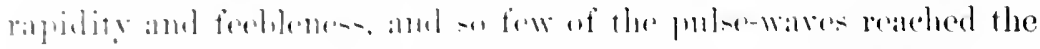

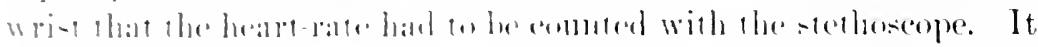

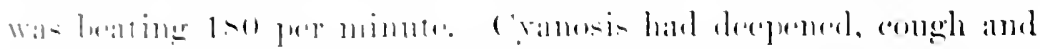

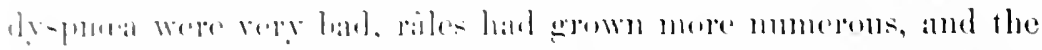

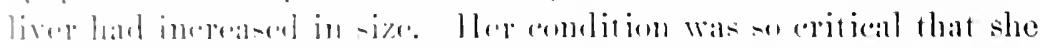

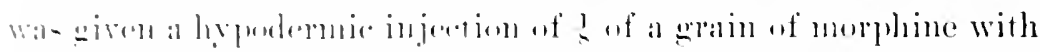

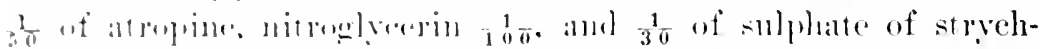

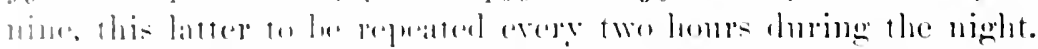

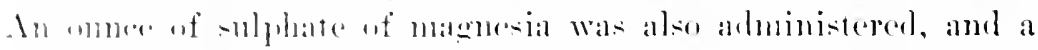

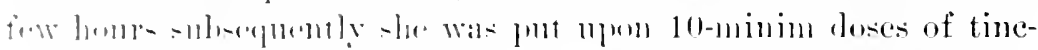

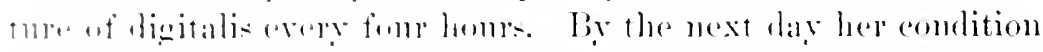

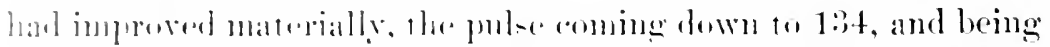

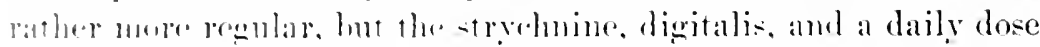

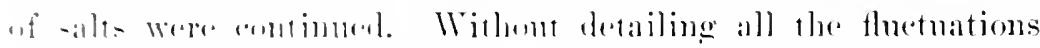

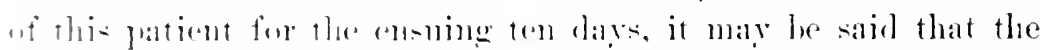

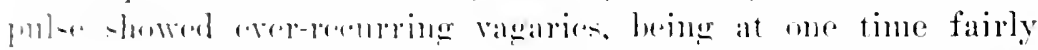

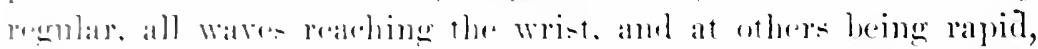

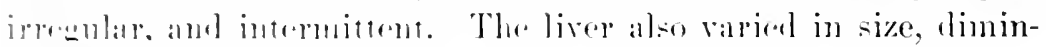

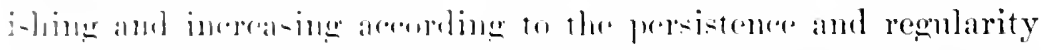

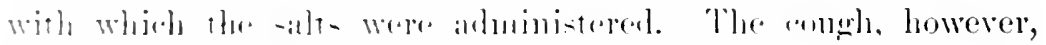

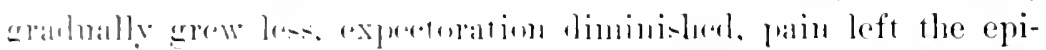

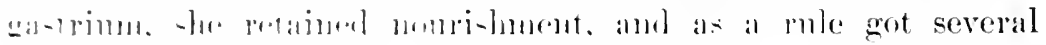

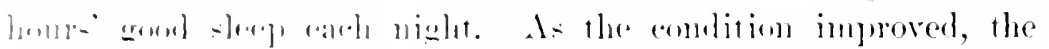

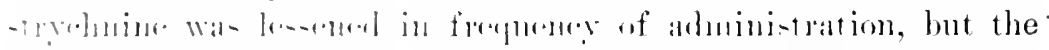

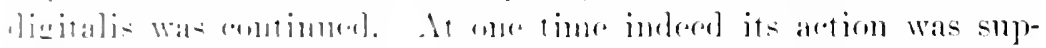

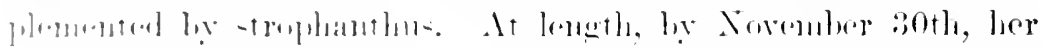

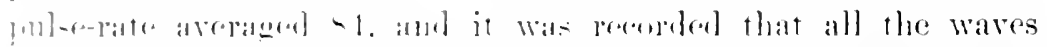

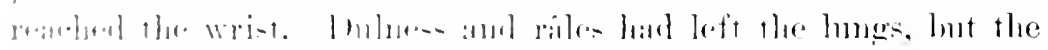

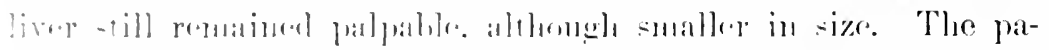

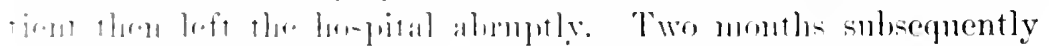

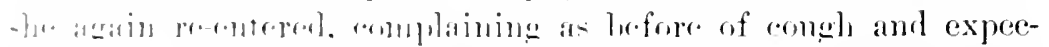

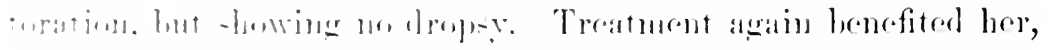

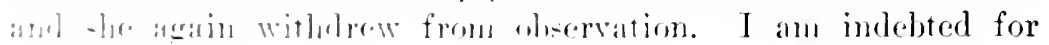


the notes of this case to Dr. J. R. Yumg, one of the internes at the time.

This case illustrates fairly well the symptoms and anenability to treatment of a case of mitral stenosis in which compensation was broken, but not irreparably so, and in which, wht signs of stasis amounting eren to a relative incompetence of the tricuspid valve, there was no cortenia. In fact, the lomut of the disturbance was borne mainly by the lungs, the dulness and râles, the dyspnoea, congh, and frothy expectoration being the lesult of the great puhmonary engorgenent. It is hard to explain why in such a case wema is absent, whereas in other individuals with apparently no greater stasis, dropsy will be a marked and distressing feature. It certainly seems to corroborate the riew that dropsy depends upon the state of the blood and mutrition of the capillaries, as well as upom the degree of capillany am venous engorgement. This patient subsequently succumbed to a third attack in the hospital.

Mr. B., aged twenty-nine, tailor, consulted me January 9, 1900, on account of great breathlessness upon the slightest effort. He gave a history of rhematism four years previous, since which time he had suffered with subacute articular pains. Gonorrhoea six rears ago, with stricture at present time. With the exception of a " bad eve," nature muknown, at six rears of age, has had no other illness. Heart began to trouble him one rear after the rhemmatic attack, but was not treated for heart-disease until the summer of 1s99. His stmptoms were great dypnoea on effort, cough once in a while at morning and evening, rertigo upon exercise. some

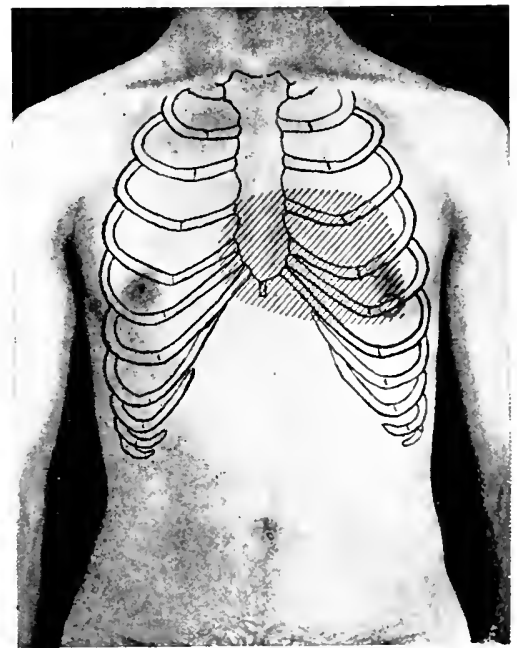

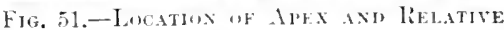

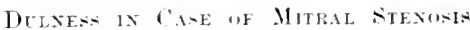

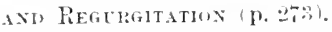
pain between the shoulders, and porm appetite hut sleep good. His pulse while sitting was weak, small, regular, and 90. The 


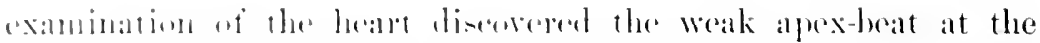

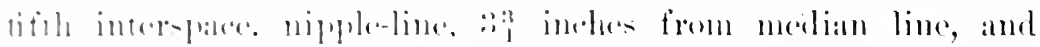

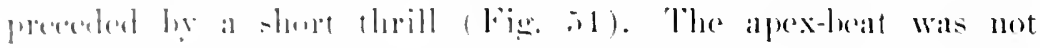
thmmpingr. Int there was matkinl epigastric pulsation. Abso-

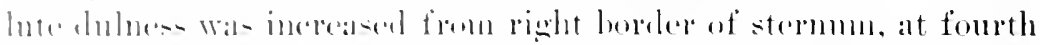

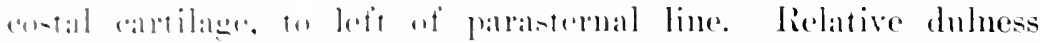

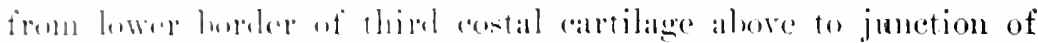

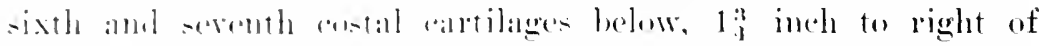
merlian line and in:

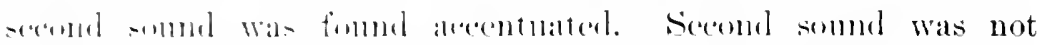
dombled al bare. hut limitul to aleal of the alvex-heat was an

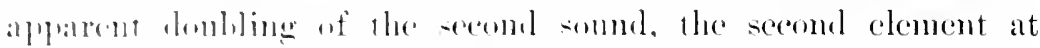
times having the chararele of a short mumum, and separated from the following posstolie mumms. At lower imor edge of the

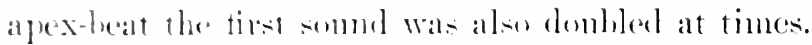

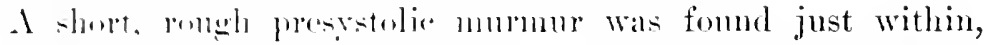
and a hlowing -ystelie at the apex. The mormms and sounds marle a rollinge tombling rhython. In dorsal decubitus the apparent lombling of - reomel smmel was very marked at inner edge of alpex. A- the heatrt aceasimally slowerl, the first somel was fomme alor dombled. the tirs rement replacing the presystolic murnur. The -rstolic mummor hecame plain and whistling with a very pro-

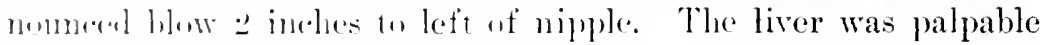

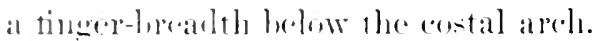

The diagnusi- mande was mitral stenowis and insufficieney, with secomdary eardiare hypertrophy and dilatation.

Mrs. A. aged thirty-there rars, woight 115 pounds, height molimn, Anerican, Was examined Mareh 29, 1901. Her father wa- living. but hat comgh, while a matronal mole and a maternal

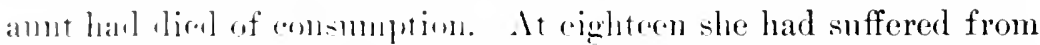
a $-r \cdot r e r$ attark of inflammatory rhematiom, and had had more o le.. joint pains for three or four years sulsequently. Of chil-

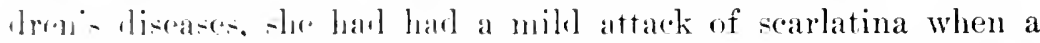

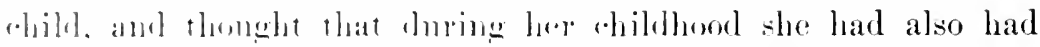

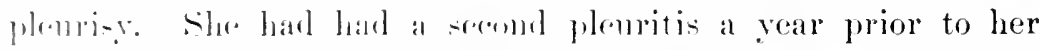

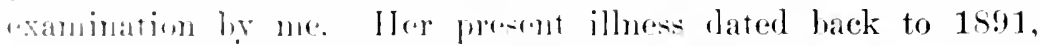

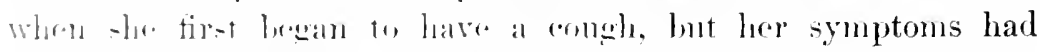

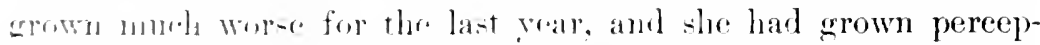
fibly faldr. In the way of symptoms, she eomplained chiefly of 
chronic congh, which was most tromblesome at night, and of considerable vellowish sputum, in which tubercle bacilli were said to have been discorered. She noticel shortness of hreath in walking and ascending stairs. The appetite was poor and the digestion weak, although bowel nowements were regular, as also were the menses. Sleep was disturbed by the congh, and there was slight pain in the right hip and the left side of the chest near the shoulder. The roice was husk, but it may be said in passing that laryosocopic inepection revealed no infiltration of the larynx.

Examination.-The pulse was 105, small, regular, and of noticeably low tension. The temperature taken at 12 x. was $99^{\circ} \mathrm{F}$. Respirations were shallow, but not hurried. The chest was moderately emaciated, very shallow in its antero-posterior diameter, and flattened both above and below the right claricle. Tocal fremitus was increased at both apices, particulariy the right. Upon the right side, dulness extended from the apex to the third interspace in front and to the midule of the scapula behind, shading off to impaired resonance as far as the tip of the scapula and below this point, becoming again more pronounced towards the posterior axillary line. In the right infraclavicular region there were bronchial breath-sounds, moist râles of rarring size, and the voice-somds were so concentrated and hollow as to strongly suggest a carity. Postriorly, respiratory sounds were also bronchial, and the act of coughing dereloped numerons fine and coarse crackling râles as far down as the interior scapula angle. It the left apex there was impaired resonance both front and back to the lerel of the second rib, and over this area breatl-sounds were broncho-vesicular, and cough produced crumpling riles that extended below the limits of slicht dulness.

The apex-beat was situated in the fith left interspace slightly within the nipple-line, was feeble, and of the character of a quick thump, and was preceded br a short ret distinct thrill that ended with the cardiac impulse. Relative heart's dulness was somewhat increased towards the right and downward, but did not reach beyond the rertical nipple-line at the left (Fig. 52). Cpon anscultation the first sound at the apex was short. sharp, and thumping, the second sound was not doubled, and the pulmonic second tone was markedly accentuated. A rather short, rongh, distinctly 


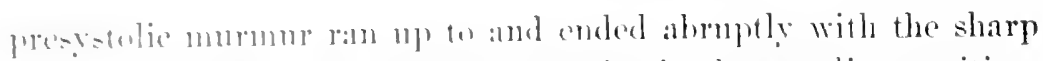

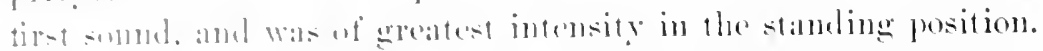

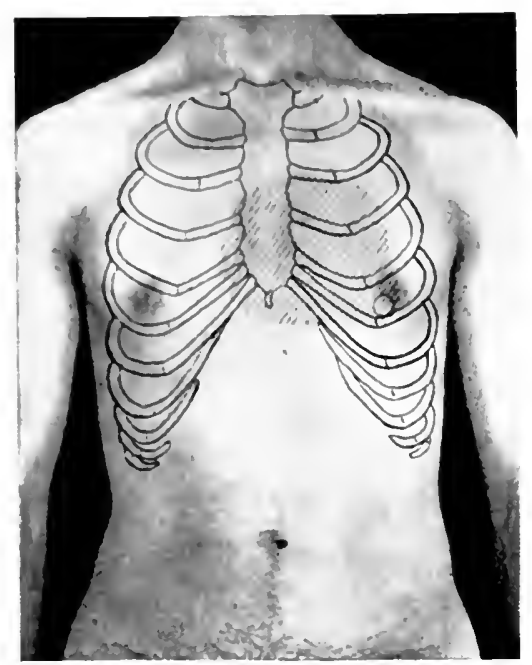

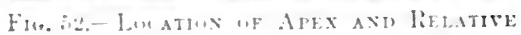

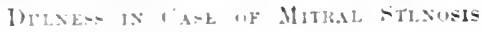
(1) -1.1

1 high-phiteded systolic whiff alecomplanied the systole in the mitral alreil, hut was not transmitred te any appreciable distance ontsisle this areal.

The aldomen was that ame thin, the lenere hepatic lowder distinctly palpable and tender to pressure, and hepatic dulners reandend from the upper margin of the sixth rib in the mamillary line to slightly belnw the inferior costal areh.

The diagnosis was elearly rhonic pulmonary tuberenlosis with softening and romica in the right lunge. incipient discase of the left upper lobe,

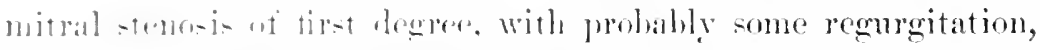

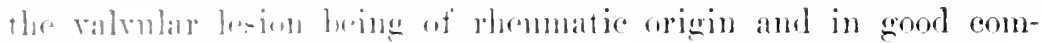

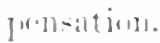

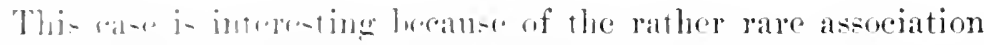
of pulmolary mberenlwi- and mitral stenosis, and womld seem to

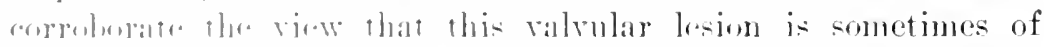

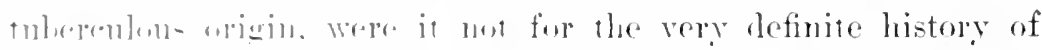

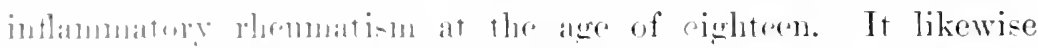

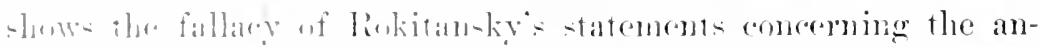

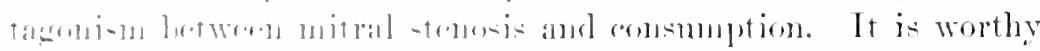

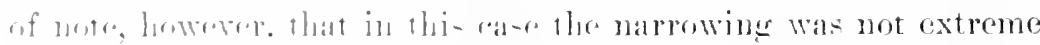

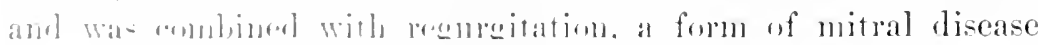

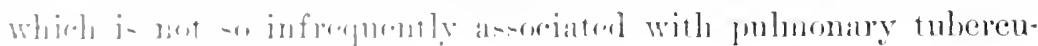

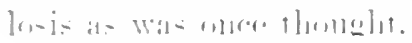

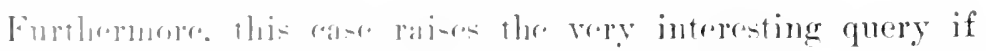

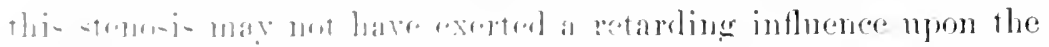

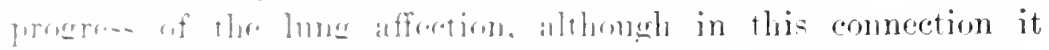

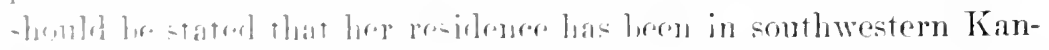
- at where the air i- dry and the altitude not far from 2,000 feet. 
For my part I am much more inclined to attribute the slow advance of the pulmonary affection in this ease to other factors, possibly to climatic influences, possibly to inherent nilkness of the tuberculous infection itself, rather than to the mitral obstruetion, since, as suggested by Sanson, it is reasonable to assume that a valvular lesion would have a tendency to impair the resistance of the organism, partieularly in one inheriting a preclisposition to tubereulous disease. 


\section{('H.11'llili V'll}

\section{AORTIC REGURGITATION}

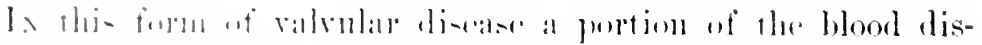

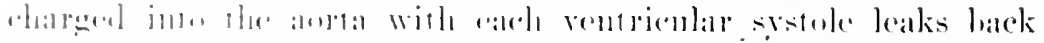

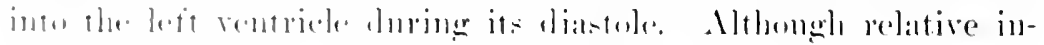

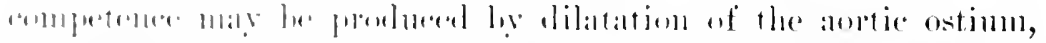

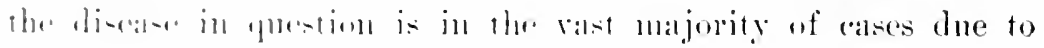

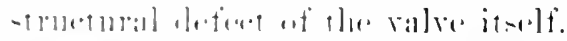

Morbid Anatomy.-Ihofects in the antic valve leading to

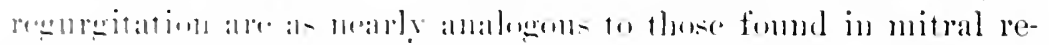

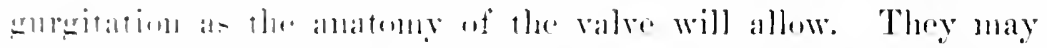

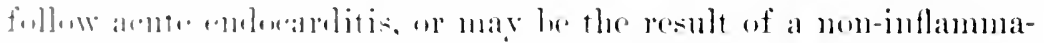

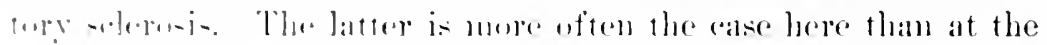

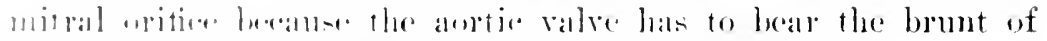

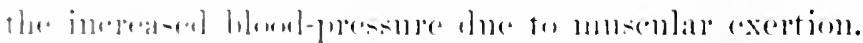

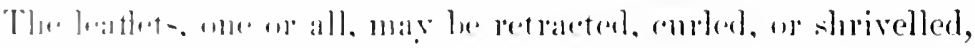

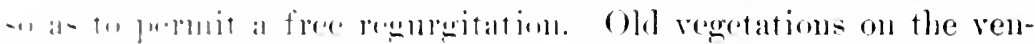

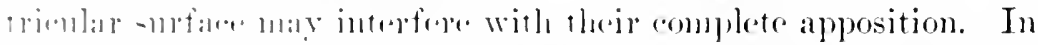

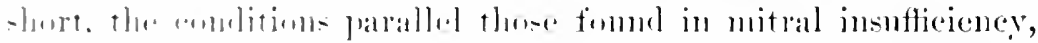

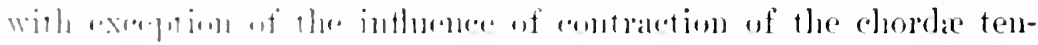

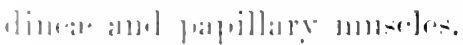

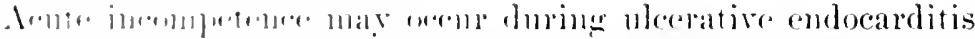

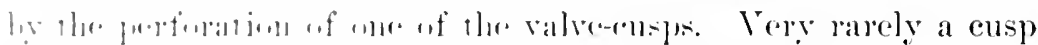

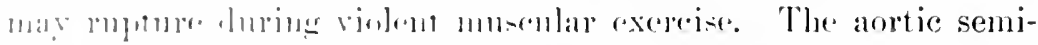

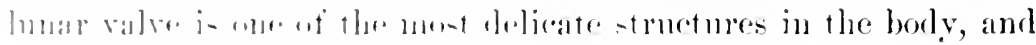

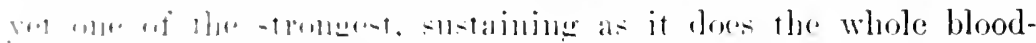

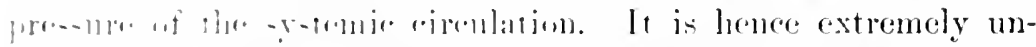

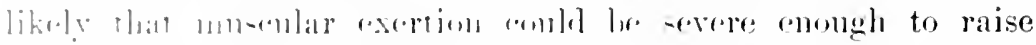

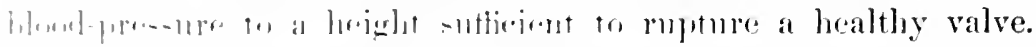

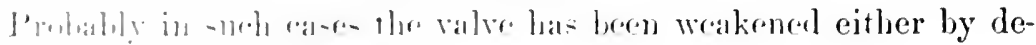

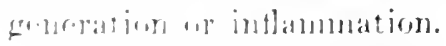

1- in mitral li-rase, remmentation is often combined with 3.- 




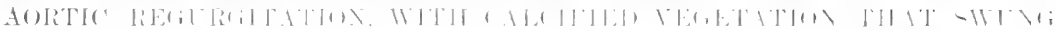

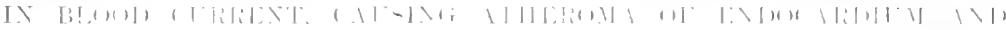

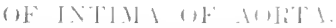



some degree of stenosis, but regurgitation may oceur withont narrowing, and occasionally, in consequence of dilatation of the ventricle, even with stretching, of the aortic ring. That such enlargement of the ring, leading to relative insufficieney, could take place, was long doubted, owing to the great strength of the anmulus fibrosus, but so many instances of the kind have heen observed that there is no longer any room for doubt.

The first effect on the heart is dilatation of the left rentricle. This is due to the impact on its inner surface of the regurgitant stream, which in repry free regurgitation re-enters with nearly the force with which it was driven out of the rentricle. Such lesions, however, are of gradual developnent, and the increasing work leads to a corresponding hypertrophy of the wall of the ventricle, which enables it not only to withstand the strain of the regurgitation, but to expel the greatly increased rolume of blood present in the chamber at the beginning of its systole. This hypertrophy in artic insufficiency is of early development and often becomes so extreme that some of the largest hearts on record are those showing this defect. The wall of the hypertrophied ventricle may be as thick as 4 centimetres $\left(1 \frac{3}{5}\right.$ inch). The apex of the left ventricle projects far bevond that of its fellow, and the interrentricular saeptum is displaced, encroaching largely on the carity of the right chamber.

As long as the mitral valve remains intact the effects of aortic regurgitation upon the heart are limited to the left ventricle. If, however, the mitral is incompetent, either from disease of the valve or relatively from the enlargement of the ventricle, the phenomena described as the results of mitral incompetency are added to those of the aortic lesion. In such an event, of course, the right heart is also enlarged, and the largest hearts have been those showing this combination of lesions. Such a heart may weigh as much as 3 or 4 pounds. Indeed, ron Ziemssen has reported 6 pounds as the weight of a specimen obtained from one of the great Stokes's patients. On account of its size such a healt is spoken of as cor bovinum. The heart presented to me br Dr. C. C. O'Brrme weighs $2 \frac{1}{4}$ pounds, and in it the regurgitation could not have been extreme (Plate II). The point of interest in this specimen is the swinging vegetation, 3 centimetres long, and containing calcareous nodules, which evidently swumg in the blood-stream, now in the 


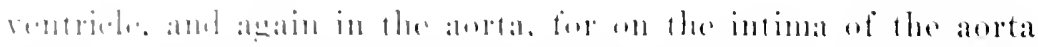

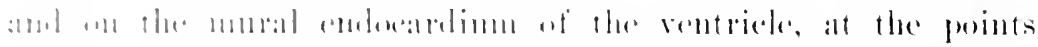

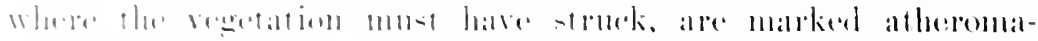

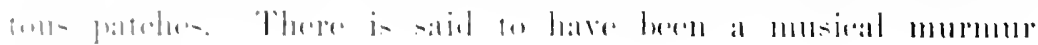
Huring litio.

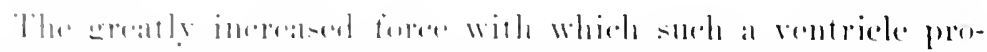

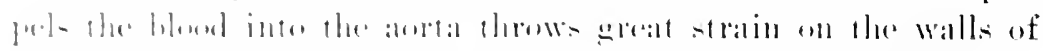

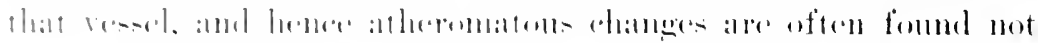

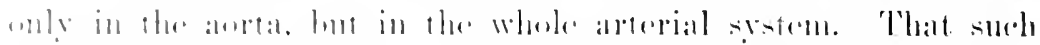

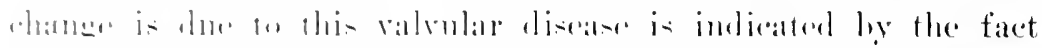

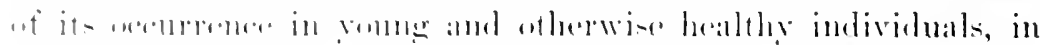

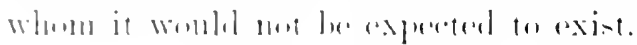

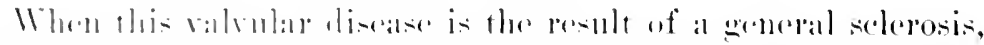

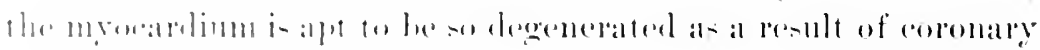

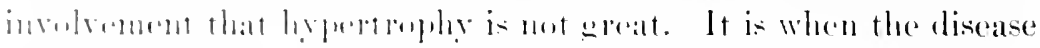

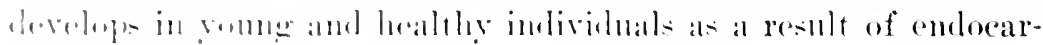

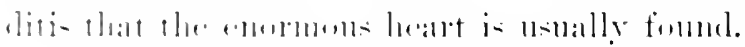

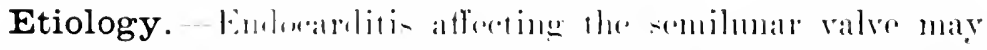

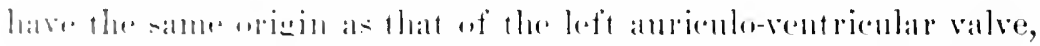

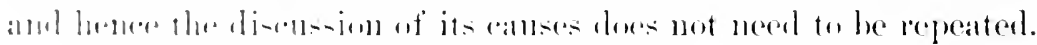

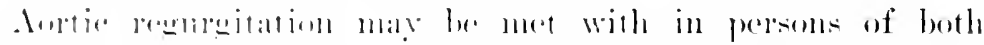

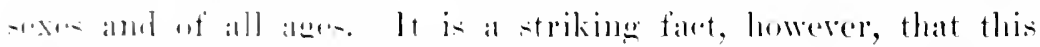

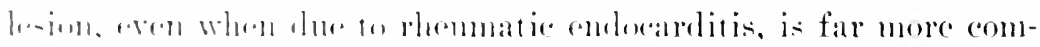

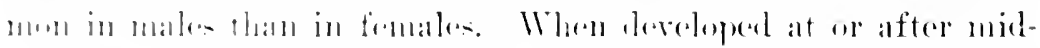

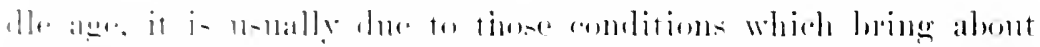

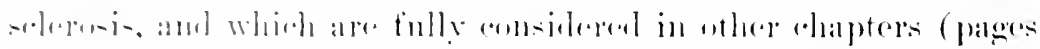

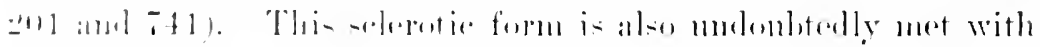

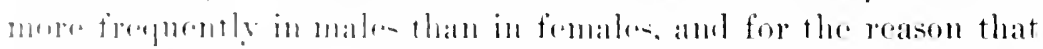

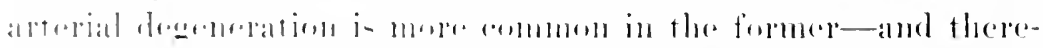

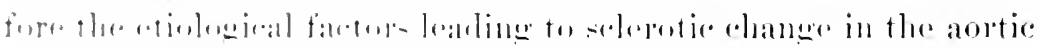

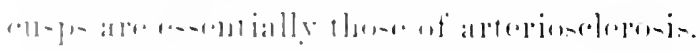

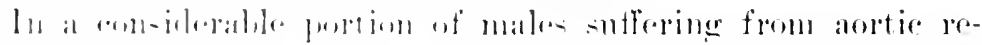

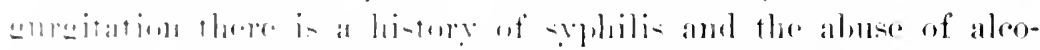

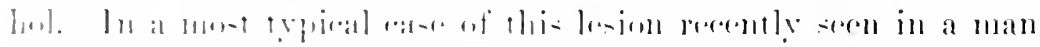

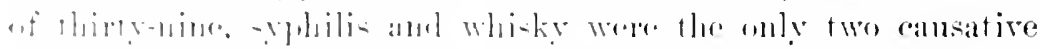

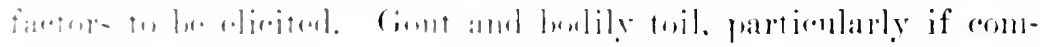

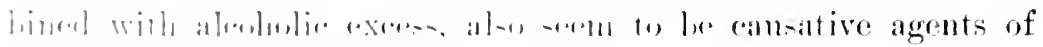

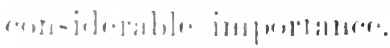

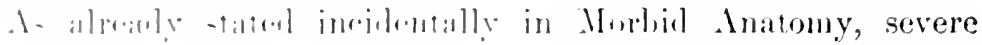


strain may bring about acute ineompetence of one of the aortic eusps through rupture at some point that had been previously weakened by inflammation or atheromatons degeneration.

There is a form of aortie insufficiency which, althongh not due to valvular defeet, vet presents the same clinical features a- the organic form, and is so frequently encomtered that it may here be briefly dwelt upon. This is a relative incompetence of the semilunar valve, and its causes are found in conditions that predispose to stretching of the rentricular wall and of the basal ring of the aorta. They are therefore (1) degenerative changes in the nyoeardim, (2) diseases of the aorta that greatly narrow its lumen, or, per contra, lead to its dilatation, and (:3) mediastinal tumours, which by pressure diminish the calibre of the aorta. The most frequent eause of this relative insufficiency is aneurysm affecting the ascending arch, or a general dilatation of the aorta secondary to selerosis. In one instance of the latter kind eoming under my notice it was associated with mitral regurgitation, also of atheromatons type, but which had existed for years. During the later weeks of life in this case aortie ineompetenee developed, and after death was found dne to extensive atheromatous degeneration and dilatation of the aorta, reaching from its origin to the beginning of the descending portion of the ressel.

In another ease in which regurgitation through the aortie valve had run its conrse to a fatal termination within a few months, post-mortem examination diselosed stenosis of the aseending aorta, about $\frac{1}{2}$ an inch above the insertion of the valve, so pronouneed that the humen was diminished by at least a half. This narrowing was eaused by a growth of fibrous tissue whieh completely eneircled the aorta, and from the history appeared to have originated in acute inflammation a sear and a half previously.

As already stated, relative aortie ineompetence nay be the ultimate effect of chronie myoearditis, which is associated with sclerosis of the aorta, and which so seriously impairs the resisting power of the ring that it gradually yiekls to the distending foree of the blood-wave as it reeoils against the closed valve. I have seen more than one instance of the kind as disclosed by the necropsy, although durng life the regurgitation had been attributed to structural defeet of the valve-segments. 


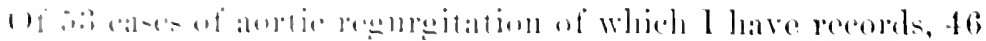

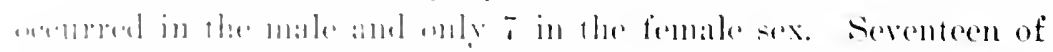

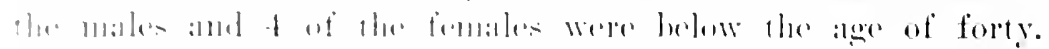

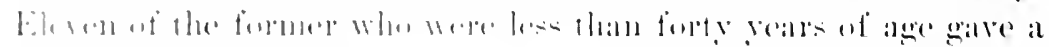

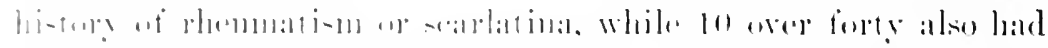

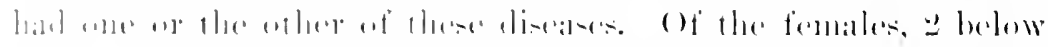

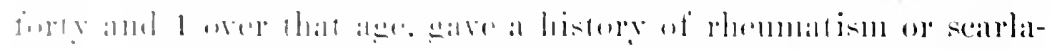

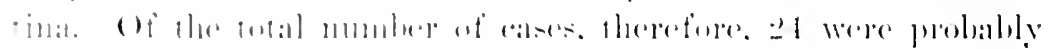

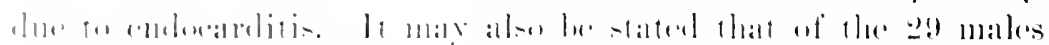

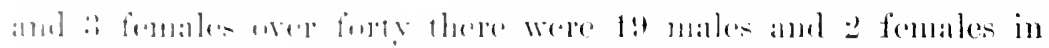

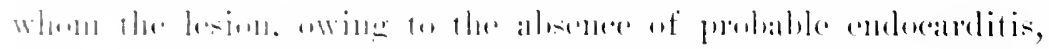

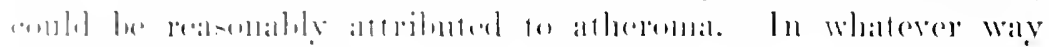

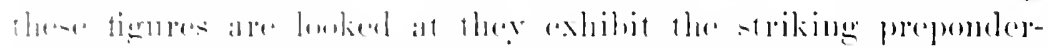

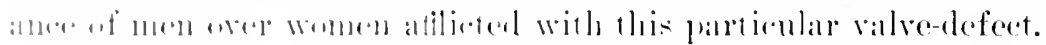

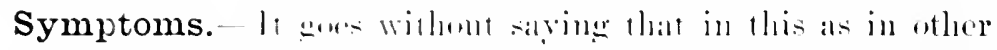

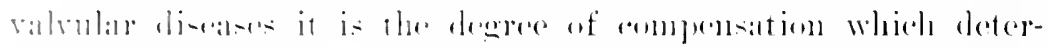

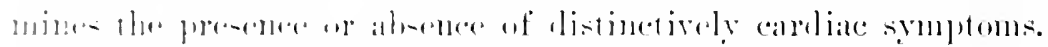

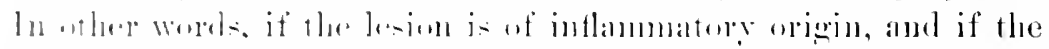

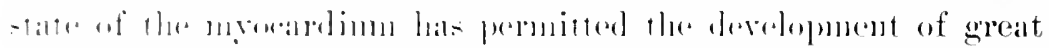

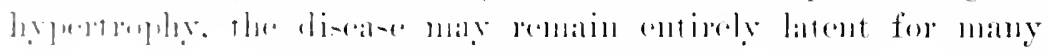

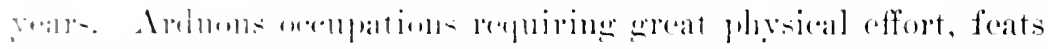

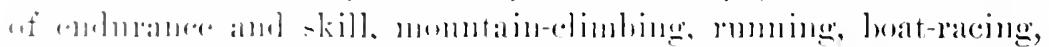

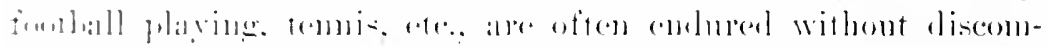

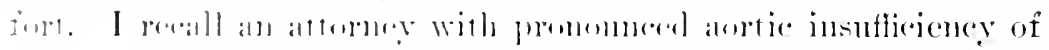

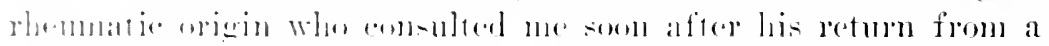

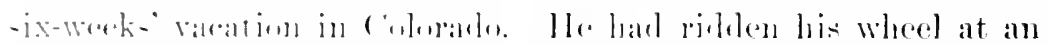

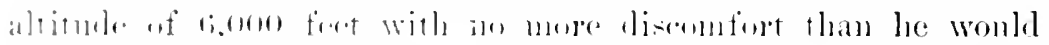

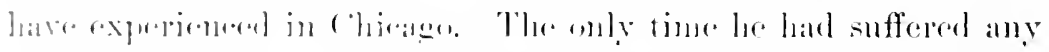

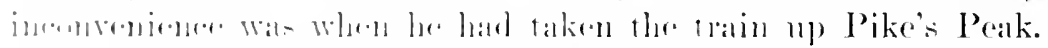

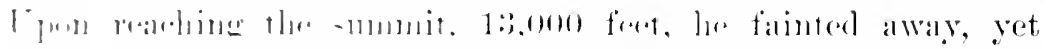

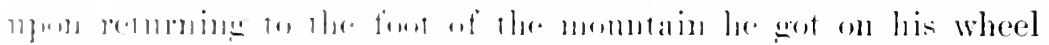

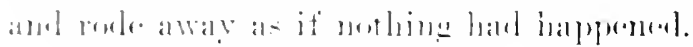

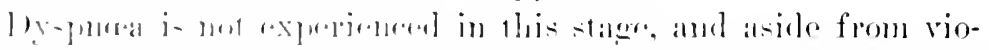

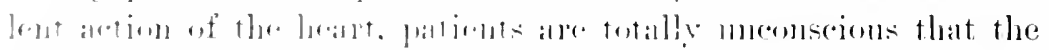

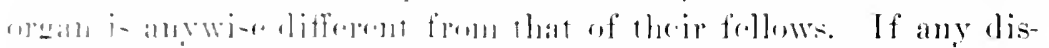

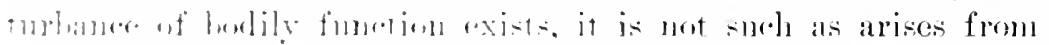

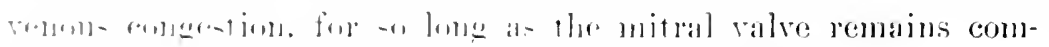

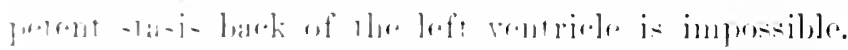

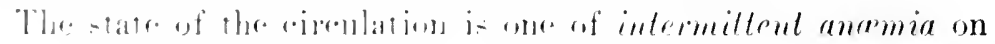


the part of the arterial system. At each systole the arteries are flushed, and with each diastole they are relatively depleted. The tendeney, therefore, is te a lack of mitrition of the varion: organt and tissues throughout the body. This is not specially manifest in some persons, while in other's there is more or less pallor and delicaey of body. The muscular system in particular is weak, and some children show inability for sustained mental effort, ret as a rule young persons with aortic regurgitation show nothing either in appearance or deportment to indicalte the existence of their lesion.

A well-compensated aortic insufficiency is not likely to incapacitate an otherwise healthy young adult for the active and even the arduous duties of professional or mercantile pursuits. Many a hard-worked medical man with this lesion is able to sustain the severe mental and physical strain of a large general practice without more fatigne than his more fortunate confrères. The only symptoms experienced by some patients are palpitation or slight vertigo, or both, and yet trivial as they may seem to be they are sometimes the earliest announcement of faltering energy on the part of the left ventricle. In one instance, more than twenty year's before the patient's death, any effort or excitement beyond a certain moderate degree, brought on attacks of such violent palpitation as to necessitate absolute repose for hours in the recumbent posture. These attacks were also produced by even small doses of digitalis, and as they were allayed by aconite they were thought due to extreme hypertrophy. In most eases such violent cardiae action is an expression of reakness rather than of excessive strength, as sometimes supposed. When dizziness is experienced, it is nsmally, though by no means always, induced hy sudden exertion, and in such cases it is generally found that the regurgitation is very free.

The cerebral anteries are flushed with each systole, but in consequence of the regurgitation blood-pressure within then is not sustained, and when for any reason the reflux inte the ventriele is intensified, transient anamia of the brain results and reptigo is felt. In some cases dizziness is produced by intermittence in the heart's contractions, and it is then a mild manifestation of what in other cases liecomes a syneopal attack. Indeed, fainting is an occasional syuptom in this disease, in consequence 


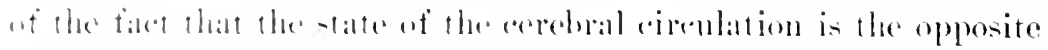
"f what nhatim-in mitral stomosis. This axplans, I think, why it

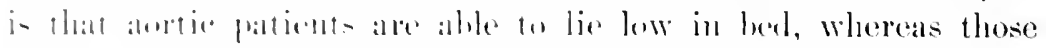

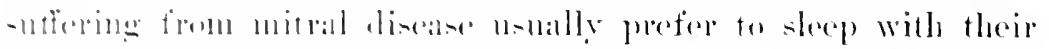

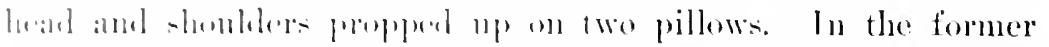

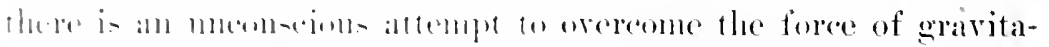

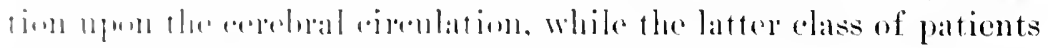

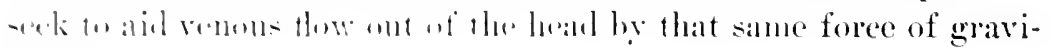
$1: 11 \mathrm{i}, 11$.

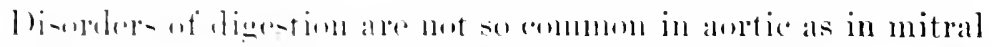

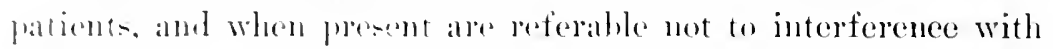
the cinentation, as hat lexen explained is the ease in lesions at the

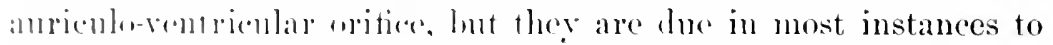

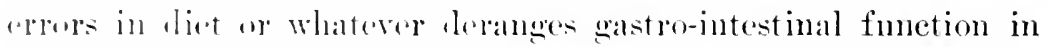
individuals who have no hearterlinatee.

The (ommplative inmmuty from symtoms enjoyed for years, it may he. ly perens whose discase is the result of endocarditis, $i=$ not the fortunate. lot of these in whom the aortic ralves have berome incempetem in consequence of sclerosis, and in whom the myoralimm is incapable of maintaining adequate compensatory

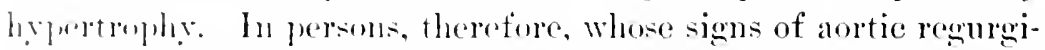
farion derelup during middle age, somptoms are apt to appear rarly and to be pronomened. These lo not differ essentially from thos rxperivened ly patients of the other elass, and are palpitatim, rertign uf mure or less intensity and frepueney, a feeling of

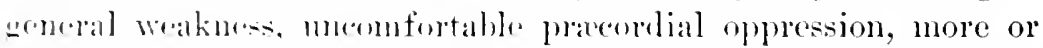
les patin that may lu listimetly anginal or of an anginoid chararele, and in particular distersing attacks of lyspmea. When there syuptoms arioce a fatal temunation is not far distant.

With IM. G. W. Mebster, ()coblor 1:), 1900, I saw an Irishman

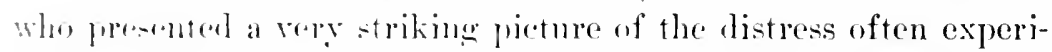

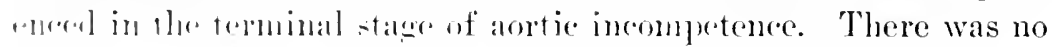
hi-tory of intammatory rhematism, but of syplitis and the im-

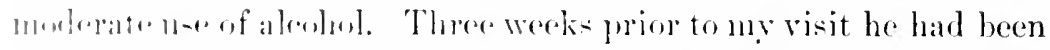

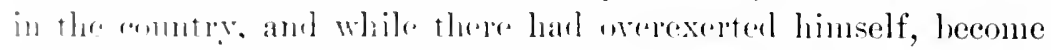

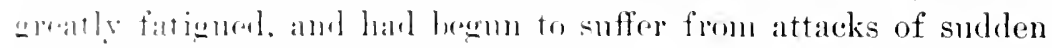
watkurs- with a forling of sufforation. Ipon his armission to

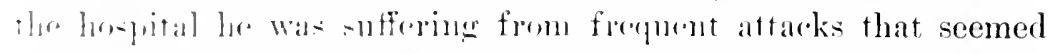

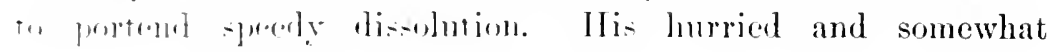


laboured respirations would suddenly become so angmented in severity that he wonld spring into the upright position gasping for breath, conghing and raising frotly mucus, while cyanosis became marked, and the pulse grew rather more rapid, irregnlar, and extremely feeble. The face becane anxions, and, in a word, the whole appearance of the man was one of direst distress. The examination on admission disclosed aortic regurgitation and a secondarily leaking mitral, with very swollen and tender liver. Hypodermics of morphine reliered these attacks in a measure, and under the free nse of cathartice. digitalis and ionlide of sorlin, the condition so much improved that the mitral no longer leaked.

I found a rather spare man of medimm stature who looked nuch older than he really was. He was semi-recmmbent, and althongh comfortable was yet breathing with apparent difficulty and greater than nommal rapidity. There was no odema, and signs of stasis were not noticeable. The temporal and cervical arteries throbbed strongly, the pulse was quick and of the character known as bisferiens, and the radial arteries were stiff. The lower border of the liver was palpable a short distance below the costal areh, but the organ was not hard or tender. Cardiac impulse was diffised and weak. the indistinct hroal apex-lieat being in the sixth interspace, midway between the left mamillary and anterior axillary lines. Permssion showed slight inerease of cardiac

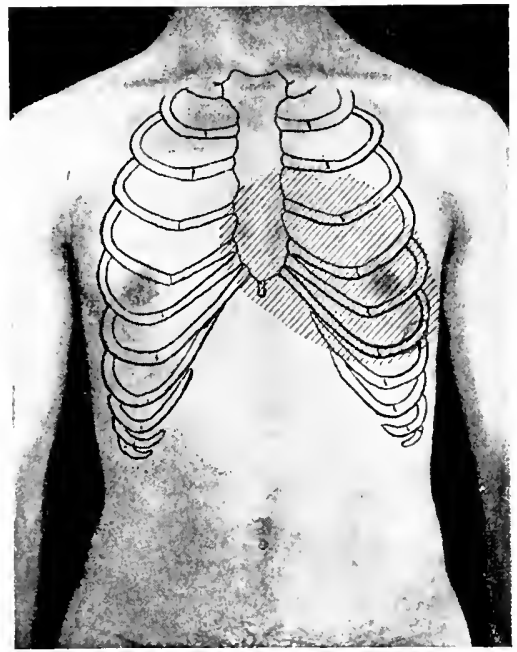

Fig. 53. - Location if Apex axil Relative Dulanes, Case of hortic Inevffichexcy (p. 284 ). dulness to the right of the stermm and downward, but very great extension of dnlness towards the left and downward. The outer border was broadly rommed, after the manner often described as indieative of preponderating diatation of the left ventricle in eases of aortic insufficiency with broken compensation (Fig. 53). When hyjertrophy predominates, the outline of the 


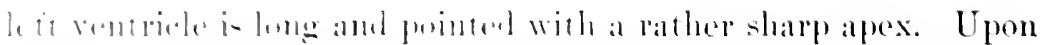

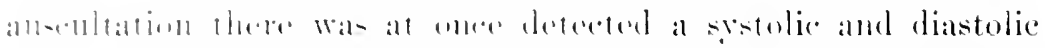

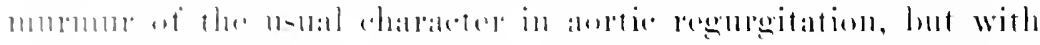

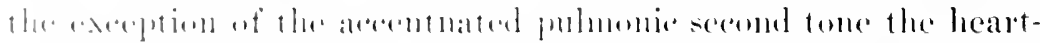

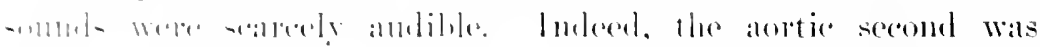

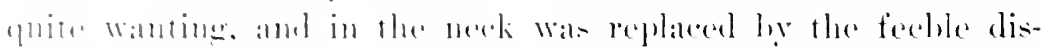

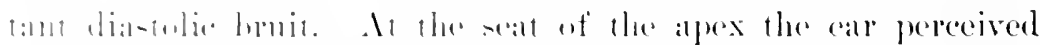

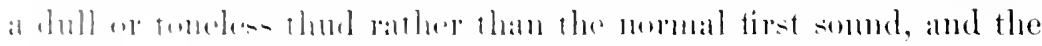

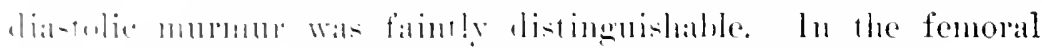

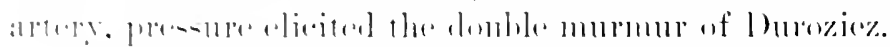

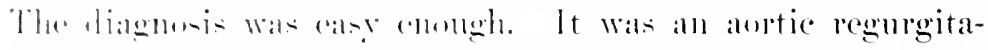

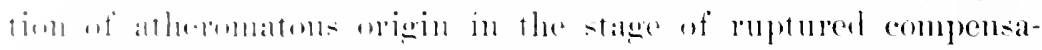

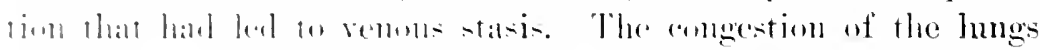

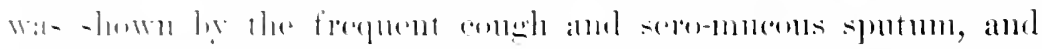

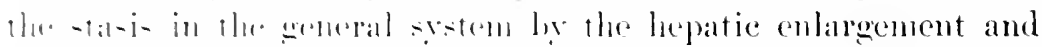

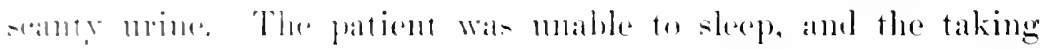
uf find was tollowed he the formation of gas, which comtributed

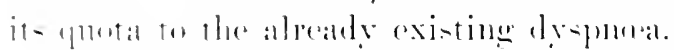

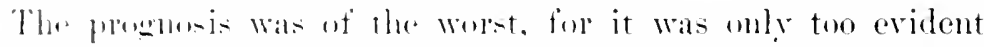

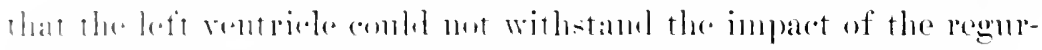
gitatim-treath. That this was fore was shown by the absence of

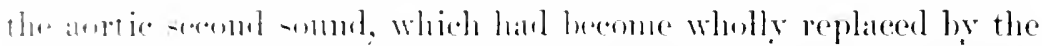

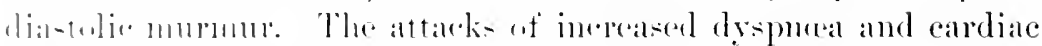

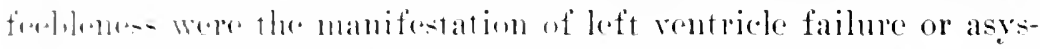

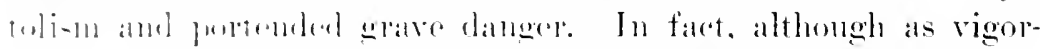

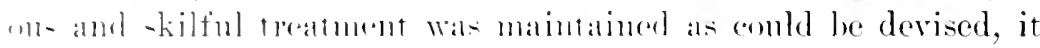

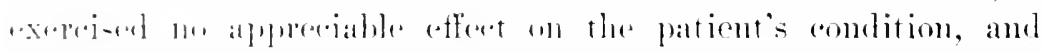

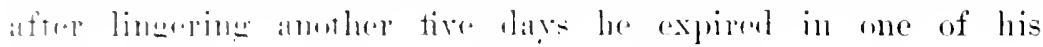
:11+110]:-

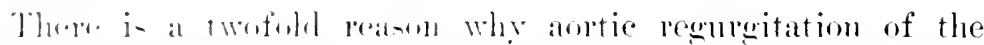

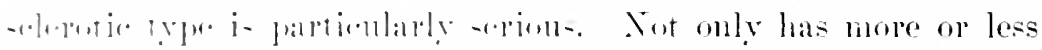

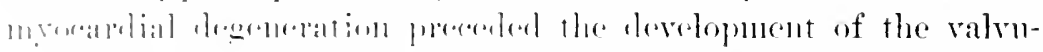

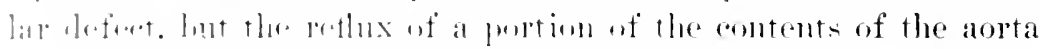

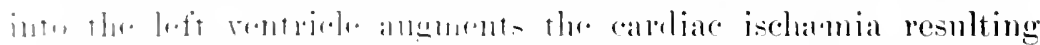

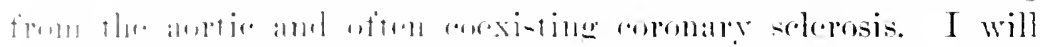

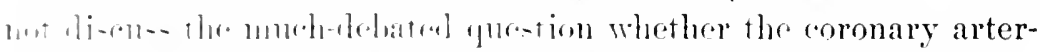

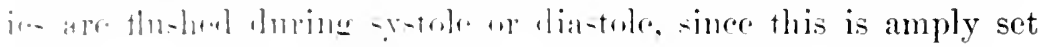

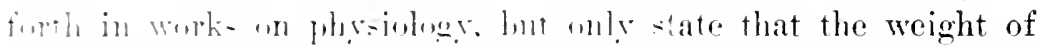

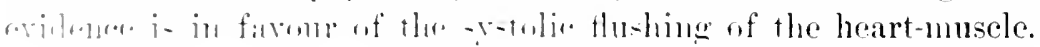


It is sufficient to emphasize the fact that in aortic regurgitation blood-pressure is not snstained within the coronary any more than in other arteries, and hence cardiac nutrition cannot be good.

There concs at length a limit in all cases to carliac hypertrophy becanse the heart-muscle beomes nure or less degenerated, and therefore incapable of mantaining the eirculation and of withstanding the dilating foree of the regurgitant stream. Its flagging energy is shown by more rapid and perlaps less regular contractions, eren, it may be, by ocasional internissions.

Therefore. the earliest and most reliable indications of failing compensation are generally show in the pulse. Even before subjective symptoms loring the patient to his medical andriser the pulse-waves are no longer of uniform frequency, foree, and rolume. The radial pulse is accelerated. hut it does not strike the palpating finger with its old-timed suddemess and rigour, the artery not being so powerfully and quickly distended as when the rentricle contracts with energy. Consequently the physician may not so readily distinguish the peculiar characters of the aortic regurgitant pulse. At irregular intervals the pulse seems to falter a little, or a small, weak beat follows its predecessor more quickly than usual, and is foilowed ly others of normal strength.

This is the expression of an accessory or extra syatole, introduced now and then into the regular series of contractions for the purpose of re-enforcement (pulsus intercurrens), or it is the result of the rentricle giving a hurried. incomplete contraction, in consequence of fatigue. Is nuscular incompetence increases, the pulse grows more irregular, or indeed lecomes permanently intermittent. It increases in frequeney, and its distinctive collapsing character, to be subsequently described, grows less apparent.

Subjective srmptoms annoy or eren alarm the patient, who begins to notice an unwonted breathlesners. Attacks of rertigo or even strncope superrene. If the patient does not now die suddenly and unexpectedly, he is likely to suffer from irregularly recurring attacks that are of grave danger becanse imdicating imminent cardiac paralysis. These are a more or less sulden feeling of great weakness or prostration, with eranosis, a feeble, irregular, perhaps aceelerated and empty pulse, drspneca, and an indescribable feeling of impending dissolution. In ardition, lie may suffer from cough with frothy, it may be bloody, expectoration 


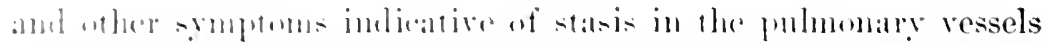

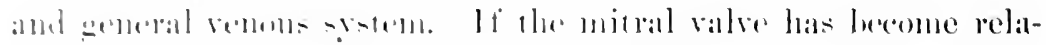

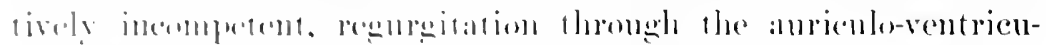

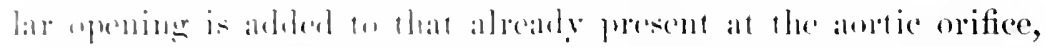

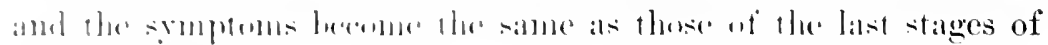
mitral discisise.

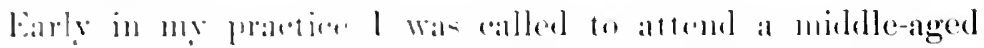

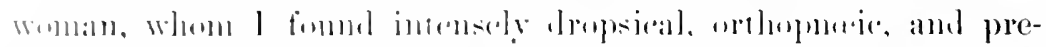

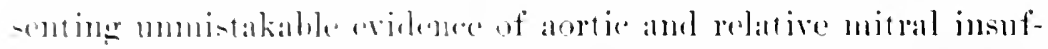

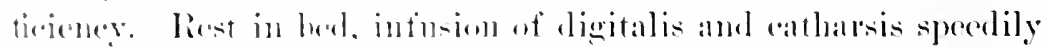

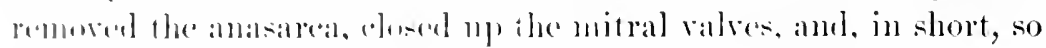

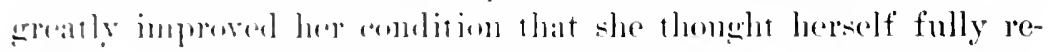

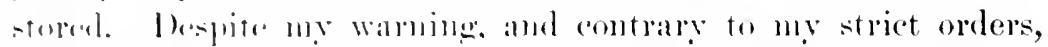
sle insisted njon latring her leed and sitting dresiod in the family

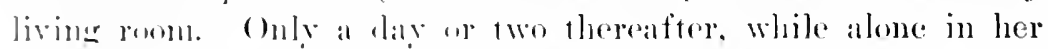

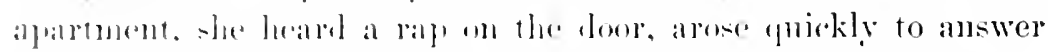
the kmock. efrened the drees, and almont immediately fell to flu How and dienl. In thi- ase I bolieve life might have been

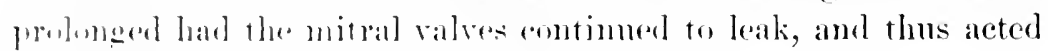

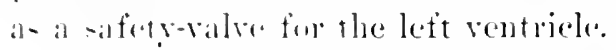

I am led ton thi- opinion by my observation of a case with I)r. Loweme at ('helinee. Ill. The paticnt was an old man, who was sufforing from allmminuria, dropser, congested liver, and orthopmas. Ijent rexmination, thele were the nsmal signs of stiffened

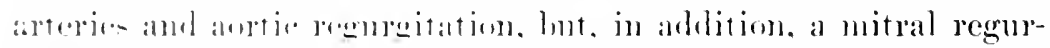

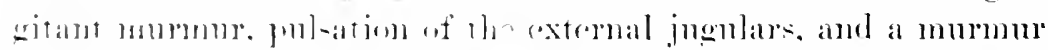

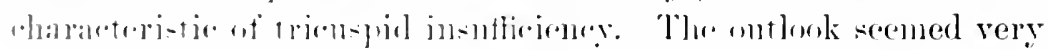

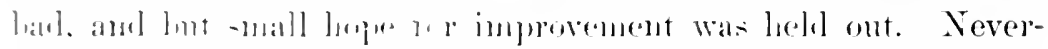

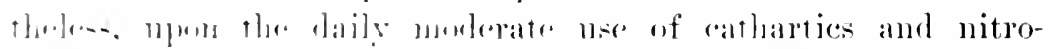

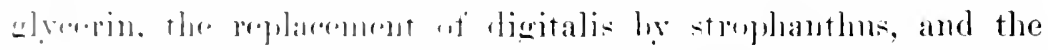

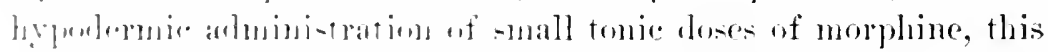

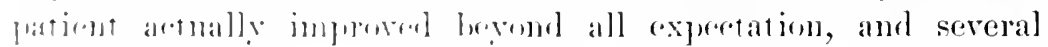

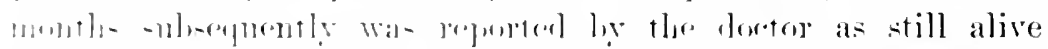

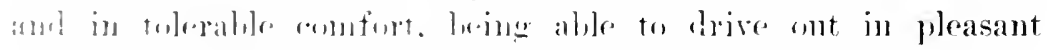

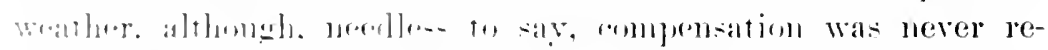

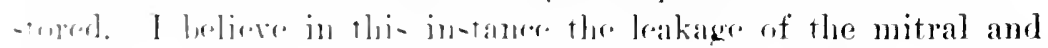

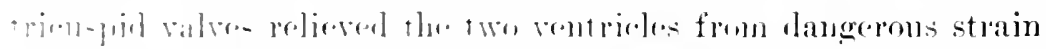

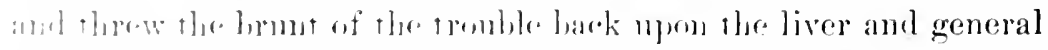

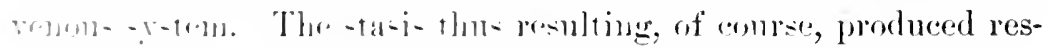


piratory embarrassment and functional derangenent of the abdonninal viscera, but actually served to prolong life.

In my care in the wards of Cook County Hospital there are at the present writing two men with aortic regurgitation in whom mitral incompetence has become added. Both present evidence of venous stasis in a moderate degree, ehiefly hepatic and pulmonary. One complains of weakness and but little else, the other of insomnia; yet in both patients things are growing slowly worse in spite of rest in bed and the usual heart-tonics. To all intents and purposes they have become converted into cases of mitral disease, the most frequent sequel of events in aortic regurgitation. The chief difference, however, lies in the refractoriness to treatment and in the liability, one might almost say certainty, of a sudden death.

In Jume, 1899, I saw with Dr. Iouston a powerfully built Irishman, weighing over 200 pounds, who was suffering from dyspnox, which had sudienly developed six weeks previously. His personal history was negative with exception of swelling of one knee some six or eight years before. This may have been a monarticular rhemutisn, and if so, it may have been responsible for the man's valvular disease. It was not followed by any symptoms, for with exception of a fall that oceasioned pain near the heart for a day he had been perfectly well up to his present illness. No history of overexertion or any other exciting cause for his dyspnoa conld be elicited. His shortness of hreath had set in abruptly while he was attending his duties as engineer, and at first had been more severe than it was when I saw him, the improvement being due to treatment. Nevertheless he was incapacitated for work, and conmsel was songht in the hope of obtaining some suggestion for his further improvement.

The pulse was arrhythmic and rapid, displaying feebly the usual characters of aortic insufficiency, and the ressels did not feel thickened and stiff. The broad, heaving apex-impulse was displaced downward into the sixth interspace and outward to the anterior axillary line. There was epigastric pulsation and a systolic thrill in the aortic area. The heart-tones were everywere audible, though feebly, and there was a loud, rongh systolic murmur at the base to right of sternum, followed by a very feeble diastolic bruit. At the apex could be made ont a softer systolic 


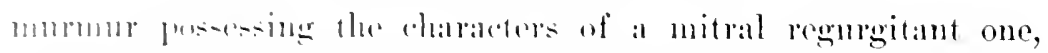

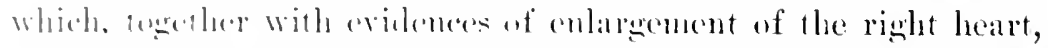
combinede! me that the mitral as well as the atortic valves were

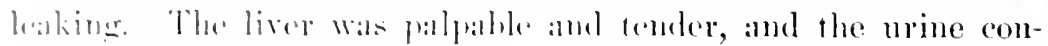
taina] a small ammut of alhmmin. I lonked nuon the mitral insut-

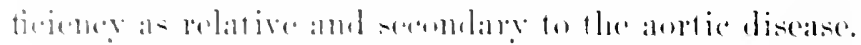

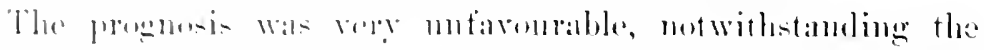

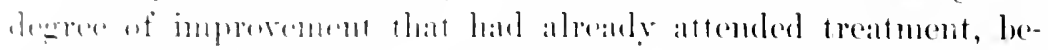

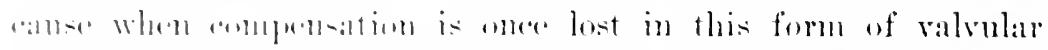

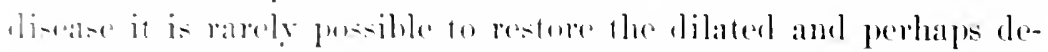

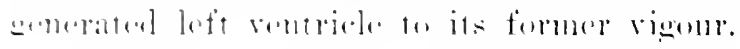

The patient was informed of his elave state, and was advised

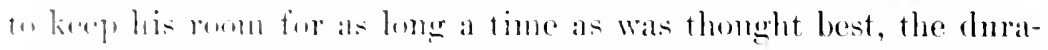

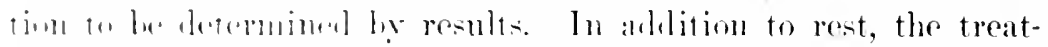
ment was to an-i-t of strelubine, digitalis, and nitroglyeerin; fond was to lu light hut sustaining, and athartics were to be

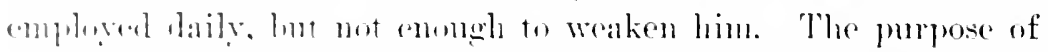
the lis-i-nanmed rumelies was chiefly to prevent the patient from

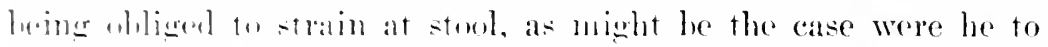

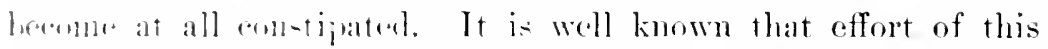

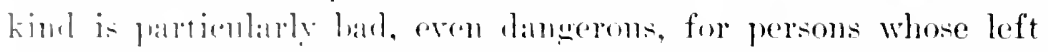
rentricte is in a state of dikatation. In aortic regurgitation the

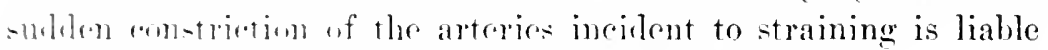
for ramer emblere and fatal diastolic arrest of the heart.

In ().onlere I saw the pationt again, and was not surprised, althemert di-allumintel. to find that in spite of treatment the dilatatim of the left rentrelo and resulting insufficieney of the mitral ralure hat inerwa-al. The artion of the heart was more regular,

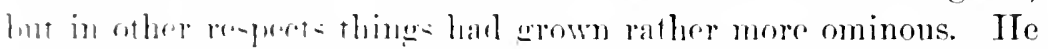

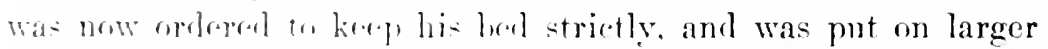

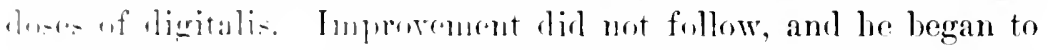
suffer momel foun -mblem paroxysus of lyspnora, which were wry alarming to hisu and his frimuls. This liver also beeame

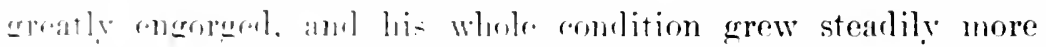

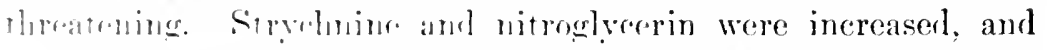
l. wa criven latily injortions of morphine, $\frac{3}{x}$ of a grain, with

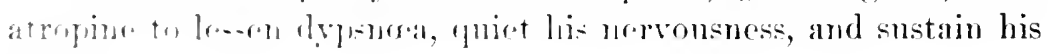
1.tesint.

It was loriglerl to gersevero in the use of digitalis, interrupt- 
ing it from time to time and substituting therefor tincture of strophanthus, to prevent the possible cumulative action of the foxglove. This was carried out until at length a singular mental state developed, characterized by delusions elosely resembling a mild mania. As Dr. Houston har observed a similar mental state once before in a patient whom I had tmmed over to his charge, and in that instance had discovered it was cansod by digitalis, he conchuded it was of the same natme and origin in this ease and promptly stopped the drug. As in the other case, so also in this, the delusions and other maniacal manifestations lasted about twenty-four hours, and then disappeared entirely. This rare effect of the prolonged administration of this agent will be spoken of in the chapter on Treatment of Valvular Diseases.

Patient was seen again in January. He was still in bed, where he had remained since the fore part of October, was quite recumbent, and breathing tranquilly, although he stated he had occasional paroxysms of dyspncea that compelled him to spring up for breath. These spells of difticult breathing had returned upon him about the 1st of January after a period of constipation. His phesician stated that as a result of vigorous purgation, digitalis, strychine, and morphine hyodermically, and restricted diet, which was kept up for nearly two months, his condition had by late autumm improved wonderfully. The enlarged liver had returned nearly to normal, his colour had grown quite natural, and his pulse stronger, of better volume, and regular, the heart-sounds stronger, and the apex-beat fairly well defined. Recently, however, the patient had become intolerant of the cathartics and prolonged rest in bed, and had inplored to be allowed to sit up.

I found the pulse about 70, with two intermissions in a minute and a half, hut rery compressible, and its collapsing chantater not well marked. The liver was palpable, particularly the left lobe, which was very tender in the epigastrium. There was no odema, althongh the feet were a little puffy. Cardiac impulse was wanting except for an oecasional vague apex-beat considerably ontside the left nipple in the sixth interspace. IIcart's dulness was pronounced, presenting in this regard a nuaked contrast to its condition in October, when it was obseured by pulmonary resonance. It was of triangular ontline, reaching to the third interspace, and from 2 inches to right of stemum across nearly 
to the left anterine axillary line. Well untside of the oreasionally

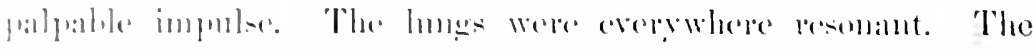

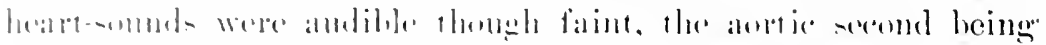

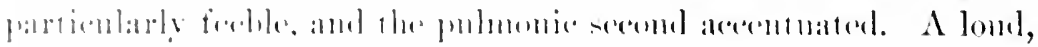

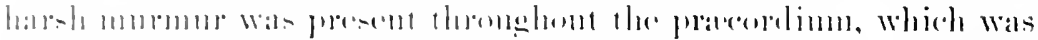

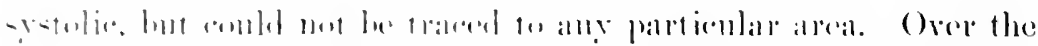

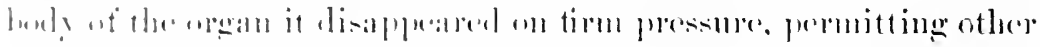

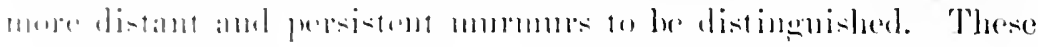

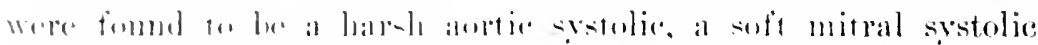

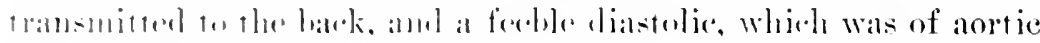

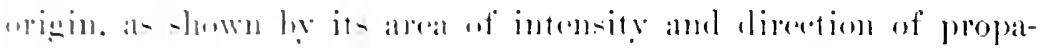
:-2:1

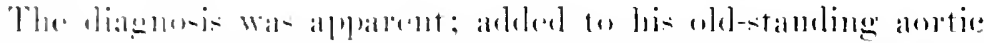
insutiteieney with relative mitral reguregitation there was a peri-

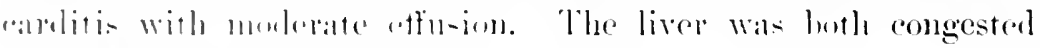

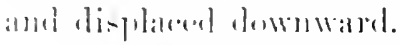

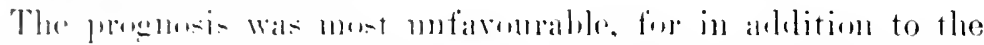

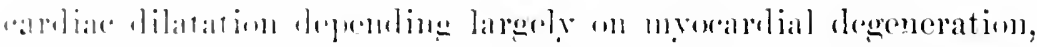

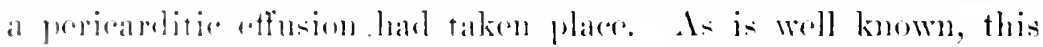

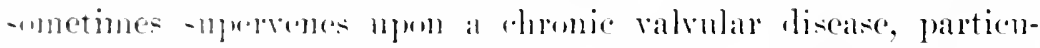

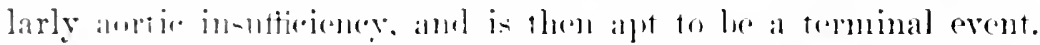
It was -talted to the family that smldem death was not improbable.

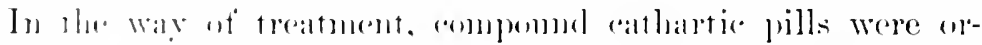

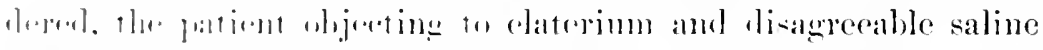

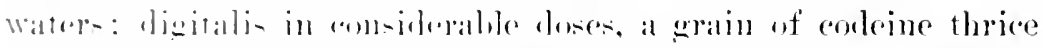

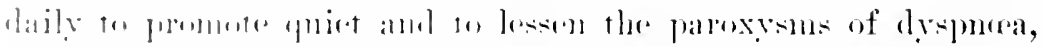

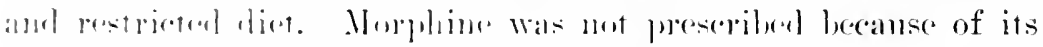

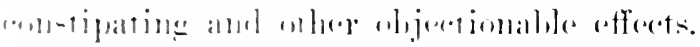

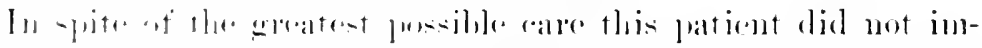

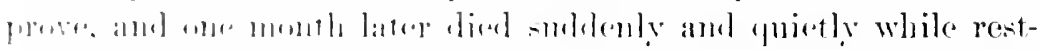

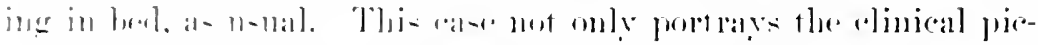

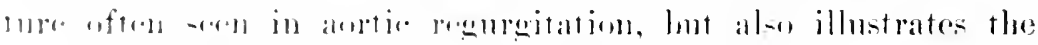

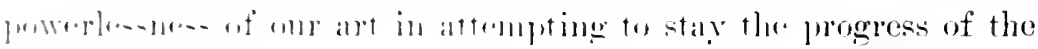
disimate.

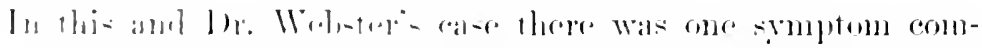

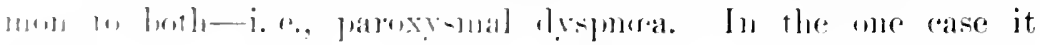

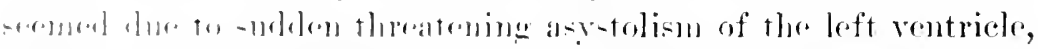

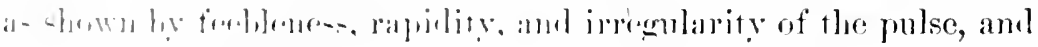

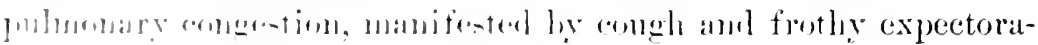


tion. In the other there was also threatening weakness of the heart's action, but the striking concomitant was the intense anxiety amounting to fear, so that the patient would spring up in bed gasping for breath and looking wild and terrified. In both these instances, moreorer, the srmptoms of eardiac breakdown developed sudilenly, and were never again wholly lost, in this respect differing markedly from the gradual onset of conpensatory failure seen in mitral affections. In both cases mitral regurgitation was superadded, but instead of the end coming with pronouneed dropsy death was sudden, hefore venous stasis progressed to that degree.

In my experience young persons who have eontracted their aortic insufficiency in consepuence of endocarditis rarely suffer from cardiac pain, while, on the other hand, I have observed mumerous instances of angina pectoris in individuals whose aortic lesion had resulted from degenerative changes. In 1891 I began to treat a married woman of about thirty who was afflicted with aortic incompetence and attacks of pracordial pain. She was quite stout, and this made examination of the heart difficult. The radial pulse was collapsing, though not as full and quick as in typical cases, and she had an aortic regurgitant murmur. The apex-beat conld not be distinctly made out, and tle large breast prevented my determining the boundary of deep-seated dulness at the left. The absence of manifest cardiac hrpertroply rather puzzled me, but erentually led me to conclude that the leak was not very free, and consequently that there was not much hypertrophic dilatation of the left rentricle. After she had been under treatment for a time she called attention to a pulsation in the neck. This was found to be just behind and above the right sterno-elavicular artienlation in the location of the innominate artery. It was attributed to aneurysun of the areh of the aorta, which thus brought the innominate prominently into view. The patient was taken to several diagnosticians for opinion, and anong others to the late Dr. Christian Fenger, by whom my diagnosis wan confirmed. This discovery of a probable aneurym changed ny views concerning the etiology and pathology of the case. Whereas the history had led me to regard the aortic regurgitation as of rlienmatic origin, I now considered it secondary to artic aneurysm, a view that seemed to account for the attacks of angina. 


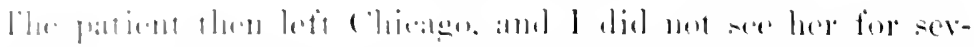

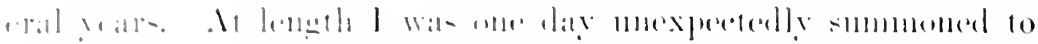

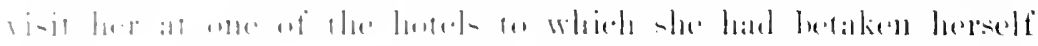

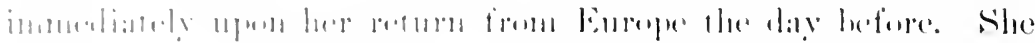

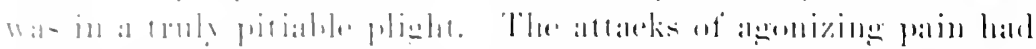

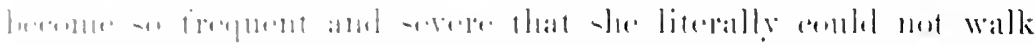

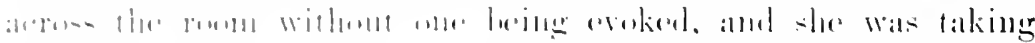

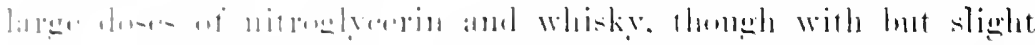

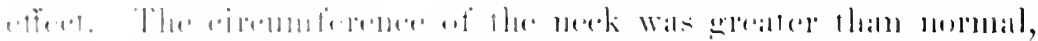

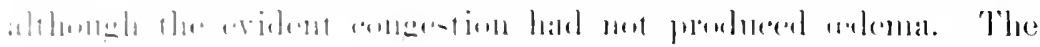

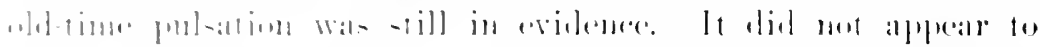

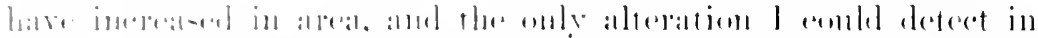

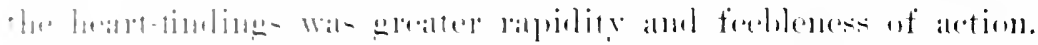

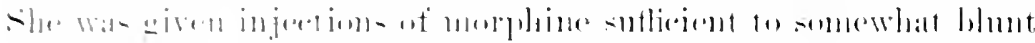

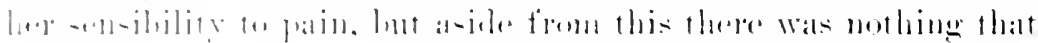

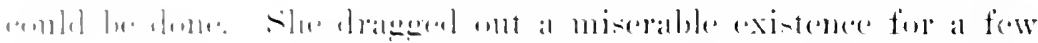

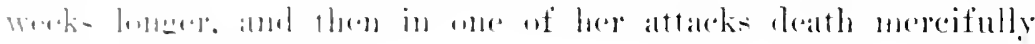

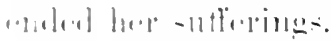

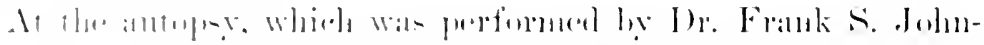

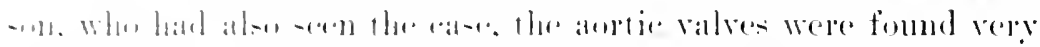

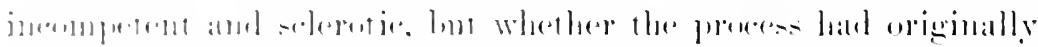

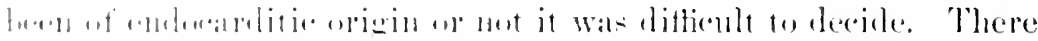

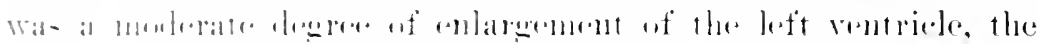
wall- wi wheh wore taltr. The two mest interesting features,

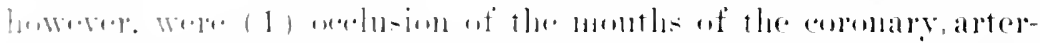

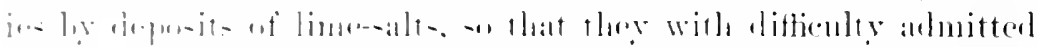

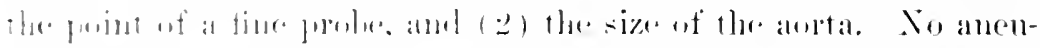

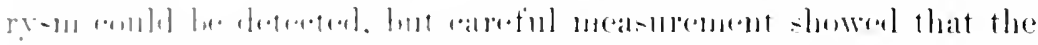

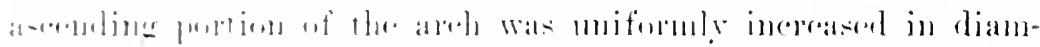

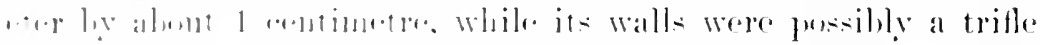

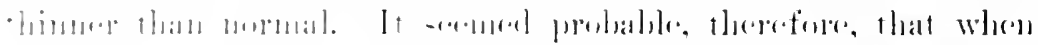

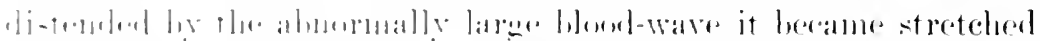

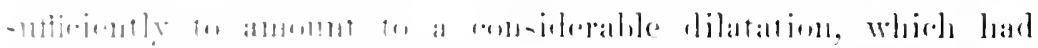

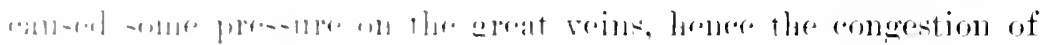

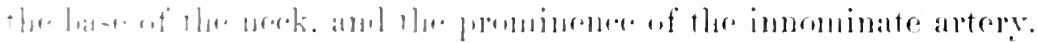

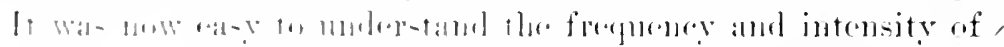

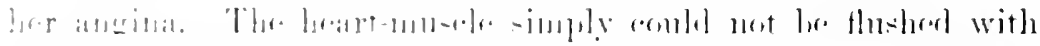

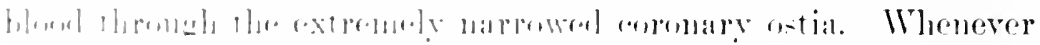

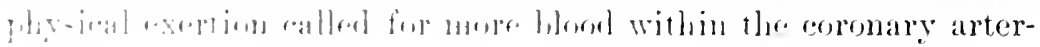


ies it was not fortheoming, and cardiac ischemia was manifested by a cry of agony.

From the foregoing, it is plain that cases of aortie regurgitation can be dirided into two classes. In the one, the lesion is the result of endocarditis, contracted during a period of life when the myocardim and arterial walls are still youmg and healthy-great compensatory hypertrophy is possible, and the discase may endure for many years without giving rise to symptoms. These appear at length only after the heart-muscle can no longer be sustained by the coronary circulation, or the breakdown cecurs as the result of fresh endocarditis ingratted on the old process in the course of acute artieular rhemuatisu. In my care, five rears ago, was a viracious young lady of eighteen, who presented the typical signs of free aortic regurgitation, a quick, collapsing pnlse, a broat, hearing apex-beat, situated far below and to the left of its normal situation, and a loud diastolic murmur. She ronsulted me because of having noticed that she conld no longer rm upstairs, dance, ride a wheel, or do other things which before were mattended with conscionsness of the heart's action. She did not get ont of breath, but was annored by forcible pounding of the heart and by the oceasional sensation as if it "gave a flop."

She had some thatulent indigestion and was eoustipated. The pulse was now and then intermittent, and for the purpose of correcting this intermittence she was given small doses of tincture of digitalis, 5 drops 3 times a day. When she next returned, after a few days, she stated that the pounding of the heart was worse instead of better. The digitalis was reduced, hut still intensified her symptoms, and was discontimued. Thinking that the intermissions might be due to gastro-intestinal derangement, she was given remedies to correct the constipation and improve ligestion. There was some improvement, lut still the heart did not become entirely regular. One day she complainesl of dnll frontal headache, some pains and stiffness of the muscles, which seemed to me a muscular rhemmatism, possibly of uricacid origin. Accordingly, she was put upon potash and salicylate of socla, and ordered to drink freely of water. This was a lappy hit, for she lost the intermittence of the pulse, and was no longer annoyed by the heart's pomnding.

A year later, belicving I had discovered eridence of a tendency 


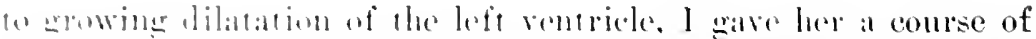

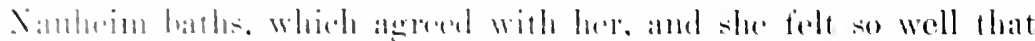

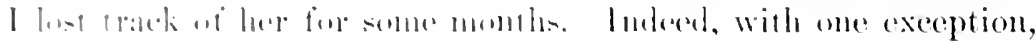

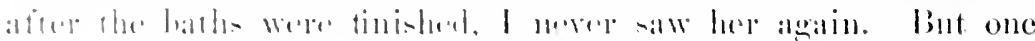

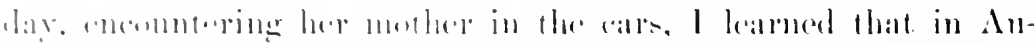

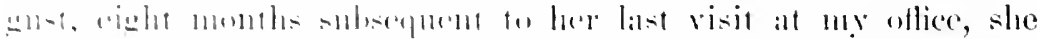

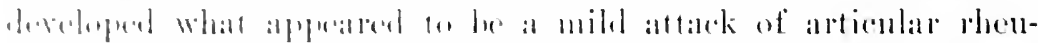

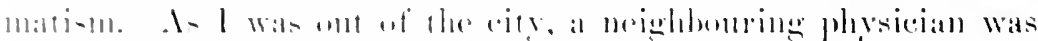

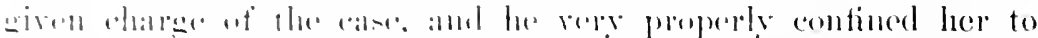

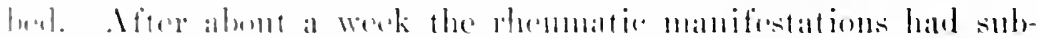

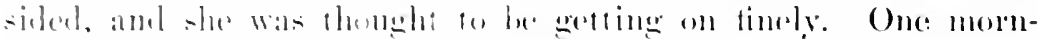

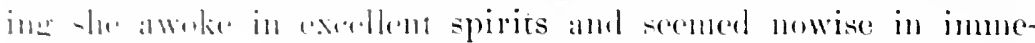

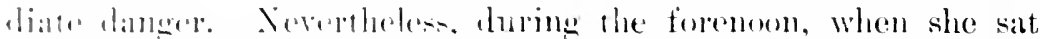

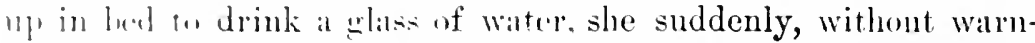

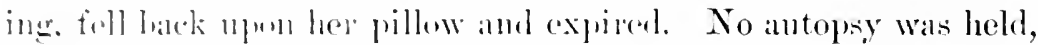
and I have nu means of knowing the exilet condition, but I believe that powathy the heart hath berome weakened by fresh endo-

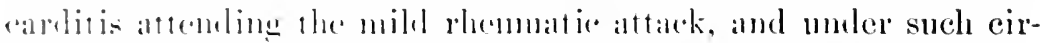
"Mun-taner the exertion of sitting up oceasioned sudden diastolic arres of the left rentricle. It simply illustrates the liability of

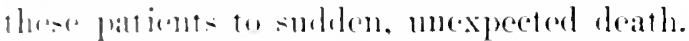

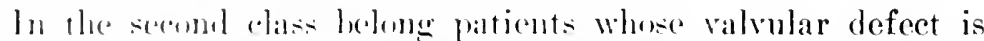
thr. leveal manifestation of degenerative dannges, which, if not due to sphilis. the goutr diathesis, strin, and the like, are associated with allameing ane. In surh persons iompensatory hypertrophy ramely proves anduring as in the yomng, and may fail early,

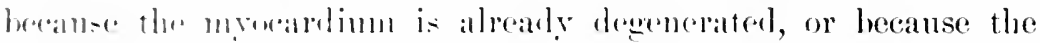

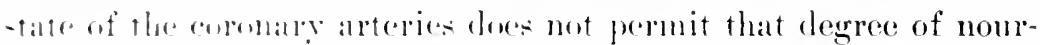

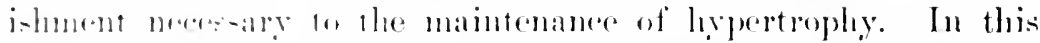

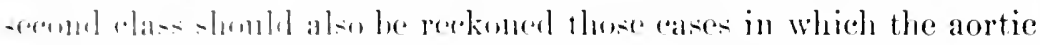

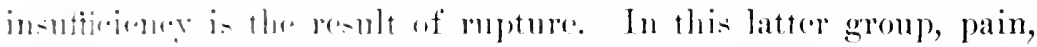

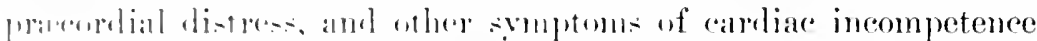
alre: reliref. Xatmrally, henweres, the alhility of the heart to compensate

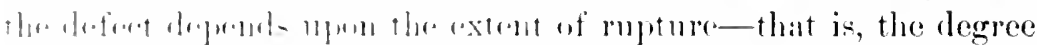

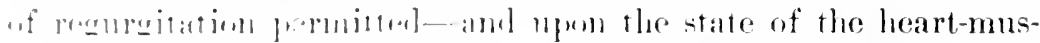

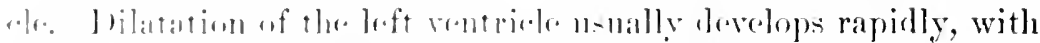

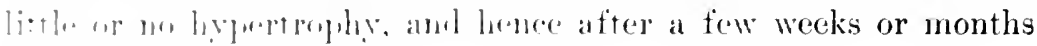
the herart -noremlunb. 
In persons suffering from slowly induced degenerative changes symptoms appear slowly, but are never so delayed in coming as in patients whose ineompetence originate in endocarditis. In most instances the srmptoms that initiate brealing compensation are such as may be referred either to cerebral anamiai. e., rertigo and syncopal attacks-or to cardiae fatigne and degeneration-i. e., irregularities of the pulse, palpitation, and angina peetoris.

When, on the other land, ardiac failure leads to stasis in the lesser circulation, or in the great reins of the general system, the symptoms gradually liecome those of the terminal stage of mitral disease-i. e., drspmera, cough, and frothy, or it may be sanguineous expectoration, disturbed risceral functions in general, cedema, and attacks of threatening asystolism. When at last aortic regurgitation has reached this stage the struggle is less likety to be protracted, and death is usnally more sudden than in defeets at the left anriculo-ventricular orifice.

Physical Signs.--Inspection. - In cases of pronounced aortic regurgitation the disease reveals its presence to the skilled eye by the throbbing of the temporal and carotid arteries. In contrast with the cranosis of mitral disease the aspect of the patient is apt to present more or less pallor, especially if the diseane has dereloped in early life. Inspection of the chest nsually detects strong pulsation of the cardiae area to the left of the sternum, the degree and extent of this pulsation depending upon the thimness and Hexibility of the chest-wall, as well as on the hypertrophy of the heart. Oceasionally a ware-like impulse is seen to pass from the base downward towards the apex-beat, while in some cases there may be slight systolic retraction of the third and fourth inter-paces to the left of the sternum, in eonsequence of atmospherie pressme, as the hypertrophied heart recedes from the chest-wall.

The apex-beat is displaced outward and downward, in some cases eren as far as the serenth or eighth left intereostal space, close to the left anterior axillary line. It is broad and hearing, at once conveying the impression of a large and powerful organ. In the young, with hroad intereostal spaces, the dimensions of the left rentricle may be almost as accurately delineated by the visible impulse as by pereussion. 


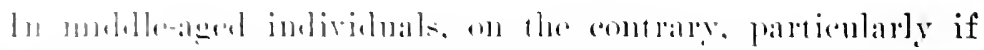

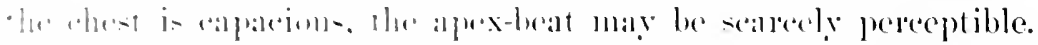

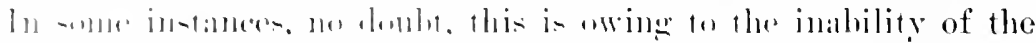

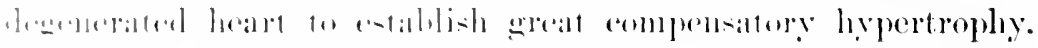

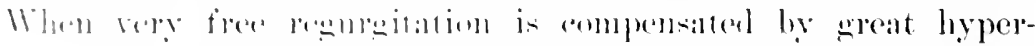

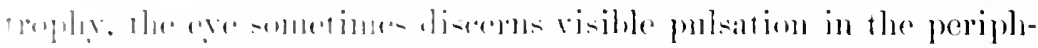

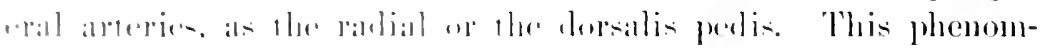

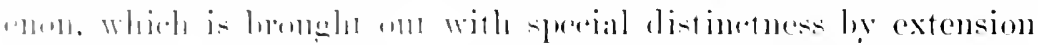

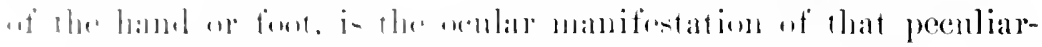

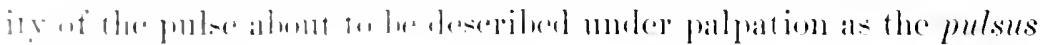
(1) $11,1,1,1,1$.

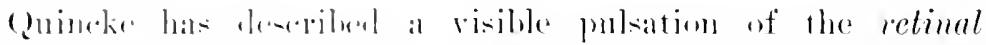

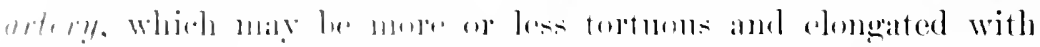

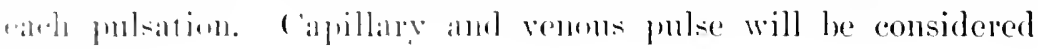
lattrle alle.

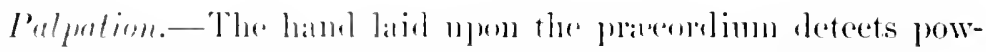

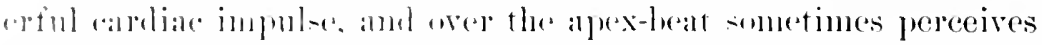

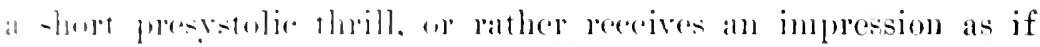
the tip of the heart - lisl ul, to its maximm impulse. The impact

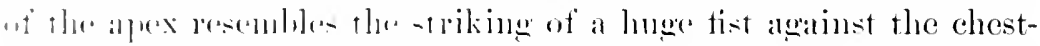
wall. alul if the gationt he slight, the whole rhest may seem to

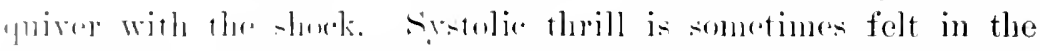

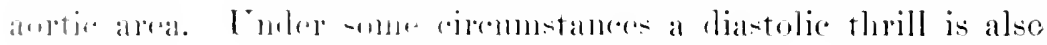
lininiticis.

The munt remalskahle featme in this part of the examination

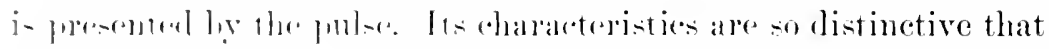

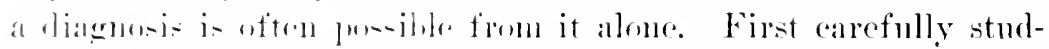

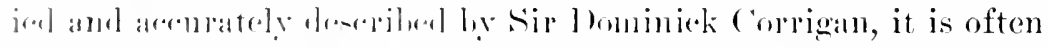

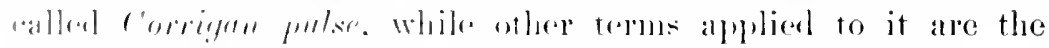

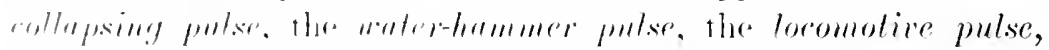

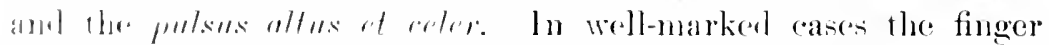

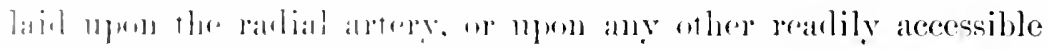

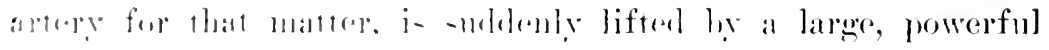

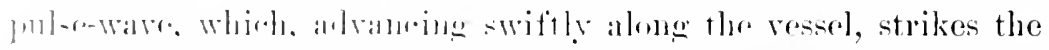

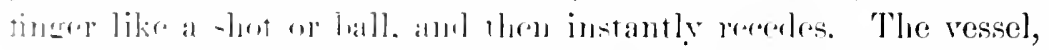

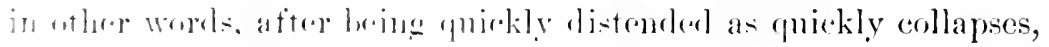

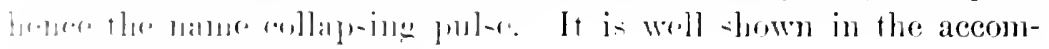

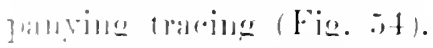

Thi- rhargetrei-tir of the pulse is intensified by raising the 
patient's hand to a level higher than that of the heart, and thus allowing the force of gravity to hasten the quick recession of the pulse-wave.

The quickness of the pulse-wave has thus been dwelt upon for the purpose of emphasizing the difference between the speed with which it travels along the artery, and the frequency with which

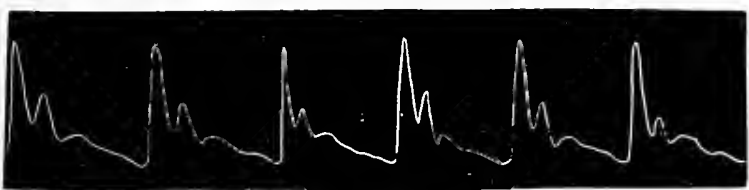

Fig. 54.-Sphygmogian of Aortic Regurgitation.

Tracing by Dr. Edward F. Wells.

the individual pulse-waves follow each other. Consequently, a frequent pulse is a rapid or accelerated pulse, whereas a quich: pulse is one that strikes the finger suddenly and is not sustained. A pulse may be both frequent and quick, as in ferer, but a quick pulse does not necessarily have to be also a rapid one. In aortic regurgitation, however, the pulse is both sudden and accelerated.

In some cases when the arteries have becone more or less sclerotic and tortnous the bounding pulse-wave seems to lift the ressel from its bed, and hence some writers have spoken of it as the locomotive pulse. To make the raison d'etre of this collapsing character understood, it is neessary to describe how the valvular disease under consideration modities pulse-tension.

Under normal conditions blood-pressure within the arterial system is maintained at a uniform height by the periodic discharge of blood inte the aorta and by the elastic recoil of the arterial walls aided by the tightly elosed semilunar ralves. The blood-stream driven against the valve by the recoiling aortic walls is intereepted and foreed onward through the arterial system. If the aortic valves, incompetent by disease, are unable to check the backward flow of the blood a portion of it regurgitates into the left ventricle, and bloor-pressure in the arterial system is correspondingly lowered instead of being maintained at a uniform level. Accordingly, the wave of blood constituting the pulsewave quickly recedes and allows the arterial walls to collapse, as it were. The hrpertrophied left ventricle, made more than nor- 


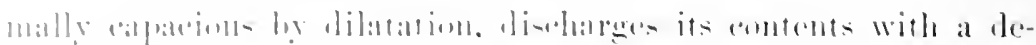

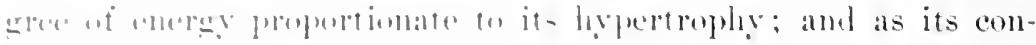

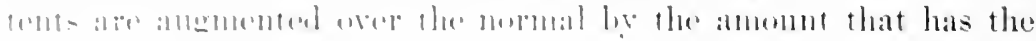

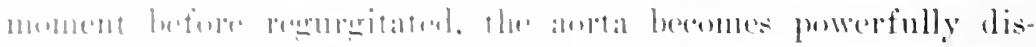

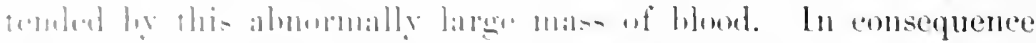

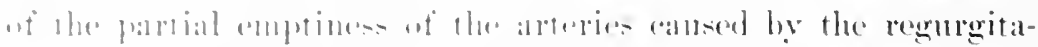

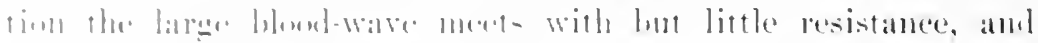

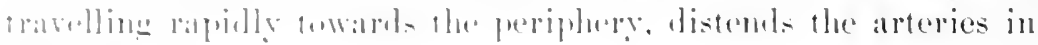
it - intris.

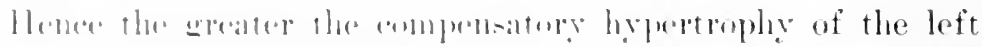

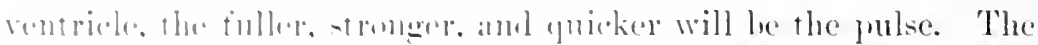

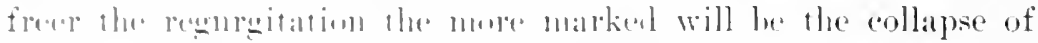

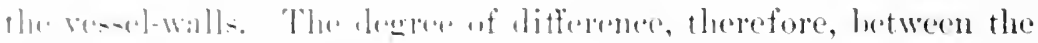

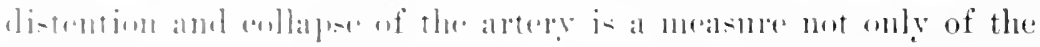

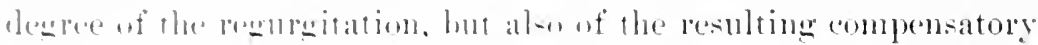

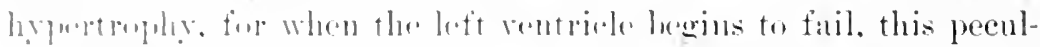

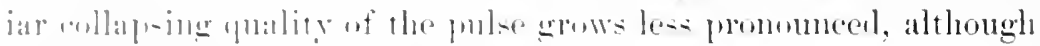
the remurevitation is no whit less free.

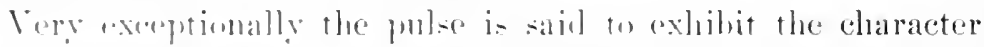

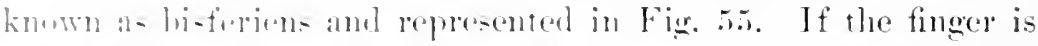

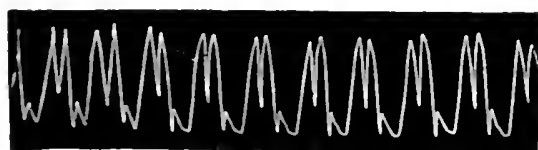

Fin, הI, I", BRTERTFE-

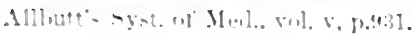
praced lightly on the artery it recerives al sensation as if the pulstr-wille were divided into two purtions, of which the serounl is the stronger. The former represents the

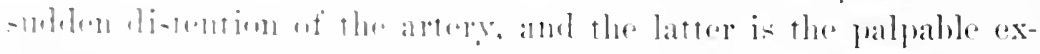

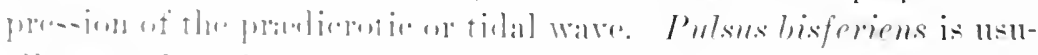

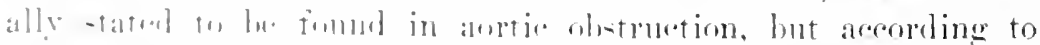

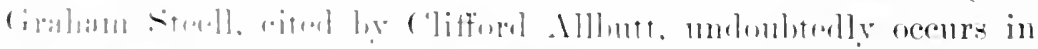

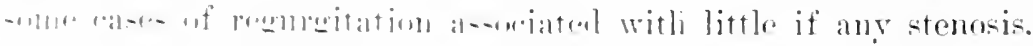

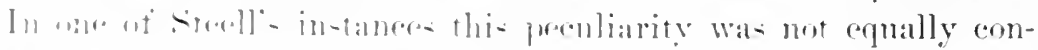

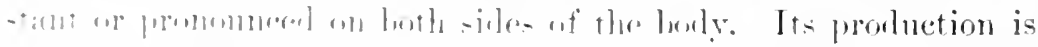

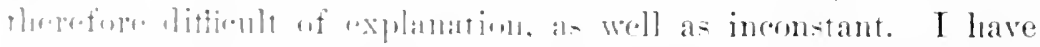

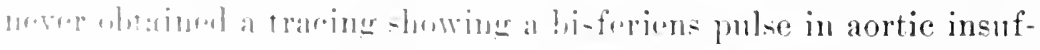

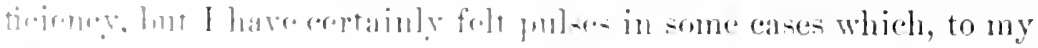

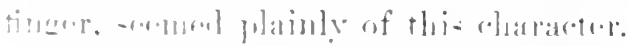

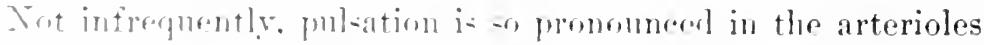
that thro finerer of the patient throh appreciably when grasped 
and the diagnosis of his malady can be made while in the act of shaking his hand.

Two other phenomena, the capillary pulse and risible venous pulse, should properly have been described under inspection, but have been reserved until now for the reason that they will be better understood after what has just been said concerning the peculiarities of the pulse. In cares in which arterial tension is very low in consequence of free regurgitation, the eapillaries are distended by the blood-wave instead of being kept uniformly filled, and hence display what is known as the capillary pulse (Quincke's sign). This may be well ween in the palm and beneath the nails when the hand is warm, or it may be eroked by frietion of the skin-e. g., of the forehead-mtil an area of hyperemia is produced. If the periphery of such a red zone is closely watched, its edge will be seen to alternatcly advance with each systole and recede with each diastole of the heart. Capillary pulsation is also sometimes plainly visible on the soft palate.

By verous pulse is meant a visible pulsation in the superficial veins. This is sometimes well marked in the subcutaneous veins of the back of the hand and the forearm when the extremity is allowed to hang down until the vessels become turgid. This venous pulse is a slow undulatory wave which, as Broadbent suggests, may be best noticed by laving a filament of sealing wax across the surface of the vein. Venous pulsation is specially pronounced when arterial tension has been still further reduced by fever. Neither of these last two phenomena is peculiar to aortic regurgitation, for they may be observed in serere anæmia which has sufficiently lowered pulse-tension. They are, however, most distinct and trpical in aortic incompetence.

Finally, when regurgitation is rery free, a distinet thrill may be felt in the cervical arteries and even in the brachials. This was well felt in a man of about thirty-five, who died suddenly a few weeks subsequently. In this case the thrill was palpable when the finger was laid ever so lightly on the ressel, and seemed to be but the palpable expression of vibrations imparted to the arterial coats by the suddenness and violence of the impact of the bloodstream.

Percussion.-As in other cases of valvular disease. pereussion affords our best means of noting to what extent and in what direc- 


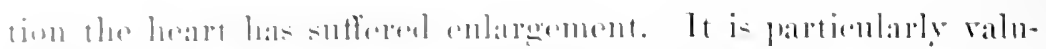

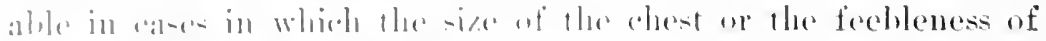

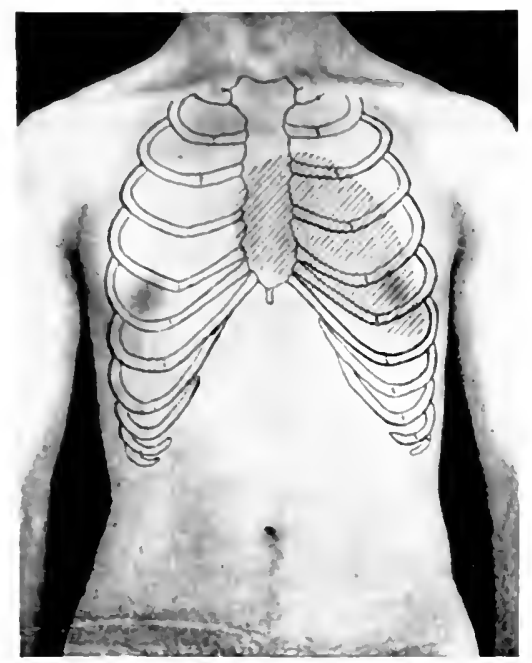

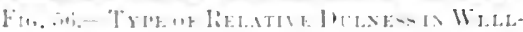

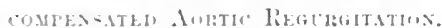
"aldiale inupulse prerents ns from julging of the size of the herald ly inspertion and

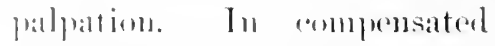

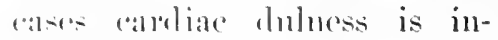
areand anly to the left and dewrouster and the ontline of the lati restriele is rather juinted (Fign. inti). As dilatiltion andes ont, the left eallodiale burler lesomes more romelent and the apex is blunt and hroald, on that one should alwars strive to perenso out the shilpe of the left ventricle ar well as its distance from the median line (Fig. 5r).

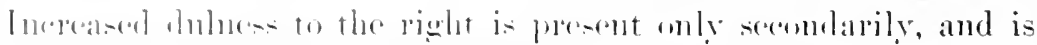

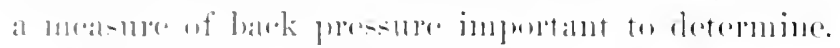

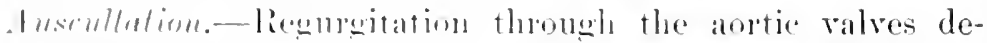

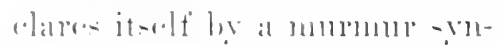

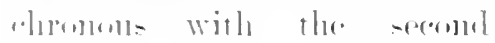

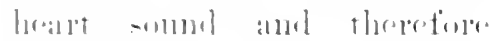
liatorlie in tinne. Whinle i-

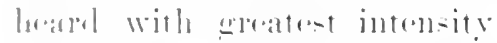

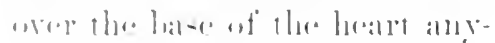

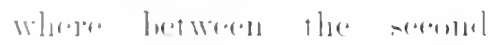

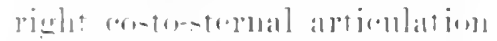
illul the jumetion of the tifth loft an-tal raldilatere with the

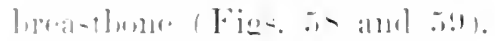
It- 1110-t 11-11al serat of maxi-

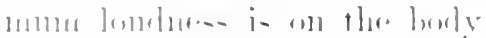

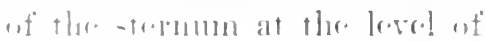

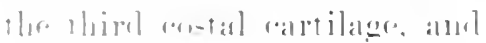

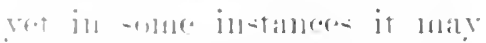

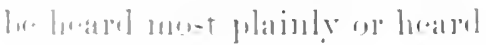

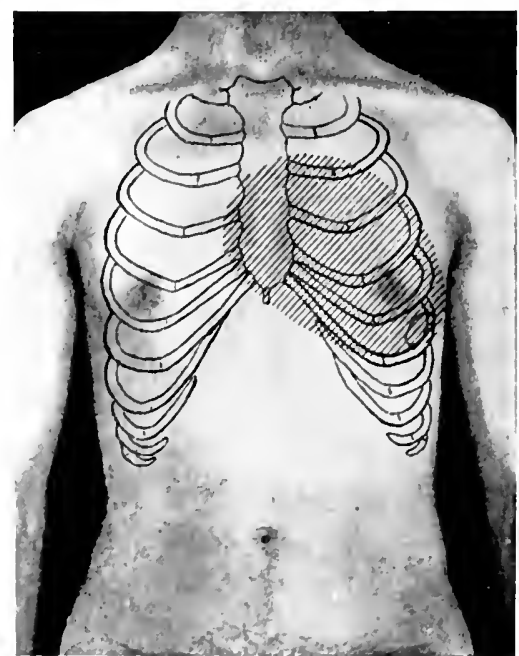

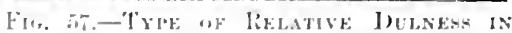

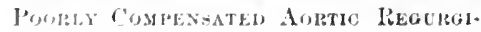
T.ITHS. 
only in the fourth left interspace, cleme to the breastbone. It is generally most distinct in the erect position or when the heart's action is excited. Nevertlieless I have certainly observed cases in which the murmur became more distinct and easily recognised when the patient was recumbent. This murmur is transmitted downward towards the ensiform appendix, and in some instances also towards the left, eren as far as the apex. When amlible, with more than usual intensity at the apex, the nummur is thought by some to indicate incompetence of the left posterior flap.

As prerionsly remarked with reference to the mitral

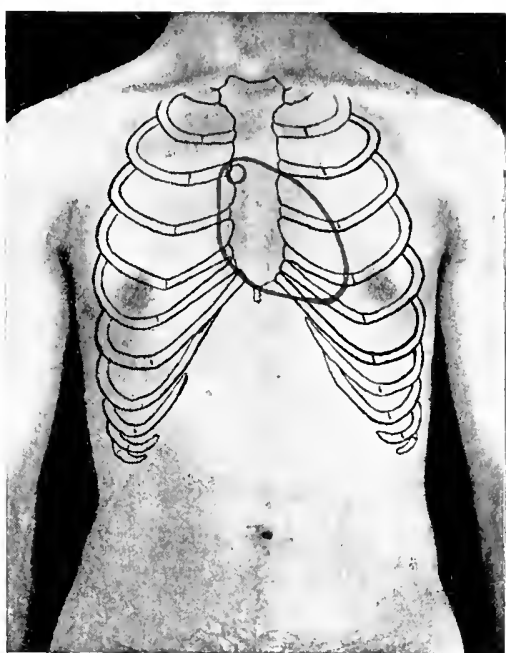

Fig. 58.-Spot of Maxinum Inteneity

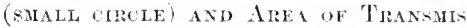

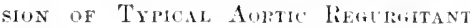
Mtrite.

regnrgitant murmur, the intensity am the extent of combluction of this aortic diastolic mumur furnish no ariterion of the gravity of

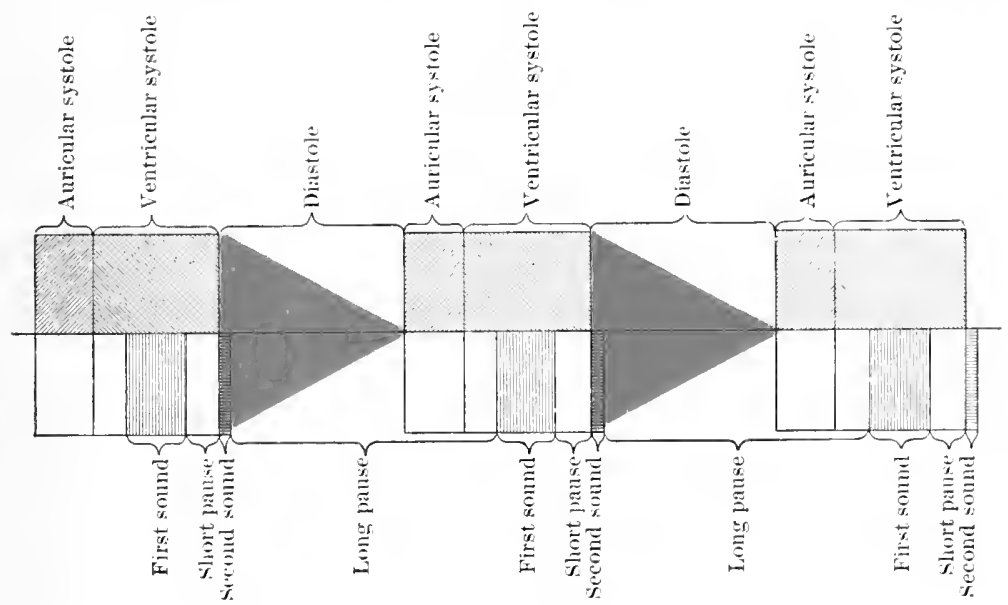

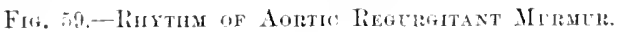

the lesion. Indeed, numerous instances have heen recorded in which no bruit at all was andible for a variable time immediately 


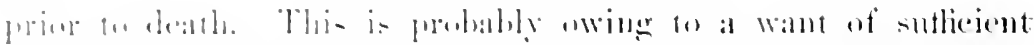

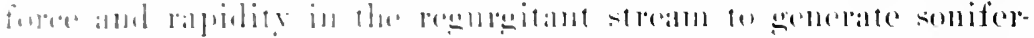
nu-vitrations. The duration of this murmur i- nswally short, amd

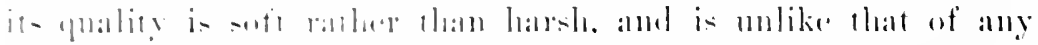

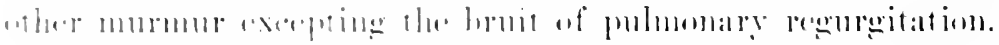

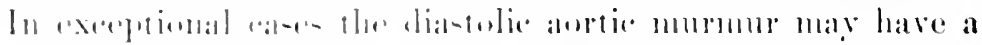

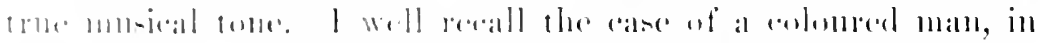

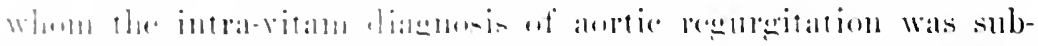

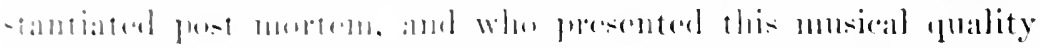

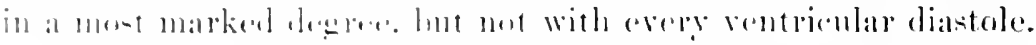

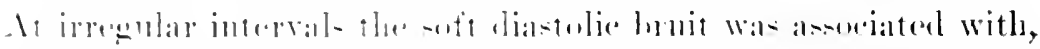

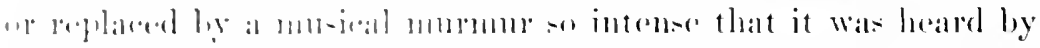

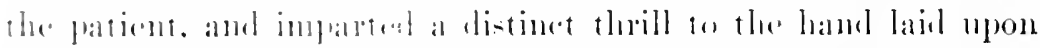

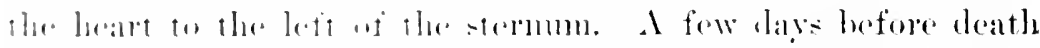

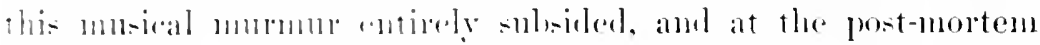
fammation mo anmlition that enmlal explain its ponbetion could

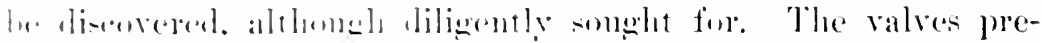

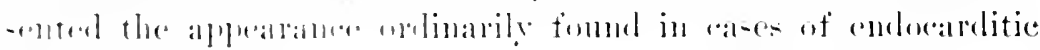
in-mtivejener.

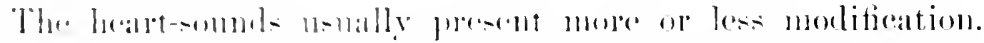

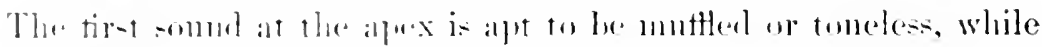

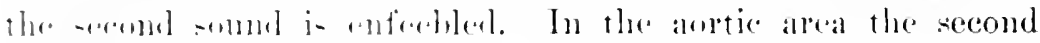

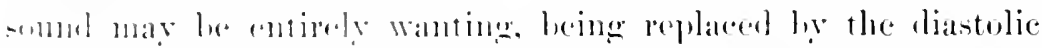

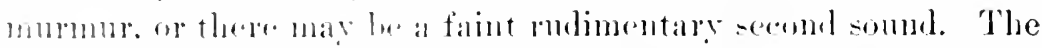

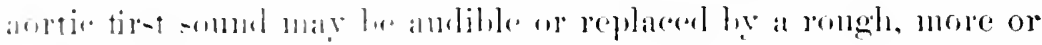

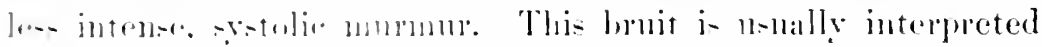

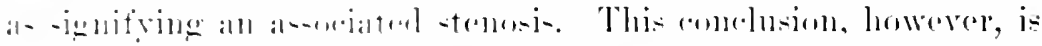

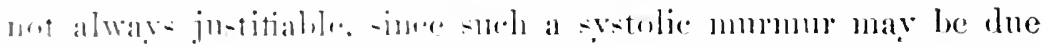

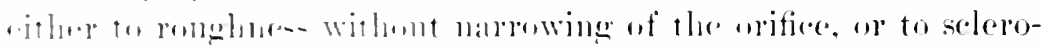

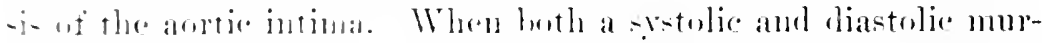

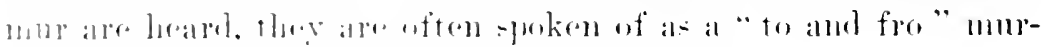

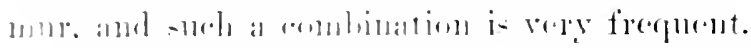

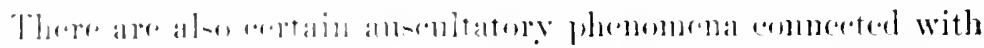

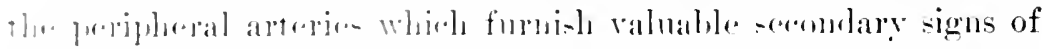

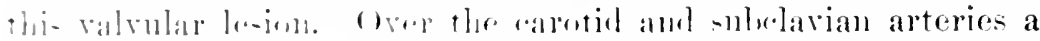

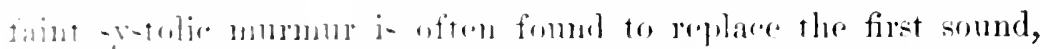

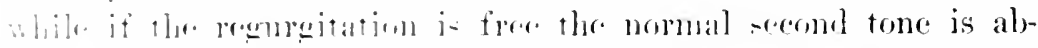

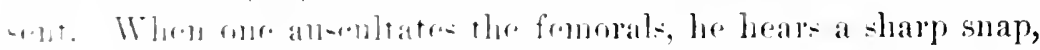

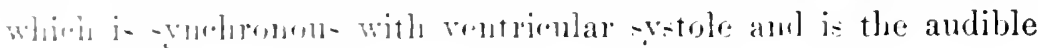


expression of the sudden tension into which the arterial eoats are thrown as they are distended by the large sudden pulsc-wave. If rather more pressure is exerted upon the vessel by means of the stethoseope, this snapping tone disappears and beeomes replaced by a distinet murnur, the murmur of constriction, which can be elieited over any artery of sufficient size when no valvular disease exists. When regurgitation is free, it is usually possible by trying different degrees of pressure to at length bring out more or less clearly not only this systolir murmur, but also a diastolic one, so that one becomes conscious of a donble murmur, of which, in my experience, the systolic is nsually the londer. This doulle femoral bruit was first deseribed by Ihroziez, and hence is ofter spoken of as Duroziez's sign. It is considered pathognomonic of aortic regurgitation, sinee in no other disease are the eonditions presented for its production. The explanation of this phenomenon is as follows:

Constriction of the artery throws the blood-stream into andible vibrations as it passes the point of pressure, and, normally, this is all; but in aortic insufficiency the blood-ware reeedes during diastole and passes again this point of constrietion, with the result that it is a second time thrown into vibrations, and a diastolic murmur is generated. In most cases these aconstic phenomena are elieited only over arteries of large ealibre, but when the lesion is very pronounced and the left ventricle is powerful, both the systolic snap and the double bruit may be heard in small ressels, as the radial and even the dorsalis pedis.

Diagnosis. - Ordinarily the recognition of aortic insufficiency is not diffienlt. In some instances it may be detected at a glanee, but when the individual is past midlle age, with selerotic arteries and a voluminous thorax, the collapsing eharacter of the pulse and a powerfial eardiac impulse may not be pronounced, and eare is requisite to determine that the condition is not an aortie anenrysm that has led to regurgitation. In all doubtful or indistinet cases partienlar study should be given to the vasular signs, since they are eonchusive, and a diastolic bruit is not. Indeed it is to be remembered that when in the last stages the heart has beeome very weak, the murmur previously present may entirely disappear. Moreover, the diagnosis of this lesion may be rendered not easy by the association of relative mitral incompetenee, or of other organic 


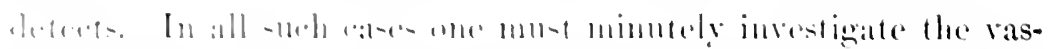

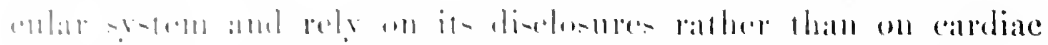

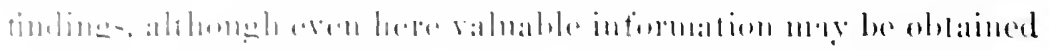

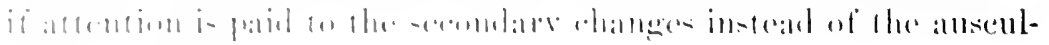

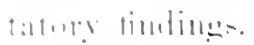

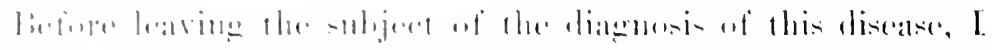

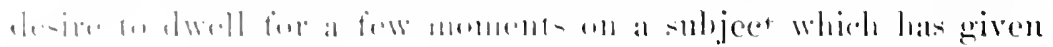

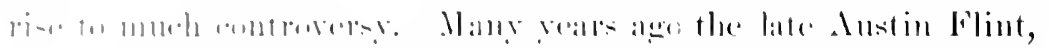

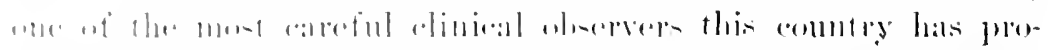

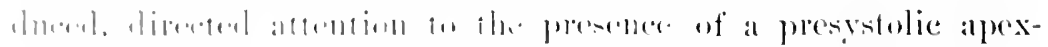

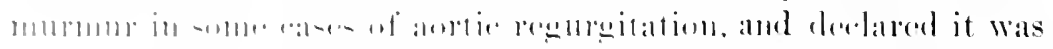

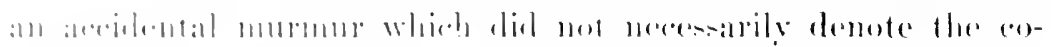

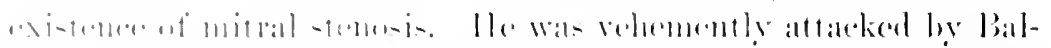

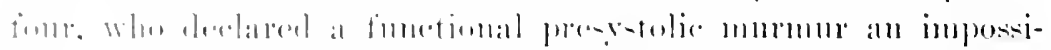

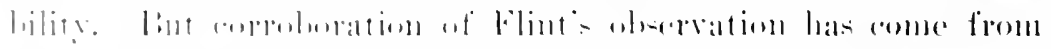

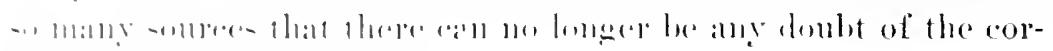

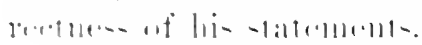

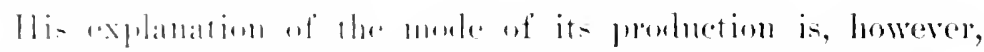

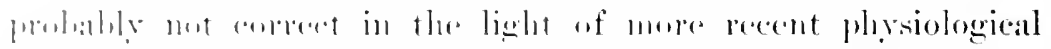

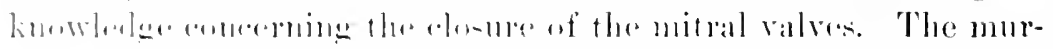

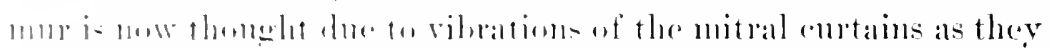

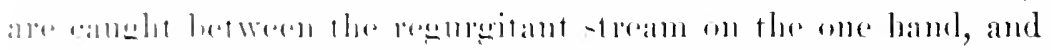

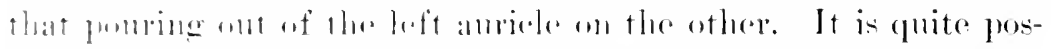

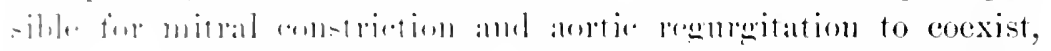

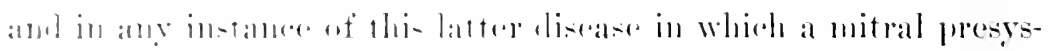

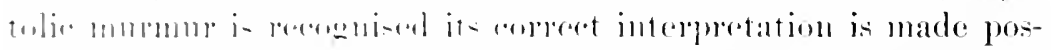

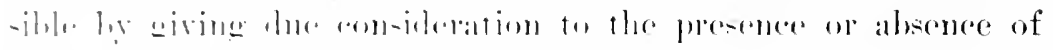

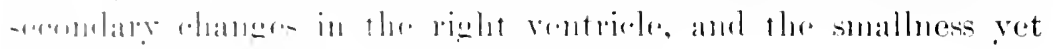

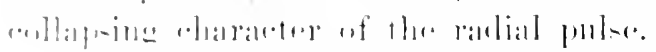

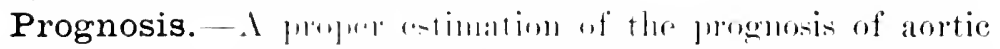

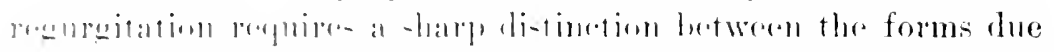

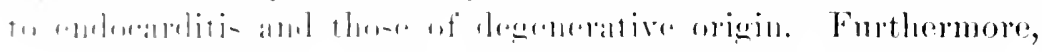

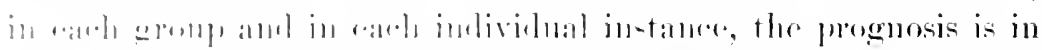

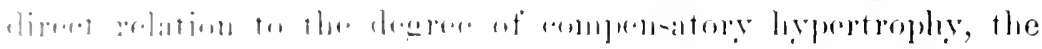

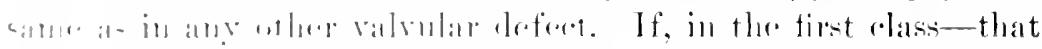

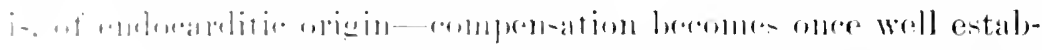

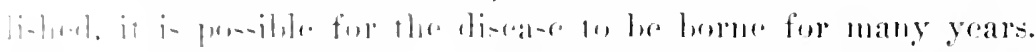

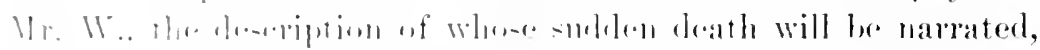

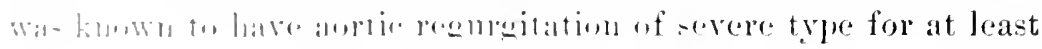


twenty-eight rears, and perhaps longer. When, however, compensation begins to fail, the prognosis is very grave, for it cannot. be so readily restored as in mitral disease. Indeed, some authors are of the opinion that compensation can never be reinstated; at the most there being hope only of retarding the downward progress.

When in the second category of cases, those of degenerative nature, compensation becomes established, it is at the best only for a comparatively limited period, owing to the probable presence of chronic nyoearditis, and when this compensation onec breals, it is irretrievably gone. Henceforth the progress of the malady is for the most part steadily downward. In all cases the prospect of even partial recovery is slight, and of restoration to a life of activity and freedom from symptoms is nil.

It is stated that very rarely a regurgitation may be converted into a predominating stenosis by the growth on the valves and ring of regetations, in consequence of fresh endocarditis; and whenever this oceurs the prognosis becomes more favourable, provided, of course, there be no myocarditis or other complications. This possibility is too remote to be ordinarily taken into consideration.

Mode and Causes of Death.-No other valrular disease so often terminates abruptly. The suddemness of the death is due to paralysis of the left ventricle in diastole. In most cases, no donbt, warning has been given of the pending eatastrophe by irregularities of the pulse, vertigo, or other symptoms which failed at the time to attract the patient's attention, or were too insignificant to inpress him with their grarity. Death follows some sudden effort, as assuming the erect from the recmulent position, springing out of a chair to leave the room, jumping on to a moving street-ear, and the like. The museular effort incident to such sudden morements abruptly raises blond-pressure within the vessels supplying the gromps of contracted muscles, and drives the blood into the left ventriele during its period of relaxation with a degree of force which the ventricle is mable to resist. It fails to respond by a subsequent systole, and the patient falls to the gromd in an attack of fatal srneope.

Fortmately for the patient, as well as for the peace of mind of his friends, assurance can be given that sudden death in the way 


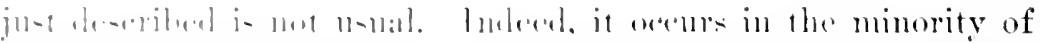

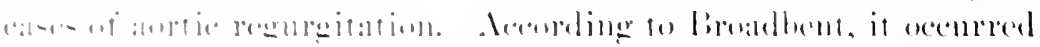

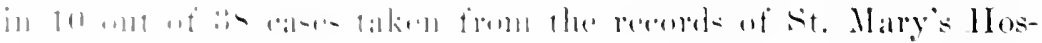

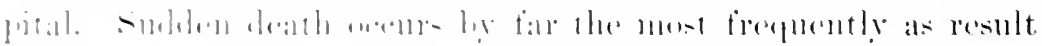

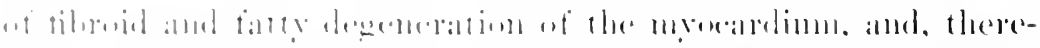

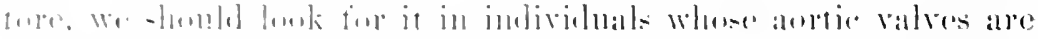

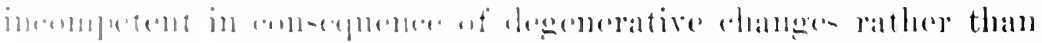

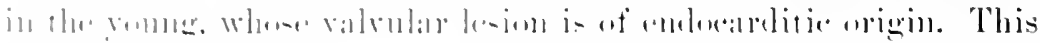

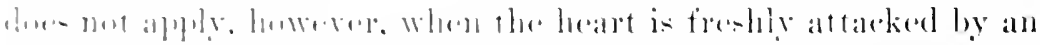

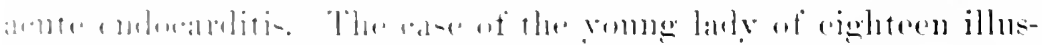

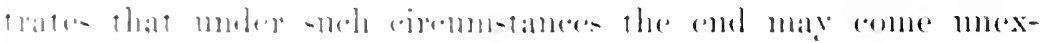

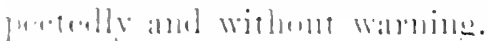

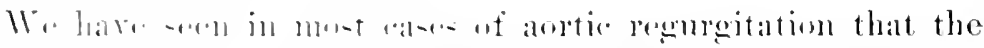

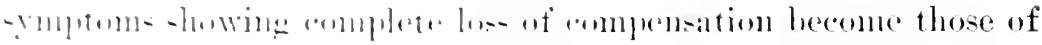

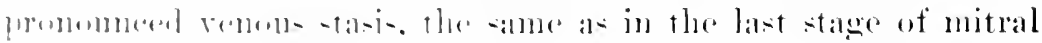

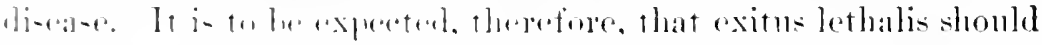

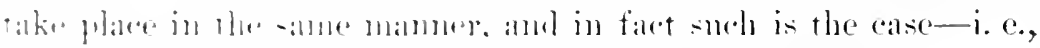

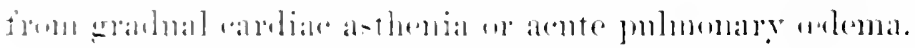

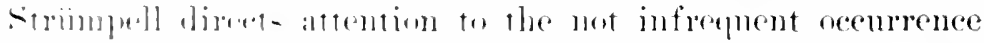

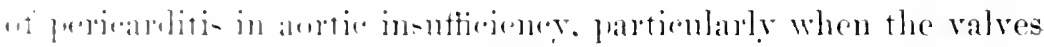
have heen attatelied hy freh intlanmations, and in such the peri-

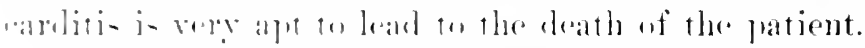

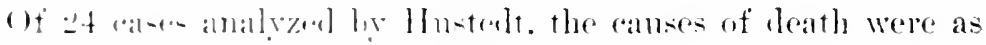

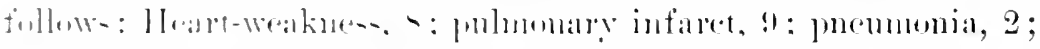

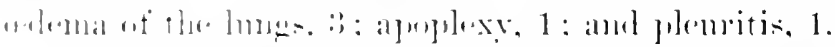

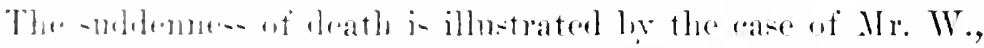

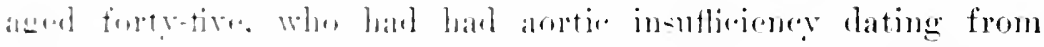

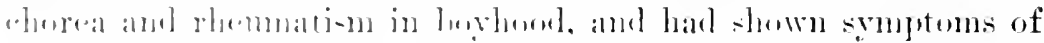

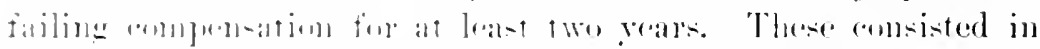

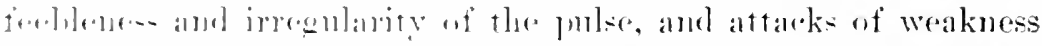

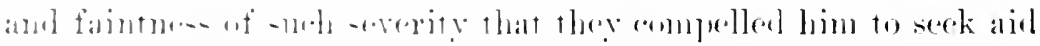

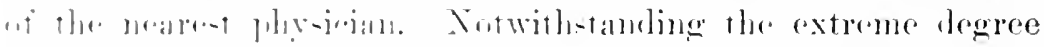

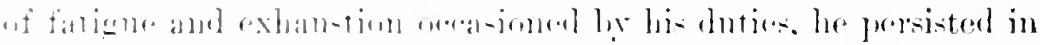

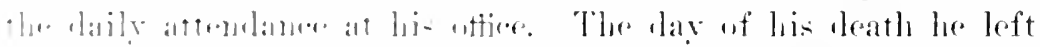

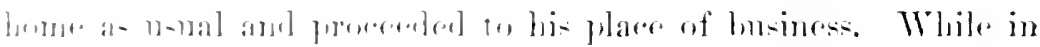

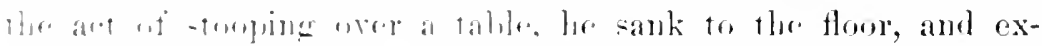

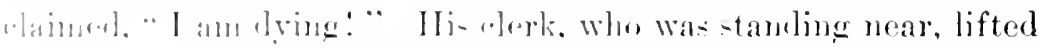

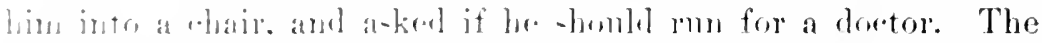

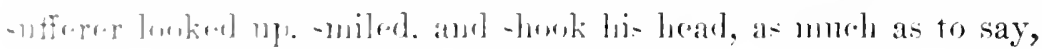


"No, it is of no use," and a few moments thereafter he quietly expired. That this patient was fully awate of his being in dailyyes, hourly-danger of death was shown by the fact that he had given explicit directions to his clerk what to do in the event of such a fatality. Reflecting upon this ease, one cannot help wondering by what knowledge this patient reeognised the signitieance of his final attack, and refused to have a medical man summoned, when in previous attacks he had always sought the services of the most accessible plyysician.

The following case is appended becanse it emphasizes in an impressive way several points with respect to aortic regurgitation. In the first place it illustrates the important part played by heartstrain; in the second, how hopeless is the prognowis in these cases; thirdly, the futility of treatment; and, lastly, the manner of death in a considerable proportion of them.

I recently witnessed the death of a gentleman of forty-two who had sought medical advice three months before on the supposition that his distress was due to some form of stomach trouble. Exeepting scarlatina at the age of six, he had never known a day's illness, and his habits had been exemplary with the one exception that he had been aceustomed to take about two drinks a day of whisky before meals. He had alwars been devoted to hunting and fishing, and had spent much time each year in the woods, at which times he had always shouldered hi- pack and tramped along with his guides, having many a time, as he said, "Done them up and come in at night fresh as a daisy, while ther were beat out" $\mathrm{He}$ had thought nothing of carrying 60 pound on his back all day through the woods, and had parthled and portaged with the best of them. When not out hunting or fishing he had been untiring in his devotion to business, and for the previous seven yealrs had worked with colossal energy in building up vast interests in the North. In acklition to tireless work with his brain in his office, he had endured and indeed revelled in efforts connected with his business sehemes, requiring and displaying extraordinary physical endurance, so that he was the marvel of his friends. On one occasion, in December, 1900, this robust man of medium stature and weight, without an ounce of superfluous fat, all musele and sinew, started with a crew of men up his railroad to inspect some work, and, as the engine was forced to "buck snowdrifts" and make a 


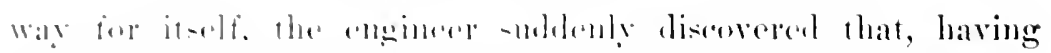

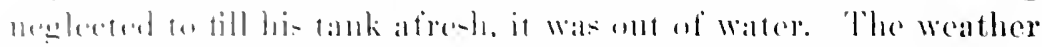

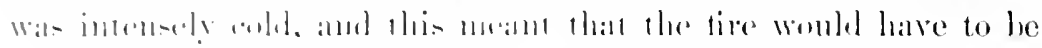

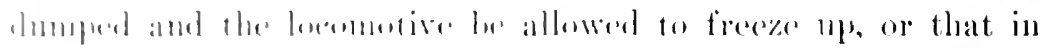

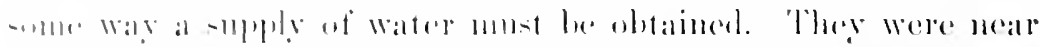
a river. and thi- imelomitable mam af whom I wite started on a

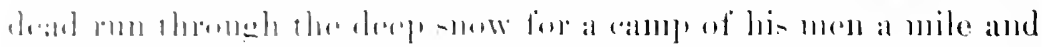

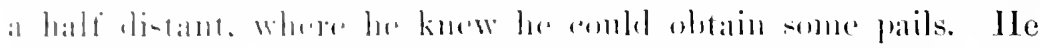

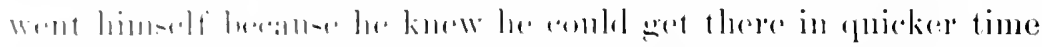

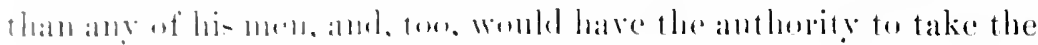

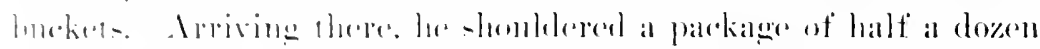

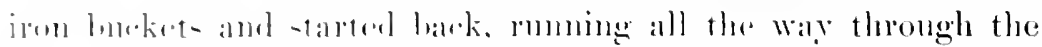

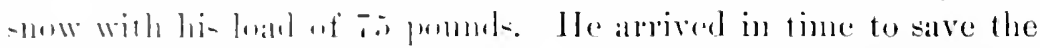

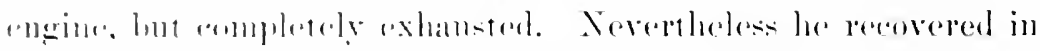

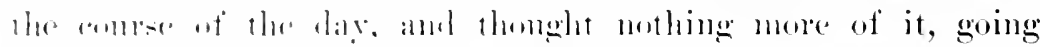

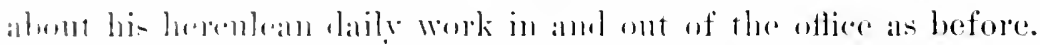

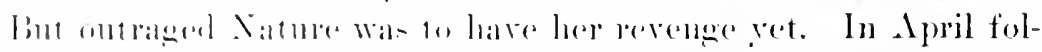
lowing his almont -mperluman effort, this man of affairs took a

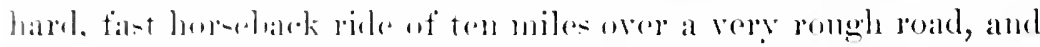

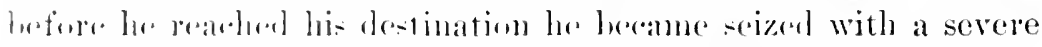

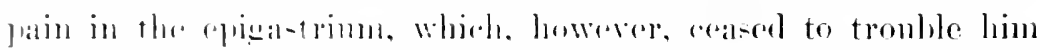
areatly after hre had dismomulal. From that time on mutil I saw

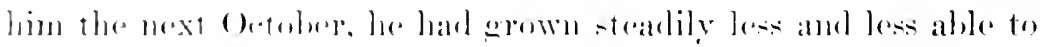

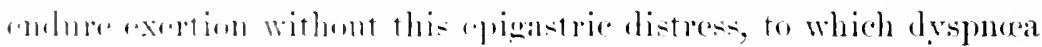

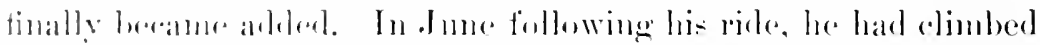

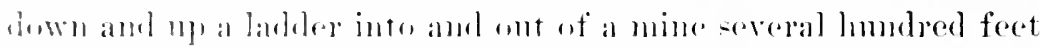

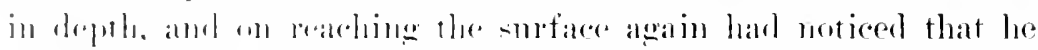
was vely mon wimled. and finm this time forward he was obliged

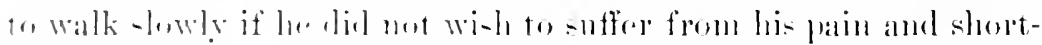

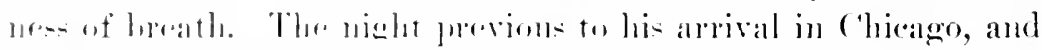

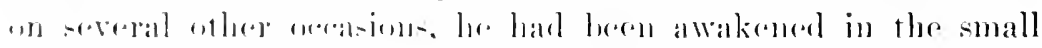

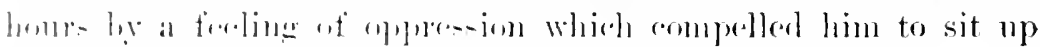

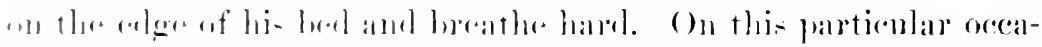
-irn hre latel attributerl his attark to the eloseness of the sleeping-

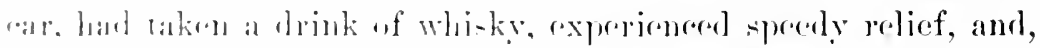

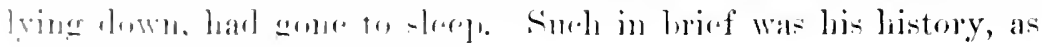

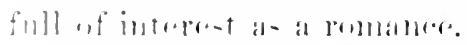

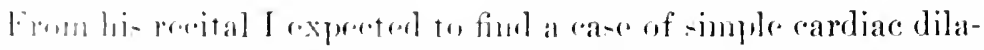

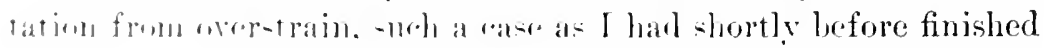


treating. Imagine my suprise, therefore, when I discovered a collapsing but not large pulse of about 110, a diffused, rather indefinite apex-beat way below and ontside the left nipple, percussion evidence of a ereatly hypertrophied and dilated loft ren tricle (Fig. 60), feelole heart-somuds, and everywere a lond double murmur plainly aortic in origin. Duroziez's sign and capillary pulse were present, and the liver was palpable and tender a couple of inches below the inferior costal margin. The left lobe was speeially swollen and sensitive to pressure. The mine was and always remained negative.

Here, then, was an arotic regurgitation, but what was its etiology? Was it possible that there had heen a ralvulitis years before and that the compensation had been broken down by his prodigions exertions, or had the heart-muscle been not quite healthy and had that run started a stretching of the aortic ring which had been increased by succeding efforts, or had the strain led to an aortitis or ancurysu, and this to insutticiency of the valves? Rupture of a cusp was ont of the question. becanse of the absence of surions symptoms in the reeks immediately snceeeding his rum. A previous valvulitis was not impossible, for it is well

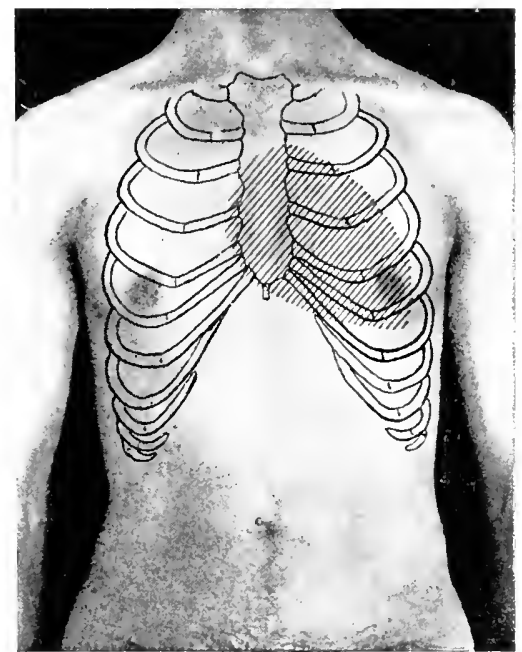

Fig. 60.-Rielative Diliess ix Cane DF Agrtio Reglegitation (p. 309 ).

First examination. known that the enownoms secombary hrpertrophy of the left rentricle sometimes developed in eases of rhematic incompetence of the aortic valyes, is capable of enduring an extraordinary degree of strain for vears, as witness some of the cases treated by the great Stokes. In this instance there was no history of anything to lead to endocarditis except the scarlatina, and that oecurred thirtysix years before, and if that had led to valvular insufficiency its presenee had never been suspeeted or loctraved by a symptom. Moreover, thirty-six years is a very long time for an aortic regm- 


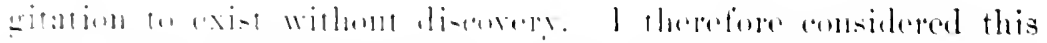

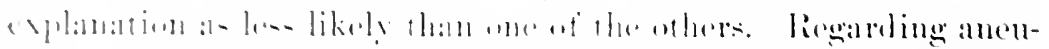

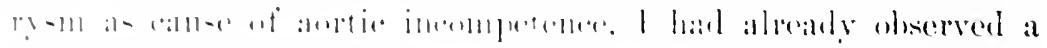

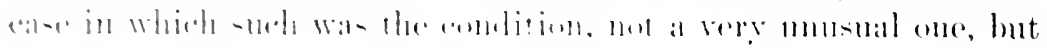

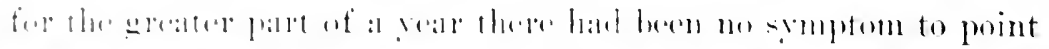

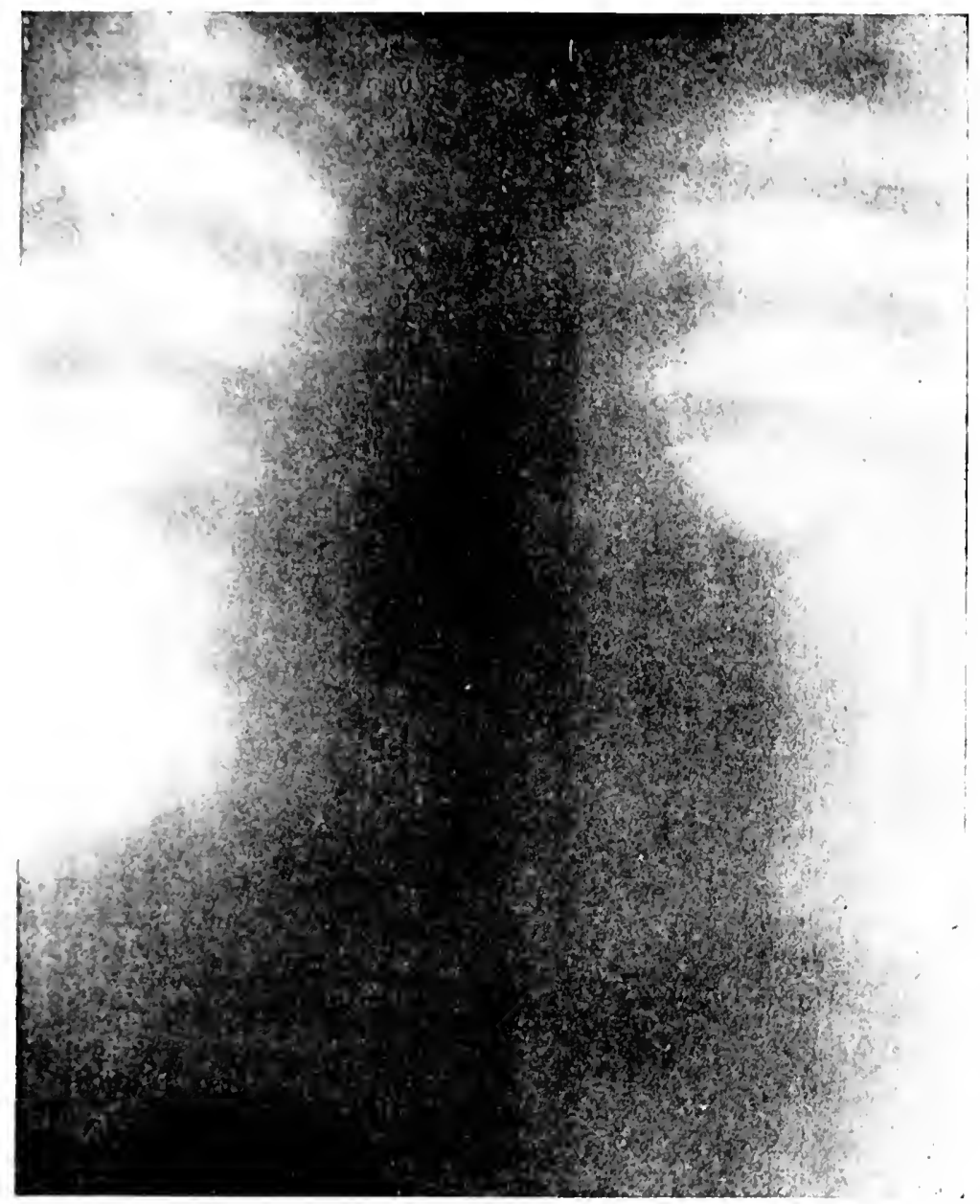

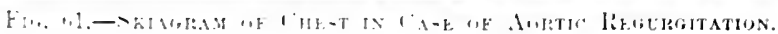

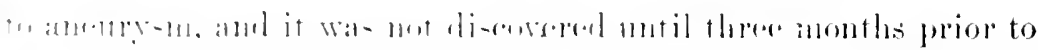

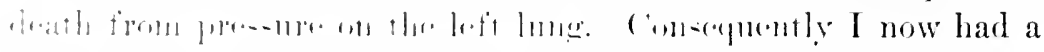

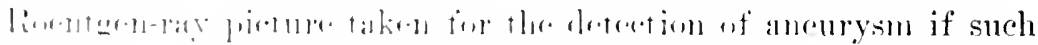

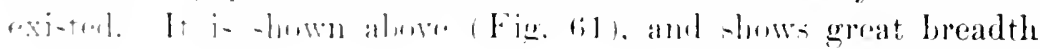


of shadow at the base over the position of the large ressels, but nothing that can be interpreted to indicate aneurysus. It aloo shows a very large heart, a veritable cor bovinum. The only remaining hypothesis was that of stretehing of the arotic ring and base of the aorta. The resole combl he felt pulsating at the level of the upper elge of the stermum, and in the antie areal could be heard a faint distinct click. erielently a fechle antic second tone.

Another case that hat been already narrated (sce page 15s) had taught me how gnaried one shonld be in attributing to endocarditis what might turn ont to be attributable to myocarditis and stretching of the orifice, especially in the absence of a clefinite history of rhemmation or other sutfireient etiological factor. In the present instance this point was of great importance in its bearing on prognosis. I believe the subsequent lack of resistance on the part of the left ventricle bove out strongly my original view of the origin of the valvular incompetence. The leak was started by the awful strain of that insane r'm, and was augmented and rendered hopeless of repair by his succeeding exertions.

The man was told how serious his condition was, and that his only hope of reinstating his heart-power lay in at once giving himself up to entire and prolonged rest in hed. Very reluctantly he yielded to the inevitable, and took to his bed. He was of a somewhat peculiar nervous make-11, and could not bo induced to remain as inactive as $\mathrm{I}$ thonght was necesary. He would, for instance, get up and go to the toilet in the adjoming hath-room instead of using a bed-pan. He womld get up and shave himself, and he would sit up in bed to eat, and on onc or two occasions arose to receive a visitor. I now blame myself for having permitted even so much latitude, yet his amnoying symptoms disappeared so promptly on being put to rest and his left ventricle came down so appreciably in size and the apex-beat. returned in such strength, that I hopel, against my tirst judgment, that the heart was going to recover its hyertrophy better than was at first feared.

At the end of a month of this enforcer inaction the patient became so restless that pormission was given him to leave his bed and, by degrees, begin to move about, under the condition that he was to lie down much of the time. He was allowed also to take a daily drive. A course of Nauheim bath was also begun in the 22 


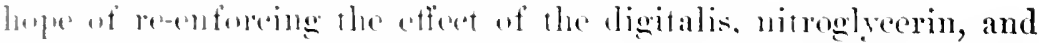
- rrednine he was talking. For a week he did not seem to suffer

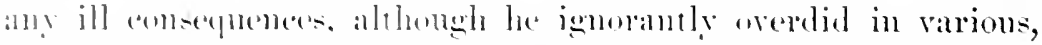
to hime semingly trivial wares. Ile would put on lis heary furlined orevenat mian-i-ted, and go into a store to make purehases, and be on his feet for an hene at a time, not realizing that he wat will far from well. Then the saline hathe did not slow his pulse and improse its priality as they shemld have done, and after a bath he did nue react to my atisfaction. So after two werks, in which it wate clear that he was lowing ground, I again molered him to hed. this thuse insisting on his having a trained nure who wate to lift hine, and in many ways save him from efforts he hat made during the arlier weeks. He now remaned fairly guicet. thengh it wat very difticult for him to learn to keep still and not to arist his mue whenerer she lifted him, tumed him, ete. Ite simply womld not nise a beet-pan, and therefore was drawn in at chair to the bath-romu, and later on was lifted on to a night-tool alongside his herl. IHis treatment consisted of digitalis and wher tomics, athartion and resitance exerdises given by a comjetent attendant. Althemgh it was realized that these last were in vinlation of the puinciple of absolute physieal repose, still they were lecided on herame they slowed the pulse somewhat, ingroved its quality, and on puieted lim that he fell asleep after the siane was were. No mere Nanhem baths were given.

As days ran intro werks, lowever, it hecame plain to me that treatment wis nut genge to restore what he had lost during the

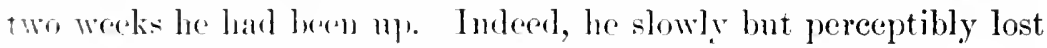
gromul. His liver swelled again somewhat and gave a very uneomfortalle fecling of fulnes helow the ribs, which he attributed to hi- fomach and to indigestion. The outline of the left ventricle very gratually heeane mone pombled, the apex less pointed, and it -impulse les rigorenti- It was at lengtlı clear that if the mitral value was not alrealy relatively ineompetent, a matter for eertain reasoms diffirnlt of fwitive determination, it would soon be(a) 1 sese

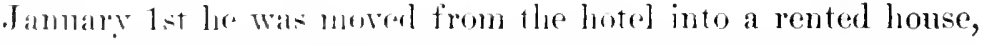
and the removal was reffected as easily and with as little disturbance to him as presible. Corertheless when $T$ risited lim a few hours later I aw at onrer that the transfer laad hurt him. His pulse was 
less strong, the heart-duluess a little larger, and his breathing a little less easy.

The feature that especially increased my anxiety, however, was the peculiar irregularity of the pulse. At varying intervals, from 5 to 20 beats, there would come a sudden quick wave closely following the one before, as if the heart were trying to catch up in its work by giving an extra contraction (pulsus intercurens). The patient, moreover, appeared totally unconscions of this peculiar action, which did not disappear during the remaining two weeks of life until the dilatation of the left ventricle had grown so extreme as to lead to relative incompetence of all the other valves. One night, apparently in consequence of flatulent distention of the bowels, he beeame extremely nervous and alarmed over a fluttering of the heart, which persisted for several hours, and until after a dose of whisky administered by the murse he fell asleep.

To add to the damaging effect of all this strain, the patient became nervous and despondent, and so desirons of getting out of doors that I agreed to his going out in his wheet-chair provided he was earried downstairs on a streteher, then placed in his chair, and on his return brought up again in the same manner. This was attempted hut was bungled in some way so that he was rendered extremely nervous, and, after all, was borne down and up in his attendant's arms. This in reality onght not to lave injured him had his heart-muscle been less serionsly damaged. $A$ it was I recognised, so soon as I examined him a short time afterward, that the walls of the ardiac carities were still more stretehed and the liver still more engorged.

He now lost his appetite entirely, passed rather poor nights, and showed a slight puffiness of the insteps. One week later he began to have very slight nausea, and on Sunday forenoon was seized with a sudden attack of vomiting. He rose up in hed and strained violently in the act in a way to make me most meass. I happened to be sitting by his bedside at the time and took oceasion to observe the pulse. This did not beeone specially accelerated but rather thready, and its irregularity somewhat more pronounced. Examination of the heart did not, howerer, reveal any marked ill effect. He was now put on kumyss, and all internal medication was stopped lest the stomach might he again disturbed. He passed a poor night and the next day complained of rather 


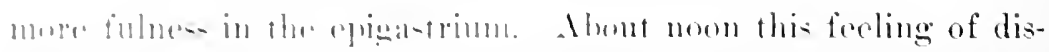

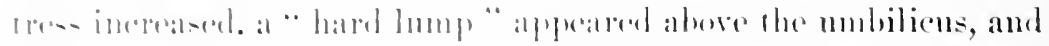

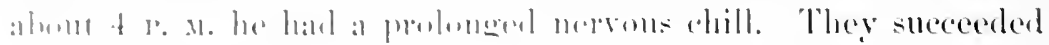

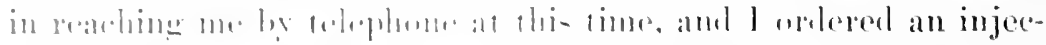

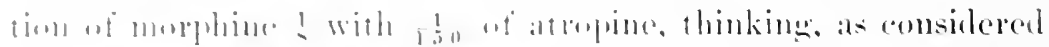

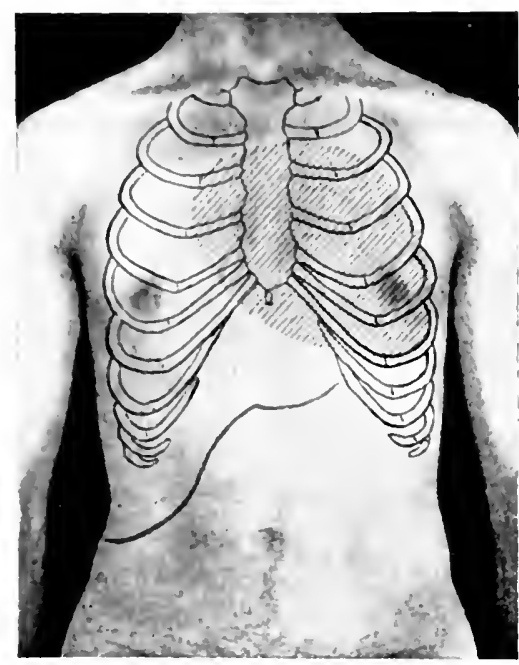

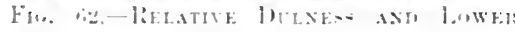

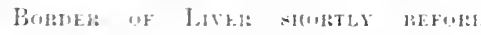

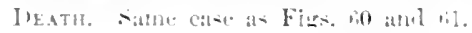

liy the morese. Ihat the pain and " knottinge" might he an areommulation of thatus in the rolom. I jon arriving an homr lalfer and examining lhe ablur m110, l al mone discorrered that the lotit lobe of the liver was ereatily swollen, tembler to flue-mene, and was throbbing firme the porpanated pulsation of the aorta beneath. It repuires only a hrief examillation of the heart to pereeive that the -train of vomiting the lay hefore haul dome its evil wolk by setting up a marked increase of harek-pressme (Fig. fi-). Tho extermal jugulars

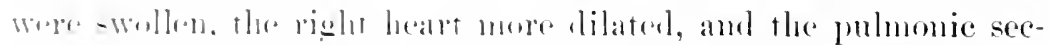

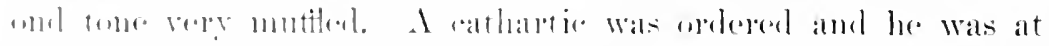

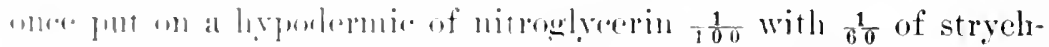

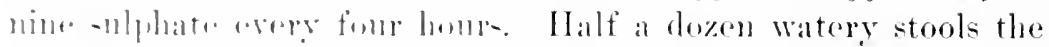

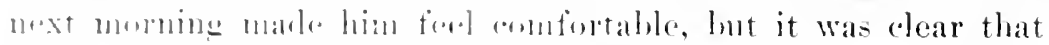

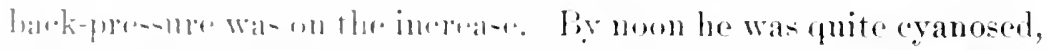
and the pul-e Wa- - mall ame weak. He was then put on 15, drops uf tatteres timeture at lizitali- arely two homs, the glonoin,

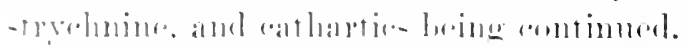

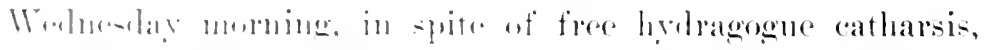

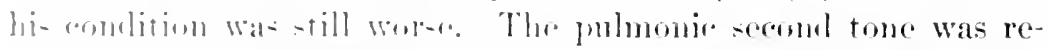

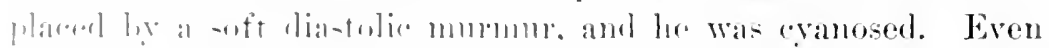

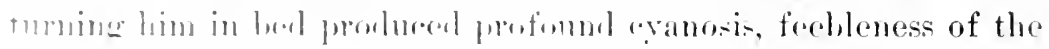

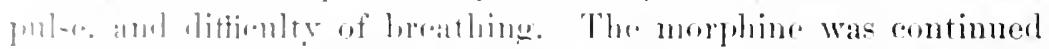

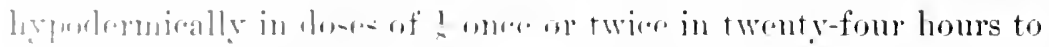

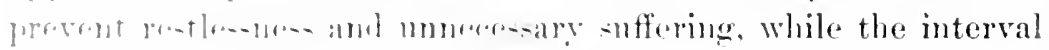


between the injections of nitroglycerin and strychnine was shortened to two instead of four hours. He then rallied for a few. hours and the cyanosis ahmost disappeared, but the heart-findings remained about as before. Morphine gave him a fairly comfortable night and Thurslay eane. The pulmonic second sound was now audible again, but the pulmonic diastolic mmmur persisted and the external jugulars and liver pulsated numistakahly, while a soft systolic bruit, evidently trienepid, could be heard at right of the sternum near its extremity.

The pulse now began to slow lown, from 96 to 90, then to 88 , and by noon to 80 , yet did not grow stronger. On the contrary, it seemed to grow smaller and wealker, while the jugular pulsation inereaser, and distention of the right auricle caused absolute dulness to reach across the sternum and heyond. He had now received 24 doses of digitalis, and helieving that it would only do still greater harm, I ordered it sopped and provided elixir of valerianate of anmonia and a 10 -per-eent solution of camphor in sterilized olive oil against pusible further sinking of the pulse. The oil was to be injected muler the skin in case of need.

The feet and ankles were now quite rulematoms, mine was very scant, the pationt perspired profunely, slept much of the time, and was profomdly eyanosed with marked puffines of the nexk and lower part of the face. More bowel movements of a watery character were secured without any impresion on the stasis. The pulse stayed at 80, very weak, and whenerer to rest him he was turned on to his back or left side, hecame listinctly worse. His greatest comfort was when he lay in the right lateral deeubitus. His respirations were 28 , and his breathing was laboured at times. Râles of hypostatic congestion were andible at the right base behind.

In this comdition things remained until $10.30 \mathrm{r}$. x., when suddenly he complained of inability to meathe, turned purple in the face, grew rigid and pulseless. The nurse hastily injected the camphorated oil as I entered the rom and hurried to the bedside. I listened for the heart-sounds, but all was still; life was extinct, his muscles relaxed and his sufferings were at an end.

This case has been detailed at this length in the belief that it might prove highly instructive on many of the points that have been already dwelt upon in regard to aortic regurgitation, and 


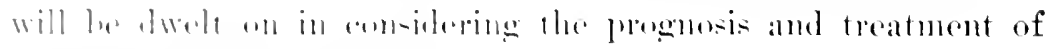

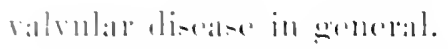

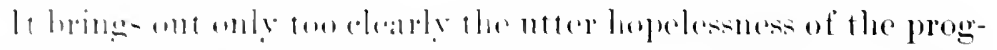

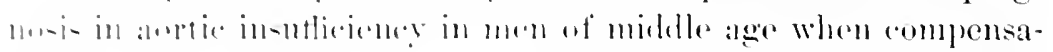

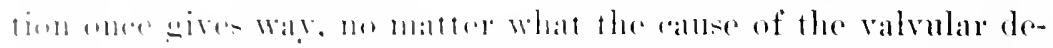

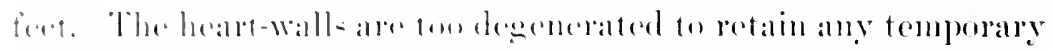

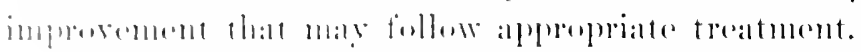

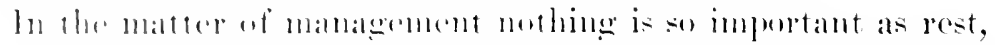

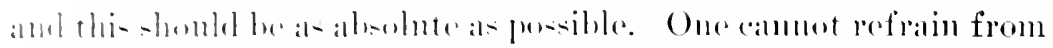

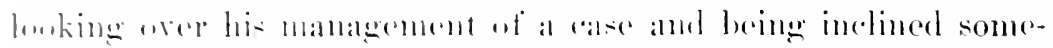

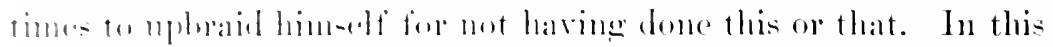

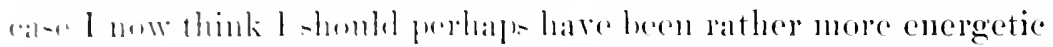

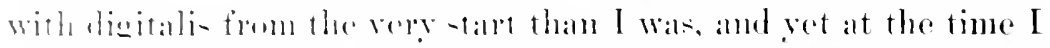

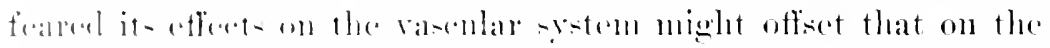
heart. In another alse I ludieve I will try phing the drug to the

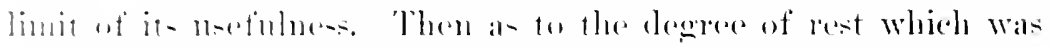
rempenl. I might have heen Jess lonicut, and ret this gentleman

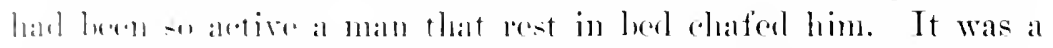

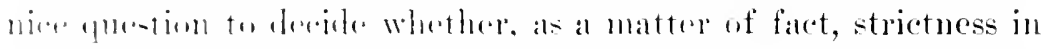

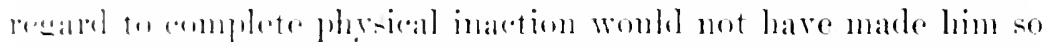

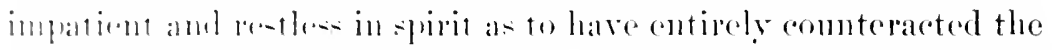
leruetit to he had from lest of herly or as to have dome him greater

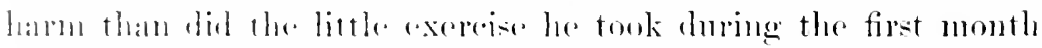

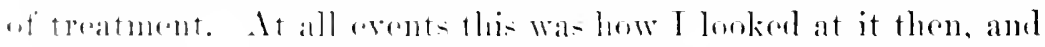
I am mot inevitalle. and no treatument andel do more than retard the fatal i- - ile. 


\section{CHAPTER IX}

\section{AORTIC STENOSIS}

Turs is a comparatively rare affection when existing alone, and, as its name signifies, comsists of a narrowing of the aortic ostimm. It is arrays a structural defect and owes its origin ehiefly to inflammatory changes.

Morbid Anatomy.--There are two types of structural change that may lead to narrowing of the aortic orifice: (1) The cusps of the valve may become adherent and stiftened; (2) growth and organization or calcification of vegetations may take place in such a way at to interfere with the passage of the blood-stream. The former defect may be due to a derelopmental error, and oecurs in congenital narrowing. It may also, howerer, follow acute endocarditis. The cusps may become so completely adherent that only a small opening, searcely large enough to admit the point of a lead-pencil, is left. Fig. 6i: shows such a heart, and also illustrates the proneness of acute endocarditis to attack a valve already the subject of chronic disease. Here a tiny row of regetations is seen along the line of maximmm contact during the elosure of the valves. In those cases of stenosis of sclerotic origin in which the cusps are not adherent but interfere with the blood-flow on account of stiffness which prevents their swinging back in the normal way, regurgitation is msually so freely permitted that the case is classed as one of insufficiency.

In the second class, vegetations on the aortie valve may assme such proportions as to induce narrowing of the orifice. These oecur most usually on the ventrieular surface of the valve segments, and in that situation of course interfere also with the elosure of the valve, producing leakage. The narrowing is usmally the predominant effect, however, of a large vegetation in this situation. An interesting type of stenosis, shown well in Fig. 64 , is that in which vegetations develop in one or more of the sinuses of Val- 


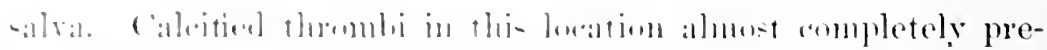

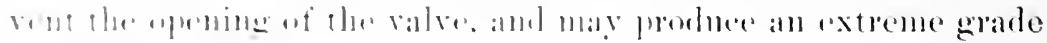
ai - $\{1011,-1-$.

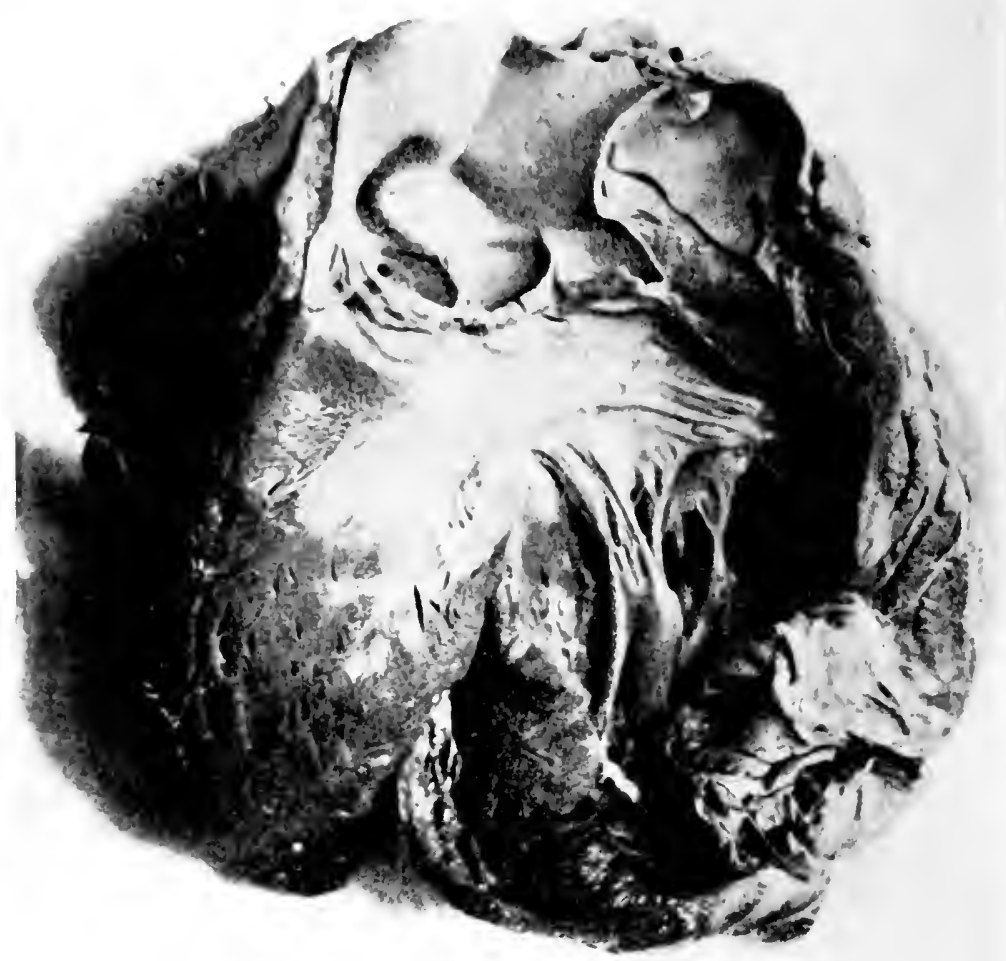

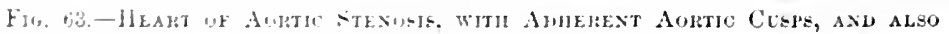
A. ITE Exinucandits.

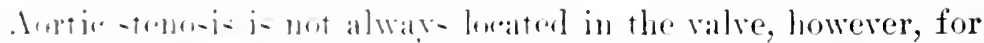

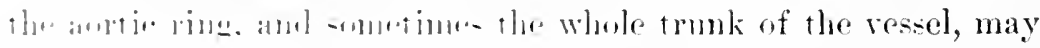

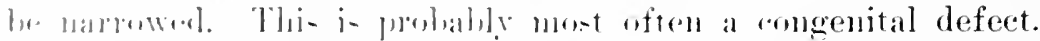

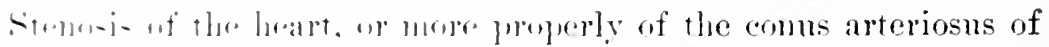

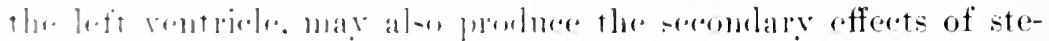
1un- uf the crifier.

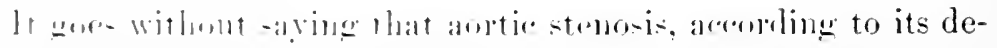

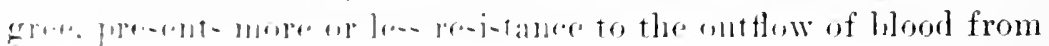


the ventricle. In order, therefore, to discharge a normal volume of blood through the diminished opening, the ventricle is obliged to. contract more powerfully and more slowly. This increased work results in the development of hypertrophy.

Fraentzel is of the opinion that dilatation of the ventricular cavity precedes the hypertrophy, becanse the wall cannot accommodate itself to its increased task. This would be the ease, doubtless, were the stenosi mblenly developed, but inasmuch as the changes in the valves learling to stenosis are bronght about slowly, the wall of the left ventricle is able, pari passu, to meet the grow-

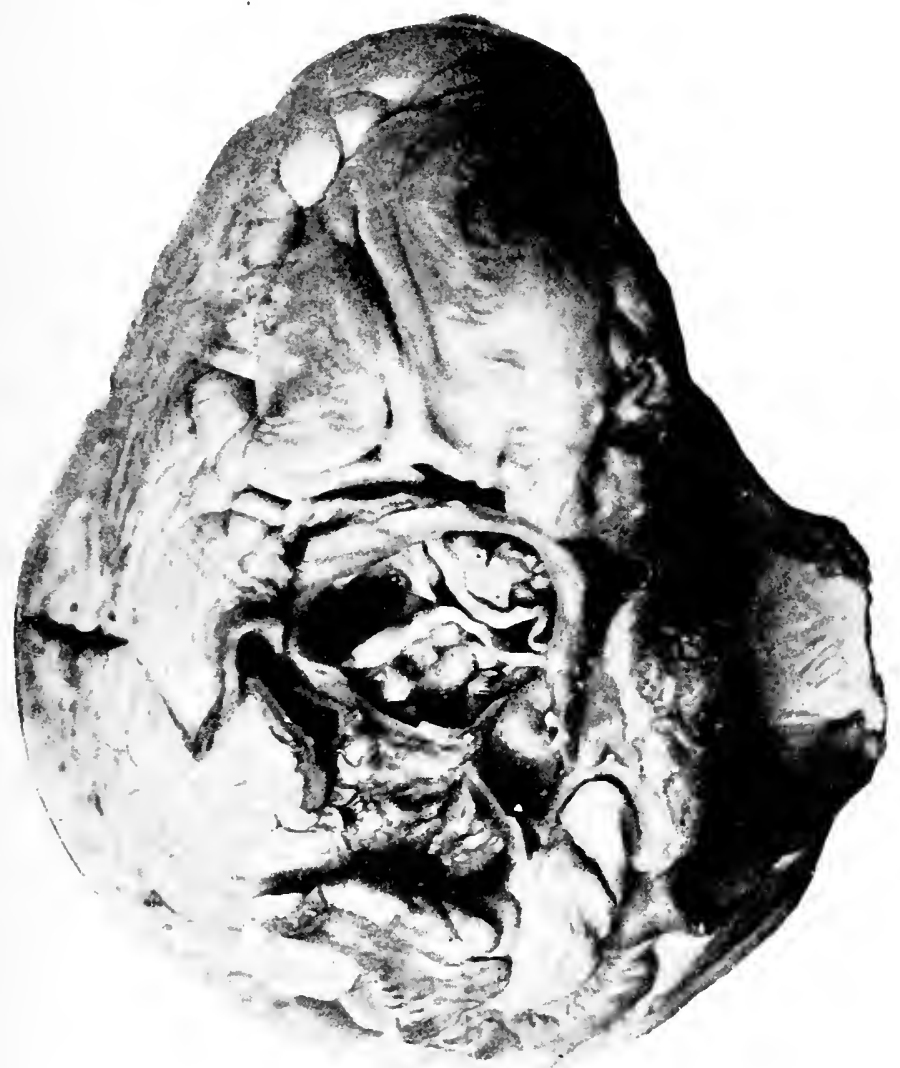

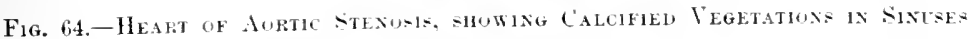
() F VALEALVA.

ing resistance. It seems clear, therefore, that hypertrophy of the left ventricle is the first result; and that when dilatation of its 
(a) ity i-allon turesut, it is cither the offeet of associated regurgita-

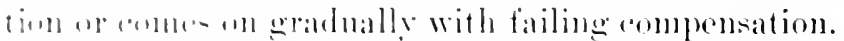

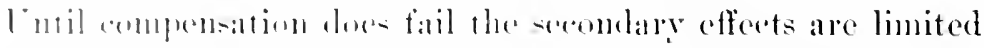

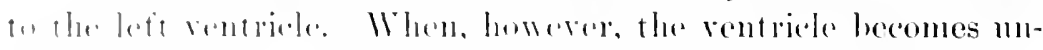

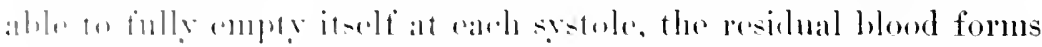

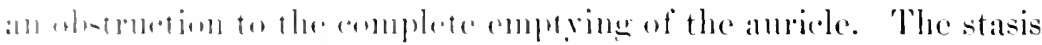

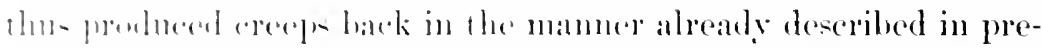

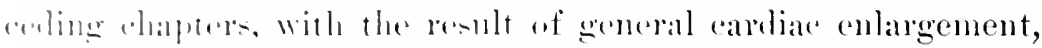

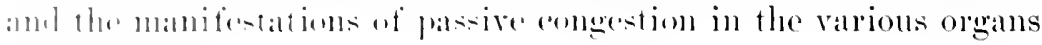
of the hentr.

lu extreme smathe of stemesis the supply of hlood to the coro-

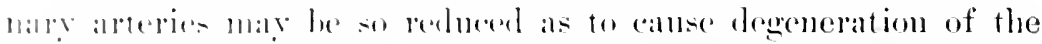
myeradimn. In this mamer the constrietion tends ultimately

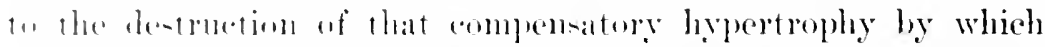

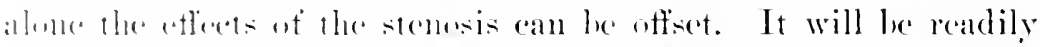
of aleit inpurtince.

Etiology. - Stemenis of the aortie orifiee is in nearly all in-

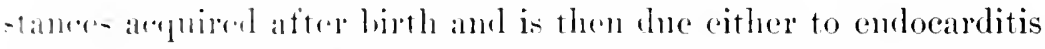

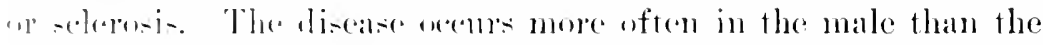

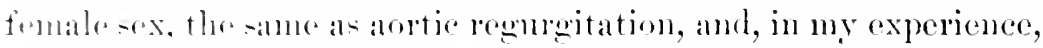

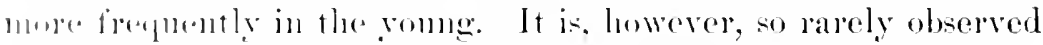

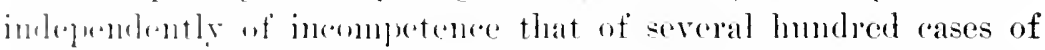

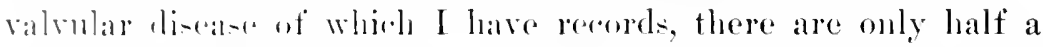

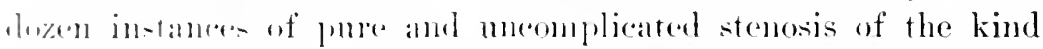

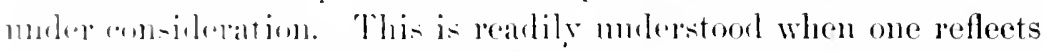
fur a moment npon the comblitions which are responsible for the

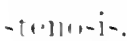

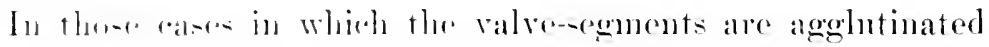

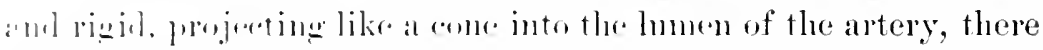
i- left a -mall nenenge at the axtremity of the eone through which

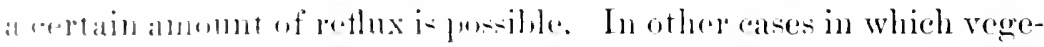

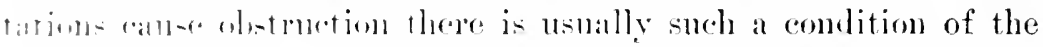

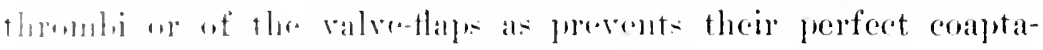

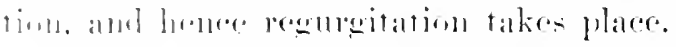

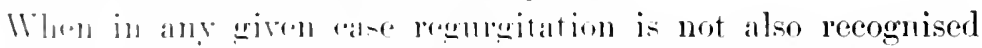

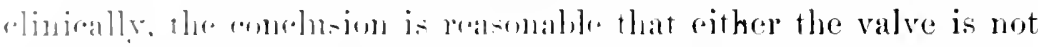

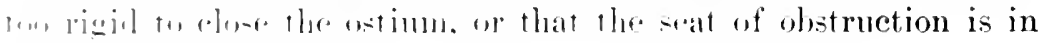
the rine we connt - 
The etiological factors responsible for the endocarditis or the degenerative changes underlying the stenosis have already been so fully considered in the causation of the foregoing valvular defeets that it would be a needless repetition to discuss them here.

Symptoms. - Stenosis of an orifice is justly regarded as a serious affection; ret in this particular lesion subjective symptoms are sometimes entirely wanting. Consequently the clinical features of each case, as well as their severity, depend npon the degree of narrowing. If this is extreme, it is impossible for the disease to remain latent, and the patient suffers either from a too inadequate supply of arterial blood to maintain nutrition and normal visceral fumction, or from the effects of stasis behind the seat of constriction.

In the slighter degrees of aortic stenosis patients are nsually capable of ordinary physical and mental activity the same as their companions. I recall a lad of fitteen who presented himself at my clinic in the Post-Graduate Medical School, becanse of some trivial digestive disorder, and in whom were discovered all the signs of uncomplicated aortic stenosis. Judged by the secondary physical signs it was not very pronounced, and the loy stated that he was a newsby selling papers on the suburban trains, in the habit of carrying heary lomdles of papers, and of jumping on and off noring trains withont any shortness of breath or consciousness of his heart's action.

It is in such cases as this that individuals go for years without knowing there is anything wrong with them, and at length learn of their defect through its accidental discovery bome medical examiner. Indeed, persons with thoronghly compensated aortic obstruction may pass through their entire lives to old age withont having ever learned of their disease. The pulse of such an individual is slower and smaller than normal, and the cardiar inpulse denotes hypertrophy, but having grown up, so to speak, with these deviations from the general rule, he pays them no attention.

If any circulatory disturbances result from the artic constriction when single and of minor degree, they are such as indicate deficient supply of arterial blood to the varions organs and parts of the body. Even these effects may he too slight to attract special attention. At the most, the circulation is not very active, and the boy may not be quite as vigorous as his healthy play-fellows. 


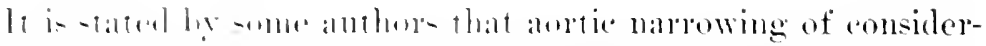

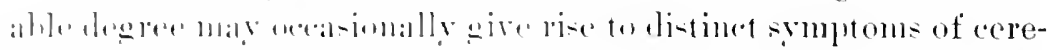

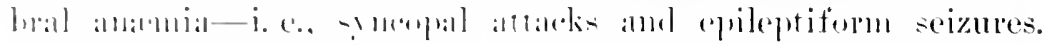

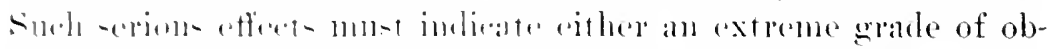

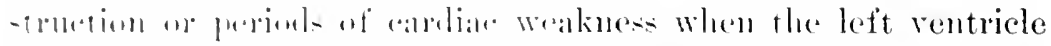

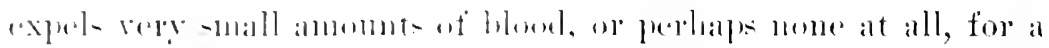

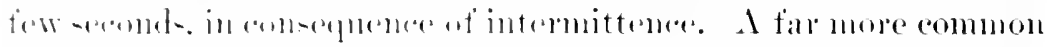

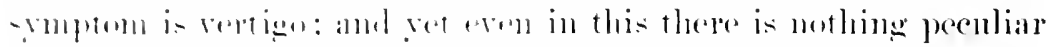

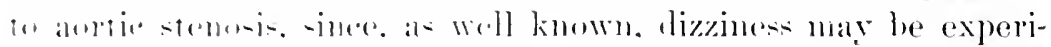

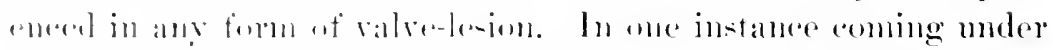

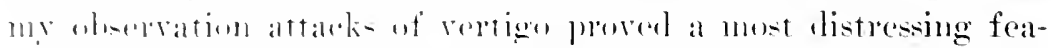

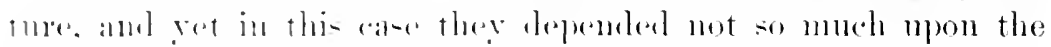

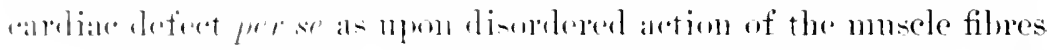

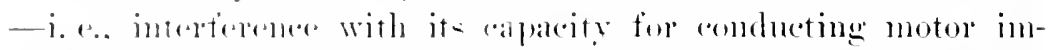

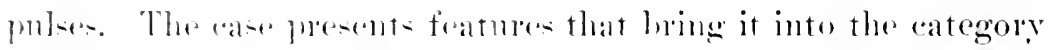

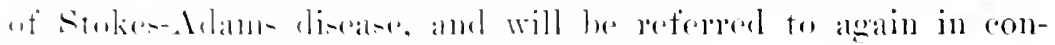

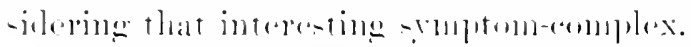

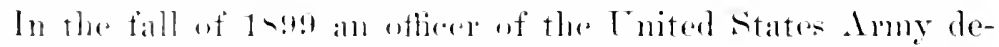

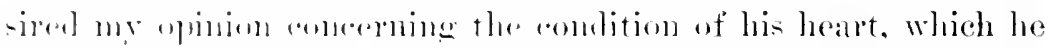
-tated wa- rely mm-nal. Il. wal-highly intelligent. and had made

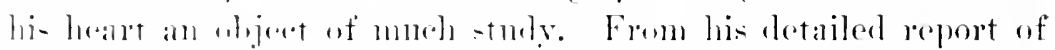

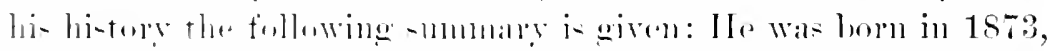

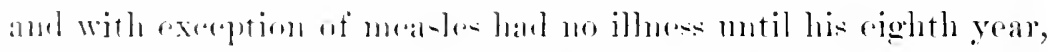

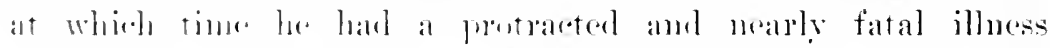

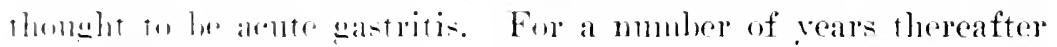
hi- ligention wa- wakk. lut he was alle to participate in the games amel-ports of his playnates withemt being ennseioms of ill

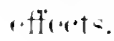

At the age of fountren we tifteen he aceidentally diseovered

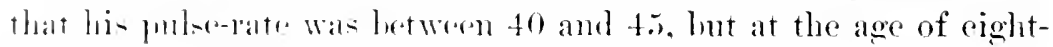

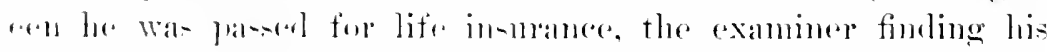

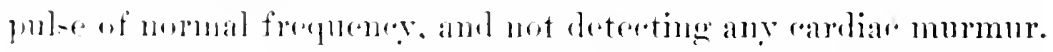

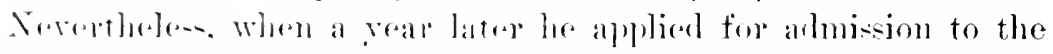
Wret Puint Military Araldemy he was told that he gave signs of

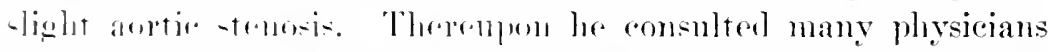

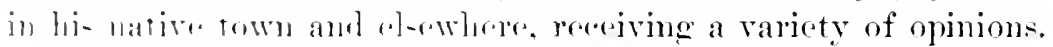

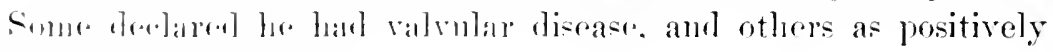

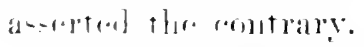

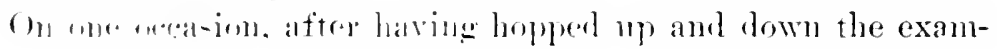


ining surgeon's office, he was fold that his pulse wa- heating 140 per minute. To make a long story short, it suthees to siy he was at length admitted to the Academy at the age of twenty, notwithstanding the discovery of his antic stenosis, the lesion being eonsidered tritling and compensation gowe. During his caldetship he was able to endure the arduous drill- with apparently no more distress than did his comrarles, althongh he noticed upon a few oceasions that the reins on his foreheal strot out prominontly.

In his senior year he, like many others of his elase, had to go to the hospital with chills and ferer that were consileped malarial, and which have not recurred since hi- leaving the Acalemy. From September, 1897, until the spring of 1899 . lue was stationed in San Franciseo, and while there harl a pulse-rate of 38 , but with the exception of slight hlurring of ri-ion and headache, that was always relieved by calomel, he had no illnes or swnptoms referable to his heart. In the fall of 1 sos, 1 prm heing examined for promotion, he was told he had aortic stenosis and mitral regurgitation, and was rejected in consequence. Tevertheless mon his record he at length olotained his promotion, and wa-tran-ferred to a post in the East.

In May, 1sos, he participated in a hicycle rile. being nnaccustomed to that particular form of exercise, although he engaged in every other kind of short and game with his fellows. During this ride lie made a sput, and then got out of breath, but otherwise appeared to suffer no inconvenience. Two hours subsequent to his return to his quarters, and while standing hy a table waiting for dinner, he sudrlenly became rizzy and was assi-ted to a conch. The junior surgeon was summoned, and finding his pulse 30 , administered whisk wh wheh somewhat relieved him and brought his pulse up to 50. From that time on he was daily distresed by spells of vertigo for some weeks, and he noted that the regular slow artion of the heart was erery now and then exchanged for a more rapid irregular one, with an oceasional violent thump against the chest-wall. It this tine his dizzines was namally relieved by assuming the recumbent posture.

He received some medicinal treatment, nature mknown, and then for a month was free from his di-tresing symptom. It returned again. however, more violently and still annoyed him in November, 1s99, the date of my first examination. During the 


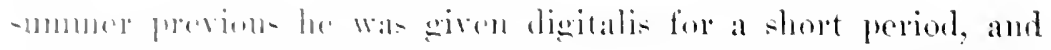

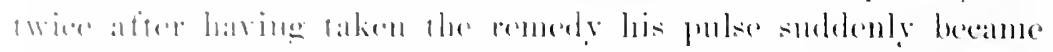

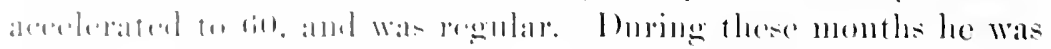

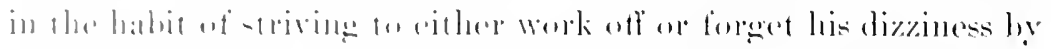

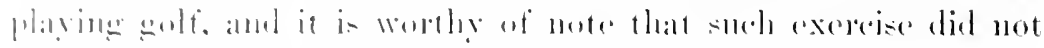

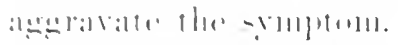

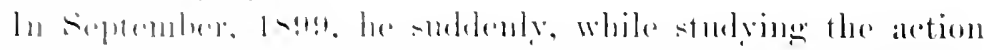

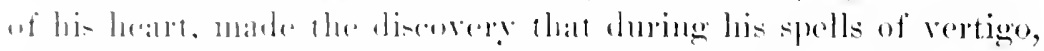

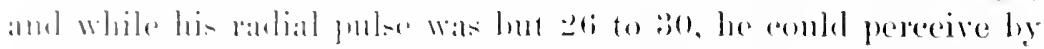
plaring his tinger aluse the elavele a series of "small pulsations

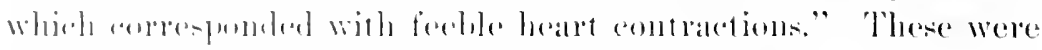

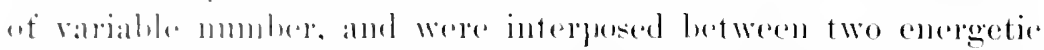

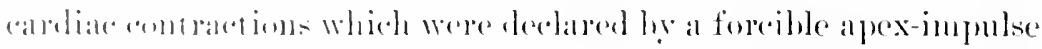
ame ly the ranlial julse. He turthemome noted that no matter

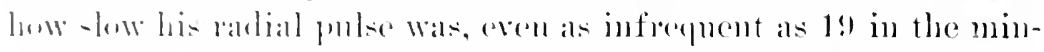

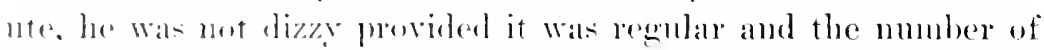
small pulsiltom- in the neek was muiform. I shall recur to this

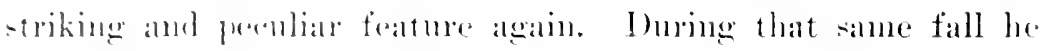

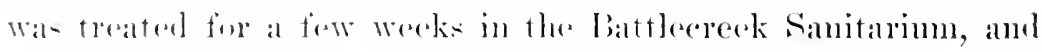

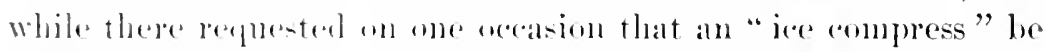
flared upon his lexar. This was dome, and upon its removal ten ar fifteen minmes later his heart grew regular and the pulse at the wrist regiotered ati. He then foll asloep, only to find next

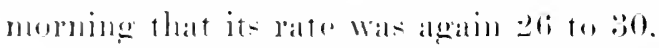

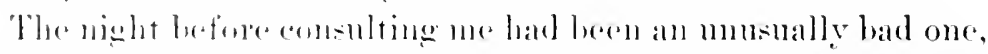
and when I saw him the fulso was 36 and irregular. Ile almitted

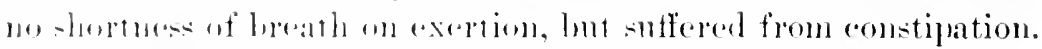

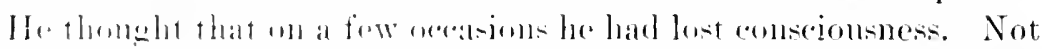
to make thi- nandative terlion-, I will sa! my exambination revealed

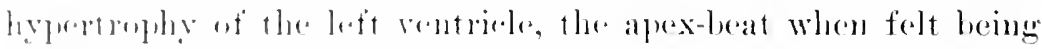

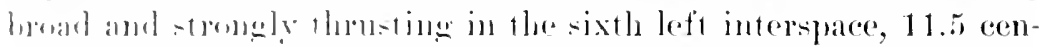
timetres the the loft of the median line and 1 eantimetre outside ot

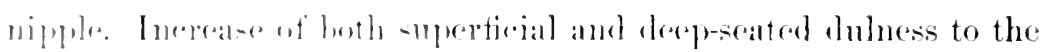

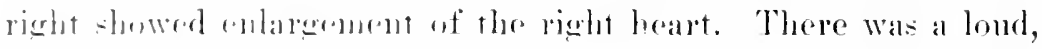

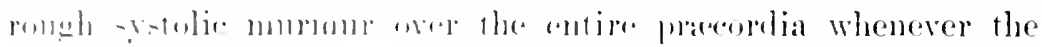

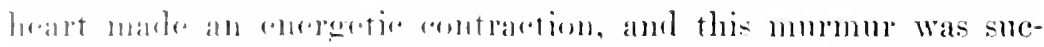

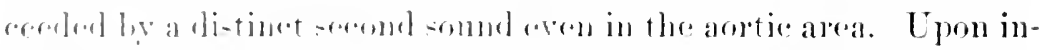
vetigating thi-buit minutrely it was fomm to have two areas of

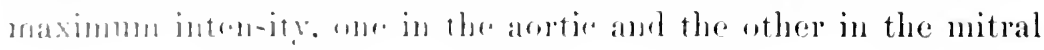


area, although I could not detect that the quality in the two regions was different. I found subsequently, however, that at the apex the murmur was softer and more blowing.

The murmur at the base was transmitted upward into the neck as well as on to the body of the heart, while that at the apex was propagated ontward into the axilla and feebly to the back. It first I did not observe the small pulsations in the neck, bnt when my attention was directed to them I perceived them distinctly enough, and I also noted that synehronons with these were teebly' audible eardiae tones, while at a much later date these fecble heart-sounds were accompanied by a faint murmur and an indistinct apex-beat. Thiese small pulsations, for lack of a better term, were of irregular number, being ordinarily two, but sometimes as many as seven, and according to the officer even more, before there would come a nomal pulse-wave. It was suggested by the patient that these were auricular in origin, but I decided that they were due to feeble ventricular contractions, and subsequent eardiograms taken by Dr. Janeway in New York established the eorrectness of my opinion.

The very interesting feature pertaining to these incomplete systoles was, that so long as they were regular and in groups of two, vertigo did not ensue. When, on the contrary, they ran up to half a dozen or more the patient felt dizzy or even fainted. These pulsations were first thought by me to be in the carotid artery, but are now known to be jugular.

My diagnosis of the cardiac disease was the same as that of others: aortic stenosis of mild degree and mitral insufficiency, the heart being in a state of still-preserved compensation; for although vertigo was a symptom, there was no dyspncea on effort and no secondary hepatic or other visceral engorgement. Two things greatly puzzled me: first, if the mitral valve leaked why did not the obstruction of the aortic orifice render the regurgitation through the mitral more serious, as is usually the effect; and, seeond, what was the canse of the vertigo, or rather the irregularity, in the heart's action.

This latter condition, I helieved, was in some manner connected with his digestive organs, but just how I conld not deeide. The urine was collected for twenty-four hours and carefully examined in the Columbus Medical Laboratory, but aside from some con- 


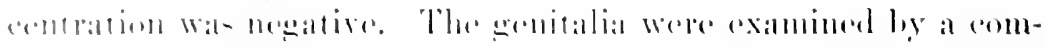

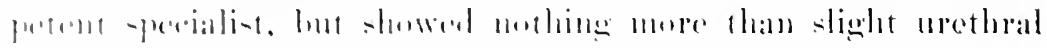

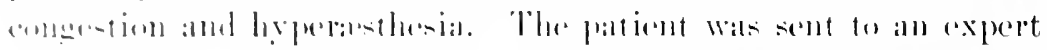

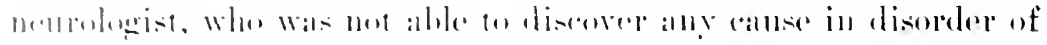

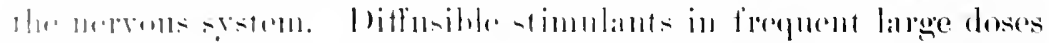

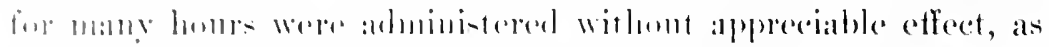

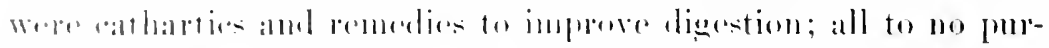

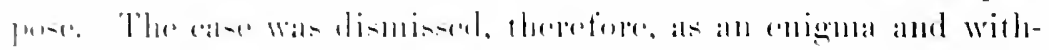

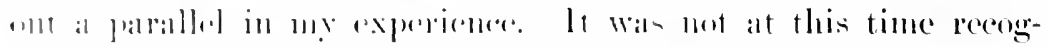

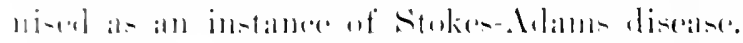

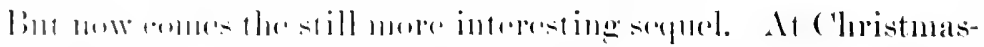

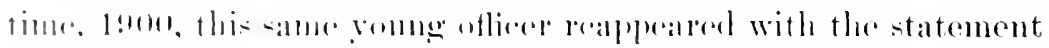

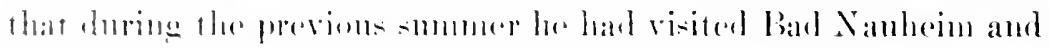

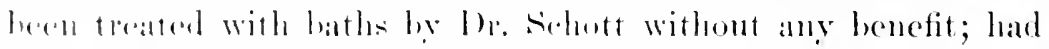

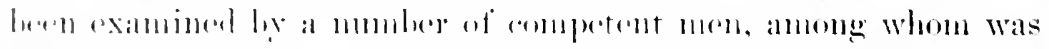

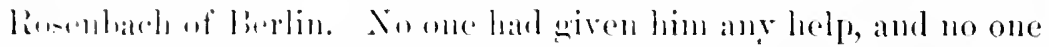

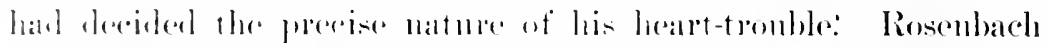

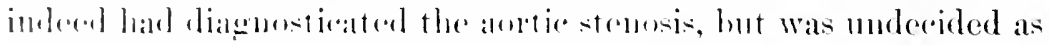
to what was the enolition at ihr mitral. I fomml things exactly at a rear entior. But stomg in my belief that the vertigo that -till antimmen was in somm way related to his digestion, or met-

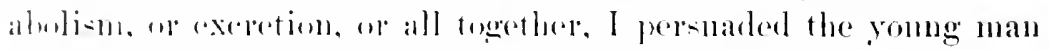

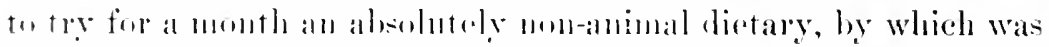

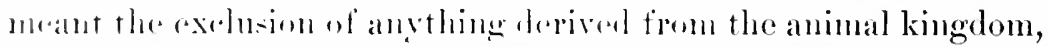
induding meat. punltry, tish, cogs, ote., with exerption of cheese

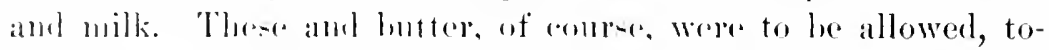

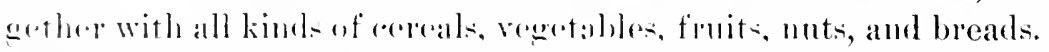

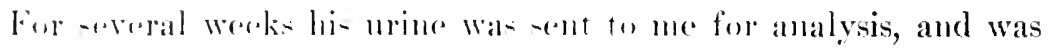

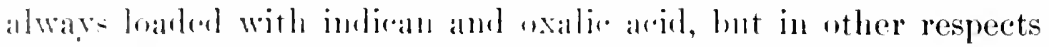
wa- normal. Xeary foml months later the patient reappeared

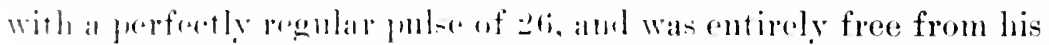

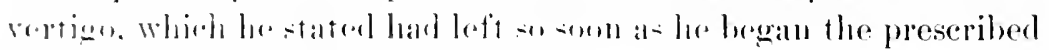

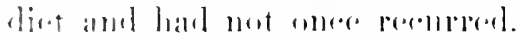

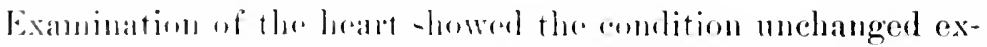

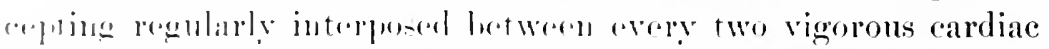

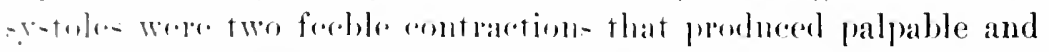

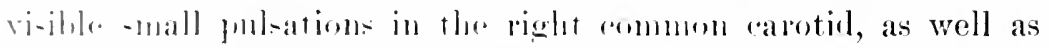

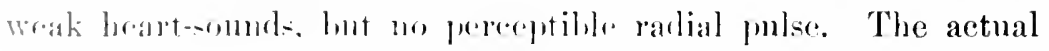

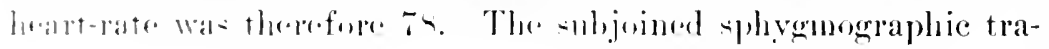


cing (Fig. 65) was taken by Dr. Edwarl F. Welles, and is by him, a competent judge, considered entirely normal except in rate.

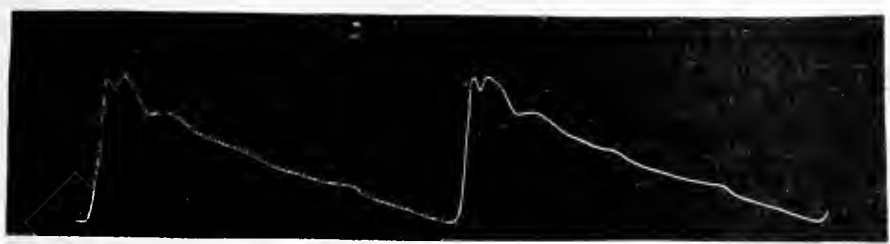

Fig. 65.-Spingmogram from Case of Aortic Stenosis (p. 324). Pulse-rate, 25 per minute.

The conclusions to which I am forced by this case are the following: 1. That this singular cardiac action is normal to this individual, and that it is only its irregnlarity that occasions symptoms of any kind. 2. That this irregnlarity was of an auto-infeetious origin, due either to the production of leveomaines or to the influence of constipation on the vagus or heart-muscle cells, for on this new dietary he has had two or more bowel movements daily. 3. That the lesion is a mild aortic stemosis together with a mitral defect, of the exact nature of which I am not certain. But as I feel sure that at my last examination I detected a very short presystolic thrill and murmur as well as an apex-systolic murmur, I am inclined to the opinion that there is both narrowing and regurgitation at the mitral ostium. Why this combined lesion does not occasion secondary signs and symptoms can only be explained on the hypothesis that the defects are slighter than would be supposed from the cardiac findings, particularly the intensity of the murmurs. The peculiarity of his normal, or at least seemingly normal, cardiac action, is still inexplicable. The symptoms in this case do not as such helong to the usual history of aortic stenosis, but are here narrated because they may be remotely referred to the valvular lesion and illustrate the vertigo said to be sometimes dependent upon narrowing of the aoric ostium.

It is apparent that the development of subjective symptoms is determined by other conditions than the mere existence of aortic stenosis. They depend upon either disordered or deficient cardiac action. When at length, either in consequence of orerstrain or of extreme narrowing, the left ventricle begins to manifest inadequacy, dilatation sets $\mathrm{in}$, and it is no longer alle to completely 


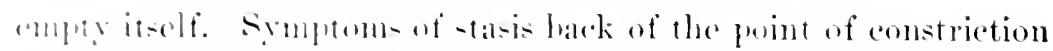

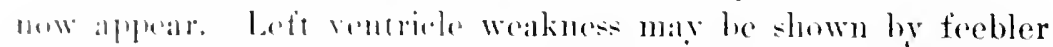

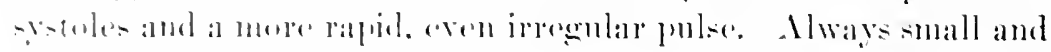

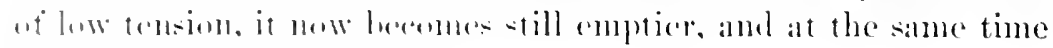
mone rapid than tormerely.

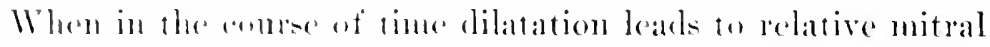

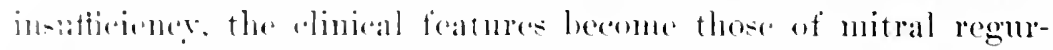

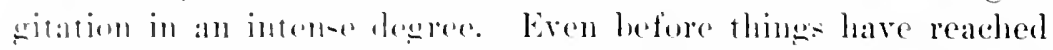

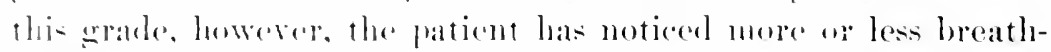

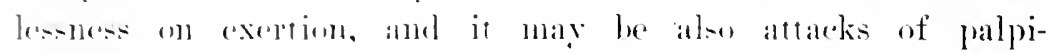
lilitill.

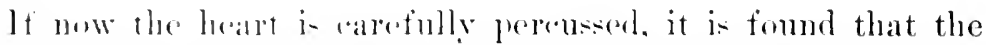
right ventriele has incleased in size, while there are in addition signs of engurgendent uf the acmeral venous sytem. This conditim may last for month before relative mitral insufticiency becomes promomucel. but as a rule the conclition grows more or less rapidly worse and the individual is no longer able to keep about herallse of drepmua and congestion. A mitral spstolic murmur is arled to that of the andic stenosis, the right ventriele, feeling the strim of momomary amestion, loegins to pulsate in the epigastrimu, the cervieal and superticial reins swell, the liver grows palfable and tromler, the mine heomes seanty and concentrated, and at last welema makes its apleallance in the feet and ankles. The "ase has now heonur anverted into one of mitral disease in the stage of loroken complensation.

When thr mitral wifies shares in the dilatation of the ventriele,

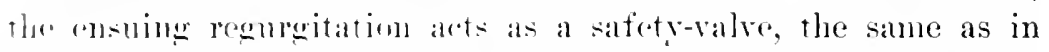
ra-re of aortic incompetenere, and artually serves to prolong life. Tot infrequently the strain wh the right heart leads also to relative trielspiel lakage. ambl we have the sigus of that lesion added tor threse of the arotic and mitral doforets. When this state is reached

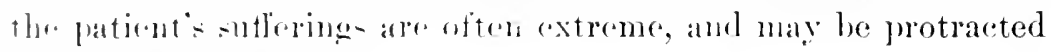
thromeh many month-

In the spring of 1 - a - I fir-t took charece of a lady of forty-one

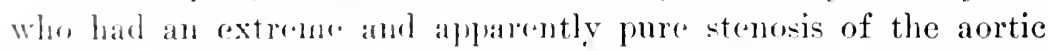
orifire of rlommatic origin. Six yoars before, the late Dr. W. W. Jaswanl dedivered lare of a som, and recognised the gravity of the ra-re lereanserof the valvular lowion. The lady did unt subsequently experienre dietinetive arodiar symptoms unti] the care of a con- 
sumptive step-son compelled her to reside for many months at a considerable altitude. Croing with him first to Colorado Springs (6,000 feet), she there suffered intensely from shortnes of breath, so that they were obliged to take Valley at a leight of about 2,ino feet. Even there she was not able to walk without considerablo drsmucas.

After the death of the young man this lady wrout abroad, and in Europe sought medical advier. She was adviced to talie a course of baths moder Dr. Schott, at Bad Xauheim, and while there laal her first violent attack of angina pectoris. This followed one of her baths. No special benefit was poduced by the halncological treatment, and she returned to America. During the winter of 1897 and 1898 she passed throngh an attack of acute nephritis, but when she consulted me the mine showed no albunin of other abnormal findings. The heart war greatly enlargod, but compensation was still fair. That summer the had a violent attark of angina following a fatiguing walk across a very meven moalow, and thereafter was never again well.

When I saw her in the fall I considered it necesary to confine her to bed for a number of weeks, and when at length she was permitted to get up she was still olliged to remain on one floor and to move about with great slowne-.. The action of the heart did not quicken much under exertion. lut the pulse grew rery feeble, the reins of the neck swelled, and she breathed with evident difticultr. She had several severe anginal seizmes, which will he deseribed in the article on Angina Pectoris. Strength was gained with great slowness, and she was rarely free from more or less cardiar distress. This took the form chiefly of hreathlessness, distention of the abdomen by flatus, and hepatic congestion.

There was never any udema, lint the ankles often folt swollen and stiff. She passed the smmuer of 1899 at the seashore under the care of my friend, Dr. Edward O. Otis, of Boston, and in the autumn returned no worse but apparently no better as regarded her heart. All these months she had heen kept on alpurved cardiac tonies and was frequently obliged to resort to hylragugue ratharties hecause of the relief they afforded. The ensuing winter was a hard one for her, as she was most of the time confincel to her apartments in the care of a trained nurse. This was necessary by reason of the possibility of an anginal paroxysm and becanse at 


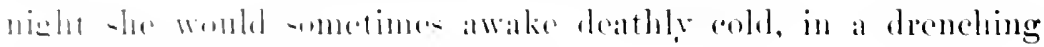

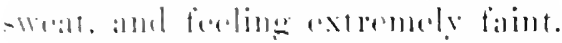

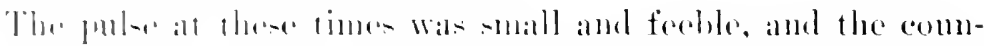

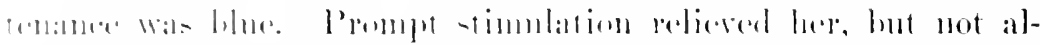

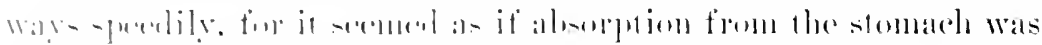

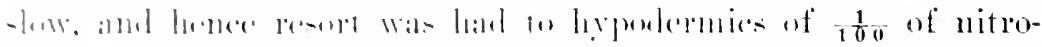

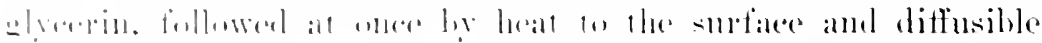

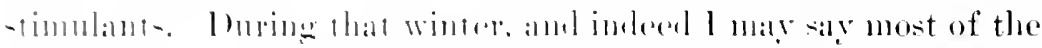

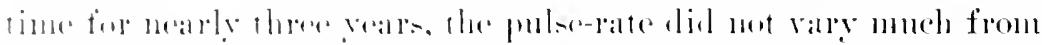

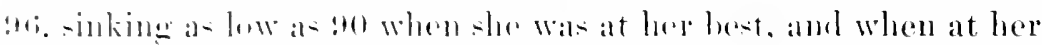

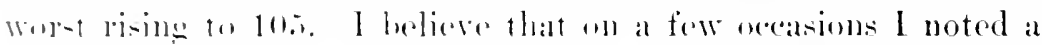

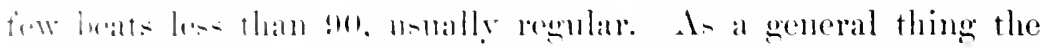

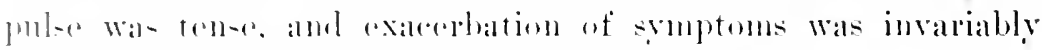

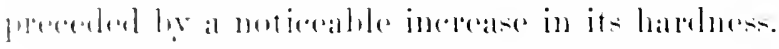

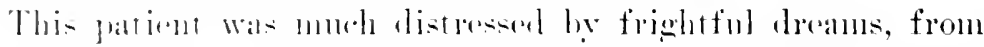
which she alweke with a stalt and a feeling of faintuess. She was

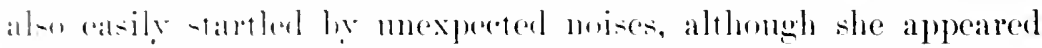
to have her nerres moler gend control. Insmmia was very dis-

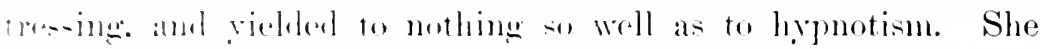

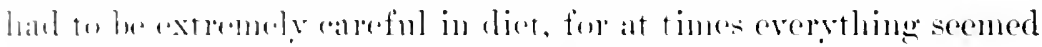

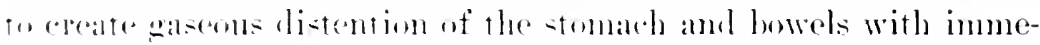

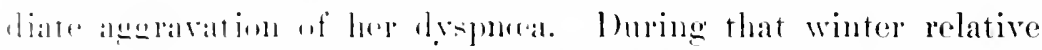
incemunetene of the mitral ralve becane comstant, and erery now and then trien-pid reanpeitation was arderd. Even withont actual

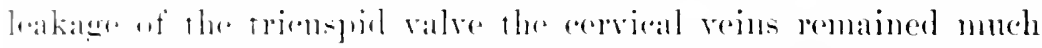
li-tendere and at times canted pain by theis pressure. I have -inee suted painful swelling of the jugular in another patient, hut

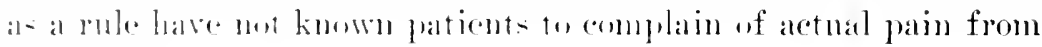
thi- rillin.

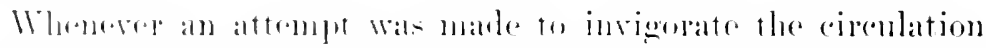

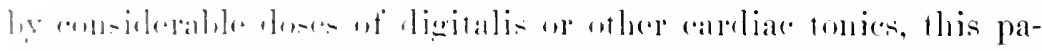

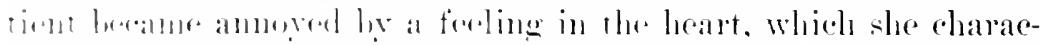

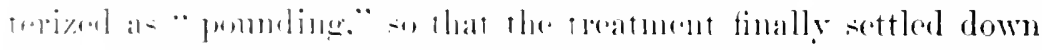

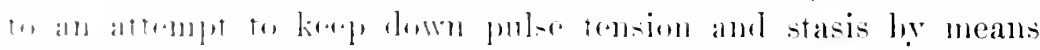

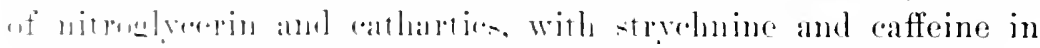

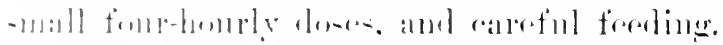

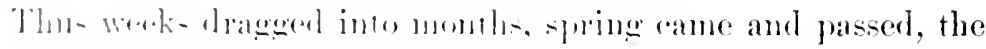

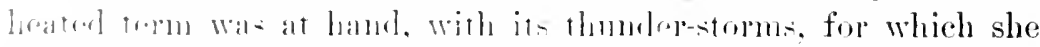

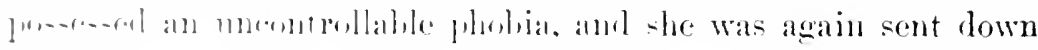


to Dr. Otis, at Rye Beach. Bry fall her condition grew so threatening from cardiac diatation and riseral congestion that she was not able to return to ('hicago mutil Thanksgiving. When at last she was able to make the jommey and reached home I found her in a deplorable state. Both anriculo-ventricular valves wore leaking, and the liver was enomonsly increased in size. The lungs were so congested that she was harassed by a frequent congh, which completely exhansted her, malle the face actnally purple, and caused her to gasp for breath for many mimnter.

The difficult sputum tras often bloody, or if not actnally sanguineons was made 11 of thick, tongh brownish mucols. The bases of the lungs were dull, and everywere were copions moist and dry râles. Heroin, strychmine hỵpotermically, energetic catharsis, and aponorphine in $\frac{1}{s}$-grain doses at last pulled her ont of her desperate condition, and by Christmas the was reasonalyly comfortable. She was obliged to remain in beci, howerer, or to exchange this for an invalid's chair. Whenever she made this effort her pulse grew weak, the reins distended, and she was unable to speak for a minute or two on account of shortness of breatl.

The excitement and fatigne of the holidays nearly used her up. Her cough retumed with increased visceral hyperamia and became so frequent and distresing that it conld only be controlled by hypodermie administation of hydrochlorate of heroin $\frac{1}{24}$ of a grain. This, however, after a day or two problued mansea and romiting, and then I actually feared the strain of emesis would make her heart stop beating altogether. As it was, after cach romiting spell she sank hack on her pillows, blue in the face. garping for breath and too exhansted to speak, while the perspiration simply poured off of her.

At length, howerer, thing mended somewhat, and if not reasonably comfortable, whe was at least not miserable. Then allumin and casts appeared in the mine in large amomts, and this patient sufferer began to fail slowly but steadily. By the middle of January it became necessary to resort to stimmlating injections of morphine and atropine to keep off the lorrille sensation of fainting which took possession of her. Strychine was increased to the limit of toleration, and in addition hypodernies of a grain of valerianate of caffeine were also given every two hours.

Stasis became so distressing, althongh wedema was never a rery 


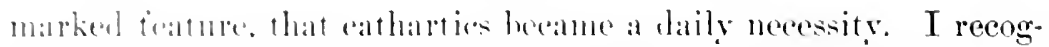
nisol fhat the norphine was a two-redgerl sword, incereasing the

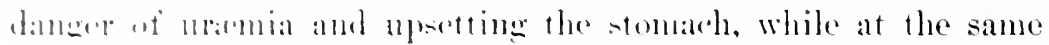
time afforling her roliof trom postive misery, and therefore it

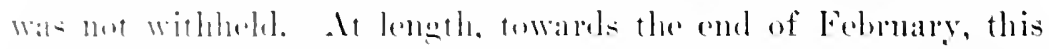

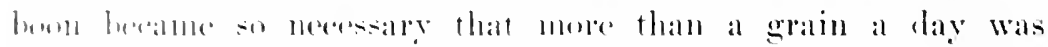

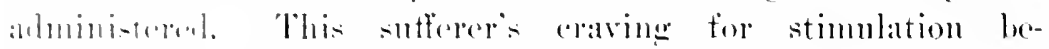

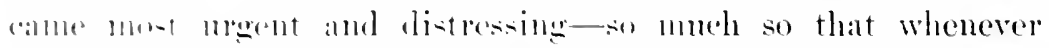
the reffore of the simmlant- passed off she at one felt a ter-

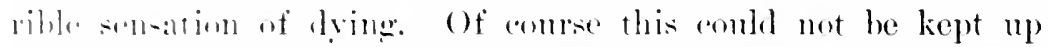
for long. and tinally. fire days before her death, the stomach Enve ont. Whether owing to the morphine, to the gastrie

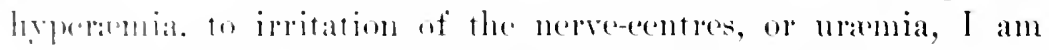

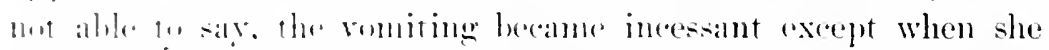

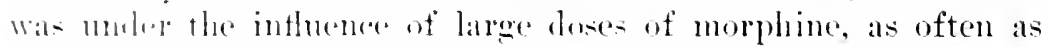
(very tive homes.

There atetully scemed to he no circulation at times, as judged hy the -tate of the vennessestem, and ret that poor leart kept right on, heating 10, times a minute, and for the most part regularly. It seomed as if the and must come at any moment through dia-tolie arest of the organ. and yet mereiful death was witheld for five wary dars. It leneth, forty hours hefore the struggle

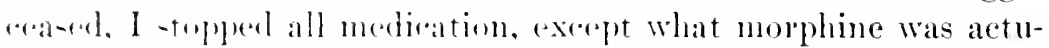

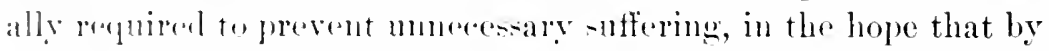
$\therefore$ deing the oml might he hastenexl. Still that heart went on, althomeh aralually growing waker and woaker. Twenty hours prior to heath -ho sank into (onma-mereiful coma-and at five "irlok in the morning the mfferer smblenly gave a little gasp, there alume a en-h of hlool to her lipe, and all was over. Death was fmolally due to pulmonary ajmplexy, in consequence of -malen arret of the loft rentricle an instant before that of the riglit.

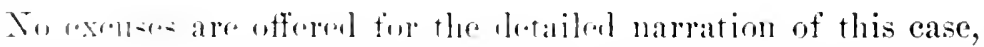
sine I luliere it is hiehly instmetive. Two rears and a half

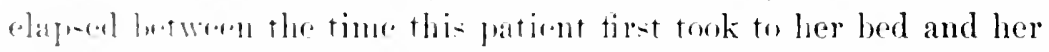
drathe and loriug all these thirty months it was one unecasing

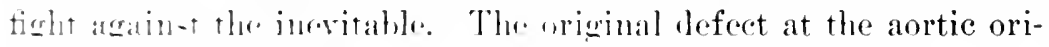

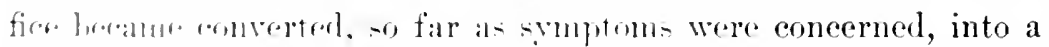
mitral and trienefid regurgitation: but with this difference, that 
the aortic narrowing absolutely precluded all prosibility of orercoming the dilatation of the left rentriele and the cloning of the. mitral valves. Every now and again treatuent closed up the tricuspids, but nothing conld restore adequate arterial circulation. The more one tries in such eases to forer the left rentricle to contract energetically the more is its dilatation likely to be increased.

In this case there was another element that hat to be reckoned with-namely, the angina pectoris and the probable degeneration of the myoeardium resulting from the cardian ischiemia that led to the angina. From the start I foresaw the ineritalle result, and we only put up as good a fight as we could.

Physical Signs. - Inspection.-1n most ares of aortic stenosis there is notling in the patient's appearance to attract attention unless it be some degree of pallor. Cyanosis is not present so long as compensation is preserved, and therefore when observed it is indicative either of some associated lesion or of cardiac inadequacy that has lert to stasis. The chief value of inspection lies in the fact that it enables one to letect the location of the apex-beat. This, in consequence of the hypertrophy of the left ventricle, is seen displaced downward and ontward, the extent of displacement depending upon the degree of hypertrophy. In thin individuals with broad intercostal spaces there is sometimes a diffused lifting of that portion of the chest-mall, overlying the left ventricle, hut this is rarely so pronounced as in aortic regurgitation.

Palpation.-The hand laid upon the priecordia perceives a slow, broad, hearing impulse, and at once preceives the impression of a powertully contracting organ. Palpation is consecuently al valuable means of examination by enabling one to juulge of the contractile enerey of the left ventricle. In corpulent persons the thickness of the thoracic parietes may conceal the real force of the apex-beat, lut as a rule feebleness of the impact, even when the apex is displacesl, is a token that dilatation of the rentricle is weakening its srstoles. Furthermore. in many cases of aortic narrowing careful palpation of the base of the heart detects a thrill or fremissement at some point along the comrse of the ascending aorti. This is generally in the second right interspace close to the alge of the sternmm, but it may be on the 


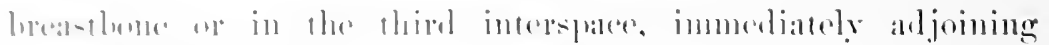

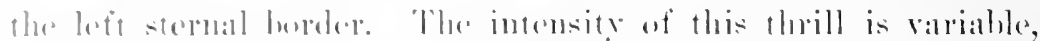

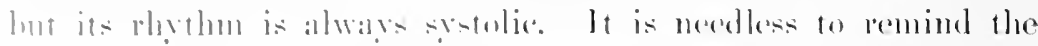

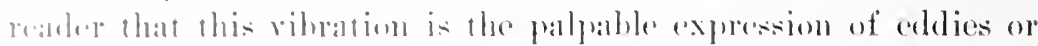

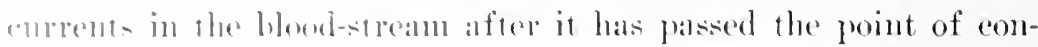
mlivtion.

The pulso of arotic stonosis is small and nsually weak in consepunence of the diminution in the amonnt of blood ejected from llo ventriele. les sime theres-

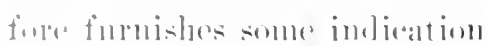

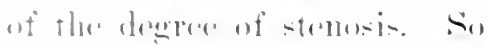

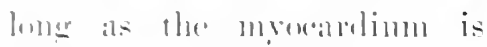

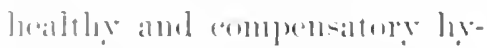

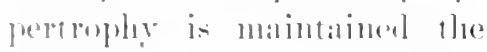

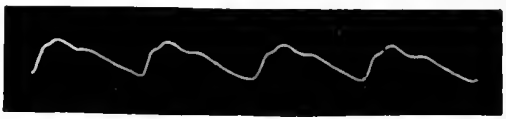

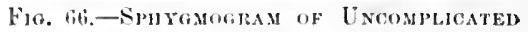
Andrth StTENosis.

Personal observation.

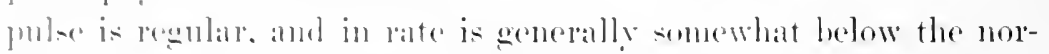
nal. Aronlelingly, an mulue acoeleratiom, or an irregularity, or intermitrence of the pulse is a sign ut weakness. If aortic incom-

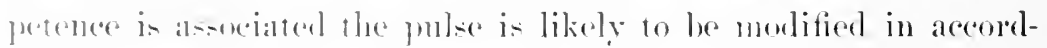

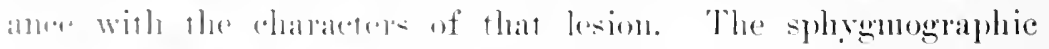

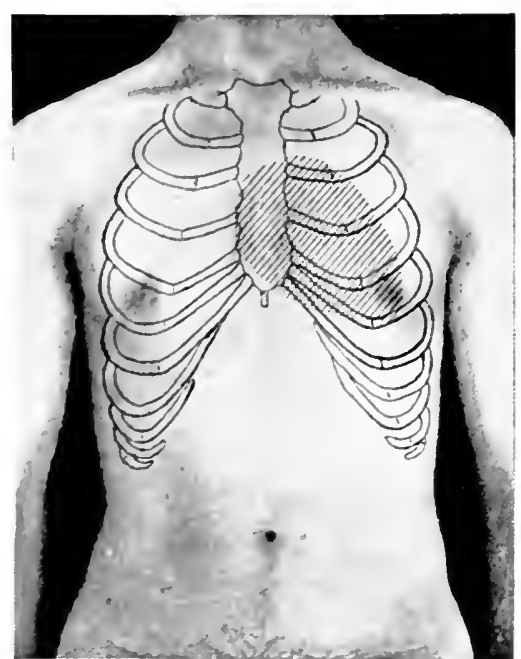

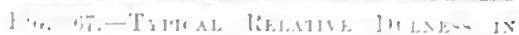

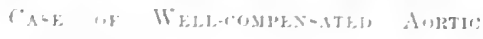
-Tr.:Bn-1tracing ut aurtic stenosis show: raluer distinctive chanalcoters. The ampliturle is not eleatr, the line of ascent is abligure, the summit rounder, the desorent sradual, and the secondary wares indistinct. 'Therese rharaleters ale shown in Fig. Git, which is the copy of a trateine olstaned from one uf my parats who prescuted flue signs of pure and nucomplicated marrowing of the atimn, llape being no diasolic murnme of regurgitatim, and the left ventricle hypretephoind with very little dilatation.

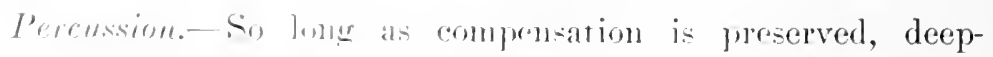
-rated rendiaf dulures is inereased towards the left and downward 
to an extent commensurate with the degree of left rentricle hypertrophy (Fig. 67). It is only when failing connensution has led to pulmonary congestion, or when aortic stenosis is united with a

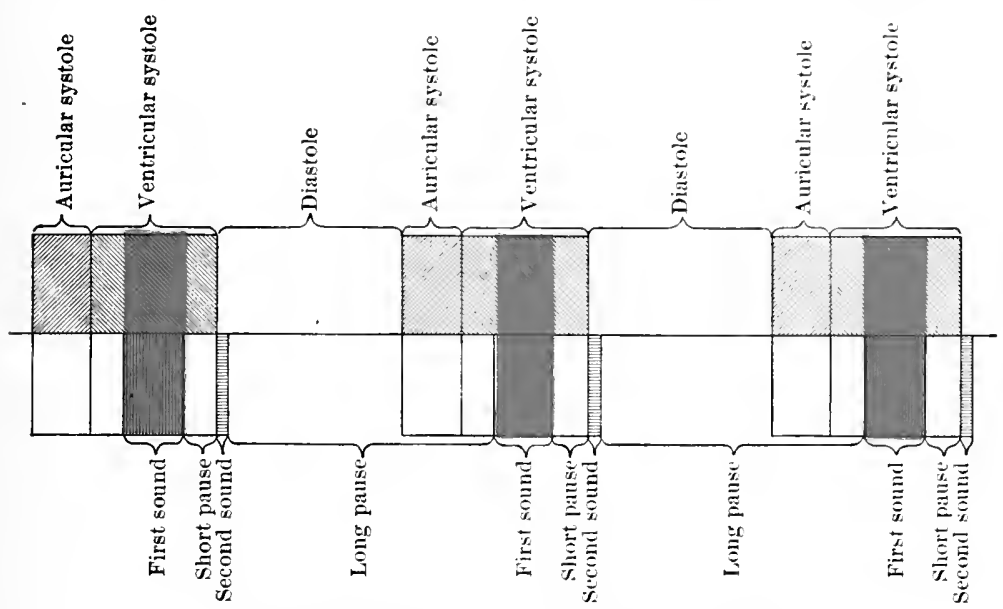

Fig. fis.-Rintha of Aortic Oestrictive Mingle.

mitral defect, that percussion detects any increase of absolnte and relative cardiac dulness to the right.

Auscultation. - The first sound at the apex is apt to be dull and muffled in consequence of the preponderance of its muscular element, while the second tone is likely to be enfeebled. Over the base of the heart in the arotic areal the ear perceives a mmimur which is synchronons with the first sound, and is therefore systolic (Figs. 6is and 699). In pure stenosis there is only this one bruit, but not infrequently there is also a diastolic murmur the to accompanying aortic regurgitation. The systolic murmur, like the thrill, is of variable intensity,

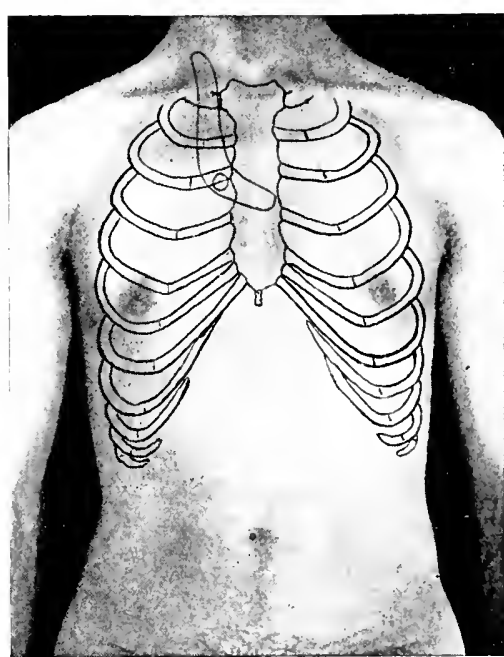

Fig. 69.-Place of Maxintul TNTexeity (small circle) axi, Prupagation of Aortio Stexutie II ragle. 


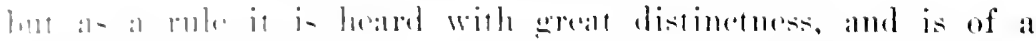

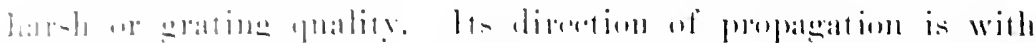

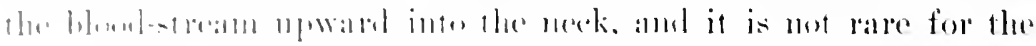

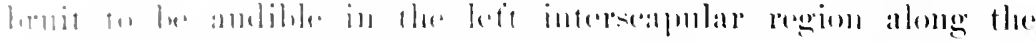

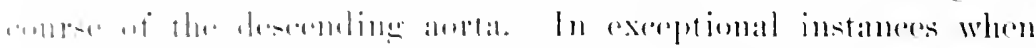

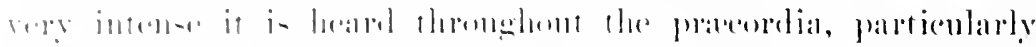

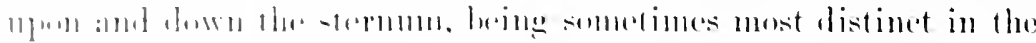

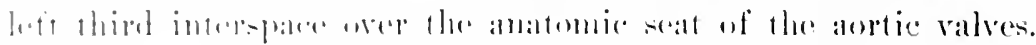

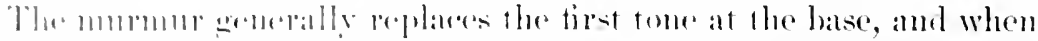

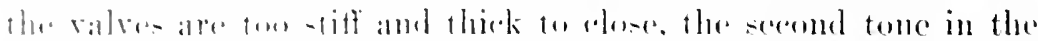

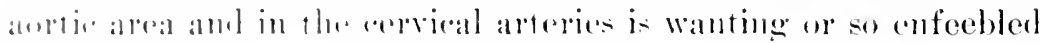

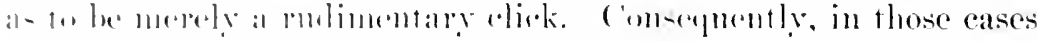

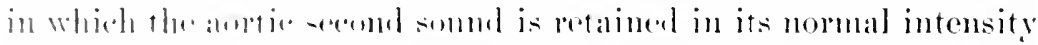

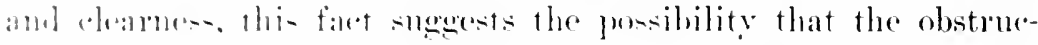

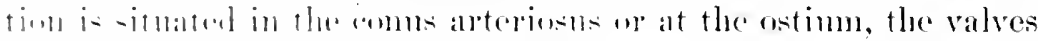

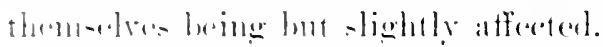

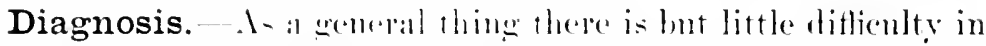

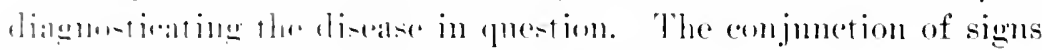
of loft ventriele lypertrophy with a s-solic momm in the aortic

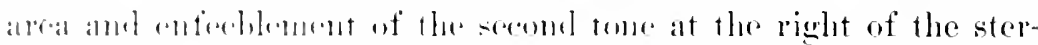

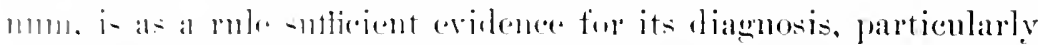

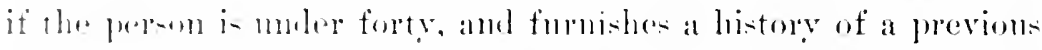
attark of rhemanti-m. There are three comblitims, however, that

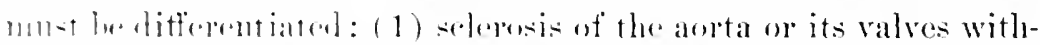

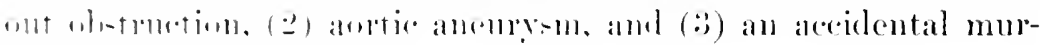

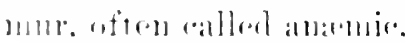

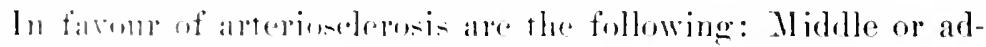

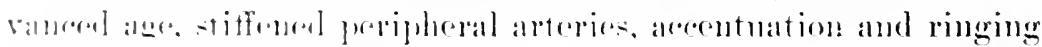

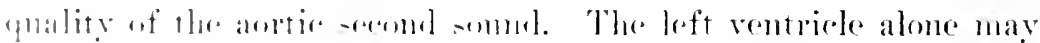

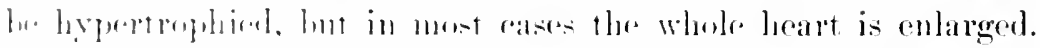

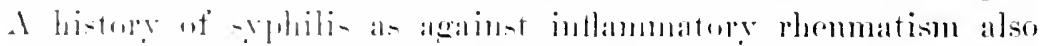

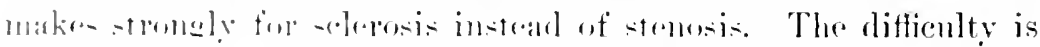

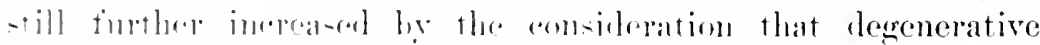

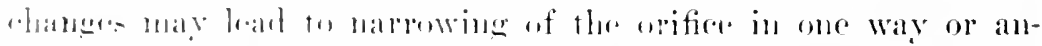

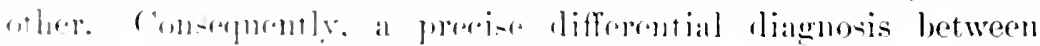

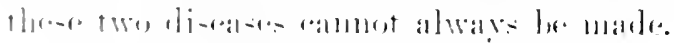

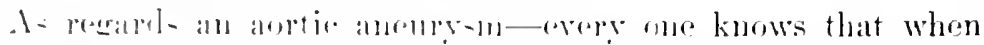

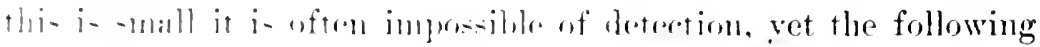
riffremolial print: ma! lo stated: The pationt's age, being forty 
or more, a history of syphilis or of injury or strain, stiff arteries, symptons of pressure, as pain, dyspura, and congh, inequality in the size of the pulses of the neek and upper extremities, displacement rather than hyertrophy of the hout, pukation, particularly if expansile and combined with bulging in the artic area, circumscribed dulness orer the mambrimu sterni or at either side, and in addition to the srstolic aortic murmur, a hooming second tone that is not quite pure or is accompanied by a faint bruit. It doubt is still entertained, resort should alwars he loat to the Xray. Indeed, if this means of diagnosis is accessible, it shomkl be appealed to for confirmation in all cases. Nodiastinal tumours pressing on the aorta are so rare that they rill not he comsidered.

If all the signs of aneurym just mentioned were present in every case a differential diagnosis would not be difficult, but mofortunately such is seldom the case. I recall a patient in the wards of Cook County Hospital who presented a conjunction of signs that rendered the cendition of his aortic orifice a subject of much controversy, and owing to his departure from the lospital were never cleared up. In this ease there was a history of srncopal attacks, and this fact, it was argued ly some, made strongly for stenosis. On the other hand, I felt quite certain of a circmuscribed area of deeprseated dulness in the first interspace close to the right stemal margin, and therefore believed the comblition was more likely an aneurysu.

Lastly, an accidental nummur in the aortic area may, when occurring in the roung, give rise to the suspicion of a stenosis. The error can be avoided by attention to the following points: The absence, it may be, of a rhematic history, the sex the patient being most frequently a female, in whom aortic stenosis is comparatively rare), the alsence of left ventricle hypertrophy, retention of the aortic second sound, the presence of other aceidental murmurs in other areas, as pulmonary and mitral, the softer quality of the murmur, greater frequency of the radial pulse, and the detection of anzenia in some instances.

Prognosis.-This depents upon the etiologry of the affection and the degree of compensation that has been estahlished. If stenosis has resulted from degenerative changes in the valses, there are likely to be associated defects in the aortic walls, and it may be in the coronary arteries, which seriously affect the blood-supply 


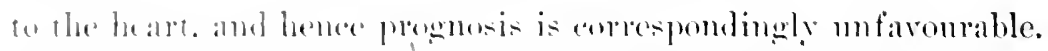

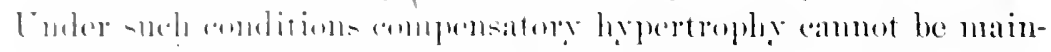

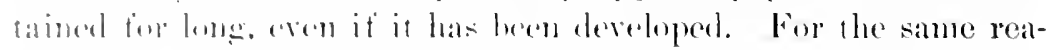

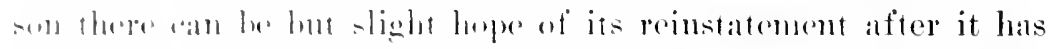

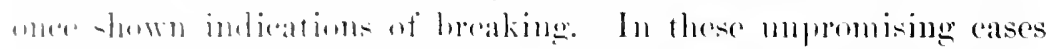

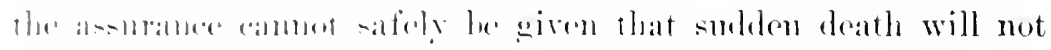

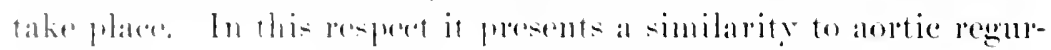
sitation.

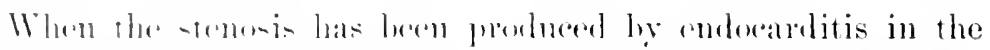

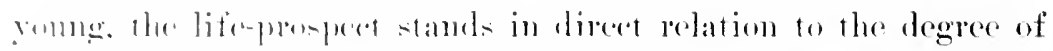

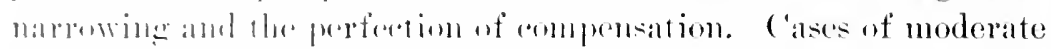

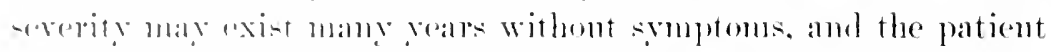

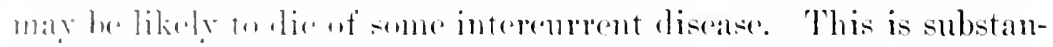

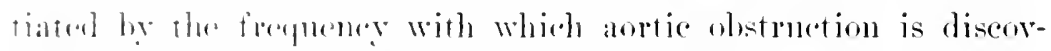

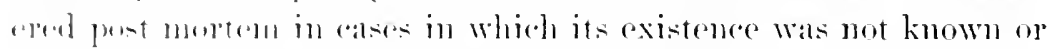
in mowine antributerl to the individual's death.

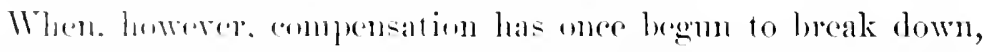

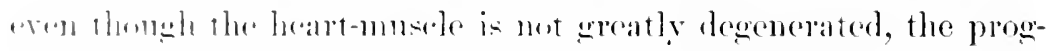

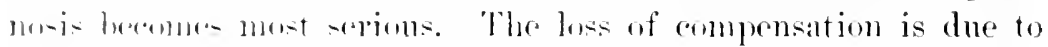
intiation an inserase of dilatation in enserpuence of the resistanes

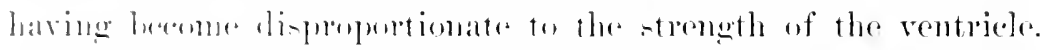

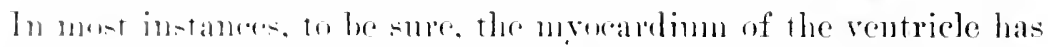

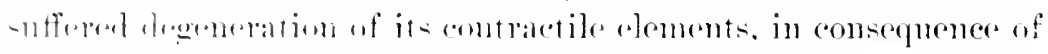

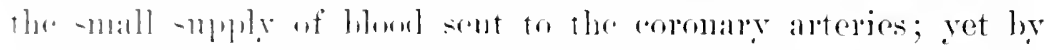

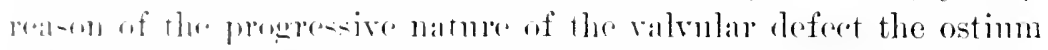

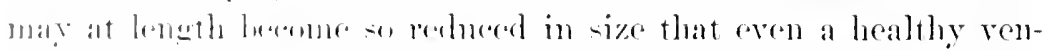

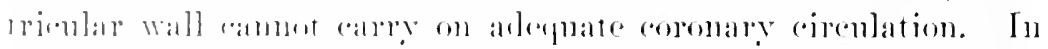

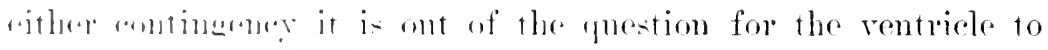

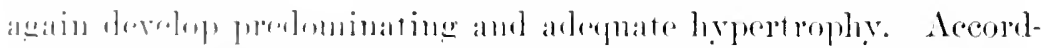

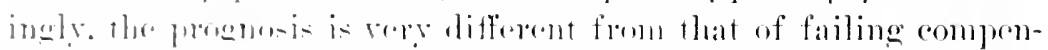

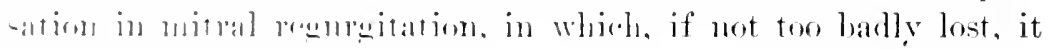

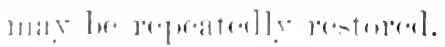

Mode and Causes of Death. Sitrmsis of the aortic ori-

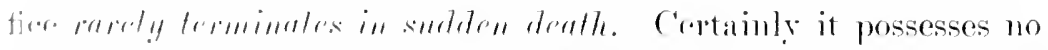

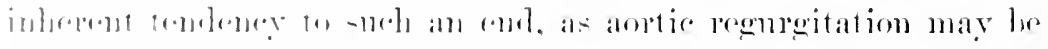

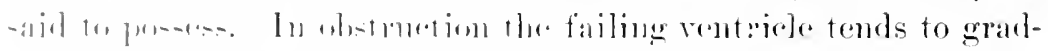

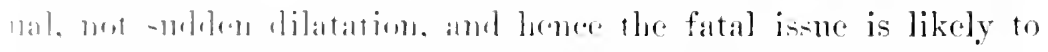

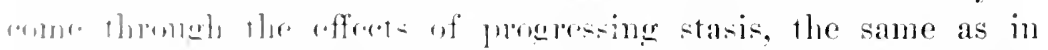

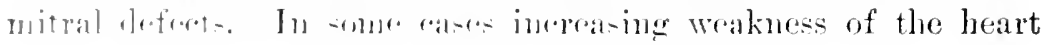


ends in fatal exhaustion before retema and transulation into the serous cavities become marked. The last weeks, wren months, of life may accordingly be highly distresing to buth patient and friends; and death be welemed as a deliverer.

Of 20 cases of aortic stenosis ILustedt fouml the following causes of death: Cardiac anthenial 2. . mulnowaly phlaisis 7 , pneumonia 3, marasmus e, pulnonary adenta, "lphlexy, mephitis,

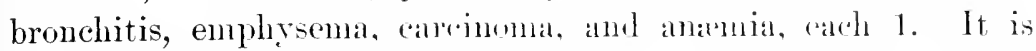
noteworthy that but 2 , or 0.5 per cent, were attributalle directly to the heart, while the remaining 20 were the to intercurrent diseases. It is also interesting to note that in 7 calsus death was dne to pulmonary tuberculosis, and that therefore aortic stenosis may be said to predispose to this disease, probably in comsenfuence of the general malnutrition, which is faroured by obstruction at the aortic orifice. This finds further corroboration in the fact that 2 died of marasmus and 1 of ancemia. 


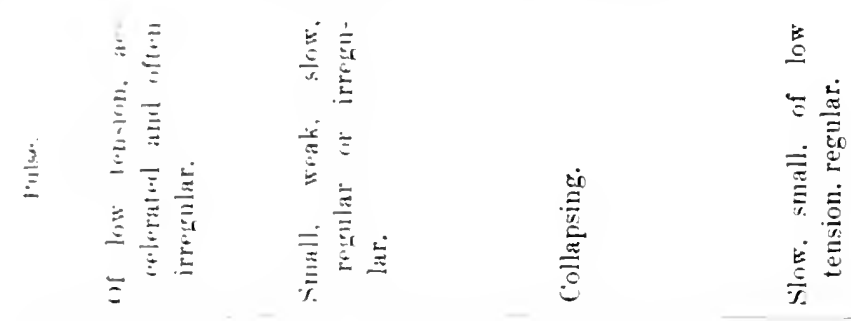

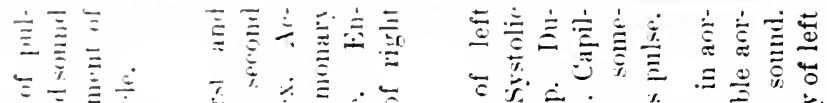

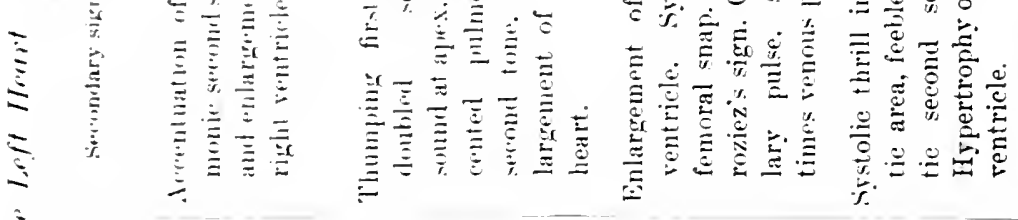

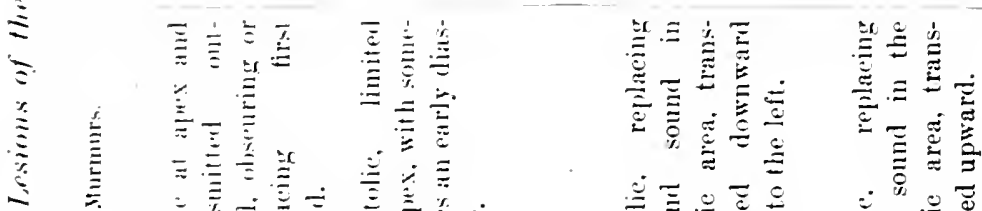

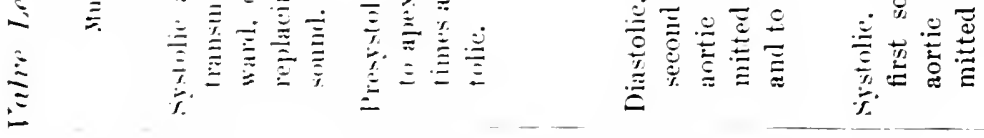

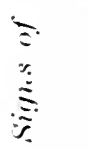

$\vdots$
$\vdots$
$\vdots$
$\vdots$
$\vdots$
$\vdots$
$\vdots$
$\vdots$
$\vdots$
$\vdots$
$\vdots$

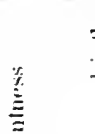

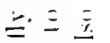

竎竎

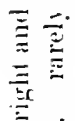

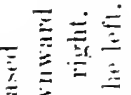

至产美

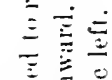

竧号

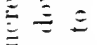

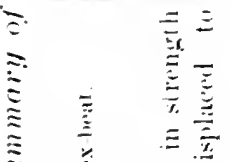

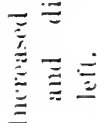

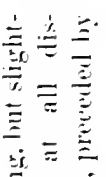

㤩:

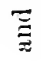

는

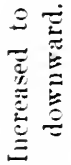

点

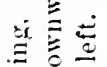

$\stackrel{\Xi}{=}$

䒿芯总

$\stackrel{5}{2}$

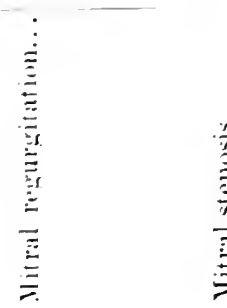

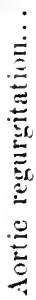



$\frac{1}{40}$ 


\section{CHAPTER $\mathrm{X}$}

\section{TRICUSPID REGURGITATION}

Thrs is the most frequent of the valvular lesions whirll affect the right heart. It is divisihle into three classes: 1. Structural. 2. Relative. 3. Muscular. By the last two is meant incompetence of the valve due either to stretching of the ventriele or to incomplete coaptation of the cusps from defertive contraction of the ring or papillary muscles.

Organic disease of these valves is one of the rarer cardiac defects, and when found as a chronic affection is gencrally congenital. It is not as a clinical entity that tricuspid insufficieney is rare; it is only the structural deformity of inflammatory or sclerotic nature that is rare. Concerning the frequeney of relative tricuspid regurgitation Gibson says: "It is incomparably the most common of valvular lesions, and that the reason this fact is not brought out in statistics now the relative frequency of ralve defects is to be found in the circumstance that incompetence of the tricuspid valve loes not in itself serionsly impair the general course of the circulation, and it is therefore often found among those who, although under treatment for varione affections, have no cardiac symptoms. It accordingly escapes observation unless especially sought for."

This is a remarkable statement, and is at wide variance with the opinion generally entertained. It would scem a piece of temerity for me to take issue with Gibson on this point, hut as I am not willing to accept the presence of a sustolic whiff in the tricuspid area as conclusive evidence of leakage at this orifice, I must conclude that I have orerlooked this regurgitation many times when he would have diagnosed it. Doubtless, in consequence of the readiness with which the safety-ralve action of this incompetence is brought into play, there may miny times be slight leaks that are not considerable enough to proluce positive venous pulse in the cervical reins and liver; but this is a matter of con- 


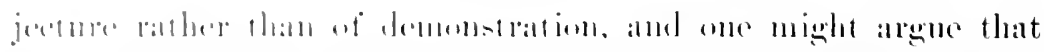

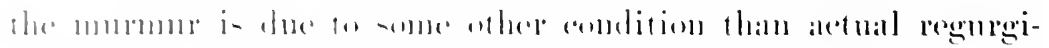
1:11inl.

Morbid Anatomy. The ehamese disomered at the trieuspid

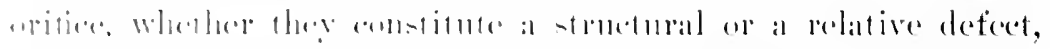

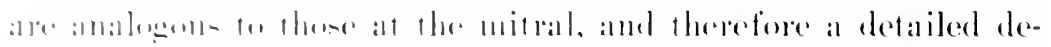

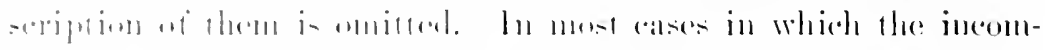

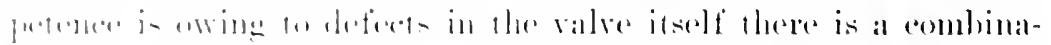

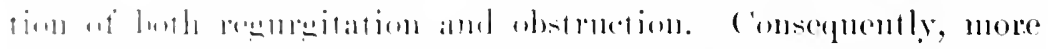

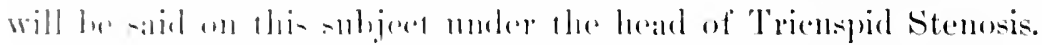

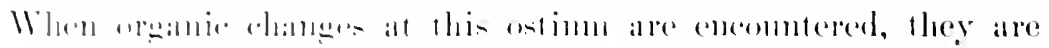

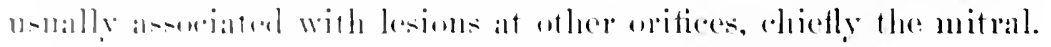

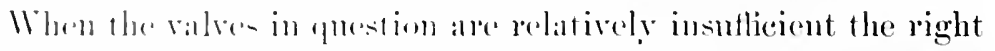

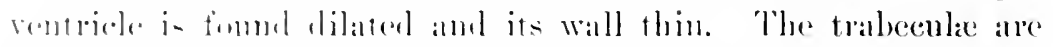

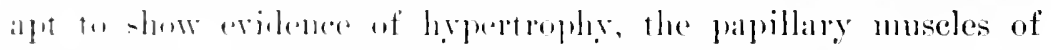

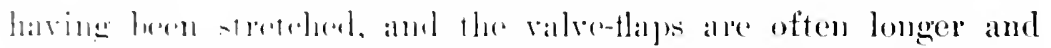

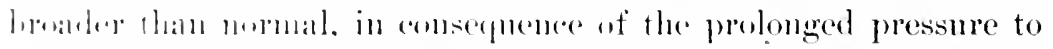

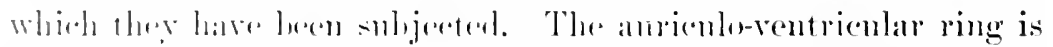

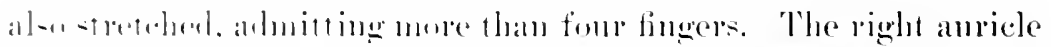

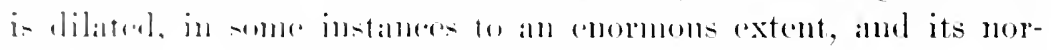
mally thin wall is sill hlimure. It is not meommon also to find that the di-temeline forece of the regurestant strean has induced

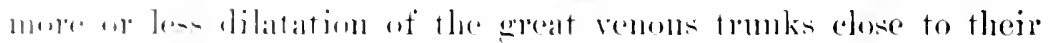
tematiantions in the alurele.

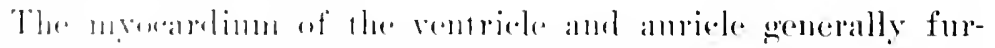

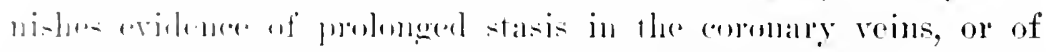

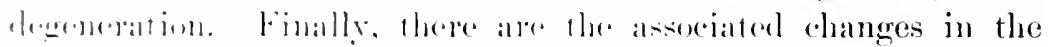

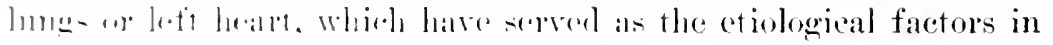

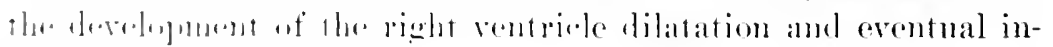

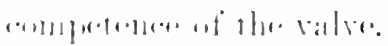

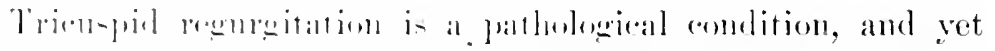

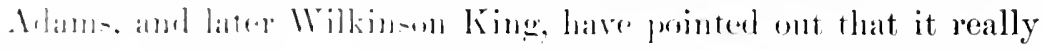

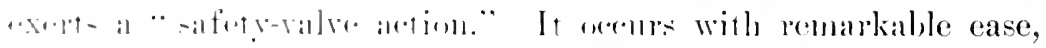

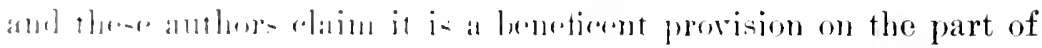

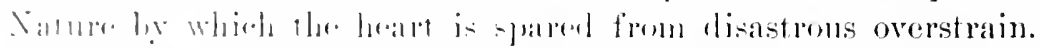

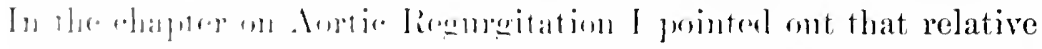

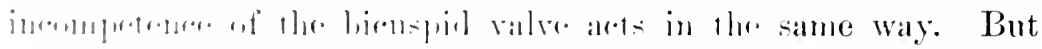

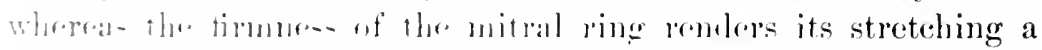

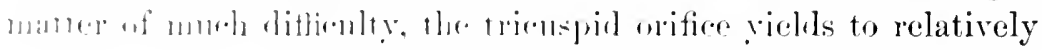


slight pressure and closes flown again so soon as the strain is removed. Consequently, as every clinician knows, leakage through. the right auriculo-ventricular valve will come and go many times in the comrse of any discase that throws excessive strain on the right ventricle.

Etiology. - Structural defects at the trieuspid orifice are generally produced during futal life, and are the result of endocarditis. Nevertheless these valves may be the seat of an inflammatory process after birth, as well as, although lut seliom, of sclerotic changes, the same as other valves. When endocaritis attacks the right heart it is usually associated with inflammation elsewhere in the heart, at one of the other orifices, and owes its origin to the same etiological factors. which to not require recapitulation here.

I shall therefore pass on at once to the consideration of those diseases and conditions that are responsible for the causation of the relative form.

Comprehensively stated, these are all those conditions which raise blood-pressure in the pulmonary system to such a point that the right ventricle is no longer capable of successful resistance. Occasionally this pressure becomes so high as to lead to relative incompetence of the pulmonary valves also, but in most cases the ring into which they are inserted proves equal to the strain, so that it is the rentricular wall and basal ring of the tricuspid valve which give way. This degree of abnormal blood-pressure is most frequently presented in mitral disease, particularly stenosis, and hence it is in these cases when compensation is wholly destroyed that relative tricuspid regurgitation is most frequently recognised. Oftentimes it follows the mitral incompetence secondary to dilatation of the left rentricle in eases of aortic valvular disease, and it is very frequently seen in the terminal stage of chronie nephritis.

In renal cirrhosis, in particular, blood-pressure is ligh and sustained, throwing great strain on the left ventricle. In time this chamber, becanse of degeneration or of the excessive peripheral resistance, hegins to vield, dilatation supersedes the hypertrophy, undue pressure is thrown back npon the right heart, and the tricuspid begins to leak. Thus, whatever is the nature of the primary cardiac disease, the ultimate effect is the same-namely, augmentation of blood-pressure in the pulmonic ressels and right 


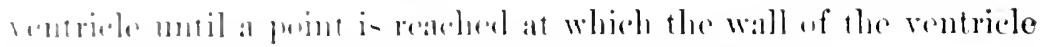
mull-trath and the ralle berome incompetent.

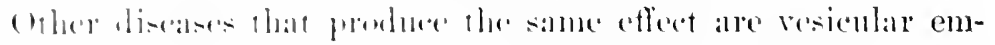

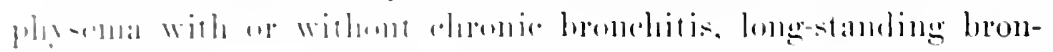

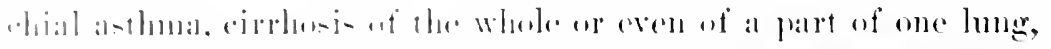

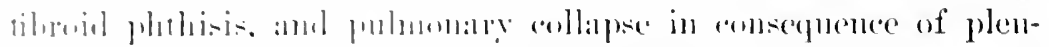

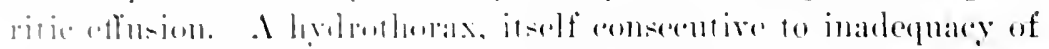

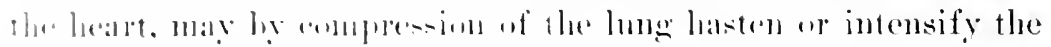

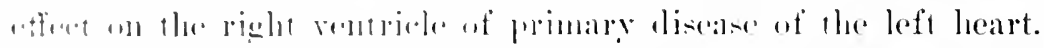

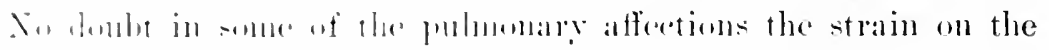

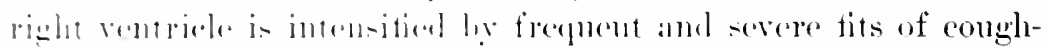

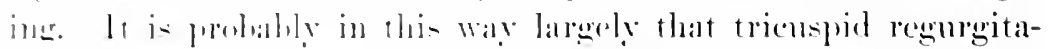

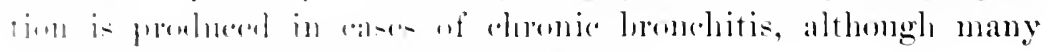

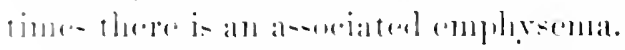

The wall at the rieht restriele is thinmer than that of the left,

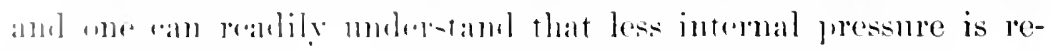

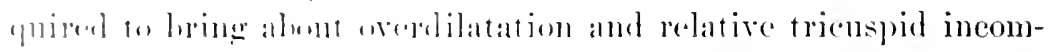

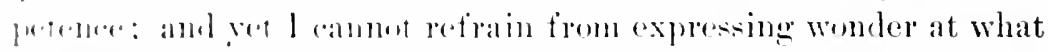

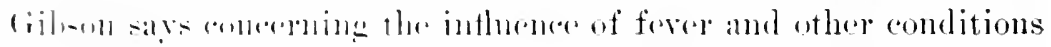

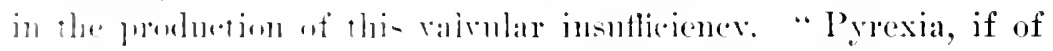
mune than hrict duration, alunet invariably leads to dilatation of the right rentricle amb trien-pid regurgitation. It does so sometime- flem simple pelaxation of the muscular sulstance, but in

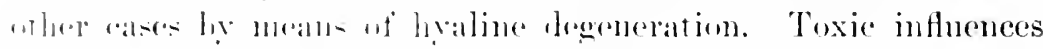

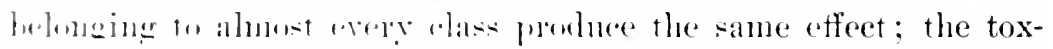

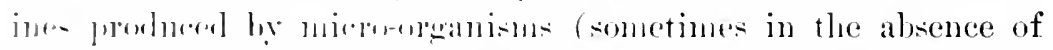

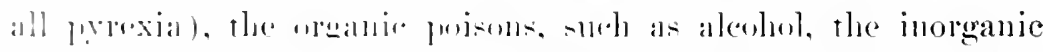

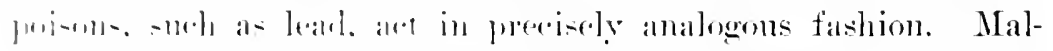

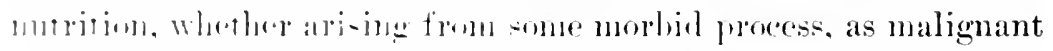

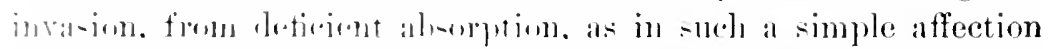

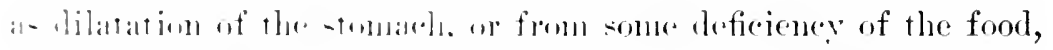

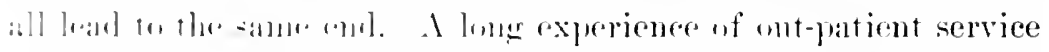

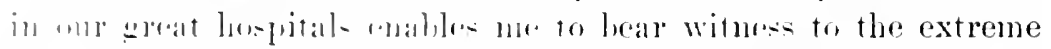

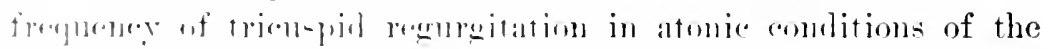

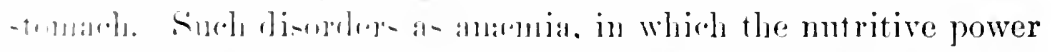

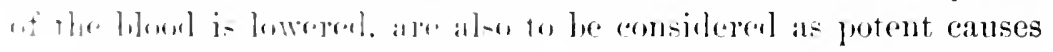

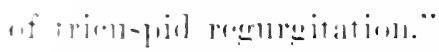

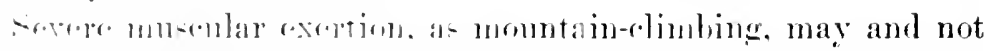

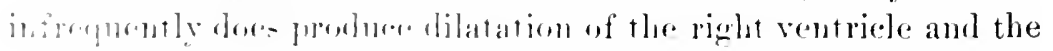


safety-ralve action of tricuspid incompetence. In such instances the protective action of this leak comes beautifully into play, for did the valve not give way and allow the strain to fall on the right anricle, great reins, and liver, the continuance of the exertion would eventually leat to damerems hemoptysis or fatal cardiac syncope from overdistention of the ventrictes.

I have within the part twelve months seen two stalwart football players who, judging from the history and the subseprent condition in which I fomm their right heart, must have gotten up trienspid regurgitation during a sanne. In hoth, the ventricle and cervical reins still showed fermanent ill effect of their violent

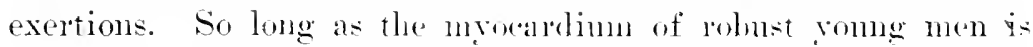
healthy, ultimate recovery is the rule: but when after midlle age nyocardial degeneration exists, individuals should beware of physical efforts that are likely to of serions orerstrain their hearts.

Symptoms. - Is a natter of fact tricuspid regurgitation exists so rarely alone-that ic, independently of some other cardiac or pulnonary disease - that on knowledge of its synptomatology is in reality derived from onr observation of the effeets it produces in conjunction with surh disorders, or with tricuspid stenosis. Nevertheless, it wonld not be difficult to deduce the symptoms from our knowledge of the influence of this affection on the circulation.

The first effect of the regurgitation is to hinder the free flow of blood ont of the right auricle, and thes bring about its dilatation. This reacts upon the contents of the two rente care, raising pressure within them from a negative to a positive one. As negative blood-pressure within these two great renoms trumks is necessary to the maintenance of the eirculation. a rise of hood-pressure within them and their trilutary reins tends to lring the bloodstream to a standstill. Stasic the induced slows itself by cranosis and turgescence of the -uperficial veins of the upper and lower extremities and by passive morgement of the abgominal viscera. The liver grows large and tense, even to the extent of tenderness and pain, particularly in the epigastrim. Functional visceral disorders in varions form show themselves, the fect and ankles swell and ultimately become odematous.

The patient is weak and easily fatigned, and after a time is 


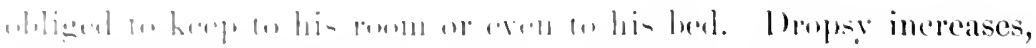

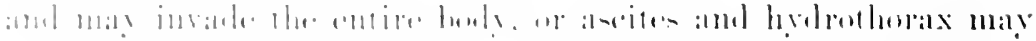

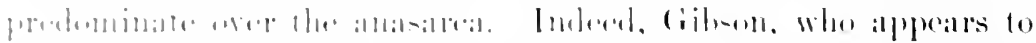

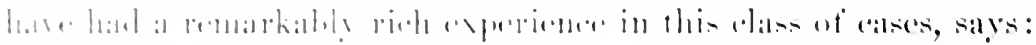

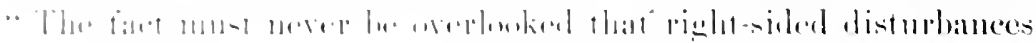

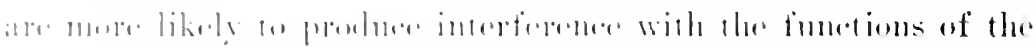

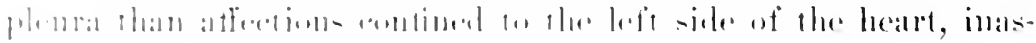

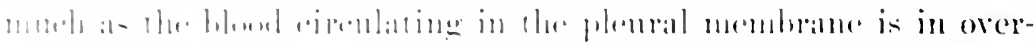

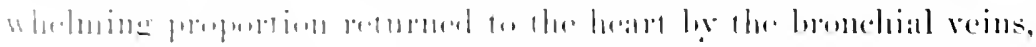

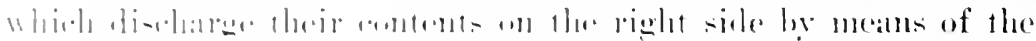

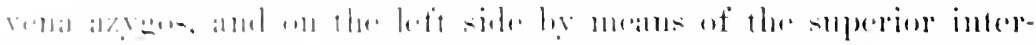

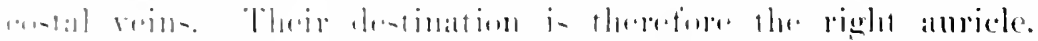

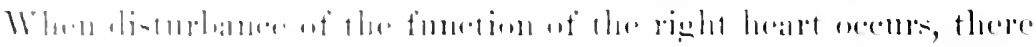

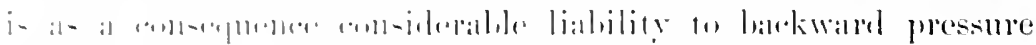

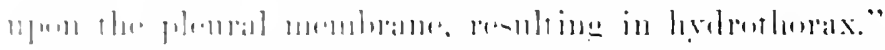

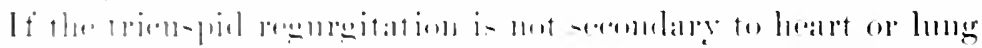

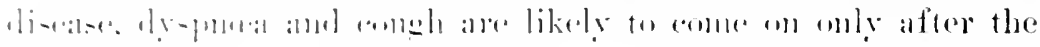

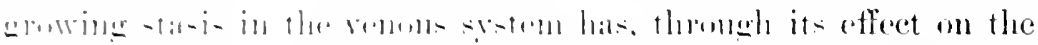

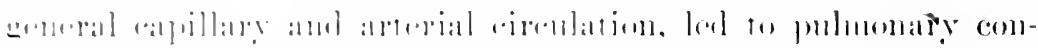

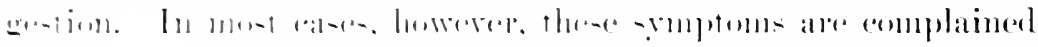

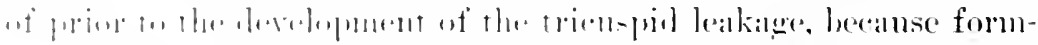

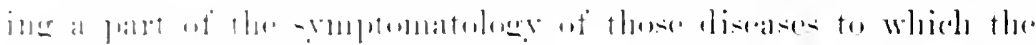

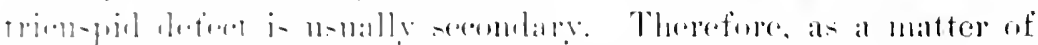

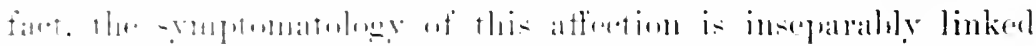

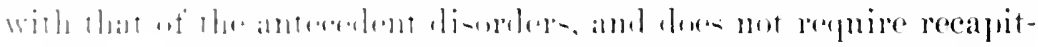

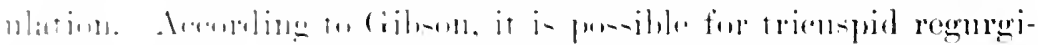

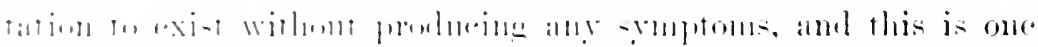

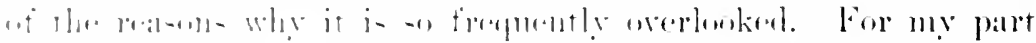

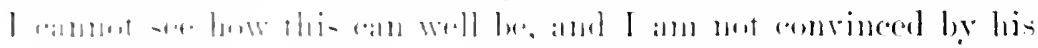

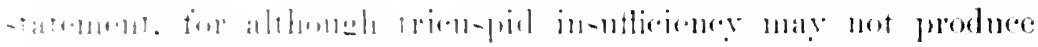

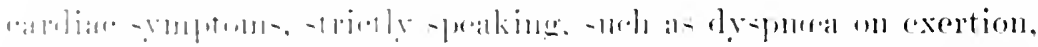

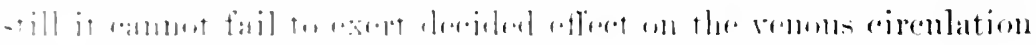

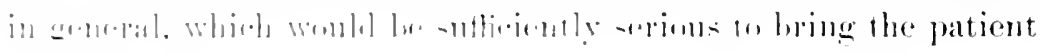

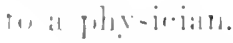

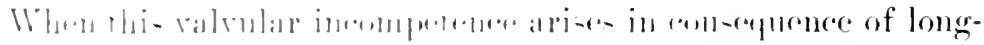

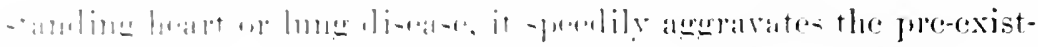

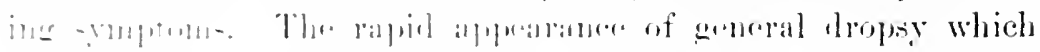

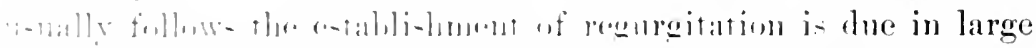

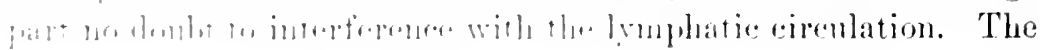


great reins into whone lohod-stream the entents of the thoracie duct are emptied are so tureid that the stasis retards the rearly-

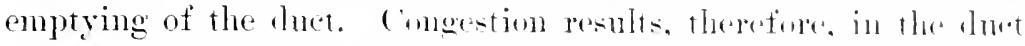
and its tributaries, injmionsly affecting nutrition and increasing the permeability of the anpillary walls. This listurlanee of the eireulation ineritably renlt from primary tricuspid regurgitation, and hence I cannot anceive of the disease remaining latent.

Physical Signs.-Inspection. - C'omtraly to what is usually. the case in diseases of the heart, inspertion and palpation afford the most, and according to some the only, relialle means of diagnosis in tricuspid regurgitation. This is partly due to association of this lesion with other cardiac or pulnonary discases that pro-

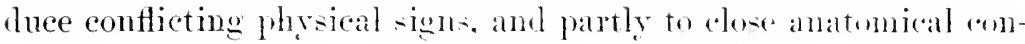
nection between the right "hambers of the heart and the great renons trunks, in eonsequence of which the contents of the latter are direetly exposed to pressure by the rethx st eam in the mamer already described. Instead of the lange reins which enter the thorax being invisible, the dilatation of the right heart leads to their permanent turgeseence, and in extreme legres eren to dilatation of the venous bulls at the root of the neck. This turgidity is specially marked, therefore. in the jugulars. Whireh mat stamel forth like great purple cords.

When incompetence of the triempid valve permits the rentrieular systole to drive part of its blowe halek into the amricle. al nearly synehronous wave is transultted rpward into the reins of the neck thromgh the superior rena rava and downward thromgh the inferior rena cara. even to the liver ar berond. This reflux venous wave declanes itself in the neck ats a visible and eren palpable pulsation. This is partienlarly promomed in the right in ternal or external jugnlar, or in luth. This phemomenum has been carefully investigated by Riegel, and h,y him shmon to coincide with pulsation in the arteries, as the carntids. This " positive venous pulse," ats Riegel call- it, is msually spolken uf as systolice,

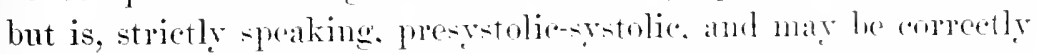
timed by comparion with the arotid pulse. Simmlandents palpattion of the artery and in-peetion of the rein will show that pulsation in the latter takes place during the rise of tle arterial pulae.

In cases in which there is lilatation of the amble got without trieuspid regureitation, a renous pulsation mar likerice be de- 


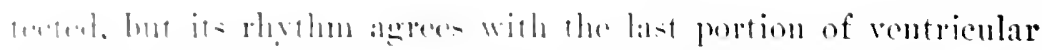

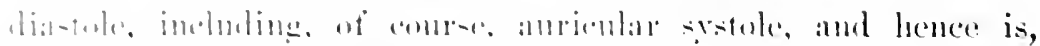

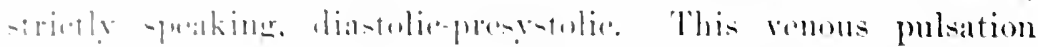

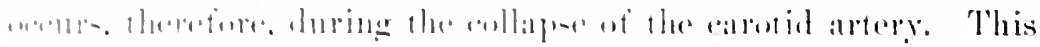

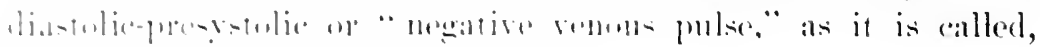

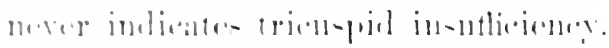

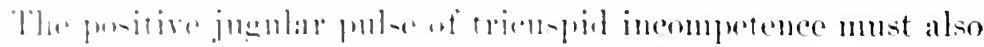

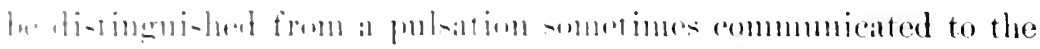

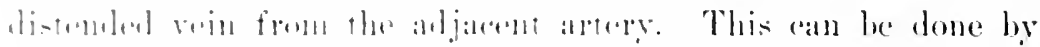

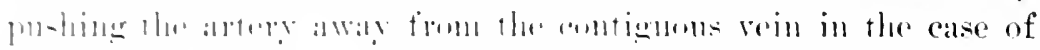

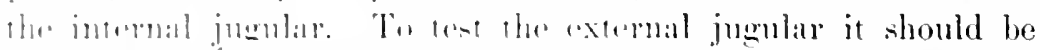

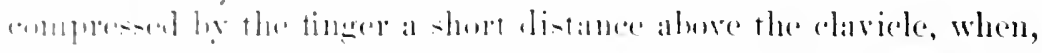

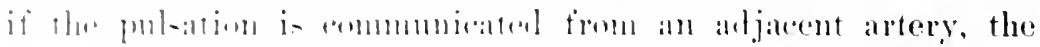

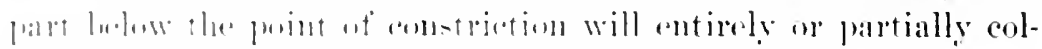

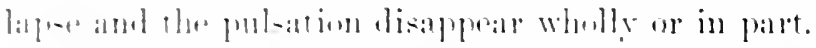

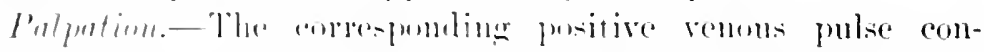

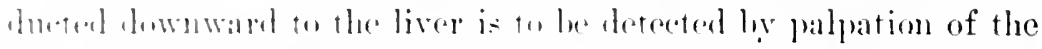

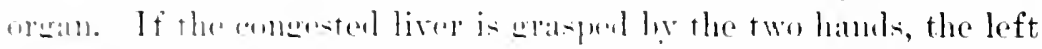

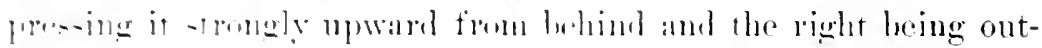

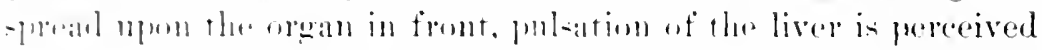

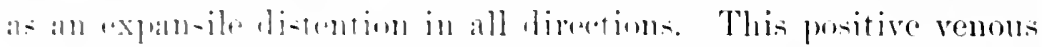
pula in the liver is therefore quite molike the morely rising and

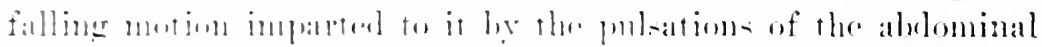

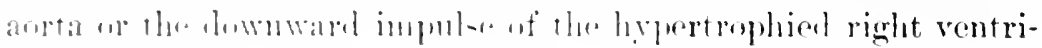
$1 \cdot l_{0}$ il liser.

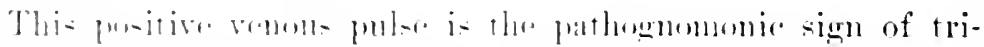

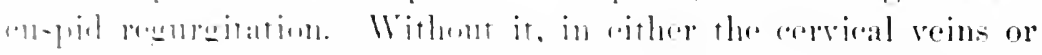

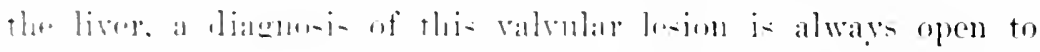

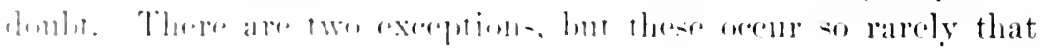

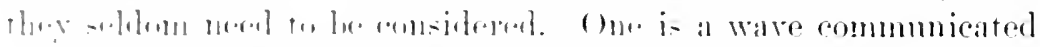

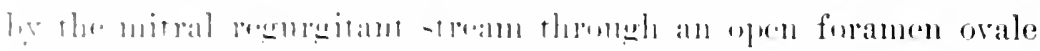

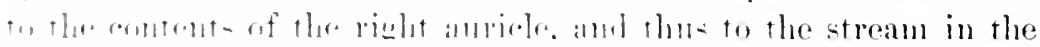

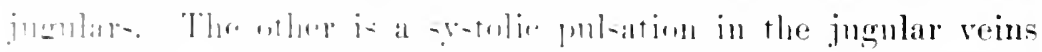

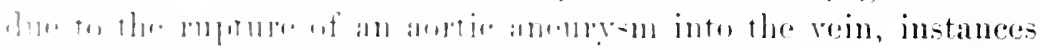

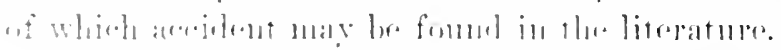

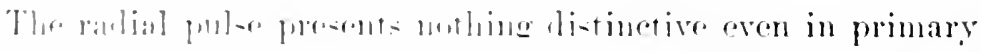

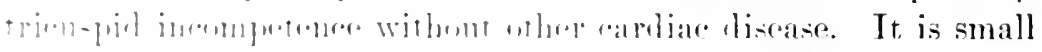

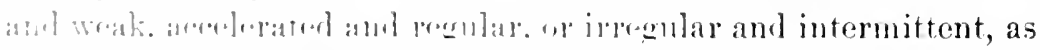

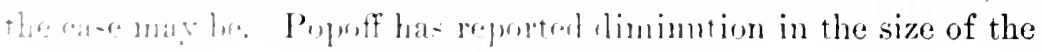


right radial as compared with the left, and attributed it to pressure of the distemeded right anricle and voins upen the right sul,. clavian artery.

Dropsy is usually prosent in eases of relative insufficioney of the tricuspid valve, in most instanes following the giving way of

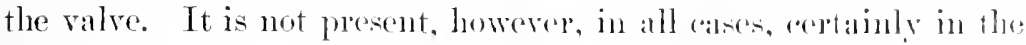
early stage of the trienspid leakage. Comsequently this absence of cutaneous oedema, notwithstanding oreat vomous statsis, is a proof that something more than stasis alome is mecessary for the production of dropser. This additional factor is, as previonsly stated, an abnormal permeability of the cappillary walls or a retention of sodium chloride.

Percussion.-This rields information of minor diagnostic inportance, becanse any alteration disenvered in the aroat of caldiat duhness may be due to an associated on anteredent cardiac or pulmonary affection. Vesicular emphysena, chronic plemitic effusion or hydrothorax, and cirrhosis of the right lung, may remer unavailing any attempt to detemine hy pereussion the arentate size of the right heart. In resicular emplisiena the borders of the lungs are distended, pushing the heart away from the che-twall and occasioning such a degree of hyperresonance that the limits of deep-seated cardiac dulness become inappreciable. When thuid exists in the right plenral carity, $o r$ there is soliditication of the right lung, the dulness thus occasioned blends indistinguishably with that of the heart. Under faromiale conditions, however, carliac dulness is formd increased to the right and downwarl, the extent of this increase being rletermined by the degree of the dilatation of the right rentri-

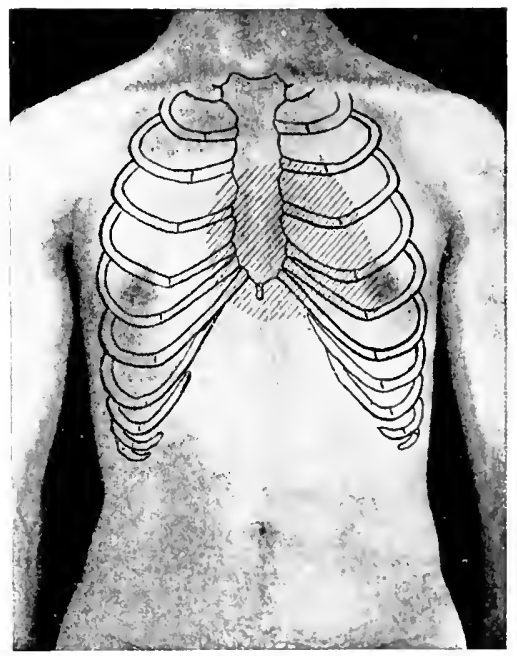

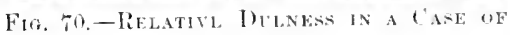

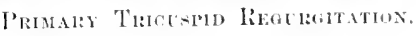
cle. In cases of primary or independent tricuspid insufficiency due to endocarditis, the right rentricle is found less enlarged 


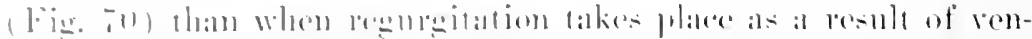

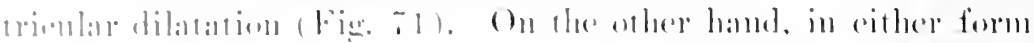

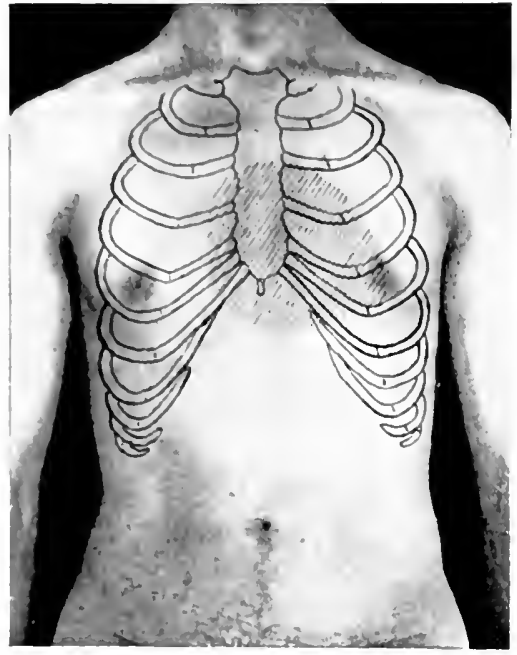

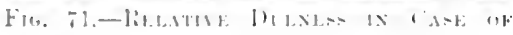

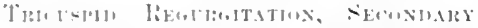

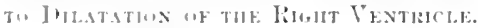
uf the alfertion. dulness is

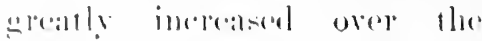
rielit amricle: and the latrese remoms trumks, reatehing fal laremel the lisht sternal borler. halt-way al more to the right mamillan line. In most instances also there is increase of alleliale duluess to the left, dependine num the natme and extrot of the acoompany-

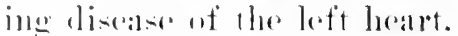

lusenllalion. - This furnishes aven less trustworthy lata tham alde obtained by per(olsionl. There is generally il blowing, stotolic murnm, said to have its maximmo in-

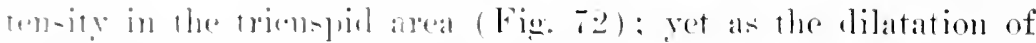

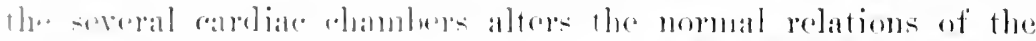

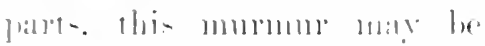

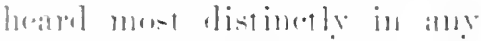
(bur of serelal siluations. It maty la al the jumblim ut the

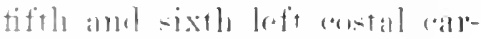

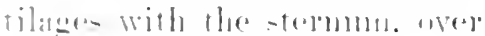

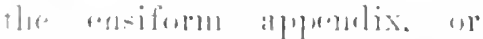

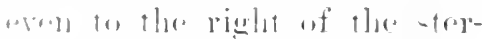
rum in she lhipl, fommls, ar

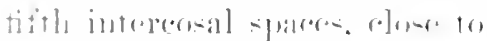
thi- hulle.

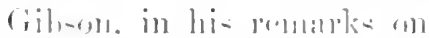

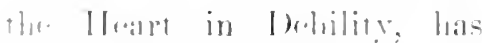

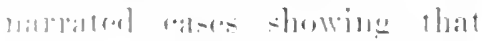

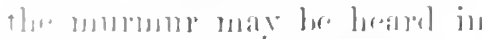

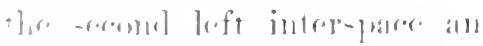

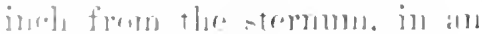

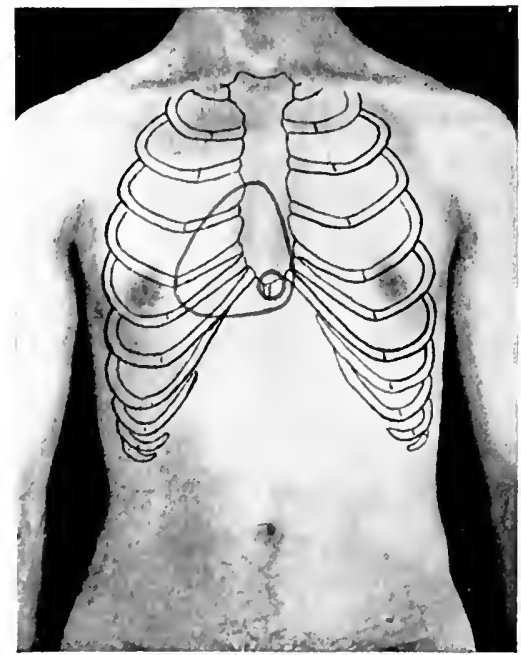

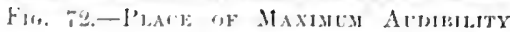

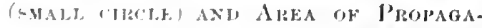

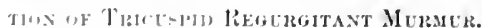


area in which a systolic pulsation is also often obererrel. In these eases there was also remons pulsation in the neck, and hence it seems probable that the murnur was that of the diveater mow malen disenssion. This is the site of a srotolic mumme fiemently andible in ehlorosis and andenia, and rariunsly explained ly Xamurn, Balfour, Russell, Bramwell, Ilandford, Foxwell, ete. fsee introductory chapter), and therefore cantion is reppired in the correct interpretation of a bruit in this situation.

The tricuspid murmur has a blowing fuality, is of no constant pitch, and differs much in loudness, according to the conditions that generate it. It is offen obsemed by other buits originating at other orifices, partienlarly at the mitral. If the ansonltator is experienced, and conditions are faromrable, he luay be alble to locate different areas of maxinmm intensity for the different murmurs, and thus be able to detemme which is tricmspid, which mitral, ete.

Regarding the heart-somnds in tricuspid insutriciency but little need be said. The first tone over the right rentricle is alp to be muffled, even replaced, by the mumme. The pulmonic second sound appears to differ in different cases. It would naturally be enfeebled, in eonsequence of the fact that lessened blood is expelled

- into the artery, but as the predisposing mitral or other discase has angmented blood-pressure in the ressels of the lungs, the second tone in the pulmonic area may be accentuated. Howerer, if in a given case of gastrectasis tricuspid regurgitation is suspected, an enfeeblement of this second sound would lend a measure of surpport to the diagnosis.

Lastly, it is quite common to hear a vasular tone, if one anscultates the vein in which the positive pulse is sech, and the tone thus obtained is, of course, synchromons with the pulwation.

Diagnosis.-Recapitulating, I wish to emphatize the statement that inasmuch as mitral mumurs may sonetimes be heard with great intensity orer the right ventricle, and he conducted far beyond the right border of the stermum, it is rery unsafe to rely upon a momur in the tricnspirl area in making a diagnowis of regurgitation through this valve. Certainly it is so execptional for any considerable leakage to oceur at this ostium withont giving rise to the venous and hepatic pulsation already decoribed, that in the absence of these pathognostic signs it is msafe to derlare that 


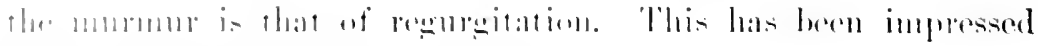

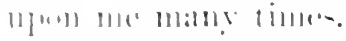

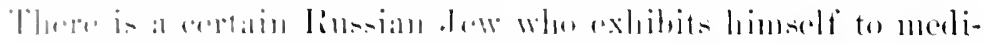

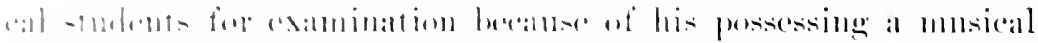

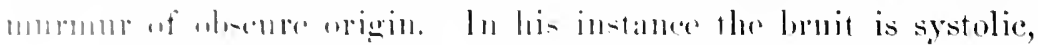

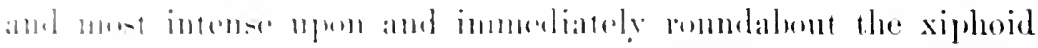

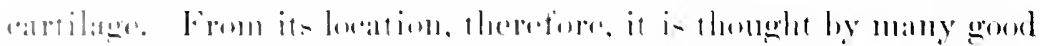

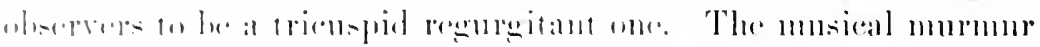

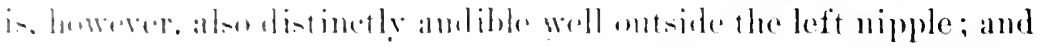

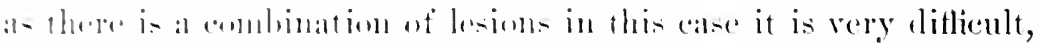

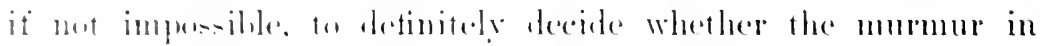
yluetion is trienspid or mitral. lt all drements on the existence

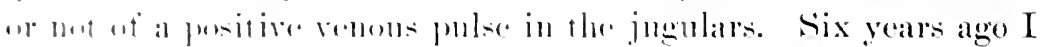

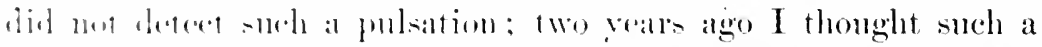

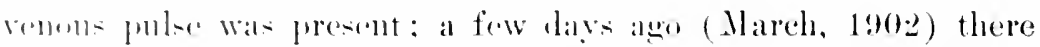

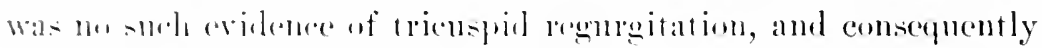

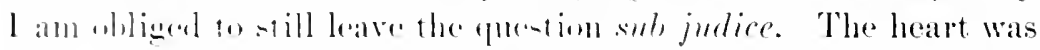

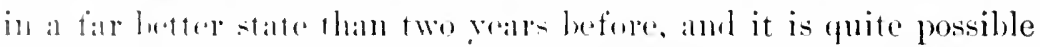
thalt a -light relative trienspid incomperenee was aceomtable for the jugnlar pulstion at that time. At all erents this interesting

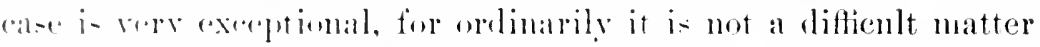

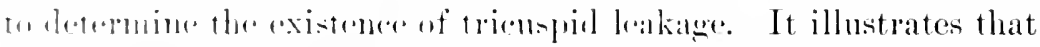

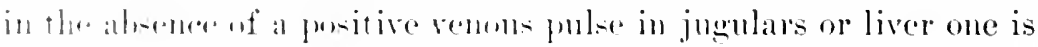

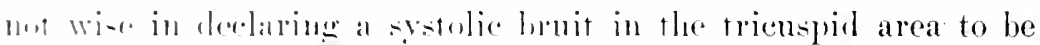
irinell-ind.

Prognosis. - Thi- ma! lw - alil tw depend upon the mature and

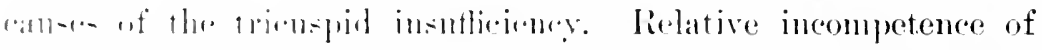

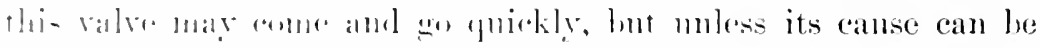

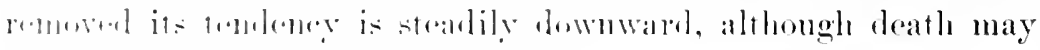

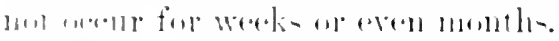

Mode and Causes of Death. The fatal tromination grad-

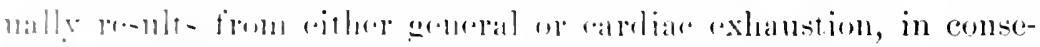

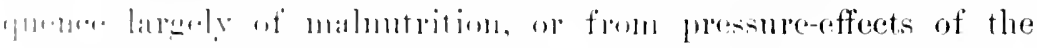

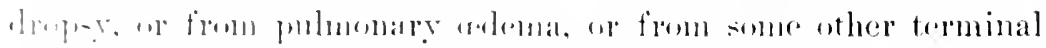

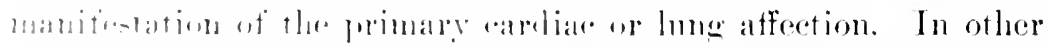

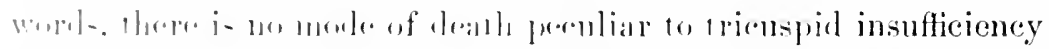

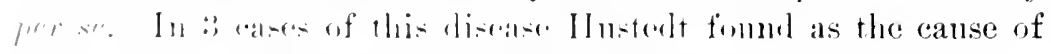

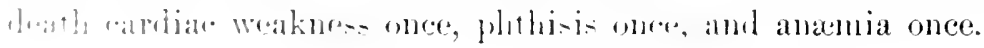




\section{CHAPTER XI}

\section{TRICUSPID STENOSIS}

ThIs is the counterpart of mitral stenosis, but is infinitely more rare. Indeed, it is said to be the rarest of all valvular defects-so much so that some writers speak of it meroly as a pathwlogical curiosity, and devote very little space to its consideration. It probably oceurs oftener than it is recognised, and ret its extreme infrequencr may be julged of by the fact that, although nany thousand neeropsies are annually marle, only 1ot cases harl been recorded in medieal literature up to the fall of 1896. Of these, 114 collected by Lendet ocenred prior to 1858 , while in the next eight years Herrick collected 40 more. Three of these were his own eases, and the total nmmber wat hrought up to 15. . It is to the latter's monograph that I am indebterl for much that will be said in the following pages.

Morbid Anatomy. - This differ's aceording to the grolip into which the respective case falls, for tricuspid stenesis may be either congenital or acquired. The former class is again subdivicled int" those due to intra-nterine endocarditis and those resulting from some defect of development. In the congenital form there are the usual associated abnormalities, such an stenosis of the pulnonary artery, defective closure of the interventricular saptum, and patency of the foramen ovale and duetns arterioms.

When acquired as a result of embearditis tricuspid stenosis presents changes analogous to those at the left auriculo-ventrieular orifice, thickening, rigidity, and athesion of the Haps. Tegetations may also be found on their aurienlar aspect, and the neighbouring endoeardium is apt to present the grayish-white appearance and thickening characteristic of mural endocarditis.

The shape and size of the opening at the extrenity of the cusps are variable, the same as in mitral stenosis. The conditions are also such as oceasion incompetence as well as obstruction. The 


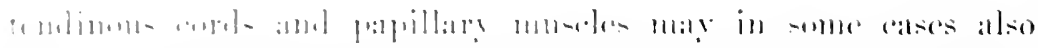

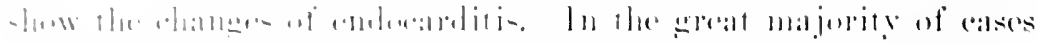

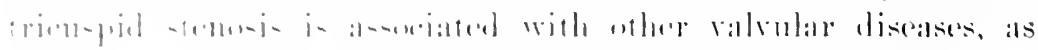

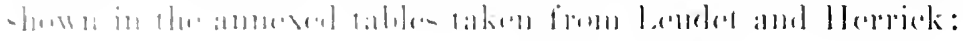

$$
\text { l. inlel }
$$

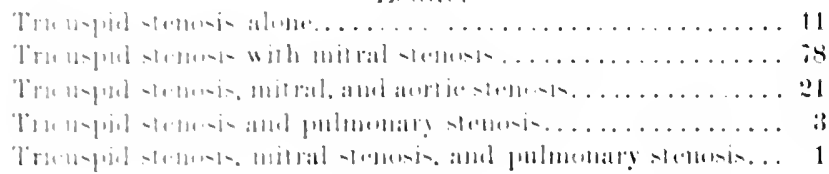

\section{Horrin}

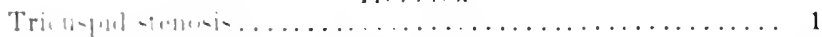

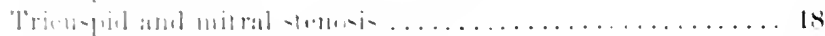

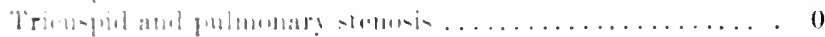

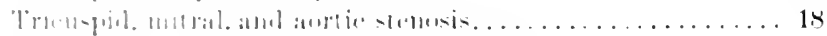

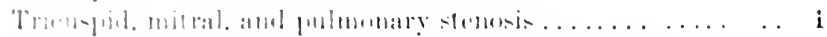

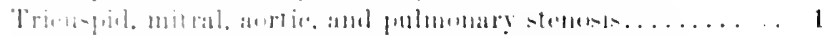

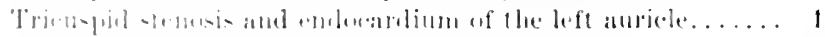

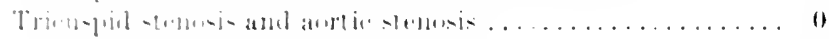

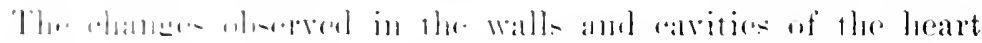

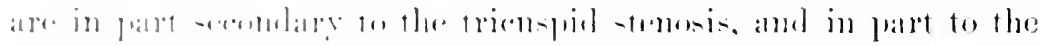

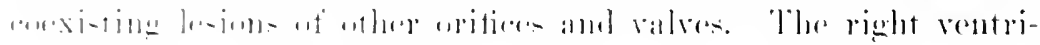

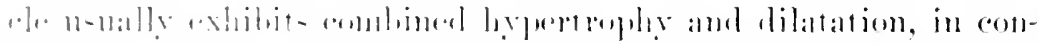

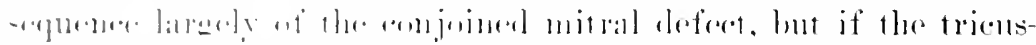

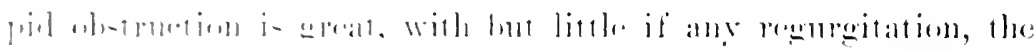

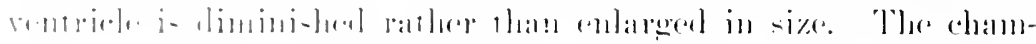

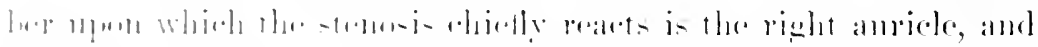

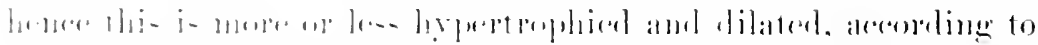

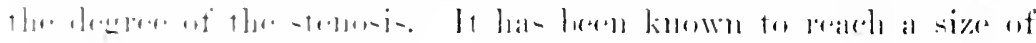

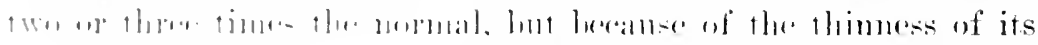

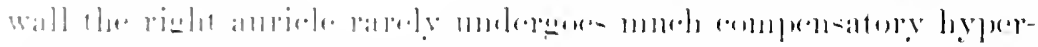

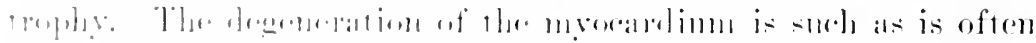

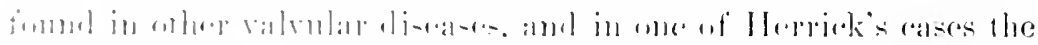

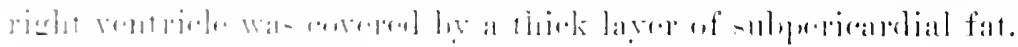

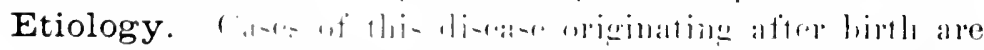

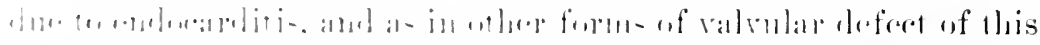

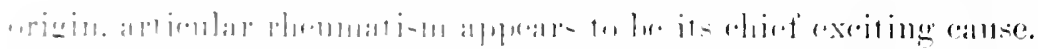

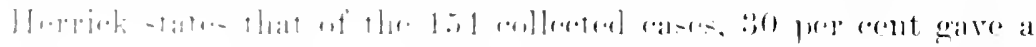

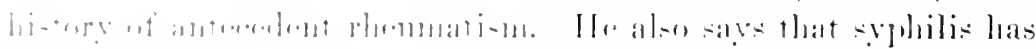

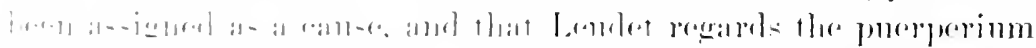

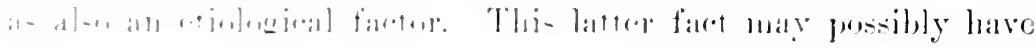


a bearing on the far greater trequency of tricuspid stenosis in the feinale than in the male sex. The disproprortion of the two sexes in. this disease is far too patent to be merely alceidental, Gilson stat ing that of $1+6$ cases of tricuspicl obstruction, 111 axcoured in females and $: 2$ in males.

This discase also ocentrs most frequently in the early deathles at life, the majority of eases falling between the twentioth and thirtieth years. In this respect it is not peenliar, for. as we know, valvular diseases of rhemmatic origin are much more frequent in the young than in persons of midlle or allvanoed age.

Symptoms. - The fact that the ablest amd nust experienced clinical observers have failed to recognise the existence of trienspid stenosis during life, and that in nowt eases it has first been detected on the autops table, may be regarded as proof that them is no symptomatologe peculiar to this affection. Its clinieal manifestations, even when steh exist, are, moreorer apt to be obsenred by those helonging to the associated lesions. Thus althomgh obstruetion at the trienspid orifice leads to stasis in the systemic veins, the liver, and other aldominal oreans, mitral discase does the same: and as the phrsical signs of this latter affection generally mask those of the tricuspid defeet, the symptoms are quite likely to be attributed to the disease in the left heart.

Trienspid stenosis tends to limit the anonnt of blond sent to the lungs and left auriele. and therefore there is nothing in this disease tending to prohnce dyspmea of effort and other symptoms referable to pulmonary engestion. In fact, were the tricuspid lesion to exist alone, the effect on the lumes would, like that of pulmonary stenosis, be one of anamia with its tendency to tulerenlosis; and it is here worthy of note that in the single instance in which Hustedt ascertained the manse of death, this wals " phthisis." It is plain, therefore, that when we leave ont of consideration the pulmonary symptoms due to conjoined mitral discase, we must seek the clinical featmres of trictspid stenosis in alt those perrersions of function incident to viseeral hyperamial and in the effects and manifestations of genoral renons engorgenent.

The jugulars are distended, and when hypertrophy of the right auricle is marked, these veins are likely to exihibit a negutivethat is, diastolic-presystolic pulsation. This was the case in one of my patients in whom phrsical signs led me to snspect the exist- 


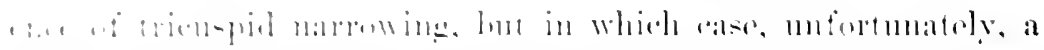

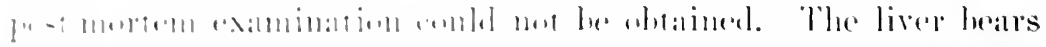

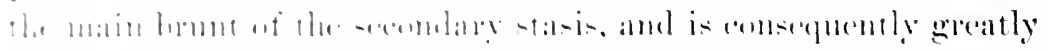

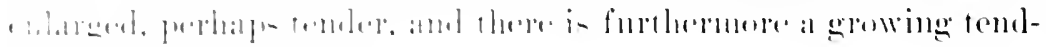
1:

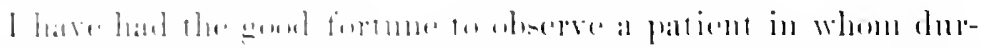

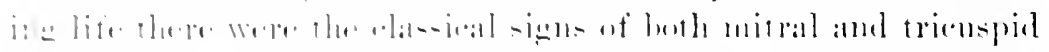

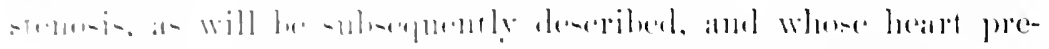

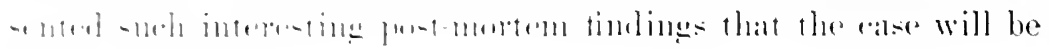
hin intrinlun+il.

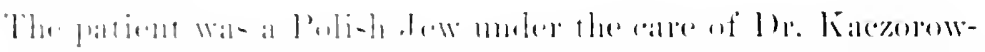

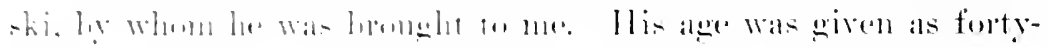

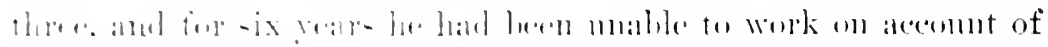

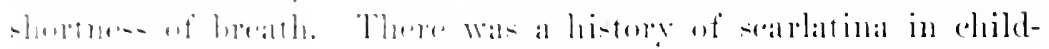

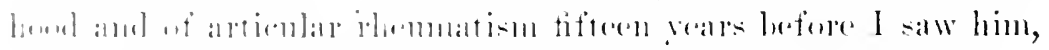

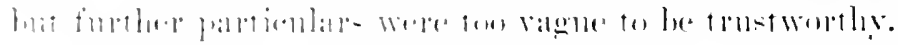

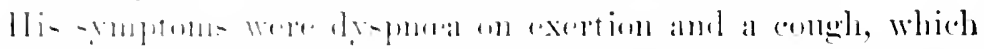

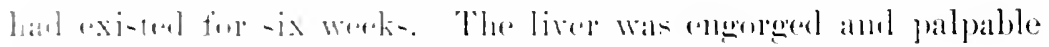

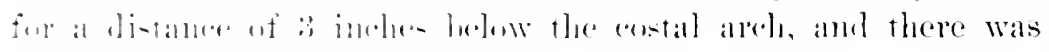

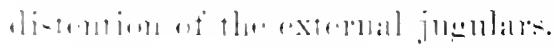

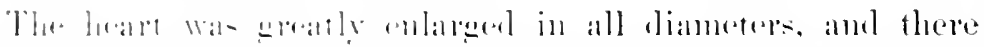

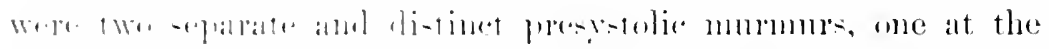

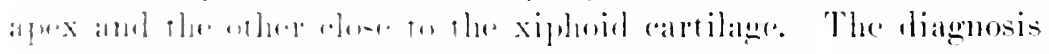

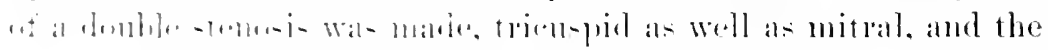

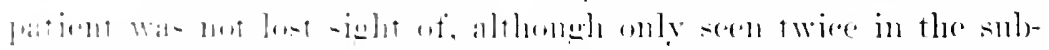
-

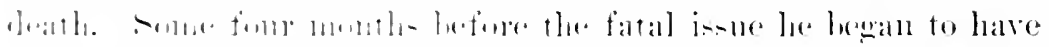

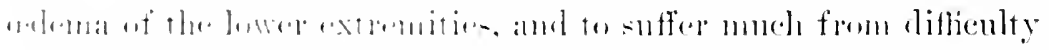

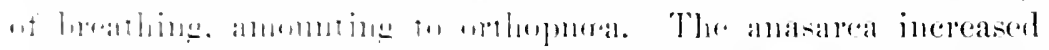

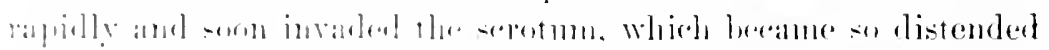

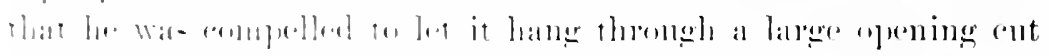

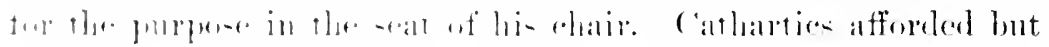

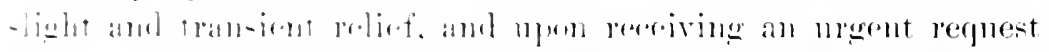

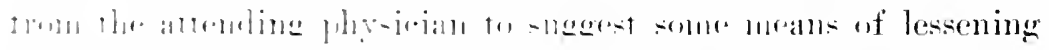

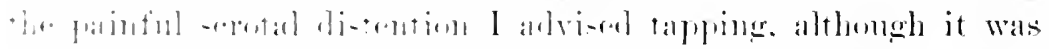

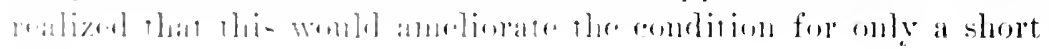
riner.

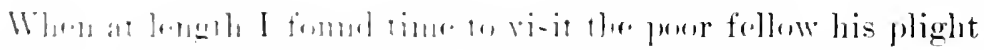

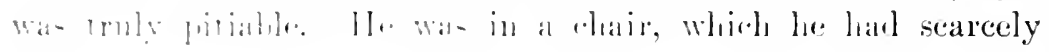


quitted for many woeks, and he presented signs of moderate ascites as well as extensive arlema of the lower extremities. The serotum was as large ar a rhild's head, of a purplish-red eolour, very hard to pressure, and bathed in bioody sermm, which trickled drop by drop into a hasin molerneath his rhatr. Owing to the inability of the patient to more or sit in any other position examination was difticult. But so far as it was yossible to determine, the eardiac findings were essentially as found and recorded fifteen months earlier.

The pulse was weak, moderately accelerated, and irregular. As eathartics, diuretics. and digitalis had all been nsed frecly, and proved of very little efticary, no additional sugestions conld be offered, and the pour sufferer was relnctantly left to wear ont his few remaining weeks of life as best he might. The blessed releace came about five weks later, and Tr. W. A. Evans made the autopsy.

There was moch snhontaneons adema and gangrene of the penis, serotum, and one of the large toes. The peritonam and right plemral eavity contained clear sermm. The rarious organs showed the nsual changes of long-standing eongestion. The heart was enormonsly enlarget on both sides and was hardened by Kaiserling's solution without leeing opener (Plate III). Howerer, an attempt was made to discorer the condition of the trienspid orifies by passing the fingers through the great renous opening in the right auricle. The tricnstid ostimu armitted three fingers to the second joint instead of fomr, as is normally the ase, and it felt firm and resisting. Noreorer, the valve conld he felt projecting across the opening.

When at length the specimen had become hardened and it was opened an interesting combination of lesions was presented. The mitral orifice was a mere buttonlole slit, and the endocardium of the left amricle showed the whitish, thickened appearance denoting prolonged high blood-pressme, and its wall was hypertrophied. The valve projected like a cone into the cavity of the rentriele, which was both hypertroghied and dilated. The cords were fused and presented mmistakable evidence of old endocarditis. There was some thickening of the aortic ensps, which had cansed moderate obstruction at that orifies, a conclusion justified by the enlargement instead of atrophy of the left ventricle usually found 
in mitral steme-i-. Ver luring life this antic lesion had not pro-

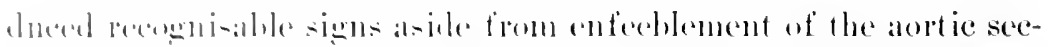

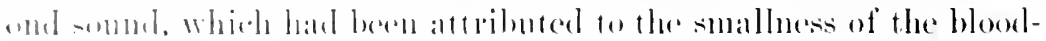

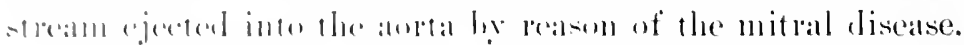

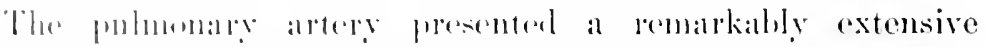

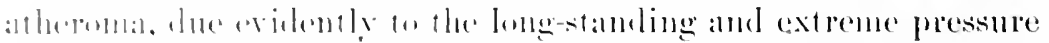

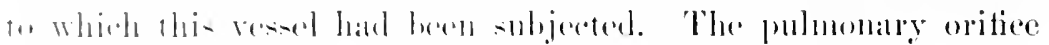

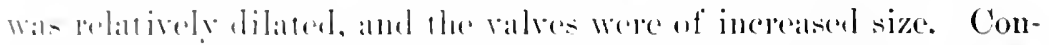

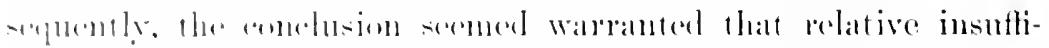

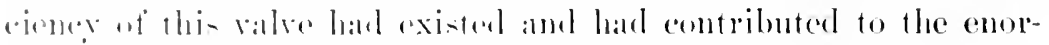

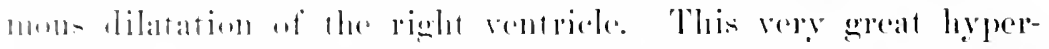

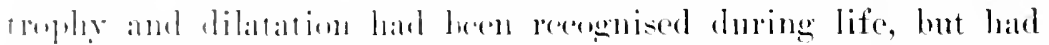
leent polt down as seomlatre to the extreme mitral obstenction.

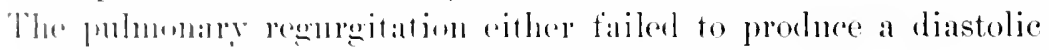

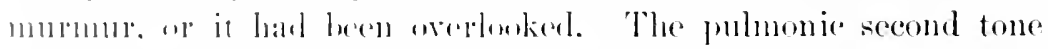

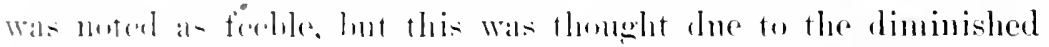

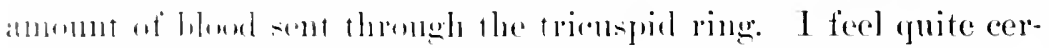
tain that an amelihle diastolie murmum diel not exist.

The riglt anricle was mot only strikingly dilated, but its wall

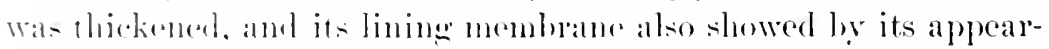

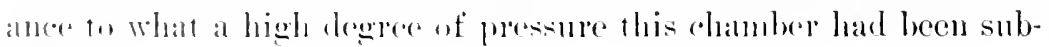
jorelome

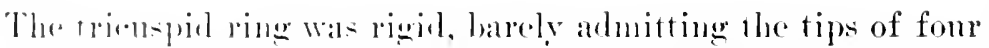

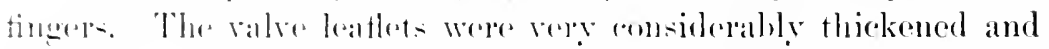

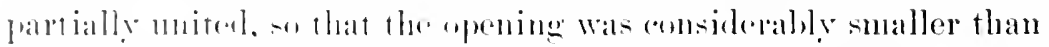

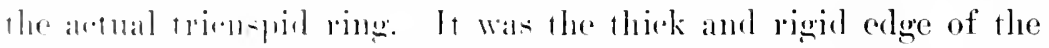

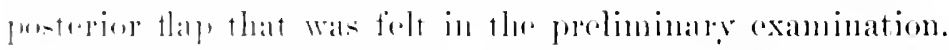

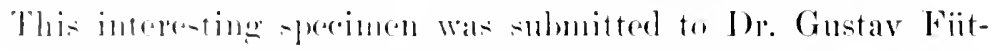

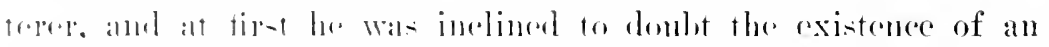

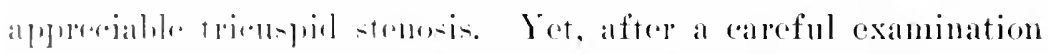
of the right heart, he arriverl at the opinion that in consideration

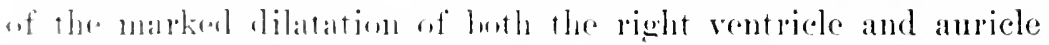

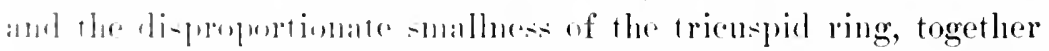

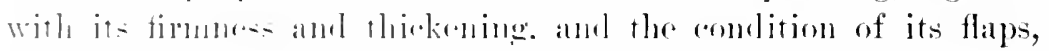

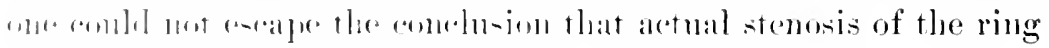
lail axi-tal.

Non

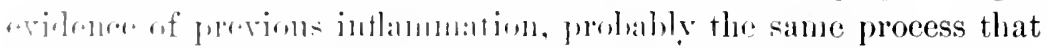

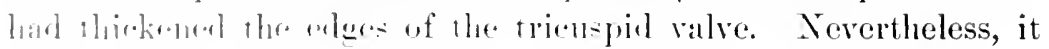


was I). Fütterer's opinion that the srmptoms had heen canserl more by the mitral narrowing and the relative pulmonary regureitation than by the stemosis of the tricuspirl ostiun. Hewever this may be, I can only assert that it had been sufticient to oceasion very positive clinical signs, else I should not have suspected and diagnosticated so rare a lesion in the presence of a pronounced mitral disease to which one might very naturally have attributed the symptoms of stasis. I must therefore stand by my belief that to the trienspid stenosis is to be attributed a not mimportant share in the production of the musual degree of general renous stasis as compared with the puhnonic. The right-siled hydrothorax, discovered post mortem, fmonished proof of the enomons stasis that had been present in the carity of the right anricle.

It all events this case illustrates the inthence of right heart lesions in the cansation of general renous and risceral stasis, while the gangrene bore witness to the profound emptiness of the arortic system.

Physical Signs. - Inspection. - I perusal of IJerrick's collected cases convinces one that there is nothing in the appearance of these patients to distinguish them from those with mitral disease in the last stages of broken, compensation. In Case 27 of lis series venous pulse was noticed, hut ordinarily there is nothing more than the ocular evidence of venous and capillary stasis.

Palpation.-The pulse is small and weak, and may be regnlar or irregular, and moderately or greatly aceclerated. In Broadbent's case ( No. 25) of Herrick's series) the pulse was reported as 100, small, and irregular, while in Eustis Smith's case ( No. 2!) it was recorded as only lio and small.

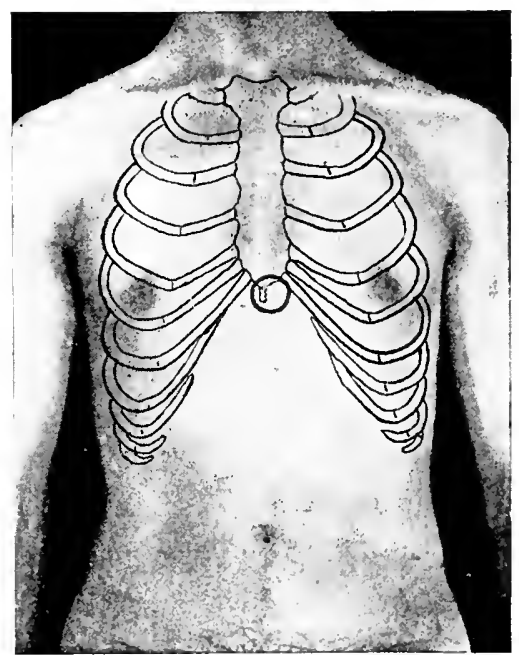

Fig. 73.--Locatun of Turala and Murutre in a Trpical Case of Tricesid śtenosis.

There is nothing in such statements that might not also apple to the pulse in mitral disease. Palpation of the pracordia is usu- 


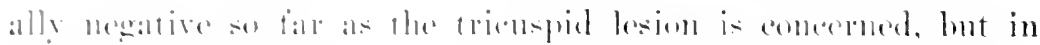

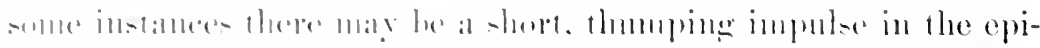

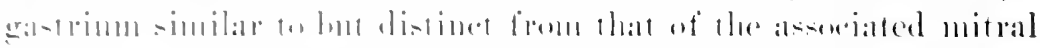

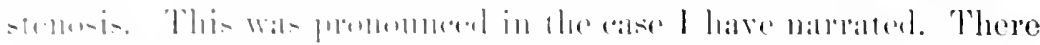

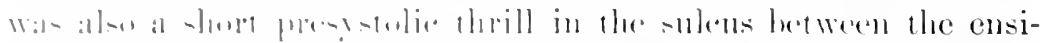

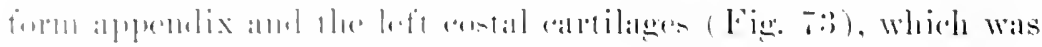

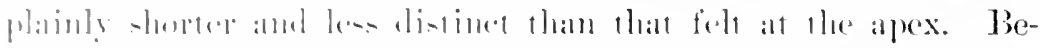

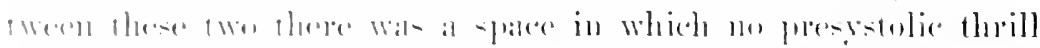

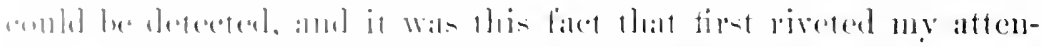

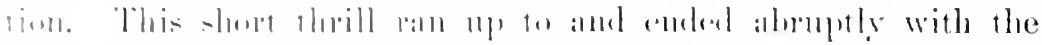

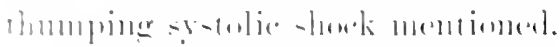

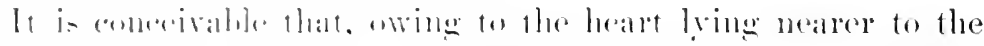
menlian lime llatn n-13al, al presstolic thrill and sharp systolie

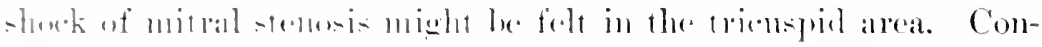

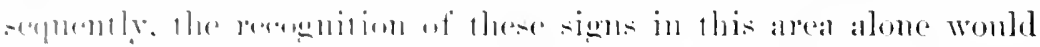

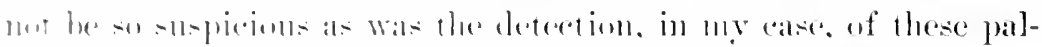

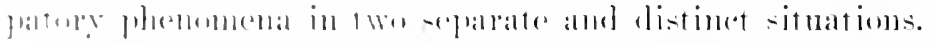

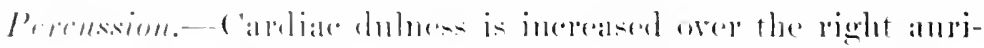

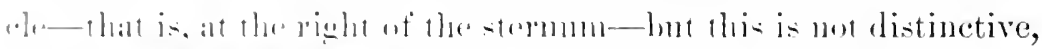

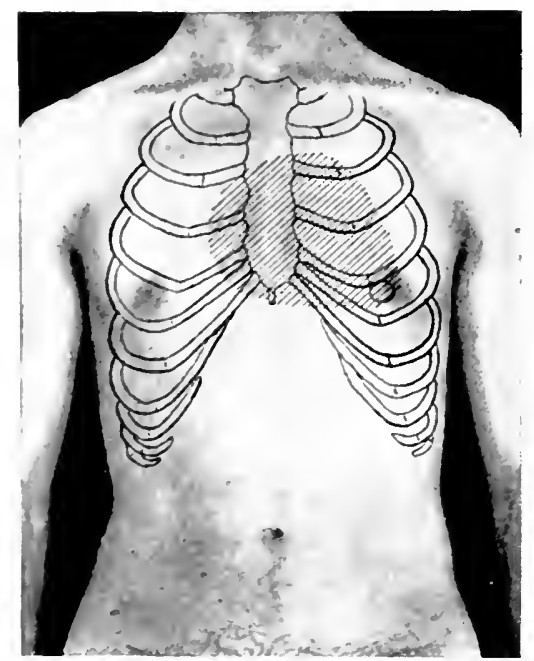

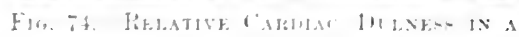
sinee it neroms likewise in milral diserate (Fig. Tt). In trienspirl stemosis it is likely to be particolarly wedl marked. It may he said. therefore, that the erilenes derived by percossion is valuable, lut not pesitive.

Arsenllation. - Unfortnnately the lexinlts of this means of cxamination ale also likely to be very imlefinite. Even if a mommom andurated at the triemspial mifies exists, it is likely io be antinsed with ol indistiuguishalile from morr-

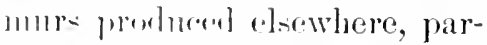

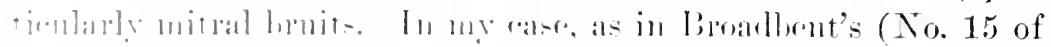

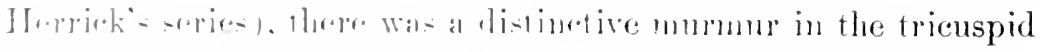

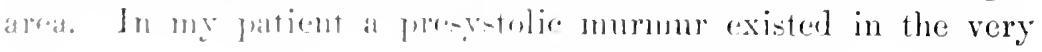


situation in which the thrill was deteeted, and it was moch shorter than that at the mitral area, was of a somewhat different pitch, and terminated in a sharp thud, the same as in bondlent's cate. bitt this was not all: when the stethoseope was passed. little by litthe, from the long, rolling mitral bronit towards the ensiformi, it was noted that there was a flase in which the mitral mumur beeaue lost, while a trifle neared the stepmunt another ancal was reached

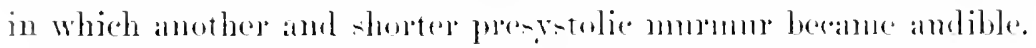
This fact slowed plainly that there were two areas of maximum

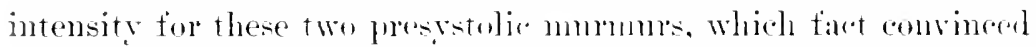
me that I had to do with two entirely separate and distimet bruits.

It may be oljected that this mummo in the epigastrimm wathe pulnomary regurgitant mmrume transmitted to that point. But in reply to this posible objection I nexl only point ont that

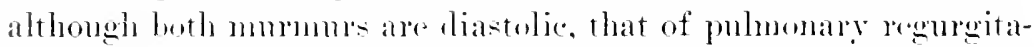
tion falls in the early part of diastole immediately atter the second somed, while a pressotolic ane aecoms just betore the tirst sound at the end of diastole.

Theoretically and pratetically. therefore, in endeavomring to establish the existence of trienspid stenosis. one must search for ausenltatory igns in the triensid area, yet must remember that owing to the enlargenent of the right heart the position of the trienspid orifice becomes changed, so that the trienspid area is a wide one. Froadbent detected the mmmm in the fifth righe interspace, close to the stemmur.

Finaliy, in most cane of this lenom mone ar less regureitation is permitted, and hence the trieuspid disease may dechare itsalf by a systolic murmmen the presstolic being either absent or so short as to entirely escape recontion in the presence of the reomgitant bruit. In hot 12 of the 154 eases was the trienspid orifice alone the seat of disease, which shows its rarity apart from associated defeets. I shomld fancer that when it exists alone, it ought to be recognised more casily than when combind, and luence obscored by coexisting distas.

Diagnosis. - Owing partly to the indefinituness of the physieal signs and partly to their being obseured hy those of associated ralvular lesions, the diagnosis of tricuspid stenosis is generally first made on the autopsy table. Some of the ablest clinieal obsorvers believe that an intra-vitan diannosis must alwars be 


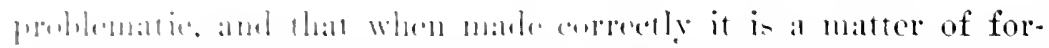

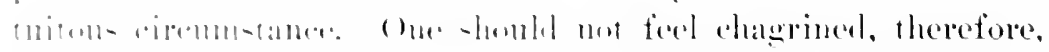

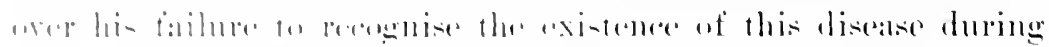

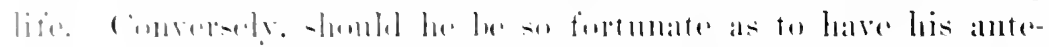

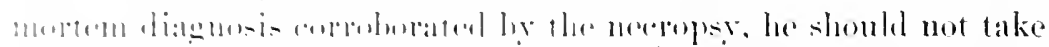

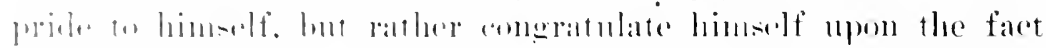

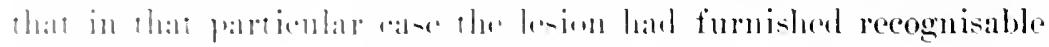

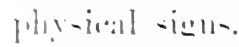

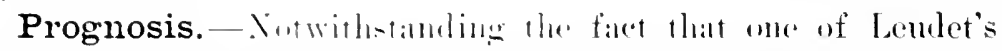

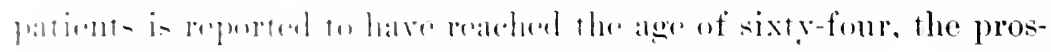

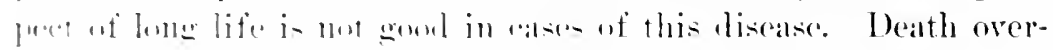

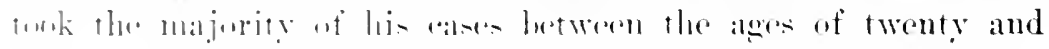
thires. Thi- hereity of life i- due probalhly not so much to the

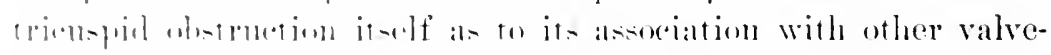

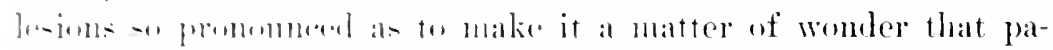

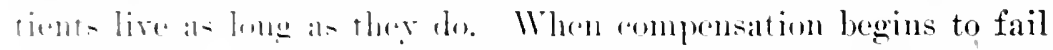
there is -mall fremenest of its resterations. The immediate prog-

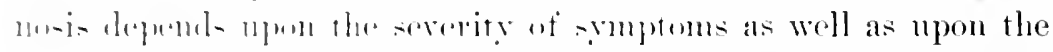

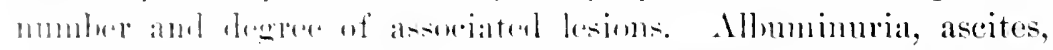

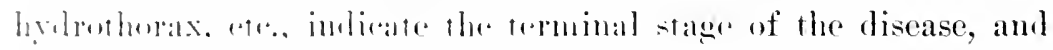

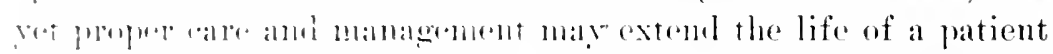

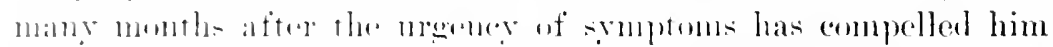

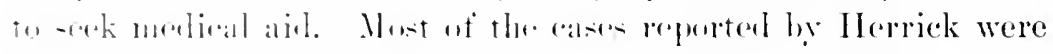

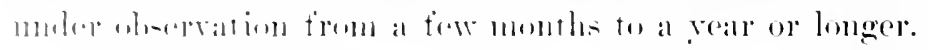

Mode and Causes of Death. - Death wenred suddenly in

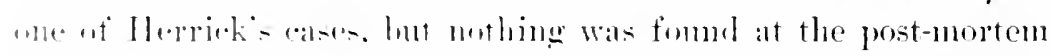
exandination to explain it, further than the ndinary ehanges in

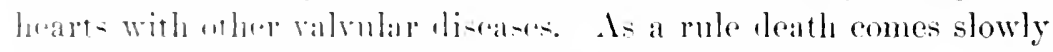

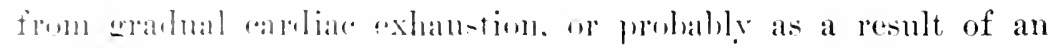

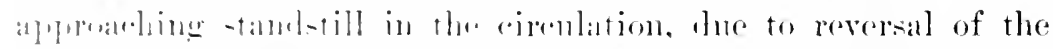

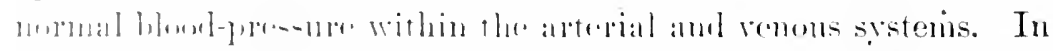

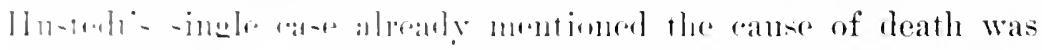

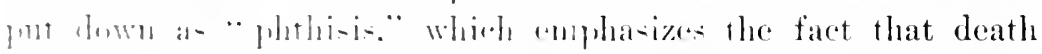

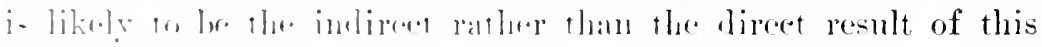
ral loular defoet. 


\section{CIIAPTER XII}

\section{PULMONARY REGURGITATION}

Tuns form of valvular lisease is the corollary of antic insufficiency but is infinitely nore mocommon, and massociated with other valrular lesions is repry rare. Althongh I have observed a single instance of chronice organie pulmonary incompetence, as determined by the history and chinieal signs, I an inclehted for the most of what will he saill to Bariés paler on the subject.

Morbid Anatomy. - This depends largely upon the cause of the disease. Thus we recognive two chief gromp: (1) 1 functional or relative incomperence in which the pulnonary artery and ling are so dilated that the ralves camnot close the orifice, but are thenselves not responsible for the regurgitation. (2) The form in which the leak results from structural changes in the valve-segments. Thus far this disease is the comuterpart, Juth pathologically and otiologically, of the other valvular lesions that have been comsitered, bnt the serond gromp of pulnonary regmeritant lesions is again divisible into the congenital and the acepuired. In this respect it conforms with what we know of rightheart defects and differs from valvolar diseases of the left heart, since congenital affections of the mitral and aortic valves are cxceedingly rare.

In relative insufficieney of the pulnomary valve the artery and ostimn are found stretehed, and the former may shew the changes of atheroma, while the leaflets are elongated and broadened in consequence of the strain to whinh they have been subjected, ret in other particulars are quite likely to be fuce from discise. This was the case in the patient with mitral and tricuspid stenosis whose history was narrated in the preecling chapter.

In those instances in which the regurgitation is the result of endocarditis, the changes are the same as in other valvular defects of the same origin, and hence do not need to. he repeated in ex- 


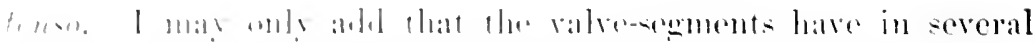

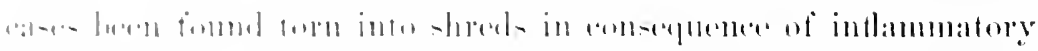

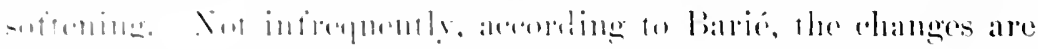

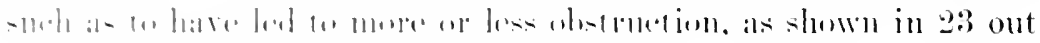

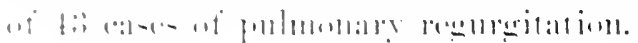

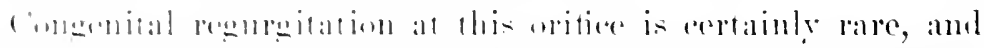

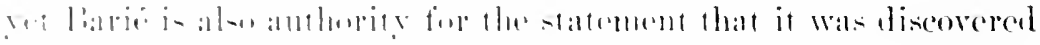

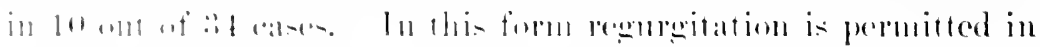

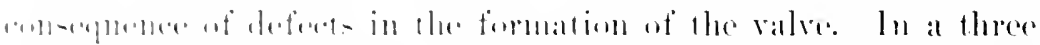

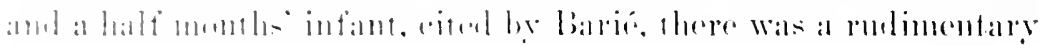

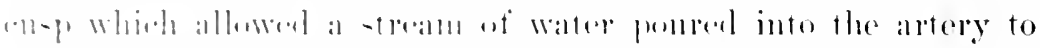
leak thromeh inte the right rentricke. In lamilland's atse the

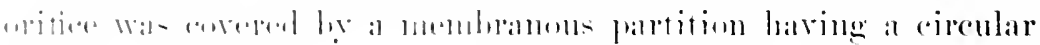

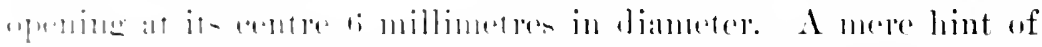

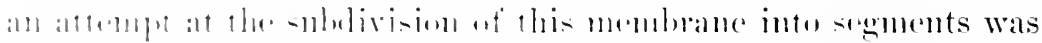

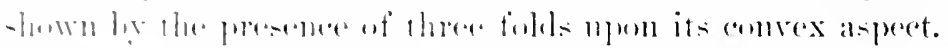

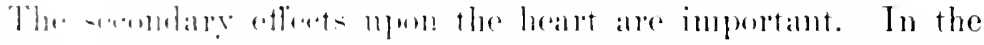

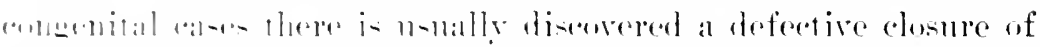

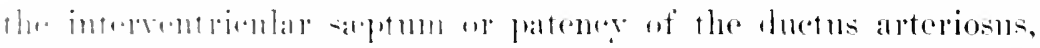

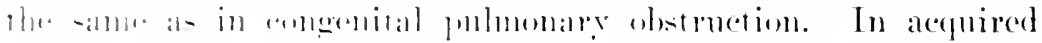

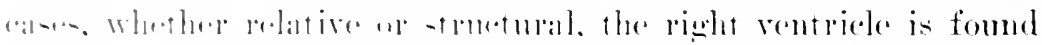

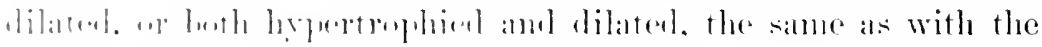

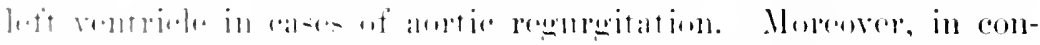
-

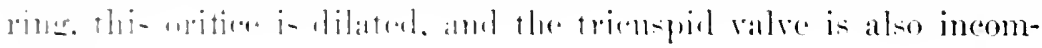
lin+i+11\}.

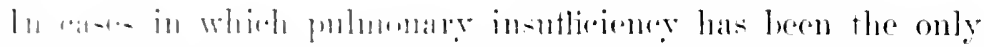

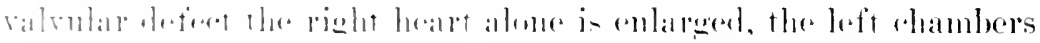

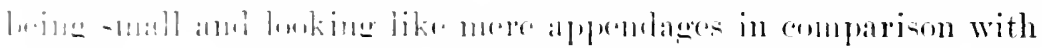

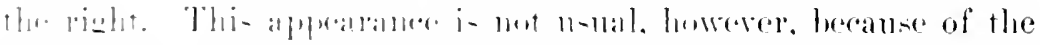

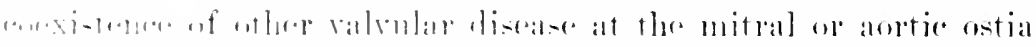
that hatre lonl be -

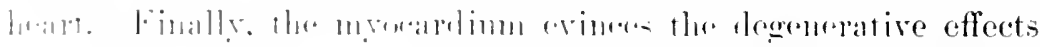

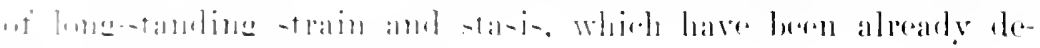

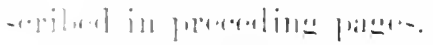

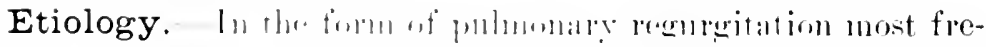

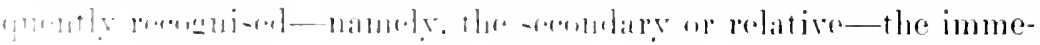

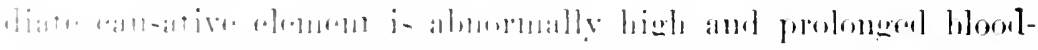

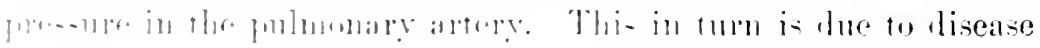


of the left heart or of the lungs. It is in extreme and long-standing mitral stenosis, therefore, that secondary inconpetence of the. pulmonary valve is oftenest encountererl.

Obstruction or regurgitation at the acotic orifice may also produce pulnomary incompetence after having set up stretching of the left anriculo-ventricular ring amd relative mitral regurgitation. Great increase of blowl-presure in the puhnonic system is so common and necesalry a result of nost calrliac and many puhnonary diseases that it is probable that the regurgitation now considered takes place far more frepnently than it is reenenised elinieally.

Of those ases in which the valve itself is rliseased the most frequent cause is acute curlocalditis. This may be of rhemmatie origin. lout it i- more often septic, and therofore a localization of pus or pnemuncoecus infection. It ocenrs in the puerperium, therefore, the sane as malignant endocarditis in other situations.

The canse of the congenital form of pulnonary regurgitation are intra-nterine endocarditis and derelopmental defects, whether due tw inflamuation or not.

Symptoms. - In thuse cases in which pulnonary regurgitation is secondary to merexisting mitral or artic disease, the symptoms of these latter atfections generally obscure those referable to the former, if inded any new ones are developed. The patients already sutfer from the effects of promonnced stasis in the lungs and renoms syotem, and when the pulmonary ralves yield to the strain and leak, the foree of the regurgitant stream is thrown upon the alrealy orophurdened and dilated right ventricle. The propelline power ot this portion of the heart is therelsy lessened, and the congestion erolywhere present is angmented-Jut ats this condition has come on eparlually, it is put down as only a further manifestation of the ineritalble assotolism.

With greater dilatation of the right rentriele the trienspid ring stretches and tricuspid regureitation is arled. This laak is more easily recognised than is the pummix, and accordingly the still more urent stasis that now comes on is attributed to the trienspid incompetence and the pulnonary insutticiency is orelooked. The serionsness of relative pulnomary incompetene comsists, therefore, not so much in the addition of any new and characteristic subjective symptoms as in the fact that it inten-ifies those already 


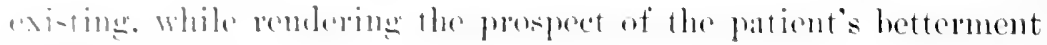
matrotivally nil.

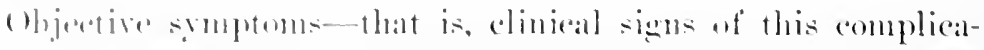
fien-alre present, theoretically at least, amel when recognisable

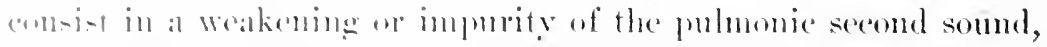

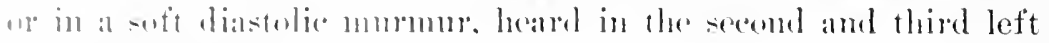

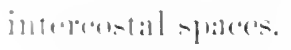

The ferm which ehiedly interests us at this time is the primary

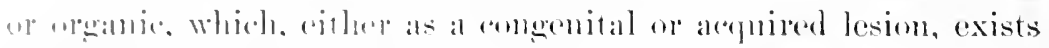

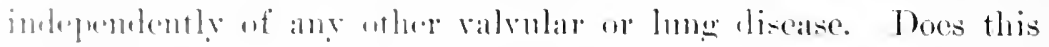

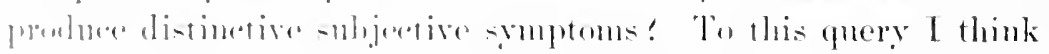
me must reply that not anly dos it mot display distinetive symp-

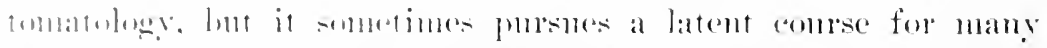

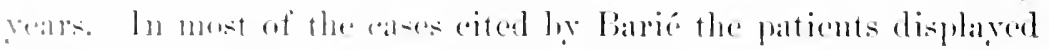

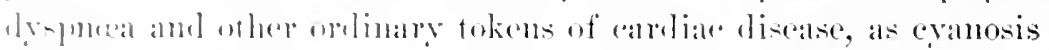

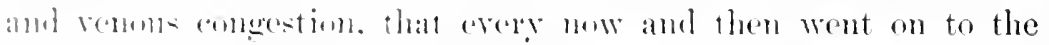

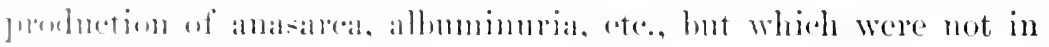

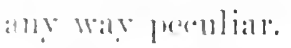

That the disalse maly le latent for many yous is proved not

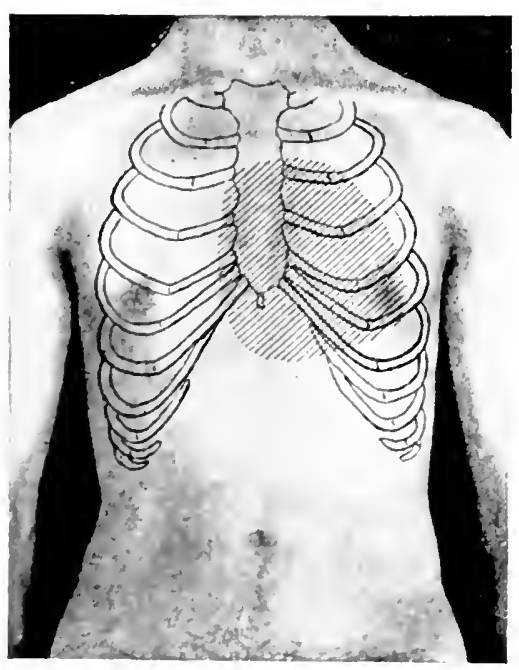

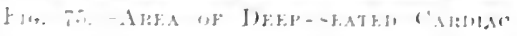

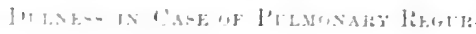

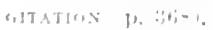

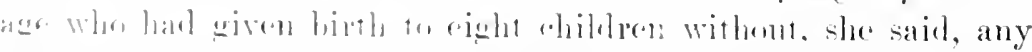

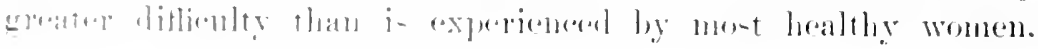
whe. in spite of her comgenital pulummary defect, attained the ane of twenty-fonr, but also be a arece that came to my motice nearly ten rearis ago. Most mufintmately an an-

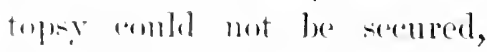
and hemere a post-mentem confirmation of my diagnowis was not harl. Yot if physical -igns colnut for anything, then this at-re, ats will be seren by the renital, was one of pulmonary regmeitalion massociated with whlur valve defects.

The patient was a married wemuan of lifty-eight pears of only by Bonilland's patient 
She was short and slight, and although she stated she harl knwwn of her heart-disease since her eighth year, it had never occasioned her any partieular disconfort. At the time of her consulting ne she had been weak, nervons, and annoyed by palpitations for sorerail weeks, but had objected to reeking needical aid becanse of prejudice and the discovery, sears before, that the orlinary heart medicines did not agree with her.

She showed moderate eranosis and distention of the external jugular veins, but no welena, and she did not complain of shortness of breath. The radial pulses were equal, moderately aceelerated, irregular in foree, and occasionally intermittent. But their particialarly noticeable feature was their smallness and feebleness. There was arident, but not great, enlargement of the liver. Thus far there was nothing in the examination of the patient to impress me as munsual.

When, however. exploraltion of the heart was begm, I was at once struck by the forcible and extensive cardiac impulse, which reached from the left nipple into the epigastrimm, quite across the median line to the right costal cartilages, and as far dowmand as

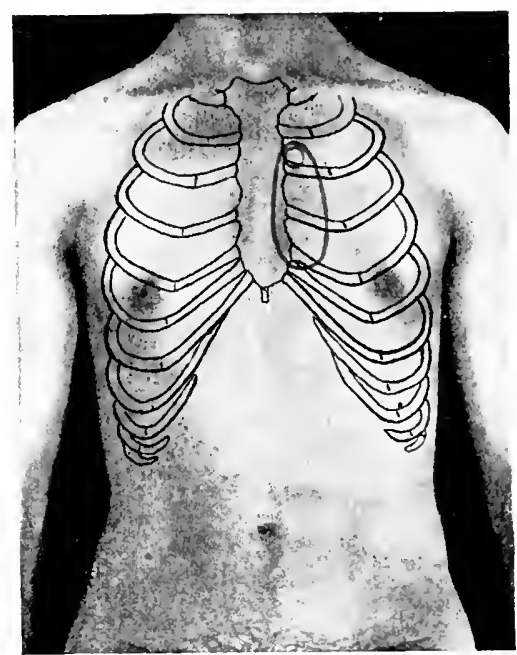

Fig. 7t. - Area of Maximiz Ixtexeiti (SUALL CIICLE) AND UF l'ROPAQATIOX (IF Meratio in Case of P'temosary RegitrGITATION (1).3bo). to the level of the eightl. This wat not at mee recognised as the impulse of the enomons? hypertrophied right ventricle, hut by carefully studying the apex-lieat, and hy tetermining the area of

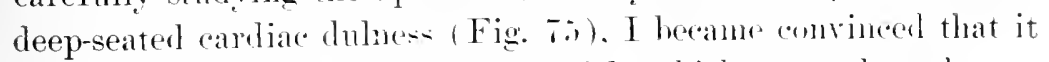
was the right and not the loft rentricle which was anlarged.

Then upon resorting to auscultation I at once distinguished a diastolic mormur, which was located at the bet of the stermun in the third interspace, was transmitted downwarl, and possessed the peculiar cuality of the aortic regurgitant hituit (Fig. 76 ). This was quite naturally taken to he aortic, until pondering on 
- he -ize af the rieghe rentriele amb the smallness of the pulse with-

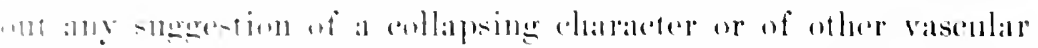

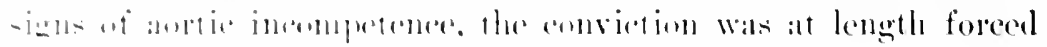

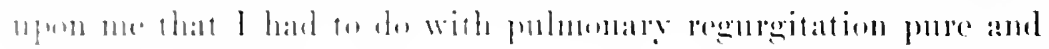
-imple.

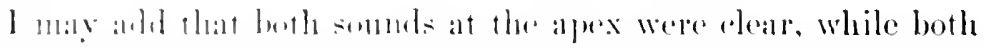

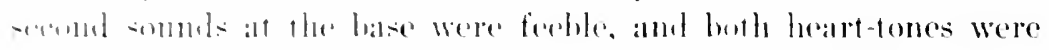

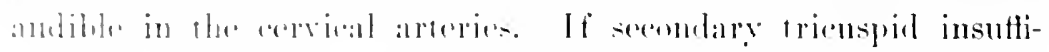

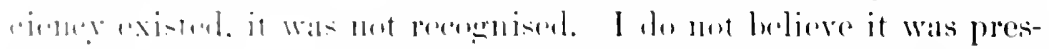

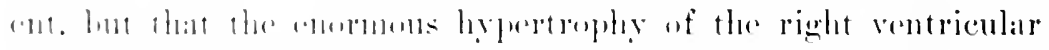

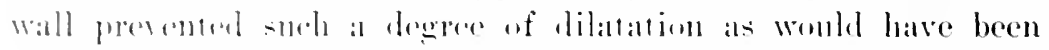

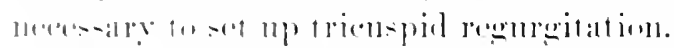

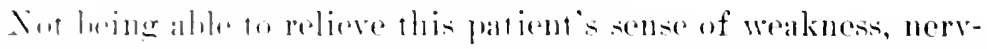

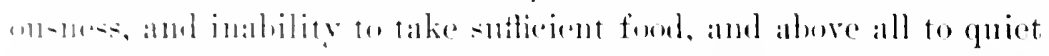

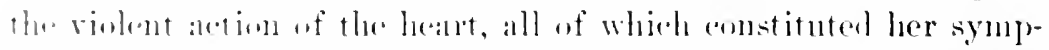
fobns. I was nut allenl in often, and attel a few weeks was notified

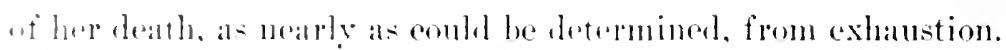

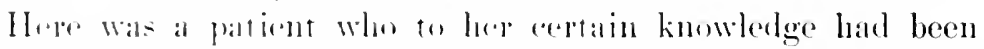

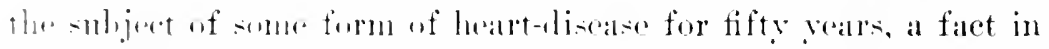

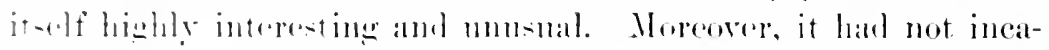

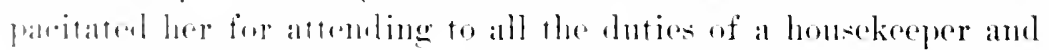

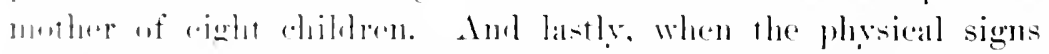

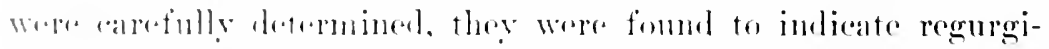
tation into the right and nut the ioft rentriele. consegnently pul-

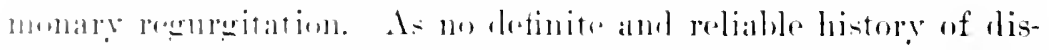

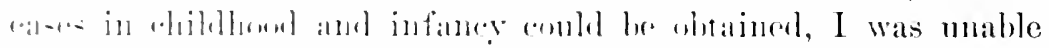

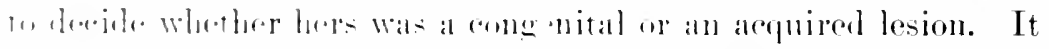

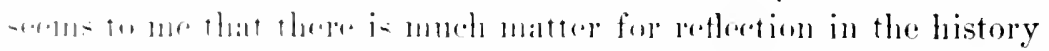

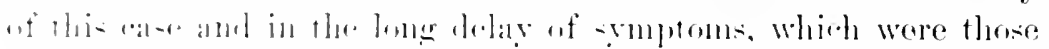

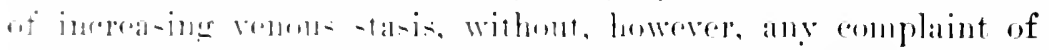

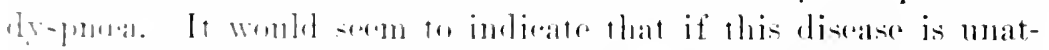

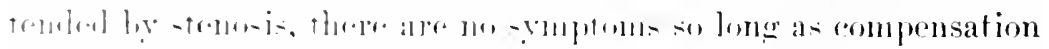

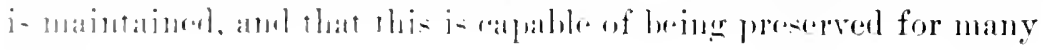
voit 12

Physical Signs. - Thro diannmi- of pmlunonary regurgitation

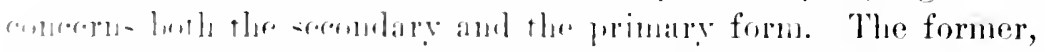

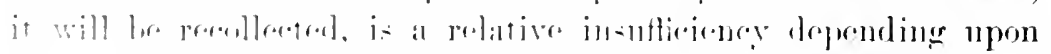

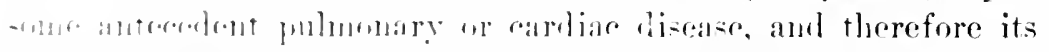

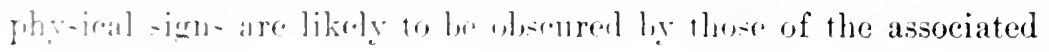


affection. The possibility of its oeeurrence in the late stages of mitral or aortic disease should always be borne in mind, and if in such a case a diastolic mumme develops in the pulmonic area, the diagnosis of secondary pulmomary incompetener may be assumed. Particulars regarding this murmur will be considered moler the head of anscultation, to which, therefore, the reater is roforrent.

Inspection.-This diseloses nothing vharacteristic in the soeondary form, the evidences of cirenlatory embartassurent being due to the associated affections. Even in the prinary form the exi-tence of visible signs of heart-disease is likely to depend mpon its severity. So long as compensation is preserved, inspection of the pracordia detects nothing more than a forcible and perhaps extended cardiac impulse, which, to julge from the aise I have briefly reported, is particularly pronouncerl in the eprigastrimm. So soon, however, as the right ventricle begins to fail ocular signs of venous stasis appear, of the same character as in other cardiac affections.

Palpation.-This is of ensilerahle service in the detection of the right rentricle hypertrophy and in the stmly of the pulse. Pulsation in the epigastrimm is forcible and imparts to the palpating hand the impression of a powerfully contracting ventricle. It is in the study of the peripheral arteries that palpation is of greatest value.

Inasmuch as the murmur is so elosely like that of aortic regurgitation as to often leave one in dombt concerning its real signifieance, the pulse must bre red on for differential infornation. In pulmonary incompetence the aortic sratem does not experience the sudden distention and equally rapid collapse of aortic insuffieiener, and consequently the pulse is not at all like that described by the term eollapsing. On the contrary, it is likely to be small and weak, presenting in this respeet a striking contrist to what might be looked for in comection with the diastolic murmm at the base of the heart.

The rate and rhythm of the pulse are determined by the state of compensation. If one could place his finger on the pulmonary artery he would discover that this vessel and not the aorta undergoes foreible distention and sudden eollapse.

Pereussion.-Pulmonary regurgitation affeets the size of the right rentricle, and consequently the area of cardiac dulness is 
increaced, dhictly downward, while that at the left is but slightly if at all chatlged. This mealle of inrestigattion is therefore of great

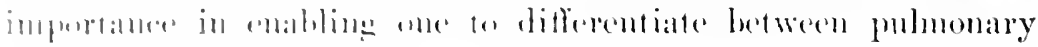

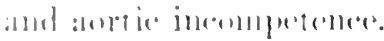

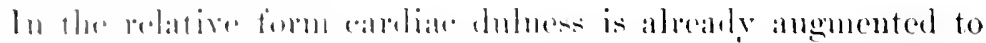

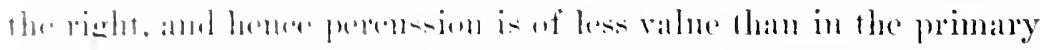

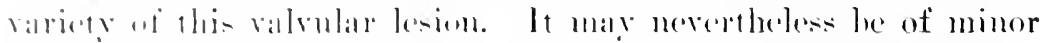

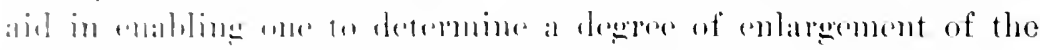

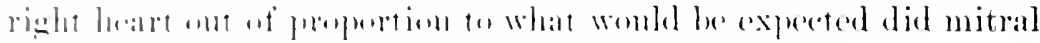

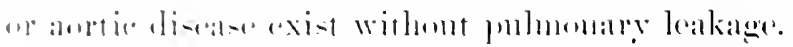

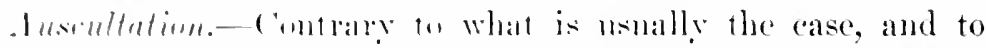

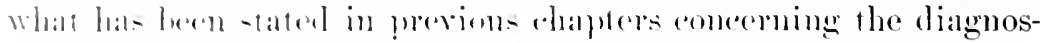

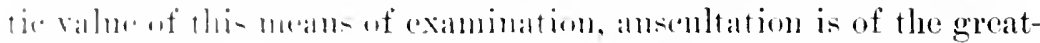
"st as-itane in the detertion of this partienlar lesion, not only

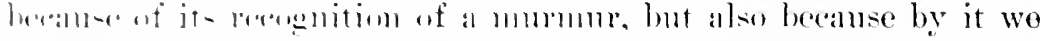

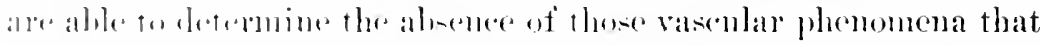

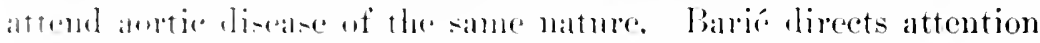

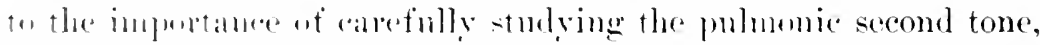

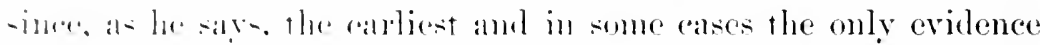

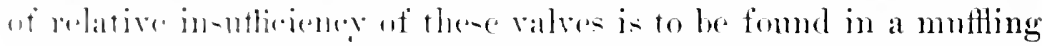
or impurity of this somml. Comsalumenty, if in a given case of

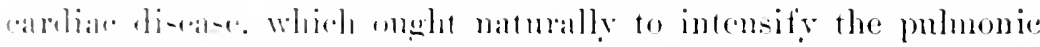

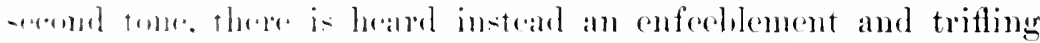
impurity of thi- somul. it shomld remder one suspicions of dilata-

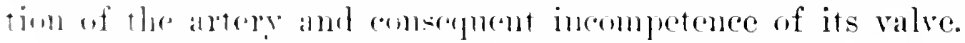

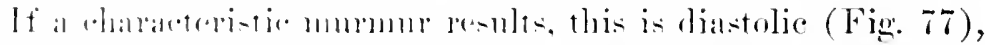

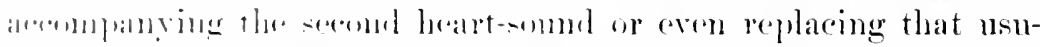

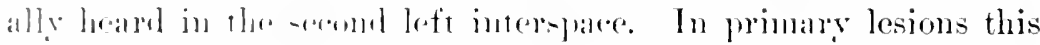
mommon i- probahly always present, and when stenosis is com-

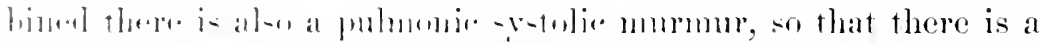

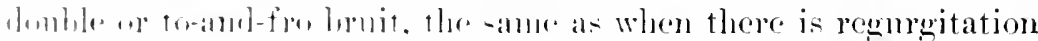

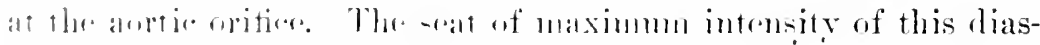

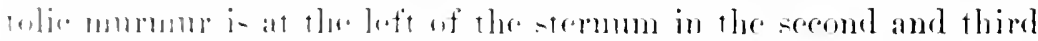
In fi inter-pale... It- direntions of tran-miscion is downward along

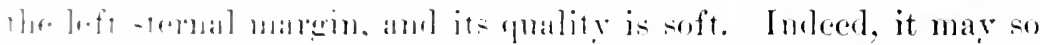

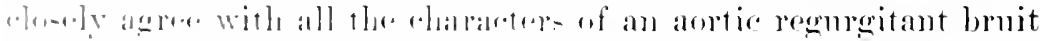

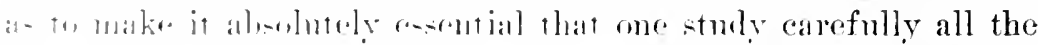

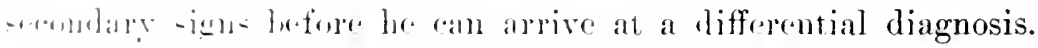

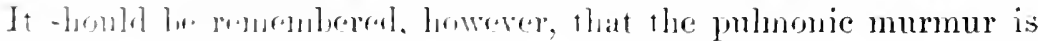


not heard at the right of the sternum, as is generally the aortic. Yet this is not alone sufficient for its recognition, since an aortic diastolic murnur is sometimes inambible at the right and andible at the left of the breastbone. Should a pulmonic erstolic murmur

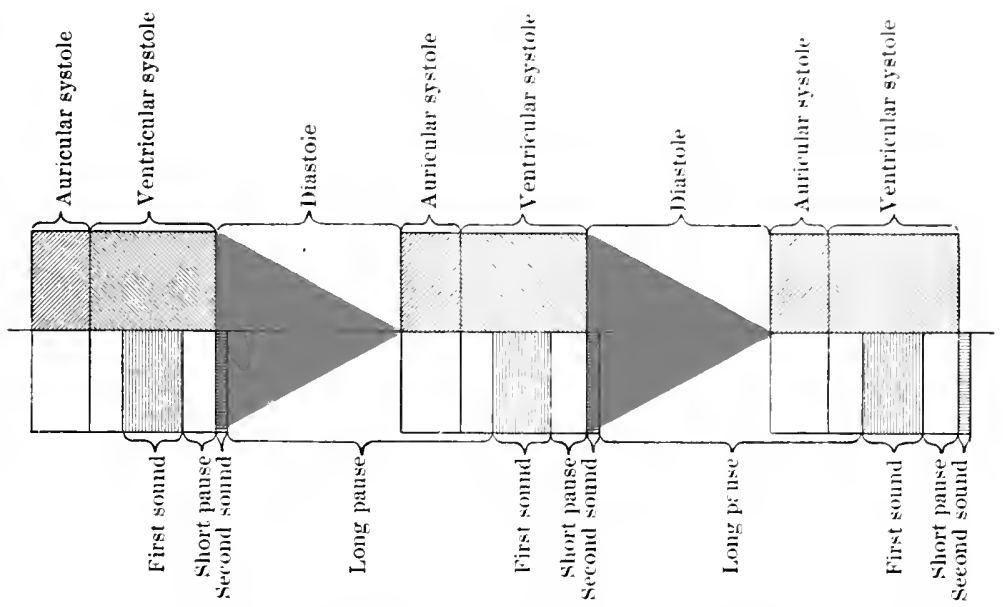

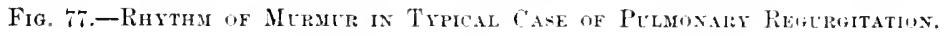

be associated, this is not transmitted into the arteries of the neck, but instead the ordinary heart-sounds are there andible, a circumstance which is of diagnostic aid.

Diagnosis. - The diffienlty which attends the diagnosis of this affection consists not in the recognition of the mumur, but in its interpretation, since it is likely to be mistaken for the bruit of aortic regurgitation. It is indispensable, therefore, to pay attention to the secondary signs, of which the most valuable are those connected with the vascular srstem. For the reasons stated muder palpation, there can be no aconstic phenomena comnected witl the arterial system in pulmonary insufticieney and consennently the absence of a srstolic snap, and still more of the double soutle in the femorals, womld, in conjunction with hyertophy of the right, not the left rentricle, and with a diastolic murnur at the left cardiac base, enable one to state quite positively that the regurgitation was at the puhnonic, not the arrtic ostimm. The foregoing remark applies to the rolative as well as the primary lesion; for even in cases of combined aortic and mitral incompetence, careful study of the peripheral arteries detects some of the characteristic 
signs wi the formeremelition. When, on the contrary mitral dis-

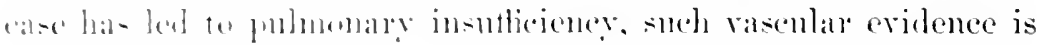
W:alltills.

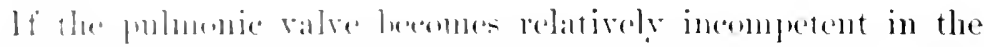

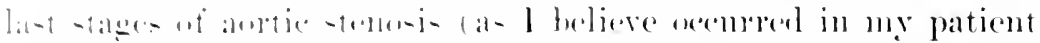

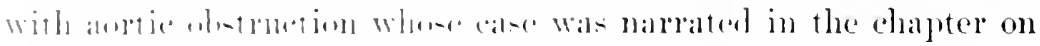

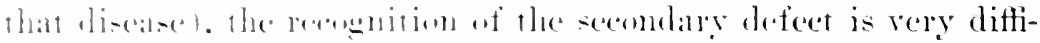

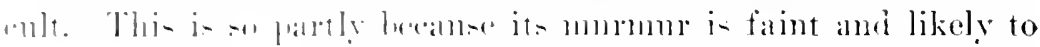

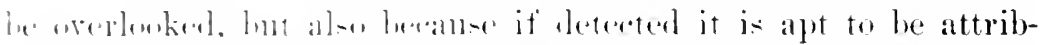

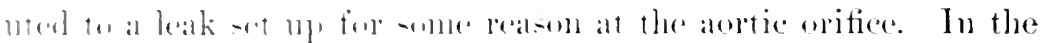

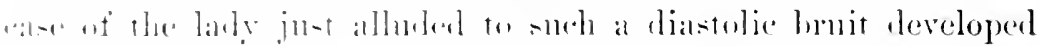

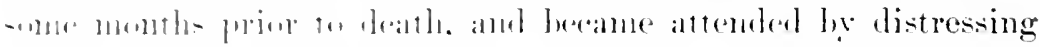
and at timen vinelent galpitation at the pit of the stomach, the

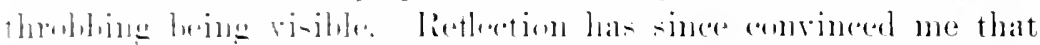

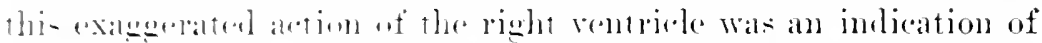

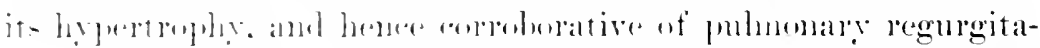

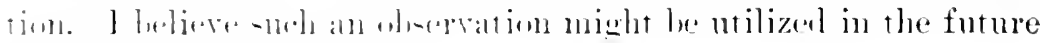

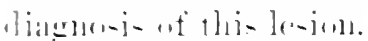

Prognosis. - Very litgle ureds to he sijl upon this subject.

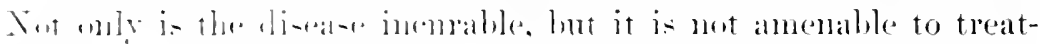

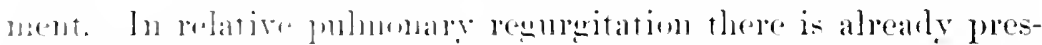

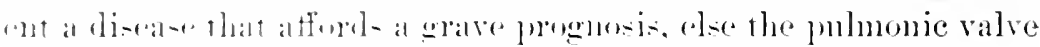

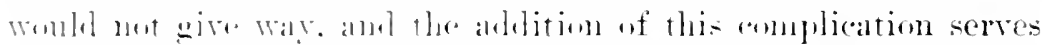

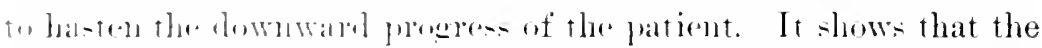

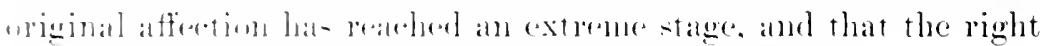

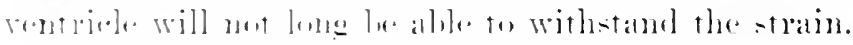

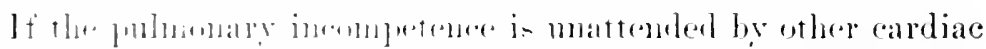

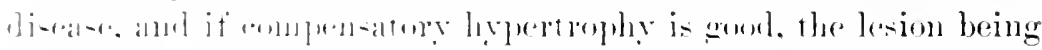

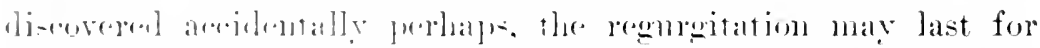

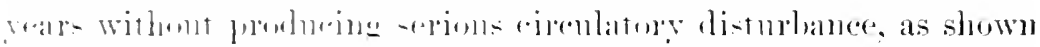

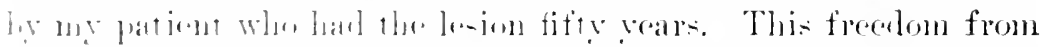

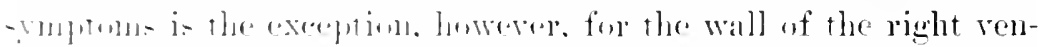

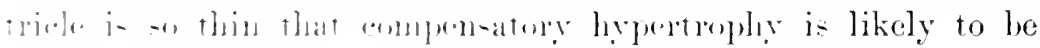

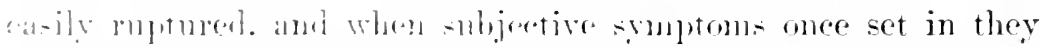

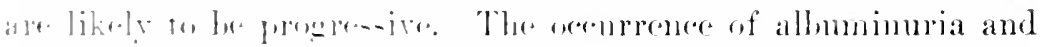

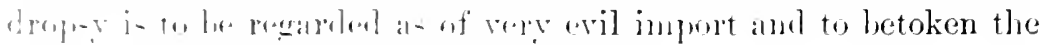

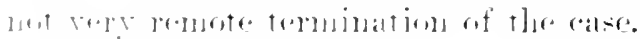

Mode and Causes of Death. - Tiarir reaks of the occul-

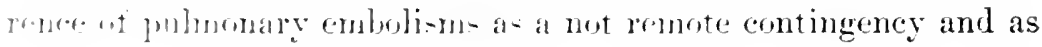


contributing to the pattient's death. The fatal termination is

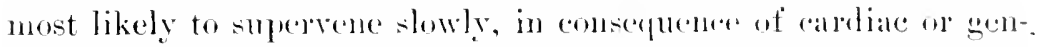
eral exhanstion, bather than suddenly, and get this batter event is

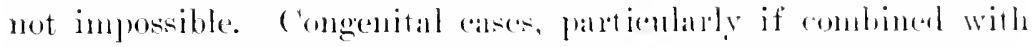
stenosis, maly lead to puhnonaly phothisis thromeh andmia of the lungs. 


\section{CIIAPTER XII}

\section{PULMONARY STENOSIS}

Tus is an whtrutive lesion which in its effect on the right rentricte is analogons to that of anrtic stenosis on the left. It differs from the latter, howerer. in its origin and anatomical charanters. It is divided into two great elasese, the congenital and the acpuired, the former constituting by far the greater number. Even when emgenital. this lesion is one of the rare forms of heartdiscase. Instanees of the aleguired affection are so extremely infrequent that since Constantin Panl's elaloorate monograph in 1-i w mly s atses have, so far as I know, been reported. For my knowledge of these eases I :m intebted to a thesis by Koehler, of Halle. in 1-51. I have not leeen athe to ascertain how many of the cases described by Paul belong to each variety. The

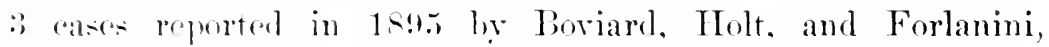
and the 8 in 1 set by . Lams. Amozan, and Siredy, all appear to have been congenital, which still further emphasizes the rarite of the acruiped form. The first ease on record of this form was Arecriber in the Attas of Pathological Anatomy by Crmeilhirer.

Morbid Anatomy. - This can be best leseribed by the repetition of a report of the a ases alwere allurled to. which was pulb-

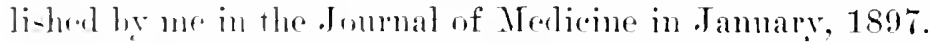

In 1 - $i:$ the late ('hritian Fonger published a ease in a male

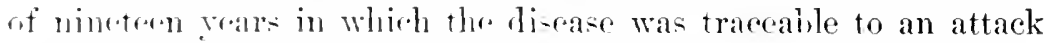
of alrienlall rhemmatisun at the age of eleven. The autopsy dis-

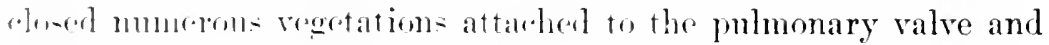
along the wall of the artery an far as its hifureation and into its main limenes particularly the left. This condition, althongh the resed was dilaterl. harl led to very great olstruction, with eonsecutive hypertroply of the riglit ventriele. The septa were intact, the pulnonary artery and its main right branch dilated. Fenger, 
from the history and post-mortem diseovery of renent endocarditis,

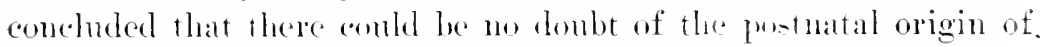
this case.

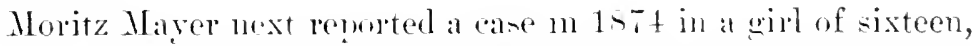
who at the age of eleven had sufferent from some pulmonary dis-

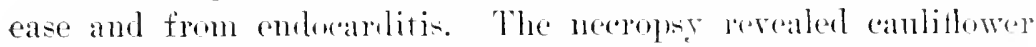
regetations attached to the wall of the eomes arteriosus and to the pulmonary valves, with secondaly hyperteplyy and dilatation of the right ventricle. The dnetus arteriosus was closed, hut the interventricular siptum contained an opening large enough to admit the tip of the first finger, and Marer explanined this defeet as having originated after hirth in conseguenes of the previnut endocarditis.

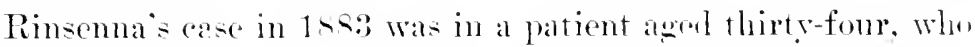
had also had acnte rhemuatisus. On post-mortem examination the pulmonary valves were fomul greatly thickenel, and to have thus cansed slight obstrnetion, hut without enlargement, of the right ventricle.

In 1sst Tramnhals reported 2 cases, of which one was in a widow of forty-three suffering from lencemia, and the pulmonary stenosis was attributed to this affection. Neither necrosis of the ralves nor micromeanisms were fomd to explain the stenosis. In his second aase. that of a homsemaid of ninotoren, there was a history of good health up to the fourth rear. when she harl an attack of rhemmatism, and her health had been impaired since that time. The fretal parsiges were found elosed, there were no congenital defects, but the puhnonary artery was dilated.

Rendu in 1sst described a case in a girl of nineteen, who had had the disease for fifteen rears, and after death the pulmonary valves were fouml fused into an inflexible diaphragm having an opening of about $\frac{1}{10}$ of an ineh in diameter. The immediate canse of death was a rapilly progressing nephritis.

Stybr's ease in 1 sen was that of a woman of twenty-four in whom the stenosis was found due to an inflammatory blending of the pulmonary segments into a tondon-like cone that projected into the lumen of the artery and contained at its apes an opening 2 millimetres in wilth. Two ollique lines that pased down the sides of the cone showed where the ensps had hecome mited. The right ventricle was enormously hypertrophied. As the aortic eusps 


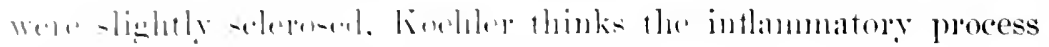

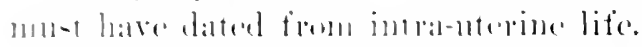

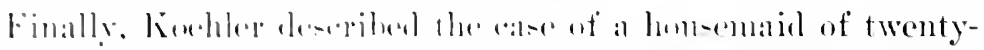

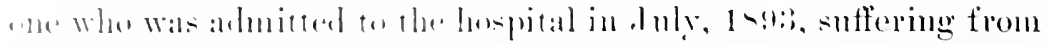

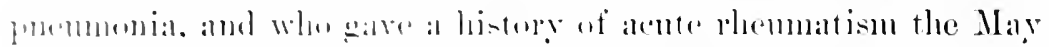

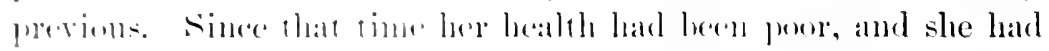

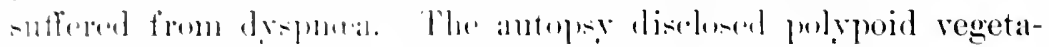

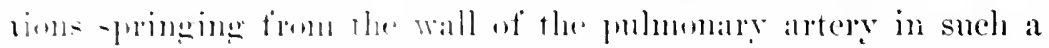

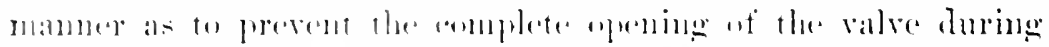

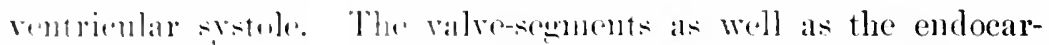
limm of the right ventriele were loblthy, lut -imilar vegetations

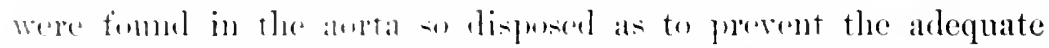

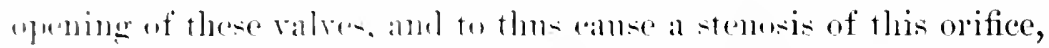
the same as an the rieldt sile. Buth rentricles. particularly the

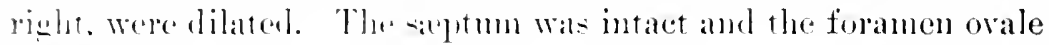
was a luserl.

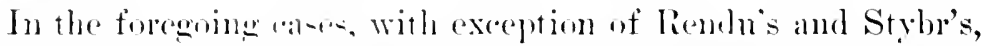
there were eridenees ut recent endowarditis, alsenere of congenital almommalitics. and dilatation, or at least no pereoptible nalrowing,

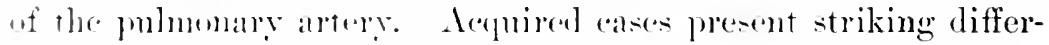
onere from most of the enemental in their pathological apjearances. hut they both have the common featme of hypertrophy and lilatation of the right ventricle.

In the congenital form the ulstruetion is lue most usually to a fusing together of the valve-segments, whele then form either a diaphraem streteloing arens the ostimm or a cone-like projection inte the artery with a -mall opening at its alex (Fig. Ts). The formmen ovale is n-llally nfen, and the interventricular septum is -nuretines ineompletr. The pmlmomary artery is always nar-

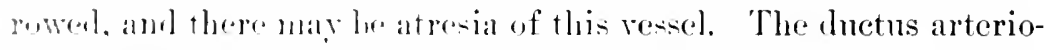

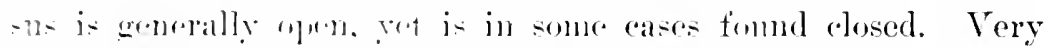

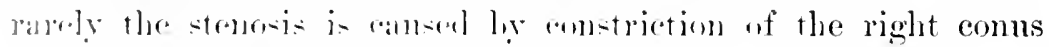

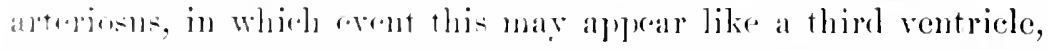

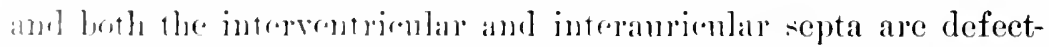

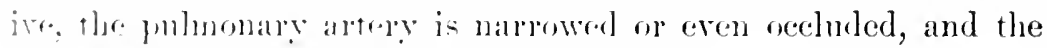

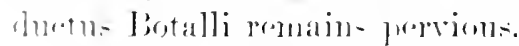

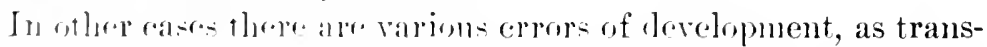

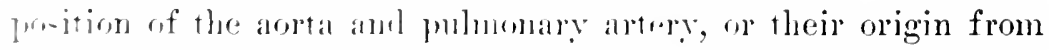
one rommon trunk; a blending of the two ventricles into one com- 
mon eavity with but one instead of two ampeles: w ane rentriele and two anrieles, or but one anricle and two ventrieles.

It is not alwars ease to deternine post unortem whether a given case belongs to the angenital or the arouired antegory. In well-

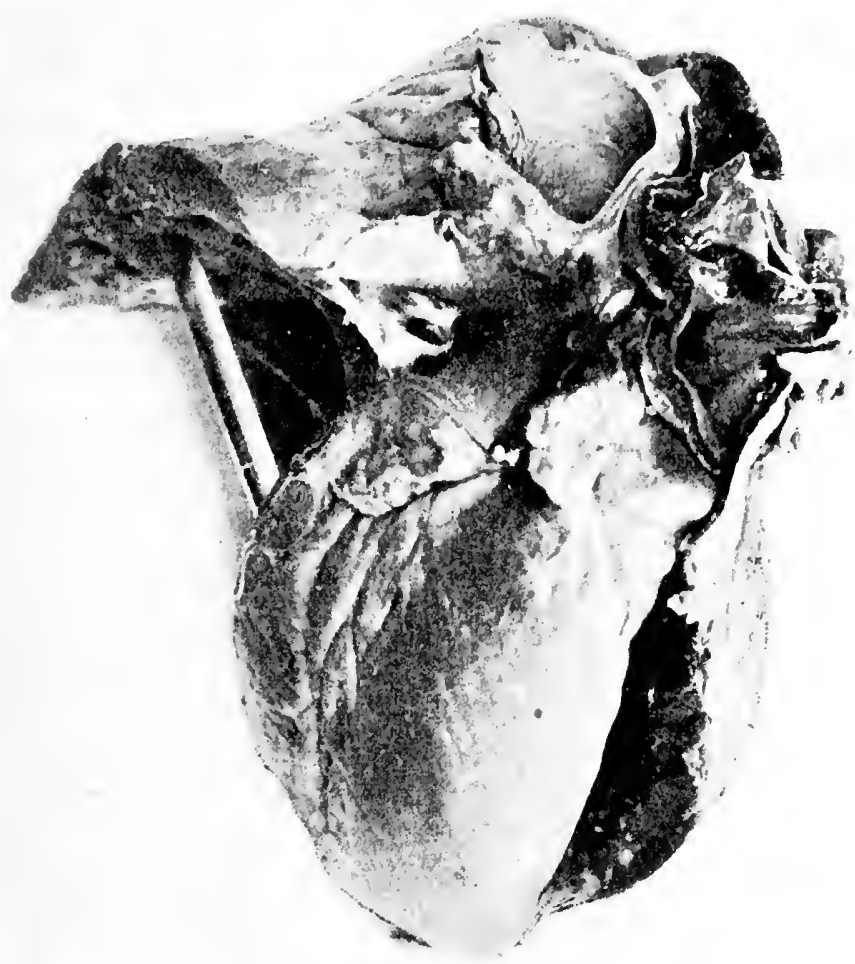

Fig. 78. Heart of a Boy, showing Cungenital stenusis uf the Plluoxari Orifice. Specimen in collection of' Dr. Gustav Füttr.rer.

marked specimens, like Fenger's, or in such as show striking abnormalities of development the decision may be easy: but in cases presenting some of the characteristics of both forms the exact nature must be left in doulst.

Aside from the evidences of recent endocarditis it is the condition of the pulmonary artery mon which pathologists rely for the determination of the intra- or extra-uterine development of the 


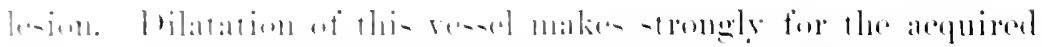

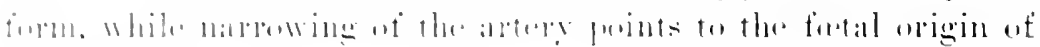
the. li-1:is-1\%

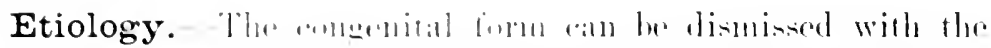

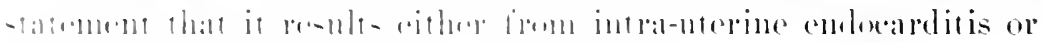

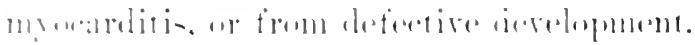

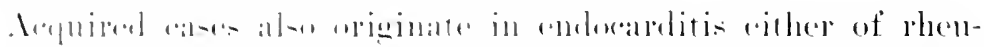

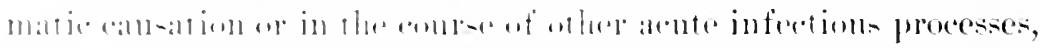

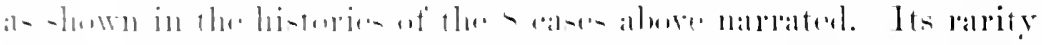

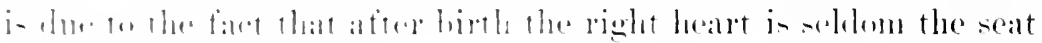
uf $: 110110$ intlallumaltinll.

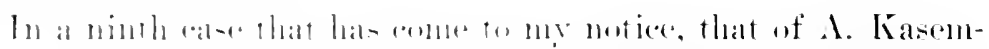

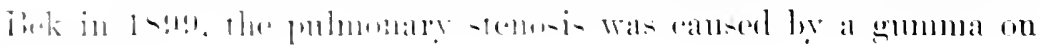
ile. ‥ ilinu.

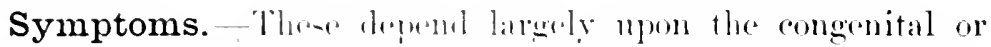

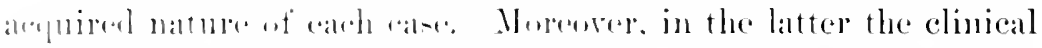

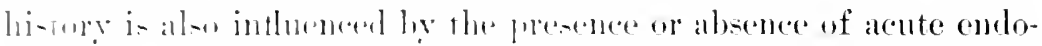

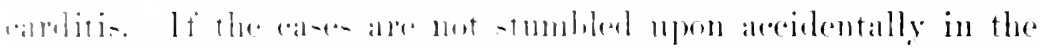
andre of examination ar treatment for sme other wholly differ-

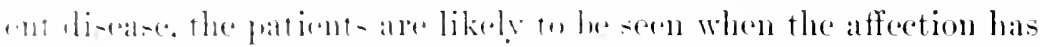

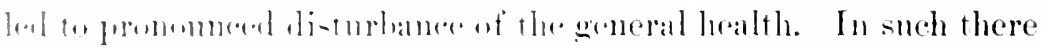

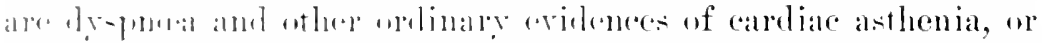

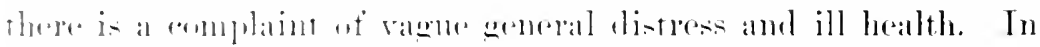
a werl. there a

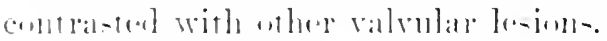

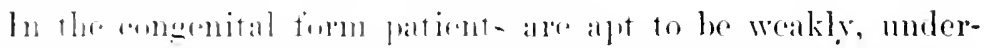

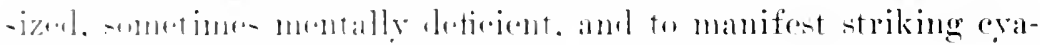

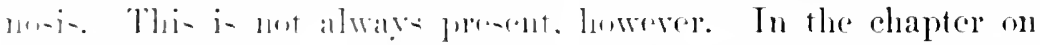

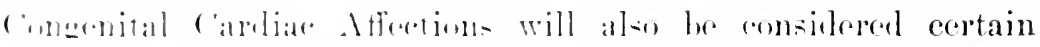

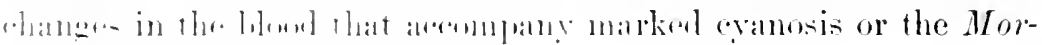

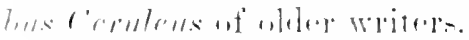

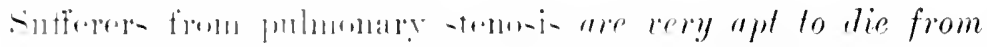

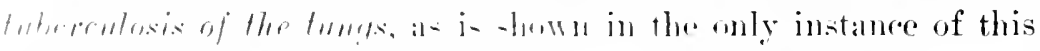

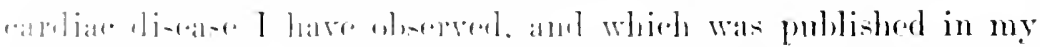

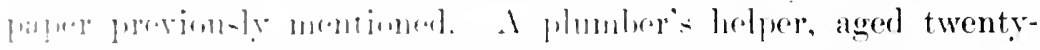

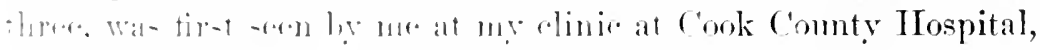

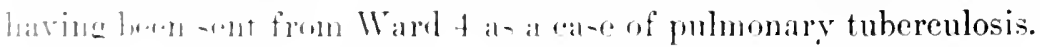
Fanily hi-fury wat mealere. Hi-fitlere had died of some wast-

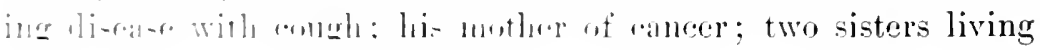


and healthy. Patient dedared he was healthy in infaney and chilethood, and hat never suffered from drspura on exertion prior to his present illuesis, and had not exhibited cratmosis. In faret he was healthy until his present illuess began three mouth betore his altmission to the lossital.

Withont entering ton much into detail, it will suther to state that he presented the usual symptoms of consmun tion, emaciation, coneh, frofuse muco-purulent expectoration, febrile temperatmere, and a rapid, feeble pulse. the finmetions of the digestive organs lemaining good. There was no cymosis. The right apex was retracted, and expamed poorly npon inspiration. both apiess shoved dnhess, bronchial breathing, and moist râles.

The precolimm limled

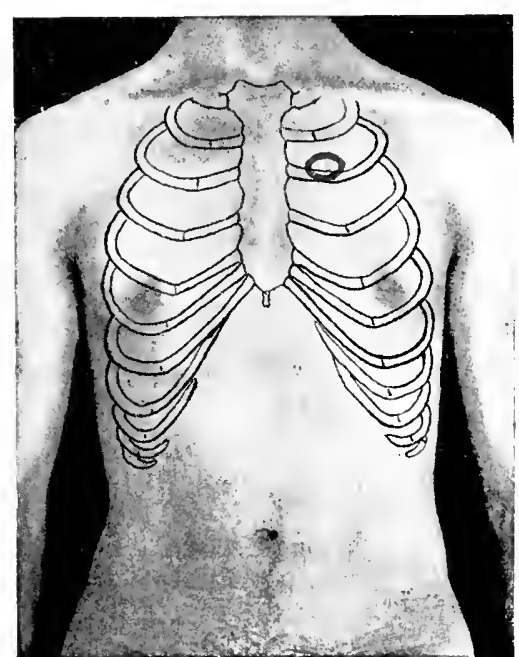

Fig. 80.-Location of Thrill and Sratolic Murmur in Case of Pulmonary steno. sis (p. 380).

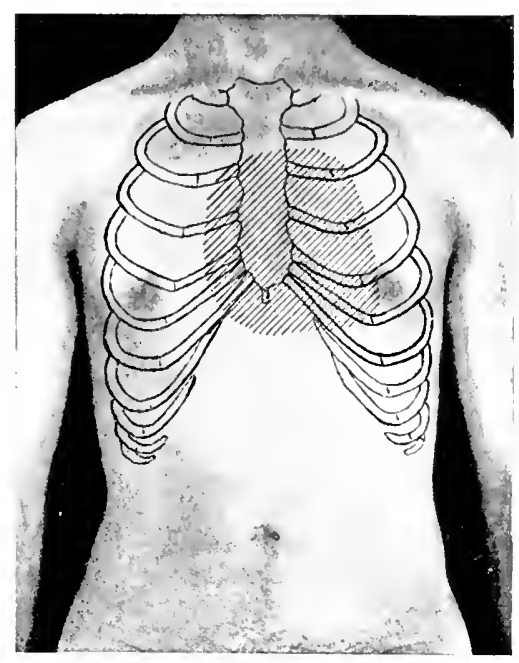

Fig. TG-Relative Cardiac Delness in

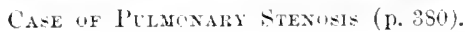
from the third rib to the epigastrinum and from left to right nimple. There was a short. weak s-rotolic thrill in secombl left interspace, 1 inch from sternmu. Abrolute dulnem was inereased from the level of the second eostal cartilage to the lower borter of the fifth rib. and from $1 !$ inch to right of stermm to $\frac{1}{4}$ inch insicle of left mamillary line (Fig. 79).

The hearts rhythm was regnlar and accelerated, the sounds heing rery fechle, the first muttled and dull, while the 


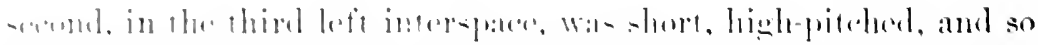

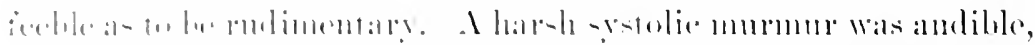

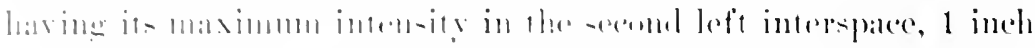

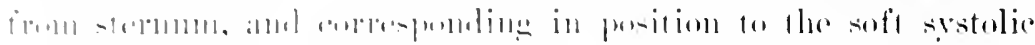

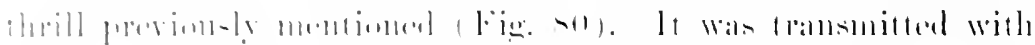

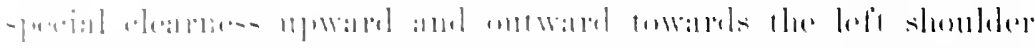

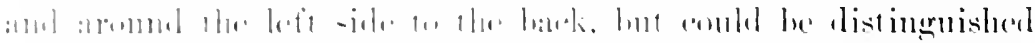

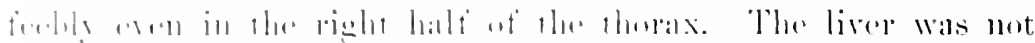

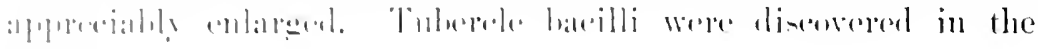
$-101111111$.

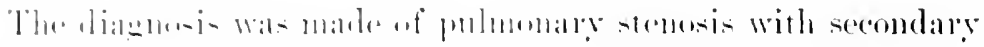

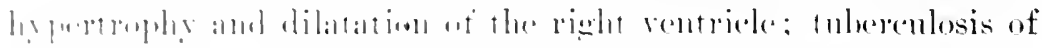

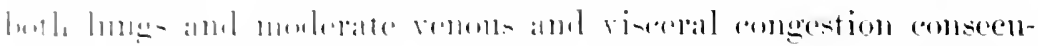

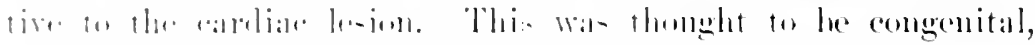

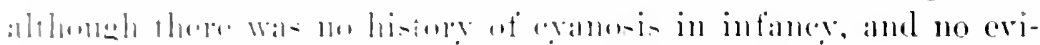

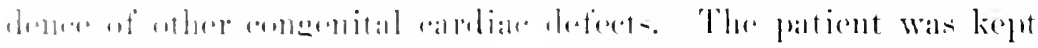

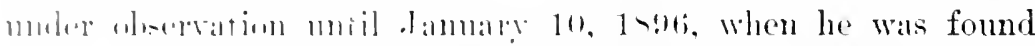

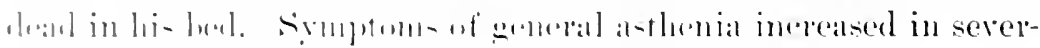

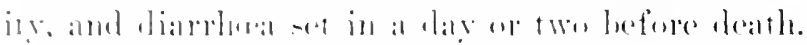

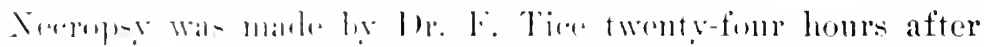

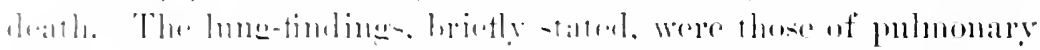

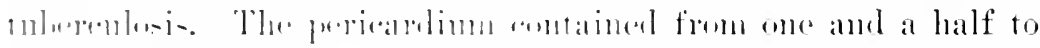

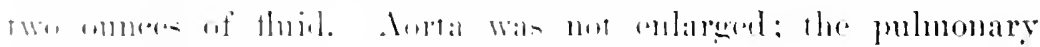

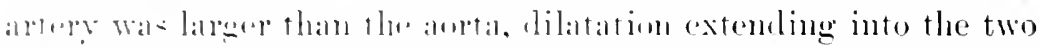

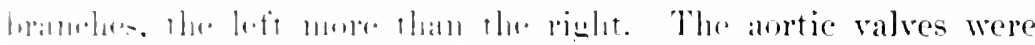

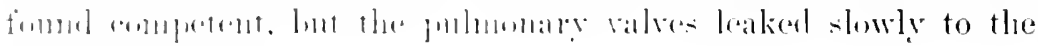

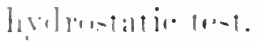

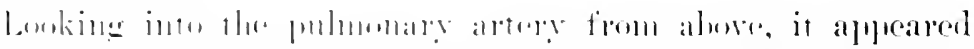

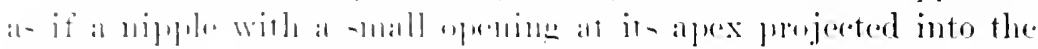

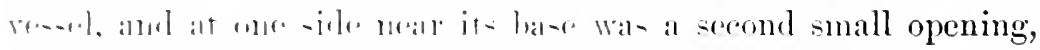

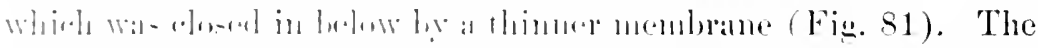

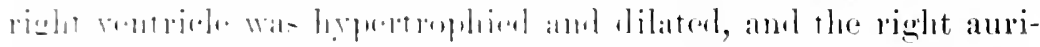

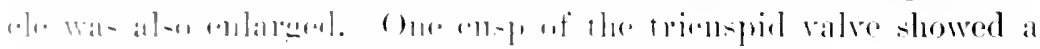

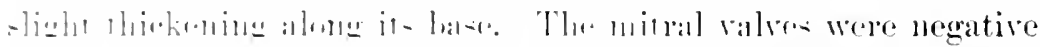

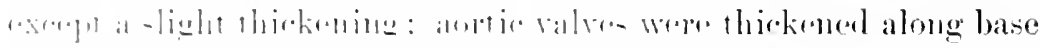

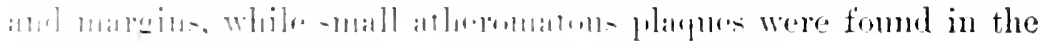

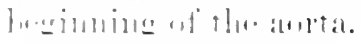

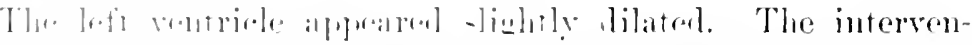

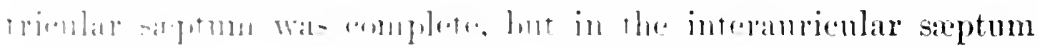


there was a ralke-like passage. which would not quite admit two matches, was prellaps:; millimetres in dimneter, and corresponded.

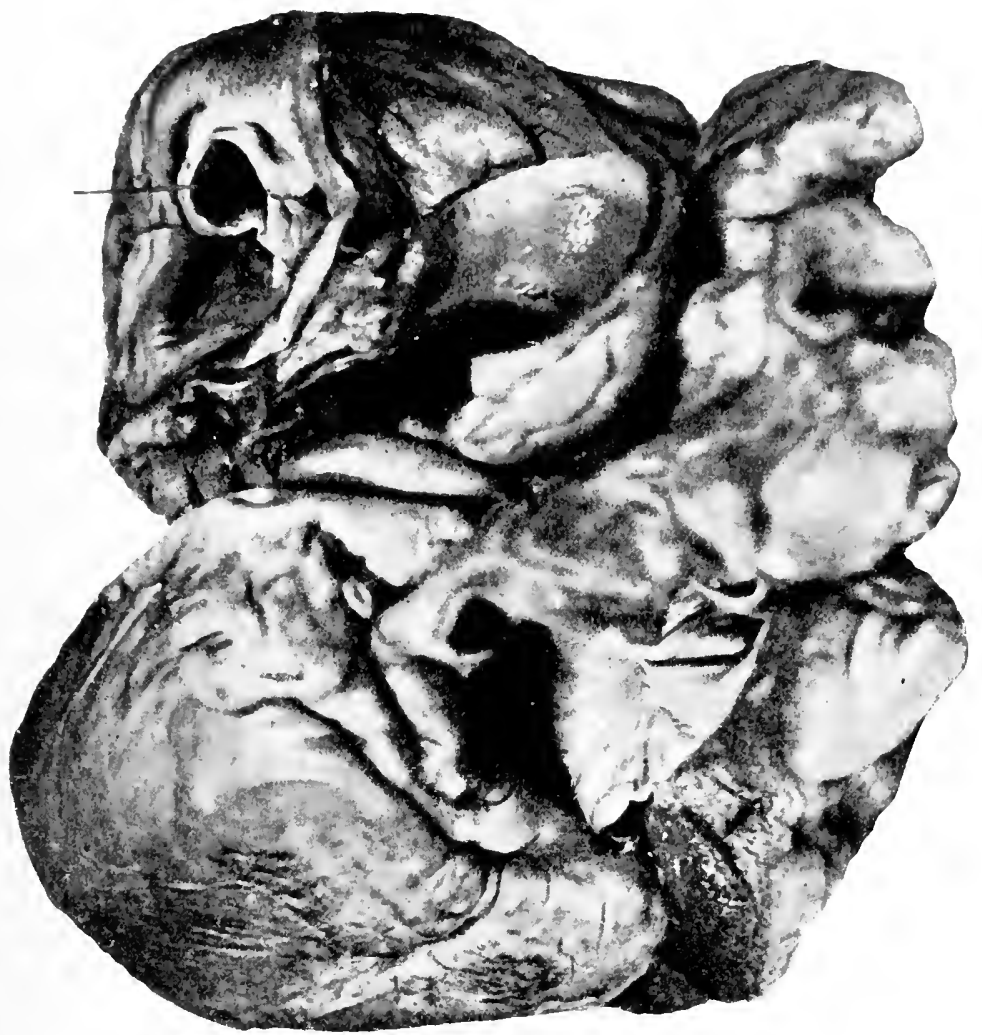

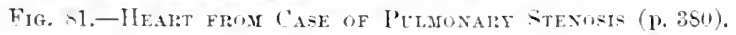

line shows narrowed pulnonary oritice.

in sitnation and shape to the foramen ovale (Fig. 82). Thus it was seen that the intra-ritam diagnosis wa-eonfirmed in its nain features. A more careful inspection of the heart, made a year later after having Jeen preserved in a formalin solution, showed that the cone whieh projected into the pulmonary artery, and represented the semilunar ralves, was mate up of a miform membrane. somewhat thicker than normal ralres. and showed no lines or ridges that intieated the points of fusim of the cusps. The opening at the apex was oral, measuring 1.5 millimetres by 8 millimetres at its broadest point. The edges of the rone were thickened, and the second minute opening at its -irle, near its base, was 


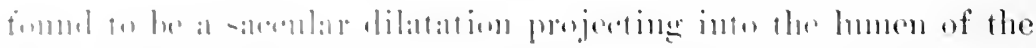

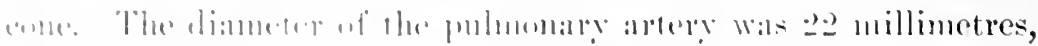

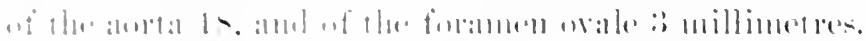

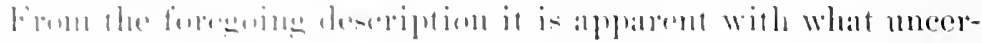

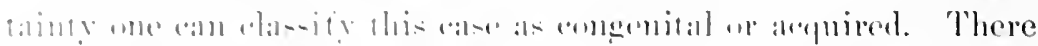

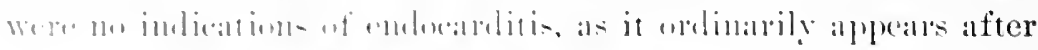

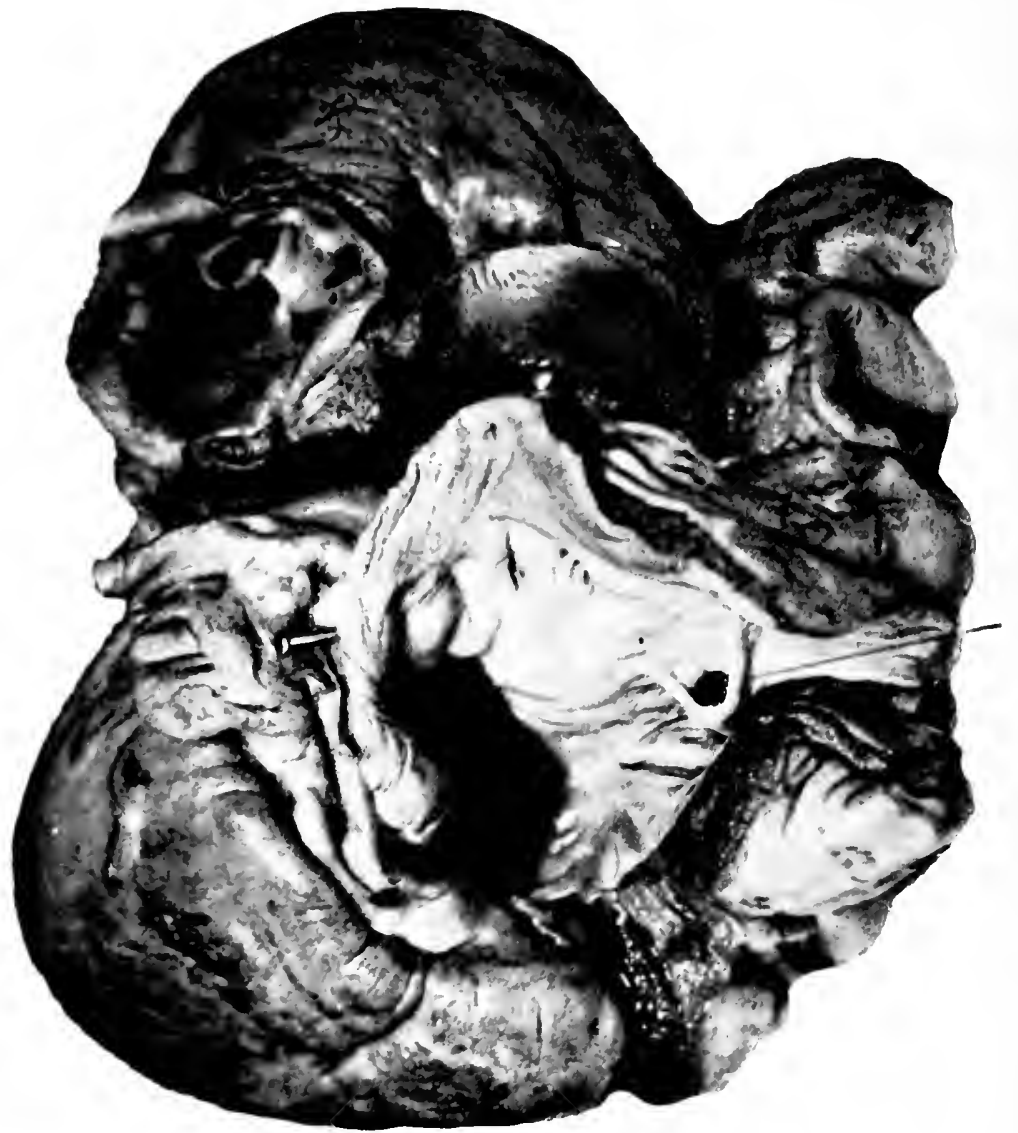

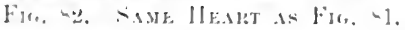

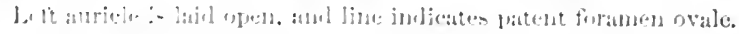

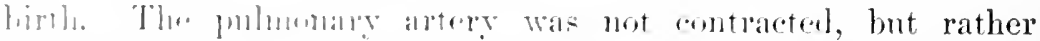

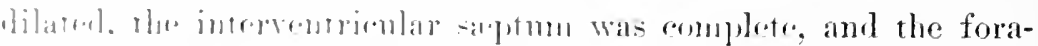

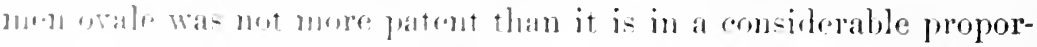

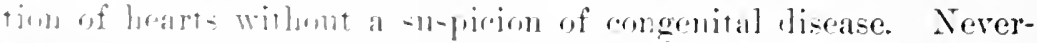

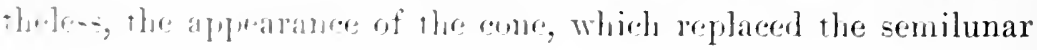


valves, rendered it polyhlo that this case was of congenital origin, and that intra-merine combanditis cansed a fusion of the sanments at a perionl suberpuent te the elosiue of the septal, and that the stemosis was not sutheient to prevent the closine of the foranen orale after hirtl. Norescer, the volume of blowel driven into the pulmonary aldere endel not have been very small, and most have been divided into fluid reins, which threw the stream against the aterial anats in such a way as to maintain ade-

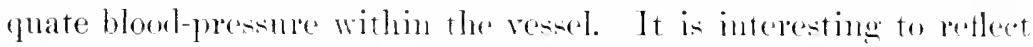

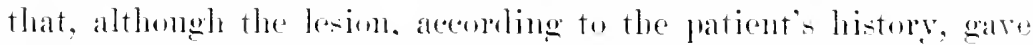
rise to no subjective smptoms, it shomld ret mltimately have led to pulnonary tuberenlosis, the uslual sefuence in such cases.

Regarding plursical igns in this calse, it is also of interest 10 note the wide propagation of the mormur. This was more malked in the left humg, and as the left brameh of the pulmonary artery was fombel to be rather lareer than the right there was probalily direct comneetion between the size of the artery and the transmission of the mummer for had the resel been nalrowed, the andible vibrations condel not have been transmitted to any great distance.

If a conclusion from a single case is justifialle. it is likely that the somptoms directly referable to puluonary senosis depoul upon its degree and upon the association of other developmental defects even more than upon the obstruction itself.

Physical Signs.-Iwspection.-Cyanosis is not always present in congenital cases, and when present is not uniform throughont the body. It is this blubh tint which led old writers to assignate the molerlying abmomality by the generie term of Morlus Cerulens. Cranosis is most applarent on the cheeks, eans, fingers. elbows, and knees, and is intensified by comghing or physical exertion. As shown by my case, it is not so likely to be present when the stemosis hat not led to or is not associated with lefects, as, e. $2 .$, patency of the foramen ovale or of the interventricular sirptum.

In the acpuired form patients are more apt to show pallor of the comntenance, and there may be turgescence of the superticial veins as a lirect result of interference with the outflow of blood from the right heart. Inspection of the procoldium detects bulging over the situation of the right ventricle-i. e., at the lower end of the stemum and the parts immediately adjacent. Such a bulg- 


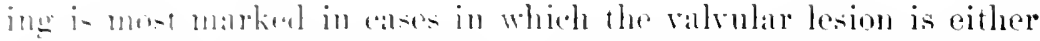

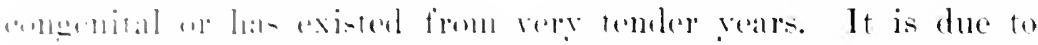

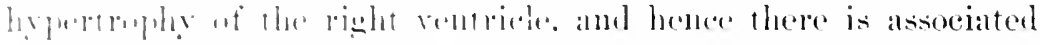

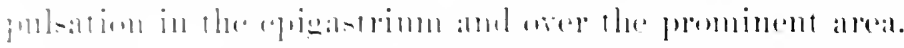

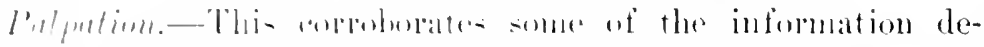

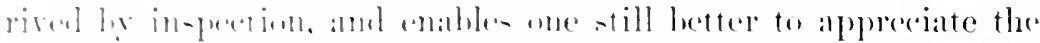

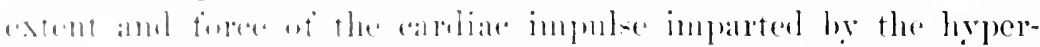

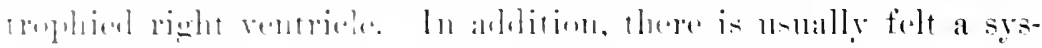

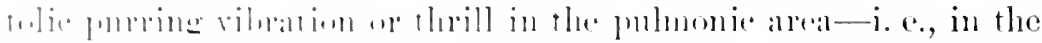

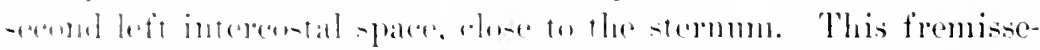

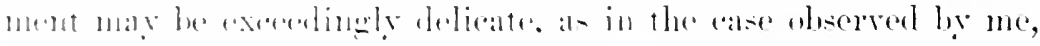

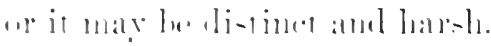

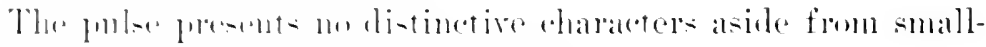

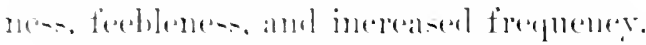

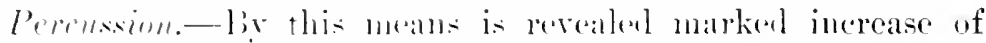

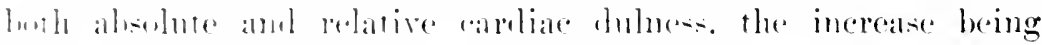

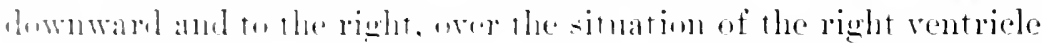

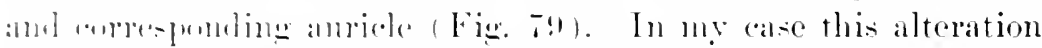

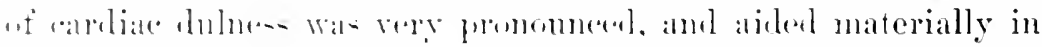

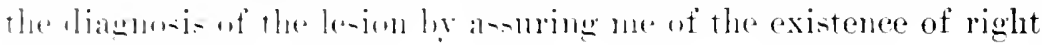

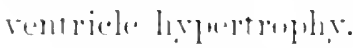

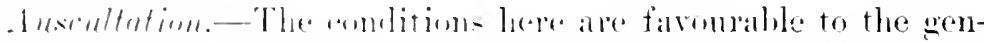

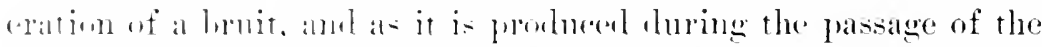

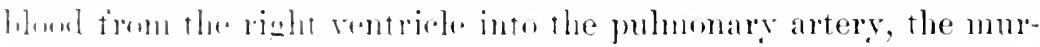

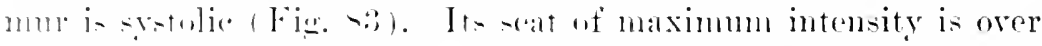
the hase of the heart. alt the le fo of the sternum, in the second and

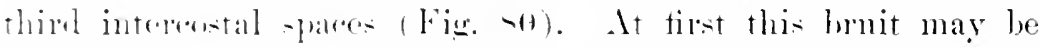
theneht to he antice in wigin, lut if it - lirection of propagation is

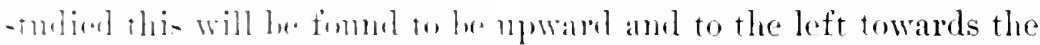

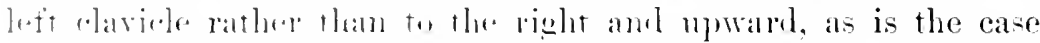

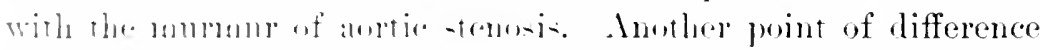

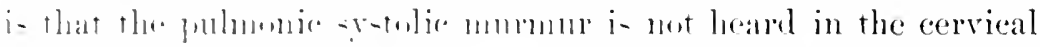

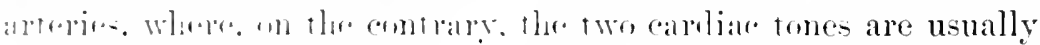

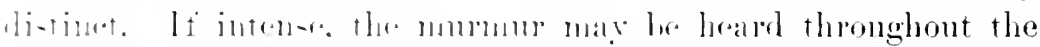

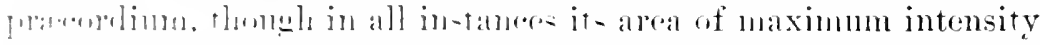

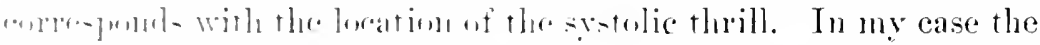

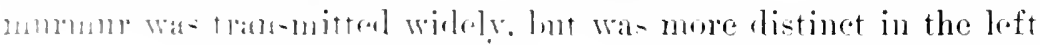
that in the rigle half of the thoma. In allecultating towards the

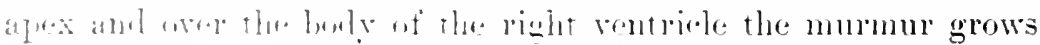


less intense, while the two cardiac smme become more distin.t. The mumme may be rough and lond, or soft and faint. The pul-. monic second somed is liminished in intensity, or may be absont altogether, whild the two aortic somds are distinet.

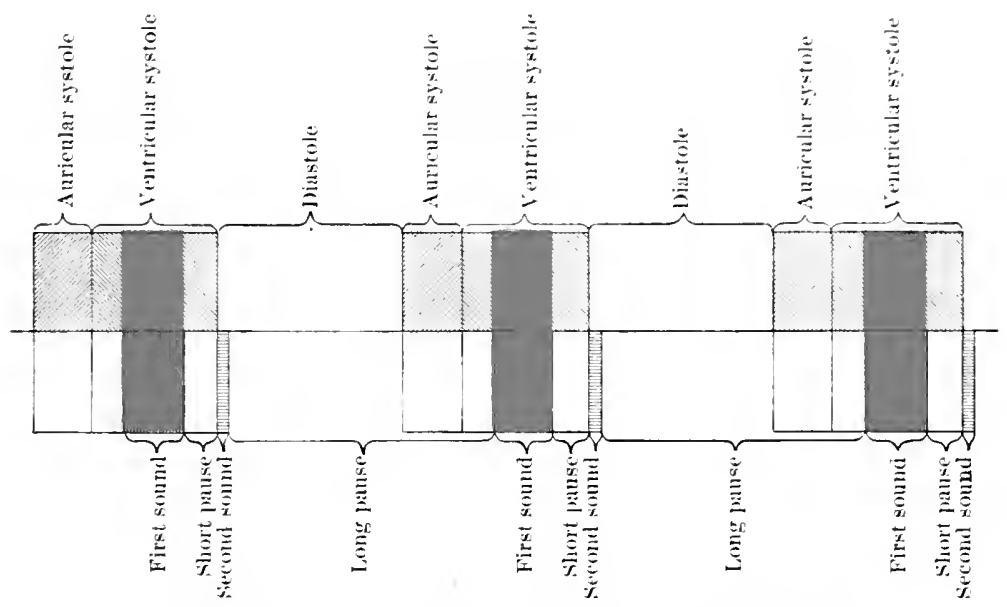

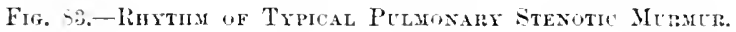

Diagnosis. - The difticulty of diagnosis in this affection lies in its differentiation from aortic stenosis or posibly in deciding whether the bruit may not be aceidental, since it is situated where such an aceidental mumm is so often heard. If, hwwever, proper attention is paid to the secondary phrsical signo as described above, in partieular to the evidence of hypertrophy of the right, not of the left rentricle, one can searcely fail to interpret the murmur correctly. If after such eareful stuly of all the physical signs doubt is still entertained, the sphromograph will be found of service in enabling one to differentiate between this lesion and aortic stenosis, for it goes without saving that pulnomary obstruction ean in nowise modify the characters of the rarlial pulse. Finally, the discovery of pulnomary tuhereulosis and of eranosis in cases in which the two lalves of the heart commmieate, furnishes a certain regree of evidence in farom of the existence of pulmonary obstruction.

Prognosis.-Patients with pumonary stenosis rarely live beyond the third deeade. Even when the disease loes not directly destroy life, it does so indirectly by predisposing to pulnonary 


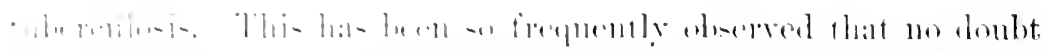

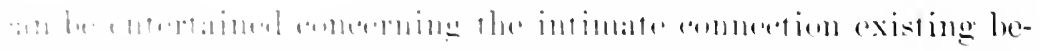

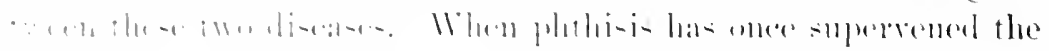

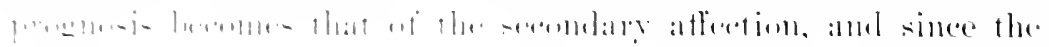

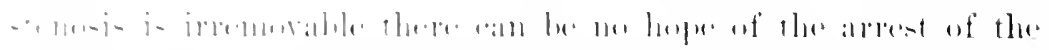

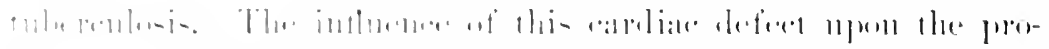

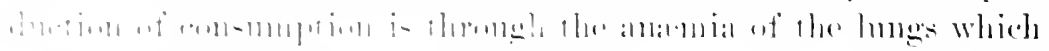

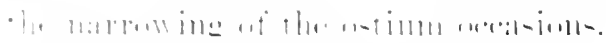

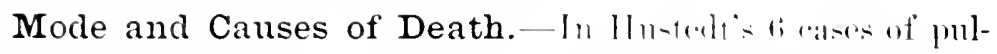

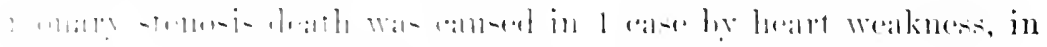

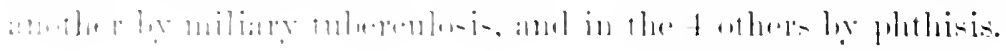




$$
\text { PLLMONARY STEYOSIS }
$$

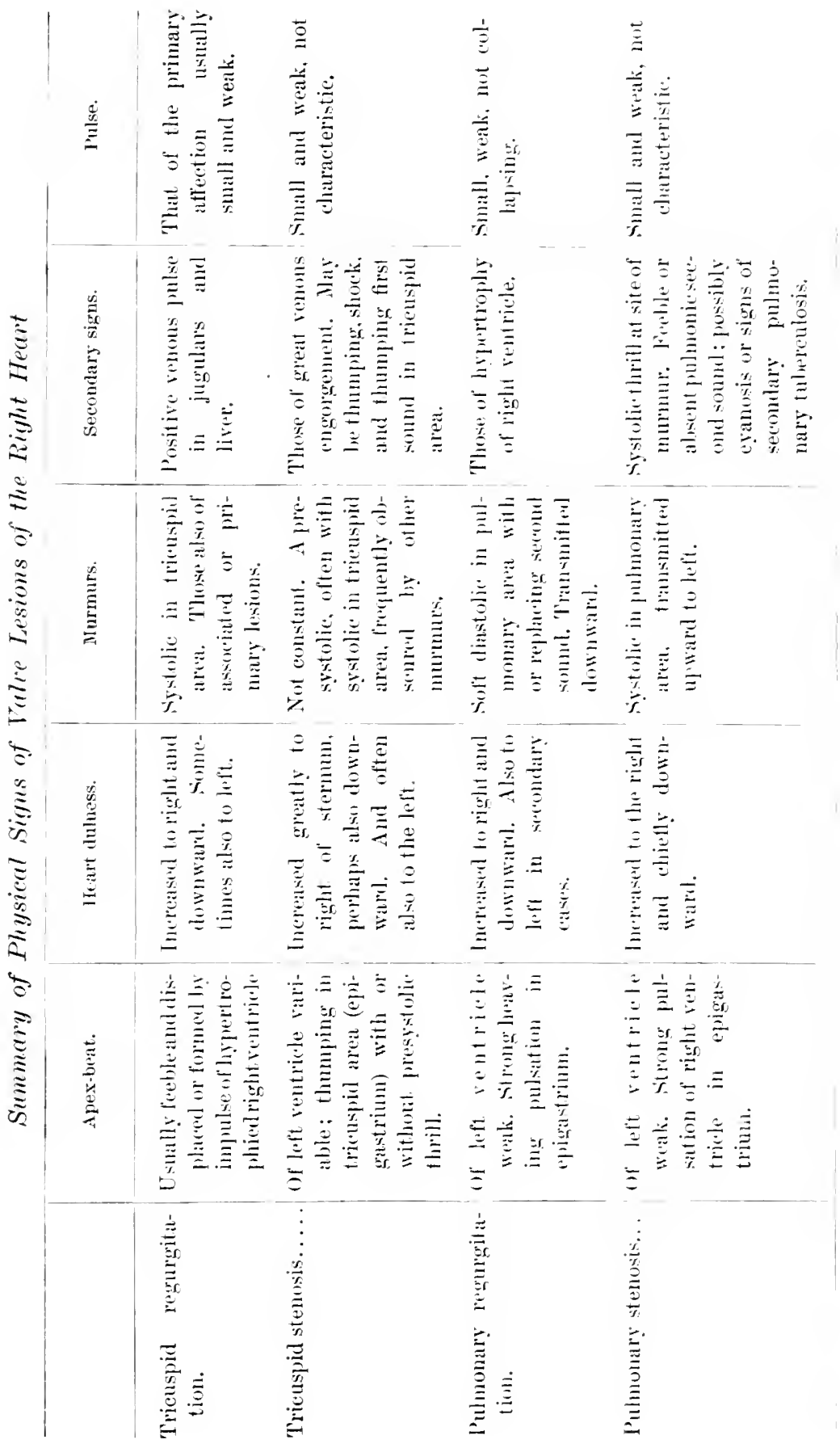




\section{('H.MP'TH Xll}

\section{COMBINED VALVULAR LESIONS}

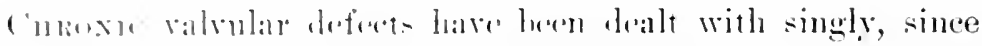
lis - duing their distinetive individual features and be brought

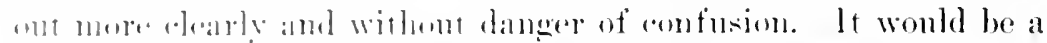

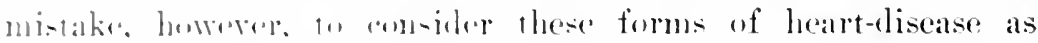

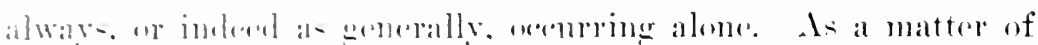
filet certain of them alle m-mally comblined, while it is possible for

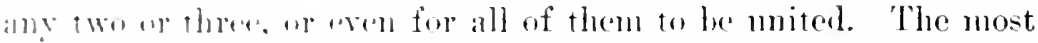

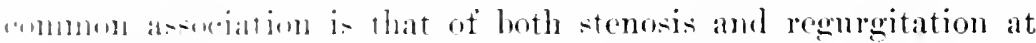
the same writien. Thus it is comparatively rare to find aortic wh-trumtion withut also some insufticiener, or the reverse, while in the anme nammer the two mitral lesims are lsually combined in varying proputims. Inteed, a moment's reflection will convince wor that the -truntural alterations sot 10 ly endocaditis are very Jurne to re-ult in lwoth incompetene of the valves and natrowing uf the astimn, the elinical features of ath ase being determined lis the prethominant lesion.

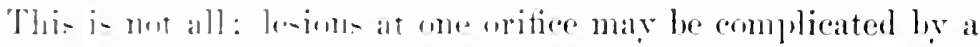

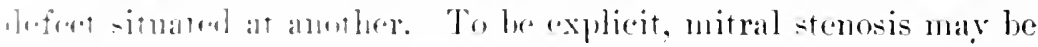
anulinend with either antic semeis or regurgitation, or both, and the sanc way with min mal insutheieney, or a donble mitral discase

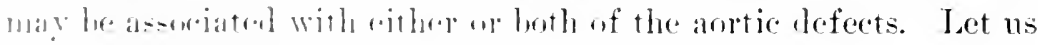

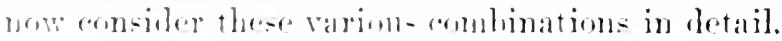

\section{COMBINED MITRAL STENOSIS AND REGURGITATION}

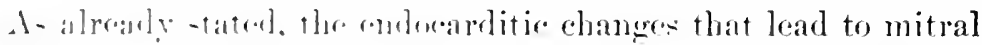

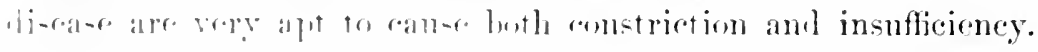

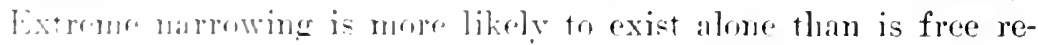

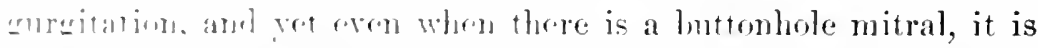

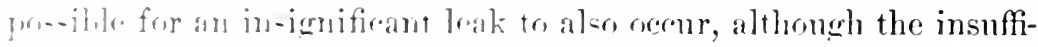

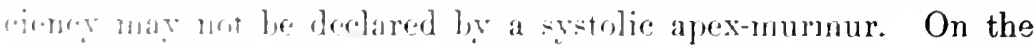
(3) 
other hand, mitral seguneuts that are too stiff to close are quite likely to depend in front of the opening in such a maniner ats to oppose some barrier to the free ingress of the blood from the andicle. In children the mitral curtains are not inferpuently so shrivelled as to form a nuere fringe abont the ring, and when such is the case stenosis is absent. In adults, particularly when the incoumpetence is the result of atheroma, pure and mmised regurgitation is the exception.

The effects on the heart are essentially those of either form of mitral disease when existing alone, and ret the lett ventricle and left anricle manifest certain modifications depending npon the association of stenosis with incompetence. The rentricle is neither so dilated as in mumixed rewroitation, nor so atrophic as when there is extrenc obstruetion. Similarly. the left amicle is moither so hypertrophied as in predominating stenosis, nor so dilated as in free regurgitation. When comjoined, the two lesions, therefore, exert a somewhat restraining influence upon each other as recards the secondary effects on the cardiac eavities directly affected. The changes in the right heart are those incident to retarded pulnonary circulation, and their extent depends upon which of the two lesions predominates.

Symptoms. - The simptoms depend upon the degree of compensation, and this on whether the stenosis or the reguratation is the greater. They have been described in considering the respective mitral defects, and do not need to be recapitulated.

Diagnosis. - The diagnosis is as a rule not difticult, fur the reason that the signs of the two diseases are combined with varying distinetmess in lifferent eases. The apex-beat is not so displaced nor so foreible as in meomplicated regurgitation, nor, on the other hand, is it so distinetly thmmping as in pure stenosis, but presents the characters of both affections. There is msmally a presystolic thrill at the apex. but it is less long and less intense than in stenosis alone, being commonly only a short vibration, which seems to be merely a prolongation of the apex-shock. Cardiac dulness is increased transversely, but chiefly to the right, and the pulmonic second sound is accentuated.

Ausentation detects a combination of both a presstolic and a systolic murmmr, the latter being well marked as a rule, and the former long and relatively pronomeed, or short and difficult of 


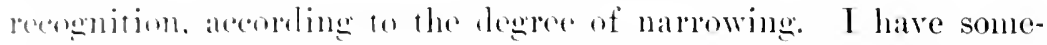

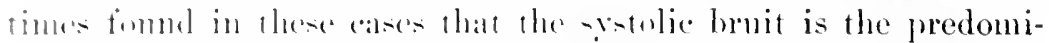
nant ane in the "rect position, while in the dorsal deenbius the

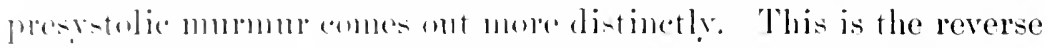
uf what has laen stated as the rule reanding the influence of

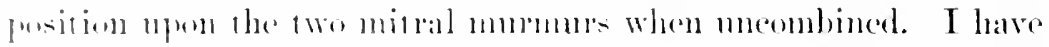

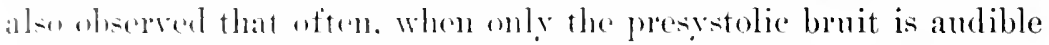

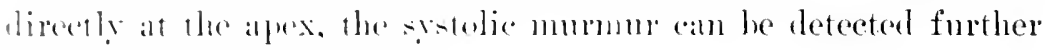
to the left and an the back.

Prognosis. -The pronosin in, other things being equal,

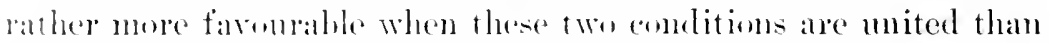
when eidere exists alome, and I beliere for the reason that they temel tor eherk eath other.

\section{MITRAL STENOSIS AND AORTIC STENOSIS}

This is an excectingly serions combination. since at both of the left estia there is a meehanical imprediment to the passage of blood fomn the pulumbary into the andic sytem. The left rentricle re"rives and disclameres an abmomully small rolume of blood, dejemeling on the dexpere of eonstriction, and hence is a thick-walled "hamber of limitul capacity, while in marked contrast are the ereatly hyperrophied and dilated left anricle and right ventricle.

Symptoms. - Srmptoms aplear tar and are pronounced in consegurnee of the ereat stasis within the lungs and body generally. Cyanus and lyspmeal are present, often in an extreme

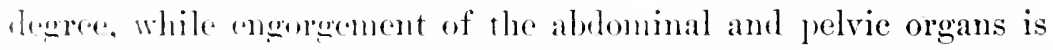
-brom by all ut it attemdant phemomena, both subjective and 1.joretive.

Diagnosis. - Tl!r pul-e is small, weak, and slow or aceeler-

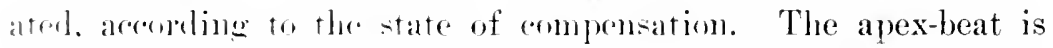
weak and precoded ly a presystolic thrill, mnless indeed it be proluresl by the inpulse of the lypertrophied right ventricle, when it may he diffused and puite strong hetweren the sternum and left niplile.

Ejponatric pulsation and a marked increase of absolute and relative "ardiac dulness to the right evince the secondary enlargeundut of the right hrart. There are heard a rough, low-pitehed

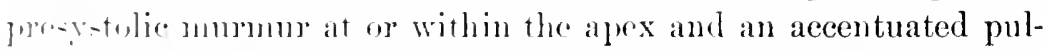
monje second ormul indicative of the mitral lesion, and in addi- 
tion, a harsh systolic but in the aortic area with a fecble second tome, showing olstruction at this olifice.

Prognosis.- The prognosis is of necessity very mfavomahle, since compensation camnot long be prescred, and when hroken can be restored, if at all, only with great difficulty.

\section{MITRAL STENOSIS AND AORTIC REGURGITATION}

This is also a serions combination, ret the degree of its gralrity is determined by the extent and predominance of the lesions.

The secondary effects on the heart are those produced by obstrueted outflow froin the lungs and left anricle, together with such as are usually eaused by reflux into the left ventriclenamely, livpertrophy and dilatation of the left anricle and right ventricle, and in the case of the left rentricle, such a degree of hypertrophy and dilatation as would follow regurgitation of a diminished volume of blood from the aorta, liminished in consequence of the stenosed nitral opening. In one case the mitral lesion predominates, and the effects on the heart and circulation are essentially the same as in meomplicated mitral narrowing. In another this defect is subordinate to the aortic lesion, and the secondary changes in the heart are chiefly such als are found in aortic insufliciency.

Symptoms.-The symptoms are consequently determined by the predominating lesion. In all examples of this combination there is more or less clyspnoa of effort, but when the mitral surpasses the artic defect in gravity this symptom is more pronomneed.

Thus I have observed two female patients with this combination. In one the aortic regurgitation was plainly the greater, and she was able to take a fair anomnt of exercise, even slow hicycleriding, withont special discomfort. If the effort became too severe it prodnced palpitation and breathlessness. The other woman in whom the mitral defeet predominated, and was still further conplicated by pericardial adhesions, showed great hepatic and considerable general renons engorgement and complained of wakness and decided shortness of breath upon even slight exertion. Both these patients broke down their compensation while under my observation, and in both this rupture proved irretrierable. The latter was given a course of baths, after having beex confined to bed 


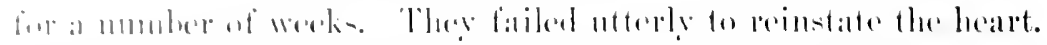

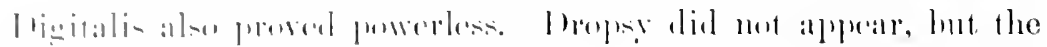

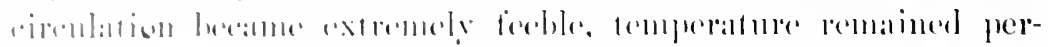

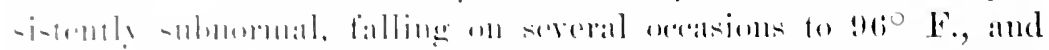

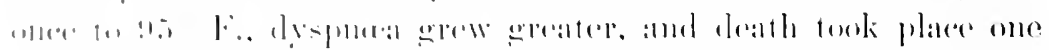

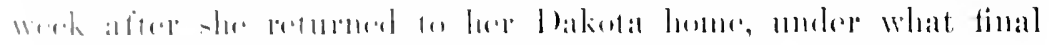

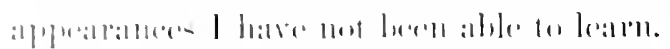

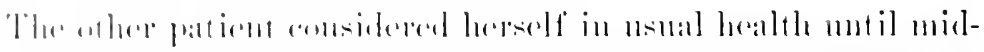

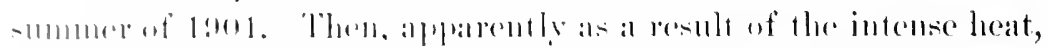

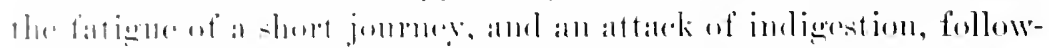

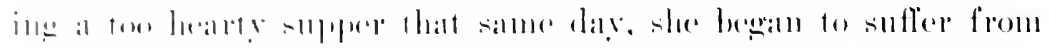

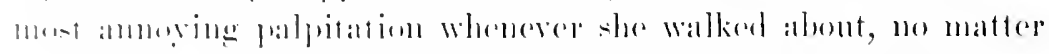

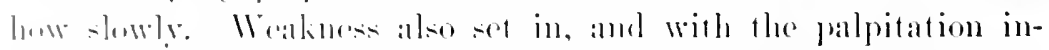

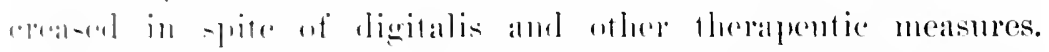

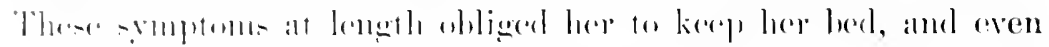

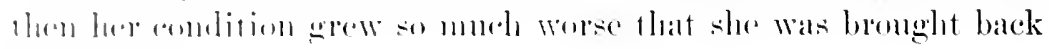

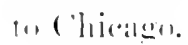

I fomml her in a deploralile plight. The pulso was extremely

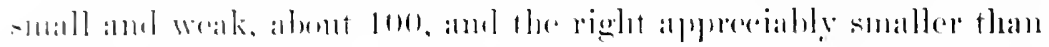

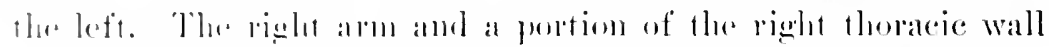

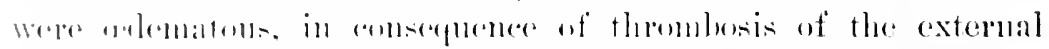

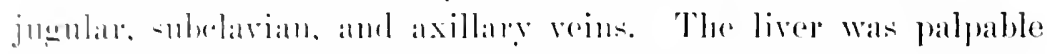

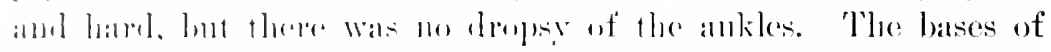

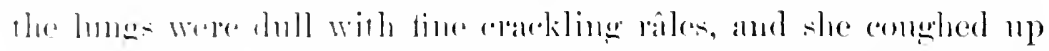

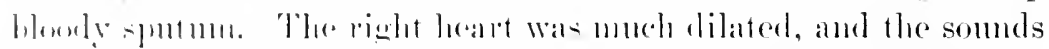

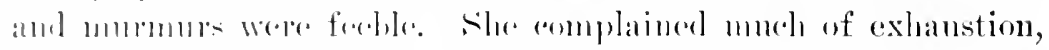

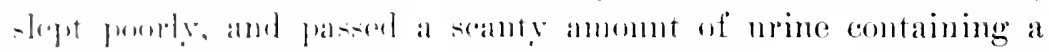
tralere uf allimmin.

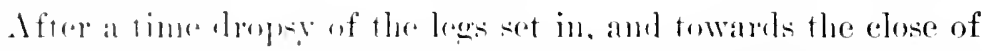

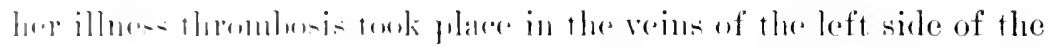

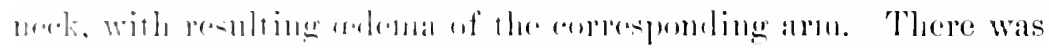

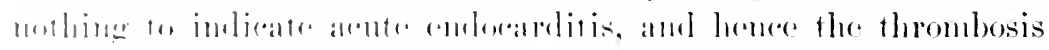

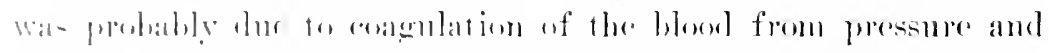

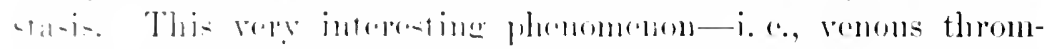

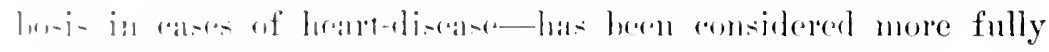

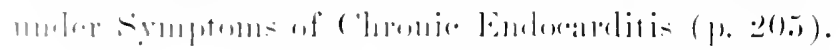

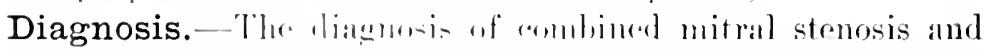

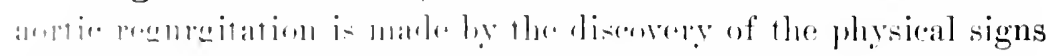

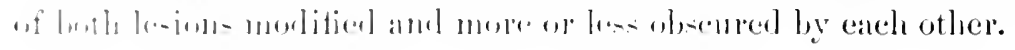


Inspection shows the alpex-beat displaced to the left and downward, as in aortic incompetence, but to a less extent. If the stenosis is considerable, and has led to right-rentricle hypertrophy, there is epigastric pulsation, and there may also be visible engorgement of the superficial reins.

On palpation the displaterd apex-heat is fouml to be less foreible and hearing than in pure antic regurgitation, and there is a more or less distinct and prolonged presustolic thrill, depending on the degree of mitral constriction. The characters of the pulse are also found modified. By reason of the stenosis it is small and weak, while the aortic lesion gives it a collapsing character. In one of my patients mentioned above this was fairly well marked, while in the other it was not appreciable by the finger, the pulse being distinguished by smallness and lowness of tension. In eases in which the mitral obstruction is the chominant lesion palpation is also likely to detect more or less hepatic enlargenent.

Percussion discovers increased cardiac dulness in all diameters, and is of great aid in the determination of the cosexistenere of these two lesions. Mitral stenosis does not canse increalse of dulness to the left of the nipple; and, conversely, aurtic regurgitation does not oreasion increase of dulness to the right. Tet in this combined lesion dulness is increased in both these directions. Consequently, the results of perenssion taken in connection with those of auscultation are of the greatest possible importance.

Auscultation.-This aliso furnishes valuable information, althongh it should never be relied upon to the exclusion of the secondary physical signs perceived ly the other means of investigation. The mitral discase is shown ly a characteristic presystolic murmur at the apex and hy accentuation of the pulmonic second sound, the aortic insufficiency by a diastolic bruit in the aortic area or npon the sternmm, and transmitted dowmard and to the left, while the second tone in the second right interspace is enfeebled or absent. If in doubt concerning the significance of this murmur, one shonld ansenlate the femoral artery, since when aortic regurgitation is also present there is a sharp systolie snap, and it may be also a double murmur in this ressel. Extreme mitral stemosis in its late stages may occasion pulmonary incompetence with a diastolic bruit, and therefore auscultation of the 


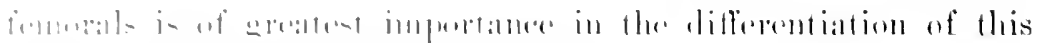

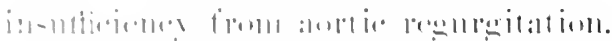

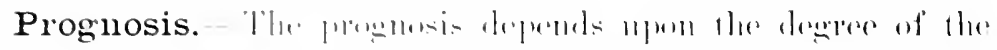

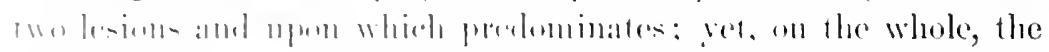

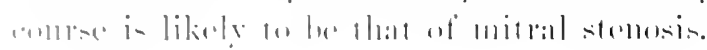

\section{MITRAL REGURGITATION AND AORTIC STENOSIS}

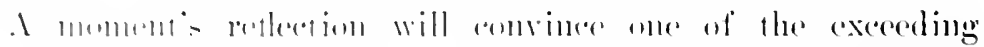

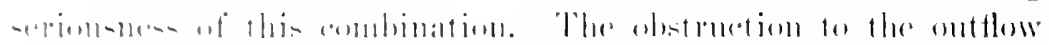

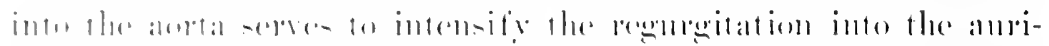

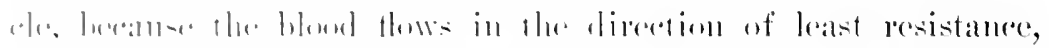

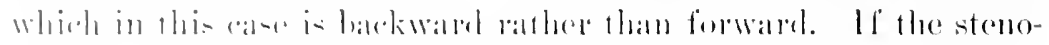

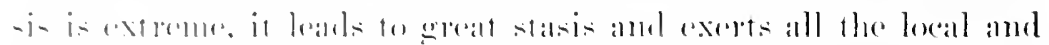

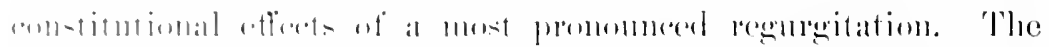

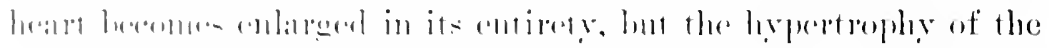

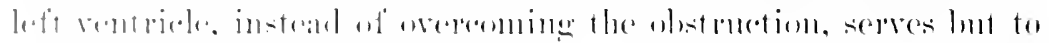

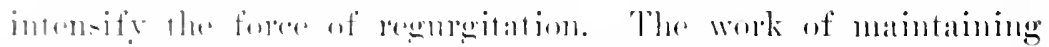

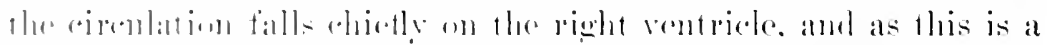

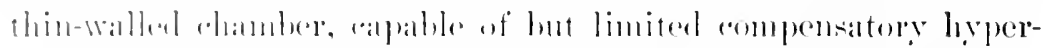

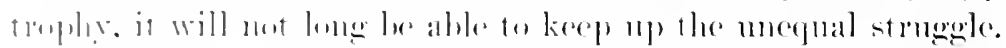

Symptoms a

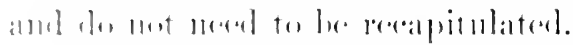

Diagnosis. - The pulse is sulall and forhle, while its rate and

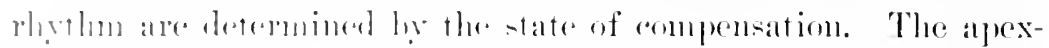

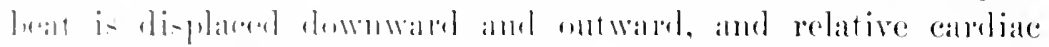

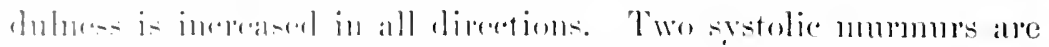

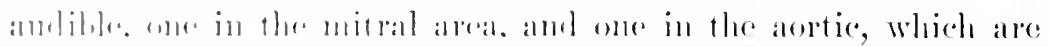

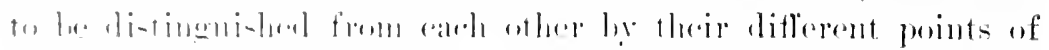

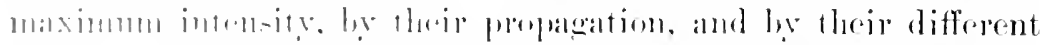

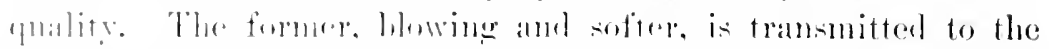

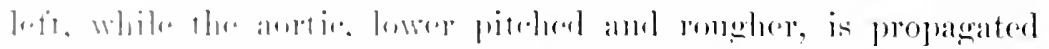

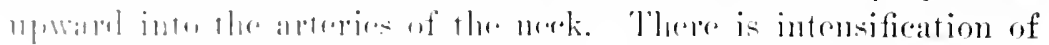

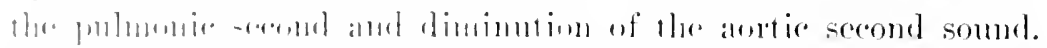

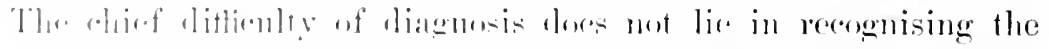

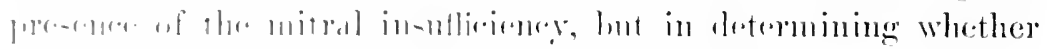

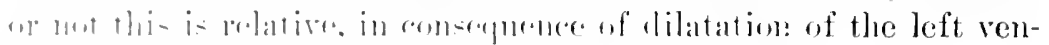

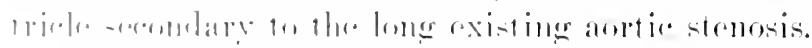

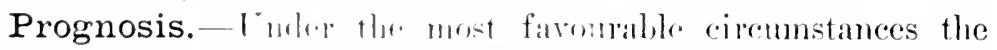

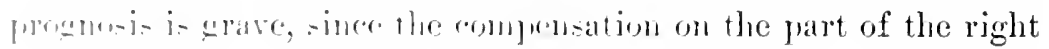


ventricle is likely to be short lived, and when oneo ruptured rannot possibly be restored. Moreorer, hoth pulmonary and triensprid insufficiency are likely to result when comprensation fails, and then render the prognosis hopeless.

\section{AORTIC REGURGITATION AND MITRAL REGURGITATION}

This combination is not infequently encomtered in the late stages of aortic insutticiency when dilatation of the rentriele has led to relative incompetence of the anriculo-ventricular valve. It may, howerer, be seen as a combined lesion when both defects are the result of structural alteration. The eombination is a grare one, and yet, as stated by Bacelli, a double regurgitation of the kind under discussion does not begin to be so serious as obstruction at the artic and leakage at the mitral ostimm.

Symptoms. - The influence of the mitral lesion is to lessen the effect of the artic regurgitation on the general system, since a part of the blood intended for the arota is diverted into the anricle, and the arterial system is not so violently distended by each blood-wave. Arterial tension does not present such a striking contrast during systole and diastole as in memplicated insufticienery of the semilmar valre. For this very reasom, however, the arterial blood-supply to the rarions oroms and tissues is diminished, and there is marked arterial anmia.

In addition there are the srmptoms of venons congestion, only limited by such capacity for compensatory hypertrophy as resides in the right ventricle. The heart is likely to attain enomons size, as shown by the position of the apex-heat far to the loft of the nipple and downwarl. and by great increase of both relative and absolute cardiac dnluess.

Diagnosis. - This is not nsually a matter of much ditficulty. The pulse is small ret collapsing, and there is increased duhess both to left and right. Auscultation reveals both a basic diastolic and apex systolic bruit, with feebleness of the aortic second accentuation of the pulmonic second, and often absuce of the systolic sound at the apex. Inspection and palpation disclose passive congestion of the renous system and abominal viscera. In case the diastolic bruit is likely to be thonght a mitral diastolic one, 


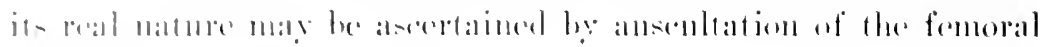

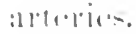

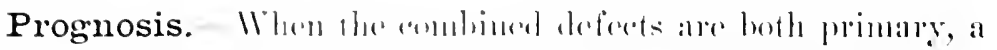
fall dene

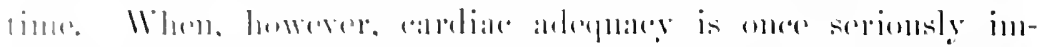

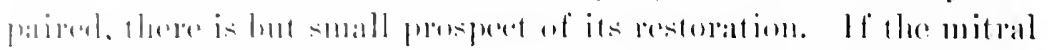

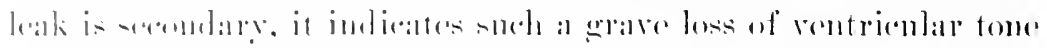

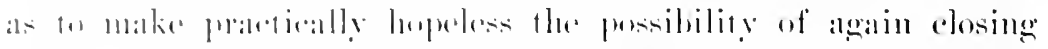

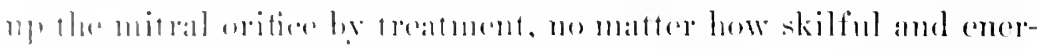

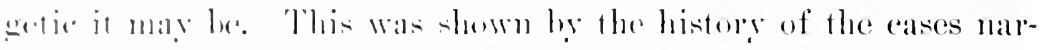

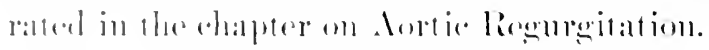

\section{AORTIC STENOSIS AND AORTIC REGURGITATION}

This ambination is mot vere inferpunent. lunt does not exist so uften as the diaguneis is made. This holds true particularly with

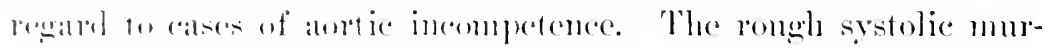

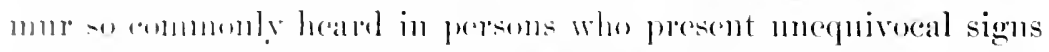

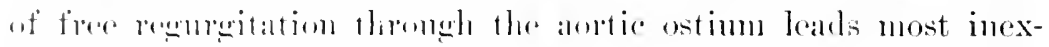

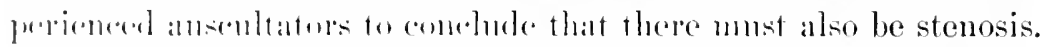

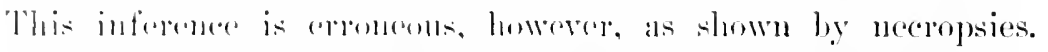

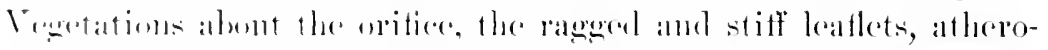

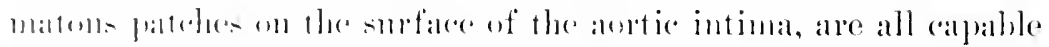

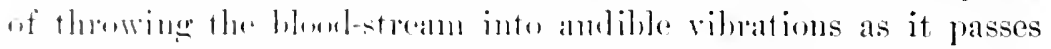
themelo the ring withent in the loast actimg as an obstruction, an inpertant fart in its bearing on the clinical features of the case.

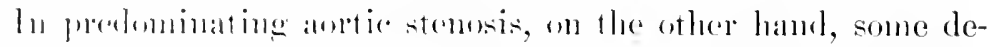

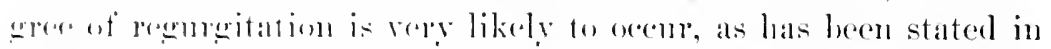

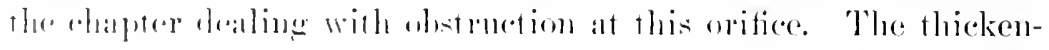
ine and rigility of the ralve flaps, wheh prevout their being

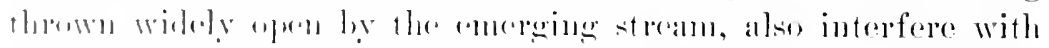

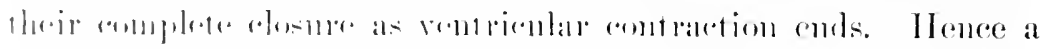

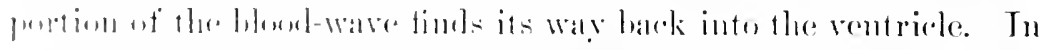
of

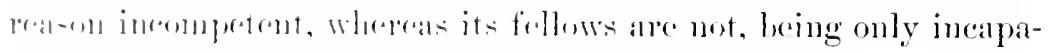

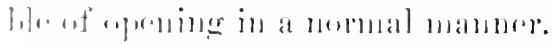

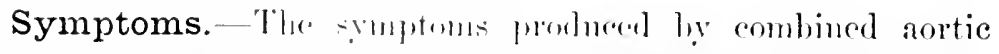

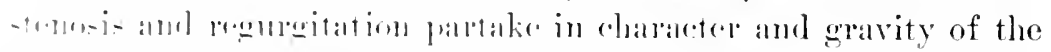

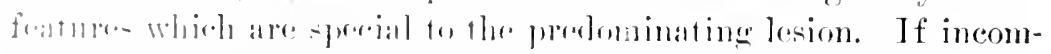

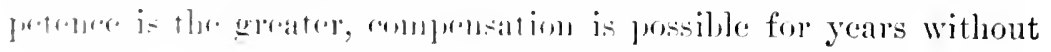


the individual being made awatre of its presence. If stenteis predominates and is pronomest, the left rentriele is not likely to establish such a degree of hrpertrophy as will maintain complete adequacy for very lomg. The rethx, eren if slight, is meatured by actual quantity, is yet sutticient to anse more or lese dilatation of the chamber, and henee the driving foree of its wall is inpaired. Consequently, the patient is more apt to notice some hreathlessuess and perhaps palpitation muder conditions that onght wot to affect him were either stenosis alone or regurgitation alone the lowion.

Physical Signs.--The physical signs are modified also ly this combination, and display in varying proportion the rharrater's of each defect. Thus the pulse is neither so large and collapsing as in pure aortic regurgitation, nor so snall and klow as in uncomplicated stenosis, but is collapwing and also small. C'apillary pulsittion and Duroziez's double femoral hruit are either absent or very imperfectly obtained.

The impulse of the heart against the chest-wall is not so foreible and extensive as in free regureitation, and the apex-beat in size and displacement partakes rather of the character of stenosis. Hypertrophy of the left rentricle is more apparent than is its dilatation with thickening.

The hand is very apt to pereecive a systolic thrill in the arotic area, and pereussion demonstrates that the heart is not so large as in uncombined aortic insufficiences.

There are two mummrs, of which the srstolic is likely to be intense and rasping, while the diastolic is of inferior prominenee in all respects. The sommls nomally heard in the second right interspace and in the cerrical arteries are likely to be absent and replaced by murmurs.

Diagnosis. - The diagnosis of this combination is as a matter of fact very diffient, and it is often impossible to determine definitely whether both conditions are united or not. This is emphatically true if the case is seen for the first time after compensition has failed. Relative mitral insufficieney or promonneed foehleness of the left rentricle may then modify the pulse. sommls, and murmurs in the manner just described. Howerer, if the femoral artery is ansenltated, and the left side of the heart is acenrately outlined by perension, Duroziez's sign will declare the freedom of the reflux, and percussion will demonstrate the enor- 


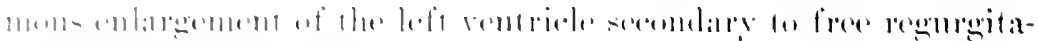

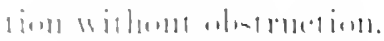

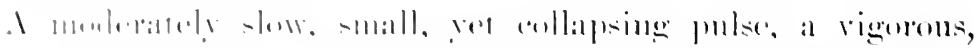

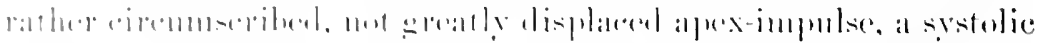

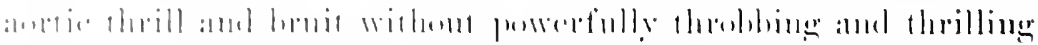

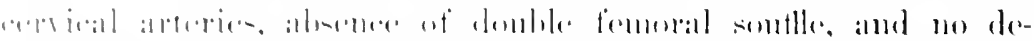

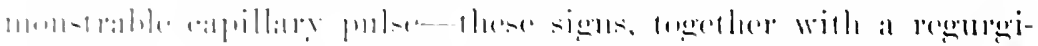

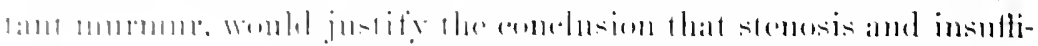

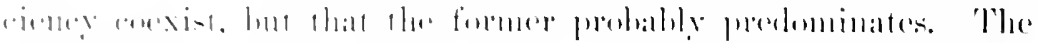

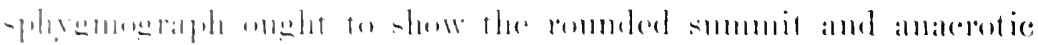

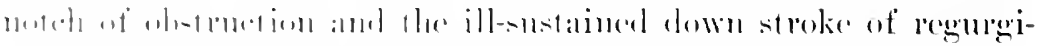

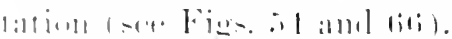

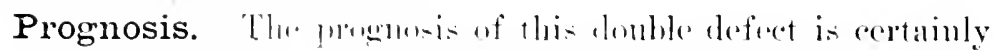

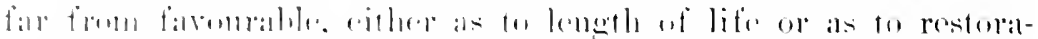

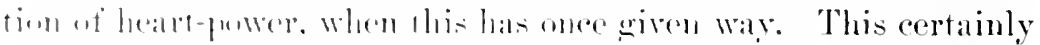

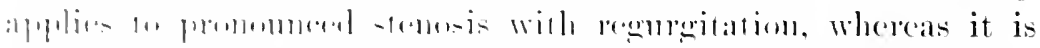

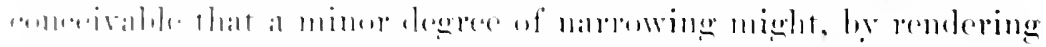

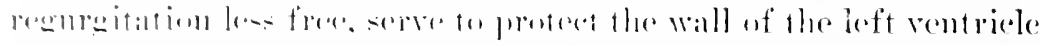

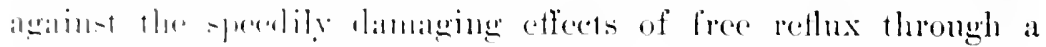
widely patrout urifice. 


\section{('IIIP'TEli X'}

\section{THE PROGNOSIS OF VALVULAR HEART-DISEASE IN GENERAL}

Somethuxa has been said alpeady on the subject of prognosis in the chapters devoted to the individnal valvo-lesions, and therefore some repetition will be unarodalile. In attempting to foreeast the course and termination of a giren wase one shonld consider (1) the special characters of the lesion, (2) the dexpee of the secondary effects in the heart and other organs, and (:;) extraneons factors of age, temjerament, mriromment, ote.

The characters of valrular disease which influenee prognosis are its nature, lócation, and degree, and these cannot always be considered separately. As a general proposition, it may be stated that stenosis is a more serions dofect tham is regurgitation, and ret its gravity depends largely on its location. Furthemone, the amount of disturbance to the cirenlation is determined so much by the degree of the local defect that this latter may render most serious a valvular disease, which from its nature and situation alone would ordinarily furmish a more farourable prognosis. In fact the foreeast is so largery based on the conditions of eareh ease that one would go far astray if he were to be guided by general principles alone.

Although aortic insufficiency is to be ramker first als regauds gravity, still a distinction should be made between cases originating in the young in endocarditis, commonly rhembatice and those of atheromatous origin, observed at or beyomd midalle age. In the former gromp great compensatory hypertroply and a healthy heart-muscle may enable the organ to functionate adequately for many years, far longer indeed than do many ases of mitral disease, although in itself this latter is considered a less serious lesion. On the other hand, when aortic incompetence is dne to a selerotic process, the myocardimn is rarely lealtly and compensa- 


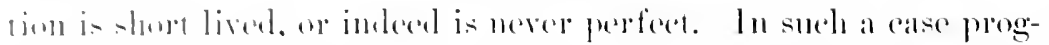

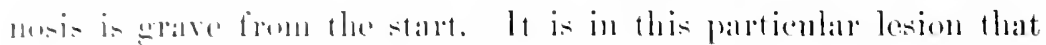

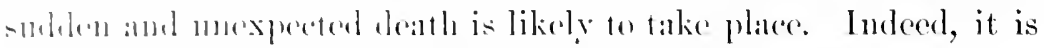

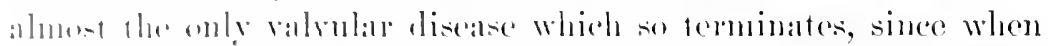

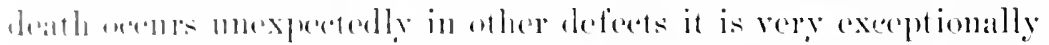

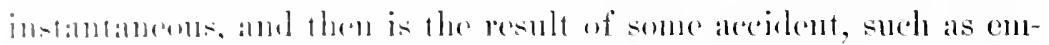

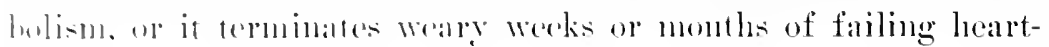
phimer.

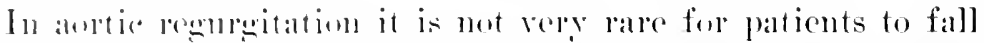
loal muexpertodly in the midst of apparently good health. When-

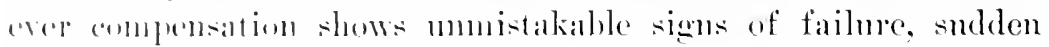
death in this diseaso is not a vory remote possibility. Moreorer, (onmpensation may he lonkm at any time by a rlemmatic attack, and omere impared it is rarely restored. Alsence of the aortie sereme somml amel dilatation of the left rentriele are therefore

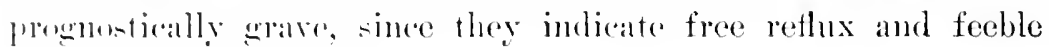
ventrienlatr resistance.

Stomesis of 1 ho andic ring presents a less grave prognosis than luxs regureitation at this orifice. The reasom for this difference is te he fomme in the efferet of the two besions on the wall of the left rantriele. A narpowing of the outlet leads to hypertrophy with relatively little dilatation, muless of comrse the olstruction be so

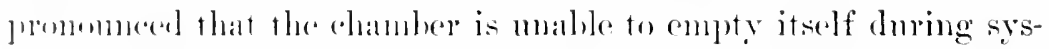

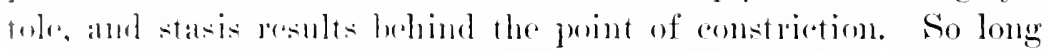

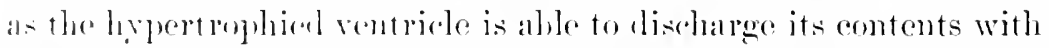
arele contlartion, and the effect of the lesion is limited to the ventricolar wall, the prosperet of a comtimuane of lifo for mamy years without distresing symptoms, and reven of death at the end thromegh

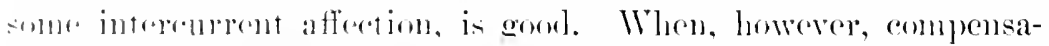
tion in this discase is onere destroyerl, there is small likelihood of

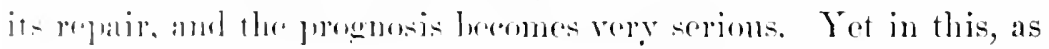
ofluer losions it is its soperity aven more than its natme and locatiom, whirh letromines the degree of its sepionsuess. An extreme

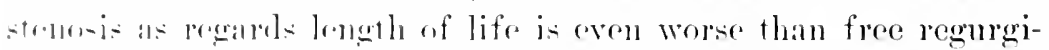

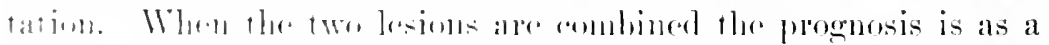

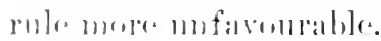

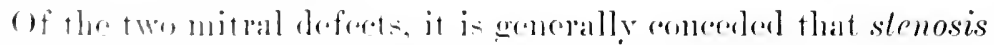

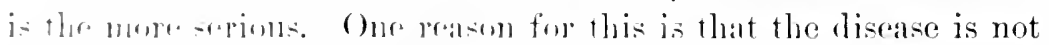
stationary, lout londs to grow mose promonnced in consequence of 
contraction of the newly formed fibroms tissue and of the increase of fibrine deposited upon the regetations. Another reason, as wo shall see later on, lies in the greater intensity of the secondany effects on the heart. Mitral regurgitation, on the ofler hand, is under ordinary circmustances the most faromrable of the fom lesions situated in the left heart. When the leak is not too free and there are no serions complications, such as aortic stemosis and arlherent pericardium, the defect in question is not incompatible with long life and great mental and bodily vigour. It is possible, however, for the regurgitation to be so free that this relatively lenign disease is thereby converted into a very serions one. Leyden states that sudden death occurs in only 2 per cent of mitral disease.

With the exception of relative tricuspid insutficiency, discases of valves of the right heart are so infrequent that nothing needs to be added to what has been said already concerning their prognosis in the respective chapters. Ineompetence of the right anriculo-ventrieular ralves secondary to other diseases is generally regarded as of serious import, not becanse it threatens life directly, having, as it is said, a safety-ralve action, but because it indicates serious disproportion between the degree of the primary disease and the strength of the right ventricle. If it ocenrs with anything like the frepuency claimed for it hy Gilson, then one should not attach to it a very unfaromable prognosis. Nevertheless the degree of importance to be attributed to it depends unch on the nature of the primary affection. It it he secondary to resicular emphysema or to valvular disease of the left side of the heart, as pronomneed mitral stenosis, the derelopment of tricuspid regurgitation monst be looked mpon as an onen of impending lisaster. This form of trienspid disease camot be regarded as a separate and intependent affection, and therefore should be elassed among the secondary effects of valvular disease, which are now to be discussed in their bearing on prognosis.

From the forcuoing it is evident that althomgly the mature and seat of valvular defects influence their prognosis, yet it is their intensity to which we must chiefly look when directing our attention to the heart. It has heen distinctly stated in previous chapters that in estimating the extent of a valvular defect one must not rely upon the intensity of the mummo, but upon the evidences of disordered circulation. These are the seomdary effeets 


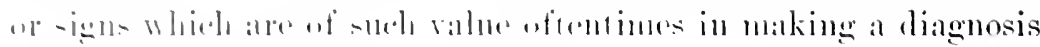

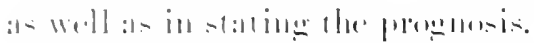

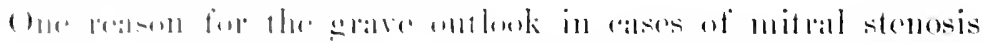

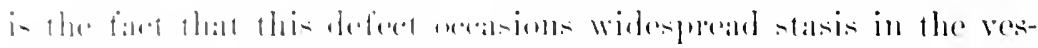

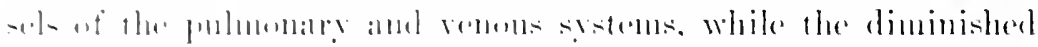

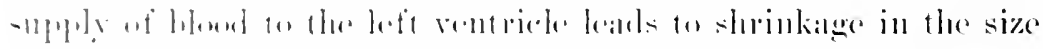

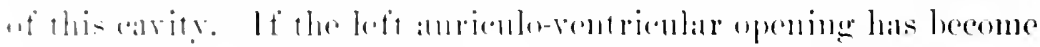

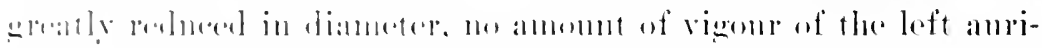

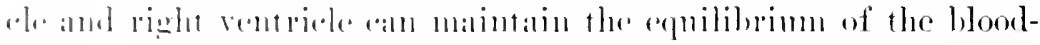

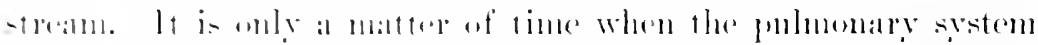

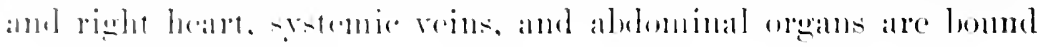

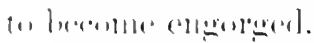

In mitral incemperenee, wh the other hand, the left anricle and

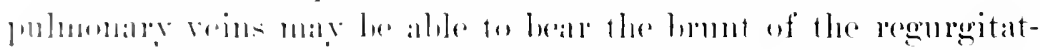

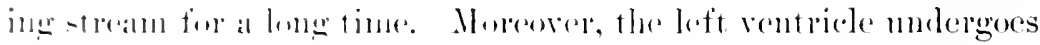

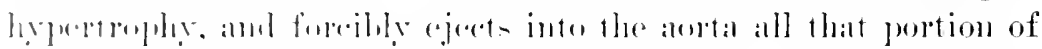

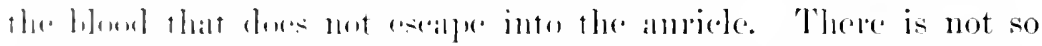

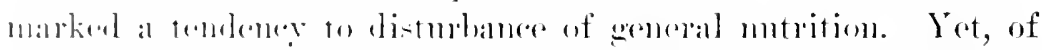

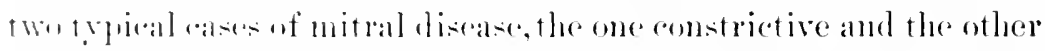

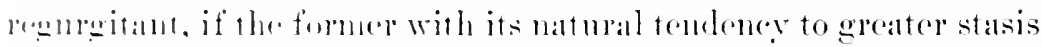

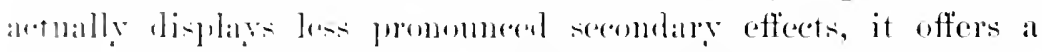

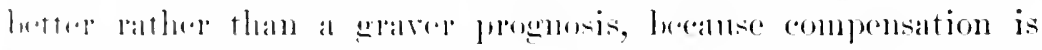
complete. The enemeral vemens statis in the regmegitant case

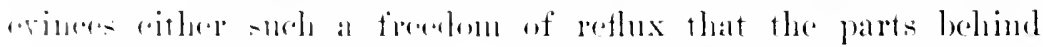

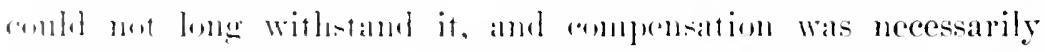
lont. of that compensation was mot alble to take place at all. Even

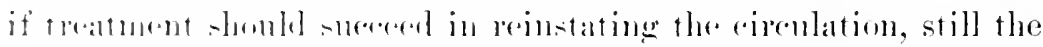

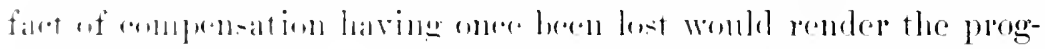

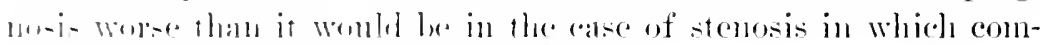

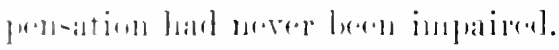

Astin, (․

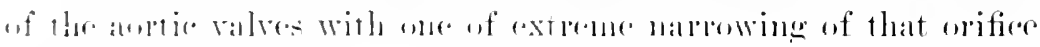
in which ditatation of the left rentriele is hegimning to outbalance

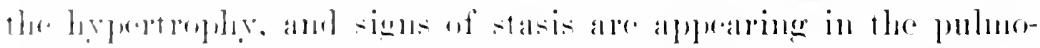

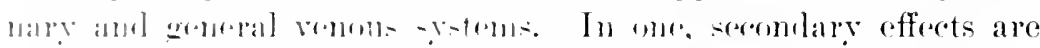

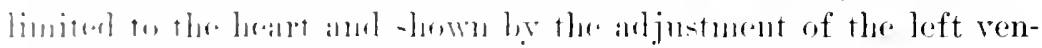

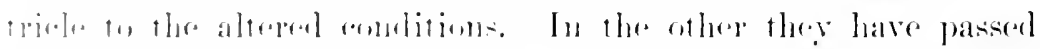

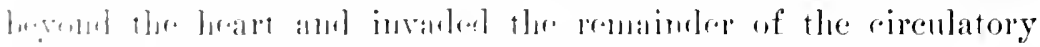
andratu- It is plain that here thre Hegres of the lesion has re- 
rersed the usual order of things as respects the prognosis in these two valvular defects.

The foregoing remarks show how unrelialle would be a prognosis in ralrular heartelisease, which wals mot hased on a careful study of the extent, even more than the nature and location, of the partienlar defect, and that individual cardiar anditions determine the relative gravity of ach case. Nererthelest, I must repeat that my experience learls me to agres with linalbent in the opinion that, generally speaking, andic regurgitation is the most serious and mitral. reanregitation the most farombalile of the four valvular diseases of the left heart. The two stemoses oceny an intermediate position, and of these, mitral constriction is the graver. This subject is still further complicated by the comsideration that there are still other factors that must be recelioned with. For the most part these are of minor inportance, and yet some of them nake strongly for or against an encouraging forecast.

Complications. - The wravity of any valvular defect is necessarily enhanced by the existence of complications, although to what extent is determined in great measme by the mature of the complication. Interemrent acute disorders, which act as complications while they last, are considerext by themselves. Tlere are diséussed only such chronic local alterations and discases of other viscera as must of a necessity mufarombably affect the comrse of valvular lesions. Pericardial adhesions, whether strictly internal or such as bind the heart to some of the surromoling parts, certainly exercise a malign influence, since they interfere more or less seriously either with the establishnent or the maintenance of adequate compensation. Their offect is specially detrimental if by fixation of a chamber in the state of dilatation they prevent its reduction and efticient hypertrophy. I have seen this more than once exhibited in a case of mitral incompetence in which fixation of the left heart threw extra strain upon the right rentricle, as evinced by its ready dilatability. When a chronic adhesive nediastinitis holds the right heart arlherent hack-pressure on the two cave and liver is increased. The psendo-cirrhosis of the liver leads in time to obstinate ascites, and patients sureenub to the hepatic complication long before they would be likely to die from cardiac inadequacy alone. Noreover, an adherent pericardium 


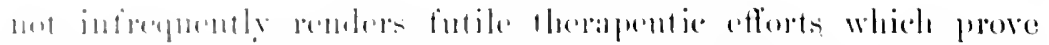

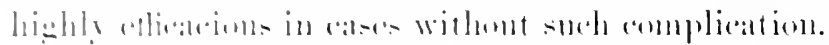

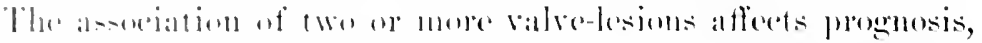

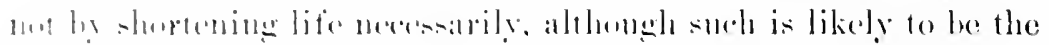

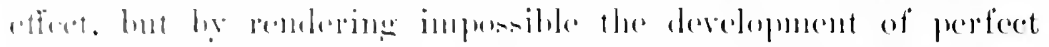

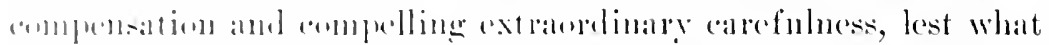

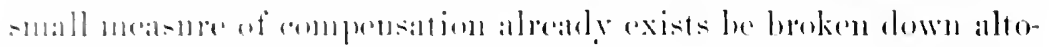

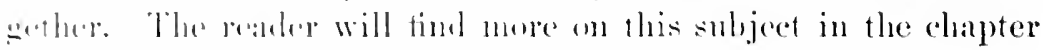

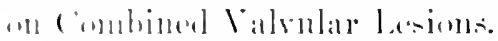

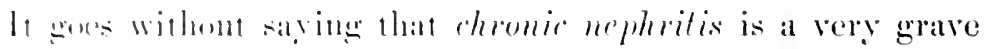

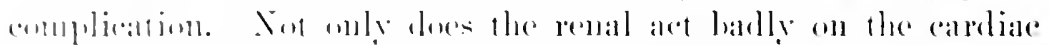
atfortion, hut this lattor, he lowering hlowel-pessure in the renal anteries. intensities the insutheieney af lhe kidneys. The evils of

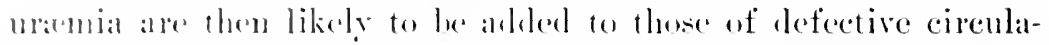
tion. The ehronic nephritis rombers it mulikely that the patient will live ant the tom of yours that womld naturally be gramted him

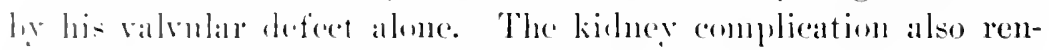

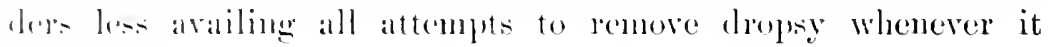
allele:als.

I'nlmenny luberenloxis is mot often seen in combination with

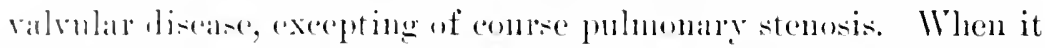

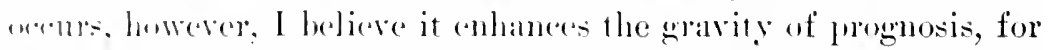
I ramon sec low they am fail to react injuriomsly on each other. Anvluing which. like valvolar discase, impairs mutrition must nec-

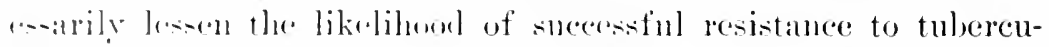

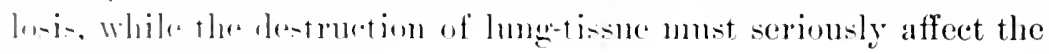

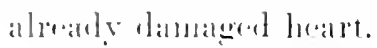

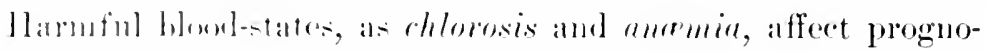

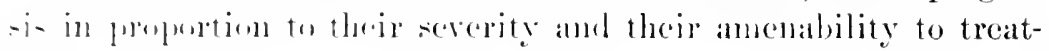
III)

Rheumatic Diathesis.-Sinne indiviluals display a marked

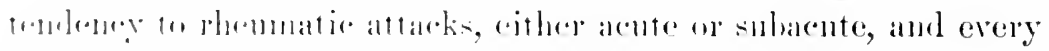

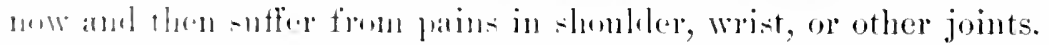

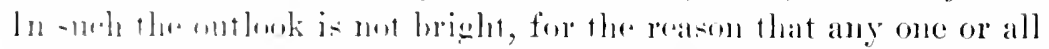

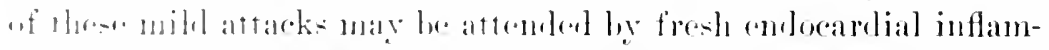

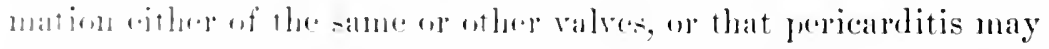

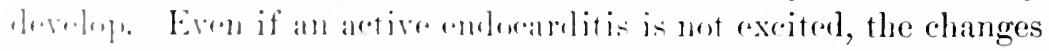

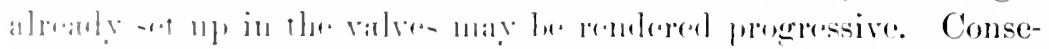

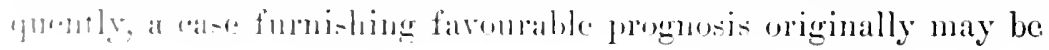




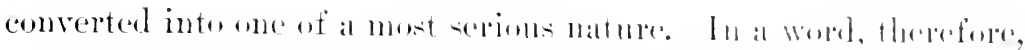

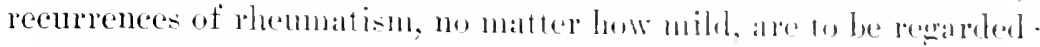

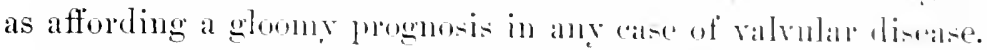

Digestive and Bronchial Disorders.-.These, like rhemmatism, get in a different way, are capalble of unfaromably affoeting prognosis. Disturbance of the diesestive function is not inferepuently

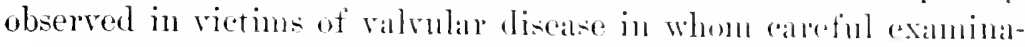
tion fails to detect signs of secomelary effects in other oreans. The chylopoietic viscera may have their function impraperl by lack of arterial blood of good quality, aldiopaths lwing of ten anamic, or in aortic cases by a defective flushing with arterial hlool, or in mitral patients by passive congestion, this last being too slight to be recognised by ordinary means of examination. Whether the indigestion is owing to surh canses or is the result of improper food or faulty habits in cating, it is likely to inpair general, and hence cardiae nutrition, and thus render frowosis less cneouraging:

A tendency to aeute bronchial eatarrhs in mitral patients not only evinces greater pulmonary congestion than is otherwise apparent, but also renders them liable to an attack of bonchitis, which may at any time severely strain compensation. In them, therefore, prognosis cannot be looked upon as so faromrable as if they were less sensitive to atmospheric changes and dicl not so easily get up a congh, for the serere expiratory effort of conghing subjeets the right ventricle to added strain.

Age.-The prognosis of ralvular disease is more seriuns at either extreme of life and most farombable in yome alults. In elderly individuals the myocardimm is apt to be more or less degenerated, and although, as Leyden believes. conpensation is often as perfect as in the romg. it is more easily destroved. Furthermore, the sclerotic process, which is nsually responsible for the valvular defect, is progressive, and one possesses no neans of forecasting whether these changes will progress slowly or rapilly. I recall the instance of a gentleman of sixty-four in whom I detected signs of aortic sclerosis and probable coronary selerosis in explanation of his attacks of angina withont any evidence of valvular incompetence or of stenosis. Yet at his leath, lest than three years subsequently, the antopsy dischsed, I have lexu informed, wellmarked insutticiency of the atlueromatous andic valves, signs of 


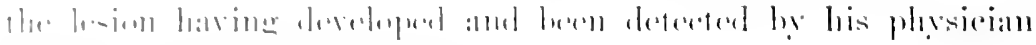

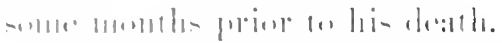

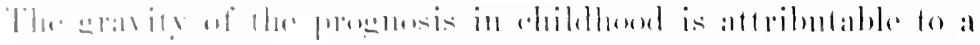

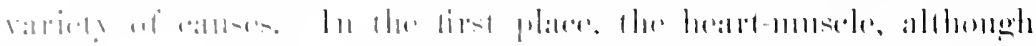

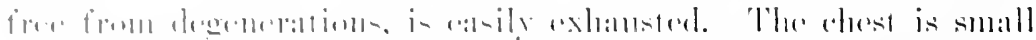

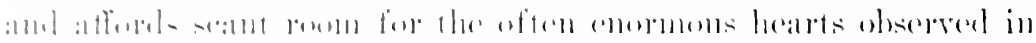

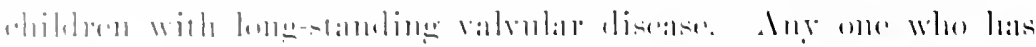

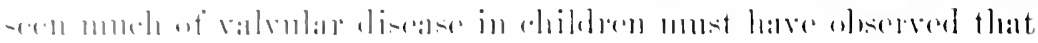

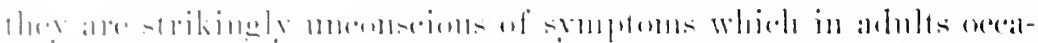

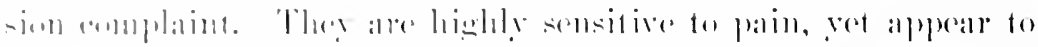

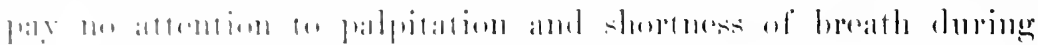

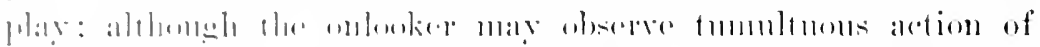

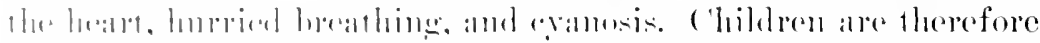

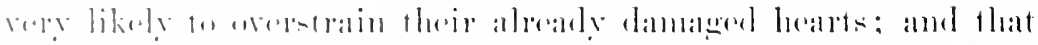

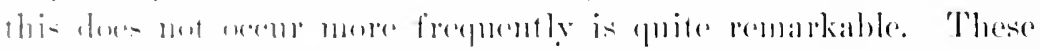

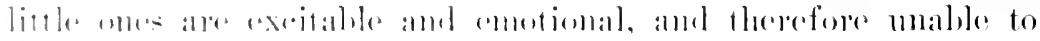

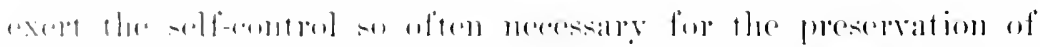
(6)

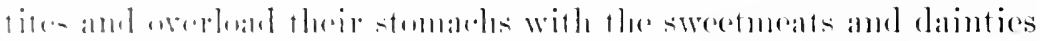

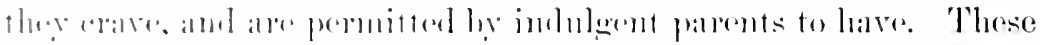

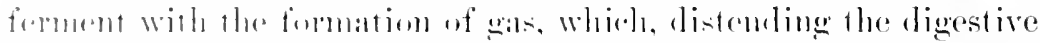

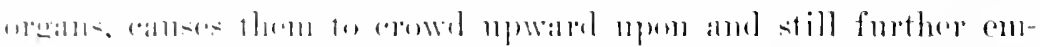

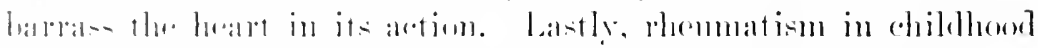

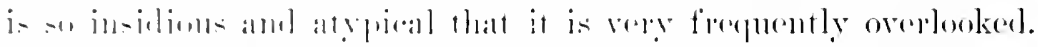

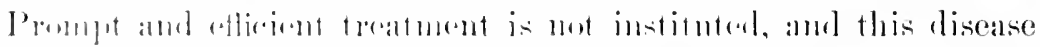

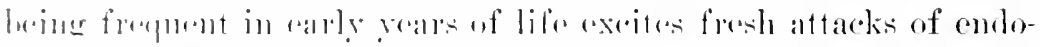

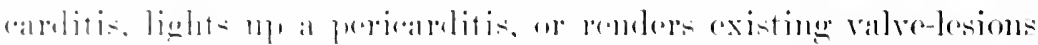

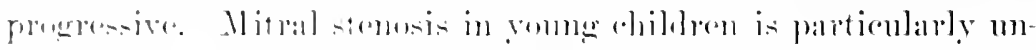

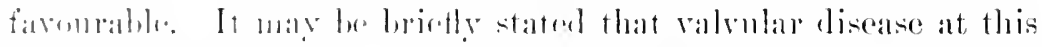
[erobul of lifo i rery likely to and fatally before the patient

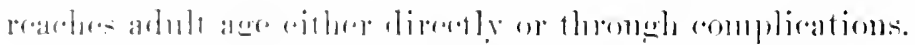

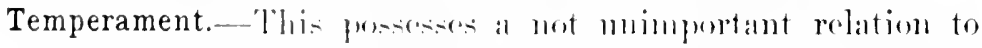

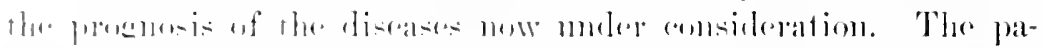

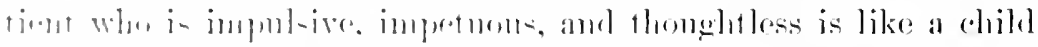

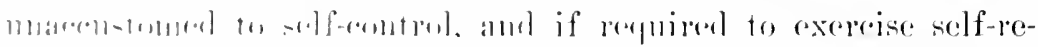

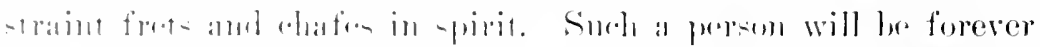

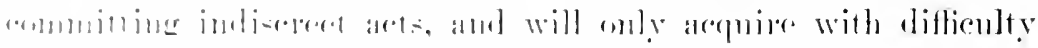

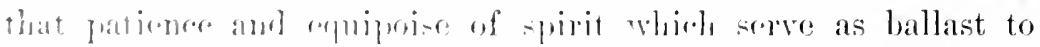

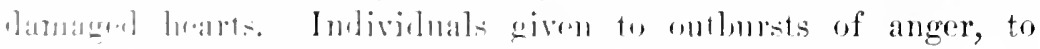


worry, to fretting over trifles, and who appear nover to becone reconciled to their phrsical dimability, an nerer be expected to retain their eompensation so woll or so long as will those who always have themedres well in hamel. Verily, all ambliopaths should bear in mind that Bible utterance, "Je that ruleth his own spirit is greater than he that taketh a city."

Sex.-Mitral disease, and in particular mitral stenosis, is more frequent in the fair sex, while men are more subject to artic insufficieney. In a seuse, therefore, sex may be said to exert a general influence upon prognosis. The inquiry that mo concerns us is how does sex affect the prognosis of a given ralvular lesion after it has once been establisher, withont reference to its nature. In other words, what is the relative prognosis, ceteris paribus, of the same defect in the two sexes. This is a rery difficult mattor for decision, since it involves questions of habits, ocenpation, ete. Females are exposed to eertain perils of pregnaner and childbearing, while, on the other hand, men have to encounter even greater dangers incident to occupations that often produce cardiac overstrain. The reader will find these influenees discussed at some length in the chapter on Treatment of Valvalar Discase in General. One respect wherein women usually furnish a more farompable prognosis than do males is that of habits-that is, a greater freedom from the injurious effects of excess in tobacco, alcohol, and venery. Women are generally held to be more emotional and excitable than men, yet in the matter of self-control they seem to me to possess an adrantage orer their brothers. The most marked instances I have ever seen of apprehension-nay, of alarin aud nervous agitation-lest the examination result in the discovery of a heart-lesion, have been in young men. The fenale sex is more prone to anxmia and chlorosis, and the injurions influence of these blood-states is too well known to require more than this passing reference. In most other respects I think the question of sex resolves itself into that of the individual.

Occupation. - This exerts a powerful influence mon prognosis. The day labourer who earns his laily bread by the sweat of his brow eannot be expecter to keep his compensation intact for so long as will he whose rocation does not subject his heart to the possibility of overstrain. All authors are agreed in the declaration that nothing in the daily life of these patients affects their hearts, 


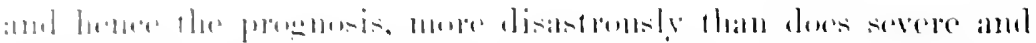

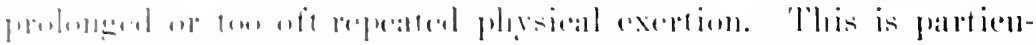

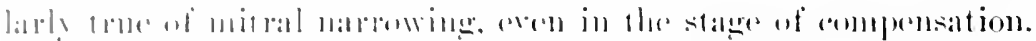

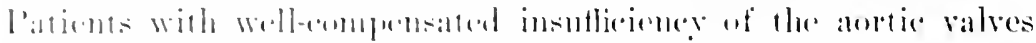

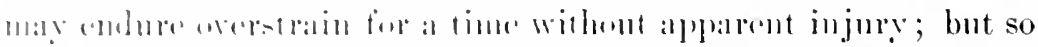

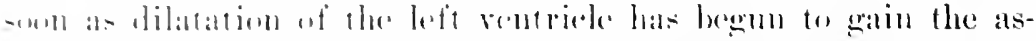

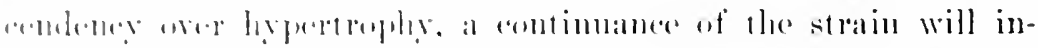

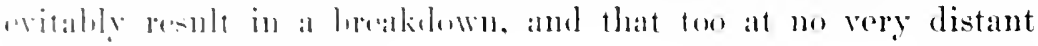
Hate in ment instincers.

Habits. Clhere are matters of ntmost importance if the lives of patient with valvolar disouse are to be prolunged. They -homlel be minutaly impuimen inte, therefore, by the medical attomlant. The daily life of these sufferers should be ordered on the principle of monlaration in all things. Whaterer is injurions (1) a healthy perend is donhly so to one with an unsomed heart.

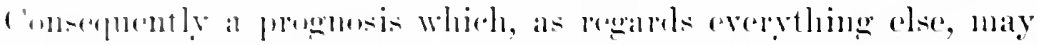

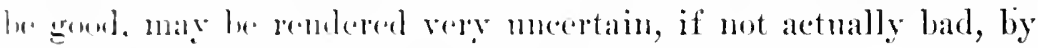
the dienerery of cril practien. By these are meant particularly

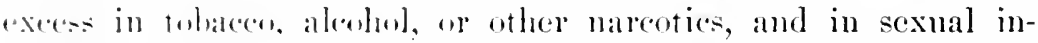
dulecure. But patients may also increase the gravity of prog-

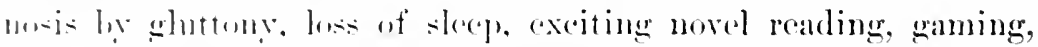
ro.-in shert. hy whatever promotes nervons and cardiac ex"itr.ule.nt.

Home Surroundings.--Thes include all those matters of sanita-

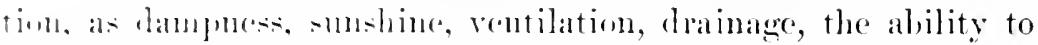

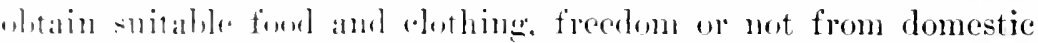

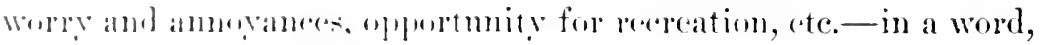
the resilnotial and social enditions which in all of us make for halply. (ontentad lives.

The promeis in the was of the poor man cannot be expected

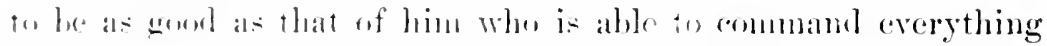

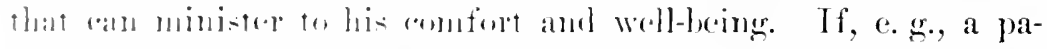
time with mitral - teme- of a falling aortic insufficiency is com-

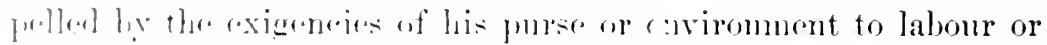

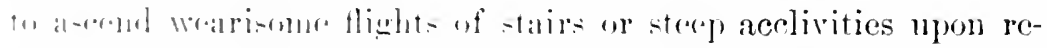
morninge to his bonure, mo matro bow often this may be, he can

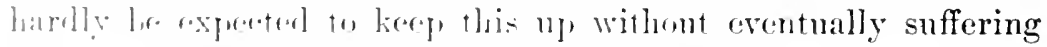
injury. The and many ethere matters may seem too obvious to repuire unention, and yet they are details which the physician 
must take into consideration if he would form a reliable progrnosis.

The Probable Effect on the Patient of the Knowledge of his Lesion.-This is a matter, in my opinion, having a dereided hearing on prognosis, and which, therefore, slould he discussed. Physicians and the laity generally believe a calreliopath must not be informed of the fact when he is found to have a cardiac defect, lest he be alarmed and become norbid and introspective. Doubtless there are many nervons, apprehensive persons who wonk be harmfully affected by such knowledge. When such is the case 1 beliere it renders prognosis less farourable, because if kept in ignorance of his true condition he is not prepared to aroid whatever may be harmful. If detrimental influenees are to be shumed, patients must have explained to them how and why these are injurions to them, since the doctor's dietmon in this reated is not enough for an intelligent person. Kept in ignoranee or put off with an evasive answer, he may be set to pondering and conjecturing, and hence to fancying his condition is worse than it really is. I believe, therefore, that it is a positive gain to a cardiopath to acpualint him with at least a part if not all of the truth. Of comrse he does not need to be informed with brutal abruptness, but gently and in a manner calculated not to frighten him unduly. The individual who cannot bear eren a part of the truth withont detriment will assuredly fumish a less farourable prognosis than he who, knowing the truth, accepts it philosophically, and determines to make the best of a bad bargain.

The Effect of Digitalis on the Patient.-It goes without saying that when valvular discase has reached such a stage as to necessitate the administration of digitalis the prognosis is not good even at the best. Thus much any one knows, but only a few, if any, are able to prognosticate how much longer the heart is going to bear up, even sustained by such a prop. In such a case, as pointed out by Leycen, a certain degree of information may be derived from a sturly of the effect of the remedr.

If the beneficial action of digitalis is quickly lost after its administration has been discontimued, and the heart manifest its need of this tonie by a speedr return of symptoms, the prognosis is serions, for it indieates mrocarelial inadequacy. It is a still more unfaromable indication if from time to time the dose of 


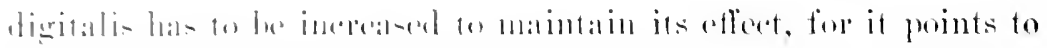

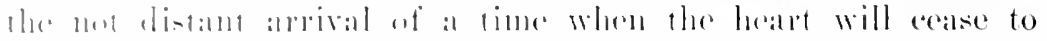

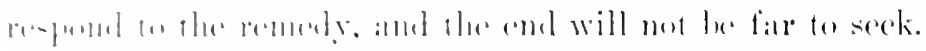

The Relation of Prognosis to Life Insurance.-Thlele wals a lime

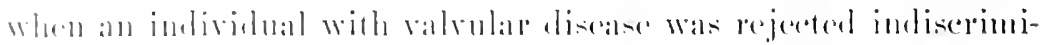

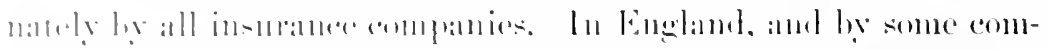

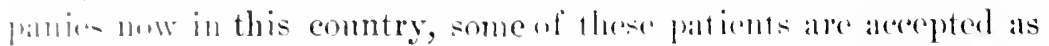
" Jefortive risks." and therefore it is in oprer to discuss this sub-

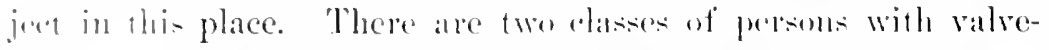
la-inn: whom I would reject except prosibly for a rory limited form of years, and only then at so high a promimm as to make it

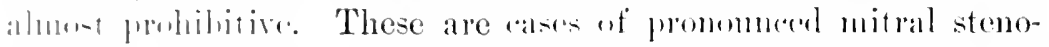
-is and insullivieney of the aortic labllets. Exen when the latter

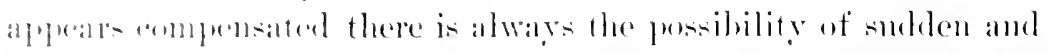

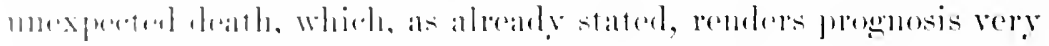

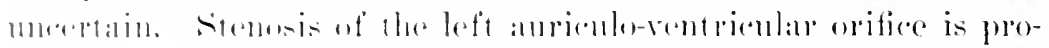

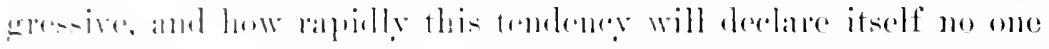

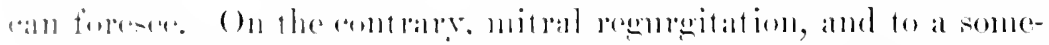

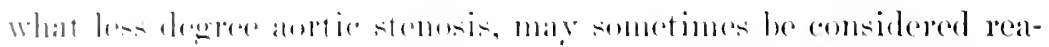
smally sate lis-ks as deforetives. It will be moted that I saly some-

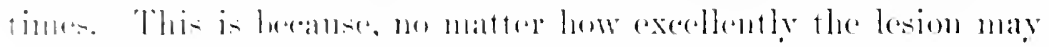

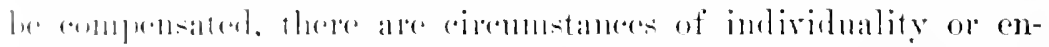

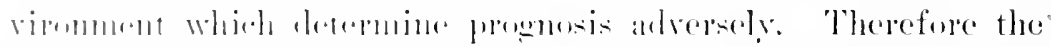

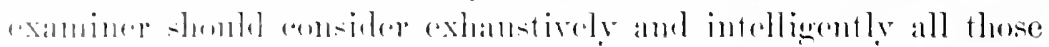

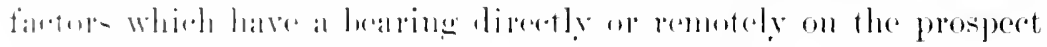

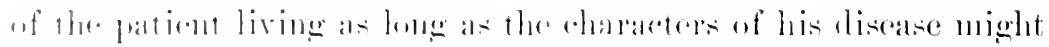

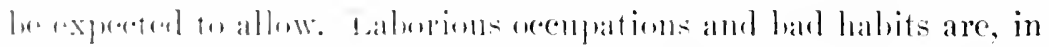

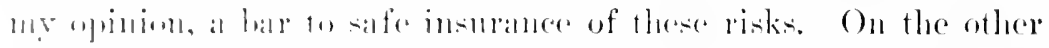

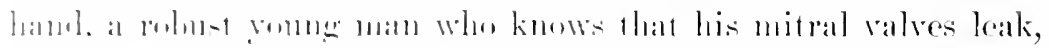

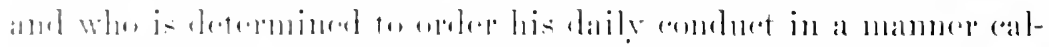

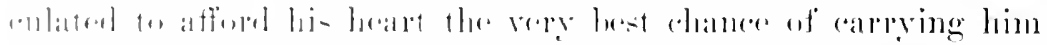

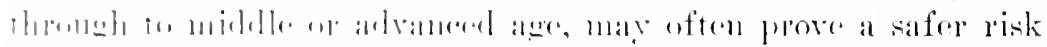

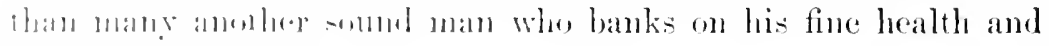

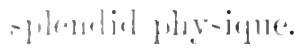




\section{CIIAPTER XYT}

\section{THE TREATMENT OF VALVULAR HEART-DISEASE}

Frons a therapentic standpoint, cances of valvular divease are to be divided into three classes, according to the state of compensiltion: (1) Those in which the lesion is compensated, (2) in which compensation is incomplete, and (:3) in which caldiale inadequacy is so pronemeer that compensation is wholly wanting. We call a ralvular defeet compensited when the cardiac pump, in spite of its defect, is able to mantain the circulation in nearly or quite its normal state, and there are no symptoms to make the patient aware of his malady. Under such ciremustances laborious oecupations, athletic exereises, and games or outdoor sports requiring considerable strength and agility are endured without more breathlessness or palpitation than are usmal with persons haring sombl hearts. In the second cliss, patients are still alble to perform their daily duties and engage in some of the less serere sports, but it is with more or less distress and revident signs of heartstrain. There are different degrees of imperfect compensation in this class, and hence it is one of wide limits. In the third class, in which compensation is wholly lost, patients are not only inciapacitated for physical exereise, but the circhatary disturbance is shown by stasis, generally by adema, and by suljective symptoms that are present even when the patient is at rest. When compensation is perfect, eximnination of the heart cliscloses the existence of a lesion, but no secondary effects in the ganeral circulation. In the second class signs of more or lese visecral and remons congestion are detected, although subjective srmptoms may be insignificant, and in the third these reach their severest grale. It is evident, therefore, that treatment appropriate to the last stage is not indicated in the first. Teither do patients whose compensation is still maintained intact require the same strict management as do those who are beginning to manifest failing heart-power. Conse- 


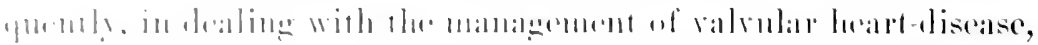

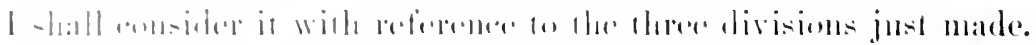

\section{1. (แ.)}

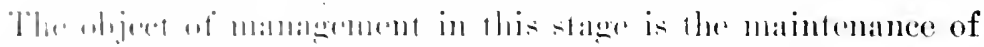

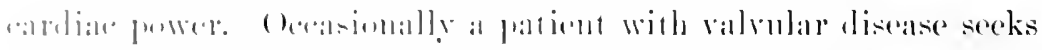

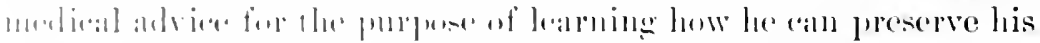

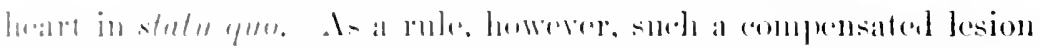

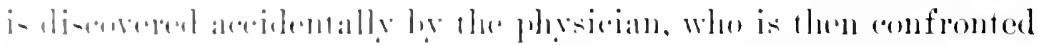

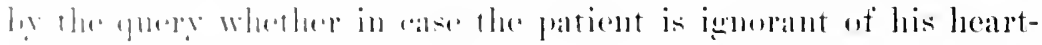

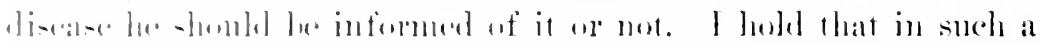

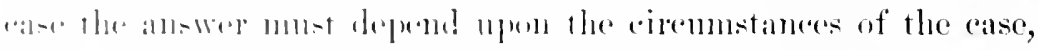
-110 h as the romperament of the imlivilual, his habits, and the

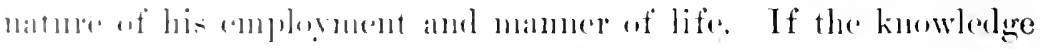

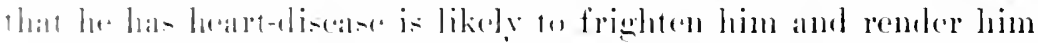

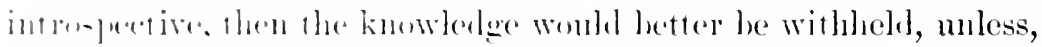
of andrse ho is lealing a kiml of existence calcenlated to break

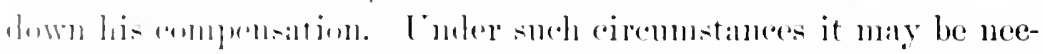

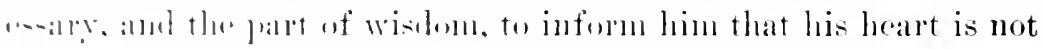
-

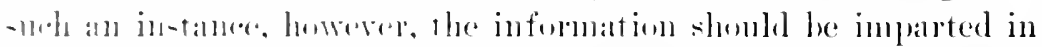

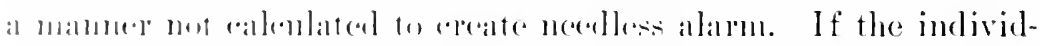

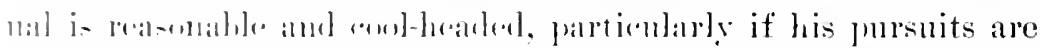

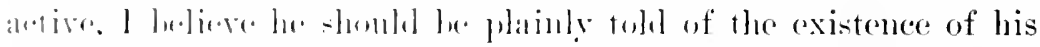

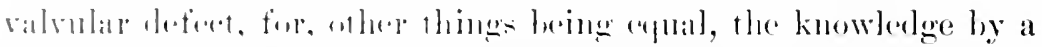

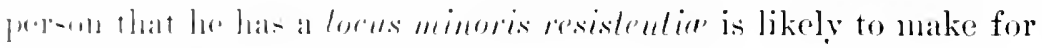

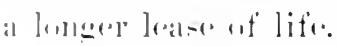

Finer. then, the aim of management in this stage is to preserve

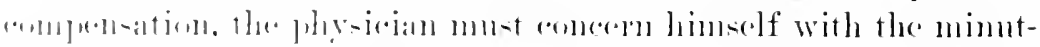

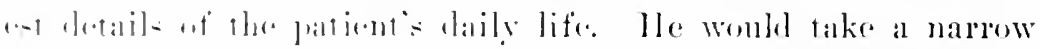

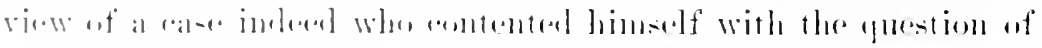

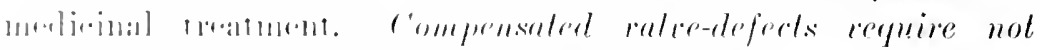

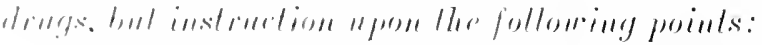

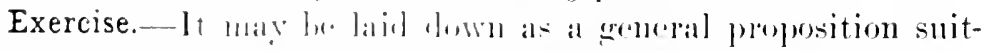

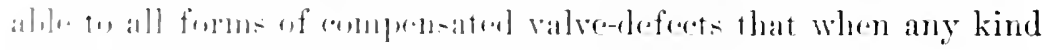

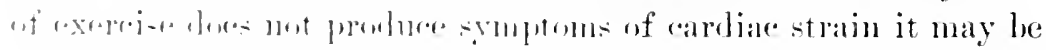

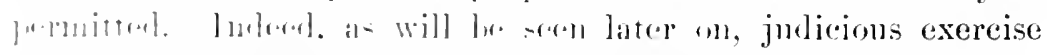

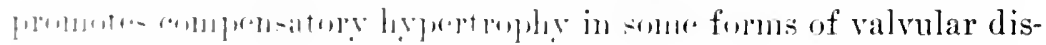

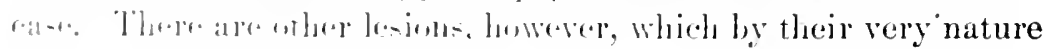


are theoretically likely to and often actually do suffer injury in time from severe botily excrtion. This statement applies particularly to cases of mitrat stenosis. If the left anriculo-rentricular opening is but slightly constricted, considerable, even severe physical effort may be endured withont symptoms, biat as al rule some shortness of breath is experienced, and patients shonld be explicitly warned against persisting in their excrtion when fyspence is felt. The effect of muscular contraction and decpened respiration incident to exercise is acceleration of the flow of renous blood to the right heart and lungs. If the blood camnot roalily pass the mitral ring, it becones dammed back in the left auricle and pulmonic veins, engorging and orerstraining the right ventricle. 'This may resist the stress for a time, but if the strain is too prolonger or too frequently repeated the cardiac walls finally vield and the hypertrophy, npon which adequate compensation depends, is superseded by dilatation. Therefore, patients with primomed mitral stenosis, even when compensated, should be cantioned against violent, prolonged, or too oft-repeated exereise of a severe kind. Hurrying up stairs or hills, running, and even very rapid walking, fast bicycle-riding, sports and games that necessitate rumning and springing withont frequent pauses to permit recovery of breath-c. g., furious sparring, wrestling and fencing, lawn-temin, basketball, and the like-are among the kinds of exereise particularly likely to harm patients with mitril stenosis, oven when compensated. On the other hand, if they indulge moderately, they may enjoy rowing, paddling, and bowling. Billiards, golf, and croquet are specially suited to them, while some may be permitted to hunt, and nearly all to fish. When the constriction is not pronounced, gentle horseback riding, slow hicycling, and eren the lighter kinds of grmmasimm work are permissible. In specifying the kind of exercise and sport to he allowed, the physician shonld always bear in mind the personal equation. The degree of the lesion and the gravity of its secondary effects, even more than the nature of the lesion, determine the patient's alility to emblure exereise withont harm. The individnal temperament, judgment, and power of self-restraint are also of great importance. The physician must endearour to inform himself as ac'unately as possible regarding the effect of any given kind of exercise on the particular patient before coming to a decision. 


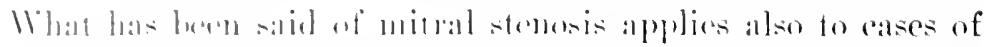

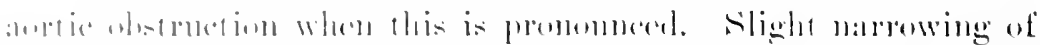

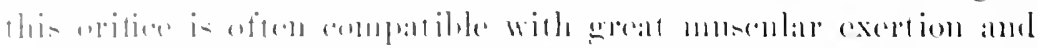

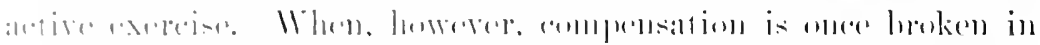

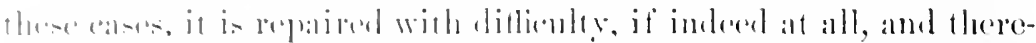

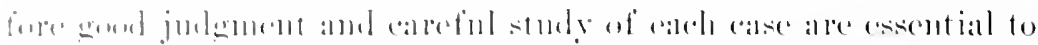

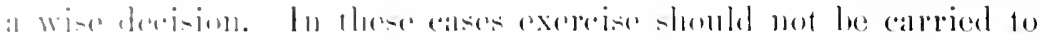

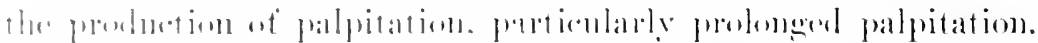

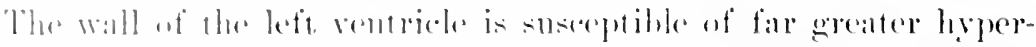

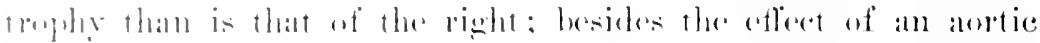

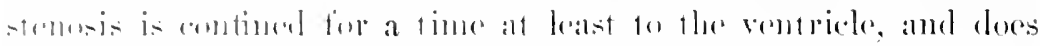

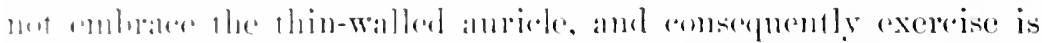
likely to he heftele endured than when the obstruction is at the mitral "1)

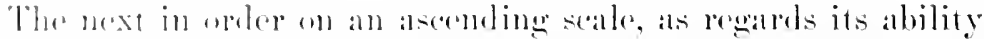

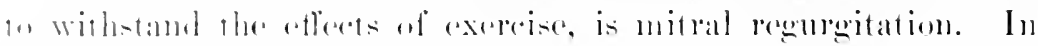

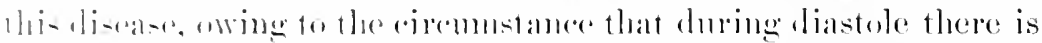

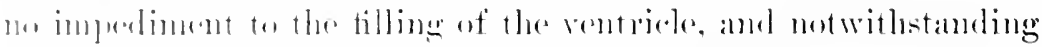

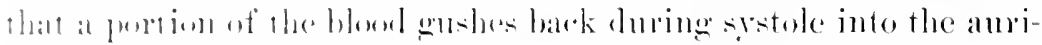

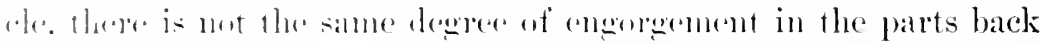

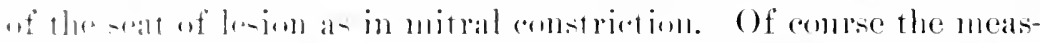

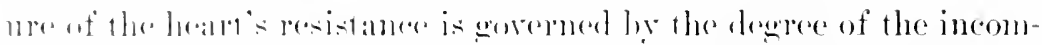

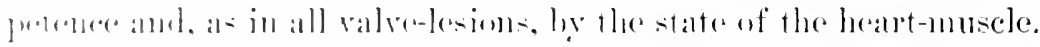

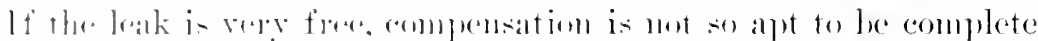

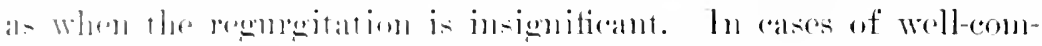

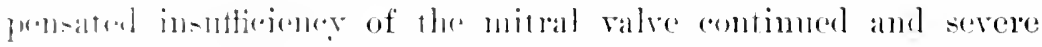

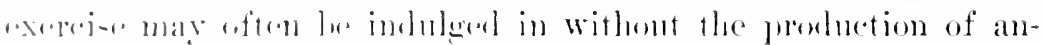

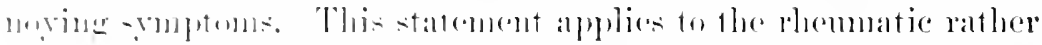
than the atherentatoms form of the lesion. I know an attorney

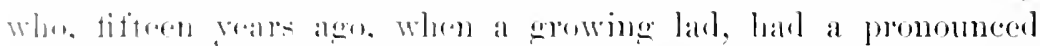

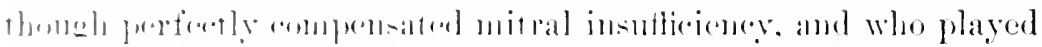

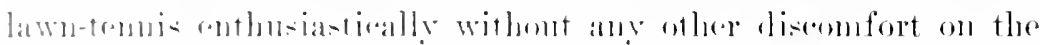

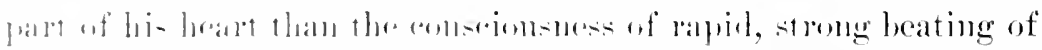

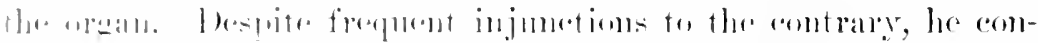

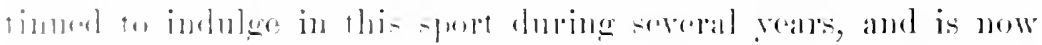

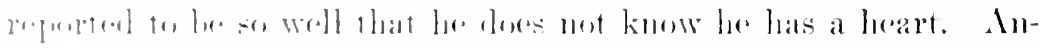

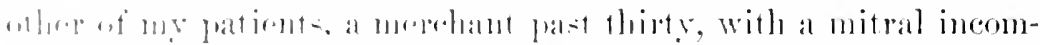

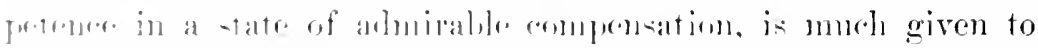

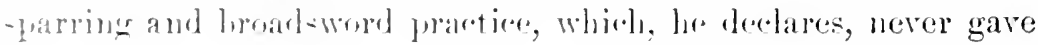


him any shoptuess of hreath and only a rapid hourt-andiom, that subsided so soon as the exertion erased. Surh instances ane not rare, and ret severe physical efforts are not withonf danger to these patients.

Such as are fond of manly sports should be arlicised of the prossibility of cardiar orerstrain, and told to desist when exessive palpitation or prononneed lyspuna is experieneed. 'They forel the better for a certain amomut of ontrlow exepeise, and when pomms and rigorous in other resprets their heart-musele, like their skeletal muscles, is likely to grow soft and wak if debalred from athletic sports altogether. Other things being equal, the state of the volumtary muscles is a fair index to the condition of the cardiac muscle. Of two indiriduals with well-compensated mitrat lakkage, one with well-knit muscles trained to exepeise, the of her mancenstomed to ontdoor sports because of sedentary pursuits, the latter may break down his compensation by some effort which womld be no more than child's play to the former. It is probable that persons with mitral regurgitation womld he more likely to suffer injury from long rmming than by games that neersitate internittent and short spurts of speed or stremgth. Momutain-elimbing, boat-racing, and other forms of contest or strength, which resperience has shown calnse dilatation of healthy hearts, will bring about overstrain of diseased ones more readily and surely.

As a general rule cases of aortic regurgitation should le placed at the top of the list as regards endmance of excreise without injury. This statement does not aply to persons who have acquired their aortic incompetence after the age of forty, and therefore probably as a part or manifestation of a sclerotic process laat may have invaded the myocardium also. In such, eren when eompensation is still maintained, exercise shonkl always le monlerate. The salvation of patients with this lesion depends on hymerpopy of the left rentricle. The great Stokes recognised this fact, and accordingly used to recommend active phrsinal exoredise to patients with this form of valve-disease. Von Ziemssen lias stated that upon one occasion, when risiting Stokes in Hullin, the latter directed his attention to a man ruming alume the strect belinet his wagon, and said that he was one of his patients with artic insufficiency who was carrying ont this kind of exoreise at his (stokes's) advice, for the purpose of developing left ventricle hypertrophy. 


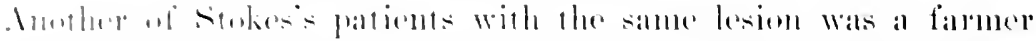

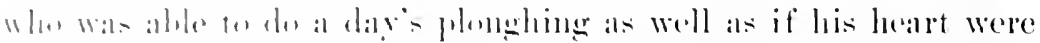

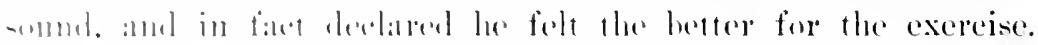

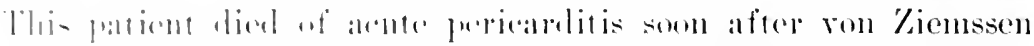

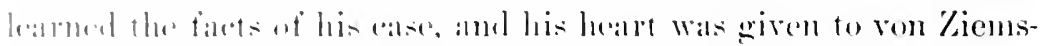
-an. Who derbarmel it weighed soveral promels and was the most

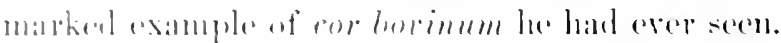

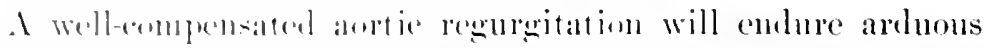

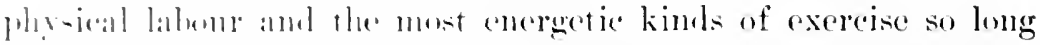

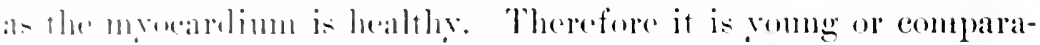

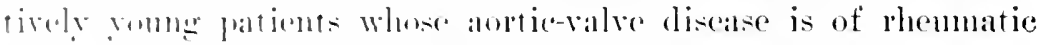

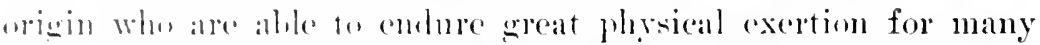

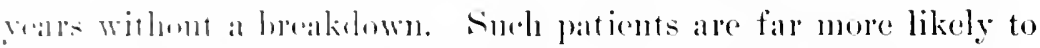

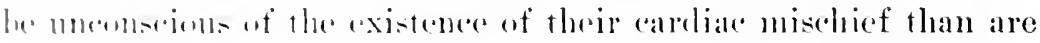
the - mhjects of mitral discase. In the former cardiate stress is

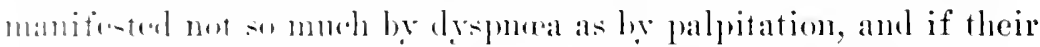

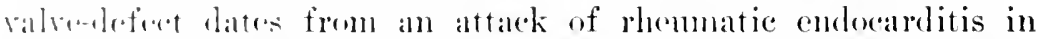
.hildlunul, as is oftun the ease, they have grown up so aecustomed 1.. threc jalpitations that they are apt to speak of them as but a manjfo-taltion of strong antion of the heart. While such patients

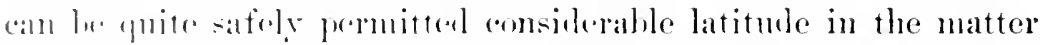
uf exroj-r. they shombl nevertheless be elosely watehed for the tir-t villoner of failing enmpensation. For so soon as the heart lewiu- 10 warre in its work, bommds must be set to their activity.

Whaterey is the nature of the valvular lisease, the plysician

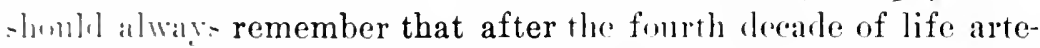

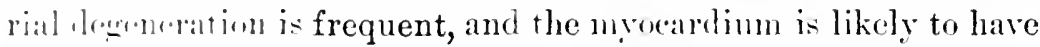

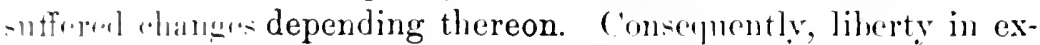

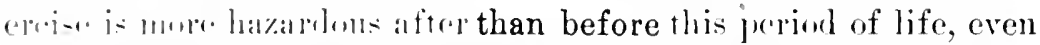

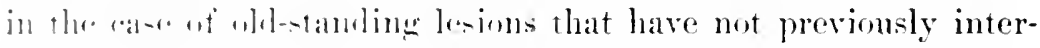
find with artire halits. From this time onward increasing cau-

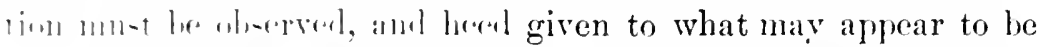

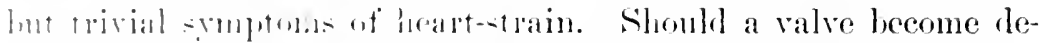
fontirr at this furionl rif life, rither as a result of condocarditis or itheremal.

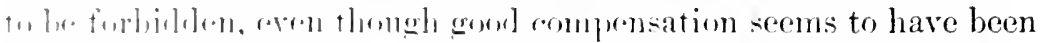

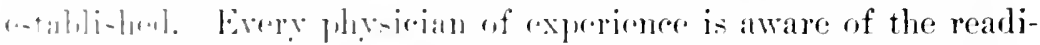

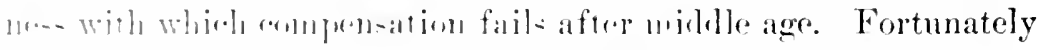

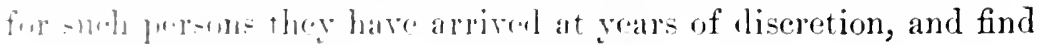


less difficulty in restraining their impulses to orede than is the ease with the romm. Exereise must now be hat hy walking, driving, easy riding, hilliards, and golf. Prolley weights, the Whitley exerciser, chuls, hmub-hells, ete., if permitterl at all, are to be user under the supervision of the medical attemlant of of a nurse eapable of detecting signs of danger. Morkantion in all things munt now be the motto of these patients.

Occupation.-The principles mulerlying the matter of excreise should also determine the selection of a suitable oceupation or the decision whether or not the patient's rocation is to be continned. The following employments are suitable for persons with mitral stenosis: Book-keeping, stenography, hanking in any capacity, or other forms of desk-work, telegraphy, clerking, cugraving, watchmaking, tailoring, shoemaking, harness-making, sardllery, ete, and for females the various kinds of needlework, trpewriting, stenography, and desk-work. Employments tha' necessitate heary lifting and the earrying of heary pareels, as porterage, rmung up and down stairs, swinging of heary hanmers, ete, are injurious, since they put added strain on the right rentriele. Dusty oceupations induce catarths and coughs, and in this respect firomr bronchial congestion, to which mitral patients are predisposed already. For the same reason they should not follow occupations which expose them to ricissitudes of weather and sudden chinges of temperature. Of the professions, jommalism, dentistry, architecture, designing, and the rarious branches of art work, are all suitable-while theologs, law, and such other vocations as require public speaking put a strain on the right heart and are less eligible. Teaching is not so bad, whereas the profession of medicinc. especially a general practice, is too ardunus and involves too much exposure for persons with pronomeed although compensited mitral narrowing. A specialty permitting office practice is not so objectionable, and yet any one with this lesion should be diseouraged from studying medicine, or beeming a trained murse or masseur.

Work with light tools, as carpentering, joinery, honse-painting and decorating, and even light gardening, may answor for some eases of aortic disease, when not admissible for serere nitral stenosis. Most of the oceupations followed by females are not too severe for mitral patients who have good compensation, excepting 


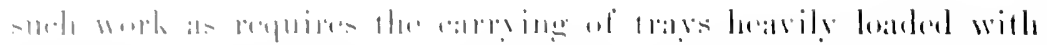

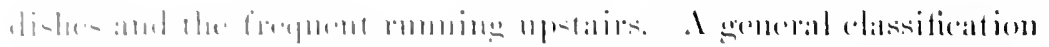

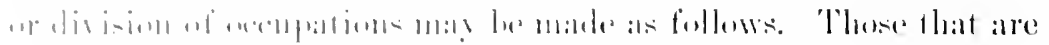

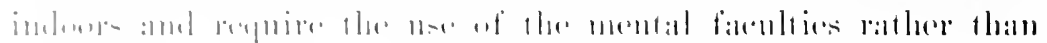

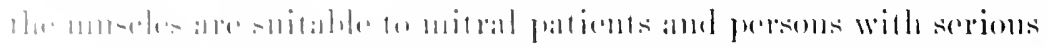

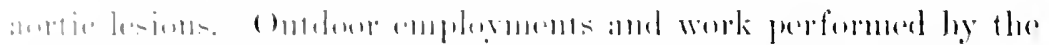

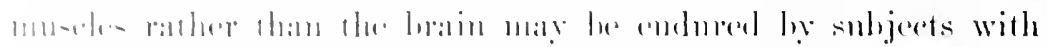

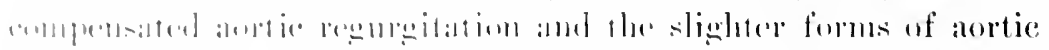

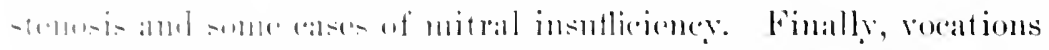

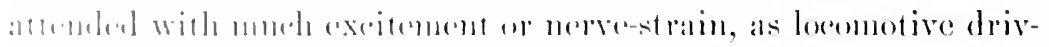

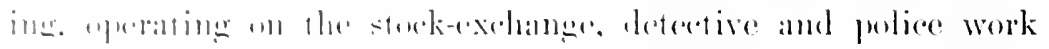

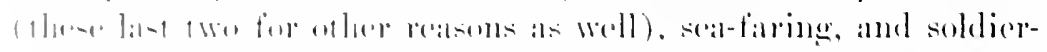

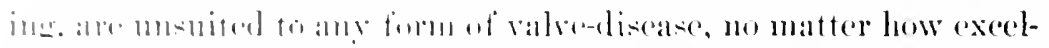

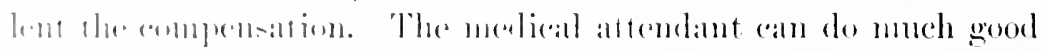

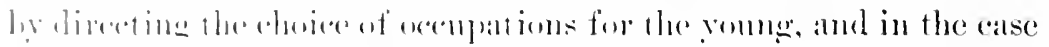

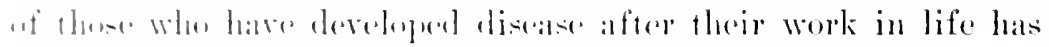

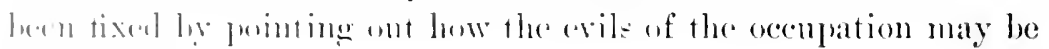
minimi\%nl.

Habits. It lats alrealy luen stated that moderation should

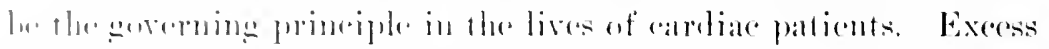

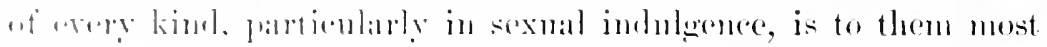

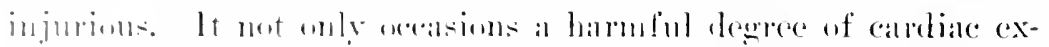

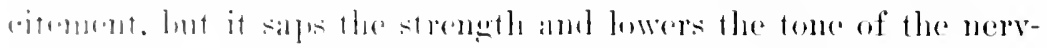

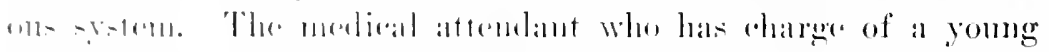

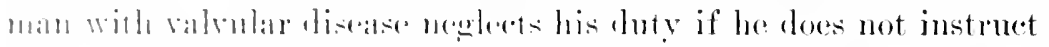

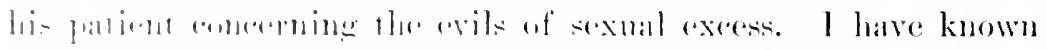

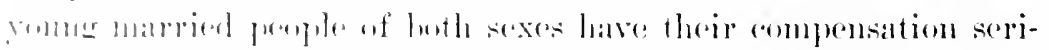

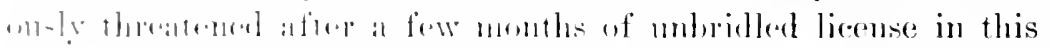

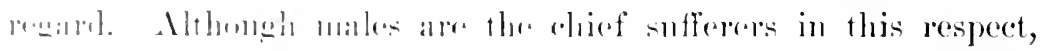

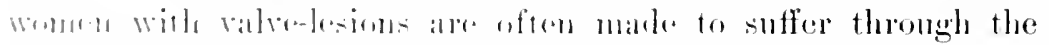

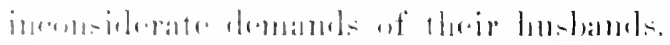

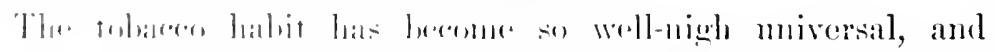

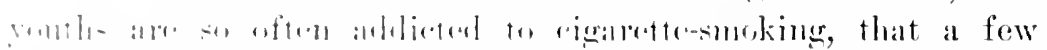

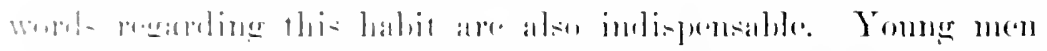

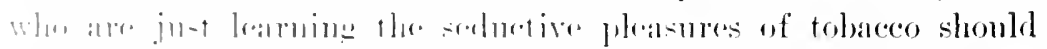

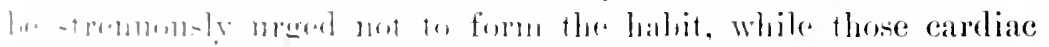

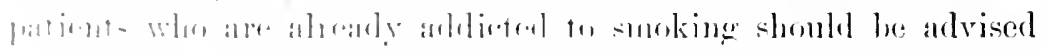

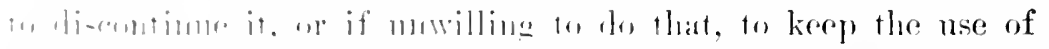

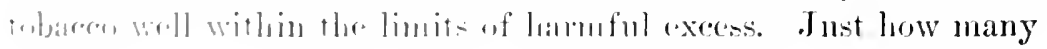




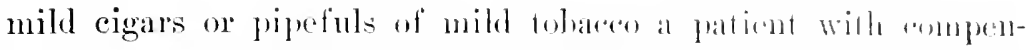
sated valvolar disease may be safely allowent to smokr daily is a question impossible of enemeral answer. The degree of imlulgenee permissible will vary in different cases, and nmst be determined by careful observation of the offect prombered in eath instanee. The inhalation of tobaceo smoke is most pernicions, partienlinly to individuals with mitral disease, since it will surely incouse the already existing tendency to bonchial inritation. If it loe true that smoking produces andmia, then those persoms mhose compensation depends upon adequate nompishnent of the heart-muscle camnot afford to have their red blood-eels impaired. It is well known that the immoderate nse of tobacco oceasions functional cardiac disorders, and, accorting to Frenel anthoritice, raises arterial tension. Since, then, a healthy heart may suffer loon tobacco intoxication, surely an unhealthy heart will expericuce the ill effects even more certainly and powerfuily. When tolsacen deranges digestion and canses insommia, as it is well known to do in some individuals, its use should be peremptorily forbiden. I have heard it stated, with how much truth I know not, that Sir Morell Mackenzic was wont to say that the injurions effect of tobaceo could be measured by its influenec upm salivary secetion. In other words, when snoking causes salivation and frequent expectoration, it is an indieation that the individual is too susceptible to its influence to safely persist in its nee.

As regards the liquor habit, I do not propose to enter into a discussion concerning the food value of alcohol and its cetect on the animal cconomy. Whatever be on views respecting the noderate use of liquor in its valuons forms, we all aceree as to the evils of its excessive employment. What has been salid already regarding the baneful effect of cardiac exeitation in eases of compensated valve-lesions applies with arkled forec to tho immorlerate consumption of alcohol. It goes withont saying, that the possibility of destroving compensation is always forecent when al patient gives himself over to a debanch. I am a firm belierer in the medicinal virtues of alcohol, but in the compensaterl stage of valvular disease the heart requires no medicinal treatment, and the only indication I can see for an alcoholic hererage is to promote the appetite and improve digestion of those indiriduals who habitually take too little nourishuent for the requirements of 


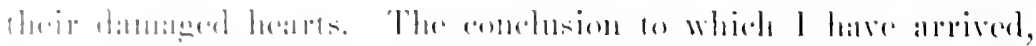

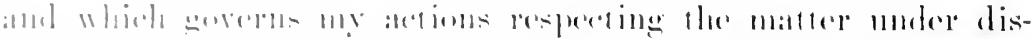

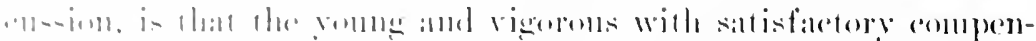

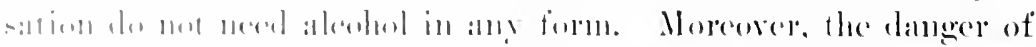

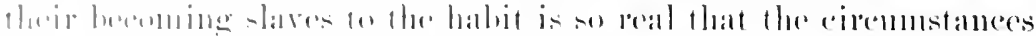

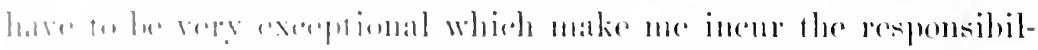

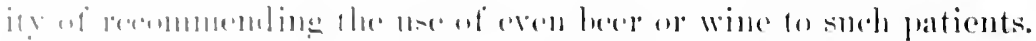

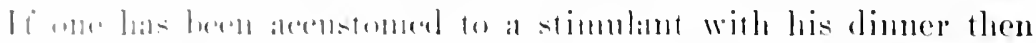

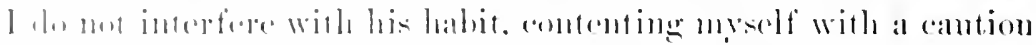

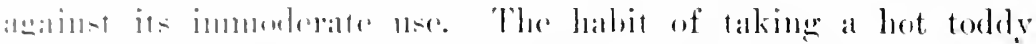

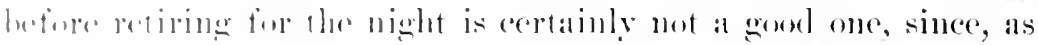

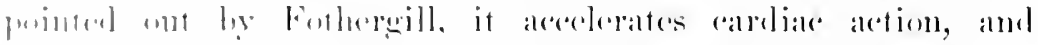

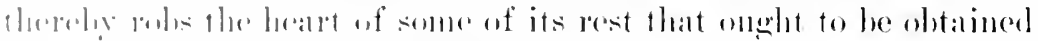

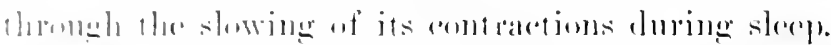

Marriage- The laneful offerts of one phase of married life

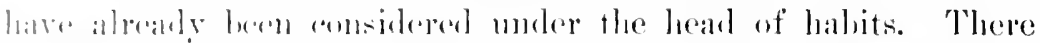

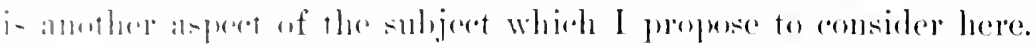
Fin the male whe has lonen waned against and will avoid the

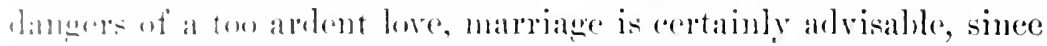
it amblues to regularity of livines and provides him with the

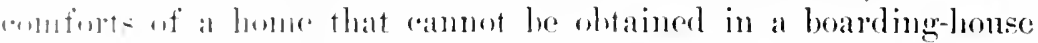

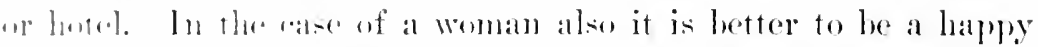

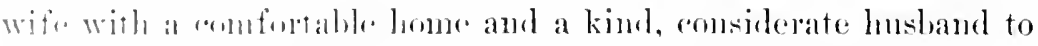
mini-tre lo her ments lian to le left alone, and possibly heart homery. It is quite amoller thinge if she is to beeome a domestie lemelese olibered to ronk and wash for the family and to bear off-

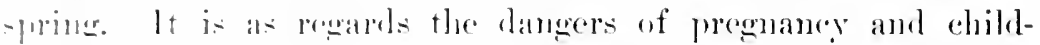

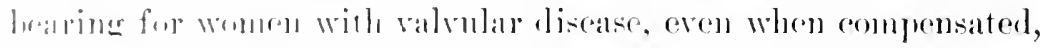

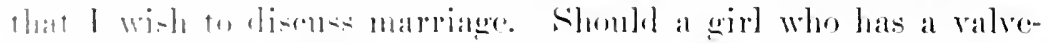

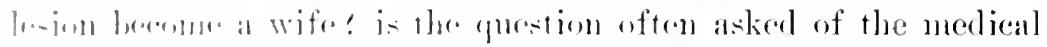

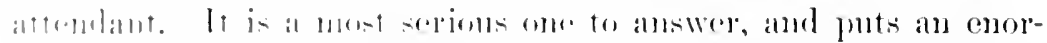

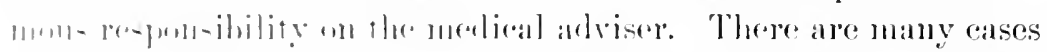
nt

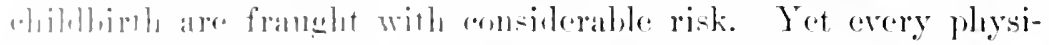

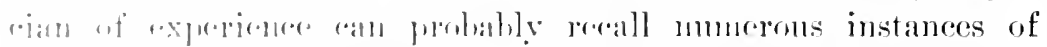

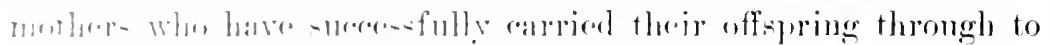

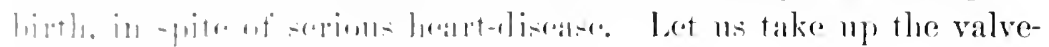

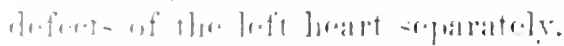

Mlinal disal-r, anl of this mitral stemosis is the form most 
frequently met with in women. Theoretieally, this is the lesion which should be the mest serimsty affected during the latter months of pregnancy and the expulsive stage of labur. As the gravid uterus rises in the abrominal anvity and when in the last two months its fundus interferes with the prepere dereent of the diaphragm, and crowds the viserat aside, dropuna and cranosis appear, and walking often occalsions serions distress. The right heart becones embarrassed in consequence of mechanical interferenee with the circulation. The pregnant uterus inperles the deseent of the diaphragm, so that the How of blood out of the great veins and through the right heart into the lungs is cleprived of the aid resulting from full and regulal respiration. Aloreover, the pressure upon the intra-abdominal veins retands the return thow from the inferior extremities, and blood-pressure in the capillaries is increased. This raises pulse-tension, and by thus inereasing peripheral resistance throws greater work npon the left ventricle. Under the most favonrable conditions this chanler discharges but a small volume of blood into the arterial system, and when its outflow is still further impeded by abnormal peripheral resistance, it results in angmented stasis within the left anricle, puluoniary system, and right heart. The vicions circle alreary existing by reason of the mitral stenosis and the strain npon the right rentricle are intensified. If this is not too severe, the woman mial be able to endure her pregnimey to full term.

When at length labonr comes on, and the expulsive stage is reached, there is imminent danger of the riglit ventricle giving way under the added stress of violent straining efforts.

The same condition obtains in mitral regurgitation, but the enlargement of the left ventricle, which if comprusation is present is hypertrophied as well as dilated, is a factor for good ly. enabling the heart to withstand increased peripheral resistance. The augmentation of arterial tension would by raising intraeardiae blood-pressure increase the regurgitation into the left anricle were it not comterated by the left-ventricle lypertropluy. The danger is that the rentricle may not be able to resist the strain, in which event the evils of the mitral incompetence becone intensified, and the right ventricle at length suffers from overstrain. Even if the injurions tendencies of pregnaney are successfully withstood, the wonan with mitral regurgitation is sub- 


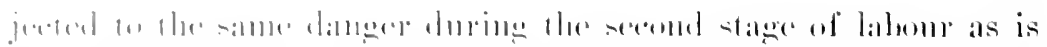

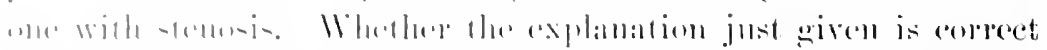

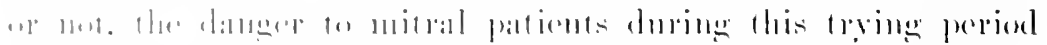

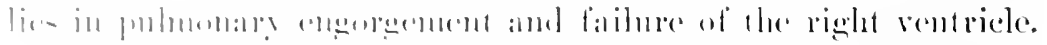

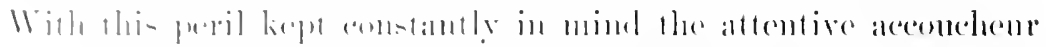

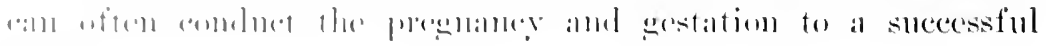
in-l14.

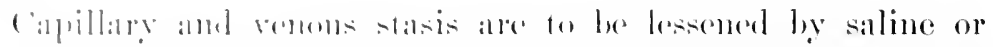

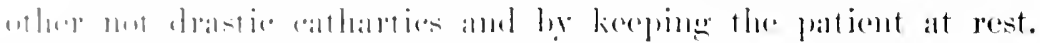

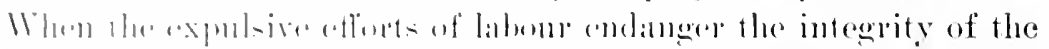

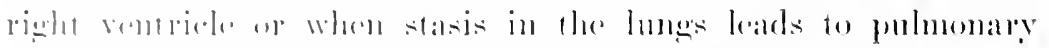

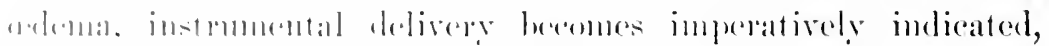

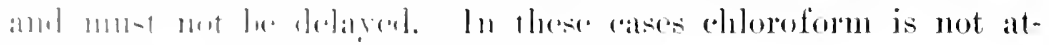

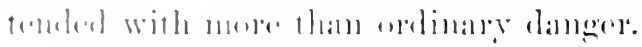

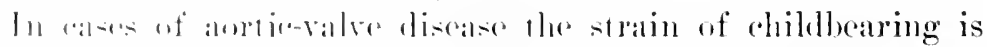

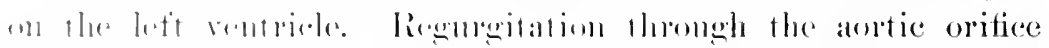
i- likely lo lo incoratiol, and in antic stenosis the angmented

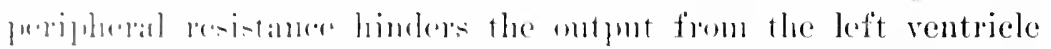

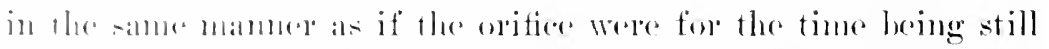

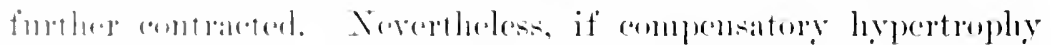

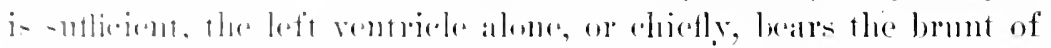

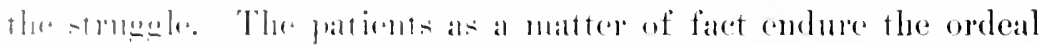

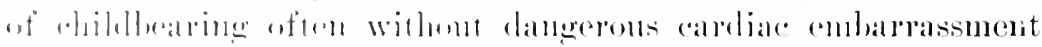

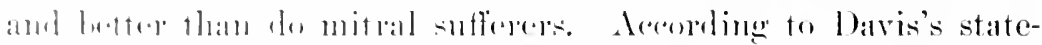

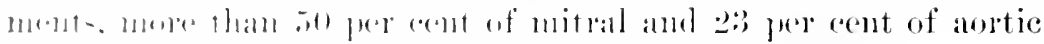

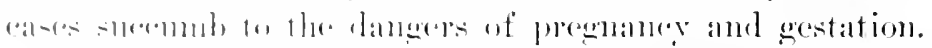

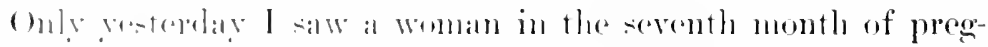

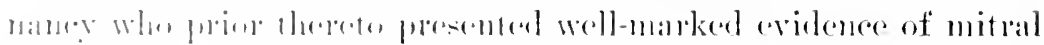

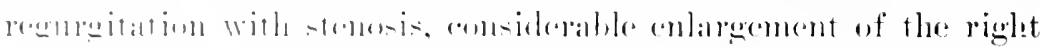

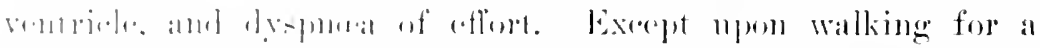

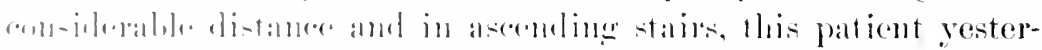

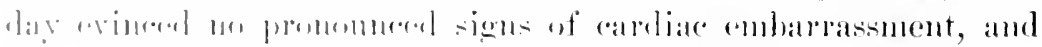

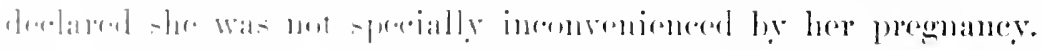

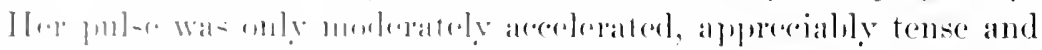
-

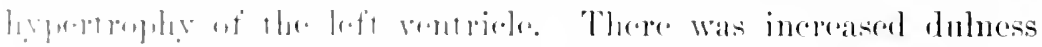

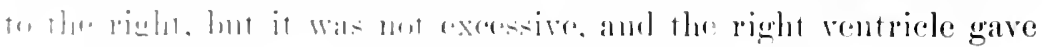

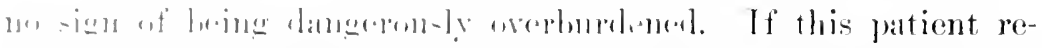

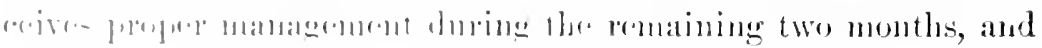


is not permitted to overstrain lierself during labour, I believe her heart will not suffer damigge from this, her eighth pregnaney. Her hnsband, who is a physician, states that she hat heart-disease at the time of her marriage, fourteen ycars ago.

The following conclusions may be stated: (1) Pregnancy is a condition of gravity, but not necessarily of peril, to women with compensated valvular disease. (2) Labour is a time of real danger, the extent of which depends npon the nature of the lesion and the degree of compensation, but is often endured withont catastrophe. (3) Mitral disease is more liable to disastrons eonsequenees from both fregunancy and gestation than are aortic defeets. (4) Even in mitral discase the degree of danger depends upon the state of compensation. (5) P'regnant women with valvular disease require special watching as libour approaches, and during the expulsive stage should be delivered instrmuentally at the earliest indication of dangerons heart-strain. (6) The perils of marriage should be clearly stated to both of the eontracting parties, and when compensation is imperfect or is maintimed with diffienlty they shonld be advised not to wed.; ( $\tau$ ) Interference with pregnaney is justifiable only when the natme and severity of the lesion render the maintenanee of compensation inpossible or when serions symptoms have alrealy supervened.

Clothing.- The plyysician who would instruct his patient in matters of importance in maintaining compensation must have regard for what sometimes appear to be things of tritling moment. Among such details is to be included the clothing. All who have much experience in the managenent of carliopathies come in time to realize the influence exerted by varying conditions of blood-pressure. The reason of one man's sneess, as contrasted with another's failure, in the treatment of heart-disease is often found in the elose attention lo pays to molue rise of blood-pressure. Take, for example, an ordinary case of mitral stemosis. Without any recognisable change in the cardiac condition or in his daily eonduct, a patient will be conscious that his breathing beemes embarrassed by efforts usmally put forth without any such effect. He consults his medical adviser, who, fimiliar with the ease, discovers by studying the pulse and state of the renous circulation that there is mwonted tension in the arterial system. Ife finds, furthermore, that there is constipation perhaps, and 


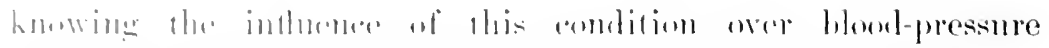

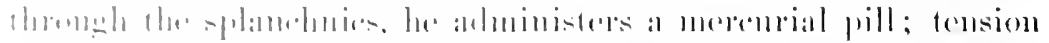

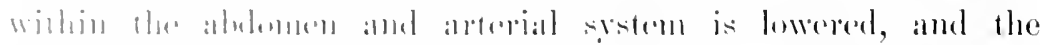

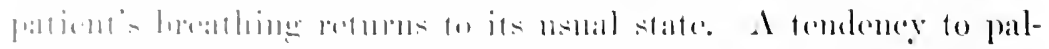

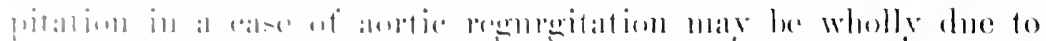

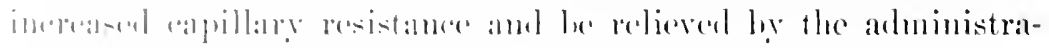
lion wi a lal-11-4lilalloll.

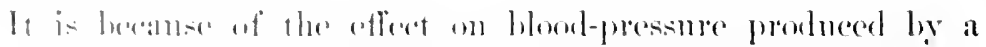

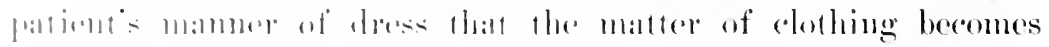

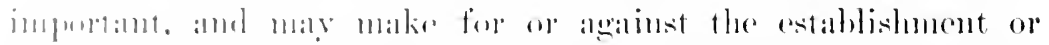

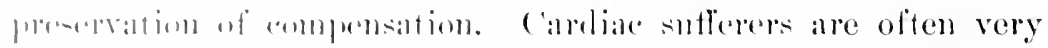

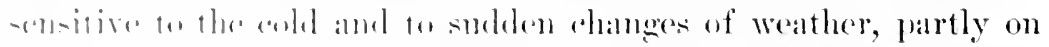

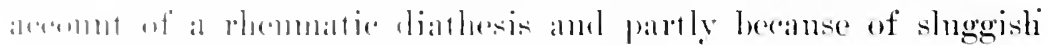

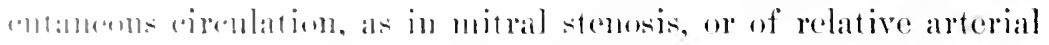

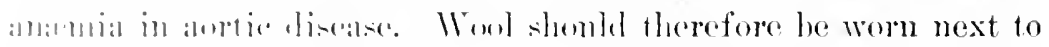
fle skin, and during satsons of low temperature the hamb and

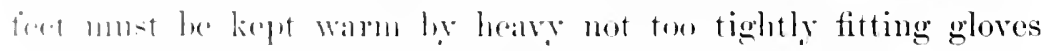
and shows. It is well to have the latter construeted with cork

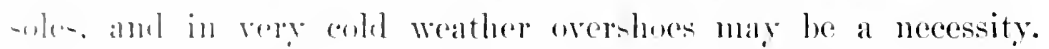

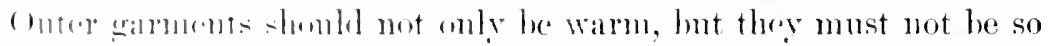

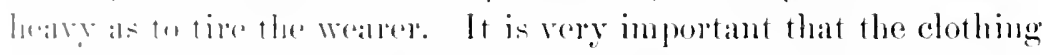

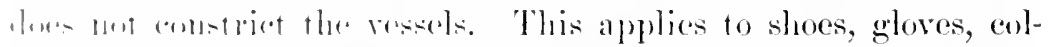

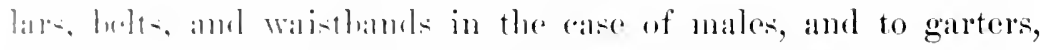

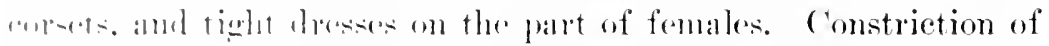

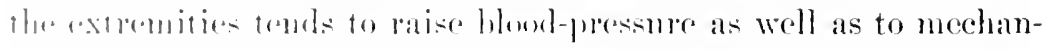

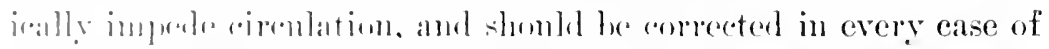

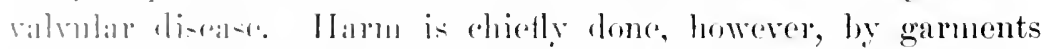

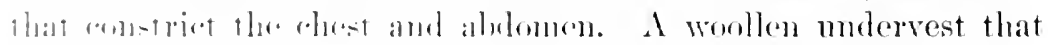

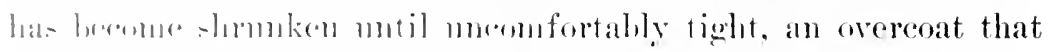

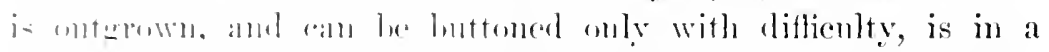

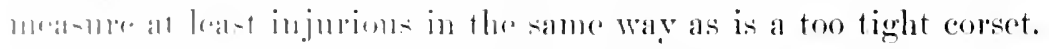

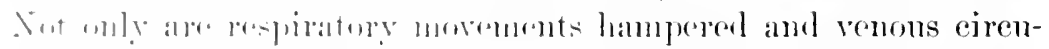

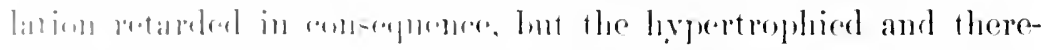

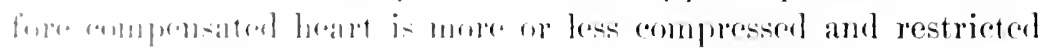

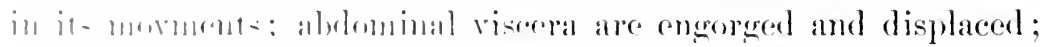

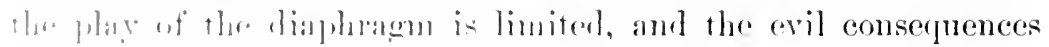

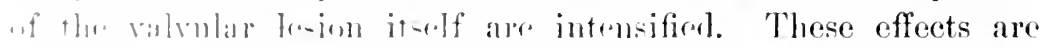

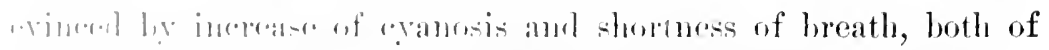

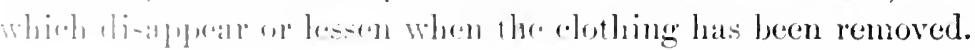


Instead, therefore, of suspending the skirts fiom lare hips, to effect which they have to be fastened smogly about the waist, it is preforable that women, particularly slender ones, wear gallments of one piece, so that the weight may be borne ly the shoulders; or they should replace the ordinary corset by a corset-waist, to which the skirts can be buttoned, thus aroiding constrietion of the waist. Not many months ago 1 was consulted by a lady on account of attacks of lyspmera and cyanosis, which at times amounted even to partial spreope. She presented sims of pro nomed mitral stenosis with considerable secomlary enlangonent of the heart and hepatic congestion. She was inelined to coppulence, and to preserve her figure wore a long, stiff eorset, which, in response to my inquiry, she declared was loose and comfortable. Sot convineed on the point, I measured her waist both on the bare skin and ontside of the corset, and thus denonstrated that when her corset was hooked she actmally measurer? 4 inches less than she did next to the skin. I then explained at some length the harm she was doing herself, and suceeded in getting her to reform her mode of dressing, much to her relief, as she subsequently acknowledged. In this instance I an convinced that the simptoms of cardiac stress under conditions of exercise were due largely to the additional inpediment to circulation and respiration occasioned he the tightness of her chothing.

Baths.-I have fonnd in mmerons instances that ladlies with valvular disease were in the habit of taking a semiweekly lont bath, and some of them confessed to lying in the water for twenty mimutes or more. Inquiry generally clicited the fact that the bath was followed by a feeling of languor, even anomnting in some instances to prostration. It is well known that such hot baths are weakening to the heart and lower rascular tone. They should be forbidden therefore, and the patients advised to content themselves with a rapid sponge-bath daily if strength permits, and once a week a tub-bath of short duration, and of a trmpolature closely approximating that of the hmman body. Mitral patients endure bathing less well than do those with aortic losions. I'ot in all cases the degree of latitude permissible in the matter of baths is to be detemined by theil offect. It they are followed by a healthy reaction-that is, ly wamth of the skin and a sense of rest or well-being-they are beneficial; but if a cardiac patient 


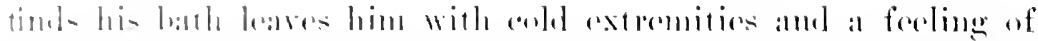

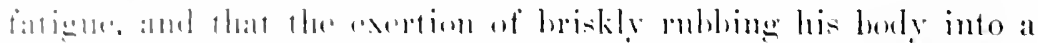

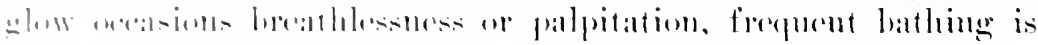
likely (1) d, him hallum.

swimming. whether in silf or fresh water, is fo he comsidered

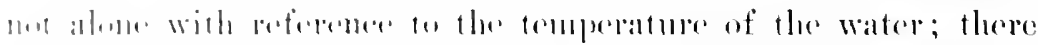

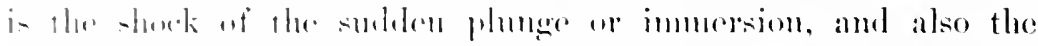

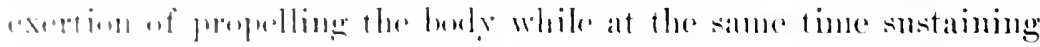

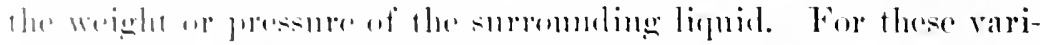

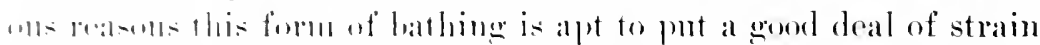

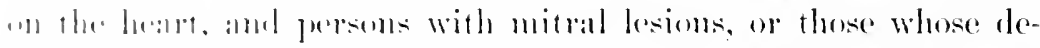
forts, of whaterel nature, are maintaining compensation with

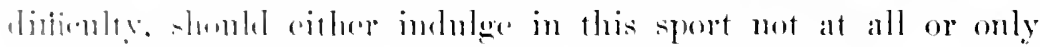
molep eneal restriotion. botle of frepuemey and duration. It is forohisho that many of the ases of supposed death from eramp in the water ale in rolity instanees of heart-failure or asystolism.

The Turkish and Rusian haths and the varions modifieations of the showerelath or domele fomel at health-resorts affect the heart and vasular syem powerfully, and should not be taken

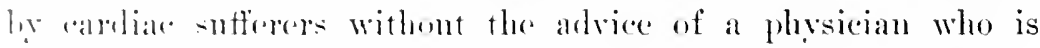
familial with their afferets and computent to decirle on the advisahility of suld haths in aleh instance.

Tla saline and andemated batss amployed for therapentic

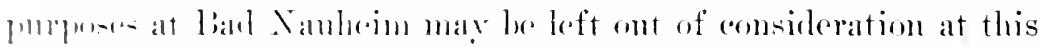
linur. -ines they are not indieated for individuals whose valvular deferess are in the stage of eompersation.

Food.-()f all matters ancerning omp patients nome is so essenlial a- that of momishment. and yot there is nothing, I venture to

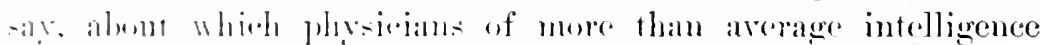

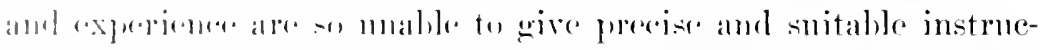

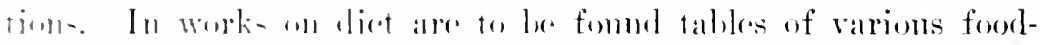

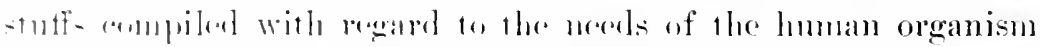

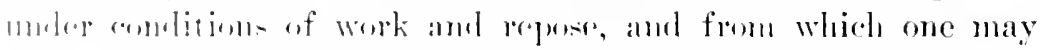

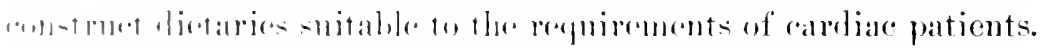
la thi- ehajuer I -hall mly make orotain goneral statements that

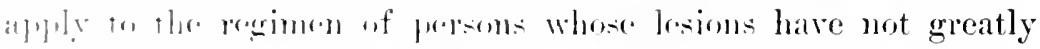

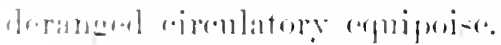

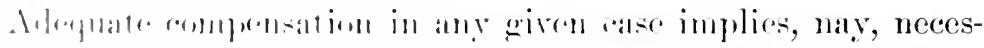

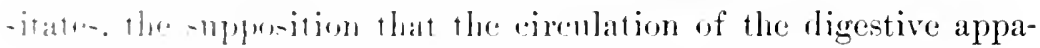


ratus is not appreciably distumber. The condelusion is warlanted, therefore, that there is no digestive disorder seromblary to the calrdiace mischief and neessitating a corresponding modification of the diet. It is only esential that the food be of good quality, wellcooked, and sufticient. The proportion of proteids suitable to arch case will be governed by the amonnt of excreise taken, the kind of work, and hle tendency or not to obesity. The sane considerations apply to the guantity as well as the quality. The proper preparation of the food is essential if digestive disorders are to be avoided. It is of importance also that moals be taken at regular hours: gluttony is injurious, and the anomut of fluids taken with meals should be definitely stated, 10 onnees being ordinarily sufficient. P'atients who are anamic must be given a liberal allowance of beet, eggs, milk, and such regetables and fruits as are rich in iron-forming compoumds; those who incline to constipation are to get a dietary calculated to correct the tendency. Tea and coffece in moderation may be allowed. In a word, so long as compensation is complete there is no indication for special rules to govern the dietary further than what would be lecpuired for the preservation of health in the sane individual were he not aftlicted with an incmable malady.

Illnesses.-- Among so many items of importance in the proservation of compensation it is difticult to specify one as greater than another, and perlaps it is mot wise to attempt to do so. Yet I wish to lay particular emphasis on this point-nancly, no illness or indisposition, apparently trivial in itself, should ever be so regardec! in a person who has suffered injury from endocarditis. This is specially true of children. In them rhemmatism is so apt to be masked that an infection of the throat, a persistent pain in an extrenity, a rise of temperature withont obvioms canse, slonld always receive areful medical attention. The intestinal tract affords so ready and frequent a portal of infection that no deviation from the standard of health is to be neglected as of no consequence. Far better is it to bear the imputation of being overcareful and fussy than to some day awake to the conscionsuess that your neglect las permitted injury to visit one of rour pattients, whose compensated valvular lesion might otherwise have gone on years longer. Tell your pationts emplatically and clearly that a tonsillitis, yes, or even an acute coryza, is never to be neg- 


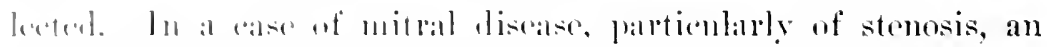

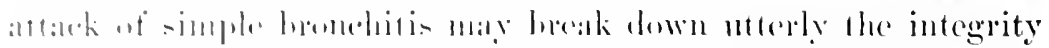

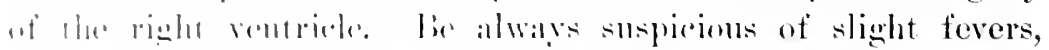

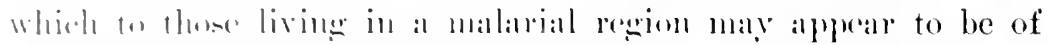

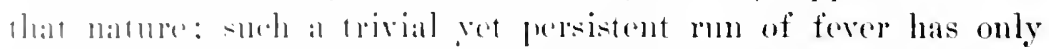

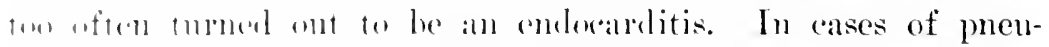

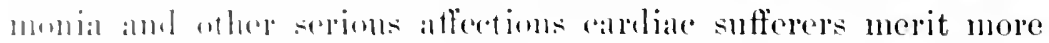

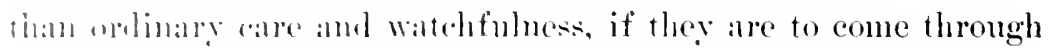
mmlanated. This is palticularly true of persons with mitral de-

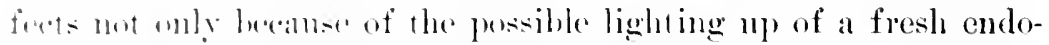
ralleditis. lut heallse the strain to which the right ventricle is

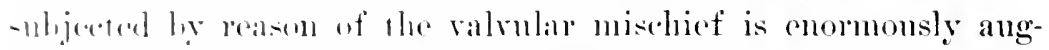

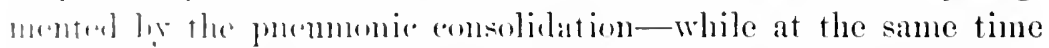

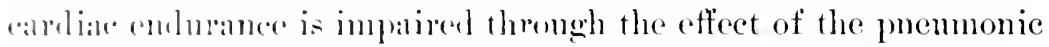
foxines wn the marearlimu. If in smeh a case paralysis of the

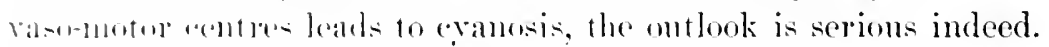

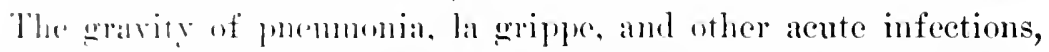

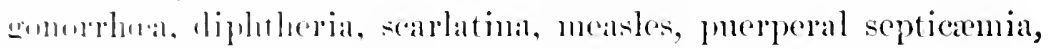
1... in all cases of complensatcel ralrular discase, is so obvious,

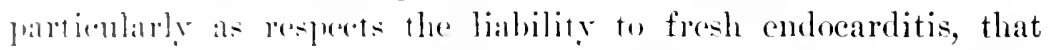

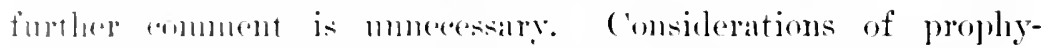
laxis repriter. therefore, that om andiopaths be properly in-

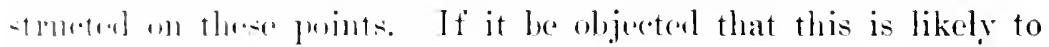

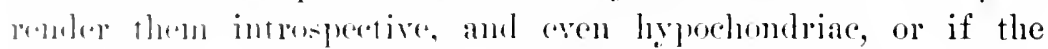

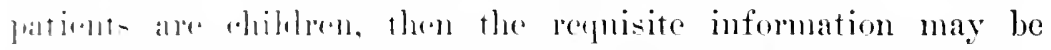
implutul to the fimily, friends, or parents. So one need fear that his motive will be mismelerstood. Indecel, I an convineed

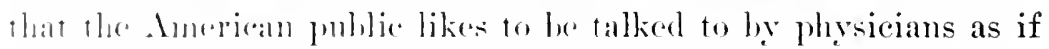

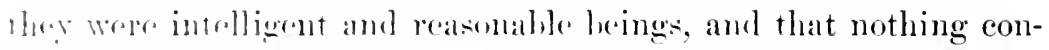

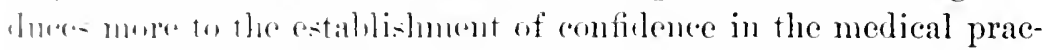
titjoner tham fornkmos and plain dealing in all matters that con-

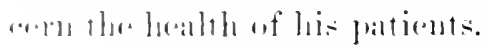

Use of Drugs. - It is an errol to supose that every individual

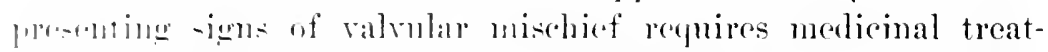

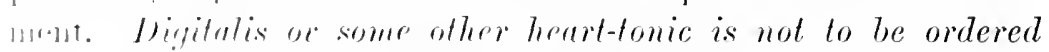

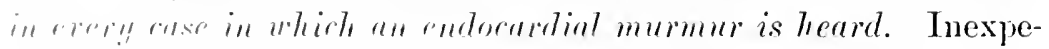

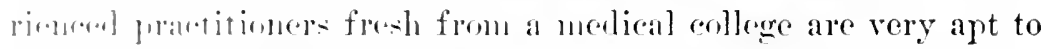
mommit thi- mi-iakr, amb comserpurntly the foregoing injunction

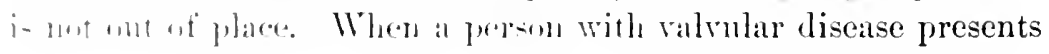


himself in your oflice, inquire mimutely into the matter of symptoms, and if he does not arknowledge any indicative of cardiac stress, renedies influencing the heart directly are not indieated. If you belong to that class who believe no person should be allowed to leave the physician's oftiee withont a preseription or a drug of some kind, lest forsooth the patient fancy he has not received his money's worth, then let it be a placebo. Is a matter of fact, there are few persons who camot be satisfied muler snch circmustances with an expression of opinion compled with somnd advice on the points under discussion in this elapter. Careful inquiry will usually bring out some pernicious labit, faulty digestion, constipation, some impairment of appetite, ete. or there may be more or less anamia, bronchial irritation perhaps, menorrhagia, some deviation from perfeet health, which permitted to go on, will in time exert malign influence on compensation. Any such condition calls for correction, and to this end medicinal treatment may he indicated. What medicaments are suitable in each instance is, of comrse, to be left to the judgment of the medical adviser.

Although slight disturbances demanding attention are often dependent upon seareely detectable disorders of eireulation, they are not necessarily so in perfertly compensated eases, and henee these patients may generally be treated, so far as regards medicines, as they would be were they wholly free from endocardial defeets.

Two conditions likely to prove more injurious to individuals with a valve-lesion, although compensated, than wonld be the case if his ralves had not been damaged, are constipation and flatulent distention of the bowel. In both there is splanchnic irritation and consequent alteration of blood-pressure, int in the latter the effect of mechanical encroachment upon the contents of the thoracic eavity must be reckoned with. Uneorrected it may contribute materially to the destruction of heart adequacy, to say nothing about the patient's discomfort in the way of prestrumdial breathlessness in mitral and tendener to palpitation in aortic disease. Both disorders of digestive function tend to impar the appetite, give rise to neuralgias, anamia, coldness of the extremities, and many other phenomena of anto-infection. Noreover, flatulent indigestion, probalny throngh the absorption of toxines, is a frequent eause of deranged eardiae rhythm. This not only 


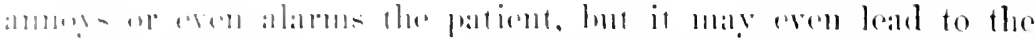

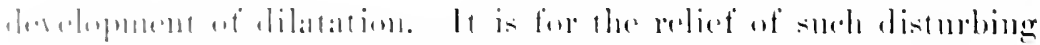

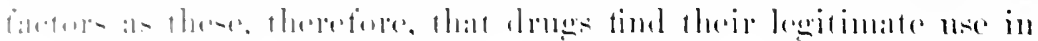

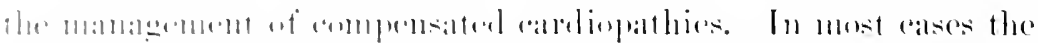

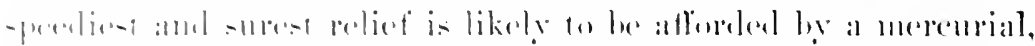

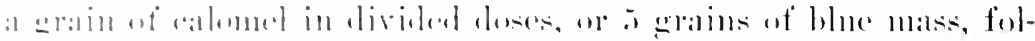

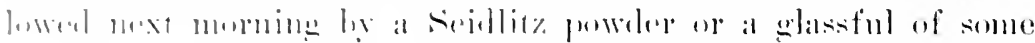

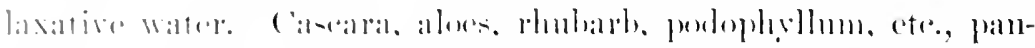

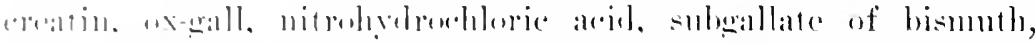

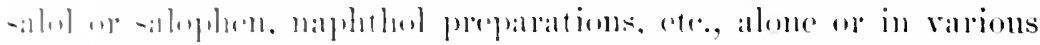
amblinations and with which the rouler is duly familiar, are

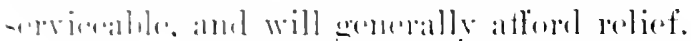

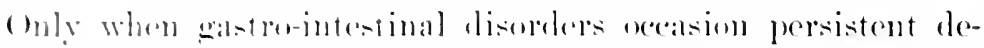

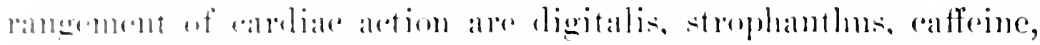

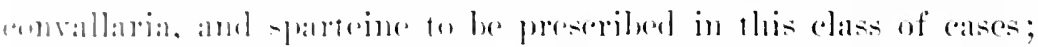

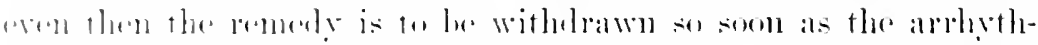

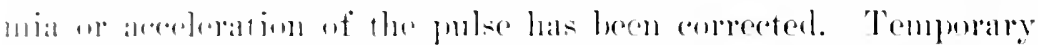

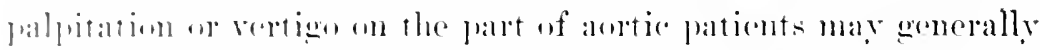

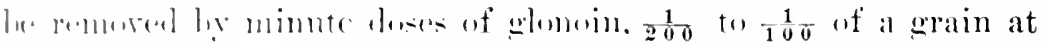

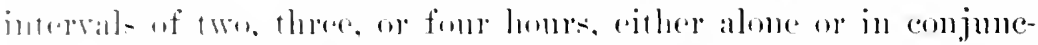

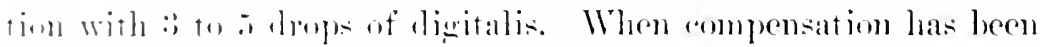

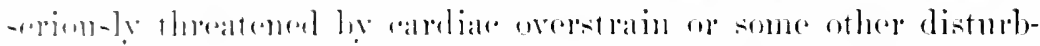

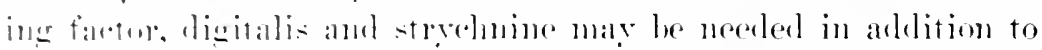

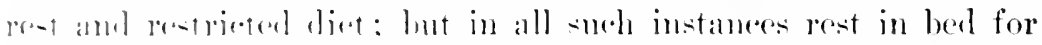

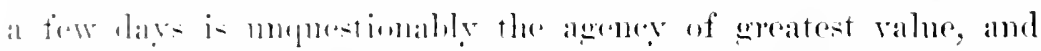

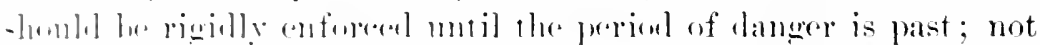
motil then is the patient to he permitted to resmone his nsual mode

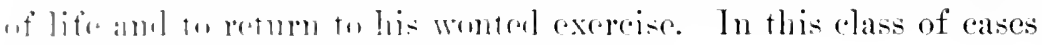

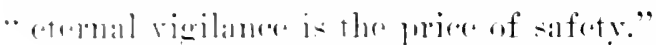

\section{Change of Climate, with Special Reference to High Altitude.-}

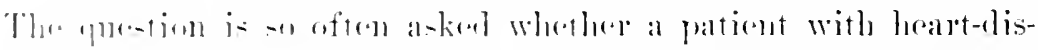

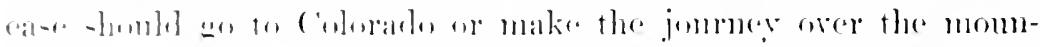

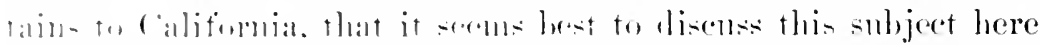

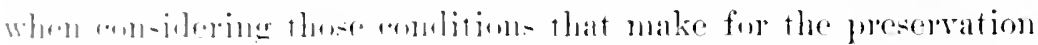

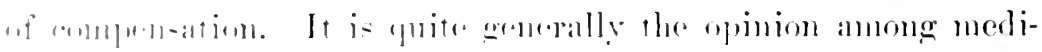

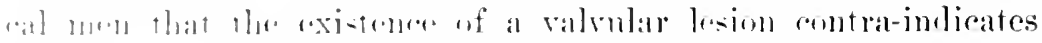

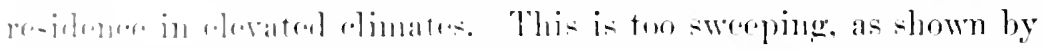

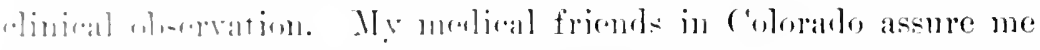

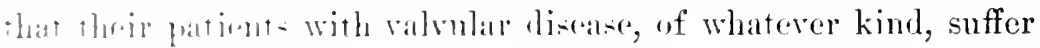


no more inconvenience firom their heartelesions in lluver m Colorarlo Springs than do persons sinilarly atfected at the sait

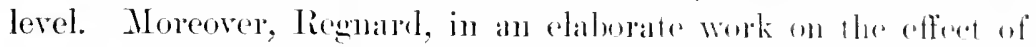
high altitude on the heart and cirembation, exprenses lhe opinion

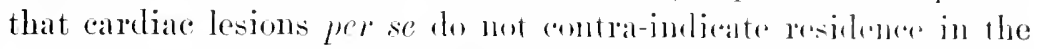
momtains when this is neessaly, and that asile from the discomfort of becoming alemstomed to the higl allitmle individuals affieted with heartelisealse do not experienee permanemt ham. Nevertheless, he womld not alvise residenere in surh a climate for a cardiopath, since there is nothing in his discase ealling for sureh a climatie treatment. This opinion impersose me as ton lurad, judging from the experience of some of my calliare patients. I have known persons with mitral and aortic regureitation to risit Colorado, and there, at an elevation of fi,oon foet, to take comsiderable exercise without discomfort, and apparently without harm. Others with vasemlar and cardiare degeneration have found the same to be true with them, and in fact one gentleman was aletually able to walk with more ease at 7,000 feet tham in (hicago. On the other hand, my patients who were not able to enclure high altitude were sufferers from mitral stenosis, aortic stemosis, and mitral incompetence, when complicated ly periourdial or plonritic adhesions. These cases were all reported and discusiod by me in a paper before the American clinatological Asinciation in 1899, and will be found in the Transactions of that rear. Singularly enongh, In. Sewall, of I lenver, in disousing my paper, stated that at that very time he harl under observation in lenver a female with promomecol mitral stenosis, who ilad formerly heen under my cale in Chioago, and who was able to endure the cleration, not only of Ilenver, lnt also of Cripple Creek situated at an altitude of about 12,000 feet. She died a year subsepuently, 1 understand, and I have often wondered if her resilence at that elevation did not ail materially in shortening her life.

As the discussion of theories is foreign to the spirit of this work. I shall not disenss at length the considerations which make me conclude that resilence in high altitudes is likely to prove

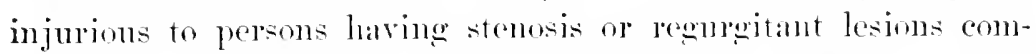
plieated by periearelial or pleural allhesions. Suflice it to say that the effect of a rarefied atmosphere is arecheration and suallness of the pulse, together with increase in the depth and fre- 


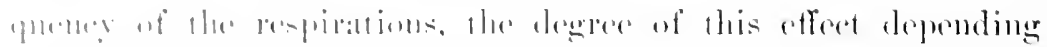

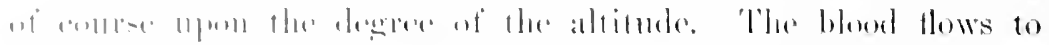

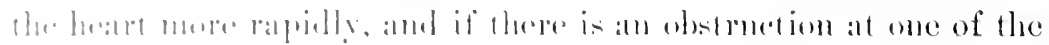

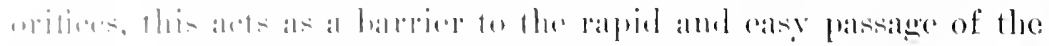

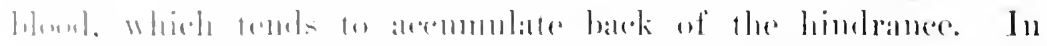

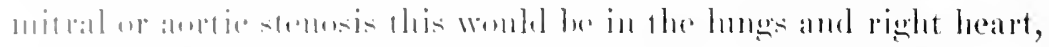

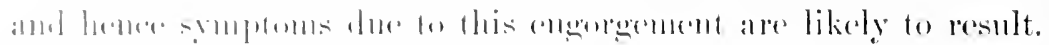

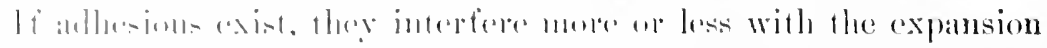

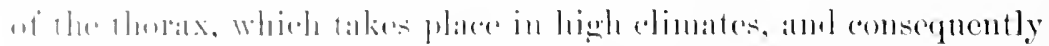

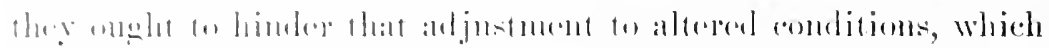

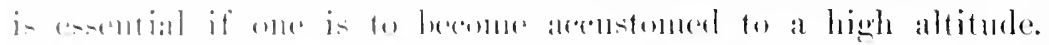

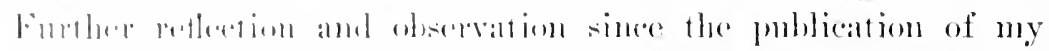

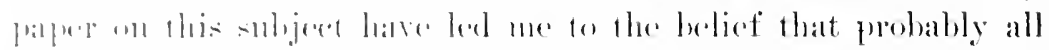

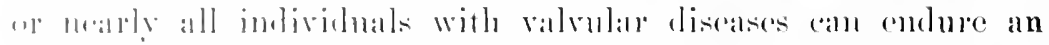

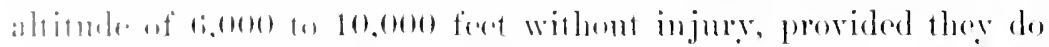

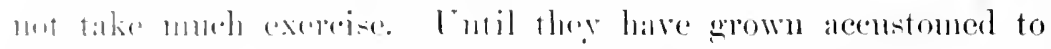
the lalentied air they shomld mot walk alt all, but remain in bed. A loas surh is llar opinion and adrice I give when consulted on phis impertant question. Finally, it is probalude that much of

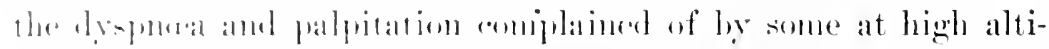

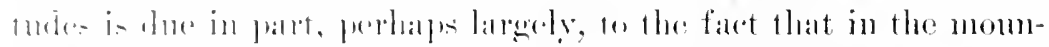
taim- the walkis are mot lovel. Hill-elimbing is trying for cardio-

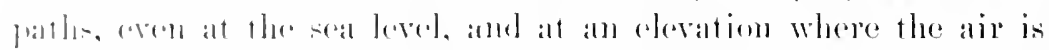

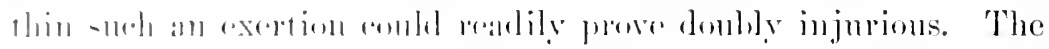

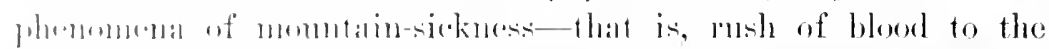

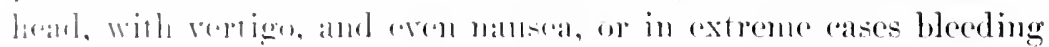
from the now amb ars-ale liable to attack healthy persons at

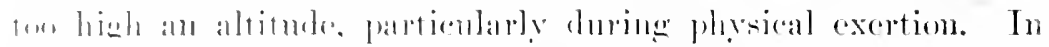

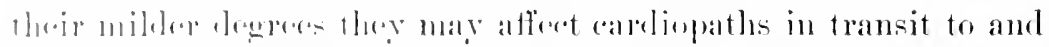

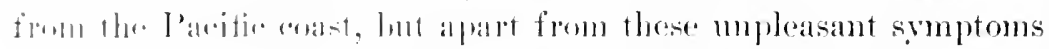

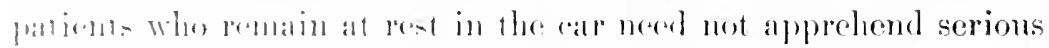

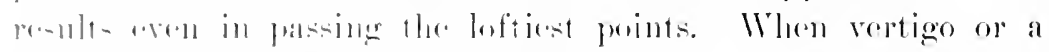

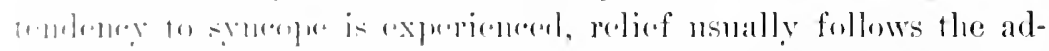

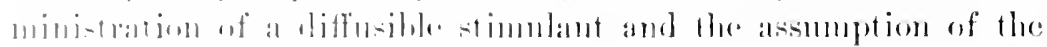

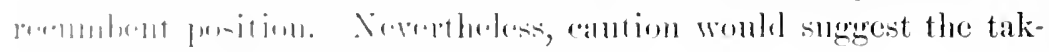
ine wi the leas lofty lontes. 


\section{CITAP'TER XVIT}

\section{THE TREATMENT OF VALVULAR HEART-DISEASE (Continued)}

\section{COMPENSATION BEING IMPERFECT}

A waxt of perfect compensation may have either one of two explanations. It may have never been adequately developed after the subsidence of the acute process that led to the valvular mischief, or having been once established it may be destroyed in consequence of a variety of causes. In the fir'st instance the development of complete compensation may be impossible, owing to the extent of the danage sustained ly the valves, in consecunence of degeneration of the myocardimu, or of the coexistence of conphicattions or conditions residing in the patient's temperament, environment, ete. In such a case the course of the disease is generally too short to admit of its being bronght into the category of chronic valvular affections. For the same reasons a long-continued maintenance of compensation may he impossible after it has once become established. In miny ases, however, it is possible to arrest the downward tendency and restore heart-power when the injurious influences are discovered and removerl. If these camnot be removed, then their haneful effects must be counteracted by all those therapeutic measures which are at our disposal.

In the management of compensated valvolar discase the physician conducts a defensive "ampaign, so to speak, whereas when compensation has failed, he is called on to wage an active offensive warfare against all those forees that are striving to destroy his patient. His sucess depends not only upon the skill with which his therapentic weapons are wielded, hut also upon the precision of his orders, and the faithfuhness with which these are executed. The treatment of valuular diseatse in this stage requires also attention to detaiks of daily life, ne matter how trivial they may appear to be, and the recognition of complications. Moreorer, there are 


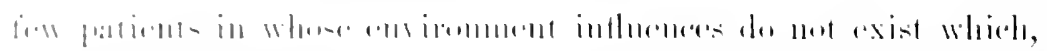

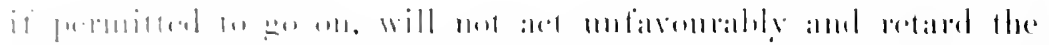

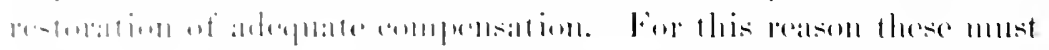

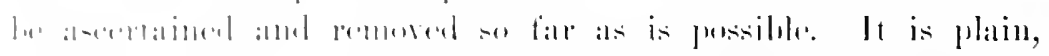

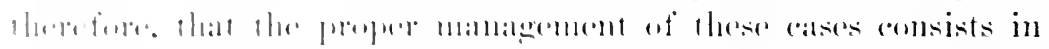

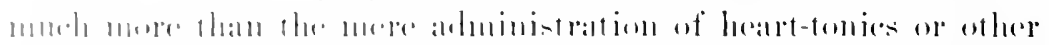

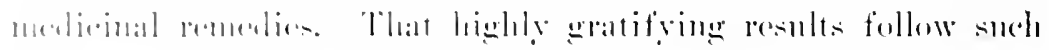

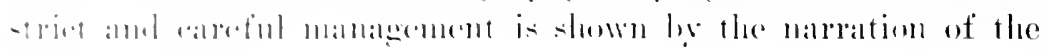

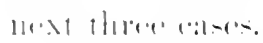

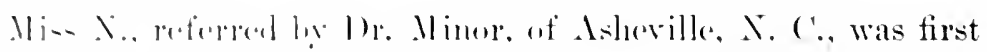

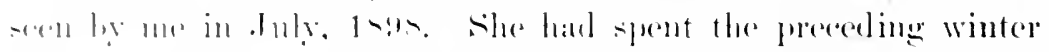

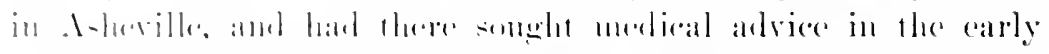

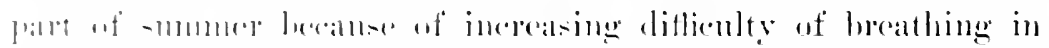

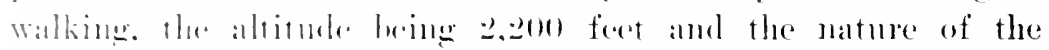

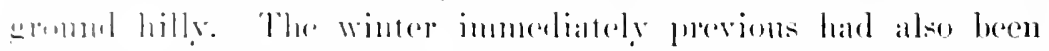

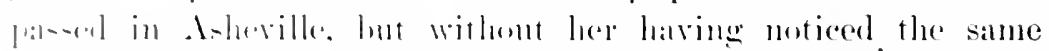

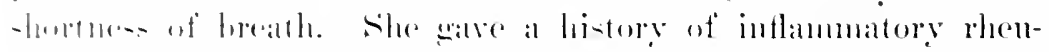

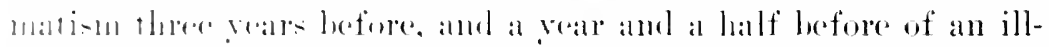

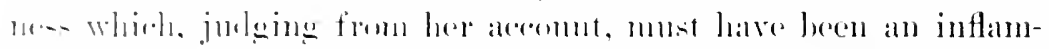
malien of a seloms memhlolue within the thorax. Her age was

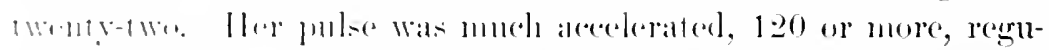

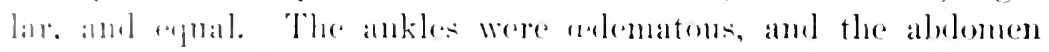

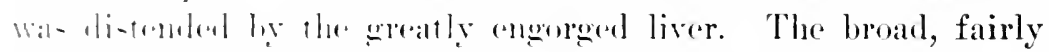

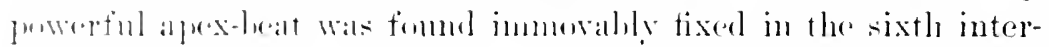

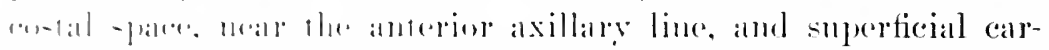

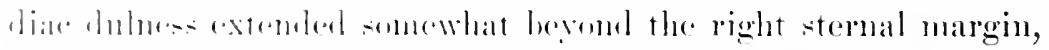

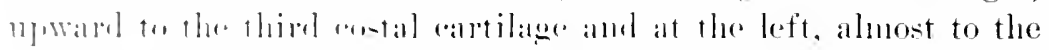
manniliary line. There was an intense howing systolic apes-mur-

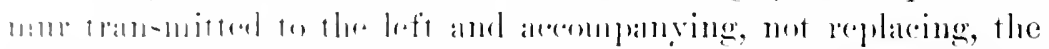

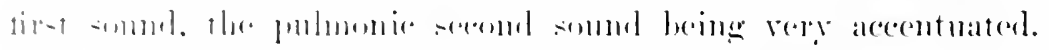

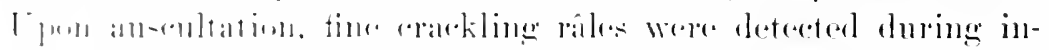

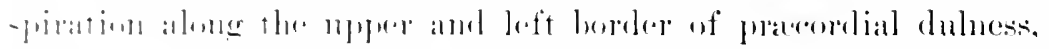

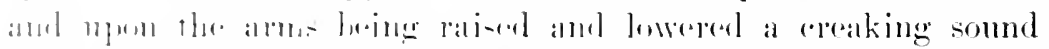

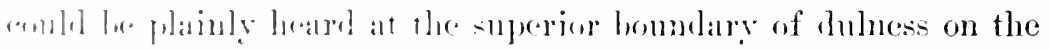
- tr.19umuls.

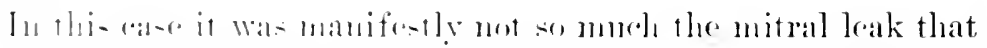

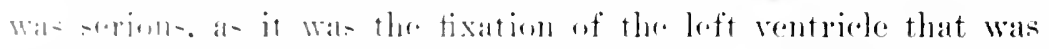

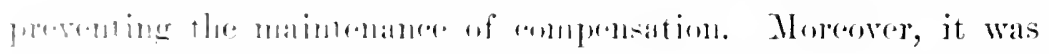

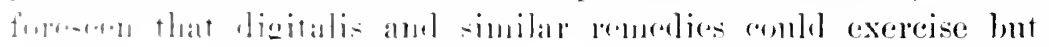


limited control orer the heart, since only slight if any reduetion in the dilatation of the left ventricle was possible ly roason of the restraining adhesions. Ftforts had to be directed, rhorefore, to lessening the resistance residing in the comgested portal system and at strengthening the right ventricle. The former was to lo accomplished by puratives, tonic doses of digitalis, and the romoval of all constricting elothing; the latter by those same moms, re-enforced by abstaining from too mmeh physical excrtion, and it need be by rest from all exercise. Aceordingly the patient was told to give up her corset, which she dirl, to take an aperient water daily before breakfast, and thrice daily 15 drops of tincture of digitalis. Stair-climbing was forbiden. Directions regarding the quantity and kind of food and the amomnt of fluits weace added. The degree of improvement was so insignificant during the next few weeks that at length absolute rest in bed was adrised and acted npon. Then benefit heeane at once apparent in showing of the pulse and diminution of dulness over the right heart. The liver also began to shrink, nine grew more abmdant, and arlema disappeared. After five weeks of enforeed rest the patient was permitted to gradually resmme her ordinary mode of life, excenting that she was not allowed to go ont. All this time digitalis or strophanthus was continned in abont the same dose (15 drops) of the one and 10 drops of the latter thrice daily, with exception of every sixth day, when it was omitted. Apex-impulse erew somewhat stronger, but never altered its position in the least; the marked change was in the right rentricle and lirer.

After a few weeks longer of such management it wat decided to try the effect of a course of Nauheim baths. They were given in her home and not at my rooms, as was then the rule with patients whom I subjected to this treatment. Whether because I could not watch their effeet as elosely in this way, or on aceount ot the hampering effert of the anlhesions (I believe it was the latter). the baths did not produce a beneficial effect. Ifeart-rate increased and showed a tendeney to mustearliness, duhness to the right became increased, and the amount of mine diminished. They were discontimued, therefore, and no permanent harm resulted. Considerable difficulty was experienced in getting this patient to give up her ("andy and obey instructions as to dict; but the habit of making her furnish me with an account of what she ate and 


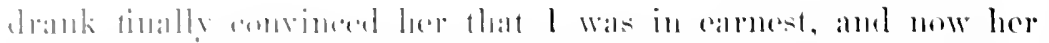

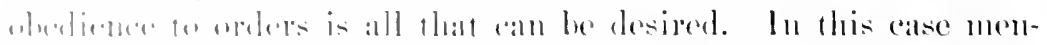

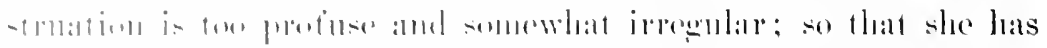

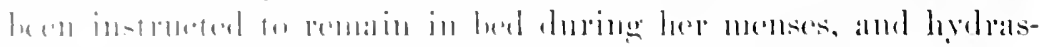

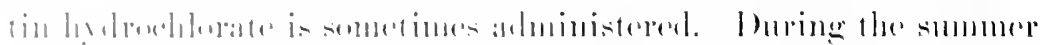

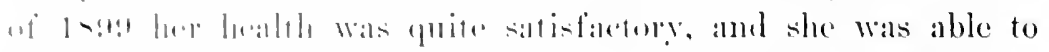

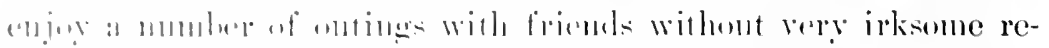

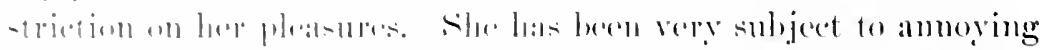

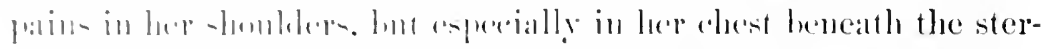
111111.

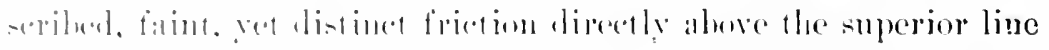

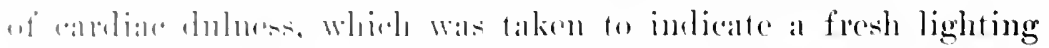

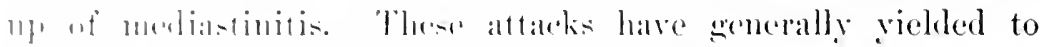

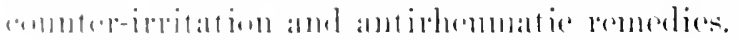

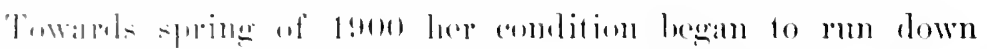

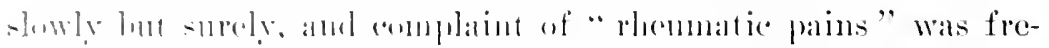

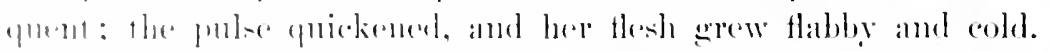

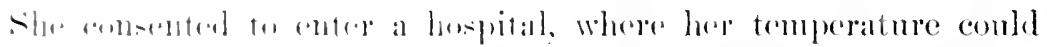

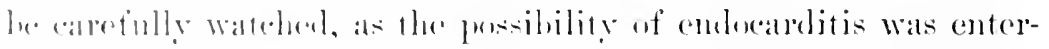

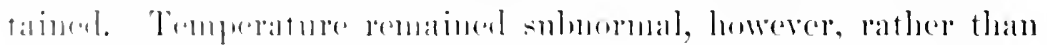

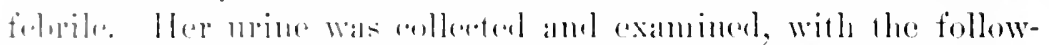

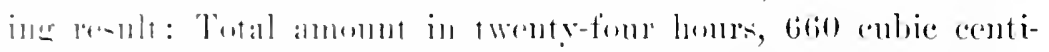

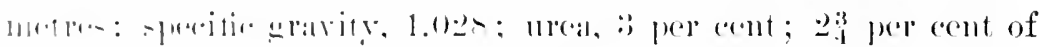

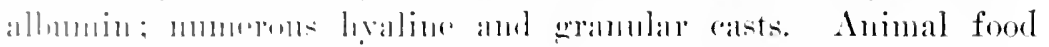

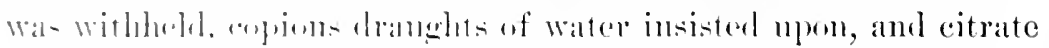

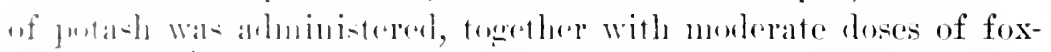

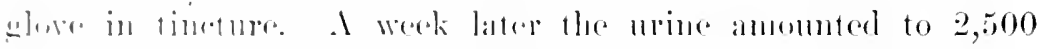

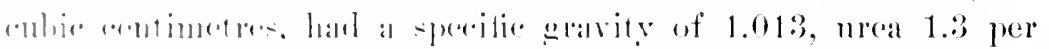

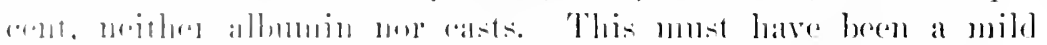

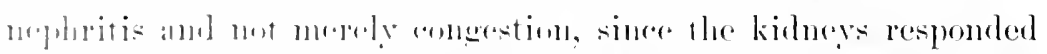

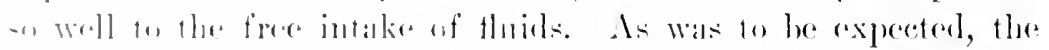

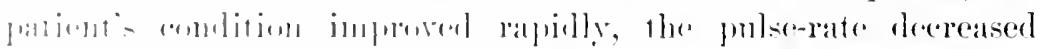

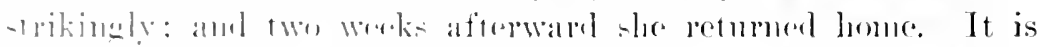

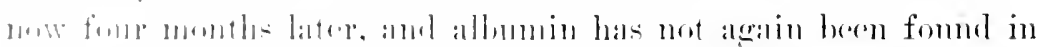

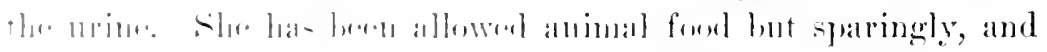

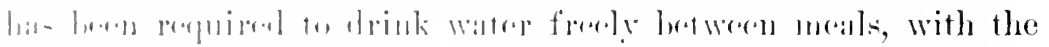

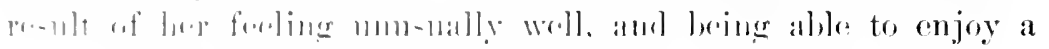

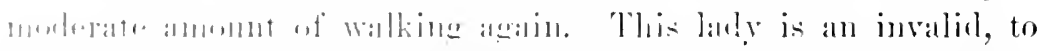

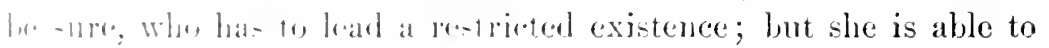


attend matinces and social fumetions of a quict kind, in fine, to get a good deal of cojorment ont of life. She cannot entertain the hope of becoming a wife and mother, and hats been so informed.

In this abe digitalis hals been taken most of the time, beeanse it has ben repeatedly proved by trial that when discanded entirely its need is shewn after a few days by incereased breathessness and subjective as well as objective rapidity of the heart's action, to 120 or more. The tincture has generally been preseribed, sometimes 10 drojs once daily, and at other times 5,7 , or 10 drops two or three times a day. Ipom a fow oceasions scantiness of the urine and adema, shown by pitting of the ankles, has necessitated the administration of the fresh infusion of English leares, a tablespoonful three or four times daily. Now and then eitrate of potassinm has been added. Snlphate of strychnine has also been taken much of the time, and whenever she hals felt more than usual wakness she has profited much from the compound syrup of hypophosphites.

She has been dependent on medicinal remedies, but no donbt a large part of her really good condition is owing to the excellent care she has taken of herself. She has dressed sensibly, wearing a loosely fitting corset-waist, and so far as possible suspending her skirts from her shomlders. Walking has been done at a slow pace and for short listances, eare being taken not to walk against a streng wind, and to stop for rest whenever shortness of breath or palpitation hats been experienced. Ascending stairs hats been aroided, or when that was impossible they have been mounted a few stairs at a time, with frequent pauses to let her heart cuict down or to recover breath. During storny weather she hat either remained indoors or has driven in a closed carriage to her destinattion. Any indispesition, howerer trivial, has received prompt attention, and a day of mwonted fatigne or exertion hats been generally followed by rest in bed or on a conch. Her dictary hats been simple and nutritions, and she has not been permitted to be in the least constipated. On the contrury, she took an aperient water every morning for a year at least, with a dose of calomel whenever her liver showed more than ordinary congestion or she felt a sense of fuhness about the waist. Lalterly the laxiltive water has been taken only every other day. Finally, she has been required to see me at regular intervals, generally two or three 


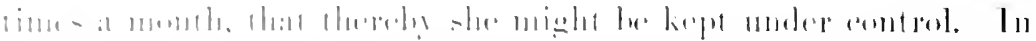

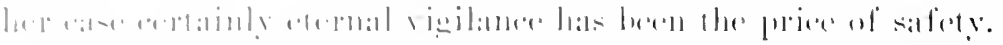

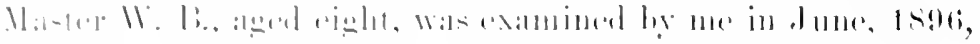

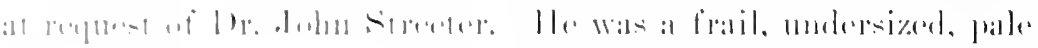

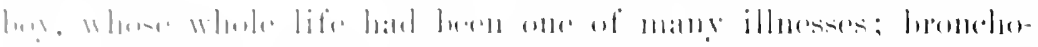

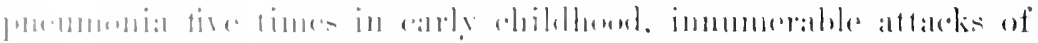

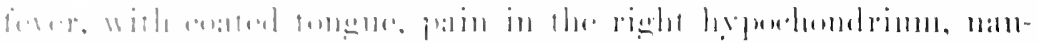

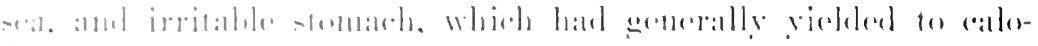

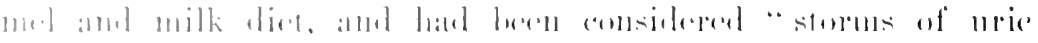

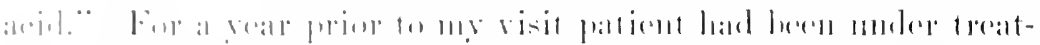

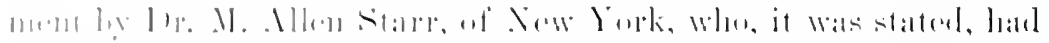

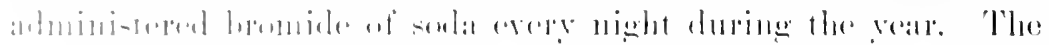

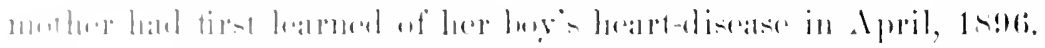

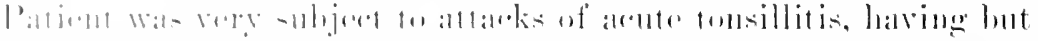

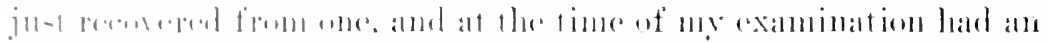

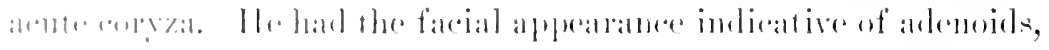

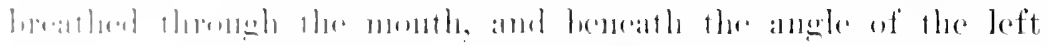

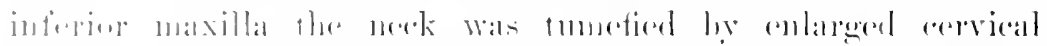

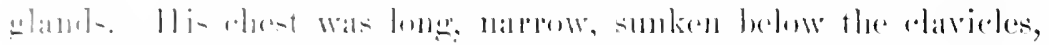

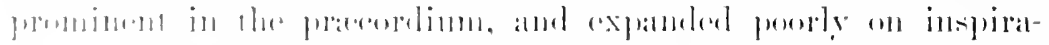

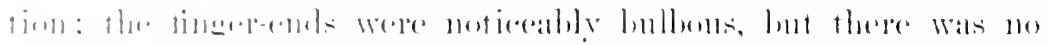

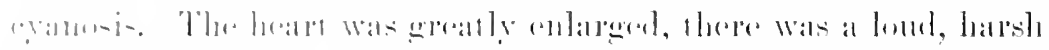

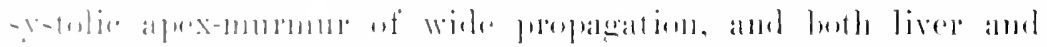

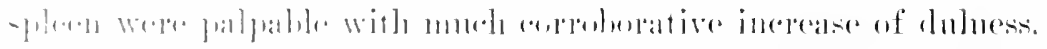

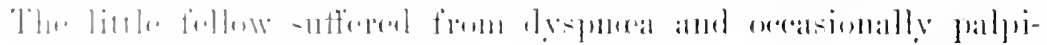

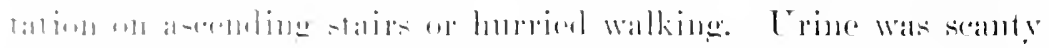

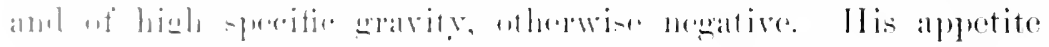

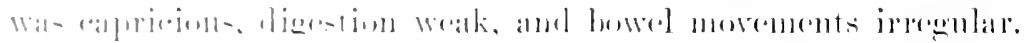

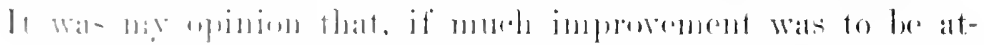

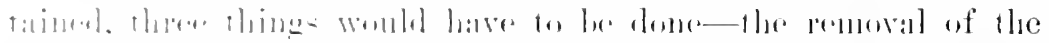

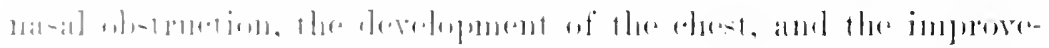

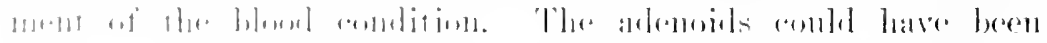

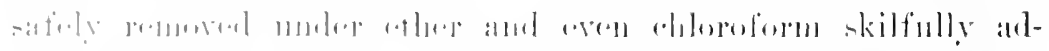

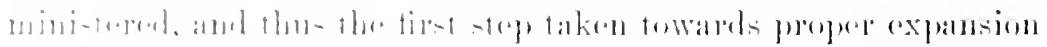

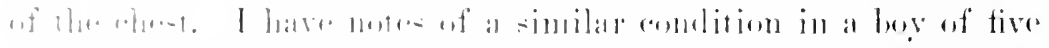

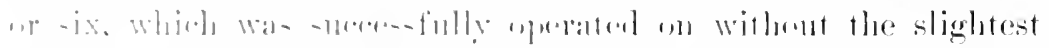

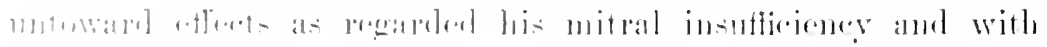

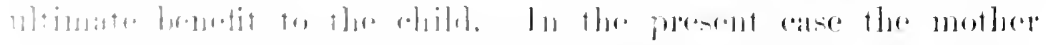

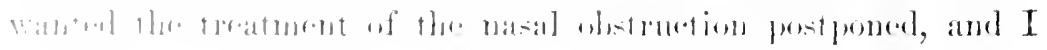


have never lealmed whether it has been done or not. It wals evi-

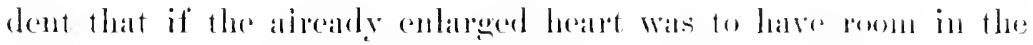

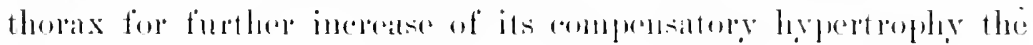
capalcity of the chest would have to be angmented. Acorodingly, his attendant, an intelligent trained nurse, was instrueted how to give resistance grmmatsties and hreathing exereises. These were intended not alone to strengthen his heart and develop his thorax, but also to facilitate blood-flow by better aspiration up out of the congested liver and abdominal ressels. A highly gratifring experience in orlere calses hat already shown how effective and beneficial such exercises are in such a conclition.

ln addition, improved nutrition was songht to be achieved through a dietary suited to his blood-state and to his feeble digestive and assinilative processes. Stanches and sugars were greatly thongh not entirely eut off, such as were allowed being carrefully selecterl-zwieback, toat, a little baked potato, ete. Meal ambl eggs were allowed in moderate amomnts, and certain fresh vegetables and fonits were added to the diot list. Snch modicinal remedies as would aid digestion, keep down fermentation, and mond the portal ressels were prescribed. 'To the last end ealomel was the drug selected, care being taken not to produce a tor powerful purgative effect. Cardiae tonies, digitalis and strychnine, were a minor part of the treatment, being administered in such doses only as would gradually tone up the heart. Some improvenent hegan to be apparent ahnost direetly, hut the family remored to the East before time was afforded to ohserve the ultimate results. Information came to me, howerer, sonne weeks subsecunently that the plan of management detailed was bringing about improvement. I have not seen the patient since that time.

W. II. W., aged thirty-nine years, male, physician, comsulted me in August, 1896, on accomt of an attark of mild anticular rhemmatism, one week previonsly, in right knee amb buth hips. He gave a history of inflammatory rliemuatism at age of nine or ten, at fifteen rementers he had shortness of hreath, and thinks he had intermittence. In 1 sso valvular disease wats diagnostieated. Imring 1895 he had an afternoon temperature from $99^{\circ}$ to $100^{\circ} \mathrm{F}$., but the canse was not discovered. In Decenuber, 1595, had a fever of $103^{\circ} \mathrm{F}$. that lasted three dars, and yielded to rest in bed and milk diet. Afterward folt better thim before. ITis 
andition was wand ilu following wintere and until his recent in-

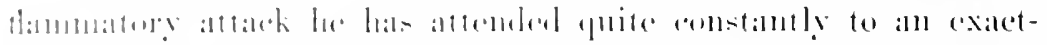

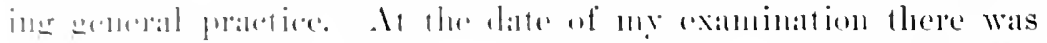

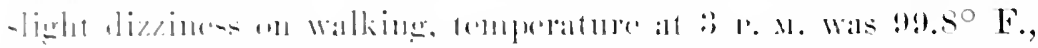

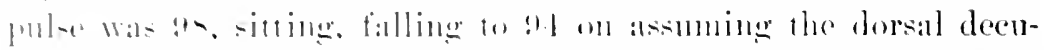

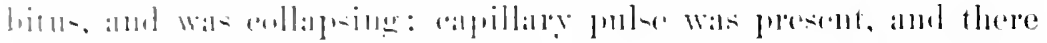

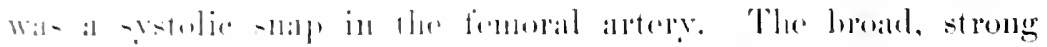

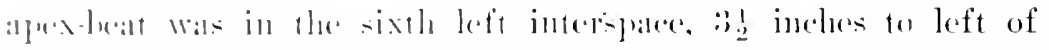

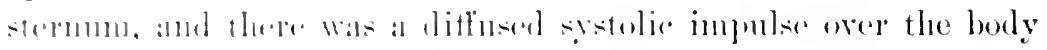

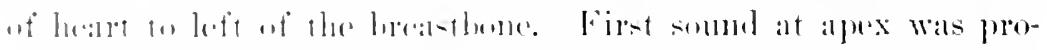

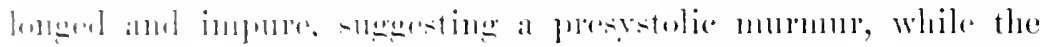

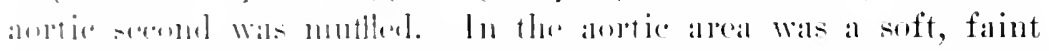

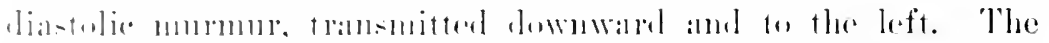

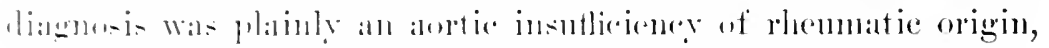

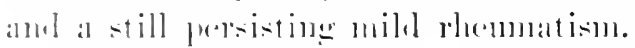

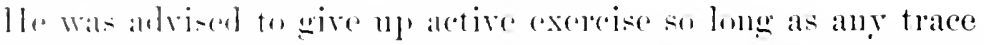
of joint intlammation persistent, and to take salieylate of soda

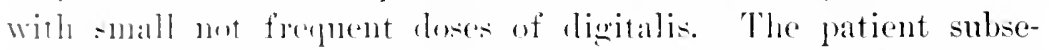

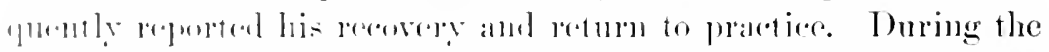

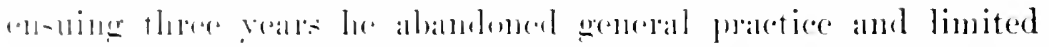

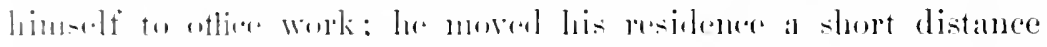

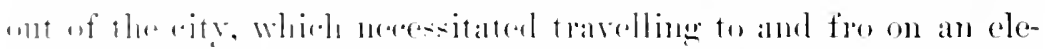

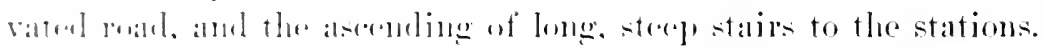
Il'

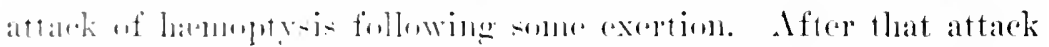

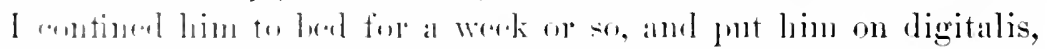

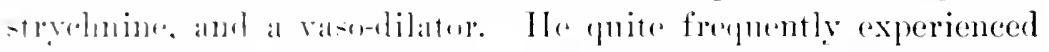

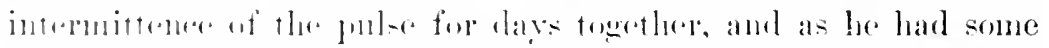

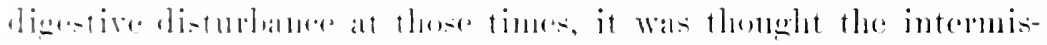

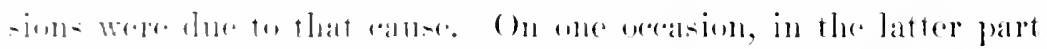

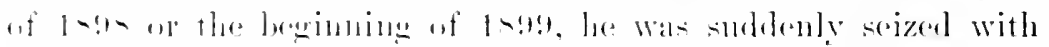

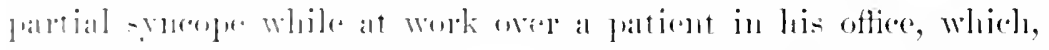

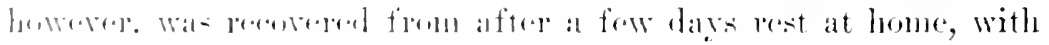

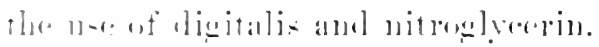

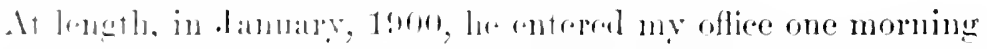

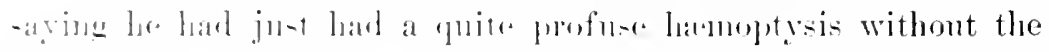

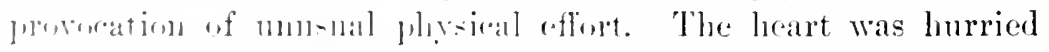

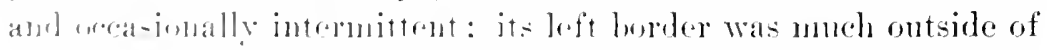
the left nipple, its aprex rathere tor, rounderl, amel its impulse 
not well defined. It was also noted that a romgh systolic murmur had developed in the artic area, which had not existed a year or two previonsly. The condition was considered rery threatening, as the hamoptysis pointed to puhnonary congestion in consequence of temporary inadequacy of the left rentriele. The entphatic admonition was given hin to return home at once and gon to bed for an indehinite tine, probably many montls. 'The advice was acted on, and he began the regular employment of small, thrice daily, doses of tirceture of digitalis, with 3 grains of potassimm iodide t. i. d., and stryehnine; glonoin was substituted now and then for the iodide.

II is dietary was light yet mutritious, and the bowels were kept free by calonel and other laxatives, as oceasion required. For a short period he had a light rum of ferer, with vague joint pains, which yielderl to salicylates. Ilis andiac action was invarialnly irregular atter beakfast, hut subsequently grew less amoying or disappeared entimely attel his monning glass of milk was abandoned, and his early meal was made more substantial. This patient remained in bed for four months, at the encl of which time his heart was fomd to have retracted somewhat in size, gained in the force and concentration of its apex-beat, and hald become noticeably steadier in action. He was then permited to resume exercise rery gradually, at first about his room, and thus by slow degrees to aceustom himself to his ordinary halbits of life. When at length he had grown able to get about as before his illness, le went into the comtry, and there, driving about with a medical firenr, soon got to feeling as woll as nsmal. Small doses of digitalis and strychnine were contimed after he left his bed and resmmed walking, for the pmpose of maintaining what the heart had anined by the prolonged rest. ('omsilering the age of this patient (now forty-three) and his history of repeated

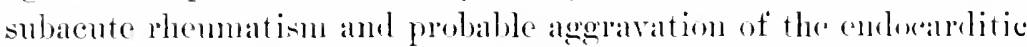
changes, the results secured were highly grallifying, and illustrate the immense value of phrsical inaction in the recombent pusture in cases of aortic regurgitation with hreaking compensation. This patient has had no return of his semptoms, so far as I have learned, up to the present writing. Nerertheless, the prognosis is not encombing, for unless the doctor is very calleful a final and irretrievable breakdown is likely to oceur at any time. 


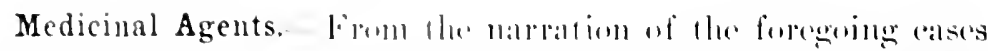

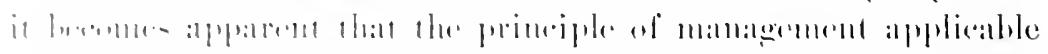

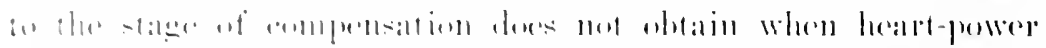

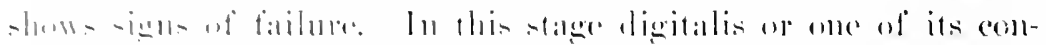

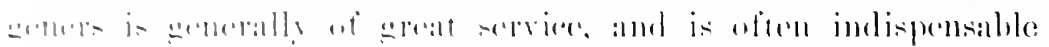

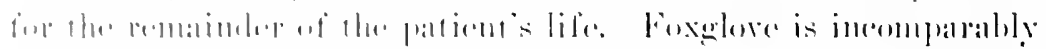

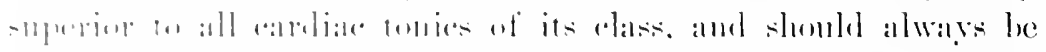

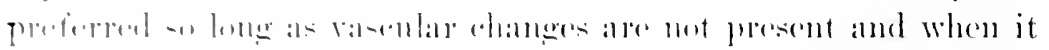

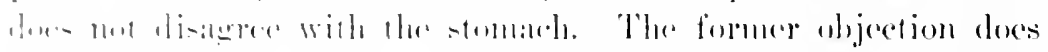

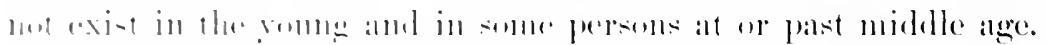

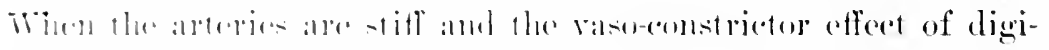

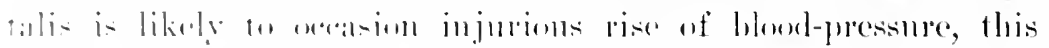

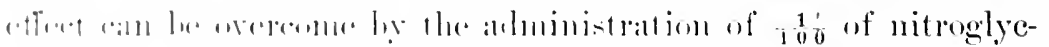

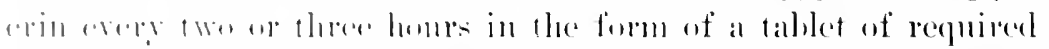

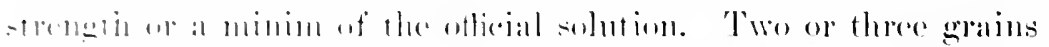

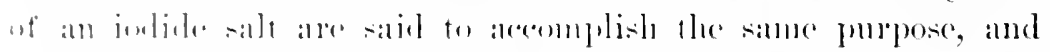

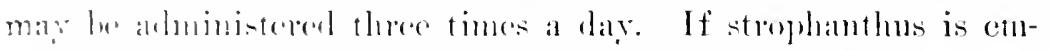

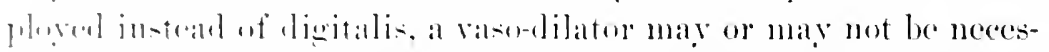

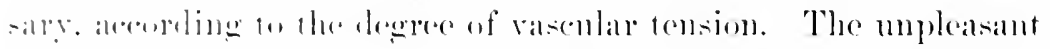

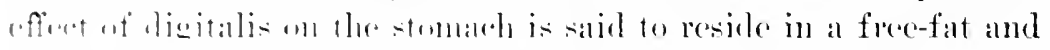

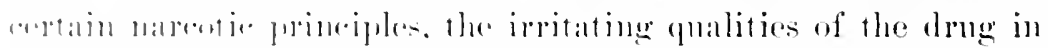

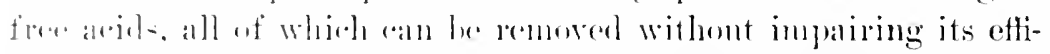
•

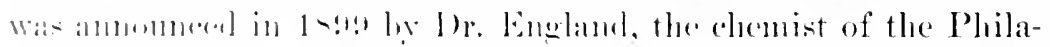

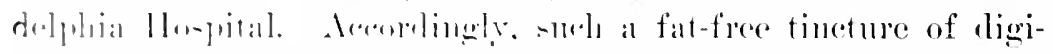

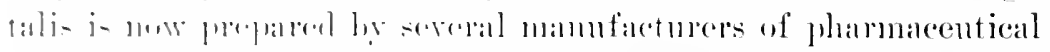

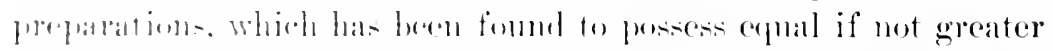

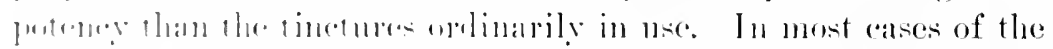

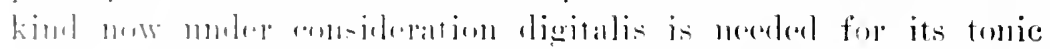

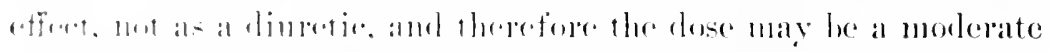

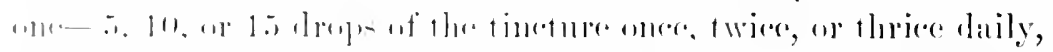

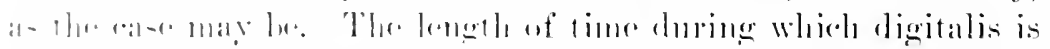

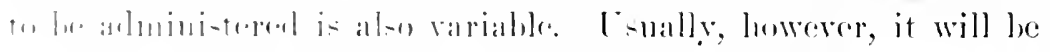

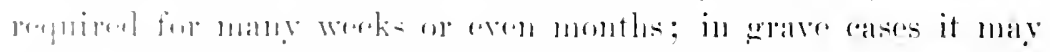

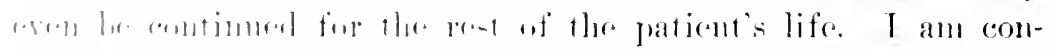

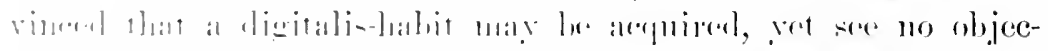

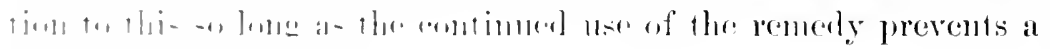

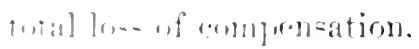

Anotler modicinal agent of gencually recegnised value as a 
cardiac tonic is stryelunine. It stimulates the leart thromgh its

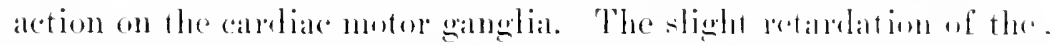
pulse-rate, which is porlued by its stimulation of the inhibitory apparatus, is transient, and therefore not to be rechoned with in considering its therapentic influence. The inerease of arterial tension, salid to result from its stimulation of the valso-motor centres, is so slight that oprinions are at rariance on this print. This effect is certainly too trifling to prove an objection to its cmployment, even in cases showing pronomeed valuentar drengemation and consequent high and sustained pulse-tension. Tho questiom of prime importance is, In what dose is strychnine to he arministered? Beliering that if it stimulates cardiac contractions in small doses through its action on the motor ganglia, it onght to do this still more powerfully in large ones, I have been in the habit of ordering doses that to many seem dangerons-that is, I

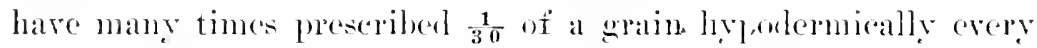
three, and even every two, homrs, milil seren or even eight injections have been given in a dar, and have continned these doses for days, and even weeks together without ill effects, so far as I combl diseover. On the contrary, they have seemed to be of pusitive benefit. Indeed, I may say it never oecurred to ne that the remody, even in these doses, conld do nore harm than oecasion the prinary phenomena of its phrsiological effect. As I have but rarely observed twitehings to result, and in these cases have fromptly discontinned the Arug, I have not thonglit to question its beneficial action. In a recent conversation with 1)r. R. G. Curtin, of Philadelphia, I was surprised to find that he stremously objects to such large doses on the ground that it is likely to prolues short and irritable systoles instead of long and strong contractions of the rentricle, such as are required to drive the blood nuwarl enepgetically. He thinks that the nemility of the casdiar nerres and ganglia become exhansted. ITe stated, morosere that ho was gratified to find, during a recent visit abroal, that such experienced clinicians as Finest Sansom and Limelor-Prouton de not exhibit the agent in large doses, contenting themselves in fatet with $\frac{1}{50}$ of a grain three or fomr times daily. Surle opinions are worthy of consileration, and are here giren in the hope of stimulating original ofservation on this point. It is diflicult to abandon notions that have dominated one for many gears and 


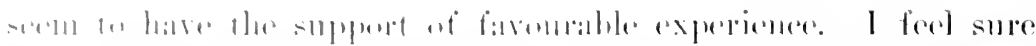

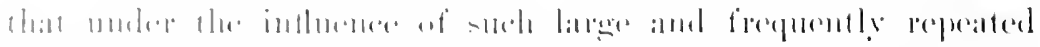

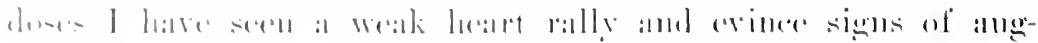

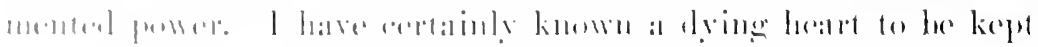

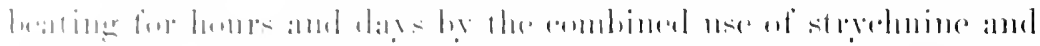

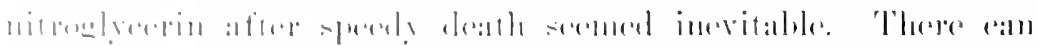

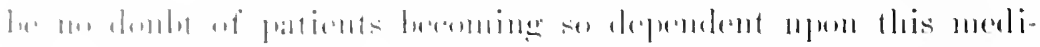

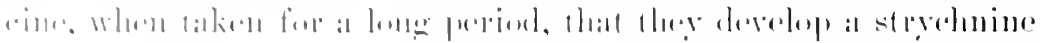

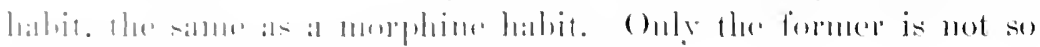

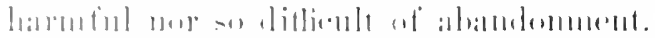

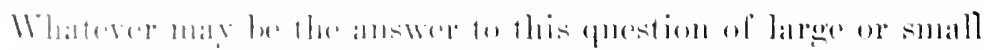

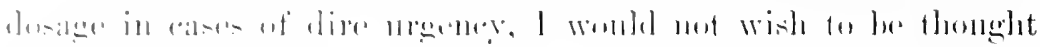

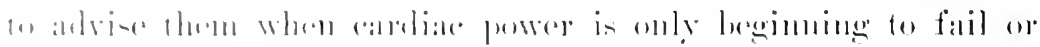

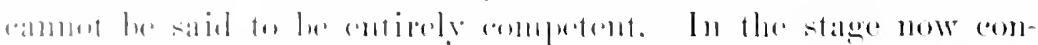

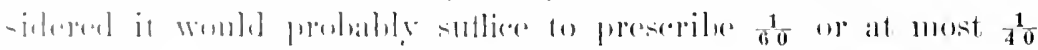

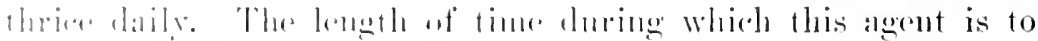

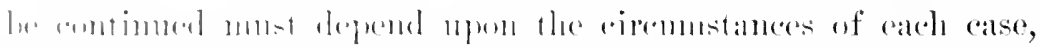

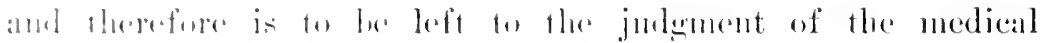

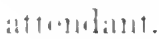

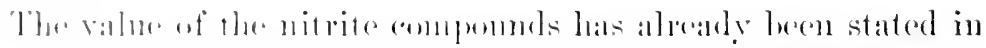

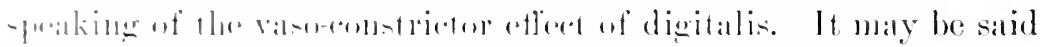

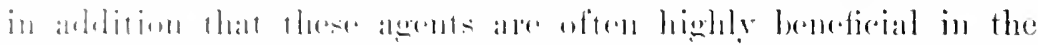

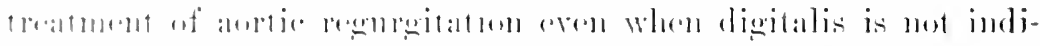

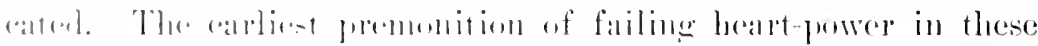

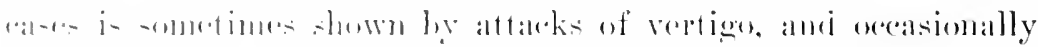

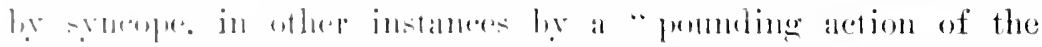

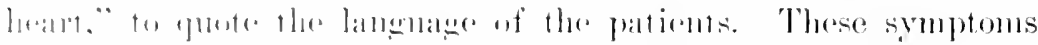

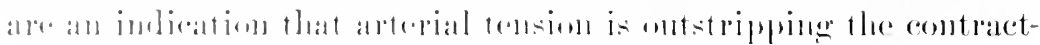

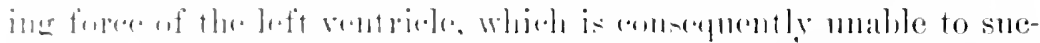

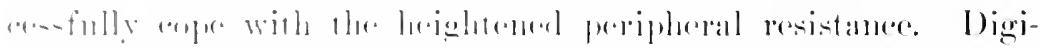

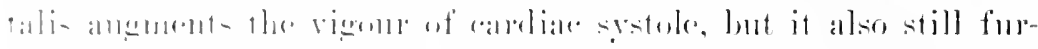

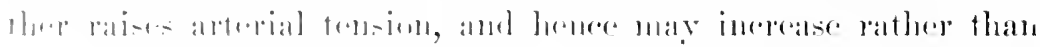

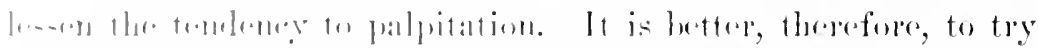

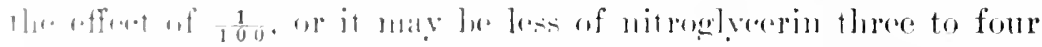

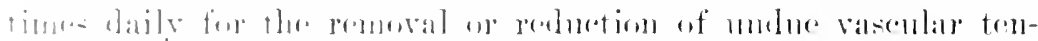

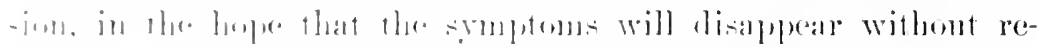

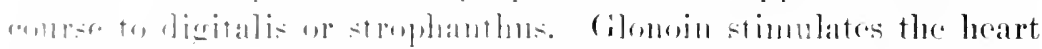

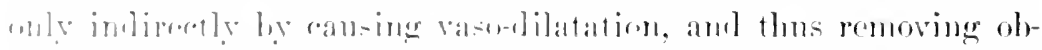

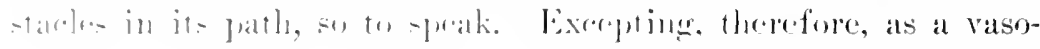


dilator, nitroglycerin is rarely to be employed in this stage of valvular aflections.

A perusal of the enses narrated in this ehapter will impress the reader with the great benefit often derived from enthartic remedies, and the important role played by them in the management of patients. Their utility was first really impressed upon me by the writings of English anthors, and to their teachings I owe much of my sliecess in the managenent of eardiopathies. I shall have more to say on this subject farther on. It will suflice at this time to direct attention to the tendeney of most valvular lesions, especially mitral and those of the right heart, to eongestion of the reins of the abdominal riscera even before signs of compensatory disturbanee grow pronomed. These congestions camnot be so surely and fuickly relieved by any ofler means; often they cannot be removed at all withont reconrse to pmrgatives.

If all that was needed was to inclease the driving foree of the left rentricle, and thus to push the remons blond onwad, then digitalis would be the remedy par exeellence. In these valvular discases, howerer, there is an impediment to the flow of venousi. e., of the return blood through the lumgs and heart. Behind this impediment the circulation becomes dammed up. The surest mode of preventing an inmondion is to provide an ontlet, and this is done by carrying off some of the water of the blood throngh the intestines. When this has onee been acomplished, then a heart-tonic or stimulant may be able to reinstate a satisfactory dearee of circulatory equilibrium. In some eases it is impossible to do more, or eren hope to do more, than kerp the stasis within bounds and rencler the heart's labour somewhat rasicr. Aloes, cascara, ete., which mload the colon relieve constipation when it exists, but they do not oceasion free watery stools, snch as are neederl to deplete the engorged portal and tributary reins. 'To this end, saline preparations or such other drugs as are not too drastic are lequired. Of these, nothing is more efficient than sulphate of magnesia in saturated solution or discolved in hot water and taken half an hour before breakfast. Its taste is very objectionable to some persons, and it is sometimes rejected by a sensitive stomach. In such an event it is hetter tolerated if to it are added half a dozen minims of the ordinary essence of ginger 


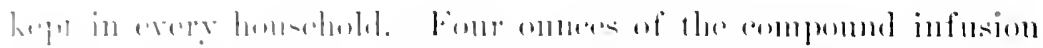

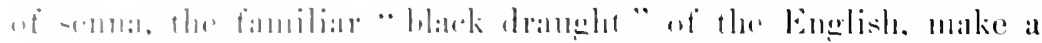

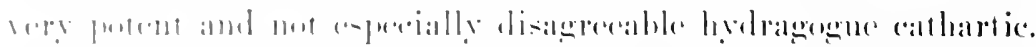

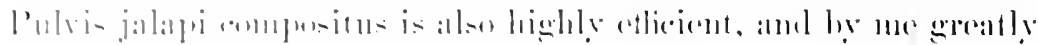

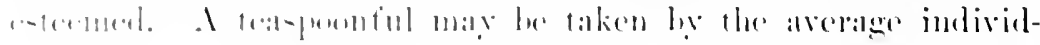

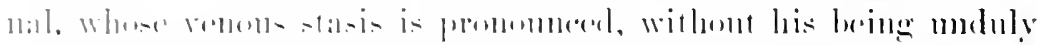

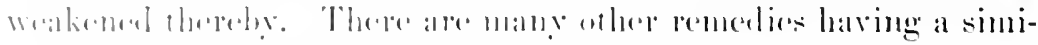

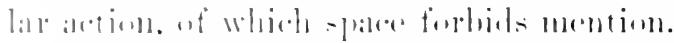

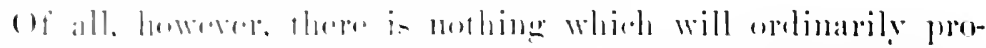

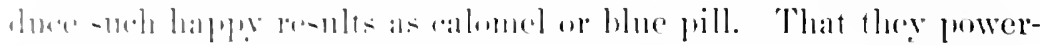

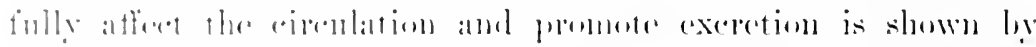

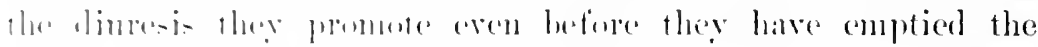

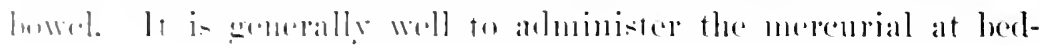
linse. and have it followed next morning by a saline. The fre-

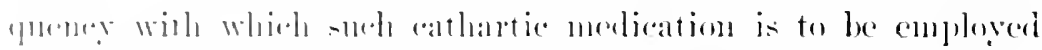

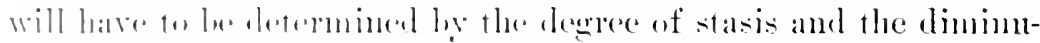
tiunt that the-lhes.

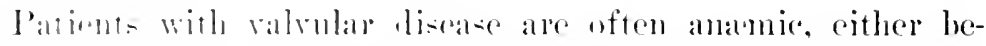

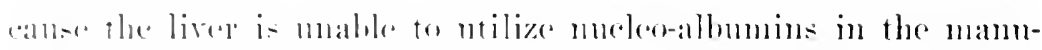

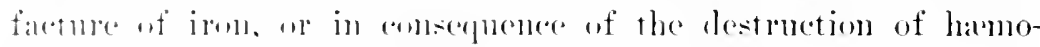

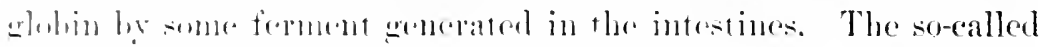

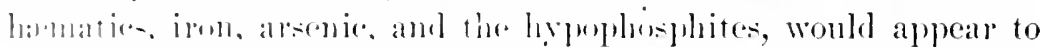

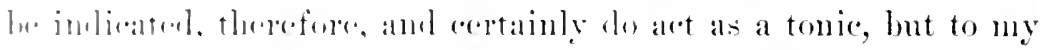
mind it i- dombtol whether their heneficial effect is not due to thro inglewing appetite and ligestion lather than to their

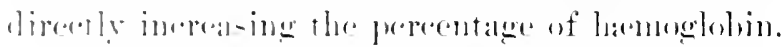

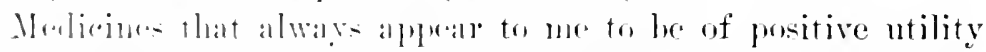

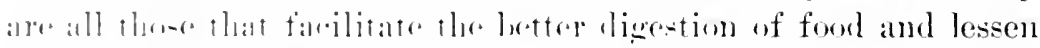

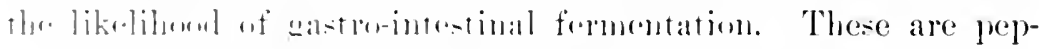

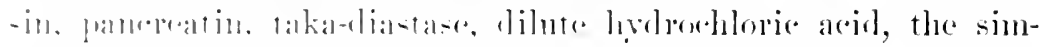

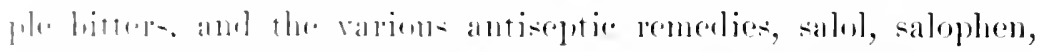

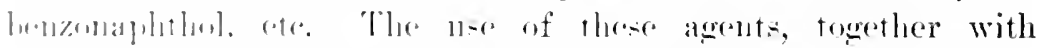

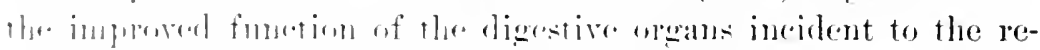

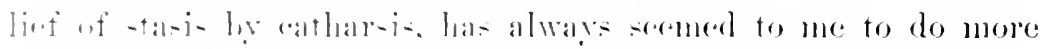

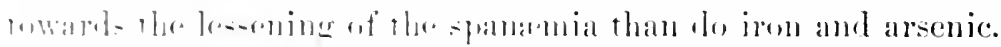

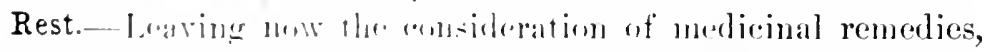

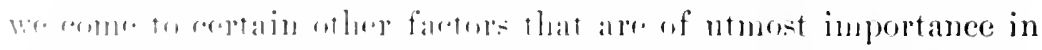

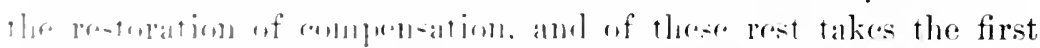

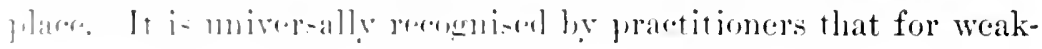




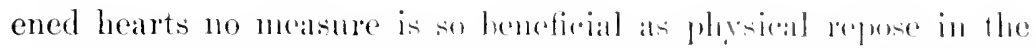
recembent position. Not so with the latity, am pationts firequently perserere with some lorme of experion in the mistaken

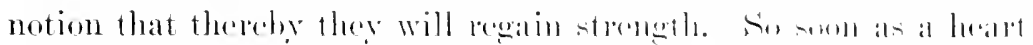

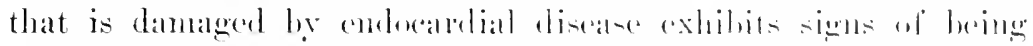

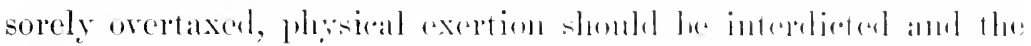

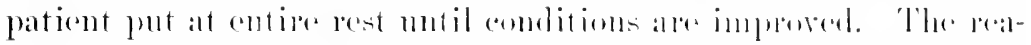

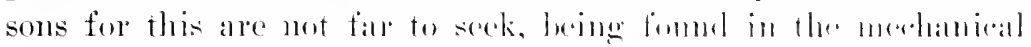

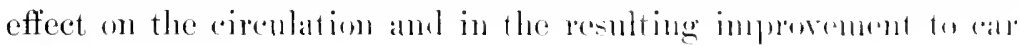
diac nutrition.

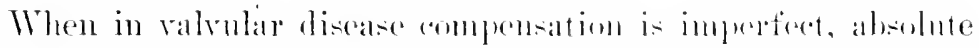

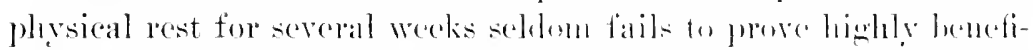

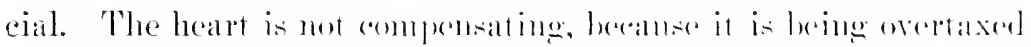

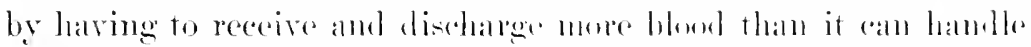

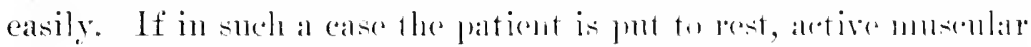
movements are abolished and resprition is lows lapid and nume

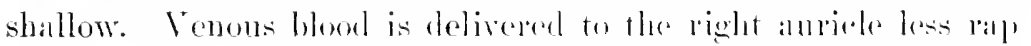
idly and the right rentriele is given lesis work to de. ('arliale

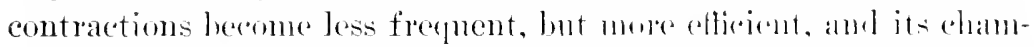
bers are better able to empty themselves. Thus the drepoatsol inflow and the increased ontfow temel to diuninish litatation and

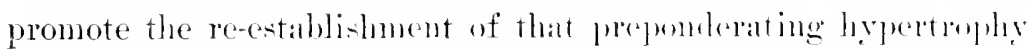

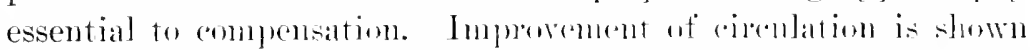

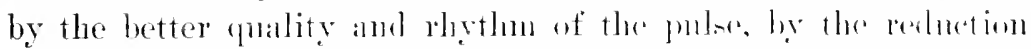

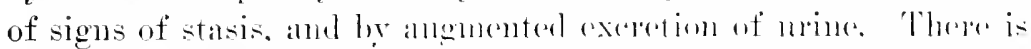

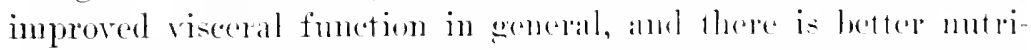

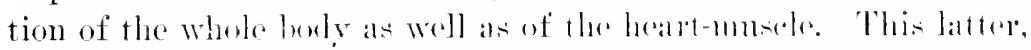

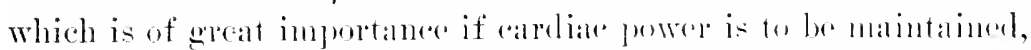

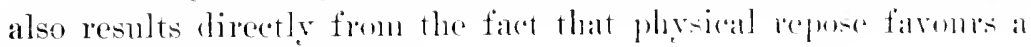

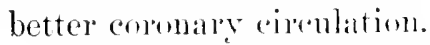

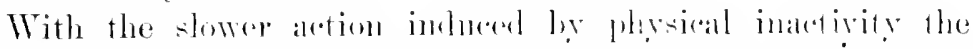

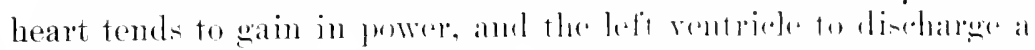

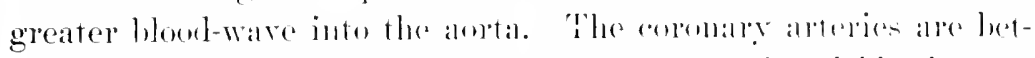

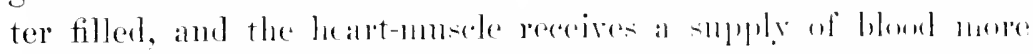
adequate to its nexpls. This, howerere, is but a palpt of the lenetit

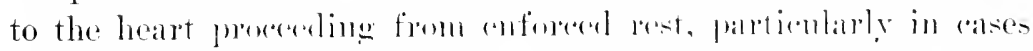

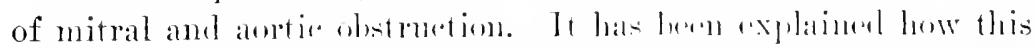
treatment lessens andiald dilatation. It is the right heald chiefly

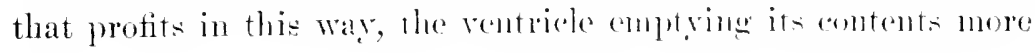




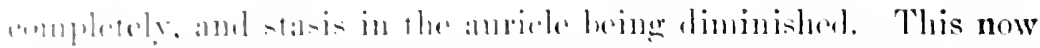

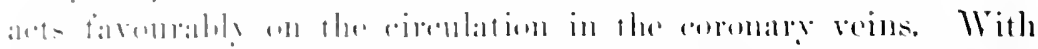

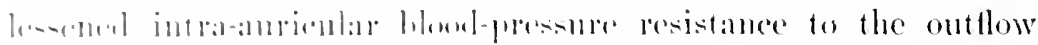

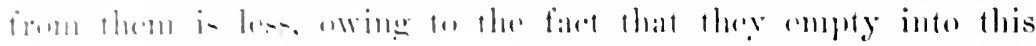

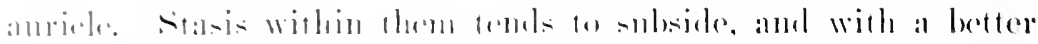

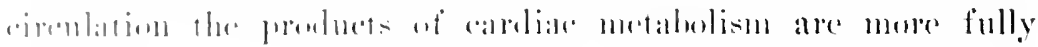
reminent.

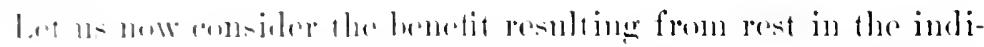

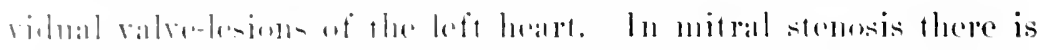

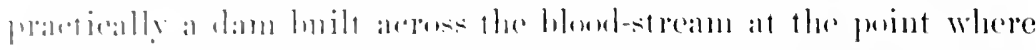

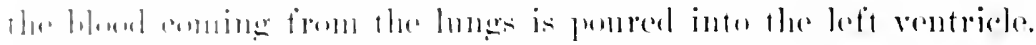

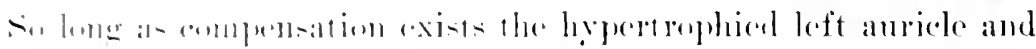

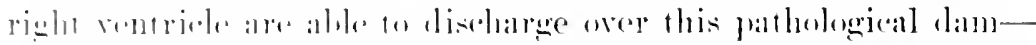

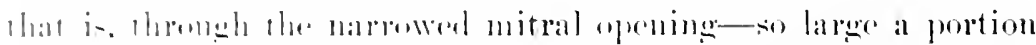

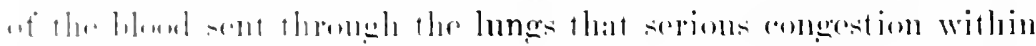

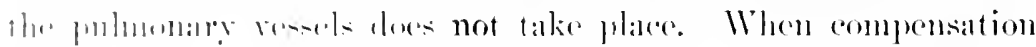

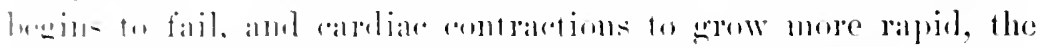

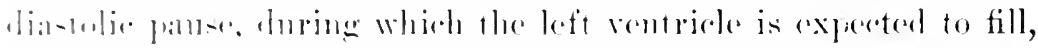
i. - hertentud, and time is nut allowed for the laft anricle to empty

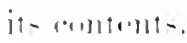

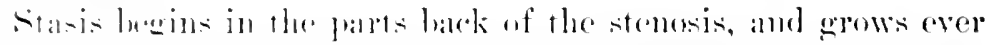

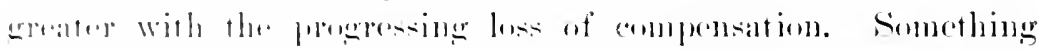

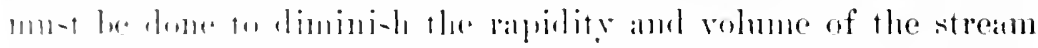

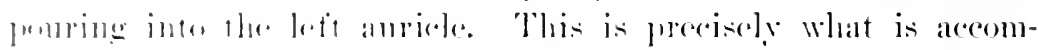

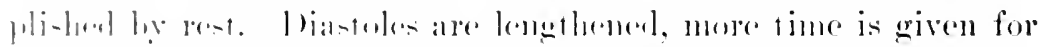

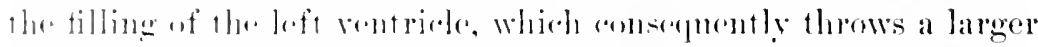

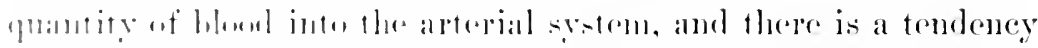

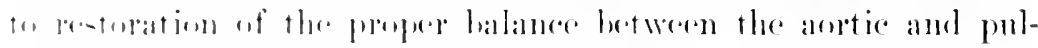

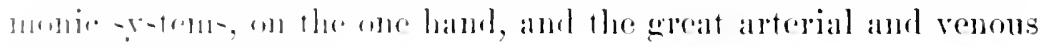

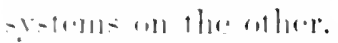

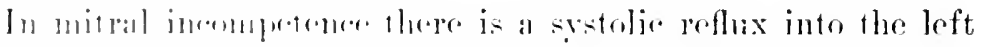

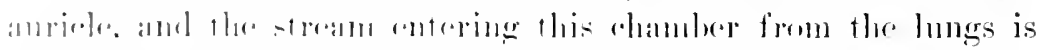

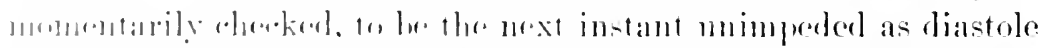

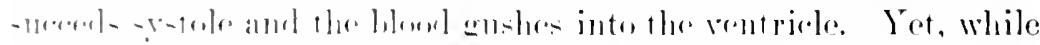

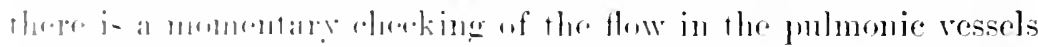

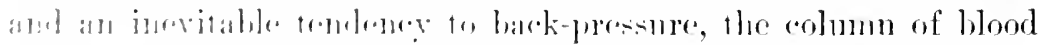

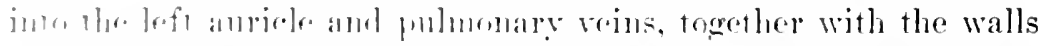

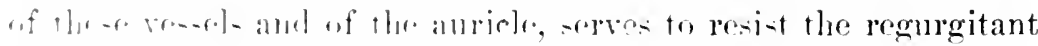
ruth frm the ventricle. So long, therefore, as this resistance is 


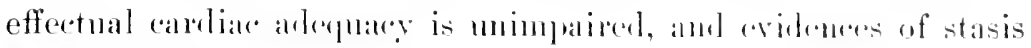
are wanting.

When this compensation bregins to fabe it is necostaly to relieve the walls of the loft ambele, the pulummary vesidels, and the

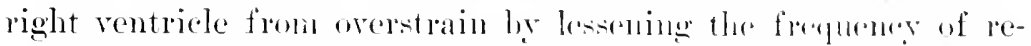

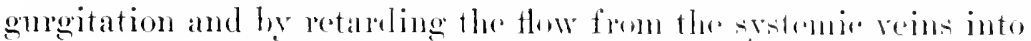

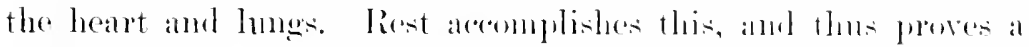

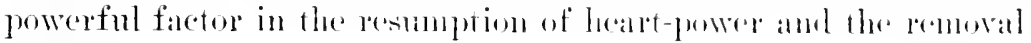
of stasis.

In the same way alio as in mitral stemosis the coronary reins

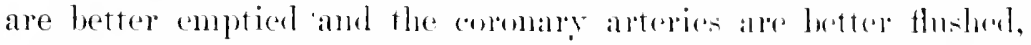

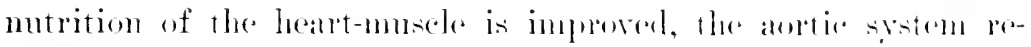
coives more blood with each sistole, and an improved eneneral nutrition results.

When in aortic obstruction compensatory hypertmply of the left ventricle begins to vield to dilatation, the contents of the ventricle are no bonger adepuately driven thromgle the stomosed orifice. Signs of stasis appear and incereatse in ploportion to loss of compensation.

Two things are now requiresl if the theratening broakelown is to be averted: (1) More foredibe contratetions on the part of the left rentricle, and (2) the delivery of less blowe to the ventricle. Rest slows the heart hy lengthening its diastoles, and lunt little if at all its systoles: while if it affects the rigome of the latter, it deres so only indirectly by relieving it of strain aml innproving its mutrition. It can do very little, therefore, towalds rembling the left ventricle to drive blood thromgh the narrowed alortic orition, and, moreover, experience has tanght that when in this discase the left ventricle legins to weaken, it is an indieation that the strmosis has overpowered the ventricle. All that is left is to spane this ahamber as far as possible. It is hy acomplishing this, ol the soromel requirement mentioned above, that rest is of sorvice in antic stenosis. It serves to retard the flow of blowel into the loft rentricle, and thus to lessen the amomnt which this ellambles is requiled to discharge past the point of eonstrietion. Therefore althongh this therapentic measure is of service in comserving heart-pener in this affection, it camnot accomplish such brilliant lexults as in mitral disease.

In aortic regurgitation failing compensation noans impaired 


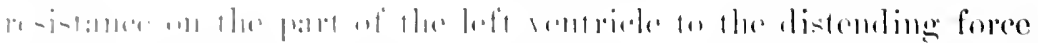

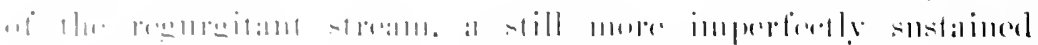

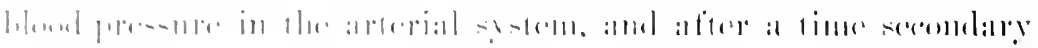

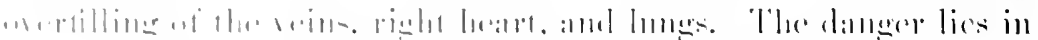

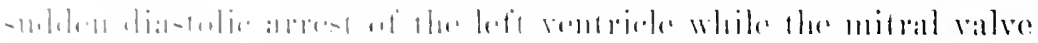

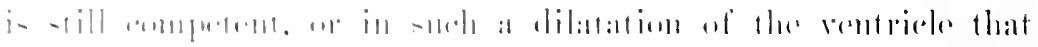

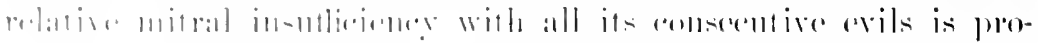

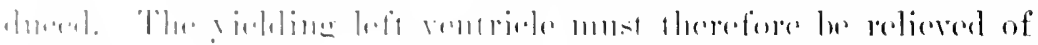

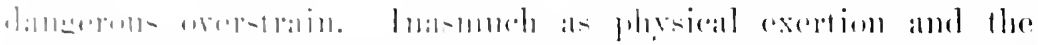

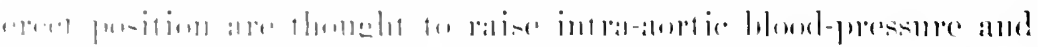

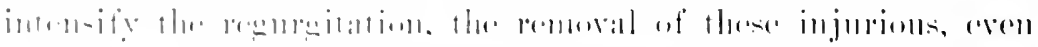

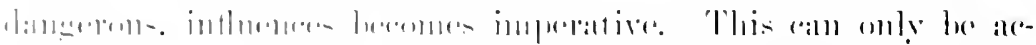

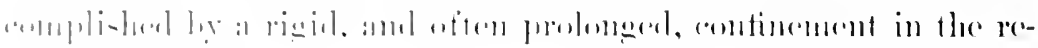

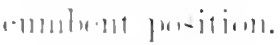

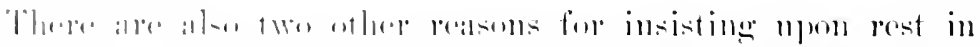

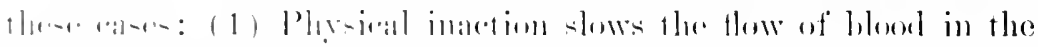

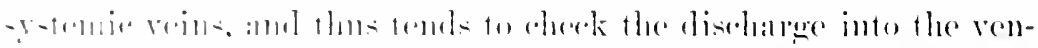

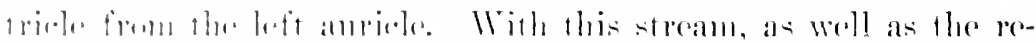

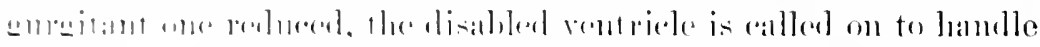

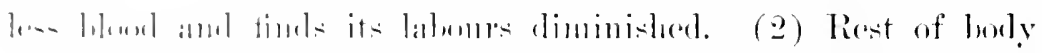

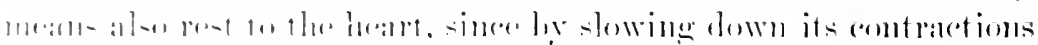

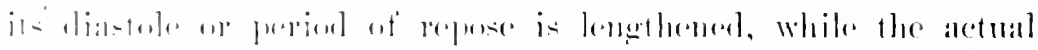

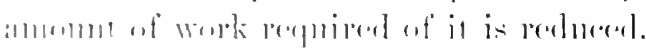

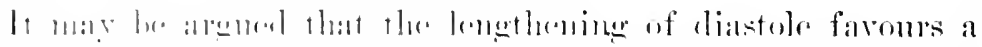

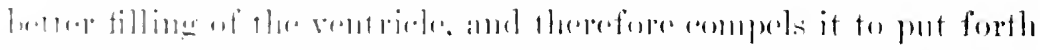

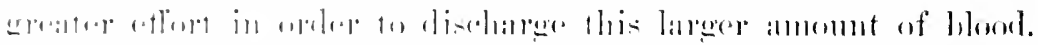

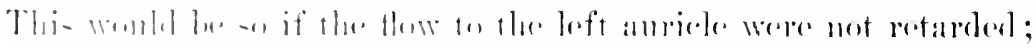

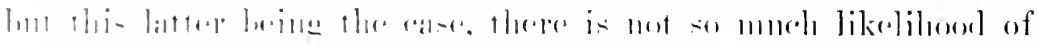

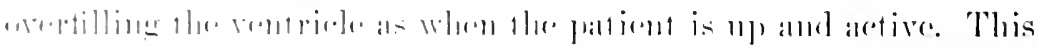

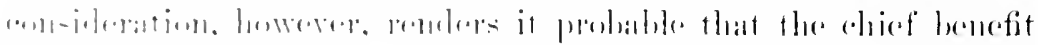

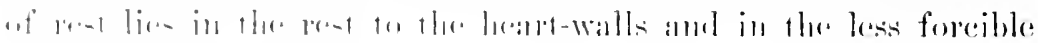

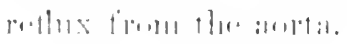

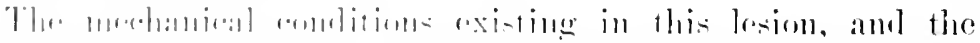

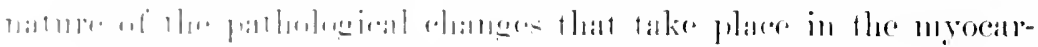

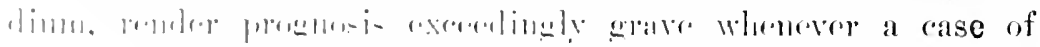

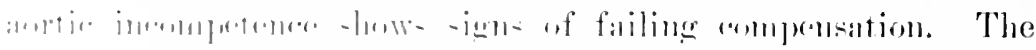

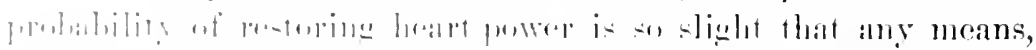

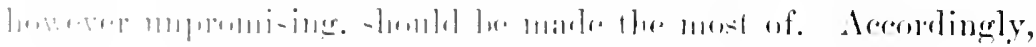

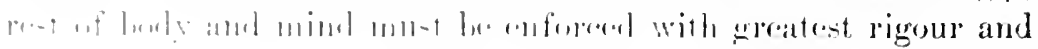


for an indefinite length of tine, not merely for weres, hut for

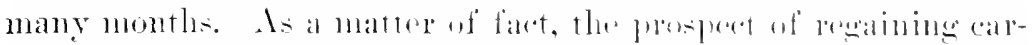

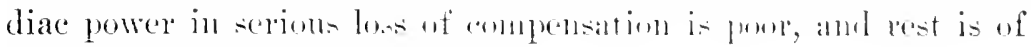
service mainly in prokngeing life.

Since, them, rest is so valuable a meams of treatment in onr

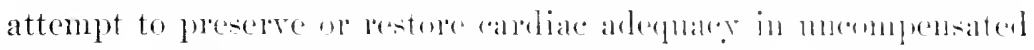

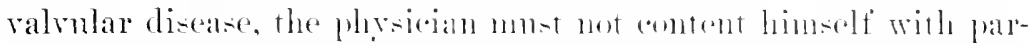

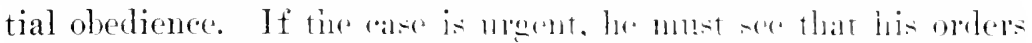
are carried ont faithtully. When a patione is tohl that rest in bed is needed, he must be madr to molerstand that he it is meant not rest for a fer homp each day, hut rest both lay and night. Moreover, it does not mean that he (an wet up at ofterl as he pleases to feteh some alticle he wants al to walls to the toilot, that is situated perhape a shopt distanee down the hall. It mentes that he is to remain in beel, amel is to hare the attention of a nurse who can spare him all aroidalle effort.

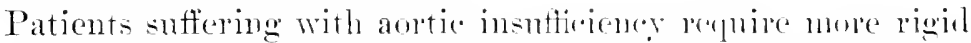
enforecment of absolute rest tham do most fersons with mitral discase. A single indiscreet affort may molo all that has heom gained by weeks of inartion. Therefore. such a pationt whe $i=$ struggling to preserve his left rentriele from anduplete destruction

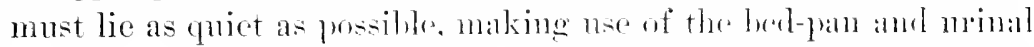
bottle, and taking his meals in the dontal deculditus. If this is impossible, as is sometimes the case with nervoms indiriduals, then they may be lifted a little highere hy the nurse. and, sulpported he pillows may take their meals in this position. Buttere

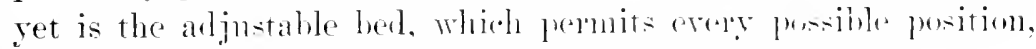
withont the slightest exertion on the part of the patient.

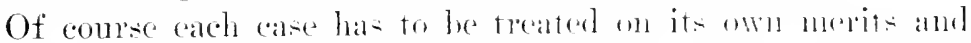
according to its own exigeneies. One pattent may le permitted

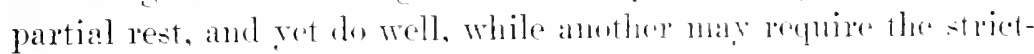

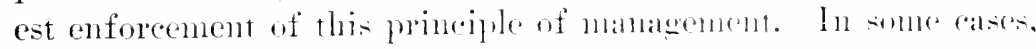

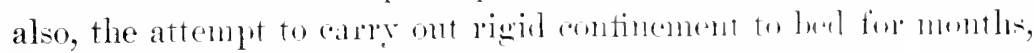

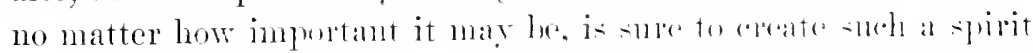

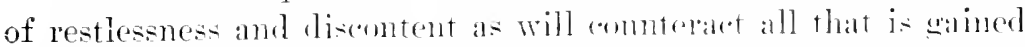

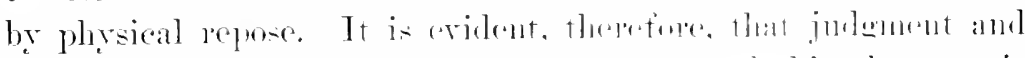
tact are often required in the enfureenent of this therapentic ageney.

Finally, when asked, as he is sure to lx, how hong rest is neces- 


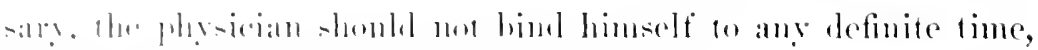

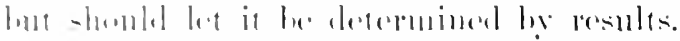

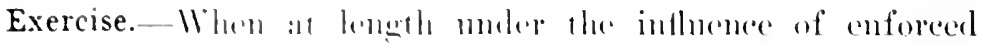

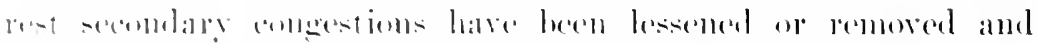

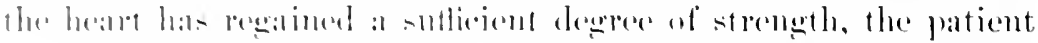

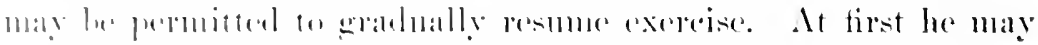
walk -lomly amd for a loref period about his room, care always

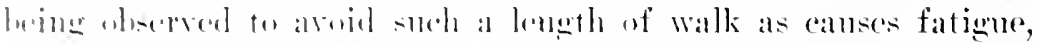

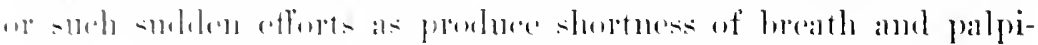

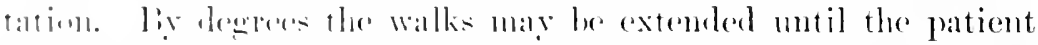

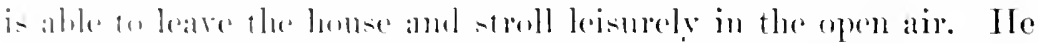

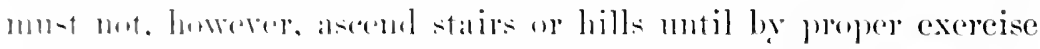

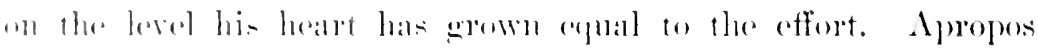
uf hill-elimhine, a word may he sail of the 'Terman ('ure, or

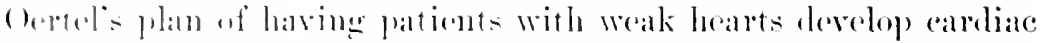

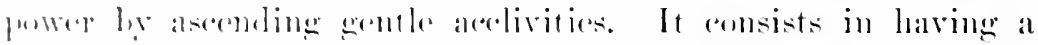

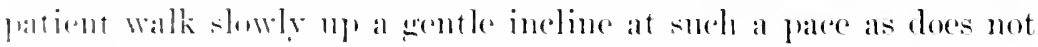

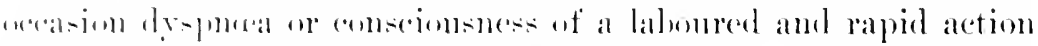
of the lesal-intallihle signs of cardiar strain. Then, when an

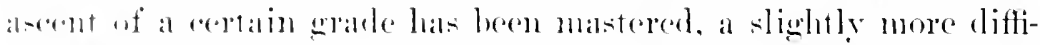

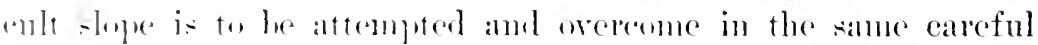
mammer a before; and thus paths of ereater and groater steepness are surmonuterl. It must always he enjobend upon the pationt thall he is to make these areents with great deliberation, not permitting limuself to talk during such offorts, and stopling to rest

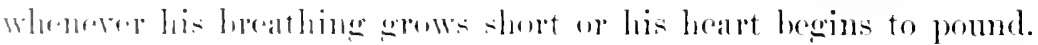

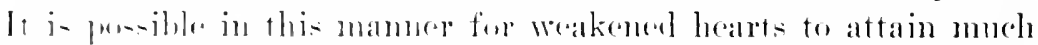

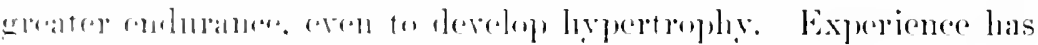

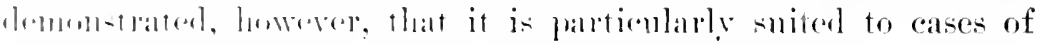

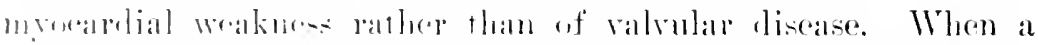

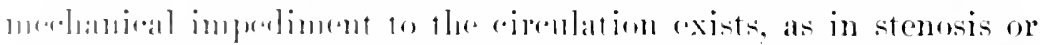

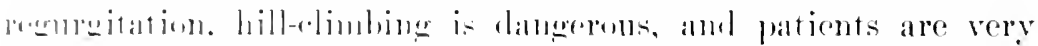

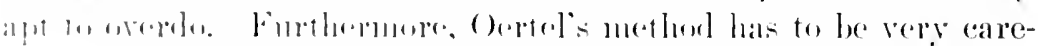

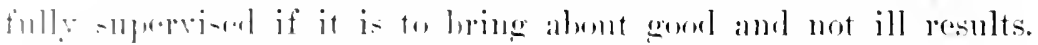

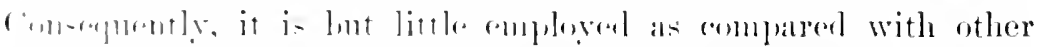

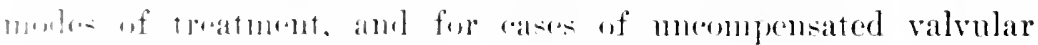

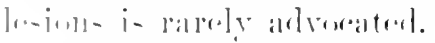

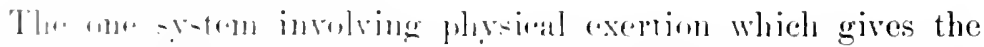

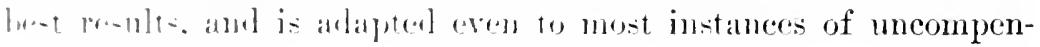


sated ralrular discalse, is that forming a part of Nanhein treatnent, and which will now he describerl.

Resistance Exercises.-Thene consist of voluntary novements by the patient of flexion, extension, and rotation of the extrem:

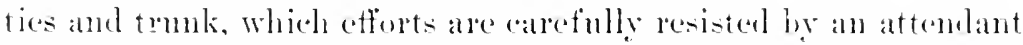
trained to the work. Sot only must the attendant mulcrstand how to resist the patient's morements withent enstrieting the part to which he applies resistance, hut he must so aljust his counter-pressure to the patient's strength as to mot oceasion respiratory or eirenlatery embarrassment. He must therefore be sufticiently skilled to defoet signs of distress and to julge whether too great or too slight resistane is being offered.

The indications of reppiratory and circulatory (molrassment, for which the attendant is to watele, are dilatation of the nostrils and sighing or irregular hreathing, increasing duskiness or pallor of the comntenance, a llawn look abont the montl, yawning, perspiration, and palpitation. So soon as any of these signs are detected the morement is to be stopped and the patient's extremity sowly allowed to assmure a position of rest. Then, after a sutfieient period for repose, the excreises may be resumed. Patients are very apt to hold the breath while exernting these movements or to hold the boly rigid, thes putting forth ceffort with more than the limb that is being resisted. The attembant shombl therefore remind the patient fon time to time to continue breathing, and shonld see to it that his puse is easy and monemstrained. Attentiois to these points will enable a patient to go throngh the series of movensents withont fatigne or strain. Furthermore, the same movenent is never to be made twice in suression, and each one is to be followed ly a briof panse. It is aloo woll in some cases to allow the individual to sit and rest orobismally during the treatment. As his endulance grows, such preatutions beeome less and less neeessary, althomgh the attendant must nover allow himsedt to be thrown off his ginad and forget to maintain clese wateh of the pationt's comelition. Nany persons of considerable musenlar strength are inclined to regald the exereises as tom cats and to think no benctit and aceme from such sentle exertions. They consequently want to have nore resistance oflered; but to all such requests the attendant must tum a deaf ear.

The last injunction to be observed is to hare the morements 


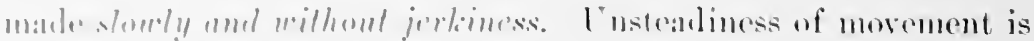

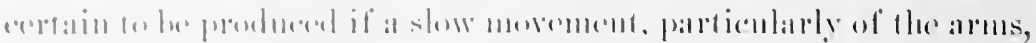

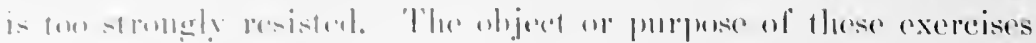

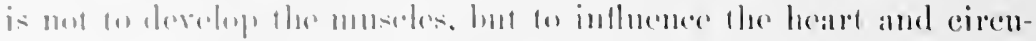
lation: all of which is anly acomplished when the varioms move-

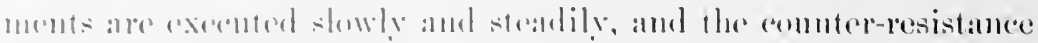

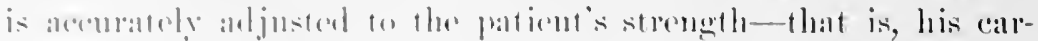
dian 1101 his mons?

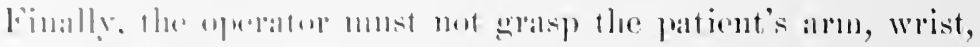

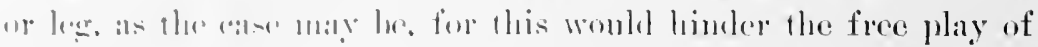

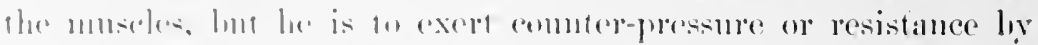

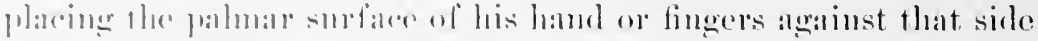
uf the gatient" simb which lowks in the diecetion towards whells

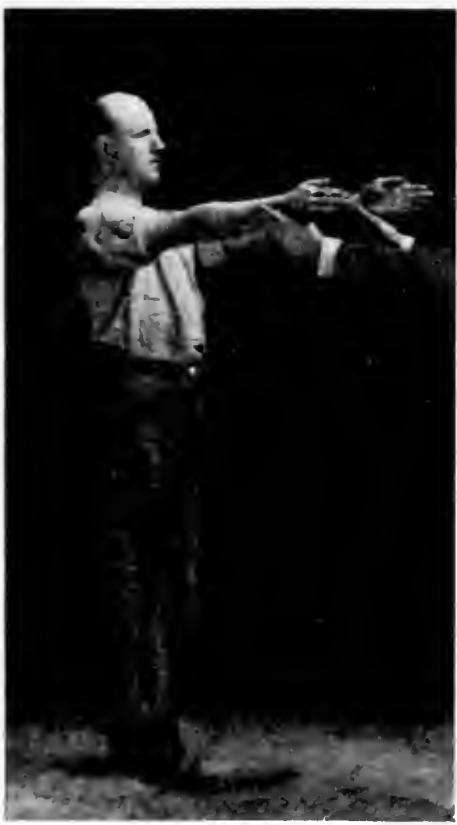

Fig. $\rightarrow \frac{1}{2}$ the extremity is to be moverel. It uften comlunces to steadiness of morement for the assistant to place his other hand against some other part of the limb or trunk than that to which resistance is applied. 'The following deserip)tion sives the exereises in the order in which they are msmally executerl :

(1) The arms are extended in fromt of the borly on a level with the shomlders and with the paluse of the lamels tonching. They are then slowly and steadily noved ontwarl motil at a line with the front of the chest, while at the same time the attendant enently resists this horizontal morement. The attendant now changes his hands, so as to exert

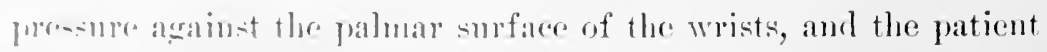
-lowly aml stemlily loring his andus back to the position whence the

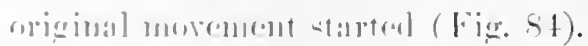

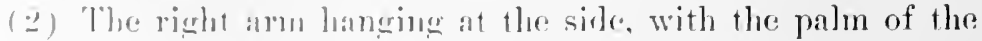
latud forwarl, the foroum is slowly flexed against comnter-resist- 
ance ly the attemalant mut the fingers touch the front of the shoulder. The attendant then changes his point of pressure to the balck of the arm, and the extremity is slowly returned to its formere position at the side (Fig. sis).

(i) This consints of precisely the same movement, but exeented by the left alm.

(4) Both arms, depending at the side, are slowly raised laterally until the thmuls meet above the head, and are then brought down to their original position, these movements being carefully resisted thronghout.

(5) The patient clinehes his hands in the form of a fist, but with the thumbs extended upon the nlnar surface of the index fingers. The tips of the thmmbs are then gently pressed together in front of the abdomen, and, a proper degree of resistance being offered, they are thus slowly raised until the hands rest on the top of the hearl, after which they are slowly lowered to the original position (Figs. S6 and $=7$ ).

(6) The arms, depending at the sides, are then clevated forward and upward withont bending them until they are held aloft on a line with the perpendicular axis of the body. They are next slowly allowed to resume their position at the side in the same careful manner in which they were raised. To properly resist this movement requiles much

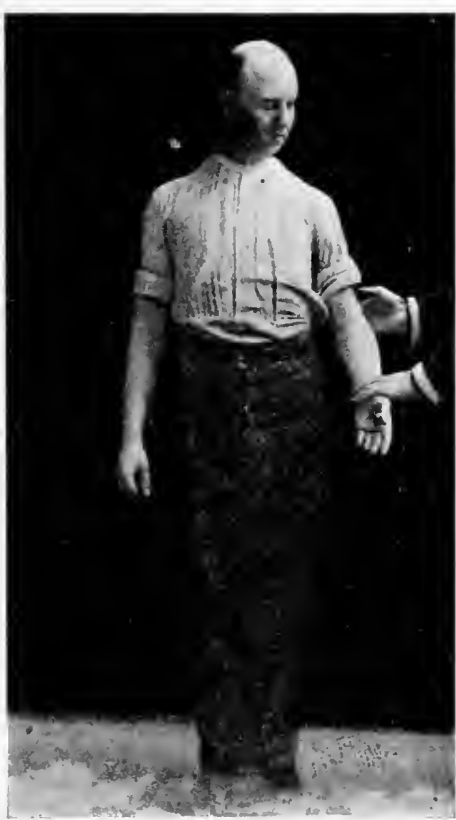

FIG. 85. practice and skill, for the reason that the hand of the attendant must be continually slipped aromm the patient's wrist to suit the changing attiturle, first to the horizontal and then the rertical (Figs. ss and s.9).

(7) Starting with the arms hanging at the sicle, the right arm is slowly rotated forward, upward, backward, and downward around the shonlder-joint as the pirot, and then in the reverse 

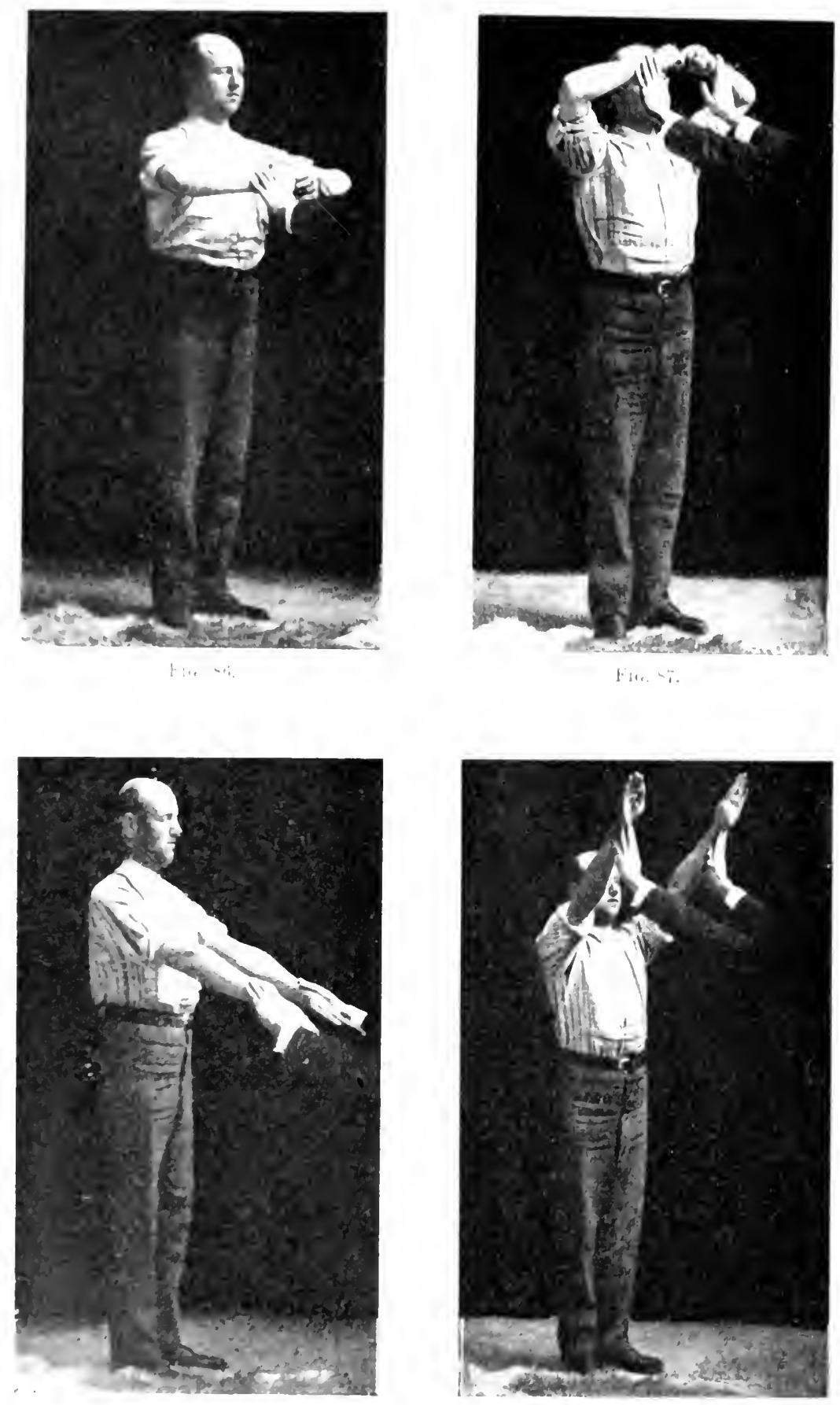
direction mntil the circle is rompleted, counter-pressure being all the time exerted by the attendant.

(5) This comsists of a similar movement, executed by the left anm. These two novements alre diflicult both for the patient and the attenclant, and slould not be wiven to patients who are rery weak or whose hearts are incapahle of withstanding much exercise. Resistance to this movenient is likewise axtremely diflieult, for the reason that the attendant has to change hands during the progress of the movement, ret withont cansing jerkiness or too much interference.

(9) The patient benels his hody forward at the hips without flexing his knees, and then hrings it back to the epeet position, while the attendant, standing at his side, resists the forward movement ly one hand against the mplere part of the sternum and the other in the midrle of the back, and the return movement of the trunk by one hand against the npper dorsal region and the other mpon the epigastrium (Figs. 90 and 91 ).

(10) Standing with the feet firmly planted ripon the floor, the patient rotates his tromk around its rertical axis, at first to the left, next to the right, and then back, so as to face forward, as before starting. The attendant resists this morement by placing one hand against the advancing shonlder and the other in the opposite axilla, and then changing his hands as the body is rotated in the opposite direction ( Fig. 92).

(11) In this morement the trunk is bent laterally, first in one direction, then in the other, and lastly is bromght at rest in the upright posture. To resist this flexion the attendant places one hand on the hip and the other against the side of the chest towards which the boly is to be bent (Fig. 93).

(12) Both arms hanging at the sides, with the palms facing towarls the thighs, are sinmltaneonsly moved hackward and upward as far as possible without bending the body, and are then bromght down to the sides, resistance meanwhile being earefully exerted by the attendant (Fig. 94).

(18) The patient supports himself by resting one hand on a chair, ant then raises the opposite leg as far as possible in a lateral direction, while the attendant resists both the upward and the return movement (Figs. 95 and 96 ). 

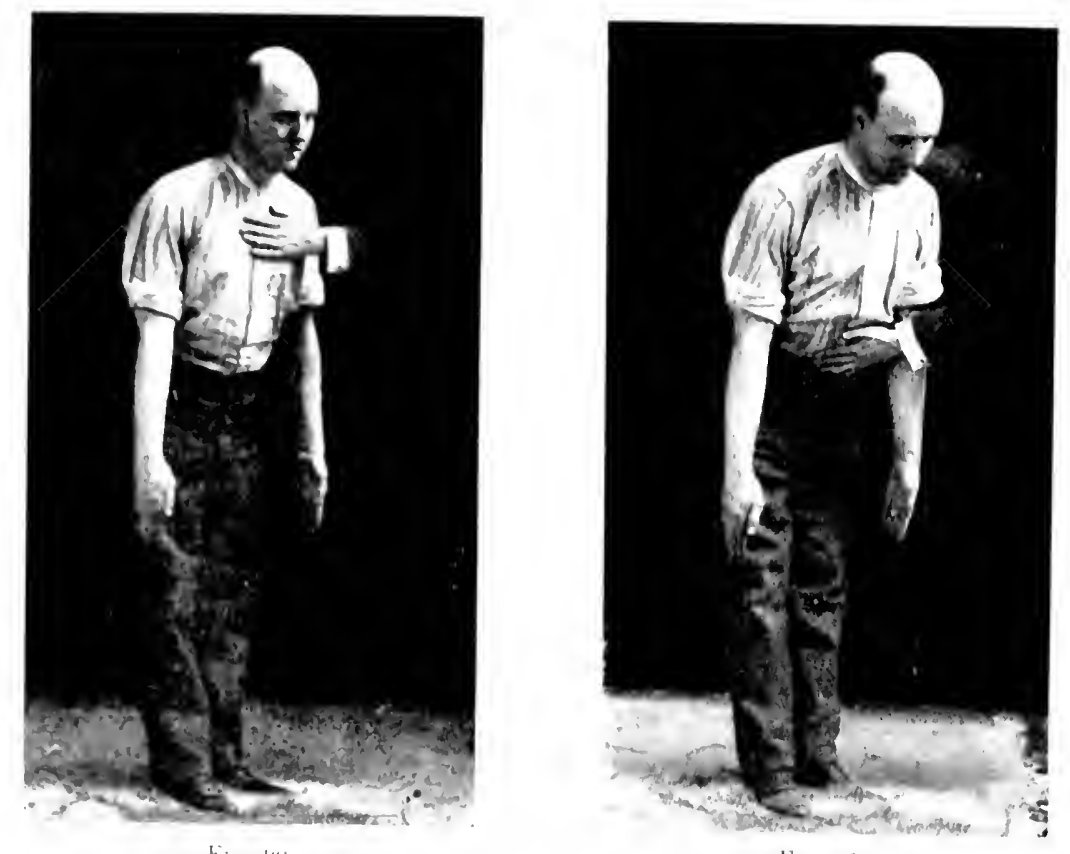

Fiti. :1.
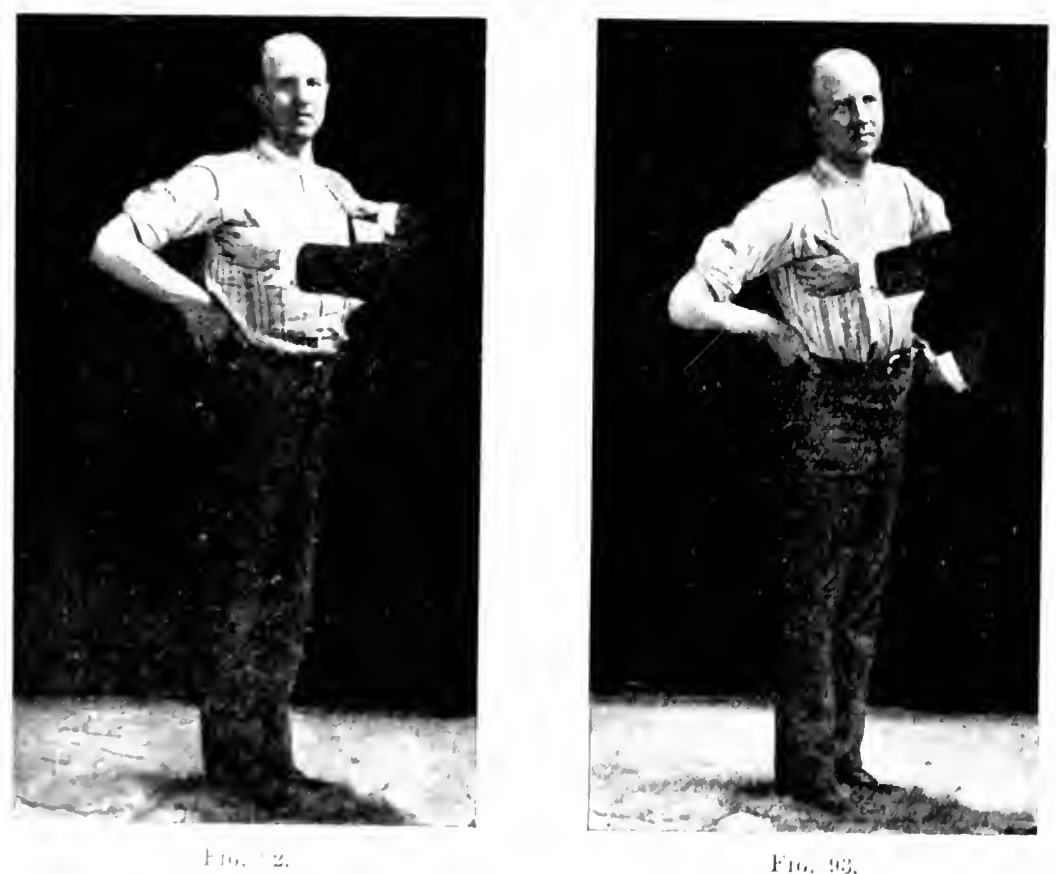


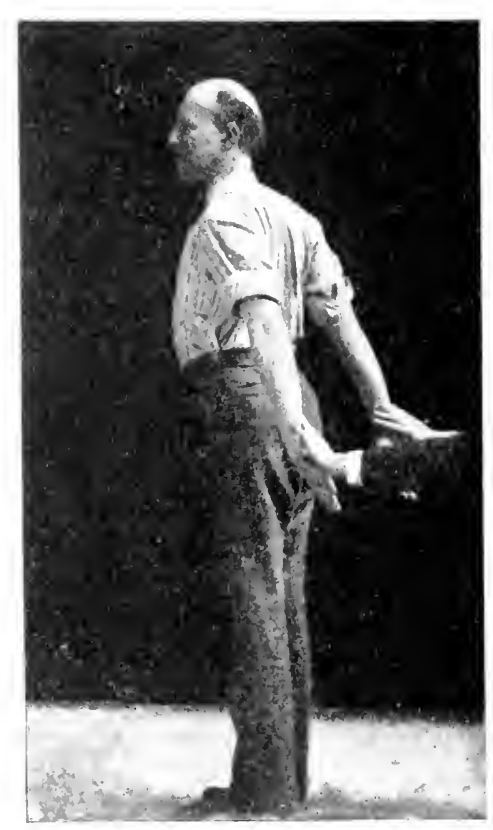

Filr. 4t

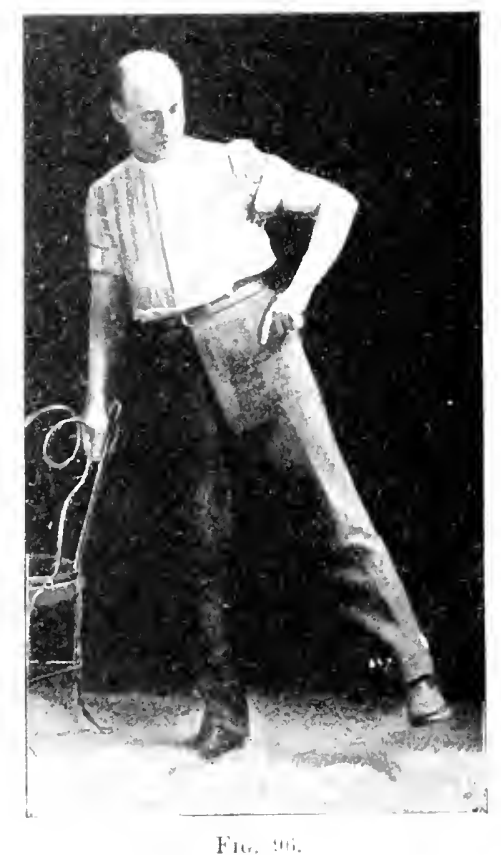

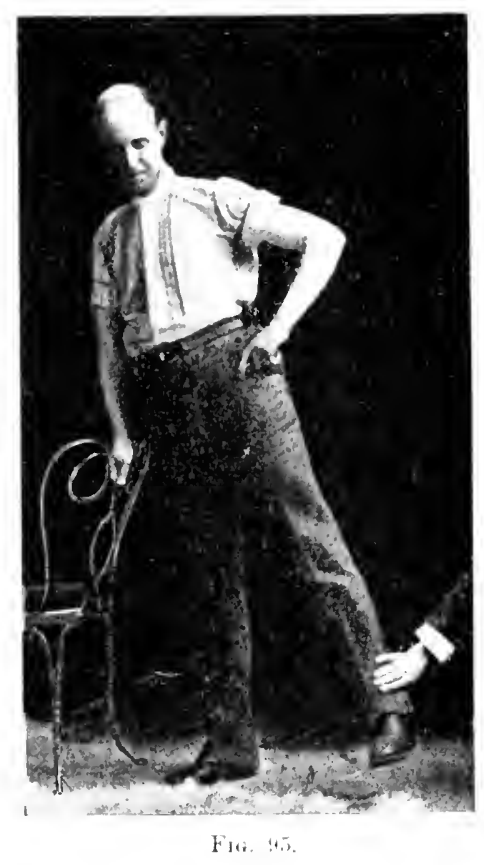

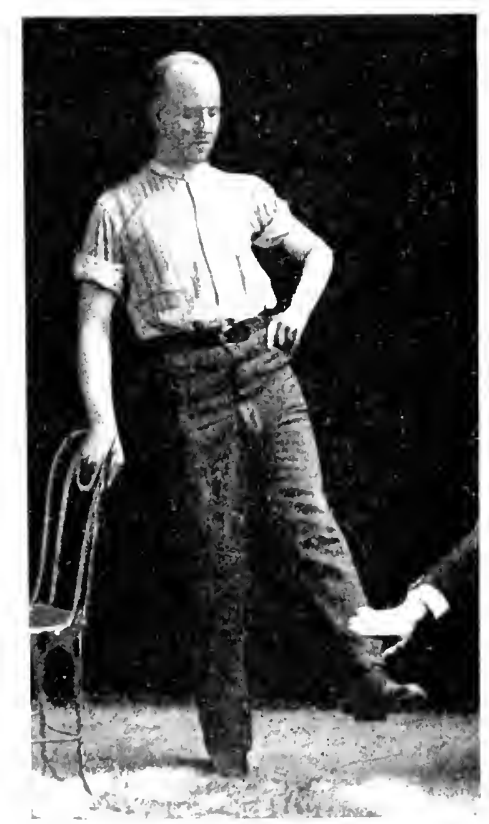

fiil 

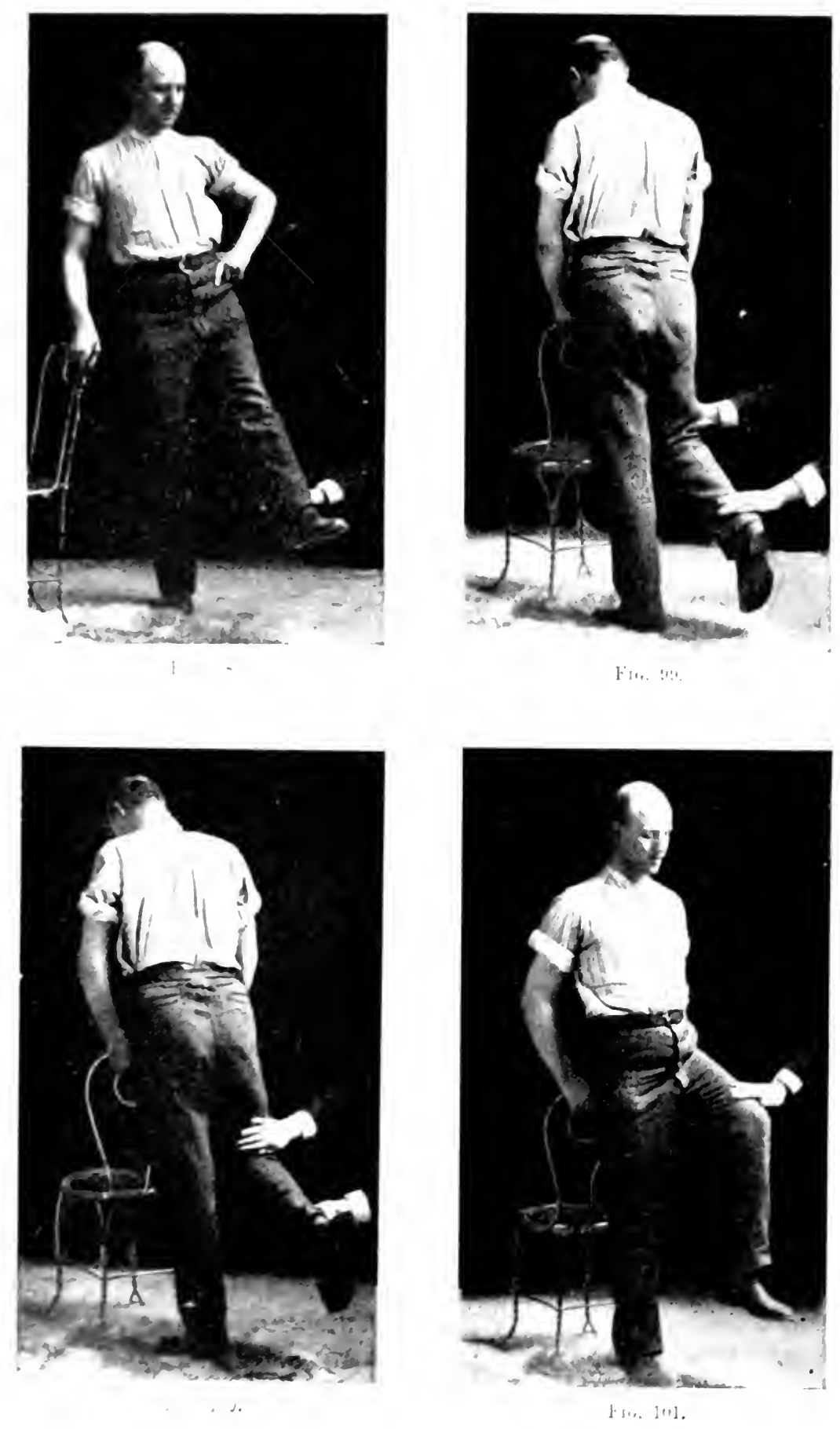
(14) This is the same movement, but done with the opposite extremity.

(15) Resting oue hand on a chair, as before, the patient extends his opposite leg and thigh, but without bemling his knee, as far forward and upward as possible, after which the extremity is slowly returned to its original position, resistance to both movements being offered by the attendant (Figs. 97 and 98$)$.

(16) This is a similar effort put forth ly the opposite extremity.

(17) Both hands supported on the back of a chair, one leg is fiexed at the knce while resistance is oftered lyy the attendant's hatnd placed at the heel. The return is resisted by the land anainst the ankle just above the instep (Figs. 99 and $100)$.

(18) This is a corresponding morement by the other leg, resisted in the same manner.

(19) Supporting himself by the back of a chair the patient flexes his thigh at the hip, the

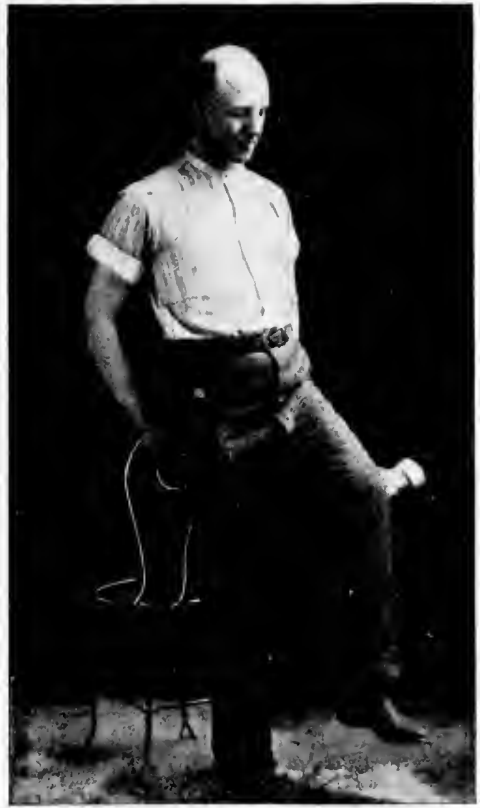

F1G. 102 leg hanging limp and flexed, while the attentant resists first the upward and then the downward movement ( Fig. 101 and 102).

(20) This is a similar morement by the opposite thigh.

If desired, additional movenents of flexion, extension, and rotation of the hands and feet may be devised. In carrying ont these exereises care should be taken that morements involving the use of the same groups of muscles do not suceed anch other directly, but are intermpted by exercises made by different sets of museles. The purpose of this precaution is the avoidance of undue muscular fatigne of weak patients. Given with requisite deliberation, and with sufficient panses for rest between movements, such a series of resistance gymmasties ordinarily takes abont 


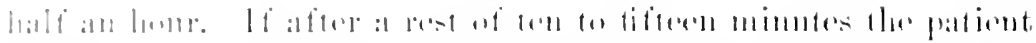

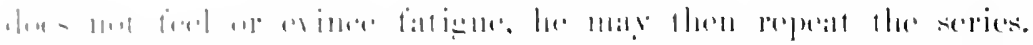

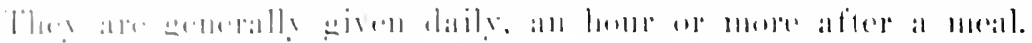

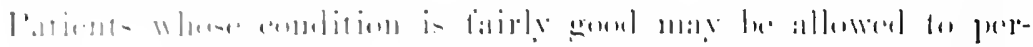

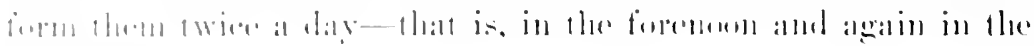
a114.110.111.

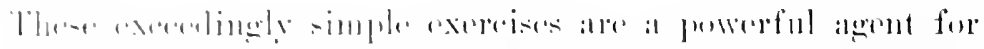

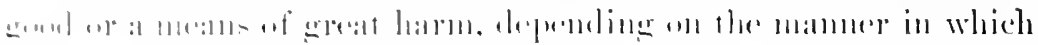

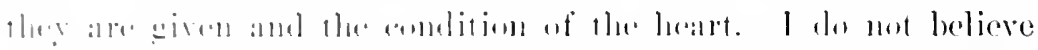

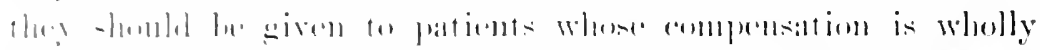

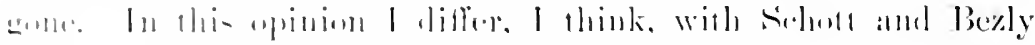

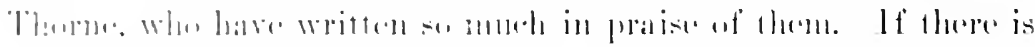

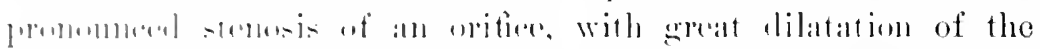

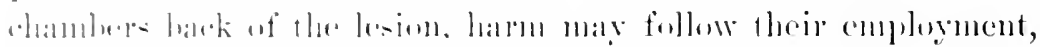

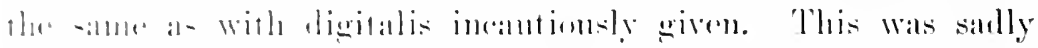

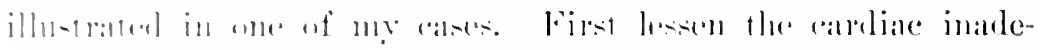

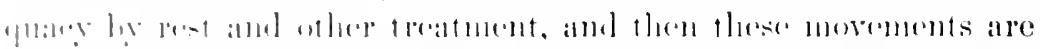

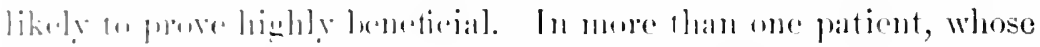

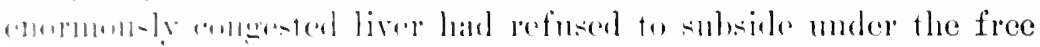

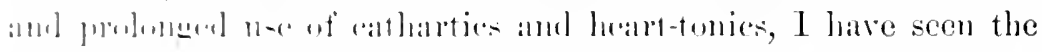

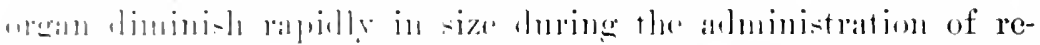

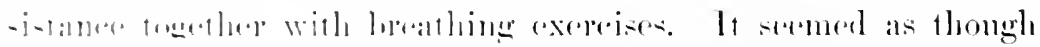

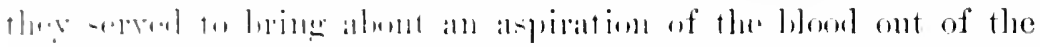

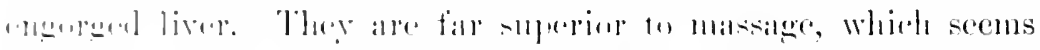

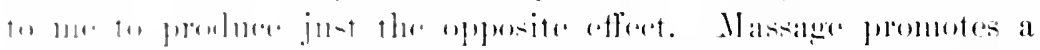

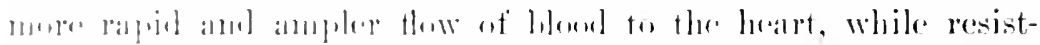

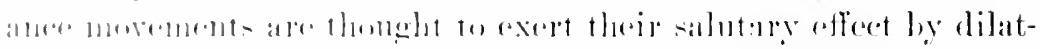

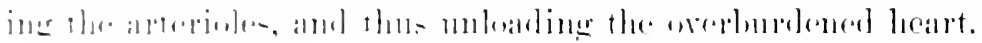

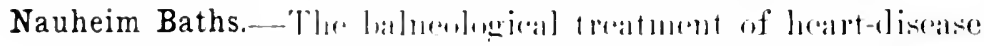

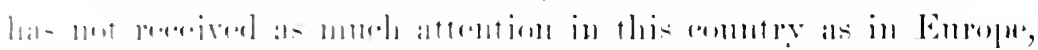

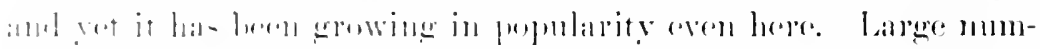

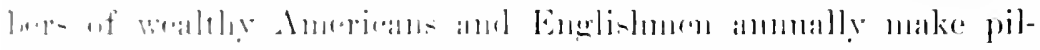

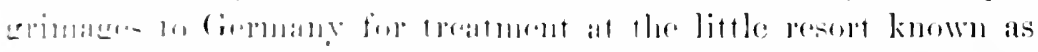

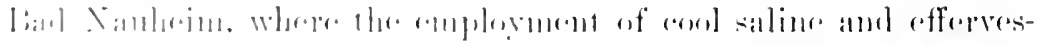

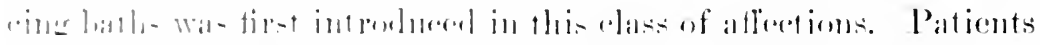

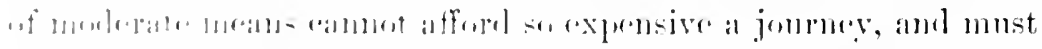

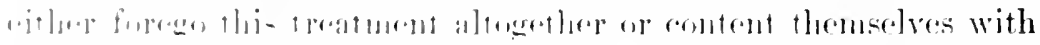

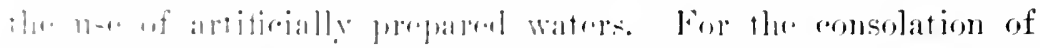

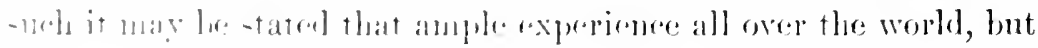


particularly in England, has shown that equally officient results may be obtained in this way as al bad Xamhein. I myself tork a course of baths at that resort in the summer of 1 s!l:? and ever since my return have been employing this plan of treatment in

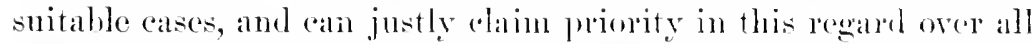
other's in this country. I latre not desired to molke a farl of this treatment, and therefore have not subjected as many patients to it as might have been done, but it is within lomuds to say that considerably orer one humbed have thus been treated by me. Some of my patients have taken the haths in Germany, generally after a course in Clicago, although one has just finished here who has previously treid the batlss at Barl Nambeim. All agree in the statement that the effects with altificial waters are the same as with the natural, the ehief and perhaps striking difference consisting in the more powerful effervesenee of the latter, particulary in the form of the Sprudel-Strom-Bad (flowing efferveseing bath). Another alrantage in farom of the latter lies in the consideration that when a patient goes to Germany he leaves his eares behind him, and while there abandons himself to the one purpose of getting well. On the other hand, I have been assured that, owing to the immense number of invalids who frequent the place, patients are apt to miss the watchful care and oversight which many of them require and receive at home.

The waters of Bad Nauheim are impregnated with varions chloride salts, the two to which particnlar virtue is attributed in their effect upon the circulation being the chlorides of solimm and calcium. In addition, the springs used for the preparation of the baths are highly charged with earbonie acid, which makes them very stimulating, particularly when used in the form of the flowing bath-that is, with a steady stream of effervescing water flowing over the body of the bather in the tub. This is comparatively rarely preseribed, being considered too exhilarating for any exeept those in fairly rolust health. It is the rule in the employment of this balneological treatment to begin with water of a temperature of $933^{\circ}$ to $95^{\circ} \mathrm{F}$, aceording to the ability of the patient to react, and with water containing 1 per cent of sodinum chloride and $\frac{1}{10}$ per cent of ealcium chloride, but no carbonic acid, this latter being added at the rul of the seeond week, or when a temperature of $91^{\circ}$ to $90^{\circ} \mathrm{F}$. lais been attained. The duration of 


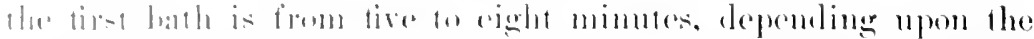

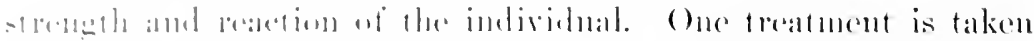

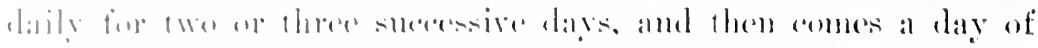

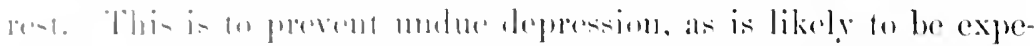

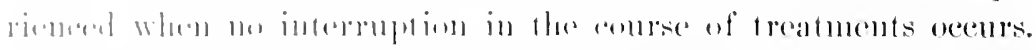

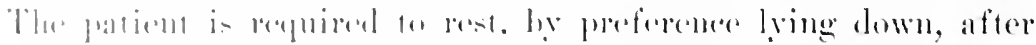

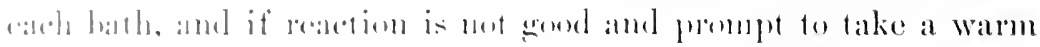

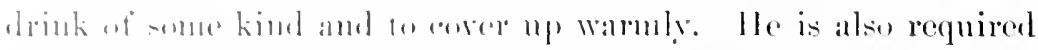

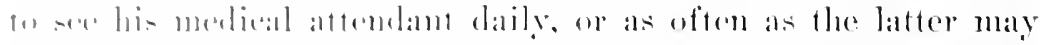

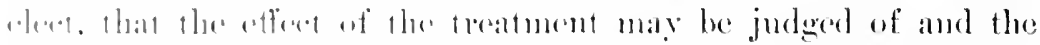

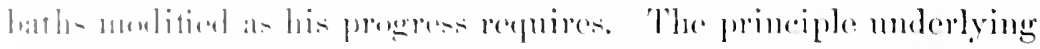

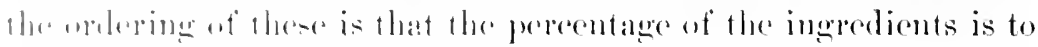

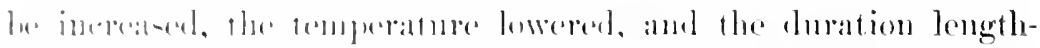

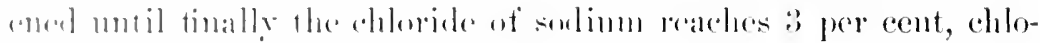
rible wi cakejum l perent, the temperature $85^{\circ}$ or $85^{\circ}$ F., and the time twanty mimutes.

The raphlity with which this ahimge am be efterted depends

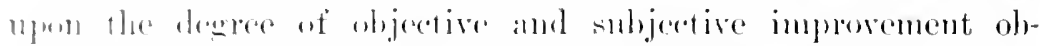
sclved. hut as a rulo this maximmon is mot attained under three or il may lue fomr werks. In the more serions cases, or such as ex-

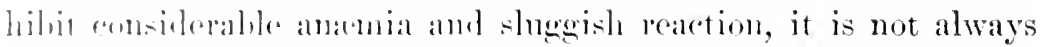

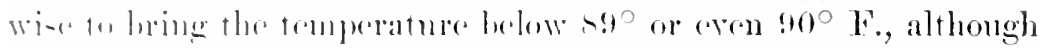
lle maximm in strongth amb duration may be the same as when

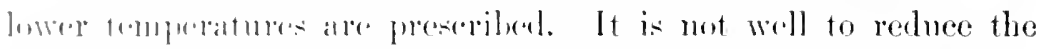
momperatme mole than a degree at a time, and whenever this is

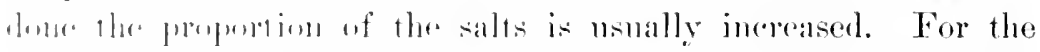

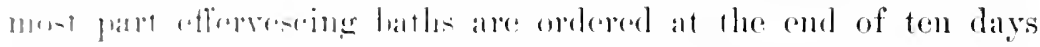

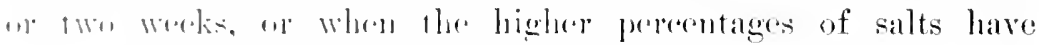

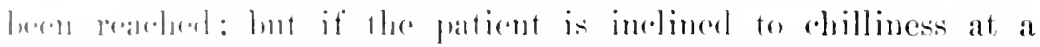

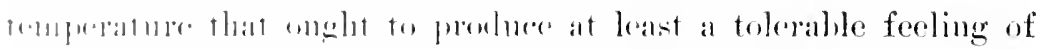

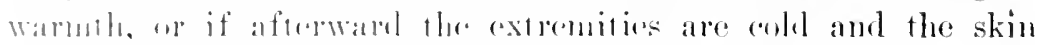

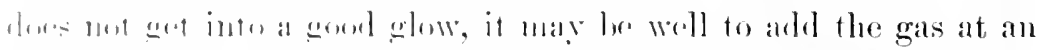

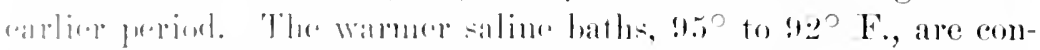

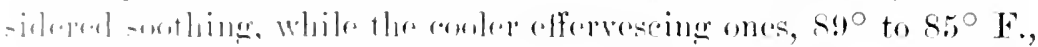

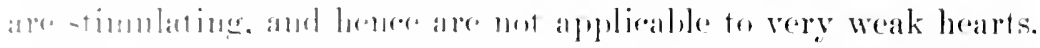

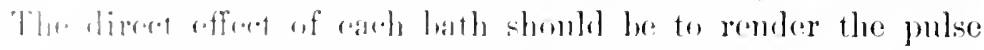

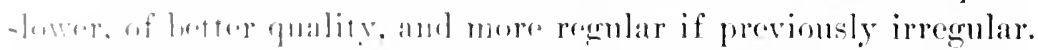

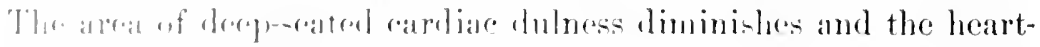

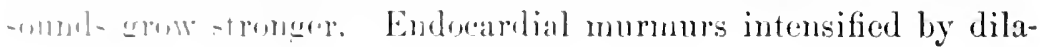




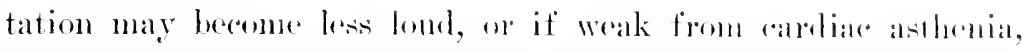
may after the bath be fommel to be more intense. 'Tlhe degree of benefit is to be determined ehiofly by the size of the heart and by the character of its action. Is a rule, ako, the paticnt is conscions of a sense of well-being and of some lessening of whaterer symptoms have anuoged him.

If the treatument has been judicionsly outered and overserest, the heart is found to gain in stremgth woek ly week, visecral eongestions diminish, as evinced by increased dinuesis, the eolour of the skin grows more like that of health, and the patient gradually gains in rigonr and ability to excrejse without discomtort.

Just how this balneological treatuent brings about inprovement is still a matter of speculation and discussion, being by Schott explained on the hypothesis of incorased tissne change together with a poflex stimulation of the heart which causes its slower and nore powerful contractions, and with a phrsiologieal stimulation of the arterioles and capillaries by the passage of the gas and salts through the skjn. By others, in particular Broadbent, the beneficial action of the baths is attributed to dilatation of the eutaneous capilaries, in eonsequence of which resistance to the work of the left rentriele is lessened and the transfer of blood from the renous to the arterial system is pronoted. The objection urged against this explanation is, that the rate of the pulse should be inereased rather than decreased, so that there must be some additional influence at work. 'The following is the view of Merlicinaluat Groedel of Bad Nauhein: "The incontestable success which our baths have on the heart's function and the entire cirenlation is only to be explained if wo believe in a direct aetion by way of the end-organs of the eutancons nerves on the central raseular and eardiae nervous system, both trophic and motor." It may also be stated that so far as concerus the demonstrable effect of the two means of treatment, the resistance grmnasties and the baths, the results if not the action are identical in diminished size of the dilated heart and inproved rnergy and steadiness of its contractions. Consequently it is enstomary at Bad Xauheim to have the patient receive both forms of treatment each day. Finally, it is nsual to send the patient away at the close of a course of baths for a rest of a month to six weeks, after which he returns for another course known as the after-cure. 


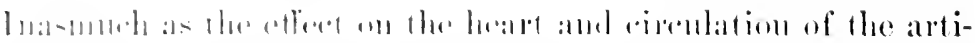

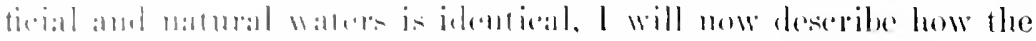

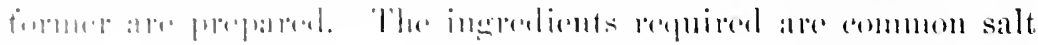

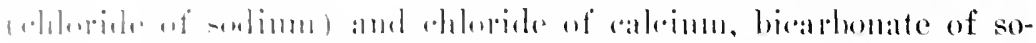

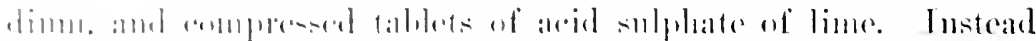

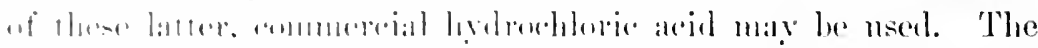

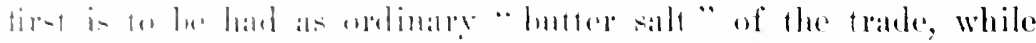

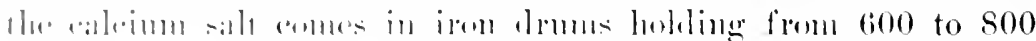

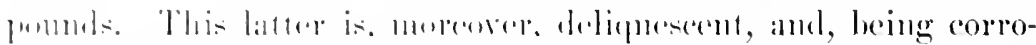

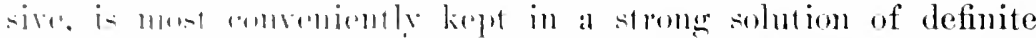

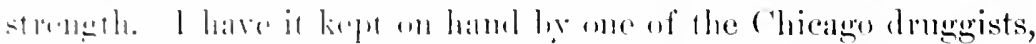

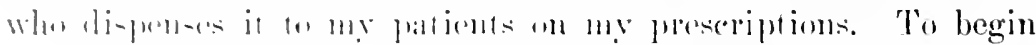
with, the haths antain anly these two ingredients, and are there-

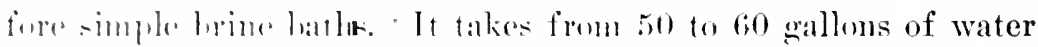

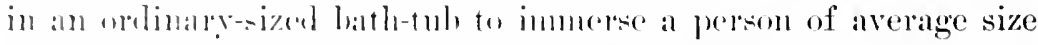

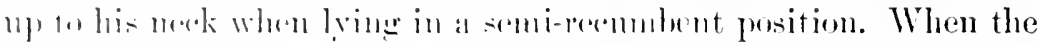
amomm of watep is limown it is an ass matter to determine the mumber of fommls of sall and the nmmber of pints of calcium-

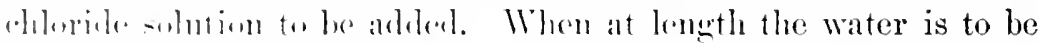

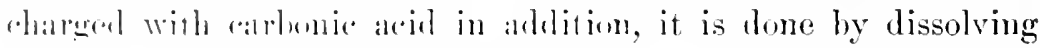

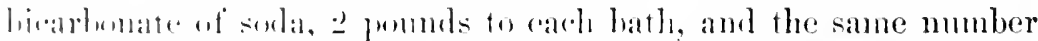

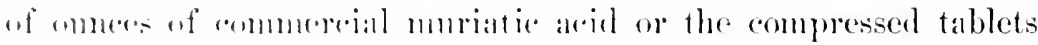

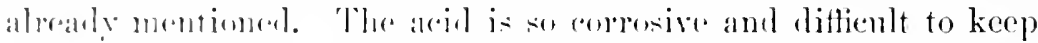

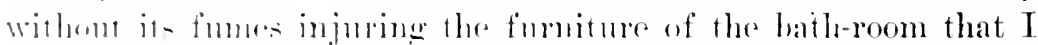

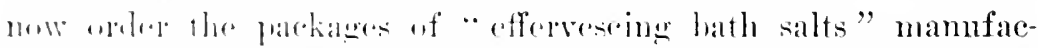

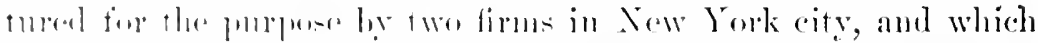

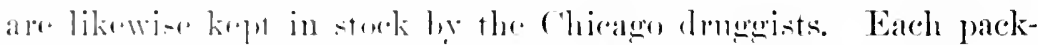

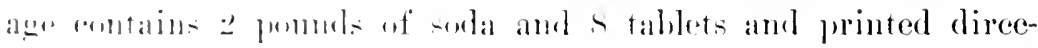

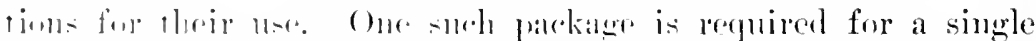

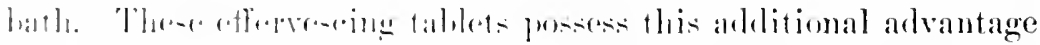

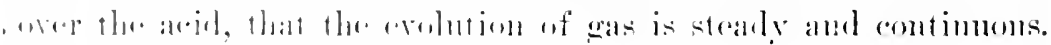

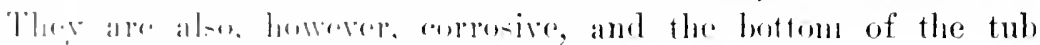

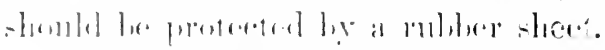

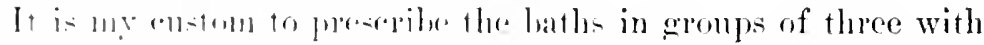

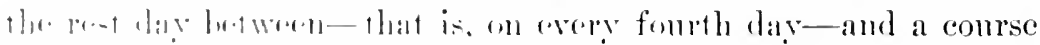

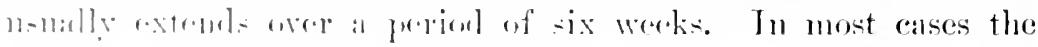

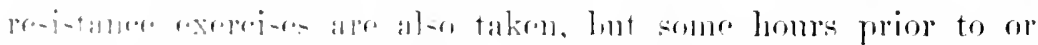
affere the hath, that the refforet rom the loald may be maintained.

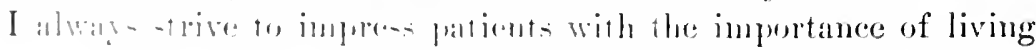


as quiet and rontine a life as possible, and in partionlan fo stremuously aroid mudue cardiale strain that they may mot destroy the benefit expected to he derived firom the treatment.

I can recall only is ases in which this plin of treatment seemed to do harme rather than gowel. Two were instances of ehronic myocarditis, the hearts being very dilated and their aletion arrhythmic. One was a mitral lesion with arlental and other signs of rather a badly destroyed compensation; but as this patient was compelled to journey some distance each day to gex his hath, it may be that the exertion thus repuired, and not the treatment, was responsible for the want of impresement. 'The romaining two were eases of serions valvular discase complicated by pericardial adhesions. In both, the engorement of the liver becane manifestly greater towards the termination than at the commeneoment of the course, and the treatment was discontinued. All ofleer patients have exhibited nuore or less improvemert, while in some instances this has been most gratifying both to the patient and myself.

I am very positive in my belief that this treatment should not be given to persons whose compensation is sholly lost, or indecel seriously broken, and therefore the consideration of this measure has been introduced in this portion of the present chapter. I have just finished giving a course of 30 baths to a lady with a pure mitra! stenosis who, when she hegan, gave inclications of failing, or at least threatened, compensation. The second somel at the heart's apex was wanting, there being only a preststolic mumur and sharp first somnd. She complained of munch ill-rlofined discomfort at the heart, and the pulse was raphe and exceedingly feeble. Before the conse was completed the seomel somm land returned at the apex, the area of eardiae duluess was distinctly smaller, and the pulse was slower and of eprater rolume. She declared she felt perfectly well. In this instance, as is often my habit, I ordered the frequent nse of a laxation water, and for a time 5-rlrop doses of fat-free tincture of digitalis thrice, then twice, and at last but once daily. I do this becamse it has seened to me that in this way I lave secured more lasting results.

Contra-indications to the employment of this halueologieal treatment are the following: Sortic ancurysu, promomecel and extensive arteriosclerosis, and, in my opinion, all cases manifest- 


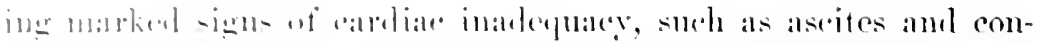

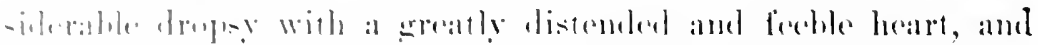

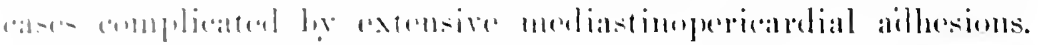

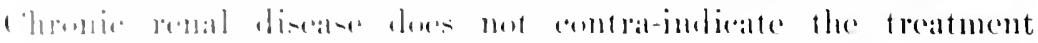

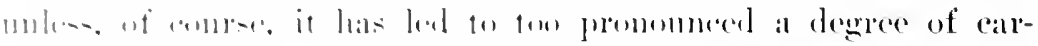

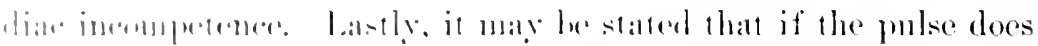

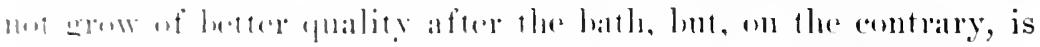

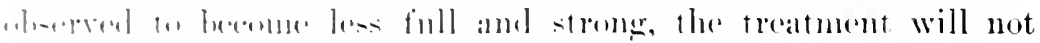

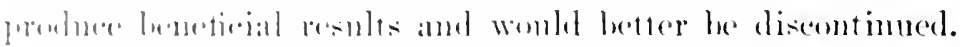

Diet.- This is a mattar requiring in this stage of valvular

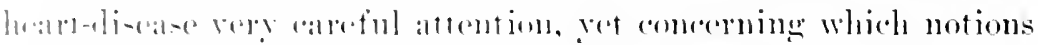

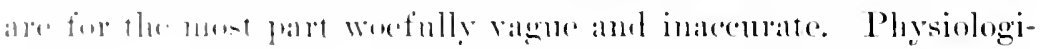

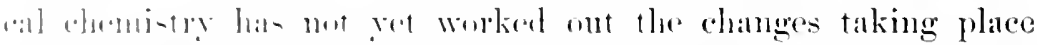
in the lignelive promess as a result of discase. We know that

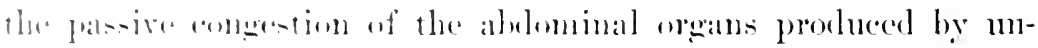

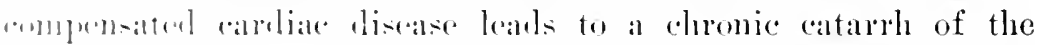

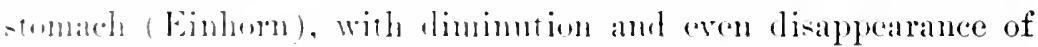

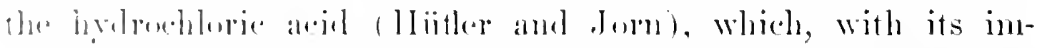

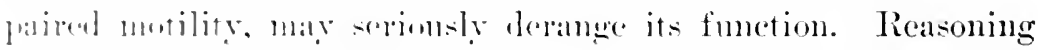

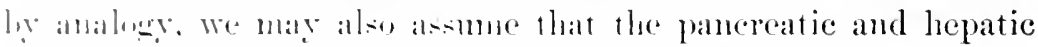

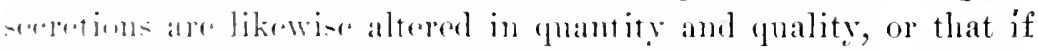

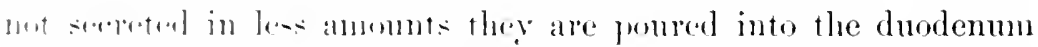

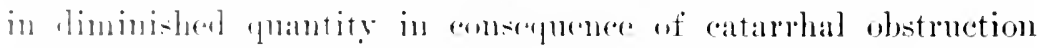
in their notthes. In-t what molification in the character of the

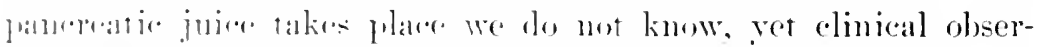

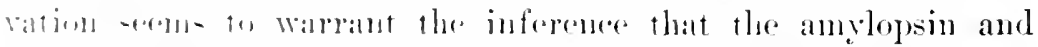

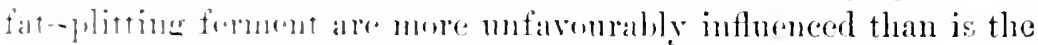
juntenlytie formente

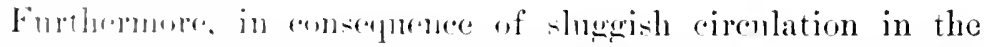

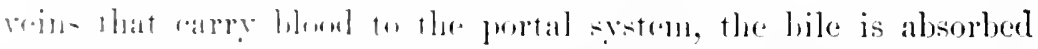

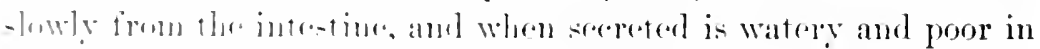

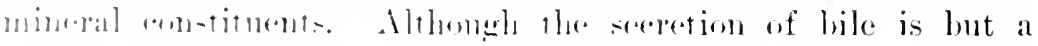

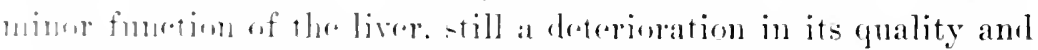
Jiminution in it- quantity must "xelt a baneful influence npon

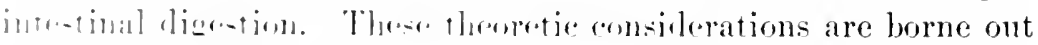

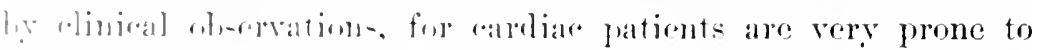

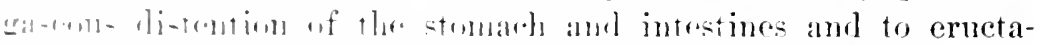
rions and of lure indiontions of formentation of the ingesta. The

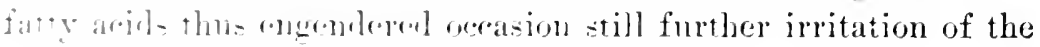


stomach and establish a viobons rirele whicle angments the evils primarily attributable to disturbed circulation.

This is not the only aspect of the case. There is alteration in the metabolic proceseses incident to derangenent in the blood-supply to the digestive and other viserera, while toxines ale lexally developed which either must be destroved in the angored and functionally impaired liver or must pass through into the general blood-stream and exert their noxions effects npon the healt and nervous system. The investigations of Husehe appear to show that the excetion of urea and uric acid is altered. Tlec retention of the former is variable, while the excretion of the latter is hindered during disturbance of compensation and incerased after this has been restored.

It is not stranger, in the light of the foregoing consiclerations, that some patients are greatiy disturbed by fermentative indigestion after the taking of the simplest and most easily digested food. Dyspnoea is intensified or developed, or they are distressed by palpitation. Others are not conseions of local disturbance, but complain of pains and aches, muscular stiffness and crumps, nerrous svmptoms, such as despondency, insomnia, and frightful dreams, fidgetiness of the lege, and sumbry other sensations that are so commonly attributed to uricacid retention. It may be remarked here, howerer, that Dr. Wesener's researches appear to show that these constitutional srmptoms, as well as many others, are due not to mic acid, but to indicamuria and oxaluria. One of my patients was greatly troubled by licadaclic, insomnia, and other nervous phenomena, and Wesener's analysis of her urine collected at the time showed an enormous exeess of indican and oxalie acid. Therempon an attempt was made to stop proteids and administer earlohvelrates in the hope of relieving her distress. It was found, however, that at once sle leegan to have so much flatulent distention of the stomach and bowels with ageravation of her dyspnoa that the non-nitrogenons diet had to be abandoned for a return to meats, etc, with all their eril consequenees.

The problem of how to meet the food requirenents of cardiac sufferers is a complex one and most difticult of solution when we have to do with the stage of imperfect comperisation. It is quite generally agreed that in cases of heart-lisease monmplieated by renal lesions the myocardium should be supplied with a relatively 


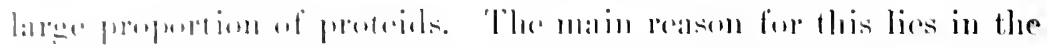

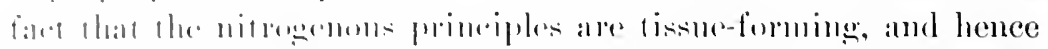

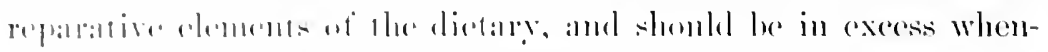

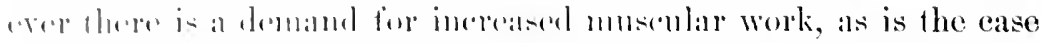

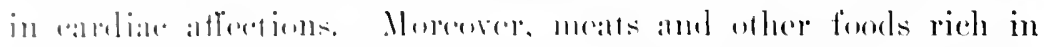

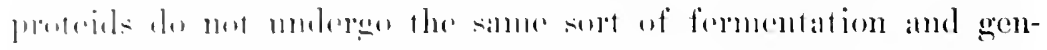

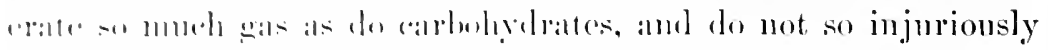

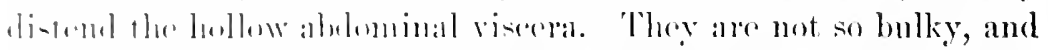
therefore. relatively do the puantity ingested, comtain a far larger

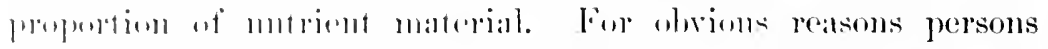

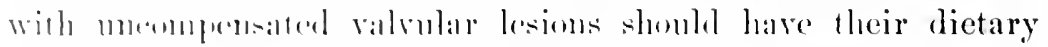

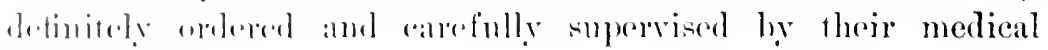
altmolulants.

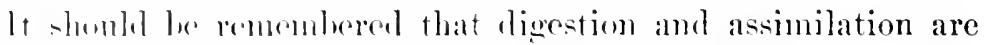

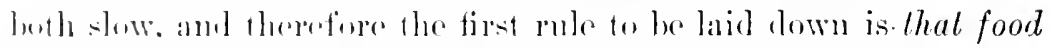
is wot to be taloen at shord inlervels, hut ample time allowed for

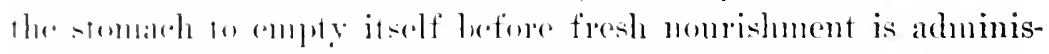

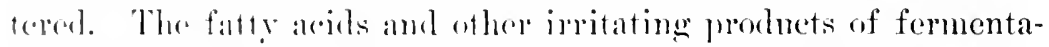
tion often oceason a focling of faintness or guawing at the epiwarleimu which is mistaken for hmeger and thomght to indicate a norel for morre form. In other asses appetite is poor and patients

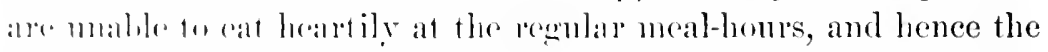
fijends and coren the physician get the irlea that the meals must

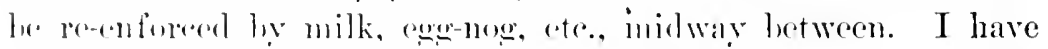

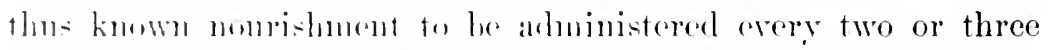
lums:- Sinch is molumbedly a mistake. The congested and per-

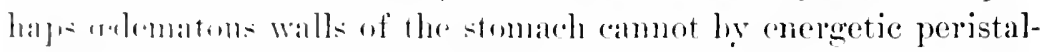

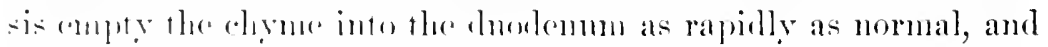

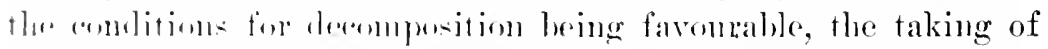

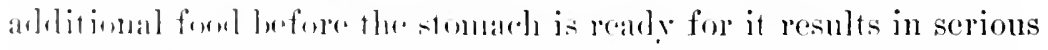

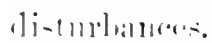

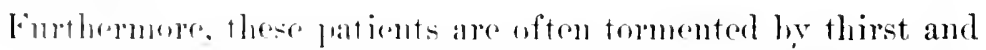

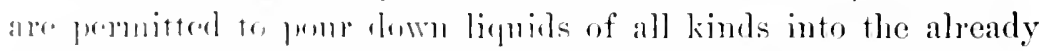
di-trmarland irritatrel visens at irregular intervals, so that ablominal distention. remotations, flatulemer, and increased dyspwerat ald to the pationt's distress. These ronsiderations have in-

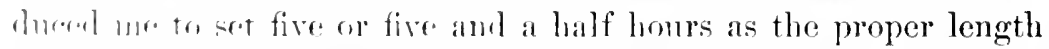

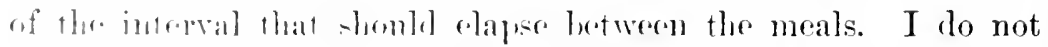
fremit wrilk to be taken lutwern times, since by being curdled in 
the stomach it is practically the same as solic foum. When in some cases the feeling of faintness and weakness makes some

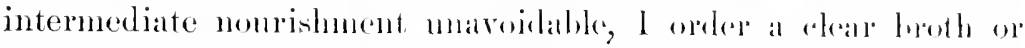
bonillon, or weak tea containing a little cream but me sugan, ete. So simple a restrietion as this hats of ten bexan fommel to work wonders in removing the thirst and epigantric gnawing. $\Lambda$ enp ful of hot water drunk an home previous to a meal serems to filcilitate the expulsion of the stomatch contents and to cheall the way for the ingestion of fresh food.

The next rule is the restriction of the quantity of thids to be taken with meals. In severe cases liquids should be linited to if ounces, and even in mild ones 10 onnees shomld be the maximum. This does not mean only water in addition to any other fluids that may have been ordered, but inchules all hiquids combined and consumed in addition to solid ingesta. The purpose of this restriction is to prevent undue distention of the stomach in thase cases in which such distention would be likely to oceasion shortness of breath or embarrassed cardiac action.

The rule is that patients are to be restricted in the amomnt of their solid food, for it is not rarely observer that they manifest a veritable bulimial, and if permitted to do so will orerload their stomach and sorely orertax their digestive and atsinilative eapacity. A simple and usually sufticient guile as to the anomit that may be safely consmued is to be found in the injunction that they finish each meal feeling they conld at more. A little, well digested, is worth far more than a good deal, poorly digested. This restriction not only lessens the danger of distending the atonic organs which it has been slown furthers decomposition, but it tends to prevent the cardiac embarrassment oceasioned by repletion. Such a limitation of the patient's food nunst not be carried to the extent of starvation; and yet if the quality of the nourishment is judicionsly selected it will often be a matter for surprise how small a bulk will suffice-nay, how it will minister to the patient's comfort.

In considering the articles of food suitable to this class of sufferers I think it best to deal with the sul,ject in a general way rather than to attempt to make up appropmiate mímus. Tea and coffee should be weak and contain snch an anomit of sugar and cream as depends upon the degree of digestive disturbance. Cocoa 


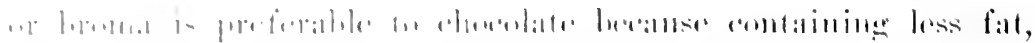

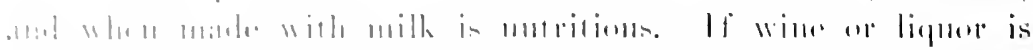

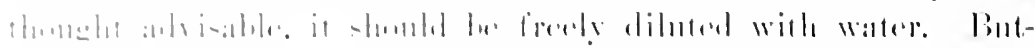

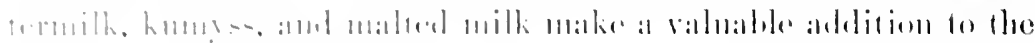

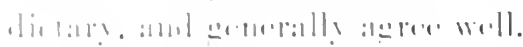

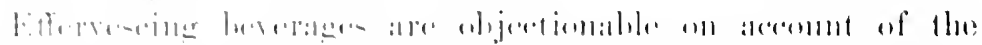

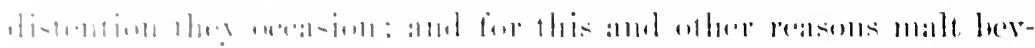

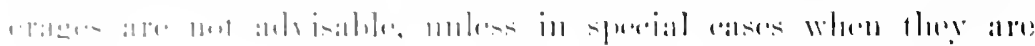

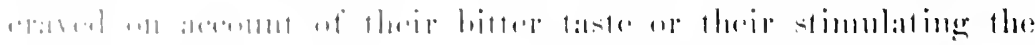
Halesing :

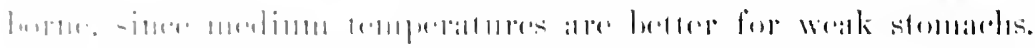

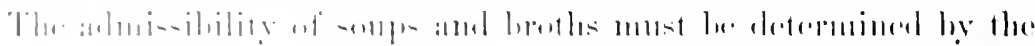

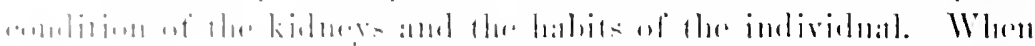

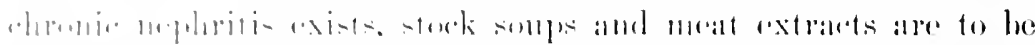

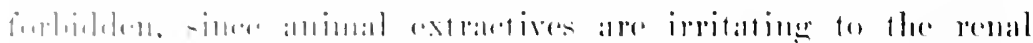

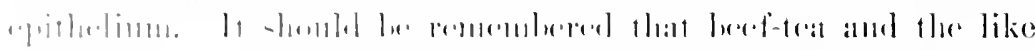

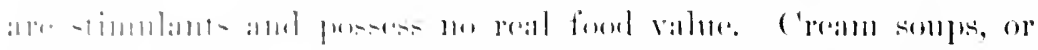

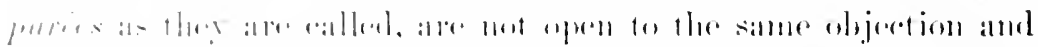

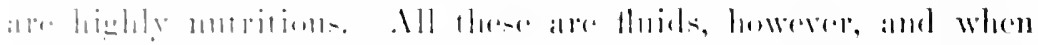

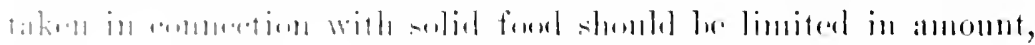

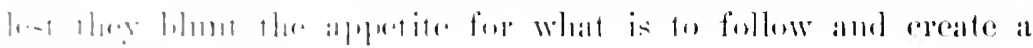

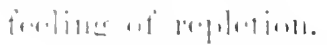

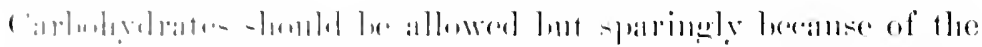

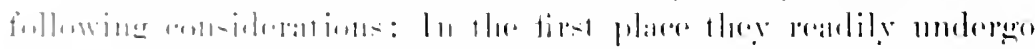

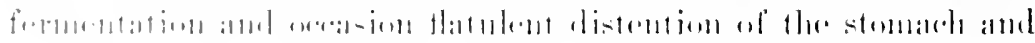

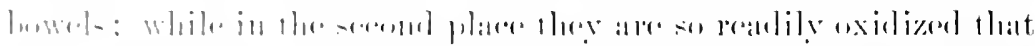

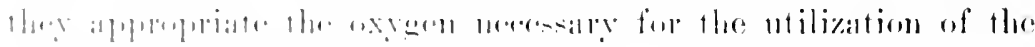

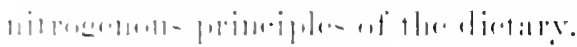

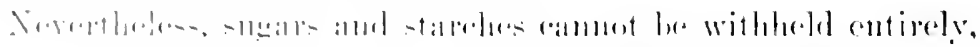

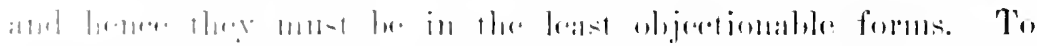

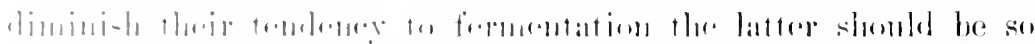

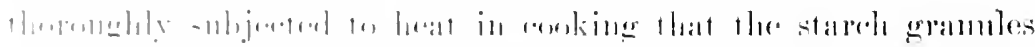

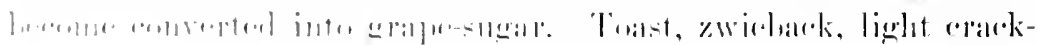

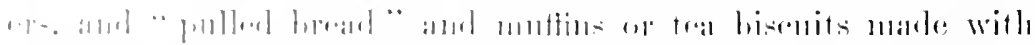

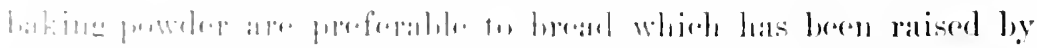

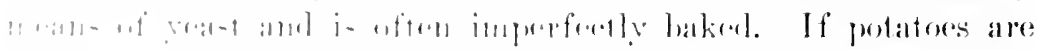

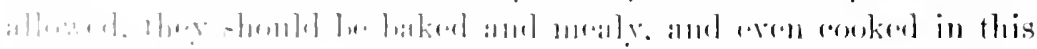

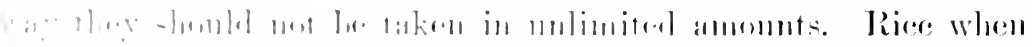

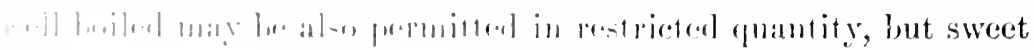


potatoes, cereals, and the multifarions combinations of flour, butter, and sugar, whether with or without eggs and milk, known as. cake, gridlle-cakes, etc., are inaduissible.

Most desserts, and in particular sweetmeats, confections, preserved and camned fruits, are to be allowed only to those patients who ean dispose of such articles without amnoying flatulence. Fruits are best in their natural state, and eren then should be ripe and fresh. Apples are particularly good becanse of their relatively large percentage of mucleo-albumin, and when baked are often better tolerated than when meooked. Pineaple has always seemed to me a particularly desirable fruit because containing a natural digestive ferment of great effieiency. As a general thing I regard it as better for eardiopaths to take fruits at the close rather than at the begimning of a meal, as they do not blunt the appetite nor ereate so much gas.

Most of the fresh vegetables are valuabie additions to the dietary, either becanse rich in proteids and other nutritive principles, or on account of their serring as relishes and containing various salts essential to the organism. Peas, lentils, stringbeans, and spinach are said to be relatirely rich in iron-forming principles. Tomatoes, cabbage, cauliflower, turnips, and kindred varieties are apt to disagree, but if well horne may be permitted. Asparagus, when not contra-indicated by renal disease, celery, lettuce, greens of various kinds, and young onions are allowable, while eucumbers, tender radishes, and olives may be left to individual desire and ability to tolerate without distress. M[ushrooms are very rich in proteids, and for renal patients supply a form of nitrogenous food that is not open to objection as is animal food with its extractives. Beets are rich in sugar, as is corn, and are likely to occasion flatulence.

Of foods rich in proteids beef and pork head the list, but perhaps are not so easily digested as are veal, lamb, and mutton, which are excellent when not too fat. All meats should be roasted, broiled, or stewed, not fried; but however prepared, they should be as free from gravy as possible and ought to be so well done as to have destroyed the germs of decomposition through whose action during the time of hanging the meat becomes tender. Fowl and game-birds form a capital arljunct to the heavier meats, as also do fish and most kinds of shell-fish, particularly oysters when raw. 


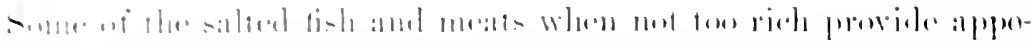

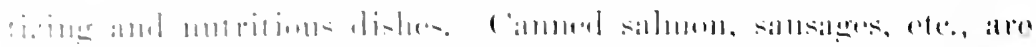

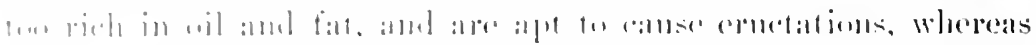

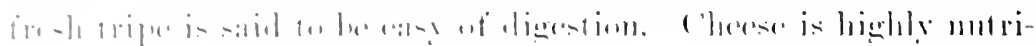

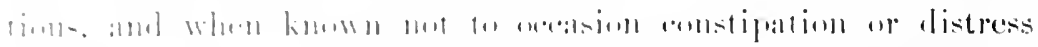

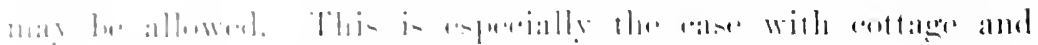

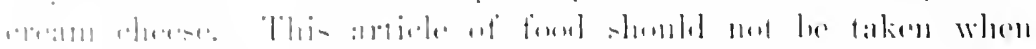

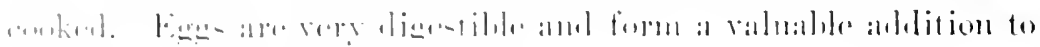

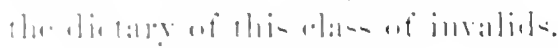

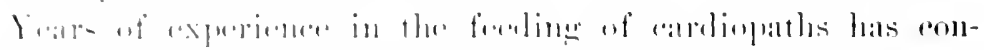

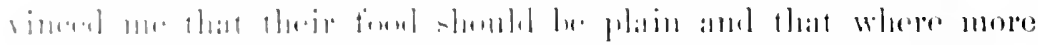

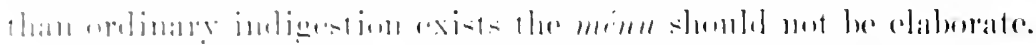

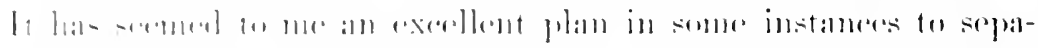

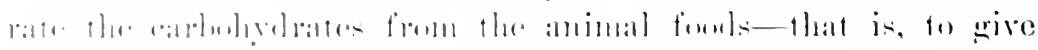

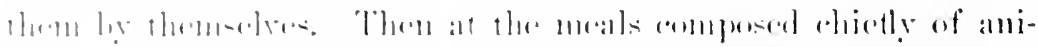

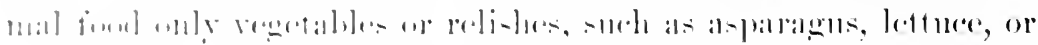

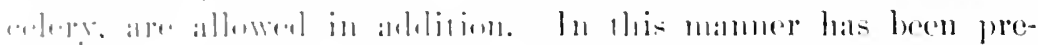

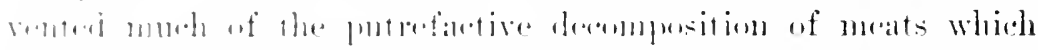

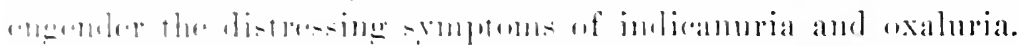

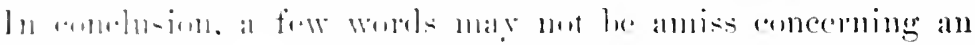

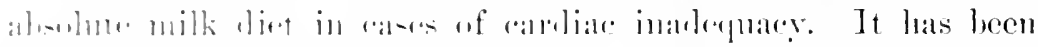

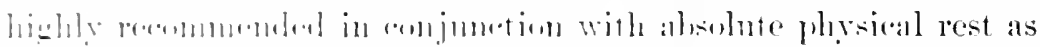

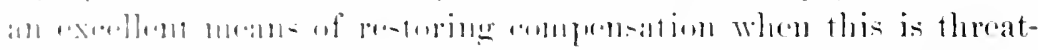

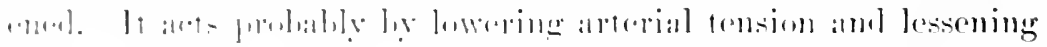

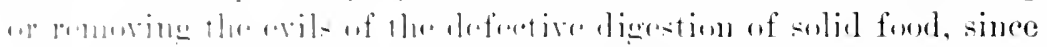

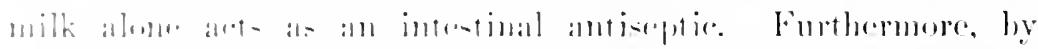

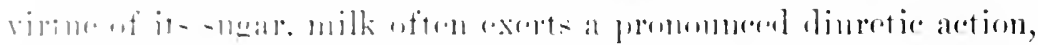

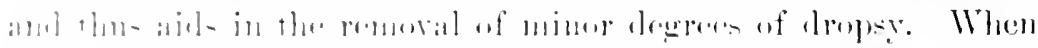

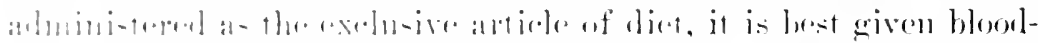

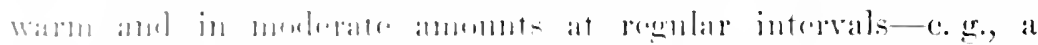

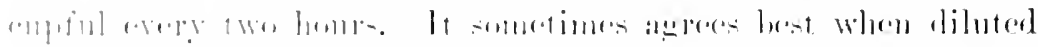

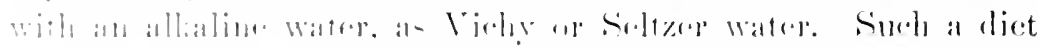
- J

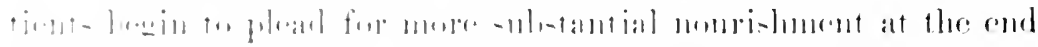

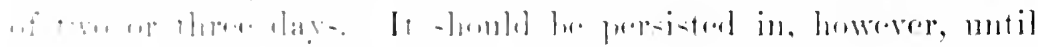

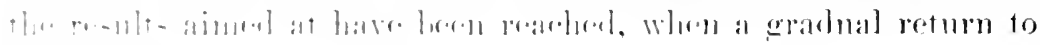

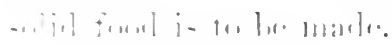

Clothing. Habits, Occupation.- Mthat las lwen sail in preced-

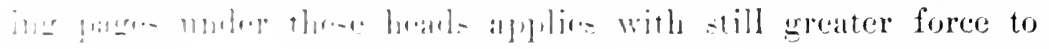


subjects of ralrular mischief when their compensation is imperfect. The influence of these factors is sulsidiary to those that have just been considerei, and ret these matters are liv no means unimportant. A too tight corset or waistcoat may so hamper thoracic movements and so impinge on the distended right or left rentricle as to frustrate all attempts to reinstate compensation by digitalis, resistance exercises, baths, ete. Constriction of the chest and abdomen is therefore to be sedulously guarded against.

The immoderate use of tobaceo will assuredy prove depressing to the heart-walls we are striving to strengthen. Mlcoholic: excess, even though intoxication does not result, injures an mcompensated heart ly causing excitation and exhaustion of the cardiac muscle-fibres. Sexual excess, perhaps even very moderate indulgence of this kind, may maintain or increase the very dilatation we are endearouring to orercome. It should therefore be strictly forbidden until such time as the heart-power shall have been reinstated.

Occupation of all kinds, particularly such as involve even the lightest possible phrsical effort, and exciting, long-continned brain work, must be laid aside while compensation is defective. Unfortumately, the circmistances of the patient do not always admit of a rigid enforcement of this injunction. When this is the case, the danger of injury from his occupation must be explicitly stated, that the work may be performed in the easiest possible manner. It is alwars well to fmomish such explanation, together with a warning, that in the event of clamage resulting from a continuance of the employment the phrsician may not he held responsible for the failure of treatment. Only by attention to retails can the medical man hope to tum what threatens to prove a disastrous defeat into a brilliant and it may eren be an mexpected victory. It is precisely in this class of cases that modem carliotherapy obtains its most signal and astonishing trimmphs. There is no other class of eases which so amply rewards intelligent and painstaking management. 
illoriti dill

\title{
the tREATMENT OF VAlVular heart-Disease
}

\author{
(cimelull,
}

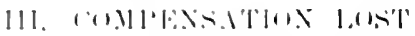

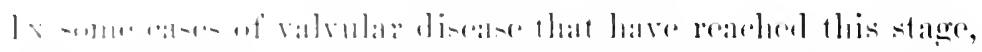

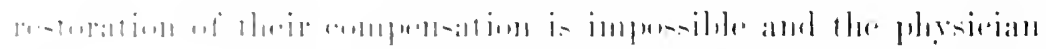

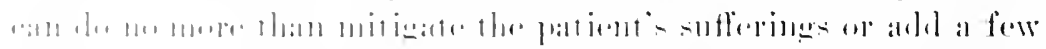

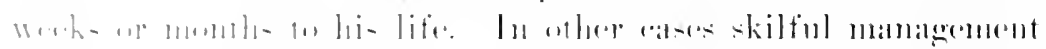

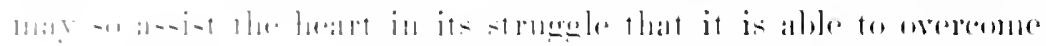

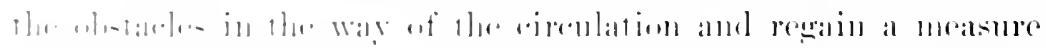

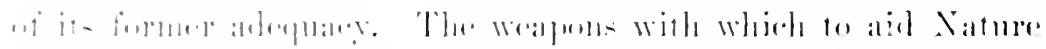

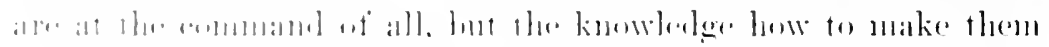

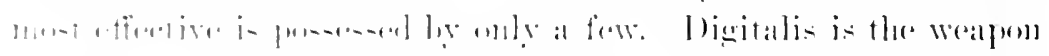

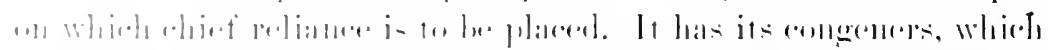

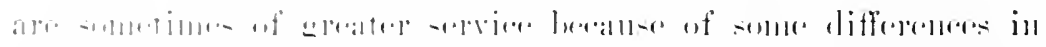

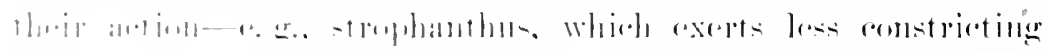
a

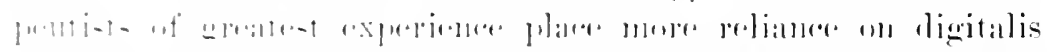

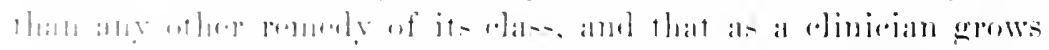

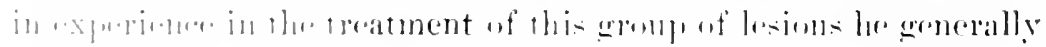

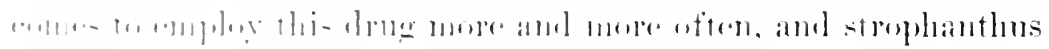

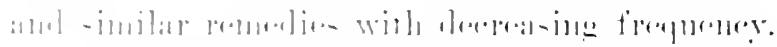

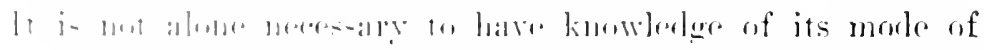

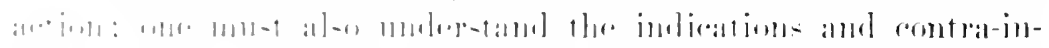

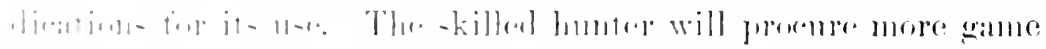

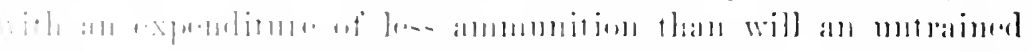

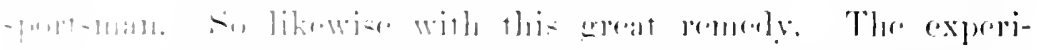

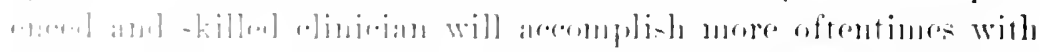

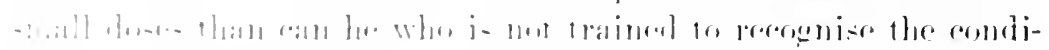

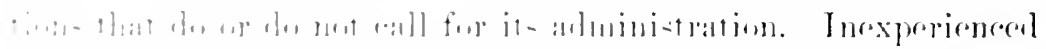

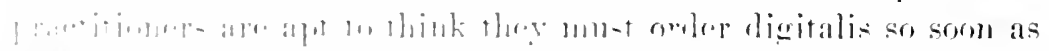

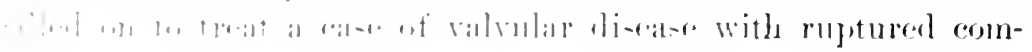
4. 
pensation, no matter how great the risceral congestion or extensive the odema. Indeed, the presenee of dropsy is generally considered the indication for digitalis, and hence this drug is preseribed as the sovereign remedy; when this fails, the case is considered hopeless. As a general proposition it is true; but in many eases the giring of digitalis at first is analogons to whipping a horse that cannot draw his load up hill. He fails, not because of lack of effort, but becanse his load is beyond his strength. Lighten his load, and the poor beast will surmount the hill without faltering. The erippled heart fails in its labours, as a rule, becanse its task has become too great, and not from weakness inherent in its myocardium. It has become like a jader horse, exhansted yet willing still, which may respond for a time to whip and spur, but will die in the attempt.

Overdilatation-that is, orerdistention-of the carliac eavities renders the heart incapahle of recponding to a drug which slows the organ by prolonging diastole and thus favouring a better filling of its chambers. The heart is already filled to its ntmost and fails to contract adequately becanse of abnomal endoeardial blood-pressure. Eren under the stimulns of digitalis its walls camnot cope suceessully with its contents. As a matter of fact, the drug only intensifies its embarrassment. The stasis within the organ must first be relieved, after uhich digitnlis may be administered with satisfactory results. This may he done by bloodietting or by catharsis; 12 to 16 ounees of blond may be drawn from the arm, or wet cups or lecehes may he applied to the pracordia. I prefer, and have nsually employed, hychagogne catharties, becanse they lessen direetly the hepatic stasis that coexists with the cardiae distention and forms another of the conditions acting as a barrier to the action of digitalis. The following is a case in point:

April 17, 1895, I was asked to treat $\mathrm{M}$ iss T., aged forty-four, who had been ill with heart-disease for about six weeks and had been given up by a number of doctors as a hopeless case. In fact, the last physician had declared nothing conld he done for her, had acted on this belief, prescribed only some codeine to relieve her congh, and had gone his way. The larly gave a history of articular rhemnatiom twenty-five years before, since which time she had been short of breath. Her present symptoms, however, dated from about six weeks back, set could not be traced to any 


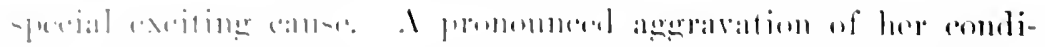

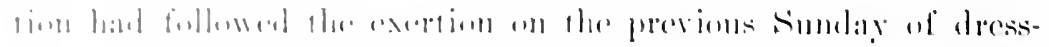

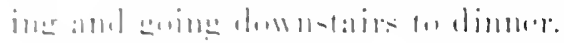

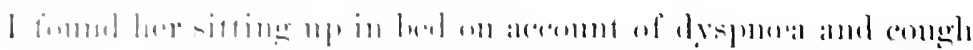

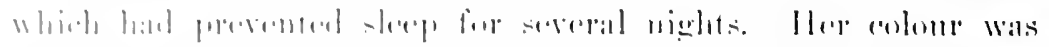

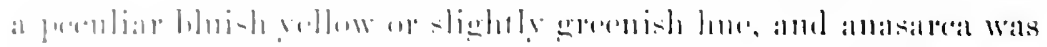

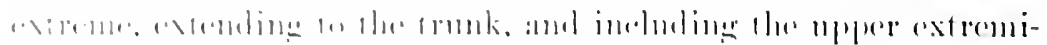

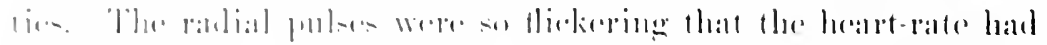

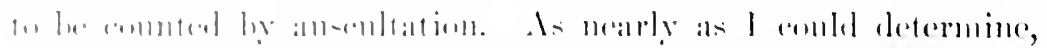

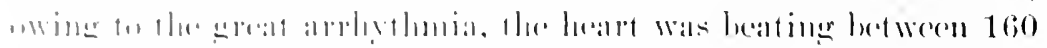

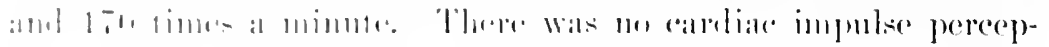

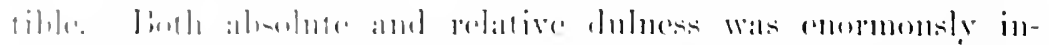

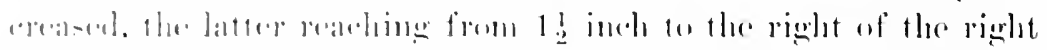

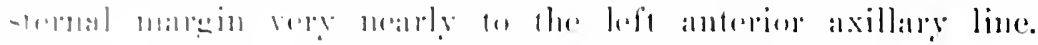

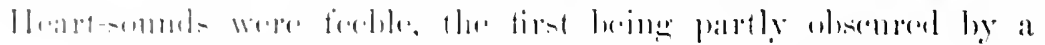

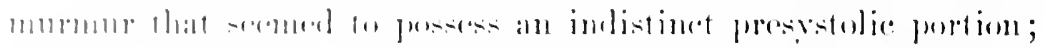

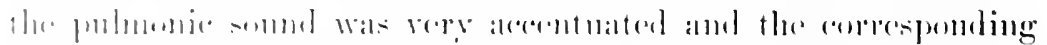

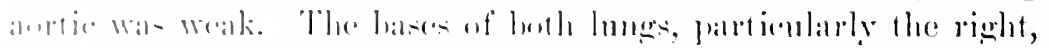

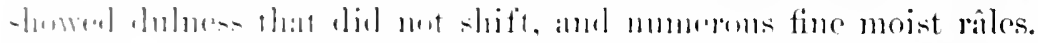

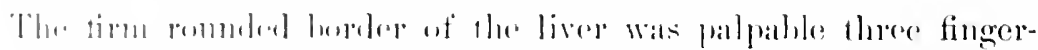

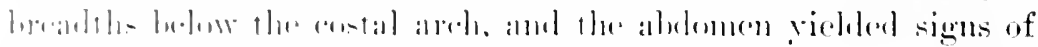

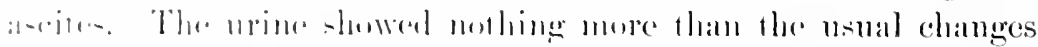
uf $10131010-1,111$.

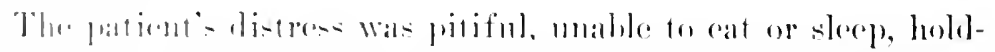

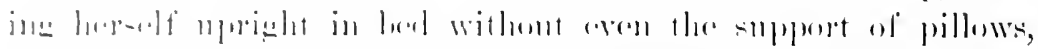

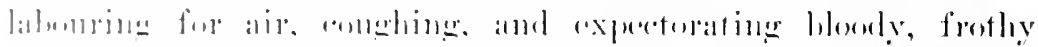

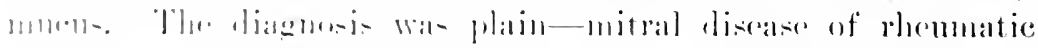

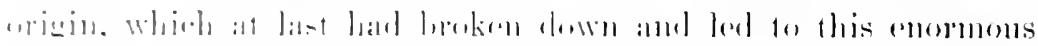

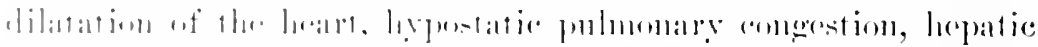

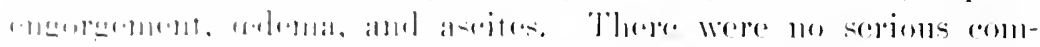

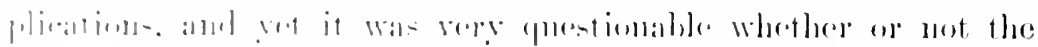

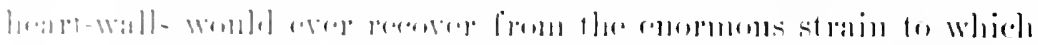

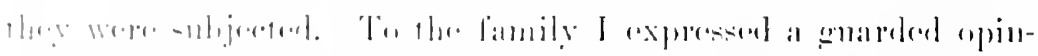

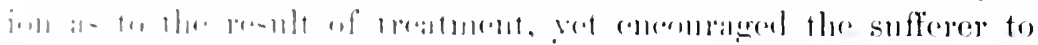

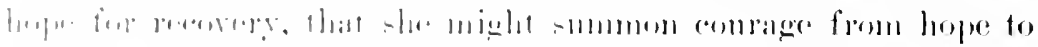

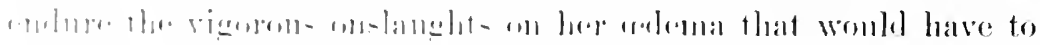

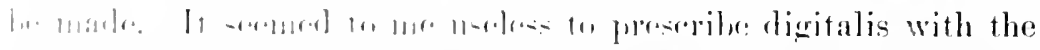

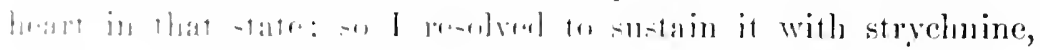

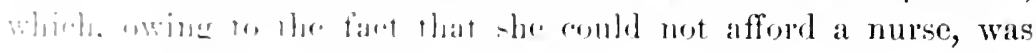


given by month, $\frac{1}{30}$ erery three hon's during the day, while each evening I injected the same dose hyodermically, together with $\frac{1}{8}$ of morphine and $\frac{1}{15 \pi}$ of atropine, to induee slecp and lessen the cough. Then as a package of simphorol had been given me for trial, I decided to try its effeet on the drops. I cathatric wats also administered, lunt not a very powerful one. The diuretic failed absolutely, and Merck's diuretin was tried with the same want of snceess. Then without changing the strychnine and evening dose of morphine it was deciderl to make use of purgationgood, rigorous purgation of the old-fashioned sort.

The patient's strength, by the way, had increased appreciably, althongh the odema had only grown somewhat less hard. She was also able to take a little more nourisment, consisting of milk and eggs. Aceordingly compound jalap prowler in teasponful doses was administered until a large number of copions watery stools were secured. Indeed at one of my risits-the first, I believe, after the powder had been ordered-she was fom sitting on the night-stool, and in response to my queries concerning the effect of treatment, stated she harl been sitting there for two hours, preferring that to the effort and fatigne of changing from bed to the stool and back again every few mimutes. The influence on the heart and eirculation was wonderful and gratifying. First her congh and drepnea subsided and the sputum lost its bloody character; the ablomen softened down, and the cedema left the arms and flanks; the pulse grew a trifle less rapid, but appreciably more waves reached the wrist; cardiac dulness became rather less extensive also. Then I decided to let up a little on the pureation and to administer infusion of digitalis carefully prepared from English leaves, strychnine and morylhine to be continued as before. The results were almost magical; the heart quieted down and daily grew in regularity and strength: dropsy lisappeared entirely, and the patient, free from congh, was alle to lie down with ease and enjoy a confortable night's sleep. The morphine was discontimuerl, lint the stryelmine was left unlisturbed.

May 1st the patient was turned over to I)r. Ilonston, who resided in the neighbourhood, and by him reports of her progress were made to me. The last time I saw the patient, about June 1 st, she was sitting dresiced on a sofa, withont the faintest trace of adema, the pulse so, perfectly regular, the heart of nearly 


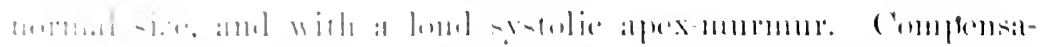

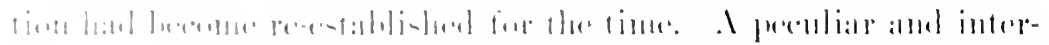

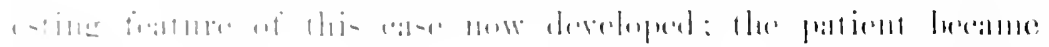

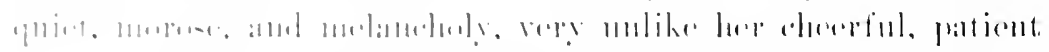

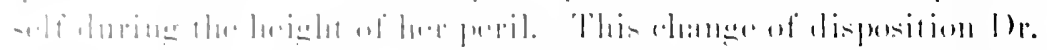

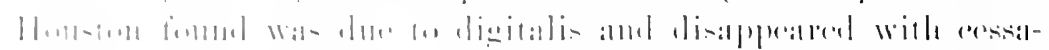

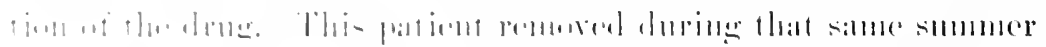

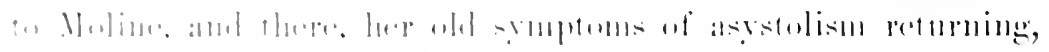

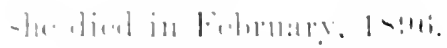

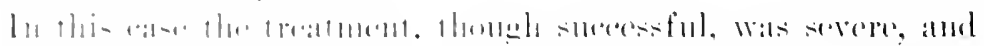

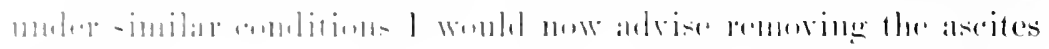

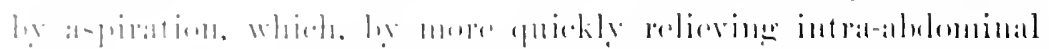

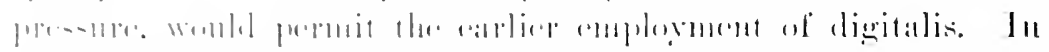

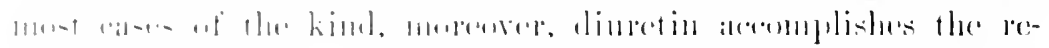

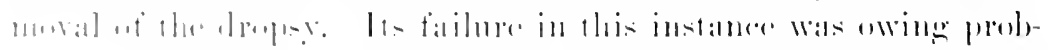

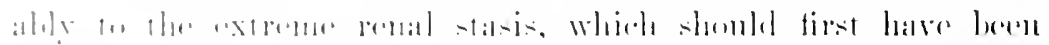

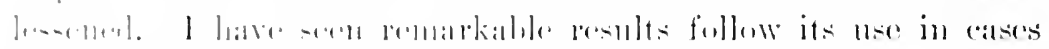

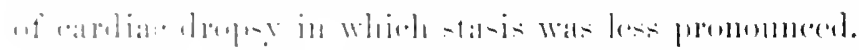

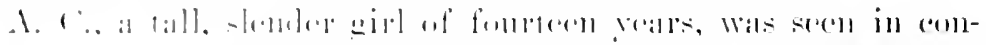

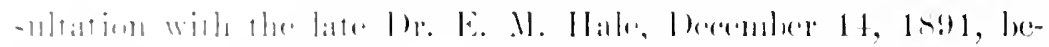

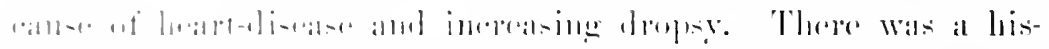

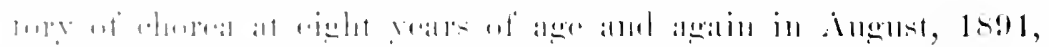

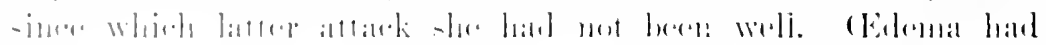

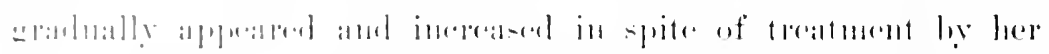

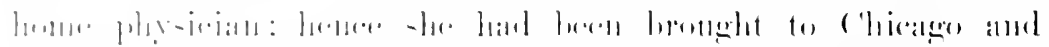

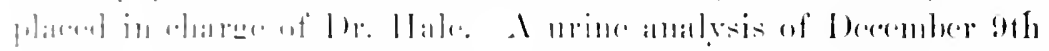

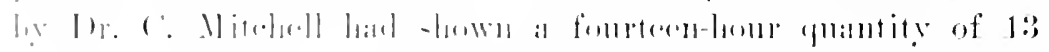

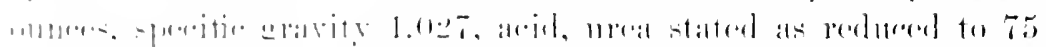

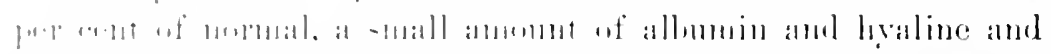

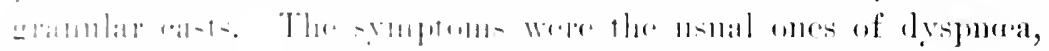

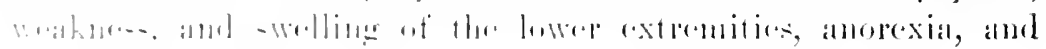
(2+11-ipialijuls.

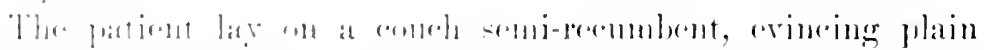

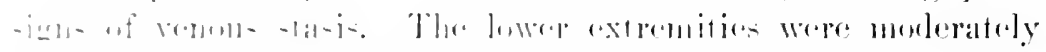

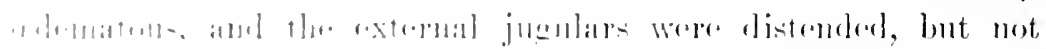

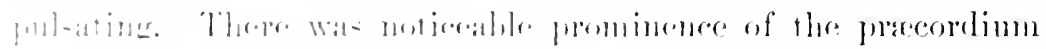

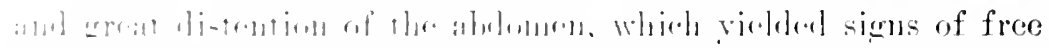

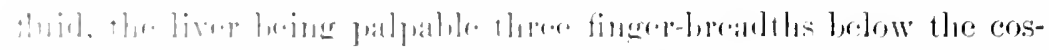

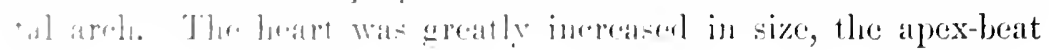


being in the sixth left interspace outside the nipple, and there was a loud mitral systolic and short presystolic murmur. My notes do not state the pulse-rate, but mention that the pulse was regular, rapid, and small. Signs of the heart being immovably fixed in position were discovered at a much later period.

In view of the fact that digitalis had been taken without favourably influencing the dropsy, it was decided to put her on 90 grains of diuretin in twenty-four honrs and administer a moderate dose of calomel. Two days subsequently the urine was reported to be 81 ounces and to contain a trace of albumin but no casts. This wilful little miss then began to be so annoyed by the frequent micturition that she refused any longer to take diuretin, and this was stopped. It was replaced by heart-tonies, first digitalis, and then $\frac{1}{10}$ grain of convallamarin thrice daily. Her improvement was so rapid that after about two weeks she was taken to her Iowa home in care of a trained nurse, by whom orders as to diet and exercise were strictly enforced. Uninterrupted gain was made until February, when the patient wearied of her restraint and my services were dispensed with. The following October I learned that she was riding horseback, playing lawntemnis, and bicyeling, but " her lips looked blue." Five years now elapsed before I again saw her, but I learned meanwhile that she had another breaklown similar to her first one, her recovery being very slow, and requiring severe purgation.

Mr next examination of this patient was in the early fall of 1896, at which time she was attending a young ladies' school in one of our suburbs. The heart was very greatly enlarged; its apex-beat was immovable in the sixth left interspace well towards the anterior axillary line; and mitral regurgitation appeared to be the predominant lesion. Hepatic engorgement was considerable and cardiac embarrassment was evident upon exertion. She was resorting occasionally to a few drops of strophanthus, but no cathartics.

She was indueed to take a laxative water at regular intervals, which speedily lessened the visceral eongestion. She also consented to try the efficacy of a course of baths à la Nauheim supplemented by resistance gymnasties. The results were gratifying, the dilatation of the right heart being appreciably reduced and the cardiac tone in general being greatly improved for the next 


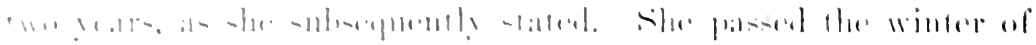

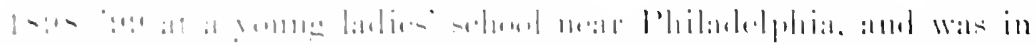

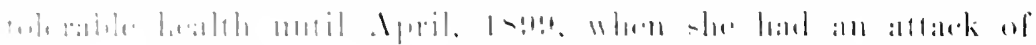

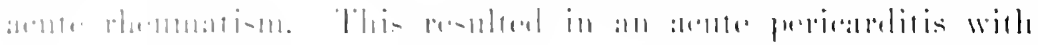

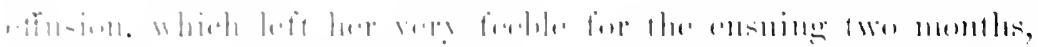

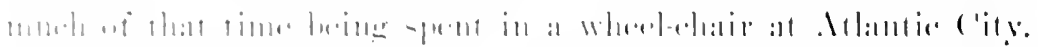

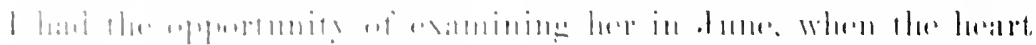

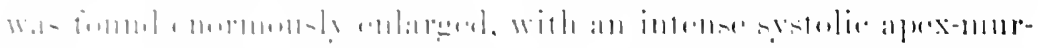

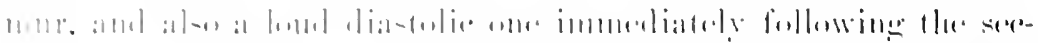

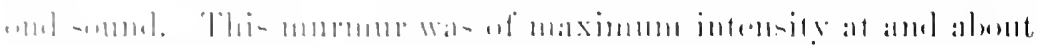

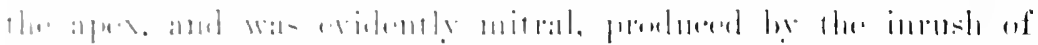

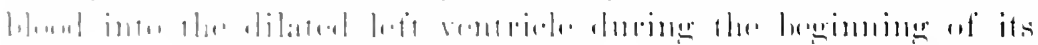

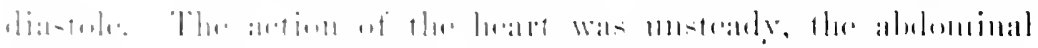

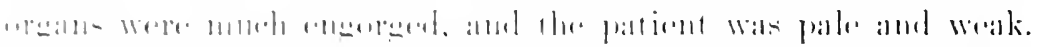

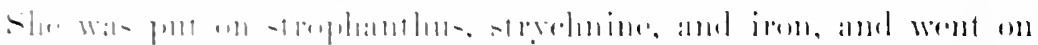

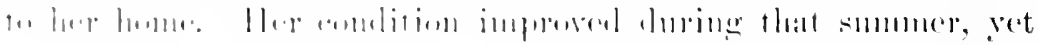

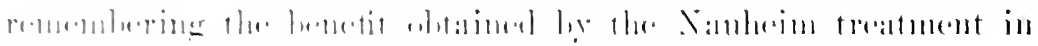

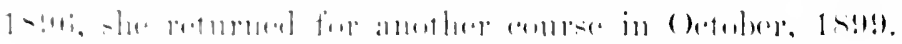

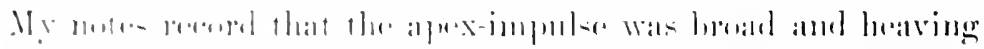

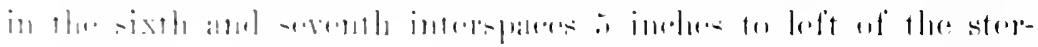

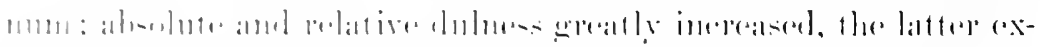

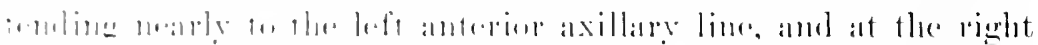

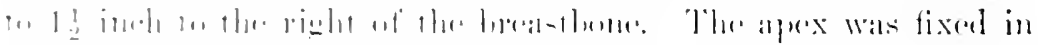

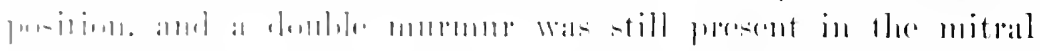

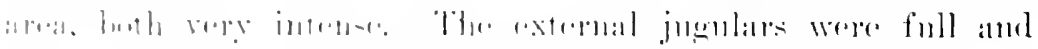

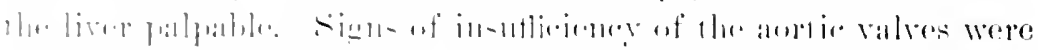

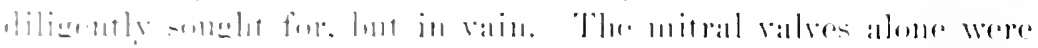

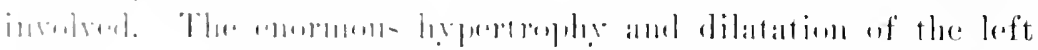

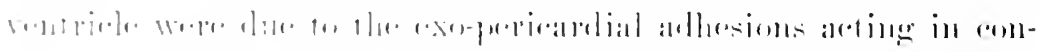

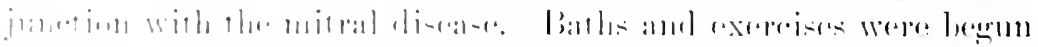

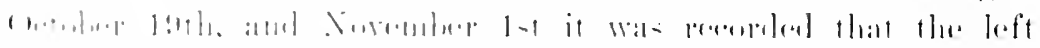

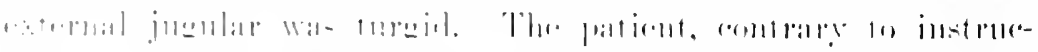

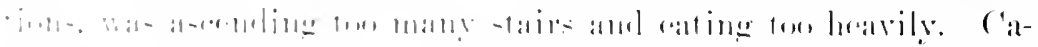

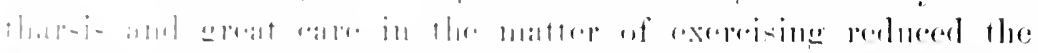

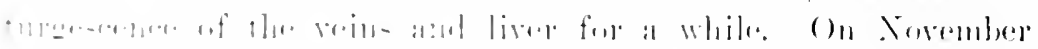

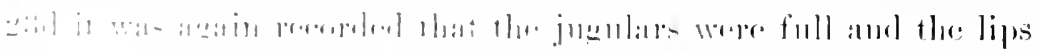

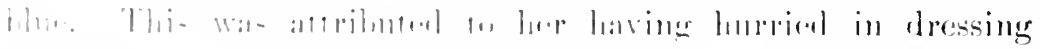

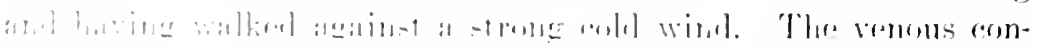

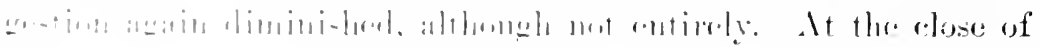


the course of treatments, which had extended through six weeks, it was noted that the left heart had not diminished in size at all. The enlargement of the right heart was less, however, the action of the heart less easily disturbed, and the patient felt stronger, having lost the weakness, perspirations, and sensation as if the "heart was trembling," symptoms of which she spoke at the date of eommeneing the treatment. The winter following she felt better than ever before.

Since the above was written this patient suffered a final breakdown, and died under my eare in May, 1901. Her last symptoms have been described in the chapter on Mitral Regurgitation.

March 18, 1896, I was requested to see Mrs. F., aged thirtyfour years, who had been dropsical for several months. The patient had had inflammatory rheumatism at the age of twelve or thirteen and again at thirty, soon after the birth of her second child, but had not been aware of eardiac symptoms until September 10,1895 . She had then been aroused in the night by a violent attaek of palpitation; and a few weeks subsequently had suddenly developed headache, paralysis of the right side of the face, and partial left hemiplegia. This had gradually improved, leaving behind a paralysis of the extensor's of the left arm and contracture of the fourth and fifth fingers. After this attack dropsy had gradually come on, and had resisted treatment by several local honceopathie physicians. For six weeks prior to my seeing her she had been unable to lie down, and had only slept by sitting with her arms supported on a table in front of her. An enormons odema extended as high as the waist and involved also the left or paralyzed arm. The greatly distended abdomen yiclded fluetuation and pereussion evidence of free fluid. The liver was made ont as greatly enlarged, and there were signs also of fluid in the right pleural carity. The pulse in the right radial was very arrhythmic, small, and accelerated; the left radial pulse was, and it may be remarked still is, smaller and feebler than the right. The external jugulars were a good deal distended but did not pulsate. The apex-beat was in the seventh and eighth intereostal spaees close to the left anterior axillary line. It was at first thought to be pushed over by the right-sided hydrothorax, as the fluid in the pleural eavity was thought to be. The first heart-sound was andible in spite of a lond systolie nurmur which was transmitted 


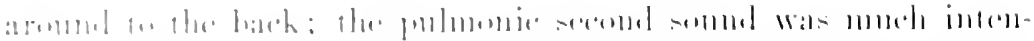

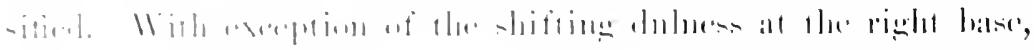

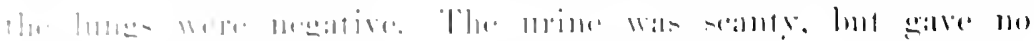

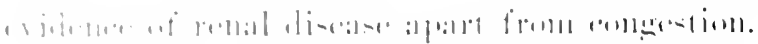

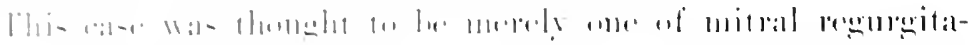

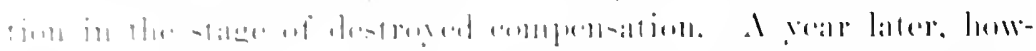

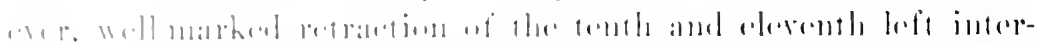

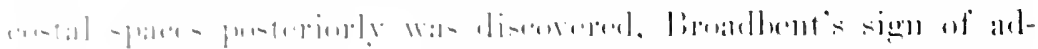

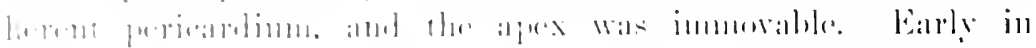

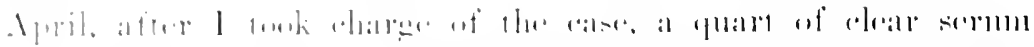

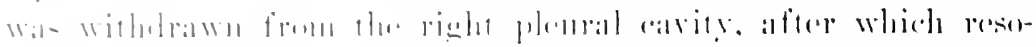

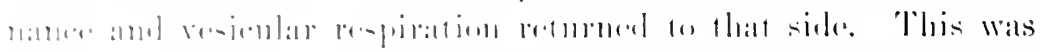

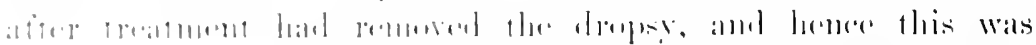

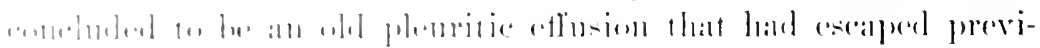

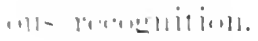

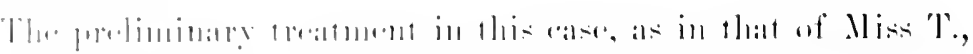

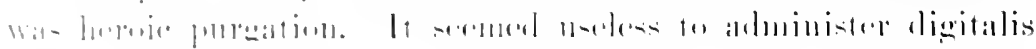

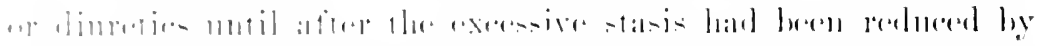

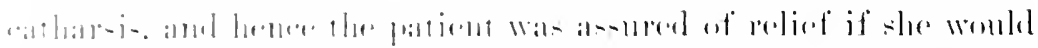

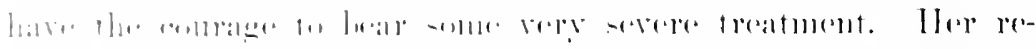

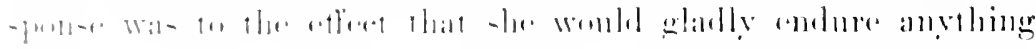

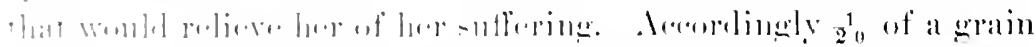

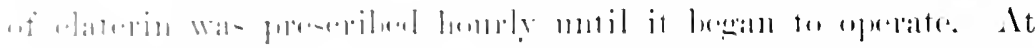

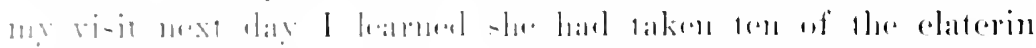

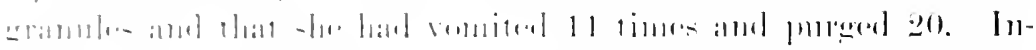

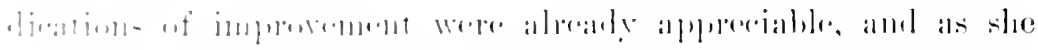

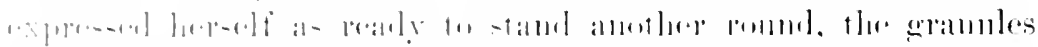

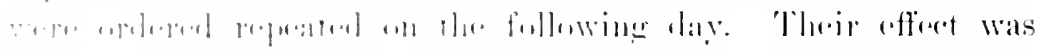

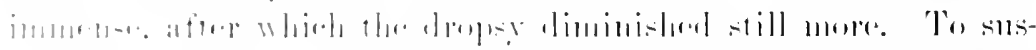

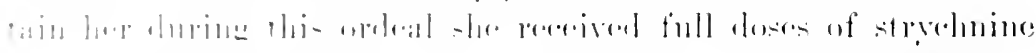

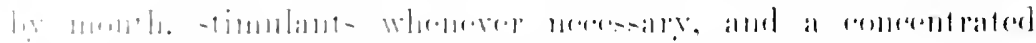

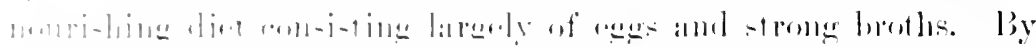

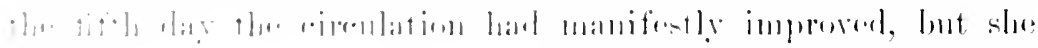

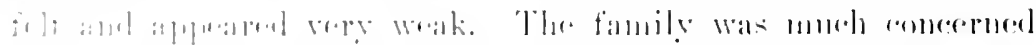

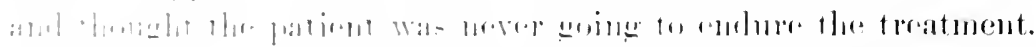

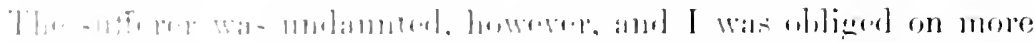

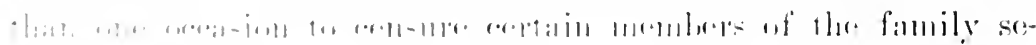

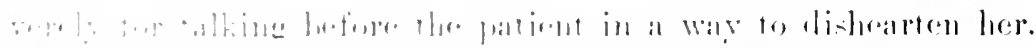

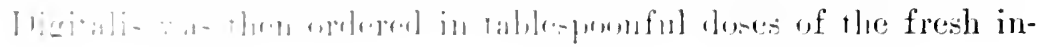


fusion every four hours, and the vigour of the eatharsis was abated, from 4 to 6 watery stools daily being still secured. ' $\mathrm{It}$ was not long before the patient was able to rest in bed, a thing she had not been able to do for nearly two months. The seepties in the family circle were now convinced and ready to assist in any therapentic measure proposed. The odema was stubborn, yet wholly subsided in about three weeks. When this had been accomplished aspiration of the right pleural cavity was performed with the result previonsly stated. Digitalis was continned daily for a year, but in the form of the tincture and for the most part in doses of 15 drops three to four times a day. The change in the pulse was very gratifying, being in Jume, as given in my notes, only 65 and tolerably regular. The liver still remained greatly enlarged and kept showing such a tendeney to inerease in size and firmmess whenever the bowels were not kept freely open that at length the patient was instructed to keep on hand a saturated solution of Epsom salts, and of this to take every morning such an amount as would secure several fluid evacuations. This order was strietly obeyed, and in conjunction with the cardiae tonies produeed the happiest results. Before the summer was past she was walking about the house and enjoying drives. Ascending stairs was strictly forbidden, howerer, and was not even attempter for at least a year.

Although this patient never lost her appetite and seldom experienced indigestion, her dietary was made very simple and of a somewhat restricted quantity that there might be no chance of her overloading her stomach to the detriment of her still enormonsly hypertrophied and dilated heart. It consisted in the main of a small dish of cereal and cream, a soft-boiled egg, a little buttered toast, and a eup of cereal coffee for brealsfist; for dinner at midday a fair-sized piece of meat, green regetables, little or no potatoes, some bread and butter, and a simple plain dessert, as plain pudding, or some fresh fruit, water in linited quantity being the beverage; for the evening meal she generally took a little cold meat with bread and butter and eooked fruit of some kind. After a considerable time, in eonsequence of the development of symptoms that seemed to indicate she was getting too much meat for the limited amount of exercise, I took away the animal food in the evening and she eonfined herself to her 


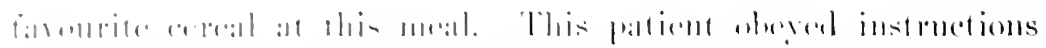

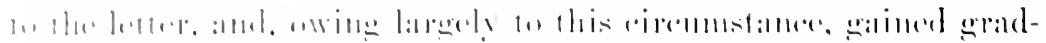

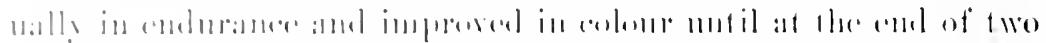

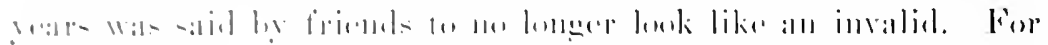

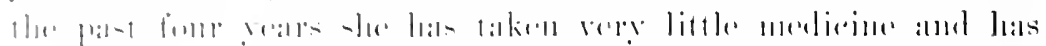

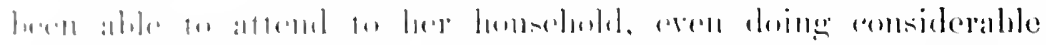

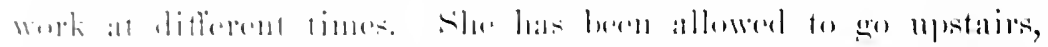

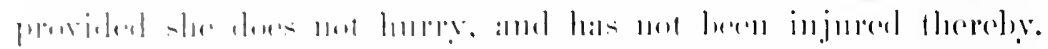

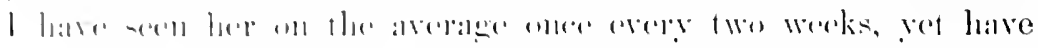

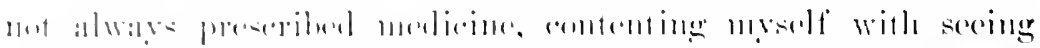

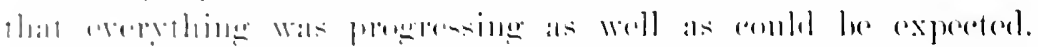

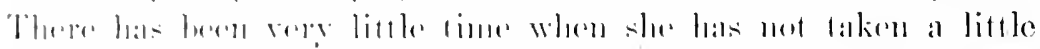

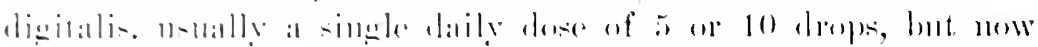

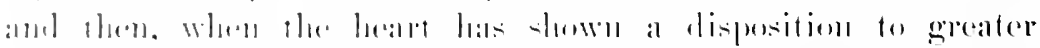

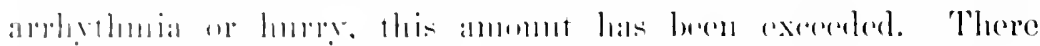

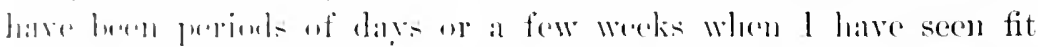

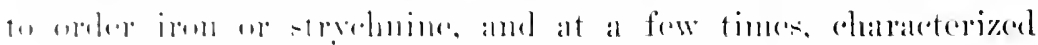

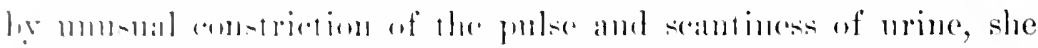

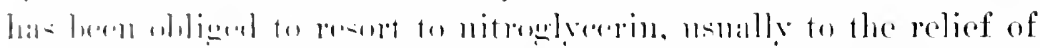

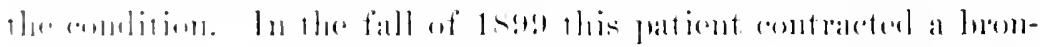

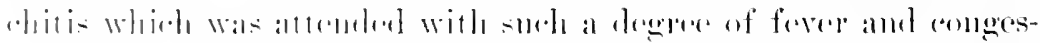

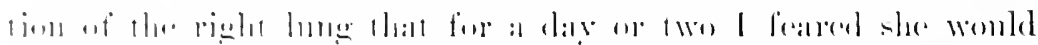

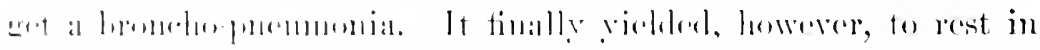

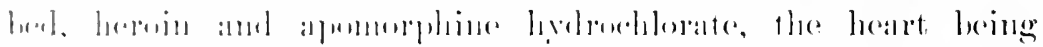

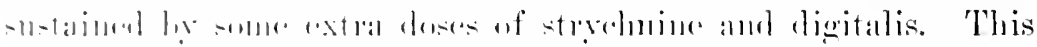

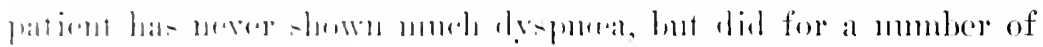

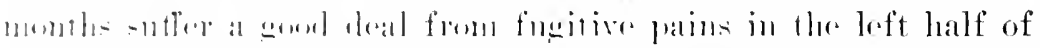

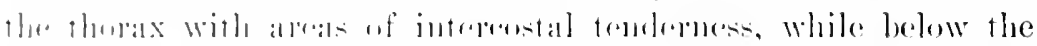

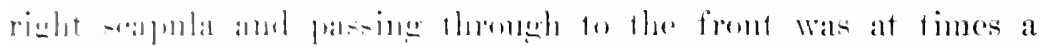

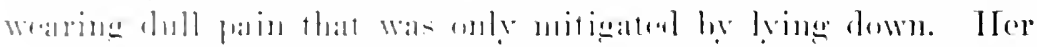

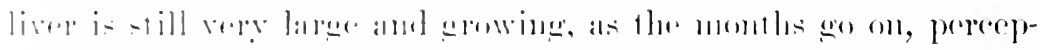

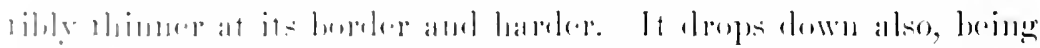

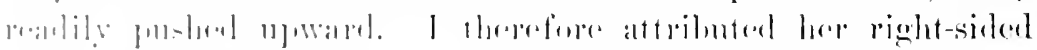

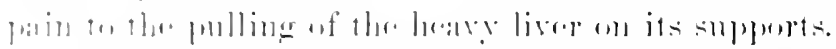

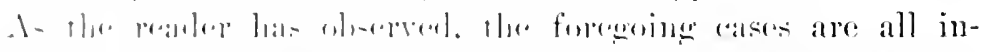

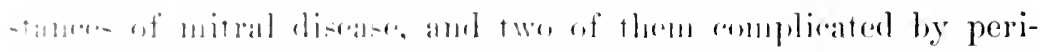

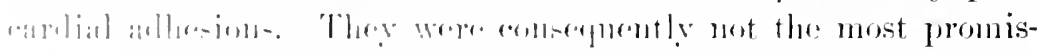

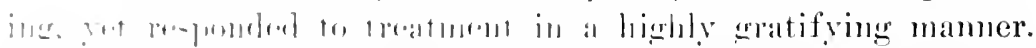

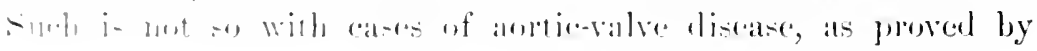


the cases detailed in the chapter deroted to Aortic Regurgitation. In 1894 I had in charge a young man nineteen years of age afflicted with insufficiency of the aortie valves of rhemmatic origin. Compensation was not badly ruptured to judge from his symptoms. He displayed no redema or marked renous stasis, almost his only subjective consciousness that all wals not right being shortness of breath and palpitation upon exertion. Yet the heart was dilated and the pulse notably arrhythmic. It was hoped benefit would result from a course of therapeutie baths and exereises. As a matter of fact some degree of strength appeared to be imparted to the heart, for the impulse became more defined, the sounds more distinct, and his subjective sensations less pronounced. Nerertheless, not many weeks had elapsed after the course of treatment when he suddenly had an attack of partial syncope, on account of which he was confined to bed and eardiae tonies were administered. ITe did not improve, and a few days later died surdenly with manifestations that strongly suggested embolism of one of the main divisions of the pulmonary artery. An autopsy was not obtained.

The Treatment of Dropsy.-When this supervenes in the downward course of valve-lesions, it is not to be regarded merely as an indication of eardiac inadequacy, but as evidence of obstruction to eapillary circulation, plus animia and greater permeability of the capillary walls. The pressure of the transuded serm still further obstruets capillary flow and angments cardiac embarrassment. It must be remored, therefore, before the strength of the heart can be restored. In this stage of valvular disease the occurrence of dropsy is rery common, and its removal is the problem first requiring solution. In some instanees this is easy and only necessitates for its accomplishment the invigoration of cardiae contractions by putting the patient at rest and by administering catharties and digitalis.

According to my experience, the infusion of digitalis exerts a more deeided dimretic action than does any other preparation or any other remedy excepting diuretin. It should be frechly prepared from English leaves, as these are more reliable than the German, which are said to contain a considerable proportion of stems. The substitution of a fluid extract for the leares in the preparation of the infusion is never to be tolerated. The addition 


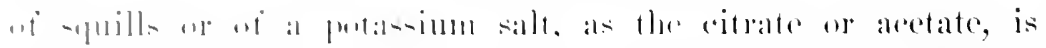

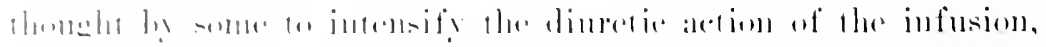

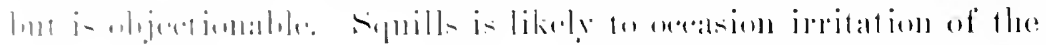

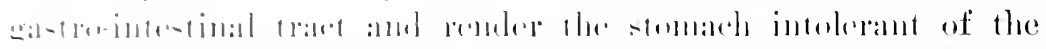

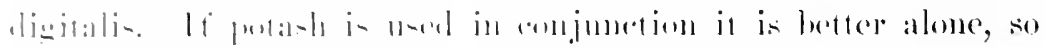

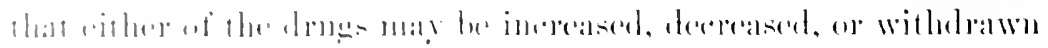

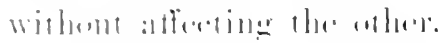

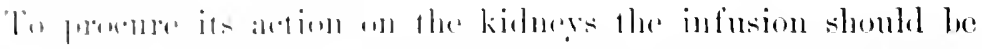

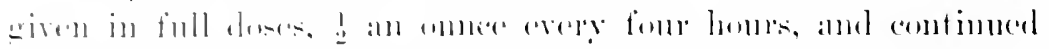

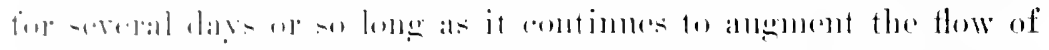

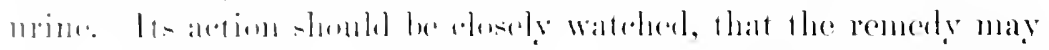

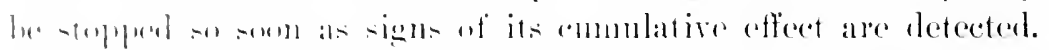

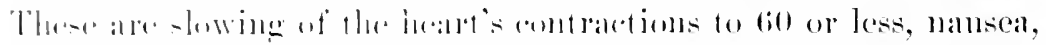

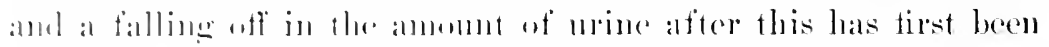

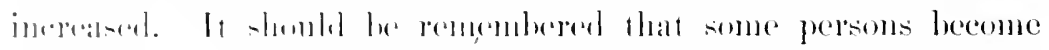

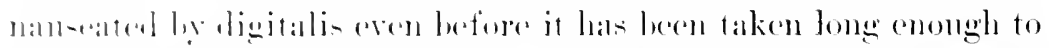

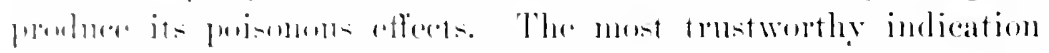

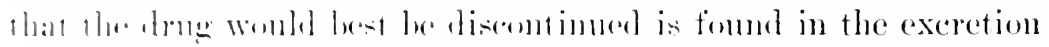

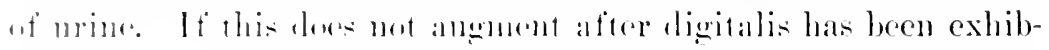

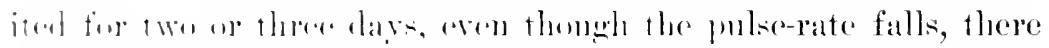

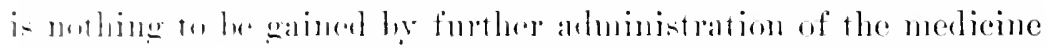

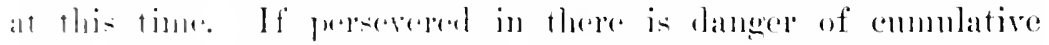

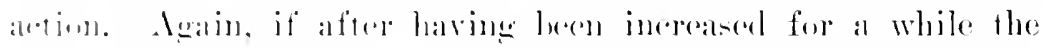

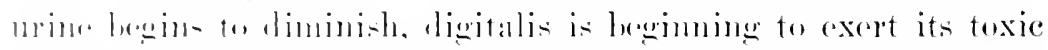
effort.

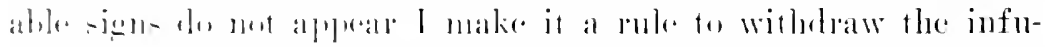

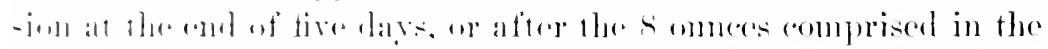

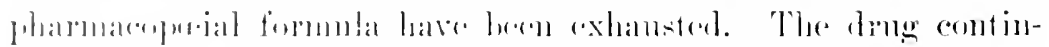

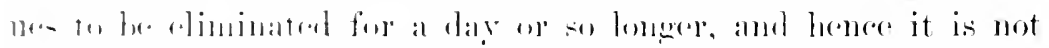

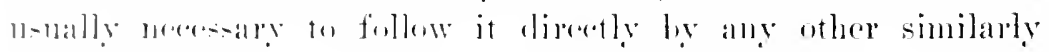

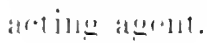

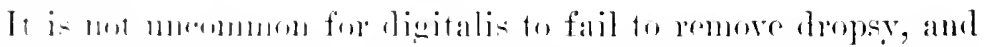

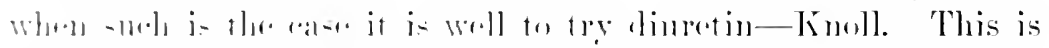

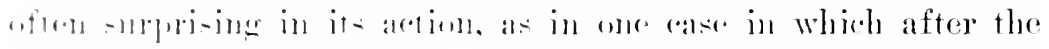

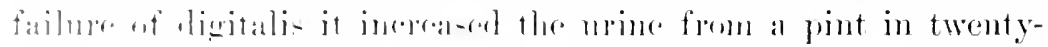

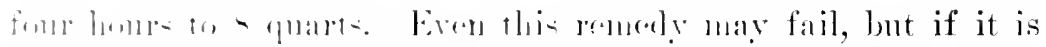

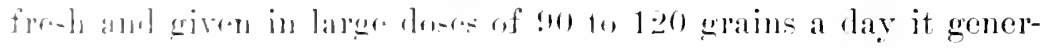

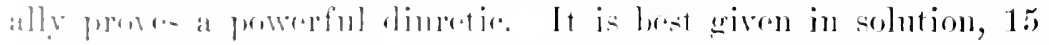

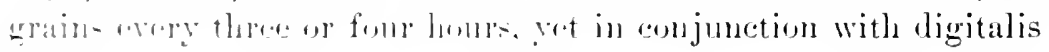


smaller doses are sometinues efficient. Diuretin has a disagreeable soapy taste, and after a time may occasion nausea and even vomiting. It also loosens the lowels in some instances. Its taste and unpleasant effects may le comteracted by the addition to each dose of a drachm or two of essence of pepsin. For the knowledge of this valuable therapentic fact I am indebted to the wife of a former patient who was compelled to take large doses of diuretin for a long time.

I have tried numerons other highly vanted dinretic remedies, but none aside from diuretin has ever fulfilled expectations. Sugar of milk and regetalle dimretics, as apocynum camnabinum and squills, have never yielded satisfactory results. Indeed, I do not see how they ean be expected to overeome dropsy when this is due to cardiac inarlequacy and renal congestion. The indications are to relieve stasis and to stimulate heart action, which they cannot do. I have not employed calomel as a dimetic since I have dreaded a possible ptyalism. When used for its effect on the kidneys, it is in doses of 3 grains several times daily in conjunction with opium to restrain its action on the bowels. Administered in this mamner it is said by the Germans to prove highly efficient in cases of cardiac dropsy meomplicated by renal disease. It seems to me, however, that one is justified in resorting to so powerful an agent only when all other means have failed.

If the dropsy is so extreme that serous transudation in the abdomen or other carities intensifies the patient's distress, it is often found that digitalis, dimetin, or caffeine, even in heroic doses, fail to increase the mine. This is die to the impossibility of securing adlequate blood-pressure in the renal arteries. Stasis in the renal reins must first be lessened if one is to induce pronounced kidney action. For this reason such enormous odema must be diminished or removed throngh the skin, bowels, or by mechanical means. Profuse sweating is not advisalle, since hotair baths and pilocarpine are too depressing for heart patients. We are restricted consequently to eatharsis and operative procedures.

The latter include punctures or incisions of the skin of the ankles to permit the sermm to drain away. This is often an efficient mode of removing obstinate dropsy, but is likely to be objected to by the patient or his friends. Great cleanliness is re- 


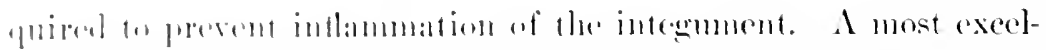

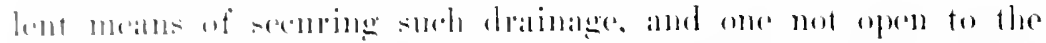

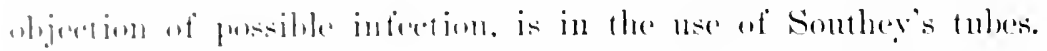

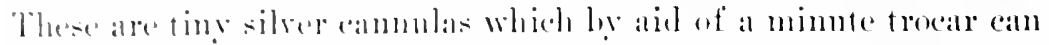
lu inserted luencath the skin of the ankles, and are then soemred in

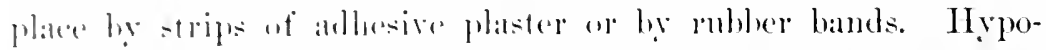

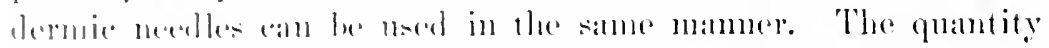

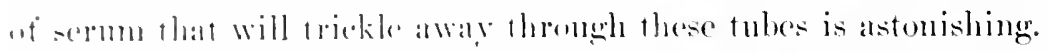

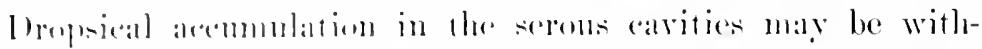

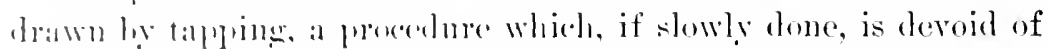

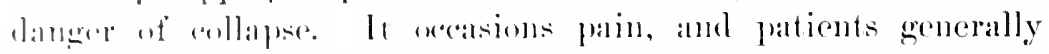

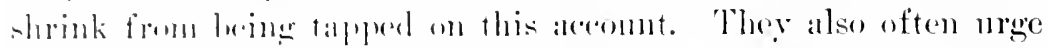
the allitional objegtion that it will have ho he repeated, and henee

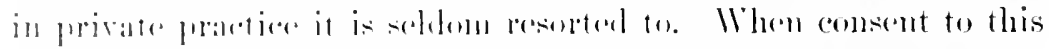

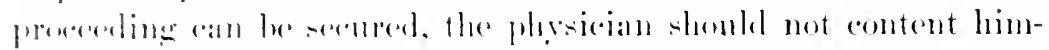

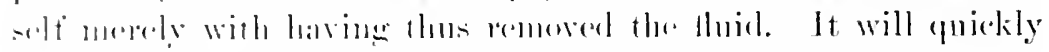

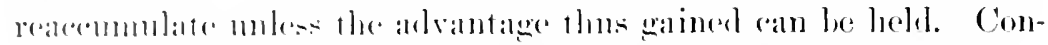

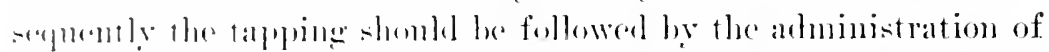
digralis a dimetin, or loth. It may he well also to administer

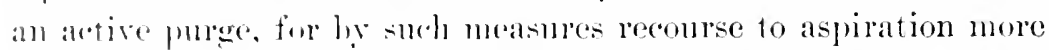
than mene maly frehaps he prevented. In the case of most private partients it will he fomml that they prefer actire catharsis. They hare hald more ol les rexperience with purgation in times past, it may les and they natmally look mpon it as less painful than being taljul.

Cathartics. Whenever it heremes mecessaly to remove serous aremmulations thromeh the intestinal trart, it shomld be remen-

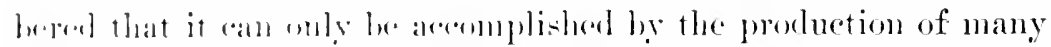
enpons wately diselanleses daily. It is mot sufficient that the de-

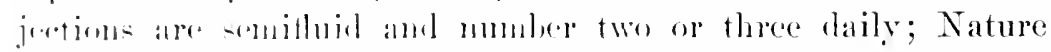

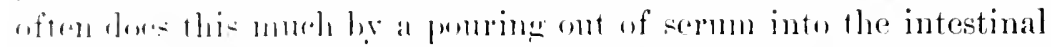

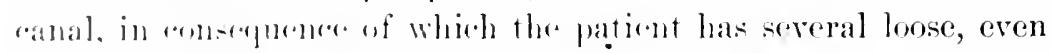

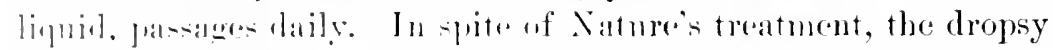

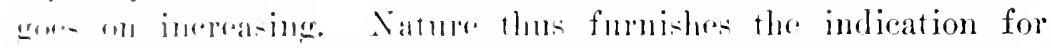

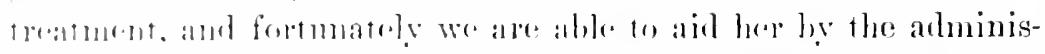

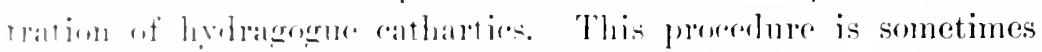

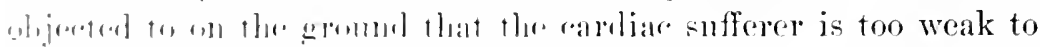
conture the droldetion. Is a mattro of fact the patient's weakness is due to his cireulanory mubarassment, and experience teaches 
that instead of being enfeebled to the degree a healthy individual would be by the purgation, the cardiopath actually finds he feets stronger so soon as the primaly effect of the catharsis is past. This is particularly true of mitral patients to whom lieroic purgation is specially benefieial. Althongh in the ease of Mrs. F. elaterin was highly suecessful, still it is so drastic that nowadays I generally order a less irritating remedy. The best hydragogue is a saturated solution of sulphate of magnesia, and of this I am accustomed to preseribe a tablespoonful hourly to an adult until it begins to exert its effect. I have known patients to take as much as 4 and eren 6 omces before getting appreciable results. The efficacy of the remedy is enhanced if the patient is not ailowed to follow the medicine by more than a swallow of waterjust enough to remove the bitter taste of the salts. If it is complained that the drug produces a bad feeling in the stomach, this can usually be comteracted by the addition to each dose of 5 to 10 drops of essence of Jamaica ginger, which is generally found in the honse. Compound jalap powler is likewise very efficient and does not prove so drastic as is supposed. Of this, a heaping teaspoonful can be safely given to an adult daily. The old-fashioned "ten ten," which is 10 grains each of calomel and jalap, was much employed by on forefathers, and is not so severe as it is thought to be. It is better, lowever, to give 5 grains of calomel with soda, or a blue pill of 5 or 10 grains, either remedy to be followed after eight or ten hours by $\frac{1}{2}$ an ounce of Epsom or Rochelle salts. Bitartrate of potassium is also a capital drug for the removal of dropsy, and by some patients is better tolerated than is sulphate of magnesia. Glauber's salts alone is too disagreeable, but may sometimes be combined with Epsom salts to advantage. It is one of the ingredients of Carlsbar water, by the way. Carlsbad salts are often preseribed to cardiac patients, but, to be very efficient for the removal of ordema, has to be given in large doses dissolved in consideralle hot water, being said to be more efficacions when administered warm. If copious watery stools are to be secured, it is best to prescribe rather concentrated remedies and not allow the intake of much water.

In case such energetic catharsis is found to weaken the patient, his strength may be sustained by strychnine, aromatic spirits of ammonia, whisky, or some other stimulant. Furthermore, the 


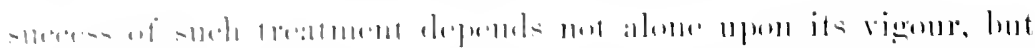

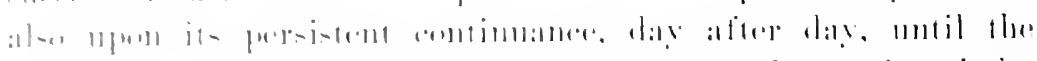

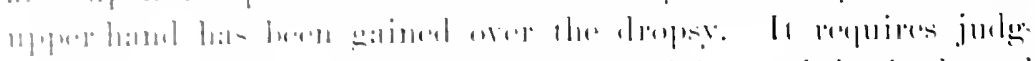

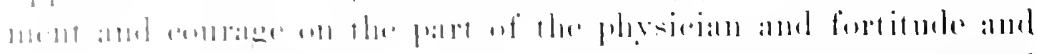

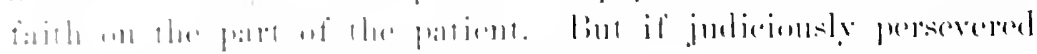

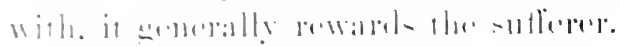

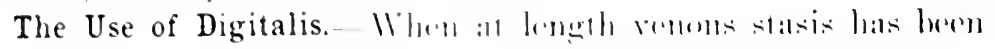

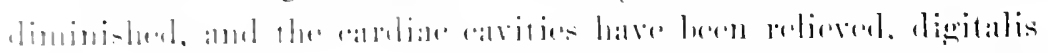

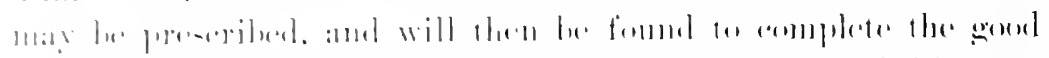

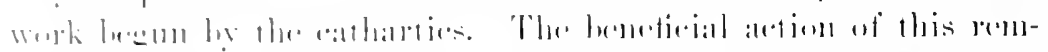

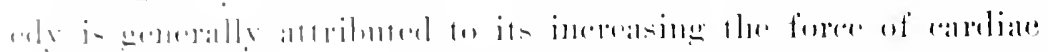

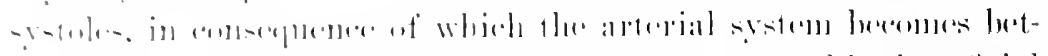

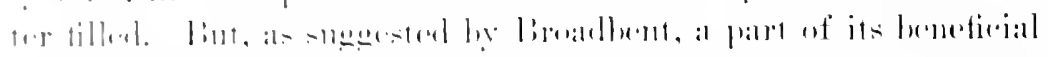

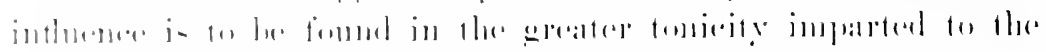

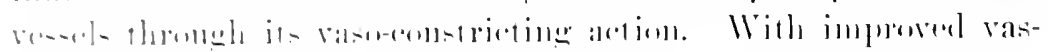

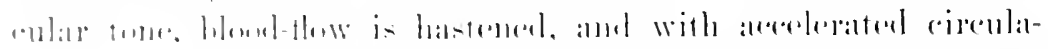

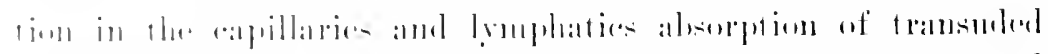

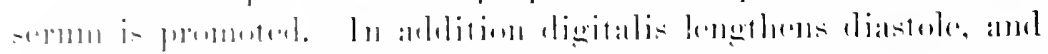

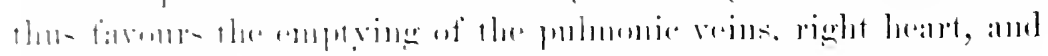

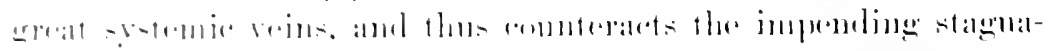

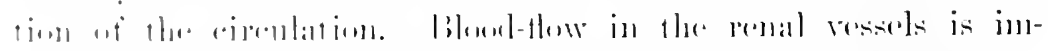

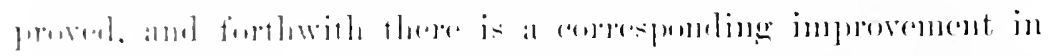

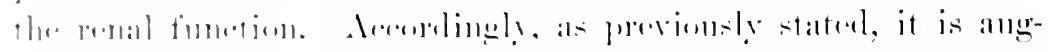

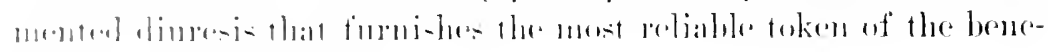

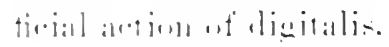

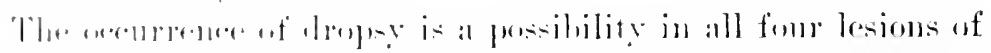

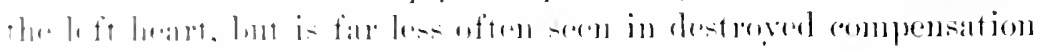

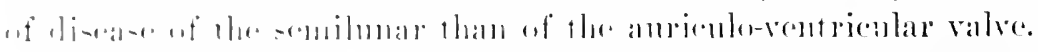

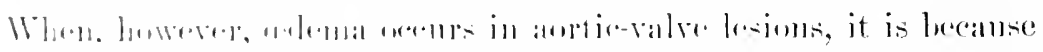

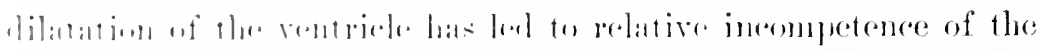

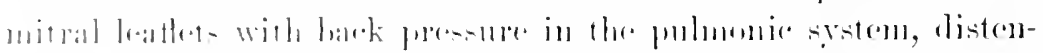

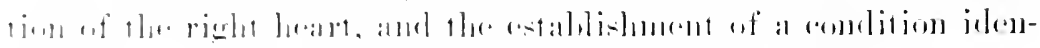

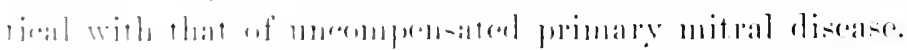

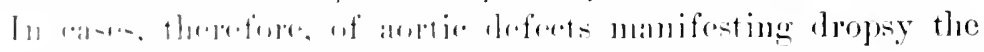

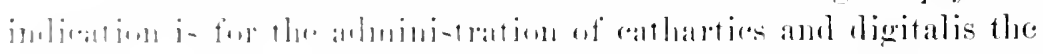

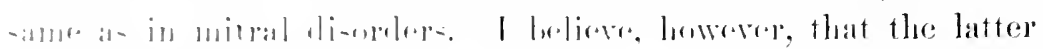

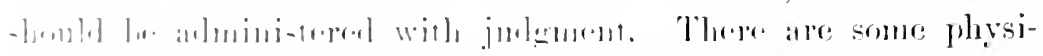

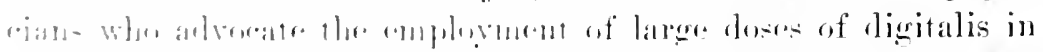

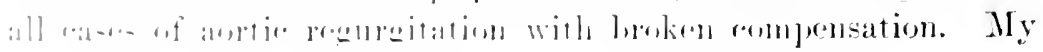


experience leads me to agree with Broadbent when he says that a distinction should be made between eases of aortic insufficiency with cedema and those without. When loss of eompensation is shown by symptons pointing to left-rentricle feebleness rather than by cedema and back pressure consequent upon relative mitral regurgitation, then I am emphatically of the opinion that digitalis must be giren with cantion. It is quite possible in such cases for digitalis to increase peripheral resistance to a dangerous degree through vasenlar constriction. Endoventricular bloodpressure is correspondingly raised, and if the ventricular wall is very feeble, unexpected death is not a very remote eontingeney. In such cases, therefore, digitalis should be given cautionsly, and its effects should be attentively watehed.

When, on the other hand, dropsy is present, the drug may be given more freely, although it is not likely to accomplish such brilliant results as in eases of mitral disease. Indeed, it has seemed to me that in some cases of aortic insufficieney with seeondary mitral leakage large doses of digitalis actually augmented pulmonary and right heart engorgement by driving more blood backward throngh the mitral than forward through the aortic orifiee. Such eertainly was the effect observed in the case narrated at the elose of the chapter on Aortic Regurgitation. Edema was not present, yet the state of the heart seemed to eall for heroic doses of digitalis in the forlorn lope of lessening the dilatation of the left rentricle. Instead of doing this, however, the digitalis appeared to aggravate back pressure, and at last cleath eame suddenly and unexpectedly.

When the mitral valve has given way in cases of aortic obstruction there is still less prospect of reinstating the ventriele by large doses of digitalis. The impediment to outflow into the arterial system is likely to cause still freer reflux into the auricle if by large doses of digitalis the physician attempts to foree the ventriele beyond a certain point.

We now come to the consideration of the question whether digitalis is equally efficient in both forms of mitral disease. Broadbent is of the opinion that foxglove manifests its happiest results in mitral regurgitation, whereas in mitral constriction the medicine is not always well tolerated. This difference is due, he holds, to the fact that the narrowing of the orifice interferes 


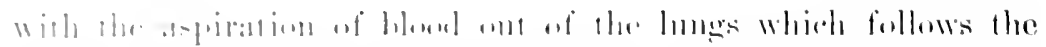

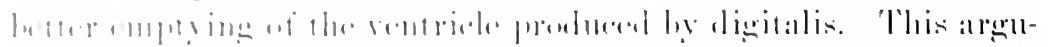

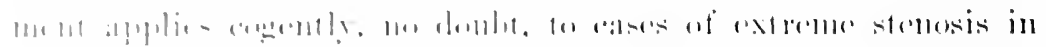

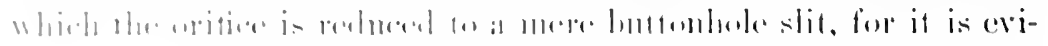

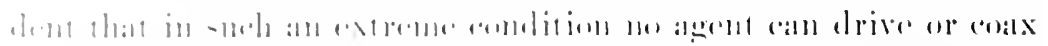

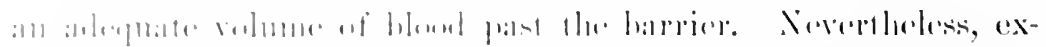

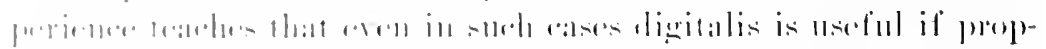

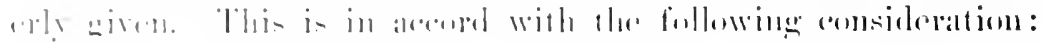

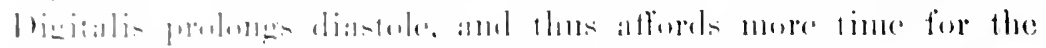

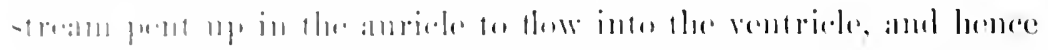

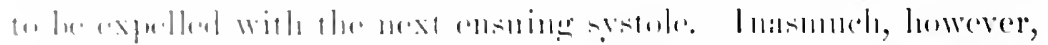

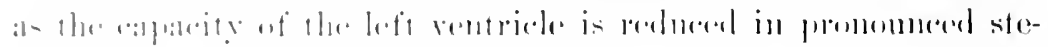

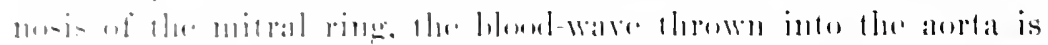

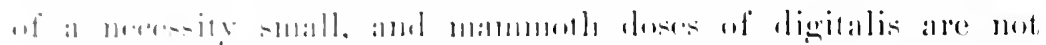

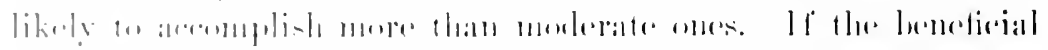

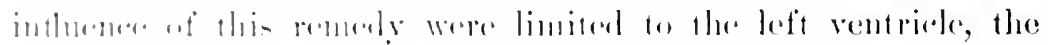

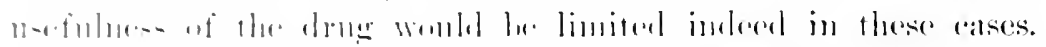

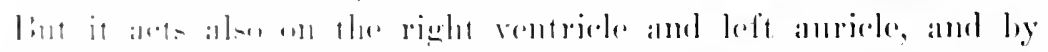

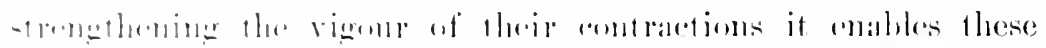

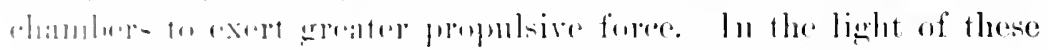

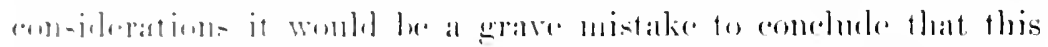

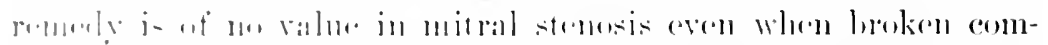

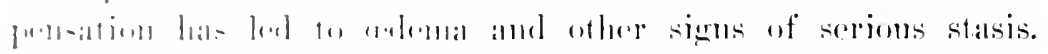

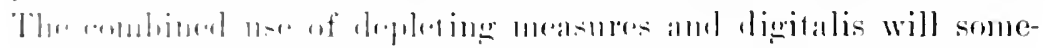

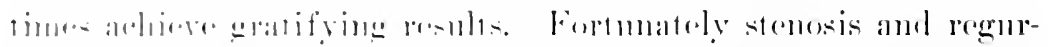

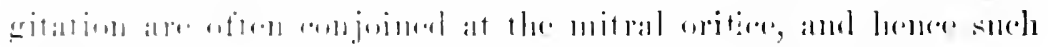

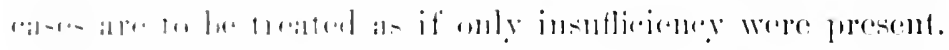

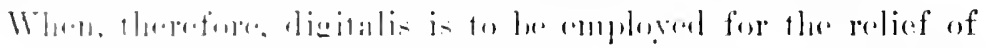

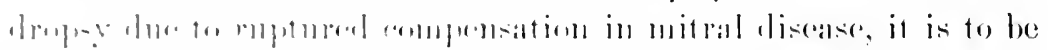

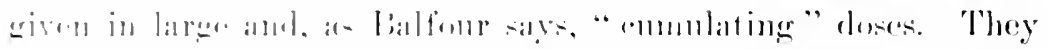

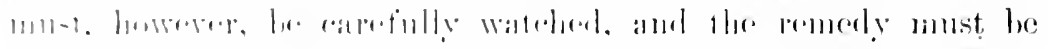
- beffend - - -

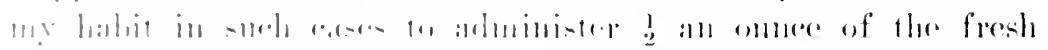

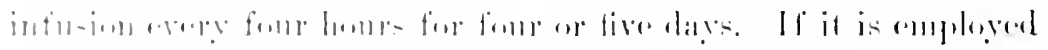

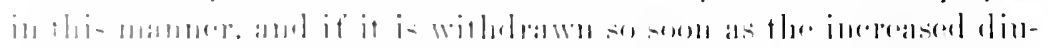

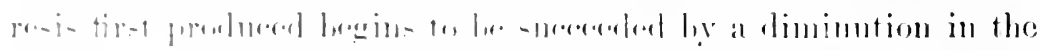

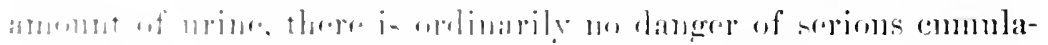

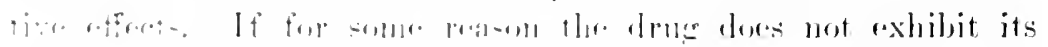

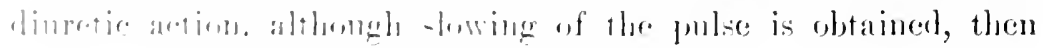


the remedy should be stopped for a day or two, after which it may again be given in smaller doses. There is no nee in administering digitalis for the relief of ordema in small doses over a long time. I have frequently seen it fail when thus given, whereas subsequently preseribed in large doses during several days it hats succeeded in accomplishing what it previonsly failed to do.

Finally, I wish to again emphasize the statement that if this unrivalled agent is to be employed for the removal of arlema it is best given as an infusion of the English leaves. The tincture, the fluid extract, or the powder, digitoxine, ${ }^{*}$ and the various digitalins, whether French or German, will not prove so efficient. The tincture is preferable for prolonged administration in small tonic doses. It will undoubtedly angment the flow of urine by energizing andiac contractions, but for the removal of cedema would lave to be given in doses that would be dangerons in the lands of the average medieal man. 'This is particularly true of digitoxine and the French or crystallized digitalia. Excepting the latter, I have tried all forms of the drug, and I think I can safely assert that all can be acconplished with the reliable tincture and properly prepared effusion that can be with the other less familiarly known preparations. I well remember ny experience with digitoxine. In one case it produced so powerful an effeet in what was considered a safe lose, that I speedily discontimed it in alarm. In the second case, that of a middle-aged woman with mitral disease and an arrhythmic pulse, the remedy was administered cantiously and without appreciable effect one way or the other, when sudelenly, almost without warning, the patient rlied. I could not say her death was due to the digitoxine, and yet I have always had an uncomfortable suspicion that it was. Therefore I would urge inexperienced practitioner's or such as practice in the comntry, where they camnot keep their patients nnder as close scrutiny as if they were near at hand-in a hospital, for instance-to content themselves with safer preparations.

Strophanthus, convallaria majalis, adonis rernalis, crythrophlein, and harimu chloride bolong to the digitalis gromp, and therefore possess dinretic properties, convallaria having been partienlarly landed by the Rnssians. None of them is the equal

\footnotetext{
* Since June, 1906. I have male frequent use of an imported solution of digitoxine with highly gratifying results in both regulating the heart and increasing the amount of urine.
} 


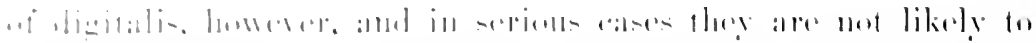
[1]

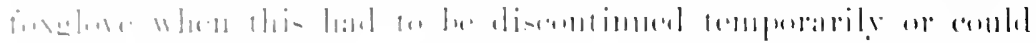

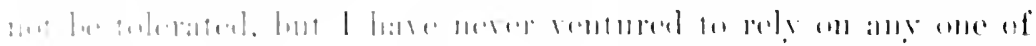

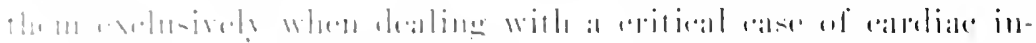

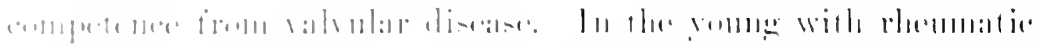

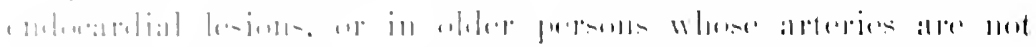

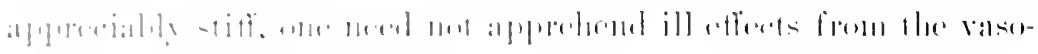

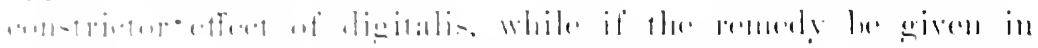

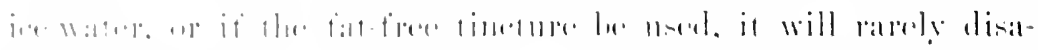

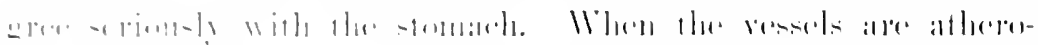

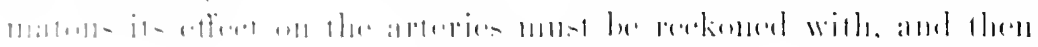

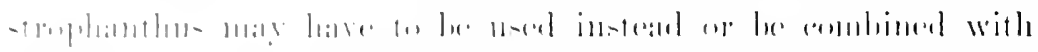

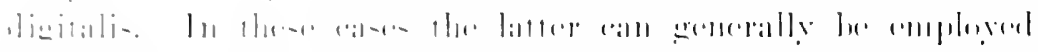

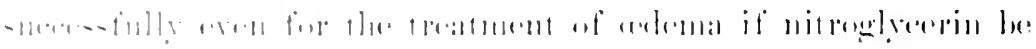

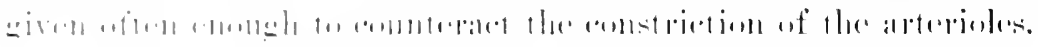

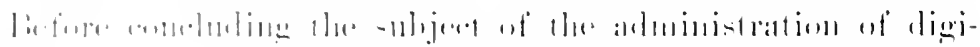

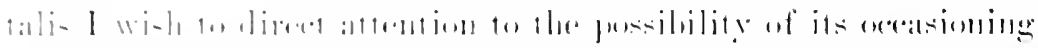

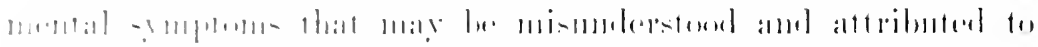

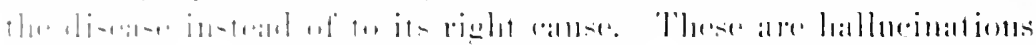

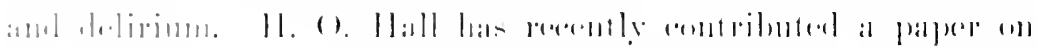

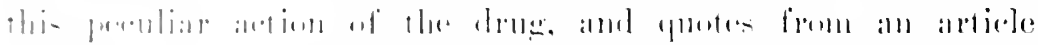

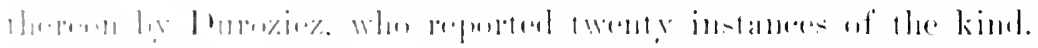

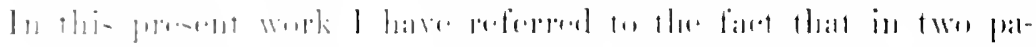

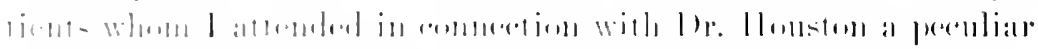

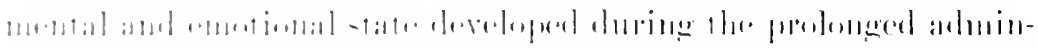

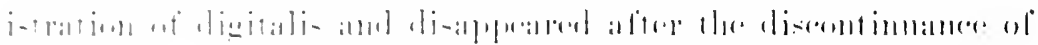

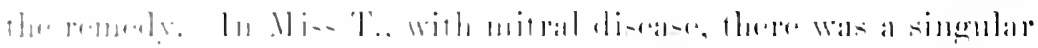

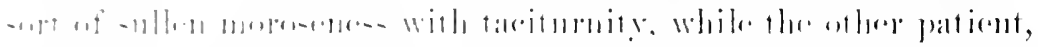

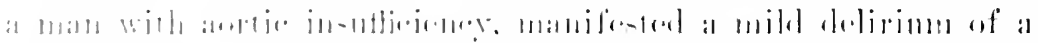

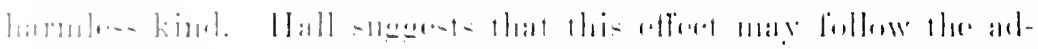

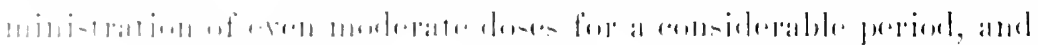

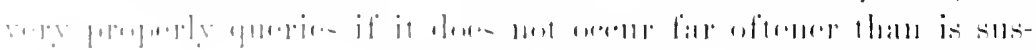

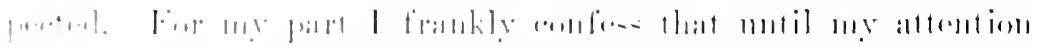

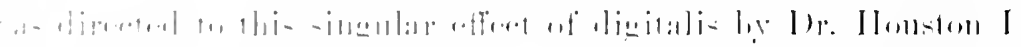

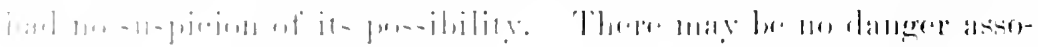

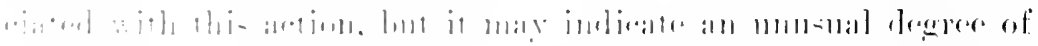

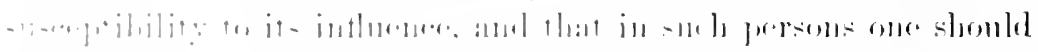

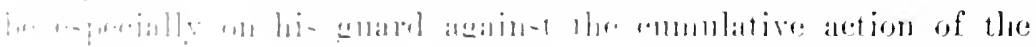


agent. This latter is no fancied one, and should always be kept in mind.

It is probable that digitalis poisoning occurs far more frequently than is suspected. I am painfully certain that in one instance the sudden death of one of my patients was dne to digitalis, which was being administered in large doses. In this case, however, the patient disobeyed my emphatic injunction to remain absolutely quict in bed, and fell dead while walking abont, just as I had warned him he might do if he got up. Since that time it has been my custom to discontinue digitalis every fifth or sixth day in all cases in which it is being taken in considerable doses or when the patients are not under frequent observation. In this way time is allowed for the elimination of the llng. Lastly, it is said that there is less danger of a cmmulative effect if a daily cathartic is taken, since it mar be largely eliminated through the bowels.

Accessory Heart-tonics. - Strychnine is a raluable heart-tonic at all times, and when compensation is lost is of great value. It should not be depended on alone, hut preseribed as an adjurant to the cardiac energizers aldeady mentioned. Arministered hypodermically it is mdonbtedly more rapid and powerful than by the month, and would best be employed in that manner. Its beneficial action is not confined to the heart, for it is a respiratory stimulant as well, tending thereby to lessen the sense of dyspnoa. Through its powerful effect as a tonic to the nerrous system it induces a feeling of strength and well-being very soothing to the tired, often irritable sufferer. It certainly helps a patient endure the insommia that so often attends his loss of compensation.

I have always been of the opinion that to display its kindly action strychnine should be given in full doses, care being had to aroid its physiological effects in toxic amomts. One thirtieth of a grain hypodermically may usually be administered every four, or in extreme cascs every three hours. I have not hesitated to order that dose as often as every two hours. or even hourly in times of great peril. The objection to such doses have been previonsly stated. (See page 445.)

Another remedy of inestimable service when the heart threatens.to fail altogether or the patient is tormented by drspnoa, particularly at night (cardiac asthma), is morphine. If adminis- 


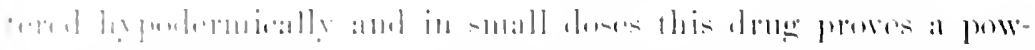

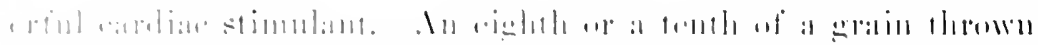

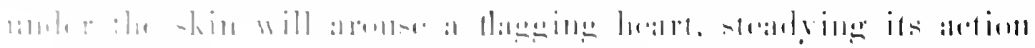

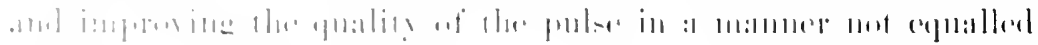

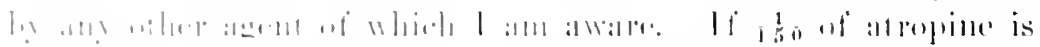

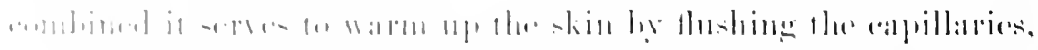

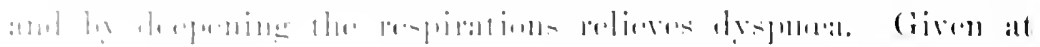

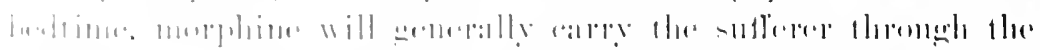

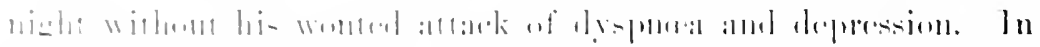

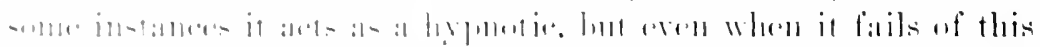

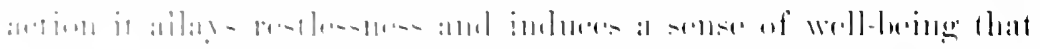

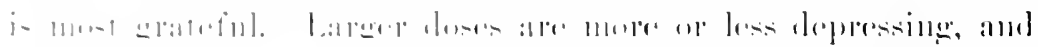

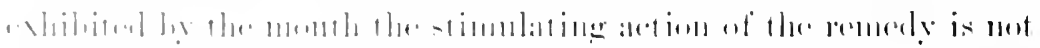

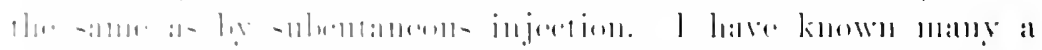

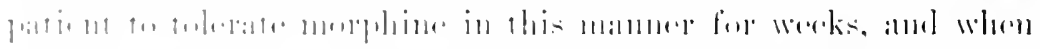

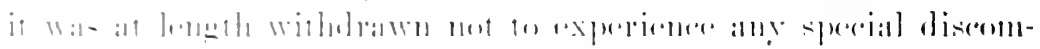

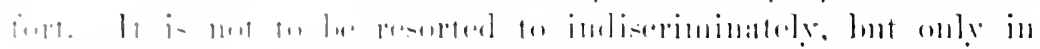

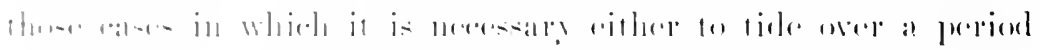

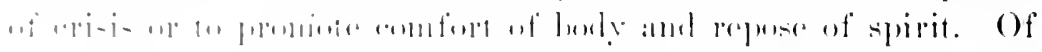

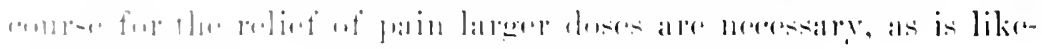

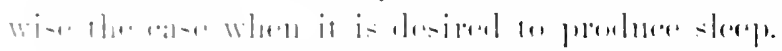

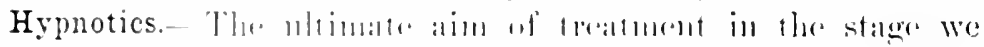

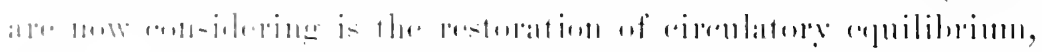

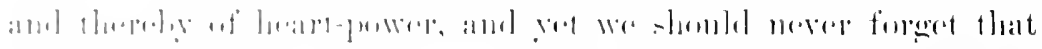
$1 h_{1}$ a

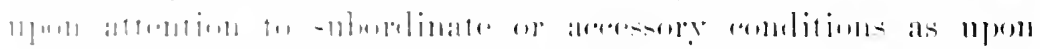

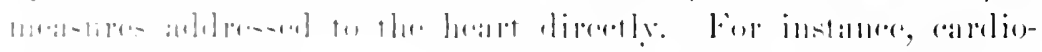

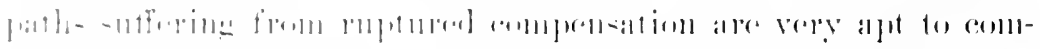

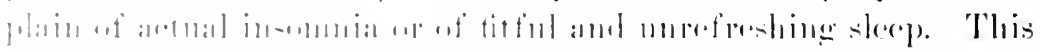

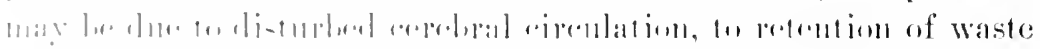

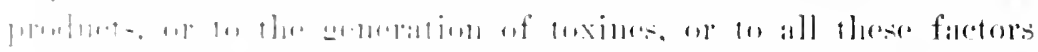

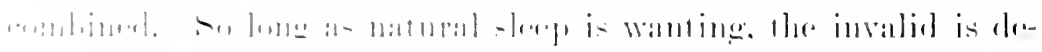

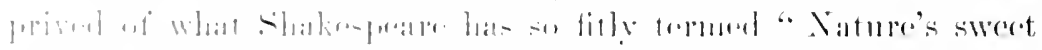

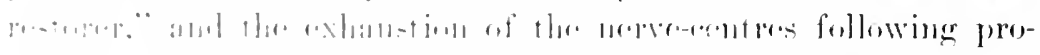

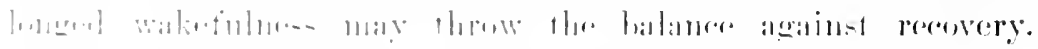

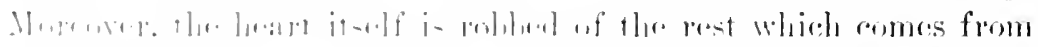

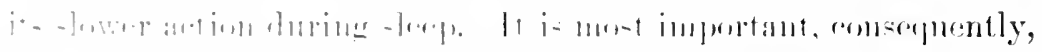

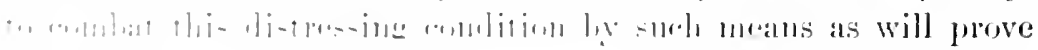
I.ar:uli... 
In some eases sleep follows the measures directed against visceral congestion and adema, or is directly induced by the hypodermies of morphine administered for relief of nocturnal dyspnoa. When such is not the case, recourse should be had to hypnotic remedies as such.

Chloral hydrate is too powerful a cardiac depressor to be safely employed in uncompensated valvular disease, or indeed in any ease in which the pulse is not strong and tense. On the other hand, chloralamide-Bayer is said to exert no injurious effect on the circulatory apparatus. If it affects the pulse at all, it is by aceelerating it while at the same time angmenting its tension. The main drawback to this agent is its liability to occasion headache next morning and its mpleasant acrid taste. To obviate the former effect, therefore, an expal amount of potassimm bromide may be added to each dose of chloralamide, while its disagreeable taste may be disguised by some palatable sirup. The remedy is perfectly safe in doses of from 15 to 40 grains, and to prove efficient otight to be given in a single full dose. A good formula is the following: Chloralamide-B. 2 grammes, spiritus frumenti 15 cubic centimetres, potassii bromidimm 2 grammes, and syrupus glycyrrhiza', q. s., ad 30 cubic centimetres. M. et sig. This dose to be taken at bedtime.

Chloralose is a hypnotic highly recommended by Balfonr in his capital work The Senile Heart. Its dose is from 2 to 8 grains, best given in capsule, and is said to tend to slowing of the pulse while at the same time lowering its tension. I formerly prescribed it a good deal, but nltimately abandoned it becanse I found that when my lady patients took 5 grains at a single dose, or were obliged to repeat a eapsule containing $2 \frac{1}{2}$ to 3 grains, they were apt to complain of nervousness the next morning; it is, however, safe and usually produces sleep quickly. Sulphonal and trional are both safe and efficient hypnoties for the class of eases now considered, since although they accelerate the pulse and somewhat raise arterial tension, they do not depress the heart. Paraldehyde in full medicinal doses of a drachm acts similarly to chloral hydrate as a soporifie, but unlike the latter is perfectly safe even for weak hearts, being said to slow and strengthen the pulse. Its action is not so prolonged, however, and patients often object to it on account of its burning taste and persistent odour 


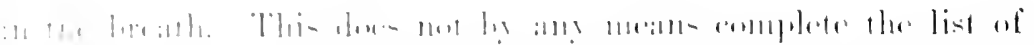

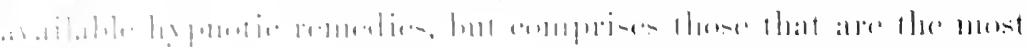

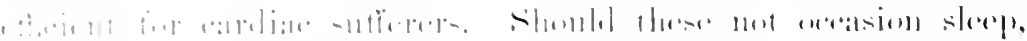

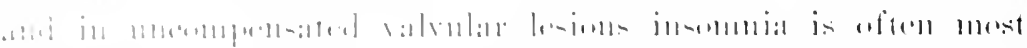

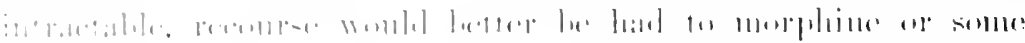

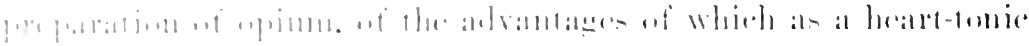

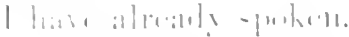

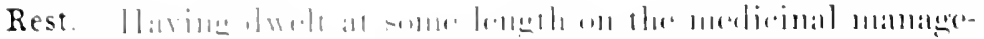

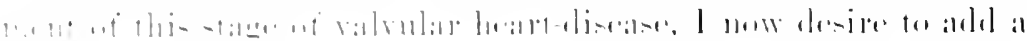

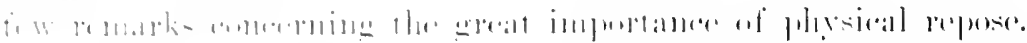

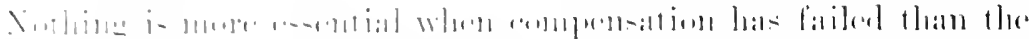

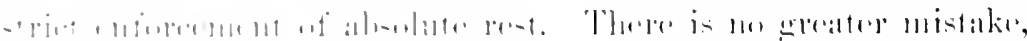

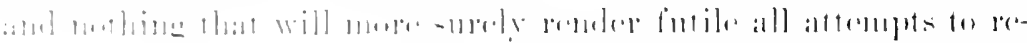

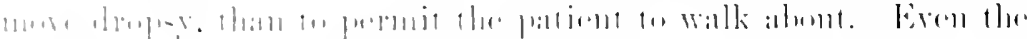

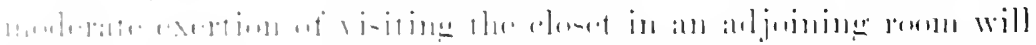

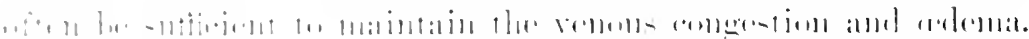

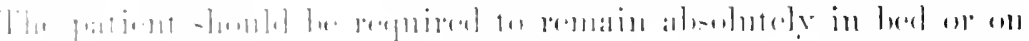

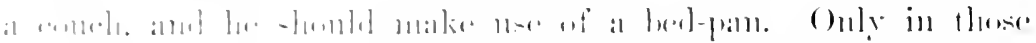

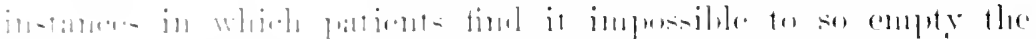

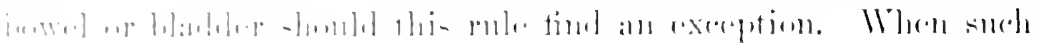

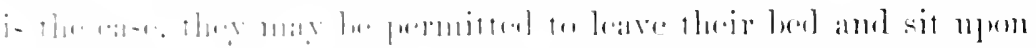

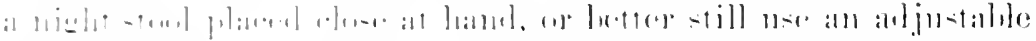

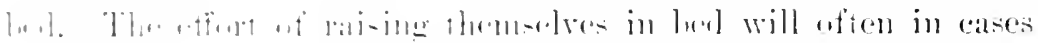

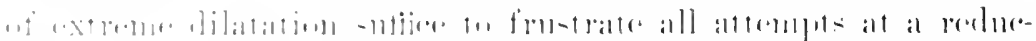

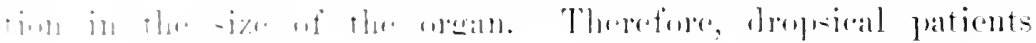

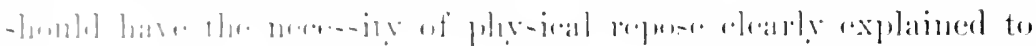

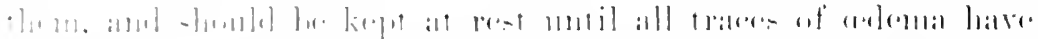

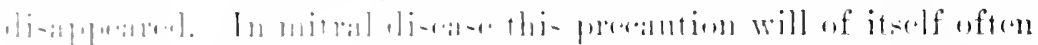

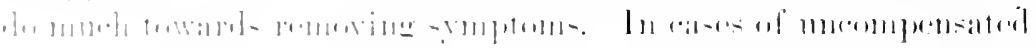

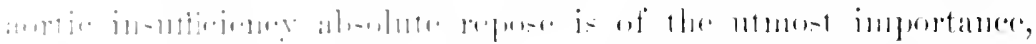

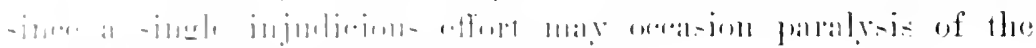

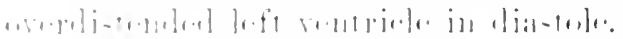

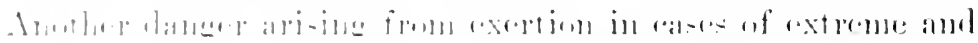

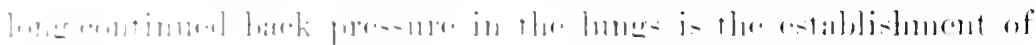

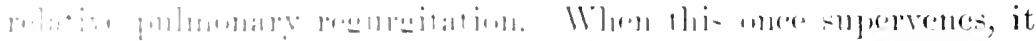

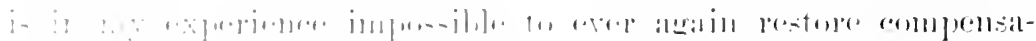

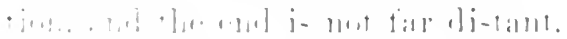

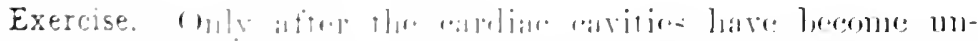

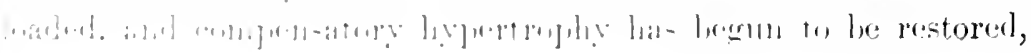


dare the patient he allowed to induge in exercise. Even then exertion must be very slight at first, and the medical attendant should observe the effeets of effort, and thus form an intelligent opinion of how far cardiac strength has become re-established. I make it a rule to be present the first time walking is attempted, so as to note the effect of exertion on the pulse.

Baths. - In this eritical stage of cardiac incompetence I believe Nauheim baths contra-indieated, and even in the matter of bathing for the sake of cleanliness patients must content themselves with the morning sponge-bath given by the murse. It involves too much exertion for them to bathe themselves, and particnlarly to get into a tub.

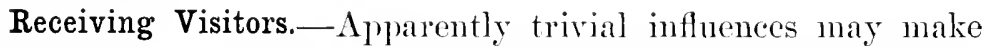
for or against the restoration of heart-power. Consequently, when there is a damming back of the blood into the lungs and right heart, this latter chamber slowld not be additionally strained by prolonged conversation. The reason for this lies in the consideration that when words are uttered the breath is held, and that with expiratory effort air is criven ont throngh the partially closed glottis. That this throws additional burden on the heart is plain, and is proved, moreover, by the clinical observation that eardiopaths nearly always exhilit breathlessness while taiking. Therefore, these invalids should not be allowed to receive visits from friends, mless perhaps from a few who can be relied on to monopolize the conversation, and who know enough to leave so soon as the patients exhibit signs of weariness.

Diet.-This is a matter of the rery greatest importance, and must not be left to the whims of the invalid or the zealons but ignorant notions of friends. The considerations and principles which obtain in cases of failing lout not ret wholly lost heartpower apply with added emplasis to these, and hence the reader is referred to what has been already said.

Although the management of this stage of valvular lesions is to be conducted along definite lines, still it is and must of a neessity be largely srmptomatic. There is a certain rontine about it, and yet the physician must be ever alert to detect signs of danger and arert it by prompt action, and equally to talie advantage of all circumstances that exert an influence for good. He should not exhaust his patient by unnecessary examinations, and yet he 


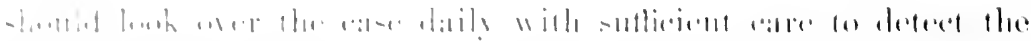

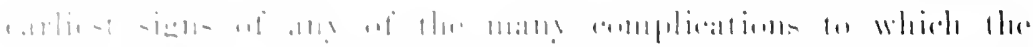

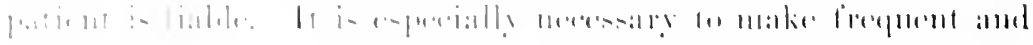

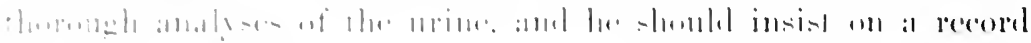

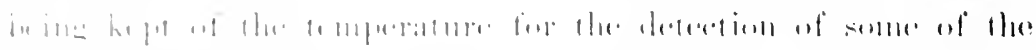

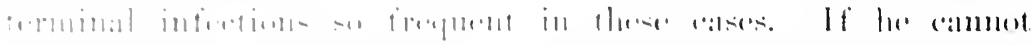

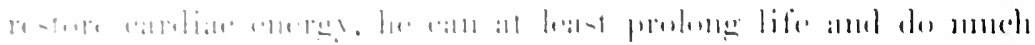

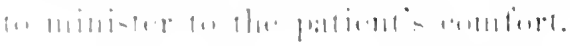

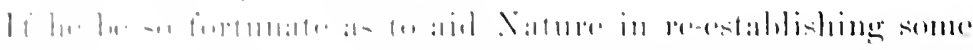

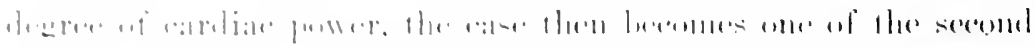

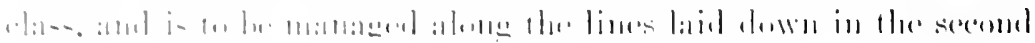

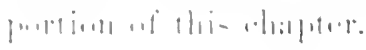




\section{SECTION III \\ DISEASES OF THE MYOCARDIUM}

\section{CHAPTER XIX \\ ACUTE MYOCARDITIS}

IT is not the design in this chapter to consider acute inflammation of the myocardium in association witli aente peri- or endocarditis, but the acute inflammation observed in the course of specific fevers and other acute infections processes, and which usually exists independently of inflammation of those membranes. This form of myocarditis is described by anthors as acute interstitial and acute parenchymatons myocarditis, the latter, as remarked by Osler, being regarded by some as a degenerative process.

The history of acute myocarditis is not clear until we come to the works of comparatively recent years. Snppurative myocarditis has been recognised since the earliest days of medieine, and by Galen was regarded as the disease of gladiators (Huchard). Beniveni, in the fifteenth century, discovered an abseess in the wall of the left rentricle, and in 155.3 Nicolas Massa found an abscess in the right rentricle with a sinuous tract extending into and perforating the auricle.

Morgagni was familiar with myoeardial inflammation, and Senac devoted a chapter to this affection.

Since the beginning of the last century the names of immmerable workers, including Corvisart, Hope, Andral, Lacnnee, and Stokes are linked with the history of myoearditis, but their views were more or less obsemre. For the most part the changes were spoken of as a softening of the heart-musele.

Bouillaud considered this softening as due to inflammation of 34 


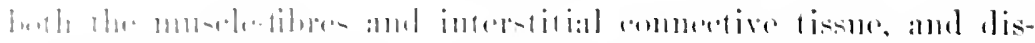

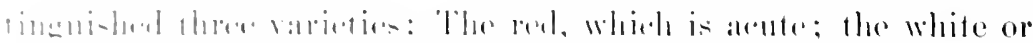

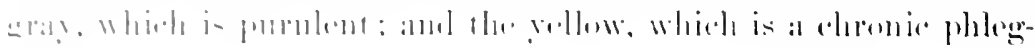
III:1-i:i.

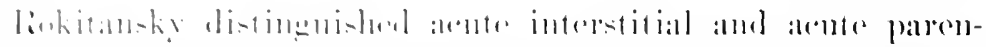

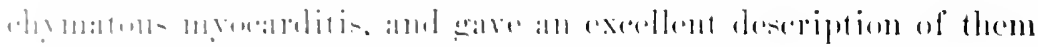

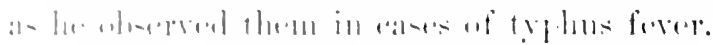

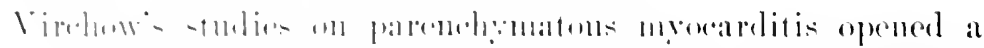

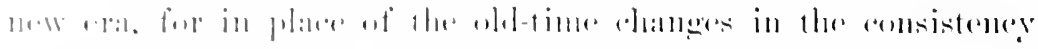

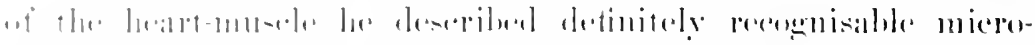

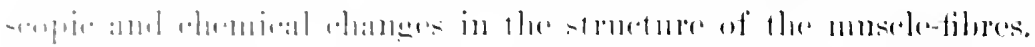

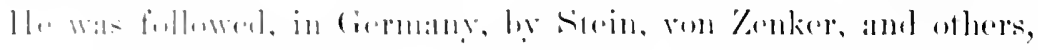

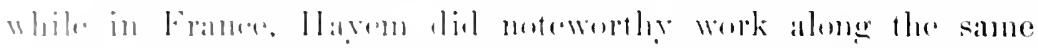

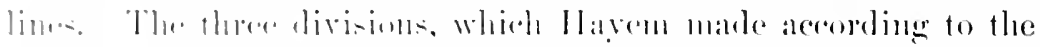

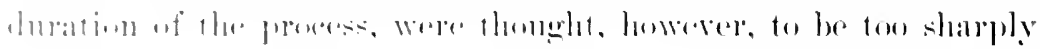
1):il11.

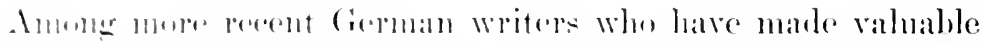

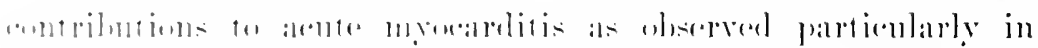

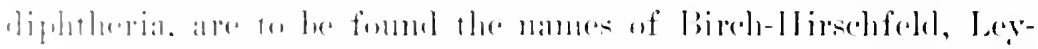

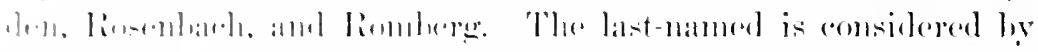

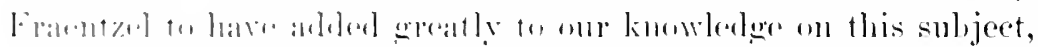

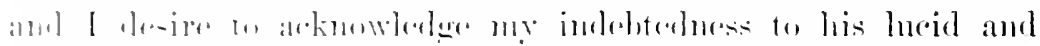

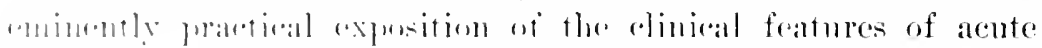

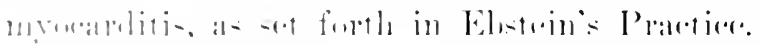

Morbid Anatomy. - The mynallimu is the musele layer

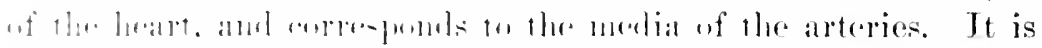
think in the wall- of the rentrinles and thinner in those of the

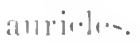

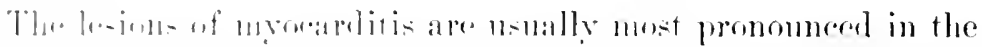

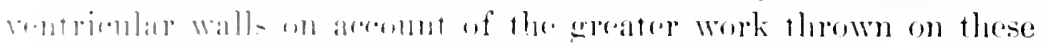

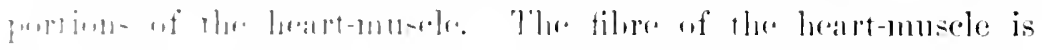

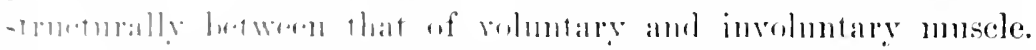

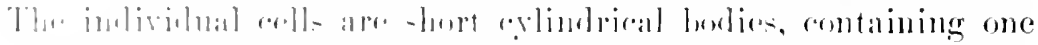

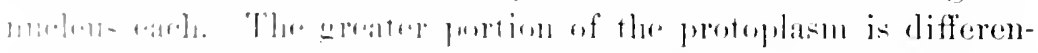

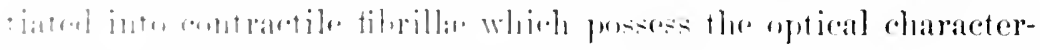

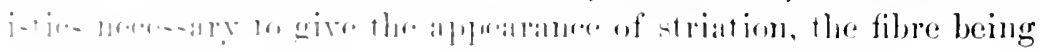

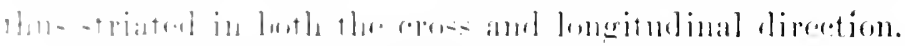

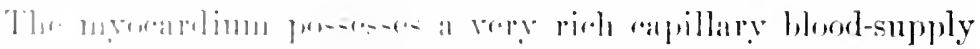

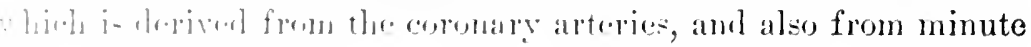


arteries opening direetly from the left ventricle. Normally there is but little interstitial tissue in the myocardium, which is separated from the pericardium by a variable layer of fat, while the endocardium lies directly on the muscle layer.

Acute myocarditis is either parenchymatous or interstitial. The parenchymatous form includes the various acute degenerations of the myocardinm, which are usually dependent on the presence of irritants in the circulation, such as the toxines of the infectious fever's. Cloudy swelling and granular degeneration are the most common manifestations of the process. In them the myocardium appears pale and opaque, and is soft, flabby, and easily torn.

Microseopically the fibres are swollen, their protoplasm more or less granular, and both the cross and longitudinal striations are obseured. The degeneration induces a more fragile condition of the fibres, so that they are often found ruptured or separated along the cell boundaries-a condition of fragmentation or segmentation. In these cases the rupture probably takes place in articulo mortis. Both these forms of degeneration are usually diffuse and not confined to any special areas.

A form of acute myocarditis which may be classed as parenchymatous, and which sometimes leads to serious results, is that which follows embolism of the coronary arteries. Infarction of the heart is followed by coagulation necrosis of the tissue involved, and is usually attended by some inflammatory infiltration of the area. Ultimately the necrotic area is replaced by scar tissue in the manner to be considered under the heading of the elironic form of the disease.

Acute interstitial myocarditis may be purulent or simple. The purulent form is usually eharacterized by the formation of abscesses, which may be many or few in number. On section these appear as whitish or grayish areas of softening, which are depressed below the plane of the eut. The larger abseesses may eontain fluid or semi-fluid puss.

Often associated with acute endocarditis, it may be a direct extension from the disease of the endocardium. In this case the foci of suppuration are larger and less numerous than in the ease of suppurative myoearditis dependent on a general pyæmia when the foci are numerous, widely seattered, and may be so small as to 


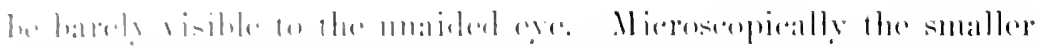

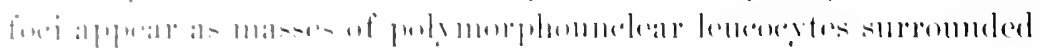

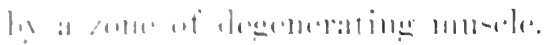

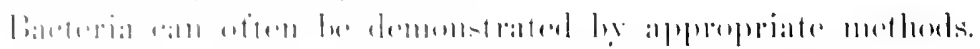

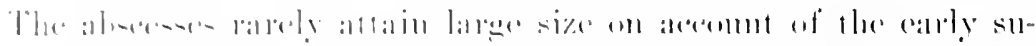

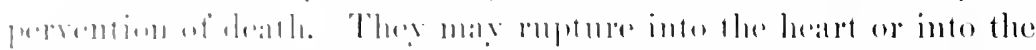

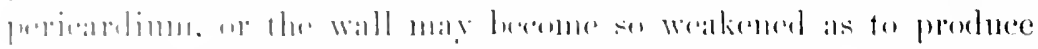

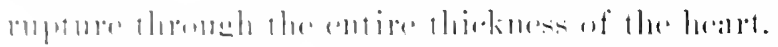

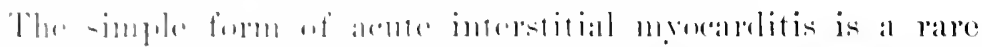

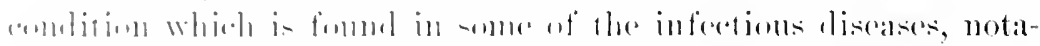

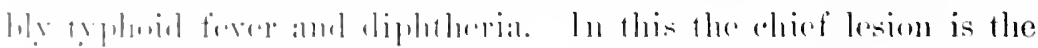

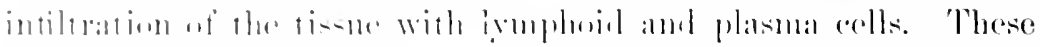

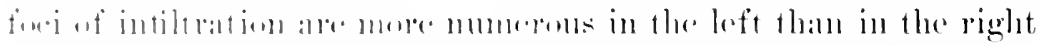

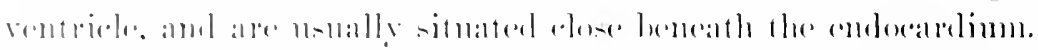

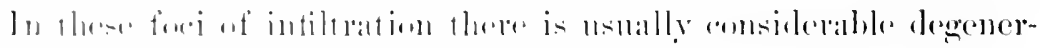

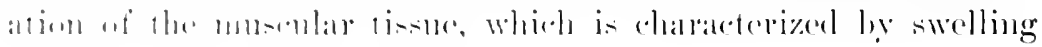

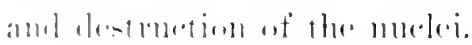

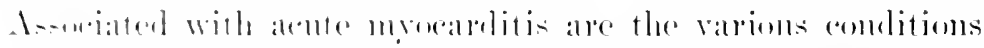

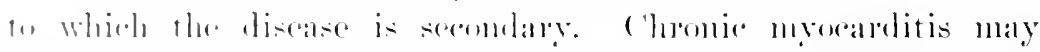

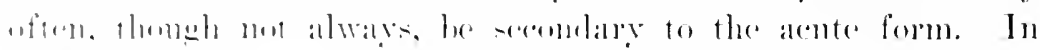

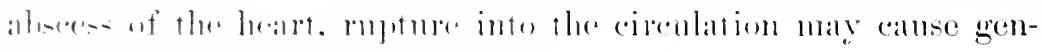

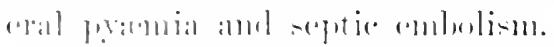

Etiology. - Nente inflammation of the heart-muscle is ob-

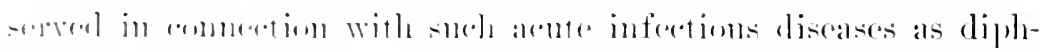

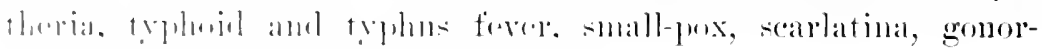

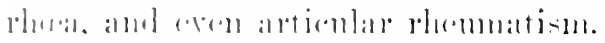

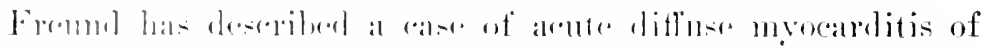

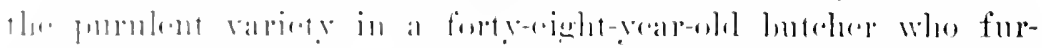

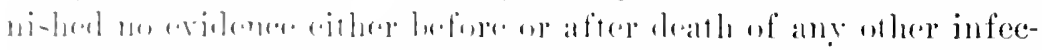

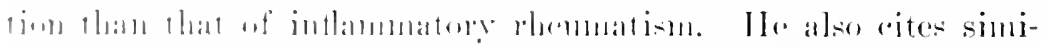

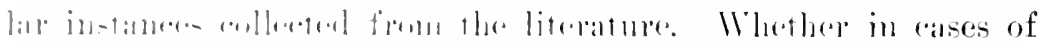

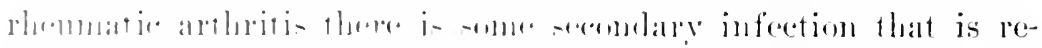

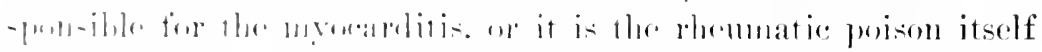

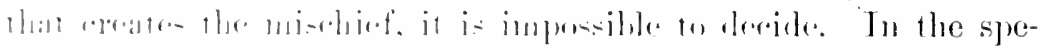

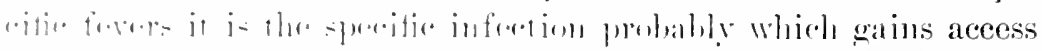

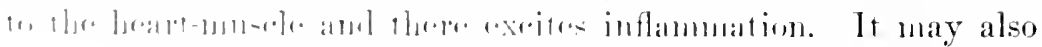

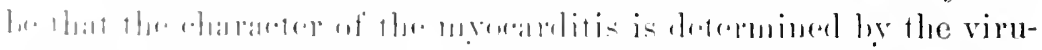

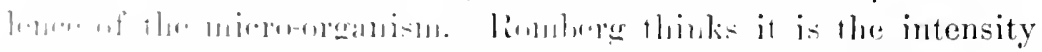

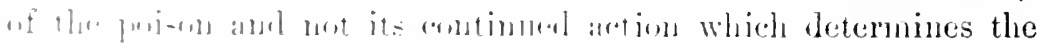


nltinate conrse of the inflummatory process, for " in many cases the discase of the heart-musele reaches its highest point a considerable time after the decline of the infection, and it is not to be assumed that all this time the toxic agency continues to increase in activity."

The process may possilly be compared, lie thinks, to the inflammatory reaction set up in a part whose function has been destroved hy a burn, or to the tabes dorsalis which derelops as an after effect of syphilitic infection.

In May, 1900, Poynton reported a comparative study of the changes in the heart-wall in one case each of diphtheria, rheumatism, and chorea. In the first-named affection, which ocemred in a child of five vears, and proved fatal on the seventeentl day, the changes were those of acute parenchymatous degeneration, the muscle-fibres showing profound destruction, in some places eren to the disappearance of the muscle-cells with retention of only the reticulum. Associated therewith was a cellular infiltration of the interstitial comnective tissue. The endocardium and perieardimm were free from disease.

In the heart of the rhemmatic patient, a young man with clinical evidence of mitral disease on admission, and a day or two later of fresh pericarditis, which lesions were found after death, the musele-fibres showed extensive fatty degeneration, but were not so profoundly disintegrated as in the case of diphtheria. There was also an exudation of cells into the connective tissue here and there around the blood-ressels.

In the ease of chorea, a child that had manifested great rapidity of cardiac action, the muscle-fibres of the heart also showed more or less fatty degeneration with scattered areas of cell exudation into the interstitial connective tissue. The changes resembled those found in the heart of a rablit that had been rendered pramie by the injection into the circulation of streptococei.

In commenting on the microscopie findings in the diplitheritic heart, Poynton pointed ont their close similarity to those described by Mollet and Regaud, and produced by the injection of diphtheria toxines into lower animals. Is to the myocardial changes in the rheumatic case Poynton was of the opinion that they were withont doubt due to the rhemmatic poison, and that they strongly suggested the likelihood of the rhemutic virus 


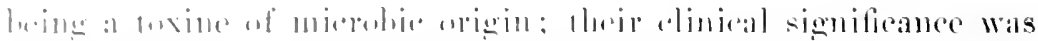

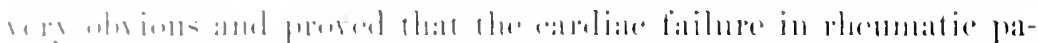

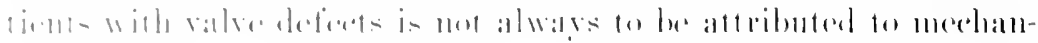

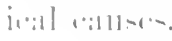

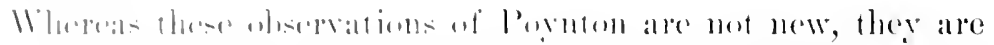

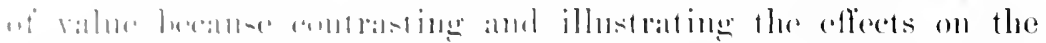

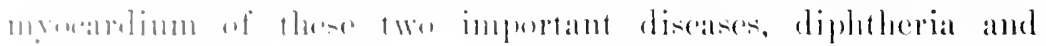

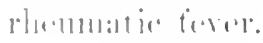

l'urulent inflemmation of the myocordimm is fomd in comnce-

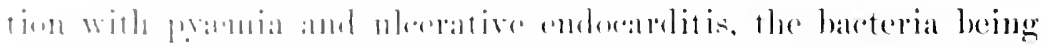

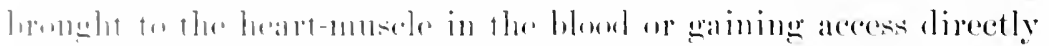

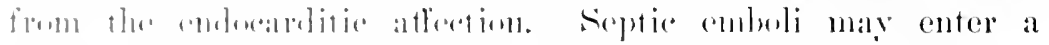

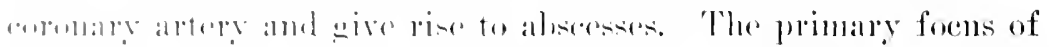

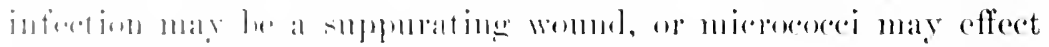

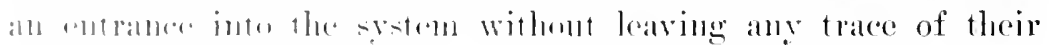
jult al antry hehind.

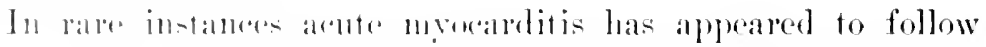

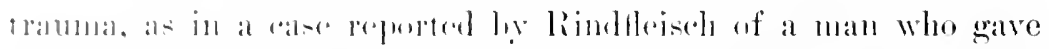

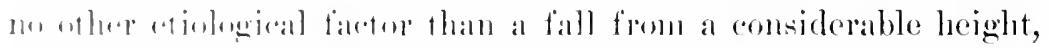

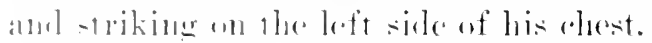

Symptoms. - The olservations of Romberes and Schmaltz

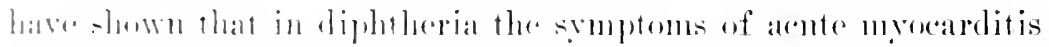

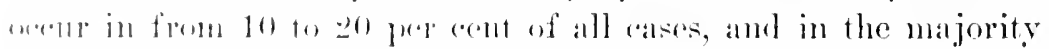

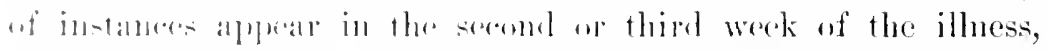

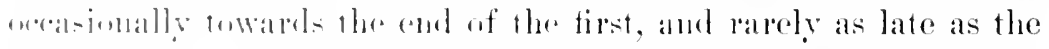

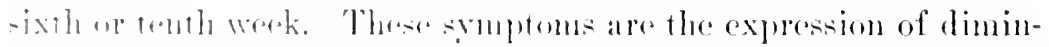

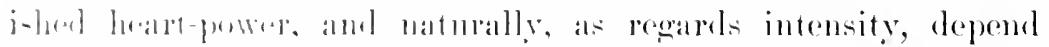

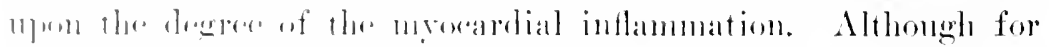

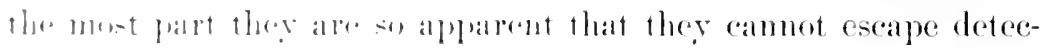

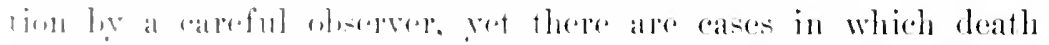

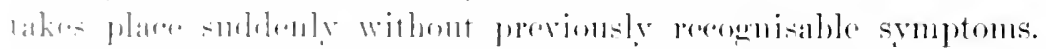

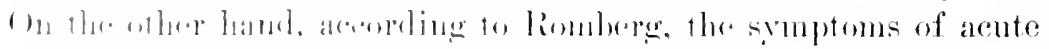

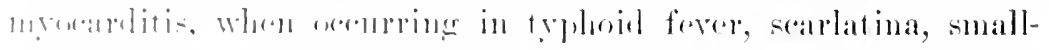

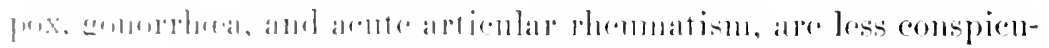

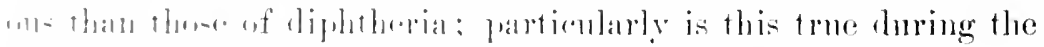

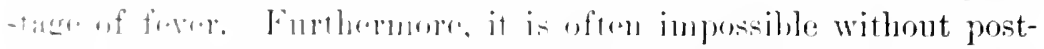

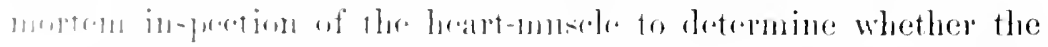

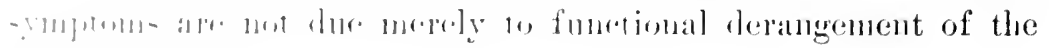
hratrit - artion. 
In all eases of acute myocarditis which is not purulent it is a subject for speculation whether the reakening of eardiac energy is due to destruction of the muscular elements, or to the mechanical effect of cell exudation into the interstitial connective tissue, or depends mercly upon functional depression (Romberg).

Subjective symptoms are not aways present, and if not wholly lacking are not always pronomed, and therefore close observation on the part of the medical attendant shonld never fail. Pallor of the countenance is present, and is often a striking phenomenon. Poynton mentions it in both of his eases of diphtheria and rhematic fever, especially the former. It is due, according to Romberg, to defective filling of the eutaneous ressels, since the blood is of normal composition. Tomiting is another symptom sometimes of great importanee, and has been dwelt on by Villy in eomnection with the cardiae failure of diphtheria. It may be so persistent as to suggest some abdominal disorder. There is anorexia, and the patient is often strikingly weak and listless, or instead of apathy may display restless anxiety. In a word, the patient conveys the impression of being profoundly ill.

The features of the ease, howerer, that most strongly point to myoearlitis pertain to the seat of misehief--i. e., the heart. The pulse is more frequent than normal, although as a rule its rate is not greatly accelerated, being 100 or thereabouts. Arrhythmia may or may not be present; often there is only irregularity in force and rolume. Its striking characteristics are fecbleness and emptiness, and as the disease progresses loss of stability as well as volume, very slight exertion being sufticient to send up the pulse-rate out of all proportion to the degree of effort.

Examination of the heart at this time may disclose some increase of dulness, particularly of the relative, to the left and upward, but also to the right. Yet in the beginning, sometimes even throughout the course of the malady, marked dilatation is not detected. Cardiac impulse is absent, and the sounds are notably feeble, especially the first at the apex, which is often so toneless as to be almost inaudible. In a few cases dilatation of the left ventricle reaches such a clegree as to permit muscular incompetence of the mitral valves, which is cleclared by a soft, it nua be feeble systolic apex-murmur. The disturbance of the circulation may 


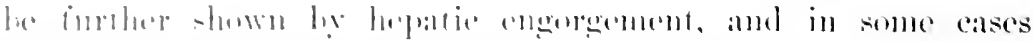

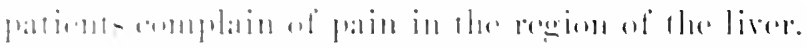

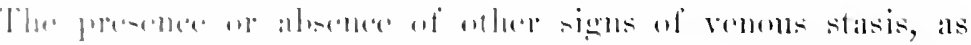

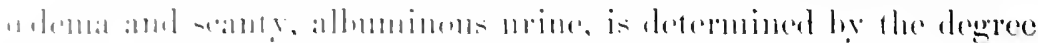

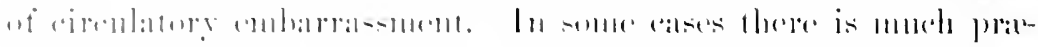

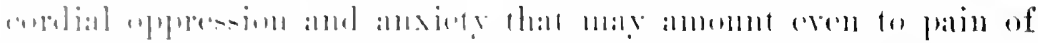

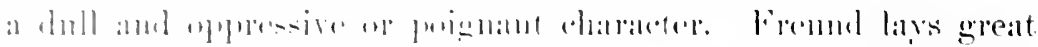

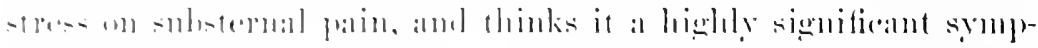

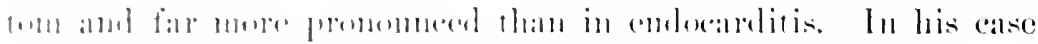

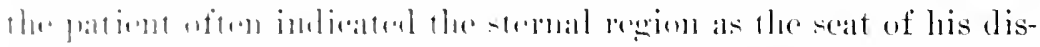
(0)

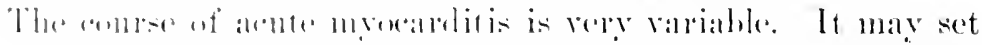

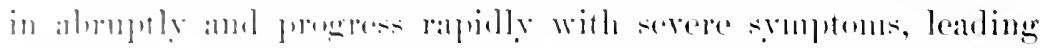

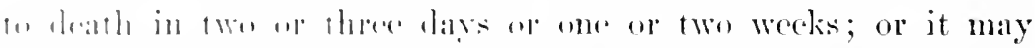

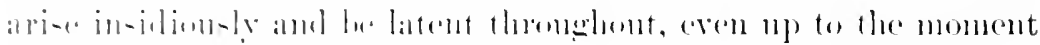

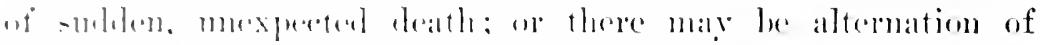

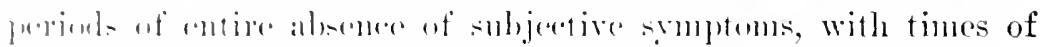

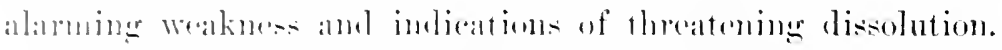

The cases which in me semse are the most dangerons are those

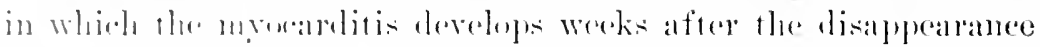

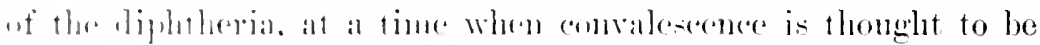

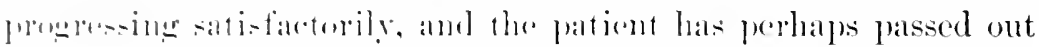

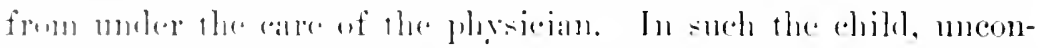

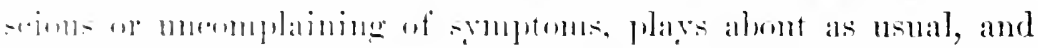

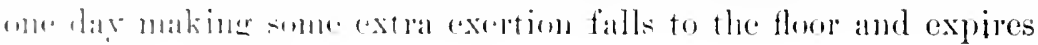
withull walnuing.

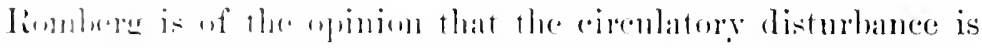

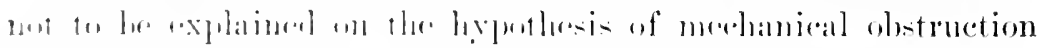

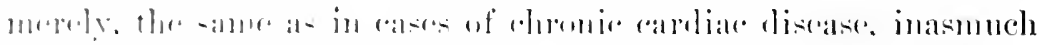

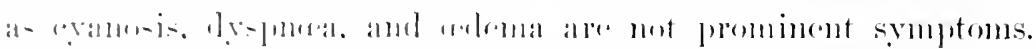

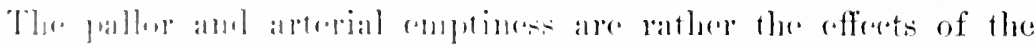

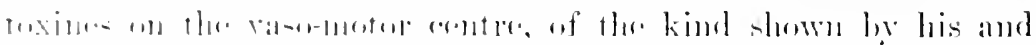

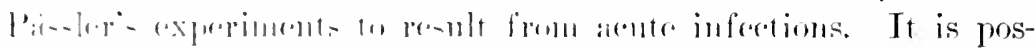

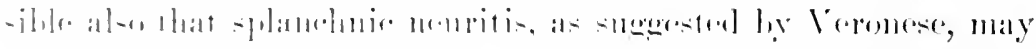

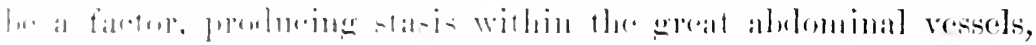

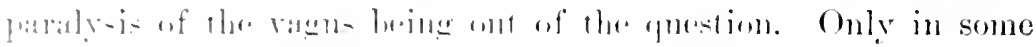
-13 - wa

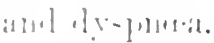

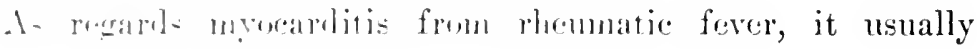


attacks hearts already the seat of acute or chronic endocarditis, or is associated with periearditis, although the muscle alone may sometimes be affected. For this reason it is not easy to recognise or definitely determine the myocanditic eomplication. Moreover, experience proves the folly of attributing to myocardial inflammation the cardiae asthenia, or even dilatation, so often witnessed in acute rhemmatism, for it is often but a manifestation of the poison upon the function of the organ. At all events, it is the part of wisdom in such cases to refrain from a positive opinion.

In typhoid and scarlet ferer it is not uneommon to observe during the height of the attack symptoms of heart weakness, which in most instances subside with convalescence, and which are perhaps the result of the action of the infection on the vasomotor centre in the cord, together with exhanstion of the heartmuscle. Nevertheless, one should guard against an inclination to look on all such manifestations as not due to myocarditis. The onset of acute inflammation of the heart-wall is often so insidious during the febrile stage, and the symptoms are so latent, that the real nature of the heart disorder is readily overlooked.

On the contrary, when after sulsidence of all active symptoms referable to the primary disease and during convalescence the pulse begins to assume the characters atready described-i. e., feebleness, cmptiness, irregularity, and conspicuons instabilityone should at once suspect the existence of myocarditis.

We frequently encounter individuals who have snecessfully weathered a severe typhoid ferer many months, even two or three years before, and still display undue rapidity and even irritability of the heart's action. I am always inclined to specnlate on the possibility of such patients having suffered from unsuspected myocarditis of mild form, and yet sufficient to have left its traces behind. Should the heart-nuscle become inflamed during or after the subsidence of acute rhemmatic manifestations, the symptoms of circulatory momarassment will be out of proportion to the clinical evidenee of ardiac disease, and yet are very likely to be attributed to such structural alterations as are discovered. There is far more feebleness, emptiness, inequality, perhaps intermittence, and particularly instability of the pulse, than there is evidence of visceral engorgement and mechanical obstruction in the 


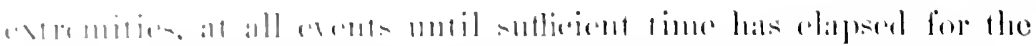

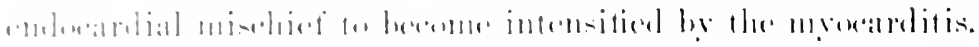

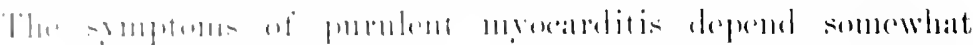

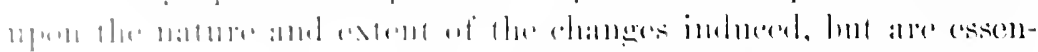

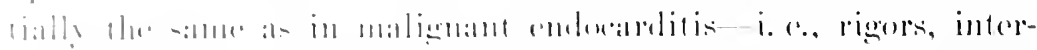

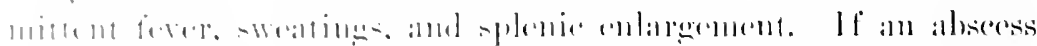

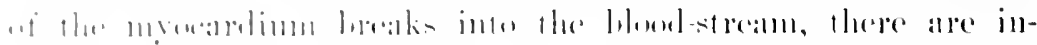

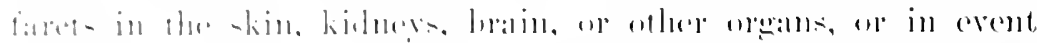

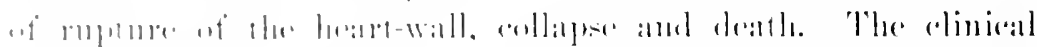

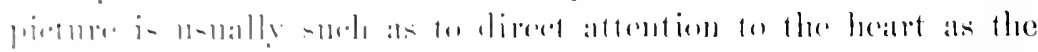

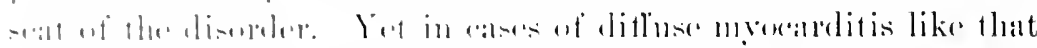

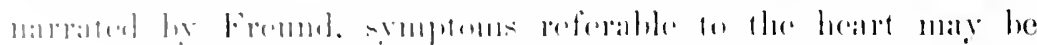

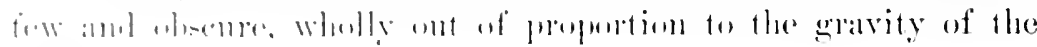
malals.

Physical Signs. - Inspetiom. - l'allor is said to be conspicu-

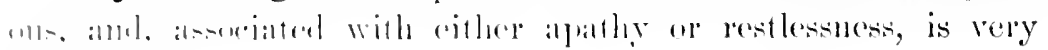

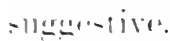

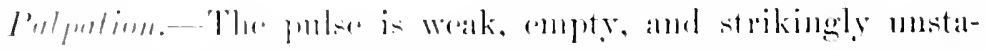

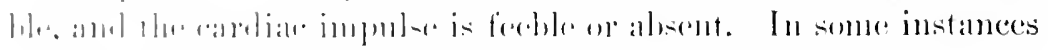

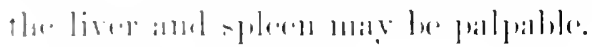

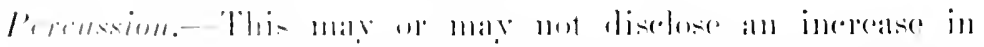

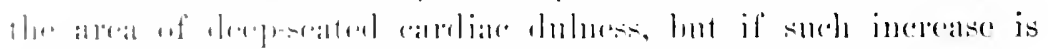

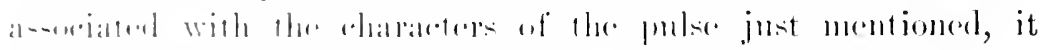

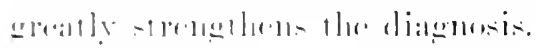

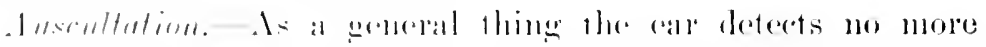

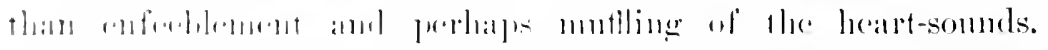

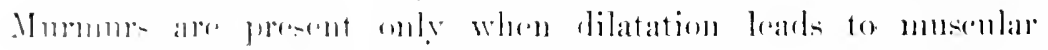

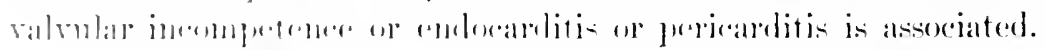

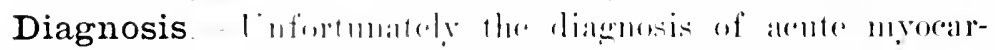

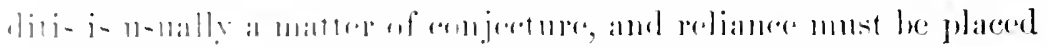

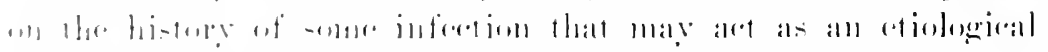

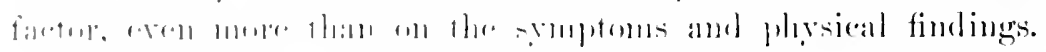

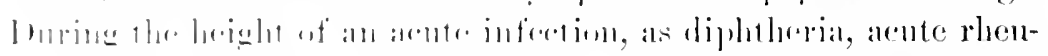

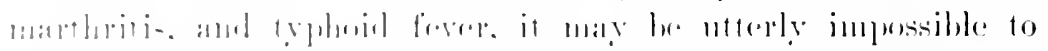

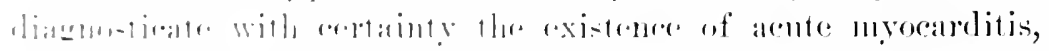

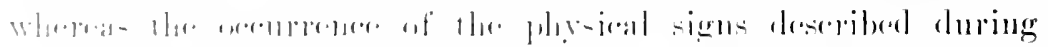

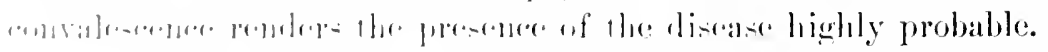

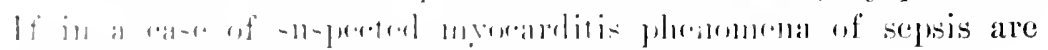

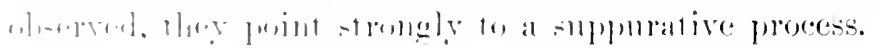


Prognosis. - It goes without saying that the prognosis is always grave, even in simple myocarditis, and in the purulent form is absolutely unfarourable. Although there is post-mortem evidence that small, scattered abscesses in the heart-wall sometimes undergo a process of cure, still a case that is sufficiently outspoken to be clinically recognisable is from its nature incurable. In acute interstitial myocarditis of diphtheria Romberg computes the fatal termination as taking place in about one-third of the recognised eases.

It is not mnlikely that in rheumatism the percentage of recorery is larger. 'This wonld appear reasonable when we consider' that the parenchymatous degeneration is not so intense as in diphtheria. Although all cases do not die, yet the possibility of sudden death should never be forgotten; and, noreover, this possibility is not wanting in any given case simply because the evidence of cardiae mischicf is slight. It is often precisely in this class of cases that danger is most imminent, since the physician, patient, and friends are likely to be thrown off their guard, and hence permit or commit indiscreet effort.

When, on the other hand, symptoms of collapse appear, the danger of death is very imminent. Increasing acceleration of the pulse and marked instability, the heart evincing a degree of feebleness ont of all proportion to the demand male mpon it, are signs of great danger. So also is abnomal retardation of the pulse-rate, as is exceptionally observed. Delirimm renders the prognosis more grave; and the occurrence of emboli is an exceedingly bad omen, since we camnot predict how many are likely to follow or where they will lodge. Favourable indications are to be found in a gradual return of strength, volume, and regularity to the pulse.

Treatment. - We possess no means of directly influencing the inflammatory process after it has attacked the myocarlium, and therefore on efforts must, in the first place, be directed to the prevention of myocarditis, if possible, and secondly, to protecting the heart-wall from all extraneous influences which can intensify the damage it is sustaining from the inflammation. To the former end is the early employment of such measures as may lessen the activity of the primary disease, which in diphtheria involves the earliest possible use of the antitoxine. The harm 


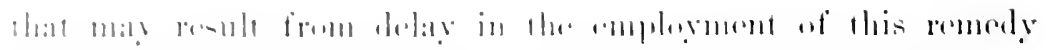

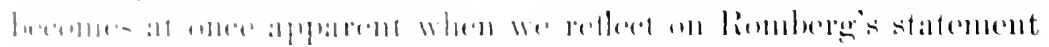

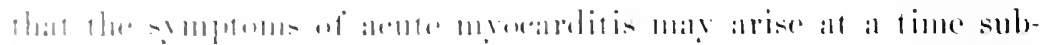

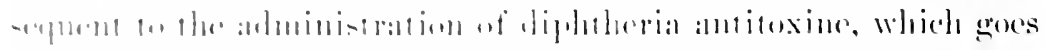

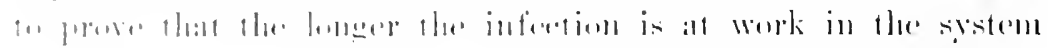

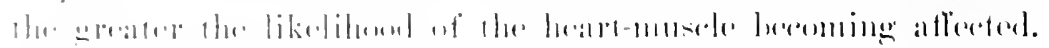

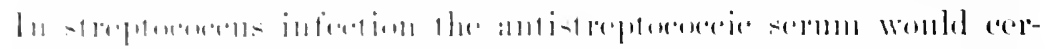

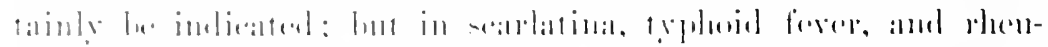

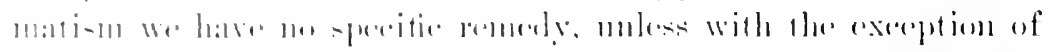

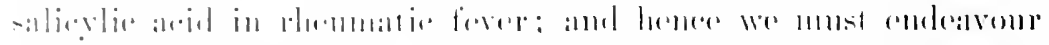

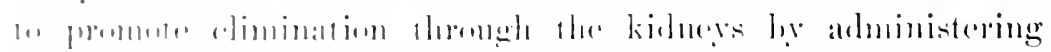

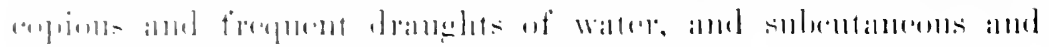

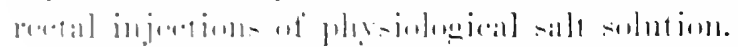

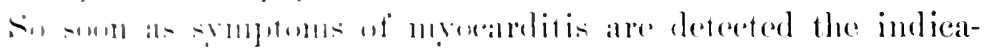

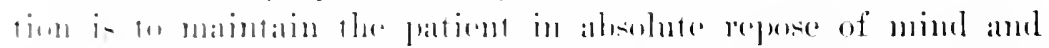

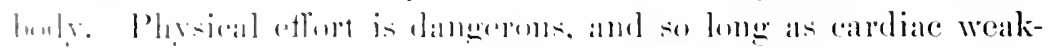

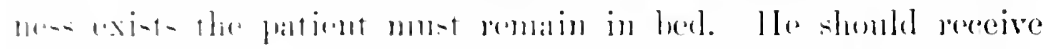

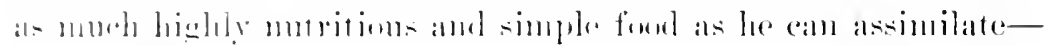

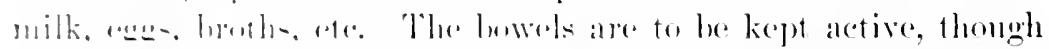

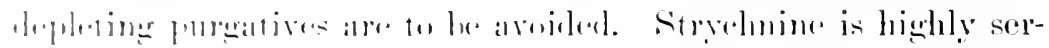

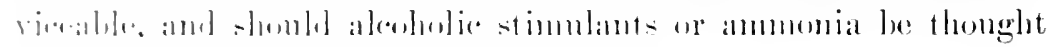

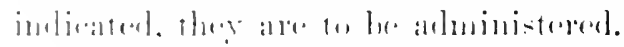

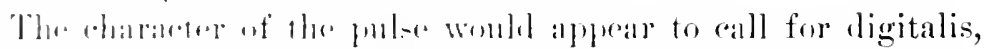

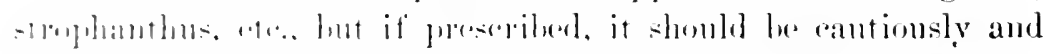

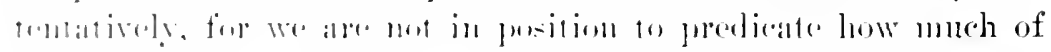

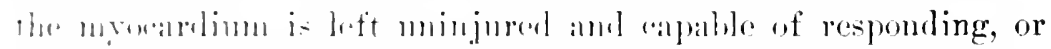

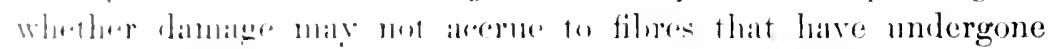

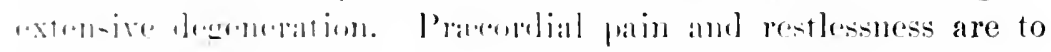

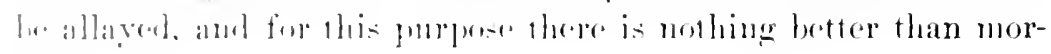
litime.

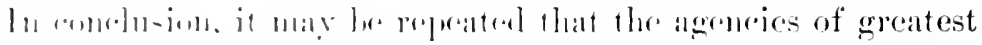

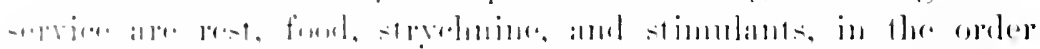

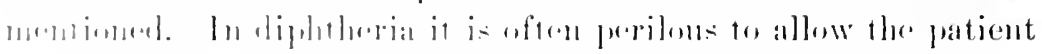

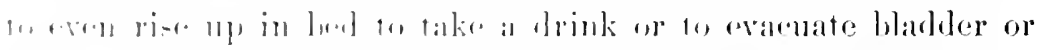

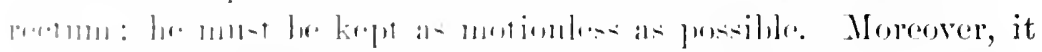

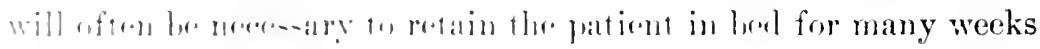

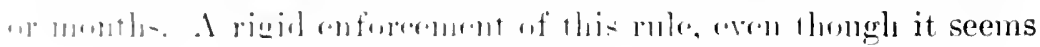

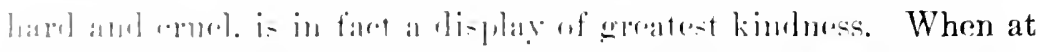

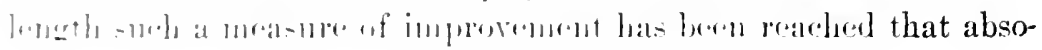


lute rest is no longer needful, the pattiont is to resume exereise by degrees, and at first with the utmost caution. Under no ciremmstances is an attempt to aseend stairs to be permitted before weeks perhaps of gentle moving about the hed-chamber have proved that the heart is no longer minduly taxed by such efforts. During this period of convalescence cantions attempts may be made to strengthen the heart by resistance exereises and saline baths. At this tine benefit may be derived from iron, arsenic, and other hematics and nerve tonies. It is needless to arld that in the case of young children it is often most difficult, yet no less important, to enforce the quiet and other measures necessary. 


\section{('II.T'Tili XX}

\section{CHRONIC MYOCARDITIS}

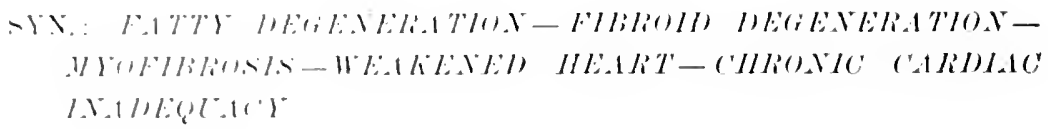

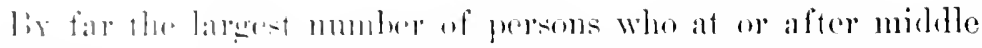

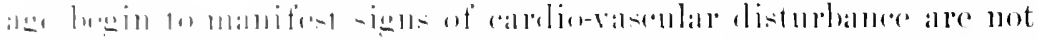

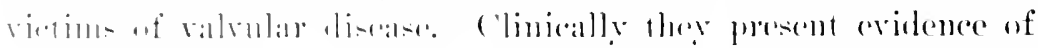

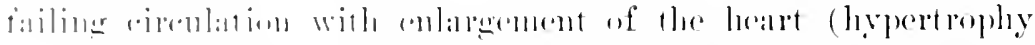
with dilataliont. and witl more or less thickening of the arteries.

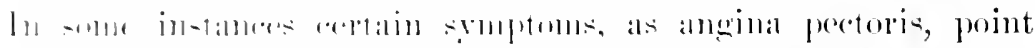

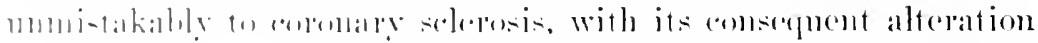

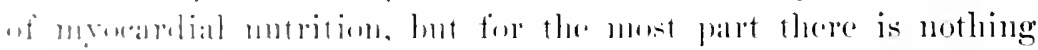

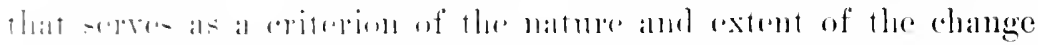

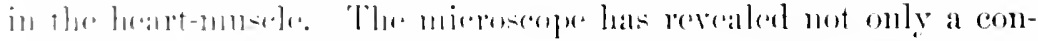

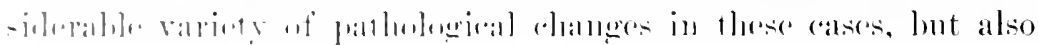

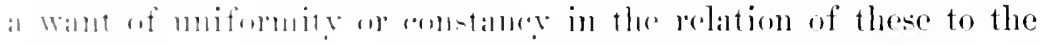

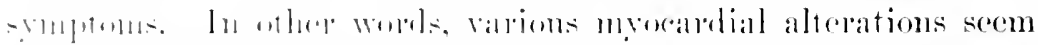

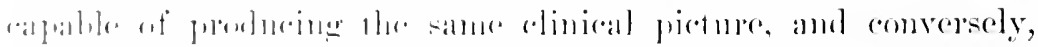

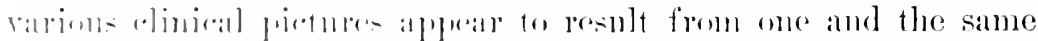

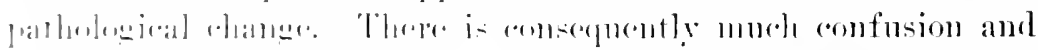

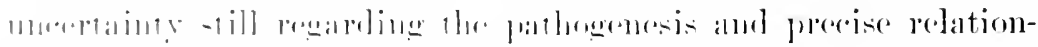

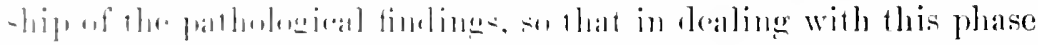

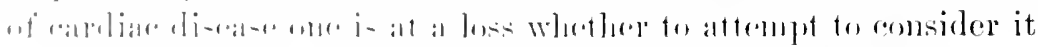

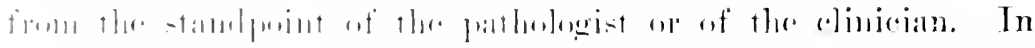
nithre a

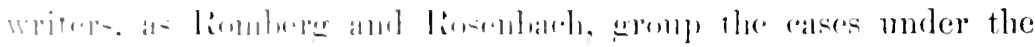

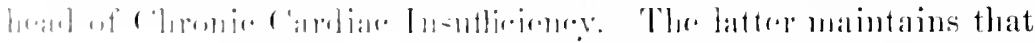

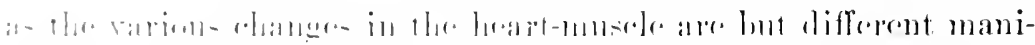

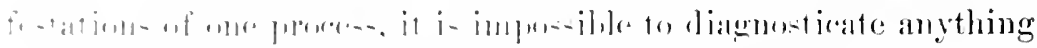

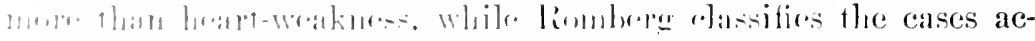

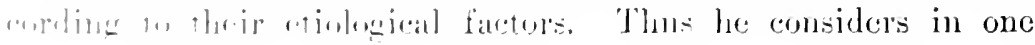


group those due to coronary disease, those to obesity, those to strain, and those to nephritis, those to excessive consumption of beer, etc. Such a division is in accord with the uncertainty of our knowledge on many points, and also has the merit of simplicity, but it is open to the objection that we cannot always be sure of the exact etiology of all cases or of the precise mode of operation of supposed causes. It also, as he himsclf admits, necessitates much repetition, and therefore I have decided to deal with these cases under the heading given to this chapter. I am well aware of the objections to snch a gromping, and know that many times it seems simpler, and non-committal in a sense, to diagnose them according to the gross clinical findings of hypertrophy or dilatation or idiopathic enlargement of the heart. Still in most cases the microscope shows more or less myocardial degeneration, and therefore I prefer the term Chronic Mrocarditis.

Morbid Anatomy.-Under chronic myocarditis the anatomical conditions usually considered are those of fibrosis and fatty degeneration. Conditions interfering with the nutrition of the heart may produce either or both of these changes, or the fibroid may be dependent on the fatty change.

Fibroid degeneration of the heart-muscle, or chronic interstitial myocarditis, may represent the final or reparative stage of the various acute forms of the disease. It is then to be regarded as a conservative rather than as a pathologic process. Thus in the case of infarction of the heart, or myomalacia cordis, the necrotic area is invaded by young connective-tissne elements, which finally are metamorphosed into a firm fibroid cicatrix. Such areas of fibrosis, or scleroses, are large or small according to the size of the original lesion. Very large areas are rarely found, as the acute disease would have probably proved fatal. Except by the formation of other infarcts this process does not tend to progress. It is only when the occlusion of many small arteries has prodnced multiple scleroses that the function of the heart is impaired.

Extreme fatty or parenchymatous degeneration, leading to destruction of the muscle tissue, may be the canse of a progressive fibrosis of the myocardium. Often the destructive process preceding the interstitial increase is a coagulation necrosis. As a rule this process is not strictly diffuse, and the appearance on section is of numerous scattered streaks and spots of a grayish or whitish 


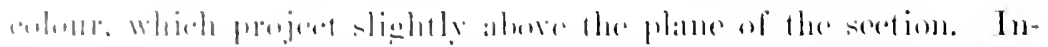

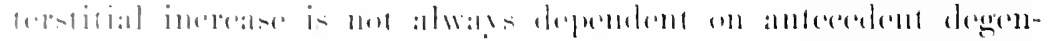

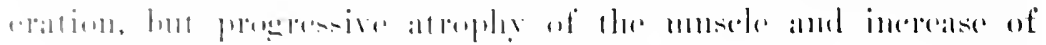

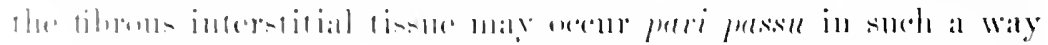

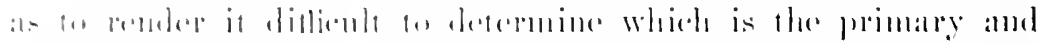

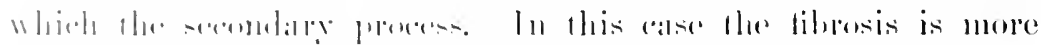

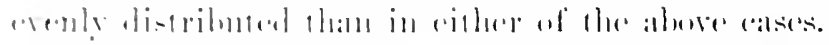

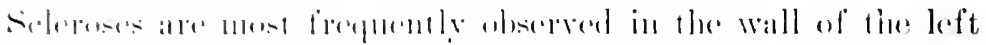

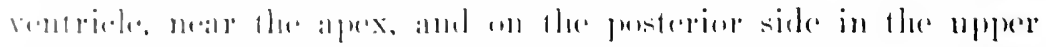

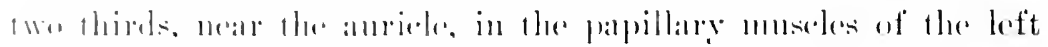

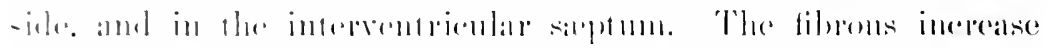

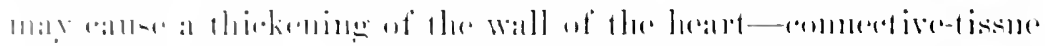

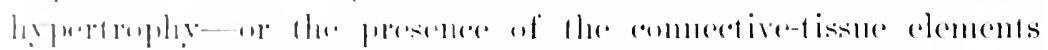

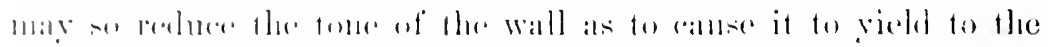
intratraliale presture with the formation of bulgings, the so-

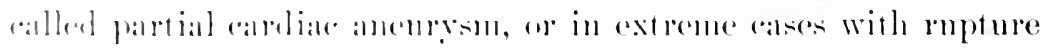
if the herist.

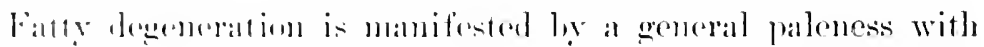

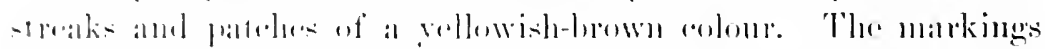

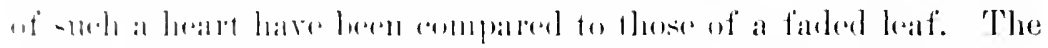

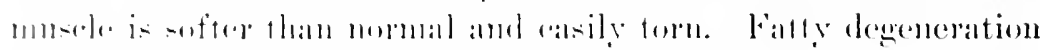

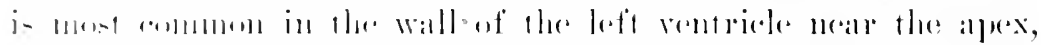

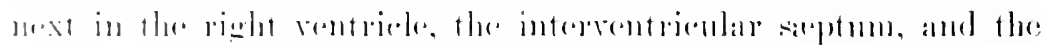

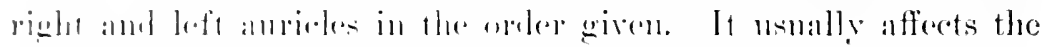

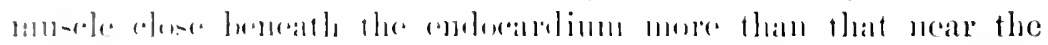

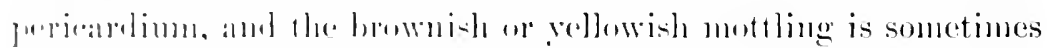

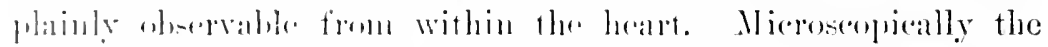

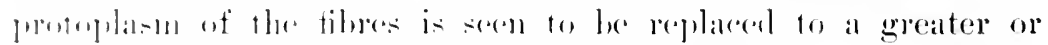
les.

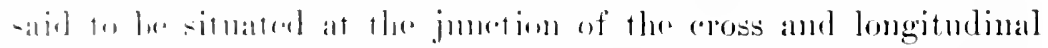

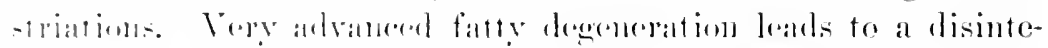

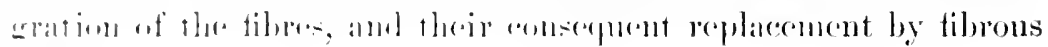
$1 i \cdots \mid 1$,

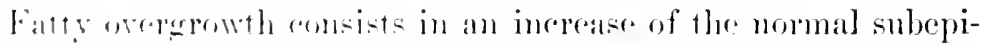

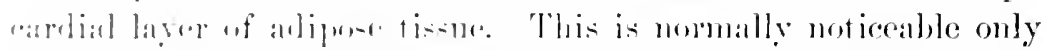

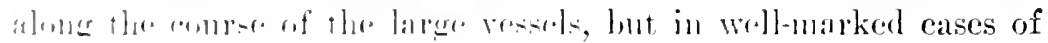

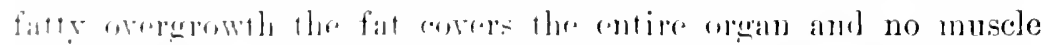

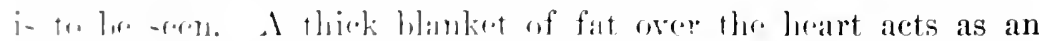
(.fferonal innerdinent to its work, lont it is in the nature of an out- 
side force, and not, as is the case in fatty degeneration, a discase of the muscle itself. Sometimes, however, the adipose tissue invades the subjacent myocardium, first penctrating between the fibres and later causing the complete atrophy and disappearance of the muscle elements. This process may penetrate the entire thickness of a ventricular wall, and of course greatly impairs its functionating power.

The senile heart presents a rarying pieture marle $\eta_{p}$ of elements from all of these conditions. As a rule the failing nutrition of old age induees a mixture of fibrous and fatty degeneration. Fatty overgrowth is common in those elderly persons who incline to obesity. The scnile heart may be hypertrophicd-this when associated with chronic nephritis and general arteriosclerosis--or atrophied in consequence of malnutrition and inaction. Very frequently this atrophy is combined with the condition of antochthonous pigmentation already descriled. This condition of brown atrophy is almost characteristic of the scnile heart.

The nutritional disturbanee which is aceomutable for these degenerations is frequently the result of the gradual narrowing or ocelusion of the coronary arteries or their branches. This may be due to a sclerosis that is part of a general discase of all the arteries, or it may be dne to obliterating endarteritis or to a local atheroma of the coronaries either at their orifices or branches. This local process is more apt to take place in the descending branch of the left coronary artery, and this aecounts for the special predisposition of the apical portion of the left ventricular wall to fatty and filmoid degeneration.

Thrombosis or embolism of the eoronaries induces the condition of myomalucia cordis already considered. The walls of the arteries may become of bony hardness, or atheromatous in patches. The terminal branches may be converted into fibrous cords impervious to the cireulating fluid. If the obliteration of one artery takes place gradually the circulation may he established through branches of the other. The reduction of the hlood-supply to the parts affected, and especially the lack of oxygen, indrces fatty degencration, and often subsequent fibrosis. The heart-muscle, probably on account of its constant activity, feels immediately any lack of oxygen, and henee the myocardinm is espeeially prone to fatty degeneration. 


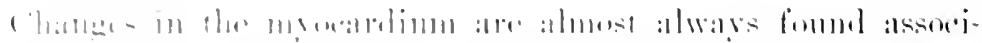

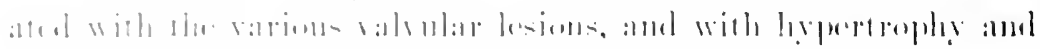

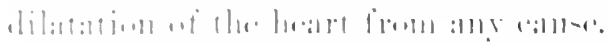

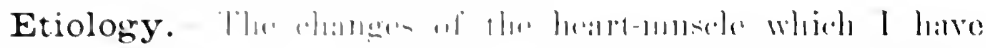

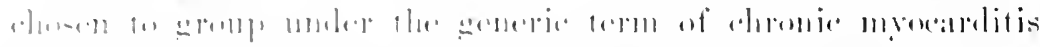

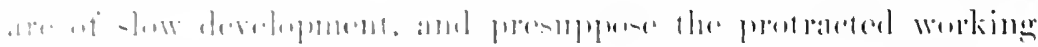

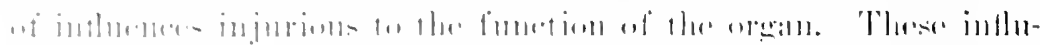

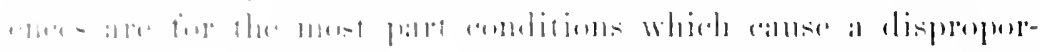

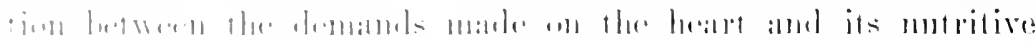

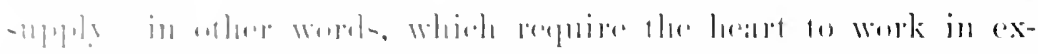

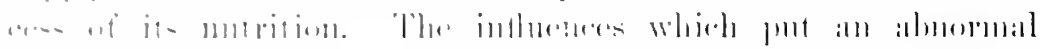

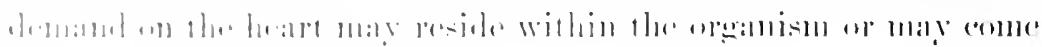

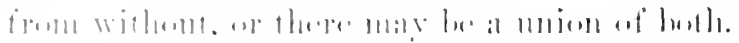

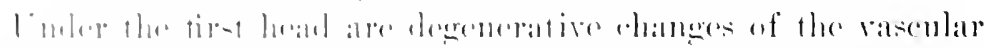

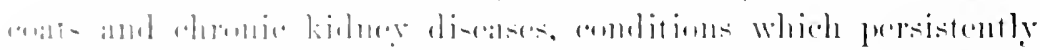

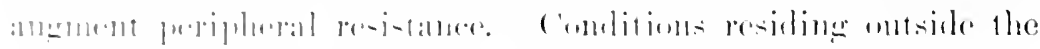

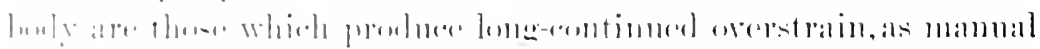

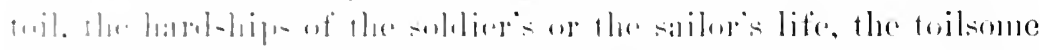

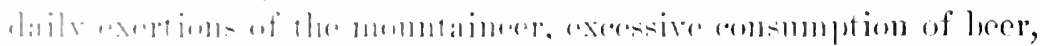

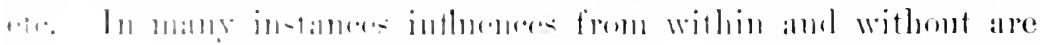

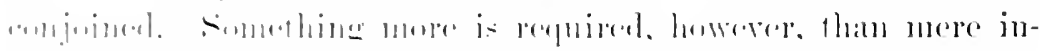

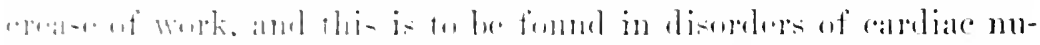

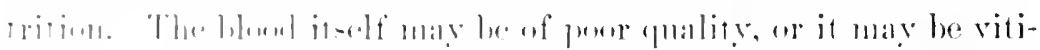

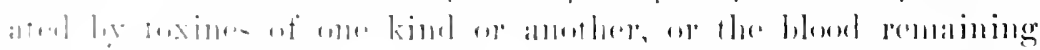

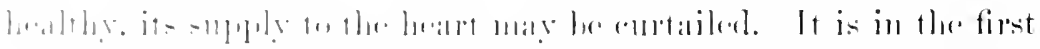

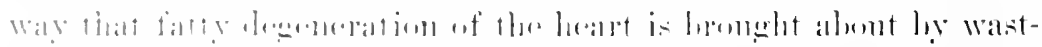

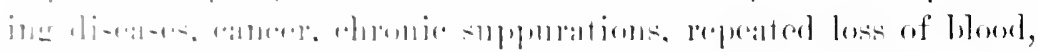

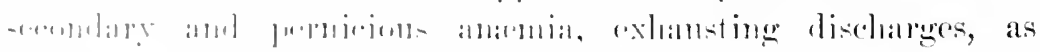

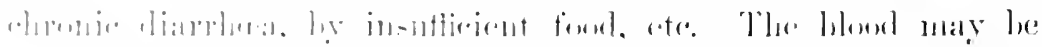

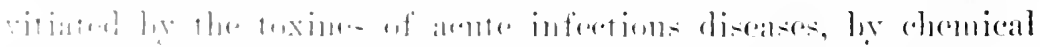

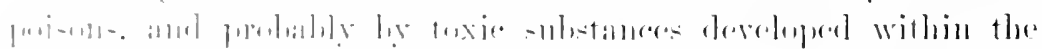

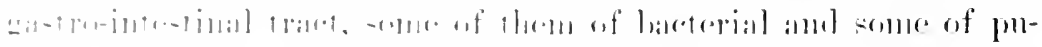

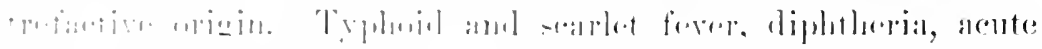

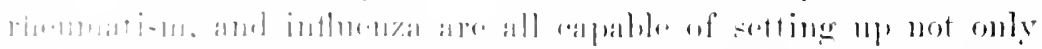

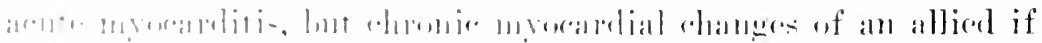

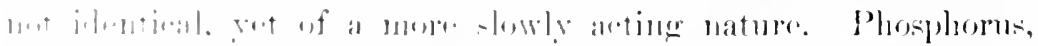

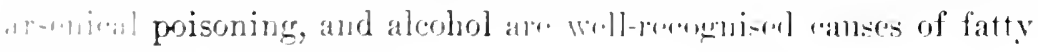

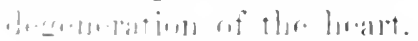

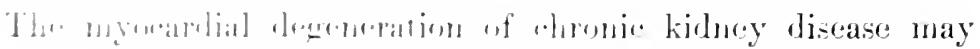


be due in part, at least, to chronie toxamia acting in conjunction with prolonged high arterial tension. The degenerations depending upon coronary selerosis are instances of the third kindi. e., of defective blook-supply.

When the two great factors, work and excessive or defieient nutrition out of proportion to that required for the work, are combined, then we not only have myoeardial degeneration, but in time also ineritable cardiac inadequacy.

The hypertrophy which so often develops in association with chronic myocarditis is the expression of an attempt at compensation. It probably evinces an effort on the part of Nature to repair the damages going on in the heart, but it also results from the necessity on the part of this organ to overcome peripheral resistance.

Fraentzel's idiopathic enlargement of the heart was thought by him to result from the consmuption of an anount of food in excess of the requirements of the organism and of the individual's bodily exercise. Hence it is found in its most typical form in persons who are large eaters, and who, in consequence of their partienlar line of work, are compelled to be sedentary. According to Rosenbach, phycsical inactivity is an important element in this class of cases. When these individnals reach micidle age they are usually found to have developed corpulent abdomens, and they generally continue to inerease in weight. In many at this time the previously existing ligh-pulse tension is still further augmented by degeneration of the blood-vessels and kidneys, often also of the liver, which retrograde changes are probalbly to be referred to the same etiologieal factors. So long as eardiac hypertrophy enables the organ to meet its denands its functional integrity is intact. At length, however, either because its nutrition lias suffered to such an extent that it cannot meet the ordinary demands nuale upon it, or because extraordinary work is suddenly requirerl, as from some undue physical effort, the heart finds itself overpowered, and symptoms of myocardial incompetence set in.

In the working elasses, in soldiers, in sailors, and mountaineers, in persons addicted to the alnuse of beer and other alcoholic beverages, who at the same time perform manual toil, influences of various linds are active. Food defective in quality or quantity, 


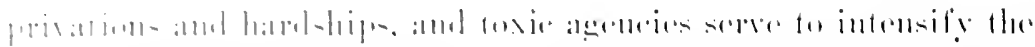

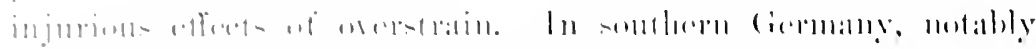

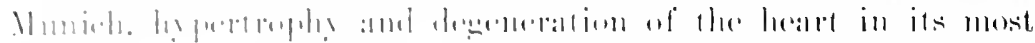

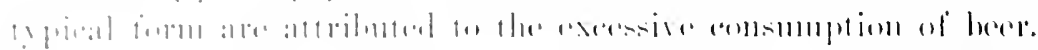

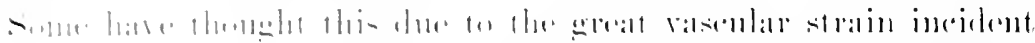

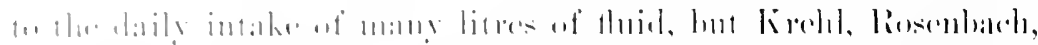

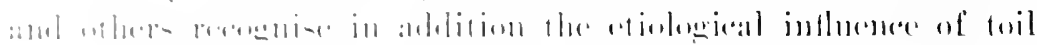

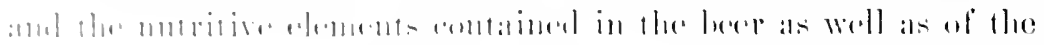

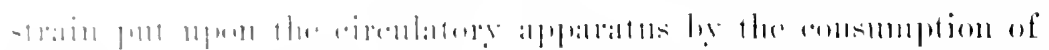

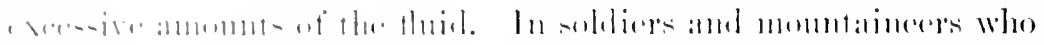

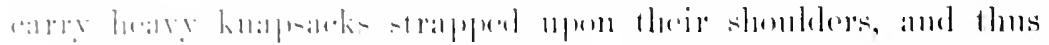

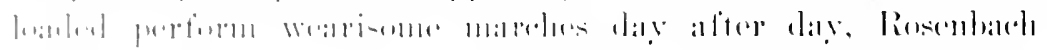

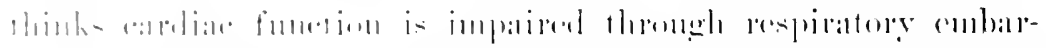

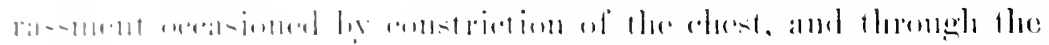

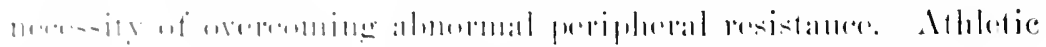
- -

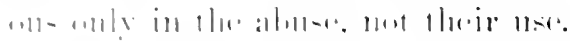

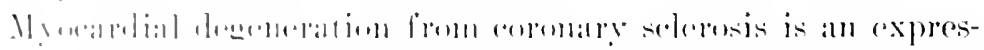

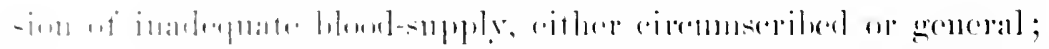

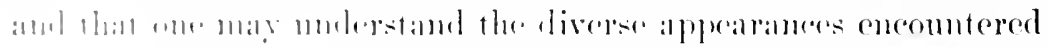

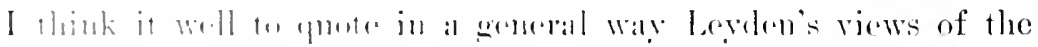

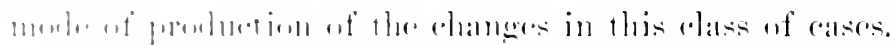

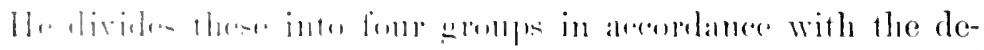

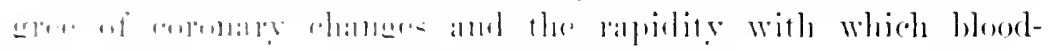

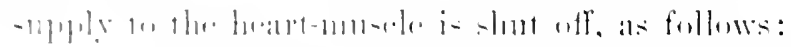

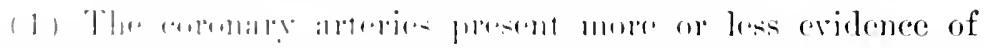

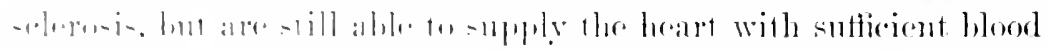

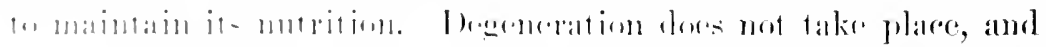

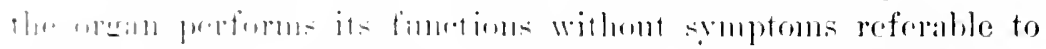

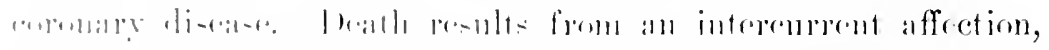

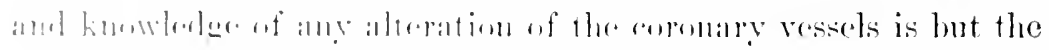

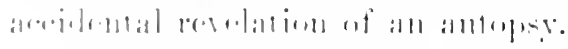

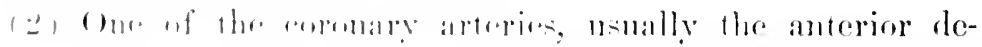

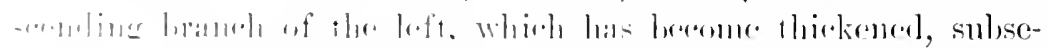

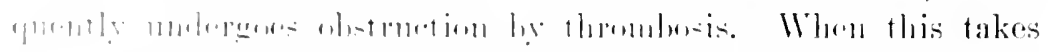

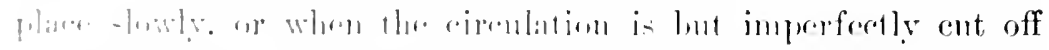

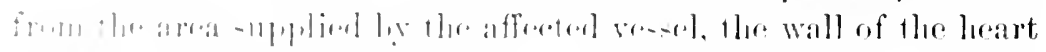

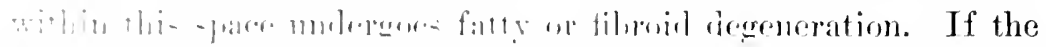

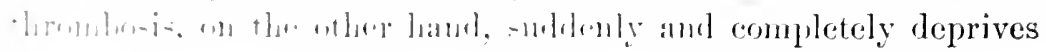


the part of its mutrition, then this area breaks down into the "myomalacia cordis" of Ziegler. Occasionally the extravasation of blood into this softened area gives it an appearance of a hemorrhagic infaret. When rupture of the heart oceurs, it is generally within such a spot of acute softening.

(3) Sclerosis of the coronary arteries is general and has come on gradually, giving rise to correspondingly gradual changes in the heart-i. e., fibroid degeneration either eireumseribed or general. When this ehronic or fibrons myocarditis is liffused, the rentricular walls are apt to be thin and dilated, whereas circumseribed areas of induration are frequently associated with hypertrophy. In rare instances this development of new connective tissue is attended with atrophy of the muscle-fibres, and the organ shrinks in size after the fashion of a cirrhotic kidney.

(4) In this gromp, the coronary sclerosis, although essentially chronic, has been hastened and intensified from time to time by acute exacerbations of the process, thrombosis, etc. The changes in the heart are therefore twofold; areas of acnte softening and fatty degeneration are interspersed anong those of chronic myocarditis. This group, which blends the second and third, therefore, is the one most often encomtered by the physician.

The causes of coronary sclerosis are obseme, but are probably those of arteriosclerosis in general. That age is of influence seems attested by the fact that more or less evidence of the change is fomnd post morten in persons past middle age, while it is rare under forty and wanting in children. Some families seem to present a remarkable tendeney to sclerosis of the coronaries and consequent myocardial disease. This has led to the suggestion of a possible hereditary influence in its prodnetion. Some individuals appear to be endower with "arterial tissne or vital mbber of poor quality, which camot be explained in any other way," as is so aptly expressed by Osler, "than that in the make-mp of the machine bad material was nsed for the tubing." In my experience individuals who display this tendency to early sclerosis usually manifest distinet gonty diathesis. They may be salil to be suffering for the sins of their ancestors. I have long had the conviction that in some families the heart is the locus minoris resistentio, in some displaying particular vnlnerability to the rhematie poison, and in others appearing mable to withstand the wear and 


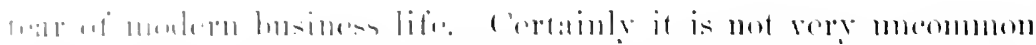

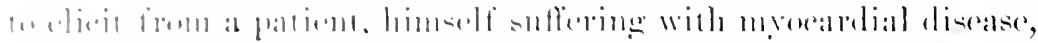

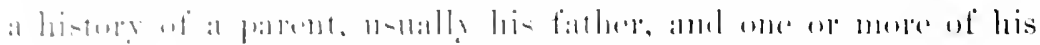

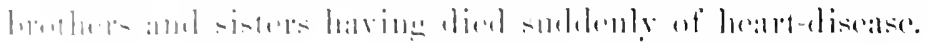

I hav in miml mow a family in which the father is reported

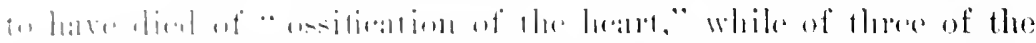

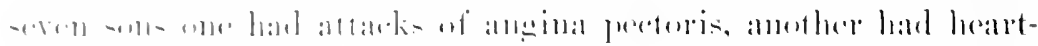

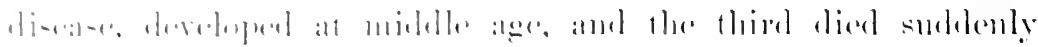

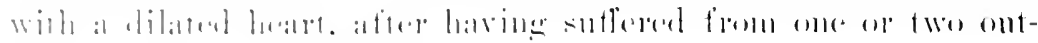

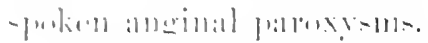

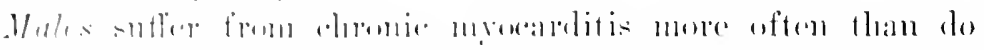

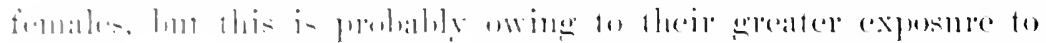

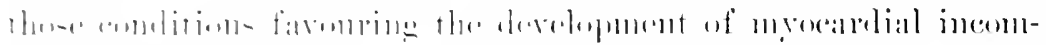

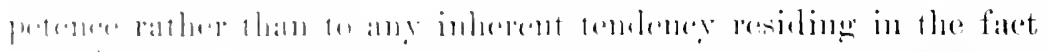

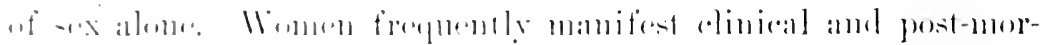

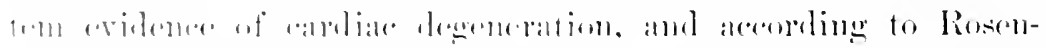

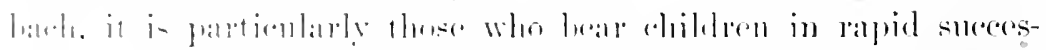

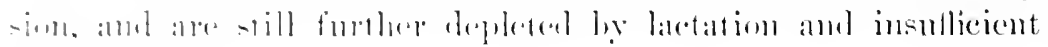
$11111, i-\ln 111,111$.

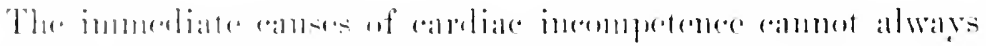

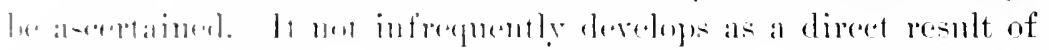

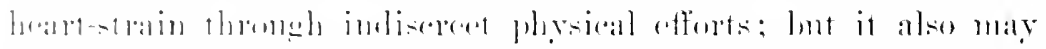

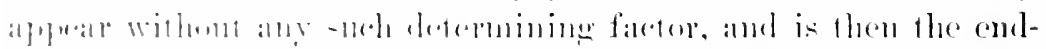

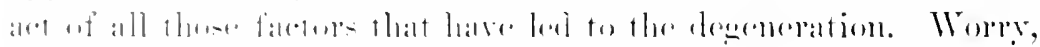

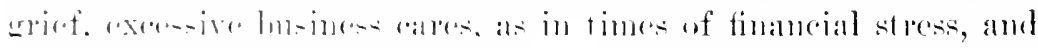

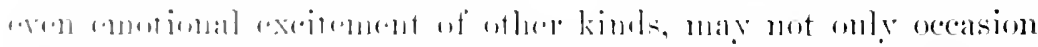

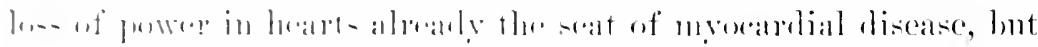

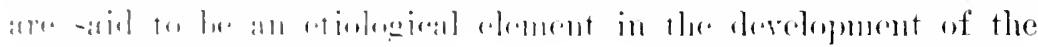

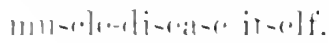

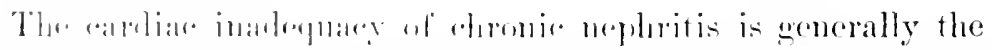

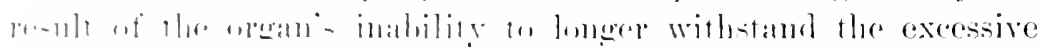

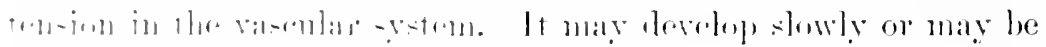

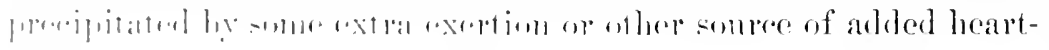
- risin,

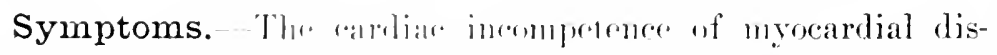

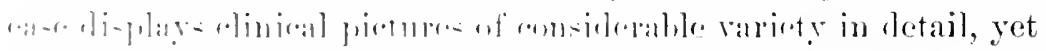

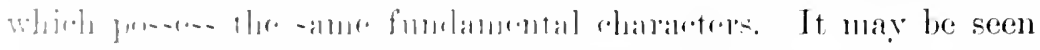

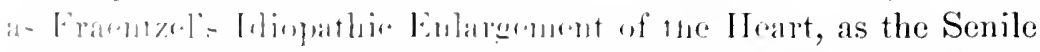

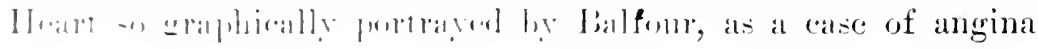


pectoris from coronary sclerosis in nocturmal attacks of dysphoa, known as cardiac asthma, and in comnection with chronic nephritis or diabetes, or both, and occasionally as a mitral or aortic regurgitation due to relative insufficiency from dilatation.

Irlopathic cardiac enlargenent occurs for the most part in middle-aged men of powerful plysique, who are intellectually active, but physically inactive. It is especially frequent, therefore, in men of affairs, as merclunts and railroad magnates, and in professional men, as lawyers and elergymen, who, in addition to sitting for long hours at their desks, generally consume large amounts of food. For years there is in such individuals an abmormally high and sustained pulse-tension, which resulting, perlaps in part, from abnormal blood-pressure within the abdominal cavity, increases as the girth of the waist increases. This state of things is borne withont special discomfort mutil the man gets well along in his forties, or has even passed his iftieth year. Then he begins little by little to notice he does not breathe quite so easily as formerly on ascending stairs, walking up a slight hill, or hmrrying to catch a street-car. At times, particularly after breakfast or a more than ordinarily hearty meal, he finds that walking at his acenstomed pace is atteurled by a feeling of nueasiness, fulness, or even dull pain in the region of the heart. As the weeks go on he finds these two symptoms become decidedly amoying, and instead of wholly subsiling after he sits down they remain as a vague sense of discomfort in the chest. IIe also perceives, perhajs, that the old exertion or some excitenent incident to his occupation produces eonscionsness of his heart's action, a veritable thongh not violent palpitation. As a rule this last symptom is not at all prononneed, heing subordinate to the breathlessness and pracordial fulness.

By the time things have reached this pass he eoncludes to consult his physician, who fiuds a strong, usually regular pulse, no cardiac impulse, an apparently nownal heart's dulness, and clear heart-tones withont mummor, but the aortic second somud decidedly accentuated. If the radial arteries are not noticcably stiff, and the mrine is negative, the real nature of the ease is apt to be orerlooked, and the symptoms are attributed to the man's increasing weight. He is told to exercise more, eat rather less, and not to worry. Perhaps he is advised to go to some springs, where he 


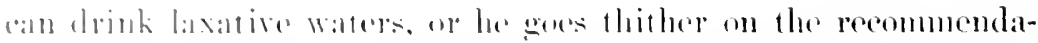

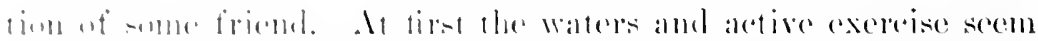

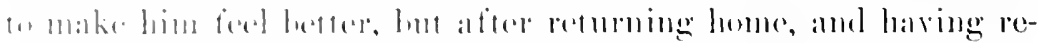

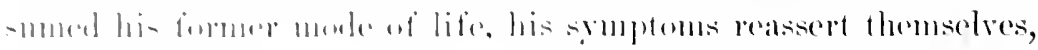

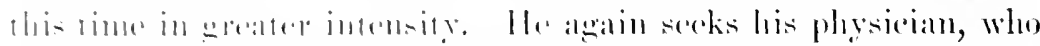

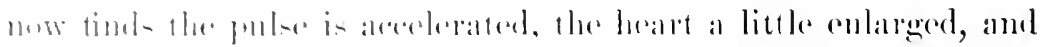

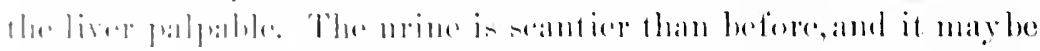

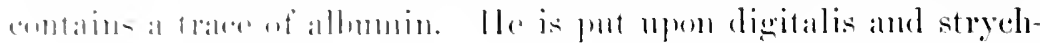

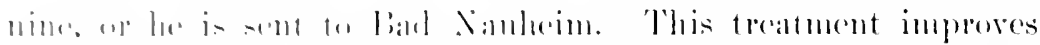

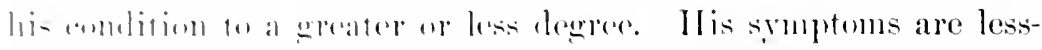

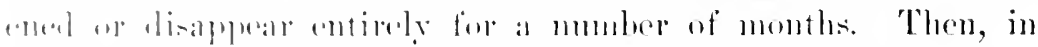

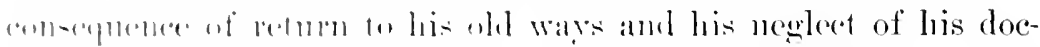

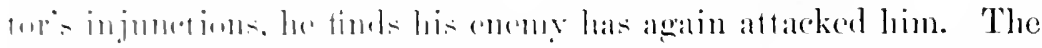

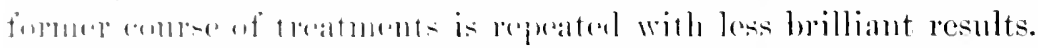

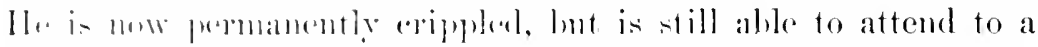

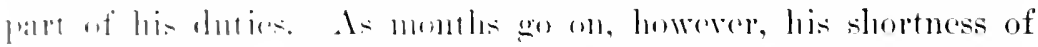

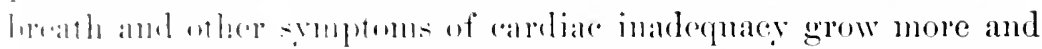

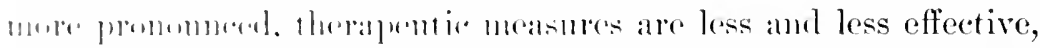

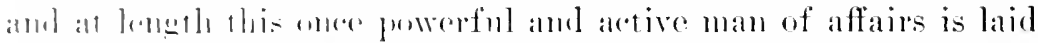

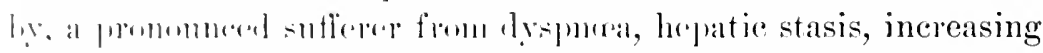
Inlollat,

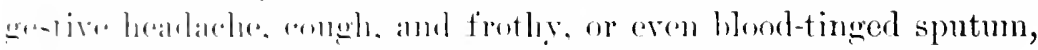

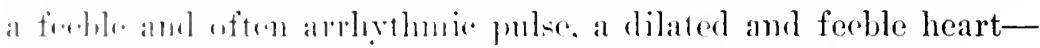

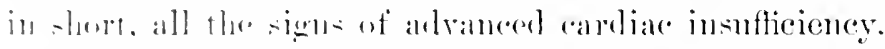

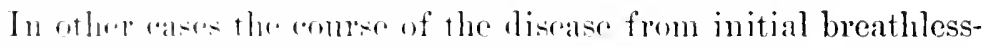

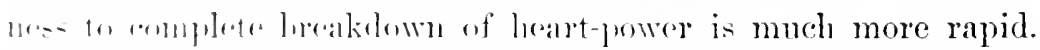
Instrad of rextruling ane two, three, or more years, it passes

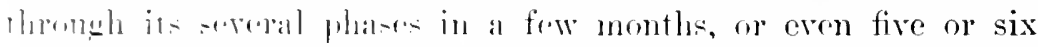

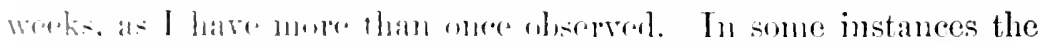

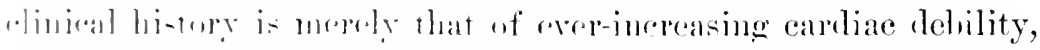

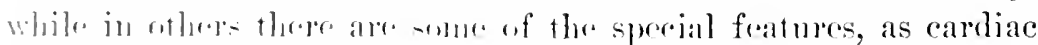

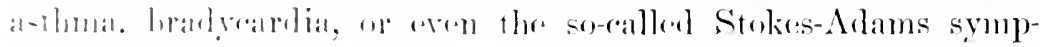

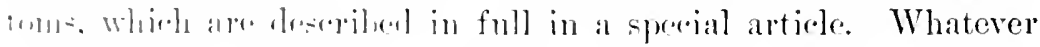

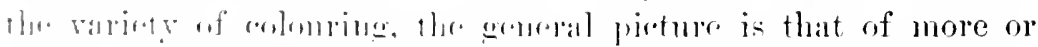

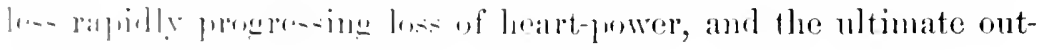

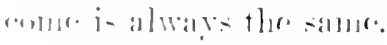

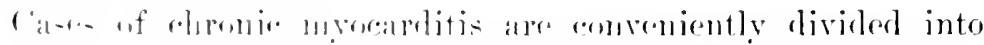

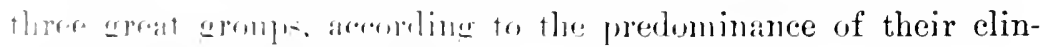
iral maniforations. 'Thorer ale: 
(1) The arrhythmic form, in which the pulse is strikingly irregular and intermittent, now slow and strong for a few heats, now perhaps rapid and feeble, or again made up of a perfect jumble of large and small, distinct and innereeptible, slow, rapid, intermittent wares that seem to fairly tmmble over calch other in their hurry, or to lag back until driven hastily onward again by the impetuonsly rushing waves behind. In a word, the pulse is so lacking in regularity of rhythm, foree, and volume that to count it accurately is inpossible.

(2) This is the form characterized by tachycardia and called the tachycarlial form. The pulse is persistently accelerated, or in a few instances become so, in paroxysms which so annoy or even terrify the patient that he comes to stand in mortal dread of his attacks of palpitation.

(3) The asthmatic form, distingnished hy attacks of alcute pulmonary wedema, which not only occasion distress and terror to the patient, but throw the friends into a state of scarcely less alarm. I have under observation at the present writing a powerfully built, active business man of sixty-three, with moderately stiff arteries and a hypertrophied heart, with feeble tones, and a scratching systolic murmur, who for the past several months has lived in a state of well-nigh intolerable nervonsuess and alprehension. As he says, he has eompletely lost his nerre, becanse last September, after some weeks of neglected shortness of breath, he was one evening seizerl with an attack of mrgent dyspnera, during which the pulse was scarcely preeptible, and the chest emitted a multitude of fine crackling sounds. IIe conghed from time to time and exprectorated a frothy white sputum. The attack subsided after the hypodermic arministration of morphine and atropine. This gentleman has had one recurrence of the kind, but in the meantime has scarcely passed a week without hours or even days during which his heart has "thumped and bumped," to use his expressive words, in a mammer which throws him into a state of great alarm. He never knows when this palpitation is to oecur, but it seems in some way connected with temporary angmentation of pulse tension. It is also quite eertain to follow excitement over business affairs.

The pulse-rate averages from 88 to 95 , but often runs up to 120 or even 140, and such is the throbbing that he can at any 


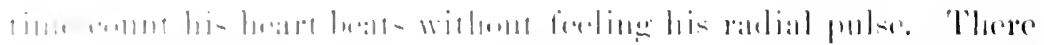

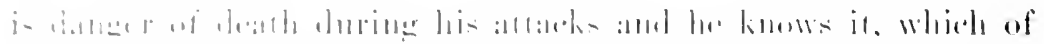

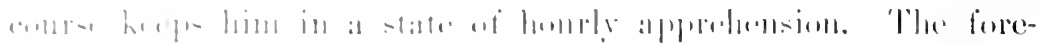

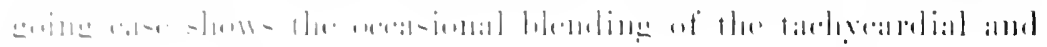

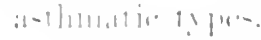

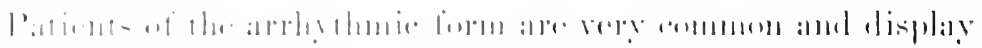

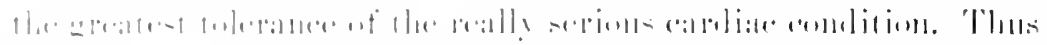

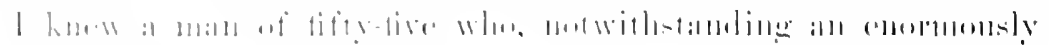

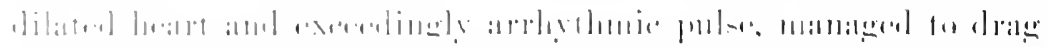

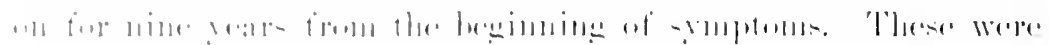

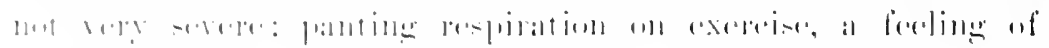

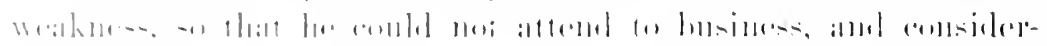

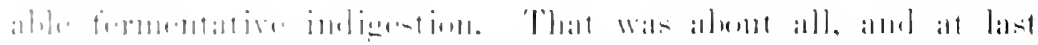

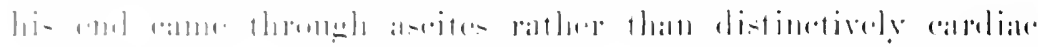
inatilinglians.

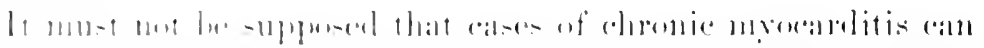

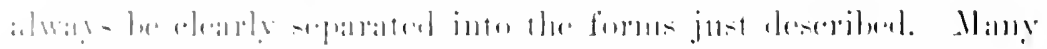

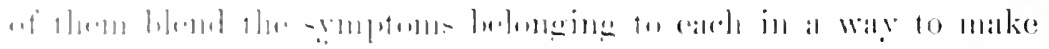

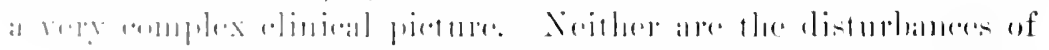

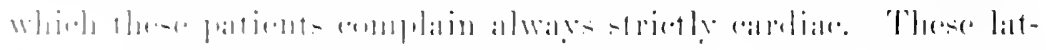

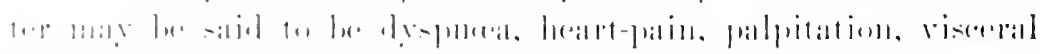

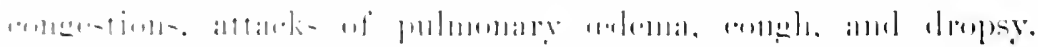

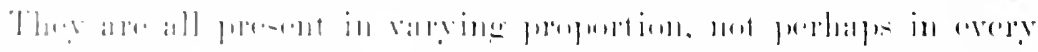

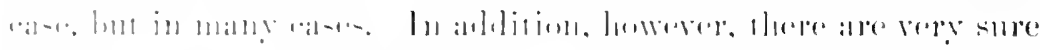

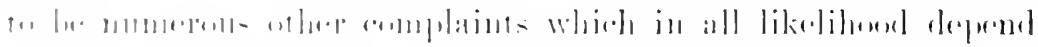

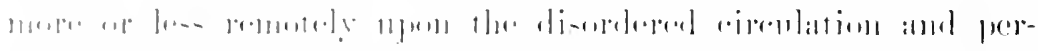

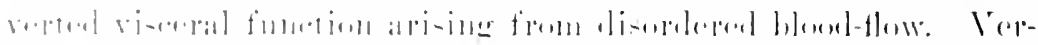

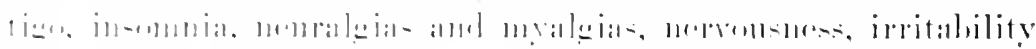

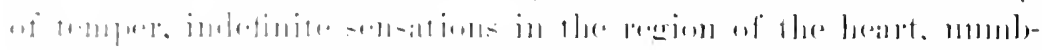

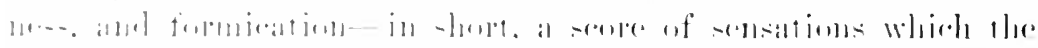

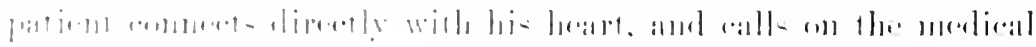

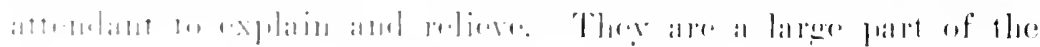

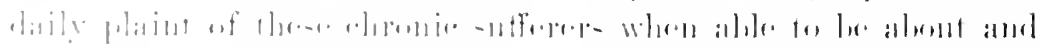

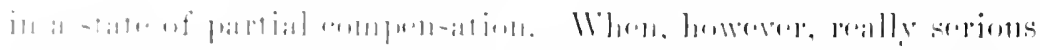

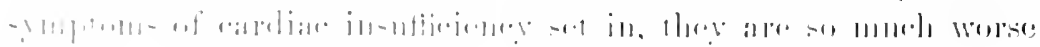

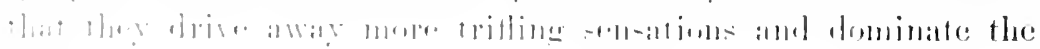
-and

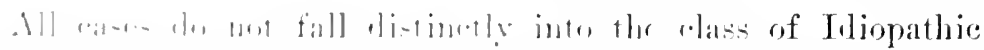

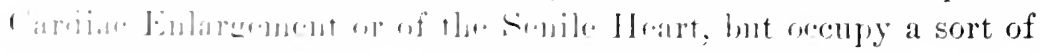


intermediate gromd. Nevertheless, it is condncive to clearuess to try to classify them, as is essayed to do in this chapter.

The senile heart forms but a part of a general degenerative process. In one case the arteries are markedly stiff and tortuons; in another the urine shows evidence of pronomeed interstitial nephritis, but in all the phenomena of cardiac incompetence dominate the scene. There are breathlessness on even slight exertion, feebleness, digestive disorders, sensitiveness to cold and changes of weather, a tendency to bronchitis, and insomnia. In some there are attacks of nocturnal dyspuca of greater or less intensity, flutterings of the heart, rertigo, or even symcopal attacks.

In other eases the breathing assmes nuore or less typically the Cherne-Stokes type (see article on Cherne-Stokes Respiration), with or withont nedema, pulmonary congestions, arrythuic feeble pulse, and the usual manifestations of progressing asystolism.

The course is usually slow, the symptous being sometimes mild, and the patient ent off by some interenrent affection, as senile pnemmonia. In some instances there is history of attacks of angina pectoris for five, ten, or eren twenty rears, and reath at last is sulden and mexpected. There are other cases, chiefly men, whose cardiac inadequacy is slown by aceeleration and arrhythmia of the heart's action, inclination to congh and wheeze, and rarions so-called gouty manifustions rather than by pronouneed dyspma or venous stasis; the so-ealled arrhythmie form. They get rather hreathless on excreise, and yet then can walk at a moderate rate of speed without much difficulty. They have times when from some ilhess, as acute bronchitis, injudicions strain of one kind or another, they are laid up in their room with a trace of cedema and indications of failing heart-power that look very threatening, and yet under good nursing and proper medical attention they rally, and after weeks or months are again able to be about, a little weaker and thimner, a little more breathless, but on the whole capable of getting considerable enjoyment out of their quiet existence.

I reeall an old gentleman of eighty with stiff arteries, urine of poor quality, and a greatly hypertrophied heart, the first sound aceompanied by a lond systolic basic murmur, the aortic second intensely ringing, who ret attended daily to the cares of a large personal property besides many other duties of a public and pri- 


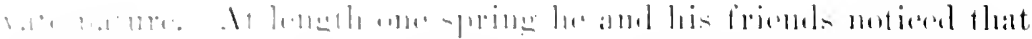

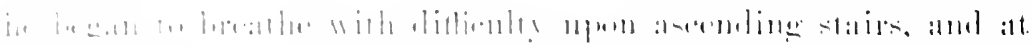

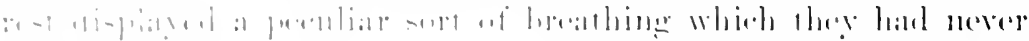

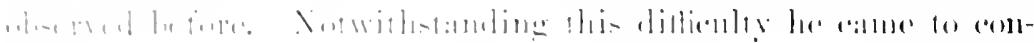

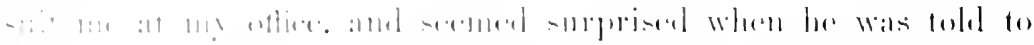

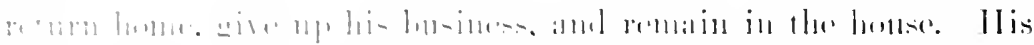

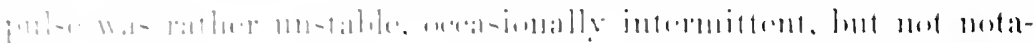

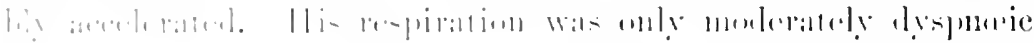

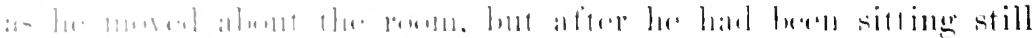

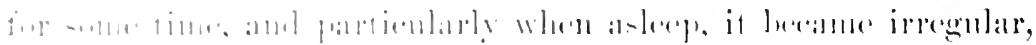

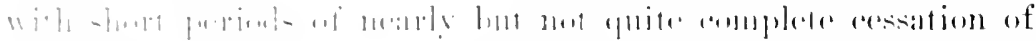

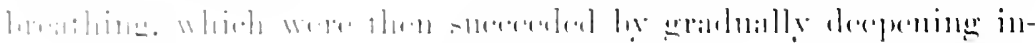

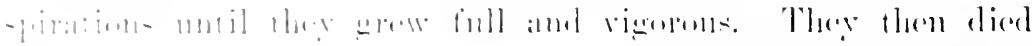

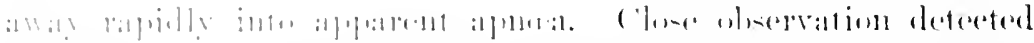

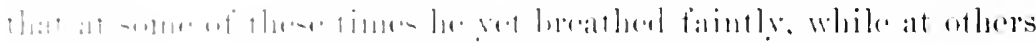

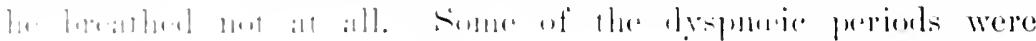

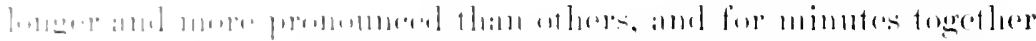

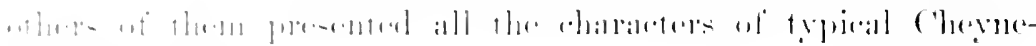

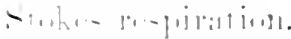

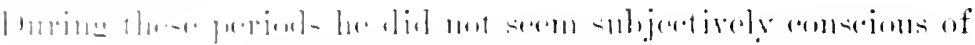

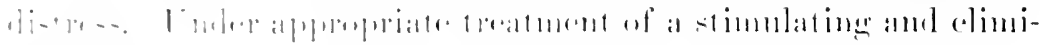

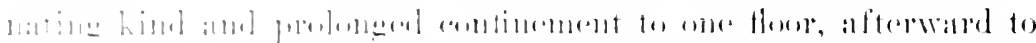

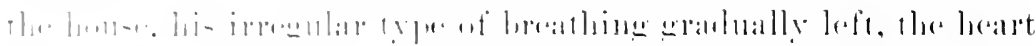

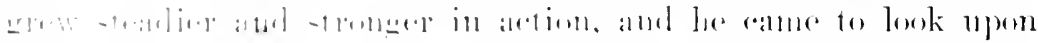

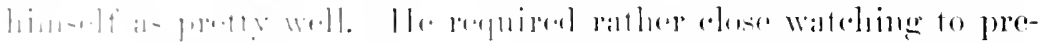

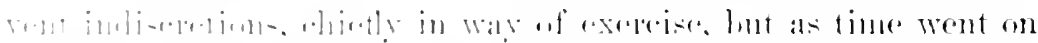

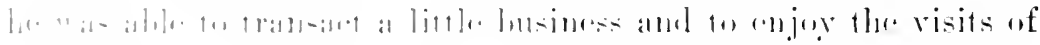

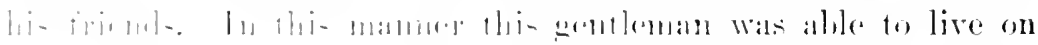

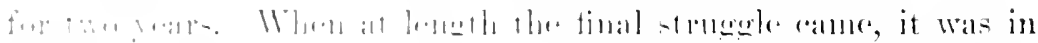

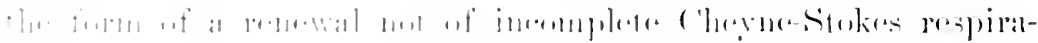

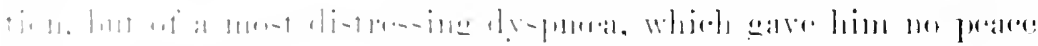

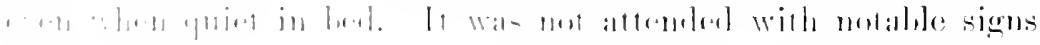

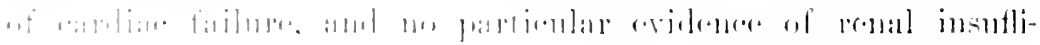

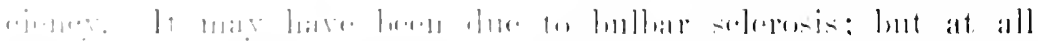

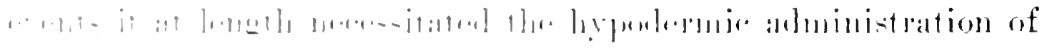

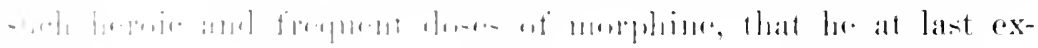

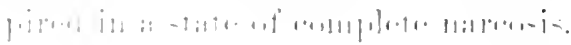

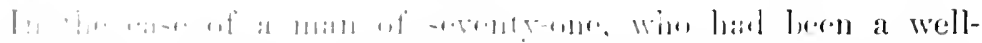

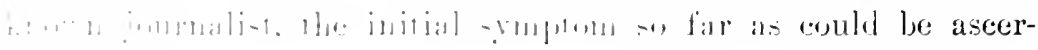


tained was an attack of dyspmea, which seized him one night after he had retired. He fell asleep, and after a few minntes sprang up in bed, clutching at his throat, exclaining he was going to strangle. This so terrified hin that at length he arose, dressed, and compelled his valet to keep him walking up and down in the garden for the remainder of the night. When I saw him the following afternoon he was still greatly agitated and suffering from choking spells. A hypodermic of an $\frac{1}{8}$ of morphine, with atropine in the ordinary combination, gave six homrs' uninterrupted sleep the next night, although during his repose his breathing was typieally Cheyne-Stokes. 'This patient's pulse was very arlyythmic, his arteries selerotic, his heart dilated, with a blowing apex-mmrmur and feeble somnds. Ilis urine was that of a moderate renal eirrhosis, and he suffered from prostatic enlargement. Ilis stomach was dilated, and he had any anomnt of flatulent distention of the bovels. Altogether it was an mpromising case, yet persistent and rigorous treatment with cardiac tonics and cathatrics, with as strict a control of the dietary as was possible with an irritable, self-willed old gentleman, at length pulled him out of his deplorable condition. For four years he was an invalid, having times of profound phrsical and mental depression, and periods of grave cardio-vaseular disturbance, during which odema nore than once appeared. These periods of distress were alternated with scasons of comparative immmity from symptoms, and yet they were interspersed with nmmerons attacks of bronchitis, mild mremie manifestations, and once an acute pleurisy with effusion that erentually necessitated paracentesis.

More than once he rallied from what it seemed must prove his final illness; and thus actually kept alive by cardiac tonies, he managed to drag out four years of chronie cardiae inadeqnacy. When at length his end came, it was quite sudden, although preceded by days of more than usual feebleness that had confind him to his bed. Although this patient displayed marked general debility, with slowly increasing cardiac asthenia, he never again suffered to any extent from his noetmmal dyspnea, and never had an attack of angina pectoris. He frequently complained of obstinate chest pains, hut these were mmistakably an intercostal neuralgia, as shown hy numerous hyperasthetic areas.

This case belonged to what may be styled the arrhythmic 


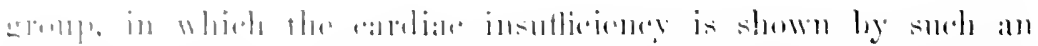

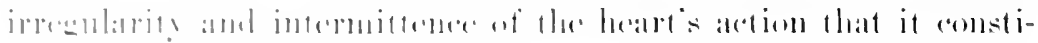

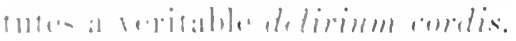

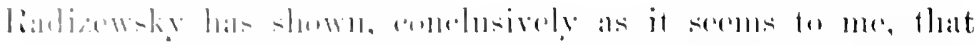

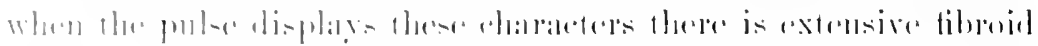

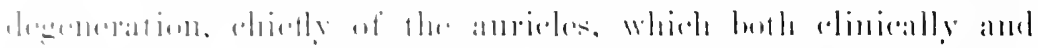

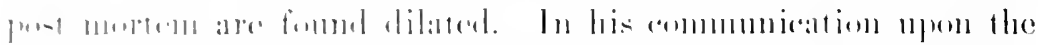

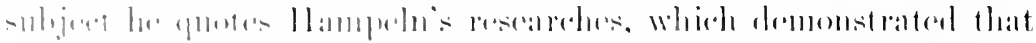

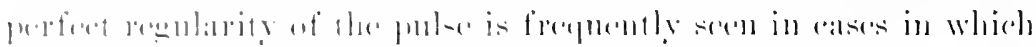

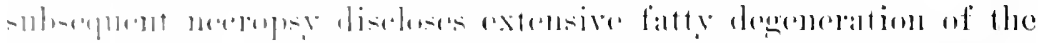

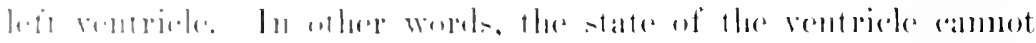

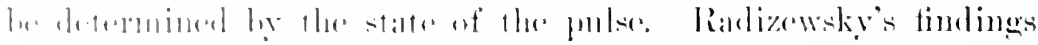

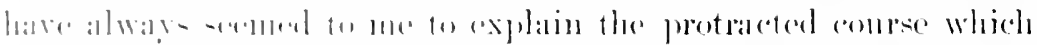

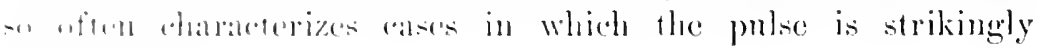
arrhishomir.

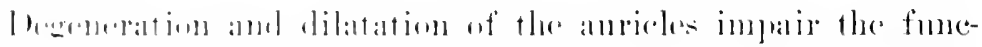

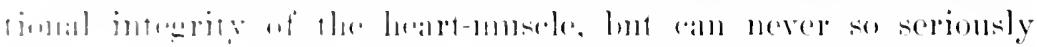

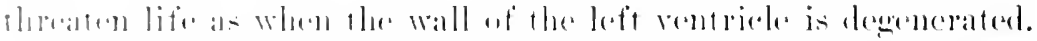

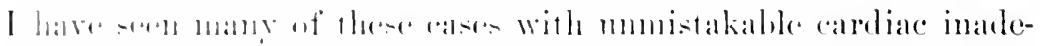

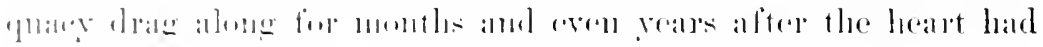

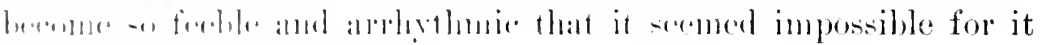

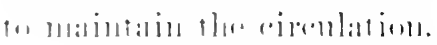

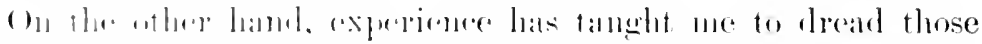

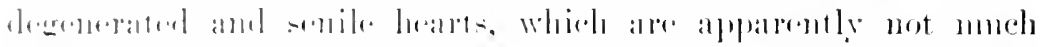

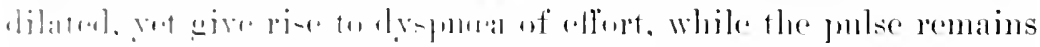

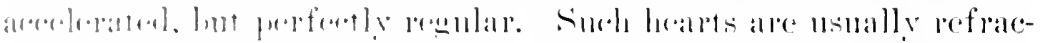

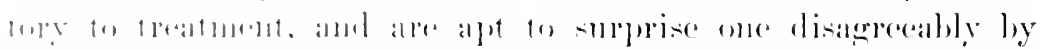

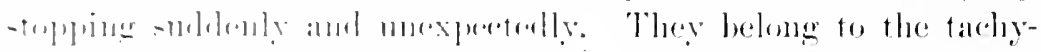

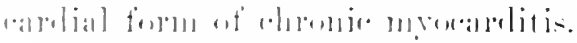

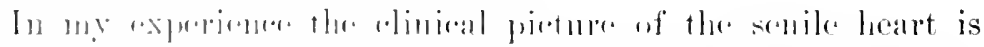

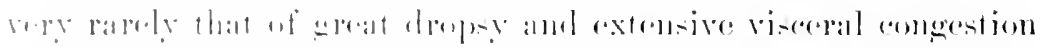

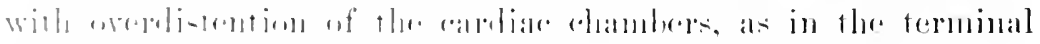

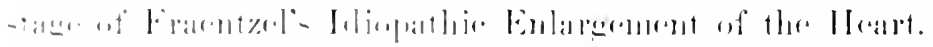

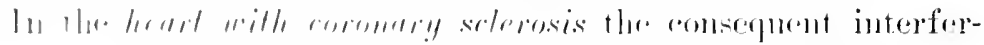

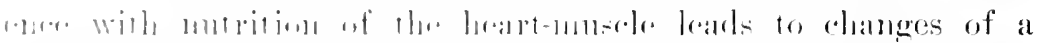

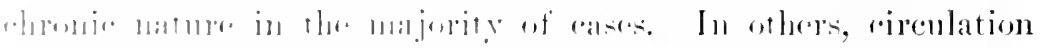

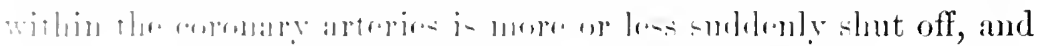

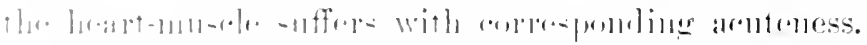

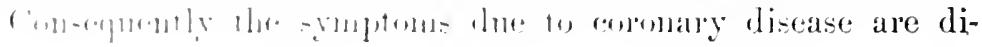


verse, and are best divided, as by Leylen, into acute, subacute, and chronic.

In the acute form the clinieal history is confined to a few days, hours, or even minutes. The srmptoms are due to coronary thrombosis with secondary myocardial softening, to sudden rupture of the heart in some area of insidions fattr degeneration, or of acute molecular neerosis (myonalacia cordis), or the symptoms consist only of a sudden diastolie arrest of the heart's action.

The ssmptoms of hecert-rupture may be a sudien sharp attack of angina pectoris or of rague precordial distress and oppression with profound prostration. The action of the heart is feeble and disordered, and the organ fails to respond to stimulants. The intellect is generally clear, but uneonscionsness may be present. In some eases there are symptoms of gastric disturbance, even vomiting, and the case is thought to be one of gastrie disorder. If life is prolonged for several dars, as rery rarely happens, the first violence of the attack abates, not to be renewed, or the angina and pripcordial distress reeur from time to time with steadily increasing asystolism and death. In other cases of cardiae rupture the symptoms are chiefly those of rapidly failing eirculation with insensibility and death from acute pulmonary arlema.

With the onset of symptoms the nearest plysician is hastily summoned, and on arriving at the patient's sile finds him moribund. Stimulants prove inert, and the doctor signs the death certificate withont having been able to aceurately diagnose the condition. If he examines the heart he discovers clear fecble somnds without any appreciable increase in the area of dulness. In other cases cardiac dulness is inereased, but unless a slow escape of blood into the pericardim produces the outline characteristic of pericardial effusion, the augmentation of dulness is attributed to clilatation, and a diagnosis is made of paralysis of the heart (acute asystolism), which seems borne ont by the weakness of the sounds and strikingly poor quality of the pulse. In such a ease recently narrated to me death supervened in half an hour from supposed acute dilatation, and yet the sae was found absolutely distended with blood.

In another form of this acute type of coronary sclerosis the patient appears as well as ordinary, having made no complaint that led to a suspicion of his having heart-disease, and yet in the 


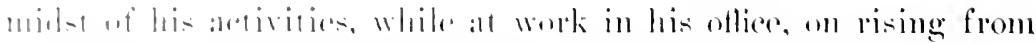

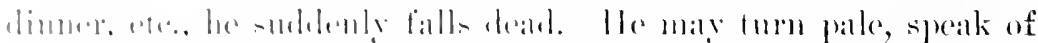

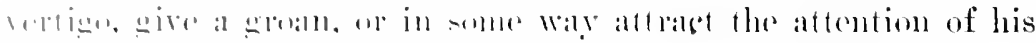

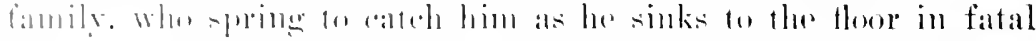

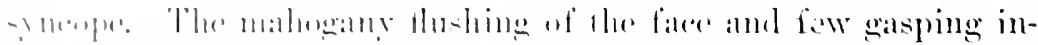

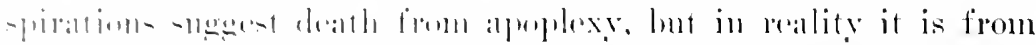

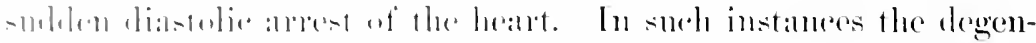

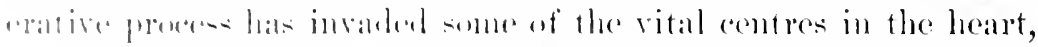

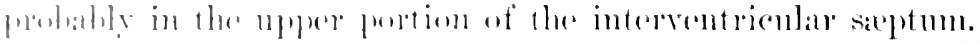

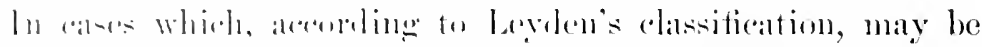

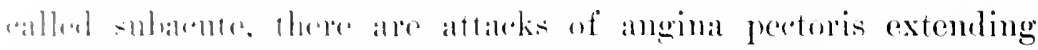

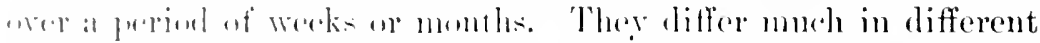

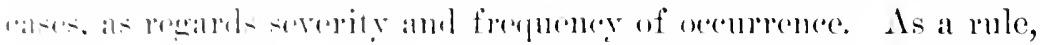

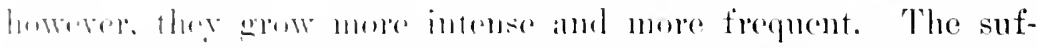

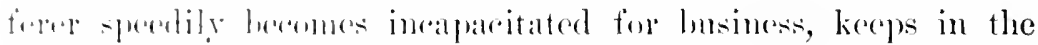

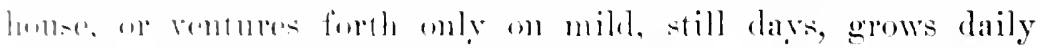

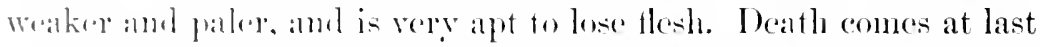

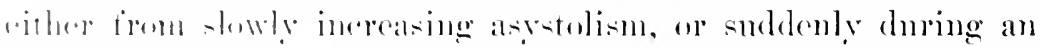

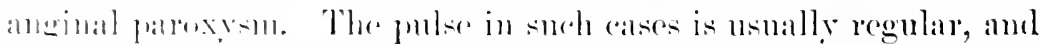

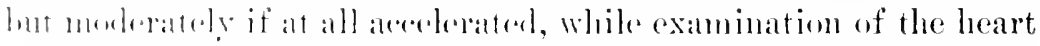

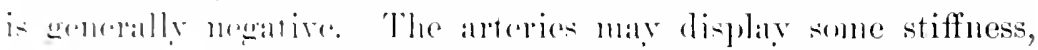
hat a-ide form the patientis an and his attacks of pain there is

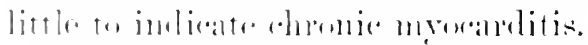

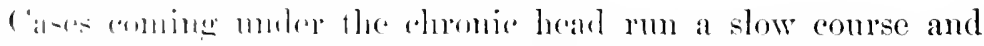

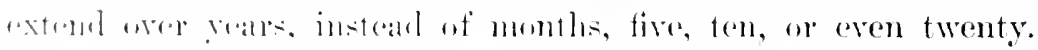

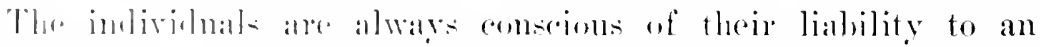

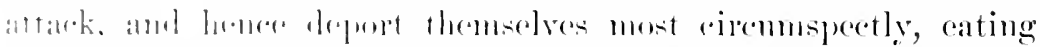

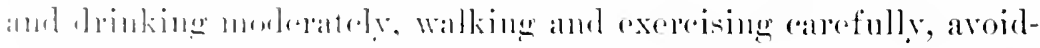

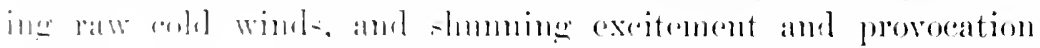

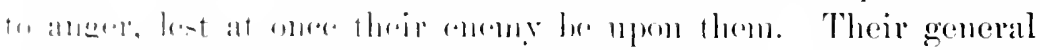

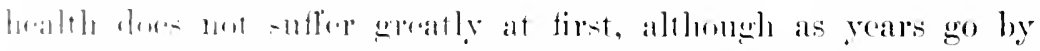
lher lowk and are like invalids. I frew experience some shortness

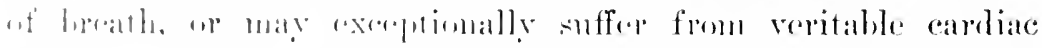

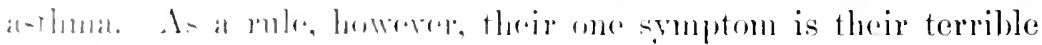

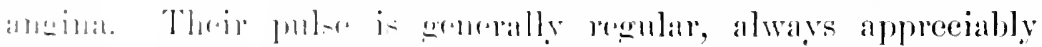

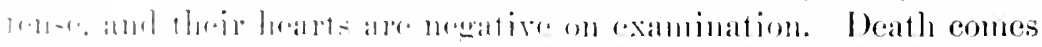

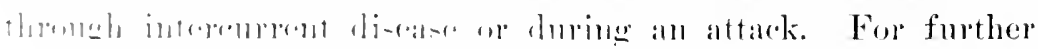

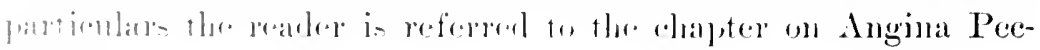
inlin. 
In general arteriosclerosis there ane often symptoms of cireulatory failure which are apt to be attribited to cardiate inadequacy alone, when in reality it is the arterial stiffness that is responsible for the stasis and adema. The heart may in such be atrophied or of normal size, but as a rule it is hypertrophied. The condition of the nyocardimm depends upon the degree of its nutrition with relation to its work, and as the aorta and coronaries share to a greater or less extent in the selerotic process, the heart-musele is not intact. Nevertheless, its driving power is often adequate for year's after the blood-ressels have become rigid and beady. At length it reaches the limit of its compensatory ability, and rascular resistanee still augmenting, the heart-walls begin gradually to yield to the strain of maintaining arterial circulation, and dilatation slowly supersedes hypertrophy.

In some cases injulicious physical effort, suddenly or too often exerted, causes acute overstrain of the already too greatly taxed heart, and symptoms of eardiae insufficieney set in rapidly instead of slowly. These are not peenliar, lut possess the ordinary characters of retarded cirenlation, breathlessness, slight wdema of the ankles, scanty, perhaps albuminons urine, pulmonary and hepatic congestion. The superficial veins stand forth still more prominently, the rigid, tortuons, meven arteries show a thready, often flickering pulse, which is acelerated and often irregular both in force and rhythm. The heart is found more or less increased in size, and its sounds are altered in quality and proper relative intensity. There may or may not be murmurs at apex or base indicative of atheromatous changes in the valves, but the aortic second tone is nearly always ringing and metallic.

The patient loses strength, and finally takes to the house permanently. Dyspoca grows apace and not infrequently assumes the characters of cardiac asthma or of Cheyme-Stokes respiration. Urine grows still seantier, dropsy alvances, orthopnoa sets in, troublesome cough, and frothy, blood-tinged expectoration, betoken ever-inereasing stasis within the pulmonary ressels, and the patient snecmubs after weeks or months to general exhaustion, cardiac asthenia, or an attack of acute pulmonary cedema.

Chronicity is the essential feature of this type of cardio-vascular inadequacy. It is not uncommon for cases of arteriosclerosis to drag on for several years under the picture of senility and gen$35 *$ 


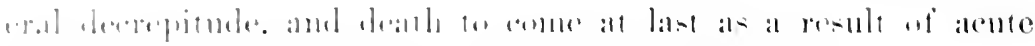

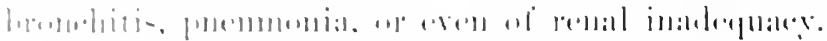

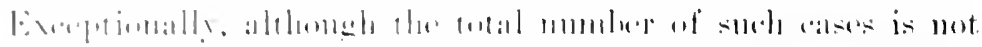

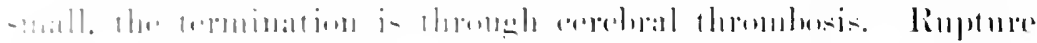

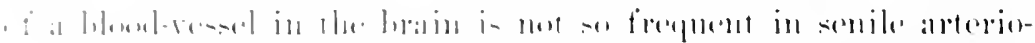

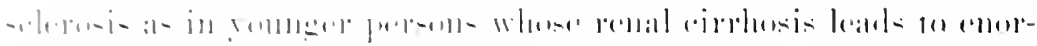

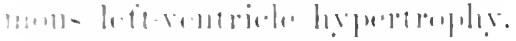

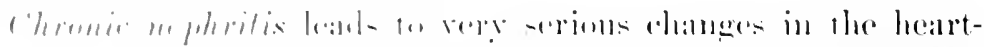

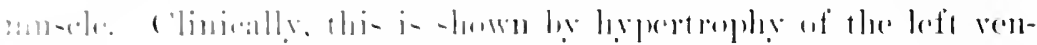

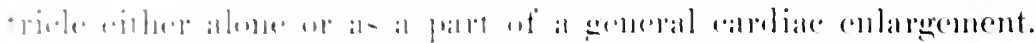

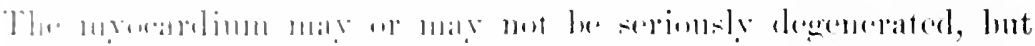

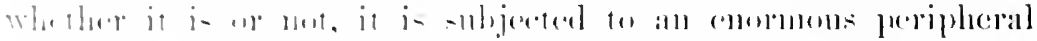

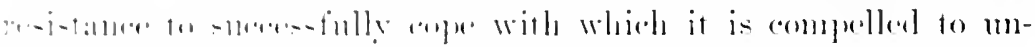

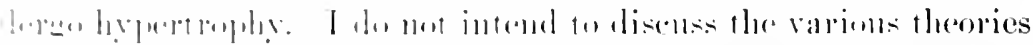

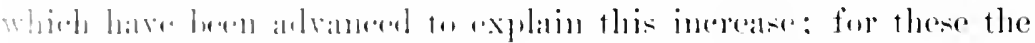

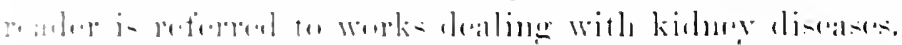

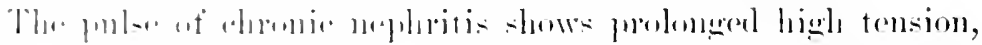

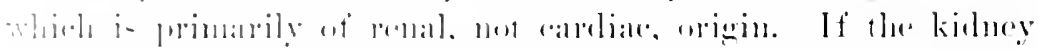

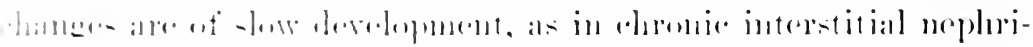

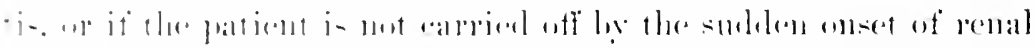

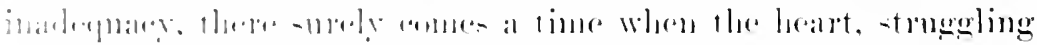

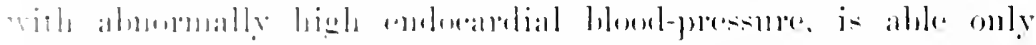

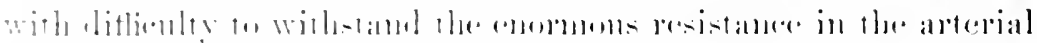

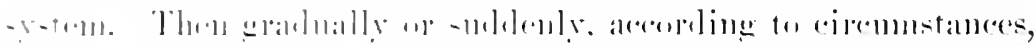

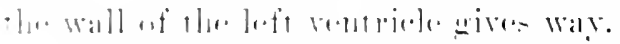

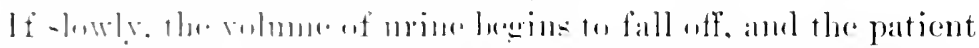

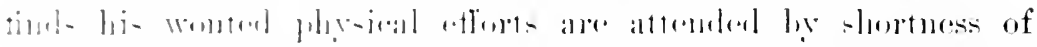

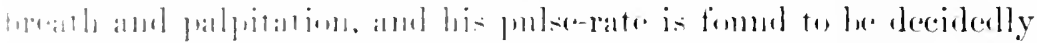

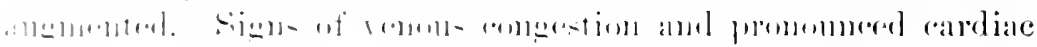

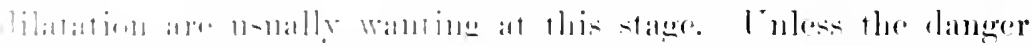

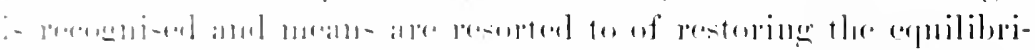

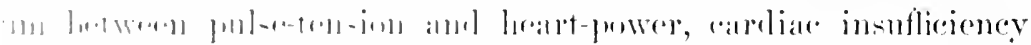

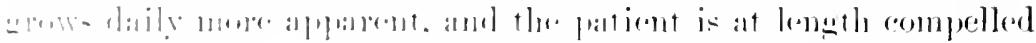

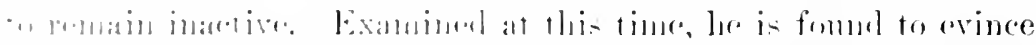

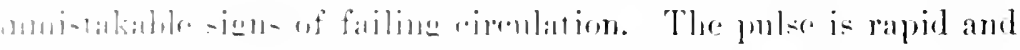

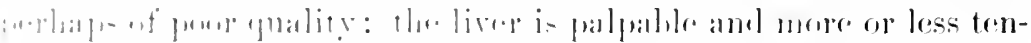

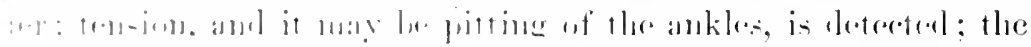

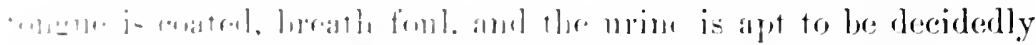
- ast and allmminem-. If the leart is examined, the apex is 
displaced and lacking in eoncentration and force, the second sound at the right of the sternum is somewhat enfecbled, and the julmonic is nearly or quite as intense.

The striking alteration in the heart-findings consists in the peculiar loduplication of the somnds at tha apex, which is known as gallop rhythm (see introductory chapter). Occurring in tho comrse of chronic Bright's disease this phenomenon is of rery evil portent, for it indicates that the left rentricle is vielding to the abnornal strain and tottering on the rerge of an irreparable breakdown. In most cases tratment is marailing, symptoms of stasis progress, and dyspnexa lrecomes most distressing. It may be of the ('herne-Stokes type, hut is more often of a paroxymal nature, coming in waves, as it were, with evidences of great agitation, even alarn, on the part of the patient, yet without corresponding signs of more than usual cardiac failure. This form of dyspurea is probably partly of toxic (nramic) and partly of cardiac origin. Nevertheless, the insutticiency of the heart ausments, renal excretion fails correspondingly, and after the lapse of weeks or a few months the patient dies with uranic nanifestations or from acute pulnonary adema.

There are other cases of Bright's disease in which cardiac incompetence sets in abruptly. This is usually owing to some indiscreet effort or cxcess which causes rapid dilatation of the left ventricle. The simptoms are much the same as in the more gradually erolved loss of coupensation, but ale apt to be of far meater intensity. Examination shows feeble apex-beat, displaced far to the left and perhaps downward, enormous increase of cardiac duhness, and a systolic apex-murmur, which often replaces the first somd, and a feeble second tone except in the pulnomary area, where it is intensified. The liver swells rapidly, is often painful and very tender, particularly in the epigastrium. Dropsy sets in, extends rapidly uprard, and invades the serous cavities. The patient suffers from orthopmea with paroxysmal exacerbations, from serere, tensive headache, insommia, or it may be sommolence, and many other distressing symptoms of combined carliac and renal inadequacy. Few clinical pictures are more distressing, and none are more hopeless.

In many cases in which there are enlarged hearts with stiffened arteries and urinary findings of renal sclerosis it is difficult 


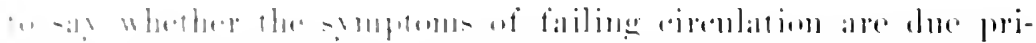

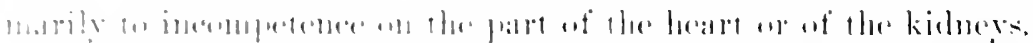

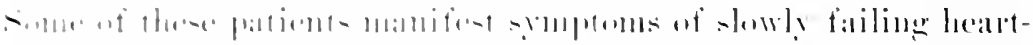

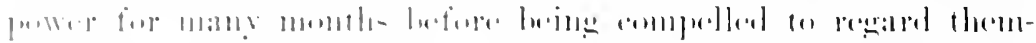

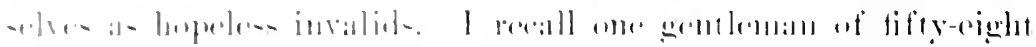

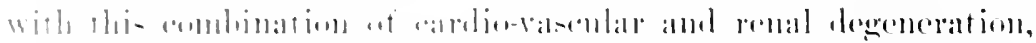

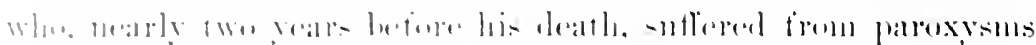

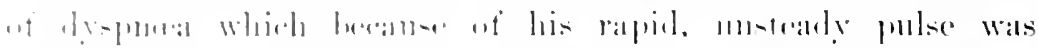

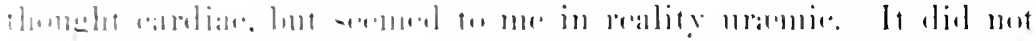

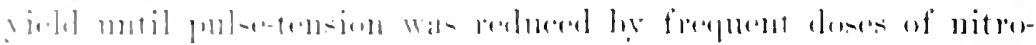

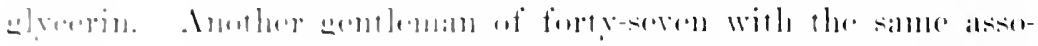

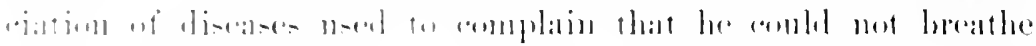

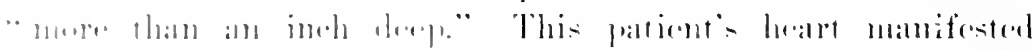

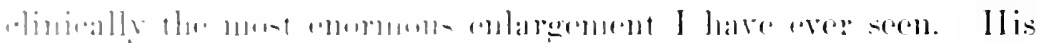

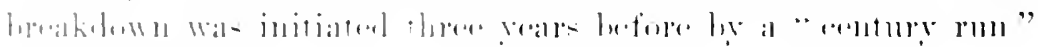

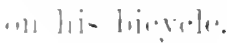

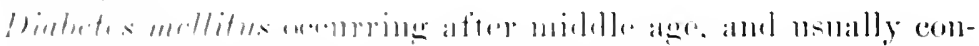

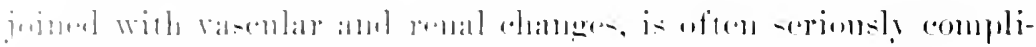

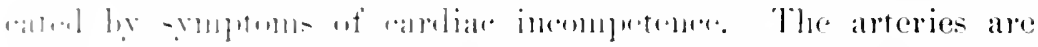

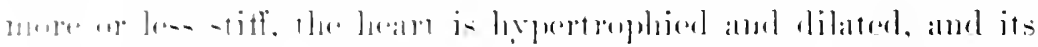

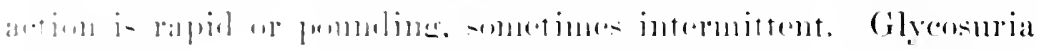

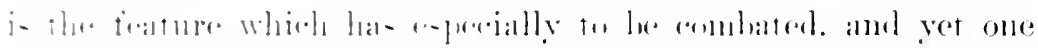

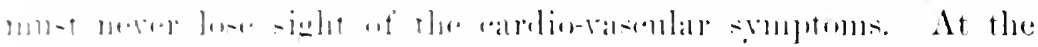

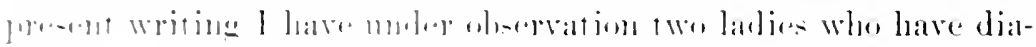

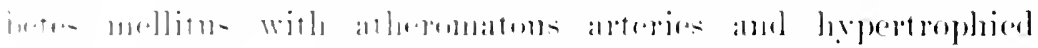

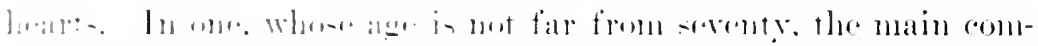

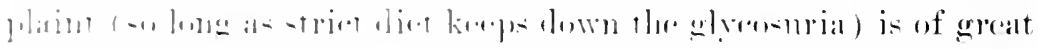

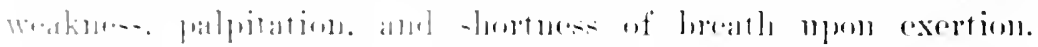

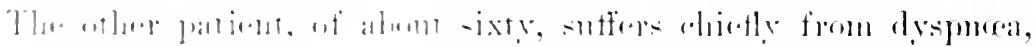

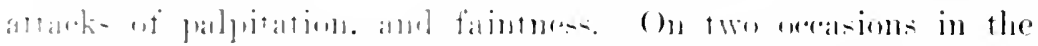

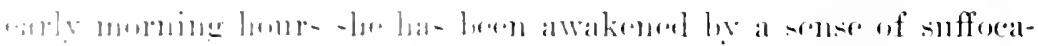

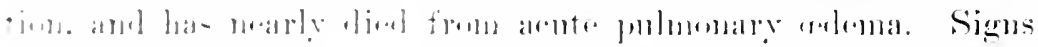

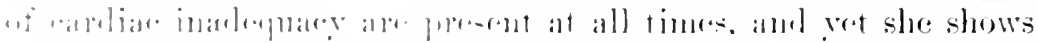

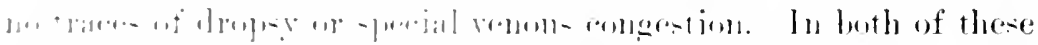

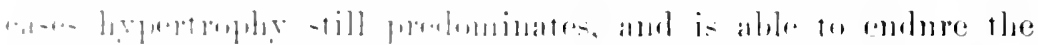

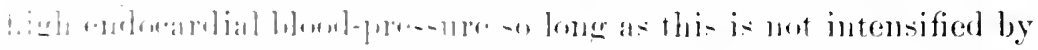

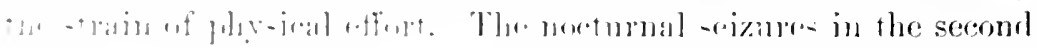

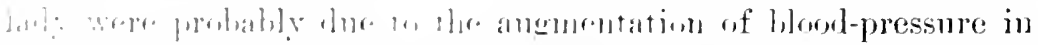

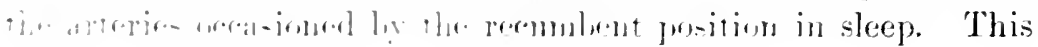


at length overpowered the left ventricle, which temporarily became weaker than the right, and acute puhnonary celema supervened. In some of these eases of chronic nyocarditis such attacks form the principal feature, and the cases are particularly grave on this account.

Cases of S'econdary Valvular Insufficiency.-Lastly, one occasionally meets with cases of myocardial degeneration which masquerade in the guise of a mitral or aortic regurgitation. I do not refer to atheromatous valvular disease, but to cases in which the valvular incompetence is relative or muscular. Arthur R. Edwards has reported a case of relative aortic insufficiency from extensive myocardial degeneration, and I have myself observed three cases in which the necropser revealed the sane condition. In all of them the clinical history was that of aortic regurgitation.

Mitral incompetence is common anc may be relative, but more often is muscular from degeneration of the papillaries or slight ventrieular dilatation. I do not now refer to Balfour's Curable Mitral Regurgitation, which is seen in ehlorosis and ancmia, or to that form seen in roung athletes as an effect of acute strain. These all yicld to appropriate treatment. I am now speaking of left-rentricle dilatation and secondary mitral insufticiency seen in cases of ehronic myoearditis. I have under observation a man of sixty-five, a veteran of the late civil war, whose mitral ralve leaks in consequence of great dilatation of the ventricle. There is no history of inflammatory rhemuatism or any other disease to oceasion endocarditis, but there is history of severe phrsical effort (climbing a mountain) ten years ago. Previons to that strain he had no cardiac srmptoms, but since then his mitral murnur and dilatation of the rentricle have been present. It times the mmrnum wholly replaces the first somul, but as the ventricle retracts under treatment by baths and resistance exercises, the first somd becomes andible and cardiac impulse palpable. I think few would venture to assert that in this case the myocardinm is healthy.

I have notes of the case of another gentleman of forty who presented the signs of a typical mitral regurgitation, and who for four vears struggled to preserve his compensation. He gave a history of mild inflammatory rhemmatism, of gonorrhaa, and of a thrombophlebitis of the right femoral vein, and therefore his valvular incompetence was quite naturally supposed to be of endo- 


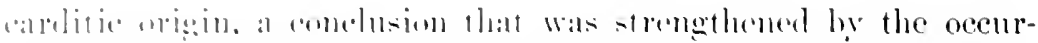

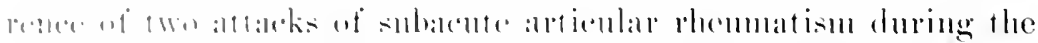

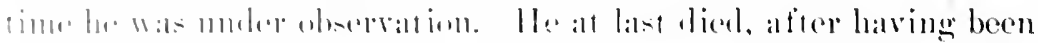

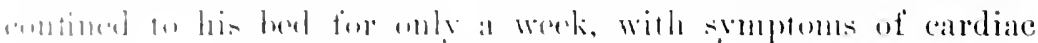

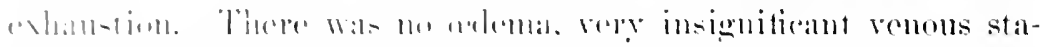

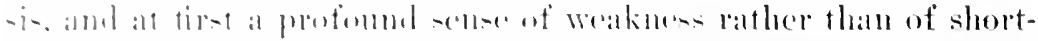

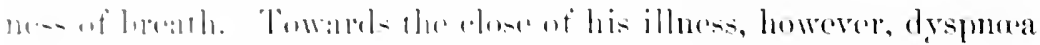

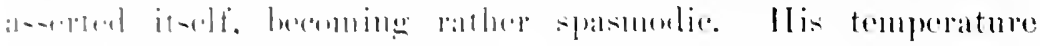

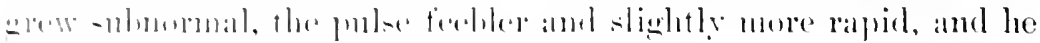

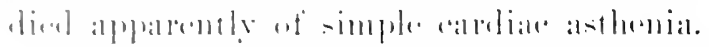

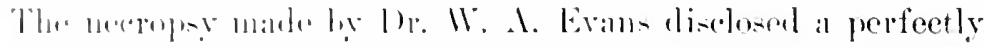

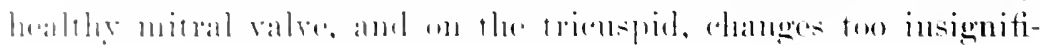

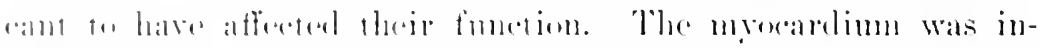

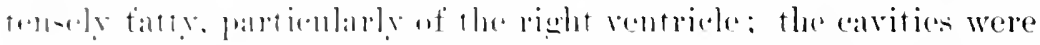

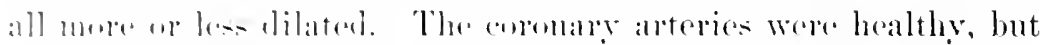

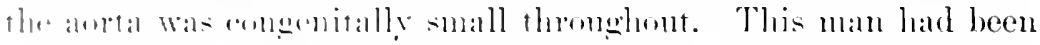

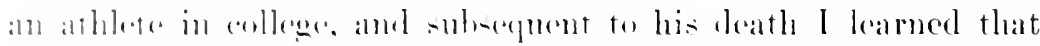

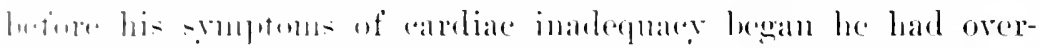

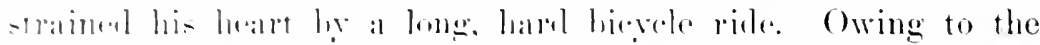

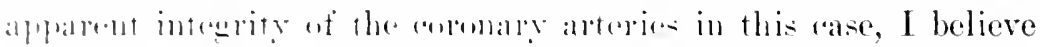

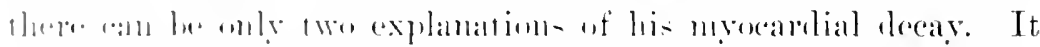

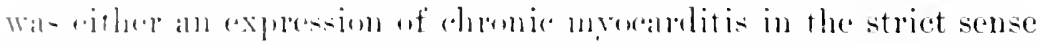

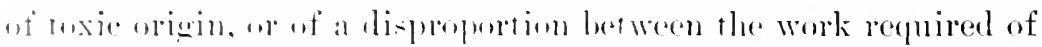

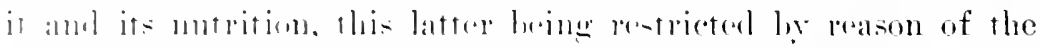

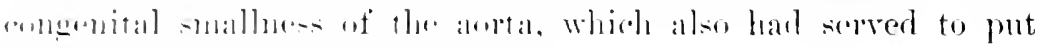

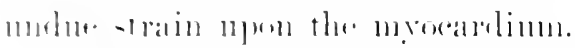

Finally, in entreluling what I have to say mom the symptoma-

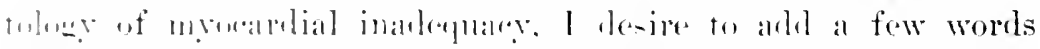

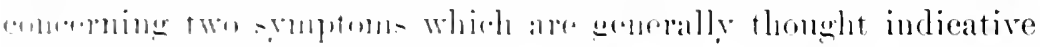

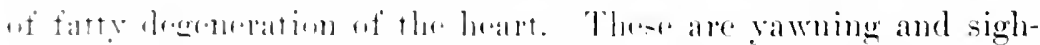

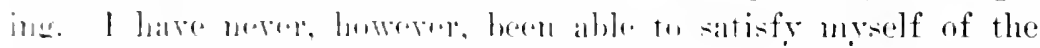

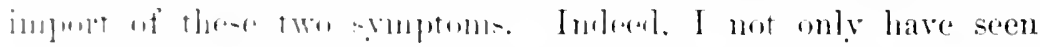

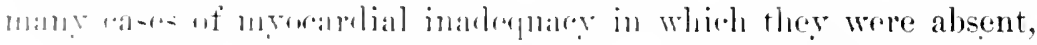

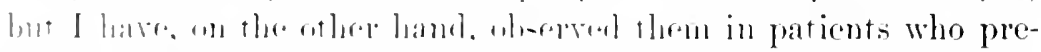

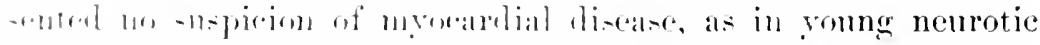

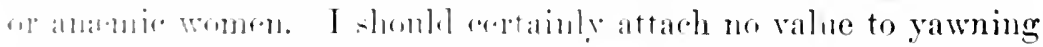

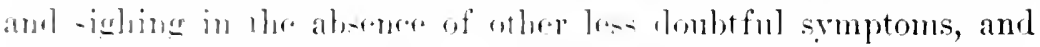

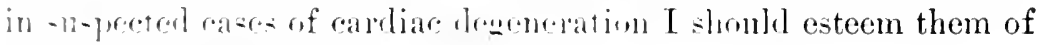
volume mingrertance. 
Physical Signs.-Inspection.-In most cases inspection is negative. If the ere detects signs of stasis, there is nothing in this fact to indieate the mulerlying condition. The general appearance of the indiridual may show to the experienced phesician signs of premature or senile decay. When hypertrophy of the left ventricle is present, this may he shown by the displaced apex-beat. But in the class of cases in which it is the most difficult to arrive at a definite conelnsion-that is, middle-aged and well-preserved men, with apacions chests, the cardiac impulse is not visible because of the chestcapacity and lung-rolume. Consequently, it may be said that the chief vahe of inspection lies in the fact of its negativeness, for other disorders of the heart than myocardial degeneration are very apt to furnish some visible indication of their nature.

Palpation.-This is of value in the determination of redema and of hepatic engorgenent eren more than in the examination of the heart. Yet by careful palpation of the precorrlinu orie is often able to loeate an apex-beat which is tom feeble to be visible. It may enable one also to perceive that the cardiac impulse hats the diffused jogging character of dilatation with hypertrophy, or the feeblo, slapping shock of dilatation. Palpation is of special value in liveloing the state of the arterial coats. If these feel thick and resisting, or tortuous and uneren, like a string of beads, they fornish presumptive eridence that the heart-muscle is not somud. Tn

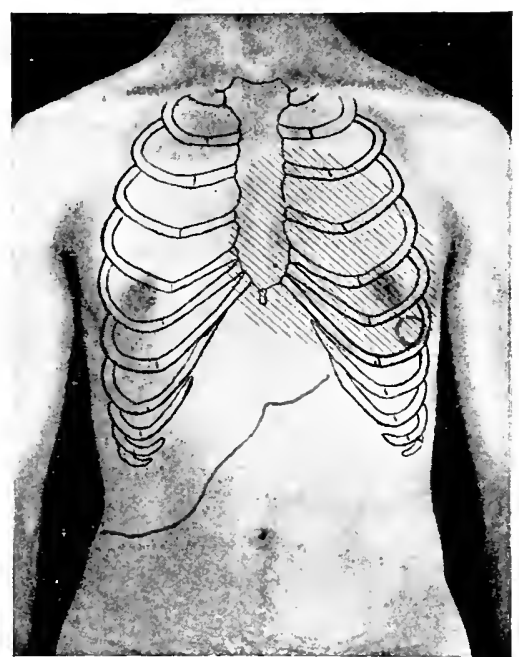

Fig. 103.-Showlyg Shape of Relative DleNEs: IN HYPETromir. Quadrilateral with rounded eorners. searching for signs of cardiac incompetence one shonld always endeavour to palpate the liver. If the lower border of this organ can be felt below the costal areh, and particularly if it is smooth, romded. firm, and perhaps tender, there is hepatic congestion, probalily secondary to more or less cardiac inadequacs. 


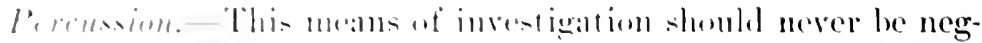

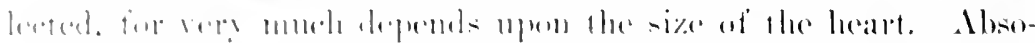

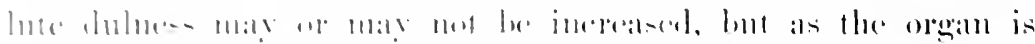

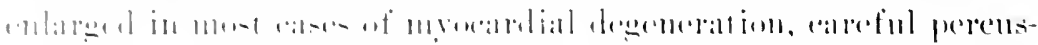

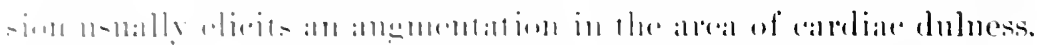

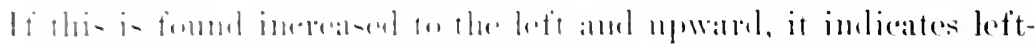

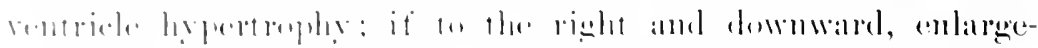

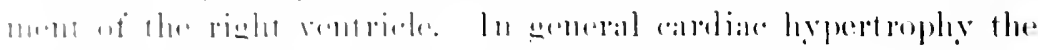

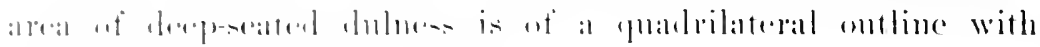

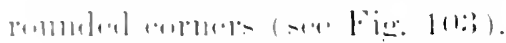

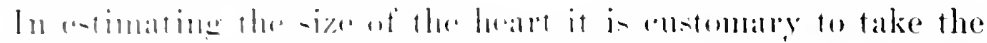

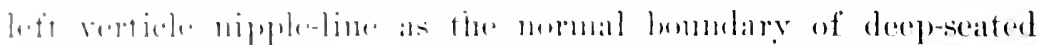

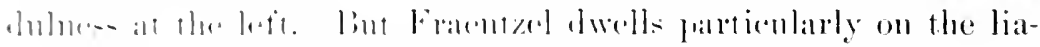

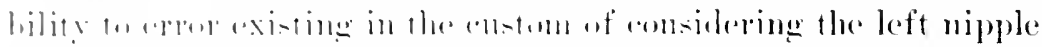

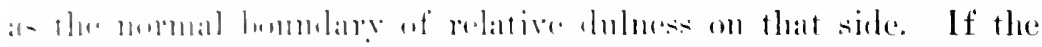

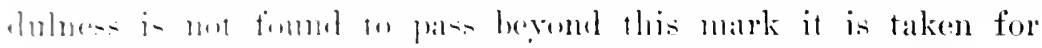

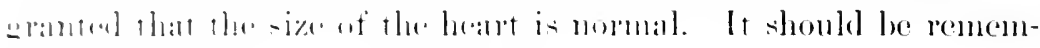

\begin{tabular}{|c|c|c|c|c|c|c|}
\hline & $A \% \cdot$ & Wreight & IIt & clit. & $\begin{array}{l}\text { ('ircumfter- } \\
\text { elloe of } \\
\text { chest. }\end{array}$ & $\begin{array}{c}\text { listance from } \\
\text { stermun to left } \\
\text { nipule. }\end{array}$ \\
\hline K. $1 \ldots \ldots \ldots$ & 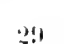 & 1.5 & $i$ & $\begin{array}{l}\text { Inchits. } \\
i\end{array}$ & $\begin{array}{c}\text { Inclues. } \\
\text { :i:: }\end{array}$ & $\begin{array}{c}\text { Inches. } \\
\text { :3t }\end{array}$ \\
\hline$T, \quad ; \ldots \ldots$ & 24 & $1: 35$ &.$j$ & $\tilde{i}$ & $: 34$ & $3^{4}$ \\
\hline$\therefore$ \& & $2 j$ & $1: 30$ & $i$ & $\tilde{\imath}$ & $: 34$ & $3 \frac{1}{2}$ \\
\hline 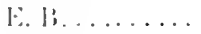 & $: 311$ & 1.01 & $i$ & !) & $\because 1$ & 38 \\
\hline $15, \ldots \ldots \ldots$ & $\because 4$ & 145 & $i$ & ij & 34 & $3 \frac{1}{5}$ \\
\hline$\therefore 11 \ldots \ldots \ldots$ & נ! & $1 \pi \pi$ & $i$ & $!$ & $3, \pi \frac{1}{2}$ & $3 \frac{1}{4}$ \\
\hline $11.11 .1, \ldots$ & $4: 2$ & $1: 11$ & i; & 1 & $40 \ddagger$ & $\because 3$ \\
\hline Ii. $\quad . \ldots \ldots$. & $\because 1$ & $14 ! t$ & $\pi$ & $i$ & $: 36$ & $\because \frac{1}{2}$ \\
\hline$F F \ldots \ldots \ldots$ & $\because 4$ & $1<. j$ & $i$ & $\tilde{\tau}$ & $: 36$ & $3 \frac{2}{4}$ \\
\hline$\therefore$. & $: 3 ;$ & $1 \% 0$ & $i$ & $\checkmark$ & $: 36$ & $3 \frac{1}{2}$ \\
\hline$F 1 ; \ldots \ldots$. & $2: 3$ & 18,0 & $\pi$ & 10 & $: 34$ & $2 \frac{4}{4}$ \\
\hline $1 ; 1 ; \ldots \ldots \ldots$ & $: 3$ & 195 & i & 4 & $: ; 0$ & $\because \frac{1}{2}$ \\
\hline$\because 11 \ldots \ldots \ldots$ & 24 & 161 & $\pi$ & !) & 3.5 & $3 \frac{2}{4}$ \\
\hline $11 \ldots \ldots \ldots$ & $2: 3$ & $14 . j$ & $i$ & 10 & 40 & 4 \\
\hline I'. $\delta \ldots \ldots$ & $\because:)$ & $15 x$ & ij & $\tau \frac{1}{2}$ & :3:5 & $\because \frac{1}{6}$ \\
\hline $1 ; 1, \ldots \ldots \ldots$ & $: 31$ & $14 . \overline{1}$ & i) & $!$ & $\because 4$ & $3 \frac{1}{4}$ \\
\hline $1, \ldots \ldots \ldots$ & ! & 1.5 .5 & ; & 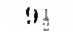 & 3 & $: 3$ \\
\hline$\because \quad \forall \ldots \ldots$ & $\because: ;$ & 1111 & 5 & 10 & $3: 3 \frac{1}{2}$ & $\because$ \\
\hline $.1 . \quad \forall . \ldots \ldots$. & 21 & $1: 30$ & 5 & $T \frac{1}{3}$ & :3:" & 27 \\
\hline [1. W . . . . . & $\because \because$ & $16 . j$ & ij & 1 & 涼 & $3 \frac{1}{2}$ \\
\hline$[\therefore-\ldots \ldots$ & $2 ! !$ & $16 ; 1$ & 5 & $10 \frac{1}{2}$ & $3: \overline{1} \frac{1}{2}$ & $\because \frac{1}{2}$ \\
\hline i. $-\ldots, \ldots \ldots$ & $: 30$ & $1: 35$ & i) & $4^{2}$ & i3i & $3^{2}$ \\
\hline . & $: ; 0$ & $10 i 2$ & 5 & $9 \frac{1}{2}$ & 38 & $3 \frac{1}{4}$ \\
\hline $15.1 . \ldots \ldots$ & $\because 7$ & $1 \times ?$ & ; & $0^{2}$ & 39 & $3 \frac{1}{2}$ \\
\hline . $\quad 11 \ldots \ldots \ldots$ & 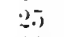 & 301 & 6 & 0 & $39 \frac{1}{2}$ & $4 \frac{1}{3}$ \\
\hline $.1 .16 \ldots \ldots \ldots$ & $2 \%$ & 1.50 & $\bar{j}$ & $7 \frac{2}{2}$ & 38 & $3 \hat{t}$ \\
\hline J. $\mathbb{H}_{\ldots} \ldots \ldots \ldots$ & 24 & $1: 30$ & $\pi$ & 6; & $: 3: 3$ & 3 \\
\hline$\left({ }^{\prime} \ldots \ldots \ldots\right.$ & $3: 2$ & 11.5 & i & $x \frac{1}{2}$ & (3) & $\because 4$ \\
\hline$r .11 \ldots \ldots \ldots$ & 4:; & 149 & 6 & () & 39 & $3 \frac{1}{2}$ \\
\hline
\end{tabular}


bered, howerer, that the distance between the midstemal and left mamillary lines is by no means always the ease. I have not infrequently found the left nipple situated 5 inches from the midsternum. Mleasurenents of twenty-nine of my stments, taken for the purpose of deternining variations in this regard, gave the results showi in the table on the opposite page.

These figures indicate plainly that the only accurate means of determining the boundaries of the heart by perenssion lies in measuring the distance to which the area of decp-seated dulness extends to the left of the median line. The size of the normal heart, as shown by perenssion, has already been stated in the introductory chapter.

One often obtains valuable information by the sense of inereased resistance on firm percussion, and hence the value of Ebstein's palpatory percussion. I am in the habit of verifying the results of perenssion in the ordinary way, by recourse to anscultatory perenssion, and am frequently surprised and gratified to see how elosely they correspond.

Auscultution.-Here, too, much depends upon the thickness or thinness of the chest-wall. If hypertrophy exists. the first sound at the apex is prolonged and of low piteh, while the second is usually clear and ringing. In some cases the systolic sound is muffled and indistinct. At the base of the heart the aortic second is sharply accentuated, ringing, or it may be so intense as to be actually banging. There is also intensification of the pulmonic second sommd when the left ventricle begins to fail, and at the base of the heart one sometimes deteets reduplication of the seeond somul. If the first in the region of the apex is short and sharp, resembling the normal second, it indicates dilatation rather than hypertrophy.

Oceasionally the heart-sounds take on the canter-rhythm deseribed at length in the introductory chapter. This characteristic rhythm is limited to one or the other ventricle, and therefore to the neighbourhood of the left nipple. It is especially likely to appear in left-ventricle dilatation consequent upon a granular kidney, but, according to Fraentzel, occurs, although rarely, in enlargement of the heart from other eanses. This gallop rhythm must be kept distinct from reduplication of the second sound heard at the base, and from that apparent or simu36 


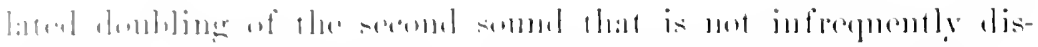

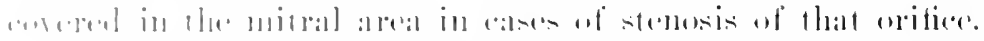

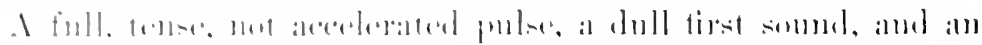

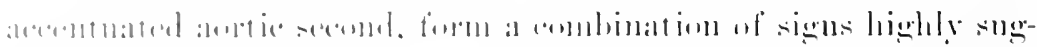

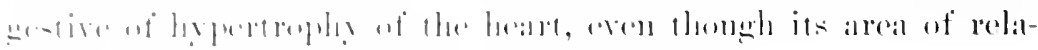

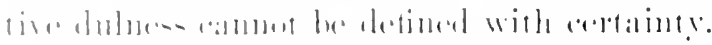

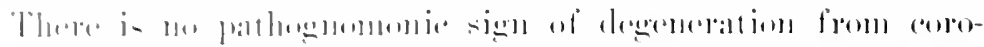

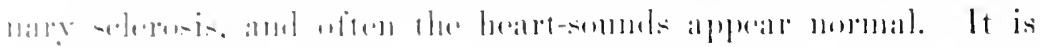

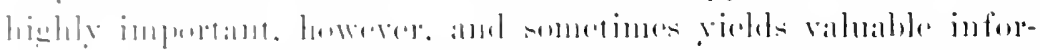

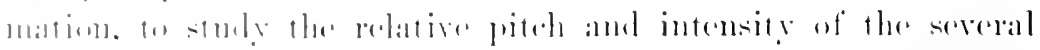

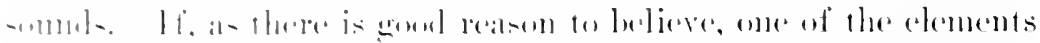

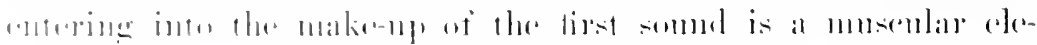

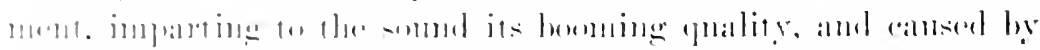

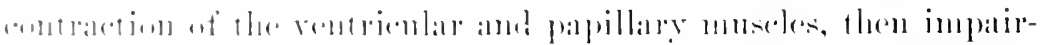

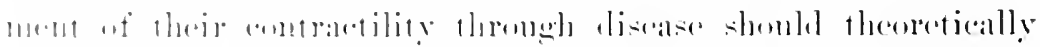

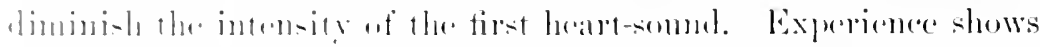

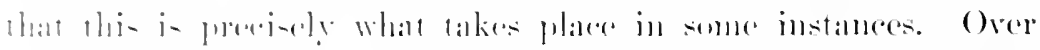

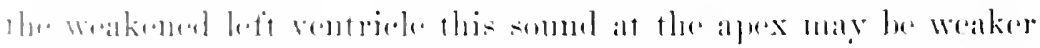

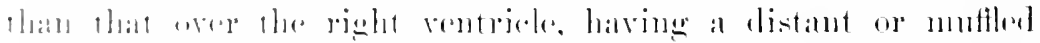

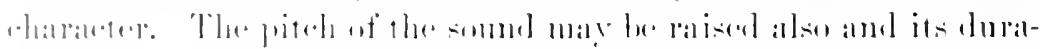

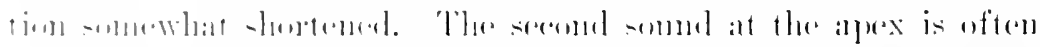

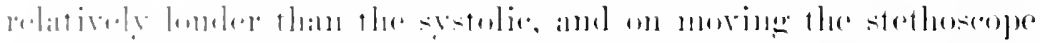

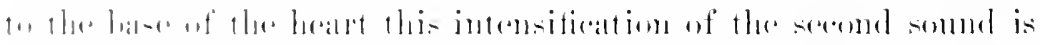

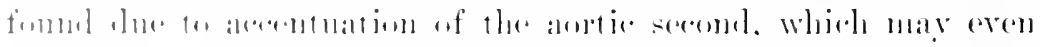

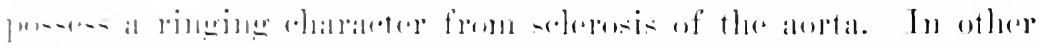

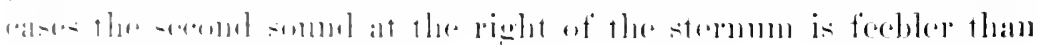

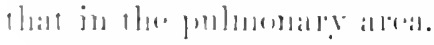

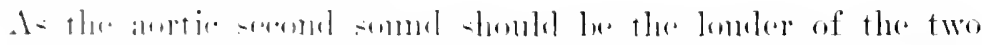

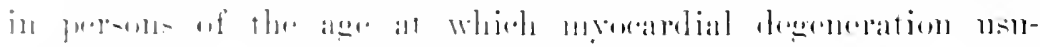

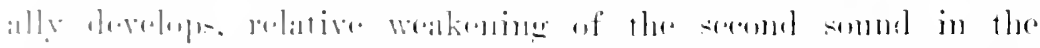

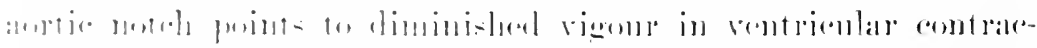

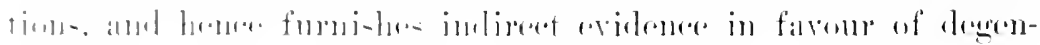
1.1911 ints.

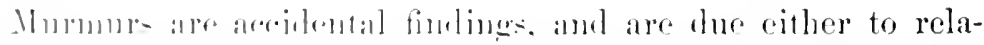

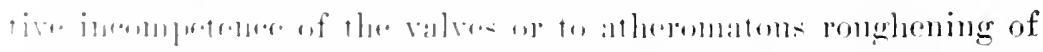

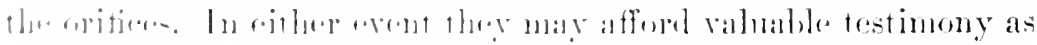

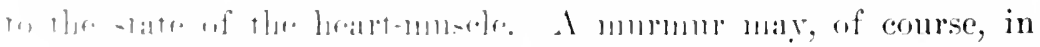

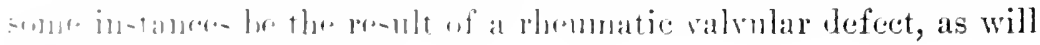

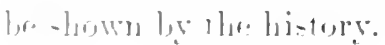


Diagnosis.-From the foregoing, it is evident that in the diagnosis of degeneration of the myocardium, but linited information is derived from a study of the heart. There is no form of cardiac discase, therefore, in the diagnosis of which so much depends on the judgment and experienee of the physician. In valvular defeets there are murmurs to serve as guile-posts; in hypertrophy or dilatation there is obvious alteration of size. In the affection inder consideration the volume of the organ may or may not be changed, and therefore great dependence must be placed on age, state of the vessels, history, and simptoms.

Age is so important an etiological factor that the development of cardiac insutficiency in an individual well on in years may be set down to legenerative changes with tolerable certainty. It is quite otherwise when heart-weakness, without obrions signs of disease, derelops in a person about the middle period of life. In such persons careful seareh should be made for traces of premature decay, for indications of renal disease, or a gouty diathesis, etc. There is an old saving that a man is as old as his arteries, and therefore the radials, temporals, and other peripheral vessels should be carefully palpated for evidences of thickening or for nodular deposits of lime-salts.

It may be necessary in some arses to make an ophthahmoscopic examination of the retinal artery for the signs of selerotic change which are said to first manifest themselves in this situation. The physician should note the appearance or not of preniature whitening of the hair. and examine the texture of the skin. I have more than once observed that persons with a strong suspicion of fatty degeneration of the heart have a skin that has lost its elasticity and feels peenliarly soft, as is often the calse in the aged.

The examiner should scrutinize the finger's and ears for chalky deposits, and the nails for those longitudinal ridges said to be indicative of the gonty state. In this way vahuable hints may often be ohtained.

The urime should be analyzed carefully, and repeatedly if necessary, for evidence of nephritis, since it is well known that degeneration of the myocardimm is a frequent accompaniment of chronic renal disease, particularly the interstitial form.

Ninute inquiry into the patient's history may elicit facts concerning fanily tendencies, personal habits, previous diseases, etc., 


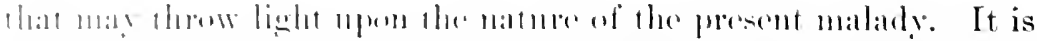

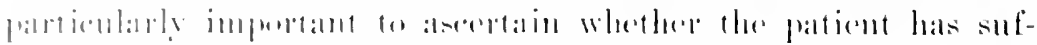

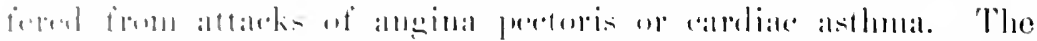

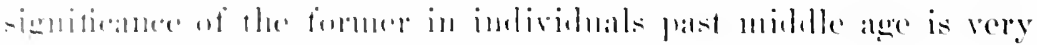

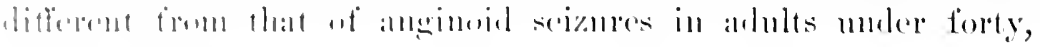

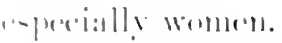

liven in -pite of the most painstaking investigation and atten-

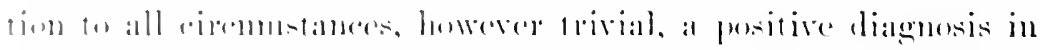

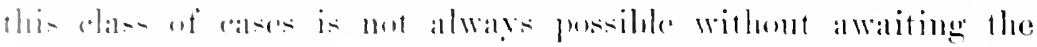

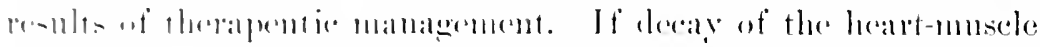

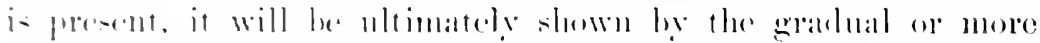

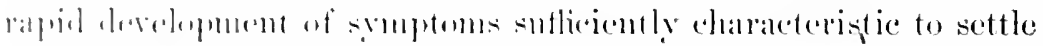

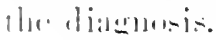

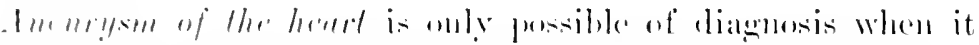

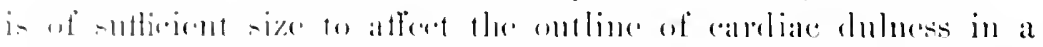

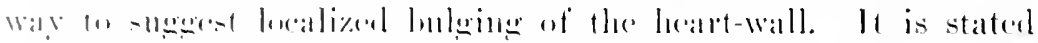

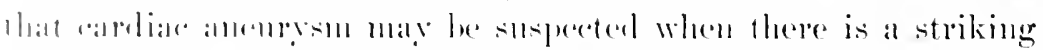

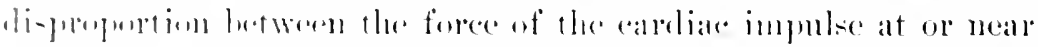
the a

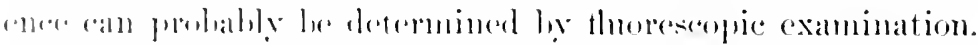

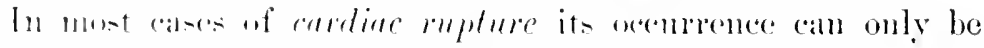

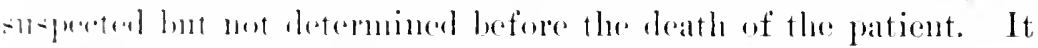

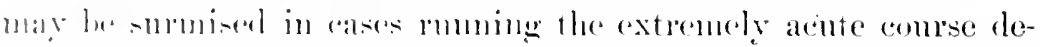

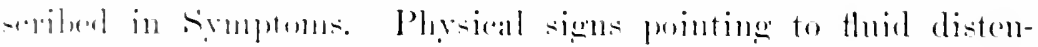

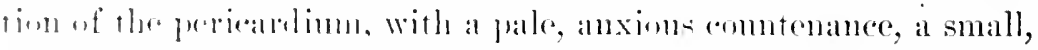

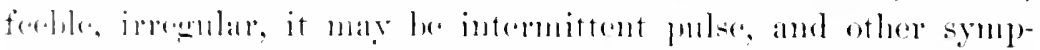

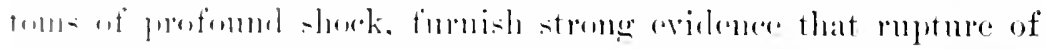

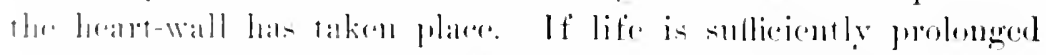

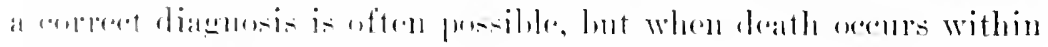

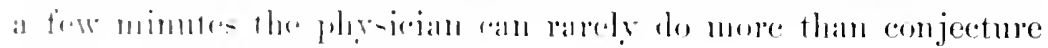

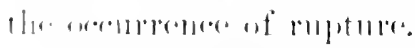

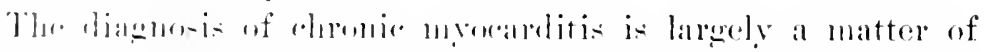

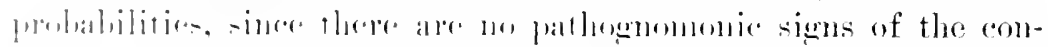

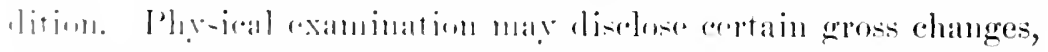

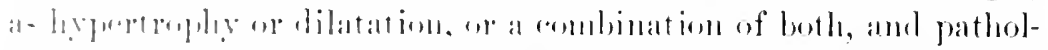

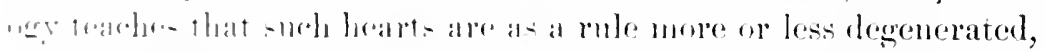

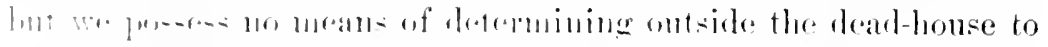

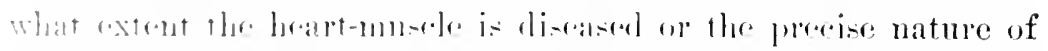

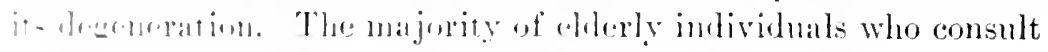


us becamse of eardiac symptoms do not suffer from the consequences of rhematic endocarditis as do the romng. They present evidence of cardiac incompetence; of this we an be certain, but concerning the state of the myocardimm we must take much for wrinted.

Prognosis. - This depends upon the eause, the degree of the hypertrophy, and the state of the heart-musele. If the high pulsetension is due to laxus consumption, and the individual is romng and robust, correction of his habits may lessen peripheral resistance, and may retard, if not wholly prevent, development of cardiac inadequacy. In cases of adranced renal or vascular disease there are two dangers: occurrence of apoplexy and the breakdown of the heart under conditions of unwonted strain. If the camse, whatever its nature, is persistent and not amenable to treatment, the ultimate prognosis is unfarourable, becanse there will at length come a linit to the hypertrophy and the heart-wall will gire way:

So long as the myocardium is functionally healthy-that is, receives sufficient nourishnent-the hypertrophy proves a preservative measure; but when incompetence sets in, the most farourable management can do no more than defer the evil day. Palpitation, and particularly intermittence of the pulse, are unfavomiale signs; they may be the first evidence that the heart is vielding to the unequal struggle, or by occasioning incomplete emptring, and hence distention of the cardiae chambers, they may hasten the eoming on of dilatation.

In forming a prognosis in any given case one must take into consideration also the age and temperament of the patient, and the state of his general nutrition. The younger the patient and the greater his self-control, the better his prospects of maintaining compensatory hypertrophy and the less the Jikelihood of injury from excesses, emotional or otherwise. The further one gets beyond middle age the stronger the probability of the cardiac insnffieieney being due to myocardial degeneration, and of the obstacle to circulation proving too much for the weakened heartwalls.

When serious symptoms at length set in there is small prospect of medical skill being able to do more than patch up the erippled heart. In a word, the prognosis depends upon the relation 


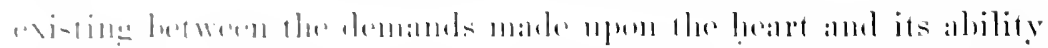

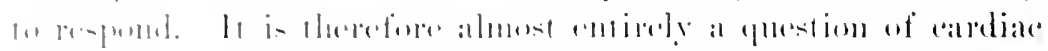

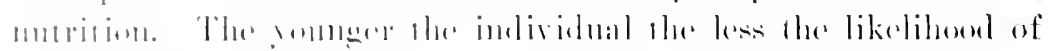
-

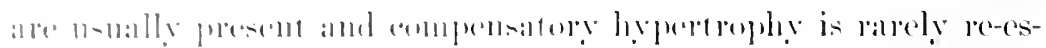

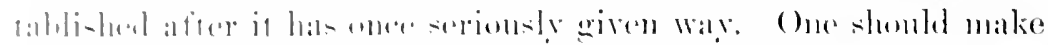

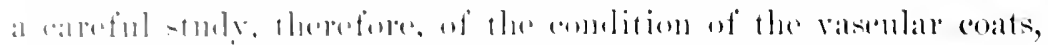

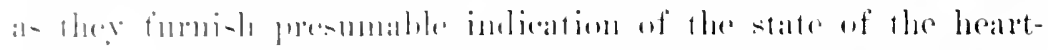

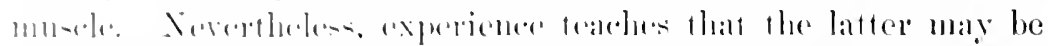

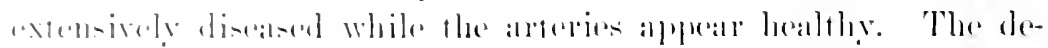

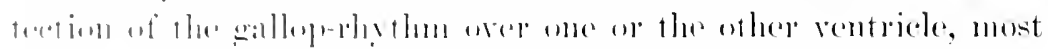

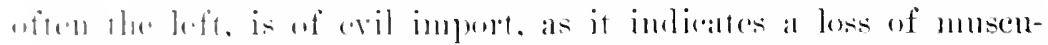

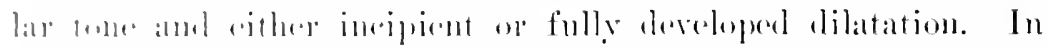

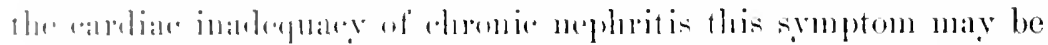

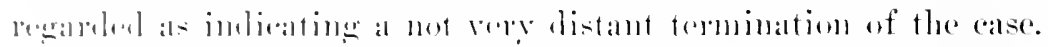

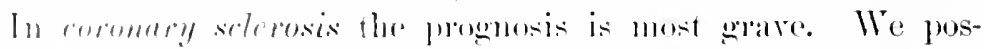

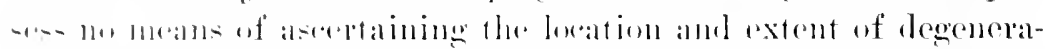

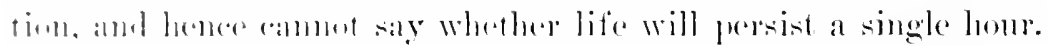

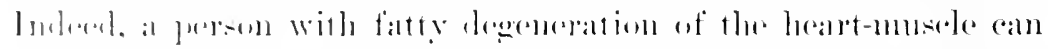

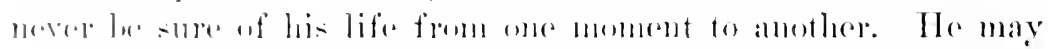

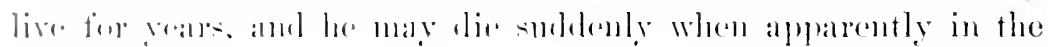
lix-i if health.

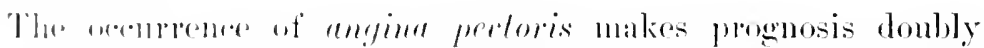

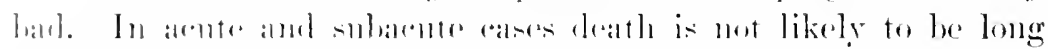

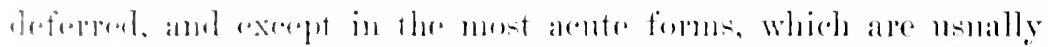

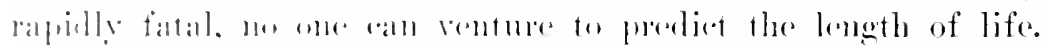

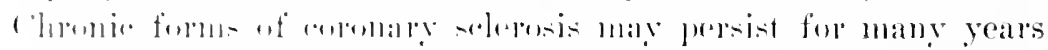

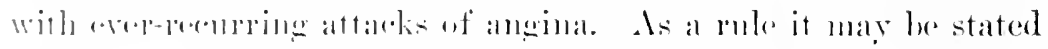

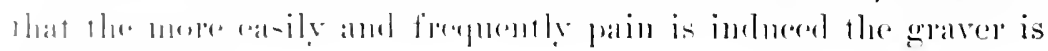

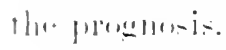

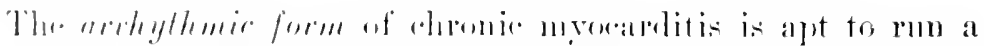

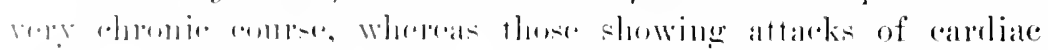

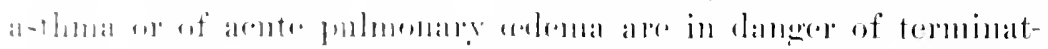

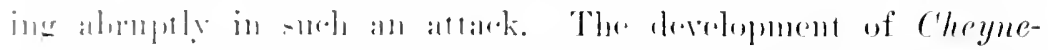

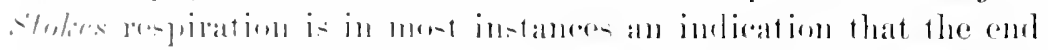

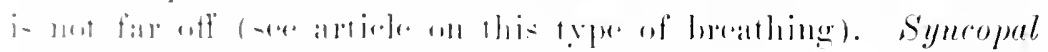

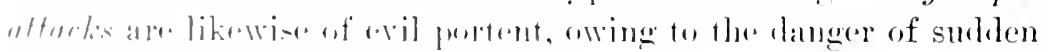

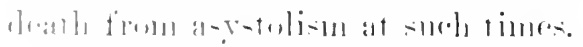

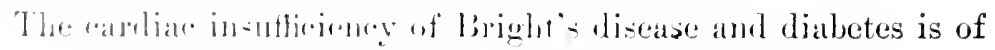


particularly great gravity, since the abnormally high pulse-tension, which is the canse of the cardiac enbarrassurent, annot be remored, and prevents the left ventriele from regaining its lost power. I serious brealidown in this class of cases, therefore, may be said to be irreparable.

Finally, the prognosis is also determined by the presence or absence of sclerotic changes in the kidness, lungs, and liver, since the healthier these organs the less the strain upon the diseased heart. Chronic gastritis, with its flatulent distention of the hollow riscera, influences prognosis both through mechanical pressure and the generation of injurions toxines.

Acute bronchitis or other illnesses, in particular pneumonia and influenza, must always fill the medical attendant with alarm, since it requires but little to throw the balance one way or the other in these cases, and acute infections are rery liable to prove the immediate cause of death in cases of cinonic myocarditis, which, withont such an interenrrent affection, might have persisted for years longer. Conditions of environment also affect prognosis, an individual who is able to spend his winters in a mild climate and avail himself of all other means of warding off injurious influences being, ceteris paribus, likely to live longer than he who is compelled to toil on for his daily bread.

In conchusion may be quoted Inchard's emphatic statement concening cases of myocartial disease: "Their evolution is latent, their begimnings insidlons, their conrse paroxysmal, their progress interrupted, their visceral complications rarious, and their explosions of cartiac insufticiency are sudien."

Treatment. - This must be considered first with regard to preservation of cardiac competence, and second with reference to the stage in which heart-power is either showing signs of failure or has actually been lost-pronounced cardiac insufficiency. Medical aid is not sought so long as the mrocardium is adequate, and if the discovery of hrpertrophy is made, it is only by accident. When, however, such discovery is made, it should be the physician's duty to eall the patient's attention to the dangers threatening him in the future, and to show him how his habits of life are likely to affect his heart.

The management is now along the line of prevention; patients who habitually eat or drink too much must have the evils of glut- 


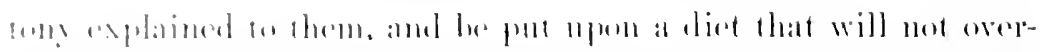

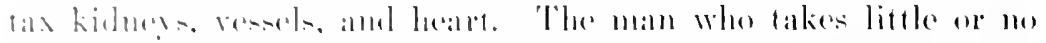

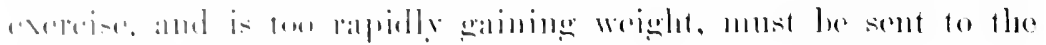

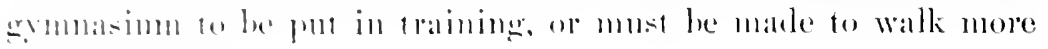

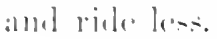

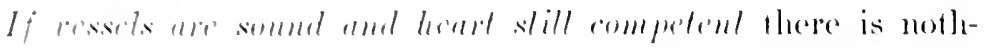

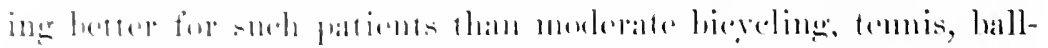

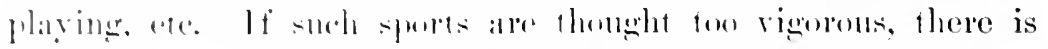

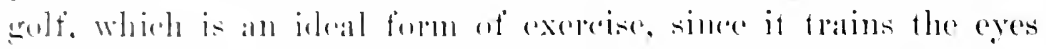
and museles withome smbjecting wate organs to undue strain.

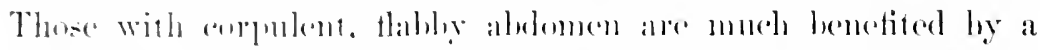

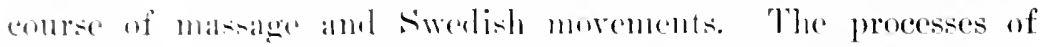
divestion and assinilation and impuroverl, and constipation, if

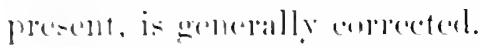

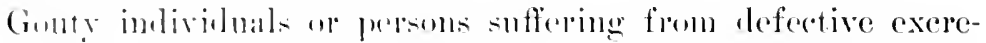

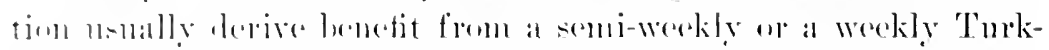
ish hath. This not mly incerases elimination, lunt lessens blood-

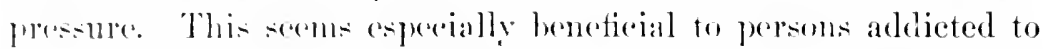

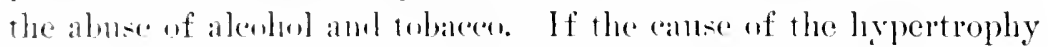
is non preventalile, or if vasemlar and renal changes are pro-

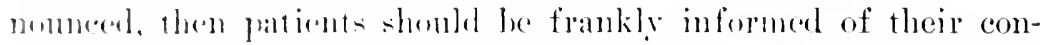

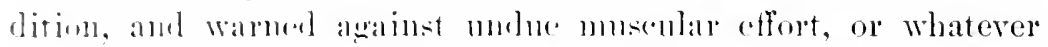

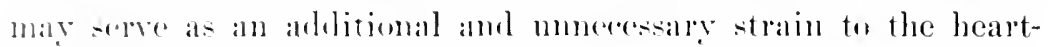
muscle. Arterial and kidney disease all for still greater strictness in the matter of aliet.

A highly nithenoms lietary often serves to intensify the albealy exi-ting bigh arterial tension, while a regetarian diet, or

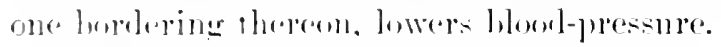

J)igertive distmblaner and constipation must, if possible, be

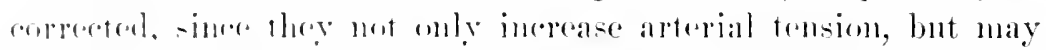

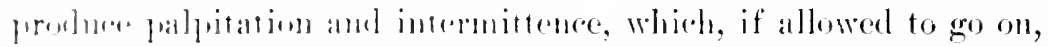

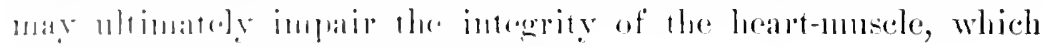

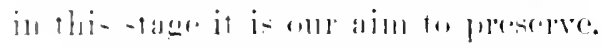

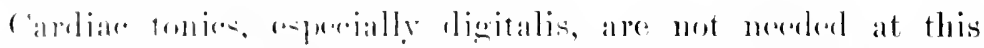

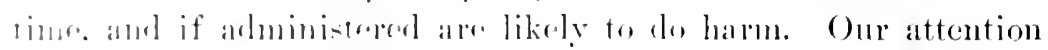

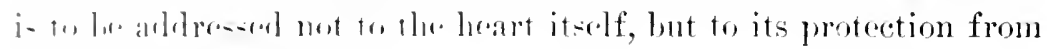
all injurian= iuthurmers.

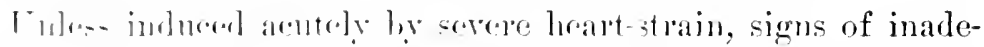

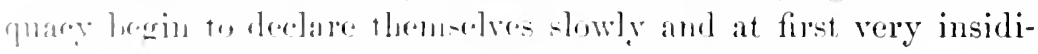


onsly, so that the managenent may Je said to pass almost impereeptils!y inte the treatnent of symptoms directly dore to:

Commencing Loss of IIeart-poner.- - Imomg the earliest signs of this secomel stage may he tachroardia and palpitation. These do not indicate exessive hypertroplyy, for such docs not exist, but are tokens that the orean is finding its work too heary. Therefore an attrmint shruld be made to discover amel remove possible somres of irritation and increaserl peripheral resistance before aconite or routrum, digitalis, or strophanthus are prescriber. The former are purerful cardiac depressents and must be nsed carefully, but in the past there vears have been employed by me frequently. The precise indieations for their ne cannot be stated, lunt secm to be a dangeromsly high blomblessure with ensequent strain of the leart-ralls.

A too rapid or violont action of the heart in this stage may le due to digestive disorelers, eonstipation, or fanlty rlimination which raise hlood-pressure and hence subside with removal of the canse. To this end I find very satisfactory a periodic dose of calonel, or blue pill followed by an aperient water.

It may le well to restricet the diet ly entting down the red meats and limiting the total amome of water and other fluids which is taken by the patient. The former raise pulse-tension by reason of their extractives, while the lattre distend the stomach and abdominal vessels, thus increasing the strain on the left ventricle.

Shomld blood-pressure still be too high, it may be reduced by one of the nitrites or by an iodide. Three to five grains of potassium iodide may he given in escence of pepsin after meals without disturling the stomach, or nitroglycerin, $\frac{1}{10}$ of a grain, may be given every three hours. Erythrol is said to be more lasting in its effects on the arterioles, but this adrantage has not seemed to me sufficient to compensate for its greatly increased cost.

Shomld such treatment fail to control cardiac action, then it is well to resort to digitalis or allied remedies. They may be giren in conjunction with iron, arsenions acid, or strechnine.

Gentle exereise is now very beneficial ly its action on the heart and rascular systen.

It causes dilatation of the intermusenlar arterioles, promotes venous flow, and thus tends to restore circulatory equilibrimm, re- 


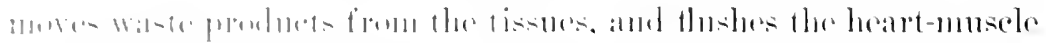

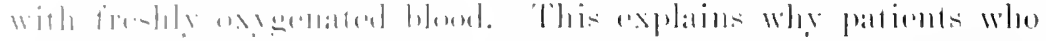

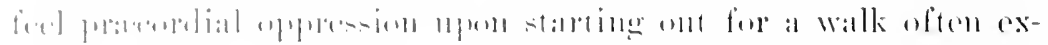

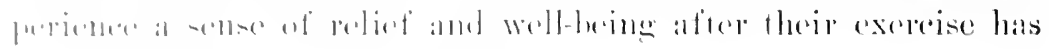

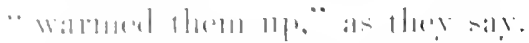

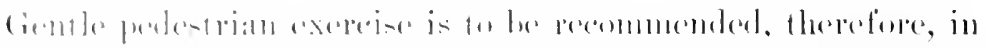

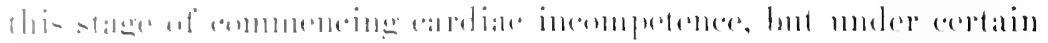

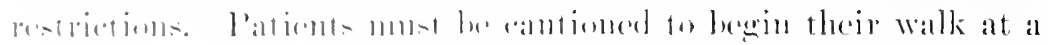

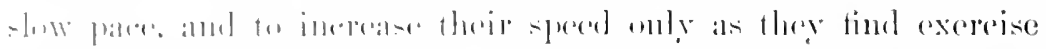

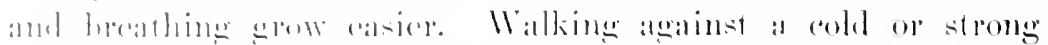

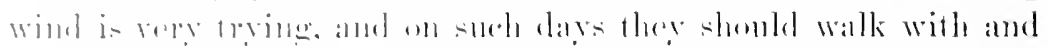

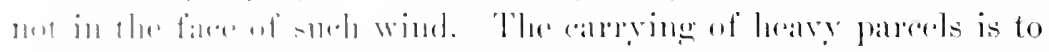

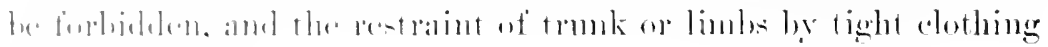
i- inallui--ihle.

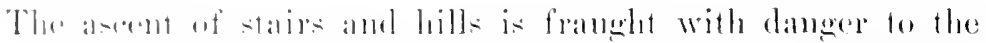

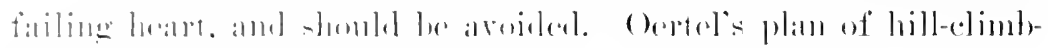

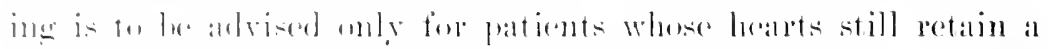

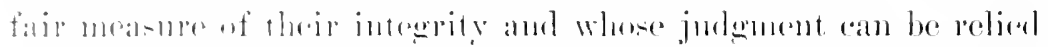

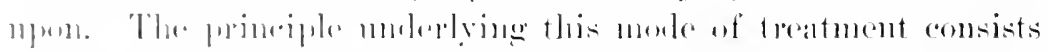

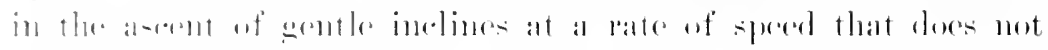

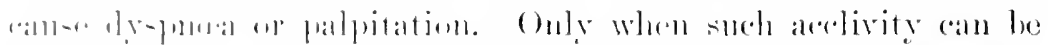

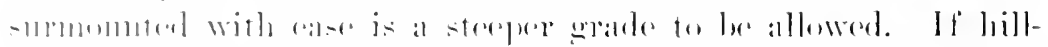

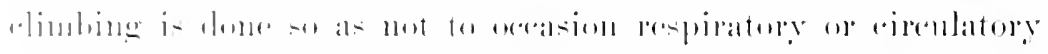

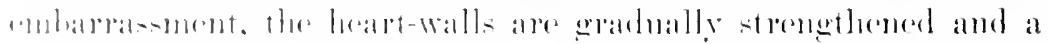

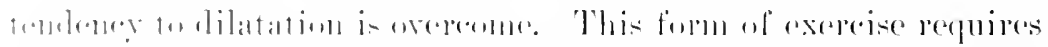

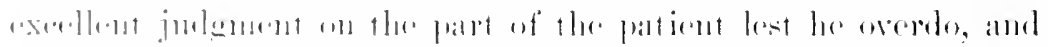

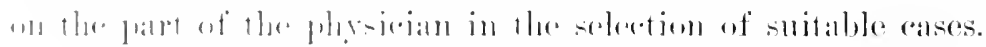

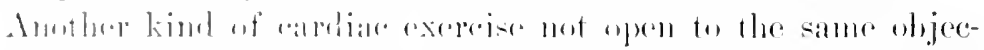

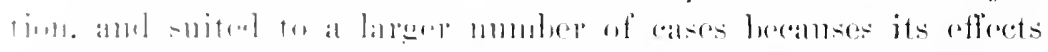

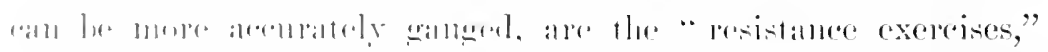

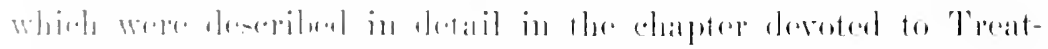

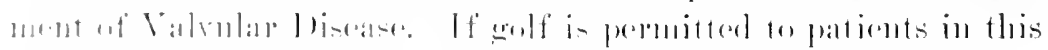

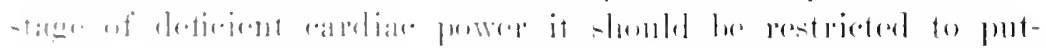

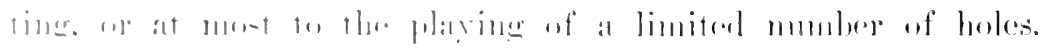

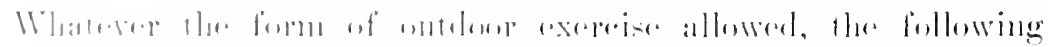

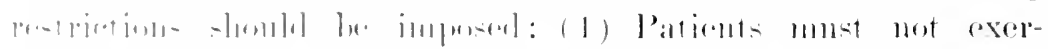

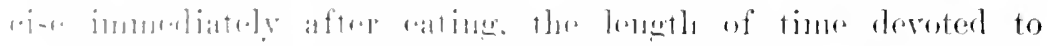

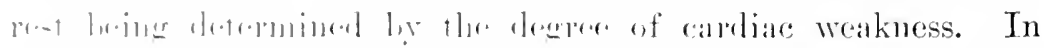

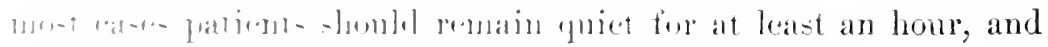


when the heart is feeble Fracntzel does not allow exercise before three or four hours after a meal. (2) Nalking or other exereise should not be indulged in to the point of fatigne. In some eases indeed it shonld be for only a short period, sereral times repeated during the day. (3) In eases showing decirled indications of a threatened loss of adequacy, rest in a recumbent posture must be insisted on at the close of exercise.

As our aim at this time is to prevent the heart from becoming still more taxed in its labours, and blood-pressure is increased by hearty feeding, it is necessary to restrict the diet. It is quantity even more than quality that is hamuful, and hence patients should be told to eat lightly. Too much liquid raises blood-pressure in the abdominal ressels, and therefore it is well to restrict it to 8 or at most 10 ounces with each meal. Alcoholic stimulants, if permitted at all, must be in the form of a light, dry wine, or still better of a modiem of whisky, largely dihnted with water. Tobaceo is to be allowed in great moderation, a small light eigar or a single pipeful of mild tobaceo after meals. IInchard, Fraentzel, Frehl, and others are very strennous in their opposition to strong Irarana cigars on the gromel that they angment arterial tension, and state that many middle-aged men with wakk hearts find ont for themselves that they are obliged to substituie mild donestic cigars for the heary Ifarana ones to which they have been acenstoned.

Excesses of all kinds are injurious, and these patients are to be warned against the harmful effect of frequent sexual indulgence. Indeed, the principle that must govern the daily life of these individuals is moderation in all things. If pationts give dne heed to the doctor's admonitions ther may snceed in holding their hearts in statu quo for a considerable time. Cnfortumately, however, the tendener of myocardial decay is downward, and henee we are called on, soon or late, to institute actire treatment for the relief of srmptoms which mark the arrival of the third stage.

Cardiac Incompetence Pronounced.-Tenous and visceral congestion now hegins to manifest itself, and calls for the more vigorous and frequent use of cathartic remedies. It is also gencrally necessary to resort to cardiac tonies, and of these digitalis heads the list, although strophanthus, spartein, convallaria, adonis vernalis, and caffeine are all useful. Whenerer digitalis is admin- 


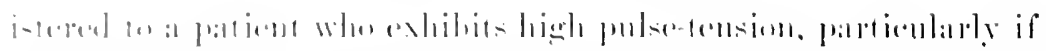

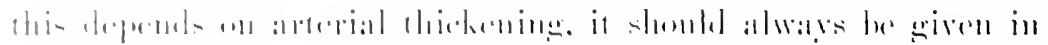

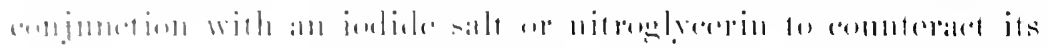

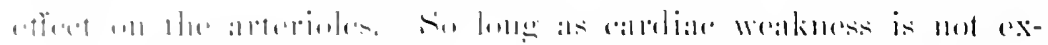

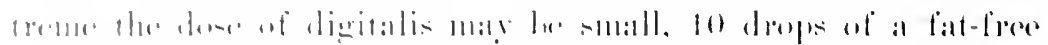

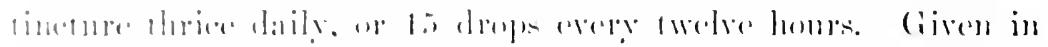

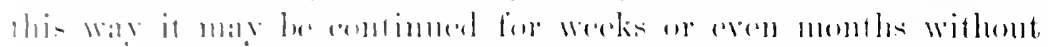

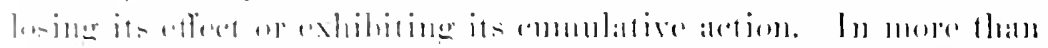

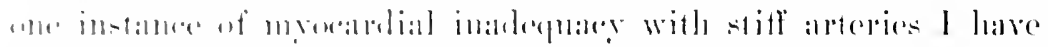

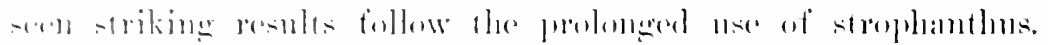

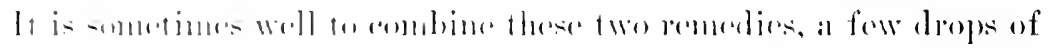

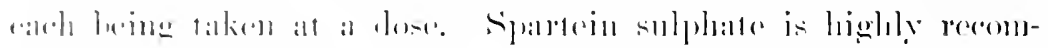

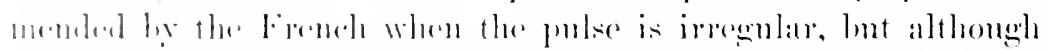

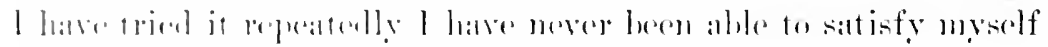

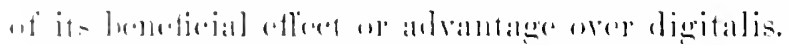

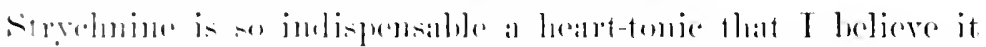

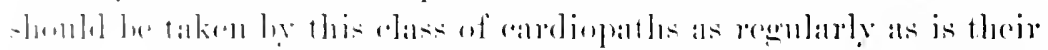

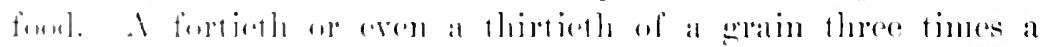

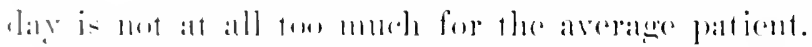

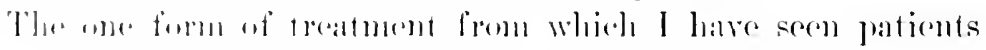

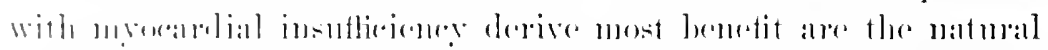

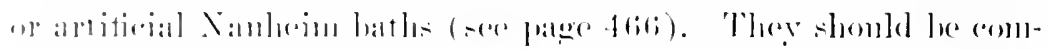

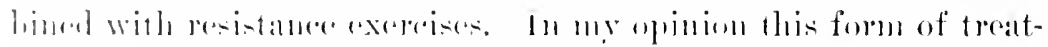

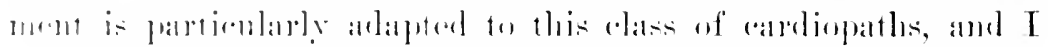

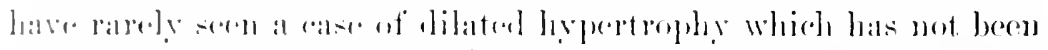

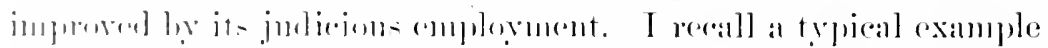

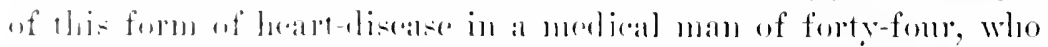

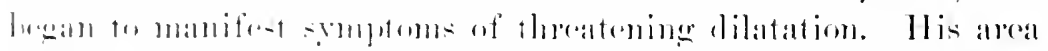

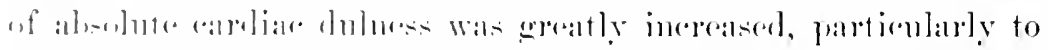

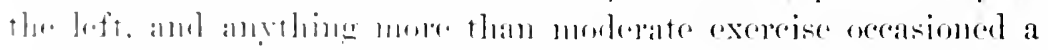

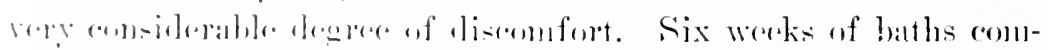

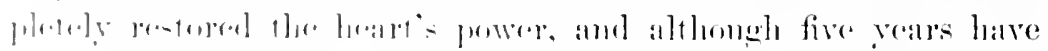

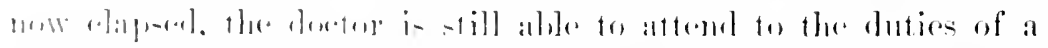

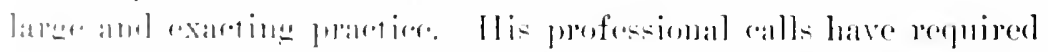

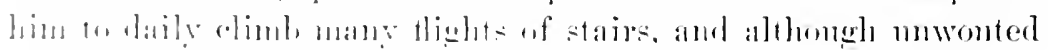

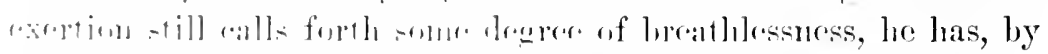

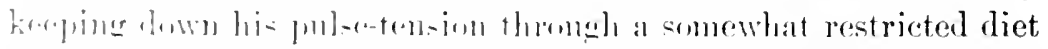

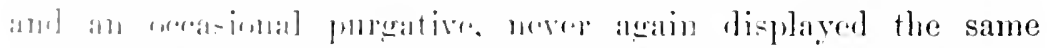

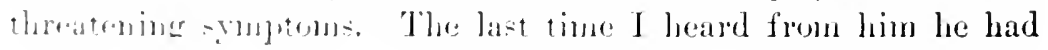


taken to a bicgele, and by atroful riding succeded in still further strengthening his heart. At the close of his conlse of baths absolate duhoess had returned to normal, and the relative become manifestly reduced. He weighed over 200 pounds, and of course still has a comsiderable degree of cardiac hypertrophy. In the summer of 1899 I treated by means of haths and resistance exercises two middle-aged gentlemen, anch with enormous hypertrophy. The symptom chiefly complained of hy one was great pracordial oppression, amonnting almost to what Gaindner would call " angina sine dolore," whenever walking was attempted about an hour after meals. IIis pulse was slow and tense, and his heart enomonsly enlarged. At the end of treatment the heart was not much reduced in size, but the somnds were manifestly stronger, and the pulse had become fuller, stronger, and slightly more rapid. Te then fassed a month at his smmmer cottage, where he daily indulged in light calrpentering, and was able to ascend the sandy hill on which his home stood withont experiencing the former disconfort. I very restricted diet and the daily use of small doses of the tincture of strophanthus and iodide of sodimm have been rewarded by contimned improvement. The second patient also derived much benefit from the baths and exereises, although, as in the preceding case, the area of deep-seated cardiac dulness did not becone permanently diminisher. I was frequently able to deternine a rednction in the size of the heart following a bath, and he always experienced a sense of well-being and lightness in the chest. In this case there was a very obstinate indigestion, and the urine always contained an excess of solids, althongh it never showed albumin or casts. His pulse was for the most part irregnlar and intermittent, seeming to be governed in this respect by the intestinal indigestion, for every time his digestive disturbance became aggravated his pulse grew more irregular. IIe was subsequently indnced to take a conrse of massage and Swedish gymuasties, with the result that not only did his corpulent abdomen become greatly redneed in size, but his digestion improved, his pulse became regular for days together, and he said he felt as well as he ever did in his life. The heart, however, still showed great enlargement.

In both these cases a change of habit as to food and exercise lowered blood-pressure, treatment of the heart restored its 


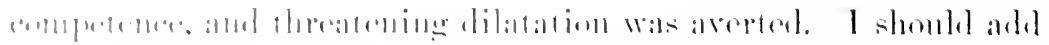

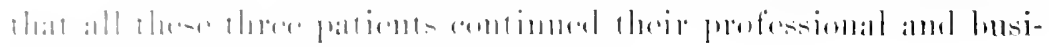

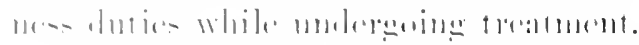

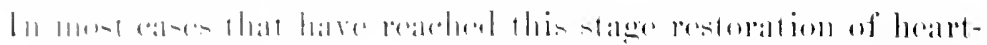

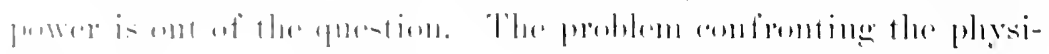

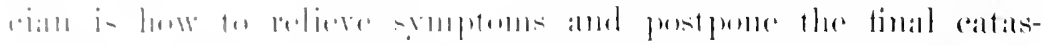

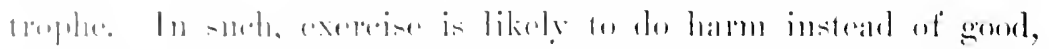

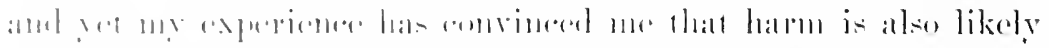

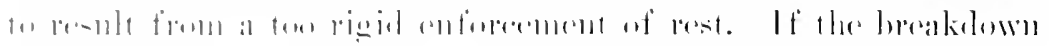

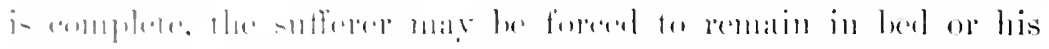

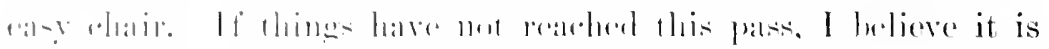

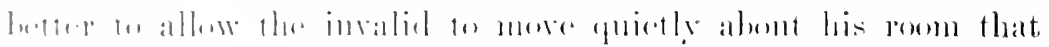

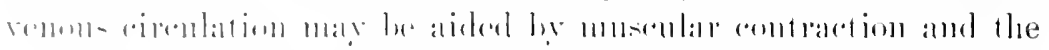

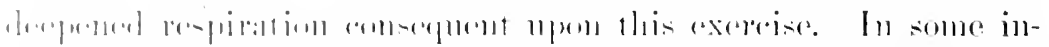

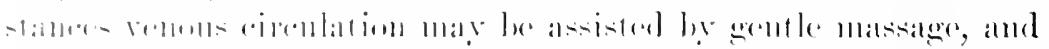

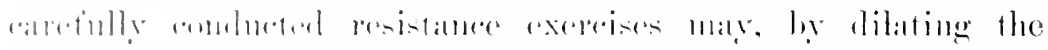

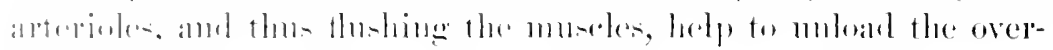

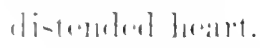

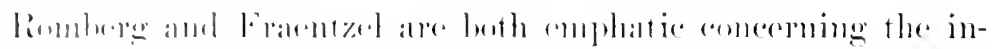

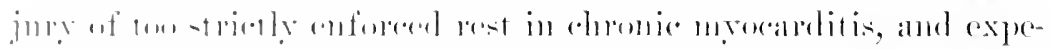

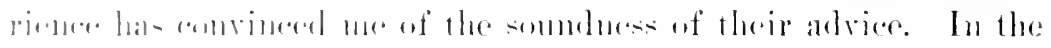

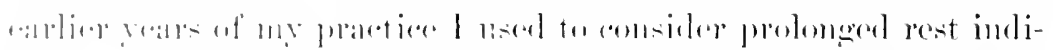

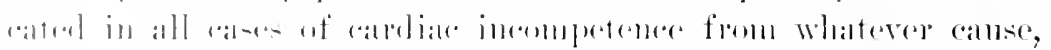

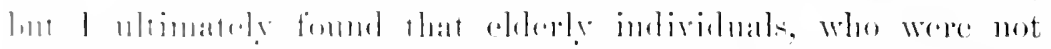

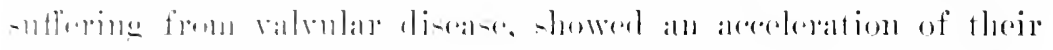

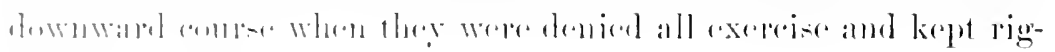
(1)

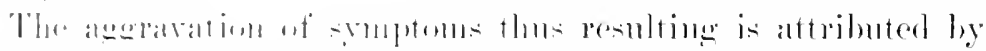

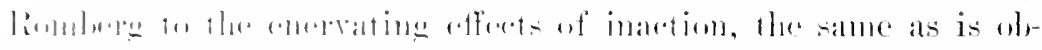

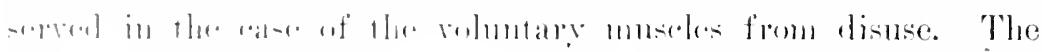

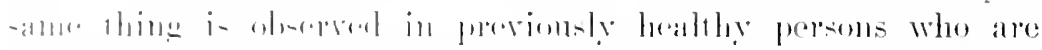

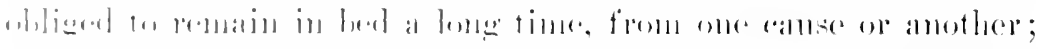
when a a

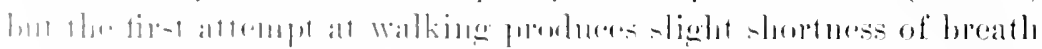

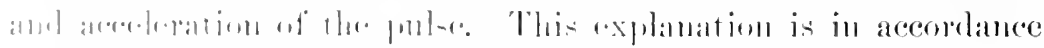

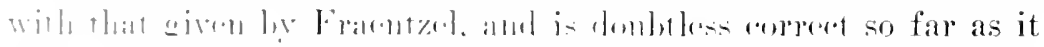

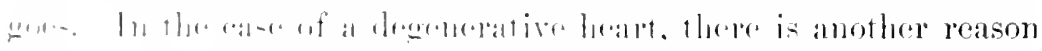

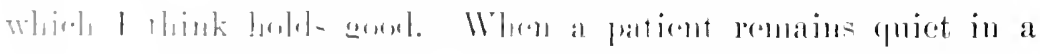
recunbent pe-ition the reneus circolation is deprived of two fac- 
fors of great importaner in its maintenance. These atre muscular

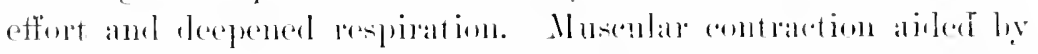

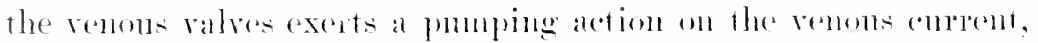
and also the flow within the abeorbents. Abolish the nse of the museles and yentemove one of the well-known anses of venoms cirendation. Furthermore, with rest in bed the patient breathes

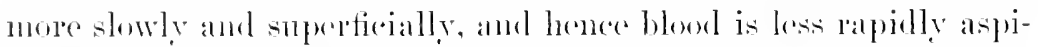
rated ont of the erealt verins into the right licald, and a second junportant faretor in maintaining venoms flow is diminished.

The work of maintaining the cirendation now devolves mpon the heart even more than muder normal conditions. It must eontract more powerfully that its driving force may he felt thrometsont the entire circle propelling the blend ouwarl in the veins. In those eases in which breathlessness om effort is a promomneed fear ture absolute rest for a time may he beneficial, but it will not do to let these patients remain quiet for ioo long a period.

The heart-mmsele is watk, and camnot be left for too long a time to eope mairled with the labsur of maintaining adequate blood-flow. Instearl, ilerefore, of complete rest, it is better that the phrsical repose be intermpted ly shert periods of gentle exercise. This last, howerer, is to be strictly controlled. The pationt must only la allowed to walk about his room, or at the most into the aljoininge room. Cnoler no eiremustanees is he to be allowed to climb stairs now to walk about som after a moal. He must be impressed with the danger of jumping up sudrlenly and of hurrying across the roum. If rery weak, and dypmer is considerable, he had better lean upon the arm of an attendant while taking his exereises.

The patient shomld also not be allowed to dress himself unaided, and he must be instructed not to strain at micturition or defocation, since, accorting to Sommerbrolt, straining during such acts raises blook-pressure reflexly, and has nore than once caused sudden diastolic arrest of the left ventricle.

If massage is employed it must not be applied to the abdomen, unles rery cantionsly, since it raises blood-pressure. Also, if resistance excreises form a part of the management at this time, those are not permissible which constrict the abdomen or necessitate the elevation of the arms to a level abore the patient's head, as they are likely to occasion dysumea and do larm. 


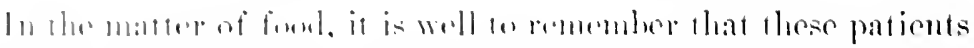

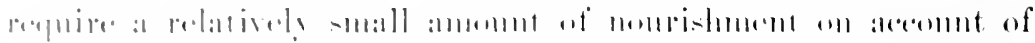

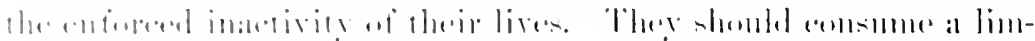

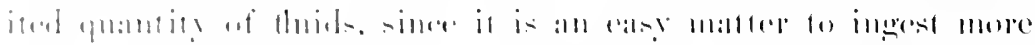

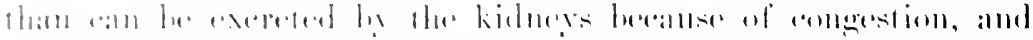

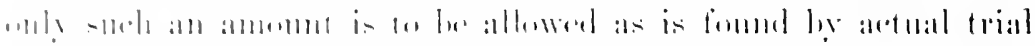

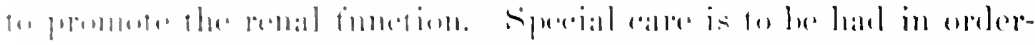

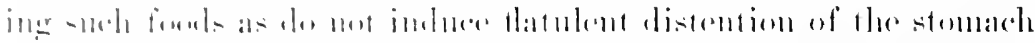

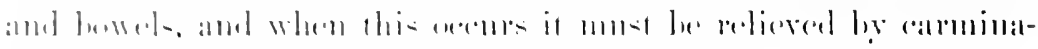

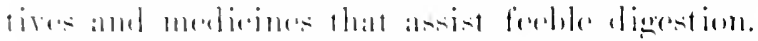

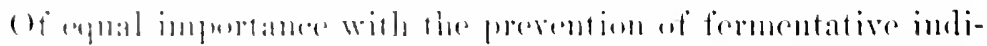

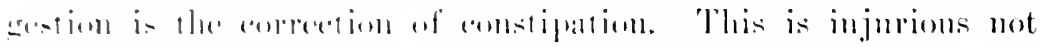

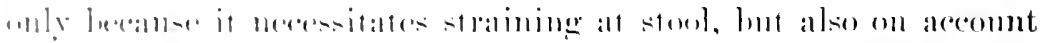

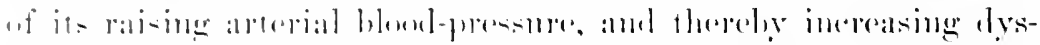

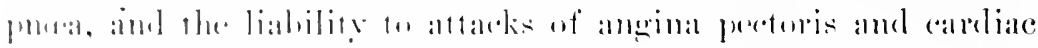
anthma. The patiom stomlel therefore take a laxative pill at bedtime. antaluing sume of the well-kmown ambinations of aloes,

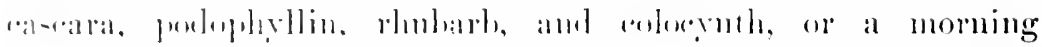
dranght of seme aperient watre. It will mot do to purge these

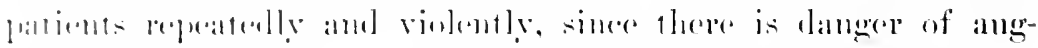

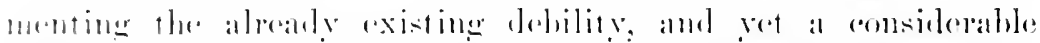

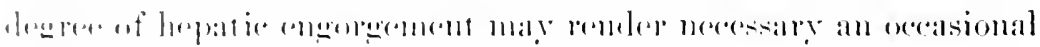
- haily lollowe.

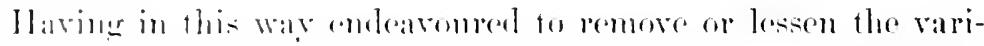

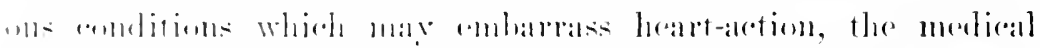

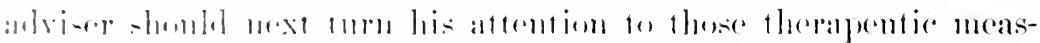

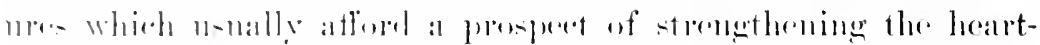

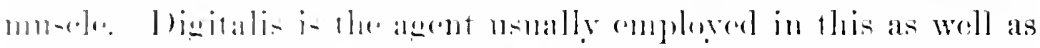

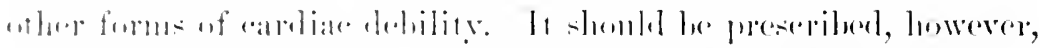

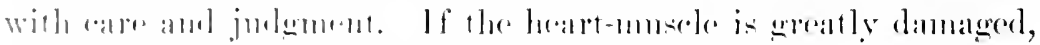

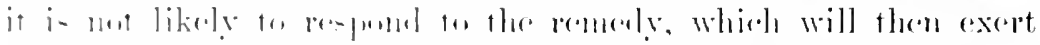

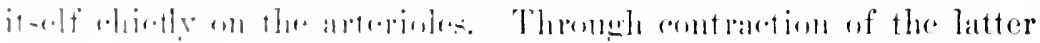

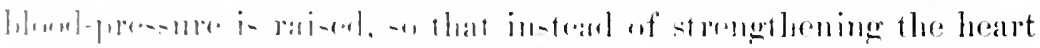

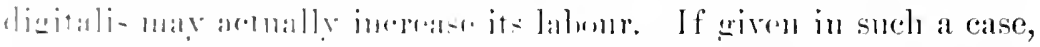

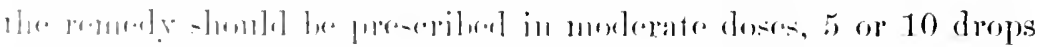

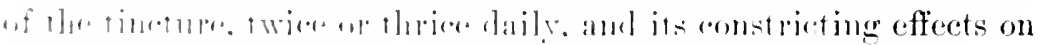

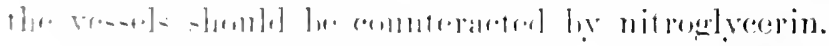

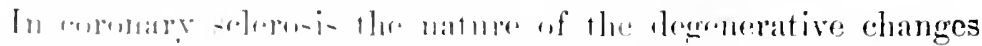

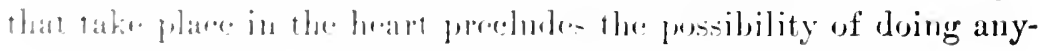


thing more than to relieve symptoms. In the most acute manifestations of the disease, the physician, who has been hastily summoned, is nstally alle to do no more than attest the fact of death. In the somewhat less acutely fatal cases with manifestations of profound shock stimulation is urgently indicated. Time should not be lost by sending for some favourite stimulant, lunt use should be made of whatever is at hand. A tablet of nitroglycerin, with which every physician is usually provided, may he placed mpon the tongne; and while an attendant follows this with $\frac{1}{2}$ an onnce of whisky or brandy, the physician shonld inject meler the skin $\frac{1}{8}$ of a grain of morphine. Twenty drops of spinits of camphor, or $\frac{1}{2}$ a drachm of aromatic spirits of ammonia, properly diluted, is also an efficient stimulant, and may be repeated at intervals of twenty minntes. Neanwhile, members of the family should fill bottles with hot water and place them about the body and linbs of the patient, who is then to be wrapped in blankets. A hot bag or bottle shomld also be placed at the pracordimm.

By these and other means every attempt is to be marle to restore the failing cirvulation. In some cases, unfortunately, all efforts are unavaling. but shomld the patient rally somewhat, stimulation is to be contimned in such doses and at such intervals as will maintain the heart's action. If after the lapse of a few hours it he thonght best to arminister food to the patient, this shonld be liquid and hot, as a coupful of somp or hot milk, to which the ammonia, whisky, or brandy nay be added. It nay now be well to order strychnine lyyomlemically, in doses of $\frac{1}{40}$ or $\frac{1}{50}$ of a grain evary two or three hours: but digitalis, stropinanthus, and the like are contra-indicated or are to be given cantionsly.

If the initial symptom is an attack of angina pectoris, nitroglycerin, 1 minim, and $\frac{1}{4}$ of a grain of morpline moler the skin, wili probably afford relief, and may be followed by hot whisky, and hot applications to the extremities and pracordinun, the subsequent nse of stimmlants being left to the judgment of the attending physician.

In subacute cases, which run their comrse in a few weeks, or at the most in a few months, the serions changes which the heartmuscle has nnderene place the restoration of compensation out of the question. Both the physician and patient must concern themselves with such measures as tend to make the downward 


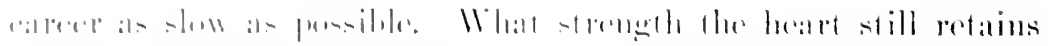

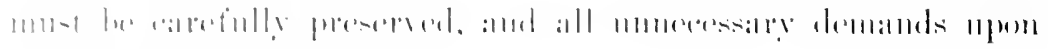

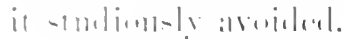

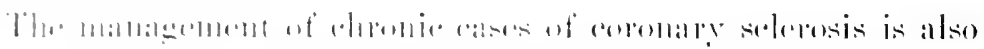

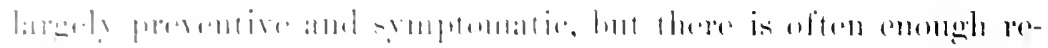

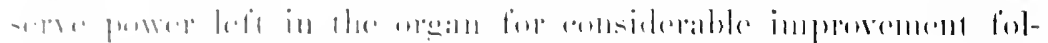

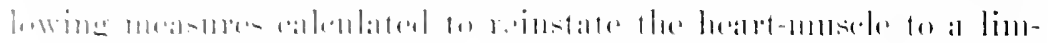

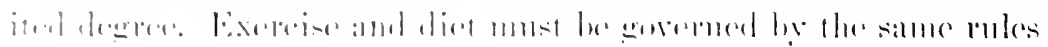

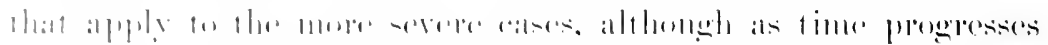

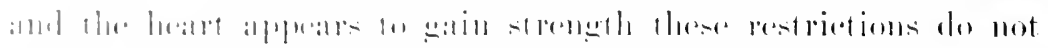

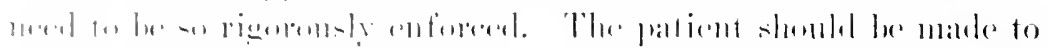

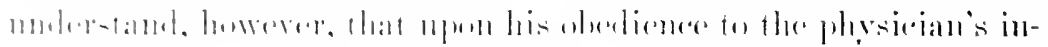

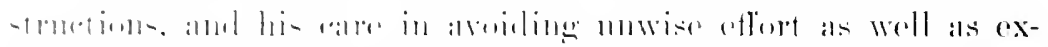

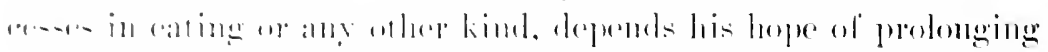

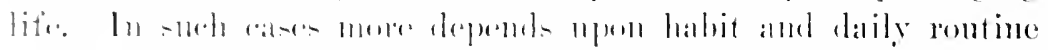

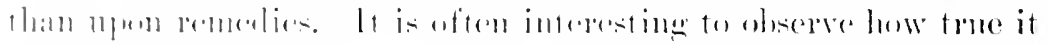

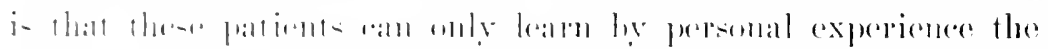

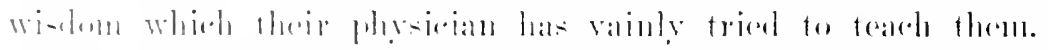

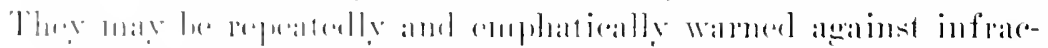

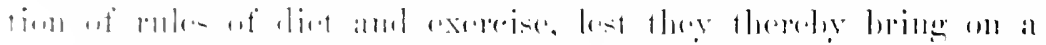

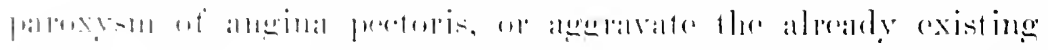

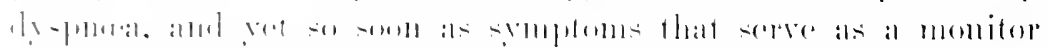

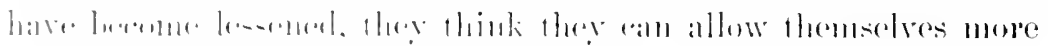

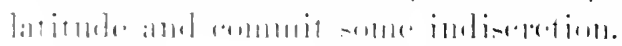

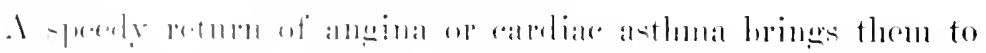

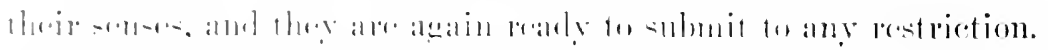

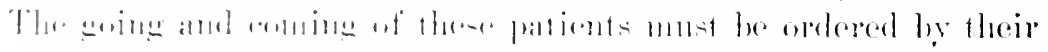

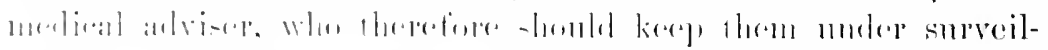

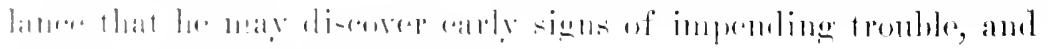

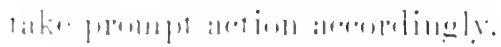

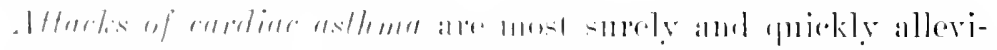

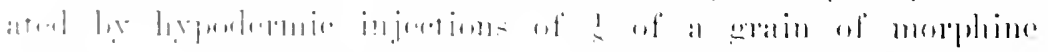

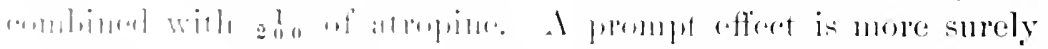

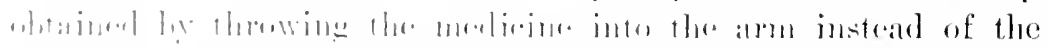

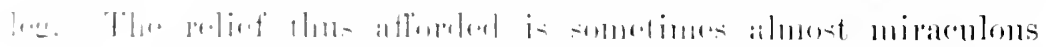

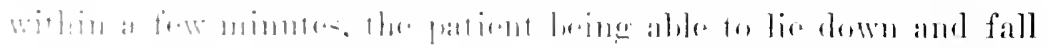

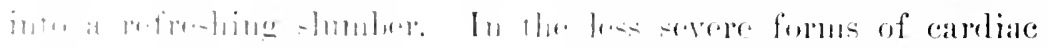

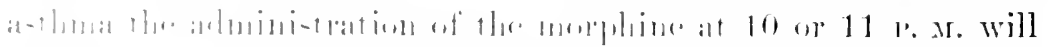

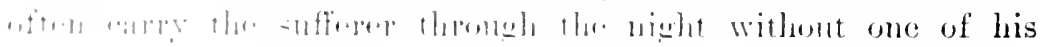


rleaded attacks. The remerly is never so efliciontly administered in any other way as muler the skin, and the dose shombl be as small as will produce the desired effect. This will ramely be less than $\frac{1}{8}$ of a grain, which dose shonld be atministered nightly without increase. Shomkl il be thought best for any reason to withholel this remedy, them insommia may he orereome ly paraldehyde, chloralanide, and bromide together, or by sulphonal.

The treatment of catroliac asthma is of a neecesity that of the paroxysm and the protection of the patient agatinst influences which may precipitate an attack. If cohnlein's explanation of its mode of production is correct-manely, that it is the result of temporary increase of left-rentricle wakness, in conseguence of which its systoles are relatively fechler than those of the rightthen efforts must be directed to the protection of the degenerated left heart against conditions which hy raising arterial tension tend to overpower the left rentricle. Blool-pressure may be injurionsly raised by the horizontal position of sleep without other factors, and the angmentation of peripleral resistance thus induced serves to oropstrain this redatively tow weak portion of the heart. We anmot abolish the need for sheep, nor can the patient be required to pass his nights in an rasy chair, hut we can guard him against other haruful influences, as constipation and flatulent distention of the bowns. The former raises blond-pressure in the aortic system; and the latter exerts injurions lnessure upon the weakened heart.

Dropsy is to be combated in the usual way, by an infusion of digitalis or dinotin-Kuoll, as laid down in the treatment of adema from valvular disealse.

The phrsician is not infrequently called to see a patient suffering from excesive distention of the right heart, conseruent it nay be mpon the rapid giving way of hypertrophy. Two lines of treatment are open to him: a resort of fiee catharsis ly some one of the drastic pureatives, as claterimu, or to venesection. 'There is no doubt of the speedr relief often following the abstraction of 16 to 20 onnces of blood from the arm, and if the urgency of the symptoms or the patient's exlanstion make the medical man hesitate to administer a drastic cathartic, no objection can be urged against the opening of a rein and the letting of blood. The relief thus afforded is justification enough for the procedure. 


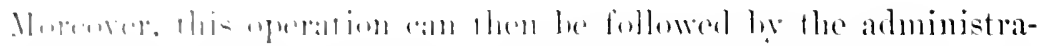

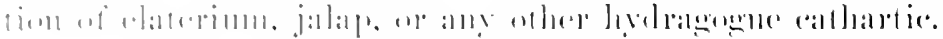

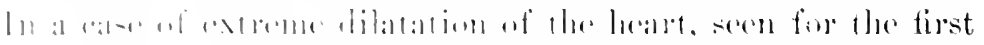

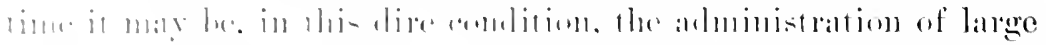

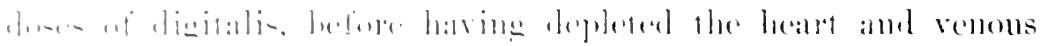

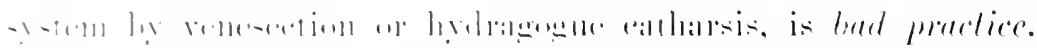

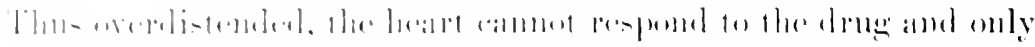

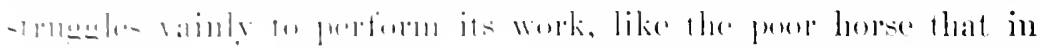

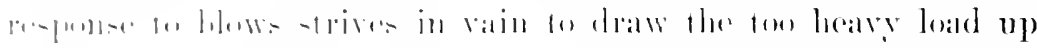

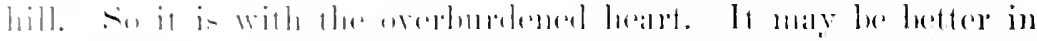

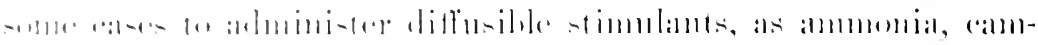

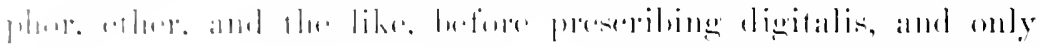

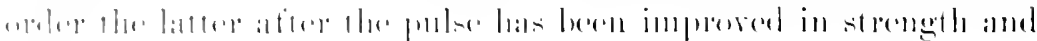

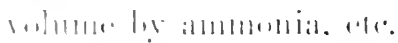

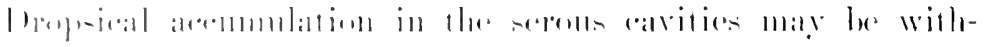

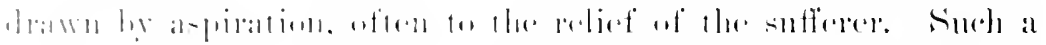

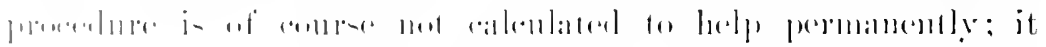

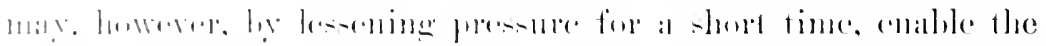

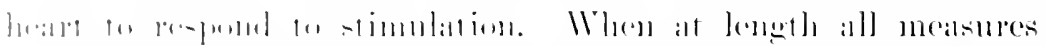

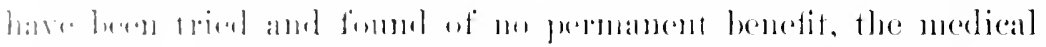

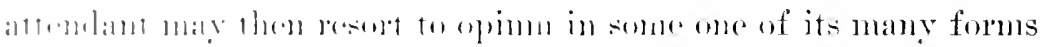

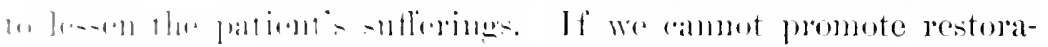

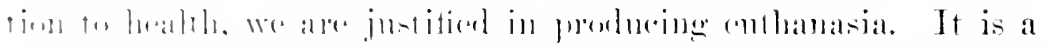

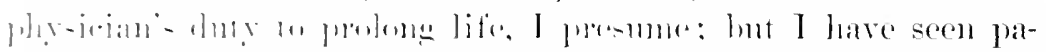

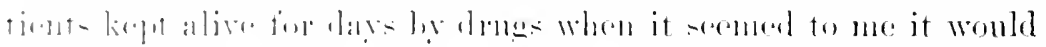

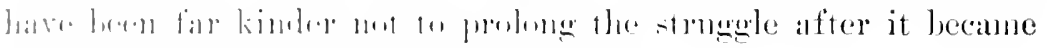

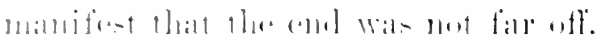




\section{CHAPTER XXI \\ HYPERTROPHY OF THE HEART}

Morbid Anatomy.-In hypertrophy the heart-muscle is increased in thickness and weight. Ilypertrophy of the organ as a whole is jurlged by its weight, while that of a single chamber is better estimated by a measurement of the thickness of its walls. This increase in size seems, according to the latest inrestigations, to be dependent on an increase in the size of the individual muscle-fibres. According to Gutch, the increase in brealth of the fibres is insutticient to account for the total increase in weight of the organ. He thinks, therefore, that the diserepaner can he explained by taking into consideration the increase in interstitial fibrous tiswe that is almont always present in hypertrophied lrearts, and also by the supposition that there is, with the increase in witth of the fibre, a corresponding increase in length. These two factors he considers snfficient to accom for the increase without supposing any nunerieal increase in the fibres, and indeed evidence of the latter is wanting. The question can, howerer, hardly be considered settled as yet.

The hypertrophied muscle is firm, cuts with increased resistance, and is usnally of a deep-red colour. Increase of museular tissue without any corresponding inerease in the blood-suply canses retrograde changes to be common in hypertrophied hearts, and in consenuence rellowish streaks of fatty degeneration, or gray or whitish areas of local fibrosis, are not uncommon. This is scen especially in the hypertropley accompanying arteriosterosis and renal disease, in which affections the blowernply to the myocardimn may be redured by reason of narpowing of the coronary ressels.

The normal heart weighs abont 900 grammes (10 ounces) in the male and 250 grammes ( 8.5 onnces) in the female. These 


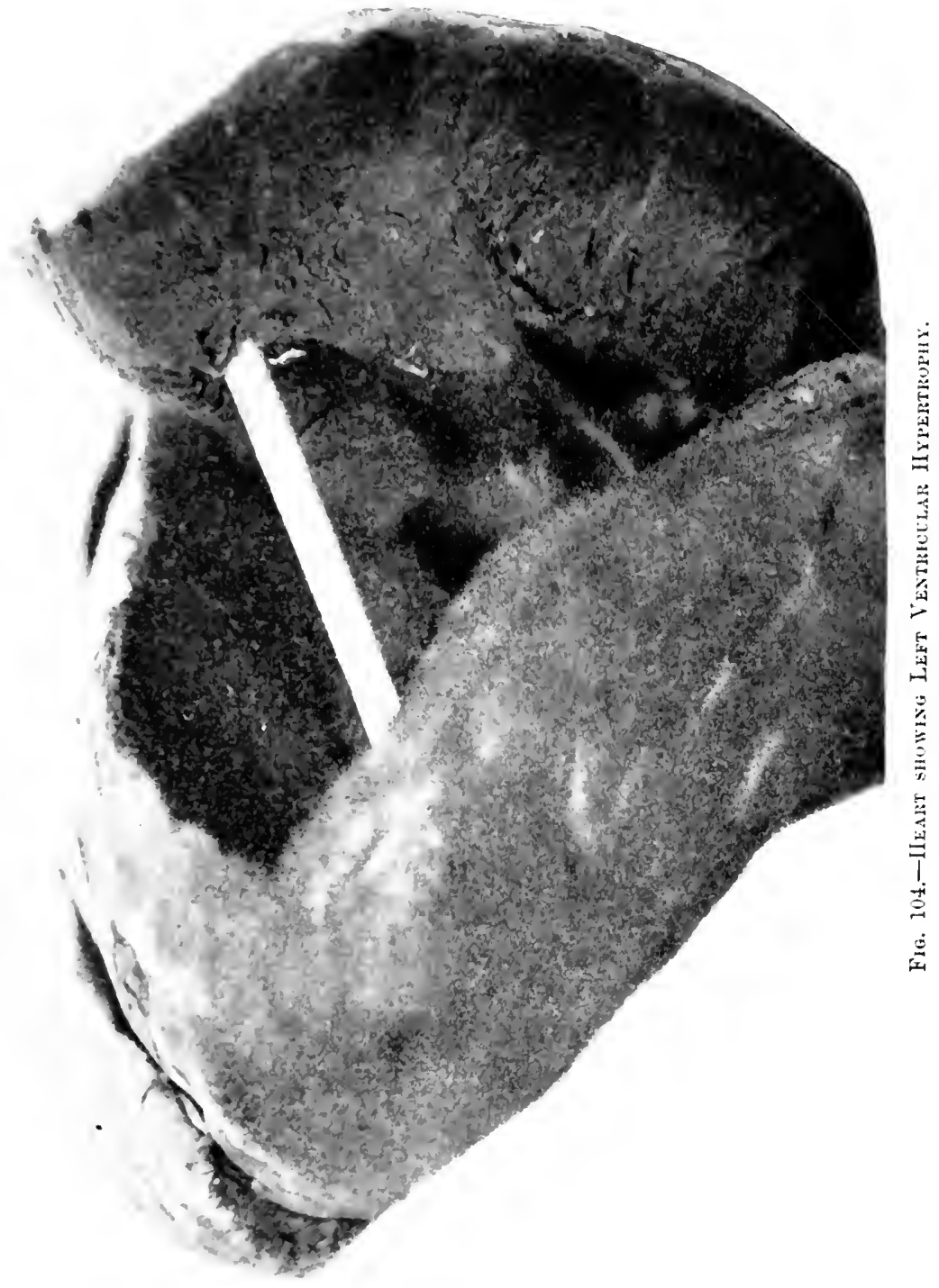


fignres are for individuals of llae avelage size, hut of comrse the licart weight ralies with that of the whole body. In hypertrophy the weight may be dombled or even tripled. Stokes is sald to have reporterl a heart weighing tig ommers, but one weighing more than 600 grammes (20 onnees) is a very large organ. Aceording to Eichhorst, a generally enlared heart may attain such dimensions as to extend from the right mamillary to the left midaxillary line. When the left rentriele is ehiefly involved the organ is conical and its apes bhunt and broad (Fig. 10t). When the right rhamber is also colareged it assmues a more puadrangular form, and the apex is formed wholly by the right ventricle (Plate III).

The papillary muscles and colmme carnce share in the general hypertrophy, the latter especially in the right chamber (Osler). Hypertrophy may he circumscribed, howerer, and then the trabeeulac, papillary muscles, either comus, or one of the auricular aplendices, may be the seat of the change. Snch local hypertrophy is not common and probably is dne to trophic changes rather than to any circulatory disturbances.

Post-mortem rigility of the lieart-nusele nay simulate hypertrophy by eamsing he heartwall to be thicker than normal, and lience increase in weiglit is the only trustwortly sign.

Concentrie hypertrojhy, or thickening of the wall of a chanber withont increase in its capacity, is but rarely net with (Fig. 10). It is nsually the result of stenosis. IYyertrophy combined with more or loss dilatation of the chanber-i. e., eceentric hypertrophy-is by far the more nsual condition. When such a heart comes to antopre, the dilatation has, as a rule, broken down the hepertroply and is the predominating foatme.

For the purpeses of comparion, I give the following figures, quoted he Eichlorst, from 'Thomal's talles:

Treight of Heart

Until the end of the first yeill. . . . . . . . . . .

\begin{tabular}{|c|c|}
\hline Second to fifth year. & $5010 \quad 70$ \\
\hline Sixth to tenth yoar & in 10115 \\
\hline Eleventh to tifterenth year.. & $1: 30$ to 205 \\
\hline Sixteenth to twentieth your... & 2186054 \\
\hline T'wenty-first to thirtieth year . ............ & 200 to 294 \\
\hline Thirty-first to fiftieth year............... & 297 to 308 \\
\hline Fiftieth to sixty-fifth year.............. & 308 10 382 \\
\hline Sixty-fifth to eighty-fifth year $\ldots \ldots \ldots \ldots$ & 832 to 303 \\
\hline
\end{tabular}




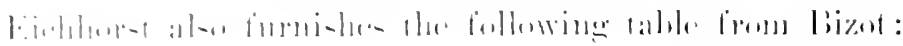

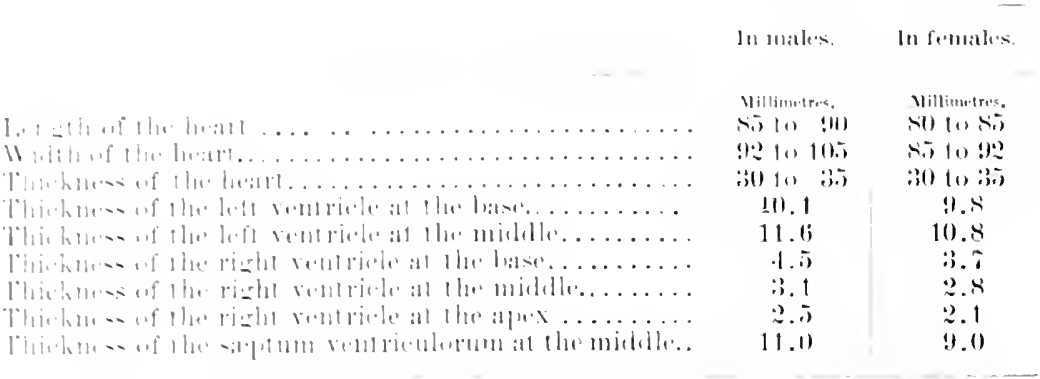

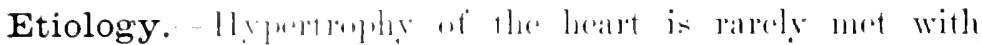

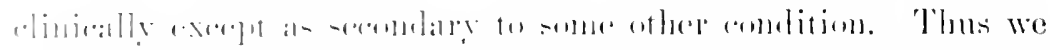

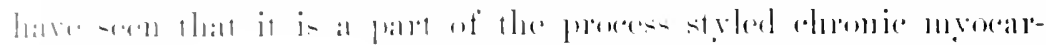

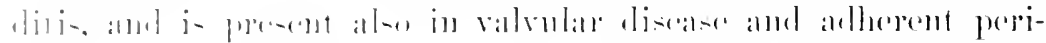

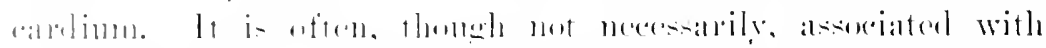

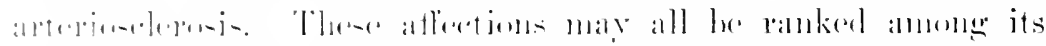

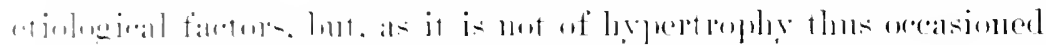

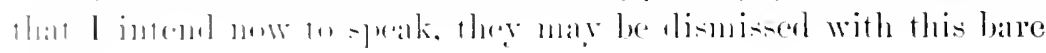
mantinus.

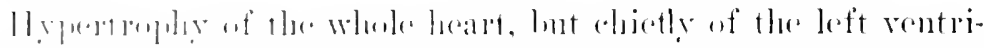

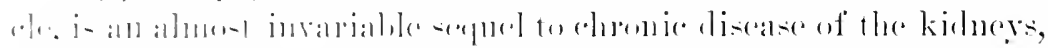

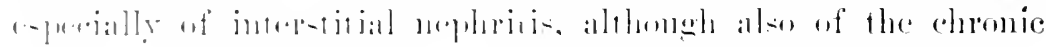

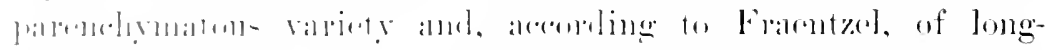

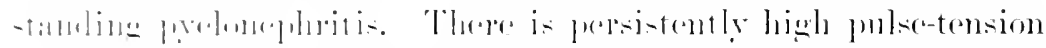

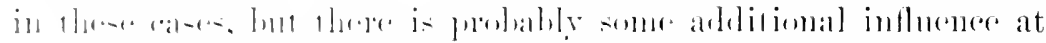

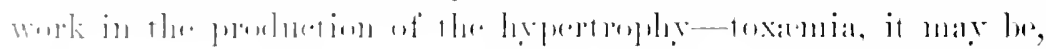

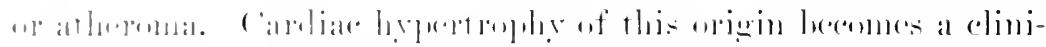

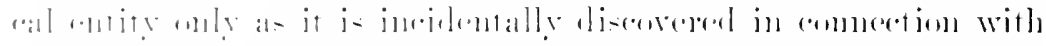

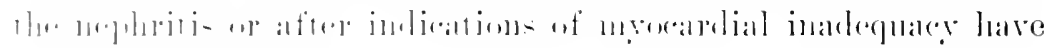

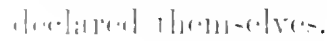

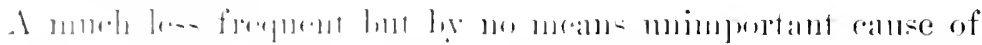

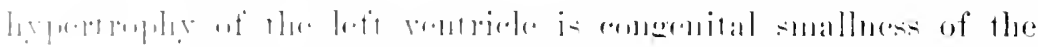

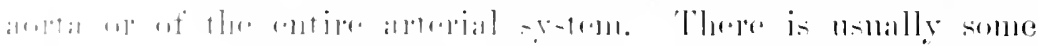

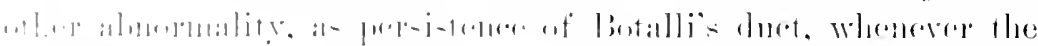

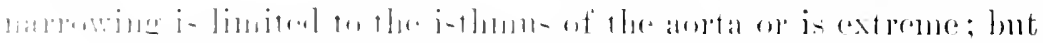

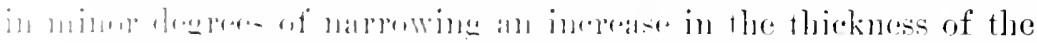

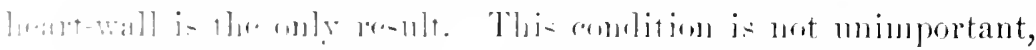

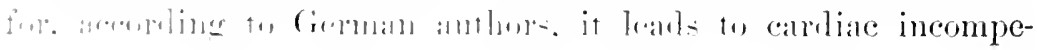


tence and dilatation in romes soldiers who ale subjected to the strain of long, toilsome manches.

In chronic bright's discase and angernital smalluess of the aorta, hypertephy derelops in eonseguence of abmomal peripheral resistance, which forees the heart-musele to perform extrat work. It therefore becomes increased in size (see Mlorhid Anatony), the same as does a skeletal muscle moler like eonditions. Set the museular filnes conld not grow in thickness and length if they did not receire sutheient nombishnent, and hence augmented mutritive supply is indispensilule. It is this consideration which leads German writers to regard the consumption of inordinate quantities of heep as an molonbted canse of the enormons learts seen anome exestive beer-elpinkers of Baralia. The intake of large amomits of fluid alome womld not be capable of producing capdiac hypertrophy, no matter how greatly they increase peripheral pesistance, but containing no inconsiderable proportion of mutritive clements, as it does, the excessive comsumption of beer furnisher all the reguisites for the cansation of hrpertophy.

It is believed that contestants for athletic lomons, particularly oarsmen and professional licyelists, develop this form of heart-disease, and dombtless some of them do. The hypertrophy is thought to result from the heart having to overeome almormal peripheral resistance created hy serere musculal effort. This is not the correct explanation, since the initial rise of blool-pressure occasioned by muscular contraction is later on followed by a fall as the intermusemar arterioles becone dilated. Therefore some other factor is responsible for the hypertrophy. This may lie in some unreconnised abmormality of the vascular system, but in the case of poufessional wheehnen and rowers is probably due to the constrained position they take during their exertions. As seen in the next chapter, the heart-strain of athletic eontests is nuch nore likely to result in dilatation.

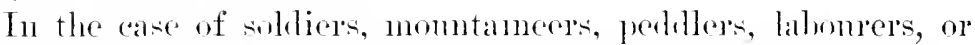
otheres whe carry heary packs strapped on their shoulders, the injurions ctfect on the heart is to be attributed to the combined influence of respiratory enbarassment and arduous physical exertion, even granting that there are no such influences at work as abuse of alcohol, atheroma, etc.

Rapid and violent action of the heart of a psychical origin is 


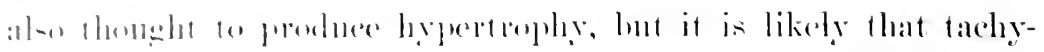

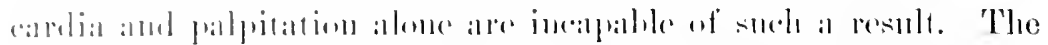

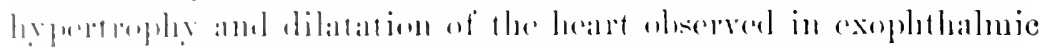

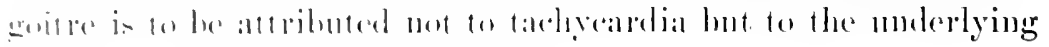

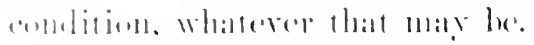

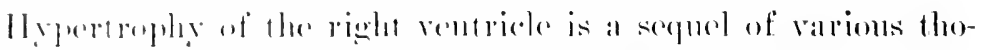

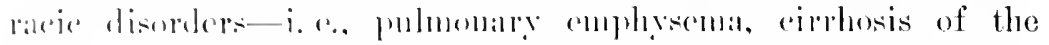

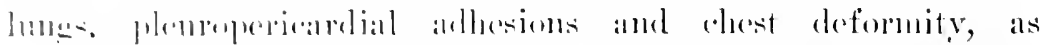

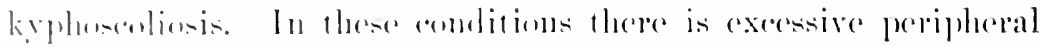

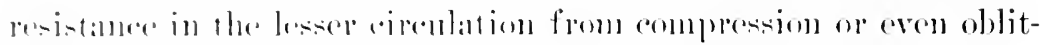

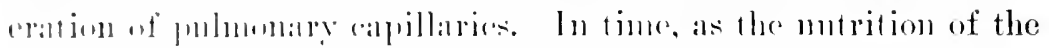
lualet suffers, its molur strain loads to dibatation and cren to de-

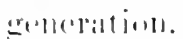

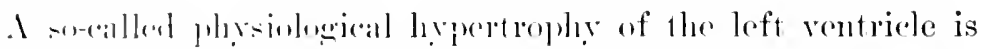

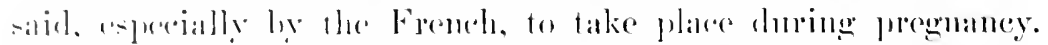

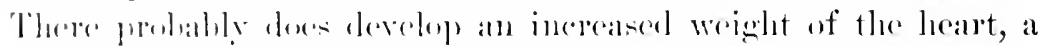

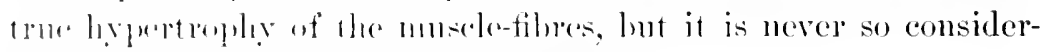

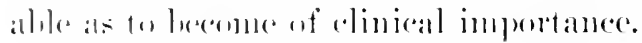

Tis tophy has to do escontially with the propulsion of an increased relume of hlowel. With the overeominge of abmormal resistance, or with a minn of luth these farturs, and alde one of them nay

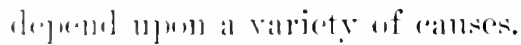

Symptoms. - llypertmply of the heart is to lo regarded as

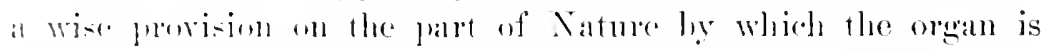

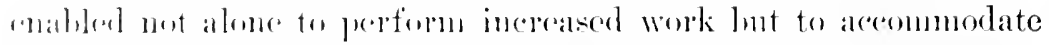

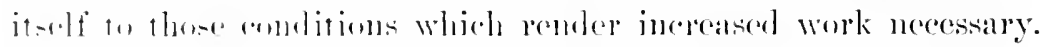

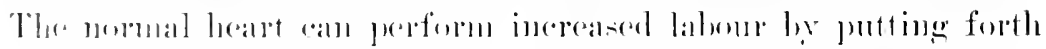

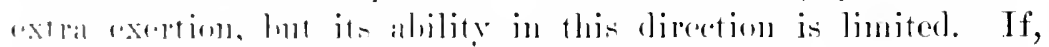

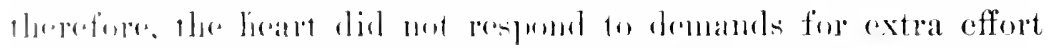

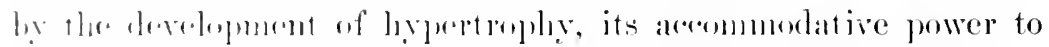

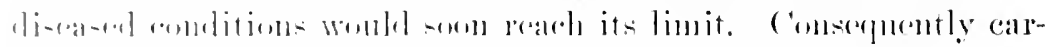

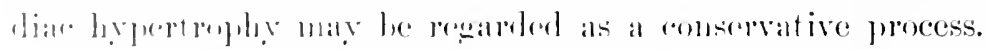

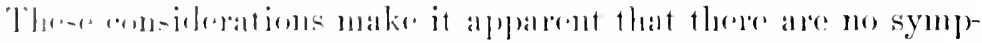

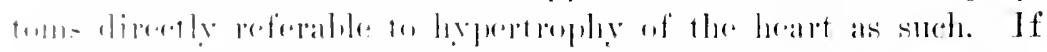

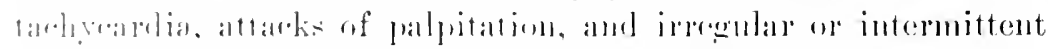

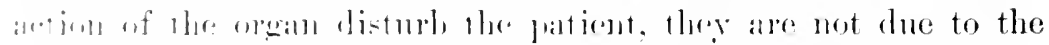

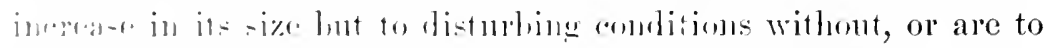
l.e pregleded at an indication of beginning inadequacy. In other 
words, the extra labour repuired of the heant is begimning to tell on it, and if the muche strain is continued, its rescrve strength will become exhansted. The hrpertrophy is discovered either' accidentally or becanse a supervening hilatation oceasions subjective sensations which bring the individual to the physician.

Physical Signs.-Lusprefion.- The amomut of information derived from inspection of the patient depends npon the degree of hypertrophy and eomtitions residing in the thoracie walls and lungs. If the chest is capareions anct the lungs are interposed between the chest-wall and heart, there may he no visible impulse. When, on the contrary, the parietes are thin and the organ is considerably enlarged, it produces risible shock which is exaggerated both in force and extent, while the apex-beat is displaced outward and in some instances downward, acoording to the degree of hypertrophy. In hrpertrophy of the right ventricle there is apt to be visible pulsation in the eprigastrimu.

Palpation.-Confinmation of the facts perceived by the eye is sobtained by the hand, and for the most part nothing wore. In some instances careful palpation enables one to locate the position of the alex-hrat when this is not visible, and to judge of the foree and extent of carliar contractions. In women with large mammary derelopment in whon inspection and percussion are futile, palpation is often of wreat aid in estimating the size of the organ. The pulse of laft-rentricle hypertrophy is full, strong, and inclined to be slow rather than accelerated. Increase in its rate comes on, as a rule, wly when dilatation begins to gain ascendeney and carliac insufticiency to declase itself. It is a pulse of high and sustainel tension, as shown by pressure of the finger on the artery and hy Garetner's tomometer or the sphygmograph. This is not due to stiffness of the vascular coats, but to the increased force with which the blood-wave is propelled hy the powerfully contracting ventricle. Such a pulse is difticult to compress, but when the artery has been thus collapsed, the wave of blood is felt to strike the palpating finger strongly, while below the point of pressure the ressel is empty and its coats camnot be rolled beneath the finger, showing that they are not thickened and the increase of temsion is not due to atheroma.

Percussion.- This forms our best and most reliable means of determining increase in the size of the heart. Absolute dulness 


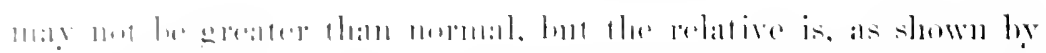

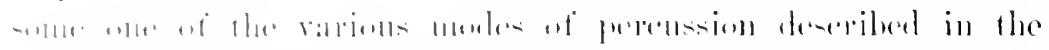

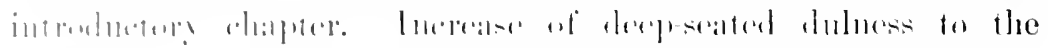

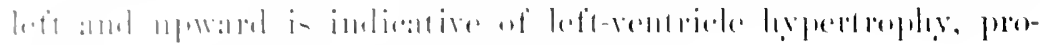

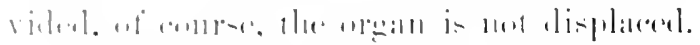

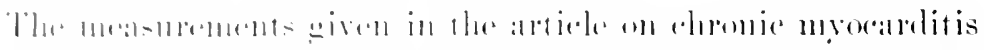

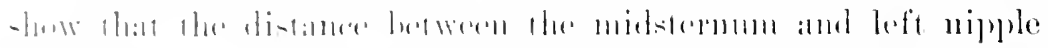

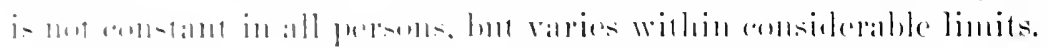

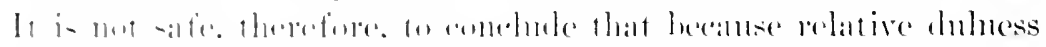

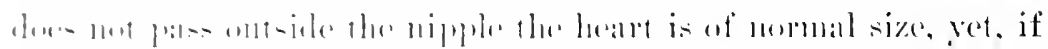

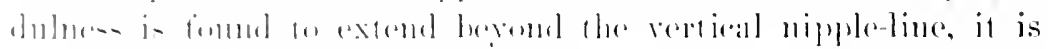

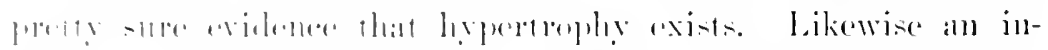

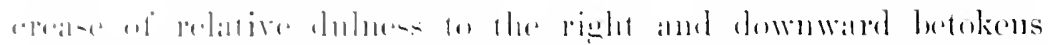

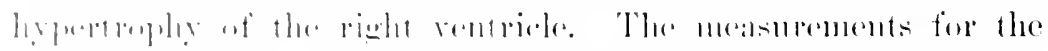

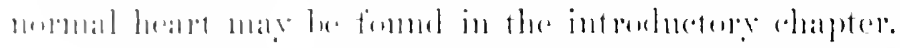

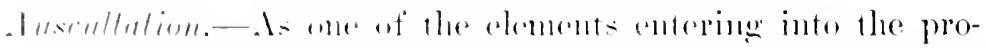

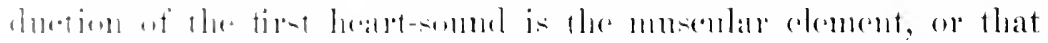

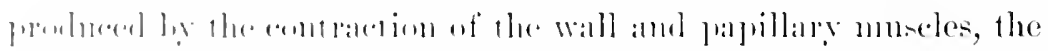

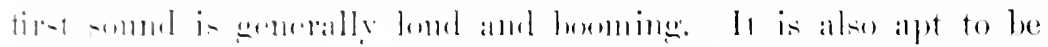

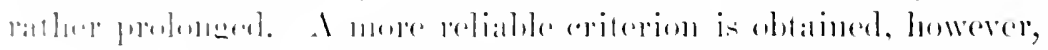

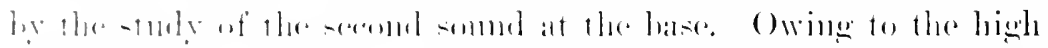

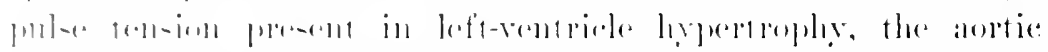

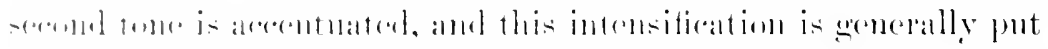

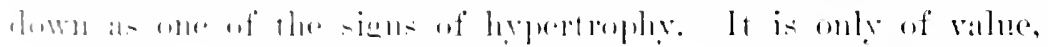

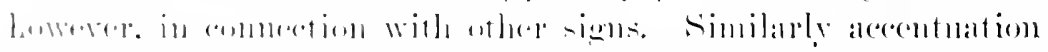

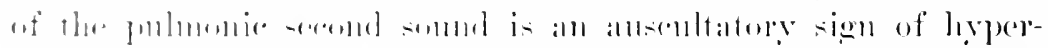

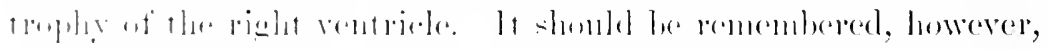

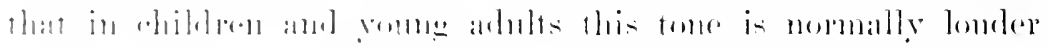

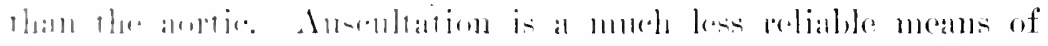

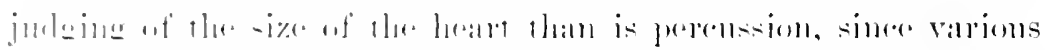

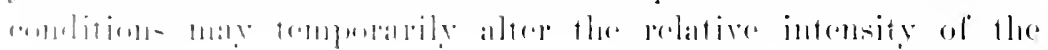
$-1,1 ! 1+1,1-$.

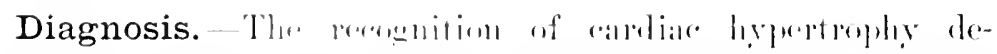

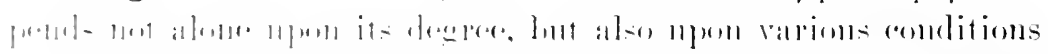

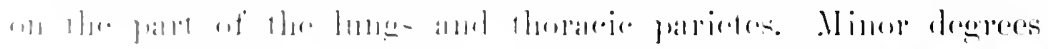

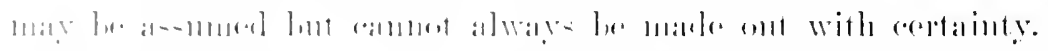

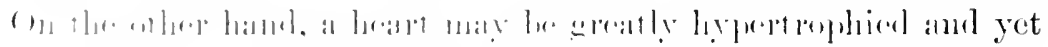

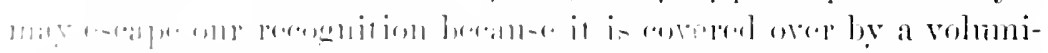

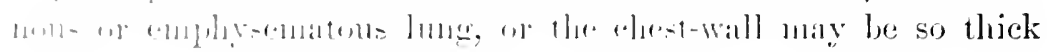


from fat and musele as to render ordinary methods of diagnosis futile.

The elinical findings generally thonght to warrant a diagnosis of cardiac hrertrophy are: (1) I full, tomse pulse which is either slow or of nomal rate, not accelerated; (2) a powerful, broad apex-beat which is displaced outward and perhaps downward; (3) increased cardiac duhess to the left and upward or, it may be, in all diameters; (t) a booming, low-pitched first somd and an accentuated aortic second somel. Ilyertrophy of the right ventricle is shown ly: (1) Epigastric pulsation. (2) increase of cardiac duhness to the right and downwald, and (3) intensification of the pulmonic serond tone. Shomld the comblition of the hungs or thoracic walls not reable ome to rely on the evidence fumished by the usual means of phrsical examination, then one may have recomse to the Humporope, which onght to settle the diagnosis besond further puestion.

Differential Dingnosis--It is handly necessury to remind the reader that displacement of the heart towards either side may simulate hrpertrophr, and therefore must be excluded. The most frequent somree of error in this direction, however, lies in the fact that scoliosis, or that forward curvature of the spinal colmmn, may cause the heart to lic close against the anterior chest-wall and to pulsate so forcibly and widely as to give an appearance of marked hypertrophy. In all cases, therefore, the shape and depth of the thorax ought to be carefully scrutinized.

In addition, I wish to refer to what Italian writers term "pseudo-cadiac lypertophy," by which is meant a comlition sometimes otsored in roung persons who are neurotic and have thin chest-walls with broad intereostal spaces. In such, owing to excitability, the action of the heart is apt to he rapid and molnly forcible. The apes of the orwan strikes in the hroad and thin intereostal space with what appears to be exagerated force and abnomal breadth, or the entire cardiac area may heave strongly with each srotole. The heart-sounds are intonsified and ringing, and altogether the organ convers the impresion of abnormal strength. Comorpuently, muless the examiner makes areful meas-

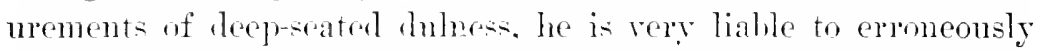
conclude that lie has to do with a hyertrophied heart.

In all cases in which hrpertrophy is suspected and physical 


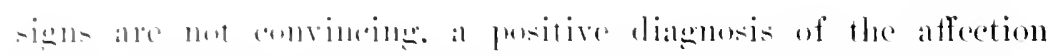

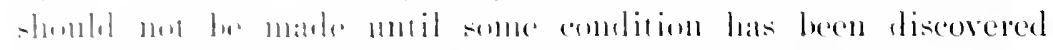

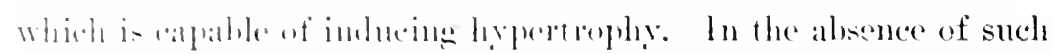

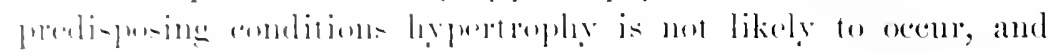

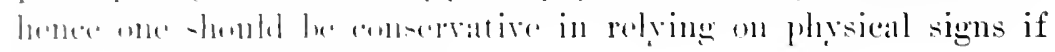

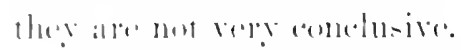

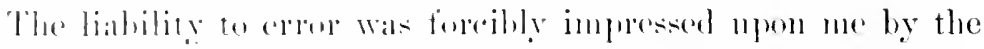

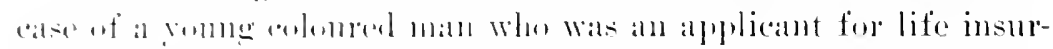

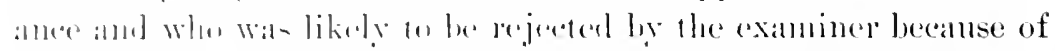

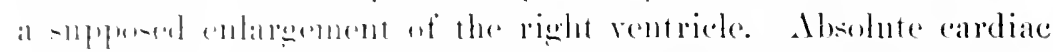

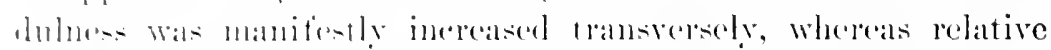

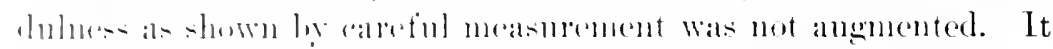

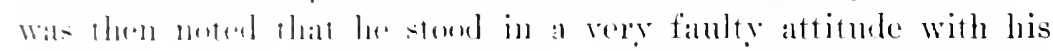

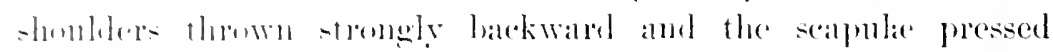

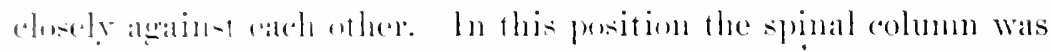

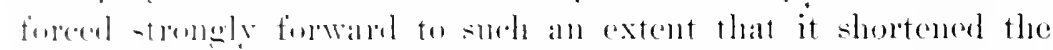

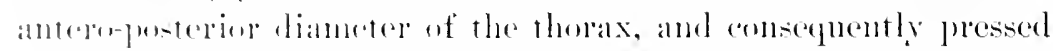

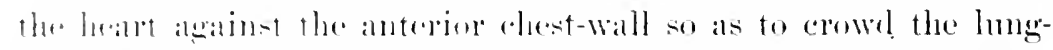

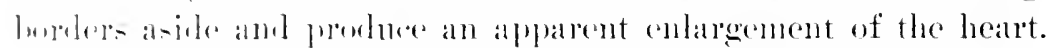

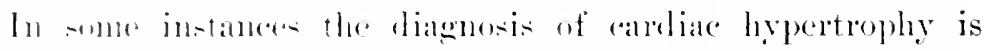

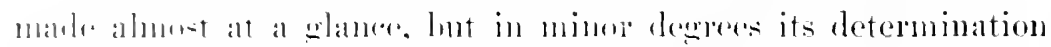

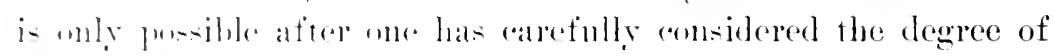

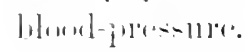

For the difforemial diagnosis of hypertrophy from dilatation

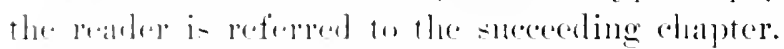

Prognosis. - The poneneis of the comdition wa are now con-

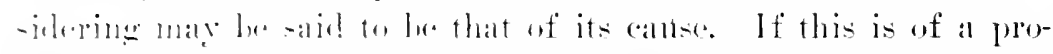

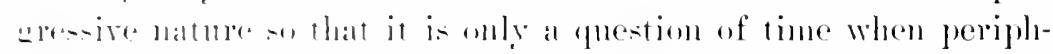

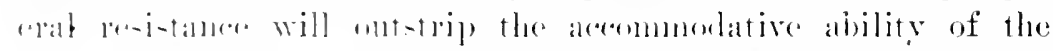

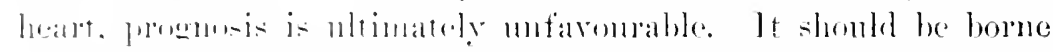

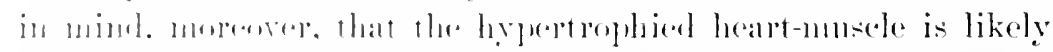

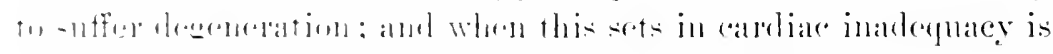

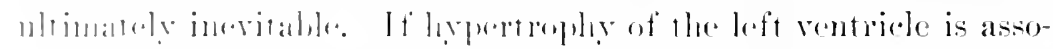

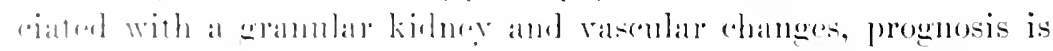

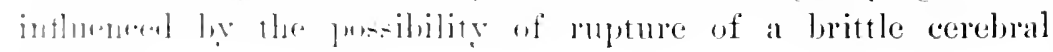
antrors.

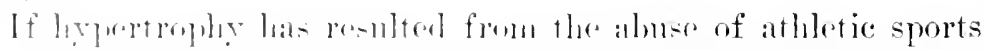

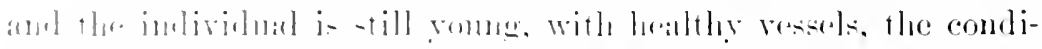
tim may not pose serions providing the exciting canse is re- 
moved. In such persons, howerer, one shonld not ignore the possilitity of congenital smalluess of the arterial system.

Treatment.-llypertrophy of the liatr loes not require theralentic interference, and hence one shonld not attempt to lessen the rigonl of cardiale contractions, as I have known attempted, by the use of aconite. The inereased thickness of the heart-wall is a conservative measure. The aim should rather be to preserve hrpertrophy and protect the heart from the inadequacy of overstrain. The underlying condition is the object of our solicitude. Valvular lesions, perieardial arlhesions, ehronie nephritis, congenital smallness of the aorta-these and many otluer eanses eannot be removed. When detected, their existence should be stated to the patient and he should be warned against the danger of hreaking down his hypertrophy by unwise phrsical efforts or any other injurions influences. If the cause lies in the excessive consumption of beer, in gluttony, in faulty athletic exereise, the patient should be plainly informed of his injurions practices and urged to desist before they lead to cardiac insufficiency.

If disordered action of the heart seems to call for digitalis, this remedy should be arministered with great eaution. As a matter of fact, such an invigorator of cardiac systole is not indieated unless signs of myocardial incompetence are actually present. When this is the ease it is no longer the hypertrophy but it is the dilatation which calls for treatment. This will be found detailed in the appropriate place. 


\section{(11.11\%li $\mathrm{X} \times 11$}

\section{DILATATION OF THE HEART-RELATIVE AND MUSCULAR MITRAL INSUFFICIENCY}

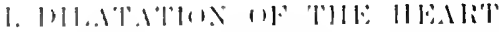

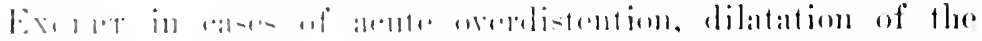

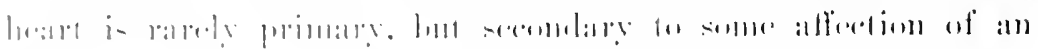

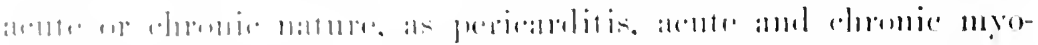

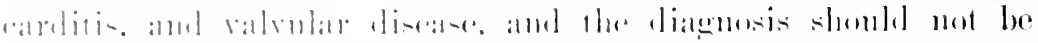

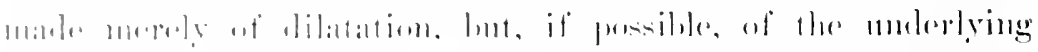

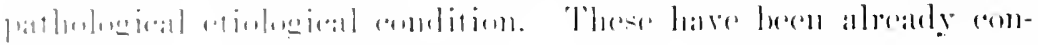

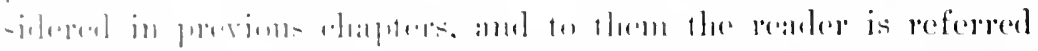

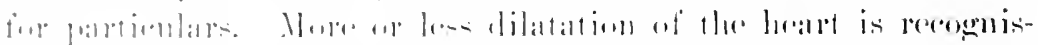

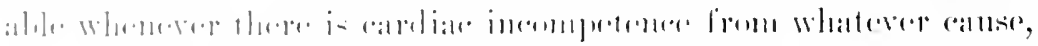

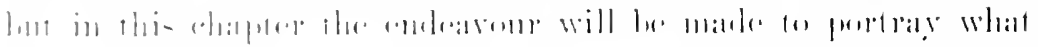

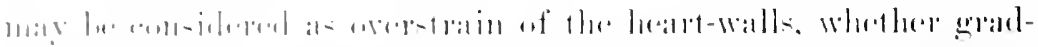

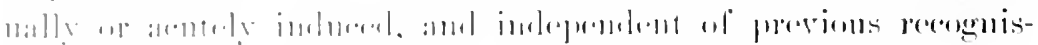

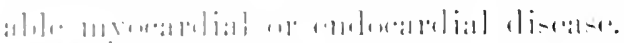

Morbid Anatomy. Liy dilatation of lla luarl is moant an

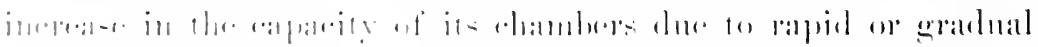

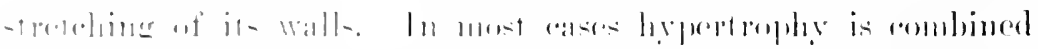

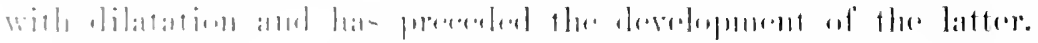

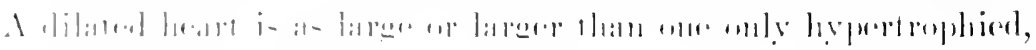

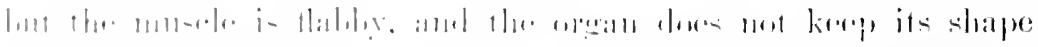

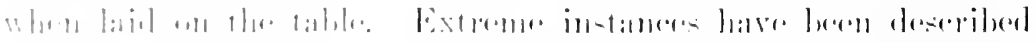

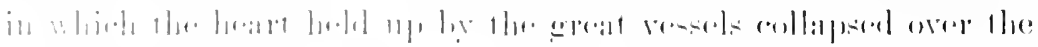

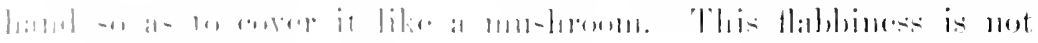

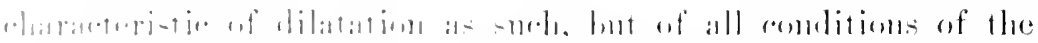

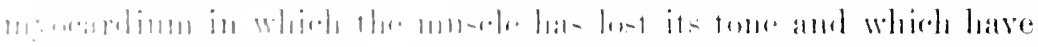

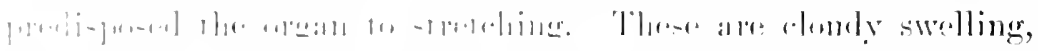

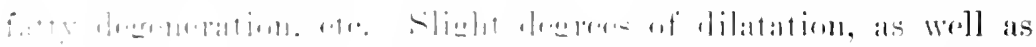

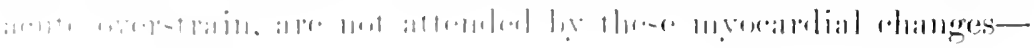
init 
PLATE III
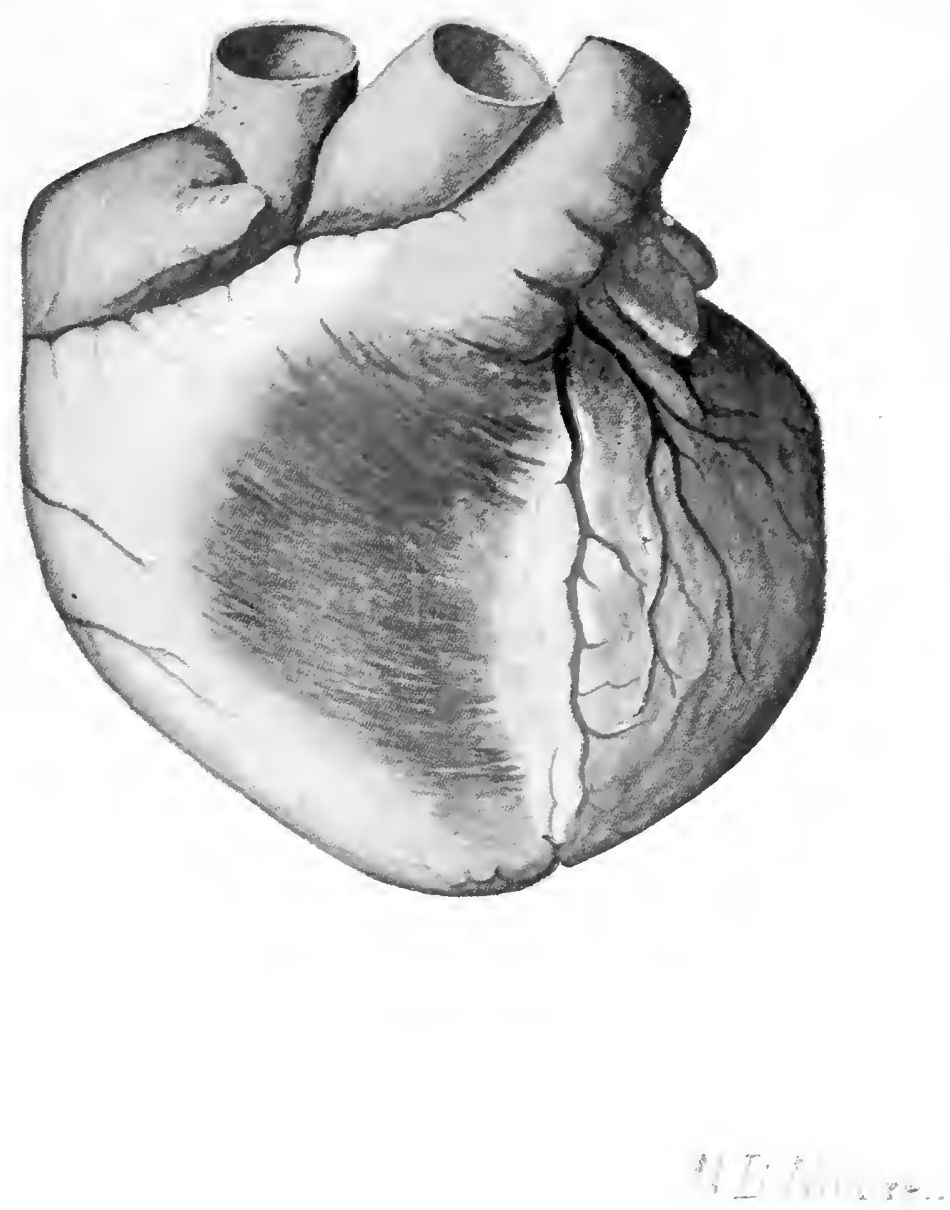

EXTERIOR OF HEAR'T OF FIG. 42. SHOWING HYPERTROPHY AYD DILATATION OF BOTH VEXTRICLES. 

they are often a part of the compensatory process attending valvular lesions. When, however, compensation breaks down and dilatation becones extreme, the walls are found degencrated and flabby. The muscle is usually paler than normal and may be clondy or of a brownish tint, due to the deposit of pigment.

As dilatation usually results from the further action of the causes that produce hypertrophy, it has much the same distribution. It may affect but one chamber or the heart as a whole. The trabeenla and papillary muscles are naturally not concerned in the process of dilatation except in so far as the latter may stretch or lengthen in order to functionate properly within the enlarged chambers. Relative insufficiency of the ralves is generally present and may be eaused by stretching of their ostia or of the cardiac walls.

Etiology.-Cardiac dilatation may be said to be the result of a disproportion between the work the heart has to do and its ability to do it. This undue demand upon its energies may have existed for years in the form of prolonged high arterial tension, and only at length become disproportioned throngh degeneration and gradual waning of the heart-power. Not infrequently it is some mexpected call for extra effort that orerpower's the heart, when without it the organ might have heen able to perform its work sucessfully for years longer. It is in this way that dilatation so often sncecels anpensatony hypertrophy in valvolar disease. In many but not all such cases the integrity of the heartmuscle has been slowly undermined by the derelopment of degenerative changes.

Such an exciting cause of dilatation may be a hasty rm, a spurt on a bicyele, the lifting or carrying of a heary weight, a prolonged debanch, ete. Inxiety, grief, and even fright, through their action on the inhibitory nerve of the heart, are calpable of indueing a stretching of the cardiace walls throngh stasis in the eavities they inclose-the "staungs" diatation of the Germans.

Romberg lays stress on the deleterions inthence in this respect of acnte infections diseases, and cites instances in which he has observed cardiac dilatation and ultimately fatal insuftieiency follow an attack of influenza. I have notes of the case of a gentleman of fifty-seren whose rilatation and eventual death from progressive carliac asthenia were attributable to his having carried 


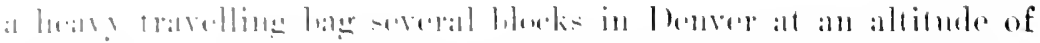

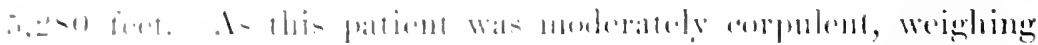

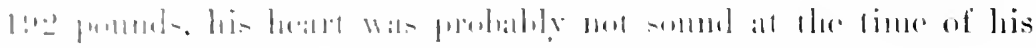

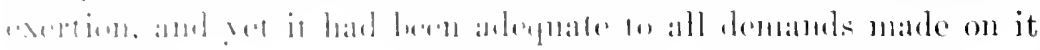

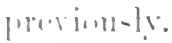

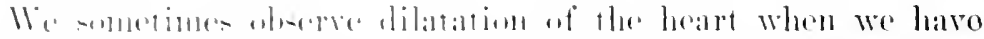

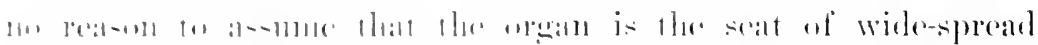

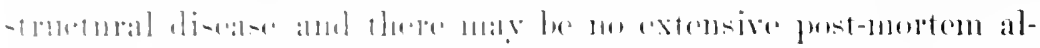

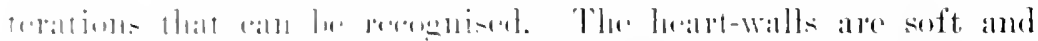

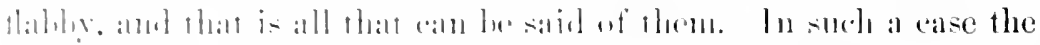

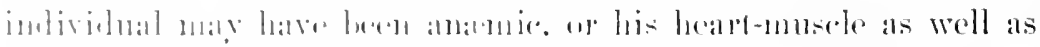

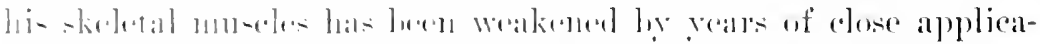

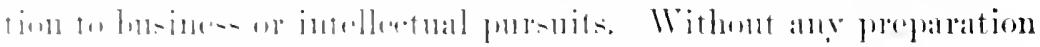

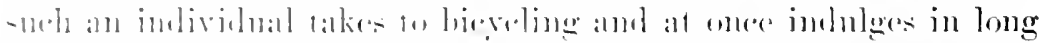
funl-at a

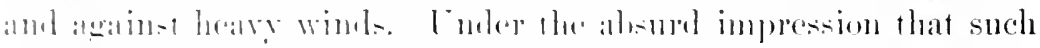

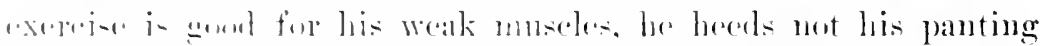

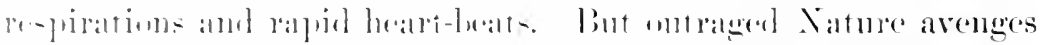

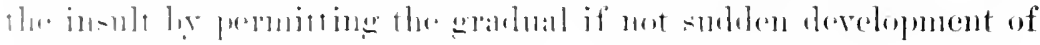

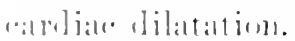

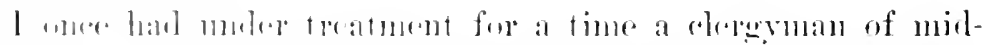

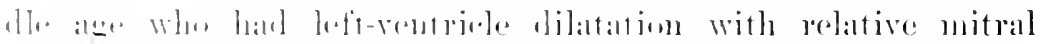

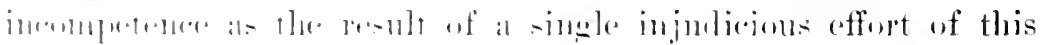

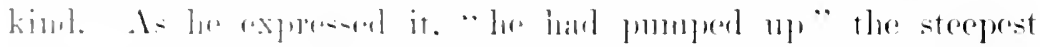

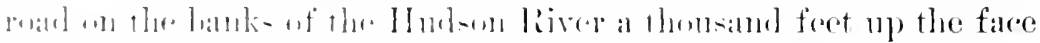

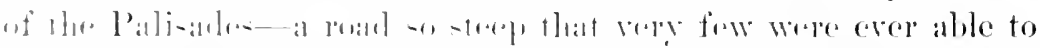

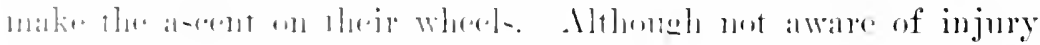

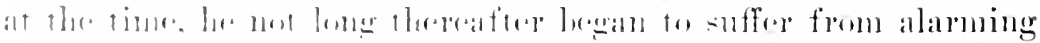

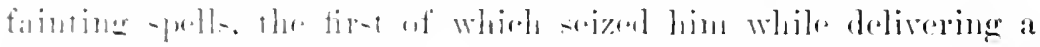

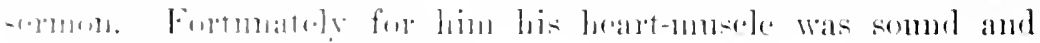

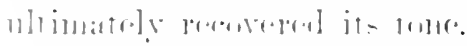

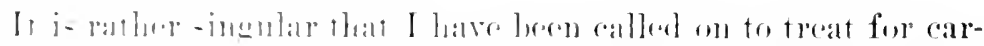

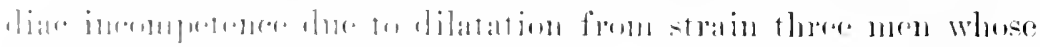

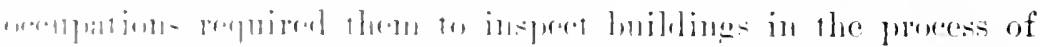

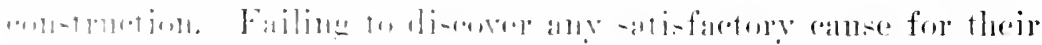

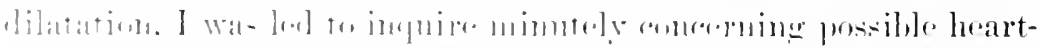

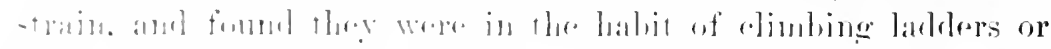

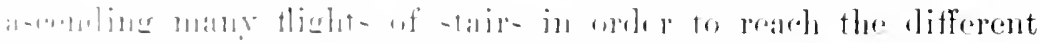

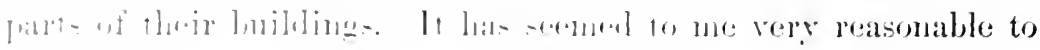


assume the likelihood of heart-strain by such excrtion, and in the case of one of these men intermittenec persisterl in spite of treatment until he exchinged lis work as building inspector for a sedentary occupation in an office.

In not a few instances the resistance of the nuyocardium is diminished by the inordinate use of tobacco or by sexual excesses, late hours and social dissipation, dancing, etc. In one case the young man breaks down in his nervons system, a second develops a congh, while still another manifests signs of cardiac dilatation that may have been suddenly or gradually induced. In most of such cases complete restoration of heart-power follows removal of the canse and appropriate treatment. In some the heart remains permanently impaired, and in others every fresh exeess is followed by renewed dilatation until at length irreparable cardiac stretehing and insulficiency remain. Such examples are not confined to the male sex.

Anemia and chlorosis predispose to this form of heart-lisease, and more than one society belle pays for the scason's round of dancing and other gaiety by slowly or acutely indnced incompetence of the dilated heart. Many a jaded matron who declares she is "worn out" by the demands of society is really suffering from serions thongh perhaps not extensive stretching of the heart-chambers. Her heart-mnscle lats grown flabby and is not always capable of entire restoration.

Fortmutely the heart-muscle is susceptible of development the sane as are the voluntary muscles. Were it not so, the athlete would be incapable of competing for the laurel wreath of victory. If, however, he is overtrained or if his training prove inadequate, the heart may be the part that suffers. Under such cireunstances acute dilatation may result from a single contest. It nsually affects the right ventricle, and stretching of the right anuriculo-ventricular ring permits the "safety-valve action of the trieuspid" to cone into play. (See the chapter on Tricnspicl Regurngitation.) It is possible, however, for the left ventricle also to beeme autely overdistended, as was shown by cases reported by IIarold Williams.

If muscnlar incompetenee of these valves is set up, then the strain is lifted somewhat from the walls of the left ventricle and shared by those of the left anricle and pulmonary veins. This is 


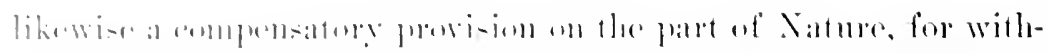

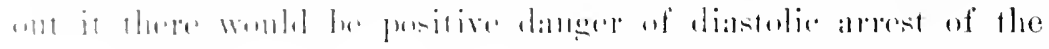

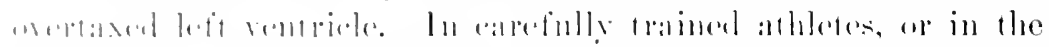

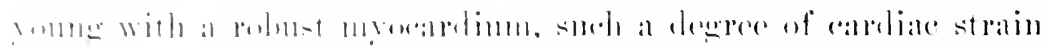

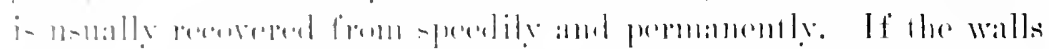

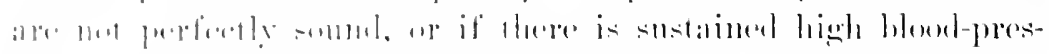

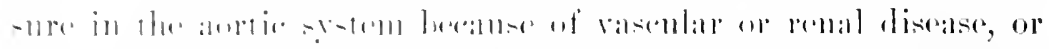

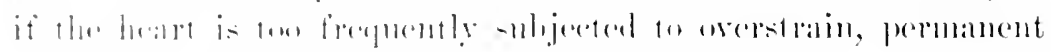

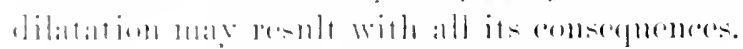

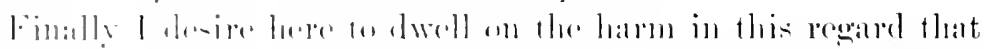

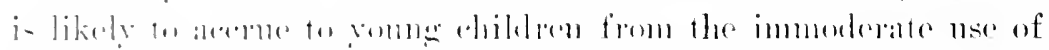

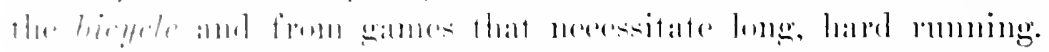

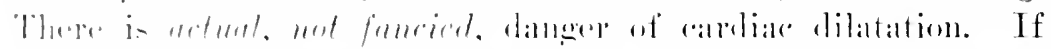

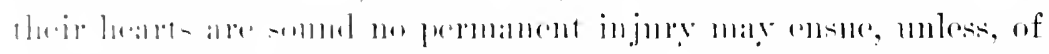

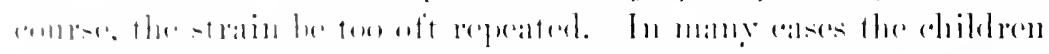

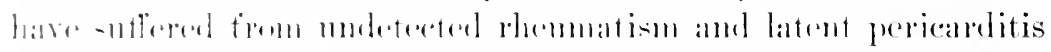

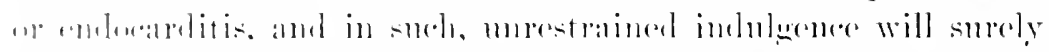

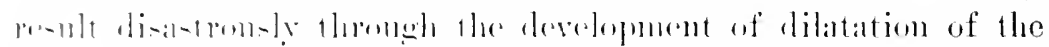

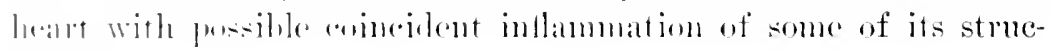
timen.

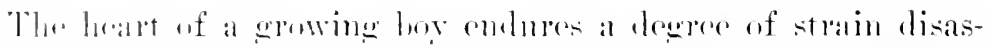

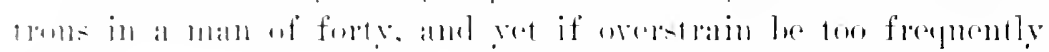

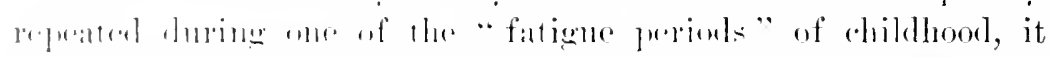

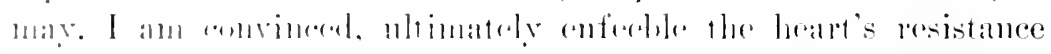

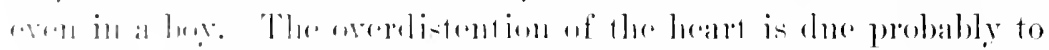

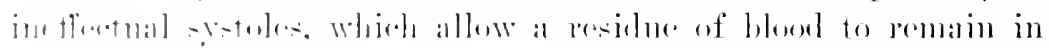

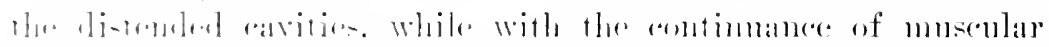

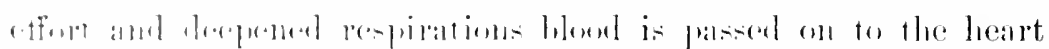

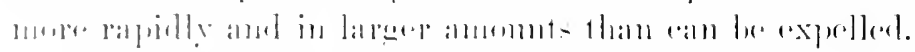

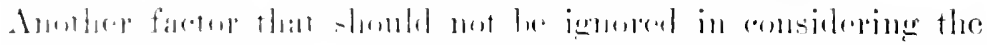

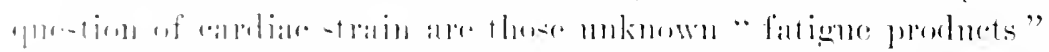

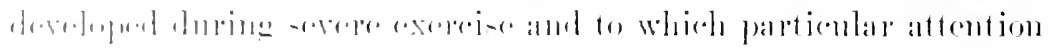

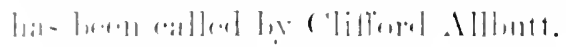

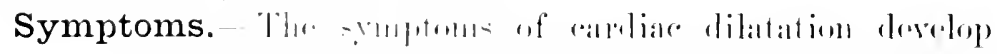

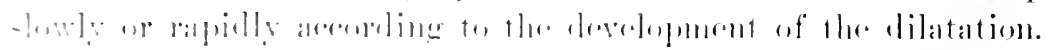

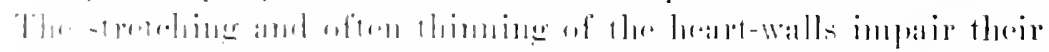

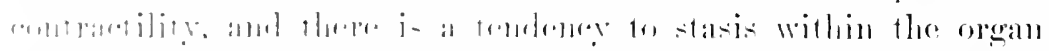

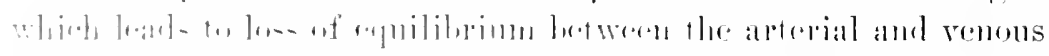

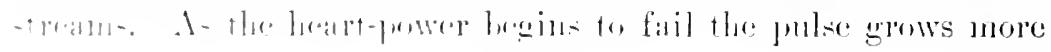


rapid, often irregular in foreo and rolume, and in many cases in-

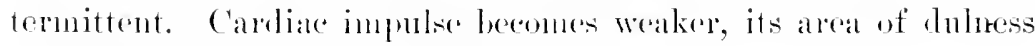
increased, and its somuls feoble.

The patient hegins to notice nore or loss breathlesiness on exertion and a feeling of nowouted lassitule that may amomt to actual weakness. His colom changes from the redrlish lume of health to the bluish gray tint of increasing capullary stasis. As cardiac inalequary advances, symptoms of viseral congestion appear. The urine lessens in amome and hecennes of high specifie grarity, often containing a trace of allumin. The liver increases in size, which nay canse a feeling of fuhness in the right hypochondrium or of dull pain in the batek below the shoulder. Its inferior marein becomes more or less distinetly palpable, being smooth, firm, and romeded, and palpation of the organ may be sonnewhat painful.

Congestion within the gastro-intestinal veins is shown by imjaiment of appotite and nore or less flatulent indigestion, so that the patient feels bloated after meals and complains of winly constipated bowel morement. Piles may develop, sexmal power hecome defieient, and women are apt to suffer from leneorrhora and derangenent of menstrual function. Congestion within the lowel extremitios learls at first to puttiness of the ankles, which by night feel tense and uncomfortalile. When the slues are remored the skin is found creased, and a ridge indieates where the mper edge of the shoe pressed. After a night's rest this swelling of the feet and ankles may have subsided, but as cardiac incompetence progresses, adena remains permanent. Pitting on prossme is now pronounced and found to eradually extend upward.

Thus gradually but steadily grow the symptoms of failing circulation, and at length, if the condition is not arrested by treatment, the patient is compelled to keep his room. Pulmomary congestion is no longer shown merely by drepuna on effort, lunt by congh with frothy, perhaps blooly expectoration, and by orthopnoea. Talking canses breathlessness and so much fatigne that the patient dreads or exen shms the effort. Examination of the lungs discloses more or less dnhess at the bases behind with fine crackling râles-in short, the signs of hypostatic congestion.

The apex-beat is now inperceptible or is but a feeble tap much outside the left nipule. Absolute and relative cardiac dul- 


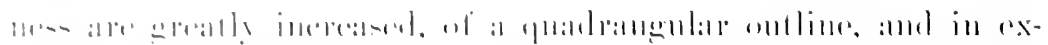

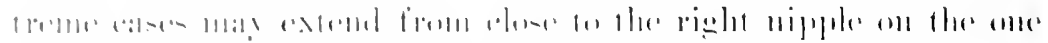

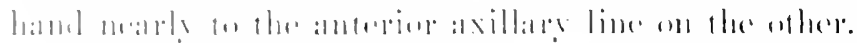

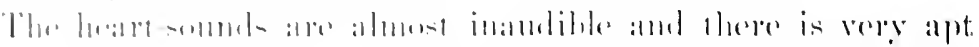

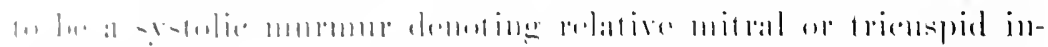

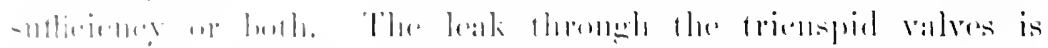

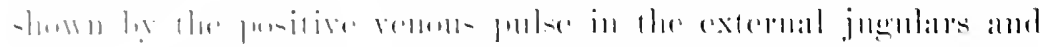

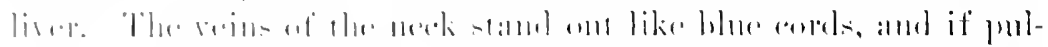

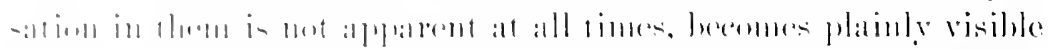

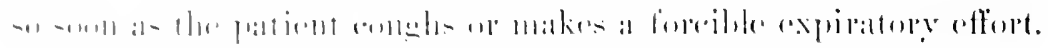

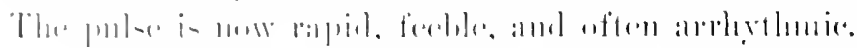

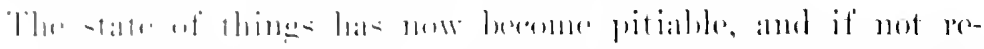

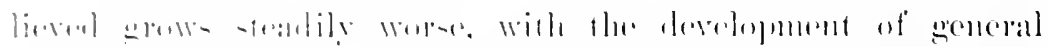

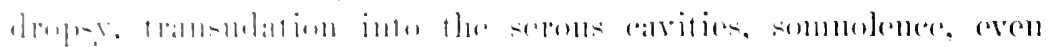

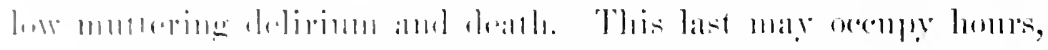

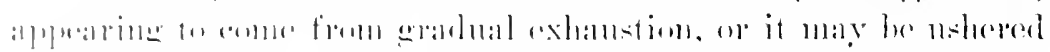

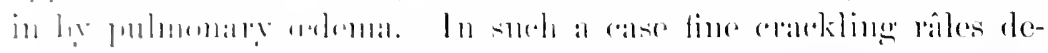

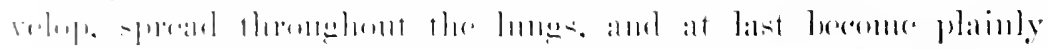

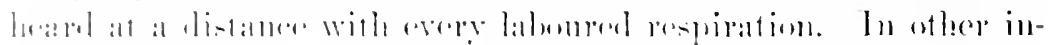

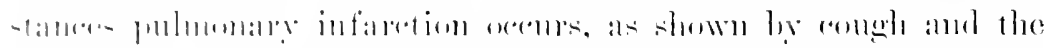

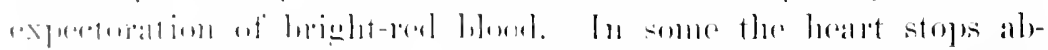

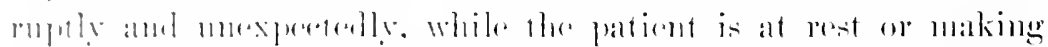

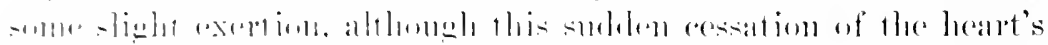

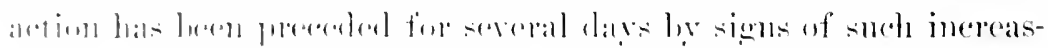

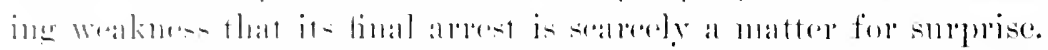

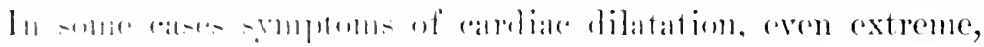

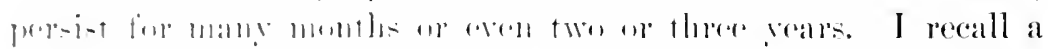

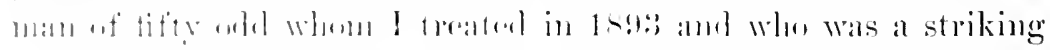

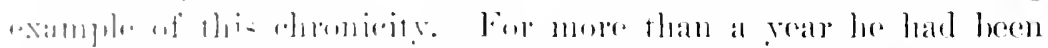

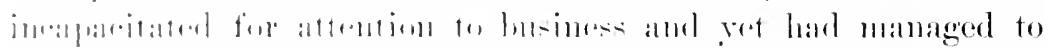

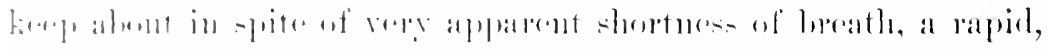

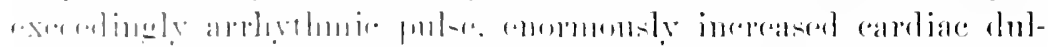

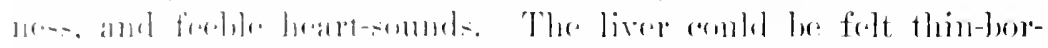

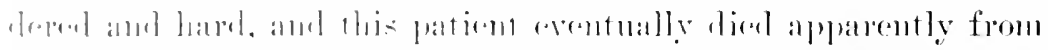

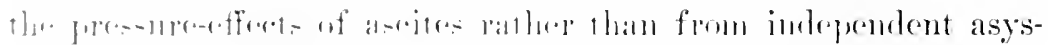

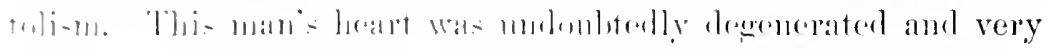

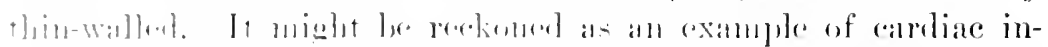

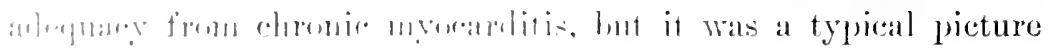

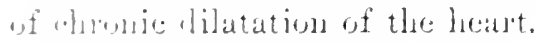


I have recently treated with highly gratifying results, by means of baths and resistance exereises, al powerfully built man of thirty-eight who was suffering from the effects of heart-strain four years before. When in apparently perfect health he endured a day of terrible fatigne from the exertion of jouneying in a severe snow-storm at the altitude of 18,000 feet. By night he was completely exhausted, lwoked line, felt cold, had a feeling of great pracordial oppression, and conde not get his breatl. After a few days' rest he felt better and returned to the East. Ite remained at busines, but when summer came on, went abroad for a rest, and in London consulted a well-known medical authority. By him he was told he hard suffered a heart-strain and was advised to give up bnsiness. He did not do so, however, with the result that he grarlually developed srmptoms of ehronic heart-disease. For some monthis before I saw him he suffered from dyspuea of effort, a fecling by night of profontarl exhanstion, and the conviction that loe was liable to die suddenly at any time. Ife nevertheless remained at bonsiness.

When I first salw him he presented the signs of mitral regurgitation with secondary enlargement of the heart, chiefly of the left ventricle. Lungs were negative, but the liver was palpable. There was no pitting, but the tissues everywhere felt tense and hard, and the patient silid he "felt swollen." Preliminary treatment by rest in bed, catharties, and a milk diet for two days reduced capillary stasis, improved the crality of the pulse, and removed the patient's sense of air-bunger. There was 2 per cent of allomin in the urine, lout althongh repeated search was made for easts, they were nerer found.

At the end of less than four months this patient declared he felt perfectly well and desired to return to business. The heart was manifestly smaller and its action greatly improved, but the mitral systolic mumur still remained. It was less lond and less harsh, however, and the first sound, originally inandible, conld be heard distinctly. The liver conld not be felt, but albuminuria persisted. This man lack never had articular rhematism or any discase to learl to endocarditis, and prior to his arduons momtain climbing hat never hat eren the slightest symptoms of heart weakness. I lave no dombt that his heart-muscle has suffered in its integrity, but I look upon this as an instance of chronic left- 


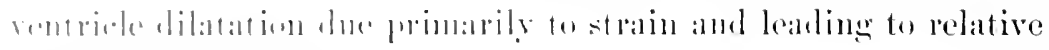

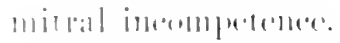

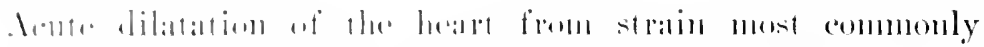

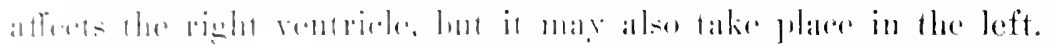

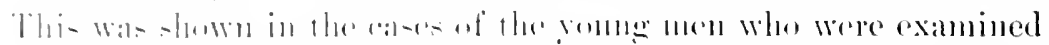

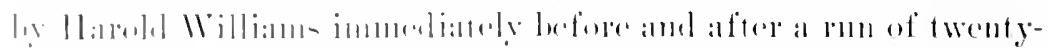

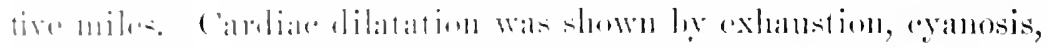

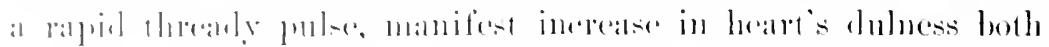

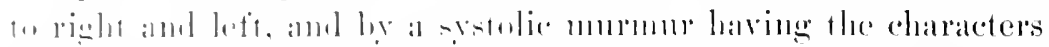

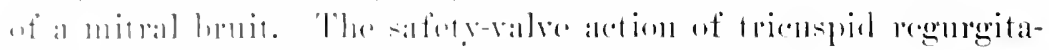

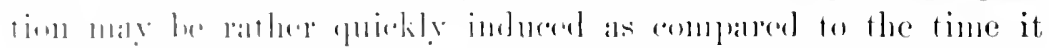

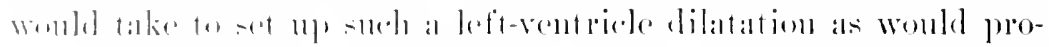

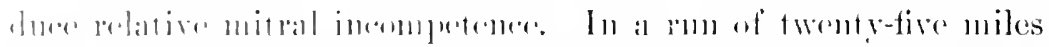

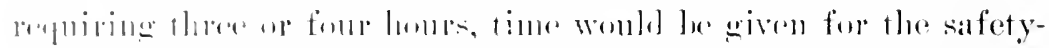

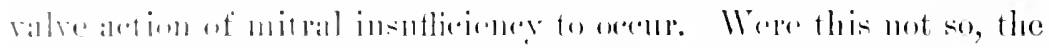

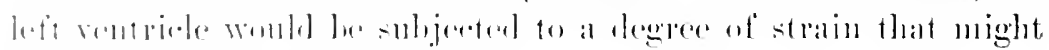

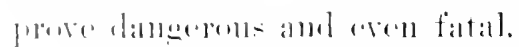

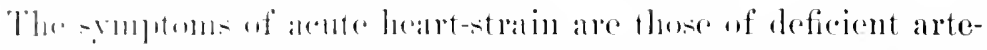

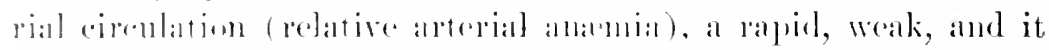

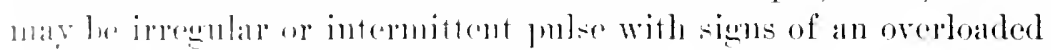

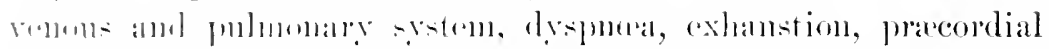

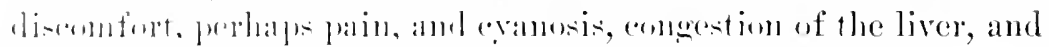

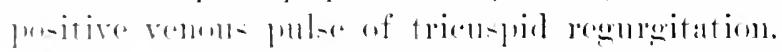

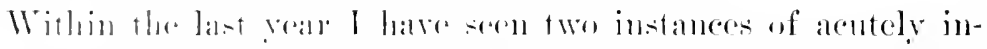

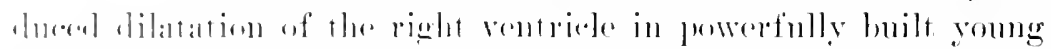

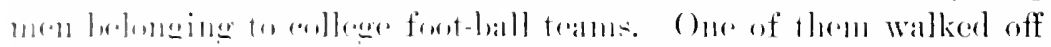

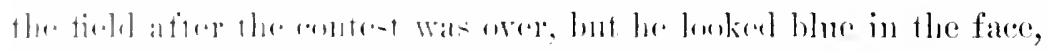

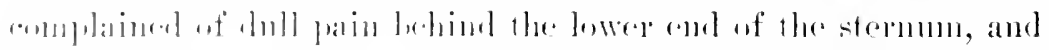

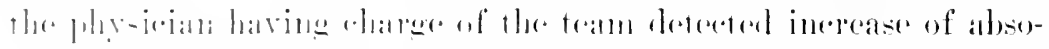

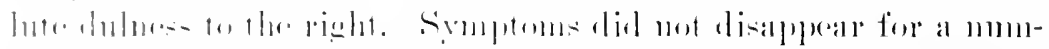

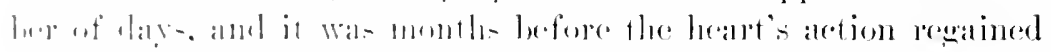

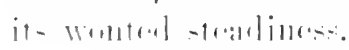

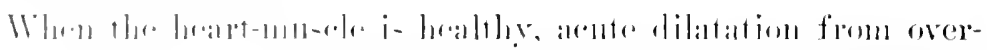

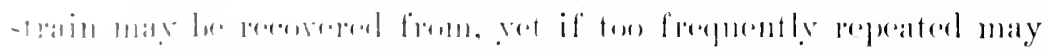

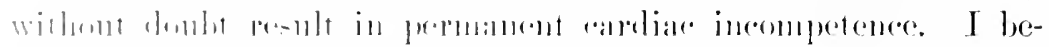

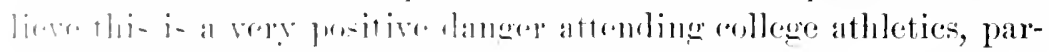

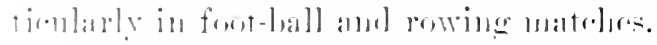

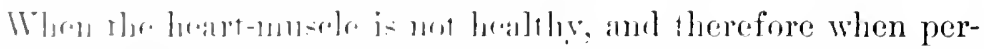

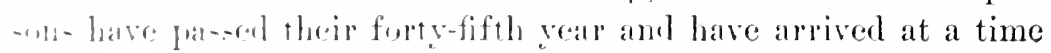


of life in which the state of the myocaldium is questionable, acute cardiae dilatation from overstrain becomes a very serions matter. The first symptoms of heart-strain may be recovered from, but more or less inadequacy is likely to rmain. In time, as a result of renewed but less severe strain, evidence of weakness sets in and the patient ultimately presents a clinical picture of gradually increasing dilatation of the leart.

Physical Signs.-Inspection.-The multiplicity of conditions which affect the pesults of inspection render's this means of investigation of comparatively snall value. The eye may perceive the well-known manifestations of cardiac weakness, but it camnot furnish information as to the actual state of the heart. There is mstally an alsence of visible calreliac impulse, but this alone is of no value, sinere it is normal to many individnals to have no visible apex-heat on aceonnt of the volume of the lumgs or the thickness of the chest-wall. In emphysema, which so commonly leads to ultimate dilatation of the right leart, visible impulse is also likely to be wanting. In all cases in which the apexbeat is not plainly visible the patient shonld be placed in a strong light and inspection made across the front of the chest from the side or from above downard. If dilatation exists a feeble apexshock may thus be sonetimes perceived outside of and below the nipple or in the epigastric notch.

Palpation.- Aside from the knowledge which this affords concerring the pulse and hepatic congestion, palpation is of service in the estination of the foebleness or strength of cardiac contractions. Thin-walled and dilated hearts may give no perceptible shock to the chest-wall, or they may oceasionally produce a sudden quick tap whenerer the organ gathers itself, as it were, for an extra effort. When the apex-beat persists, it is not like the broad heaving impulse of hypertrophy, but is a rircmiscribed feeble stroke of a slapping character. This is partienlarly the case in longstanding dilatation with still some degree of efficiency.

Percussion.-This is, als a rule, om most valualle means of determining if dilatation of the leart is present, hut it may afford very mreliable evidence in cases of pulmonary emphysema. If the state of the lungs and of the thoracic parietes renders percussion available and if dilatation exists, the area of deep-seated if not of superficial dulness is found inereased in accordance with the 
degreen of diatation and the chambers affereted. In dilatation of

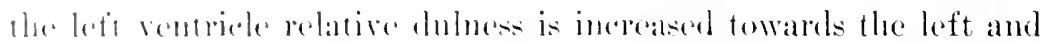

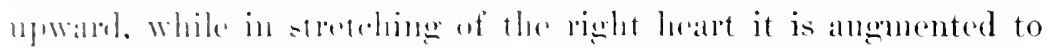

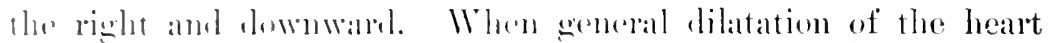

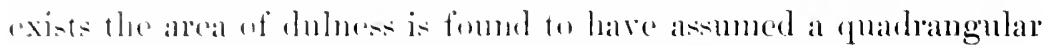

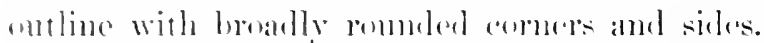

1 uscullation.-The he:art-sombls ane feeble, altered in intensity

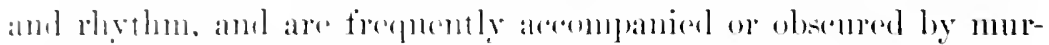

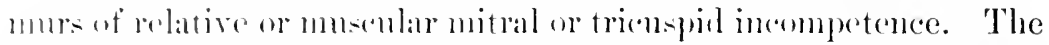

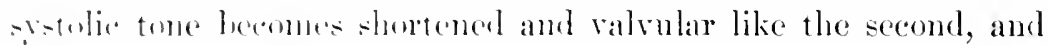

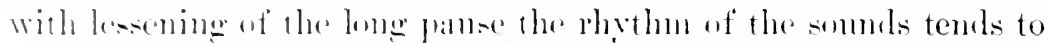
assme that of the ticking of a small clock or watch. In cases of gereat weakness and rapirlity of heartaction the tones follow each "ther in quick sncersion, or hat a single sound may be detected.

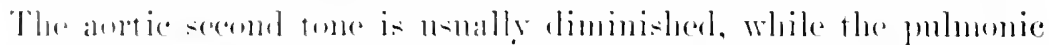

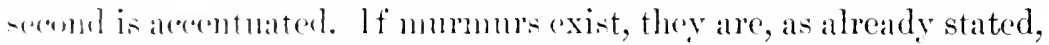
thre of relative or musenlar incempetenee of one or both anriculorentrienlar valves depending on the degree of dilatation. The ansilutator should not forget, however, that it is possible for bruits of presexisting valumlar discase to be present, and therefore he must not hastily conelude that the mumur is necessarily due to dilatation alone. In many ases he must await the result of treatment before deredinge definitely on its real nature.

Diagnosis.- The rengentitum of andiale dilatation is ordi-

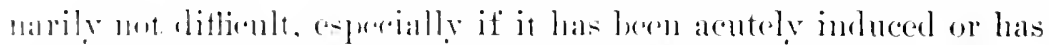
frogresed to the production of considerable inadequacy. Minor degeres of stretehing are not always easy of detection and reguire mimute incpuiry inte the history and symptoms, as well as painsraking physial examination. In skwly indued dilatation there

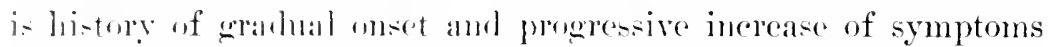
"ff "arliar incompetenere, while there are clinical findings of (1) a

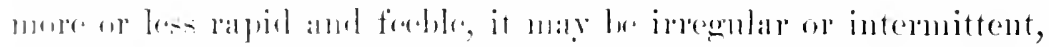

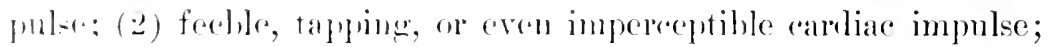

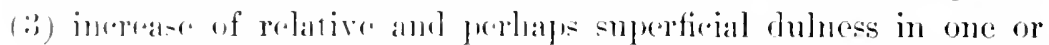

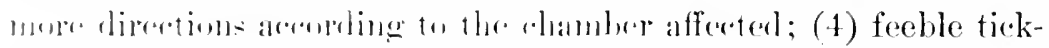

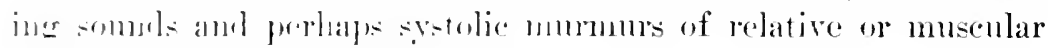
mitral or tricu-pid in-ufticienere.

In arote oresterin the phenomena of ardiac embarrassment follow some nnnenal exertion and an casily recongnised, while the 
patient is apt to display more or loss eyanosis and ofler evidence of impending stasis.

Differential Diagnosis.- - Aente dilatation of the heart ean seareely be mistaken or confonded with any of her condition provided due attention is paid to history and objective symptoms. Distention of the ardiac carities that has developed more slowly and has grown extrenc may, howerer, be mistaken for pericardial effusion. The differential points are fully dealt with in that chapter, but special emphasis may here be laid on the necessity of determining the relation of the onter and inferior margin of decp-seated dnlness to the position of the apex-beat. In cardiae dilatation dulness does not pass beyond the limits of cardiae impulse, whereas in pericardial distention the apex-inpulse is situated within the onter border of dulness. This, and this alone, is the trustworthy eriterion of lifference between the two affections. In other reopects there is often a striking similarity.

Dilatation and hypertiophy ean scarcely be confounded if dne attention is paid to the characters of the pulse, to the natme of the impulse, and to the greater fecbleness and rapidity of the somnds in dilatation. A simply dilated and ret not specially degenerated heart camot often be distinguished from a degencrated and hence secomdanily dilated organ, and it is not always prodent to attempt such distinction.

Prognosis. - Dilatation of the heart shonld never be regarded as a trivial matter, and yet the degree of its gravity depends upon the state of the heart-1nuscle, the extent of the dilatation, and the length of time it has existed. It is the integrity of the myoeardinm in the romes and in trainer athletes which in them makes the heart recores so quickly and well from the orerdistention cansed by strain. On the other hand, it is the likelihood of the heart-walls being not quite somnd which render's prognosis serions when dilatation supplants hypertrophy or when elderly individuals suffer leart-strain. Stiffened arteries do not neeessarily mean that the heart-walls are seriously degenerated, and experience abundantly proves that in some cases proper treatnient may restore a dilated heart even when the vasenlar coats are thickened. Nevertleless, under such conditions stretching of the cartiae chambers is always a grave affair, and only too often there is but 


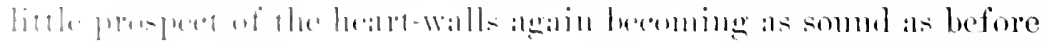
ille injinl?

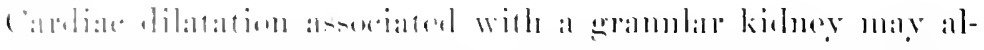

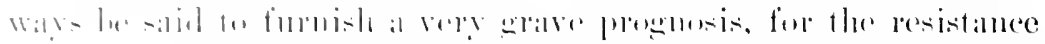

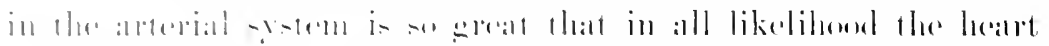

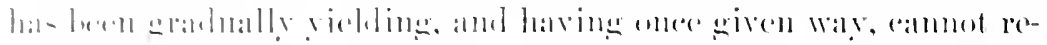

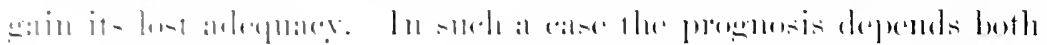

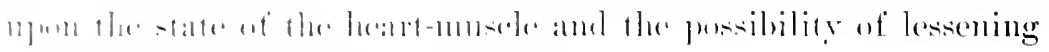

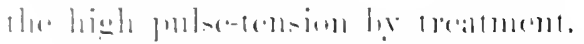

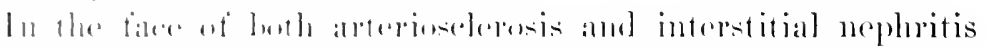

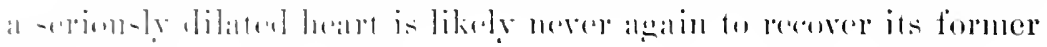

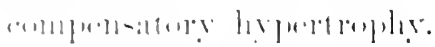

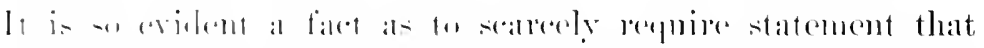

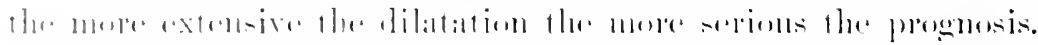

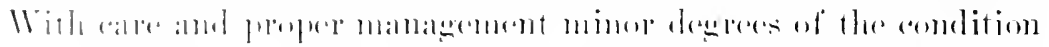

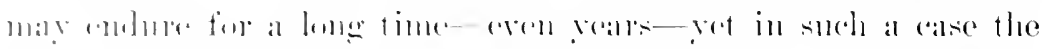

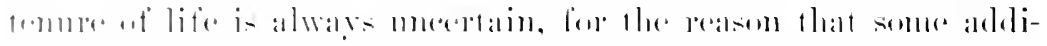

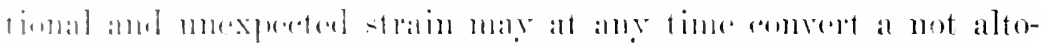

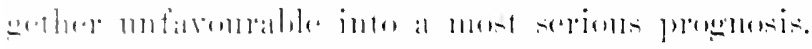

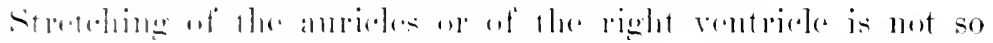

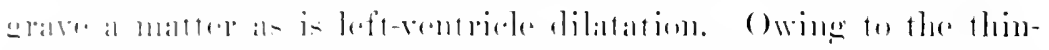

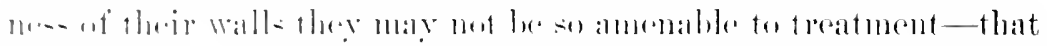

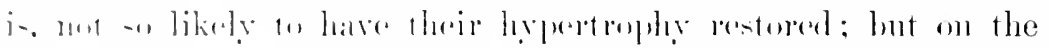

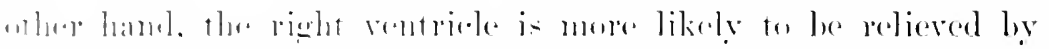

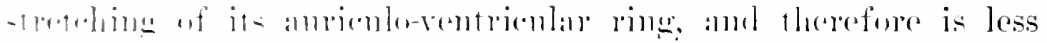

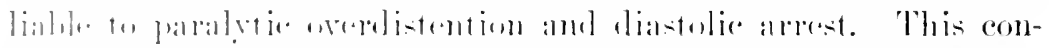

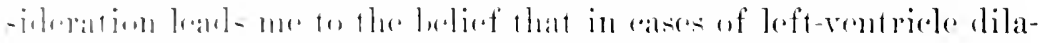

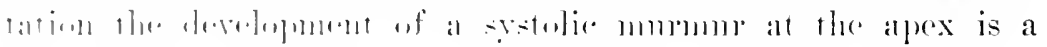

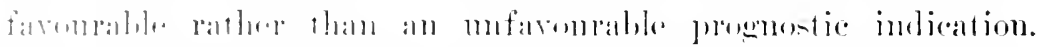

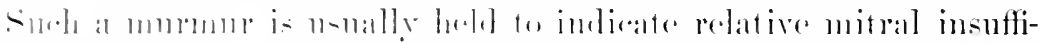

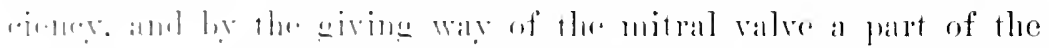

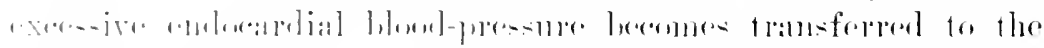

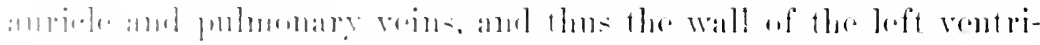

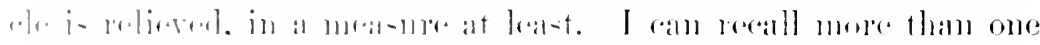

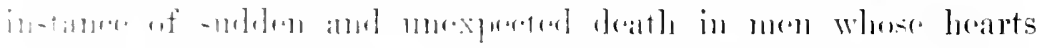

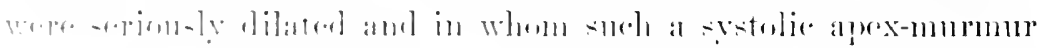

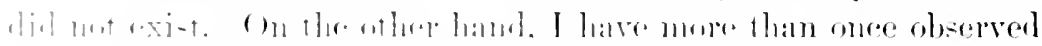

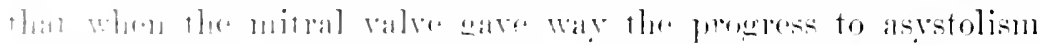

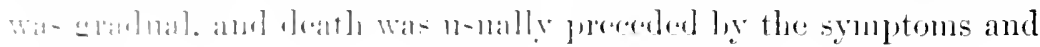


signs of renous stasis, extending through a period of weeks or months.

It is also evident that prognosis is largely governed by the length of time the dilatation has existed. If the myocardium is still healthry, as in the roung, a chronic dilatation may yet be recovered from. In persons past middle age the condition is likely to resist treatment if it has become chronic, and if in sueh the pulse is persistently arrhythmic, it is to be looked upon as an indication that the heart-muscle is not sound or that the auricles are greatly dilated. According to Rarlizewsky, habitual irregularity of the pulse points to preponderating degeneration of the walls of one or both auricles. If this be correct, then arrhythmia in connection with chronic dilatation of the heart is a better prognostic sign as regarels length of life than is tachyeardia with perfect regularity of rhythm due to a dilated rentricle. In acute dilatation from orerstrain, als in tont-ball or nomntain climbing, the prognosis is as a rule good, for with rest and proper treatment the heart is likely to return to its former healthy condition. Repetitions of its abuse may, howerer, eventually indnee permanent inadequacy.

Another clement that enters into the question of prognosis is the degree of subjective srmptoms produced by the dilatation. If drspuna be less than one would be led to expect from the apparent aravity of the condition, the case is likely to pursue a chronic course; if, on the other hand, the shortness of breath he out of proportion to the apparent size of the oram, or to the amount of exertion performed by the patient, or if the dyspnoca assumes the form of earliae asthma, then the prognosis is bad, unless the ureney of this symptom can be accomted for by an assoeiated emphresena or lironchitis.

If skilful treatment succeeds in producing only temporary improvement, and the heart drops back to its formel state so soon as treatment is discontimed, or less rigonous, it is an indication that the heart-muscle is either too weak to be regenerated, or the peripheral resistance is too great to he permanently overeome. A steady thongh gradual loss of ground, in spite of treatment, proves that rery little is to be expected from any management, no matter how skilful.

Except in cardiac strain of effort in the young, one should never rentule to prognosticate the length of time it will take for 


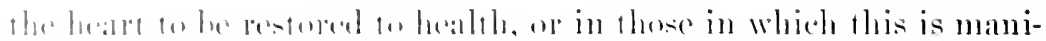

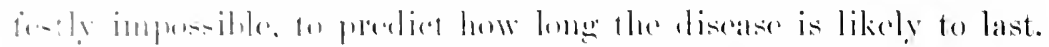

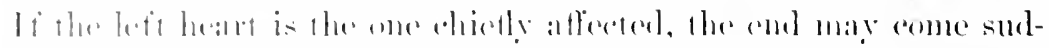

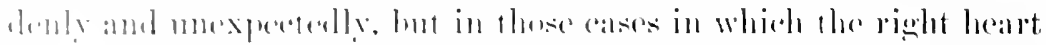

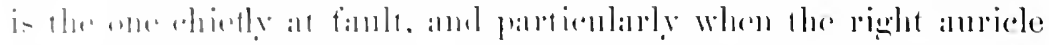

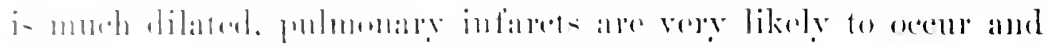

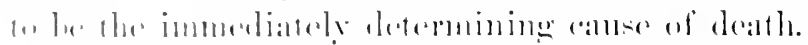

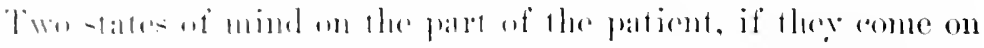

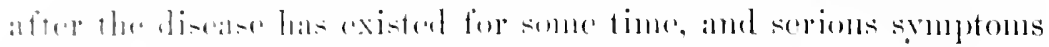

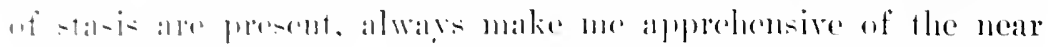

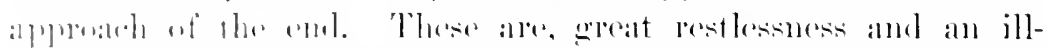

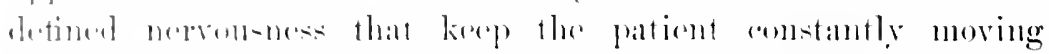

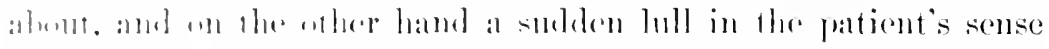

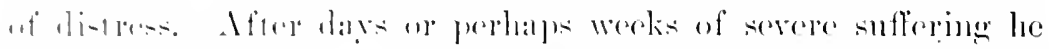

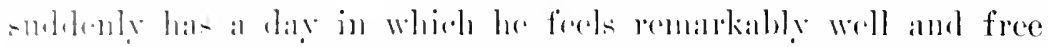

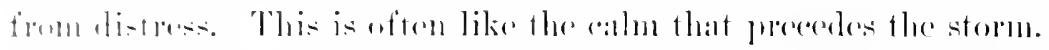

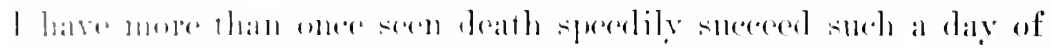

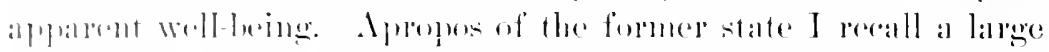

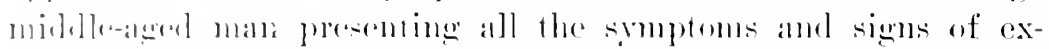

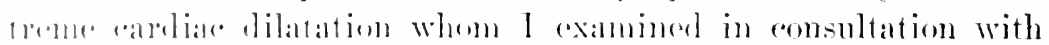

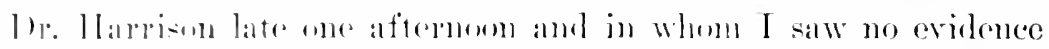
that the and was inmenent: le hade leen in that condition for a

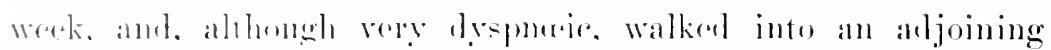

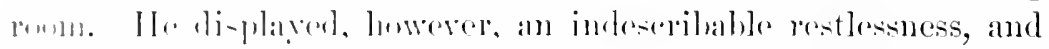
l... than there lowl's after we left him he died suddenly.

Treatment. - In dilatation of the lacat sudromly induced

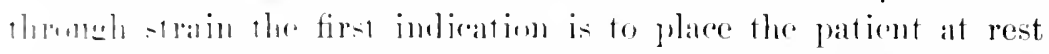

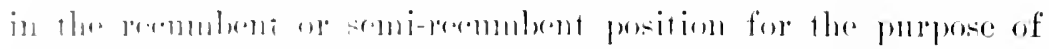

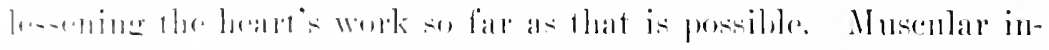

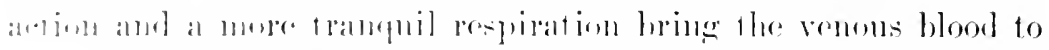

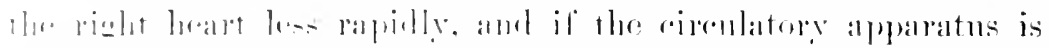

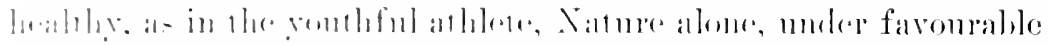

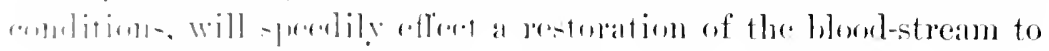
in - furmure repuilibrimus.

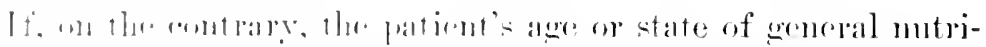

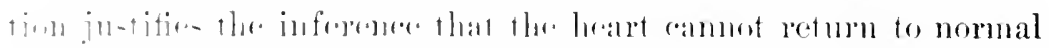

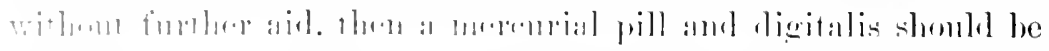

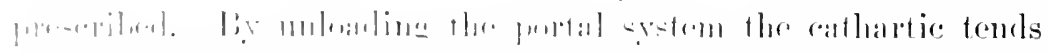

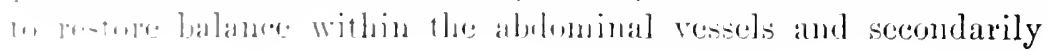


in the system at large. Five grains of lilue mass followed by $\frac{1}{2}$ ounce of Epsom salts right homrs thereafter, or a grain or two of calomel at bedtine and a glassful of the solution of citrate of magnesia next noming, or any one of the numerous aperient waters in the market, will prove highly efticient to that end.

The purpose of the digitalis is to slow down the heart and enable it to empty its distended cavities effectively. This may be accomplished by the administration of 10 to 15 minims of the tineture every six hours for four or five days. Improvement will be shown by a reduction in the rate and corresponding gain in the force and strength of the pulse, Jy disappearance of cyanosis and other signs of renous congestion, by increased dinresis, and a gradual return to nomal in the size and sounds of the heart. Strychnine and nitroglycerin will probably not be required. It is well, however, to insist on light yet nutritions diet until the normal state of the cireulation has been regained.

When permanent cardiac insufficiency is threatened from repeated heart-strain or from the grachal giving way of hypertrophy in the face of relatively too great peripheral resistance, the principles of treatment must be the same as in any other form of heart-weakness. The first indication is to relieve the orertaxed heart. Therefore the patient must be put at physical rest for a length of tine which is to be detemined by results. To the patient's query, " How long must I stay in bed!" do not permit romiself to make a definite answer, but tell him that is to be determined by the rapidity and degree of improvement. In other respects the sane general plan of action previously detailed for cases of lost compensation is to be followed, but raried to meet the peculiarities of each case.

Most cases of cardiac dilatation which the physician is called on to treat are not instances of acute strain, but of chronic cardiac insutticiency. They are to be managed, therefore, in aceordance with the principles laid down for the treatucnt of inadequacy fron chronic myocarditis, and the reader is refered to that chapter for details.

There are three measures, however, of which it may be well to speak with special relation to eardiac dilatation:

(1) Bloodletting.-Occasionally a patient is encountered who from one cause or another is suffering from great overdistention of 
the right heart. The andion is atromely foolde and disoldered,

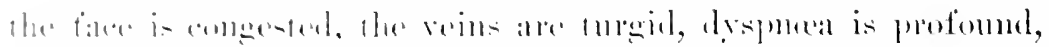

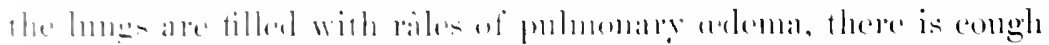

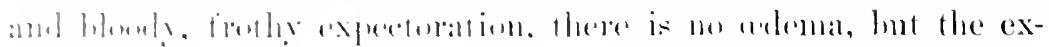

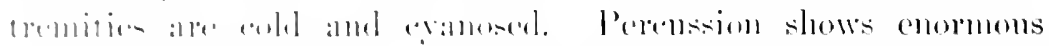

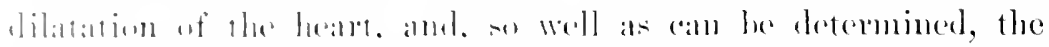

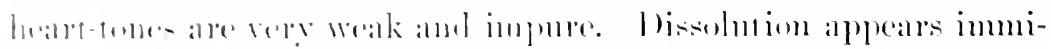

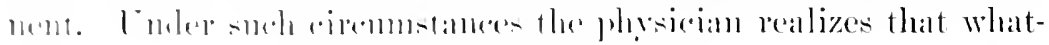

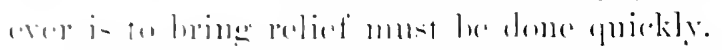

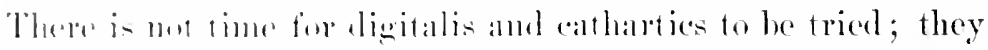

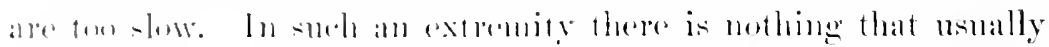

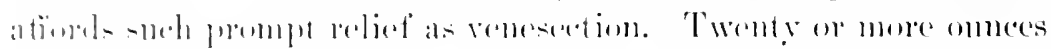

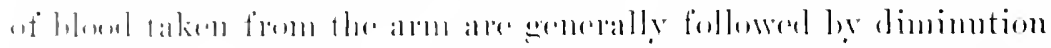

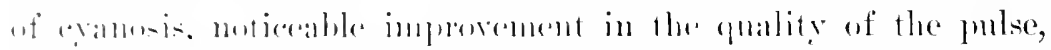

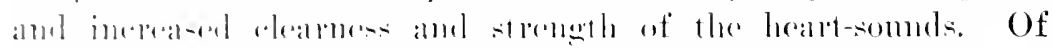

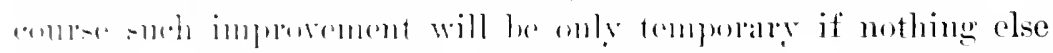

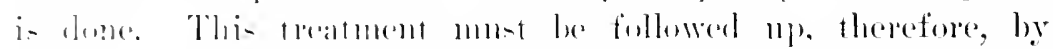

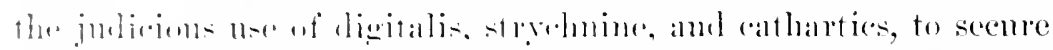

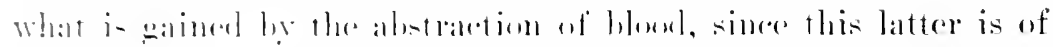

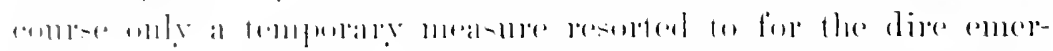

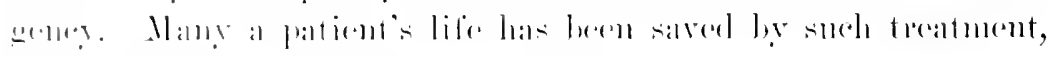

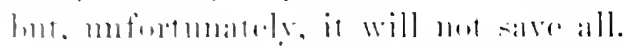

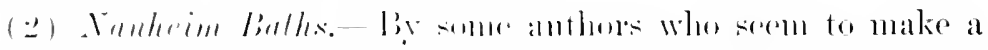

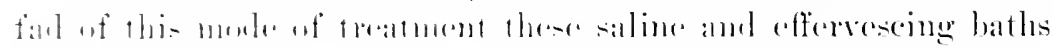

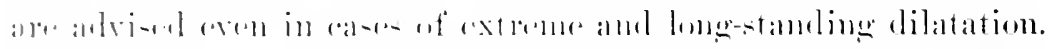

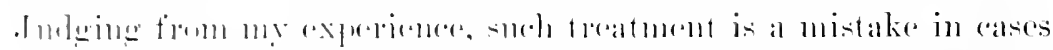

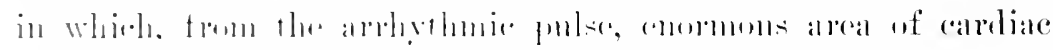

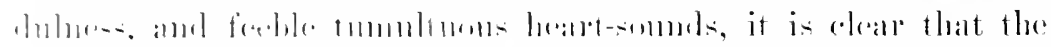

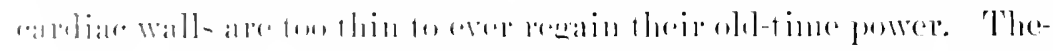

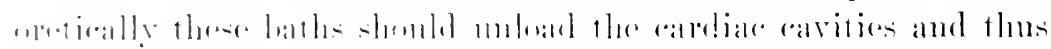

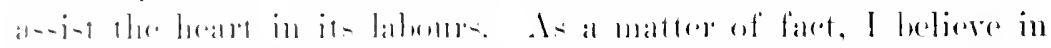

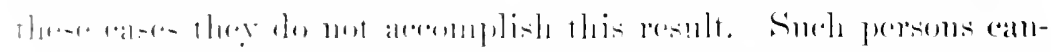

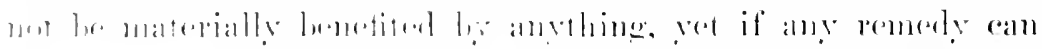

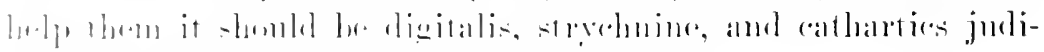

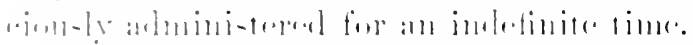

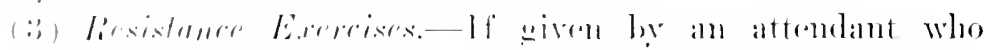

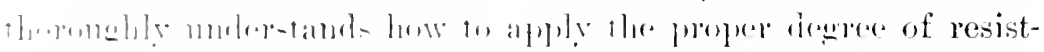

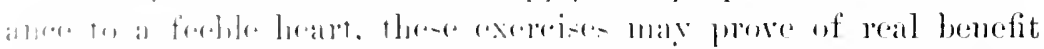

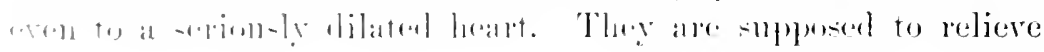


the cardiac carities by diverting a part of their contents to the peripheral ressets, and as a matter of fact they are followed by a demonstrable decrease in the area of eardiac duhness. Nevertheless I do not believe it is possible to create so remarkable a deerease as is claimed by Theodor Schott, who finds in this effeet a means of differential diagnosis between a dilated organ and a pericardial affusion. When employed in the condition now considered they must be given with vory great gentleness, and novenents are to be onitted which neeessitate the elevation of the arms above the head as well as bending of the trmuk at the hips, which are eapable of angmenting dyspmea and aggrarating the dilatation. Even when permanent inprovement in the patient's condition does not result it is generally fomd that for a time at least there is a lessening of his distress and an improvenent in his colour. I therefore recomment their trial in all cases of chronic cardiac di]atation.

Should cases of chronic cardiac incompetence be not improved by the measures just spoken of, then it is reasonable to infer that the case has passed beyond the stage in which anything more is to be hoped from treatment than the amelioration of symptoms. One may yet do what he can with digitalis, strychnine, nitroglycerin, diffusible stimulants, and cathartics. In the majority of cases morphine will now have to be given, and if administered hypodermically to serure confortable nights, the remedy is gemerally of the greatest serrice. In many instances morphine thus given will prolong life and ease the sufferer's path to the grave.

Only a few months ago Dr. George F. Roberts, of Minneapolis, ealled me to see a gentlenam of nearly sixty who presented a typical pieture of a dilated heart. The myocardimm was probably degenerated, but his arteries were soft and urine was negative, so that one conld not say there was more than cardiac incompetence from dilatation. Ile was in bed and dyspnede, but his suffering arose from vertigo, which cance every few minutes and lasted from afew sceonds to a mimte or more. During the rertigo his radial pulse wholly disappeared and the heart-sounds hecane excedingly rapid and feethe but perfectly resular; the cavities were not being emptied. Snddenly the action of the heart wonld change, becoming slow, strong, hut irregnlar; the pulse would return and the 


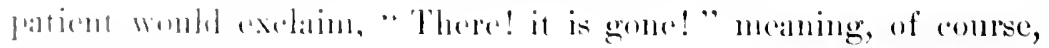
this disinder.

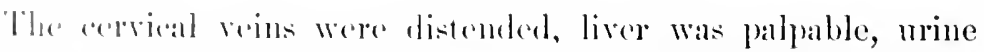

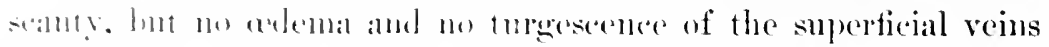
wrer dla tomk and limbs. C'ardiac impulse was alsent and the

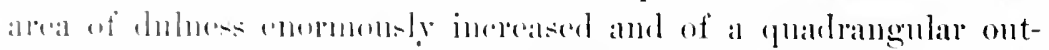

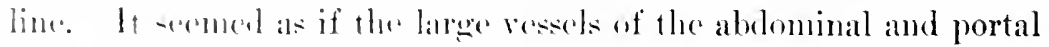
Yolems were holding the most of the hood.

Veneswetion was indiated and might have afforded temporary reliet, hul for reptain reasols it was not performed. Instead, nitrugrorin, ammplur, and valerianate of caffeine were injeeted

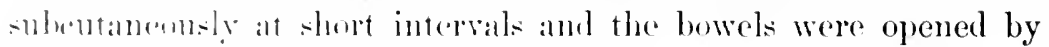
allomel and a saline. Vertign was rolicyed by this means, but cirenlation was not matrially improved. The heart-walls were two gleat y stredehed and probahly degenerated to regain their adeyuacy. and the pationt died about ten days subsequently.

\section{I1. RELATIVE ANI MUSCULAR MITRAL INSUFFICIENCY}

Relative. - Bis this term is meant that varicty of incompetenee which results from oreredistontion of the loft ventricle and is enamutereat in its most typical form in the acute heart-strain just

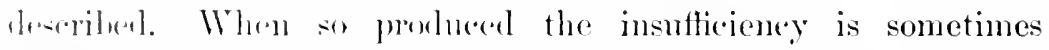
groken of as prinary, to distinguish it from the sublivision known as seromblary. It is the latter, or secomblary, that not infrequently lereloge in the latr stage of aortir stenosis and regmegitation and hat $\therefore$ often heren referred to in the foregoing pages.

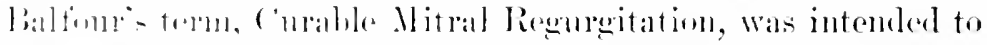

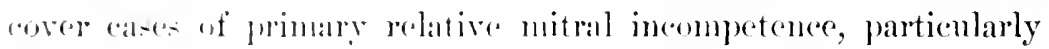
a- sorn in riblowio sirls, since it is very amenable to treatment.

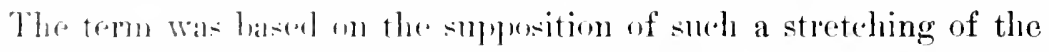

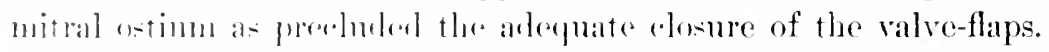
In the light of mune leserent knowlenge, howerer, it is likely that

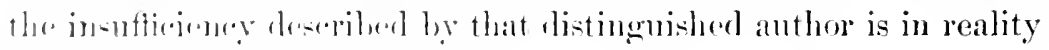

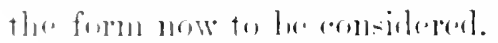

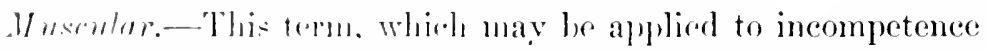

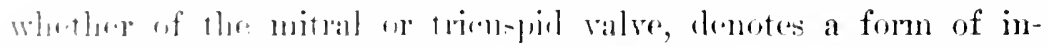

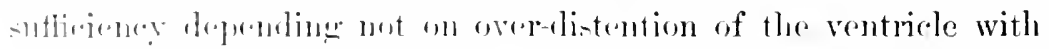

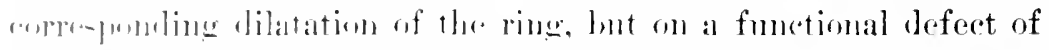
the musenlar morelanison by which momally the valve is enabled 
to elose. For onr knowledge of the facts mulerlying this subdivision of mitral incompetence we are indelnted to the Lcipzig Sehool, whose views it must be confessed have been very tardily accepted by English and American authors.

Pathology.-The morbid anatonical andition mulerlying relative insufficiency of the aurienlo-rentricular valres is dilatation of the ventricle. This dilatation must reach such an extreme grade, howerer, as to carry with it more or less stretching of the mitral ring, as shown by its admitting more than three fingers. The valve itself is structurally intact, or in eases of long standing the ensps mas be longer and broader than normal and the papillary muscles be flattened and elongated as a result of the pressure to which they have been subjected. In brief, the organ presents the changes previonsly described muler Dilatation of the Heart, either with or withont structural disease at the aortic orifice.

In muscular mitral insufficiency the left ventricle may or may not present evidence of dilatation, but if this condition existenl during life it was not of so high a grade as is the case when relative incompetence occurs. In many instances the pathologist is surprised by finding nothing at first sight to explain the mumur heard before death. The mitral ostimm is not dilated and the valves are intact.

Closer examination, however, discloses changes in the musculature which interfered with the perfect coaptation of the valve-flaps. These are the changes of acute or chronic mocarditis, which farour the vecurrence of more or les dilatation and lefective action on the part of the ring muscle or propilaries, an hoth.

Three factors are concemed in the rlosme of the auriculoventricular valves, (1) the pressure of the blowl within the rentricle upon their ventricular surface, (2) the contraction of the ring muscle at the base of the rentriele by which the orifies is narrowed to a mere chink, and (3) the contraction of the papillary muscles and consequent tightening of the cortar temline: The combined effect of all these elements is the perfect apposition of the valve-flaps throughout practically their entire surface, and not merely at their margins.

If now, in consequence of inflammation or legeneration, the wall of the ventricle dilates sufficiently to prevent the nitral ostium from becoming adequately contracted during systole, or to inter- 


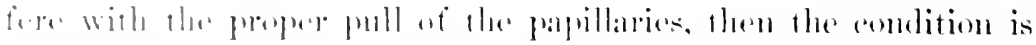

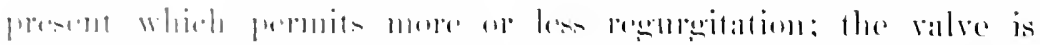

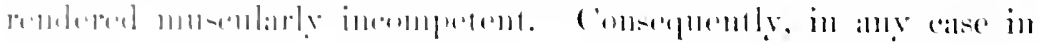

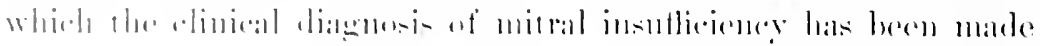

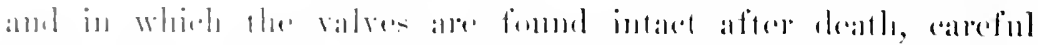

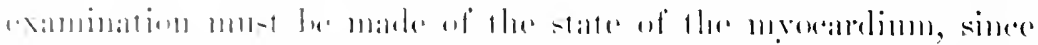

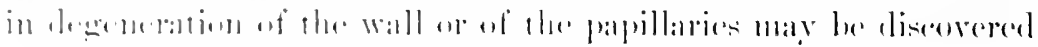

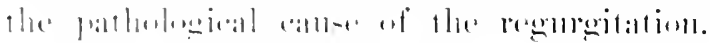

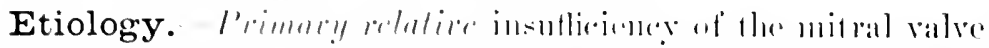

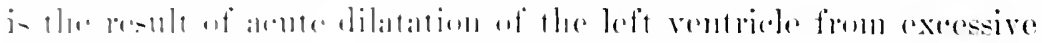

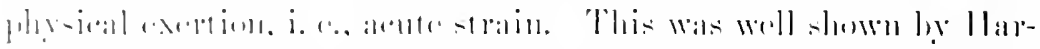

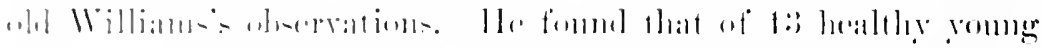

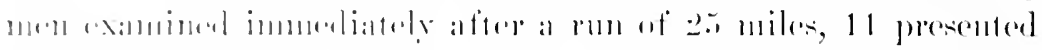

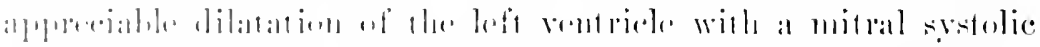

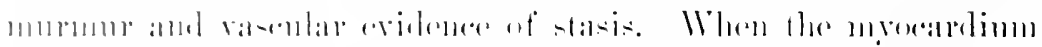

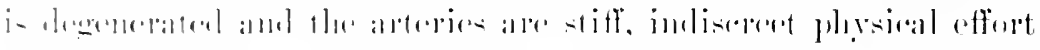

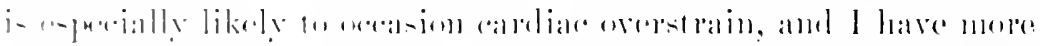

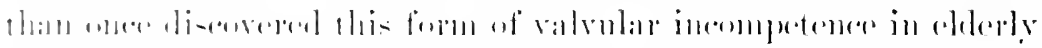

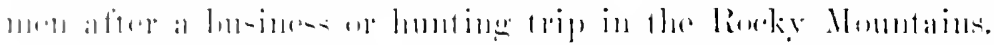

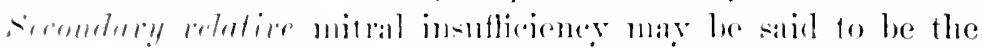

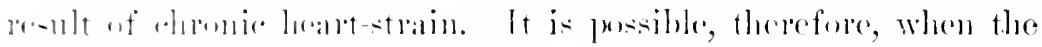

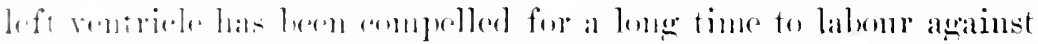

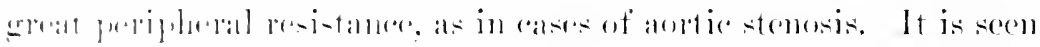

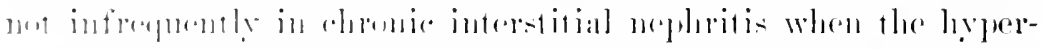

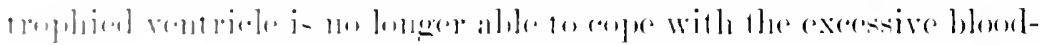

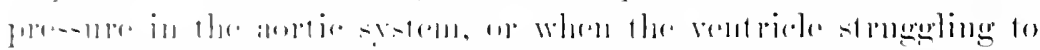
J

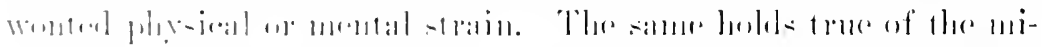

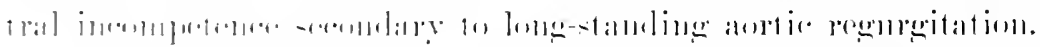

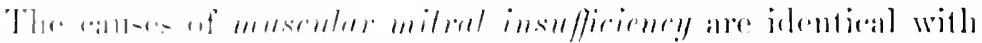

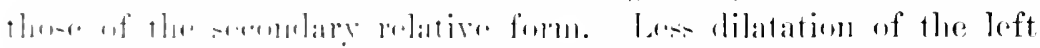

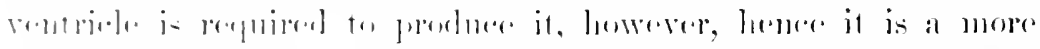

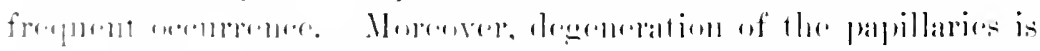

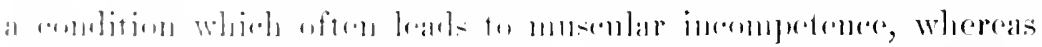

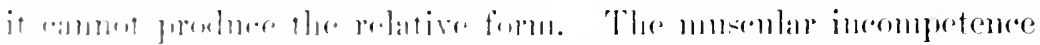

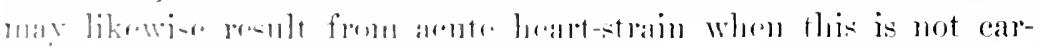

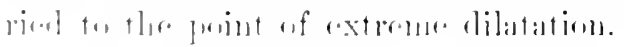

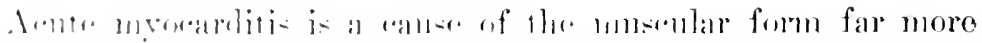

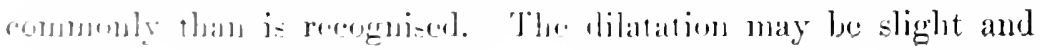


escape recognition, and hence the apex murmur is generally sup. posed to indieate enderarlitis. Such an error is the mone likely since the acnte myocaditis develops in the conse of some acute infection, as rleumatism, diphtheria, typhoid feror, ete. The ultimate subsidence of the murmur pari passu with the return of the ventricle to normal size probalily proves the condition to have been muscular and not endocarditic.

The Curable Mitral Regurgitation of chlorosis and grave ancmia, which is probably muscular in the strict sense, is due probable to the blood-state, which by depriving the heart of requisite nutrition lessons its resisting power so that a moderate grade of dilatation superrones.

Symptoms are those observed in cardiac inadequacy, and need not be letailed here. Their intensity and, to a certain extent, their character depend mon the freedom of the leak and the rapidity of its development. Tn the slighter grades of muscular mitral incompetence srmptoms may be so mild as not to draw attention to the real scat of tromble, and it nay be diftieult to decide how munch of the elinical picture is dne to the leak and huw much to the muleriving cardiac, vascular, or renal condition.

Rolative mitral insuftioneney of acute heart-strain produces pononned symptoms, riz., pracordial distress, drspmea, a foeling of wakness that may amonnt alumost to syonere, cranosis or an ashen pallor of the comntenance. Anamic or chlorotic girls with "curable mitral regurgitation" are apt to display breathlessness, muscular woakness, and sometimes slight ankle puffiness, which is due to rlie state of the blood rather than the heart.

Physical signs are essentially the same as in mitral regurgitation of endocarditic origin, but with slight differences. In relative insufficiency percussion is apt to show greater increase of clulness to the left, while in muscular incompetence the murmm is more typically blowing and generally accompanies, but does not replace, the first somnd at the apex.

Diagnosis. - The reconnition of the mitral insufficiency is generally easy. The difficulty lies in differentiating the forms we are considering from the incompctence of endocardial inflammation. The main differential points are the following:

(1) Age, the individual in most cases being past forty. History of articular rheumatism wanting, but in the primary rela- 


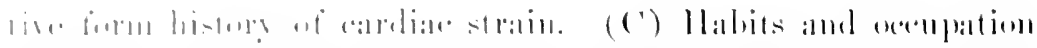

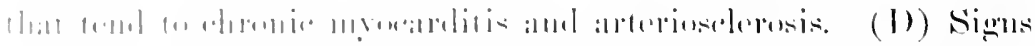

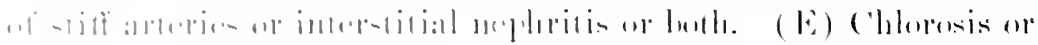

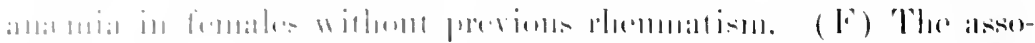

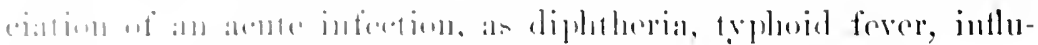

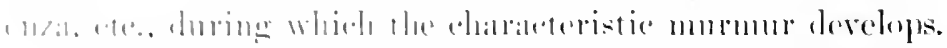

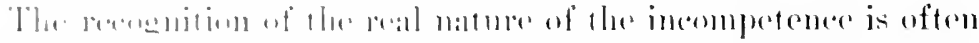

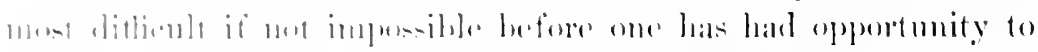

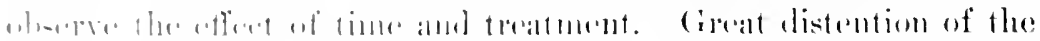

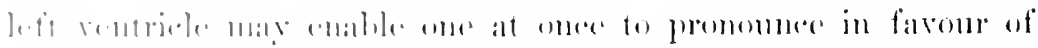

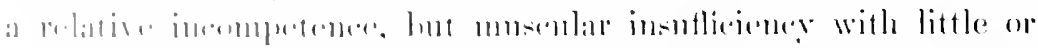

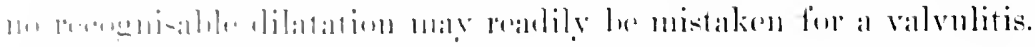

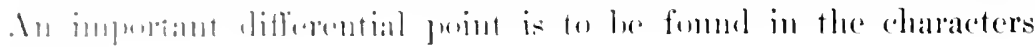

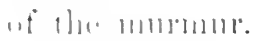

In mo1-n

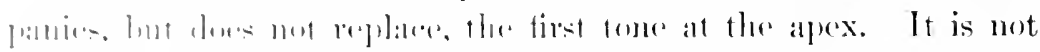

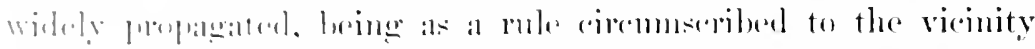

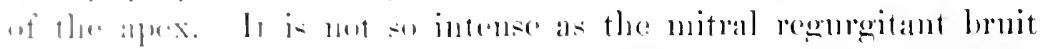

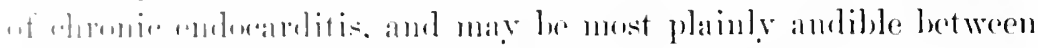

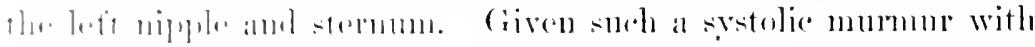

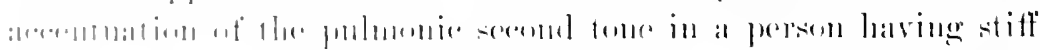

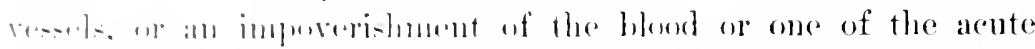

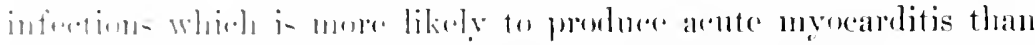

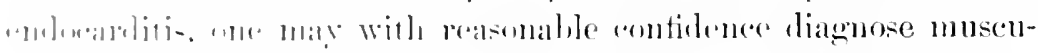

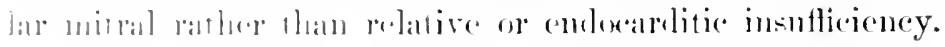

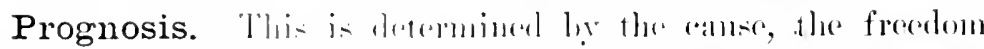
of the laik atml the an of the pationt. The relative incompetence

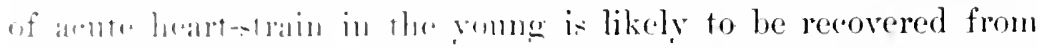

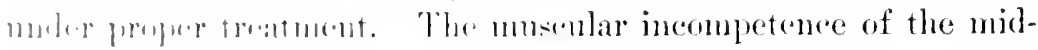

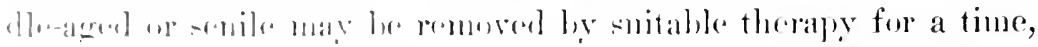

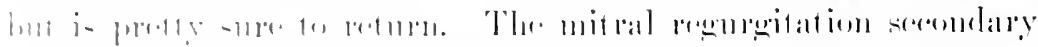

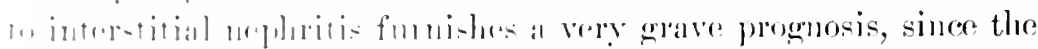

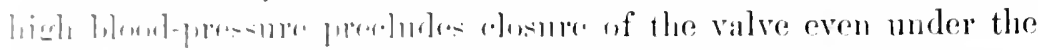

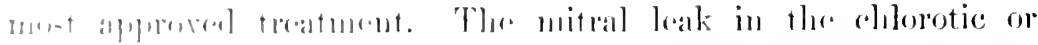

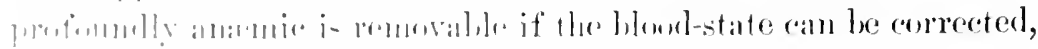

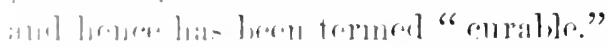

Treatment. Thi-in hlat uf the mulerlying patholugieal con-

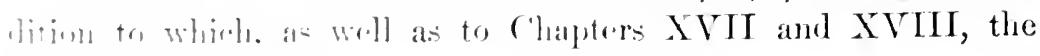
realer is referered 


\section{CHAPTER XXIII}

\section{FATTY HEART}

\section{CARDIAC INADEQUACY OF THE CORPULENT}

FatTy heart is the term most commonly employed to designate, not fatty degeneration of the heart-muscle, but a deposit of fat beneath the epicardium and between the muscle-fibres-a condition varionsly styled fatty orergrowth and fatty infiltration.

Morbid Anatomy.-In this discase the subepicartial layer of adipose tissue is strikingly, sometimes enormonsly, increased. The fat is particularly abundant in the interventricular and interauricular grooses, especially the latter, and along the branches of the coronary arteries. It is usually thicker over the right than over the left ventricle. It is not only deposited on the surface of the organ, but makes its way between the bundles of innsclefibres, which, examined microscopically, are seen to be more or less widely separated and to have beenme attenuated or atrophied. In some instances there may even be masses of fat beneath the endocardinn.

Pathology.-It is generally believed that when cardiac insufficiency declares itself in fat people it is owing to an excessive deposit of adipose tissne mpon the heart or to fatty degeneration of the heart-muscle. Romlerg has, however, set forth in so actmirable a mamner the real pathology of this condition that I shall avail myself of much of what he says.

He agrees with Leyden in the view that the old emepption of fatty heart as an independent affection must be abandoned, and, insteal, makes the term fatty heart inchule those disturbances of heart action manifested by the obese which either bear a direct relation to their obesity or have developed independently. That their cardiac insufficiency is not dne to fatty orergrowth is substantiated by the observation that hearts loaded down with adipose 


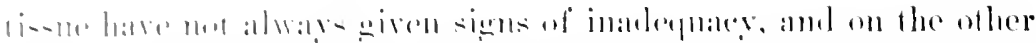

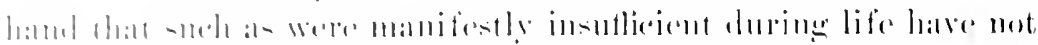

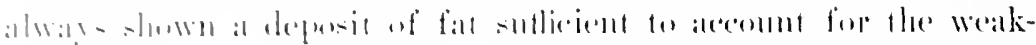
114...

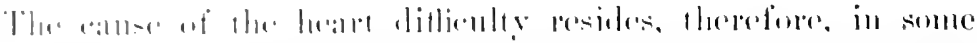

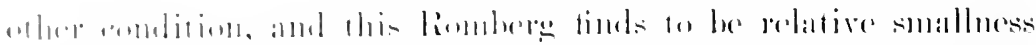

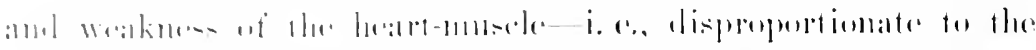

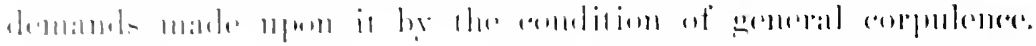

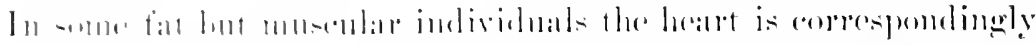

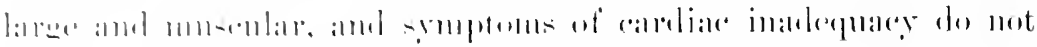

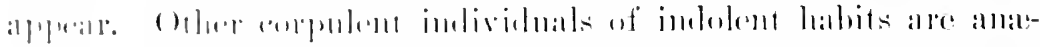

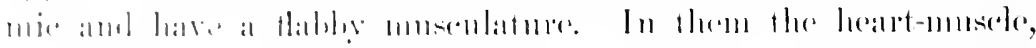

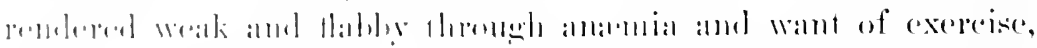

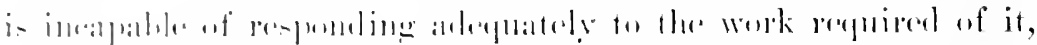

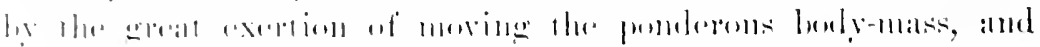

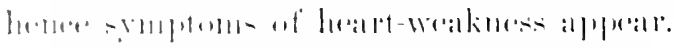

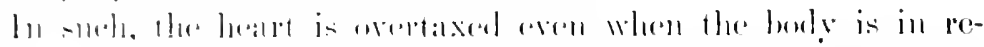

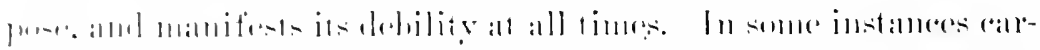

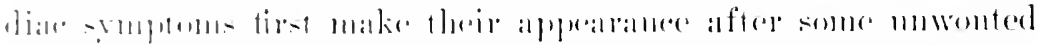

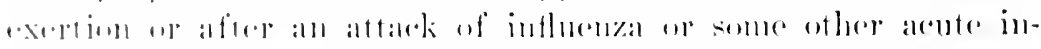

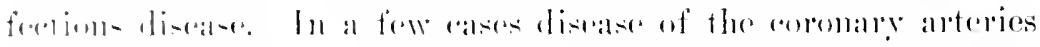

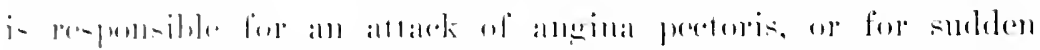

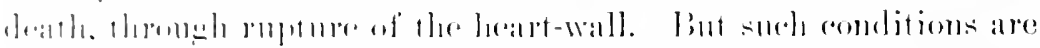

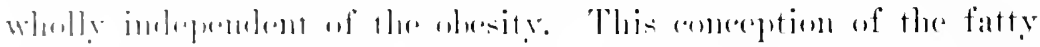

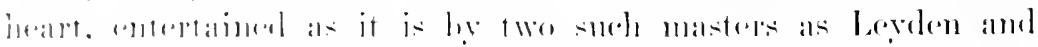

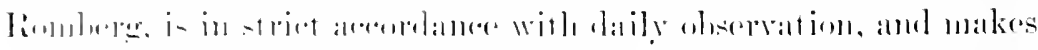

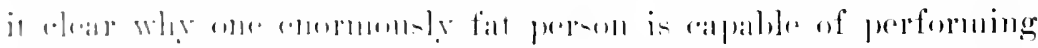

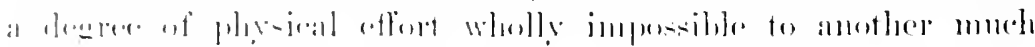

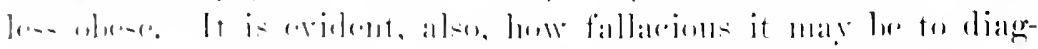

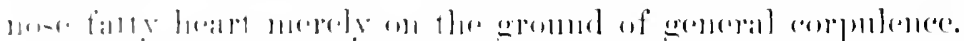

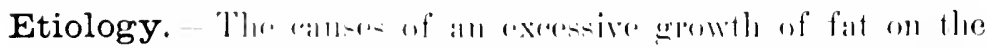

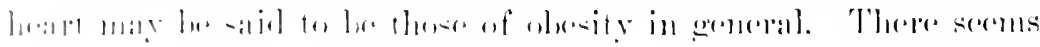

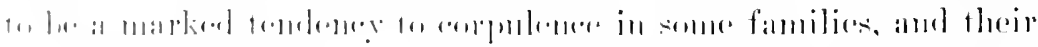

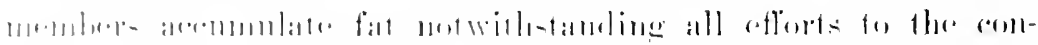

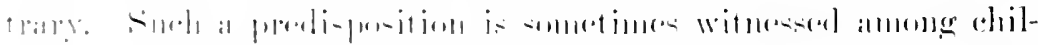

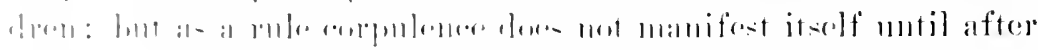

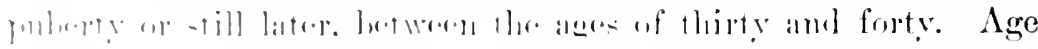

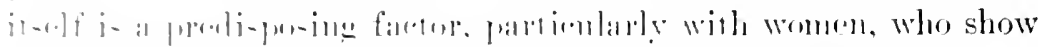

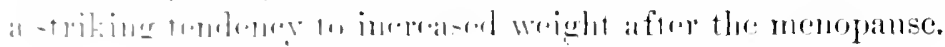


The female sex in general is said to show a greater inclination to corpulence than does the male sex, yet the difference in this regard is probably to be attributed to differences in ocenpations and habits, since women generally take less exercise than men. They are, moreover, apt to be chlorotic and anamic, and it is well known that fat and anamia often go together, in eonsequence probably of the diminished oxidizing power of the blood. People of sedentary pursuits are esprecially liable to take on fat, and with fanily inheritance and occupation combined, obesity becomes inevitable.

Of all eauses, the one most potent next to inherited tenlency is consumption of food rich in carbolychrates conjoined with an excessive intake of fluids. Ghuttony (huxus eonsumption) eonduees to ohesity aren thom there is not a relative disproportion in carbohyrlrates. This is especially injurions when added to inadequate exereise. 'The tom free drinking of fluids is another potent factor, and when in the form of malt licuors, fat may be taken on very lapilly. The excessive nse of alcohol in any form, moreover, is said to favour the development not only of fat in general, but in particular of the reposit of adipose tissue upon the heart.

The foregoing are the leading causes of fatty orergrowth, but it must be remembered that the nodern eonecption of fatty heart is not necessarily a surphus accumulation of adipose tissue beneath the epicandium and between the bundles of musele-fibres, but a manifestation of cardiac insufficiency attributable primarily to general obesity. Consequently, in studying the etiology of the heart-weakness exhibited ly corpulent people, we must bear in mind what was said above encerning the pathology of the fatty heart. Whatever tends to mutermine museular strength in general produces a weak heart-muscle, and in the obese such influenees are specially deleterions.

Luxntrions living, inctolent habits, excesses of all kinds (including the abuse of tolaceo), andmia, and chlorosis-all tend to produce a flably heart-minsele. Such a heart is ineapable of that driving power necessary to force the blood through the extensive system of eapillaries created for the supply of new adipose tissue, in addition to those ramifying in the organs, muscles, bones, ete. Under the demands of a quiet existence such a heart may show no 


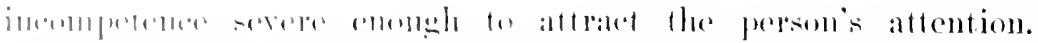

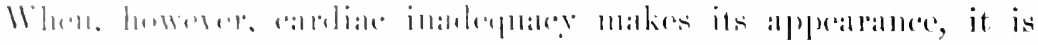

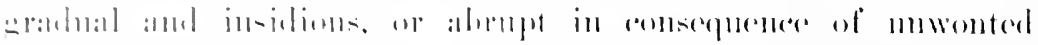

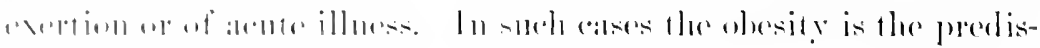

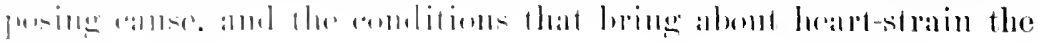

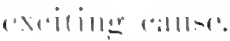

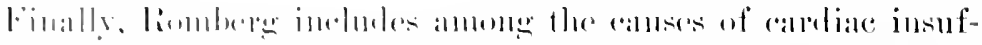

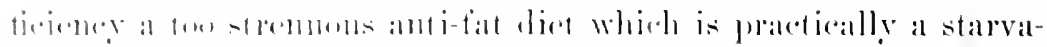

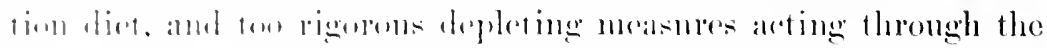

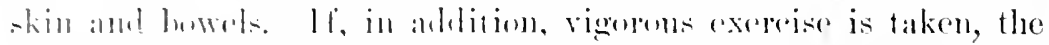

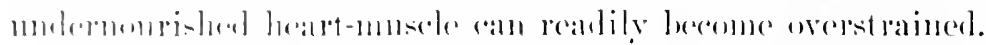

Symptoms. - There is molling in the syuptoms peculiar to

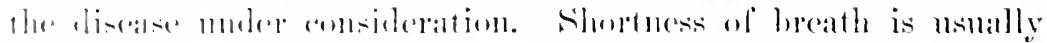

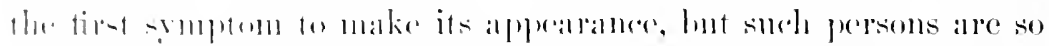

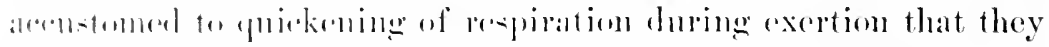

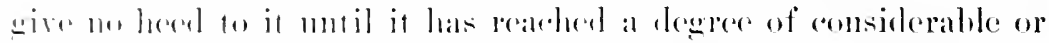

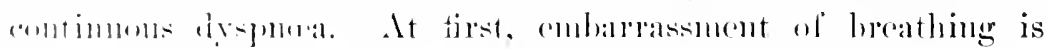

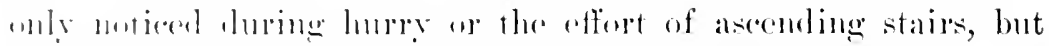

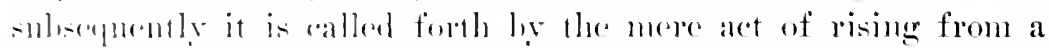
rhair amel walking areses the roum. Stooping or bending forward

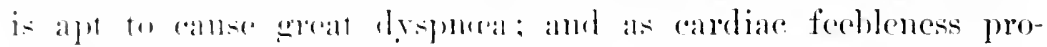

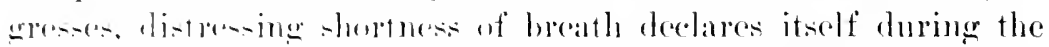

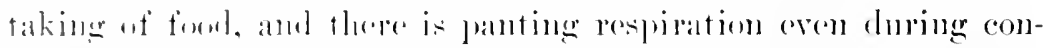
rel-ation. At ionght in this, as in wther forms of heart-disease,

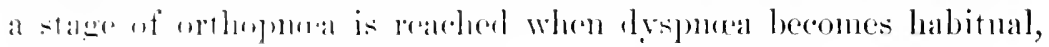

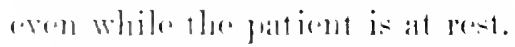

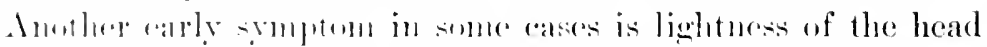

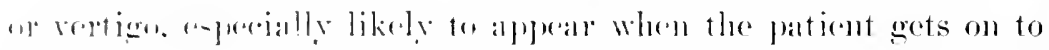

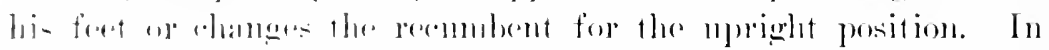

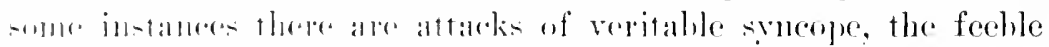

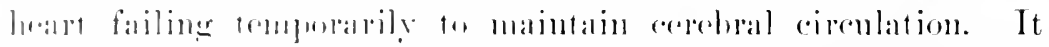

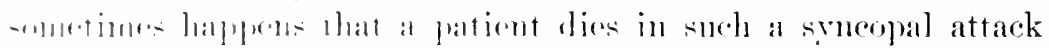

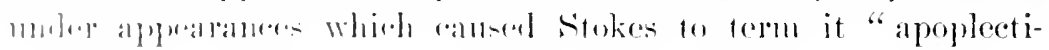
fillu."

Anether - -

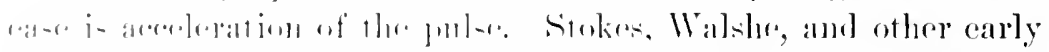

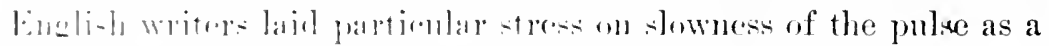
-ien of fattr lieat. lint as a mattre of fact it is more common for

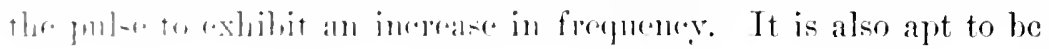




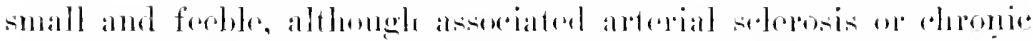

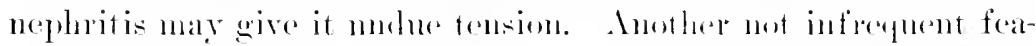
tmre of the pmlse is instability--i. e.e a lack of stradiness in its rhythm-fhethations taking place in its rate without alpatrent eause. Irregularity in force and volmme and intermittence, however, are not common.

Tn some instanees the earliest srmptoms are referable chiefly to the digestive organs. The patient finds that his usmally small appetite has become stili more diminished, or that so soon ar he has eaten a little he is oppressed by an mucomfortable sense of fulness and shortness of hreath. Tumenchable thirst impels him to drink large anwmuts of water or tea, which hut inclease his oppression, and he is amoyed by frepuent prurtations of gas. His bowels ane sluggish and comstipated, and his urine becomes scanty and high-colomred. The is apt to fall asleep in the chair, particularly after meals, while at night he is wakeful, or if he sleeps, is halassed ly nightmale and dreans. Headaches, mstally dull and heary, but sometines of a neuralgic character, are not nucommon.

If the circulation has not become too serionsly embarrassed, and particularly if the lieart-muscle is intact, the symptoms being due to a disparity between the sige of the body and the power of the heart, then measures alculated to reduce the obesity and thus restore the proper relation betwen body weight and heart power may reinstate the patient's health. In vere many cases, unfortunately, this is impossible; the heart-muscle has become serionsly damaged through atrophy or degeneration or coronary selerosis, or serious dilatation has been set up in eonseruence of long years of overstrain, or as the result of some single indiscreet effort. Srmptons of failing circulation now appear and progress steadily, it may be rapilly. Congh and frothy mucons expectoration, attacks of astlmma and raldiac pain of an anginoid rharacter, or even of true angina pectoris, are adeled to the previonsly existing drspmua. Hepatic congestion and tenderness, seanty alhmminous mine, and urlema of the ankles are liseovered, and before long the patient presents the well-knom pieture of the final stage of heart-disease which has been so often deseribed in these pages. It scarcely requires phrsical examination of the ehest to eonvince one that the heart is dilated and overburdened. Orthopnoa com- 


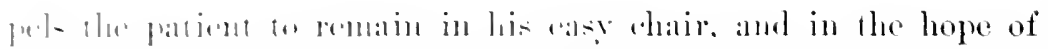

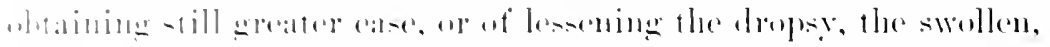

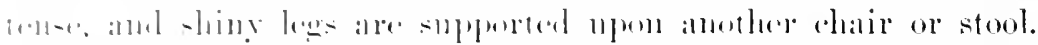

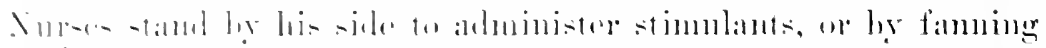

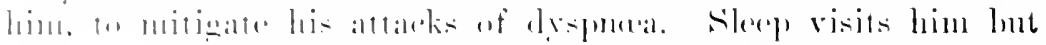

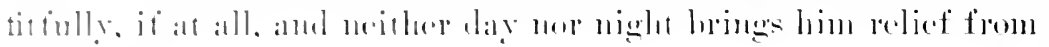
hi-

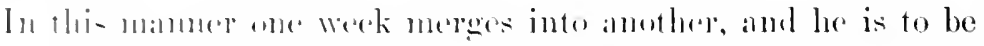

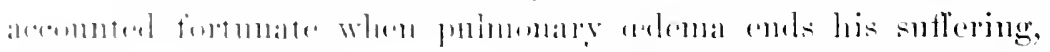

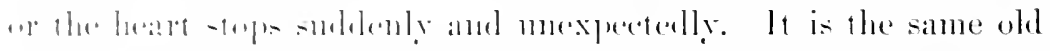

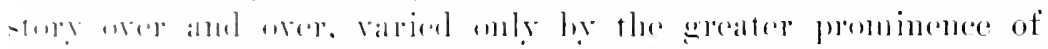

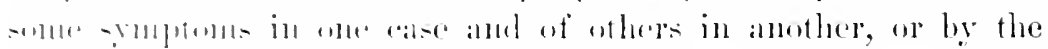

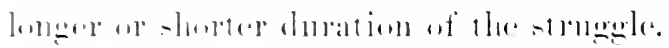

Physical Signs. Impertion-Cllesity remlers examina-

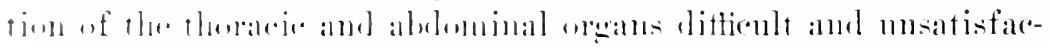

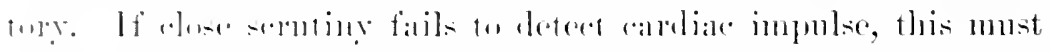

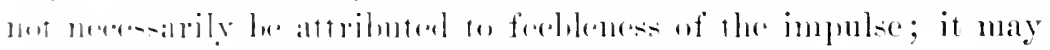

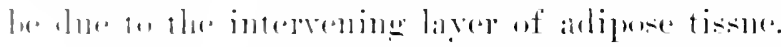

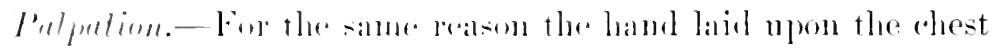

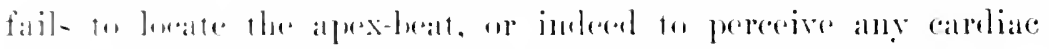

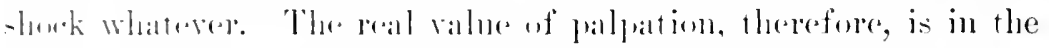

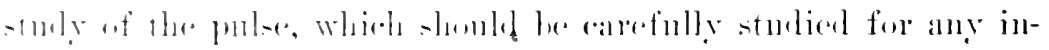

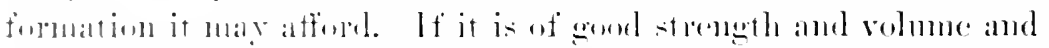

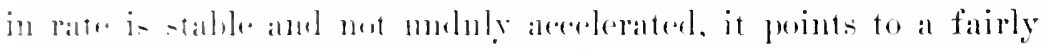

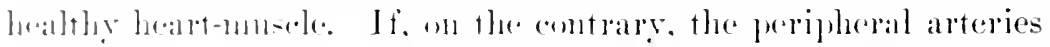

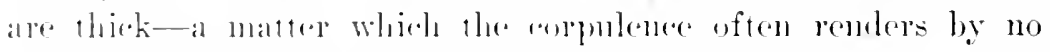

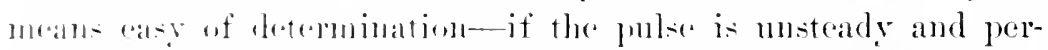

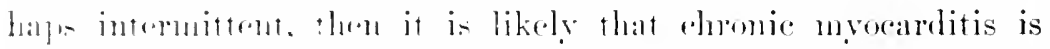

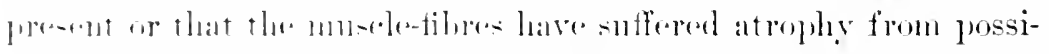

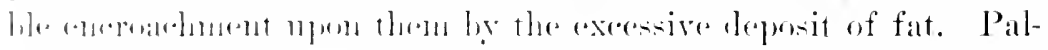

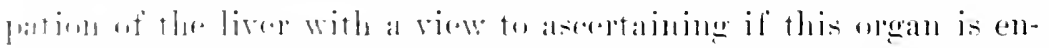

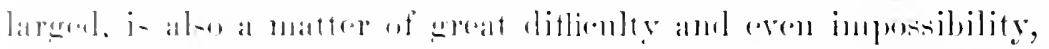

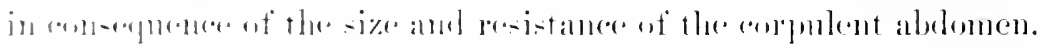

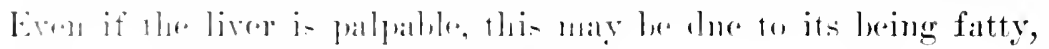

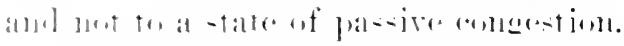

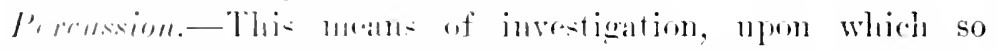

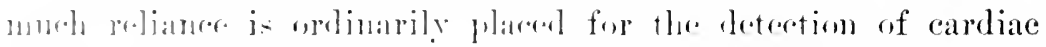

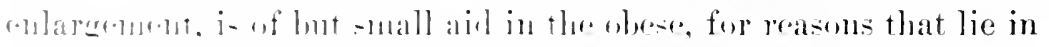

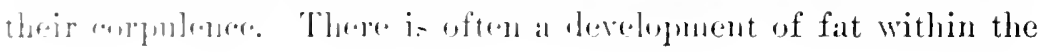


mediastinum which gives an area of dnhess that may be thonght to belong to the heart, get in reality loes not. Furthermore, the mass of fat within the onentum and upon the ablominal walls impedes the deseent of the diaphragm, if it does not actually crowd it upward, and thus canse the heart to assume an abromally high and horizontal position. When this is the case the area of cardiac duhness is increased transversely and upward, giving a false appearance of increased size of the organ. Consepmently extreme care is necessary in, hrawing any conclusion from an increase of pracordial duhness. If, however, by percussion in the various ways described in the introductory chajter one becomes satisfied that such an increase toes not exist, it affords presumptive evidence that the sympitoms are due to potential, not structural incompetence.

Auscullation.--This is likely to afford the best evidence of the real state of the heatr, and yet we know that the muscle may be serionsly diseased withont any appreciable change in the heartsounds. If these are found to be only rather distant and feeble but still clear, and the aortic second sound of gool relative strength, it is in farour of the integrity of the heart-muscle being still preserved. If, on the contrary, the first sound is disproportionately teehle, perhaps impure or even obscmed by a systolic apexmurmur, if the aortic second sound is weak and the pulmonic second unduly lond, there is reason to believe the heart is enlarged. This may be a simple hypertrophy with dilatation, or there may be in addition myocardial degeneration. Physical examination alone does not enable us to decide; we must endeavour to determine this goint hy the study of all those factors outside of the heart which nuke for or against cardio-vascular decay.

Diagnosis.-- It is not a difticult matter to diagnose cardiac inadequacy. The real problem to solve is whether the heart is only potentially mequal to its work or is incompetent in consequence of fattr overgrowth or of myocardial disease. If the pulse is normal in rate and quality, and if subjective symptoms are felt only upon exertion, are slight and quickly subside after cessation of effort, the heart-walls are presmmaly intact. This conchusion is strengthened if minute inquiry fails to elicit history of cardiac strain, acute infectious disease, had habits, or any other infuence that may serve to impair the integrity of the myocardium. On the 


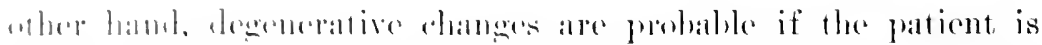

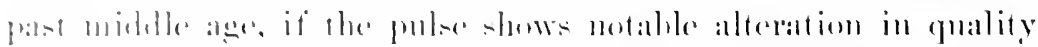

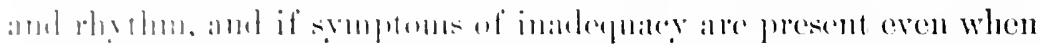
the pattent is at lest ar mot making monemted demands on his

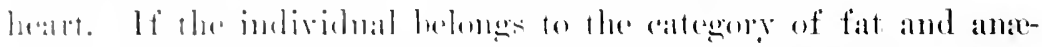

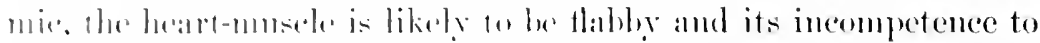

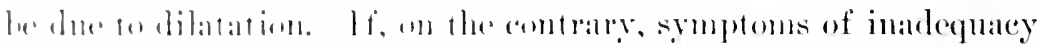
derelep in the fat and pletherie, whese skeletal museles are firm

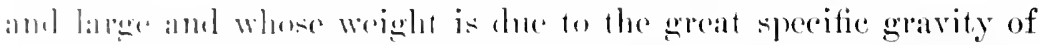

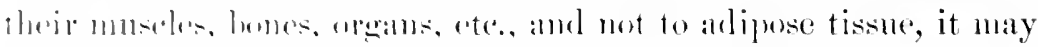

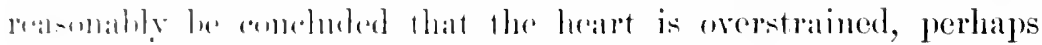

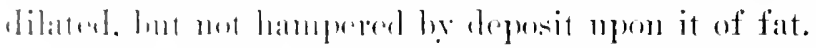

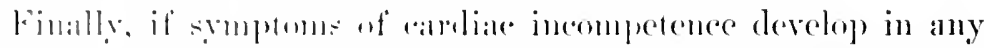

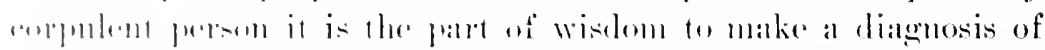

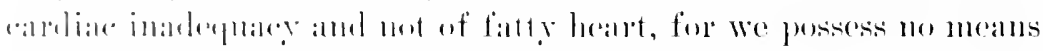

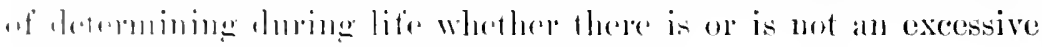
Anpeit af fill within the he:art-musede.

Prognosis. - This depends 10 mon the condition which is re-

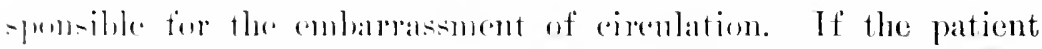
is yomman and musnlar and the antere of the heartweakness is fomm to lie in potential, not structural disability, or if the symptom- Hate from some reent cardiale strain, the heart-muscle having

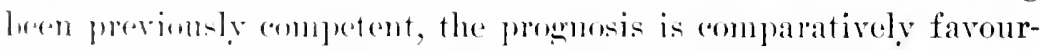
ahlue since alpherpiate treatment may restore compensation. If, m the other hamel, the pattient's muscollature is flally,y, he is anamir. and gives a history of indelent hallits; if his stmptoms have

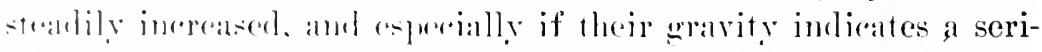

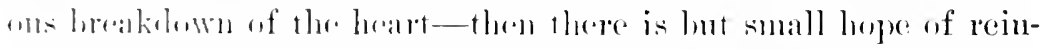

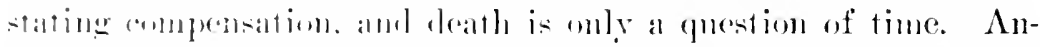

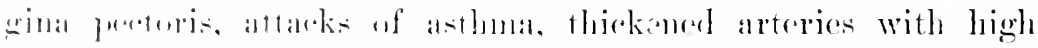

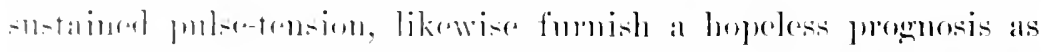

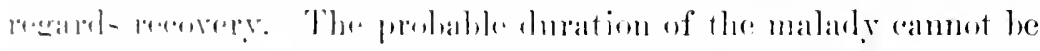

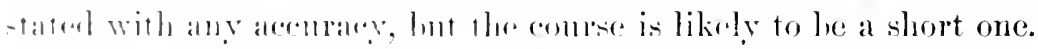

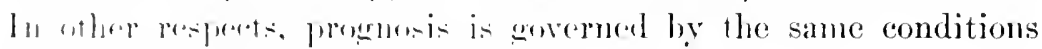

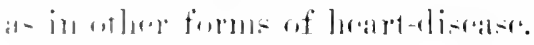

Treatment.-It i- n.ential, in the correct management of

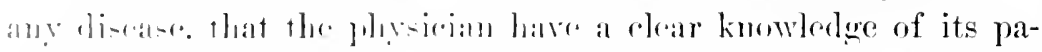

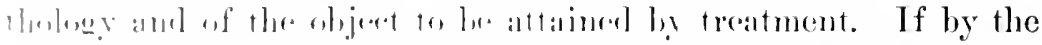
whl "falfy heart" were suraist simply a heart overgrown and 
infiltrated with alipose tissue, then the plain indication of treatment would be the absorption of execssive fat, and the object woukl be accomplished by putting the pationt upon a régime calculated to reduce his obesity. In this chapter, however, the disease has been considered from a different standpoint. It has been looked upon as a condition of potential weakness, the heart becoming relatively inadequate to the requirements of the circulation, rendered necessary by the size of the body. There may or may not be an undne deposit of fat mpon the heart itself. This being the pathology of the disease, the indication is to restore or establish a proper relation between eardiac power and body weight. This is to be accomplished by measures that will either invigorate the heart-muscle withont reduction of the obesity, or will bring about the latter without the former, or will do both. By the patient, it is generally thonght that the rednetion of his corpulence is all that is necessary; but Romberg repeatedly utters an enphatic warning against such an idea. He states again and again that ham rather than benefit is likely to follow the incliseriminate employment of the ordinary anti-fat cures, since they increase the already existing heart-weakness. 'The need of such a warning' was forcibly impressed npon me only this past winter.

A corpulent man of fifty-five, who had yet been able to exercise without special discomfort, conchnded he wonld try a reduction-cure at Marienbad, Germany. By vigorous use of the waters and an unreasonable amomt of walking he rednced his weight 45 pounds in a few weeks and returned home feeling, as he said, "fine." Nevertheless, he had not been home long when, on attempting to walk to his place of bnsiness one morning as nsual, he was seized with great shortness of breath, that compelled him to return to the house. This was the beginning of the end, for he failed steadily in spite of the most approved treatment, and died in less than six months.

Depleting measures should be confined to cases in which eirculatory distmrbance is attributable to obesity and not to cardiac insufficiency. Such cases are found for the most part in persons who are still young, or have not yet passed the age of forty. It is often a matter of great difficnlty to determine whether the tronble resides in the heart or not, and therefore an anti-obesity plan of treatment shonld not be decided on hastily or without thoughtful 


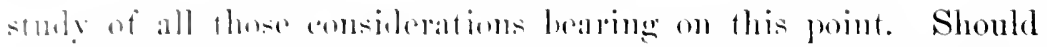

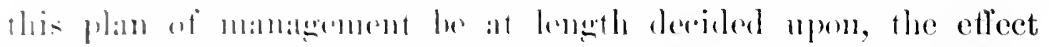

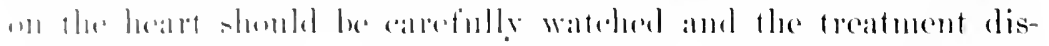

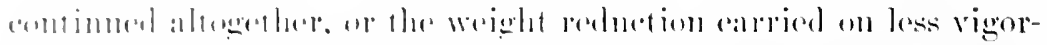

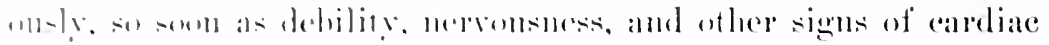

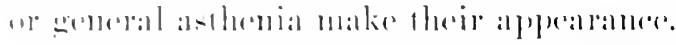

It is of importance also whalt system of dietary is selected. There aresereral woll-known anti-fat dictaries, sueh as Banting's,

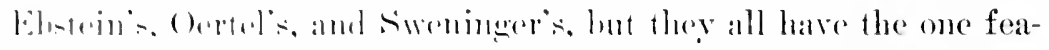

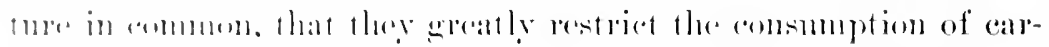

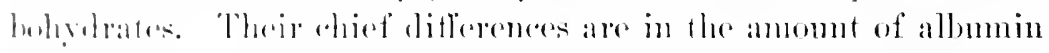

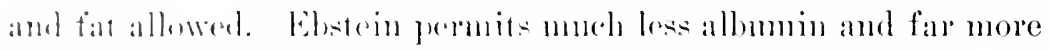

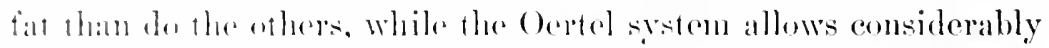
more allumin aml far less tat, and anain more carbohydrates. They all restriet the ensmuption of fluids. Whatever differences they pusess, they all attain their end by eansing an absorption of falt, luth by the taking away of fat-forming food and, with the

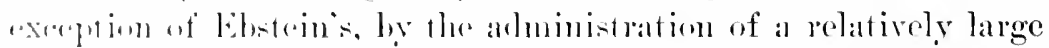

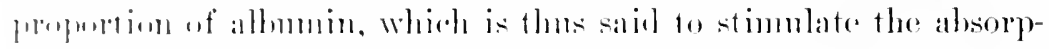

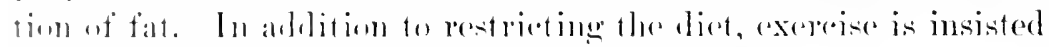

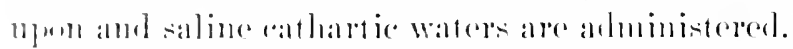

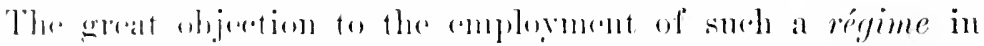
rales of serallad fatty heart lies in the facet that muless the indi-

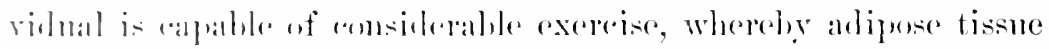

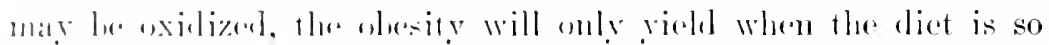

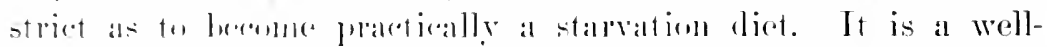

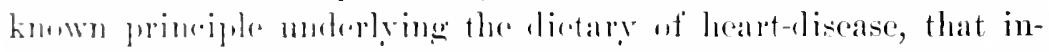

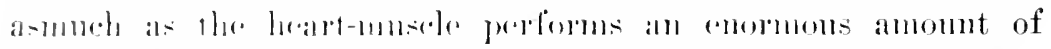

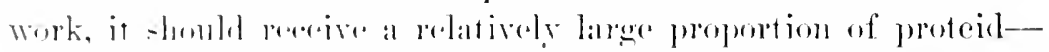

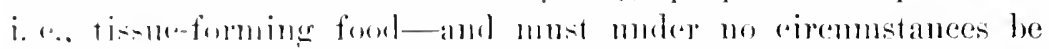

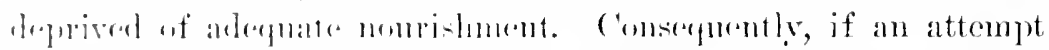

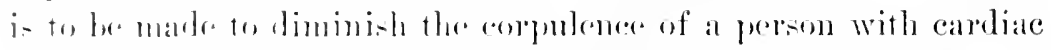

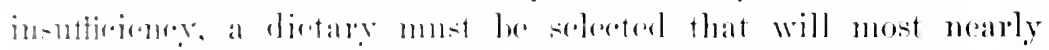

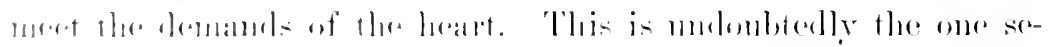

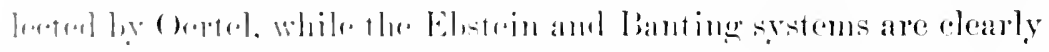

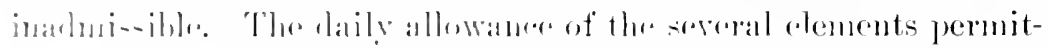

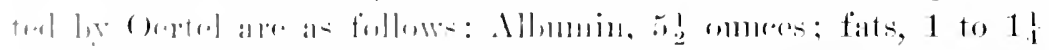

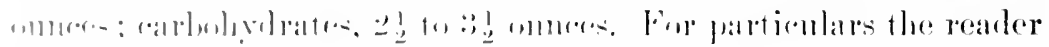

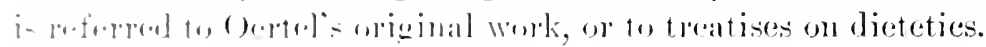


In carrying out a diet for the reduction of obesity in the class of eases now under consideration, it is very unsafe to produce a too rapid loss of weight. In my opinion this should not exceed 2 , or at the very-outside: pounds a week, and in many eases 1 pound is better. Consequently the physictan shomld keep an aceurate record of the weight, and many times will have to morlify the diet given above by increasing the alhumin or starehes, or both. If the physieian is in doubt concerning the actual state of the heart-muscle, or if the patient finds he is unable to take adequate exereise, then massige will often be found of great service by promoting oxidation of adipose tissue. It also aids the circulation.

The daily use of laxative waters is essential, and Germain Sée reeommends the administration in moderate doses (5 to 10 grains) of iodicle of potassimm three times a day.

For the past few years the publie and profession have heard much concerning the efficacy of redncing fat, of the alternate daily use of Vichy and Kissingen waters. From ny rather limited observation of their effects, I am inclined to the opinion that if these waters are to prove efficient they must be combined with exercise and at least a moderate restriction in the eonsmuption of carbohydrates.

In elderly perple, or those with feeble museular development, or in such as already display pronomed symptoms of cardiac inadequacy, energetic treatment for the reduction of eorpulence is hazardons, to say the least. In many instances the weakness of the heart will be intensified. Romberg is of the opinion that such persons should not be suljeeted to the possible dangers of such treatment; while to make a routine practice of depleting all fat patients certainly eannot be too strongly condemned. Nevertheless, I believe in most eases, even when the heart is primarily at fanlt, some modification of the diet will nsually prove beneficial. Some of these patients are anemic as well as morpulentsome because they have been light feeders for years, others be(ause they have habitually taken too little albumin and too much starch and sugar, while still others have eonsmied altogether too much fluir, particularly at meal-time.

In the first class, attempt should be made to secure more adequate nourishment through medieinal or other measures ealcu40 


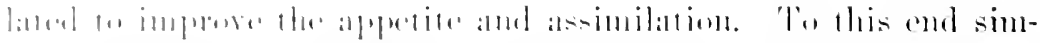

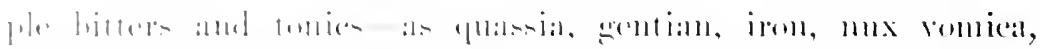

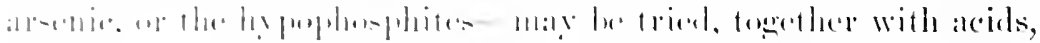

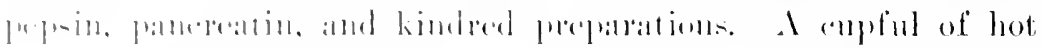

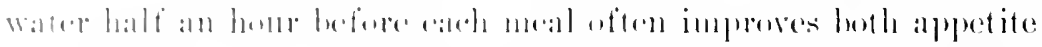

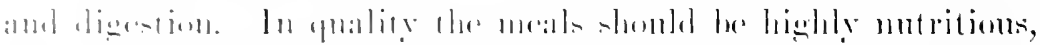

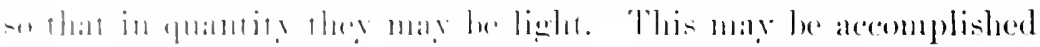

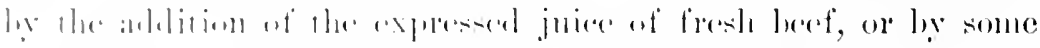

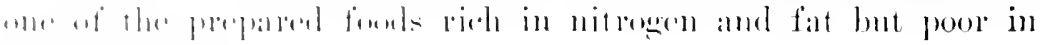

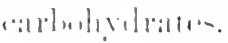

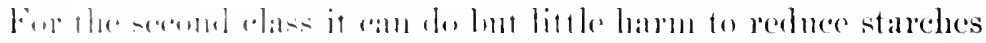

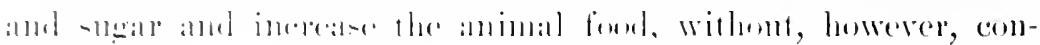

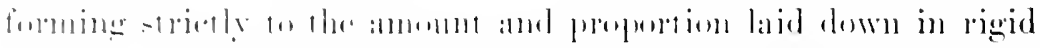

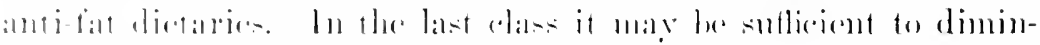

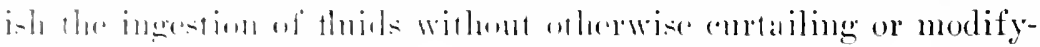

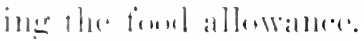

In all imlirilnals who display more or less heart-weakness

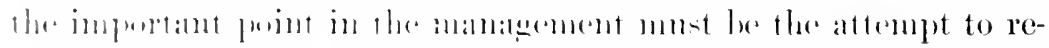

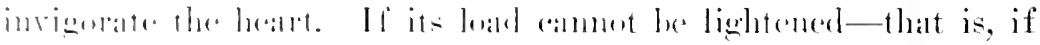
lile and

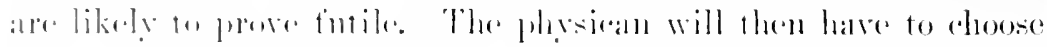

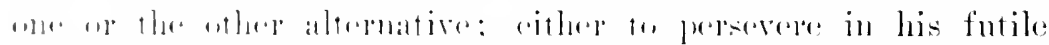
at

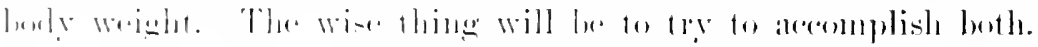

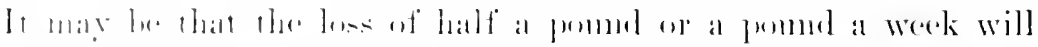

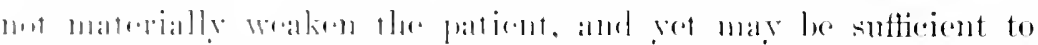

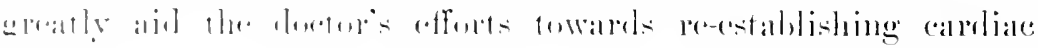
justre

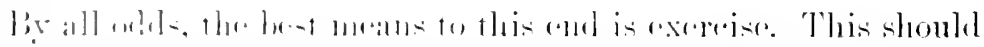

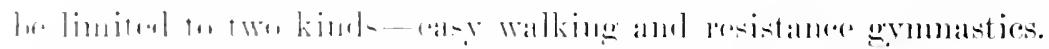

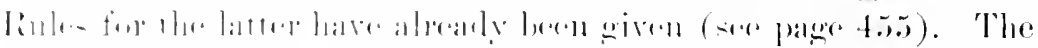

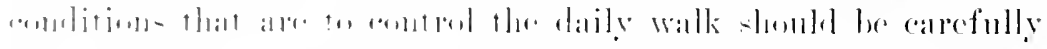

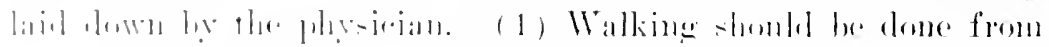

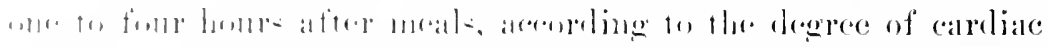

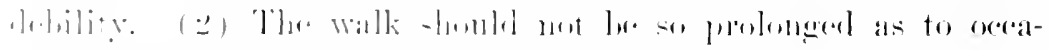

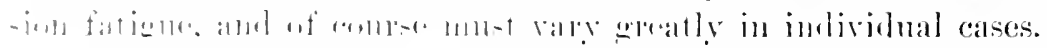

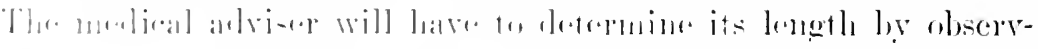

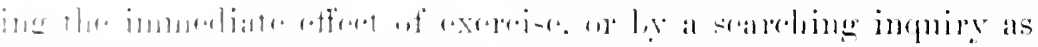

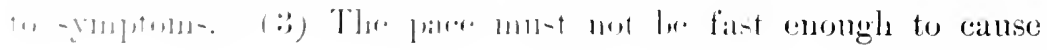


shortness of breath or palpitation, and it is alwass best to begin very showy, the gait to be quickened only as the exereise produces a feching of wall-being or lightness in the elest. (1) The patient must not walk against a strong wiorl, and must eonfine his exereise to level aromid. Attempts to carry ont the Oertel srstem of ascending an incline are not to be permitted motil a considerable degree of compensation has been established. If the patient is exceptionally intelligent and his judgment cam be redied upon, it may be sate to allow him a little latitude in this regard; but patients are more likely to do themsdres latrm by essaying paths that are tero steep, than they are to derive benefit from accustoming thenselres to aseculing gentle acelivities. Therefore in a large majority of instances the fourth rule should be strictly insisted moll.

When heart-weakness has rearhed such a degree that walking even alwout the room oceasions decided dyspura, there is no prospect of improvement from exereise, and life will probably be prolonged by keeping the patient quiet and relving on skilful massage or very carefully condncted grmnatics. Another highly useful and often very promising measme for restoration of heart-power is the balneological treatment-i. e., saline baths as given at Bad Tanheim and already described. In the hands of one cxperienced in their use these baths are rarely likely to do harm, except in those cases in which dilatation has become extreme, or other contra-indications are present.

Among therapentic mrasures are inchuder also the ordinary heart-tomics, such as digitalis, strophanthus, and their congeners, as well as strychine and cardiac stimulants, nitroglyeerim, ammonia, camplor, and valerian. The same rules govern their administration in these as in other cases of carliac insufficiency from whaterer canse. Romberg is of the opinion that but little good is to be expected from digitalis; but in my opinion, if its vaso-comstrictor effects can be comnteracted by nitroglyeerin or indide of potassimm, the remedy should theoretically smpport the failing leart in cases of obesity, as well as in anc other nonvalvular disease. If pulso-tension is persistently high, strophanthus may be of use, either alone or combined with digitalis and stryclmine. The last-named heart-tonic shonld never be onitted.

In all cases of obesity blood-pressure is ligh within the ab- 
Hominat reserts, and therefore I firmly believe that if any results

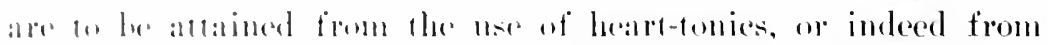

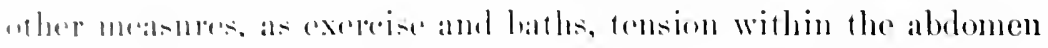
must he lessened ly the persintent use of athatrtic remedies.

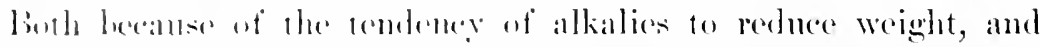

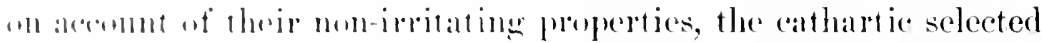
should lo a saline aperient water-llunvadi. Rubinat-Condal,

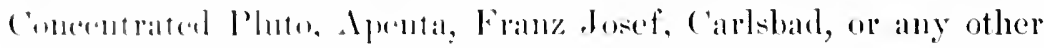
of the woll-known alperiont watters on the market. ('alre should

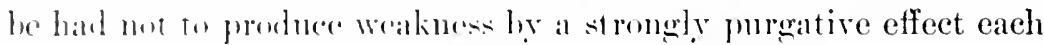

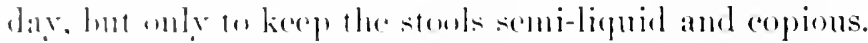

It is nemilly well to introdues a duse of ailomel or blue pill

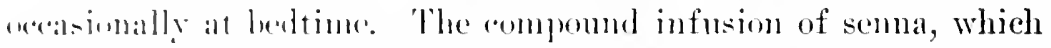
is anly the ald English " Black l langhat," 4 ounces of which may be taken at a time, forms a capital jurnative for occasional use.

sperial mamagement is repuired be complications, as, for example, the mic of iodide of putash or soda in chronic arteriosclero-i., onmetimes olserved in obese patients, nitroglycerin and morthine in ases of angina perotoris or ardiac asthma. When at last cardiac power is ntterly lest, dinretin-knoll may be of service in reducing dropsey or at least holding it in ebeck. Overdistention of the alliac carities, particularly the right chamber, may be temprarily relieved and the patient's suffering ameliorated by renesertion. ()wing to the associated and unia, the amount of blowd thes alstracted shomld be small, 6 to 12 omeces being usually sufticiont to render tle pulse soft and full. Other measmes for the relief of the pationt mus be left to the physician's judgment and to the iperal indiuation of earell case. 


\section{CILAPTER XXIV}

\section{CARDIAC ASTHMA-CHEYNE-STOKES RESPIRATION- BRADYCARDIA-STOKES-ADAMS SYNDROME}

In this and the succeeding chapter are considered certain phenomena that aire sometimes encountered in the course of myocardial disease, and in the opinion of the anthor may not inappropriately be discussed in comnection with disorders of the myoeardium.

\section{CARDIAC ASTHMA}

No one symptom is so frequently a feature of cardiac disease as dyspnca, and with the possible exception of precordial pain there is no subjective disturbance so distressing. In many instances, moreover, it occasions such obvious suffering as to be actually harrowing to the spectator. True cardiac dyspnoa is due to the swelling and rigidity of the lungs caused by stasis within them, and consequentiy forms an important, part of the clinical picture in most eases of cardiac inadequacy.

It would be a mistake, however, to attribute the dyspnoca of cardiopaths solely to eirenlatory embarrassment. Thus it may be due to pain, in consequence of which the individual fears to breathe with his enstomary depth and slowness. In other cases it may result from nervousness or apprehension, as e. g., during an examination of the heart. In all sueh instances, however, it is usually easy, by giving due consideration to the state of the cirenlatory apparatus, to reengnise the true canse of the breathlessness.

Cardiac dyspnoa is par excellence a dyspnoea of effort-i. e., it is either eroked by exertion or intensified by the same. This breathlessness of effort may be regarded as the earliest manifestation of failing heart-power, and so long as cardiac incompetence is of minor degree, is confined to periods of physical exertion. There nearly always eomes a time, however, when dyspnœa becomes more or less constant even during rest and when apparently trivial conditions intensify the shortness of breath even to the point of positive air-hunger. This has been repeatedly 


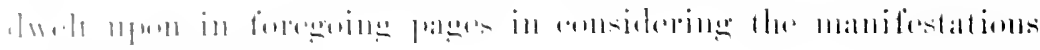

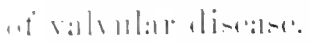

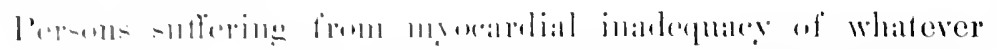

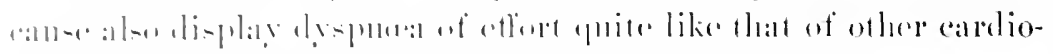

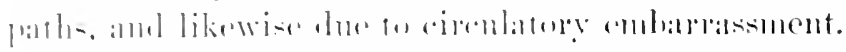

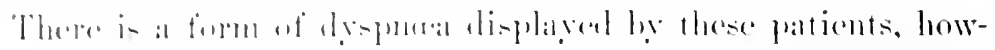

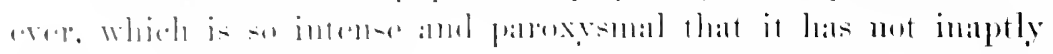

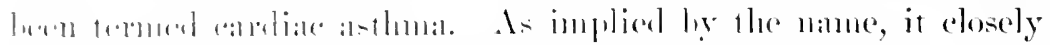

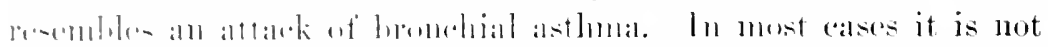

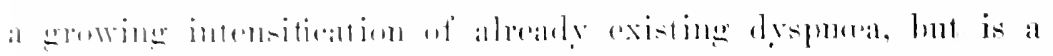

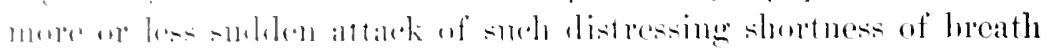

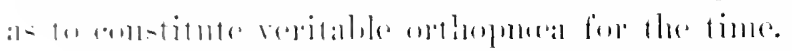

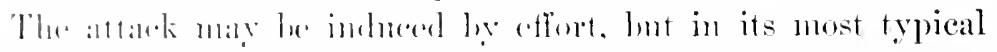

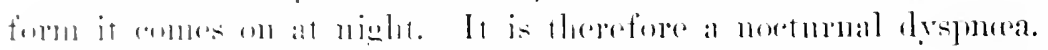

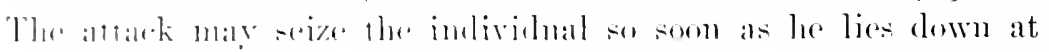

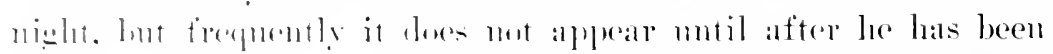

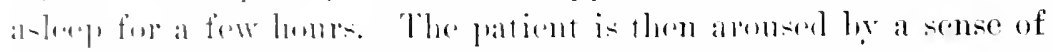
"19pr...

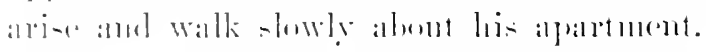

lu its millest manifestanims this is all, but gememally the

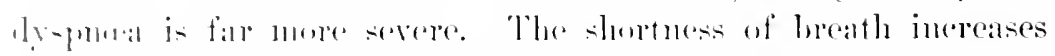

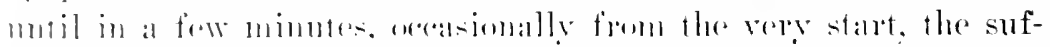

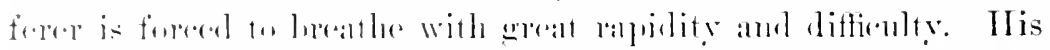

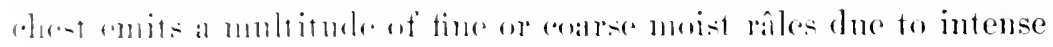

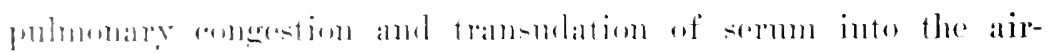

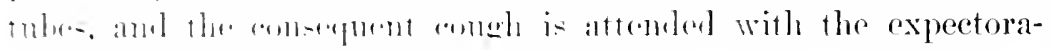

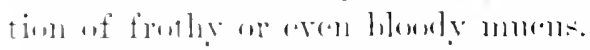

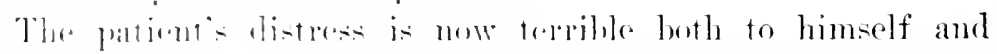

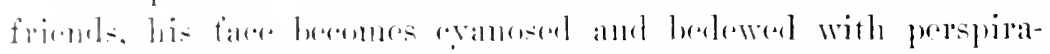

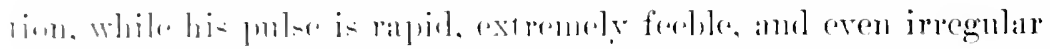

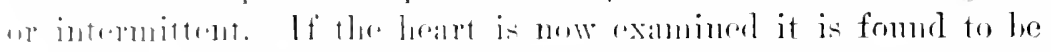
lilatrel. while its smmels alre extremely falit, partly in comse-

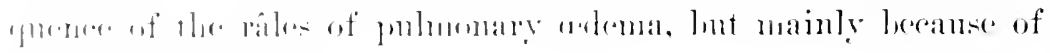
andiare watkmon.

smoll an attark may last for minutes or aren homrs, yet with

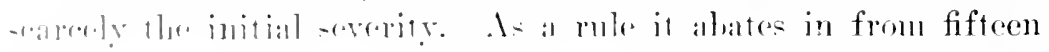

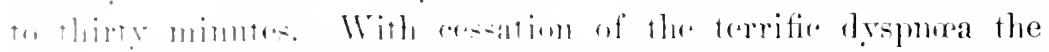

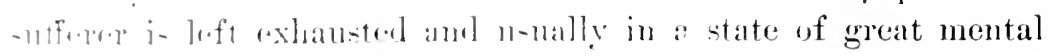
aluitatiols. 
The eanse of this cardiale asthuna is belicrest to be temporary weakness of the left ventricle and disproportionate strength of the right ventricle. 'This andition on the part of the two ventricles leads to congestion of the hung and conserquent dyspmoxil. As the stasis increases and pulmonaly arlema oecurs, dyspmera becones increased in conseguence of mechnimial interforence with oxygenation of the blood. C'ertainly such an explanation fits the clinical manifestations of an attack.

The predisposition to "ardiac asthuna is furnished by degeneration and enfeeblement of the left ventricle, while the immediate or exciting cause may be fomd in whaterer temporarily overpowers the rentricle-i. e., mulue physical effort. Coitus, by reason of the mion of both effort and excitement, seems particularly apt to exeite an attack. 'The ocenrrence of the attack after some hours of sleep is thonght to be explained lye the angmentation of bloodpressure said to be incident to the recmubent posture. Inchard states that blood pressure is increased by the reembent position, while Gaertner, on the other hanr, claims that his tomometer shows an actual though slight derease of pressure. If this is so, some other explanation is renuired for the orourence of carliac asthma during sleep. This may he found in the ardided work put npon the left ventricle in maintaining blood-flow by muscnlar inaction, and the more aniet respiration incident to sleep.

It is needless to remark that such attacks are highly dangerous and call for prompt and cnergetic treatment. To this end stimulants are indicated, and nothing is so efticient as the hypodermic injection of $\frac{1}{x}$ of a grain of morphine combined with the atropine fornd in the ordinary lyporlermic tablet.

\section{CHETNE-STOKES RESPIRATION}

This is a rhythmieal form of lyspmexa, first earefully deseribed by the two eminent physieians whose names are now inseparably linked with this distressing symptom. It is characterized by alternating periors of dyspmoa and apnoa, which recur at regular intervals and supplant normal breathing.

The phenomena of this type of respiration may be deseribed as follows: After a period of suspenderl hreathing or apnoa, respirations return, at first slowly and superficially, each succeeding one quicker and deeper, mutil at length the inspirations become 
mpikingly rapid amel forrihle, and maximum lyspmon is attained.

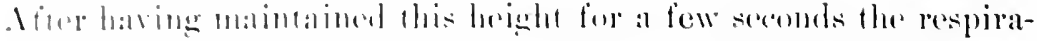

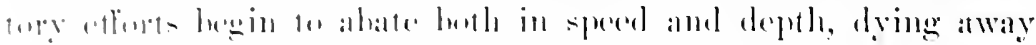

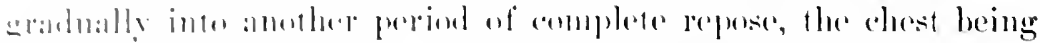

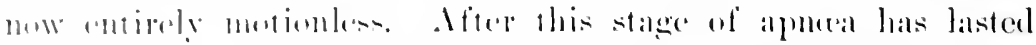

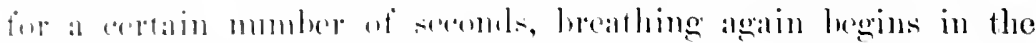

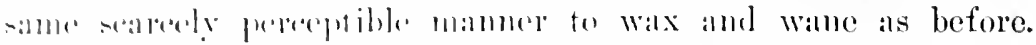

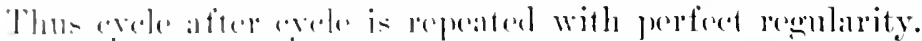

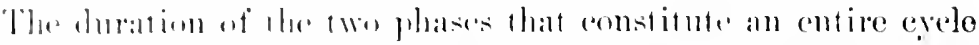

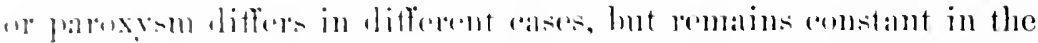

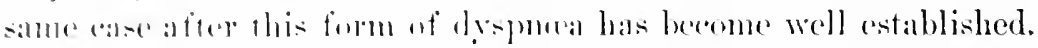

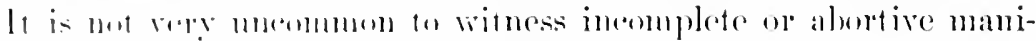

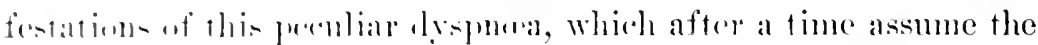

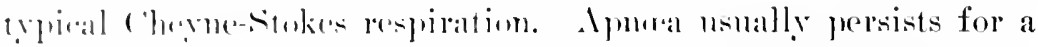

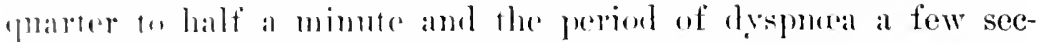

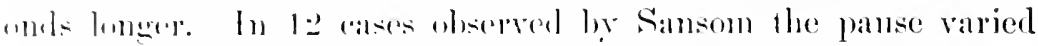

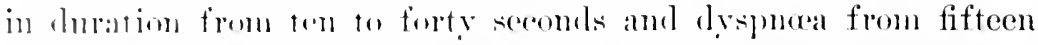

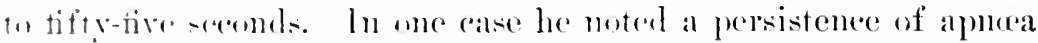
for - ixty and ut dy-pmal for sixty-tive soromels, while he cites

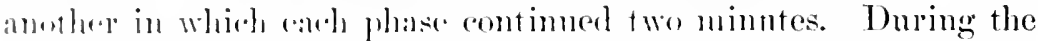

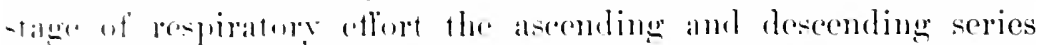

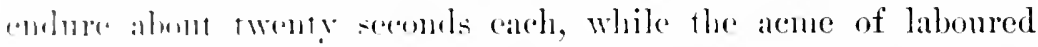

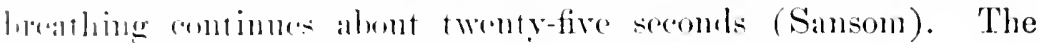
loneth of this geriul-i. e., of lyspmat-is mot the same in all cases. homerel.

Patients exhibiting ('herne-Stokes respibation nsually retain

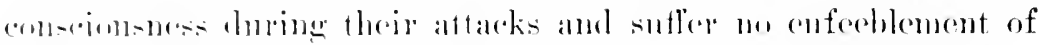

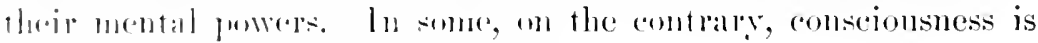

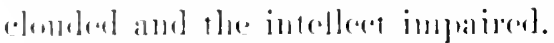

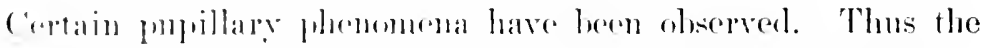
fuppil-are antracted duringe apmea and dilated in the stage of

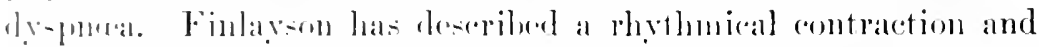

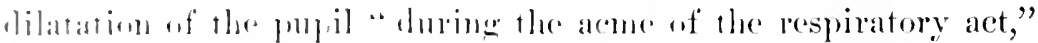
dilatiner with inspipation and antrating with expipation.

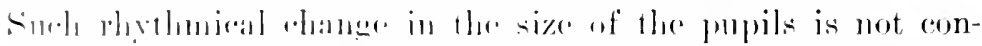

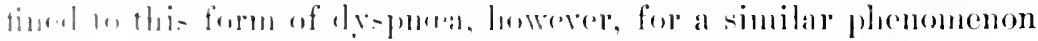

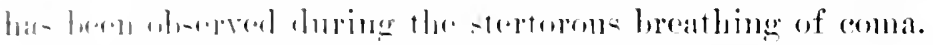

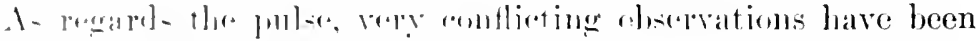

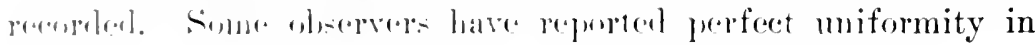


the pulse-rate during both periods of the eycle, while I.ittle, quoted by Sansom, witnessed 15 heartbeats during an apnosal period of ten seconds, and only 6 in a like period in the dyspnoal stage. Others have reported retardation of the pulse during apnoea, and a relative acceleration during the period of drspuna. Aside from changes in rhythm, the tension of the pulse is said to be raised, the pulse feeling larder and firmer than normal.

Diseases in which Cheyne-Stoles Breathing is Obseried.The following list is taken from Sansom's work on the Diagnosis of the Diseases of the Ileart and Thoracic Aorta, and shows that the cases in which this form of drspmea is observed are by no means exclusively those of cardiac disease. (1) Cases attended with cerebral affections-viz., cerebral hamorhage, tunours, tubercular meningitis, epilepsy, shock from surgical injury with uramia, aleohol intoxication, opium poisoning, and insanity. Cases attended with lesions of the heart and sreat vessels-riz., fatty degeneration of the heart, pericarditis, atheromatous disease of the aorta, aortic aneurym, valvular disease (double aortic, with mitral insufficiency, mitral stenosis, dilatation of aorta coexisting, aortic regurgitation and obstruction), and chronic Bright's disease. It is ritl discases of the aorta and its valves that it is most frequently associated, but it may ocenr, in the absence of ralvular disease, when the coronary arteries are obstructed. In any of these conditions it is most probable that the arteries at the base of the brain are atheromatons, and the concurring affeetions of the heart and brain speedily lead to death. (3) Cases of certain acute febrile diseases-riz., diphtheria (IIitterbrenner), typhoid fever (Whary), pueperal septicumia, scarlet ferer, pnemonia, pertussis (with inanition), and influenza.

Theories to Erplain Cheyne-Stohes Respiration-Before giving a lurief statement of the leading theories which lare been advanced to explain the rhythmical alteration of breathing, it may be well to state certain phrsiological facts concerning respiration. (1) Inspiration is a result of the contraction of the inspiratory nuscles in response to a nervous impulse sent ont from the respiratory centre in the upper portion of the nedulla oblongata, close to the calamus seriptorius, but extending to the upper portion of the spinal cord. (2) Expiration is for the most part a passive act dne to the elastic resilience of the lungs.

(3) The 


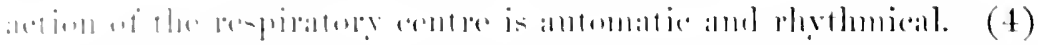

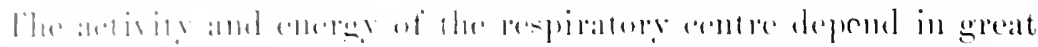

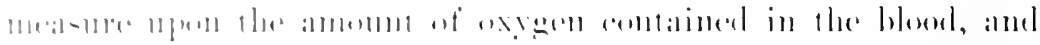

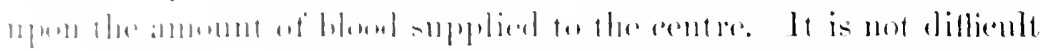

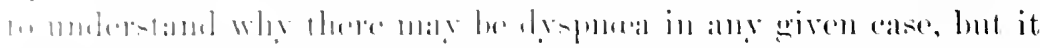

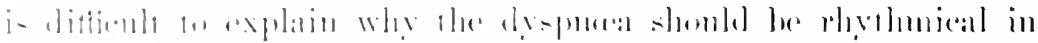

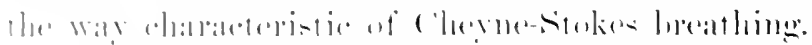

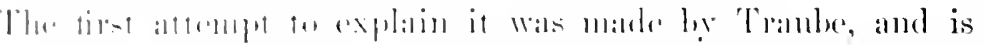

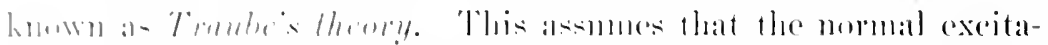

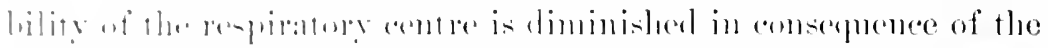

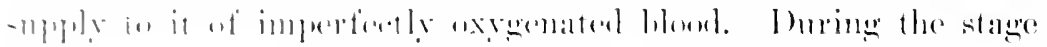

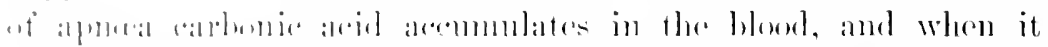

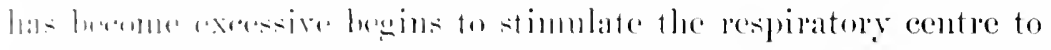

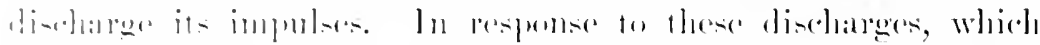

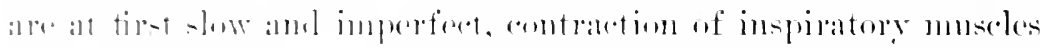

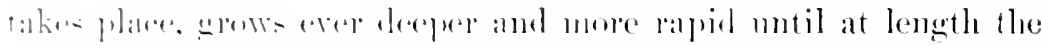

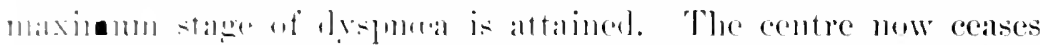

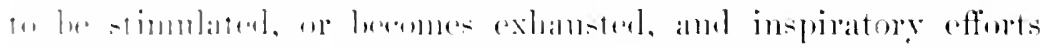

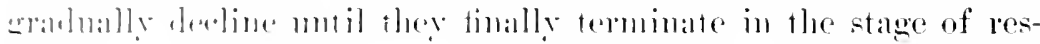

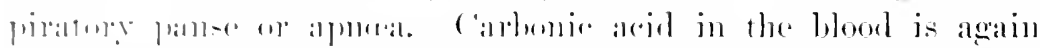

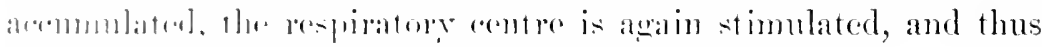

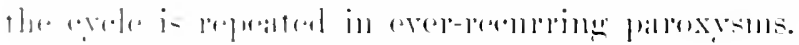

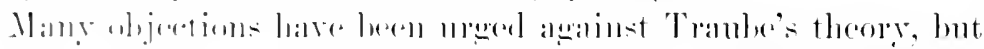

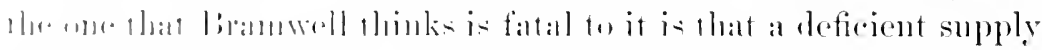

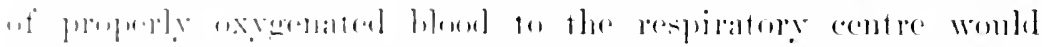

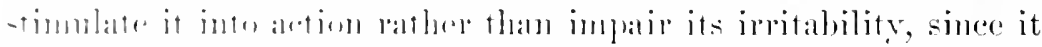

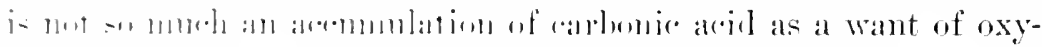

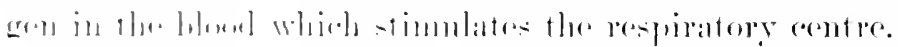

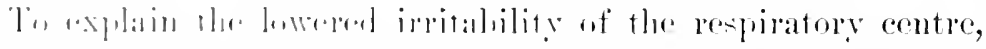

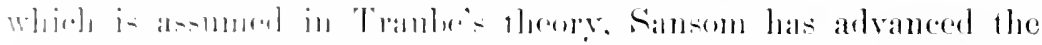

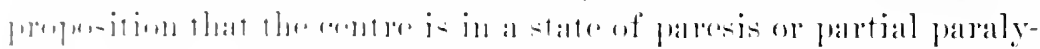

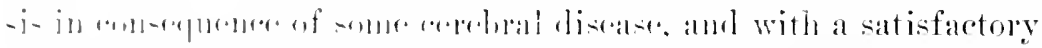

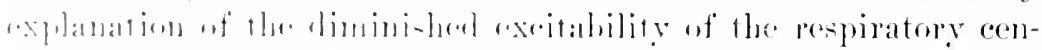

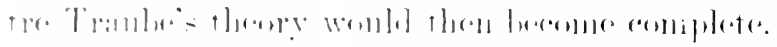

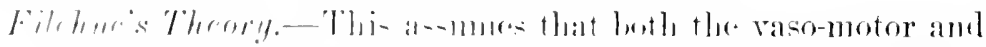

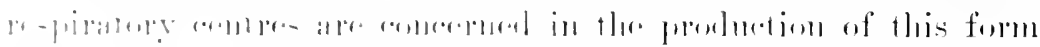

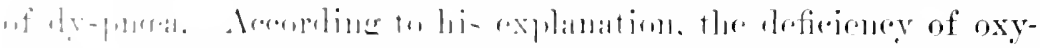

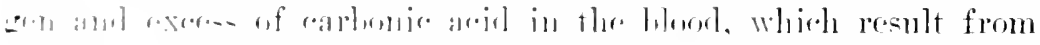

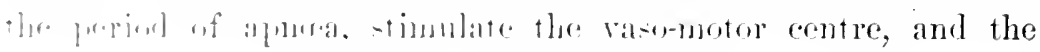


arterioles of the brain, als well as those throughont the borty, becone contracted. This constriction of the arterinles dininishes the supply of blood to the respiratory centre, and in consepatenee this centre is stimnlated to discharge, and inspiration begins. So soon, howerer, as respiration has becone energetic and the bloon properly acrated, stimulation of the vaso-notor centre ceases, arterial spasm is no longer maintained, the respiratory centre receires a proper supply of arterialized blood, and dyspnara is no longer experieneed. The respiratory acts gradually die away and the period of apneca is again reached. There again ocenrs stimnlation of the vaso-motor centre, and another eycle is repeated. Bramwell is of the opinion that if Filehne's theory is correct, then Cheyne-Stokes breathing shonld orem much more frequently than it really does. He sarys: "I am disposed, therefore, to think with Dr. Sansom that something more is necessary, and that there must be some alteration of the respiratory centre itself in addition to the condition which Filehne's theory supplies. A state of irritable weakness wonll, in my opinion, acoomt for this condition."

Bramuell's theory in explanation of Cheyne-Stokes breathing is based on the supposition that the respiratory centre consists of two parts: an inspratory and an expiratory, and that, as snggested ly Rosenthal, "the inspiratory centre is the seat of two conflicting forces, one tending to generate inspiratory impulses, (the diwharging portion of the inspiratory centre as we may call it), and the other offering resistance to the generation of these impulses (the restraining or inhibiting portion of the inspiratory centre)-the one and the other alternately gaining the victory, and thus leading to rhythmical discharge." Bramwell assmmes that renons blood exeites the discharging portion, restrains the inhibiting portion; while oxygenated lolool depresses the former portion, and intensifies the action of the restrining portion. If the discharging portion is in a condition of irritable weakness, and therefore more easily exeited to discharge, but also more quickly and easily exhansted, or if hoth portions are in a condition of irritable weakness, then there is a condition of things, Branwell thinks, which satisfactorily explains the phenomena of Cherne-Stokes breathing. At the end of apmona the blood is highly venons, and therefore gradually excites a paroxym of tyspnea, by stimulating the discharging and restraining the inhibitory 


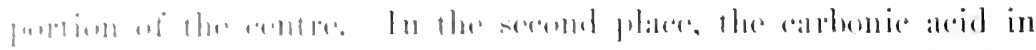

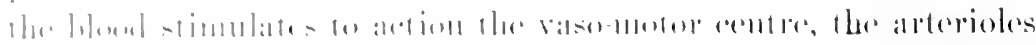

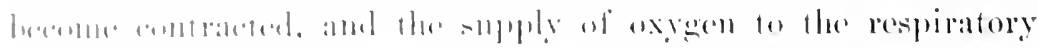

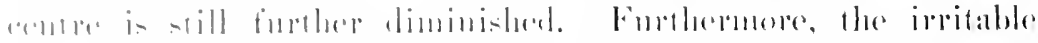

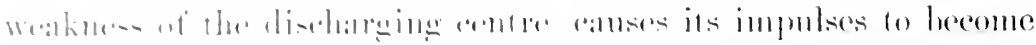

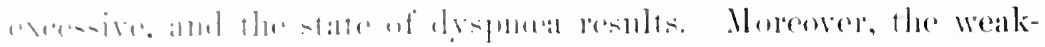

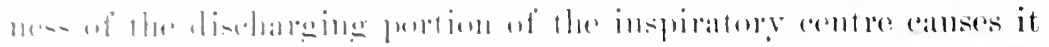

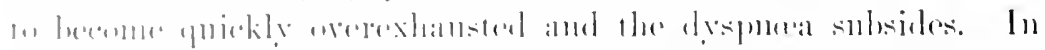

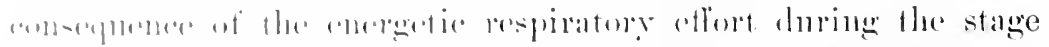

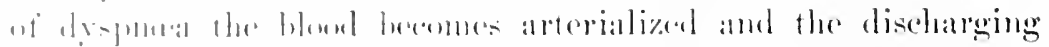

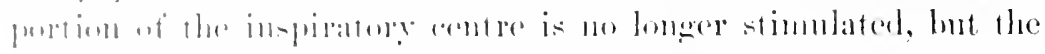

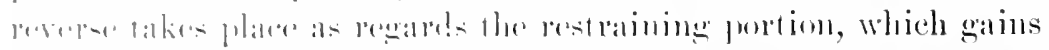

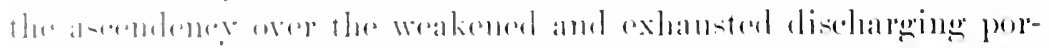

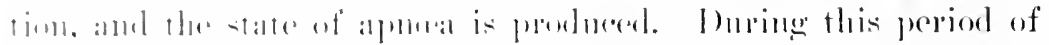

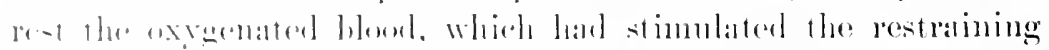

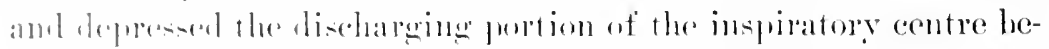

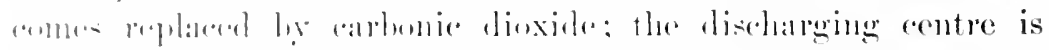

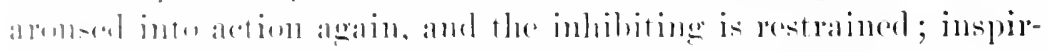

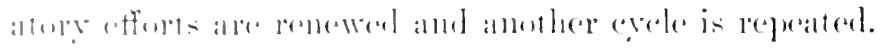

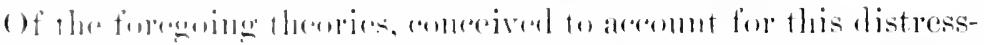

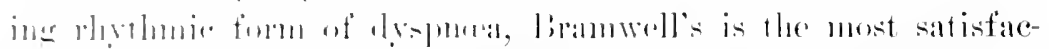

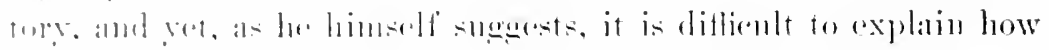

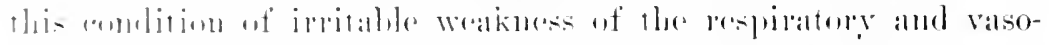

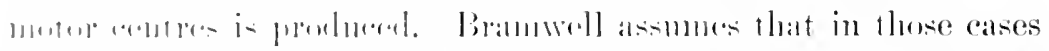

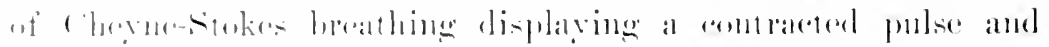

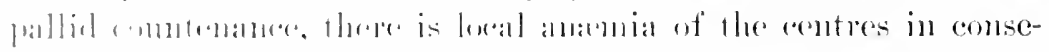

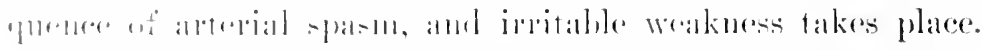

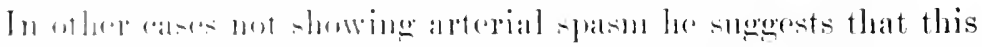

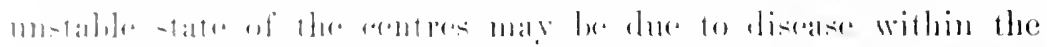

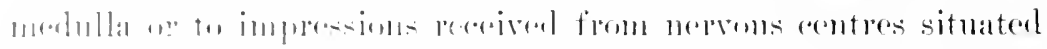

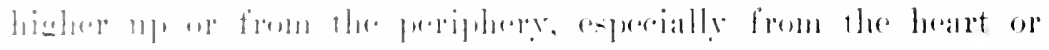

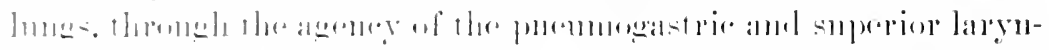

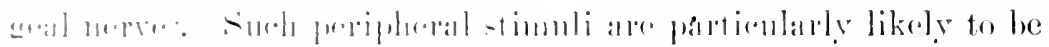

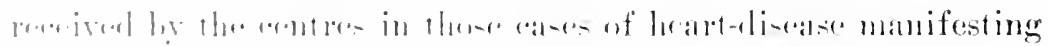

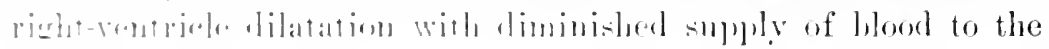
line-.

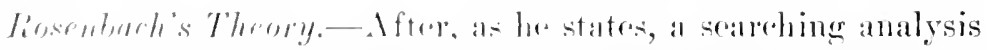

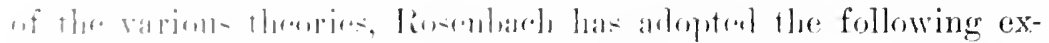

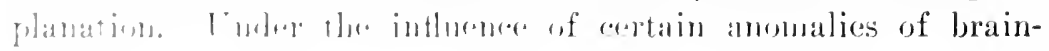


nutrition there develop, localized disturbances in the brain or in individual centres, particularly in that of respiration, which disturbances lessen the excitability of the affected part and augment the normal exhaustibility of the same. Therely are produced remissions in the activity of the respective centres with loss of tone in the vaso-motor and vagus centres, or complete intermissions, such as a pause in the respiratory act, with a kind of paralytic state of the cerebrum, manifested by a periodic sleep with contraction of the pupils and movements of the eyeballs. So soon as the fatigue and exhaustion of the centre have disappeared in eonsequence of cessation of respiration and an angmented internal activity, and its excitability returns, respirations again set in and continue to inerease, becanse the excitability of the nervous apparatus grows out of proportion or waxes nore rapidly than the stimulus to activity wanes in eonsequence of organic work. So soon now as the abnomal exhanstibility of the centre again begins to be felt, it supersedes the stimulus, and therefore the functional activity of the centre lessens, and finally ceases altogether when at last the centre has become completely exhausted. Whether or not respiration takes place is determined by the ability of the centre to respond to stimulus, and the depth of the respiratory act depends not upon the strength of the impulse, but on the functional capability of the nerrous apparatus. He thinks that of the various nerrous centres the respiratory is the one that suffers most readily and often alone, while the vaso-motor centre is relatively much less frequently affected, and paralysis of this means death.

He furthermore thinks that a regularly intermitting pulse, pulsus bigeminus and alternans, may be a manifestation of periodicity in the function of the ragus and raso-motor centres in certain eases of nutritional disturbance of the brain, and are analogons to the Cheyne-Stokes phenomenon. As Rosenbach states, this explanation of this abnormal type of breathing differ's from others in the assumption, not of a periodic alteration of the stimulus, but in a rhythmic change in the excitability of the centre which presides orer respiration, even to a complete abeyance of its function for the time being. He assmes that this rhythnical periodicity as regards excitability is to be referred to some peculiar characteristic inherent in the nervons apparatus by virtue of which it is capable of being exhausted and again aroused to activity. 


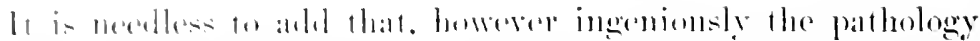

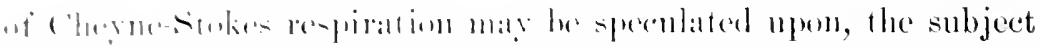

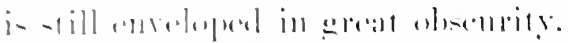

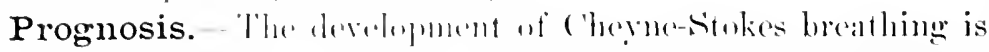

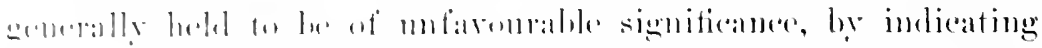

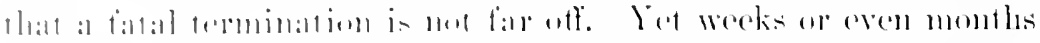

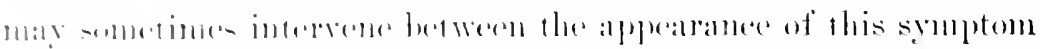

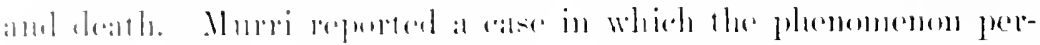

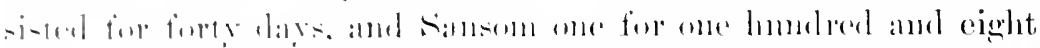

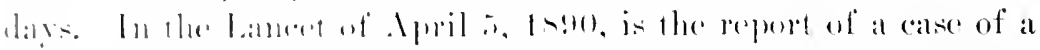

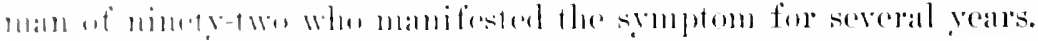

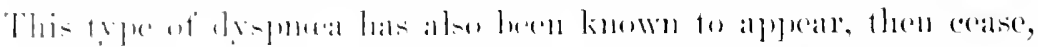

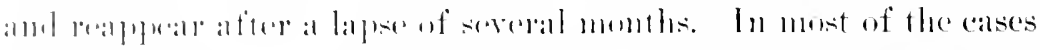

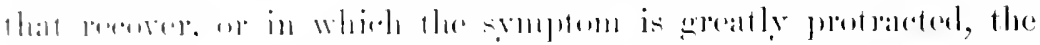

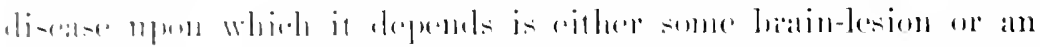

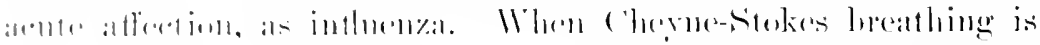

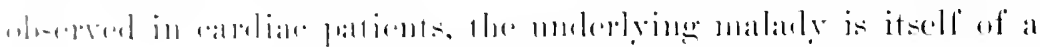

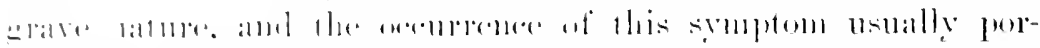

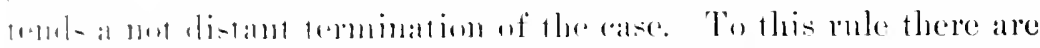

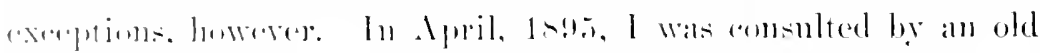

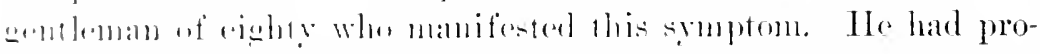

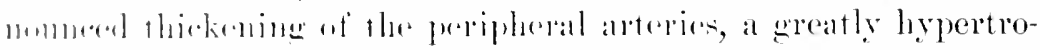

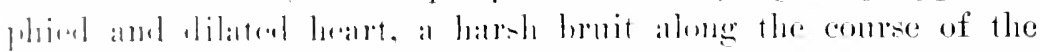

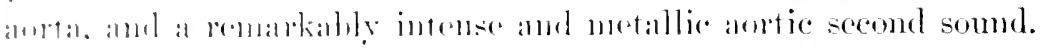

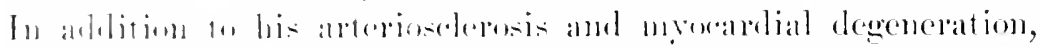

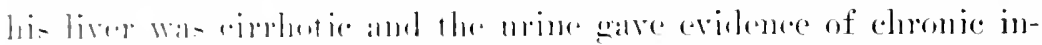

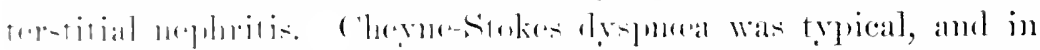

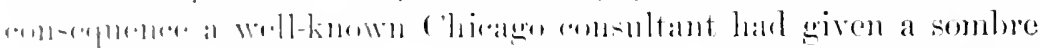

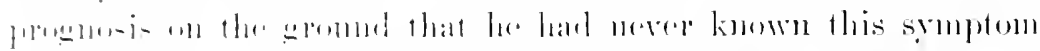

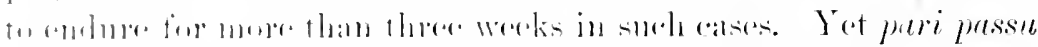

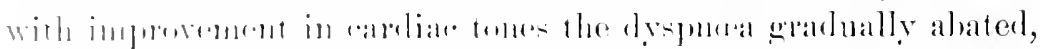

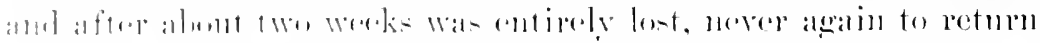

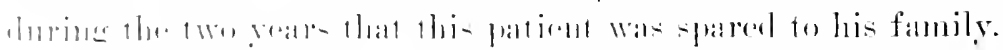

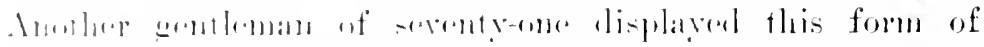

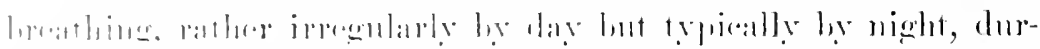

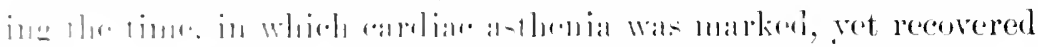

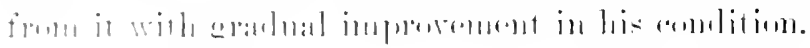

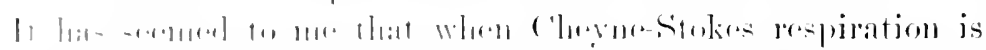

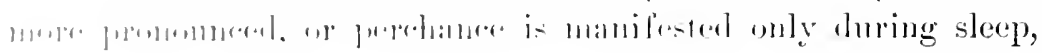


it is not of so grave a prognosis as when present with equal intensity both waking and slerping. Mnrer, and reconty Penbrie, have called attention to a physological cheye-Stokes respiration observed in healthy persons during sleep. But the paticnt of serenty-one was not healthy, and therefore the noctnmal manifestation of Cheyne-Stokes dysmo during his periods of muconscionsness in sleep conld not be regarded as physiological. Finally, the prognosis must be looked npon as specially grave in those cases which also manifest obseration of the mental faculties.

Treatment. - When Cheyne-Stokes ryspnoea is a symptom of cardiac disease the treatment must be essentially that of the muderlying condition. Set we are called on to mitigate the patient's distress so far as this is possible. This is best accomplished by the hypodermic adiministration of morphine, which, if it does not remove the dyspnua, blunts the patient's sensibility. The value of morphine in this class of cases has been the subject of some contention in Germany. At the meeting of the Congress for Internal Nedicine at Wiesbaden in 1892 , Unverricht read a paper in which he expressed the decided opinion that morphine and atropine are powerless for the removal of C'heyne-Stokes breathing. Other observers have gone so far as to assert that morphine intensifies rather than relieves this symptom. Stadehnann made 2.5 observations upon the effect of morphine and atropine, alone and combined, npon this trpe of breathing. The observations were made mon two patients, and the doses were 0.01 to 0.02 ( $\left(\begin{array}{lll}1 & \text { to } & \frac{1}{3}\end{array}\right)$ of a grain of morphine, and 0.001 to $0.0015\left(\frac{1}{60}\right.$ to $\left.\frac{1}{40}\right)$ of a grain of atropine. The effects were neither miform nor constant. They sometimes shortened the period of apnua, sometimes that of dyspnual, and at other times they lengthened one or the other or both. In 5 experiments morphine lessened or removed the Cheyue-Stokes respiration, and in 4 it ageravated the symptom.

Although Stadelmann's ohservations were so inconstant and unreliable as to the cffect of morphine that they seencel to confirm Enverricht's assertion, he nevertheless conchuled that on the whole the effect of this agent was to mitigate the severity of the attack. Norphine certainly seems to exert no injurions effects; and since it moloubtedly blunts the patient's sensibility and indnces sleep, there can be no contra-indication to its employment, eren if it scems occasionally to change an inegular or muperiodic 


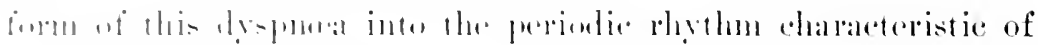

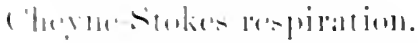

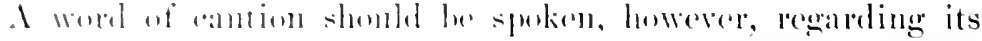

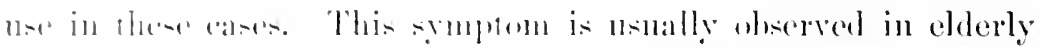

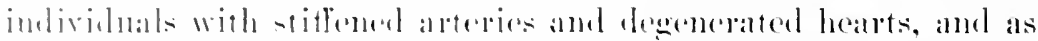
the kidneys rery anmmomly palticipalde in this jathological pro-

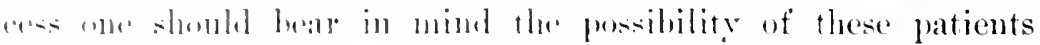

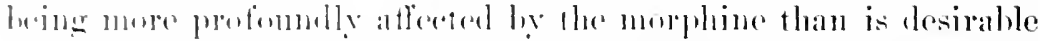

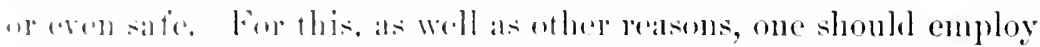
the smallest dese hat will remelep the patient comfortable. In

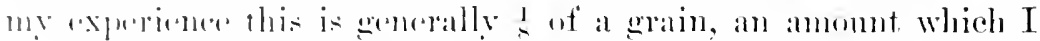

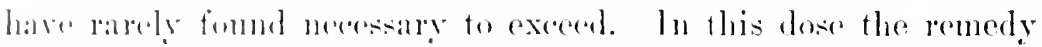

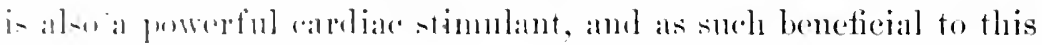

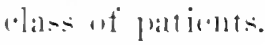

\section{IBR.IIY('ARI)IA}

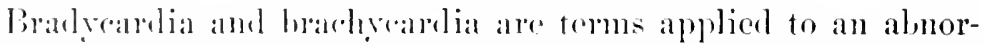
mally slow pulso-ratr-that is. to one of less than dio beats to the minute. Allnett in his system of medieine oljects strenumsly

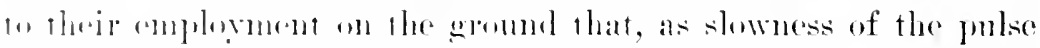
is hut a sumptom, Gley are likely to mislead the student ly seemine to ratio the srmptom to the importanee of an independent dis-

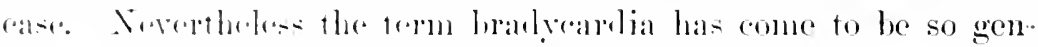
rally used that I have thomght hest to folluw the enstom of most writers and give it surial ansidelation. I know by experience

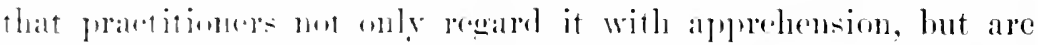

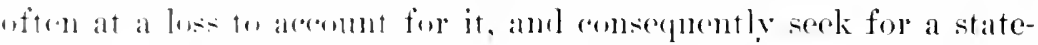

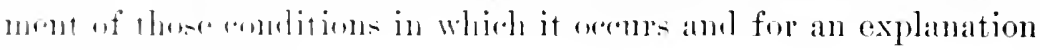
uf it: signitionncer.

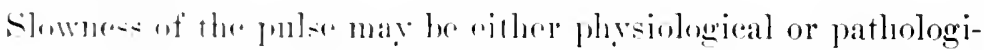

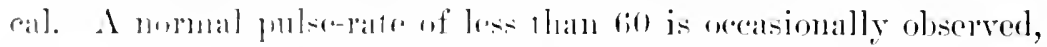

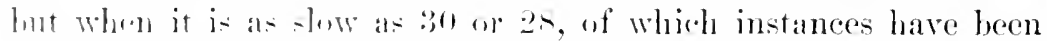

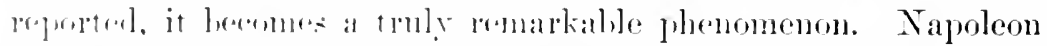

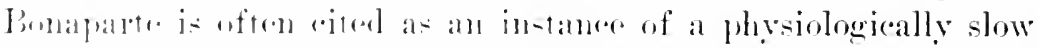

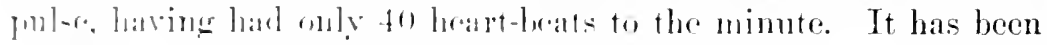

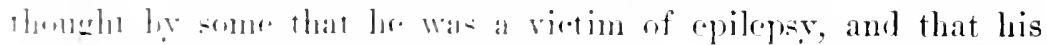

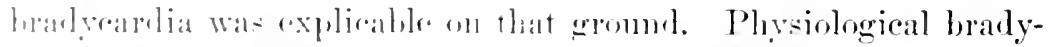

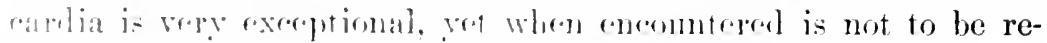
garded as anywise likely to affect the general liealth. 
Osler states that slowness of the pulse sufficient to merit the appellation of bradyeardia is sometimes a family peculiarity. Under physiological hordyeardia must also be included those instances sometimes yet very lanely observed in commedion with hmoger and cases of transicut slowing of the pulse said hy Blot to be seen in abont es per cent of women during the puerperium. In such cases the ralle may sink to 44 or eren to 34 . Mllbutt has noted bradyeardia in a healthy man of forty-nine giren to excessive sexual indulgenee, and has likewise seen it in children as a result, he thinlis, of masturbation. In his own case his pulserate foll to 48 and to 44 in consepuence of exhaustion, for it was lestored to its normal rate after a rofreshing sleep.

Romberg, in writing on diseases of the heart in Ebstoin's Practice, displays characteristic German exactitude by limiting his comsideration of brarlyardia to cases associated with cardiac disease. This appears to ne to be too exact, since showness of the pulse nuy by the ignorant be thought to inclicate heart-disease. I have decided, therefore, to enmmerate the discased conditions of whatever kind which, according to Riegel, may be associated with abnormal retardation of the pulse. As a basis for his classifieation he made a study of 1,047 cases in which a pulso-rate of less than 60 was observed. (1) Bradycardia may oecur during convalescence from acnte infections diseases, as puemuonia, diphtheria, typhoid ferer, ervipalas, and acute rheumatism. Sansom also incimles influenza among the acute disorders capable of producing slowness of the pulse, an obserration in which Allbutt concurs. It is believed that exhaustion is the canse in such cases. (2) Riegel observed this symptom in 379 cases of disorders of the digestive organs, as chronic dyspepsia, gastric nleer, eancer, and icterus. The oceurrence of a slow pulse in cholamia is a matter of frequent observation. Grob is also said to have seen bradreardia in connection with resophageal cancer and typhlitis. (3) The phenomenon under consideration is sometimes met with in discases of the respiratory organs, particularly emphysema and (4) in diseases of the heart and blood-ressels, specially degenerations of the myocardium depending on coronary sclerosis, atheroma of the aorta (Sansonu), but is not frequent in valrular defects massociated with other alterations of rhythm. In 1 recorded case embolism of a coronary artery was attended with a pulse-rate of 8 to the 


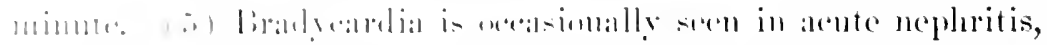

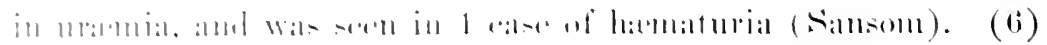

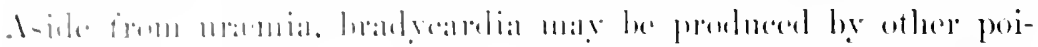

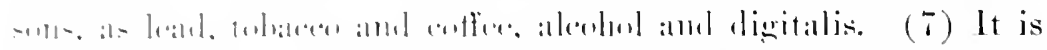

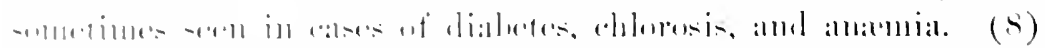

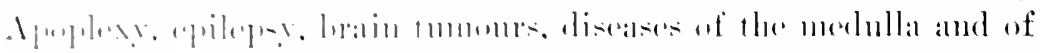

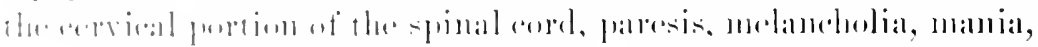

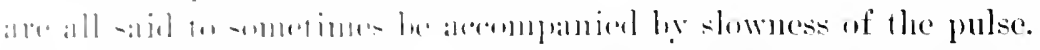

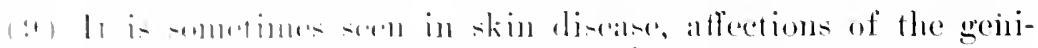

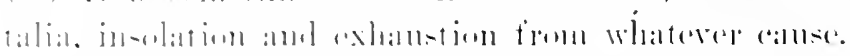

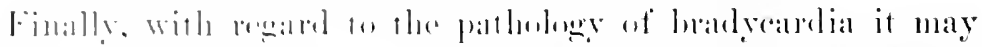

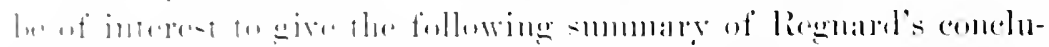

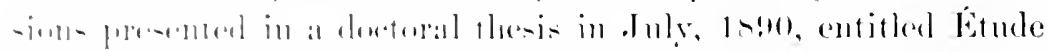

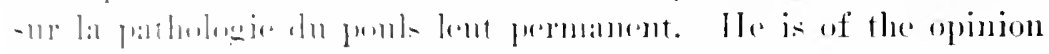

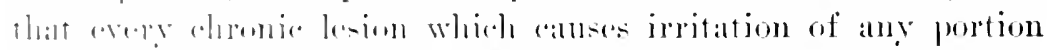

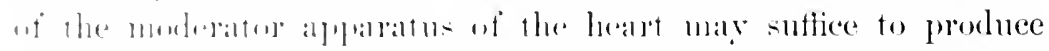

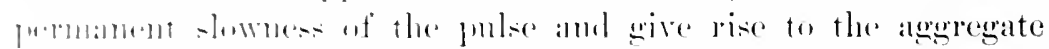

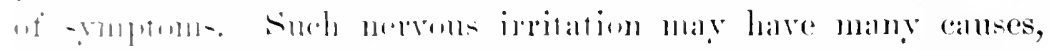

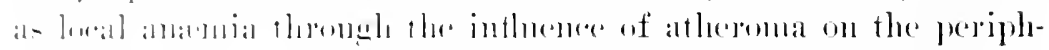

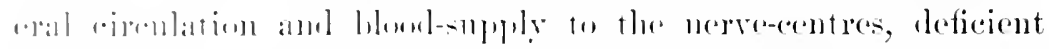

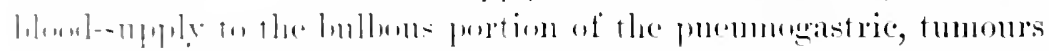

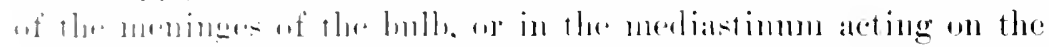

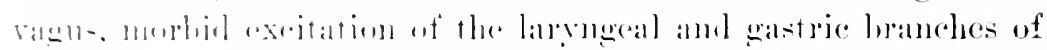

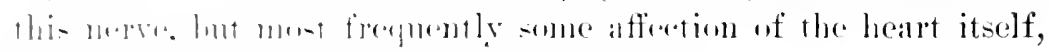

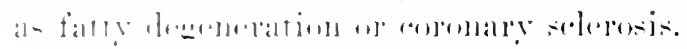

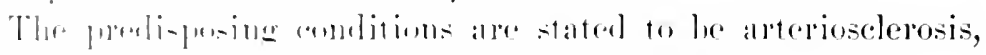

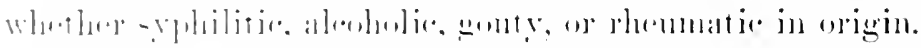

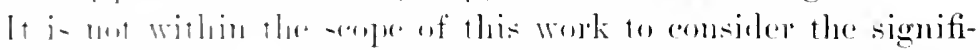

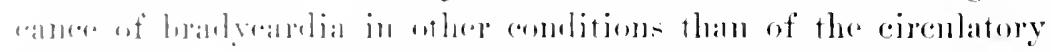

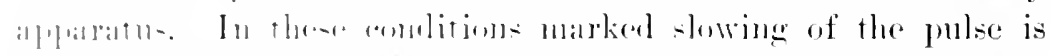

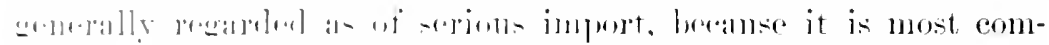

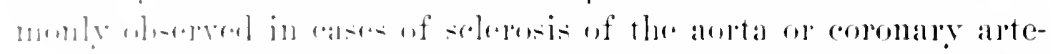

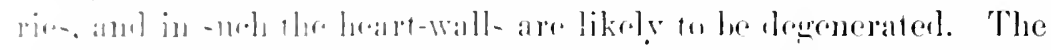

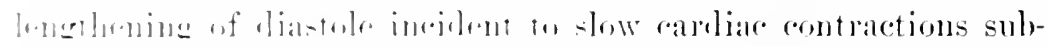

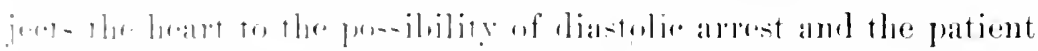

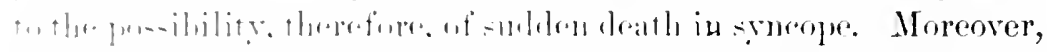

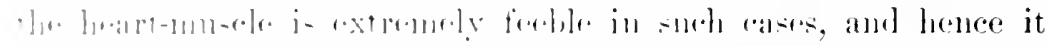

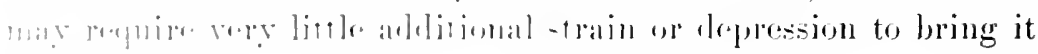
i, il -talul-till. 
T have notes of an old man with rigil atrepies and eloromice

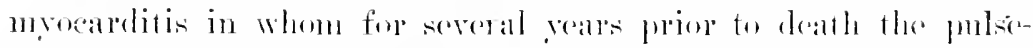

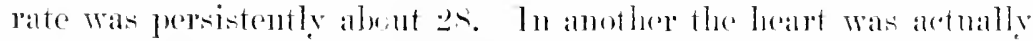
slow, but as smly every of her sytole sent a blond-wawe to the wrist. the pulsc-rate was in reality only halt as fast. It in rsorential, therefore, in erery instanes of smspected bradreardia that the heart be ansentated to dotermine whether there nay not be appaldent instead of actual bradycardia.

\section{STOKES-ADAMS DISEASE (Heart-Blork)}

By this temu is designated a lemarkable symptom-oomplex comsisting in bradyeardia, reptigo or syncope amd epileptiform convulsions. Alams in 1九2t and later Stokes were the first to describe atses, and hence this symelrome is called ly their names. For many years it was romsidered a spereial disease and was stmelied

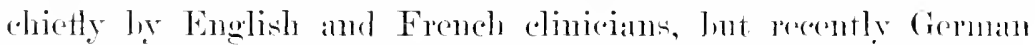
and American physicouns have contributed valuable ardelitions to om knowlerlge, particularly encerning the so-alled bundle of Ilis.

Heartblock is a more general terme sinee it includes not only the Stokes-Adams symeleme but all cases in which there is intrerference with the conduction of stimulus to contraction from andele to rentricle through the bundle of Tris. Notwithstanding previous work, it may be said, it is the experimental sturly of Erlanger which has made intelligilile the pathology of instances of StokesAdams disease that have come to autopsy in the past fer years.

Etiology and Pathology.-These are no longer olsenre and a subject for speculation, as was the case up to 1!):3 when the first edition of this work appeared. The varions theorics one propounded are now only of listorical interest and hence will not be described in this place. Experiments and just mortem rameinations have explained not alone the pathology of heart-block, but also the morbid anatomical elanges underlying the Stokes- Mans symdrome. But before the cansation of this symptom-eomplex can be stated it is advisable to deseribe hriefly the system of comducting fibres which are shown hy lkchoff and Tawara to comnect the right ampicle with the rentricles.

This system of fibres begins at the anterior colece of the coromatry vein, thence passes along the right sirle of the intermuicular sep- 


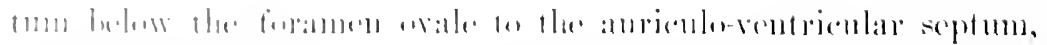

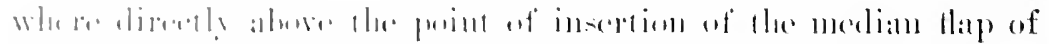

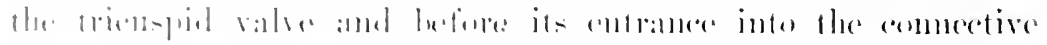

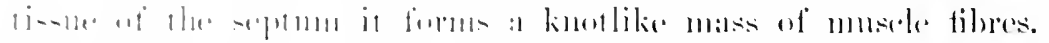

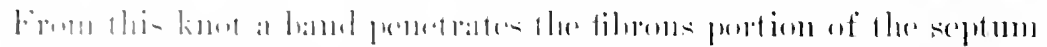

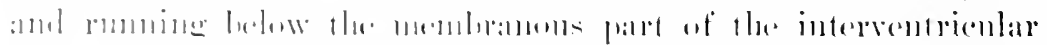

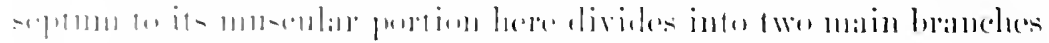

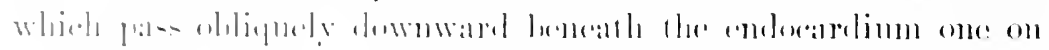

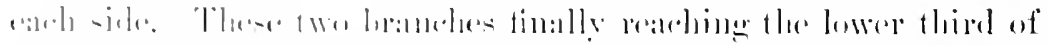

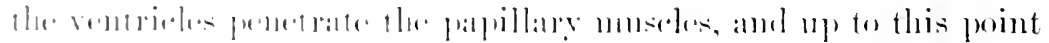

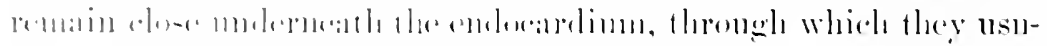
ally maly la -

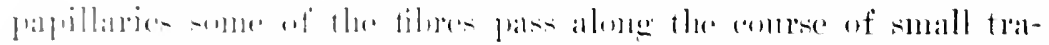

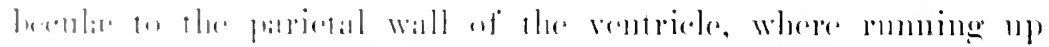

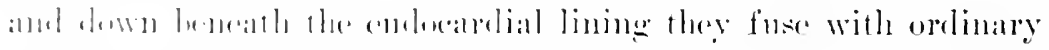

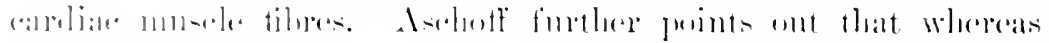

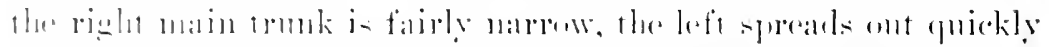

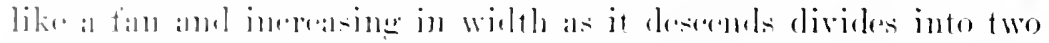

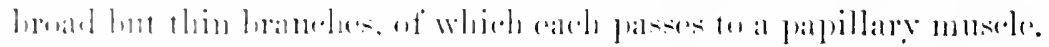

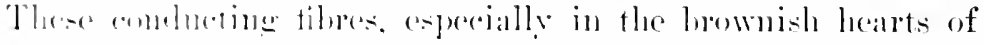

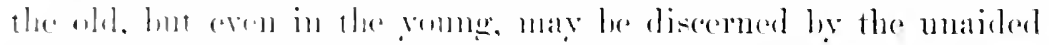

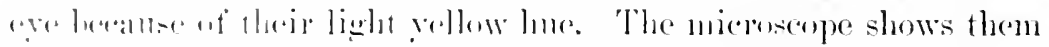

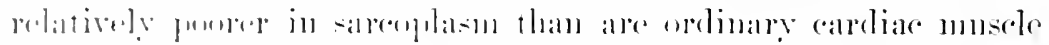

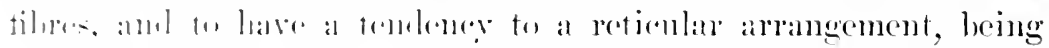

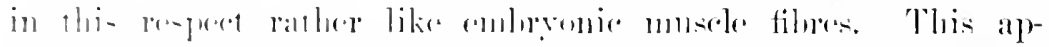

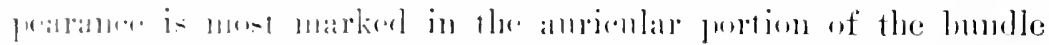

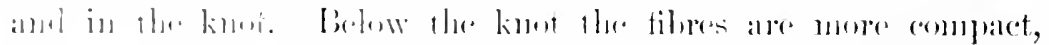

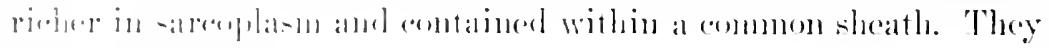
stain lint fonly.

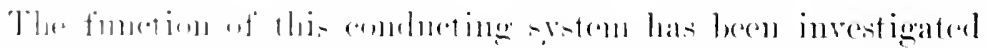

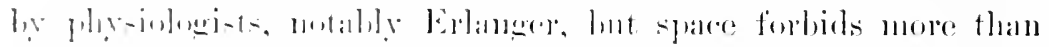

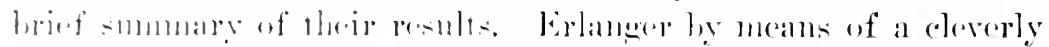

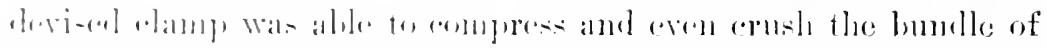

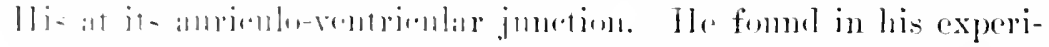

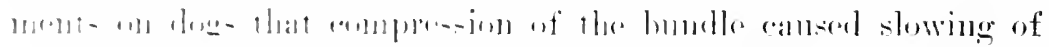

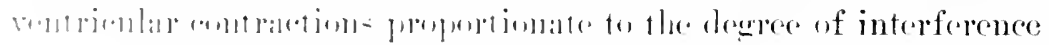

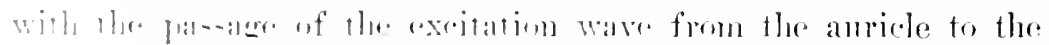

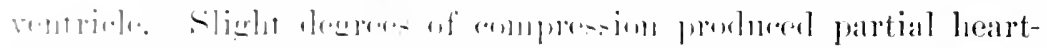

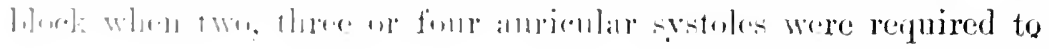


stimmlate the ventriele to contratetion. With still greater compression the vertrienlar respense was sill more interfored with, until

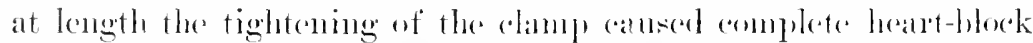
or dissociation of anricles and rentrieles. When this state was

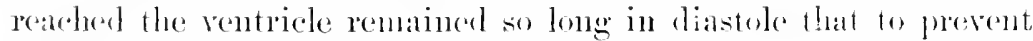
the deatle of the dog the inherent power of the rantriele to eontriet had to be aroused by tapping.

From the precoling description of the course and function of the conducting filores (the bundle of JIis) we are in position to molerstand the efology and symptoms of Stokes-drams disease. In a worl, it is a manifestation of heart-block which when complete results in the death of the individual. Since Stengal's case was reported in 190.5 a number of others have come to antopser, so that now the following has heen ascertained eoncerning the pathologieal omolitions respomsible for this remarkable symolrome.

These cases have all shown discase either of the comdueting fibies themselves or of the contiguous struetures of such a mature as to interfere with the conduction of stimnli from anricle to ventricle. Space prechules a detailed accomnt of these cases, hut the following morlid anatomical lesions have been discoveref.

In Stengel's case there was a patch of athroma which cxtended from the base of the anterior mitral leatlet into the endocarim directly over the bundle of His, and on removal of the endoeardimm was seen to involve the conducting fibres at their anrienlorentrienlar junction. Tn the case of Jellick, ('onerer and Ophuels there was anamic neerosis of the muscular septum in the region of the bundle of Ilis in consequence of recent thombosis of its nutrient artery. Sehmoll's ase showed scar tissue in and around the bundle of His with atrophy of its fibres. Thandford, Grumbam, Keith, Niller and recently Sshton, Norris and larenem have reported the discovery of gmmmata so located as to involve the system of comblucting fibres in some pald of theil comses. In Sendler's case there was a rantilaginons tumor of thr interventricular septunn.

Thus it is seen that syphilis appears to have a rery rlose connection with the Stokes-Adams syndrome and a number of clinical olservers have noted their etiological relationship. Finally heartblock las been seen frequently in association with degenerative ehanges of the myocardimm and with ehronic endocarditis. 


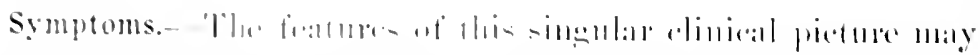

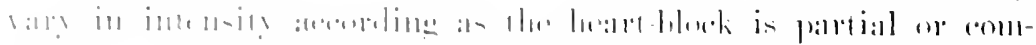

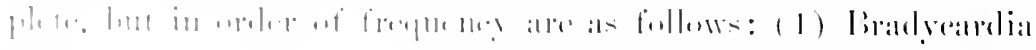

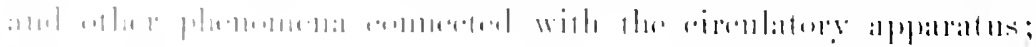

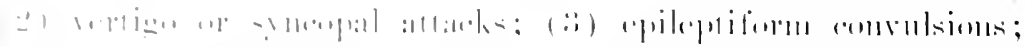

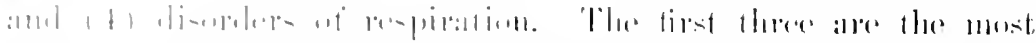

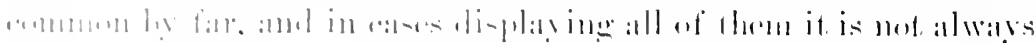

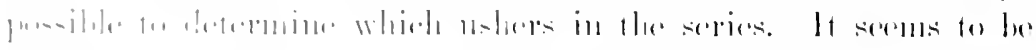

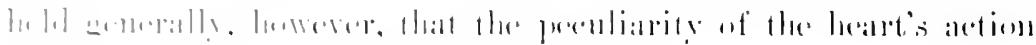
-

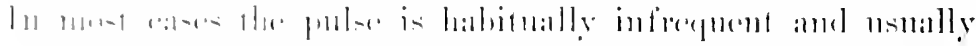

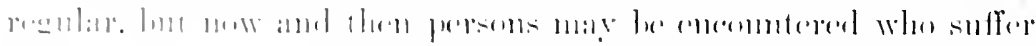

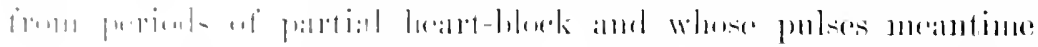

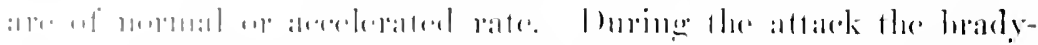

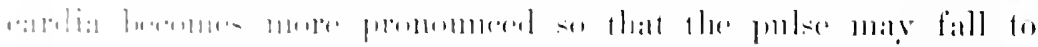

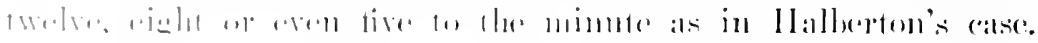

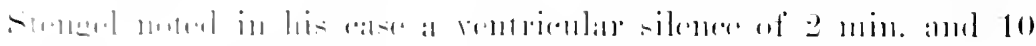

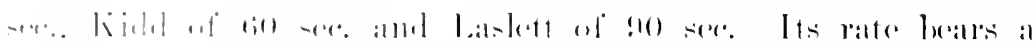

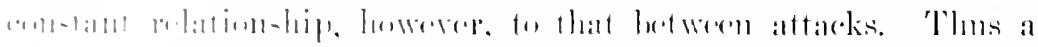

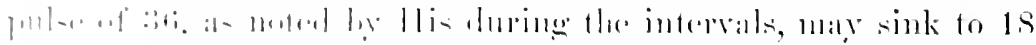

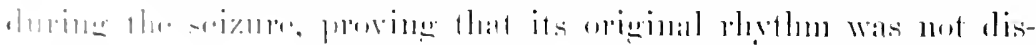

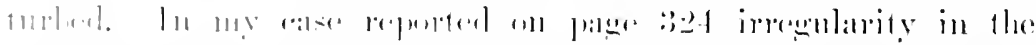

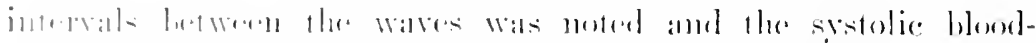

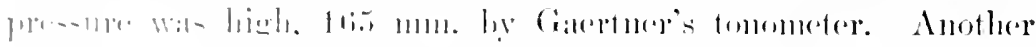

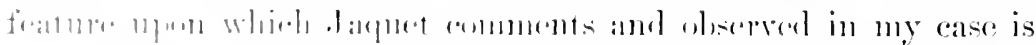

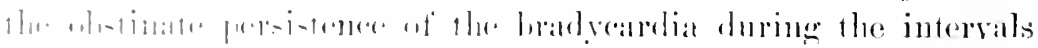

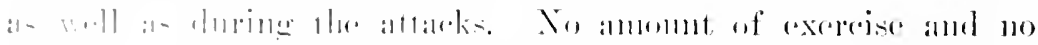

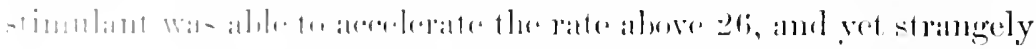

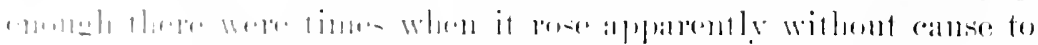

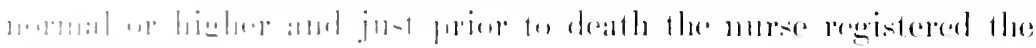
1.1il-1. $: 1-1,11$.

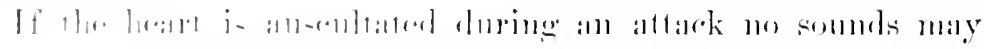

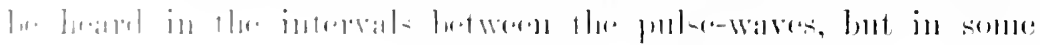

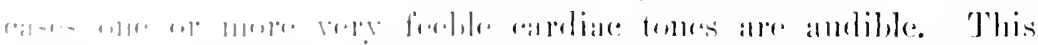

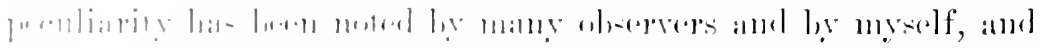

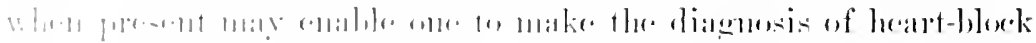

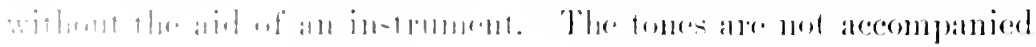

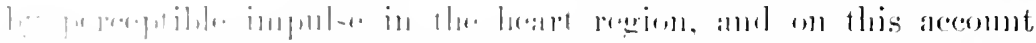

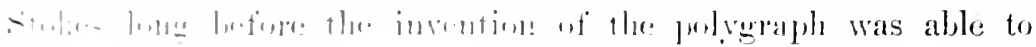


forecast correctly the faret proven instrumentally that they are due to auricular systoles.

Another interesting and singular phrommenom first dreceribed by Stokes is the appearance in the intemal jugular veins diecelly above the elavieles of two or nume tiny pulsations oremping in the interval between ventricular sytoles. For many years these feediles venous pulses were not understood, Stokes and oblers believing them to be amienlar in origin, while Jayuet and others as stomtly maintained them due to weak or abortive contratetions of the verutricles. In the description of my case already alluded to I gave reasons for believing they were ventricular, hut tracings ly Mare-

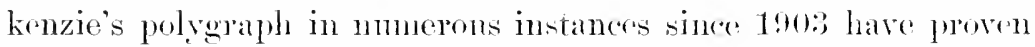
beyond question that they are synchronous with andicular sistoles. Indeed it is on the oceurence of these withont answering vontricular contrations that reliance is placed for the diagnosis of leart-block. The number of such venous pulsations depends upon the degree of heart-block. In my case they were generally two in number, but during the Stokes-Adams attacks reached as many as seren.

If a simultameous tracing is recorded of pulsations in the jugular and in the carotid and such tracings are carefully noramed and interpreted, they indicate plainly that these anricular pulsations or contractions do not call forth answoring spstoles on the part of the ventricles. In other words there is a lose of conductivity of the stimulus to contraction from the anricle to the rentricle, and when, as in my case, these ampioular contuactions number as high as 5,6 , or 7 , a condition of complete heart-block exists.

Tertigo is rexperieneed to a greater or less degerese in all rasers, and amoyed my patient for over two vears before more alaming symptoms appeared. The assumption of the dopsal deceulitus may not prevent its ocenrenee or eren mitigate its sererity. That this should be so is rearlily intelligible when we consider that the prolonged diastole of the left ventriele must oecasions some degree of cerebral anamia. When this lark of arterial flow to the luain becomes more pronomeed it may be declared by distinet fainting fits.

Syncope may or may not he experienced, hut in cases of eomplete heart-block is a prominent symptom. The uneonseionsness 


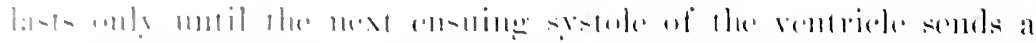

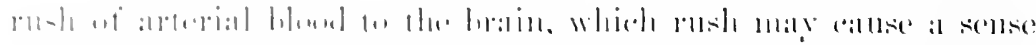

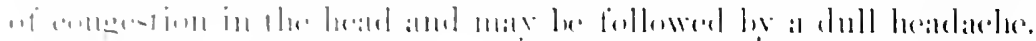

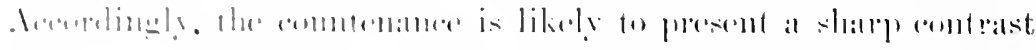

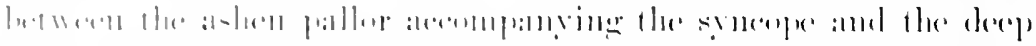

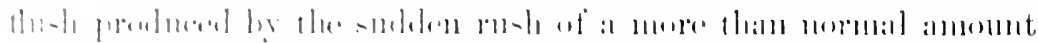

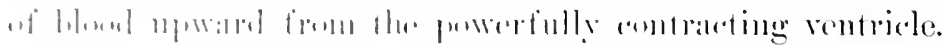

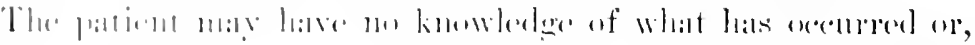

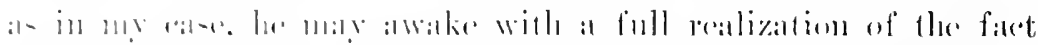

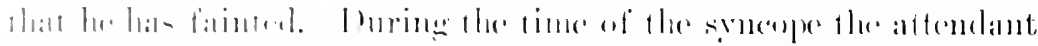

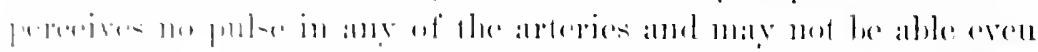

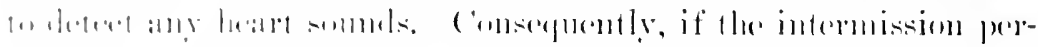

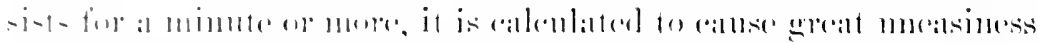

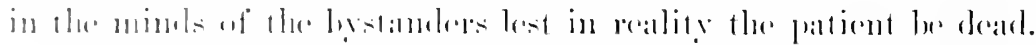

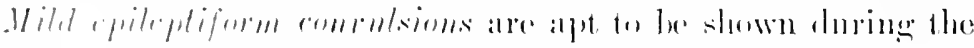

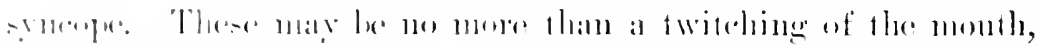

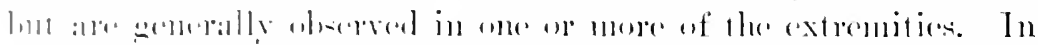

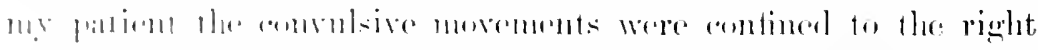

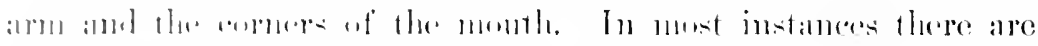

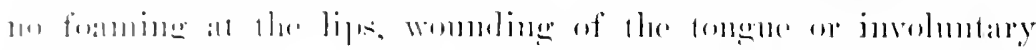

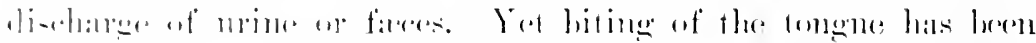

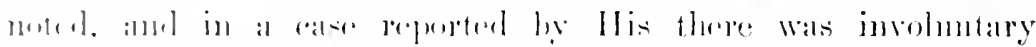

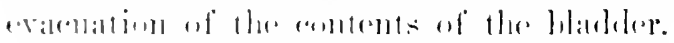

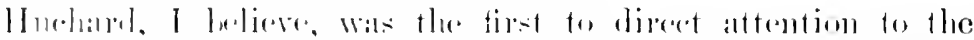

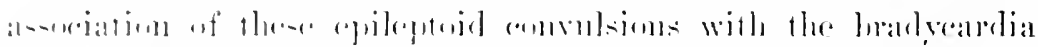

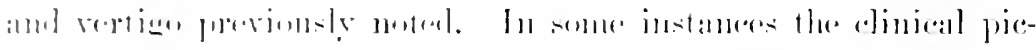

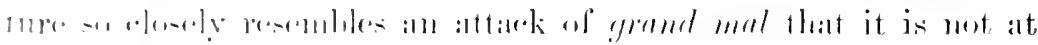

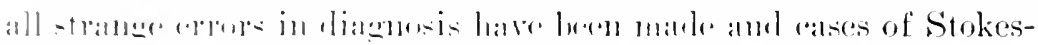

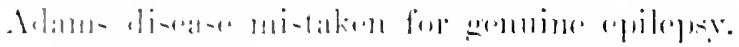

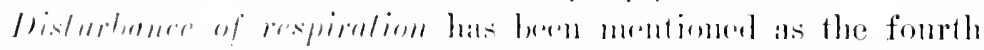

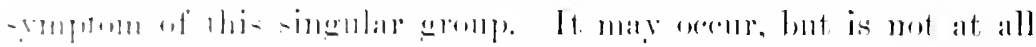

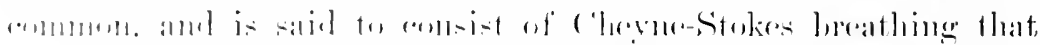

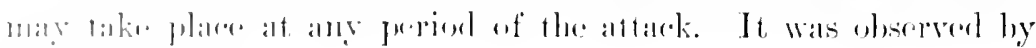
lij-. I linliner.

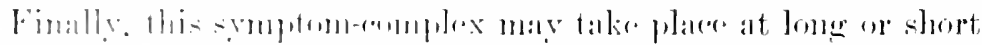

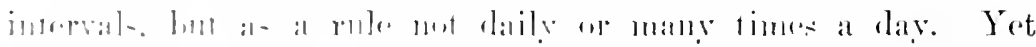

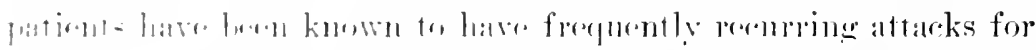

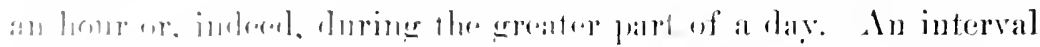

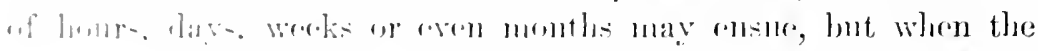


lesion on which depends the interference with anductivity is so grave as to leat to complete heart-block the symptom-fore intervils are not likely to be so long. It is radily intelligible why this should be so in cases of complete leant-block depenting upon structural alterations in the bumble of llis, lont why an individual shonlet display the plenomena of Stokes-Akams discase at irregenlar intervals through a period of years, as in ny case, and then dic suddenly serms not quite clear. It is probalole, howerere, that other extraneons influenes serve to depress the irritalility of the ventricular muscle, thus rendering it less sensitive than ordinary to the enfecbled stimuli from the anrieles, or that for the time boing they still further diminish the conductivity of the stimulus to contraction itself. Cpon snch a hypothesis it is explicable that the interference with the passage of the stimulus from the auriele or the reduction in the irritability of the ventriele may reach such a degree at any time as to lead to a fatal symeope. Curiously cnongh the young man whom I had under observation for so long is reported by his nurse to have walked to his resielence, seated himself to read the morning paper, and a few minntes thereafter to have died suddenly, although his pulse directly after his return to the honse was ruming at 120 per minute.

In this patient the influences which seemed to call forth his attacks appeared to resicle in the intestinal tract. This eonelusion seemed warranted by the fact that during the time he was having attaeks his urine was deficient hoth in quantity of water and in solids, with an indiean perentage strictly within normal limits. Upon cessation of the attacks his mine improved in character and in partienlar the indiran rose to three to four times the normal amount. Noreover, when lie adopted a strict vegetarian dictary designed to correct his ehronic eonstipation he enjoyed many months of immmity from his symptoms. That there was a comdition of auto-infection which, acting npon a diseased conducting system, in some way evoked the seizures is in line also with the observation nuade by .Jaquet, since in his patient many months of freedom followed the correction of constipation and indigestion, while upon return of these ligestive disturbanees four attacks supervened, in the fourth of whieh the man died.

Heart-block may develop at any age, but inasumch as the lesions likely to affect the bundle of His somewhere in its course 


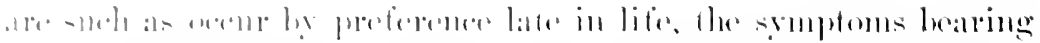

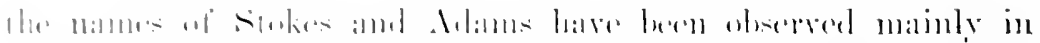

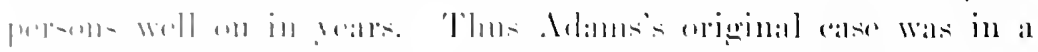

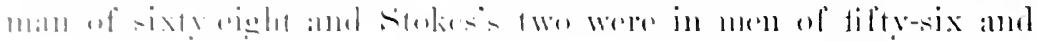

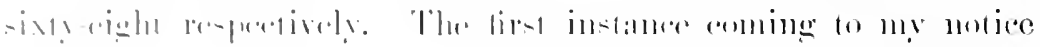

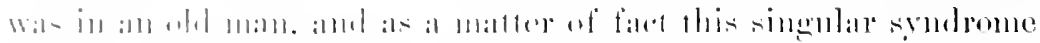

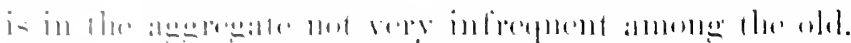

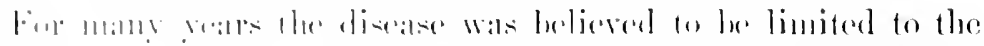

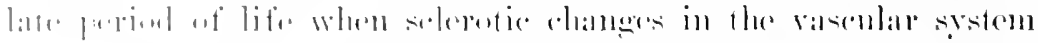

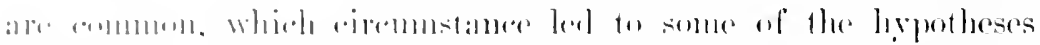

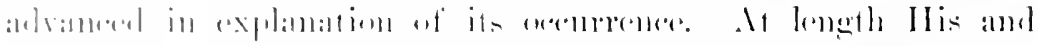

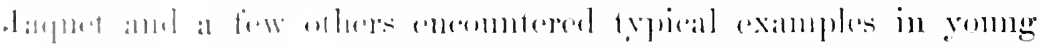

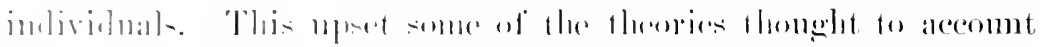

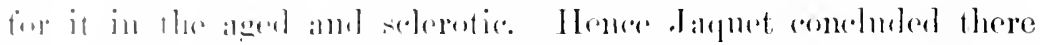

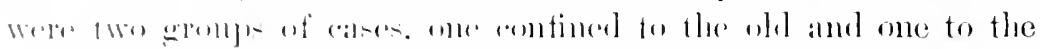

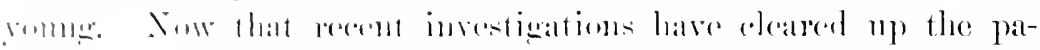

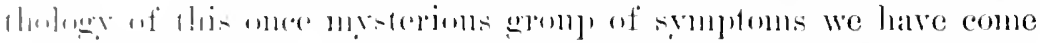

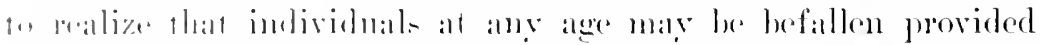

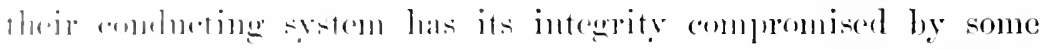

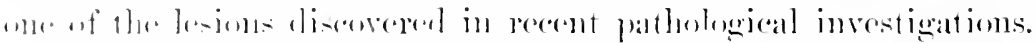

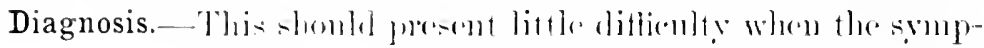

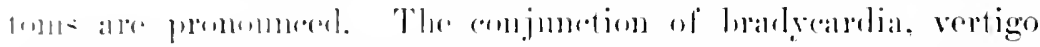

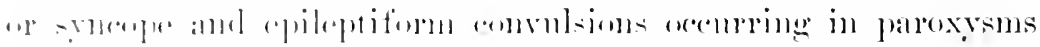

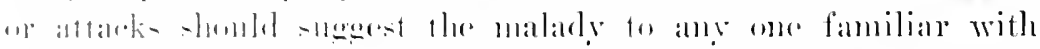

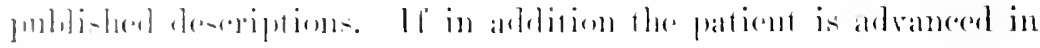

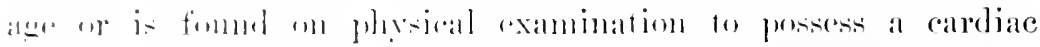

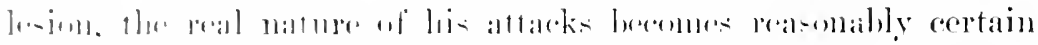

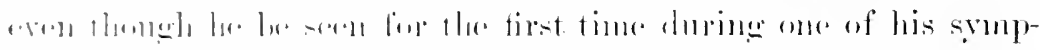

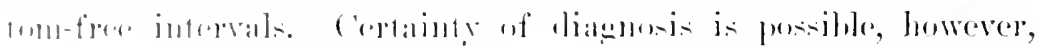

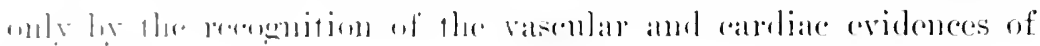
lin:ill-1,1, ink.

There signe and-i-t in fwo or more visible pulsations of the

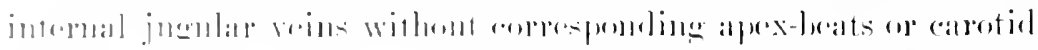

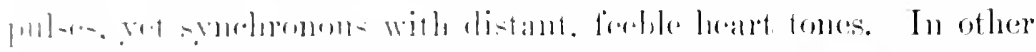

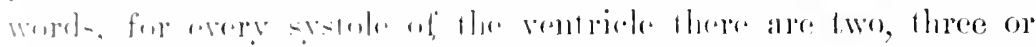

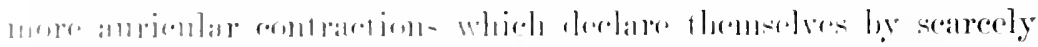

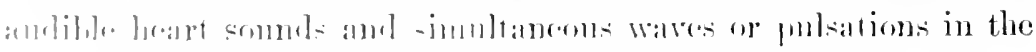

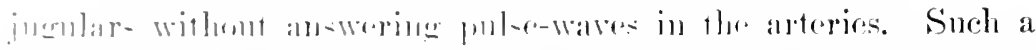
-riats of thines ran exist renly when there is a block to the passage 
of stimuli from the anriele to the ventrieles and lecues the deteretion of these cardio-vaseular signs astablishes the nature of fle case berond peradrenture.

Stokes-dilans disease must be differentiated from epilepsy amd from functional disorders of the heart's antim. It is distinguished from the former by the absence of the epileptic ery, of biting of the tongue and of involuntary evacnation of bladder and reetnm and, if the physician be so fortumate as to witness the attack, by the extreme slowness of the pulse and the cardio-valsenlan signs of heart-block.

Funetional disturbances of eardiac rhythm may be differentiated in farorable eases by inspection of the cervical veins and auscultation of the heart, but the only precise methed of identifying extra-systoles on the part of aurickes or ventriedes which may simulate partial heart-block is by resort to some form of polygraph, Mackenzie's or Ilirschfelder"s modification of the Erlanger splygmomanometer. By careful measmement of the venous and arterial tracings thus obtained one can determine the exact timerelation of the pulsations and so ascertain whether or not a blecking of the contratetion-walves exists.

Prognosis.- This is excedingly grave sinee complete heartblock is liable to cause death at any moment. I fine cases have been reported which appear to have recovered, lut since StokesAdans disease is generilly due to structural lesions within the bumlle of His, the probability of recovery is very remote. The eases offering such a possibility are those presenting a specifie history in which the symptoms may be dne to gumma involving the conducting fibres. Even in sneh, howerer, the artministration of iodides is not always eapable of hringing about a cure. If the patient is old and selerotic le will suecmub to his malady in all likeihos luring an attack.

Treatment of this discase is highly moatisfactory becallse of the fact that with the pessible exception of syphilitic disorders of the heart we have no means of removing the camse mulcrlying the heatrt-lilock. We are restrieted, therefore, to a symptomatic line of therapy, and even this is murofitable in most instances. Between attacks the general health may roceive attention, and digestive disorders, constipation, ete, should be removed. The individual should be wamed against acts which may over- 
ri:iti

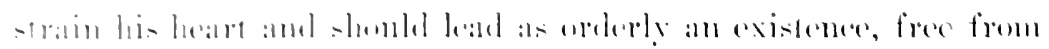

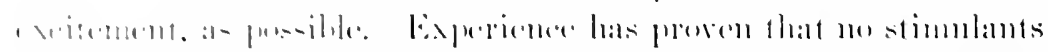

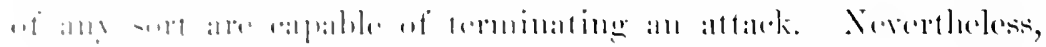

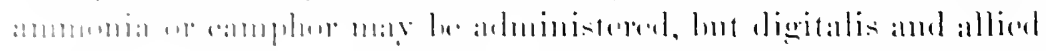

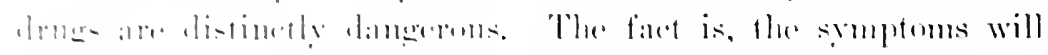

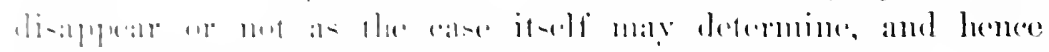

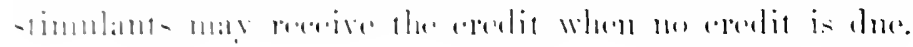




\section{CHAPTER XXT}

\section{ANGINA PECTORIS}

Definition.-Attacks of intense pain in the region of the heart, with more or less disturbance of cardiac action, nsually accompanies by a feeling of constriction of the chest and a sense of impending death.

History,- Mlthongh this form of heart-pain was not systematically described until the latter part of the eighteenth century, yet a graphic account of his own sufferings from this complaint was given by Seneca, and in 1707 Morgangni gave a clear description of a paroxysm in a case of aortic aneurysu. In February, 1768, Rougnon addressed a letter to M. Lorry which contained the description of the death of a certain Captain Charles, who, from the account given by Rougnon, appears to have suffered from attacks of angina pectoris. It was Heberden, however, who in .July, 1768 , first systematically described this formidalie complaint and who gave it the name by which it is now universally recognised. The names of John IInnter, Erward Jenner, and Parry are also intimately associated with its early history, Inunter having experienced it in his own person, and having ultimately died in an attack.

Jemner in 1799 pointed out a definite connection between selerosis of the coronary arteries and angina pectoris. He is said to have refrained from publishing his views at an earlier date out of consideration for his famons friend, John Hunter, who during his life had held contrary opinions concerning its etiology. Parry gave it the name of "svincope anginosa," for, although he recognised its connection with coronary disease, he considered the attacks due to paralysis of the heart.

From this time forward the literature of the profession teems with eontributions on the subject and with divers theories con- 


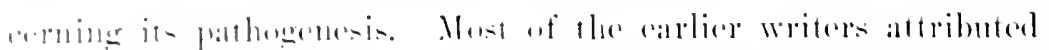

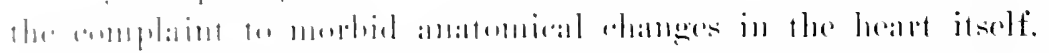

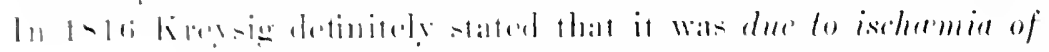

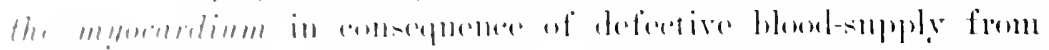

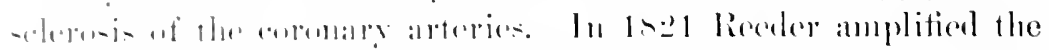

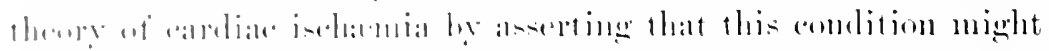

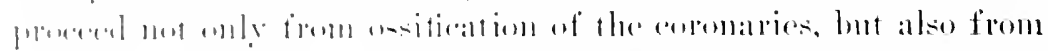

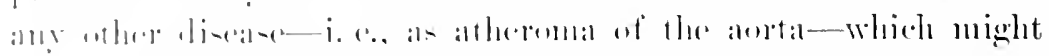

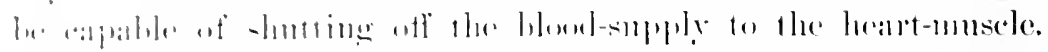

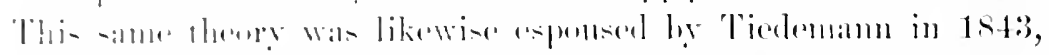

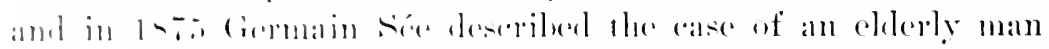

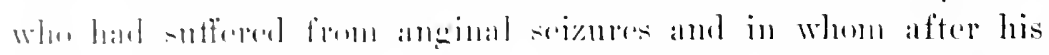

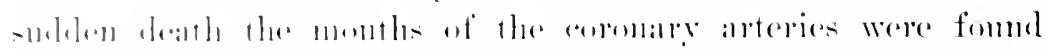

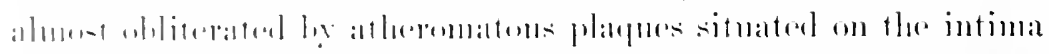

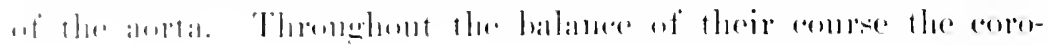

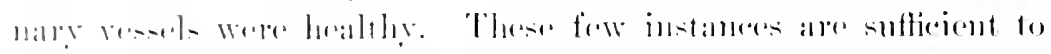

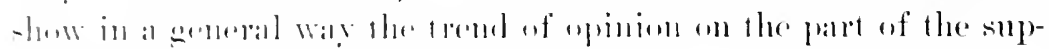

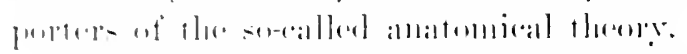

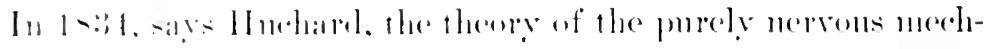

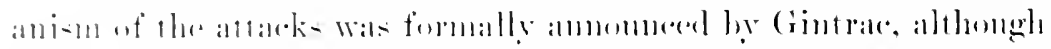

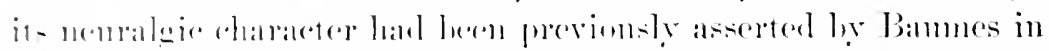

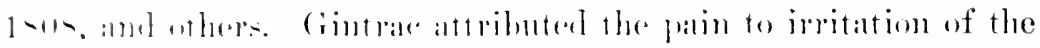

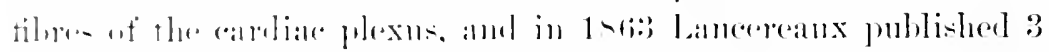

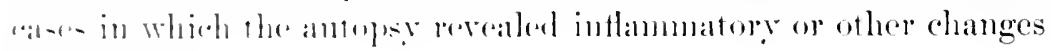
uf 1 hi- jolr.ins.

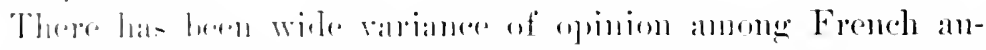

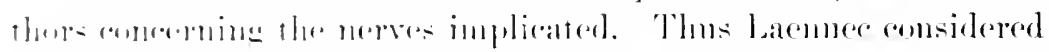

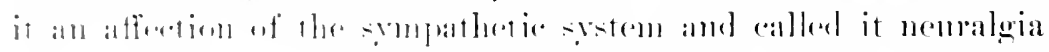

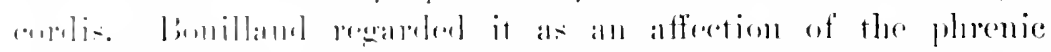

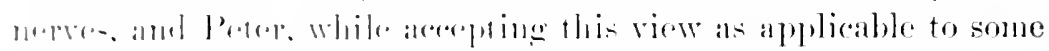

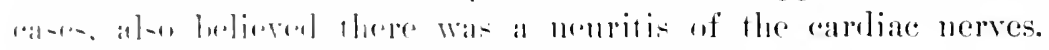

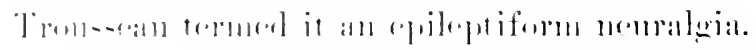

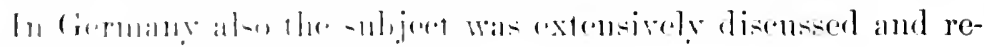

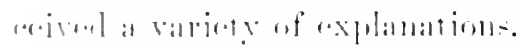

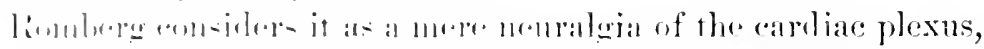

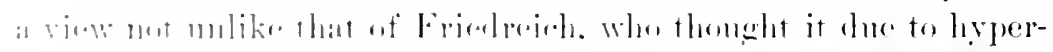

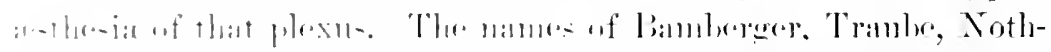

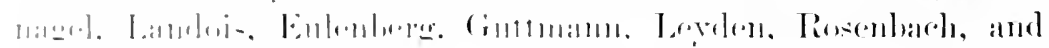

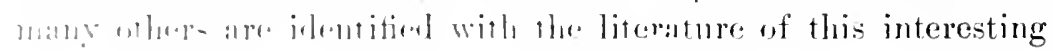


subject. Landois, who in $186: 3$ suljjected the question to a eritical study from a plysiological stamlpoint, divided angina peetoris into four groups, as follows: (1) Cases aused by disturbance of the excito-notor or accelerator nerves of the heart; $(2)$ those due to irritation of the cardiac branches of the vagus: (:3) cases alrising from reflex irritation of the ablominal viscera-" angina reflectoria"; (t) such as arise from vaso-motol disturbance in rarious parts of the body-_" angina raso-notoria." Enlenberg also contributed an elahorate article on this subject in Ziemssen's Cyeloperdia of Medicine, vol. xiv.

Leyden consider's the attack due to degenerative and inflammatory changes in the heart-muscle depending npon disease of the coronary arteries, which changes lead to inpairment of the heart's function.

Aceording to Rosenbach, some alteration in the contractions of the cardiac muscle takes place, which alteration may, but does not necessarily, lead to functional weakness. In consequence of this change, irritation is imparted to the sensory tract, and this stimulus sets free the varions forms of pain and anxicty characteristic of stenocardia, in accombance with irritability of the sensory apparatus and the functom of the respective nerves composing it. Painful scmsations are nore or less pronounced according to whether the sensory centres are or are not acenstomed to the irritation to which they are subjected.

According to Rosentach's view, this true heart-pain is an indication of the heart-muscle being less able than usual to accommodate itself to sudilen change taking place in the performance of its work; or, in other words, its ability to respond to demands from withont for a lisplay of extra effort is impaiced. Now and then, also, obstacles residing in the heart itself and capable of interfering with its perfect action may interrupt the performance of its regular work and in like manner give rise to the phenonena of angina pectoris.

During the century just ended many contributions to this interesting subject have appeared in England and America, of which the most noteworthy were by Latham, Gairdner, and Osler. The last mentioned, in his Angina Pectoris and Allied States, deals with the affection in a very complete and entertaining manner. The most exhaustive discussion of the subject, however, to 


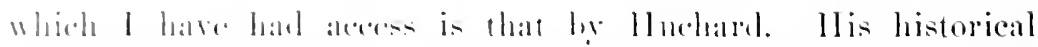

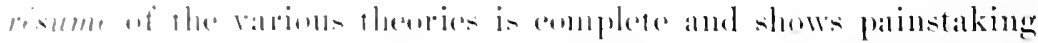

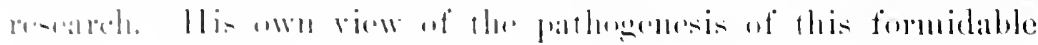

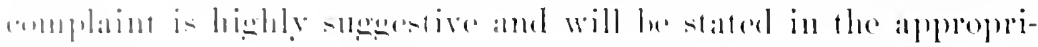
att? Hitc?.

Pathology and Etiology.- It shomld le alearly muderstood

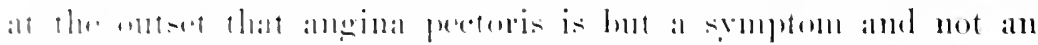

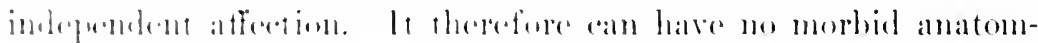

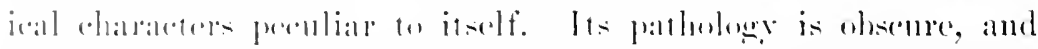

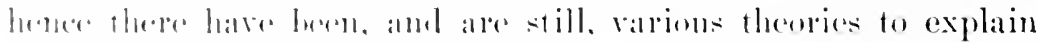

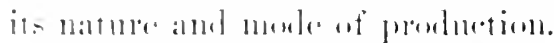

It may" he stated in a anderal way that anginal peetoris is divisible bute two forms: ane incolrable and likely to terminate

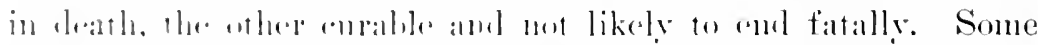

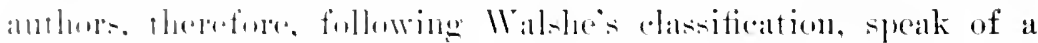
true and a fallo angina. ()-ler malkes this distinction, while Bal-

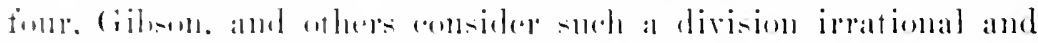

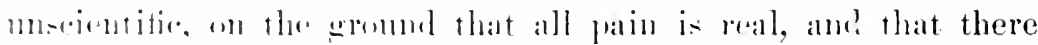

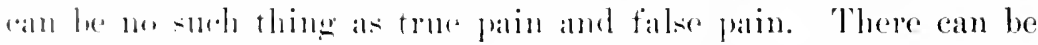

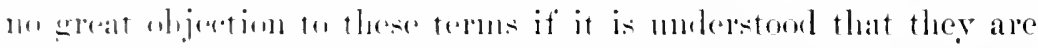

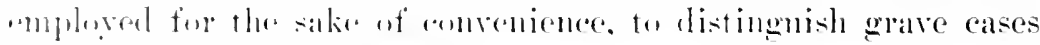

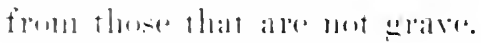

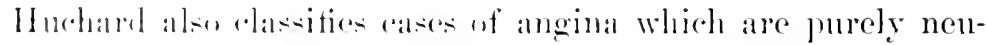

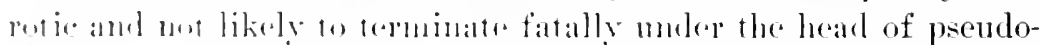

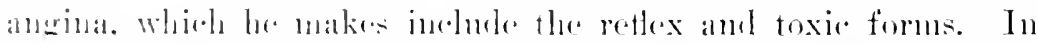

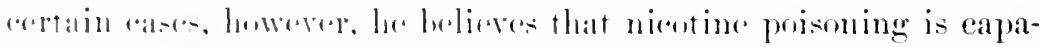

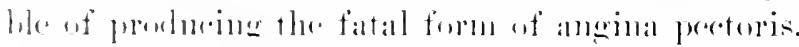

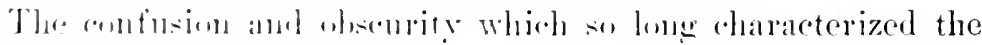

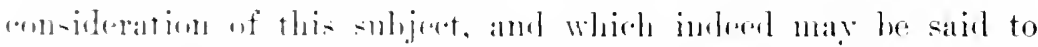

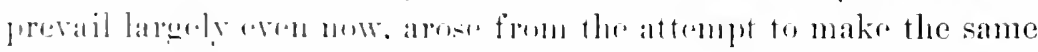

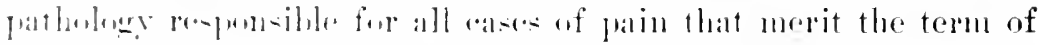

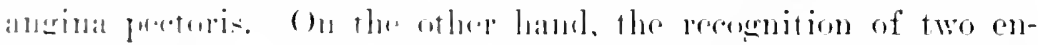

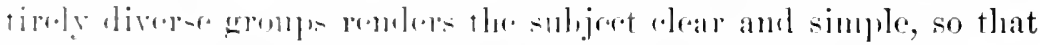

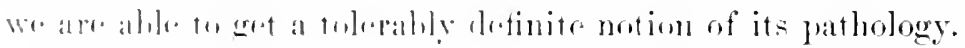

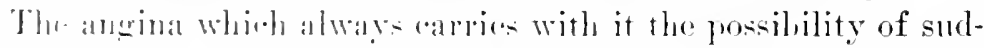

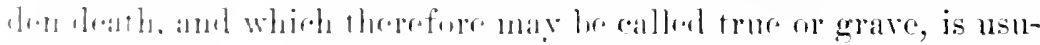

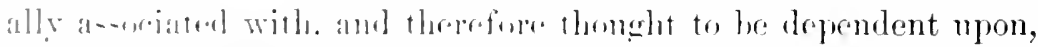

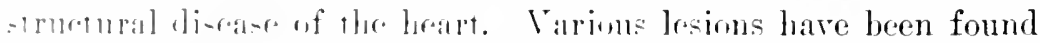
in fatal care, but the are all of such a kind as to interfere with 
the blood-supply to the heart-muscle. Coronary selerosis is the most frequent, but inasmuch als all cases of this disease are not attended with angina pertoris, it is evident that there must be something more than mere selerosis of these arteries. Accordingly it has been determined that it is not so much the fact of disease of these ressels as it is that this disease must interfere with cardiace cireulation if it is to give rise to attacks of angina pectoris.

Shutting off of the blood-supply to a limited portion of the myocardium-i. e., by thrombosis of terminal twigs or eren of a branch of considerable size-does not apparently always oceasion this pain. If, however, one main trunk, or, still more, if both trunks are occluded, or if their lumen is sufficiently narrowed withont being actually obstructed, then attacks of angina are very likely to occur. Aceordingly, a condition which is specially apt to result in anginal seizures is narrowing of the months of the coronary arteries by the sclerotic process, as has been repeatedly proved at the necropsy in cases of this terrible agony.

It is upon the evidence furnished by such discoveries that the theory has been reared of ischamia of the heart-muscle being the essential pathological factor in the causation of the fatal form known as true or grave angina pectoris. In this variety pain is usually absent so long as the individnal is at rest or is not making exertion that recpuires unwonted labour on the part of the heart. Under such conditions the cirenlation of blood within the myocurdium is sufficient for its needs, but when some emotion or extra physical effort calls for unusual heart-work, the narrowed coronary arteries are incapable of supplying the organ with an additional volume of how and the ischermia is intensified for the time being. Therenpon an attack of angina pectoris is evoked. According to this hypothesis, the nerve-filaments or ganglia with which the myocardium is so richly supplied beeome irritated by this deprivation of required blood and send an impression through the eardiac plexus up to the centre, which then responds by discharging a sensation of pain along certain nerve-trunks connected with certain segments of the spinal cord. This will again be considered in greater detail.

The pain thus induced promptly canses a cessation of exertion and consequent lessening of the heart's work. As the organ resumes its aceustomed tranquility its blood-supply proves again 


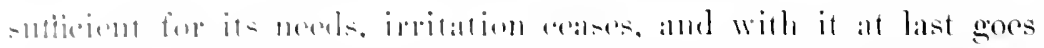

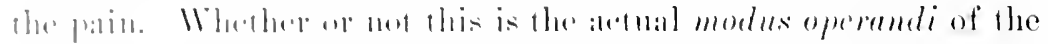

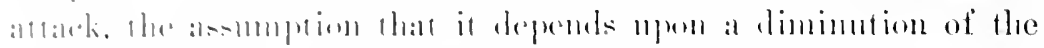

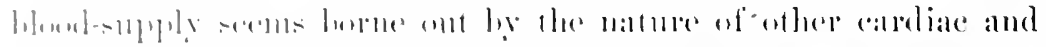

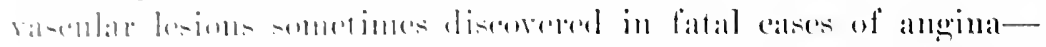

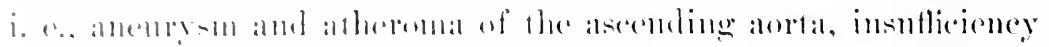

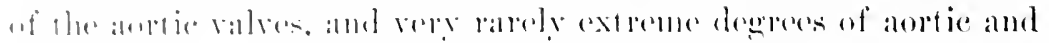

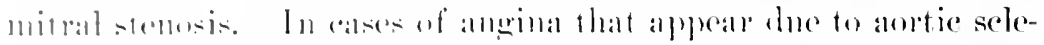

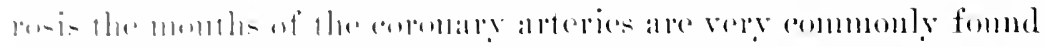

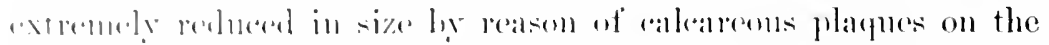

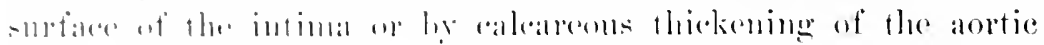
wall. While the (onts of the mutrient alteries ale also genelally

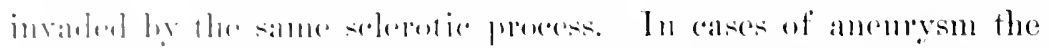

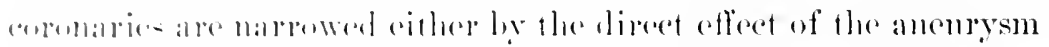

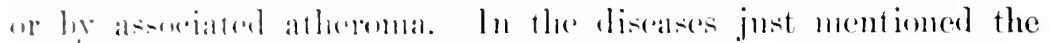

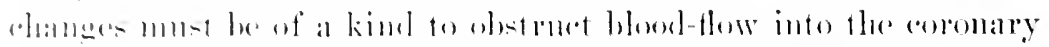

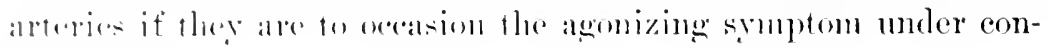
-inlerition.

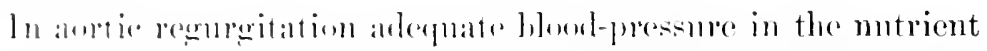

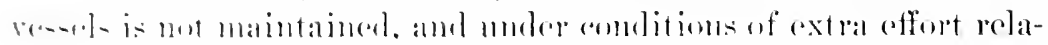

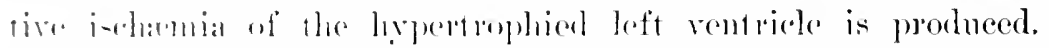

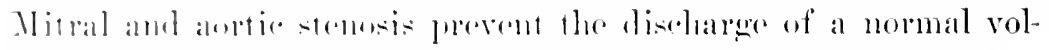

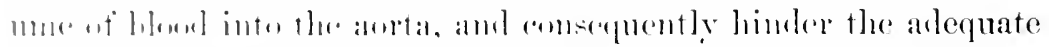

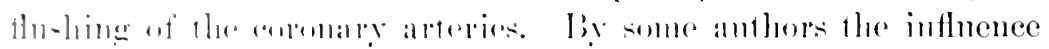
of ralvolall deforets in the ansation of angina is denied without

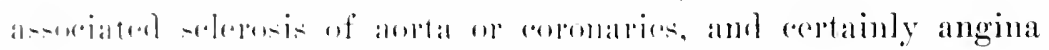

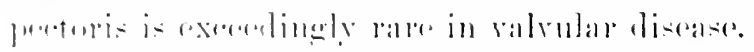

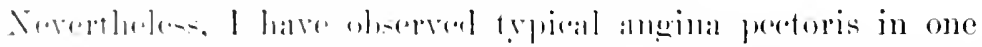

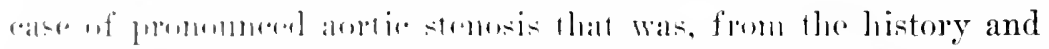

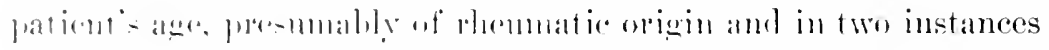

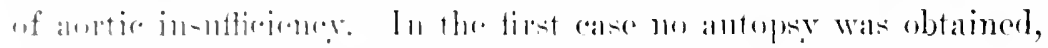

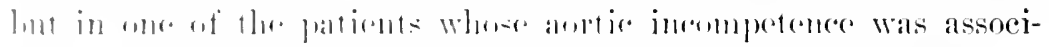

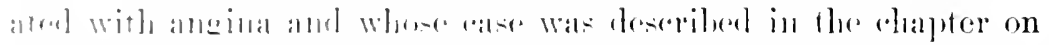

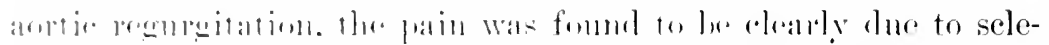

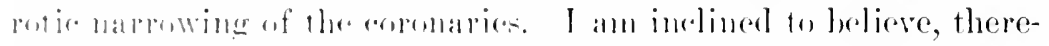

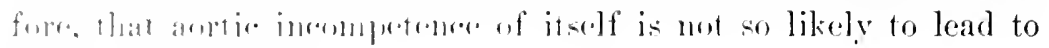
alleillat a- is - $-1010,-i=$.

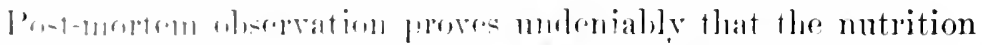

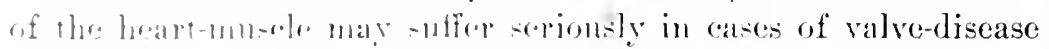


withont associated coronary sclerosis, and that such myocardial degeneration is particularly likely to be found in long-standing and extrene stenosis of the aortic orifice. This indicates that during a long period of time the demands on the energy of the heart outstripped its mutrition owing to the small suply of blood sent through the stenosed orifice into the aorta and coronary system.

If in such a state of thing's the supply of blood to the heartmuscle is still further diminished, althongh but temporarily, then it is possible for a paroxysu of angina pectoris to occur. The influences capable of determining such a temporary increase of cardiac ischamia may be raso-notor spasm, affecting the coronaries, as snggested by Powell, or the contimuanee of undue physical exertion after such effort has begun to orertax the heart. In extreme aortic stenosis cardiac overstrain is shown by still greater feebleness of the pulse, and when such is the ease the coronaries are still more imperfectly flushed. There is temporanily a relative eardiac ischamia which makes an attack of angina pectoris possible. Fortunately such attacks are rare, yet on the hypothesis of cardiac ischicmia as the canse of angina the conditions favourable to its production are present.

Finally, it shonld be stated that the degenerative changes diseovered in the myocardim of persons who have died in a paroxysm of angina pectoris probably bear no direct etiological relationship to the pain. Were it not so, this formidable agony would be far more common than it really is. Such degenerations of the heart-muscle are to be looked upon as the result of the pathological condition in the coronaries or aorta which have led to the angina.

It now remains to consider how the morbid anatomical conditions just mentioned act in the pathogenesis of this obscure complaint. They are to he regarded as predisposing factors merely, which to be operative require some additional influence, since, if such were not the case, all persons in whose heart such changes are found after death ought to have suffered from angina pectoris. This we know is not the case. It is this consideration which has given rise to the various hypotheses propounded in explanation of the symptom-complex. The best known of the theories have been stated alreary in the history of the complaint and do not call for repetition. I would direct attention particularly to Rosenbach's and to that of cardiae ischemia. 


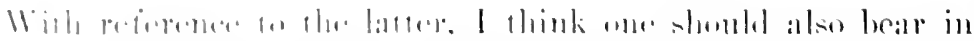

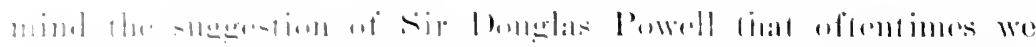

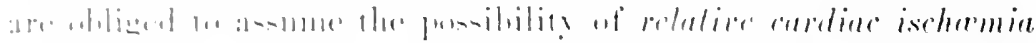

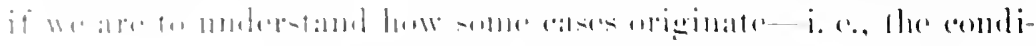

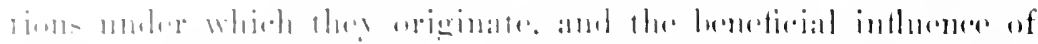

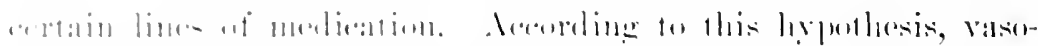

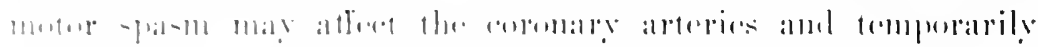

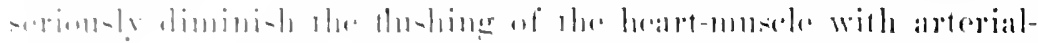

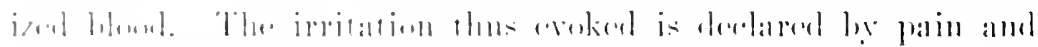

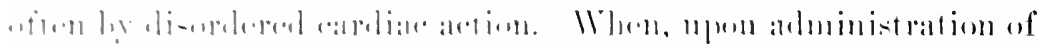

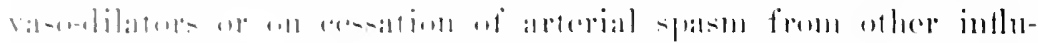

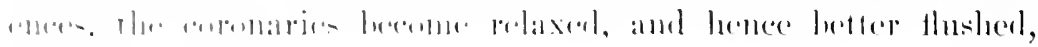
impitition andere.

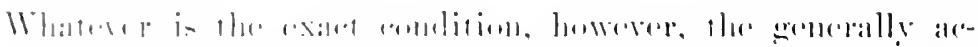

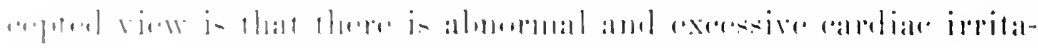

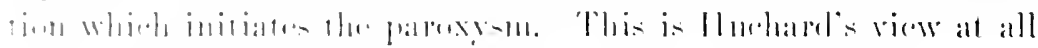

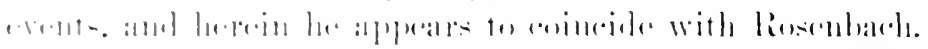

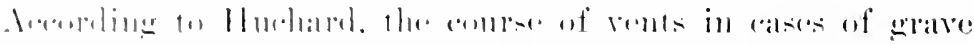

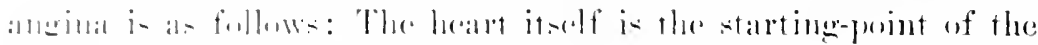

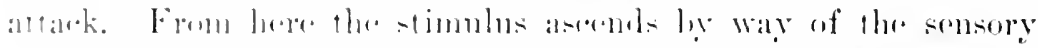

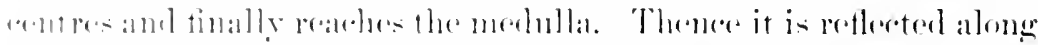

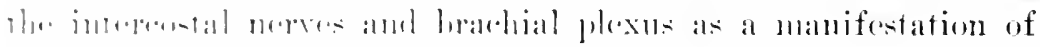

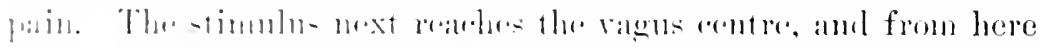

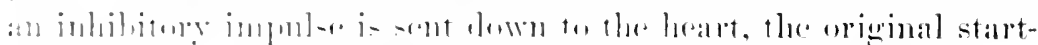

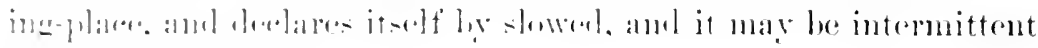

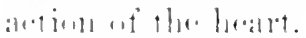

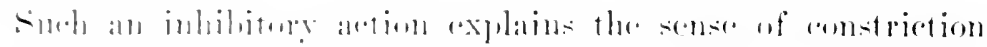

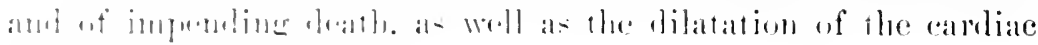

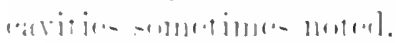

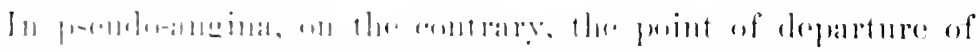

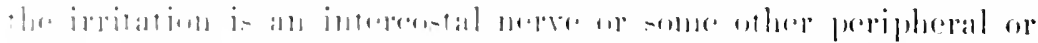

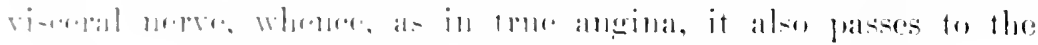

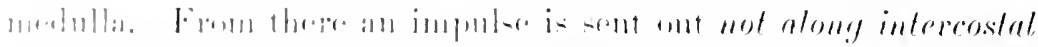

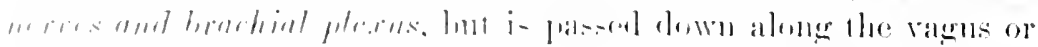

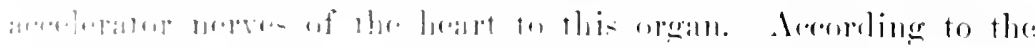

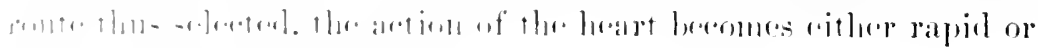

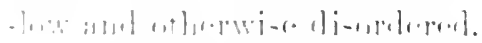

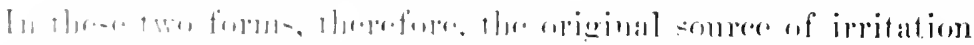

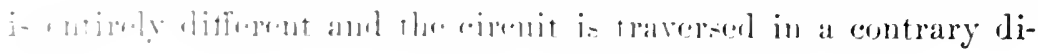


rection. To my mind this is a highly satisfactory explanation of the differenees in their elinieal phenomena. It likewise proves sarvirable in making up diagnosis an! prognosis and in deciding on the mode of managenent.

Learing now the pathology of angina pectoris, which, however much we nay speculate mpon it, is moleniably obscure, we come to the consideration of the remaining predisposing eauses as well as the influenees which directly excite an attack.

Aside from the anatomical conditions alrealy considered, we are at once inpressed by the important part played by age. Angina pectoris of coronary origin is emphatically a complaint of indiviluals who have passed midcle age and have entered their sixth or seronth decale. This is an age in which the effects of arteriosclerosis usually declare themselves, and yet angina of this origin is sometimes observed before the fiftioth or even the fortieth vear. One or two instances are on record of its ocenrence in elitderen. Tevertheless snch facts do not invalidate the correctness of the statements made concerning the inportance of age.

Males are much more frequently affected than are females, and of men who are befallen it is a noteworthy fact that it is especially the well-to-do and well-fed. Regarding the inflnence of sex, Osler states that out of his 40 cases but 3 ocenred in women. I have notes of 32 cases, and of these, 7 were in the female sex. Of 2 that came to antolsy, 1 was a woman of sixty-six with aortic and mitral stenosis, with sclerosis of the aurta and coronaries; wbile in the other, as alrealy stated, there was coronary obstinction and aortic regurgitation, both of sclerotic origin. Of the remaining 5 cases, 1 was in an aged woman presenting well-narked signs of arteriosclerosis, a hypertrophied left ventricle, and a harsh systolic hasic bruit. Another was a comparatively young female with aortic regurgitation of uncertain origin, but whose questionable habits always made me suspicions of the likelihood of syphilitic infection. The third was in the lady of forty-four with signs of pmre aortic stenosis whose case has been already described in the chapter on Aortic Stenosis, and will be again alluded to in this. The fourth was in a woman of fifty with aortic regurgitation, due probably to arterioselerosis, to judge from her history and the arterial thickening. The fiftl case was that of a woman of fifty-six who was corpulent and had thickened arteries 


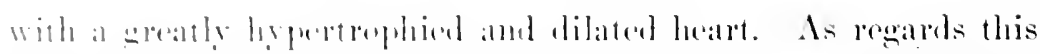

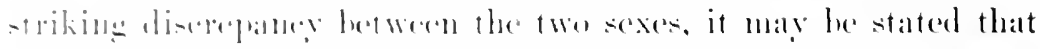

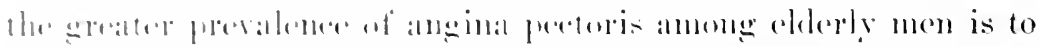

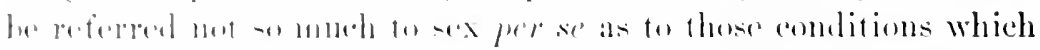

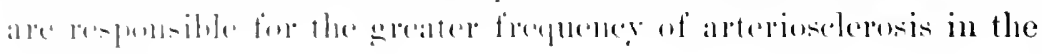
mall. $-1 \times x$.

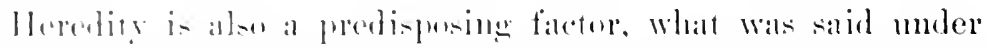

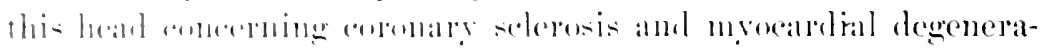

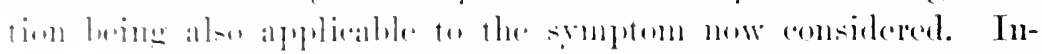

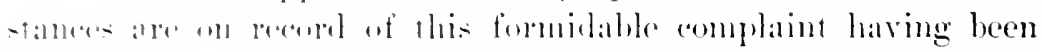

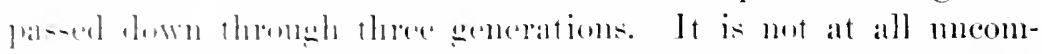

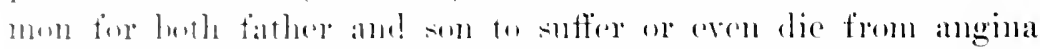

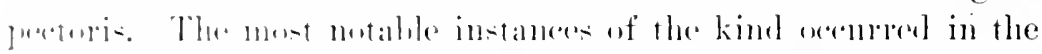

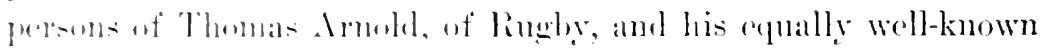
-m. Manther Amold.

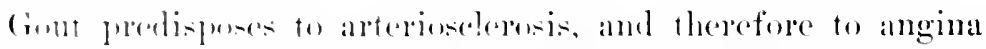

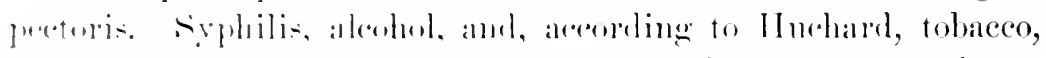

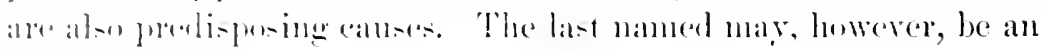
r.xeit inger alllice.

The erriting reuses of true, or commaly angina, as ll wehard

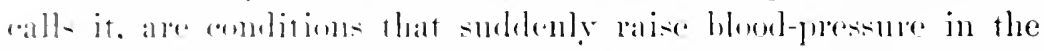

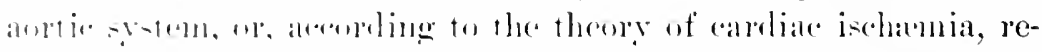

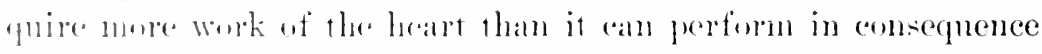

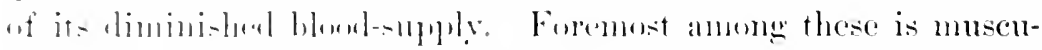
lal reffort. The pationt may have hale nu promomition of the mal-

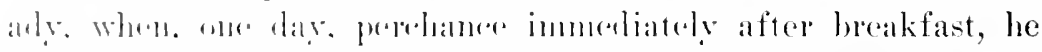

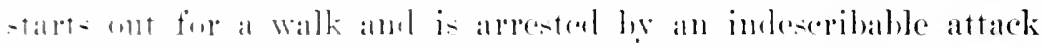

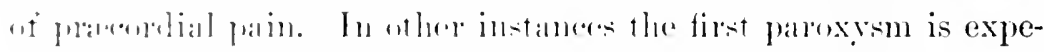

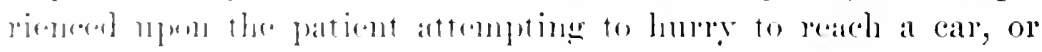

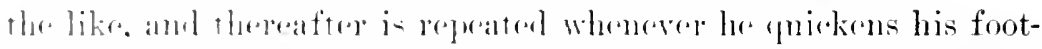

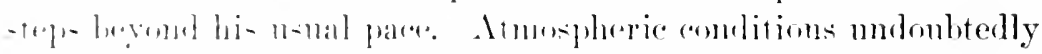

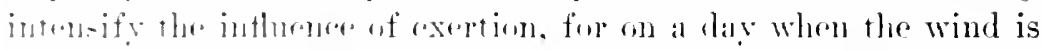

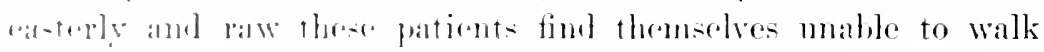

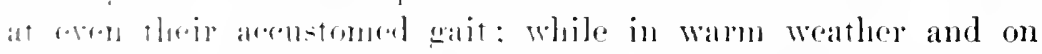

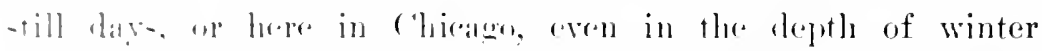

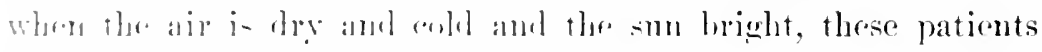

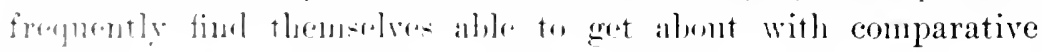
(*isutiont.

I have know patients who wold walk with ease when the 
stomach was empty, yet who invariably experienced pain, of greater or less severity, whenever attempting to walk soon after breakfast. This is undoubtedly to be explained by the augmentation of arterial tension, produced by the presence of food in the stomach. Nevertheless the rise of blood-pressure thus oecasioned is of itself not sufficient to eroke an attack, since it requires in addition physical exertion.

Emotional states, as anger, worry, or excitement from whatever canse, which accelerate and intensify cardiac action, are also capahle of evoking an attark of angina pectoris. This was illustrated in the historic case of John Hunter, who was wont to say that "his life was in the hands of any rascal who chose to amnoy or tease him." As a matter of fact, Inunter died during a paroxysm brought on by a fit of silent rage in consequence of having been flatly contradicted at a meeting of the Board of Governors of St. George's Hospital, Oetober 16, 1793. His eoronary arteries were found ossified and the aorta dilated. I knew a gentleman of this city, a great sufferer from ferocious attacks of angina for many years, who frequenty declared that nothing was so barl for him as a fit of temper.

It is very remarkable how diverse are the effects of exertion in different persons, or in the sane individual at different times. I reeall the instance of a gentleman of fifty-two, who, hy the way, had been an inveterate smolier of strong IIavana eigars, and who conld not walk out of an evening without suffering from his angina. Tet on one oceasion he assisted in carrying a loaded bookcase up a flight of stairs without experieneing the slightest pain. This patient nltimately died suddenly. I have another gentleman under occasional observation who invariably experiences more or less pain of a true anginal character the first thing in the morning when he goes into the bath-room to dress. The taking of a cool bath is almost sure to evoke one of his seizures. Exeitement and exertion combined are particularly apt to call forth an attack. For this reason coitus is especially injurious to some of these patients. The influence of cold in determining a paroxysm has been referred to, and is shown by the inability of pationts to face a cold wind, particularty when damp as well as cold, and by the effect of a cold bath.

Distention of the abdominal viscera by flatus and the taking 


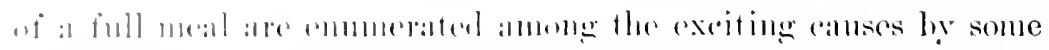

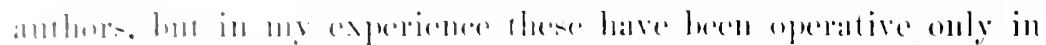

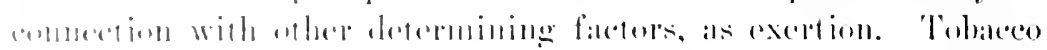

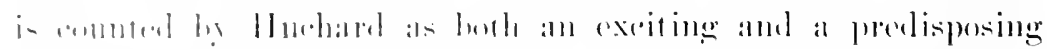

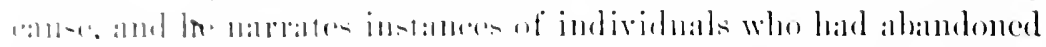

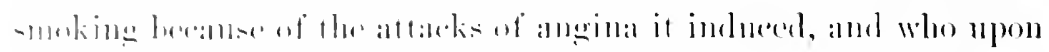

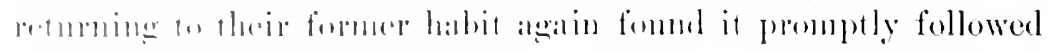

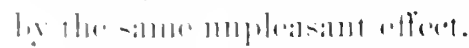

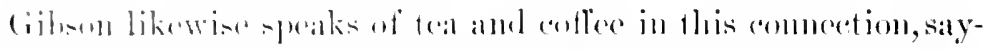

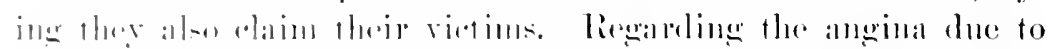

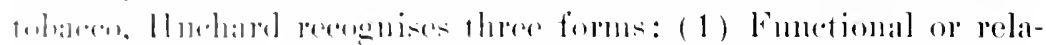

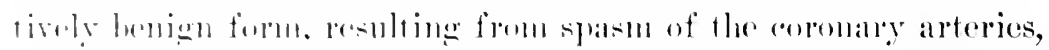

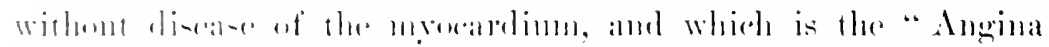

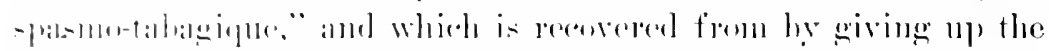

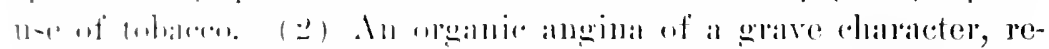

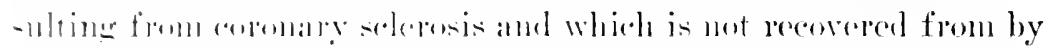
the alsimtemment of the teblacen hathit. This is the "Angina

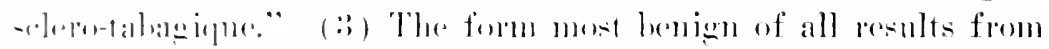

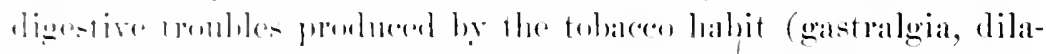
tation of the stomach, and insemsilility" of the mucons membrane). Thi- i- thr "Angina wa-tro-talagigne." Strictly speaking, these all. with the pessille axerptims of the second furm, belong to the

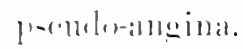

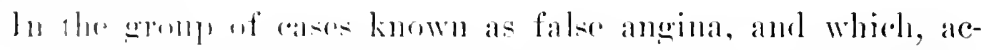

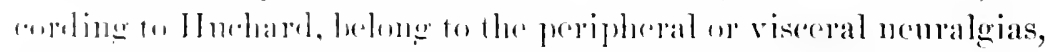
and which will le andirlered in comnertion with cardiac neuroses,

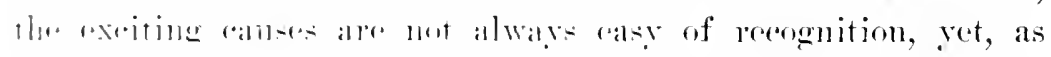

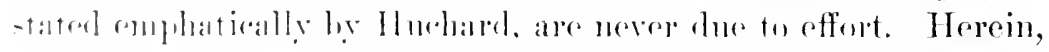

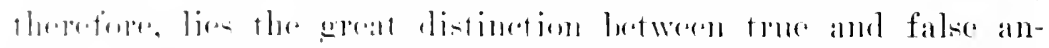

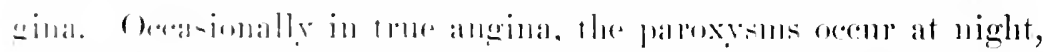

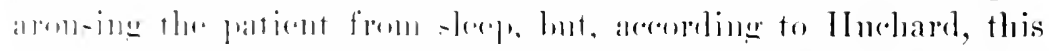

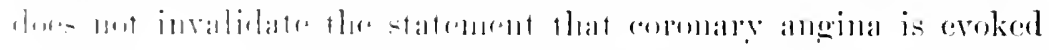

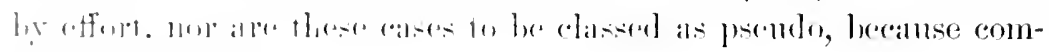
ing on its night.

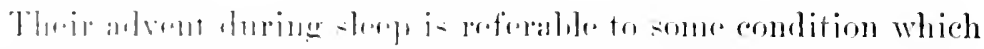

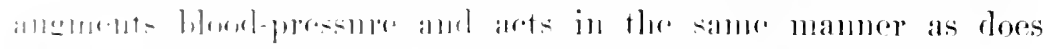

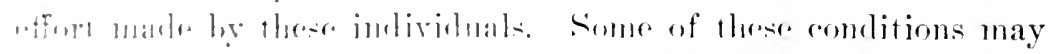

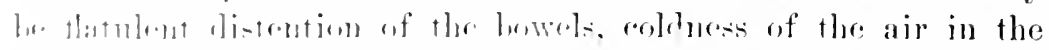

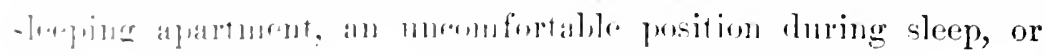


the recumbent posture itself, which is known to angmont bloodpresinure (Iluchard).

Clinical History and Features of an Attack.-The sufferer flom angina of coronary disease is most often an chlorly man of aboit sixty years of age who has been engaged in mercantile, professional, or literary pursuits rather than in manual labour, and who often presents the appearance of well-preserved health. Ile not infrequently states that prior to his first attack of angina he nevor had any symptoms that marle him think his heart was affected, and that were it not for this symptom he would still think his heart as sound as ever.

Questioned concerning the symptons for which he consults the physician, he says he has a pain in the front of the ehest, which he loeates at the upper and middle portion, frequently putting his hand over the mambrimm stemi. IIe describes this prin at coming on suddenly, usually during a walk, and becoming so intense as to compel him to stand still mitil it goes away, which it usually does in a few moments. Further inquiry hings out the fact that associated with the pain is a feeling of oplression or weight on the chest, and in sone cases a sense of impending death. The essential features of an attack, therefore, or the chatracteristic triad of symptoms, as it may be called, are (1) a substernal pain, that is nsually so severe as to be an indescribable agony, (2) a sense of great constriction of the chest, a feeling as if this were being crushed or squeezed together, and (3) a sense of speedy or impending dissolution.

The duration of a paroxysm is not long, generally not more than a few minutes, probably because the riolence of the agony necessitates a cessation of the affort oceasioning it, and with the removal of its exciting eanse the attack subsirles. Oceasionally it persists for twenty minntes or more, and when it ocrums in the mirlle of the night it is apt to last lomger than do day attacks. Thus it is seen that the pain may come on cither ly day or by night, but as a mle and particularly in mild ases it is more likely to manifest itself dming the waking hours and when the patient is exposed to some obvionsly exciting canse. Nocturnal seizures are apt to be more severe as well as of greater duration, because, according to Huchard, the rise of blood-pressure incident to the recumbent posture does not subside quickly eren after the 


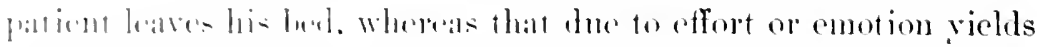

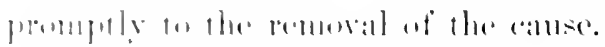

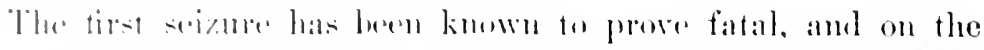

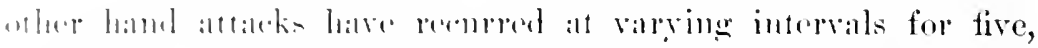

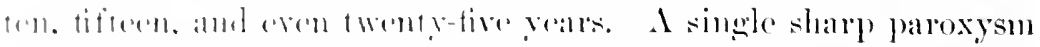

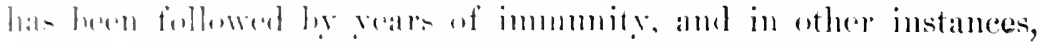

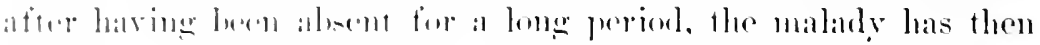

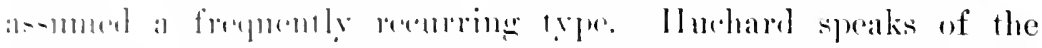

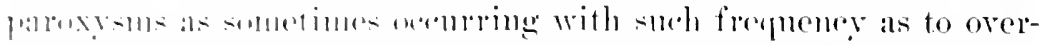

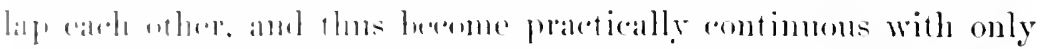

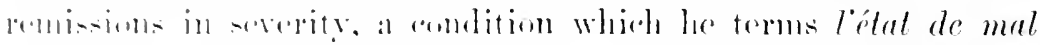

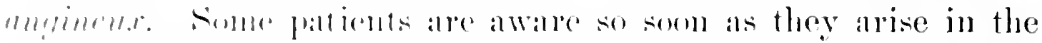

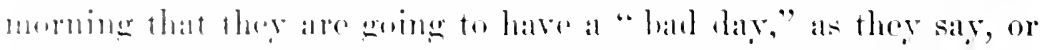
that they will have to he more than malully cautions lest they preripitan an attalek. As a rule, howorer, anginal seizures come on :H huptly whthut waming and with such agonizing intensity that the = $=1$ therer is compelled to stop in his tratels and remain standing,

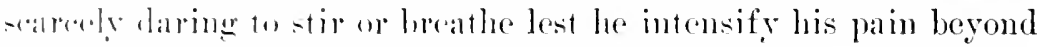

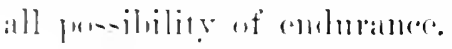

At whlere tiune he leatns against al tree or wall for support, or

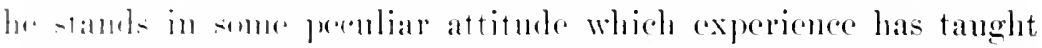
him will smowhlat mitigate the sorerity of the pain. He may

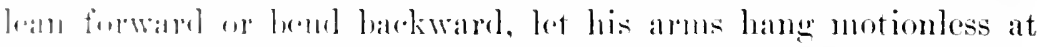

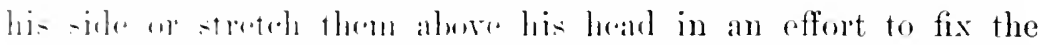

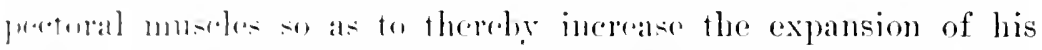

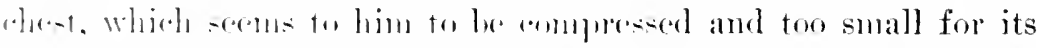
contents. lint whaterer his attitude, it is, aceording to Inechard,

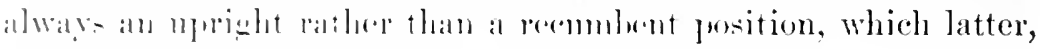

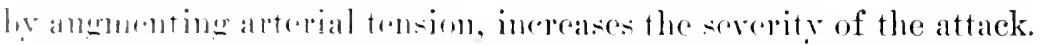

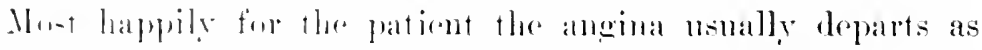

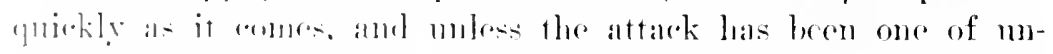

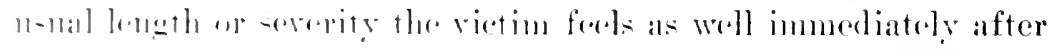

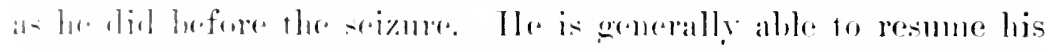
walk ald homgh perlatpe rather more cantionsly than before. Such

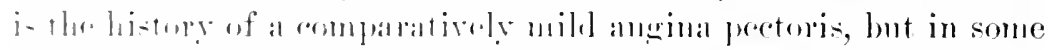

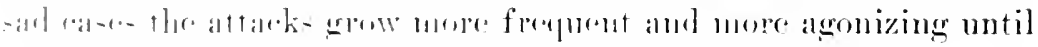

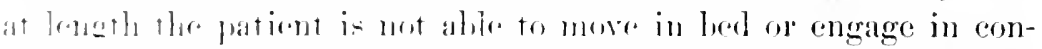
r.rentim withont frightful :uffering, and life becomes a miserable axi-norim. 
It now becomes necessary to (onsterler the featumes of anginal attacks in detail. It has loen stated that the pain is substernal; that is, that its seal of maximmm intensity or its point of departure is bemeath the mpere or middle thind of the breastbone. It is for this reason that bammes applied to the complatint the name of sternalgia. The pain may remain centred bencath the sternum, but in most instances it radiates into the side of the thorax and along the course of the brachial plexus into the left shoulder or down the corresponding arn to the elbow or still farther, as far as the wrist, or even into the two fingers supplied by the ulnar nerve. In some cases the pain takes origin in the region of the apex-beat or epigastrium, or, as in the ease of one of ny patients, just above the ensiform appendix, whence it shoots into the left shoulder and clown the left arm.

In rare instaness the attack starts in the arm, at the wrist or elbow, and thence passes into the chest to the region of the heart. In one of Troussean's patients the paroxysu began in the back of the neck, and then darted forward into the tongue and front of the thorax. Very exreptionally the pain may take origin in the left interseapular region or at the arljacent dorsal spines. But whatever is its point of departure the anguish radiates nore or less widely throughout the chest, flashing from the cardiac area into the left, sometimes the right arm, and in some cases into both arms, or upwarl into the side of the neck or the oceiput, or, instead, downard into the left half of the abdomen, and now and then even to the thigh. These latter lines of radiation are, however, very uncommon as emmpared with its comrse into the left shoulder and arm.

Very diverse terms are employed by patients in attempts to deseribe their agony. It is spoken of as erushing, grinding, tearing, cutting, burning, scalding, or, in want of appropriate adjectives, as indescribable, frightful, and the like. One of my patients, a lady with extreme aortic stenosis, depicted her anguish as "a feeling as if my chest were being emshed bencath the wheels of a passing train."

The sensation of pain is sometimes lost in the terrible distress occasioned liv the sensation of the ehest heing squeezed in a rise, or of the walls being foreed together from before backward. 


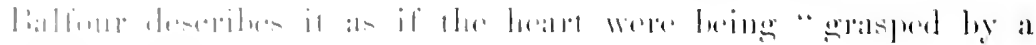

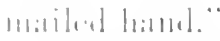

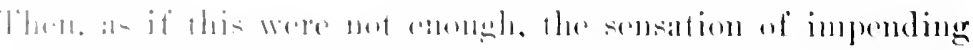

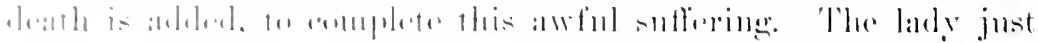

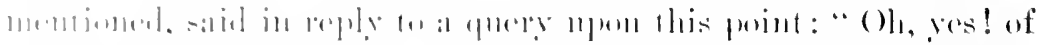

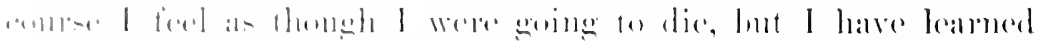

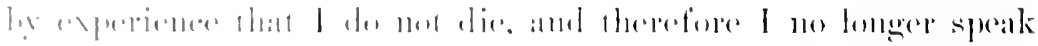

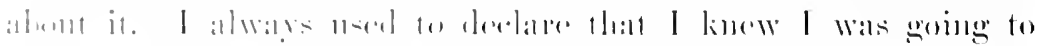

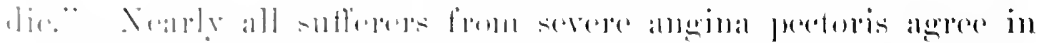

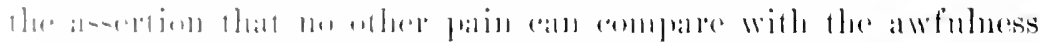

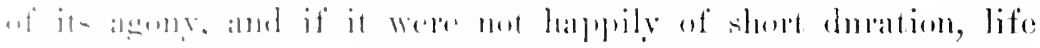

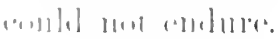

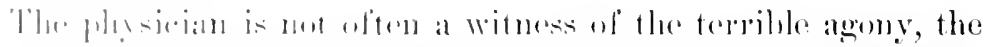

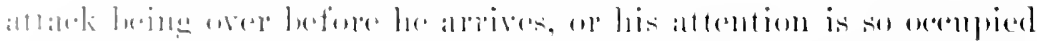

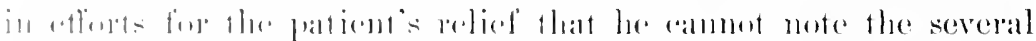

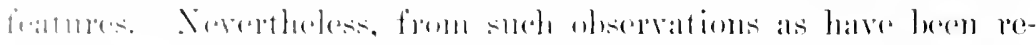

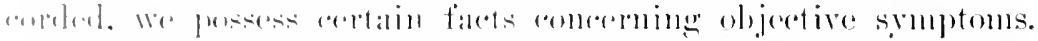

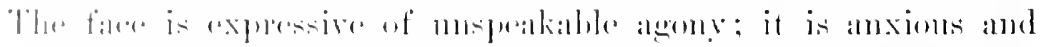

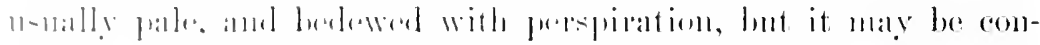

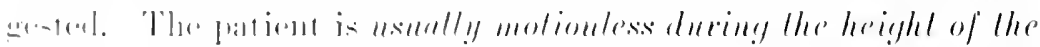

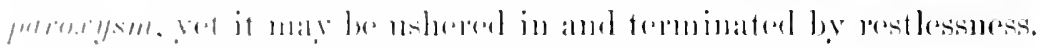

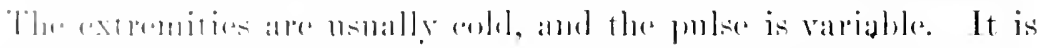

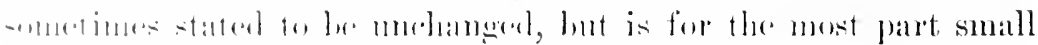
:1111] $11 \cdot 11-1 \cdot$.

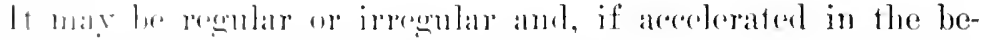

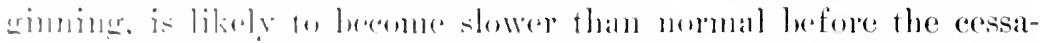
tion of the fain. The size and rate of the pulse have given rise

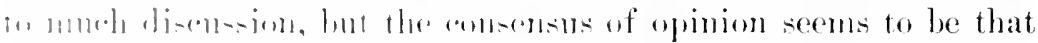
it i- -mall, flatring in the ammlition of susm, and that its rate is

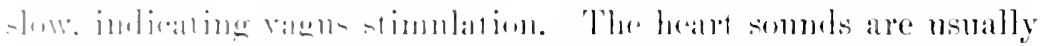

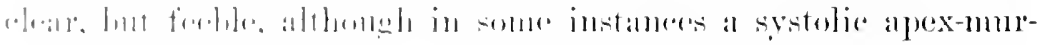

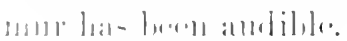

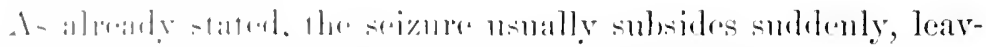
ing mothing more than a foreling of weakness behind. The pain in

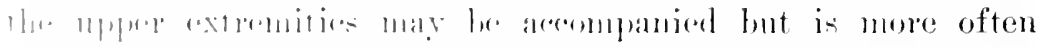

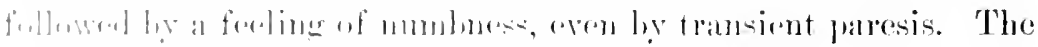

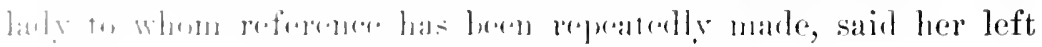

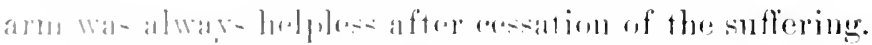

In the an of my aned fomale pationt, alrealy montioned as 
having arterioselerosis, the face wats thushed during the attank, and the cessation of pain was followed by voniting. I have stated. that patients remain motionless during the paroxysus, yet I have known two instances, both men, who thonght they obtaincel some relief by walking gently about the room while the pain wats on. One of them was a well-known attorney, in whom the necropsy verified the diagnosis of coronary sclerosis and fatty degeneration of the left ventricle. In the other alse the age of the patient, the thickened peripheral arteries, and the history of the attacks, left no doubt as to the nature of his angina. Jonglats Powell states that when relief is produced by quiet walking it has seemed to him to indicate a fairly sound state of the heart-musele. This may be so in some but not all cases. Mr. II., the attorney, was found to have extensive myocardial degeneration, and henee seme other explanation is needed in his case. In my ofleer pattient, the gentleman was not only able to endure without pain certain gymnastic and breathing exercises which produced great perspiration, but he declared that he felt better for them. That they did not eall forth his suffering the same as did walking against a wind, may have been the to the lowering of arterial tension whieh they indneed.

The extremely rariable course of the malady and its not infrequent termination in death during an attack are also noteworthy features. In historic instanee is that of the Rer. Dr. Chalmes, who is thought to have died during a paroxysm of angina, since he was found dead in his bed with a bowl beside him into which he had emptied the eontents of his stomael. I knew a similar instance of an old gentleman who, after having suffered attacks of angina pectoris for twenty years, was found lifeless in his bed in a hotel with a wash-bowl resting on the bed in front of him and containing romited matter. I knew of another elderly gentleman who, while in attendance upon a lawn fîte, was seized with a paroxysm of prireordial pain, romited, and inmediately died before assistance conld reach lim. So far as eonlel be ascertained, it was his first and only attack.

Before lecaring this subject, it should be nentioned that Gairdner has deseribed what he calls angina sine dolore. What he means by the term is best deseribed in his own words: "Apart from what has been varionsly termed cardiac asthma, dyspnoea, 


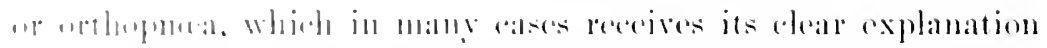

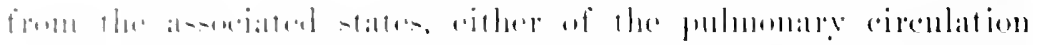

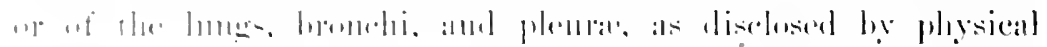

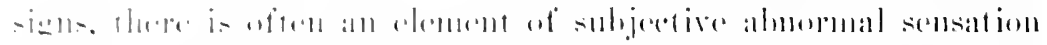

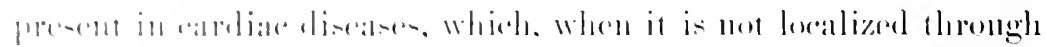

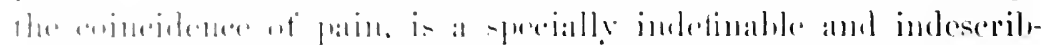

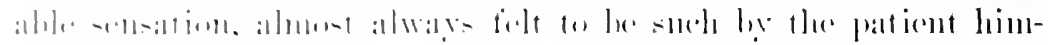

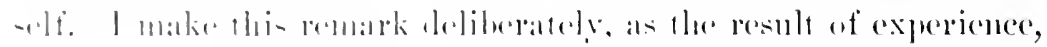

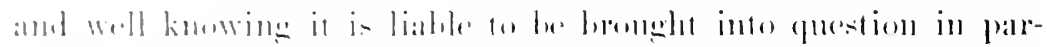

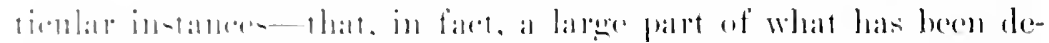

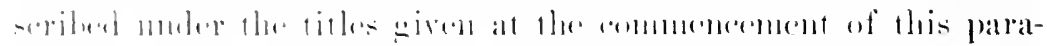

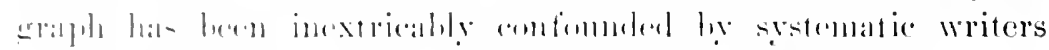

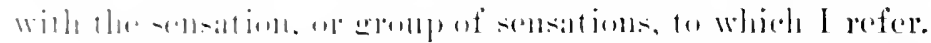

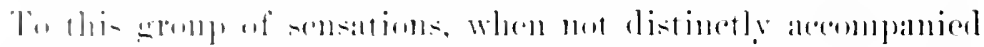

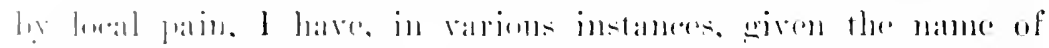

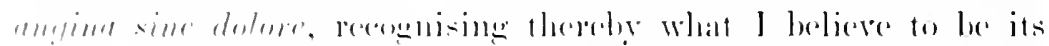

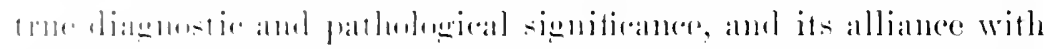

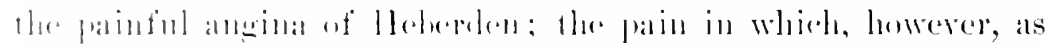
we halme almanly 1)...1.... anl1 in kiml."

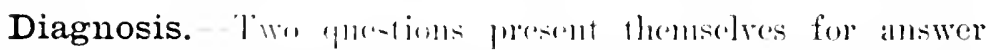

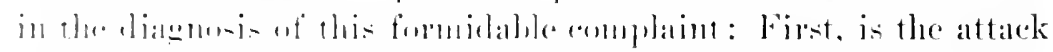

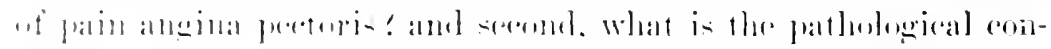

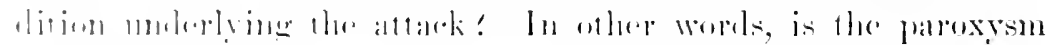

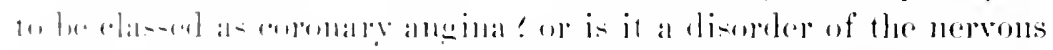

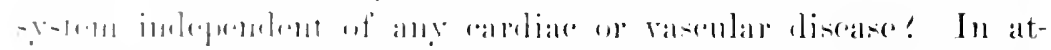

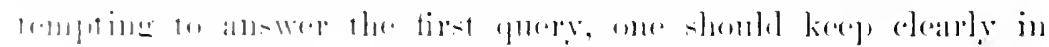

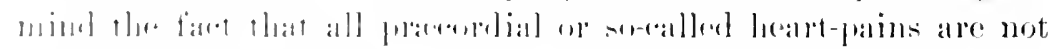

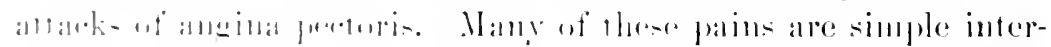

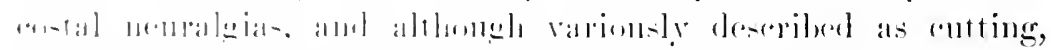

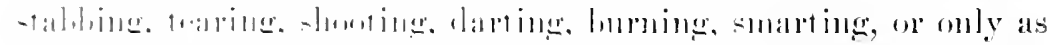

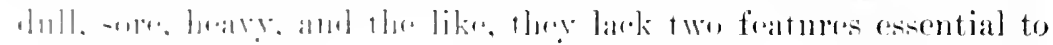

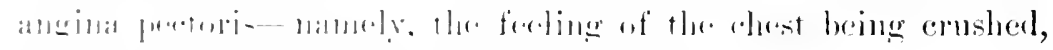

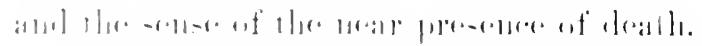

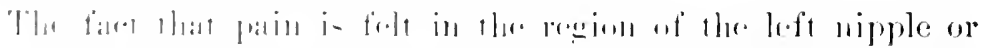

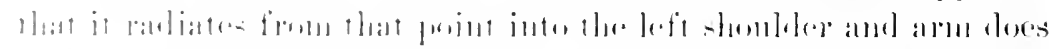

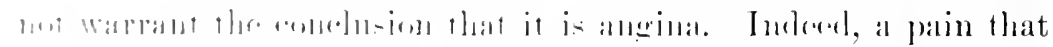

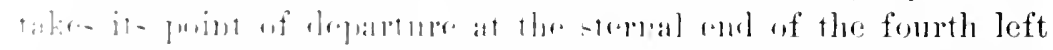
intr-pares on in the tifll left intersyace below the breast, whatever 
be its direction of radiation, is more likely to be an intercostal neuralgia, since the agonizing suffering meriting the name angina pectoris is most trequently substernal. Moreover, in cases of intercostal neuralgia there are usially well-defined tender spots corresponding to the points of origin of the pain. Another characteristic of these intereostal neuralgias is their coming like a sudden stab or thrust, and then leaving as quickly, the points where they appeared being sore to the touch. When, as in some instances, the pain is permanent or is continnous, with exacerbations and remissions, the very length of the attack stamps it as intercostal neuralgia and not angina pectoris.

Moreover, these pains are most frequently met with in ancmie, nenrasthenie, or otherwise neurotic individuals, or such as present symptoms of gastric disorder, and althongh by no means limited to the female sex, they are nore frequent in women than in men, and generally in such as have not yet reached the age at which vascular degenerations are to be expeeted. In nost eases attention to the points just mentioned enables one to readily differentiate intercostal neuralgias from the true heart-pain of angina. It is far otherwise, however, with those attacks of precordial pain which display the features of true angina pectoris, yet which in reality do not belong to that dass.

In other words, is it Ifeberden's angina with its possibility of sudden death! or is the pain a pseudo-angina, and hence not of the same serions inport? The answer to these queries is to be found in the consicteration of the following points: (1) the age and sex of the individual, (2) the state of the arteries and heart, (3) the influence of effort in evoking a paroxysm.

Attacks of praceordial pain that oecur in young persons, no matter how elosely they resemble coronary angina, are prestimably symptomatic of irritation in some other organ than the heart, and if such attacks are in women the presumption is the stronger that they are false angina. If, on the contrary, they occur at an age when vascular degeneration is conmon, they are much more likely to be of the grave kind, even though they oceur in fenales.

The detection of stiff arteries or of signs of heart-disease is in favour of true angina, and yet pain of viseeral disturbance may oecur in women past forty with hypertrophied hearts, particularly at the menopanse or in such as have suffered all their life from 


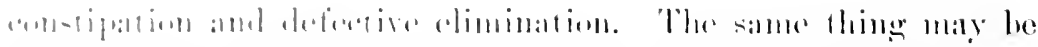

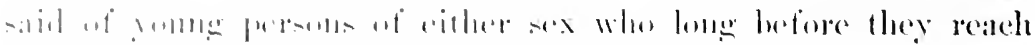

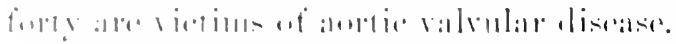

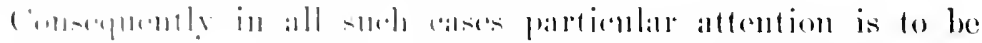

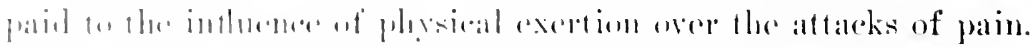

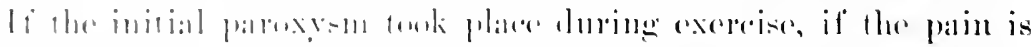

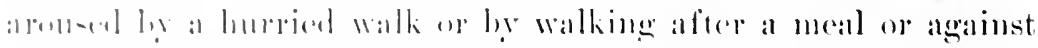

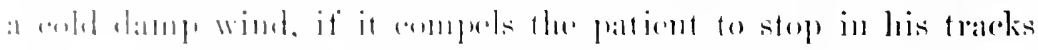

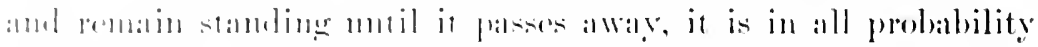

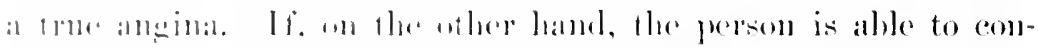

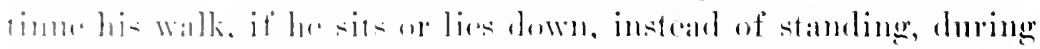

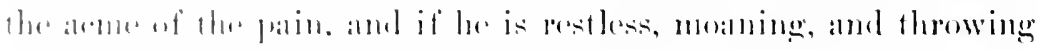

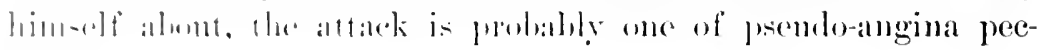
minis.

In earse of a mixed nature deseribed by IInchard, in which

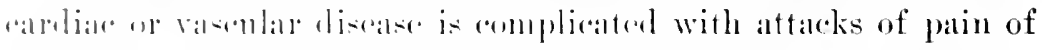

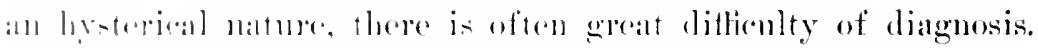

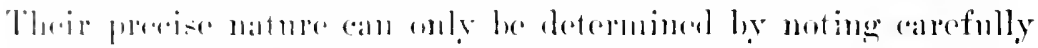
the inthenen of effort in poweking the seizunes and hy the discov-

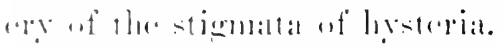

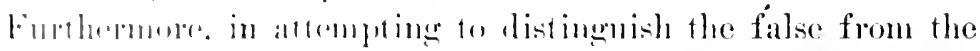

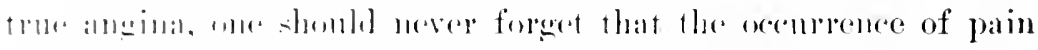

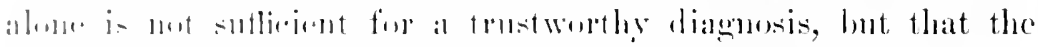

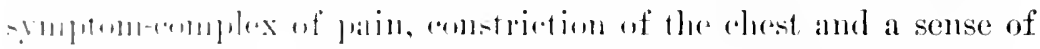

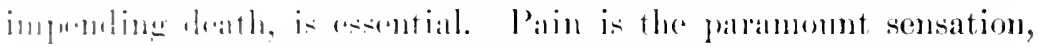

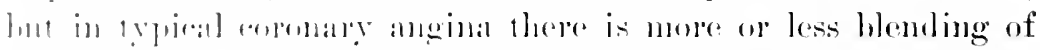

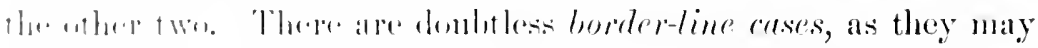

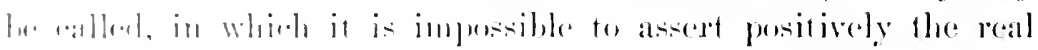

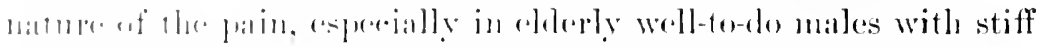

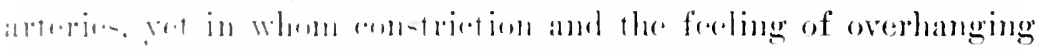

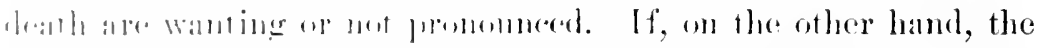

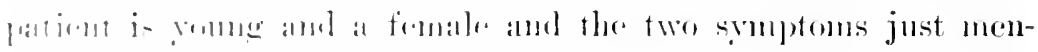

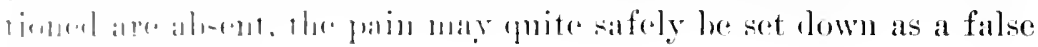
illenillit pentriti:

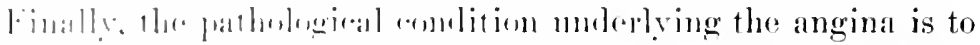

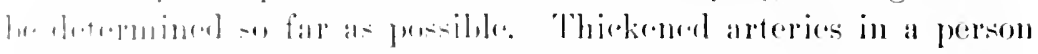

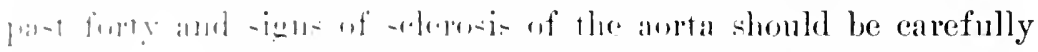

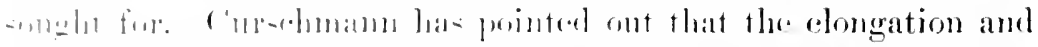

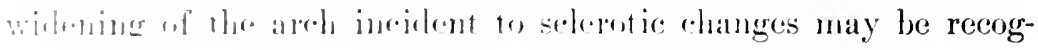


nised by careful study of the cervical arteries. In the fossa jugnlanis, particularly during the ale of swallowing, may le seen, or, still better, felt the pulsation of the transicese portion of the aorta, while the pulsation of the subelarians is situated abmormally high and the calrotids areh unmaturally forward and feel stiff and perhaps slightly irregular. There may he slight dulness at right of the stermum, appreciable only upon decp percussion, and the second aortie tone is sharp and ringing. The detection of such signs would surongly support the conclusion that the angina was due to coronary degeneration, and was therefore nost gralse.

Musser has reported a series of cases in which there was typical anginal seizmres so long as the left ventricle was hypertrophied, ret in which with supervention of dilatation the attacks of pain disappeared. These observations have led Musser to conclude that in some cases angina pectoris is dne to increased intracardiac bood-pressure. In all such instances the exact nature of the underlying condition camot be made with certainty, and one must content himself with the diagnosis of the angina and of the cardiac comdition withont attempting to do more than speculate on the connection between the two.

Prognosis. - Is hats been repeatedly stated, there is always a possibility, and, according to IInchard, a strong probability of sudden death in a paroxym of angina pectoris. Even if the patient does not sncemmb during an attack, the complaint is incurable. He should be advised, therefore, concerning the gravity of his affection, and his immediate family should be warned of the likelihood of a fatal termination. IIow long a patient is likely to live, subject to these attacks, is a matter of too great uncertainty for an expression of opinion by a prudent physician. It is always well to reassure the sufferer, however, by the statement that patients have been known to experience the symptom for a long term of years, and that its severity and the frecunener of its occurrence are likely to be modified by appropriate medical treatment and by the care exercised by the patient.

Other things being equal, it may be said that the more severe the attacks the greater the danger of death. Mlso, the more easily the paroxyms are eroked, the more extensive is the coronary obstruction, and the graver the complaint. Increasing frequency of 


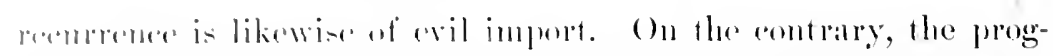

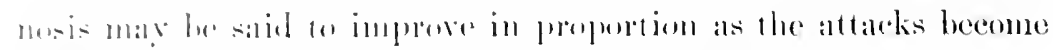

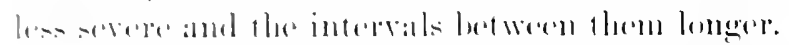

Anerding a l'owells assmuption, previonsly mentioned, the

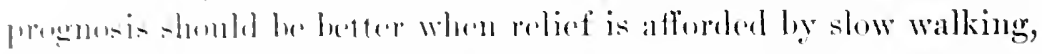

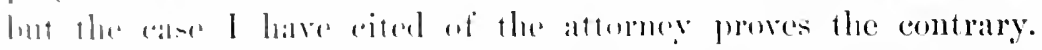

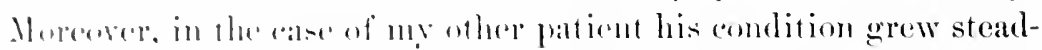
ily worece in spite of his abiligy to omdere the exereises to which

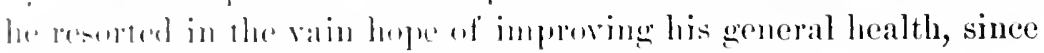

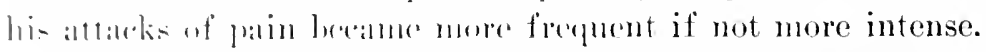

Treatment.- This includrs, tirst, measures addressed to the

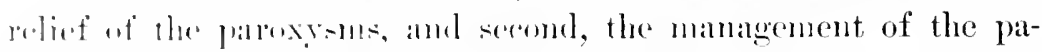
tiont - daily life during the intervals between the seizures, with a

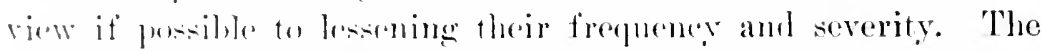
treaturent of the attarks hats already been considered in the ehap-

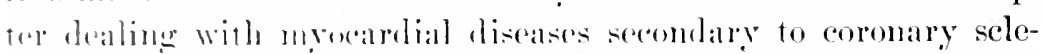

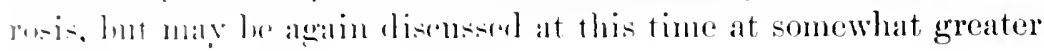
longhts.

Vay many aml divors remedies have lieen used either solely foredien the pain, w to strengthen and regulate the heart's action,

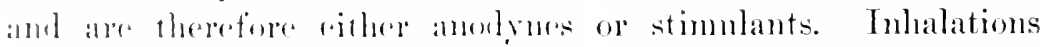

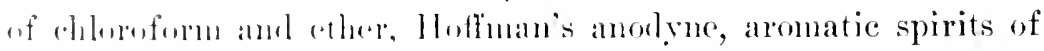
almumbia, opiates, rambinative dranghts, such were the measures

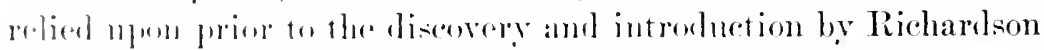
and lamber bimlon of nitritre of anyl. Two merlicaments which in the experienee of the junfesion the world over have proved of the higher value in anteolling the attaleks of angina pectoris,

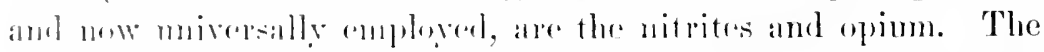

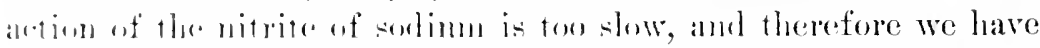

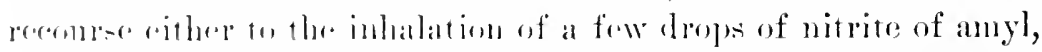

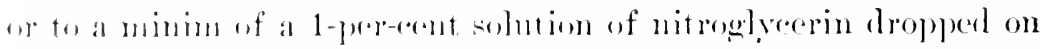

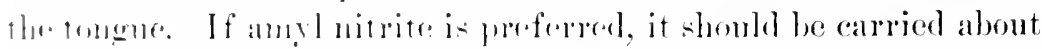
ly the pationt in the forme of nitritr-of-amyl poarls, containing

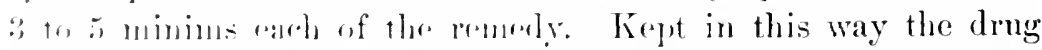

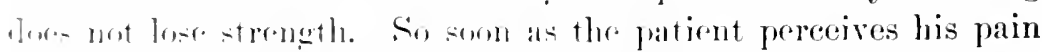

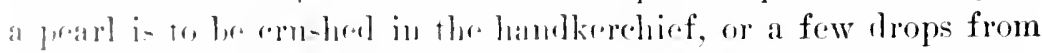
a vial may he lomerel throresu and the fumes inhaled, or the sufforer may herathe thron dieretly from the vial. The action of

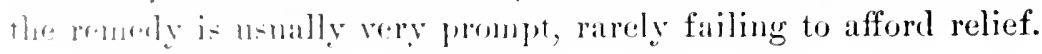


There is usually no danger attending its use; at the most, only a dull headache is prodnced. If nitroglycerin be preferred, it is most conveniently and usually administered in the form of a tablet triturate containing 1 minim of a 1 -per-ent solution. If the tablet is dissolved on the tongue instead of being swallowed, its effect is more promptly induced. This is especially the ease if the oceasion for its use is soon after the taking of food. The remedy can also be clropped on the tongue or taken in a swallow of water when the solution is preferred, but this method is not only less convenient, but it necessitates the loss of valuable time, when seconds of agony seem like hours to the sufferer.

Abatement or eessation of the attack generally takes place in a few seeonds; but shonld this not be the ease a seeond or even a third tablet may be employed at intervals of two or three minutes. Special indications for one or another of these remedies are found in pallor of the eountenance and a small and tense pulse, whether slow or accelerated, regular or irregular, and internittent or not, and in other signs of arterial spasm. The nitrites are essentially raso-dilators, and stimulate the heart only indirectly through their dilating influence on the arterioles. Through their aetion, the wiry, and it may be slow, pulse grows softer, fuller, and more rapid, while at the same time there may be felt some constriction of the throat and tense or throbbing headache, symptoms which to the patient are of small moment in comparison with the relief from his frightful agony.

It has generally leen my ohservation that in elderly individuals with sclerosis of the temporal, and presumably therefore of the cerebral arteries, the head symptoms occasioned by the nitrites are far less pronounced than in yonnger persons whose ressels are less stiff, and hence more responsive to the action of the drug. When phenomena of rascular spasm are absent or when relief does not promptly follow the use of the nitrites, recourse would better be had to opium in some form. A method of administration that vields speedy results is indicated, and therefore it is best to give morphine hypodermically and in a dose that will suffice without repetition-c.g., $\frac{1}{4}$ or even $\frac{1}{2}$ of a grain.

v The lady to whom reference has been repeatedly made was compelled to resort to both nitroglycerin and morphine, and in addition frequently took a teaspoonful of sulphurie ether in sweet- 


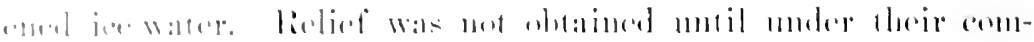

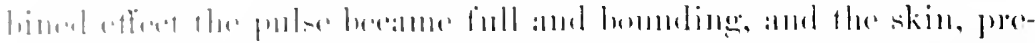

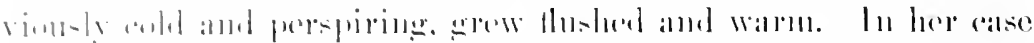

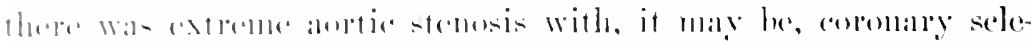

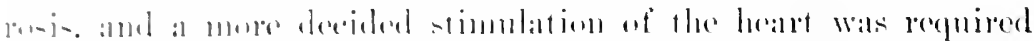

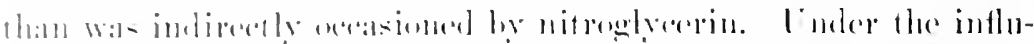

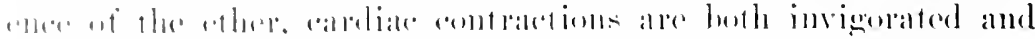

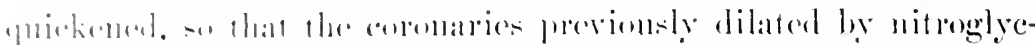

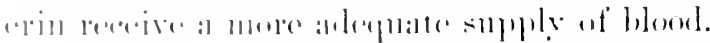

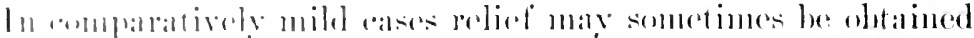

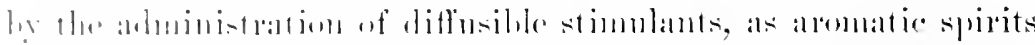

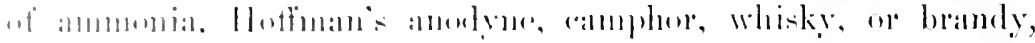

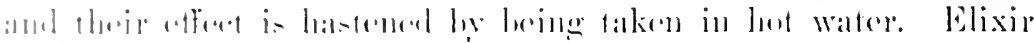

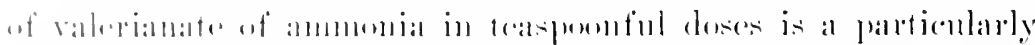

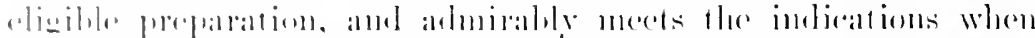

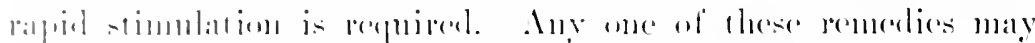

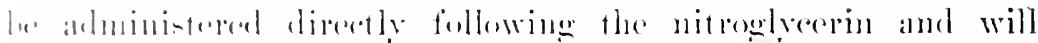

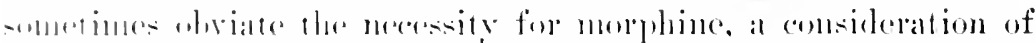
-mone impurtanere in chlerly imlividuals who, as well known, are

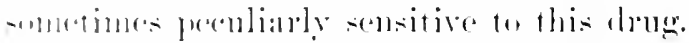

In mortmrnal attarks, which alre alpt to be severe and polomed,

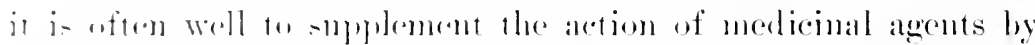

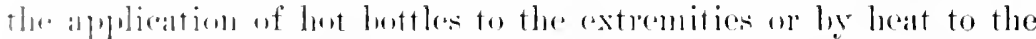

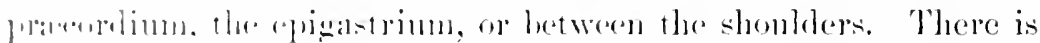

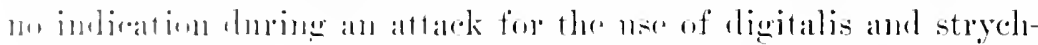

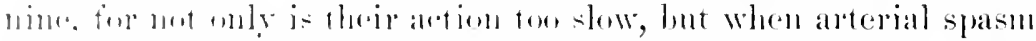

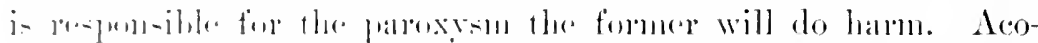

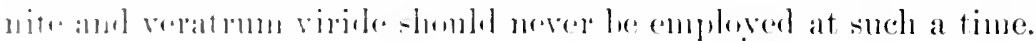

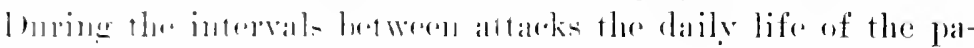

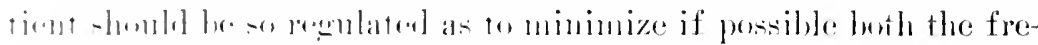

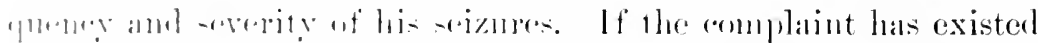

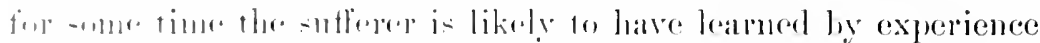

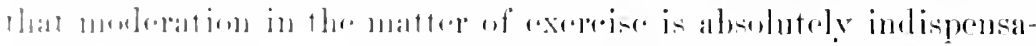

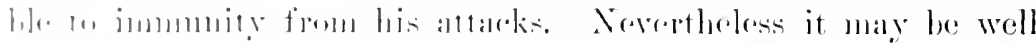

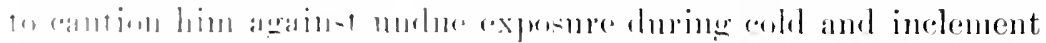

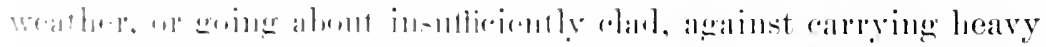

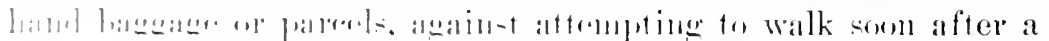

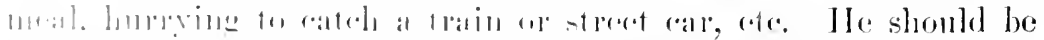

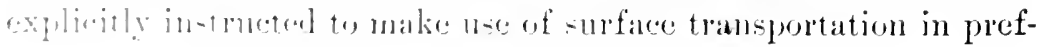


renere to elevated roarls, which have to be reached by long flights of stairs, sinee the inclination to hasten up the last few steps as the train is hearlappoaching is almest irresistible, and such a spurt may precipitate an attack. Patients shomlel also be instrueted concerning the harmfulness of immorlerate coitus, fits of passion, orereating, the too free indulgence in tobaceo and aleoholic stimmlants, of becoming excessively fatigned, etc.

The hands and feet should be kept wamly covered, and it is often well for these patients to wear a chest-protector both front and back. Those who can afford to pass the inclement seasons in a warm, equable clinute should be adrised to do so, since they can there take outdoor exereise withont fear of encountering cold wints and of contraeting attacks of bronchitis.

Sufferers from coronary angina have habitually high and sustained arterial tension, and as it is sudden and nnexpected angmentation of this tension which often precipitates a paroxysm, it is essential that their blood-pressure be lowered. This ean usually be accomplished, in a measmre at least, by revision of the dietary -that is, by the restriction, or in some instances ly the exclusion, of meats and the substitution of a largely regetable dietary.

Rumpf, of Hamburg, interdicts the nse of foods rich in limesalts, as eggs, milk, cheese, spinach, ete. Theoretically, such a restriction is called for when there is arterioselerosis, but practically, it will be found diffieult to adecuately nourish the patient if all foods rich in plosphates as well as meats are excluded. Furthermore, a too restricted dietarr grows monotonous and leads to anorexia and feeble digestion.

The principles laid down for the dietary of cases of myocar. dial degeneration are equally applicable to these patients, and therefore the reader is referred to that chapter for details. Should arterial tension be not sufficiently reduced by regulation of the diet, then attempts must be made to aecomplish this in other ways. To this end appropriate doses of nitroglyeerin nay he given every two or three hours during the day, or moderate doses of an iodide salt, three times daily, may accomplish the result. 'That snch is the effect of iodine intemally is generally held, and yet Rombere asscrts that both clinical olservation and experiment show this not to be the case. In some eases it may not be necessary to give nitroglycerin daily, but only on those days when the patient finds 


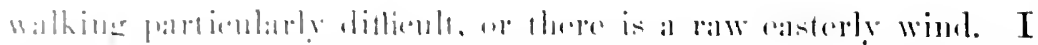

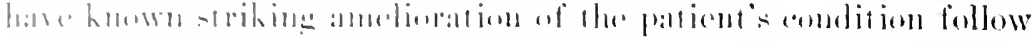

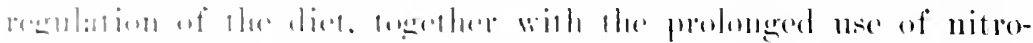

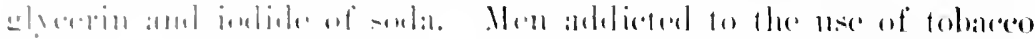

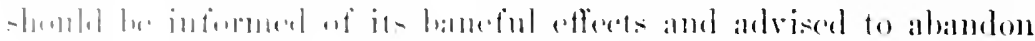

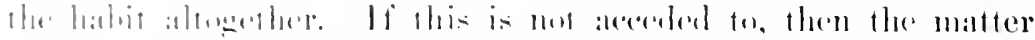

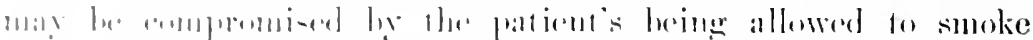

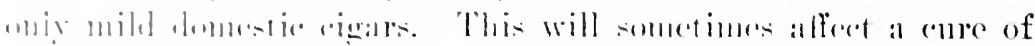

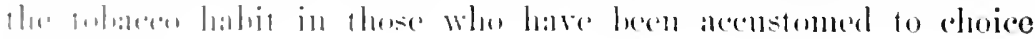
$11: 11: 11: 1-$

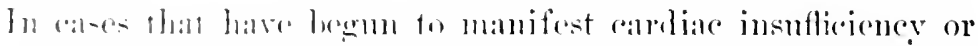

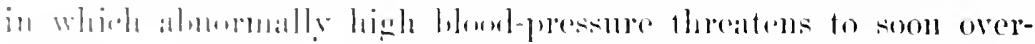

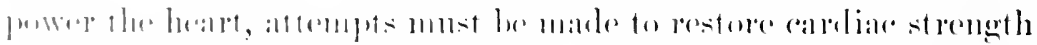

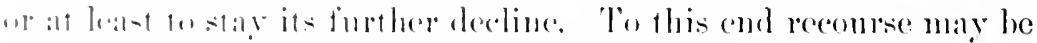

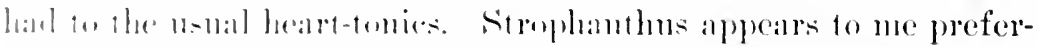

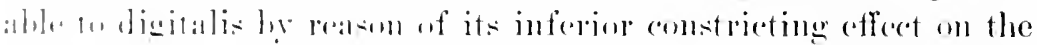

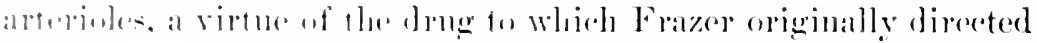

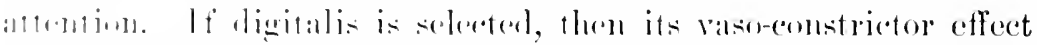

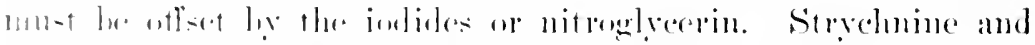

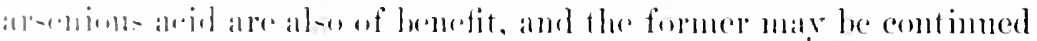

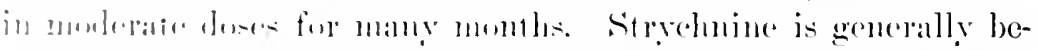

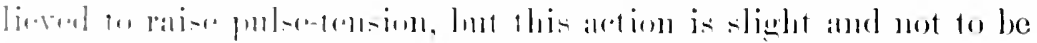

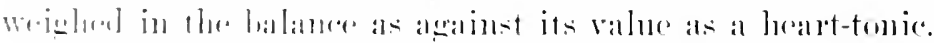

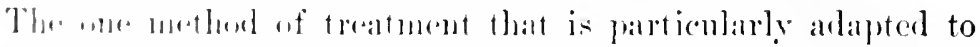

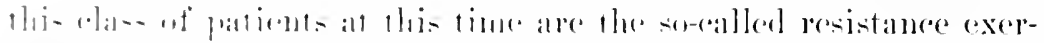

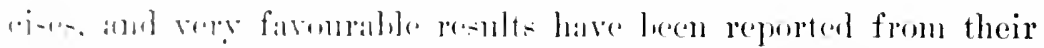

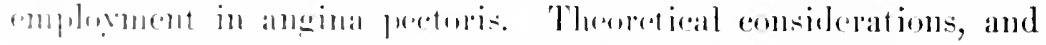

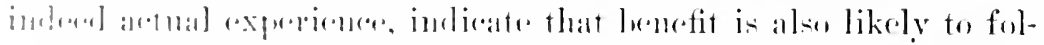

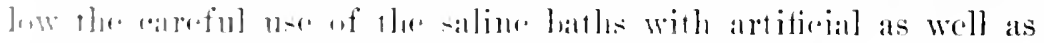

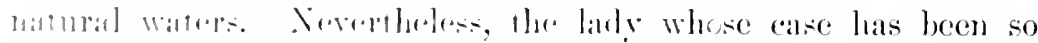

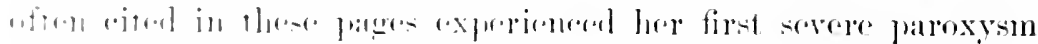

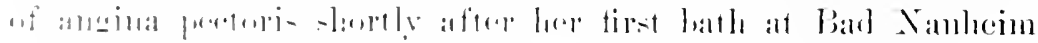

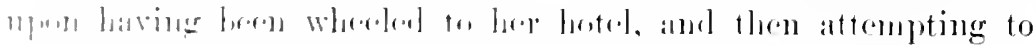

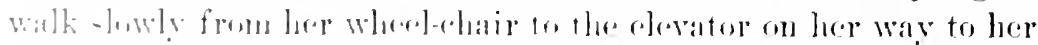

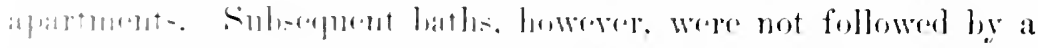

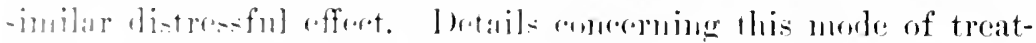

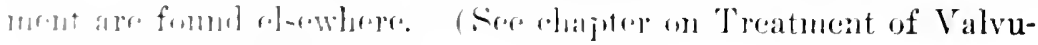
latr lowate in (jencral.) 


\section{CHAPTER XXYI}

\section{SYPHILIS OF THE MYOCARDIUM-NEW GROWTHS IN THE MYOCARDIUM - ATROPHY OF THE HEART -SEGMENTATION AND FRAGMENTATION OF THE MYOCARDIUM}

\section{SYPHILIS OF THE MYOCARDIUN}

Morbid Anatomy.-The most common myoeardial manifestation of syphilitic infection consists in fatty degeneration of the cardiac muscle. This is not different in any way from fatty degeneration from other canses, and so is not recognisable except in the presence of other evidences of the disease. Associated with the arterioselerosis of syphilis is a diffuse interstitial mroearditis, which is also nsually classed as a luetic lesion. It seems probable, howerer, that in many cases the induration is dne to the presence of the arterial discase, rather than to the direct action of the syphilitic poison.

Gumma of the heart is very rare, and especially so in the congenital form of the affection. The part of the heart most commonly affected is the wall of the left ventricle. The gummata appear as soft grayish masses surrounded by hyperplastic fibrous tissue, or if older, as dry eascous areas of a yellowish white colour. Very rarely a softening gumma may rupture into one of the cavities of the heart.

Etiology.- Syphilis attacks the myocardium only in the tertiary period of the disease, and after a lapse of five or ten years or longer following the initial sore. It is not eonfined to either sex, but appears to have been rather more frequently discovered in males. As regards age, it may be said to be more frequent at or after middle life, rarely in childhood for the reason that the disease is generally acquired, not eongenital. 


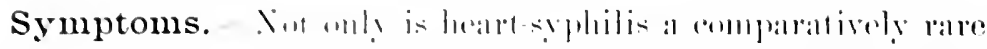

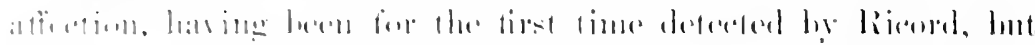

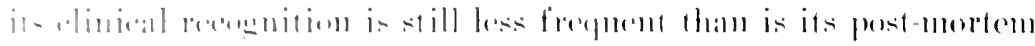

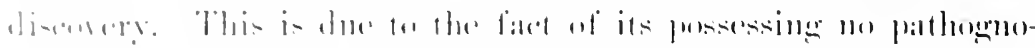

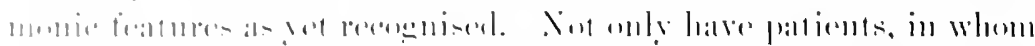

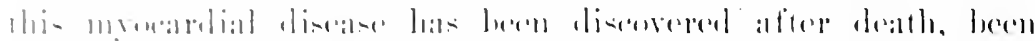

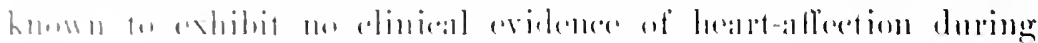

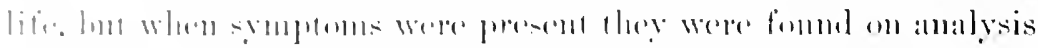

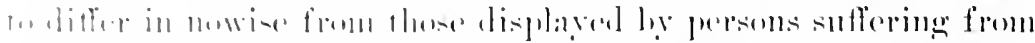

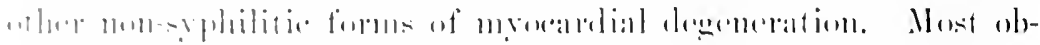

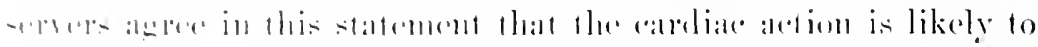

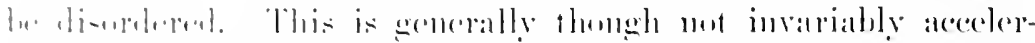

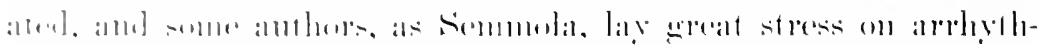
mia linen moned in an indereribille praneoldial distress which may or

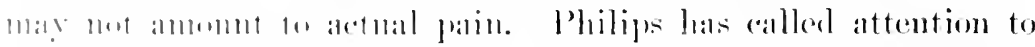

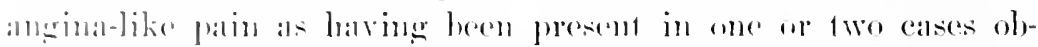

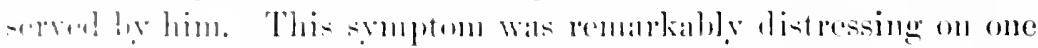

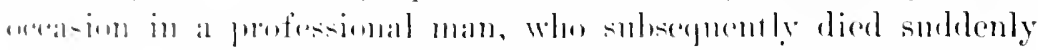

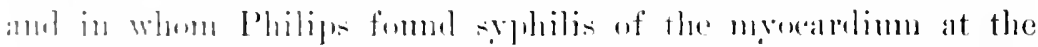

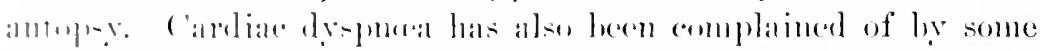

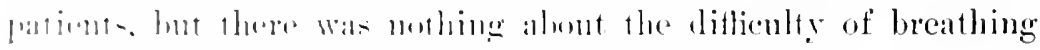
that wat: in anywion perolliar.

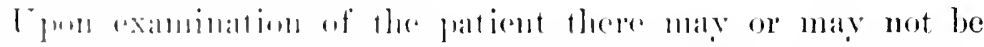

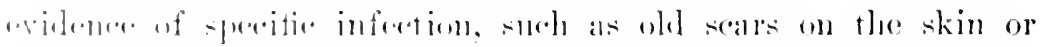

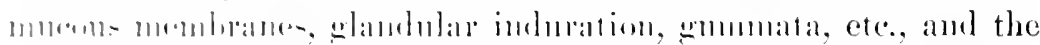

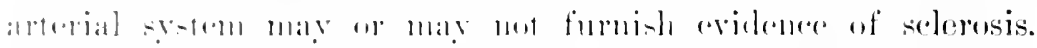

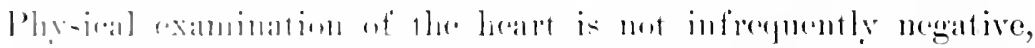

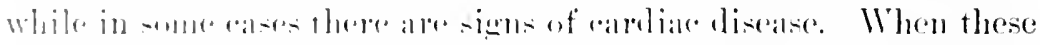

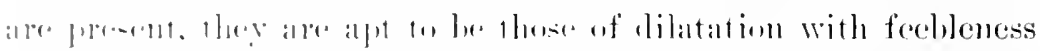

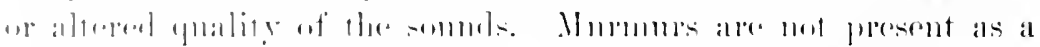

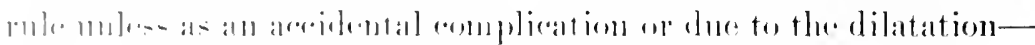

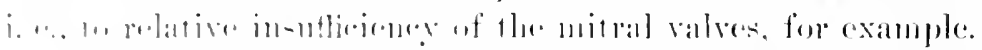

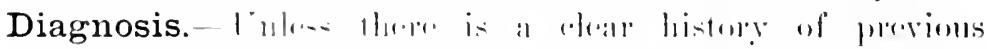

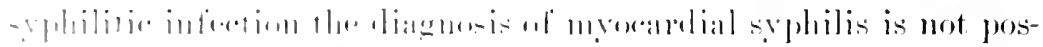

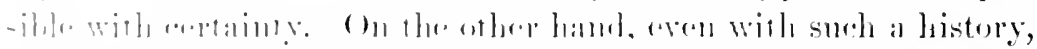

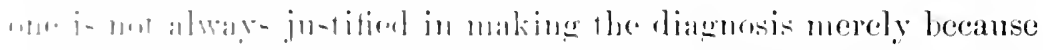

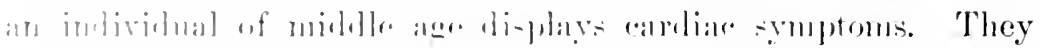

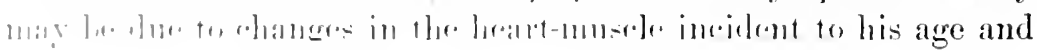


not at all to syphilis. It one camnot discover syphilides of one sort or another, he should grive the patient the benetit of the doubt until the futility of all other modes of treatment has been proved. The association of srmptoms and signs of myocardial disease with a history and with clearly demonstrable lesions of the specific infection renders the existence of syphilis of the heart-wall very probable. If the cardiac manifestations ocen in an individual not yet fifty years of age the supposition is greatly strengthened. Very often the diagnosis will have to be deferred until the results of specific treatment have been ascertained. Except by men of wide experience in this particular line of diseases the diagnosis of this cardiac affection must necessarily be a matter of guesswork in most instances. The clinical obscurity enveloping this affection is shown by the relative frequency with which it is found at the autopsy as compared with its intra vitam recognition.

Prognosis. - This may be said to be good prorided the disease is recognised in time to institute proper treatment. In undiagnosed cases the prognosis is barl, since they are likely to terminate fatally. Death is apt to be sudden and mexpected. I know of no statistics going to show how long may be the duration of the disease, but it is probably a rery chronic affection, having existed years, it may be, before the coming on of cardiac symptoms. The rapidity with which death is likely to follow the development of symptoms is likewise a matter of individual difference depending on the extent of the myocardial change, which is itself a matter we cannot obtain definite knowledge of during life. If the heart be extensively dilated, its action greatly disturbed, and the patient's symptoms pronounced, the prognosis is grave, and even specific treatment is not likely to do more than effect a partial recovery.

Treatment.- This, it needs hardly be stated, is the employment of iodides, with or without mercurials, as the physician determines. Being a tertiary manifestation, reliance is to be placed chiefly on the iodides. Ordinarily other remedies of the class of cardiac tonies are not necessary. But here again the nedical adviser must decide. Their emplorment is symptomatic, and digitalis in conjunction with the specific medication may be of service in cases in which the action of the heart is much deranged and the patient's distress from dyspnoea is considerable. What has 


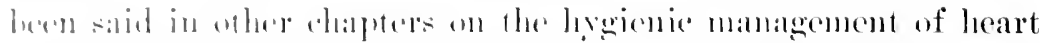

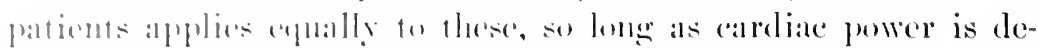
tiliente.

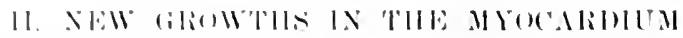

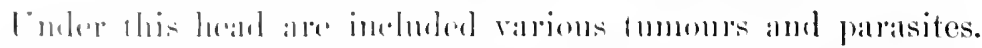

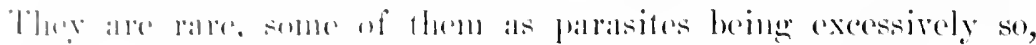

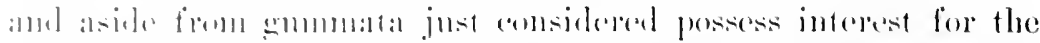

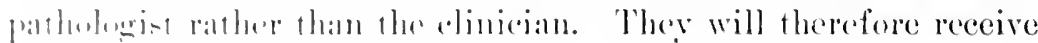
mly brief memion in his work.

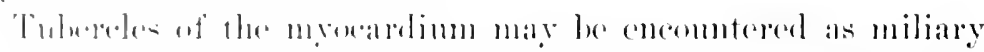

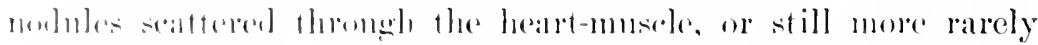

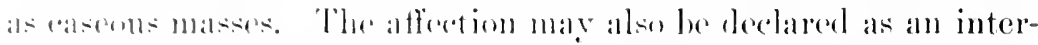
sitial mancanditis, which, howerer, possesises no distinctive feamile's.

Pallateites and arts in this sination are still nore infrequent

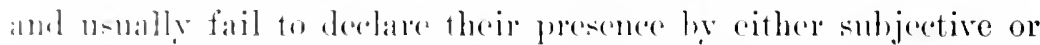

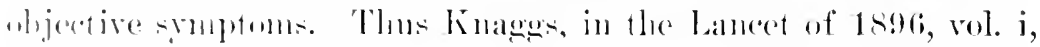
1. 20:1, nalrates the instance of a man who died suddenly, and

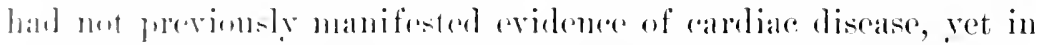
the wall of where left ventricle a liydatid eqst was found at the meneres.

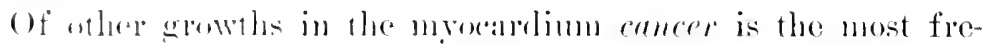

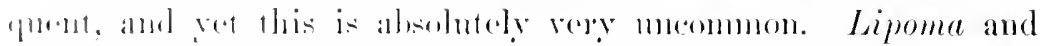

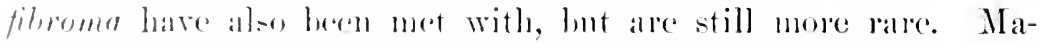

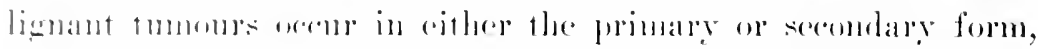

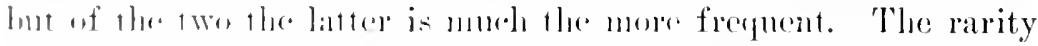

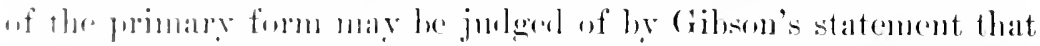

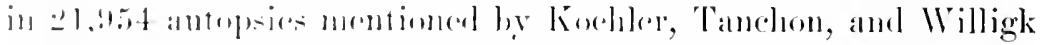
flepe were mly 21 instances of hearteancer, while Petit fomd but 7 in the literature.

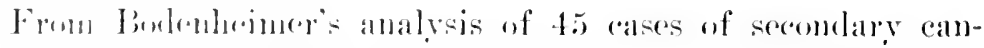

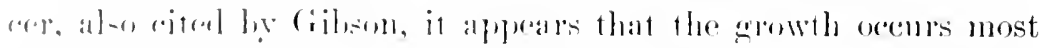

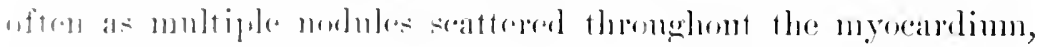

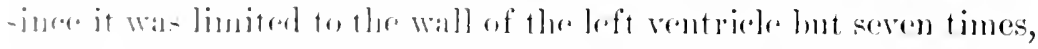
wo that of the right restrielo. three times, and to the right anricle

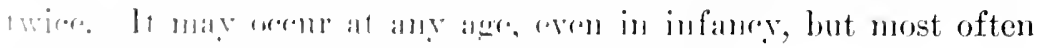
affere forty-five, and is more freplument in males.

The animal mante-tations of myorardial cancer are too in- 
definite and uneertain to permit an intra-vitum diagnosis. The heart may be irregular and feeble in action, may furnish perenssion evidence of dilatation, but in such findings there is nothing to distinguish these from ordinary cases of myocardial degeneration.

The prognosis is unfarourable, and yet for the most part life is destroyed in secondary cases by the original disease. In primary heart-eancer the temure of life will depend largely upon the seat and nature of the tumour.

Treatment is of course purely symptomatic, sinee if the action of the heart is disordered and the real cause of the disorder is unsuspeeted or not, physieians find themselves limited to the administration of heart-tonics.

\section{ATROPIIY OF THE HEART}

By atrophy of the heart is meant a diminution of the organ in weight and size. The eondition may be partial or general. The former is exemplified in the smalness of the left ventricle seen in extreme mitral stenosis.

General atrophy may be the result of age, when it is spoken of as physiologieal, or the effect of disease-i. e., pathologieal. Congenital. smallness of the heart is sometimes designated as atrophy, but, as preferred by Virchow, should be properly termed hypoplasia of the heart. It is usually associated with congenital smalluess of the genitalia.

Morbid Anatomy.-The atrophied heart is of a brownish red or yellowish colour, often firmer than normal, sometimes presenting a wrinkled appearance, owing to puekering of the epicardium (like a withered pear, Eichhorst), and beneath the mieroseope the individual muscle-fibres are seen to be diminished in size, their transverse striation obsenred and stained by a deposit of brown or yellow pigment near their nuclei. Adipose tissue is everywhere absent.

Etiology.-Various causes of general eardiae atrophy are enumerated, but those most often and powerfully operative are conditions which induce marasmus-i. e., pulnonary phthisis, caneer, diabetes, and ehronic suppuration, as from disease of a bone. Thus IV. Chureh is said to have obtained from the body of a woman who died of slow starration in consequence of pylorus 


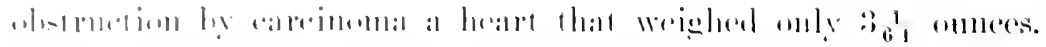

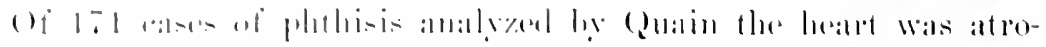

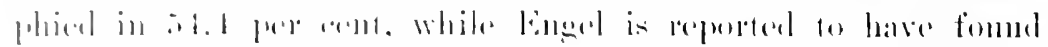

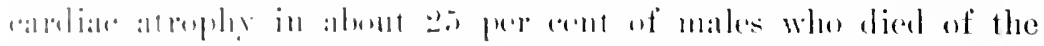

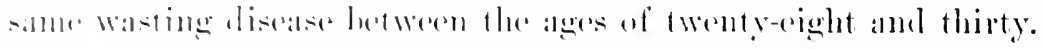

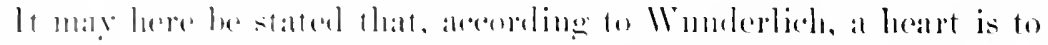

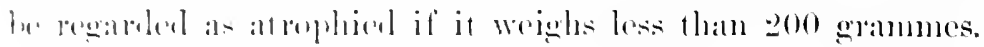

Symptoms.- 'Tle alinial manifestations of atrophy of the

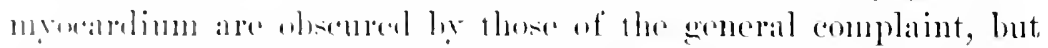

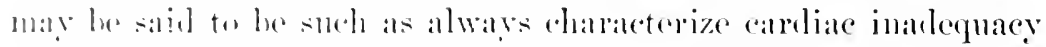

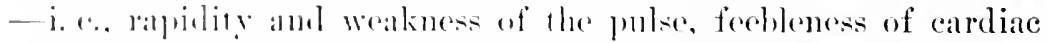

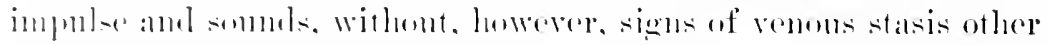
thatu -light melema. As a matter of fact this uelema is due to mal-

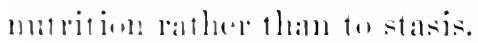

Diagnosis. - The diagmeis is likewise olsemed ly the signs

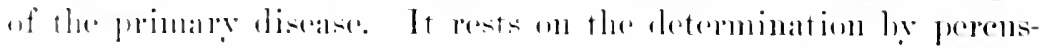

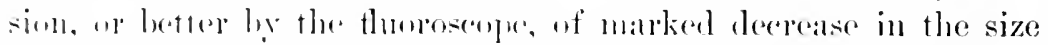
of the heart, tegether with evidence of prolonged and extreme (11)alciatiun.

Prognosis. - Tho prognosis is that of the general cachexia,

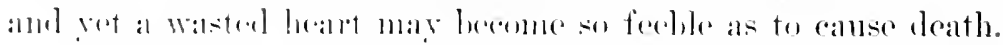

Treatment.- The traturent is that of the prinaly disorder, sinee it eam do but little and to anlminister heart-tonies.

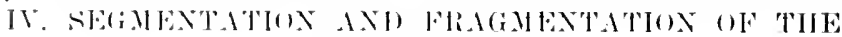

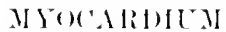

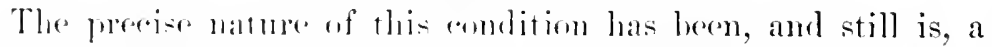

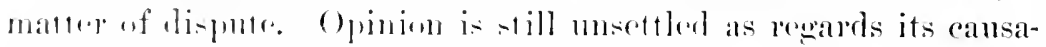

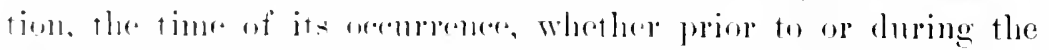

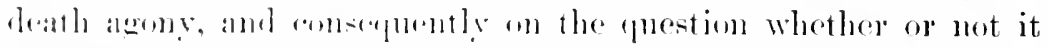

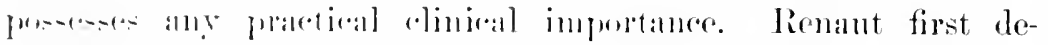

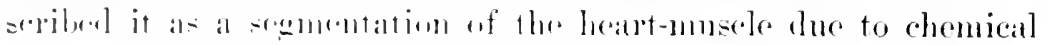

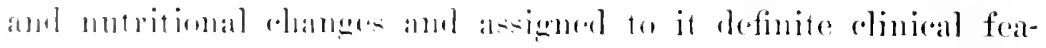

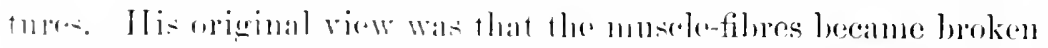

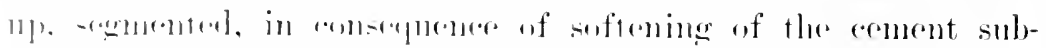

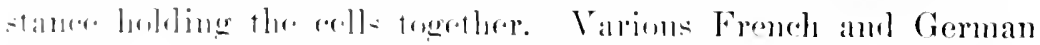

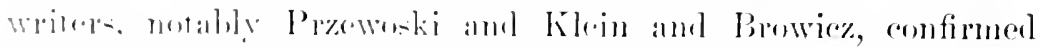

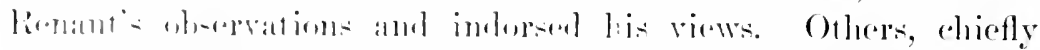

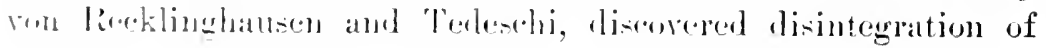




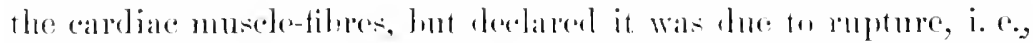

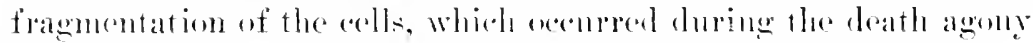

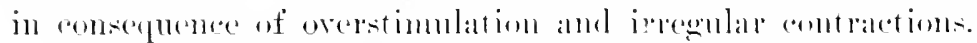

Although they fommel fragnentation in otherwise nomal hearts of individuals who had died sudelenly by violenee or otherwise, still in the majowity of instances it was in hrallts that showed chronie fibrons and fatty ehange, or the fragmentation was diseovered in persons who had suffered from acute infections or lesions

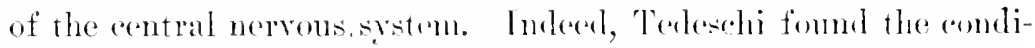

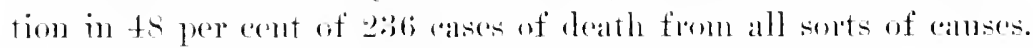
The statennents of ron Rereklinghansen cansed Remant to modify his views somewhat, and in 1s!t, at the first French comeress for

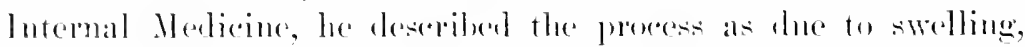
"gigantism" of the muselerecells and alteration of the intereon-

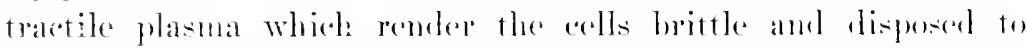
fracture, while at the same time there is softening of the cement that leads to secomentation. liemaut still helel, therefore, to his assertion that the proess constitutes a distinet and recognisabie clinical entity.

Since that time the subject has been diseussed by numerous observers, chietly in France and Ciemany. English and Anerican writers have had little or nothing to say on the subject, because, it may be, of its being still sub judice, and as yot not helieved to possess practical value to the clinician. The only important contributions that have, so far as I know, appeaned in this country at this present writing, are he Ludwig I Lektoen and John Bruce Marecallmun. The former male a careful sturly of a large number of hearts from lower animals, both small and latere, and from over 100 human beings that haw died suddenly as a result of violence, or slowly or smldenly in eonsopuence of a preat variety of alente and chronic affections, some of them cases of rither independent or secondary leart-disease. Hektoen's observations agreed with those of writers on the Continent as respects the fiequeney with which dissociation of the heart-muscle mentrs in both sexes, at all ages, in all surts of acoute infertions and ehomie dis-

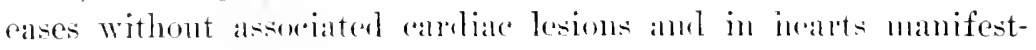
ing the ordinary inyourdial degenerations, hypertrophy and atrophy.

Thus, of 190 cases of deaths from a great varicty of causes 


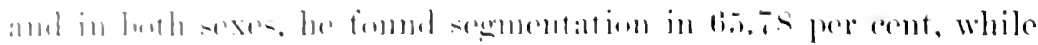

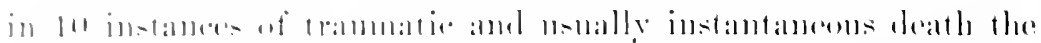

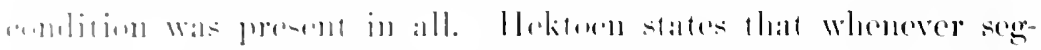

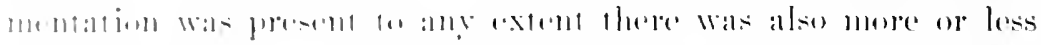

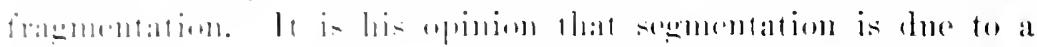

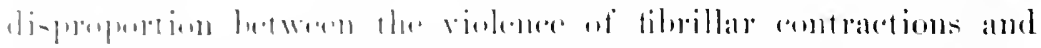

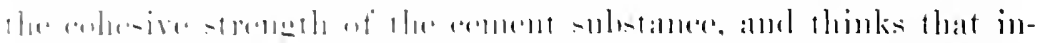

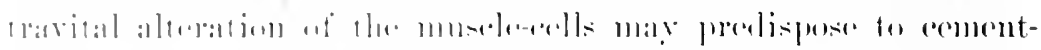

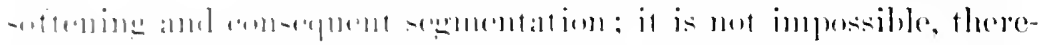

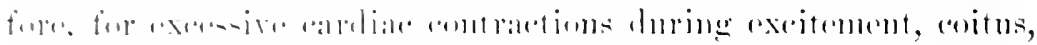

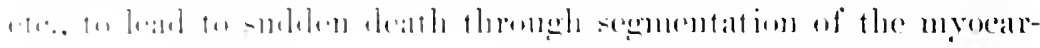
dimin.

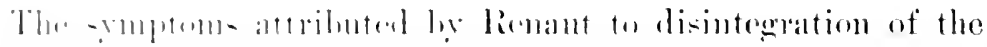

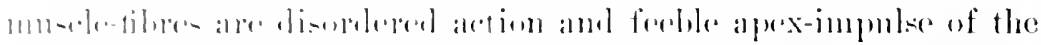

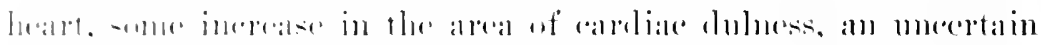

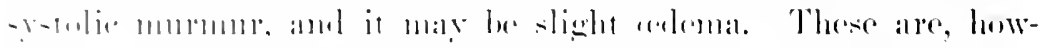

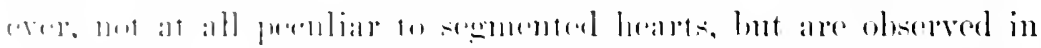

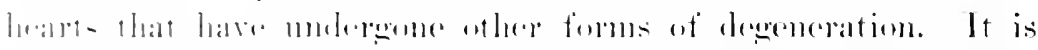

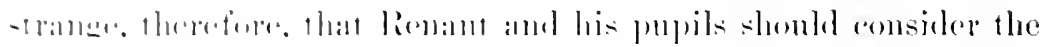

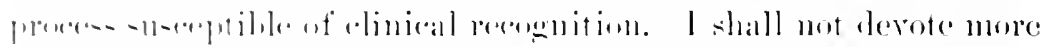

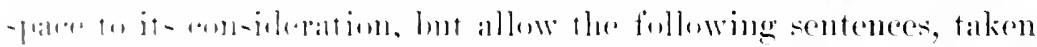

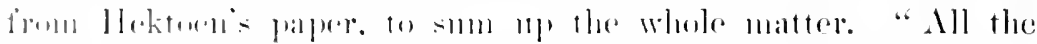
oflure

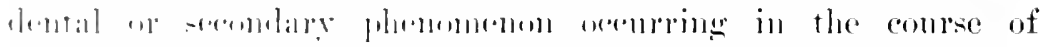

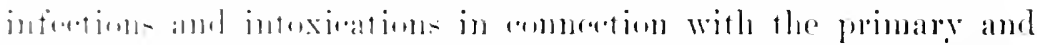
-

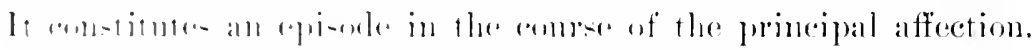

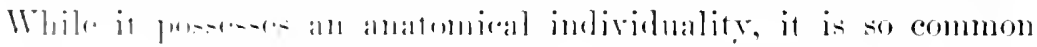

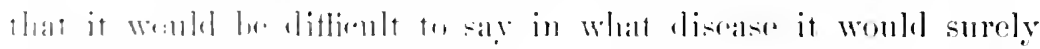

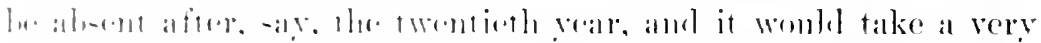

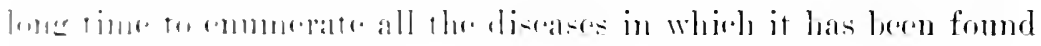
pron.tu. 


\section{CIIAPTER XXYIT}

\section{PEDUNCULATED AND BALL-THROMBI OF THE HEART}

Arove the tumours of the heart may be included those rare formations which are found in the cardiac carities and are in reality thrombi. They differ from cardiac thrombosis (marantic) in the chronicity of their development, the changes they undergo, and in their elinical history, since they do not give rise to emboli. Like vascular thrombi, some of them undergo organization, and when attached to the imner surface of the heart-wall by a pedicle are known as pedunculated thrombi or true polypi of the heart.

Others, alled bull-thromt)i, have either become detached from their pedicle, or having been formed by the deposition of successive layers of fibrin upom a primary nuclens, and mattached, mll about free in the chanber where they are formed. Both rarieties are exceedingly rare, but of the two, ball-thrombi have been much less frequently encountered.

At the Remion of Russian Physicians at St. Petersburg in 1893, in honour of Pirogoff, Pawlowski reported a case of true heart polypus that had come under his observation. In this paper he stated that diligent research in the literature up to that date had enabled him to collect only 25 cases, including his own. William Welch, howerer, in his admirable article on cardiac thrombosis in Allbutt's Srstem of Melieine, states that he has found $s$ others in the literature, making $39 \mathrm{in}$ all. Small as is this number, that of ball-thrombi is still less. Fon Ziemssen, in the report of a case at the Tienna meeting of the German Congress for Internal Medicine in 1890, stated that he had heen able to collect only 4 cases besides his own. His research for published cases had been superficial, however, for Welch mentions 4 cases, with a reference to a fiftl, that had heen reported in England prior even to ron Recklinghausen's, which by German authors was consid- 


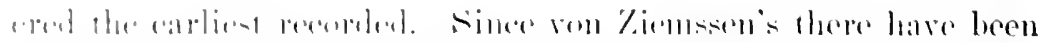

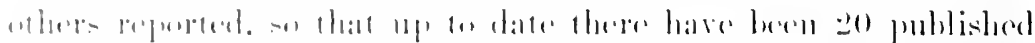

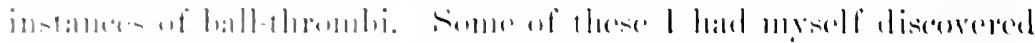

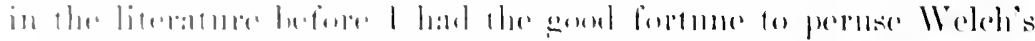

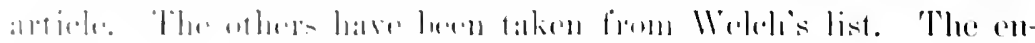

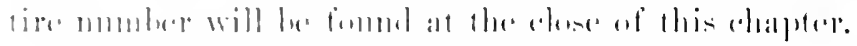

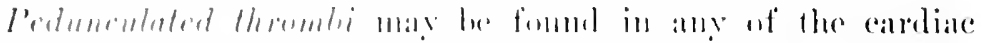

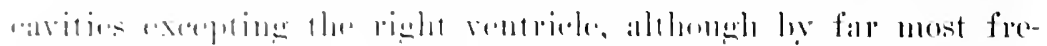

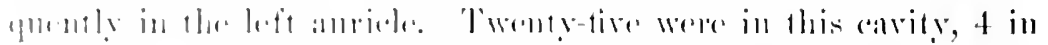

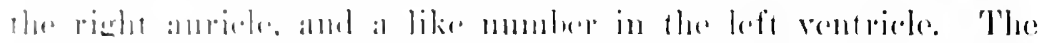

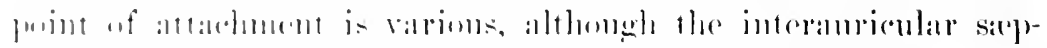

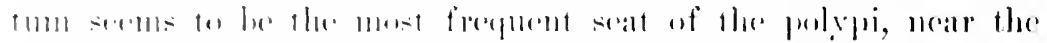

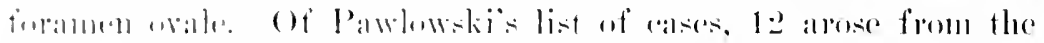

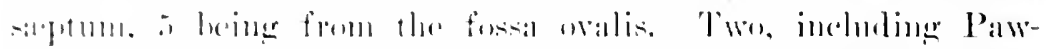

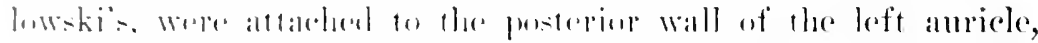
- within the appendix, aml 1 to the mitral valve. In the other

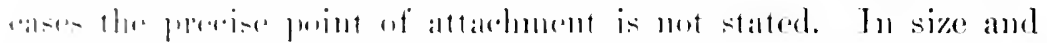

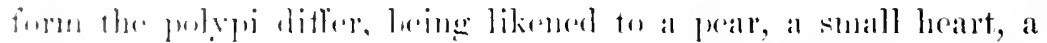

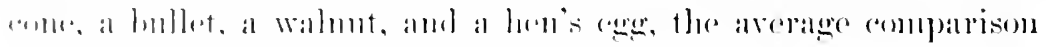

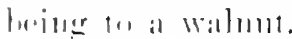

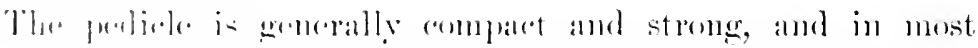
(a) - the the a

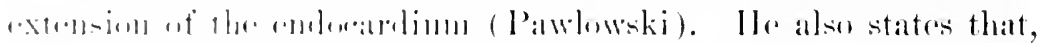

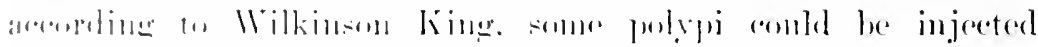

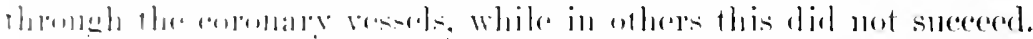

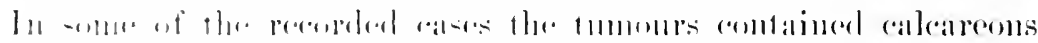

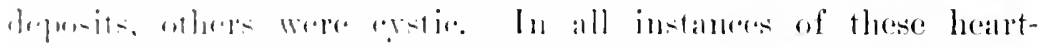

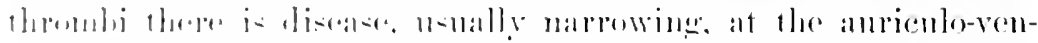

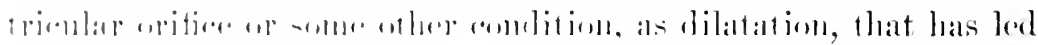

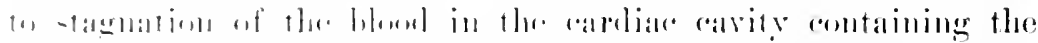

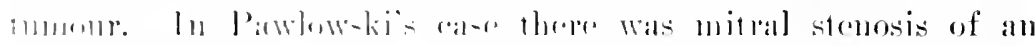

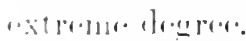

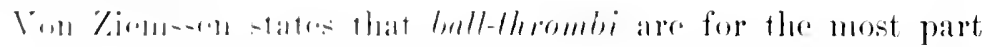

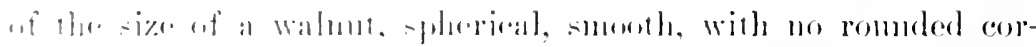

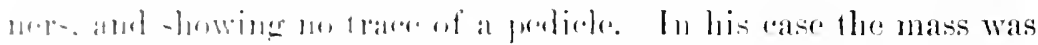

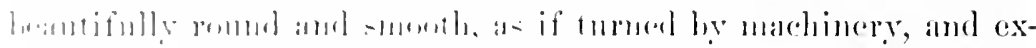

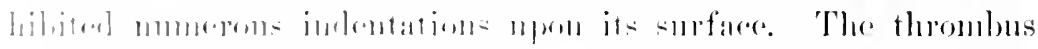

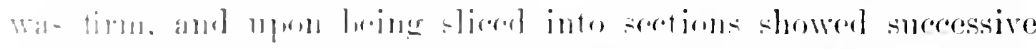

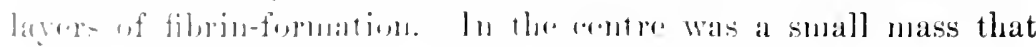


had eridently served as the basis upon which the fibrin had been deposited. Rimning up through the thrombus in radiating lines towards the eiremuferenee were delicate fibrous bands, which terminated each in a depression on the surface, and appeared by their organization and contraction to have oceasioned the superficial indentations. The mitral orifice was also greatly stenosed in von Ziemssen's case. It may be remarked in passing that in his paper von Ziemssen alludes to his having had two other cases of pedunculated heart-thrombi, but Pawlowski does not include them in his list, and I have not diseovered where they were published.

In Wood's ease the ball measured $1 \frac{1}{2}$ inch in diameter, was of a dark-red colour, and made up of an outer wall $\frac{1}{8}$ of an inch thick, composed of a large number of fibrinous lamina and containing a mass of coagulated blood. The feature in this case, considered by Welch as mique, was that "adherent to the wall of the auricle, near the mitral valve, was a firm, oval thrombus on the free surface of which was a superficial concavity which formed a "kind of socket for the loose ball to roll in."

In one of Legg's eases, that of a woman brought into the hospital dead, two loose balls were discovered in the left auricle. In Osler's second ease Welch states that an ovoid thrombus, resembling in size and shape a thick chestmut, was found with its smaller end sticking in the moderately narrowed funnel-shaped mitral orifice, from which it was readily removed. "At one pole of the thrombus was an irregular ronghened spot indicating a former attachment, probably to a thrombus in the appendix."

In Arnold's case the ball-thrombus was elastic, as if composed of fluid incased by a thin membrane. At one spot the surface was roughened and of a speekled appearanee, as if at this point it had once been in contact with the wall, while elose by was a short thread-like prolongation which might have served as its means of attachment. The endocardium of the auricle was smooth and of normal appearance. The appendix was filled by a thrombus, broken down at its eentre, and attached by a ribbon-like extremity to the internal aspect of the tip of the appendix. This mass projected into the eavity of the auricle. It is reasonable to infer, therefore, that these two thrombi were originally one, a small fragment having become detaehed and ultimately converted 
inte the hall. The mitral wition was the seat of obstructive di-c:i1-1".

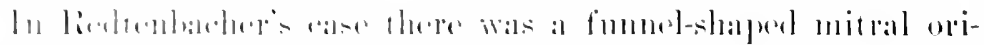

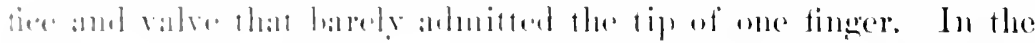

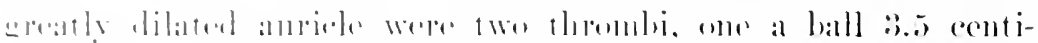

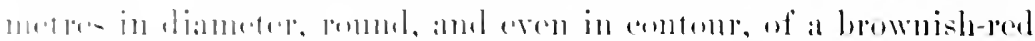

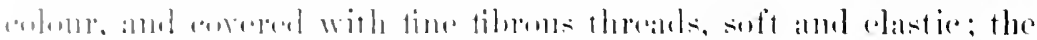

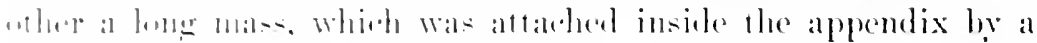

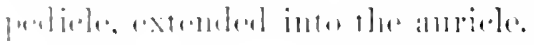

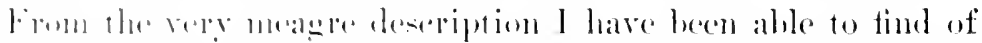

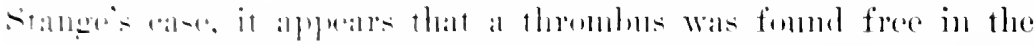

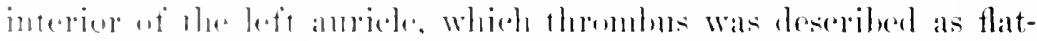

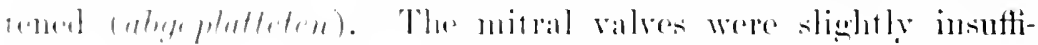

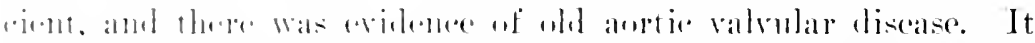

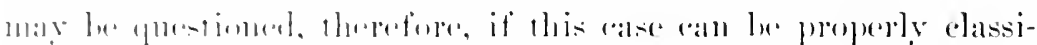

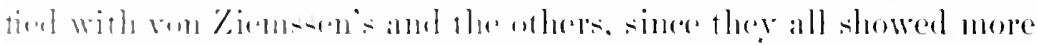

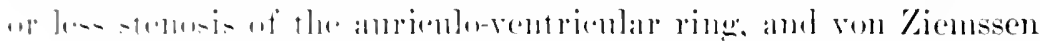

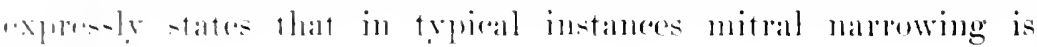

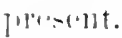

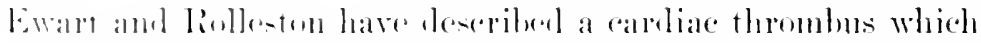

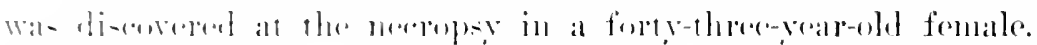

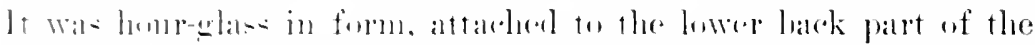

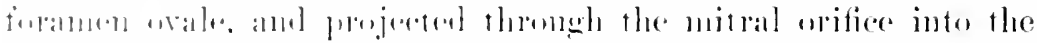

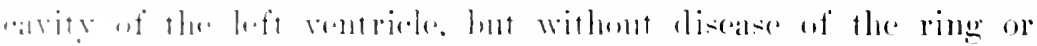

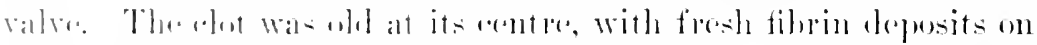

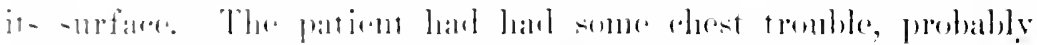

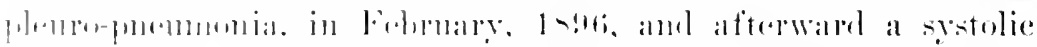

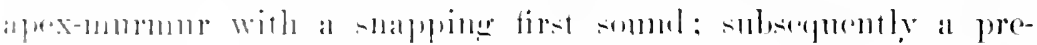

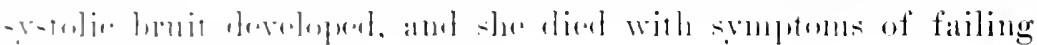

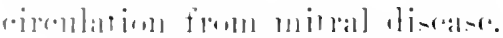

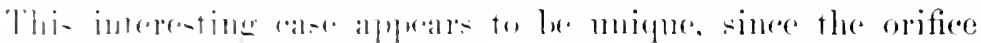

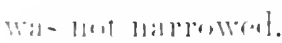

Pathogenesis and Etiology.-Two tlerories ale offered to

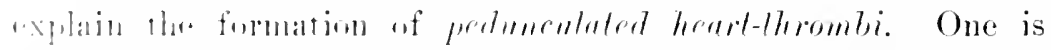

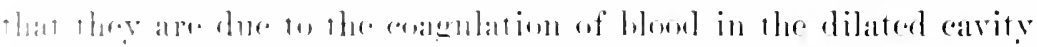

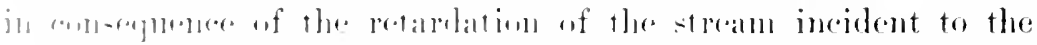

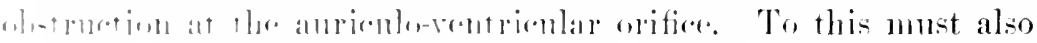

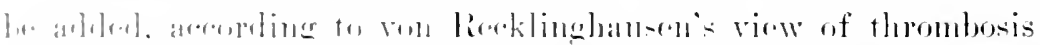

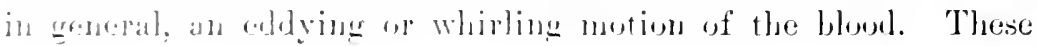


thrombi beeome attached to the wall, and subsequently undergo organization.

The other explanation is the one adraneed by Bostroem, and acepted by both Welch and Romberg as applicalsle to some of the cardiac polypi at least. This is that trme heat-polypi are thrombosed rarices of small veins in the interauricular saphtun or result from hamorrhages into the sirptum. This view is based on Bostroen s examination of two such polypi, one of which he showed to be a thrombosed rarix, the other, which filled the right anricle, to be the result of hamorringe into the wall. "Thelefore," says Weleh, "it would appear that the nature of these formations is not always the sane." It is this difference in the nature of heartpolypi which has led to the diversity of opinion concerning their (1) igin.

Ball-llerombi are without donbt true heart-clots which may have been formed by the deposition of stecessive layers of fibrin probably upon a central nuclens or matrix. The question that does not appear to have been settled in respect to every reported case is whether they were formed as detached masses, or were originally parts of an attached roagnhum, from which they had become broken off. Some of the balls have presented rongliened spots and tiny rudimentary pedicles, which seemed to make it reasonably certain that they were once attached to thrombi discovered in the appendix. The smooth rounded form appears, as snggested by von Recklinghansen, to have been caused by their rolling about in the blood-stream.

Neither sex is exempt, ret women are more frequently befallen than are males, probably for the reason that they furnish a larger contingent of examples of mitral stenosis. Polypi have been found in the young and the old, yet, singularly enomeh, Pawlowshi's list fails to comprise any case between the ages of twenty and thirty, a ciremonstance which he thinks may be ntilized in arriving at a diagnosis. Is regards ball-thrombi, lowerer, there are several eases which were observel in persons of an age falling in this third deeade of life. Finally, there must be a constrictive valvular disease to lead to stasis and coagulation of the blood.

Symptoms.- Whether the tumour is a pedunculated polypus or a laall-thrombus, the svmptoms are such as characterize an extreme degree of circulatory enbarrassment arising from stenosis 


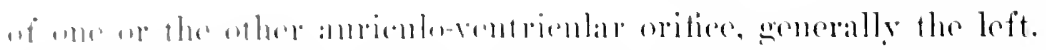

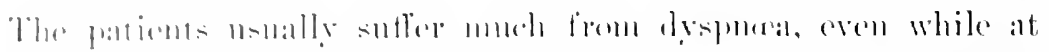

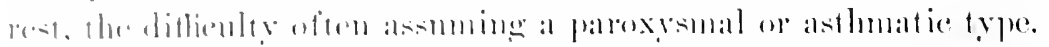

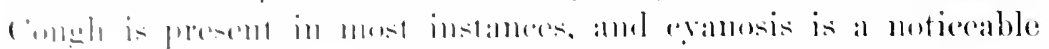

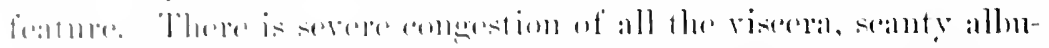

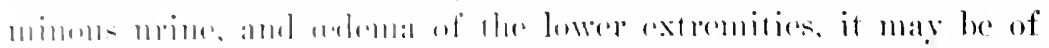

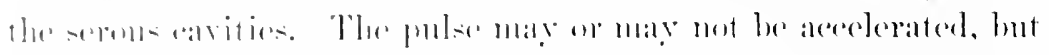

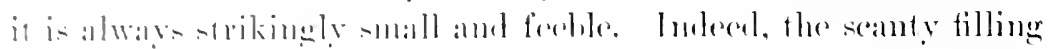

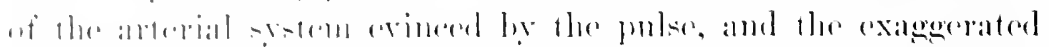

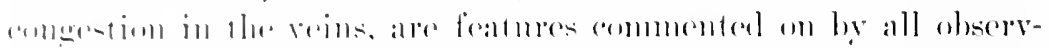

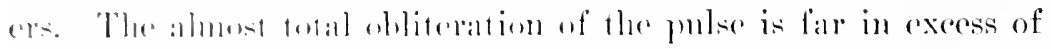

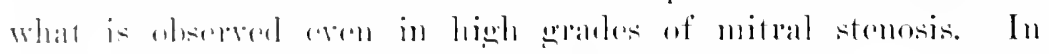
rhythm the pmlso is mot peremlials, since it may he irregmar, inter-

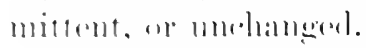

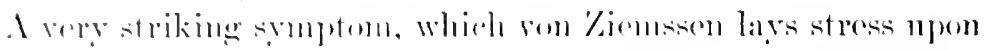

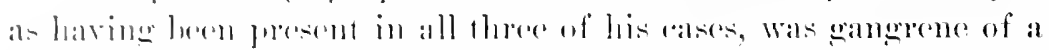

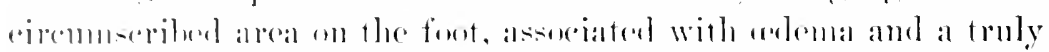

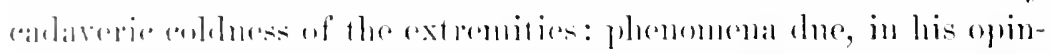

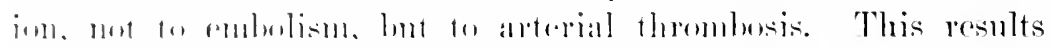

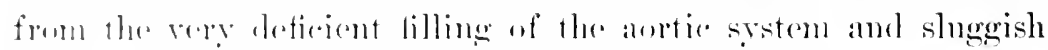

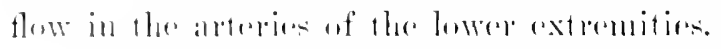

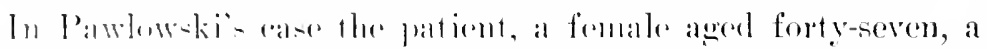
a

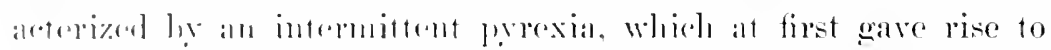

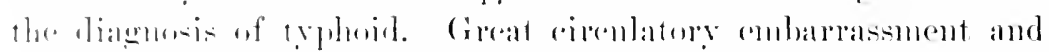

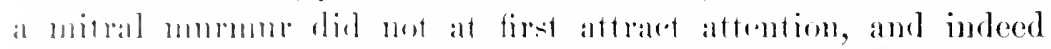

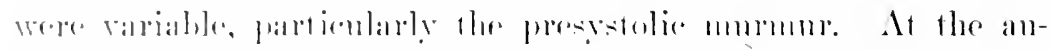

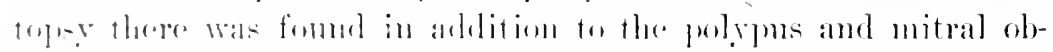

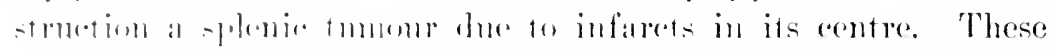

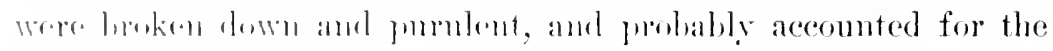

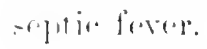

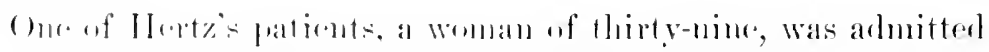

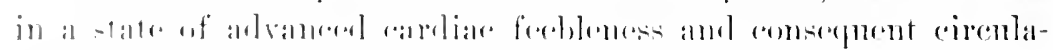

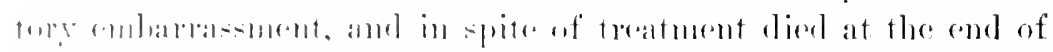

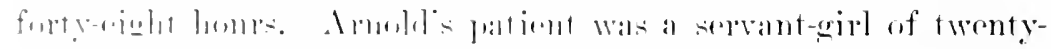

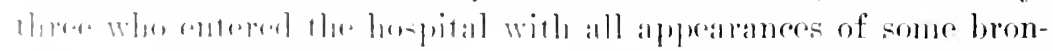
rhial ar purammole afferetinm. A mitral lesion was discovered.

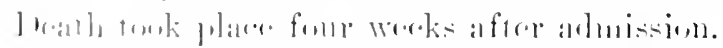

In J'moll's rate lle pationt was a man of fifty-eight who was 
ill five months with most distressing symptoms of embarlassed eirrolation, breathlessness, vertigo, cold sweats, and absence of pulse that were thought to depend upos mitral diseatse and secontdary failure of the right ventricle. Wath was the result of asphyxia. The necropsy disclosed a pertunenlated thrombus in the right anricle 3 inches in leneth and attached to the sirptum.

It is thus seen that, howerer great may be the differences in the duration of the srmptoms, these all evince a similarity in the manifestations of valvular olstruction of an extreme degree.

As regards the physical signs, these may be said to be those of a stenosis of an amriculo-rentricular orifice, usmally the left. It must be remarked, however, that the characteristic presystolic nummur is not always present. Indeed, ron Ziemssen states that after the thrombus has formed and begun to produce symptoms, the diastolic-presystolic mumm which previously existed may disappear. A rery suggestive character of the murmur in such a case is its intermittency, coming and going, andible upon one examination and alsent at another. This must depend in some way upon the presence of the mass, at one time the flow being sufficiently forcible to wenerate a hruit, at another too languid and suall to produce sonorous vibrations.

Diagnosis. - This is obvionsly a matter of great difficulty if not of actual impossibility. So far as I can learn, an intravitam diagnosis has not heen recorded. The existence of the thrombus must always he a matter of conjecture rather than certainty. Howerer, if in a case of apparent mitral disease, or indeed of carliae feebleness from any other eanse, the embarlassment in the circulation be areater than seems aceunted for by the lesion discovered, if localized gangrene of the foot oceurs in a case of mitral disease, and evidently not due to arteriosclerosis or embolism, and lastly if a presystolic or other mumur comes and goes in an maccomntable fashion, one may entrotain the suspicion of a heart-thrombus. One camnot from these data diagnose it with certainty.

Ton Ziemssen considers three conditions indispensable to an intra-ritam diagnosis of an antochthonous cardiac thrombus: (1) There must be the physical signs of a mitral stenosis, since this lesion was present in all the typical cases on record. The evidence of this valvular defect must have been found at a time prior to 


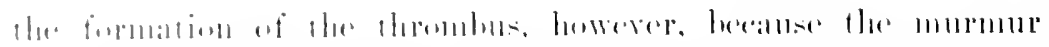

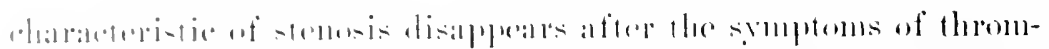

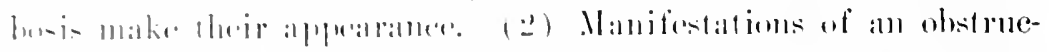

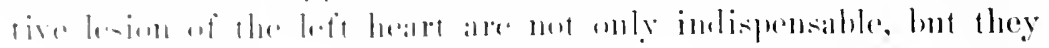

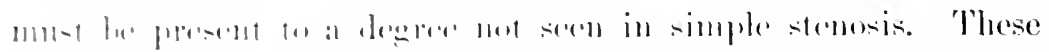

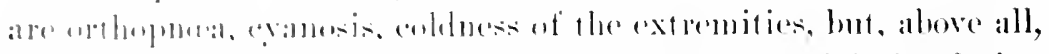

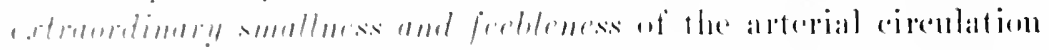

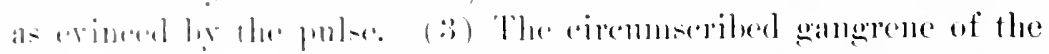

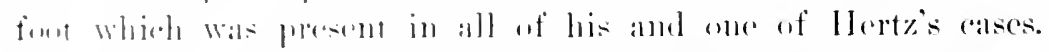

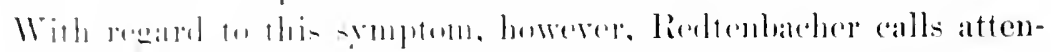

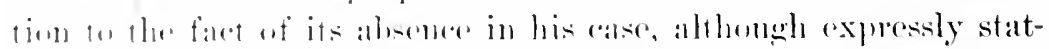

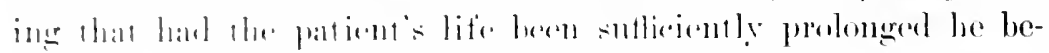

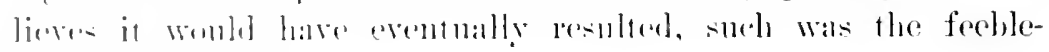

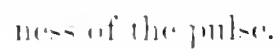

Prognosis. - This is alsolutely mufaromulde, since the de-

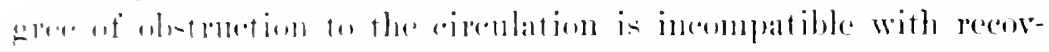

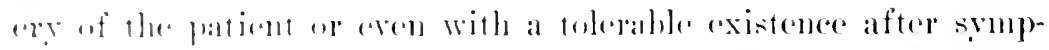

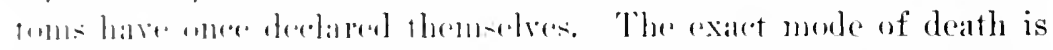

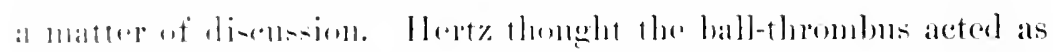

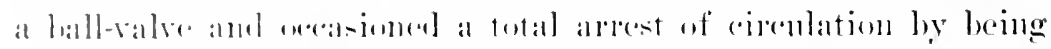

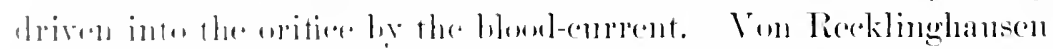

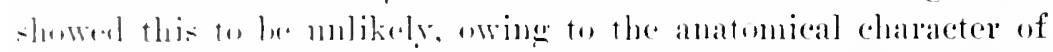

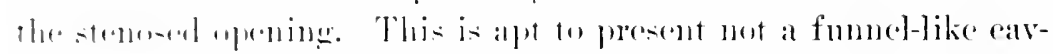

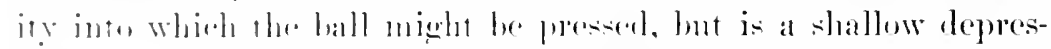

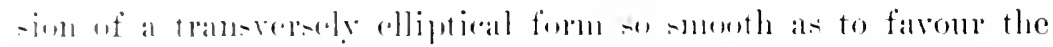

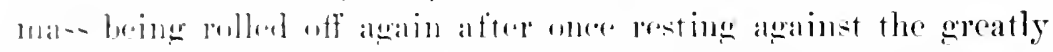

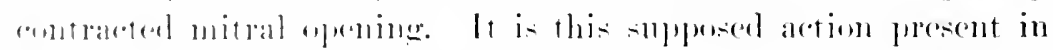

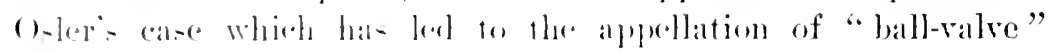

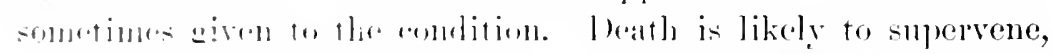

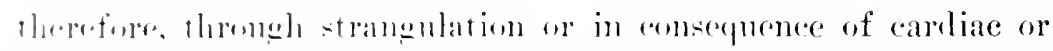

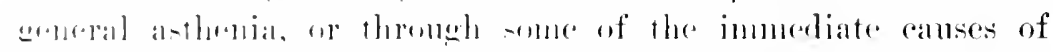

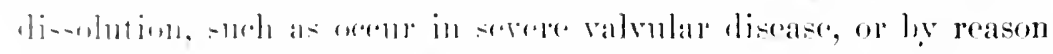

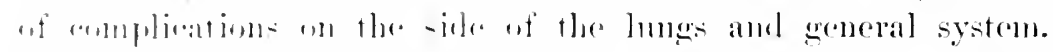

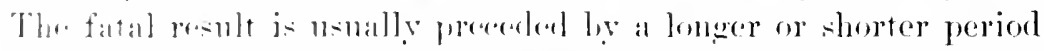

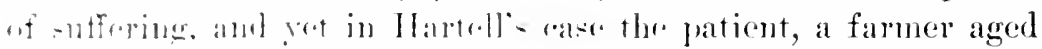

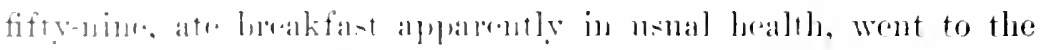

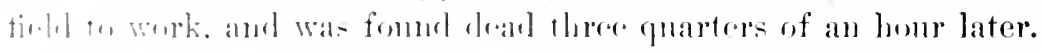

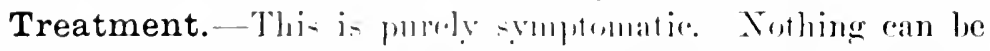

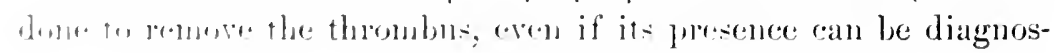


PEDUNCULATED AND BALI,THROMBI OF THE IIEART GT9

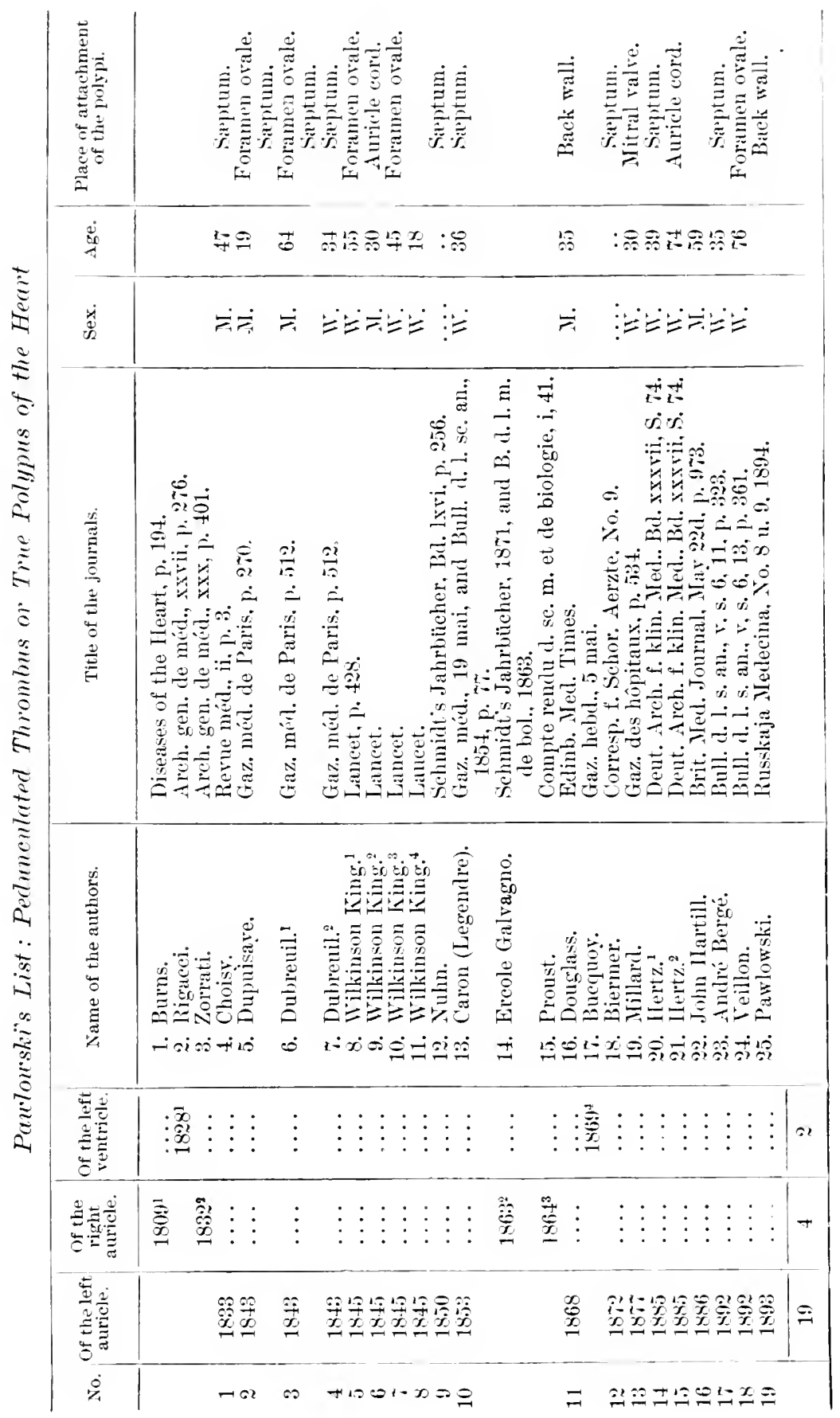




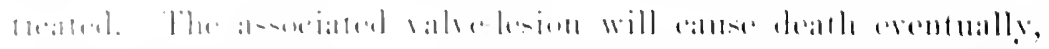

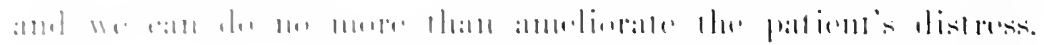

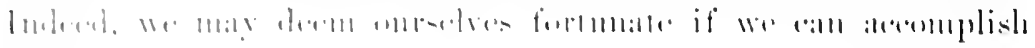
llii-.

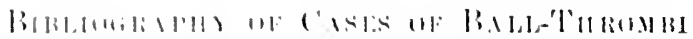

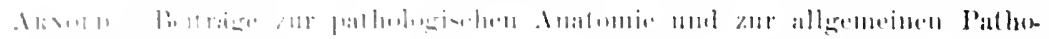
$1,12,11,11: 1,1-! n 1$.

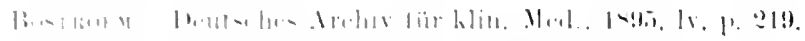

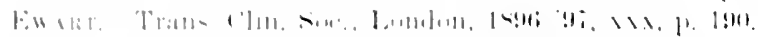

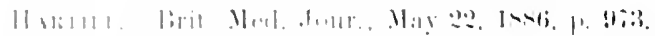

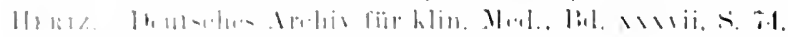

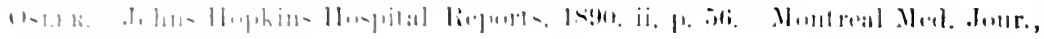
$1 \div ! 1 \%, 11,1 ?: 3 ! 1$.

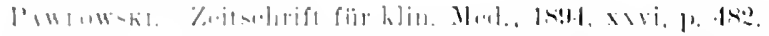

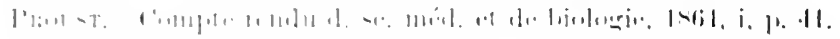

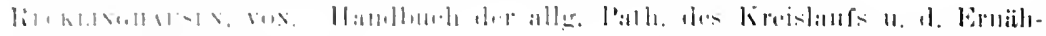

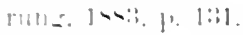

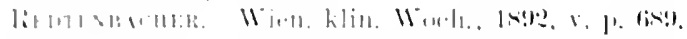

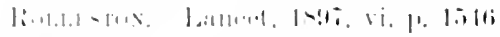

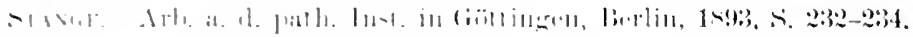

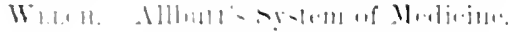

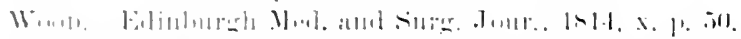

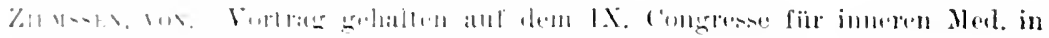
11.11. 1-!n!. . ?-1. 


\section{CHAPTER XXYIII}

\section{DEXTROCARDIA}

Tuns term signifies a transposition of the heart into the right side of the thorax. This condition may be congenital or aequired. Most congenital displacements of the heart oeeasionally met with possess interest chiefly for the pathologist. The organ may be situated in the cerrical region, within the abdominal eavity or upon the exterior of the ehest (ectopia cordis).

\section{CONGENITAL DEXTROCARDIA}

This form is the most frequent of all displaeements and is of elinical as well as pathological interest, inasmuch as the physician may be ealled on to determine whether the displacement is pathological or normal to the individual concerned, and therefore deroid of danger. In most instances this ahnormal situation of the heart is associated with transposition of the other viseera, a condition which has received the name situs riscerum incersus. That this is not invariable has been noticed by Bresehet.

The displaced heart ocenpies the same relative position on the right side as it does normally at the left, while the stomach and spleen are in the right and the liver in the left hypehondrium. The position of the intestines is also reversed, so that the rectum lies in the right instead of in the left iliac fossa.

Symptoms.-Congenital deetrocardin oceasions no symptoms unless it be associated with other ardiac amomalies, as sometines is the case. It is stated, howerer, that patients with this displacement of the heart are apt to develop puhnonary tubereulosis. Apropos of this possibility I recall the case of a Miss A., who applied to me for an exanination beeause she had had her attention directed to the fact that her heart pulsated upon her right side, and she desired to learn if it possessed any special im- 


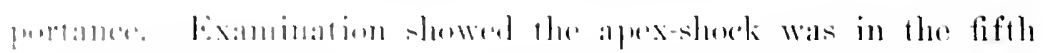

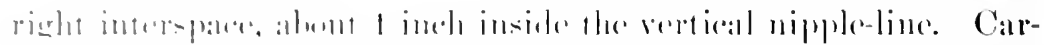

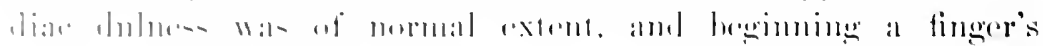

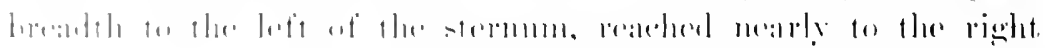

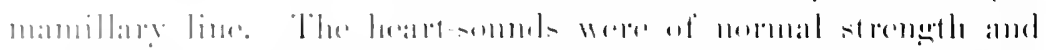

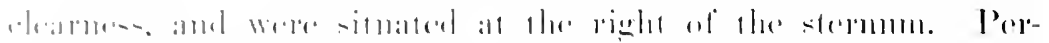

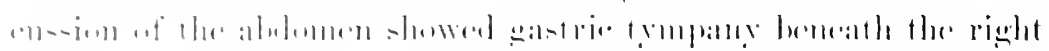
antal la

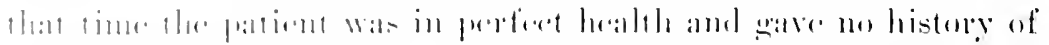

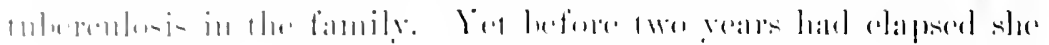

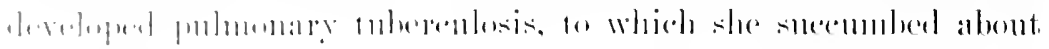
:1 yar latrer.

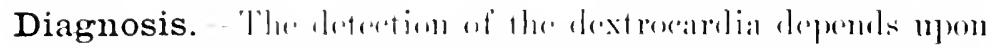

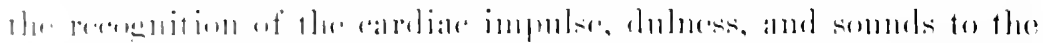

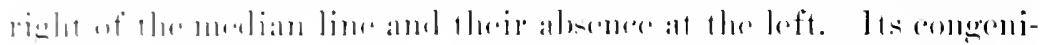

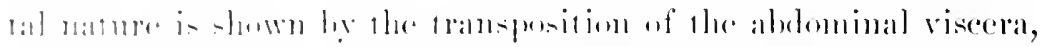

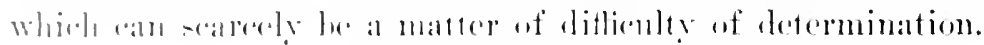

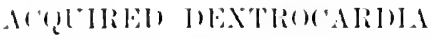

Morbid Anatomy. - This: form of dextroendial may be

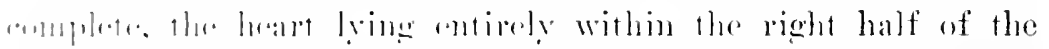

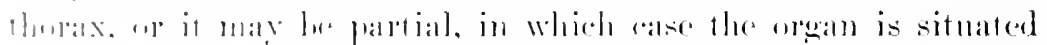
mainly lut mo wholly to lhe right of the modian line. As this

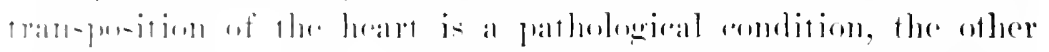

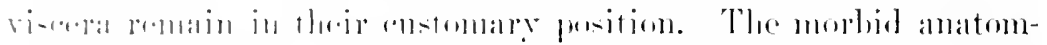

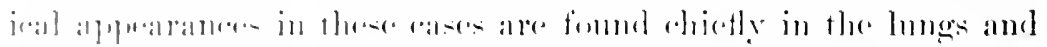

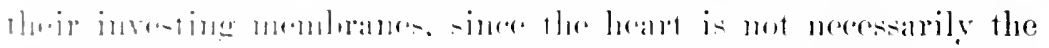

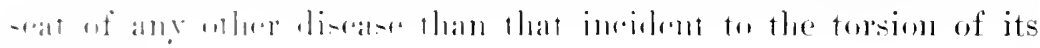

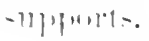

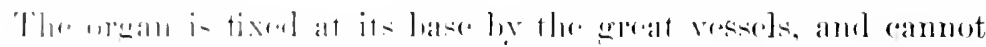

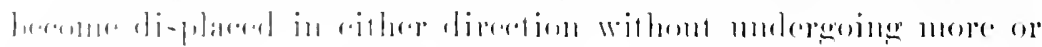

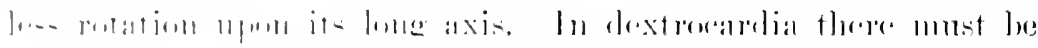

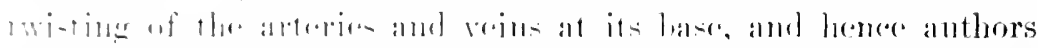

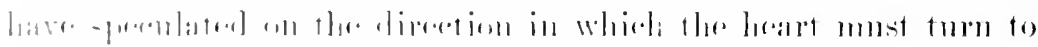

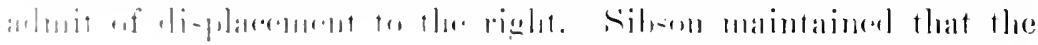

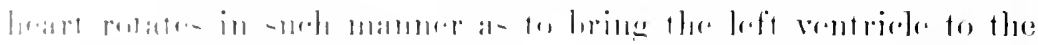

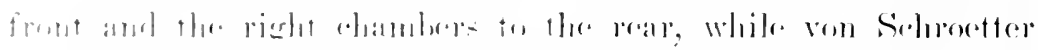

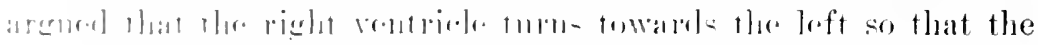

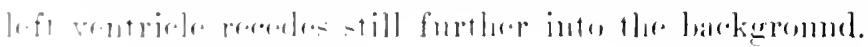


$A$ monnent's reflection will anvince one, however, that the direction in which the heart rotates is delermined ly the displacement and twisting of its supports or hy the point of attachuent of adhesions and the angle in which they pull. In a paper on dextrocardia, contributed by ne in 1888, this question was fully diseussed, and I there reported 2 cases which proved conchisively that the heart may rotate in either direction, so that both Sibson and von Schroetter were right. (For details see Medical News, 1884-1888.)

The twisting and strain to which the aorta and pulmonary artery are subjected may exert a detrimental effect on the heart. 'Thus in the case of a child which I reported the aorta was found constricted by the superior vena cava, which was stretched tightly across it, and the narrowing of the aorta thus occasioned had led to dilatation of the left ventricle. It is possible, therefore, for this abnormal and constrained position of the heart to lead to its hypertrophy and dilatation and to constriction as well as stretching of the large vessels at its base.

Etiology.-This is foumd in pathological processes that exert either pressure or traction upon the heart. The former is brought about through the acemulation in the left pleural eavity of air (pneumothorax) or of liquids (plenritis with effusion and empyema). With the absorption or artificial removal of the exudation the heart usually returns to its normal situation, but the formation of plemritic arlhesions and obliteration of the left pleural sac may serve to maintain the organ in its acquired location. The pressure exerted may be sufficient to push the heart entirely beyond the median line, so that its apex strikes the chestwall outside the right mamillary line, and Walshe says this may take place within thirtr-six hours. Ordinarily the organ is not greatly displaced, and the apex may come to lie at any point between the midsternal line and the right nipple.

When the heart is drawn over into the right side, it is throngh the traction exerted by plemro-pericardial arhesions acting in conjunction with nore or less eirrhosis of the right lomg. This was the cause in all three of my cases. The primary canse may be a tramma, or tuberculosis of the lung may be the initial etiological factor. Whaterer be the predisposing eause, the pleuritic adhesions undergo contraction slowly, and a considerable length of 


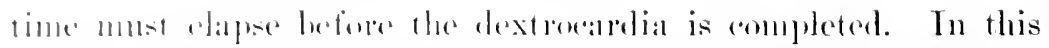

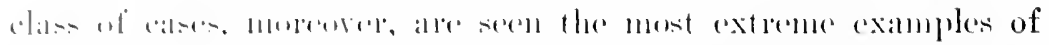

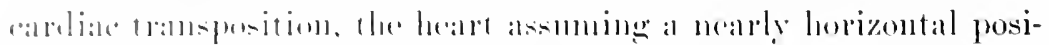

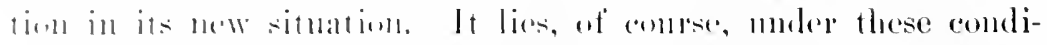
inms. inmuediandy hemath the anterior ahest-wall and is mocov(י) linl line.

Symptoms.- 'Thres may entsist of those pluenomena ordi-

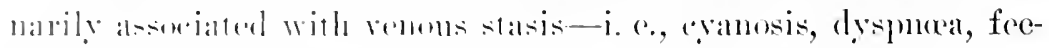

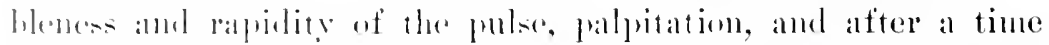

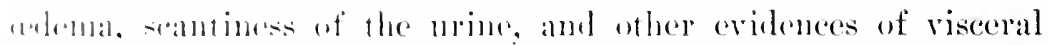

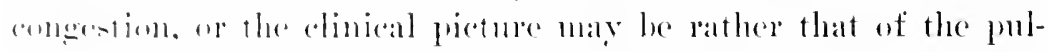
monaly atfertion with or without symptoms of cardiac insuffi-

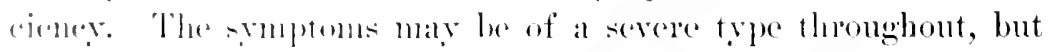

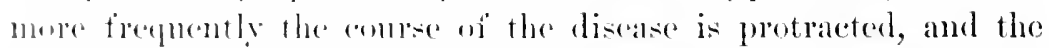

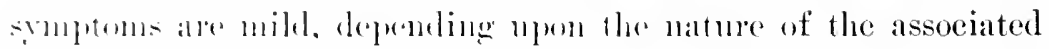

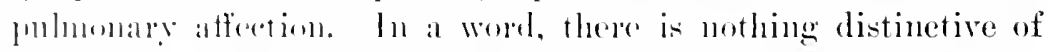
the relinical history of these asese muless it be their chronicity.

Diagnosis. - The detertion of the fact of the dextrocardia

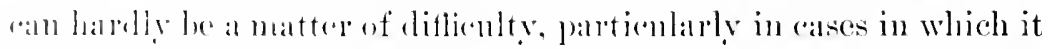

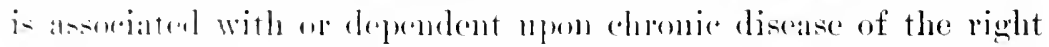

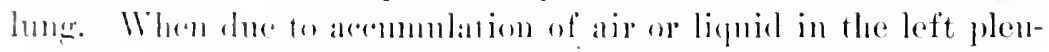

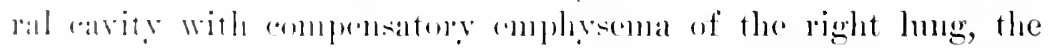

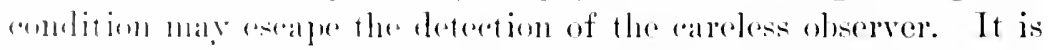

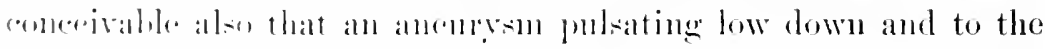

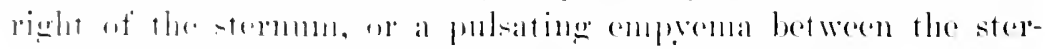
mom amb right nipple, might misleat the inceperienced or super-

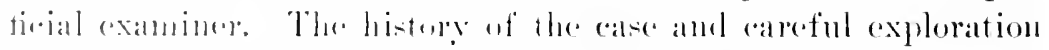

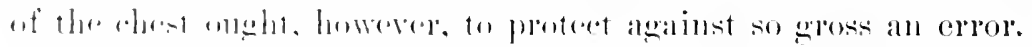

Inspetion and I'alpution.-These disclose pulsation in the

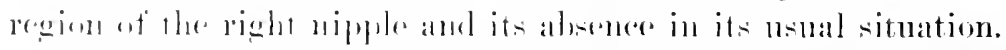

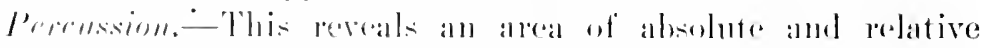

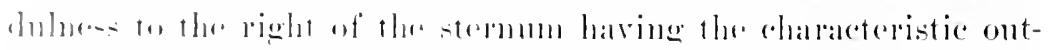

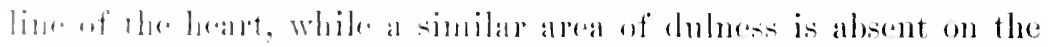

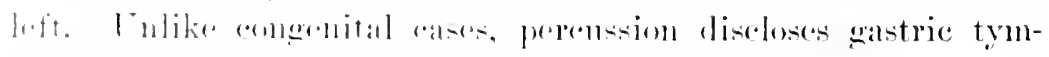

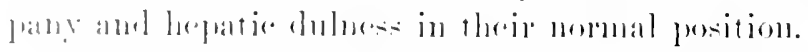

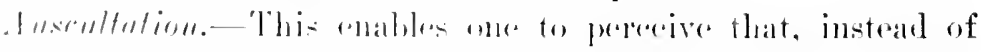

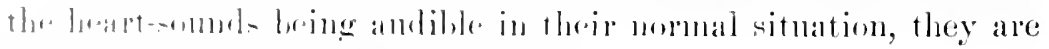

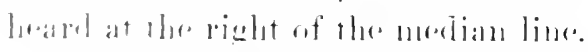

The lugrical signs, be which are recognised the pulmonary 
diseases that bring ahout an aequired dextrocarlia, to not need to be here stated.

If occasionally cardiac murmur's are heard in this class of eases, it is not always easy to determine whether they are organic from ralvular disease, or are accidental and due in some way to the alterations in the cardiac walls and large vescels incident to the rotation of the organ. The history of eases of acquired dextrocardia shows that aceidental bruits are not uncommon. For the differentiation of the murimurs one must rely on the rules that have been stated already in the introductory chapter.

Prognosis. - In most instances this may he said to be that of the lung condition, and ret in a case of complete aequired dextrocardia with presmmably considerable torsion of the resels, the condition is likely to shorten the prospect of the patient's life. Terertheless, one of my patients was alive and in ordinary health fourteen years after my first examination. The prognosis in each ease depends num the evidence or not of cardiac feebleness and disordererl circulation, all of which signs have been sufficiently set forth in previous chapters.

Treatment. - Tlis must be based on the indications of each case and the principles that apply to other forms of cardiae inadequace. It is needless to remark that nothing can be done for the relief of the dextrocardia in those instances in which it is owing to traction from permanent disease within the right half of the thorax. 


\section{('II.MP'Tli XXIX}

\section{CONGENITAL DISEASES OF THE HEART}

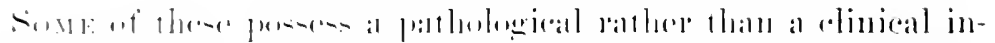

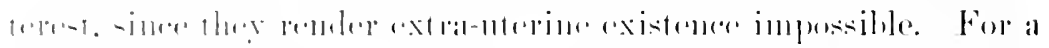

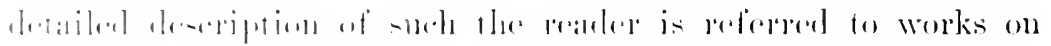

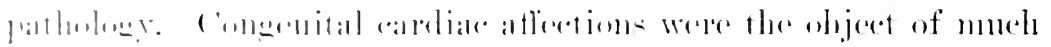

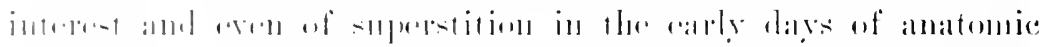

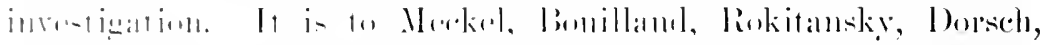

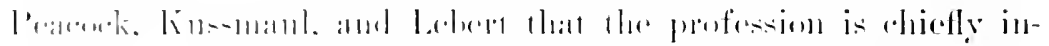

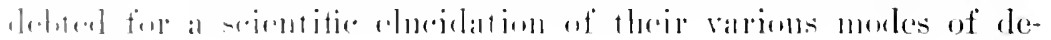
$r+1+1,111+11$.

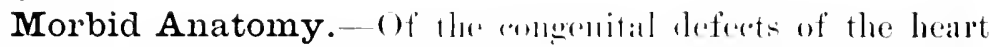

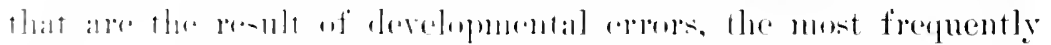

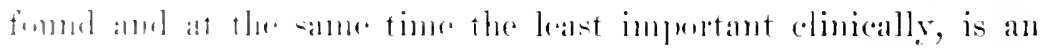

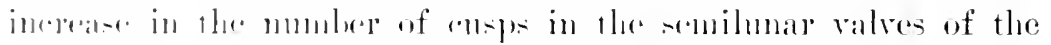

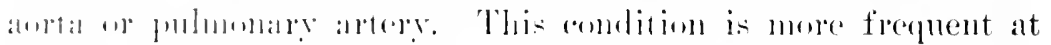

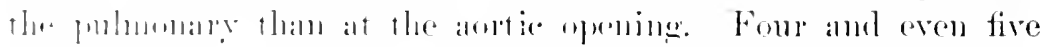
-

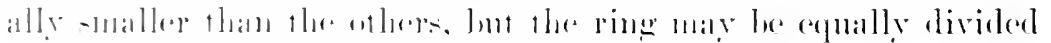

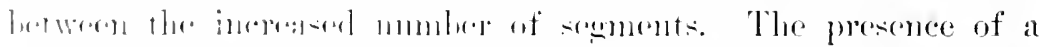

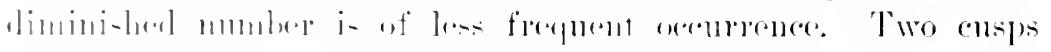

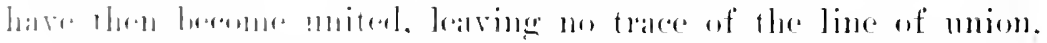

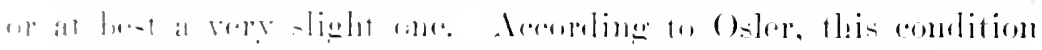

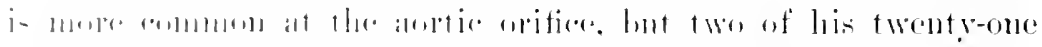

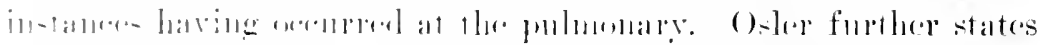

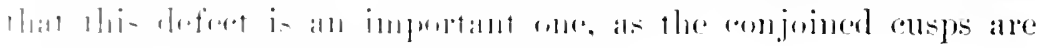

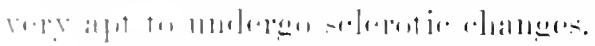

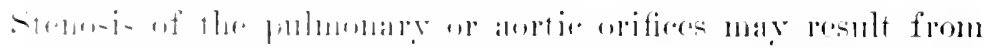

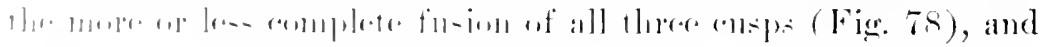

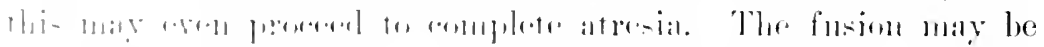

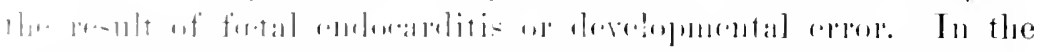

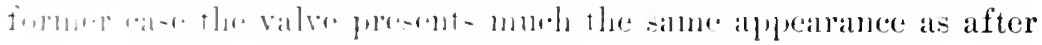
is $\rightarrow$ is 
postnatal endocarditis. Vegetations may corer the eusps, project inte the ventricle, or fill the simmes of Valsalva. At other times, however, the mited valves may present no signs of endocarditis, being combined to form a fumnel, which nay show signs of very slight sclerosis. Stenosis or atresia of the anriculo-rentrienlar orifices is of mueh less frequent ocenrener than of the arterial openings. In either atse the congenital discase is more frequent on the right side on aceount of the more frequent location of fertal endocarditis on that sirle. Pott says that for one congenital aortic defect there are twonty-five pulmonary and tricuspid.



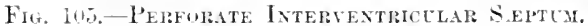

Pulmonary stenosis, already considered in a special chapter, is a by no means infrequent congenital anomals. Lortic obstruction is far less frequently congenital. In either case if the obstruction 


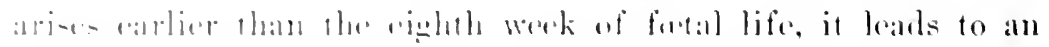

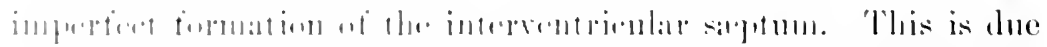

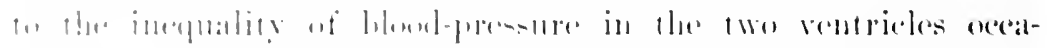

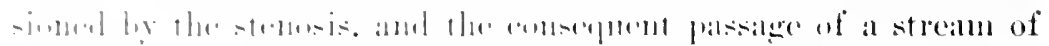

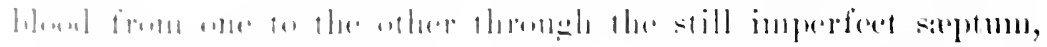

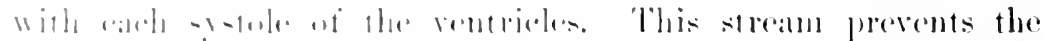

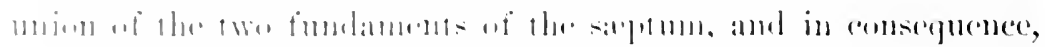

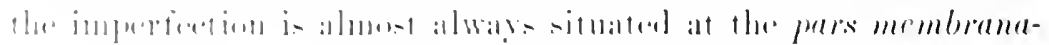

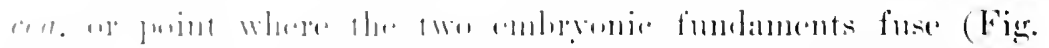

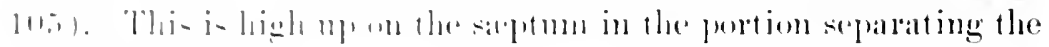
1wn inni arterimi.

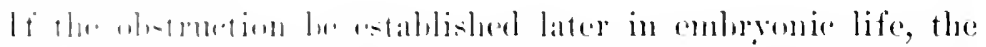

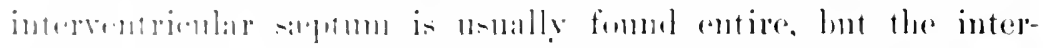

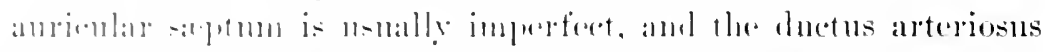

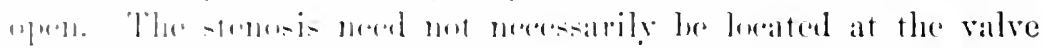

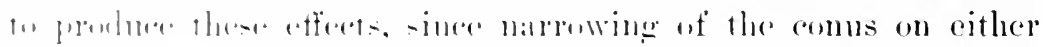

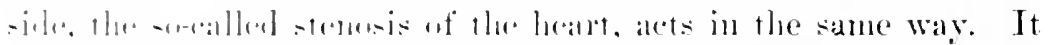

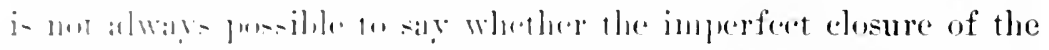

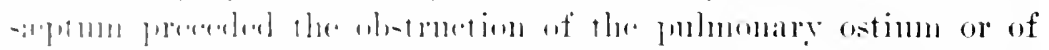

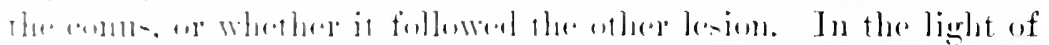

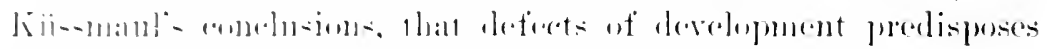

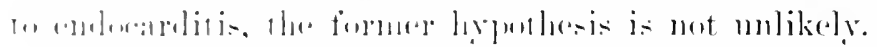

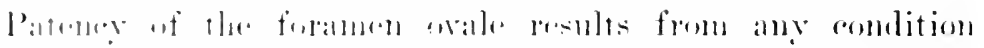

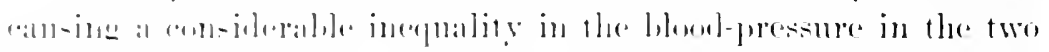

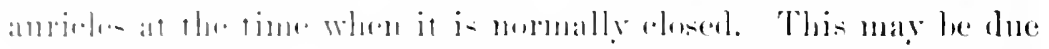

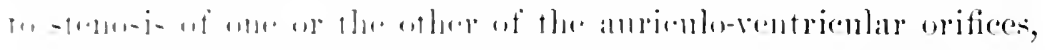

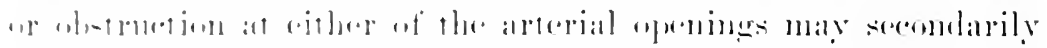

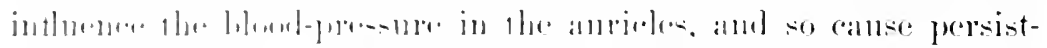

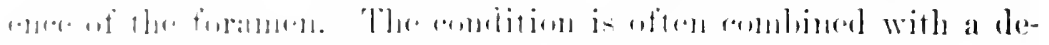

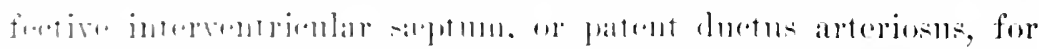

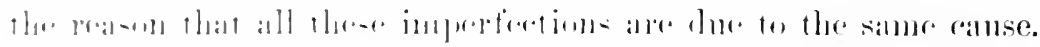

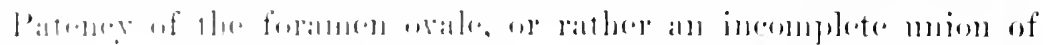

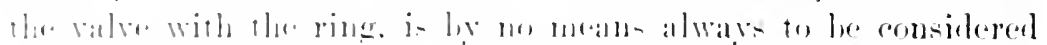

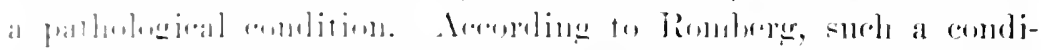

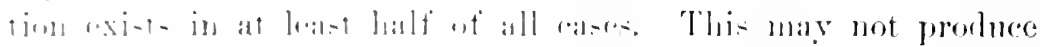
-

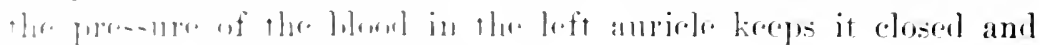

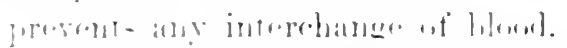

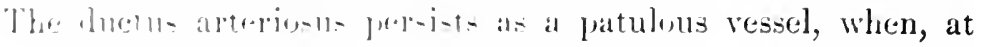


the time it shonld normally be obliterated, the blood-pressure in the alorta and pulunenary artery is so mergual that a current flows througl the duetus from one to the other. Thus in a case of pulmonary stenosis developing anly in fortal life, the contents of the right rentricle, experiencing difficulty in passing through the pulmonary orifiee, enter the left chamber through the imperfect interventricular saptum, and only a diminished quantity of blood passes into the pulunomary artery.

On the other hamul, the aorta receives an increased anount of blood on ancount of the extra supply to the left ventriele from the right chamber throngh the imperfect sieptum. Thus the tension in the aorta is rendered higher than that in the pulmonary artery, and a portion of hlood passes into the latter vessel throngh the ductus botalli. The stream in the ductus, it is to be noted, is in this. case flowing in a direction opposite to that normal in futal life, which is from the pulmonary artery into the alorta.

Persistence of the ductus may depend on aortic ats well as pulmonary defect, and may he due to a congenital reduction of the ealibre of the ressel, as in Fig. 107. The extreme case of atrewia of either artery necessitates the patency of the cluctus for the carrying on of the eirenlation.

Etiology.--There has been much speculation upon the determining factors in the development of congenital affections of the heart. Fortal endocarditis is quite generally attributed to the ageney of infections diseases operating through the maternal circulation. It has not been at all clear what influences learl to the production of developmental anomalies. Some have sought to account for these in tenlency or inclination to perversion of growth impressed upon the germ by the parent, and hence regard such abmomalities as stigmata of degeneraer.* This hypothesis is hased laregely on the fact that developmental defects of other parts of the borly are not infrequently associated with congenital cardiac anomalies. Other's, again, hold that these abmormalities, de-

* F. Simpson, in 4,252 antopsies of the insane, foumel fenestration of the aurtic valve on times; of the right semilunir, 18 ; of the mitral, 6 ; and of the tricuspid, 2. It was especially frequent in mes. Supernumerary and rudimentary valves were fomm very often. It would he interesting to know how these findings would complate with those from the sime numbre of necropsies of the sane. 


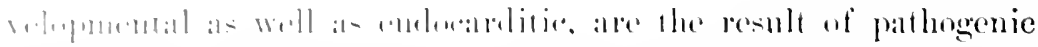

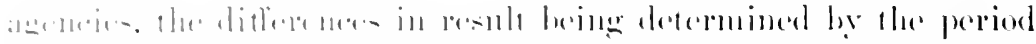

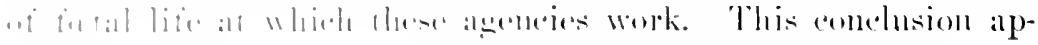

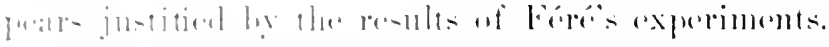

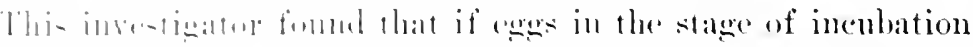

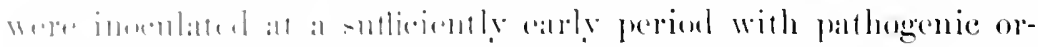

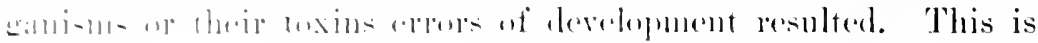

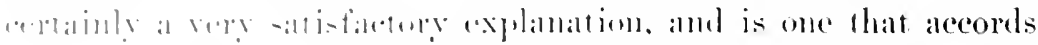

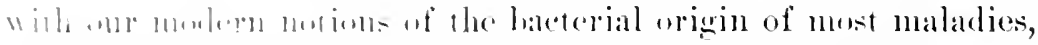

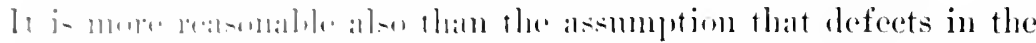
-

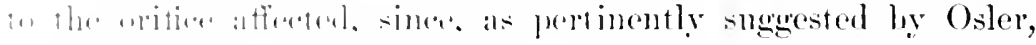
it i- dithenlt in mulertaml how an inflammation comlel fail to

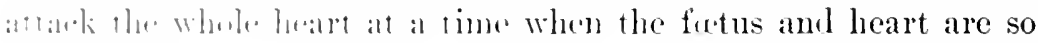
diminutire.

The rean for the perdeminance of endocarditis in the right

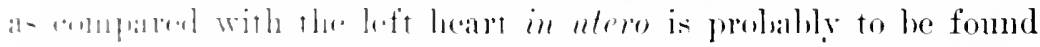

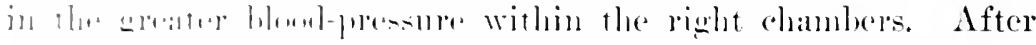

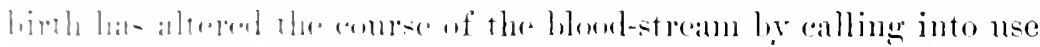

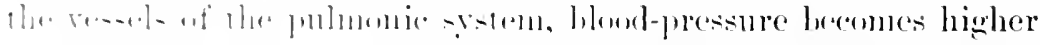

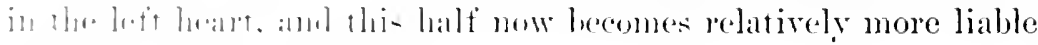

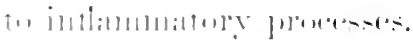

Symptoms. The dienders now under comsileration do not

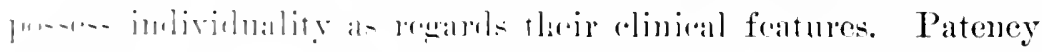

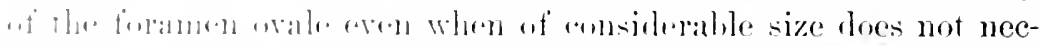

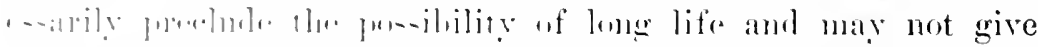

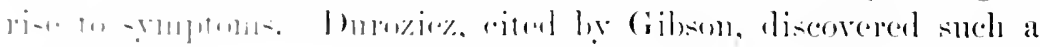

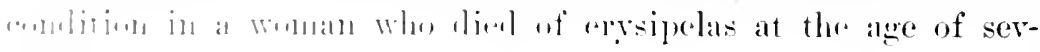

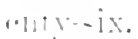

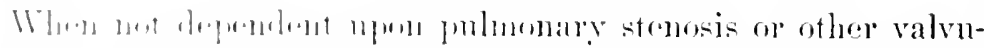

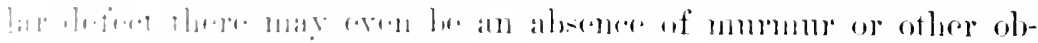

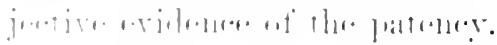

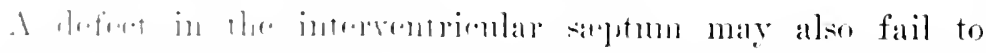

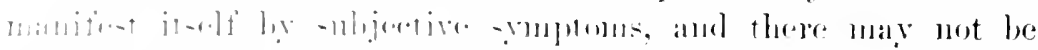

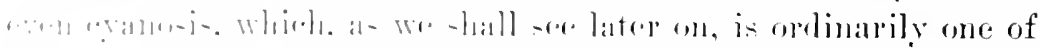
H. nom

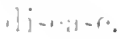

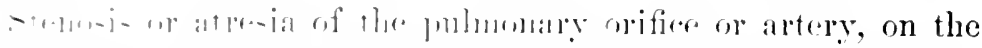

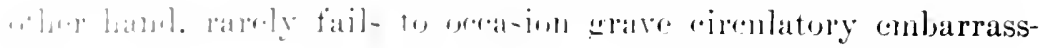


ment, and henee well-marked subjective and objective symptoms. It is in this the most frequently reegnised congenital affection, therefore, especially when attended by saptum imperfections, that

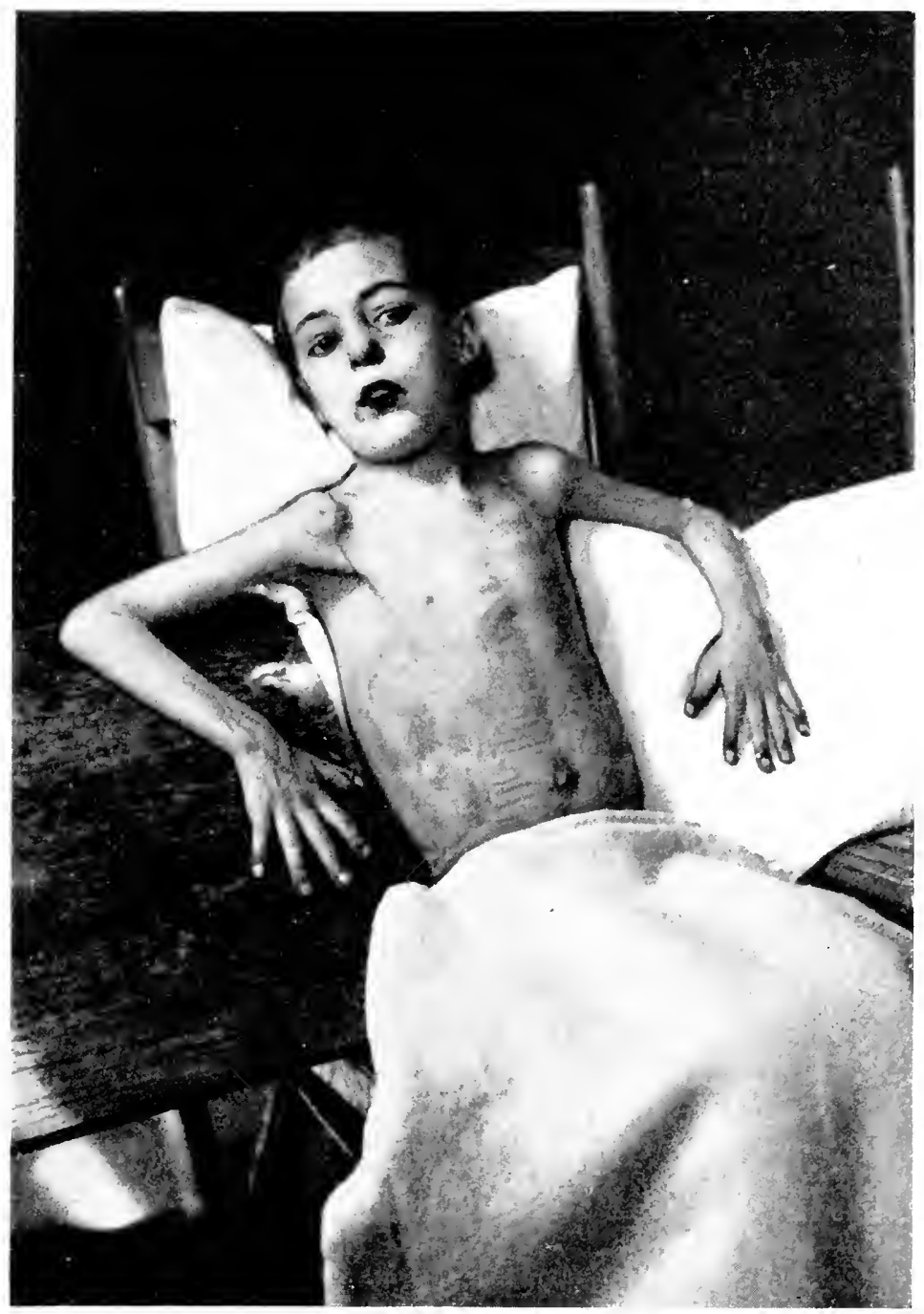

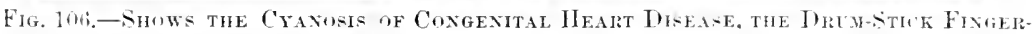

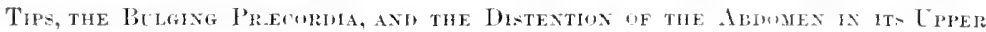
ZONE DEE TO HEPaTIO GONGE

patients complain of symptoms. It is worthy of note in this connection, however, that my patient, whose ease was narrated in the 


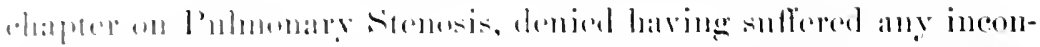

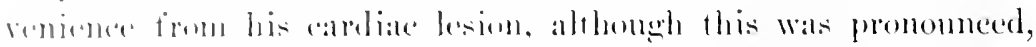

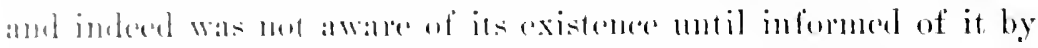

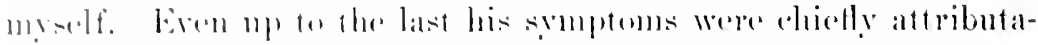
he ter the tuberenteris of the lunges, which was secomdary to his valvulatr disciase.

chihlens whe are burn with sorions disorder's of the heart

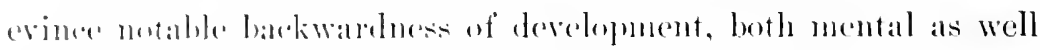
at hendily. Thoir intelledual processes are shogishe and they

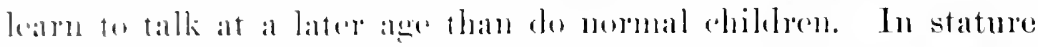
they are monally stmoted, aven dwatish, and they are apt to presont cortan striking poroliantios in appeatrance. The nostrils and lips are thiek and protruling, and the chest is more or less

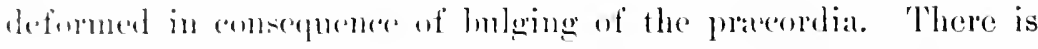
marked chubling of the fingers and toes with incouration of the natile, on that ly (ieman anthors they are likened to drum-sticks (Tremmelschlecter).

The most elatranteristic foiture, howerer, in persons with con-

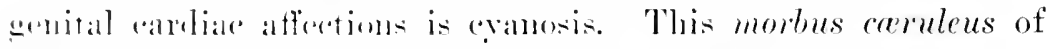
11] anthers is a general hut not miform bineness of the skin and muneme membranes, which is sometimes of so deep a hue as to he actually purple. It is most internse in those parts that are naturally recl-the lije. nostrils, cars, checks, nails, clbows, and kners. It is always intensified by exertion and during the act of angrhing.

Ther erameis and ofluer visible cirenlatory offects of congenital

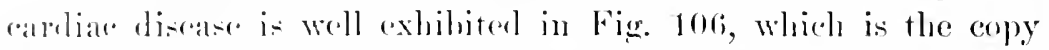

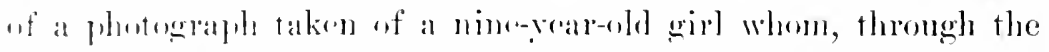

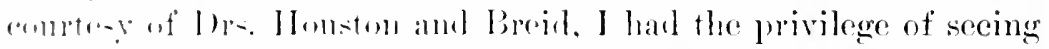

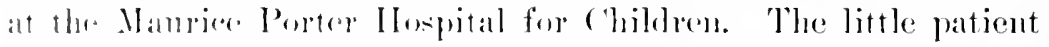

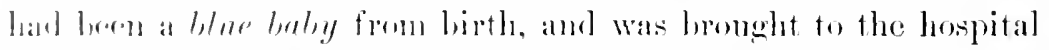

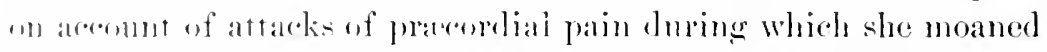
"nntimm-ly and displayerd signs of great ramliae foebleness. I

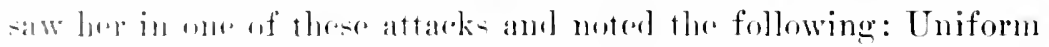

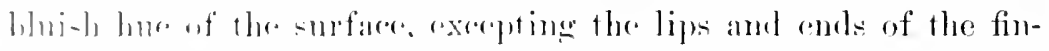

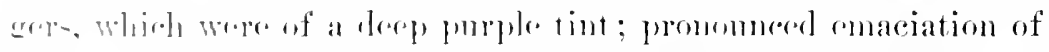

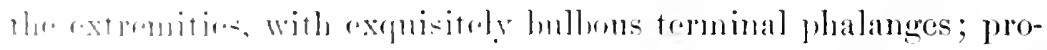

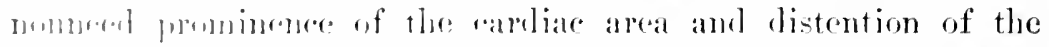
hepatie region at far as the umbilicus; turgesecence of the external 
jugulars; rapid and extremely thready pulse; rpigastric pulsation, but no aedroma.

Superficial andiac duhness was greatly increased in all directions, and doepreated duhness was of a quadrangulal outline, reaching from the second costal eartilage to the serenth in the median line, and from 2 inches outside of right sternal margin nealy to the left anterior axillary line. Its great breadth at its upper part over the auricles was especially noticeable. The heartsounds were very feeble, and over the body of the heart was a scarcely audible ret apparently systolic murmur. When, howerer, a hypodermic injection of $\frac{1}{24}$ of a grain of morphine, given to relicre the patient's distress, had stimulated the heart and enabled it to partially empty its overdistended chambers, and the little sufferer had grown quiet, the bruit came out loud and distinct. It was then found to have its maximm intensity in the third left interspace, close to the sternum, and to possess a very short presystolic portion.

From the great dilatation of the anricles, the position and character of the murmur and evident signs of impeded venons circulation, it was thought likely that this was a case of patent foramen orale, or other saptim defect, but whether or not with any other lesion could not he determined. The congenital nature of the defeet was attested by the plus percentage of hamoglobin, which was 115 per cent, and the number of red cells, which were in the reighbourhood of $7,000,000$.

It is needless to remark that cyanosis is not limited only to congenital heart-lesions, since it is also present at times in acquired cardiac disease. In the latter eases, however, it is never so intense.

Many attempts have been made to explain the ocenrence of cyanosis, hut as yet none is generally accepted as quite satisfactory. It has been attributed to venous stasis and to deficient oxrgenation of the blood, and apropos of this theory it is stated by Vierordt that Mioritz found the $\mathrm{CO}_{2}$ increase to between 45 and 46 per cent. Romberg thinks the eyanosis may be attributed to the abnormal admixtme of arterial and renous blood. The intensity of its lue is due to the dilatation of the eapillaries (Vierordt), which takes place to a far greater extent than can be the case in those diseases in which stasis derelops more rapidly. 


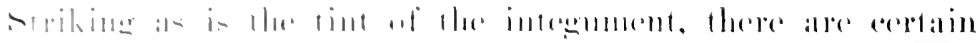

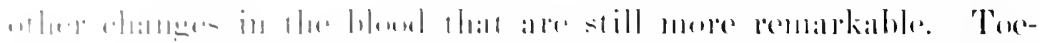

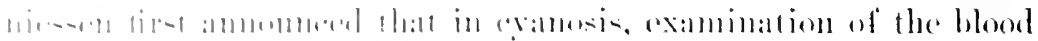

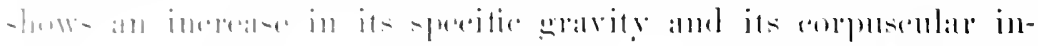

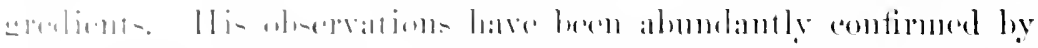

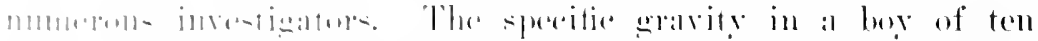

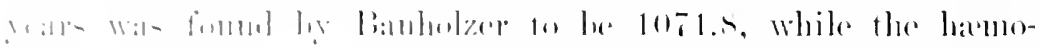

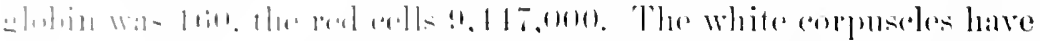

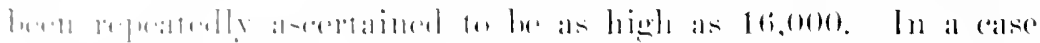

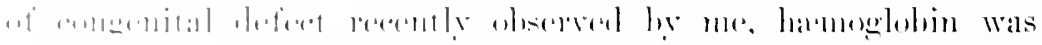

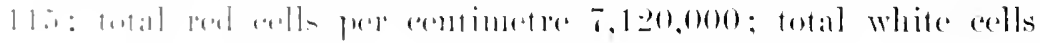

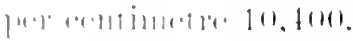

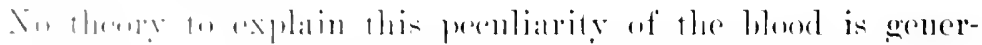

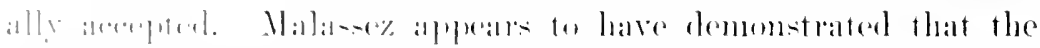

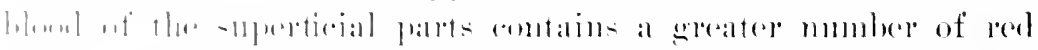

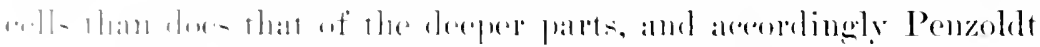

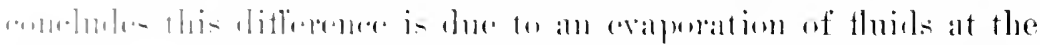

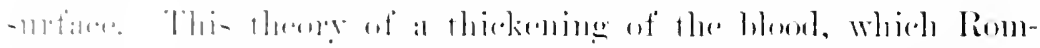

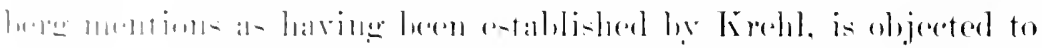

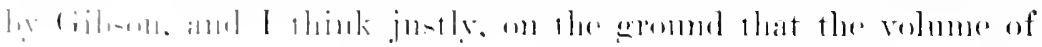

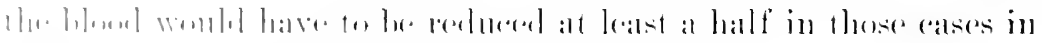

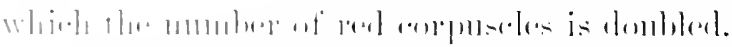

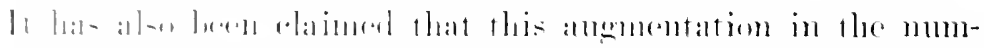

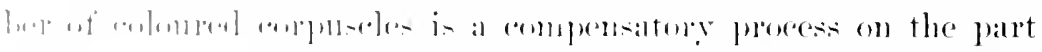

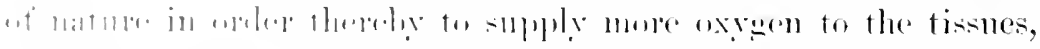

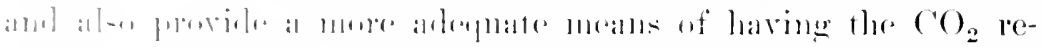

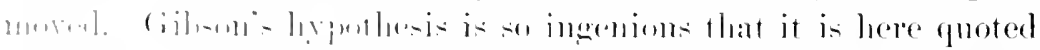

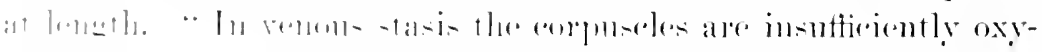

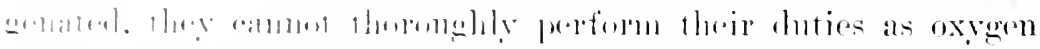

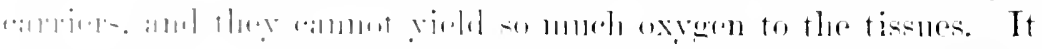

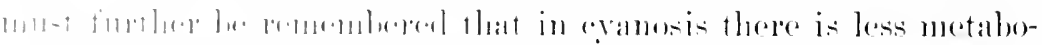

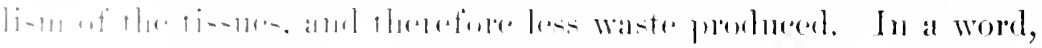

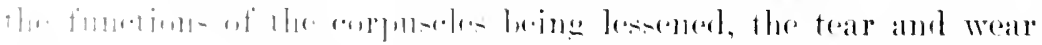

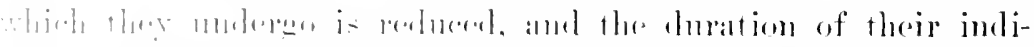

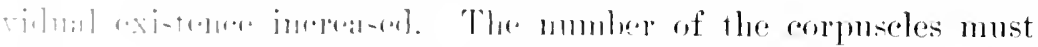

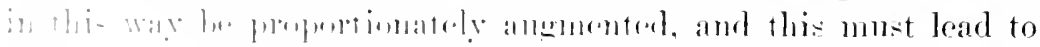

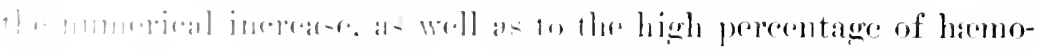

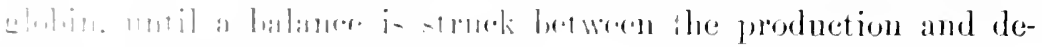

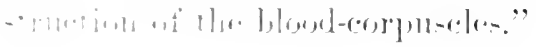


In contrast to the nsual results of l, lood examinations in these cases Monille is cited by Vierordt as having found a reduction, the red cells ranging between $3,500,000$ and $4,500,000$, yet this in no way invalidates the general proposition that the corpusenlar elenents are increased in cranosis. Finally, it shonld be stated that a similar thomgh less striking increase is observable in evanosis in acquired heart disorders.

Laemec and Rokitansky attributed to eranosis a protective influence against the derelopment of pulmonary tuberenlosis. Their views are erroncons, howerer, since it is a well-known fact, as has been stated in the chapter on Pulmonary Stenosis, that patients with this affection, in which cranosis is particnlarly apt to occur, are especially prone to tuberculons disease of the lungs.

Another smmptom in cases of cranosis is coldness of the skin, particularly of the extremities, and hence these patients are remarkably sensitive to cool atmospheres. They are also rery subject to dyspnea and often manifest pronomed shortness of breath on comparatively trifling exertion, as was present in my ease; but this, as we have seen, is a srmptom common to all forms of cardiac disease in the stage of defective compensation. In these cases, when dyspna is a marked feature, there is nsually evidence of considerable visceral stasis. In congenital cases, on the contrary, breathlessness is not infrequently pronounced out of all proportion to the signs of engorgement in the varions organs, aside from the eapillary dilatation emphasized by Vierordt.

This lack of such renous stasis as would ordinarily be expected in cardiac disorders of such evident gravity, is attributed by Romberg to the slowness with which the reins have been required to accommodate themselves to their almormal burden (ueberlastung). Nevertheless, the deficient arterial blood-supply and the shggish return of venons blood and the defective metabolism lead to disturbances of function on the part of the varions visceral more or less severe and commensurate with heart-power. The rariations in the pulse will be spoken of in comnection with the phrsical signs now to be considerert.

Physical Signs.-Inspection.--This is of special vahe only in the cases in which there are evanosis, a dwarfish appearance, clubbing of the fingers, precordial bulging, and other signs 


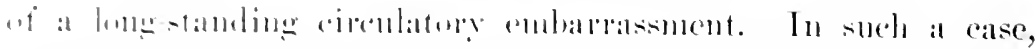

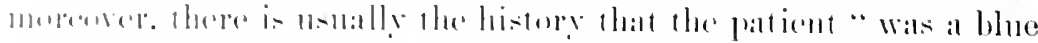

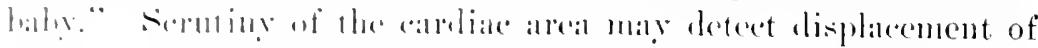

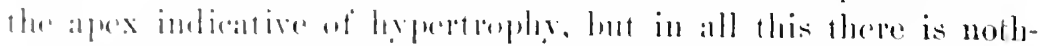

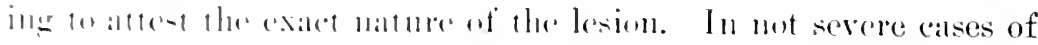

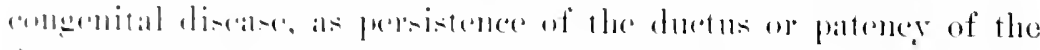
foramen wake there maly he nothing whaterer in the patient's

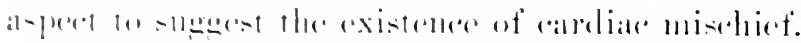

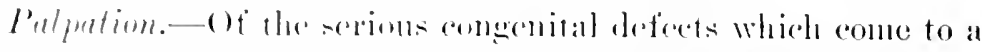

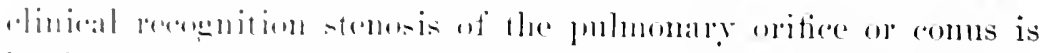

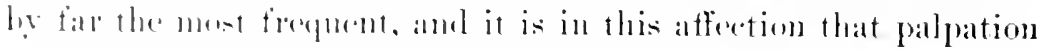

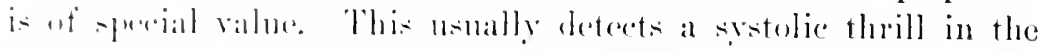

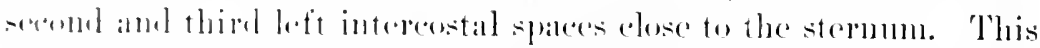

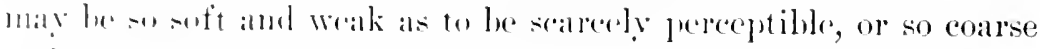

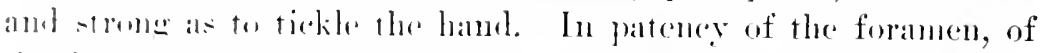

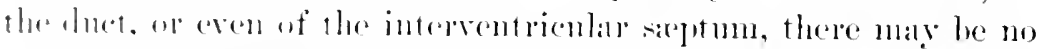
thrill mulese andiated with sone olstruetive lesion, als just mentimenel.

For the mont part anthors pay but little attention to the pulse,

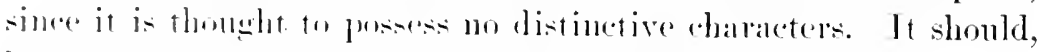
luwere be giren particular sturly in eases of pulmonary steno-

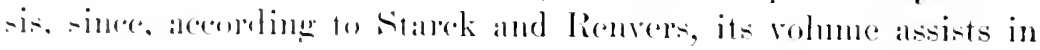
detemining the puestion whether or not there is asure of the

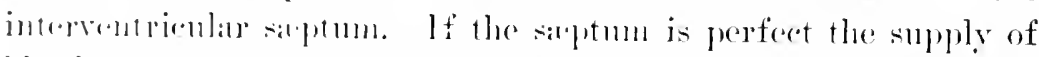

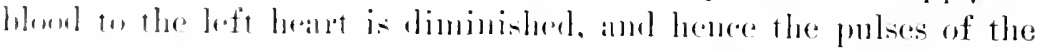

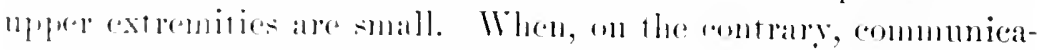

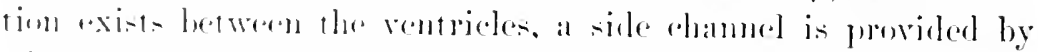

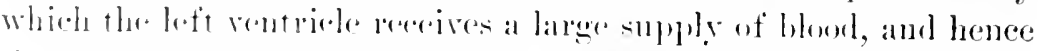
the pulen are of ereater rohume. Comserpently, if in a given

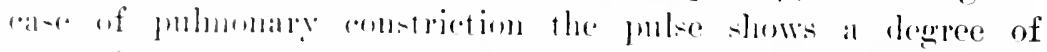

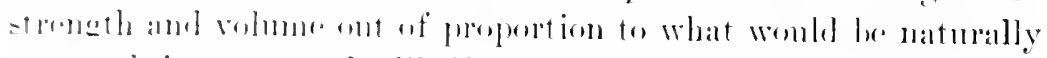

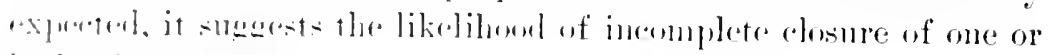
lwoth withe septa.

keli-ke is repertent to have tatted that whell persistence of

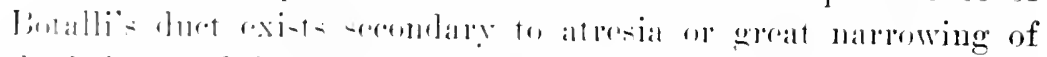

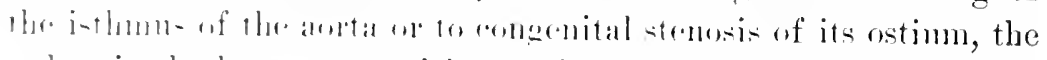

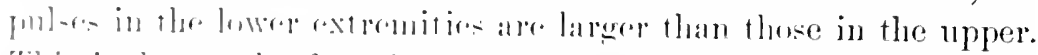

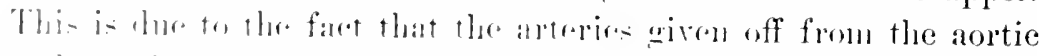

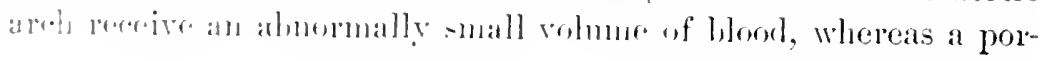


tion of the blood pent up in the pmlnonary artery and intended for the ascending atortal throngh the left rentricle is switched off throngh the patent due: and enter's the descending aorta, thus supplving the lower extrentities with a disproportionate share of blood.

Percussion.-As in acquired heart-disease this means of investigation slomld not be neglected, since it is of extrene importance to discorer possible modifications of eardiac dnlness. In pulnonary obstruction the absolute and relative dulness are both increased to the right and downward in consecpnence of the rightventriele hypertrophy. In patent foramen ovale and a defective ventriculan saptum the rardiac outline may or may not be increased transtersely, acoording to the severity of the lesion. When the ventricular sinptum is incomplete the erreater bloodpressure in the left rentricle forces a portion of the contents throngh into the cavity of the right rentricle. This chanber becomes surcharged, and tends therefore to hypertrophy and dilatation, which condition is slown by increase of cardiae dulness in that direction. Neverthelese, in looth patency of the saptum and foramen massociated with other lesions pracordial dulness may in some cases rentain normal.

Auscultution.-This nsnally furnishes the most valuable information concerning the presence and natme of these eongenital affections by the detection of a mmrmur. Yet in cases of saptum defects, inchding of conrse the formuen, there may be no murnur of any kind. When such a bruit exists, it is nsmally a lond systolic mumur hearl throughout the cardiace areal, partienlarly orer the base. It does not appear to be linited to any area, as are the nummurs of aconired valvular disease; and this fact, when noted, possesses a certain amount of vahe.

Robert Magnire thinks that the srstolic bronit of a defective ventricular siptum is most distinct over the sitnation of the interrentricular groore, and decreases in intensity as the stethoscope reedes from this line in either direction. As, however, the only case he has reported, so far as I have been able to learn, has not yet come to a necrops, the proof of his contention is wanting, and althongh the statement may appear plansible, it camot yet be aceepted umreservedly.

Worcester has reported a case of patchey of the foramen orale, 


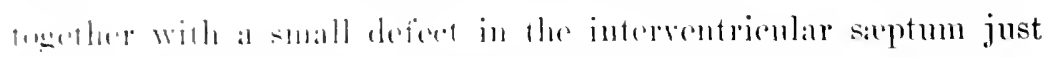

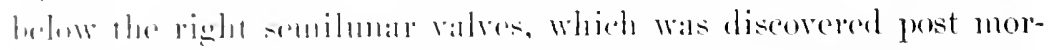

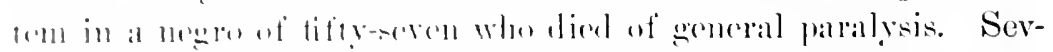

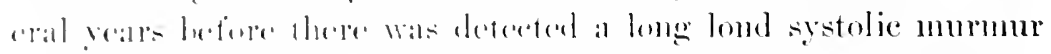

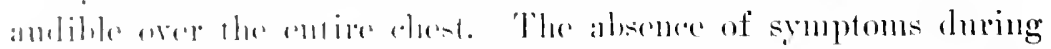
life is to he inferenel from the fact hat he serverl as a soldier

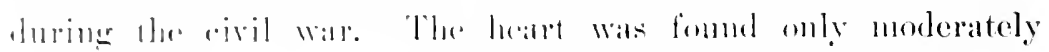

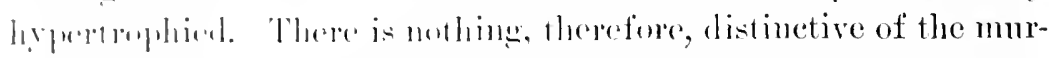

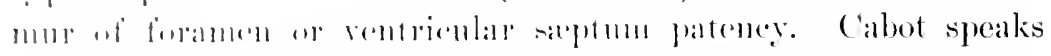

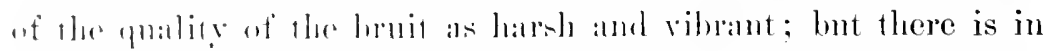
this statement molimg alt all distinctive. In the ase of a boy

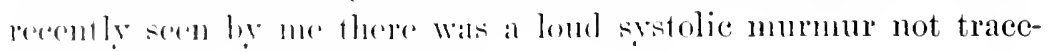

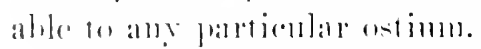

Fur a leneription of the mummur of phlmonary stenosis, as

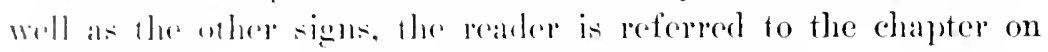

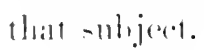

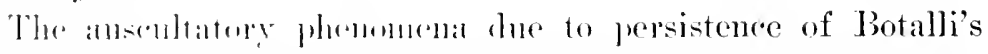
dure ane lus dereribed in the nallation of a case I had under

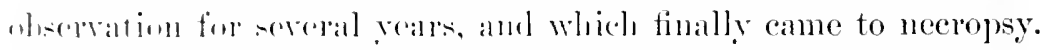
The paldont was an muldesized woman of fwenty-one who suffered

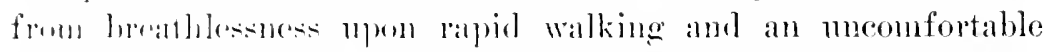

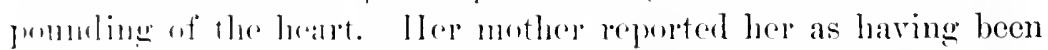

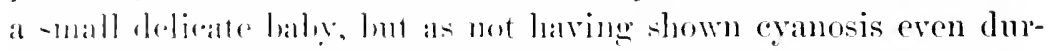

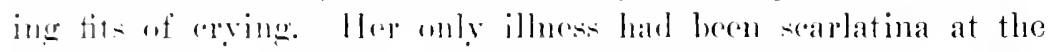
age of nime. The rarlial pulses weres small, regular, equal, and

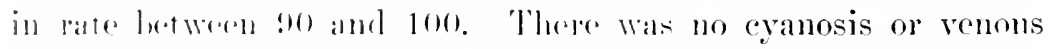

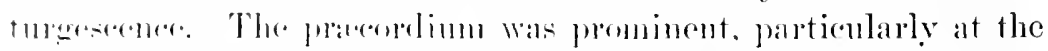
Int of the strmmu, hut war mot pigeon-lueasted. The apex-beat

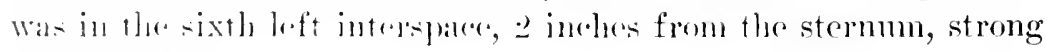
and diffin-r.d.

There was a soft, not very distinct thrill in the second and

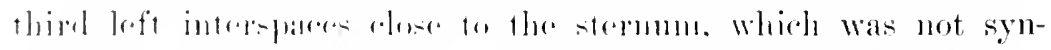

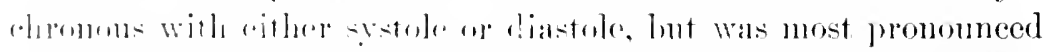
at the

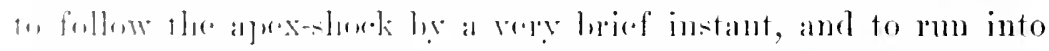

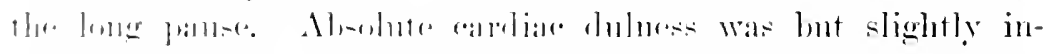

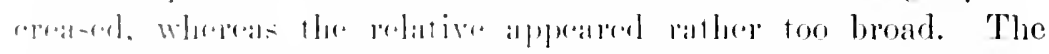

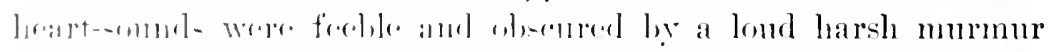

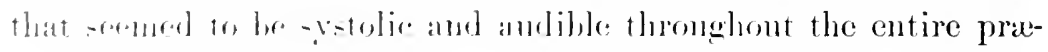


cordia, but most planinly at the base, and was lomsmitted to the lower angle of the left seapula.

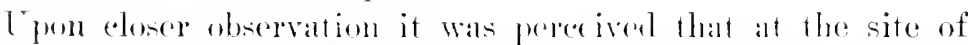
the thrill the murmu: becane a continuous memitting roar, having

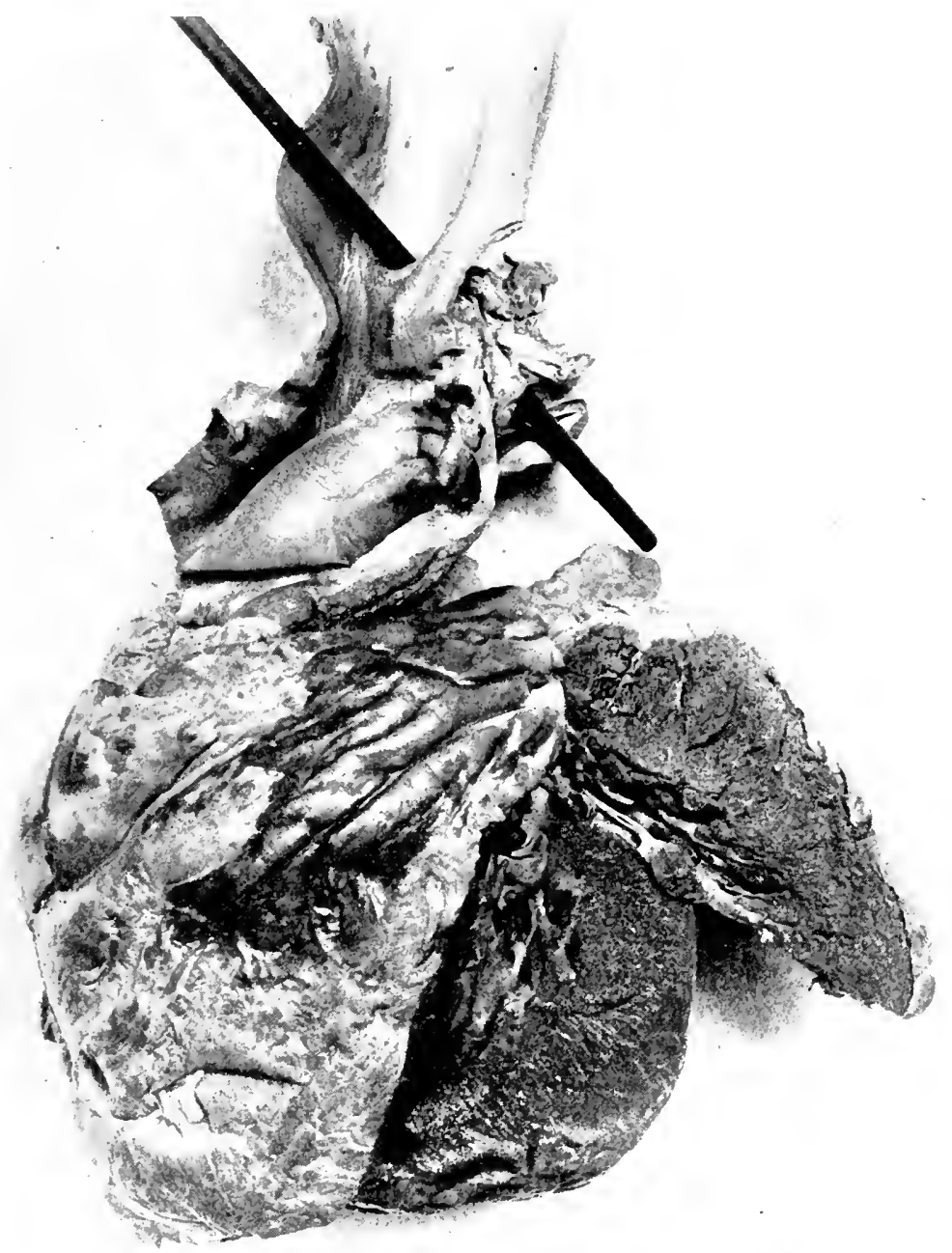

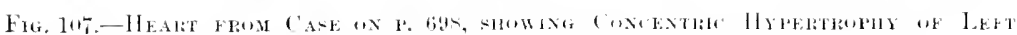

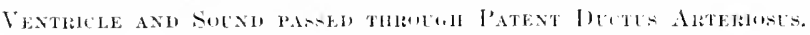

its maximum intensity just after the first sound and its minimum towards the end of the long silence, hut never entirely ceasing. 


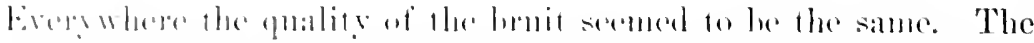

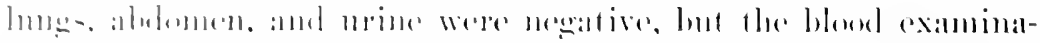

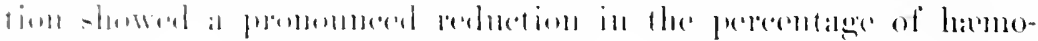
shlin.

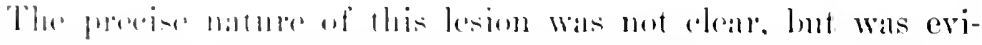

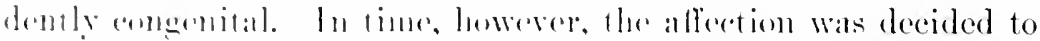

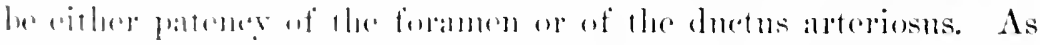

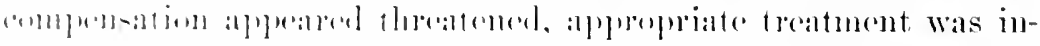

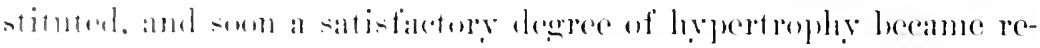
atshli-hard.

T" maki a lome story short, this pationt nutimately married and was deliverent of a child, palssing throngh both pregnaney

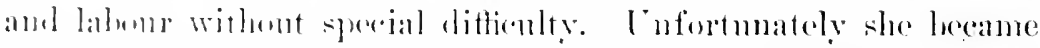

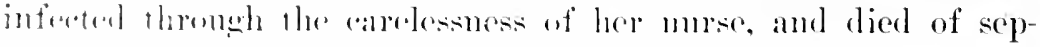

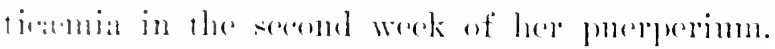

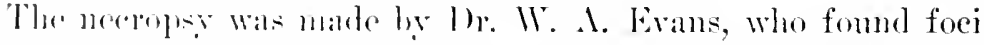
"f suppuration in the right kidney and liver, but no svidenee of intlanmation in the aldiale struetures. The specimen is presented in Fig. 10-. The left ventricle wats concentrieally hyper-

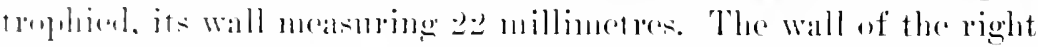
rentric|lo meis:ured 11 millinetres, amd was therefore also thicker

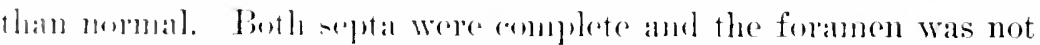

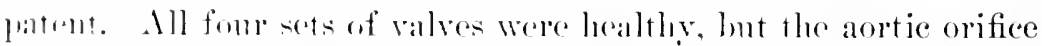

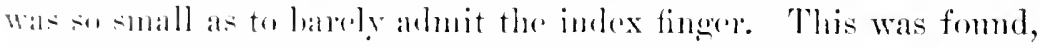

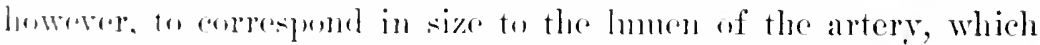

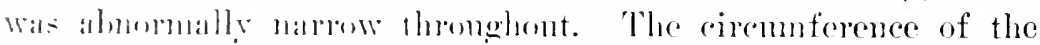

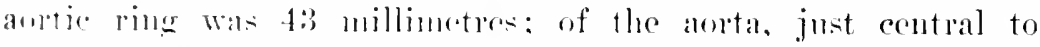

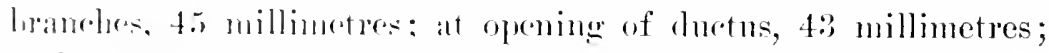

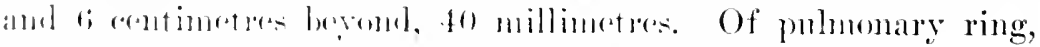

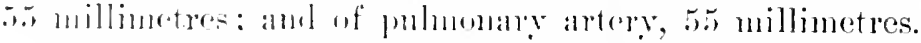

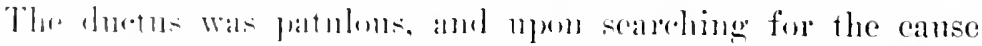

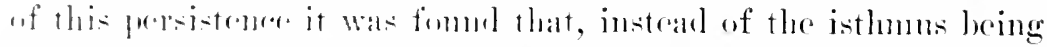

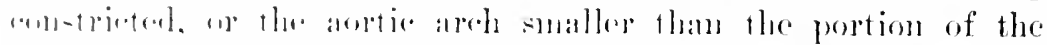

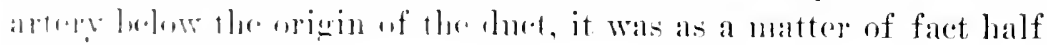

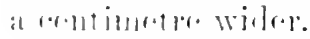

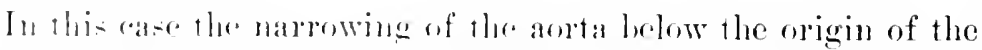

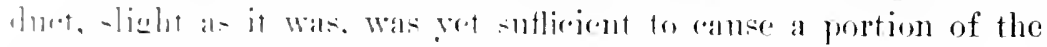

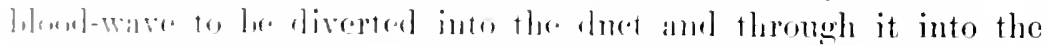

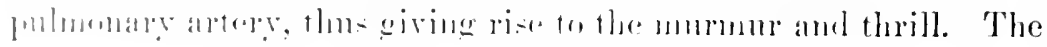


left-rentricle hypertrophy wals secondary to the antic narrowing. This was an instance of chlorosis aortica, and aecomted for the fact that treatment hial never been able to restore the hamoglobin to its nermal pereentage.

I have under obervation at the present tine two other patients, one al woman, the other a young man, who present ahmost identieal physical signs and who, I believe, are also instances of this same congenital anomialy:

Diagnosis.--As there are several affections cmbraced by the term Congenital Candiac Affections, it would be wearisone and mmecessary to recapitulate the physical signs by which each may be diagnosticated, and hence the reader is referred to what is stated above nuder the caption of p? to be here stated that the congenital nature of the affection must be determined by the history and in sone cases by a blood examination. If there is a history of the individnal haring been "a blue baby" or of his having been feeble from birth with evidenee of circulatory embarrisument directly after birth, and if the child's appearance corresponds nore or less to that described under inspection, there is strong likelihood of the cardiae disease being congenital. In many instances the parents are able to state that the family doctur discorered signs of heart-disease as soon as the infant was horn or in its carliest weeks of life.

If the person presents well-narkerl cranosis, and if examination of the blond dischese the changes previonsly describedi. e., an increase of hemoghobin and red corpuscles orer the normal-the diagnosis of a congenital defect can be positively made. In some cases, at of pulmonary stenosis, there may be nothing to prove eonehsively during life whether the discase is congenital or acquired. In such a care, however, probabilities are always in farour of its prenatal origin, owing to the great rarity of the aequired form.

Finally, in doubtful ases of persistence of Botalli's duet, it is stated that by means of the fhoroseope a positive diagnosis may be made.

Prognosis.--. Is stated in the smptomatology of persistenee of the formen, this abnomality may oceasion no signs of its presence, and patients may reach an advaneed age, and die of some intercurrent affection. Enassociated with an affection of the pul- 


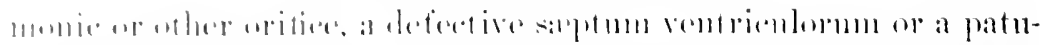

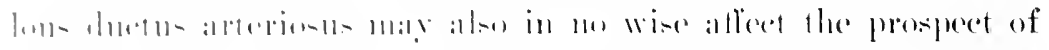

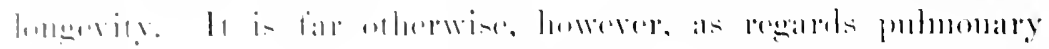

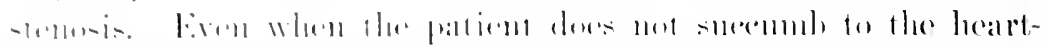

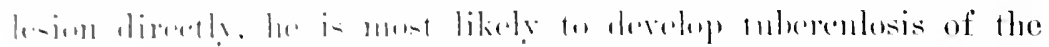

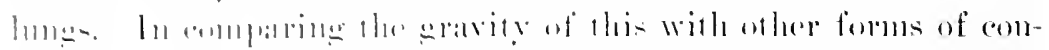

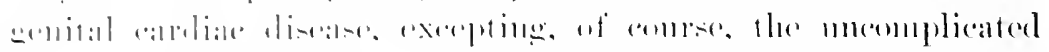

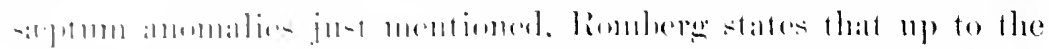

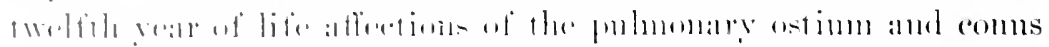

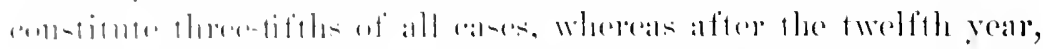

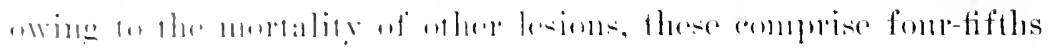

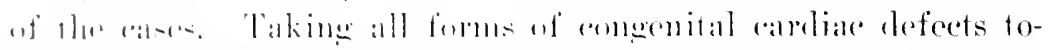

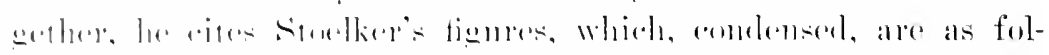

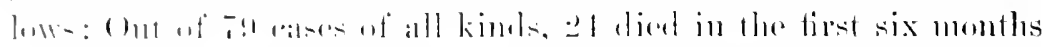

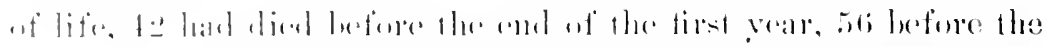

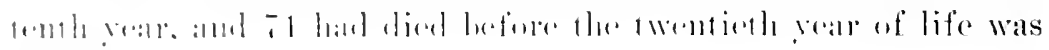

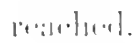

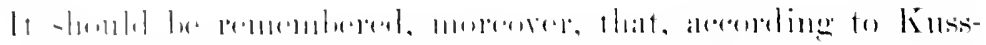

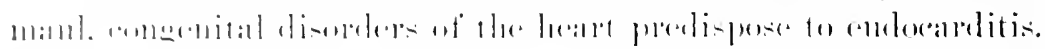

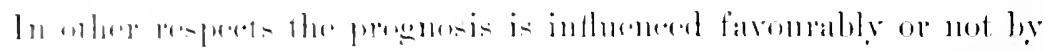

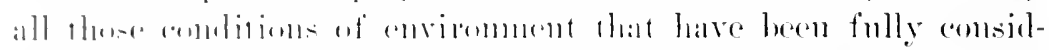

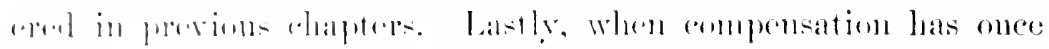

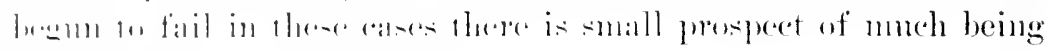

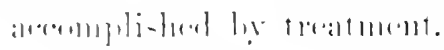

Treatment. I- may la intirued firm the proceding sen-

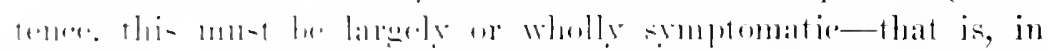

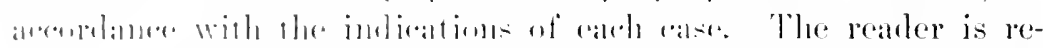

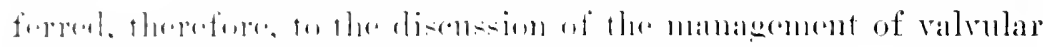

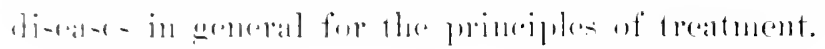




\section{SECTION IV \\ CARDIAC NEUROSES \\ SYN.: FUNCTIONAL DISORDERS OF THE HEART}

\section{CIIAPTER XXX}

\section{PALPITATION, TACHYCARDIA, CARDIAC PAIN, PSEUDO-ANGINA PECTORIS}

Pathology.-There is a class of disorders which manifest themsches clinically by a perverted action of the heart, or by pain and other sensations in the cardiac region, or by a combination of the two, ret in which no structural alteration of the organ can be detected. They are often spoken of, therefore, as functional disorders of the heart. Objection is made to this term on the ground that in oratuic cardiar disease there is a disturbance of function, ancl, strietly speaking, such affections may also be designated functional drangenents. Furthermore, it cannot be aftirmed absolutcly that some as yet undiscoverable alteration of the structure of the heart dnes not nuderlie or attend its perversion of function. Ifowerer logical surh rasoning may be, the term functional has been sanctioned by usage, and is generally understood by the profession and the laity to mean an affection which is not asociated with demonstrable structural lesion. For this very reason it $\mathrm{i}$ often alvisalle in speaking to the patient or his friends to designate the disturbance as functional. $A$ fear or an exaggerated notion of the grarity of the complaint may thus be allayed. Although from force of habit I frequently speak of these affections as functional, I yet prefer the designation cardiac neuroses, since one cannot observe these rases without coming to the conchusion that the manifestations on the side of the heart are the expression of a disorder of the nervons system. 


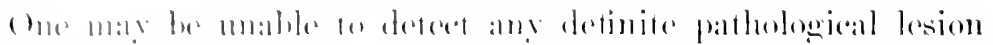

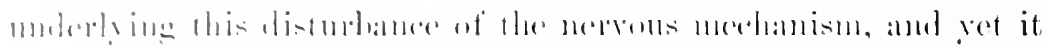

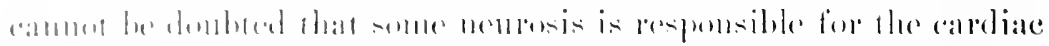

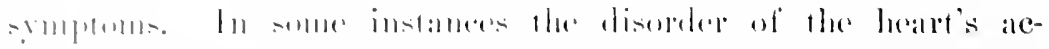

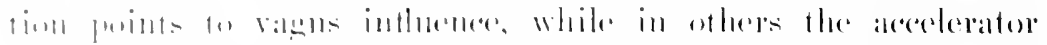

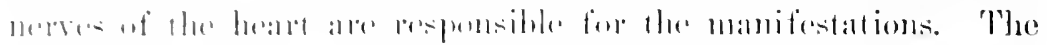

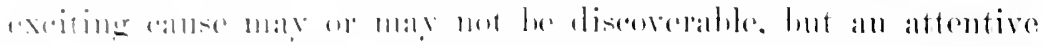

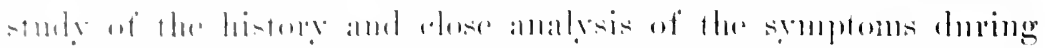

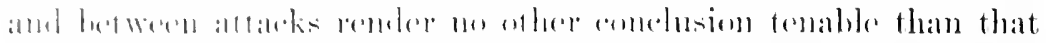

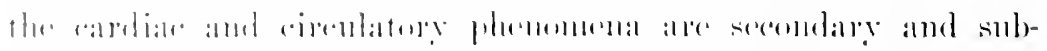

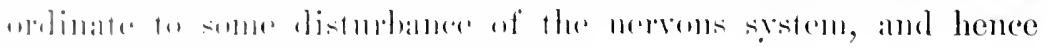

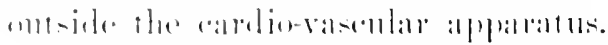

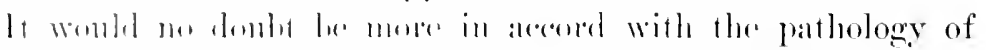

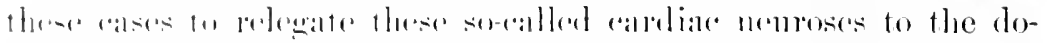

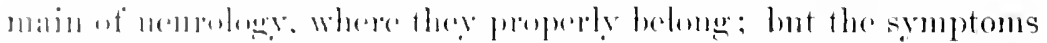

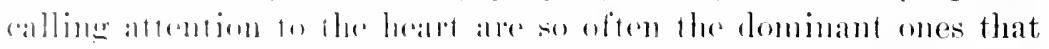

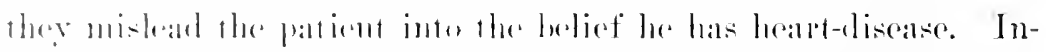

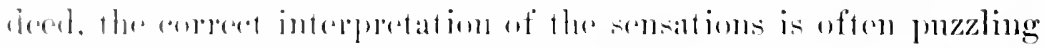

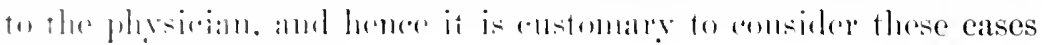
in works of this kimel.

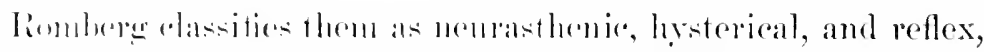

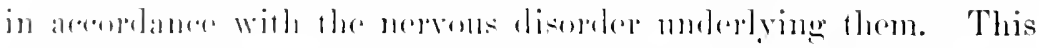

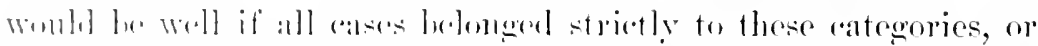

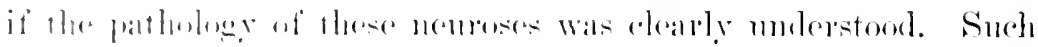

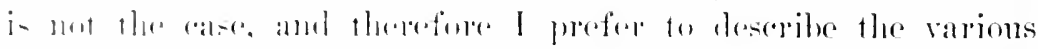
mantestaltions without attempting to divile them accosding to

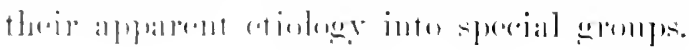

\section{S'ran?}

Palpitation. - This is a transint lorangement of carliac ac-

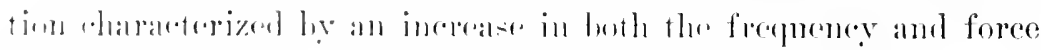

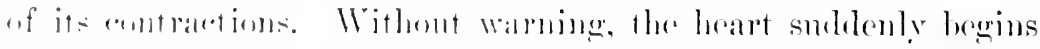

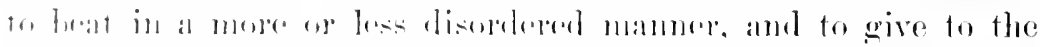
imlivilual the sensation of a pumding or knocking against the

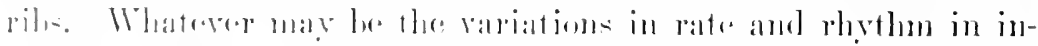

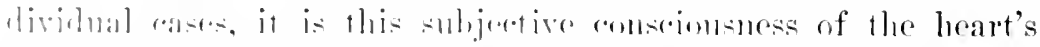

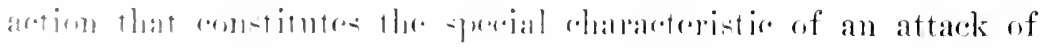

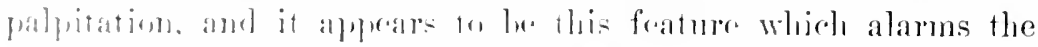

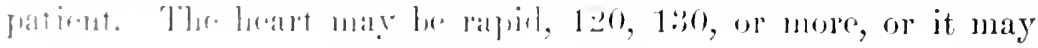


remain below 100 , but whatever its rate its action is violent. In the matter of rhythm also there are differences. Ordinarily the pulse is regular, but it may be irregular in frequency and force, and may be even intermittent. When this is the case the individual is likely to be thrown into a state of great alam.

Each time the heart intermits, it is ammomeed by a sensation of the organ suddenly falling or sinking in the chest; it is often deseribed as a "sinking feeling." This is sneceeded the next instant by a powerful throb, a sensation as if the heart gave a flop or jumped up into the throat, and with this very meomfortable fecling the patient is apt to make a sndden exclamation or outery, and perhaps quickly press the hand against the precordia, as if trying to grasp the refractory organ. The heart may then quiet down, or it may race off as madly as before. It appears to me that in strictly neurotic persons withont any discoverable organie mischief it is more common for the heart's action at these times to be rapid and regular (tachyeardia).

During the attack of palpitation there is often a violent throbbing or pulsation in the arteries of the neck or in the abdominal aorta, or in both situations. The hand placed against the pracordium readily appreciates the energetic beating of the organ, and not infrequently the eye pereeives a rapid rising and falling of the cardiae region. As it is so often expressed by the friends, " you can see the heart beat through the colothes." If the radial pulse is examined dnring such an attack or "spell with the heart," to quote the popular phrase, it may be fomd full and quick, or if the rate be extremely rapid, small and feeble. Vaso-motor changes are also very apt to accompany the seizure. The face flushes or pales, as the case may be, and the hands and feet are usually cold.

One of the most typical examples of palpitation was presented in a young man who consulted me only a few days ago. He was twenty-two and an athlete of superl physique, standing 6 feet $2 \frac{1}{2}$ inches, weighing 200 pounds, and with muscles of steel. He is an expert boxer, and can endure an arduons sparring-match without palpitation or shortness of breath. Two years ago he passed through an umusually severe typhoid fever, from which he made a good recovery with the single exception of sudden attacks of rapid, violent beating of the heart, that almost invariably came on 46 


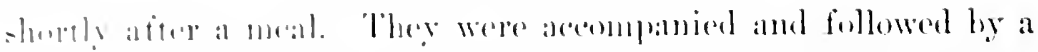

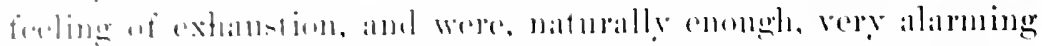

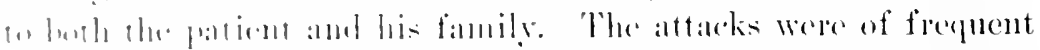

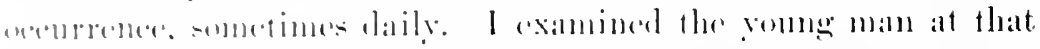
fime amb was malle to discorer any indieation whaterer of car-

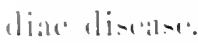

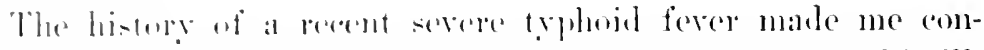

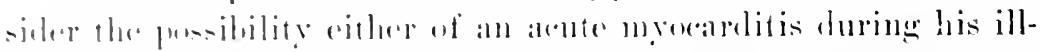

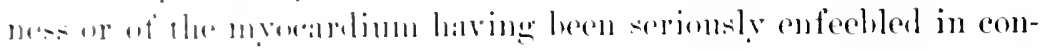
-

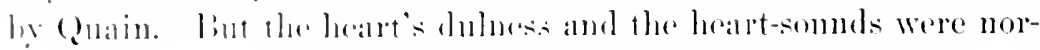

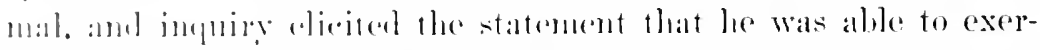
aine inderal hanl hut just returned froun a shooting trip in the menntains of Xonth carolina, withont experieneing any shortness

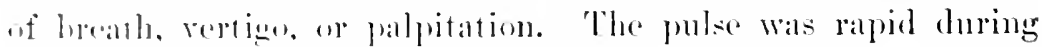
my uxamination, lut its volume and force were execllent. I therefire asinred him thal his attacks were of a functional nature and

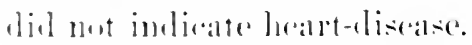

Ilis flen at that time was rather ton flahty, and he said he

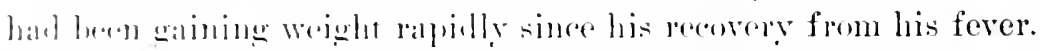
Minne inguip into his babits, aliot, ote., bought ont the fact that

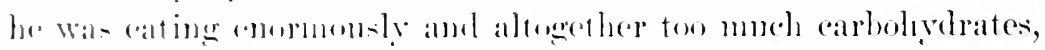
and was in the lablit of drinking a larere anomut of water with

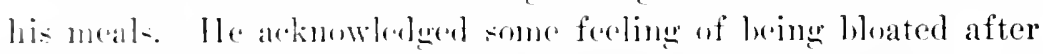
ratiner. It was aneluded, in the alsenee uf otlee etiological fac-

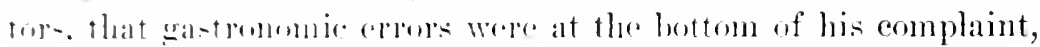
and he was andised to rout ont his sweets and starehes, to limit his

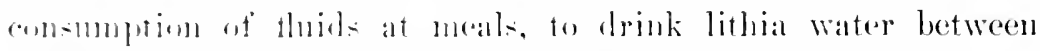

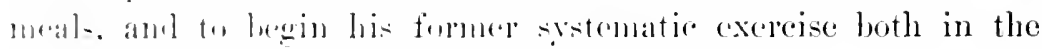
grombarimm and ant of losers.

This rogime was faithfully alderel ont, with the result that

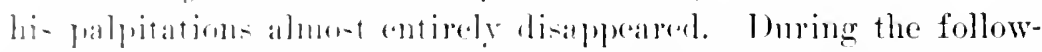

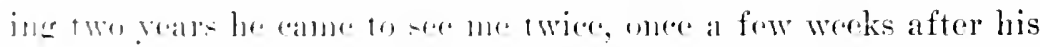

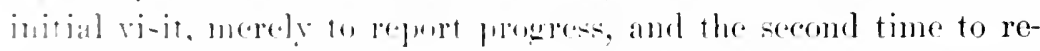
rojre an examination for lifre insulance, which on my recommendation wa-gantral hin.

This- Jast werk. low werer. lue "alue again with his father, who

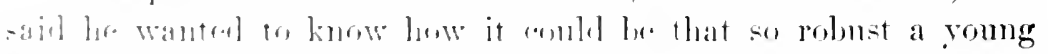
matu ould still have his attacts of palpitation without there being 
something wromg with his heart. He then explained that the Sunday previous his son was about to start for church with his wimther, when all at once he was discovered by his father lying on the floor and his heart beating so fast and hard that it conld be seen through the clothes. The attack lasted abont twenty minutes.

The young man then spoke up and said he thid not see any use of being coneerned about the affair, as he knew perfectly well what had brought the attack on. II had eaten too hearty a breakfast, consisting of coffee and three pieces of German coffee cake, besides fried ehicken and fruit. An examination was then made, and a more normal heart I have never listened to. The pulse was steady, regular, and 80 , standing. The apex-beat was in the normal sitnation, absolute dulness was not inereased, and the relative measured 3 inches to the left and 1 inch to the right of the sternum. The sounds were elear, of normal relative intensity, and entirely free from imurmurs of any kind.

It was without hesitation, therefore, that the opinion expressed two years previonsly was reiterated. It was not quite clear why the attacks shonld take place in so powerful and an apparently perfectly well yomg man, hut there was certainly an etiological connection between the attacks and indiscretions in the way of a too liberal allowance of carbohydrates. There was either a temporary abeyanee of vagus control or a stimulation of the accelerator nerves of the heart. Whether this was an instance of reflex irritation or of some toxic influence resulting from indigestion, was not at all clear. But it would be ordinarily classified as a reflex cardiac neorosis.

In the foregoing case precordial pain or other sensations of an allied nature were never complained of. It is quite common for an attack of palpitation to be accompanied by a painful sensation in the region of the heart or for the exaggerated eardiae action to follow the pain. At other times the patient may complain of the heret's pribations as painful. In still other cases the chief complaint is of an indescribable feeling of distress or discomfort "at the heart," which is usmally but not invariably attended or sneceeded by palpitation. Such symptoms are frequent in inclividuals who are hysterical. This class of eases is well illustrated by the following example:

A physician, aged twenty-four, height 6 feet 1 ineh, weight 


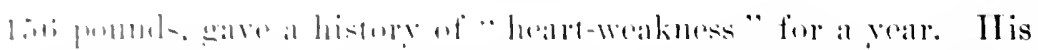

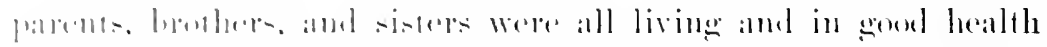

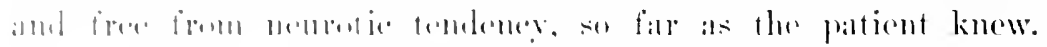

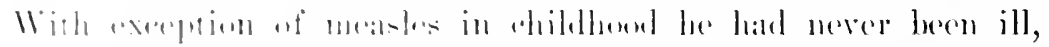

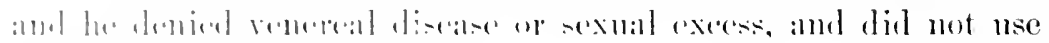

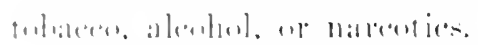

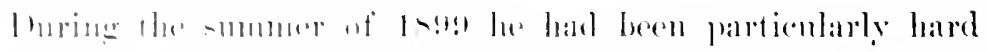

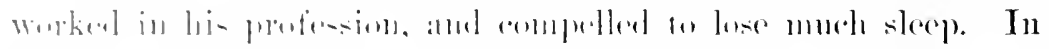

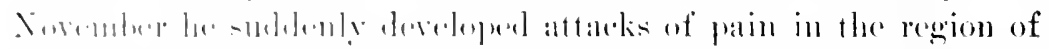

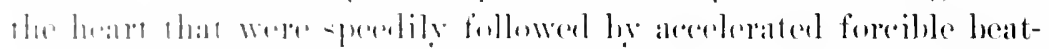

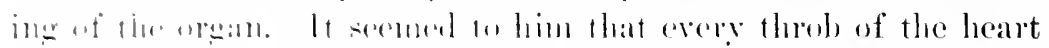

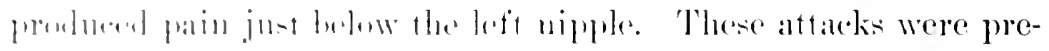

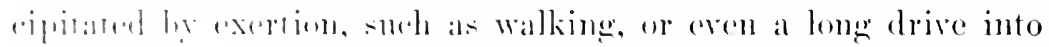

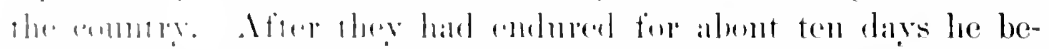

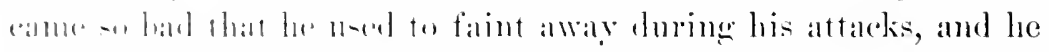

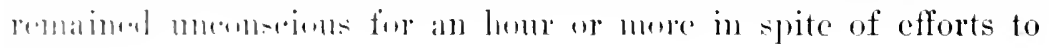
revive him.

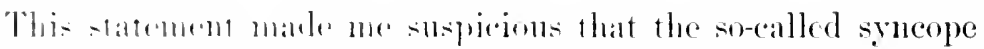

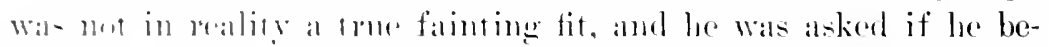

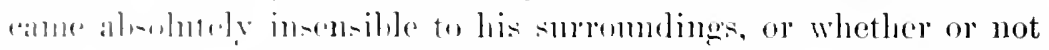
ho knew in a dim way what was heing dome to him. Te then

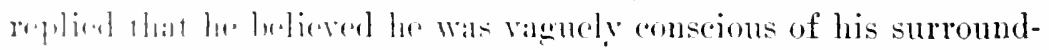

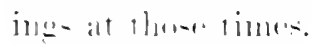

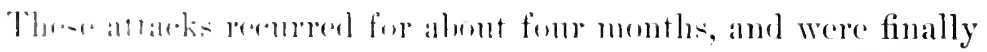

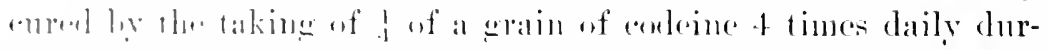

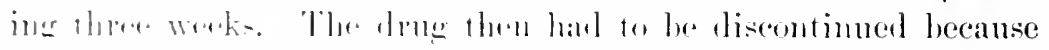

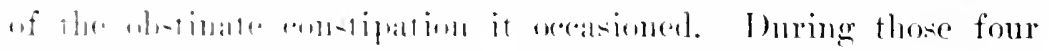

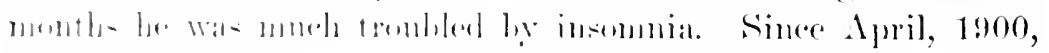

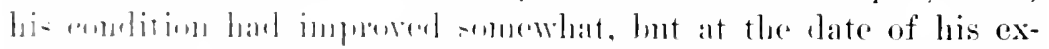

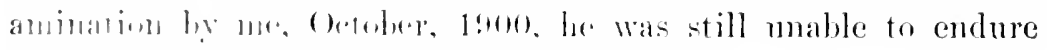

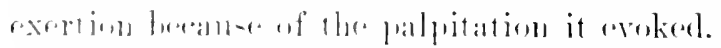

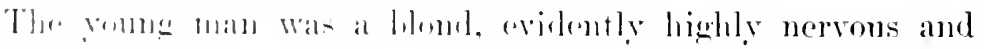

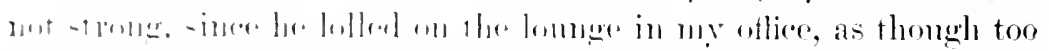

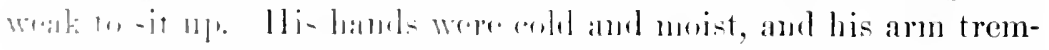

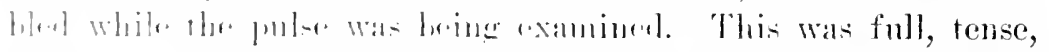

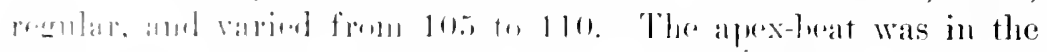

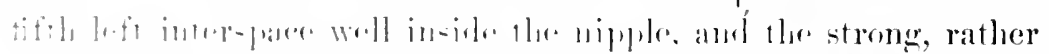

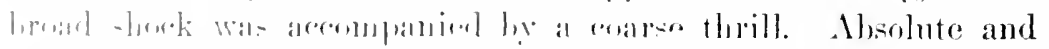

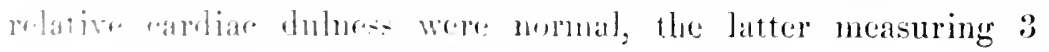


inches to the left of the sternal margin and 1 inch ontside the right stermal horder.

The first sound at the apex was partially obsenred by a rongh vibrant murmur of whizzing quality, which was londest in the ereet position, disappeared in the right lateral decubitus, and was scareely andible when the patient lay on his left sile. It was increased in intensity at the end of deep inspiration and grew ahmost inandible at the close of expiration. The second pulnonic sound was not accentuated.

The liver was not palpalle and its duhess did not pass below the inferior costal margin, right nipple-line. The abromen was negative. The patient reported his mine as negative, contaning neither albumin nor sugar. He was not conscions of indigestion, and the bowels were not constipated.

The diagnosis was made of a cardiae neurosis with an aceidental murmur and palpitation.

The patient was advised to spend the winter in the South, where he conld be in the open air, to take morlerate, regular exereise, and endearour to build up his nervons system, and to school himself to regard his malarly as not organic. In the way of medieation he was advised to take strychmine, give up the nse of digitalis and allied heart tonics. Up to the present writing $I$ have had no further report from this case.

This patient illustrated another feature of hysterical patients with disordered heart action. IIe declared he was always conscions of its pulations, and could tell how it was beating withont having to feel his pulse. To test him in this matter I took hold of the wrist and comted the pulse, and then told him to count aloud his heart-beats. In this he ntterly failed, and I became convinced that his sensations were imaginary. This is not always the case, however, for in some instances the cardiac action is sufficiently exaggerated to be perceived by the patient. Sometimes, too, when the pnlse-tension is high the individual can perceive pulsations in the extremities.

The powerful influence of the imagination and the readiness with which an attack of palpitation can be elicited by trivial canses are illustrated by the following case:

A law student, aged twenty-fonr, songht arlvice because of palpitations since the age of fourteen. Family history was nega- 


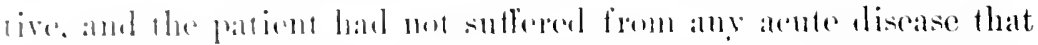

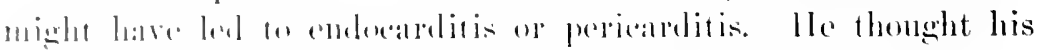
tronhle with his heart datenl from his study of physiolegy in

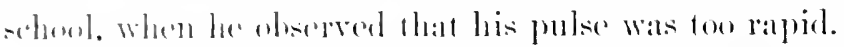

Af ill arents. frem that time on he has been subject te fre-

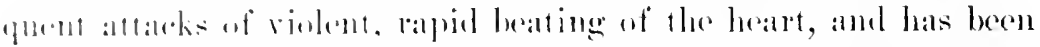

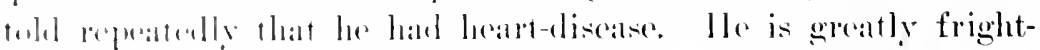

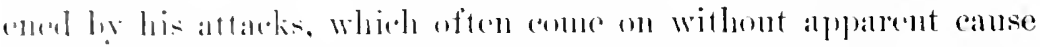

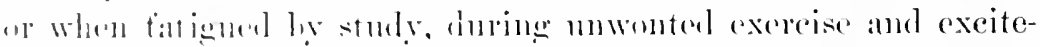
ment, ol cren tore elose application to his books. He is greatly troulled with Hatulenee, and this often sets the heart to palpilattug. Juring an attalek $l_{10}$ is exhansted, alamed, and notices palticulatry a violdent heating in the stomach. Pollutions ocenr every two or three werks, and are followed next dily by extreme weariness, nervonsuess and lialility to his palpitations.

Examination showed him to be a tall, slender man with thin rhestand bual interental spaces. The abelomen was thin, rather soiphoid when in the dorsal decubitus, and the abdominal aorta pulsaled visilly. There was gurgling in the comrse of the trans-

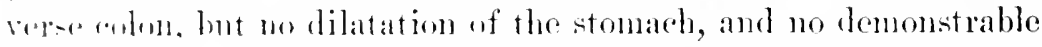
mentepeptesis. The pulse was full, soft, rapide, and regular. The action of the licald was exrited and almormally foreible, and the cervical anteries pulsalted strongly.

The aljex-beat was in the normal ponsition, eardiae dulness was not increased, and the someds were clear, but too ringing. No murmurs eomld be dreceted. Huring the examination the patient herame very nerroms and exlibited a fine tremor, the hands being warne and moist.

There comlly be no drould of the nature of his fancied heartdi-case, and he wals emphatically assured that his tronble was a

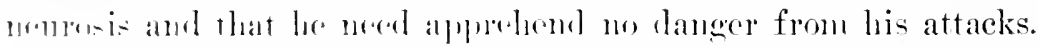

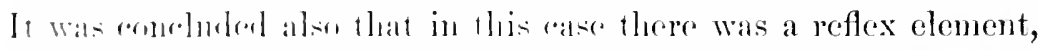
:mol that the ranke of his palpitations lay in such an excitability

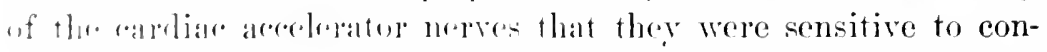
diting whicle would be wholly inardentate to alrouse them in a mormal individual. The chronicity of the affection made prog-

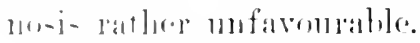

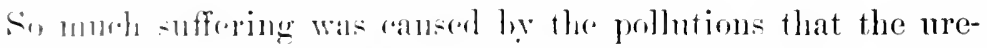
thra was explored, resulting in the detection of nothing more than 
hyperesthesia of its posterior portion. Loeal treatment was instituted by the speeialist to whom the patient was referred, but with no appreeiable effect on his attacks of palpitation.

The following extremely instructive case exemplifies the association of a veritable phobia with a distinct hysterical element and a reflex irritation, or at all events an imaginary reflex irritation:

The patient was a German-American, married, aged twentysix, of medium height and weight. She sought medical aid beeause of "weakness, palpitation, and sinking spells." Her family history was negative, excepting that her mother and sisters were nervous. The patient was donbtful concerning her having had the ordinary diseases of childhood, but denied rheumatism or other illness of an acute or infectious nature. Said she had had stomach trouble and been nervous all her life, and at ten years of age had heart-tronble that came from her stonlach and persisted about a year. From that attack she recovered without treatment, and she remained well with exception of nerrousuess until two or three years before marriage, at which time she had some nervous trouble that lasted a vear and a half.

During her pregnaney she suffered much with her heart and stomach. The confinement was diffieult, necessitating the administration of chloroform and delivery with forceps. She thought the chloroform weakened her heart very much, and she was not strong enough to nurse her baby. That was two and a half years ago, and ever since she has been a nerrous wreek.

She has "heart attacks" from exercise, excitement, and after eating. These have been much worse the last four months in spite of treatment, and last week came as often as twice a day. Excitement, as from anger or domestic wrangles, which unfortunately are too frequent, at once give her a sinking spell, and she lies exhausted for hours, her heart beating very rapidly at such times, occasionally as much as 160 a minute, in this respect resembling paroxysmal tachycardia. At times the taking of some article of food or a remedy which disagrees with her stomach will instantly produce palpitation with extreme exlaustion. At these times she is alarmed, but is speedily quieted and her pulse slows down upon the arrival of a physician. She thinks she has been relieved a little by strophanthus, and has very strong notions re- 


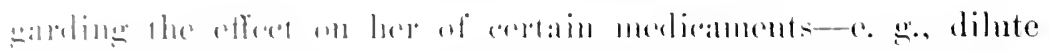

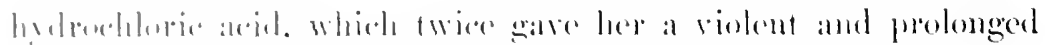
allatek al palpilation.

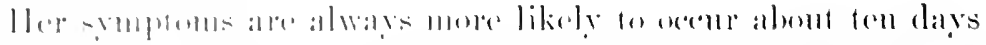

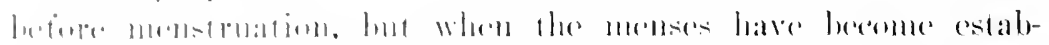

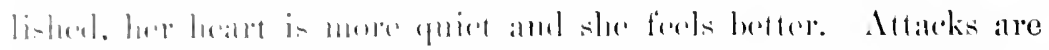
alow rere ind

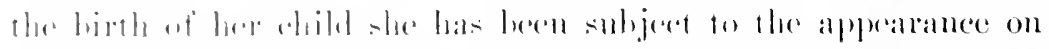

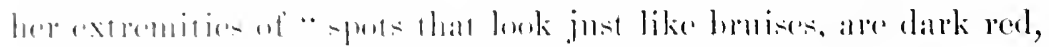

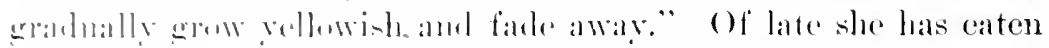

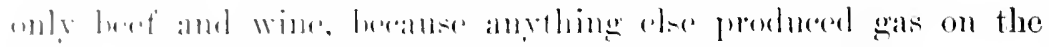

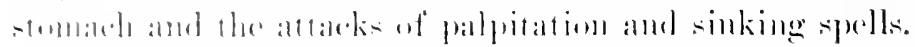

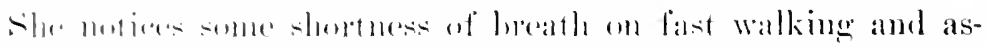

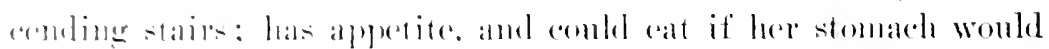

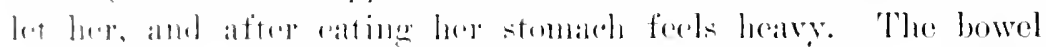

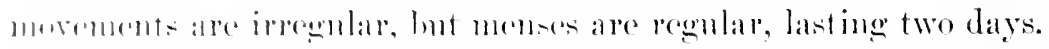

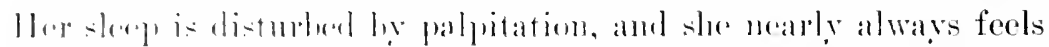

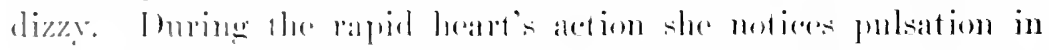

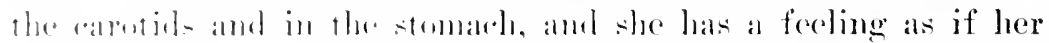

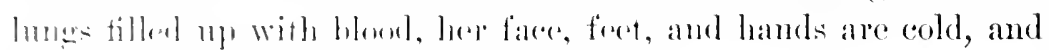

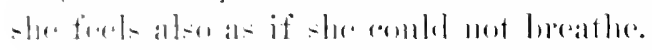

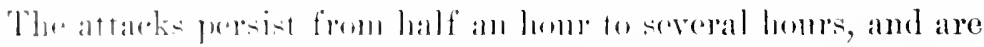

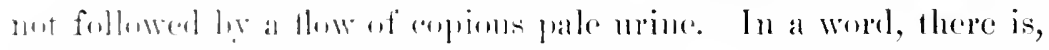

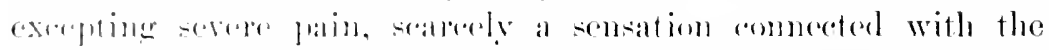
healt of which this highly memotic and imaginative woman does

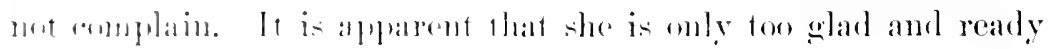

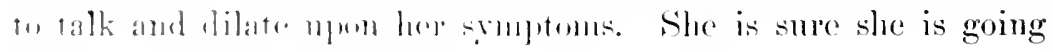
to dir in ame of her altalelis.

Plireinal exannination showed pulse 106, small, regolar, lut

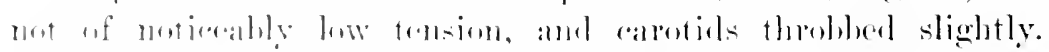

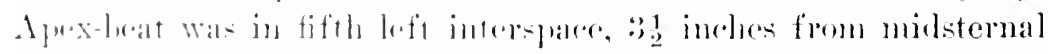

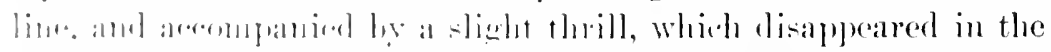

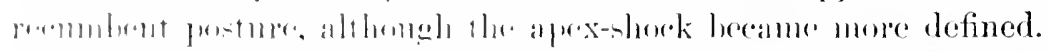

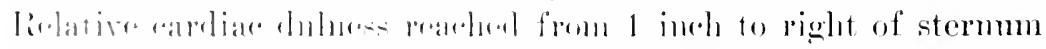

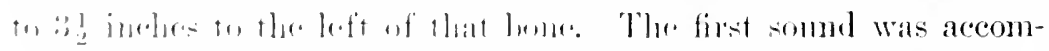

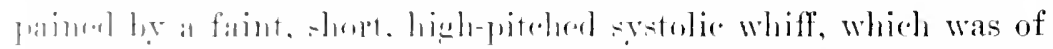
linipol tran-mi-cion mpwald and to right and was slighly louder at ranl of inopiration-and hoth pulmonic and aortic second 
sounds seemed accentuatel. In the standing position the abdomen bulged relatively too much below and was too flat above the um-. bilicus. The right kidney deseended to a little below the costal arch, but could not be grasped. The liver conld not be made out as having dropped downward. Gastric tympany reached 3 inches below and 1 inch too far to right of the mubiliens, and there was splashing. The abdominal aorta pulsated with abnormal foree, but could not be distinctly palpated. The abdominal viscera evidently dragged somewhat upon their supports, and gastroptosis was undoubtedly present. The pelvie organs were negative. The lungs were negative, and there was no oedema about the ankles.

A week subsequently, after having been linited to two meals a day, and having enjoyed a week of immunity from her attacks, her heart's action was found slow but somewhat irregular in frequency. The apex-thrill previously noted was discovered to be a short but very distinct presistolic one, and the first sound was unnistakably thmmping. Tpon the patient assuming the recumbent posture the second sound, exactly at the seat of apex, was doubled and a low-pitched short mummir accompanied the first sound. I was therefore forced to conclude that this patient had mitral stenosis. Nevertheless, her symptoms were those of a cardiac neurosis rather than of an organic lesion.

She was sent to a well-known neurologist, who reported that, althongh distinct hysterical stigmata were not discoverable, he yet believed there was an hysterical element in the case. In addition, I could not rid myself of the belief that the condition of the stomach and bowels had much to do with the production of her attacks. At one time they would follow an indigestible meal or a relaxation of the bowels snfficient to merit the term of diarrhera, at another some emotional disturbance, as a quarrel with her husband or an ungratified sexual desire-in short, a considerable variety of disturbing causes.

This case gave me endless trouble and perplexity, until at last, acting on a hint furnished by her statements concerning the etiological influence of diarrhora, I preseribed a combination of astringents which kept her bowel somewhat constipated. She then became more and more free from her fearful attacks, and with increasing freedom from them regained a measure of confidence, so 
that at the present writing. 1901. I have not seen her for nearly

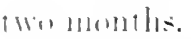

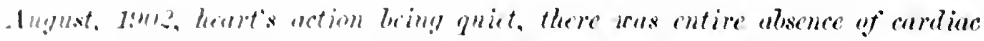

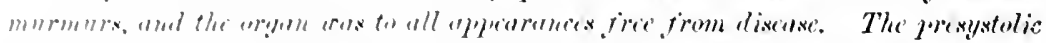

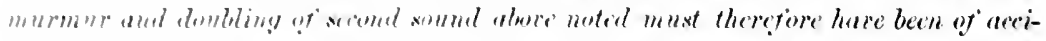

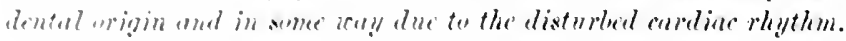

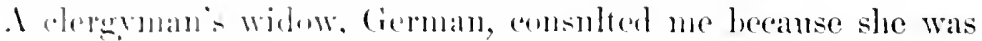

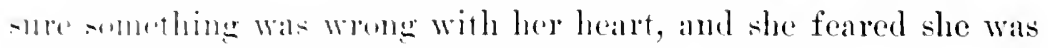
-utherise form the disease her hushand died of. This was Graves's

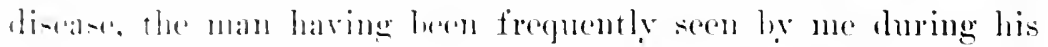
life and tinal jllness. For two years after his death she remained

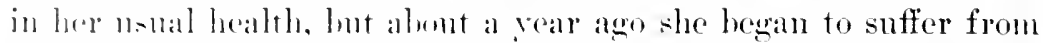
"suells with her heart," which were hromeght on hy exeitement, and smmetimes, she thomght, ly the taking of food that did not agre with her stomaled, for with the eructation of gas the palpitation lewan. It still other times the attacks came on without any apparemt ramse.

The artion of the healt was likened to "rope jumping." She

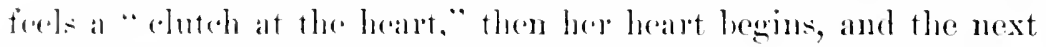
moment she is " entirely gome," the face bejng " deathly pale and the hamels cold as iece" Nothing relieves her so quickly as a little luandy. hast week she had two attacks. She sail she often notiend a gureling in the left side of her abdomen, and this gave her moreh moneines. Her apletite was poor, and she was in the habit of loinking coffee four or five tines a day. She was constipated, lut her menses were regular. Her account of her eomflaint was not that of a nemasthenie, and the we was nothing in

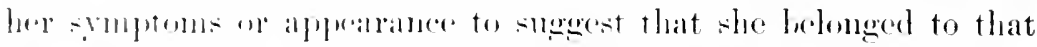
rela. of sufferers. Seither was there any history of nemetic dis-

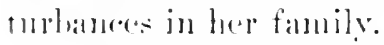

Shre was thipe rears of age, rather spare, and of medium hereht. There was no throblinge of the ratrotids, no tremor, no

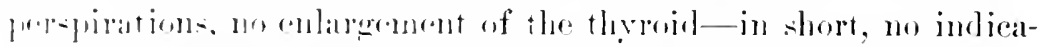
tion of Graves discase. The julse was 90, equal, regular, and of

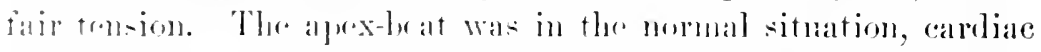

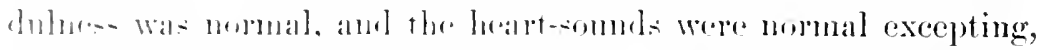
Jerhape, that thr firt was rather tor ringing. There were no

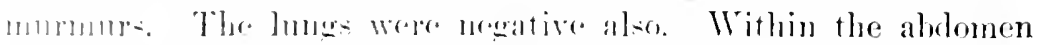
wa- the intregeting finding that areomed for her gurgling. The 
ablominal walls were relaxed, depending haglike and bulging in the hypogastrimu, while the epigastrie region was too flat. An indistinct splashing was elicited, and gastric tyutpany extended weli down into the pelvis, but not more than an ineh to the right of the median line. It hegan at the level of the ninth instead of the serenth costal cartilinge, and was too long vertically in proportion to its lateral dimensions. The kidneys and other viseera could not be made out as prolapsed. She looked antemic.

Here, then, was an individual whose organs were apparently normal with exception of the stomach, which was prolapsed but not dilated. No other condition conld be discovered to account for her palpitations, and accordingly she was told that the attacks were probably due to the gastric disorder, perhaps intensified by the undne use of coffee. She was emphatieally assured that her attacks were not dangerons and was ordered to secure an abdominal supporter, and so arljust her elothing as to avoid the dragging of her skirts upon the abdominal parietes and pressure upon her stomach.

She was given tincture of nux vomiea before and dilute lyylrochloric acid in essenee of pepsin after meals. For the attack of palpitation with pallor of face and eoldness of the extremities she was given tablets of nitroglyeerin. Coffec was forbidelen, and instructions were given regarding a simple and nourishing diet. At present writing the srmptoms still persist, but are less severe.

Tachycardia.-The physician is frequently called on to treat cases of habitually rapid heart's action, which are so annoying to the patient by reason of his subjective eomscionsness of the same that they may be said to be a persistent palpitation. In many instanees this is the exaggerated eardiac action of Graves's lisease, yet it is so prominent a symptom that it brings the patient to the doctor in the belief that the heart is the real seat of the tronble. As exophthalmic goitre is a disorder of the nervons srstem instead of the heart, it will not receive special consideration in this work. There is another class of eases, however, which likewise present tachyeardia and attacks of palpitation as their main symptoms, and which becanse sometimes associated with throid enlargement would seem to be ineomplete forms of Graves's disease. The individuals are highly nervons, easily agitated, manifest more or less tremor, and in some instances have a warm unduly perspiring 
skin. Ther do mot shew explthtalmos, amd if gôtre is not pres-

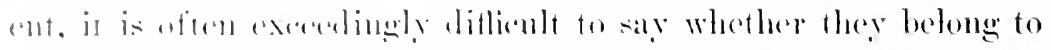

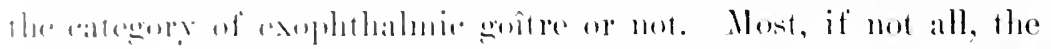

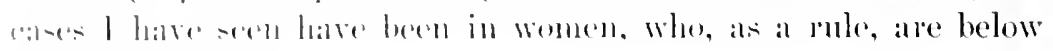

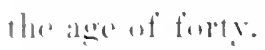

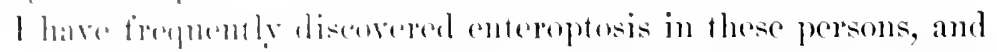

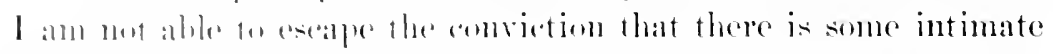

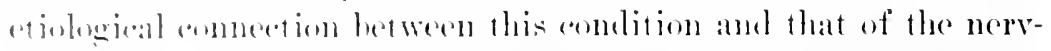
n11- -y-10m. In sume there has heren cridence of noderate cardiac

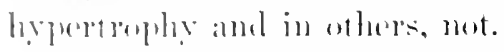

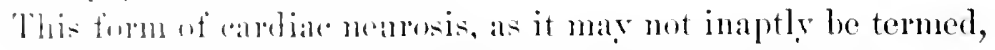

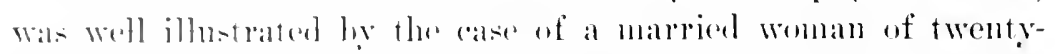
seren who cande for treatument on areoment of symptoms that made here fear heartediscase. One sister had died of pulmonary tuberculo-is at the age of twonty-four, and I may say, in passing, that

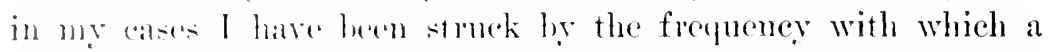
history of entsmetion in some near relative has heen obtained. The patient hat uet heen in her previowsly good health since her lant combinement, two amel a half rears before. Ier home was in a romete smberl, in a lomely simation, and as night approached and here hushant lid mot retmen she regularly grew nervous and applehrosive. Silue had lost weiglit, and for a considerable time had molinel that luer healt heat too fast. Recenty it had taken to griving a " thep," amel erery time this ocenered it threw lier into a tale of alam and agitation. Her neck had grown full, but she had given this no attention in comparison with the action of her heart. She was a bearty feerler, and all her functions appeared to

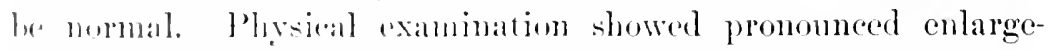
mout of the thyourl, which was firm and withent thrill. There was un monninenee of the wedalls, but there was a fine tremor

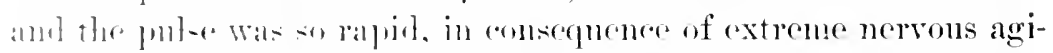

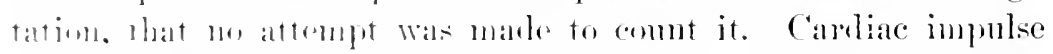

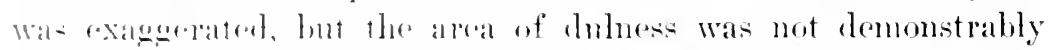

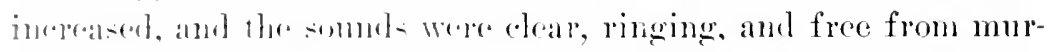

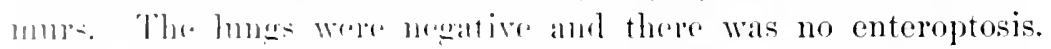

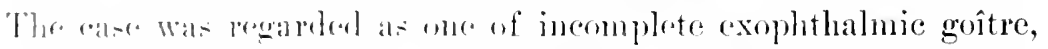

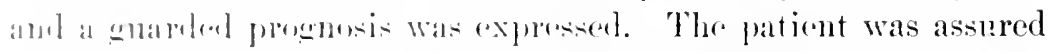

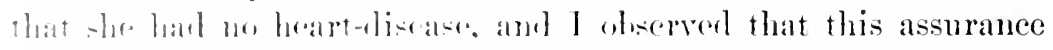
at oner farourably intlueneed the heart's action and nervousness. 
In conclusion, it may be stated that under the prolonged nse of iodine to the neck and internal medication addressed to relief of symptoms and improvenent of digestion and general health, this patient ultimately made a complete recovery, the thyroid becoming of normal size and the tachyeardia disappearing entirely. There was evidently a nemrosis in this case, as shown by the powerful domination of her emotions over the action of her heart. Whether there was any direct connection between the thyroid enlargement and the atchycardia and palpitations I an not able to say, but her nervousness certainly disappeared pari passu with the decrease in the size of the gland. Nevertheless, her pulse-rate was invariably inflnenced by the state of her digestion and elimination.

I recall another case of rapid and pounding cardiac action in a female who presented fine tremor of the extremities, but no other signs of Grares's discase, and who was ultmately found to be pregnant at the time. As she was positive that her symptoms lad first attracted her notice after the cessation of her menses, and the heart's action quicted down somewhat as the pregnaney adranced, I have not been able to determine what the connection, if any, was between the two conditions. This patient wals unmistakably nenrotic, as shown by both her family and personal history. Whether such eases are instances of incipient or inconplete Graves's disease or not, they are instances of cardiac neurosis so fir as the action of the heart is concerned.

The foregoing cases present some of the srmptomatology of heart-neurosss so graphically that it was thought best to introduce them before considering the etiology, althongh in so doing the general plan of this work is departed from. It is believed they will throw some light on the cansation of some of the most commen manifestations of functional cartiac disorders. As there is no demonstrable alteration in the structure of the refractory organ in trpical cases, there is no morbid anatomy to be described. If a valvular lesion or dilatation of the heart is found in a person displaring the symptoms of neurotic disturbance of cardiac action, a combination which is not at all infrequent, the anatomicopathological changes on the part of the heart are not to be regarded as dependent upon the neurosis. There may be an etiological connection in so far as the organic heart-lesion may, through 


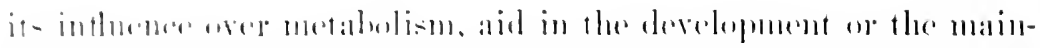

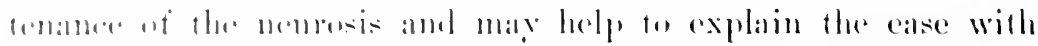

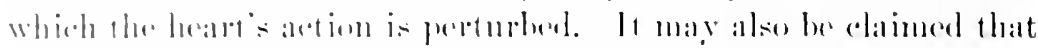

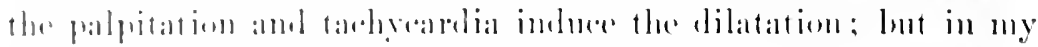

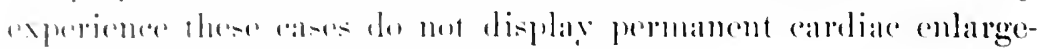
ment to an extent that aills for treatment.

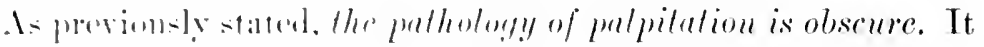

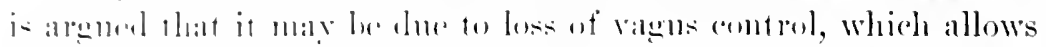

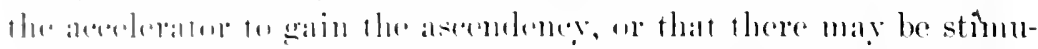
litten of this latter imlependent of an aberanee of the inhibitory

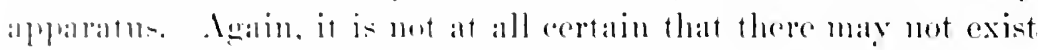

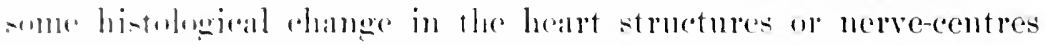

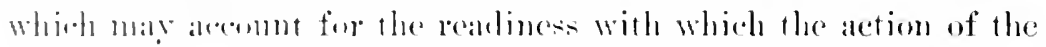
heart beome distmbed moler anditions that are inoperable in the heillhy individual. As Rombere sils, arterioselerosis sometime develeps in nemrasthenies at an momsually early period of life: and whe can say that there may not he some comection betwern this falct and the carliale manifestations? These are matwers of efrecolation purely, and in the present state of our knowl-

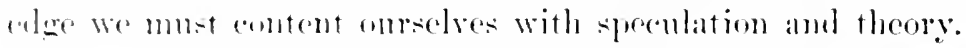

Cardiac Pain.- This is anethere rexeedingly frecplent symptom in nemperie patients whe suffer from fancied disease of the heart.

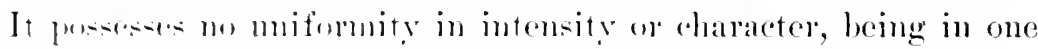

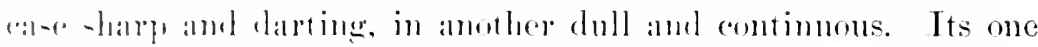
fratture. (commen to all, is its location in the heart-region, usually

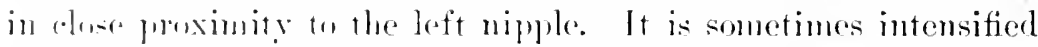

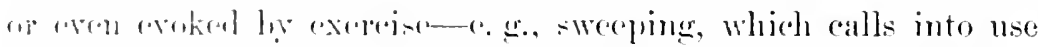
the morreles of that fortion of the ehest. In some instances it

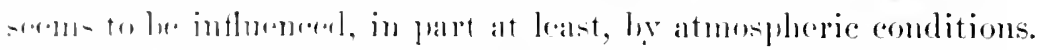

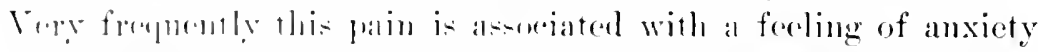

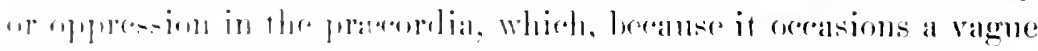

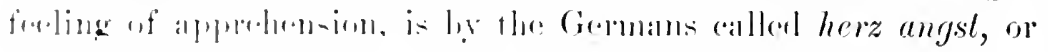
ansirety of the leant.

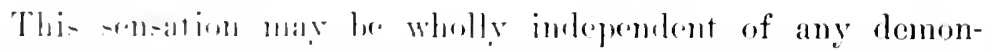

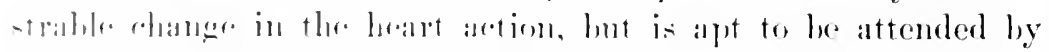

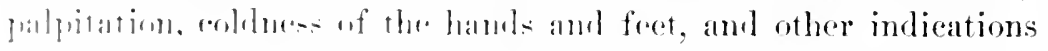

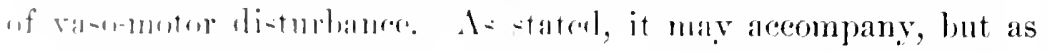

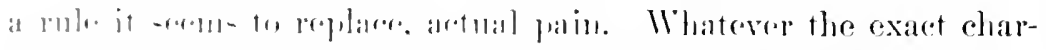

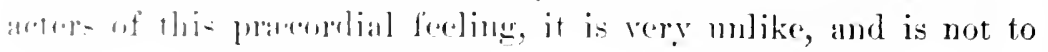


be confounded with the painful seiznres which are designated angina prectoris, whether true or false. The differenees alre so marked that no mistake ouglit to be marke, and yet it is possible fer the feeling of eardiac anxiety to be mistalken for the constrietion of the rhest present in grave angina and the feeing of apprehension for the sense of inpending death.

Pseudo-angina Pectoris. - From the standpoint of seientific accuracy this term may be and doubtless is oljectionable, since there ean be no such thing as a false ehest pain. Nevertheless, this term is sanetioned by the nage of the best writers in this comtry and Europe. It inchdes those pracordial pains which elosely resemble attacks of coronary angina, and are therefore spoken of by Osler as "allied states." The essential difference between them lies in the fact that prendo-angina is independent of struetural disease of the heart or its nutrient vessels, and that it is not likely to cause sudden death.

Tn true angina there is some condition within the heart which initiates the stimulus sent to the nerve-entres. In the psendo form the starting-point of the painful attack is, aceording to Inchard, not the heart, but some peripheral or visceral nerve, most commonly one of the intereostals. The impulse thence passes to the mednlla, and there, reaching the sensory centres, evokes a sensation of pain that radiates into the chest or down the arm with phenomena that point to a coincident stimulation of the vasomotor and vagus ecentres. Often it is some painful point on the chest, generally one in the region of the left nipple, which acts as the starting-place for an attack. Whether such is the pathology of these cases or not, it certainly seems to me to afford a fairly satisfactory explanation of the essential clifference between these two forms of angina.

Writers reeognise three great varieties of this neurotic form: the reflex, the raso-motor, and the toxic. Of these, angina reflectoria is the most common, althongh no one can observe these cases without coming to the conchusion that they are all very apt to blend indistinguishahly with each other. Irritation within the abdominal organs is thought to be the most common starting-point of an attack of the reflex varicty, and yet the vaso-notor form may likewise find its origin in some disturbance within the abdomen as well as in any part of the body. IInchard dwells imuch on 


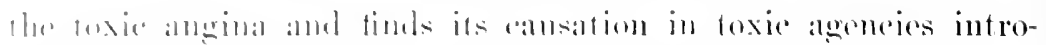

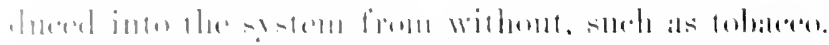

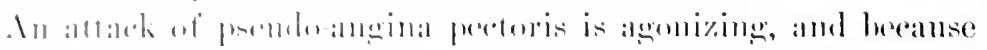

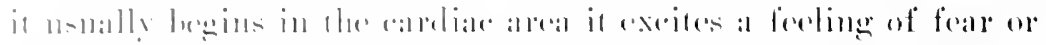

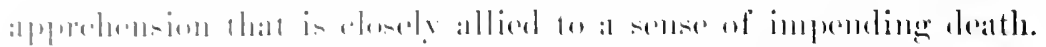

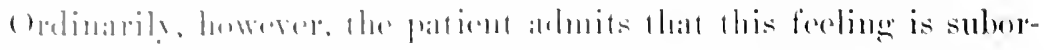

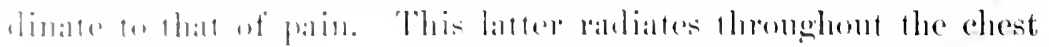

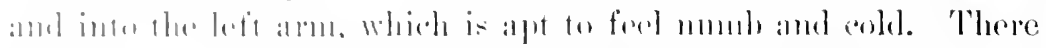

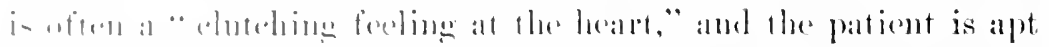

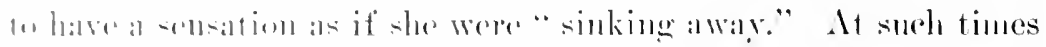

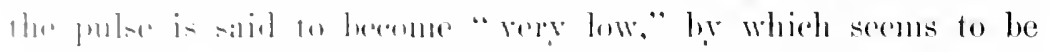
meant -low and weak. In eases of the vasu-motol type the face is

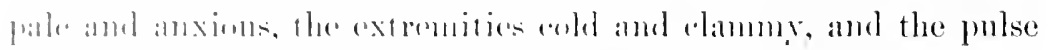

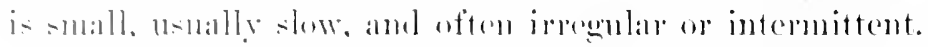

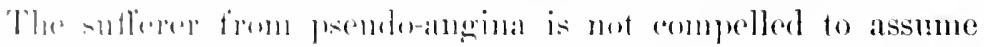

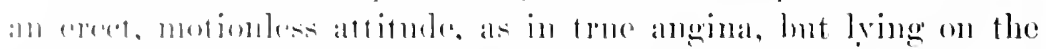

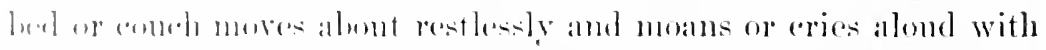
faine It is this feature of the attack on which reliance is eliefly

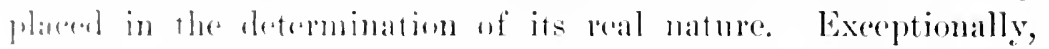

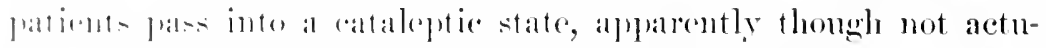
ally mmonseroms. rigid, and it may be oold, presenting in this

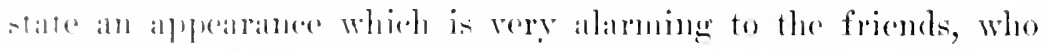

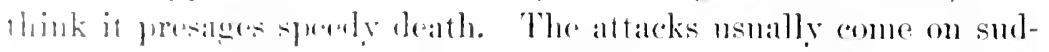

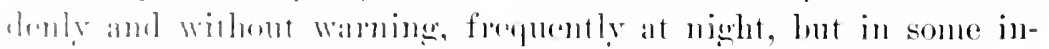

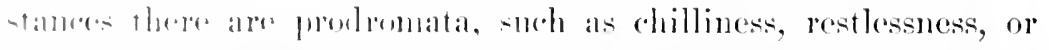

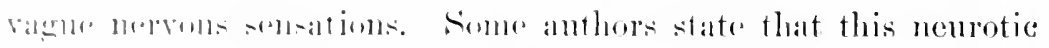
form of aneina display a temdeney to periodicity by recomping at

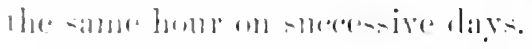

The duration of the serzures is lomeres than that of true angina,

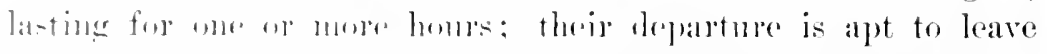

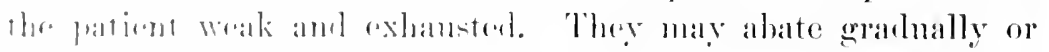

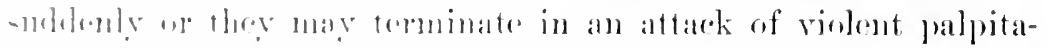
tion. Numbures and helplessuese of the arm into which the pain

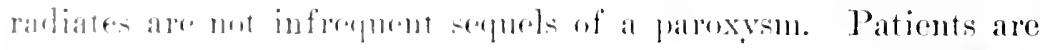

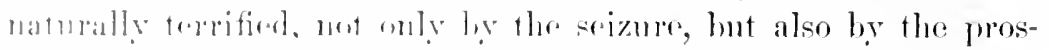

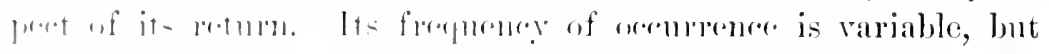

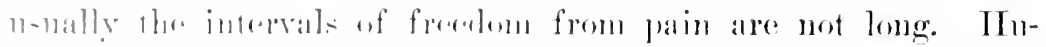

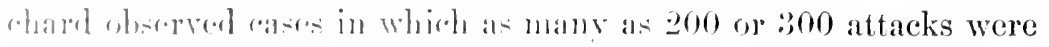

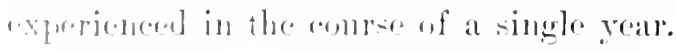


In pure angina reflectoria without vaso-notor phenomena irritation originates in sone distant part and the pain radiates thence inte the cardiac area, from which it spreats along the intereostal nerves and "ren into the left an'm. There is nsmally an associated feeling of anxiety and constrietion, but the neuralgie element is the nore pronomed. Huchard cites a catse, not observed by himself, however, in which the paroxysms of pain originated in the eicatrix of a womd received many years before. This was situated at the bend of the elbow, and the attalek of pain was precipitated ly movements of the joint, ly friction of the clothiug, and eren by gentle stroking of the scar. Squeezing of the middle finger was also capable of arousing a paroxym, and this fact together with their cure by acupuncture led him to conchude there must have been an hysterical element in the case. He also quotes the instance of an offieer who experieneed an attack of psendo-angina in consequence of painfrl irritation of his foot by one of his decorations, which had fallen into his boot, and there remained during the dir. In such an individual there must be a highly neurotic tendener. Osler narrates a single case in which this form of angina followed attacks of romiting, and therefore appenred due to gastro-intestinal irritation. Such attacks have also been known to result from exposure to cold.

In the raso-motor form the exciting eause may likewise be exposure to cold or eren the washing of the hands in very cold water. In this group there are phenomena of widespread vasomotor spasm as well as pain, as might be expeeted.

The strictly toxic form is exceedingly uneommon and presents considerable diversity as regards the severity of the attacks and the prominence of certain features. Pain is often subordinate to a feeling of anxiets or precordial oppression and there is disturbed eardiae rhythm in the way of retardation or acecleration, irregularity, and intermittence of the pulse. In tobaceo angina there may be rertigo, pallor, a contracted pulse, tendener to syneope, precordial anxietr, coldness of the hands and feet, and eold perspirations. Aecording to Inchard, there may be other associated srmptoms which are referable to nicotine intoxication, as dizziness, timnitus aurium, drsphagia, and eephalalgia, a sense of suffocation or drspnoa, general weakness, cerebral confusion, spinal tenderness, and disorders of vision. Although anginal 


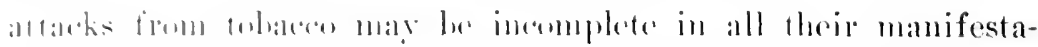

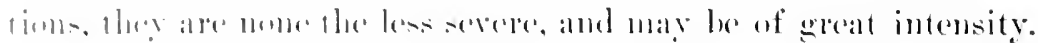

Etiology. - Mllhom the antomatid action of the heart prob-

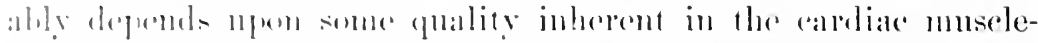

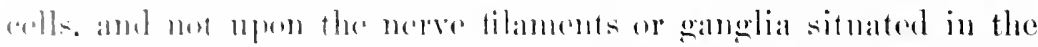
leart-walls, still there atu be mo dould of the powerful influence

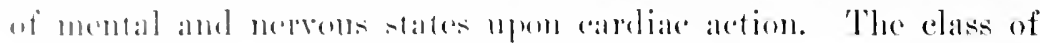
disombers mow amsibleded is genemally thomght independent of struetural discaso of the hoart, althomgl persons with organic ear-

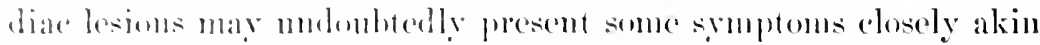

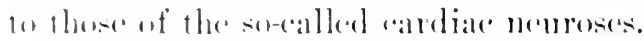

The predispering allses of the so-ealled fumetional or neurotic disturlances of cardiale artion and of the rarions sonsations referahle to the healt ale those disolders, memasthenia, hysteria, ete. which for want of definite knowledge of their pathologe are called nemroses. P'soloses, such as hypolhondria, may also he attended ly disturbane of caldiac action and other symptoms referable to the healt. (onsequently in every case of caldiac nempsis the ply reician slomld andeavour to aseertain and expect to deal with

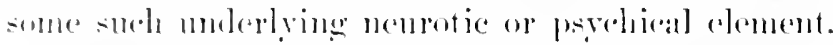

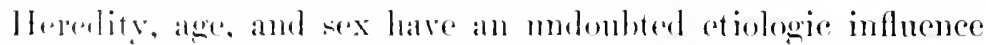
over fumetional disorders now ensidered. Most of these patients precent a ciear family listory of nemroses, and some of them have manifested motahle ardiar action from childhood. It is particubarly in the fomale sex that the semptoms which have been deseriluel are ancomntered, and ret some of the most pronomned

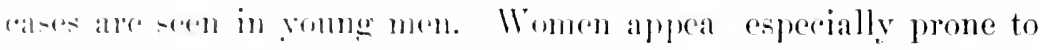

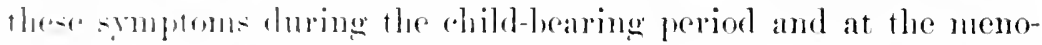
fanse. There attarke of palpitation, heart-pain, or what not, are vory apt to be conked during the days immediately preceding mentruation. 'This is not leanse of any direct retiologic eomection lesturent the two. lnt simbly becanse at this time, as at the

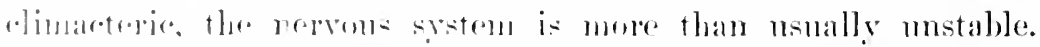

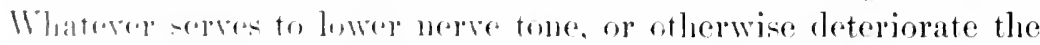

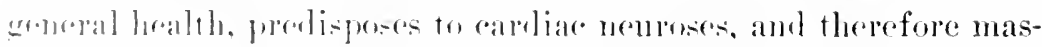

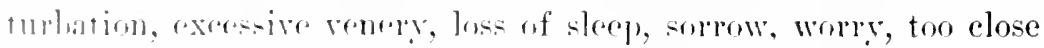

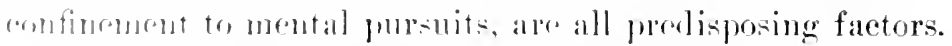

Ther influeneres whirh arot as rexciting rauses are ton numerous and rations and often too obserure to warrant the attempt to enu- 
merate them in detail. Patients are very apt to speak of having a " nepous shock," by which may be meant sone sudden start or fright, an mexpected picee of bat news, and the like. In many instances the more suggestion, whether subjective or made by another, that they have heart-disease suffices to excite an attack of palpitation. This is particularly the case with hrsterical subjects, and I have known a word casually dropped, by being wrongly understood to apply to himself, to throw such a person into at violent hit of palpitation with coldness of the hands and a feeling of intense anxicty. On the other hand, a reassuring word will sometimes as promptly quiet the action of the heart.

There is often a close connection between the taking of food or a remedy and the onset of symptons. This is sometimes dombtless the result of suggestion, at others of the formation of products of indigestion, and when this latter is the case it is diffieult to say whether it is through a retlex or mechanical action or is the effect of the absorption of toxins. The symptoms not infrequently come on so quickly that there would hardly scem to be time for the formation and action of toxins. In neurasthenie individuals fatigne is undoubtedly an exciting factor. I have known a woman to take a short walk and immediately upon her return to be seized by a sinking spell with either rapid or slow and feeble pulse and coldness of the extremities, symptoms easily thought to indicate leart-failure, yet in reality due not at all to cardiac weakness. Ordinarily in eardiac neuroses an attack of palpitation is not produced by a reasonable amount of exercise. In fact, moderate exercise, as walking, is more likely to quiet down the heart. Nevertheless exceptions may oceur, as was the case with one of my patients, a highly neurotic young man without demonstrable signs of organic disease.

Cases of psendo-angina reflectoria have been shown in the description of srmptoms to result from irritation of the abdominal viscera, from irritation of a peripheral nerve, and undoubtedly also from disturbanees with in the pelvic organs. It is my opinion that the same sort of influences may exeite an attack of palpitation instead of pain. The same thing is true, $I$ believe, as regards the impressions which are said to arouse an attack of psendoangina through the raso-motor centres. Palpitation of this origin is not common, however, any more than is pure vaso-motor psendo- 


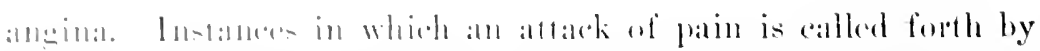

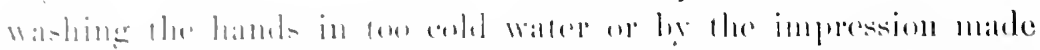

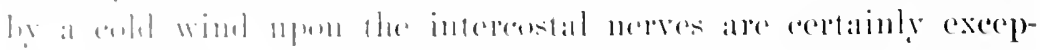

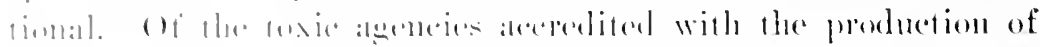

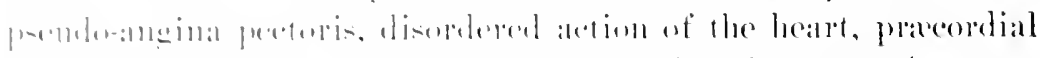

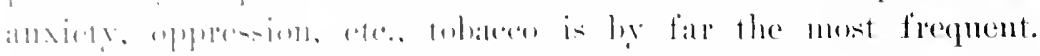

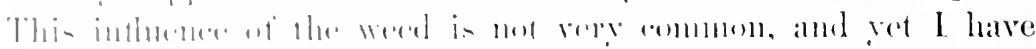

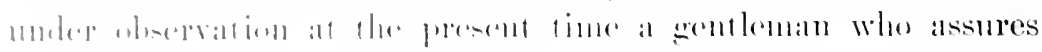

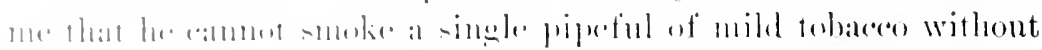

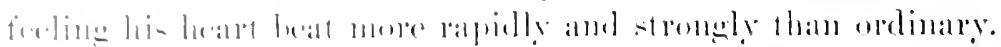

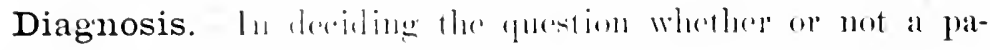

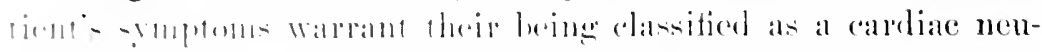

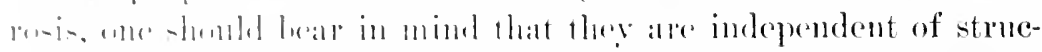

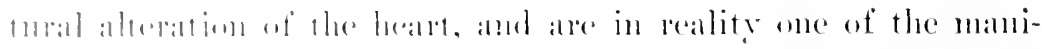

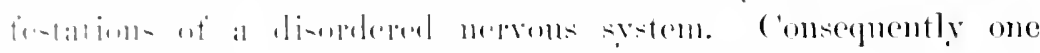

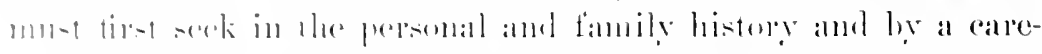

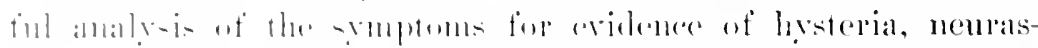

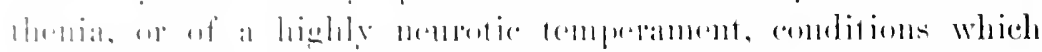

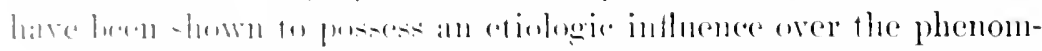

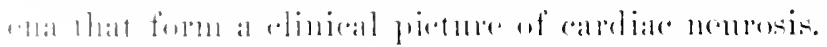

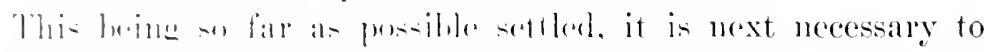

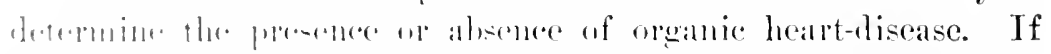

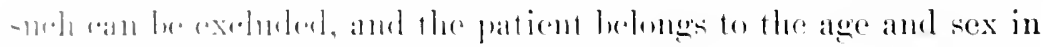

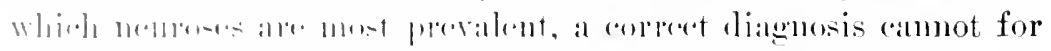

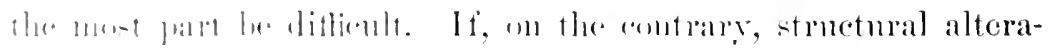

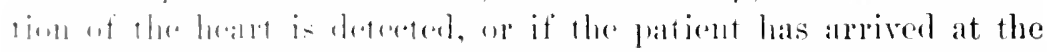

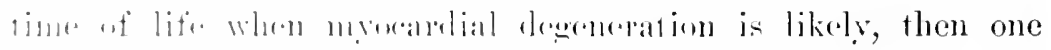

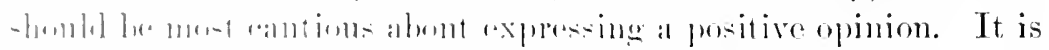

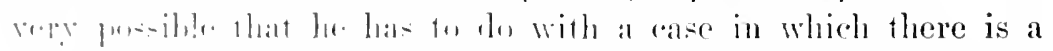

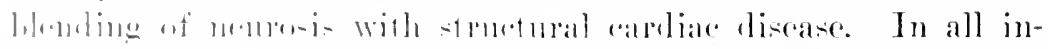

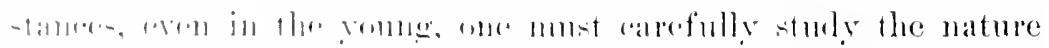

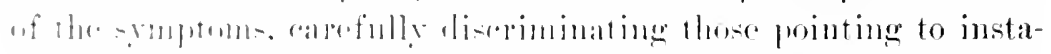

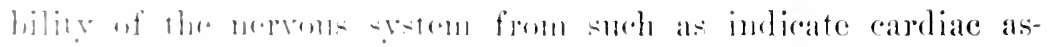

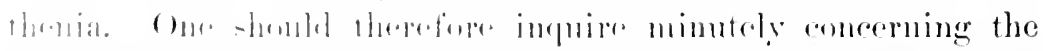

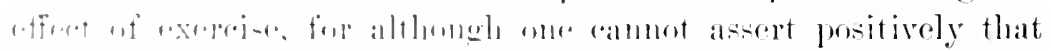

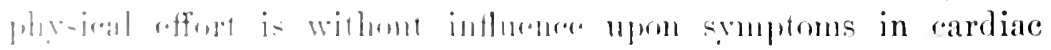

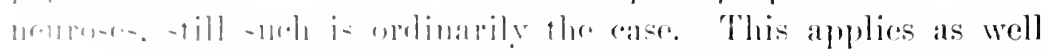
1. atumbalion of arrliar artion ats to the differential diagnosis of Ir-rodratugina. 
Furthermore, without wishing to set it down as an infallible guide, I desire to give it as the result of years of observation that, if the patient is not subjectively aware of disorders of his cardiale rhythm, there is probably myocardial discase eren if objective proof of the same camnot be had. The reverse does not obtain. The matter of dyspmora requires close study. Patients with eardiac inalequacy from whatever cause experience shortness of breath upon exertion and not during repose exeept in an arlvanced stage. Neurotic individuals, on the contrary, mless markedly nemasthenic, are able to walk withont breathlessness, whereas they are very apt to complain that they are mable to draw a long breath, or that they feel a "catch in their breath." They breathe superficially, and every now and then take an musually deep inspiration, which is followed by a feeling of great relicf.

If one is summoned hastily to administer relief to a patient in an attack of palpitation, a sinking spell, etc., a correct diagnosis is not always easy at first. Valnable information may be obtained, however, from inquiry into the history as regards previons attacks, mode of onset, ete., and from attention to the absence of signs of organic heart-disease and of secondary stasis. Furthermore, the patient generally displays nervons agitation, fright, etc.

In those eases of palpitation which manifest throbbing of the aorta either in the episternal notch or in the epigastrim, the differential diagnosis from anenrysm may be made ly attention to the following points: (1) The history of attacks of palpitation and their association with symptoms of nenrasthenia or liysteria; (2) the age and sex of the patient, who is generally yomg and more often a female; ( 8$)$ the absenee of pain, of signs and symptoms of pressure, of a localized tumour having an expansile pulsation and thrill: (4) the absence of an area of dulness upon the manubrim sterni or at either sude, or at some point along the course of the abrlominal aorta; (5) the faihure to detect the ausenltatory phenomena, of bruit and accentuation of the vascular sounds usually present in anemysm; (6) the evidence derived from the spliyomograph and the X-ray.

In determining the significance and nature of pain in the cardiac region one should meet with but little difficulty if he rememhers the following points: (1) The absence in nemotic cases of signs of structural eardiac disease; (2) the spontaneons origin of 


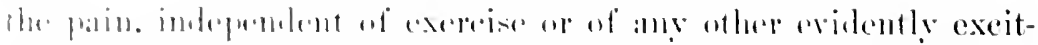

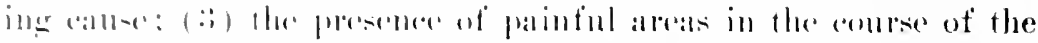

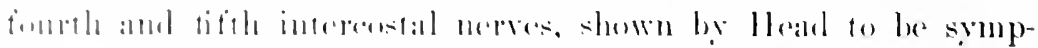

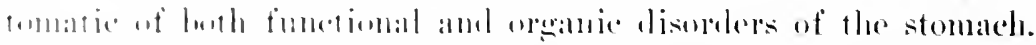

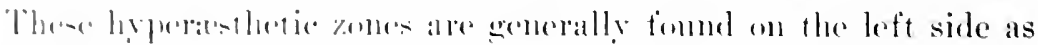
follow-: (.1) near the lett nipple. upen the fifth rib, or in the in-

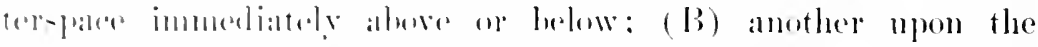

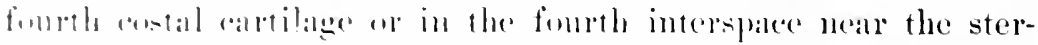

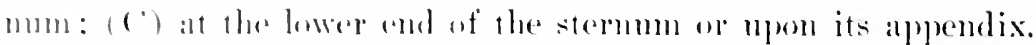

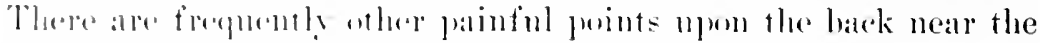
inferier ander ot the salpula. The tender areas semptomatic of

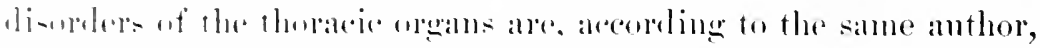

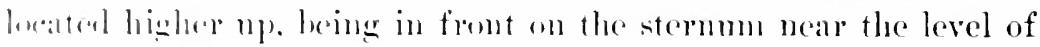
the third aotal atrtilage and on the thied rib, or near by, just within the vorionl mamillary line. When the tember points first mentinmed are disorered close inguive will usually elieit sympboms of imligestion or the so-ealled anto-infection.

For the most part the corrent diagnosis of the psendo-anginas is litficult only in pationts at or after middle age, and in them the enestion is likely to be rendered still more difficult by the dis-

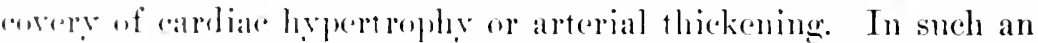
rent a positior diagnosis must often be deferred until time throw- finther light on the case. In most ases, howerer, a cormet diagnosis is posible ly the discovery: (1) That the attacks, ar brevims memtiomed, arize indegendent uf, and are as a rule

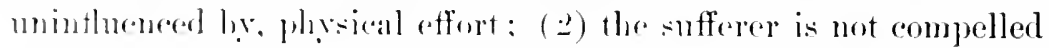

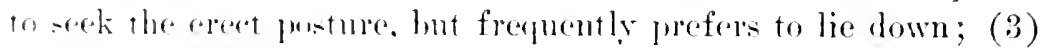
he lese mot present a pireture of silent motionless agony hut noans or aries alome and mores about restlesty: (4) the attack is of moreh lowere duration, often lasting several homrs; (5) it is often

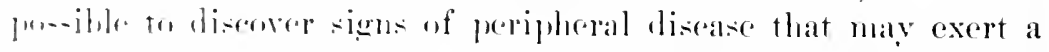
rettex influromere to get a history of influenees that are operable theremeh the basm-motor syotrom or aret as a toxin. As regards tobac-

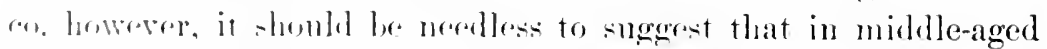
mon whe are smokers cononary selerosis is much more likely to be thre ratler than is theoir tohaceos.

Prognosis. - This is practically that of the underlying neu-

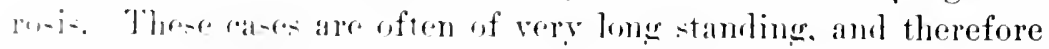
for.ent a correpondingly mafaromale prospect of eme. In the 
young, when the case is ummistakably one of neurosis, the assurance can unhesitatingly be given that death will not result from the attack of palpitation or psendo-angina. When the diagnosis is doubtful, the patient may, for the moral effect, be told that his cardiac symptoms are functional, yet the friends should be warned of the possibly grave nature of the case. In strictly nenrotic suljects the prognosis depends, moreover, upon the possibility of the removal of all those influenees of enviromment which unfarourably affect the patient. In Graves's clisease, or those allied states associated with enteroptosis, the prospeet of obtaining immunity from their tachyeardia and palpitations is very unpromising.

Treatment. - This must be directed not alone to the relief of the paroxyms of palpitation or pain, lut also to the removal if possible of the underlying neurosis. It is not the province of this work to disenss the management of neurasthenia and hysteria, and therefore the reader is referred to works dealing with the subjeet. It need only be remarked here that the physician who would sncessfully treat cardiae neuroses must command the entire confidence and respect of his patient, and he must use the influence thus gained for their proper moral management. He must display no liesitation or vacillation in his suggestions and no irresolution in their enforcement.

Treatment of the Attack.--In most instances the medical attendant first sees the pitient in one of his seizures, and is therefore called on to act encrgetically and promptly. Tet he shomld never be in such haste that he eamnot first gain a tolerably correct notion of the nature of the disorder. IIe should never display alarm, and even if he thinks so, he should never tell the patient he is in danger of dying. On the contrary, he should endeavour to reassure the patient both by word and the ealmmess of his manner. Whether the attack is one of palpitation merely, or one of intense pain, the treatment is essentially the sane, for there are usually associated symptoms of vaso-motor disturbance.

Palpitation.-I have never been able to see the wishom of resorting to digitalis or renerlies of similar action for the arrest of an attack of palpitation. These remedies are slow of action, the attack is in most instanees short-lived, and before the digitalis takes effect the tumultuons heart-action subsides spontaneonsly, or 


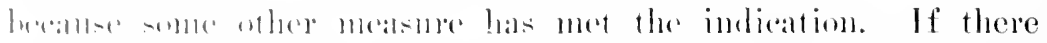

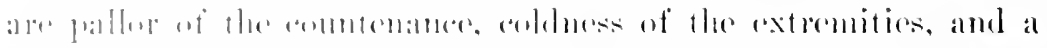

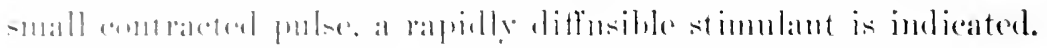

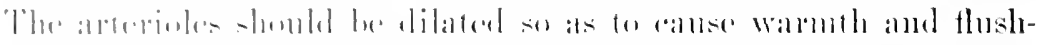

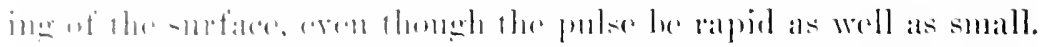

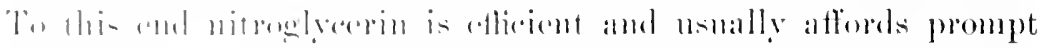

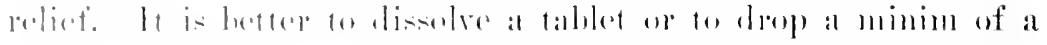

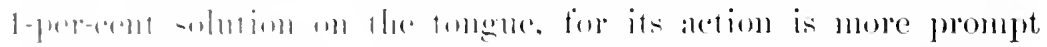

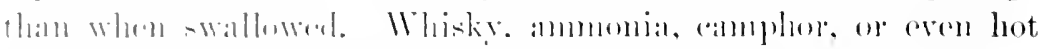

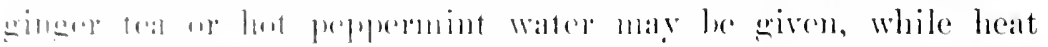

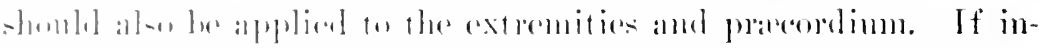

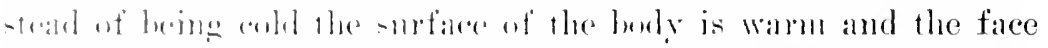

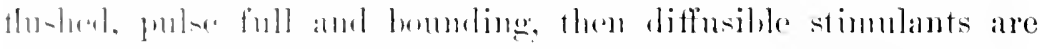
comblatimdicated. It is mow hettre to apply jee to the pracerdium

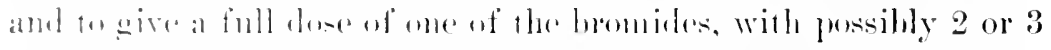

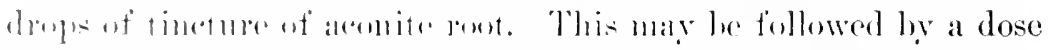

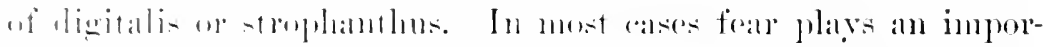

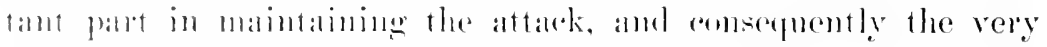

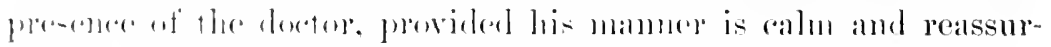

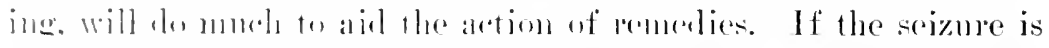

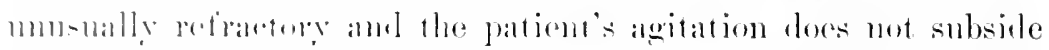

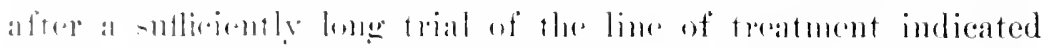

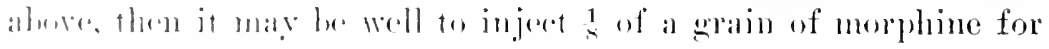
it: raluantive offinet.

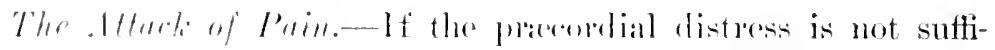

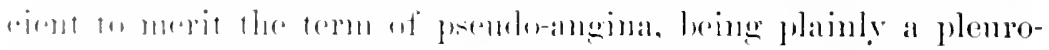

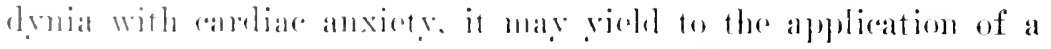

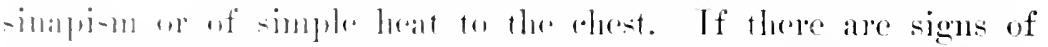

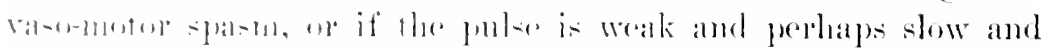

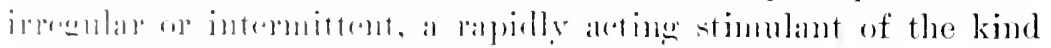

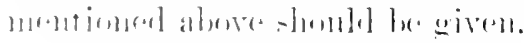

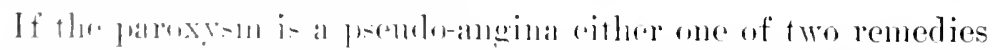

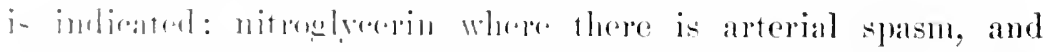

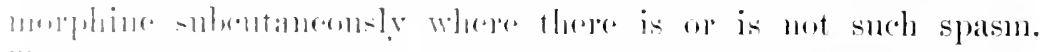

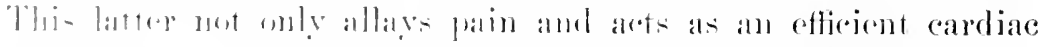

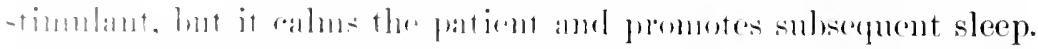

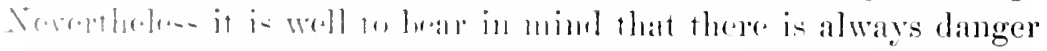

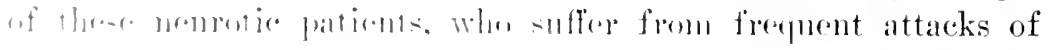

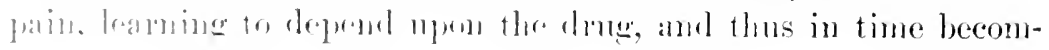


ing vietims of the morphine halbit. The same olyection applies to the use of alcololie stimulants for the treatment of an attalek of palpitation, sinking speels, ete, and therefore it is better to rely on other harmless but equally effective stimulants.

In conclusion, the plyssician should searele for and endeavour to remove all those sources of visceral or pripheral irritation which serve to distur') the nervous system between attacks or may seem to act ats exciting caluses.

Enteroptosis, dilatation of the stonacll, digestive indiseretions, or any other condition that may alecomt for the eardiac symptoms are to be treated in accordance with the principles applicable to such cases and the special indications of each case. Great amelioration and sometimes entire relief of the distressing attacks of palpitation follow so simple a measure as the wearing of a properly fitted abdominal supporter in eases of ptosis of the stomach or other viscera. In addition, attention must be paid to the clothing, that too tight skirt-bands or corsets may not inerease the dragging of the abdominal contents upon their supports. Properly given, massage is often of much benefit in these cases.

Finally, in all case the exciting canses should be carefully sought out and the patient impressed with the necessity of avoiding ail those influences which may precipitate an attack. IIe should be told that if he is to get better he is to aid in his cure by obcying instructions to the letter, since medicines alone are incapable of eradicating his disorder. 


\section{CHAPTER XXXI}

\section{ESSENTIAL PAROXYSMAL TACHYCARDIA}

Thus is a highly interesting and rery puzhling derangement

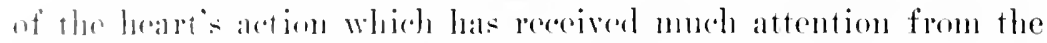
menlieal profecion since 1 stiz, the date, acording to IIerringham, of the publination by layne Cotton of the tirst recorded ease.

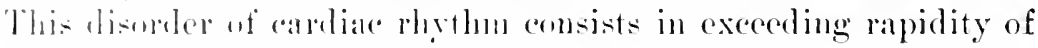
artion, and oxcurs in attaleks of variable duration and frequeney, dering which the heartheats mumber 160 or more to the minute. Menlial men in the British Isles halve always been keen observers, and luepe again, as in angina pectoris and bradyeardia, have sigrnalized their powers of olsepration. ('ottom, Edumunds, Watson,

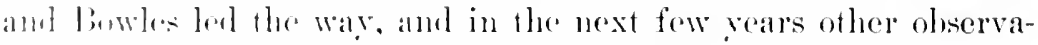

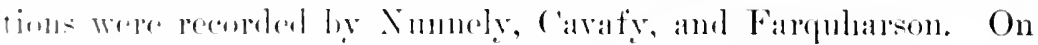
the combinent we tind the names of 'Tuebzek, Cierhandt, Bomveret,

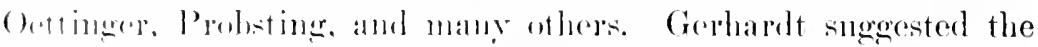
teme Tarblycardia in the year 1sist, and in 1sss Bouveret sug-

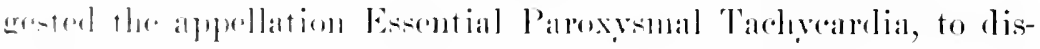

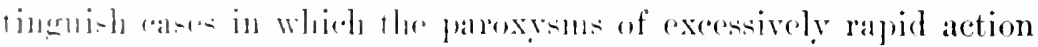

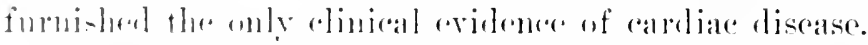

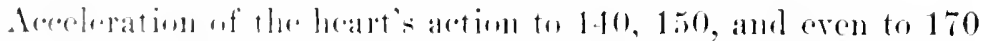
in the minute is anuctimes oluerved in alses of valvular lesion,

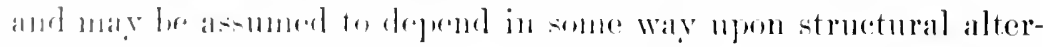
ation of the walls dure to the valve dofect. But in throse arses

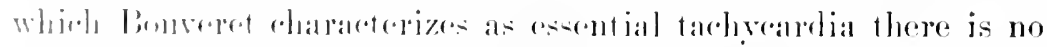

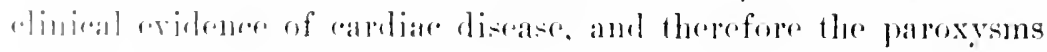

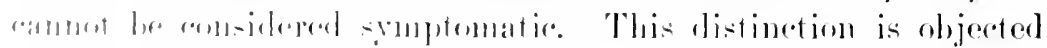

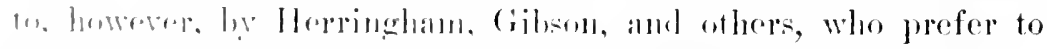

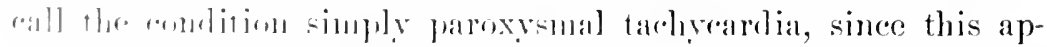
plim lomatly to all atses in which typical attacks of excessively rapilal antion recur. 
Clifford Allbutt objects to the term paroxysual, saying, "The interpretation is that tachycardia is a fairly uniform symptom group; and, as one of its eminent characters is its paroxysmal oceurence, the addition of this qualification to the nane is superfluous."

Pathology.- There are no anatomical changes that can be definitely associated with essential paroxysual tachycarlia, and likewise there is no established pathological basis upon which an explanation of the phenomenon may rest. Prior to 1897 six postmorten olservations had heen made in this class of cases, but they failed to disclose any constant or muiform lesion. In one, the wall of the left ventricle was in a state of pronounced fibrous degeneration, and in two the hearts were extensively fatty, while in three others no special changes were noted aside from dilatation. As these alterations have been found over and over again, indeed, are very common in hearts that have never manifested this peculiar disorder of action, it is plain that there is nothing in these post-mortem findings to explain the occurrence of paroxysunal tachycardia. Consequently various theories have been offered to account for the attacks.

Tuehzek suggested paralysis of the vagus, and Nothnagel, irritation of the sympathetic, sufficient to overcome the controlling influence of the pneumogastric. It has also been suggested that there may be a combined action of the two, ragus paresis and accelerator stimulation. Objections are urged against all of these theories. Tuchzek's theory has been widely accepted, and yet experiments on animals have failed to produce so extreme a rapidity of heartaction as is seen in these attacks, and Allbutt believes that in man abeyance of the inhibitory control of the vagus would not send the pulse up beyond 120. Likewise, stimulation of the cardiac aceclerator nerve is said not to increase the pulse-rate bevond 150. Ascribing the rapid action to a combination of both necessitates the assumption of some cause which acts simultaneously on both nerves, and this, in Allbutt's emphatic words, "sins against the conony of causes."

Bouveret's suggestion that it is a bulbo-spinal neurosis, and Talamon's that it is of an epilpetic nature, are both not acceptable. Samuel West has ureed that the attacks are due to alterations in the myocardium, to which Herringham would add changes in the 


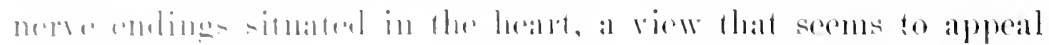

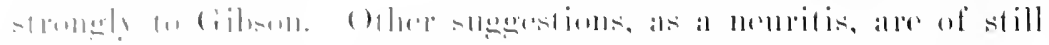

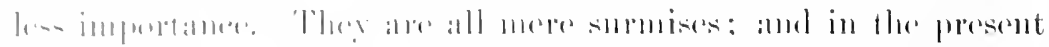

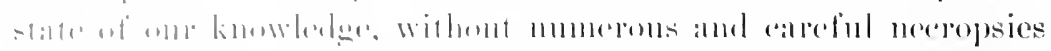

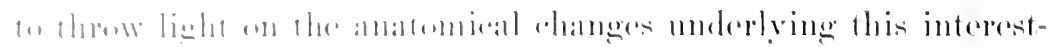

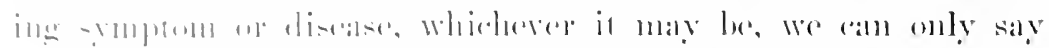

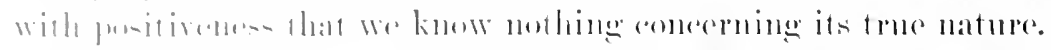

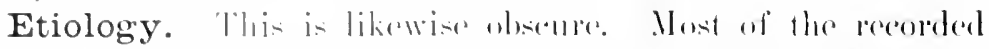

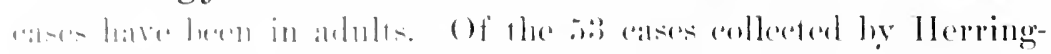

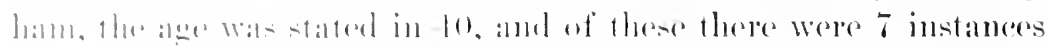

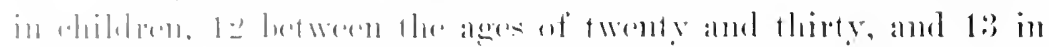

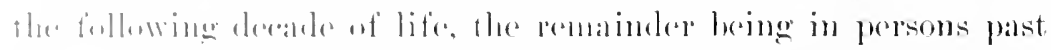

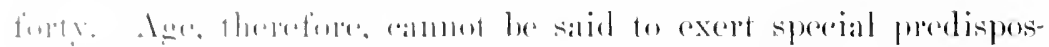

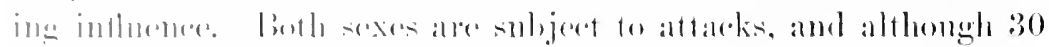

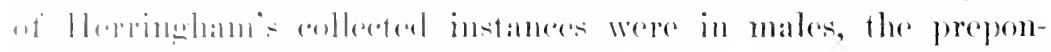

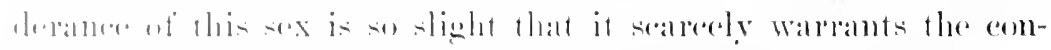

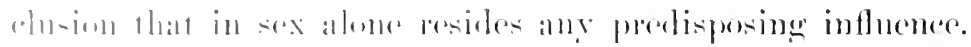

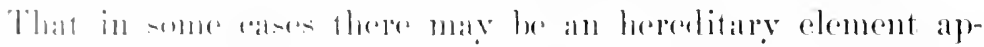

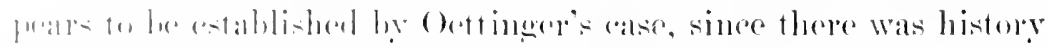

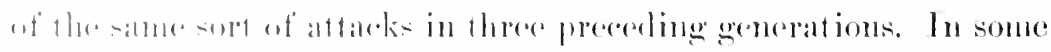

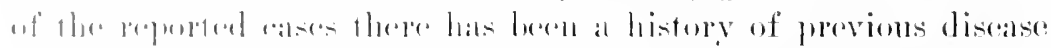

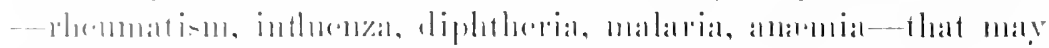

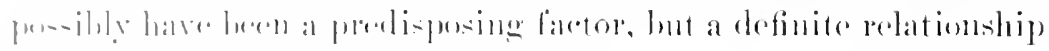

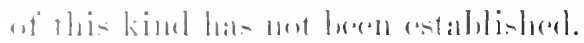

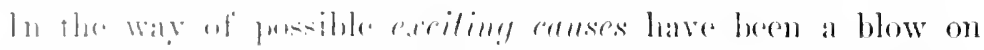

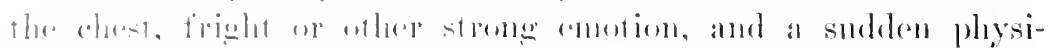

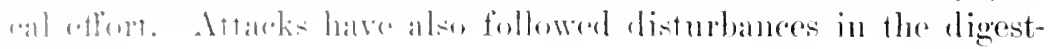
ivis tratci.

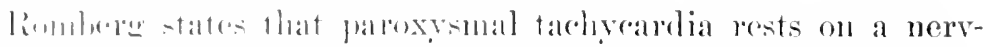

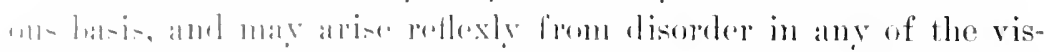

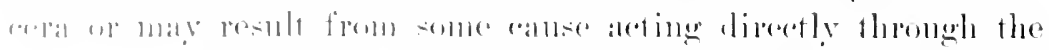

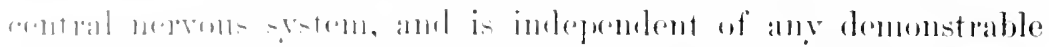

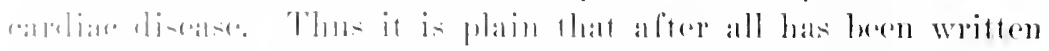

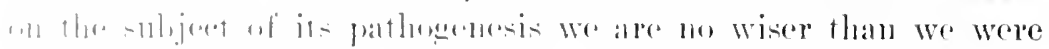
infore.

Features of the Paroxysm.--'Wo comlitions are essential if

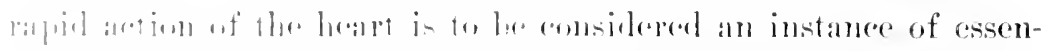

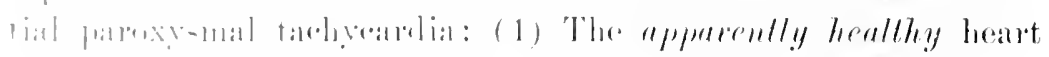

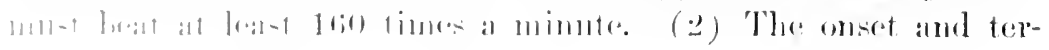


mination of the attack must be so sudden and abrupt as to give it the character of a paroxysm. Althongh a pulse-rate of less than 160 is frequently observed in persons with some structural disease of the heart, still in essential tachyeardia the number of cardiae contractions is often vastly in excess of this number, ruming as high as 200 , and in a few instances even to 300 a minute. The pulse is small, thready, and often meountable, becanse the extreme frequency of the waves and the emptiness of the ressel cause the pulse-wares to rum together in an indistinguishable manner. To determine the heart-rate, therefore, one must eount the heart-beats by auscultation instead of by palpating a peripheral artery.

The rhythm of the contractions is usually regular, but irregularity and inequality in their force are sometimes observed. The extreme rapidity of the cardiac systoles is at the expense of their

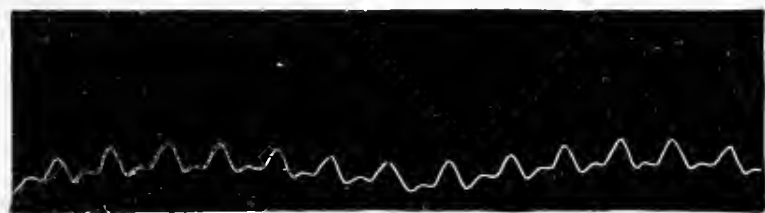

Fig. 108.-Sphygmogram from Case of Paroxysual Tachycardia.

strength and efticieney, blood-waves of normal volume are not discharged into the aorta, the arterial system beeomes relatively empty, and the pulse is one of strikingly low pressure. This is illustrated by the appended tracing (Fig. 108) kindly furnished me by Dr. E. F. Wells from one of his cases.

The paroxysms begin abruptly and generally without premonition. Indeed, upon the oceurrence of the first attack the patient does not always know what is the matter with him, and is only able to say he feels bad. If the tachycardia is short lived, the patient may experience nothing more than a vague feeling of discomfort and his outward appearance may not disclose anything unusual to the ordinary observer. There may be, however, pallor or flushing of the countenance. In some instances there are pracordial oppression and even pain, numbness or tingling of the arm (Gibson). Palpitation or fluttering of the heart may be complained of, and rertigo is sometimes experienced. Most sufferers from this complaint, notwithstanding repeated attacks and the 


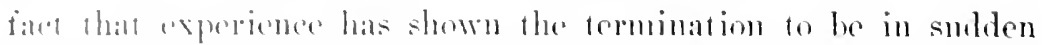

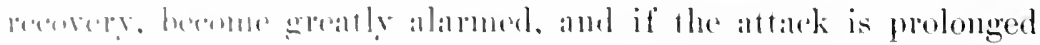

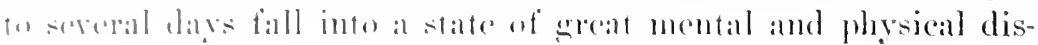
tims.

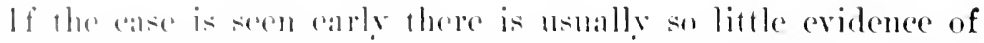

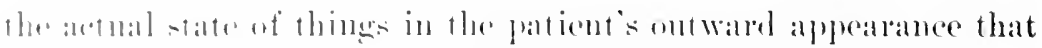

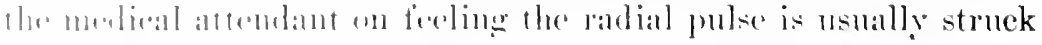

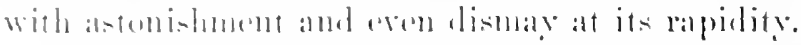

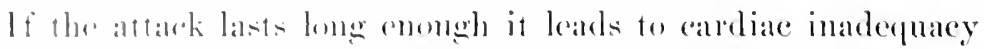
and the hlond tonds to aleommlate in the hearteravities. The heart

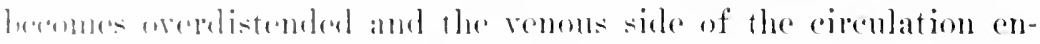

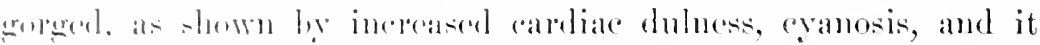
may lue hy pulstion of the jugulars (Cibson). There is pulmo-

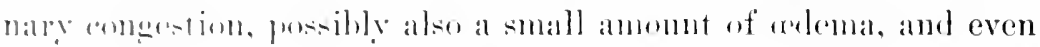
allomimuria. The heart-sumels ale foeble and the first at the apex 111 y hecome almost imandible.

In must atses the duration of the paroxysm is not suffieient to labl to such marked signs of stasis. The attalek subides sudHenly after a few hours and the patient is loft very much as he Wal- hefore. fouling perhaps tired and dreading a reenrence, but

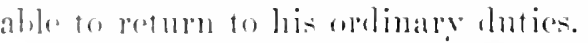

A striking peruliarity of smeh a paroxysu, whether long or

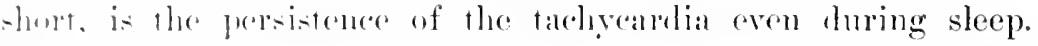

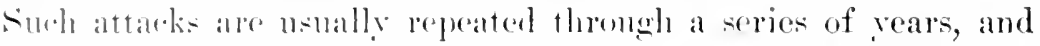

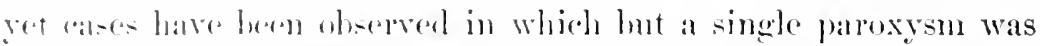

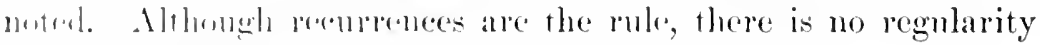
in their loperitions.

Throle dulation is likemise valuble, sinee the paroxysms may

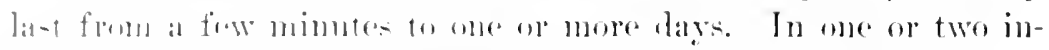

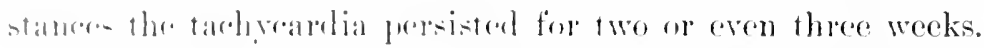

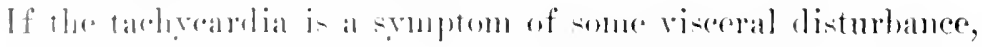

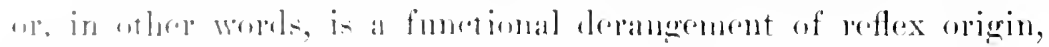

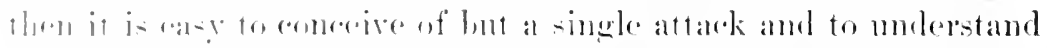

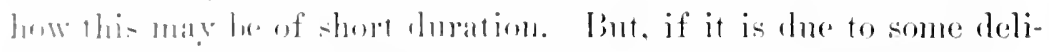

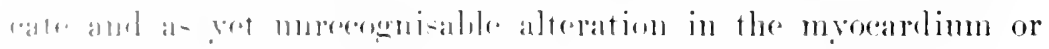

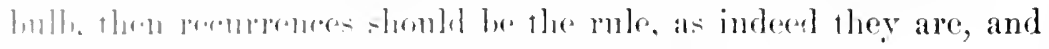

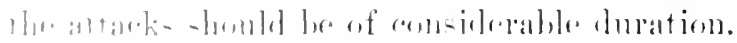

Diagnosis. The Jutromination of the fact of tachycardia i. nest ditfirnlt. The point to he decided is whether the rapid ac- 
tion is an instance of essential paroxysmal tachyeardia or is of the kind called symptomatic. If it belongs to the former class, it shonld fulfil the following requirements: (1) $\Lambda$ heart-rate for the time being of at least 160 a minnte, (2) abruptness of onset and equal suddemess of termination, (3) failure to detect evidence of heart-disease either during or between attacks.

If, on the other hand, there is evidence of myocardial or endocardial disease, the tachycardia is symptomatic and not essential, no matter how rapid may be the pulse. In this class, however, it is not usual for the heart's action to exceed 150 a minute. Most instances of "heart hurry" belong to this class, and yet it is probable that the essential form occurs more often than is reported, either because the attacks come to the notice of the family doctor rather than of the consultant, or because the attacks are so transient that no physician is called in. Althongh I have repeatedly observed symptomatic tachycardia and have known several individuals who gave a history of the essential form, among them a medical man, I have not actually witnessed a paroxysm.

Prognosis.-In the essential form the prognosis may be said to be favourable so far as life is concerned. There is always an element of mneertainty in any case of extreme and protracted "heart hurry," but if a paroxysm terminates speedily no damage to the heart may be sustained. The real diffienlty lies in the uncertainty of the length of time during which an attack may endure. In the aged, the feeble, and persons having a definite eardiae lesion such paroxysins are not devoid of danger. In most cases of paroxysmal tachyeardia the seizure may be expected to terminate abruptly and spontaneously, but how long the patient is to remain immune from a repetition is a matter of too much uncertainty for the prudent physician to express an opinion. The history of eases shows that in most instances other attacks are to be expected.

Treatment.-The plain indication is if possible to arrest the paroxysm. This is ealled for, notwithstanding the fact that in the majority of cases the tachycardia has not caused death. Although a patient may have had repeated attacks that have ceased spontaneously, yet tachyeardia is such an uncertain quantity that one can never be quite sure how another paroxysu may affect the heart. Unfortunately it is the same with this as with other mala- 


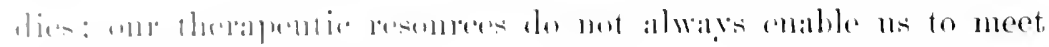

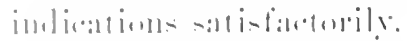

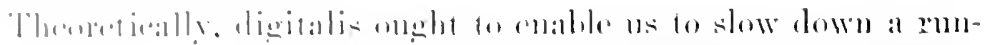

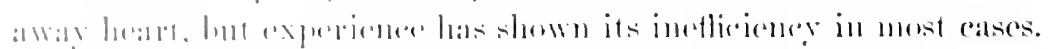

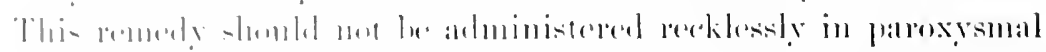

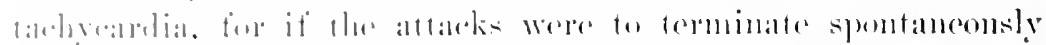

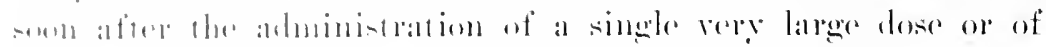

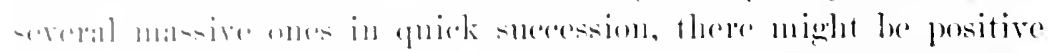

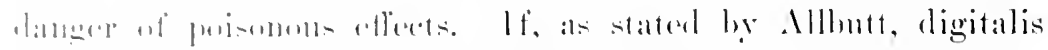

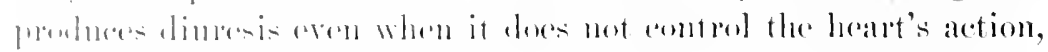

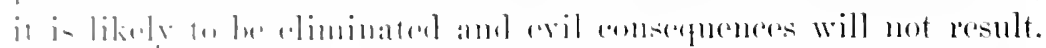

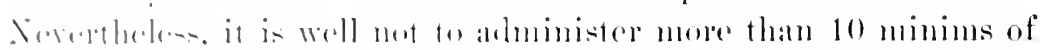

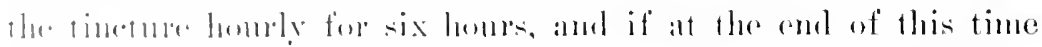

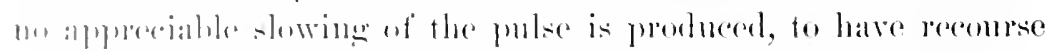

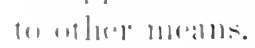

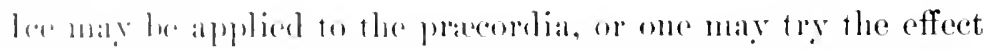

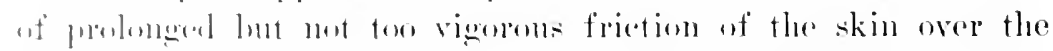
mplere pertion of the spinal column, which has bech said to slow

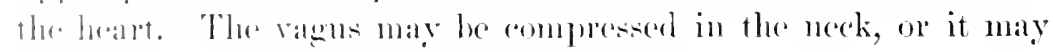

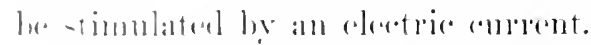

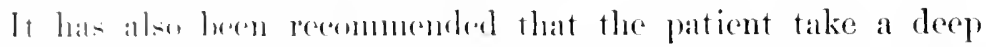

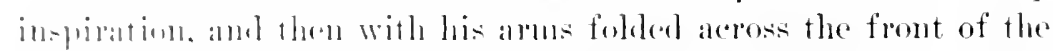

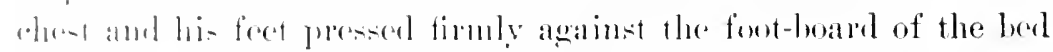

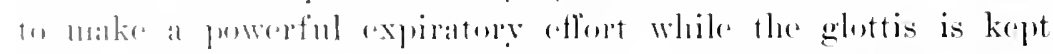

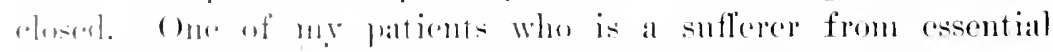

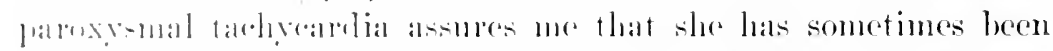

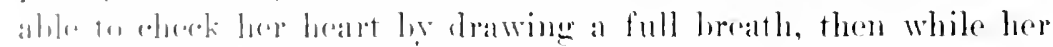

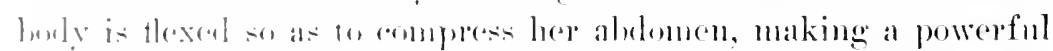

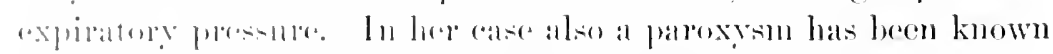

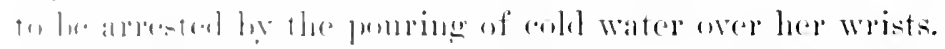

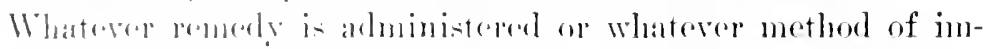

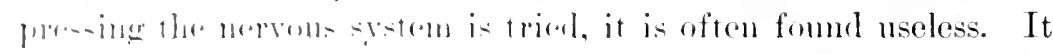

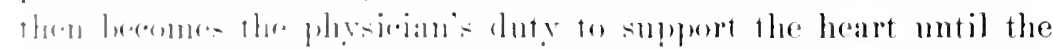

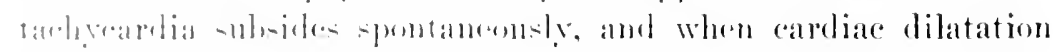

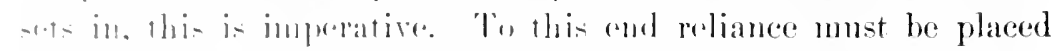

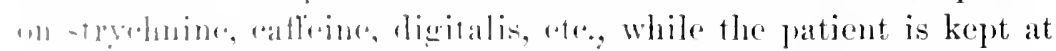

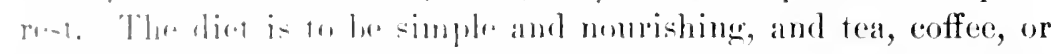

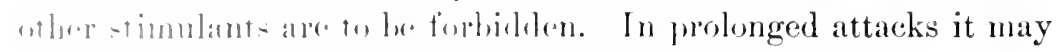

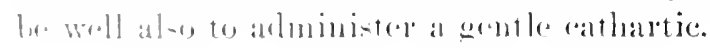


It may not be possible to prevent rearurenees, and attempts in that direetion may seen to be something like firing in the dark, yet the patient should reeeive medical attention between attacks. In eases exhibiting subsequent signs of cardiae strain or in which there is an unstable nerrons system, sneh regular treatment is specially advisable. Gibson recommends tonics, a course of the Nauheim baths with resistance gymmastics and such other measures as the experience of the medical attendant and the exigencies of each case suggests. In some instances it may be well to give digitalis or other heart-tonies for a iong time. Every effort should be made to discover and remove any source of reflex irritation, and the daily life should be as healthful and free from excitement as possible. 


\section{SECTION V

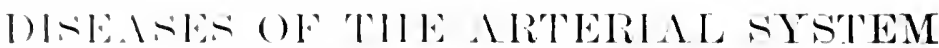

\section{CII.TPELR NXIT}

\section{ARTERIOSCLEROSIS}

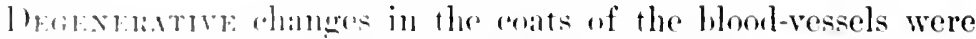

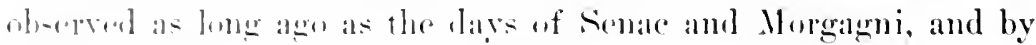
then invortinaturs wore deserilued as an inflammatory process. It is to linkitansk and Virrhow, howrerer, that we are indebted

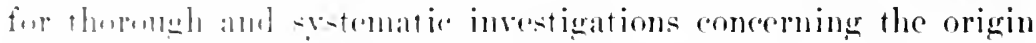

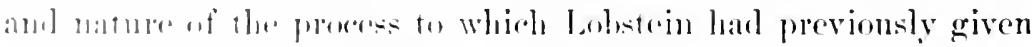

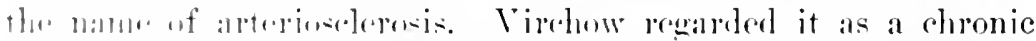
alpriti-and puintorl out its simblarity to the slow inflammatory

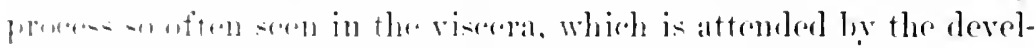

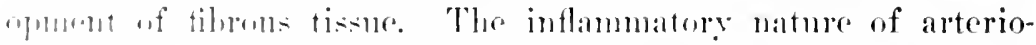

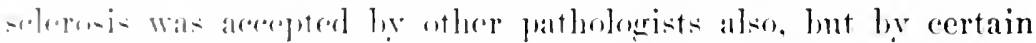

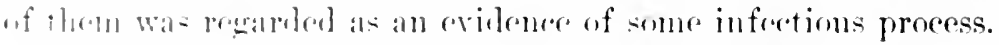

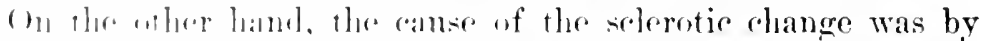

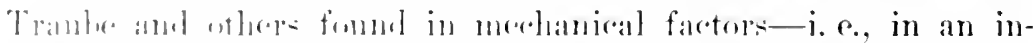

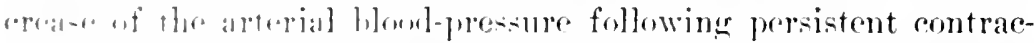

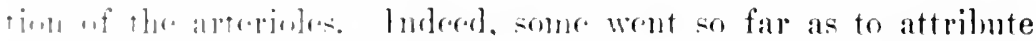

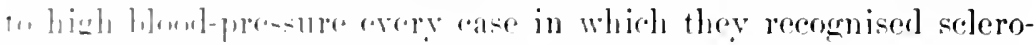
-i- and -

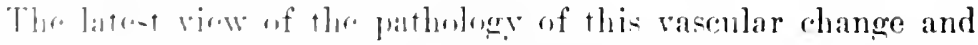

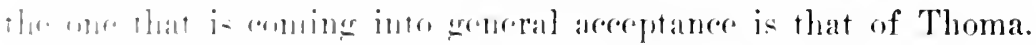
(

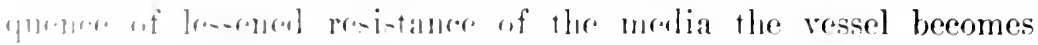

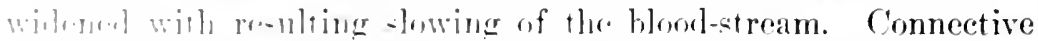

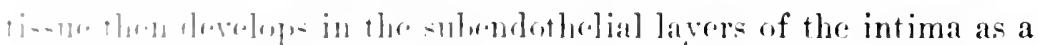

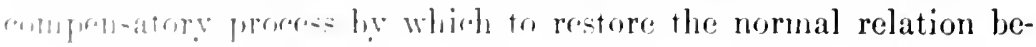


tween the artery and its contents. Although in most instanees the vaseular change is an attempt to make good a loss of elasticity. and widening of the artery, still it may develop when the normal relation between the ressel and its contents is lost by reason of decrease in the volume of the blood. Romberg, to whom I am indebted for the historical data just given, finds 'Thoma's view highly satisfactory, since it seems to explain the development of arteriosclerosis in eases which were previously unaccountable by Traube's theory. Noreover, it has been founded on an immense amount of earefully stidied material.

Morbid Anatomy.-Arterioselerosis consists essentially in a degeneration of the media with secondary compensatory thickening of the intima. It may be localized, eonstituting the nodular form of Couneilman, or it may be diffuse. In the nodular or eireumseribed form whitish or yellowish patches are seattered along the inner surface of the vessel, which stand up from the surrounding level and are of a romded contour. In the diffuse variety the arterial wall is stiff, and more or less dilated, while on the surface of the intima may be zones of nodular thickening and ealcareous or atheromatous patches. In old persons the arteries are stiff, more or less tortuous and dilated. The inner surface presents numerous ealeareous plates and atheromatous uleers.

Examined microscopically, the thickening of the intima is found due to development of connective tissue between the endothelium and underlying elastic tissue. Ifter a time, degenerative changes take place in this newly formed connective tissne which consist in hyaline transformation of the outer portion witl areas nearer the endothelium of fine detritus in which fat droplets are seen. These areas of necrosis constitute the so-called atheromatous abscess. When these areas break into the lumen of the vessel depressions are left, known as atheromatous uleers. The borders and bottoms of such uleers are rough, and hence may become the seat of white thrombi. By the deposit of lime salts in these atheromatous patches calcareous plaques are formed which project above the surface of the intima, while by formation of chalky particles in the wall the artery may become transformed into a tube of almost bony hardness.

In the middle coat changes of a degenerative nature take place which lead to weakening and dilatation of the artery and conse- 


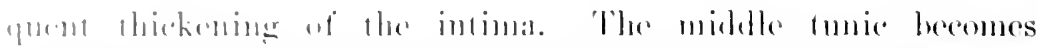

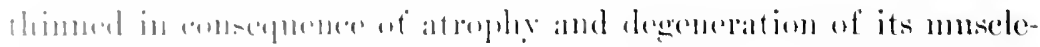

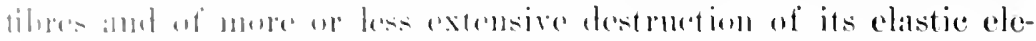
month- In

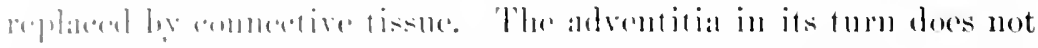

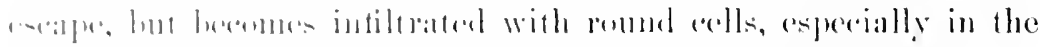

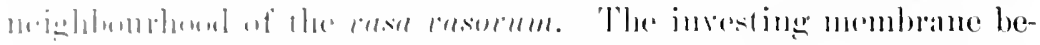

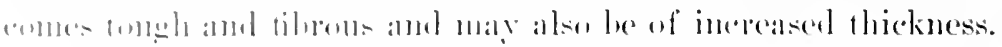

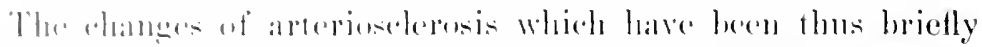

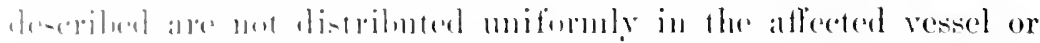

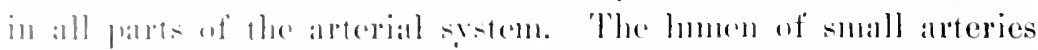

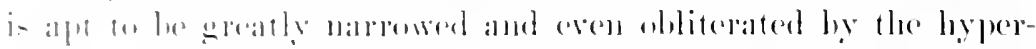

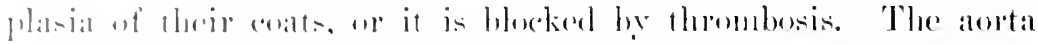

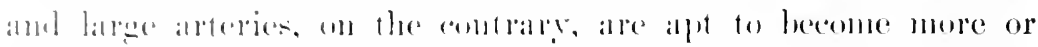

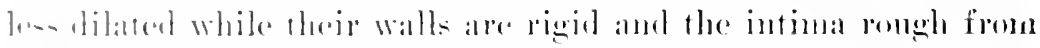

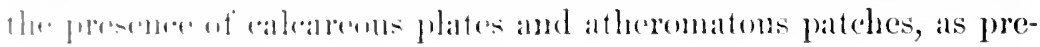
viols-ly dearibied.

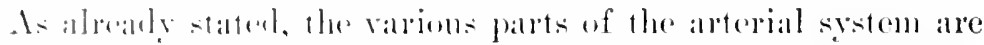

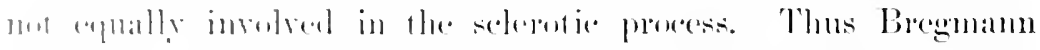
fommel as a lesult of analysis of the cases investigated muder

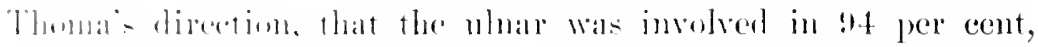

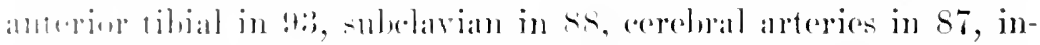

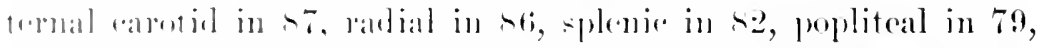

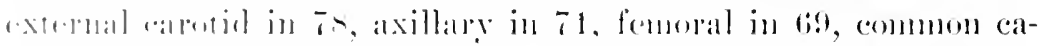

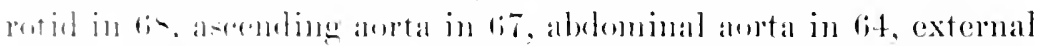

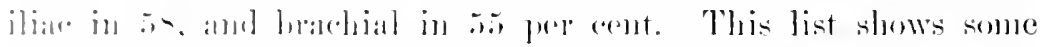

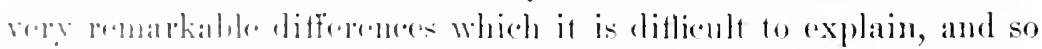

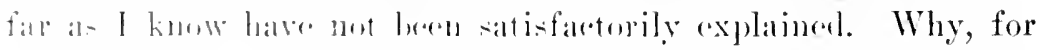

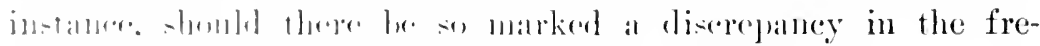

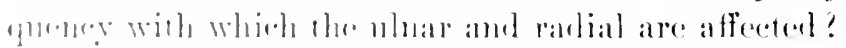

This- matter will again be reforrent to in eonsidering the eti-

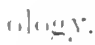

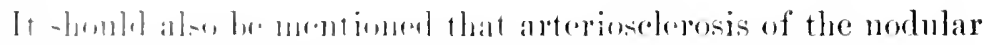

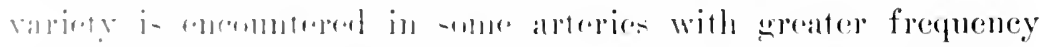

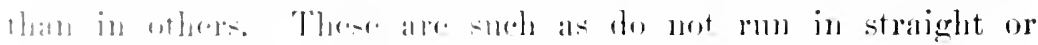

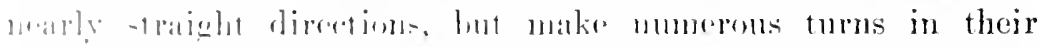

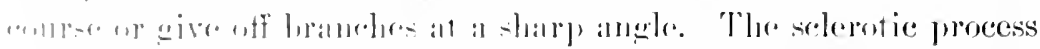

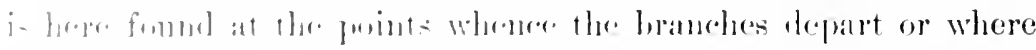

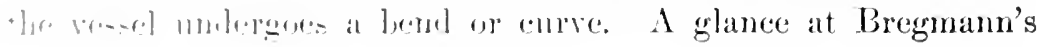


tables, quoted by Rombers, and compiled with special reference to the nodular form, shows that the abdominal aorta heads the list, while the common carotid, internal carotid, aseemeling aorta, and cerebral arteries follow close after in this order.

On the other hand, the ratlial is generally affected with the diffuse form, owing probably to its nearly direct course and the arrangement of its not numerous branches, conditions which permit uniformly high blool-pressure, and hence development of sclerosis thronghout its length.

Associated with seleroic changes in the vascular system are alterations of a sinnilar nature in the varions organs, particularly heart, kidneys, and liver. In the senile form the heart may be decreased in size, whereas in the diffuse variety, that encountered in comparatively young and robust men, the licart sometimes reaches enormous dimensions. Councilman found instances in which the heart weighed two and nearly three times the normal. The myocardium is apt to show filnous degeneration, the coronaries to be sclerotic, and the aortic valve to be opaque, sclerotic, and in some cases incompetent.

The kidneys are especially likely to show the sclerotie change on microscopic examination, althongh to the naked eye the changes may be so slight as to be easily overlooked. The ealsule is atherent and somewhat roughened on its surface, which may present dark red depressed areas due to atrophy. The capillaries of the glomeruli are thickencd and may be obliterated and exhibit extensive hyaline degeneration. Atrophic changes maly be present in the liven, particularly in comection with senile arteriosclerosis.

Etiology.-The great frequency of sclcrotic changes in the arteries of old people very naturally attracted attention and suggested a close etiological connection between age and this disease. It has been thought directly due to senility, and henee a necessary part of advanced years. That arteriosclerosis is not an invariable accompaniment of age, however, is well known, and Gibson states that when Thomas Parr died at the age of one hundred and fiftytwo his arteries were found by Harvey to he free from any evidence of degeneration. Such facts indicate that to the mere influence of age per se camnot be attributed the development of arterial degeneration. The explanation given by Romberg of the conneetion between the two conditions seems to me to be the best I have 


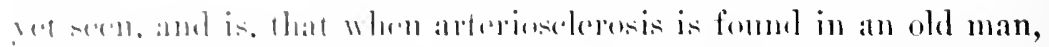
it is heanter the amditions of hlend-pressure which lead to the

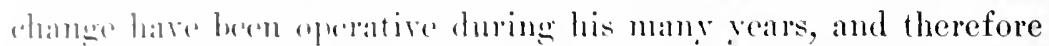
hatre anme to manifest themselves more extensively than in a rementere individual.

dills an withom dombt more often and extensively affected with this rhangw than are females. This is owing not to any spreval influmere inherent in sex, but to the greater exposure of men to arempltions. habits, and conditions of life in general which ather hlunl-pressure injurionsly. The influence of ocenpations which nevesitate arduons phrsical exertion, and thereby subject

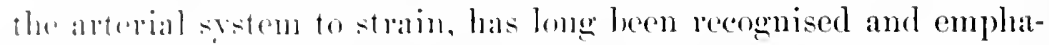
-izol, farriemarly ly the English. Thus day labourers, smiths, mincess, atc.. are very apt to develop arterioselerosis, sometimes at a complatively arly age, and lomulere points out that in them it is the vessels of the extremities that are specially prone to discalse. It is probahle, also, that among the labouring elasses other fareors ale at work beside plysical toil, such as abuse of alcohol and syphilis. Nevertheless, strain of the vasenlar eoats by severe

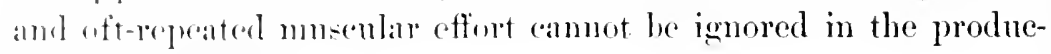
tim of $\therefore$ - lo loris.

()f liscases which lean to this degenerative process syphilis is pertalp the most important. Its relation to the form of endarteritis known as olliterans was drecribed by ITeubner, and is quite

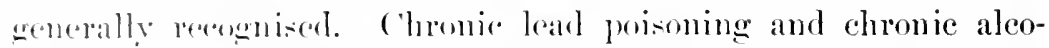

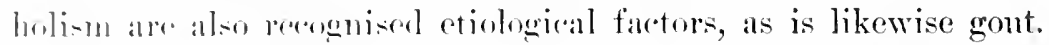
Ifow the-1 alet in not funite elear, whether as suggested by Tranbe

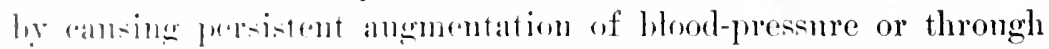
thre artion uf their prisoms diperely on the vasenlar coats. The raresive use of tobaceo is also brelieved by some writers (Huchard,

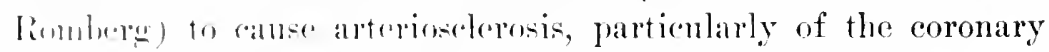

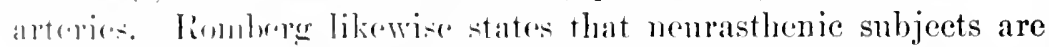
prome for alperial dregendration, as he believes, in consequence of

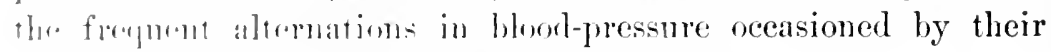

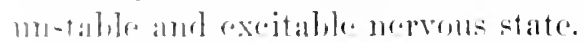

The mammer in which these, and other predisposing conditions

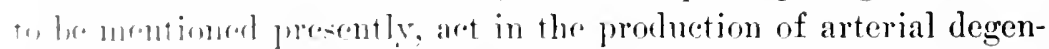

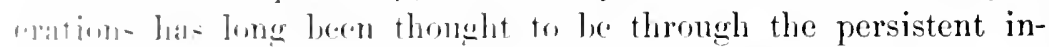
rrater of blomi-pressure occatsioned ly them. Nevertheless expla- 
nation based on such hypothesis was not altogether satisfactory and did not clearly account for the pathology or etiology of the changes observed. In the light of 'Thoma's investigations and views, however, we are now able to understand much in the etiology which was before obscure.

It will be remembered that, according to his view, the thickening of the intima is an attempt at the preservation of the normal relation existing between the calibre of the vessel and the pressure of its contained blood. The loss of such proper relation or equilibrium, as it may be termed, is brought about either by dilatation of the artery in consequence of lessened elasticity or by diminution in the rolume of the contents. Loss of elastic resistance on the part of the vessel is due to degeneration and atroply of the elastic fibres of the media, and this destructive change in the middle coat may be due to the long continuance of excessive bloodpressure or to sudden, frequent alternations of blood-pressure.

Diminution of the volume of blood is seen very much less frequently, but is met with in the arteries of amputated extremities (Romberg), and, according to the same author, in the renal artery in interstitial nephritis. Of course the former requirement-i. e., increased pressure--is far more often and widely operative than is lessened blood-pressure. Accordingly, when we have to do clinically with arteriosclerosis we have to scek out some underlying condition, disease, occupation, or habit, that has caused long-continned and greater internal or endarterial strain than the ressel was able to bear. Slowly the middle coat has been forced to give way before the intrarascular blood-pressure, pari passu the intima has taken on compensatory thickening and by degrees the sclerotic process has declared itself.

In some individuals blood-pressure has been abnormally high quite uniformly throughout the body and arteriosclerosis is general. More commonly, perhaps, the conditions influencing the change are local and the degeneration is confined to or at least far more pronounced in certain parts, as extremities, brain, coronaries, ete. For example, the frequency with which the anterior tibial is involved is explained by the fact that this artery is compelled to bear the distending weight of a column of blood which is heavy by reason of hydrostatic pressure (Romberg).

It has been frequently and forcibly pointed out (Fraenkel, 


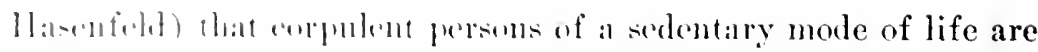

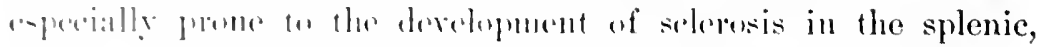

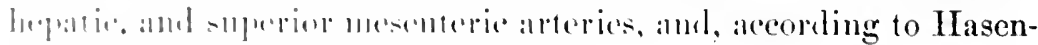

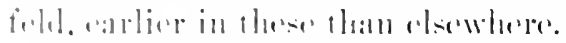

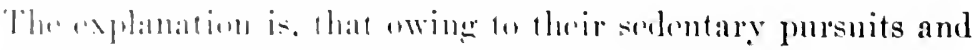
the ir hatrinat anm-multion of mone fond than the requirements of their inatire lives demant (luxus comsumption) the ressels of their ligentive nratus ane persistently wertaxed. In other words,

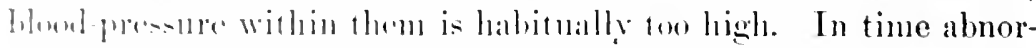

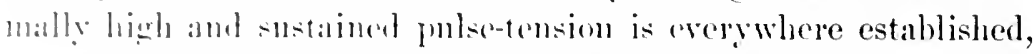

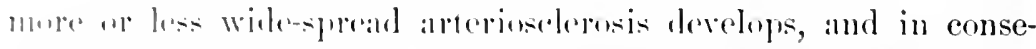

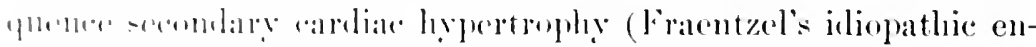
lallenement of the lexart) results.

Amblere interesting phase of this puestion of blood-pressure matce the the terelepment of solerosis in ressels which are ex[necel an valrying degrees of pressure, ascillations from low to

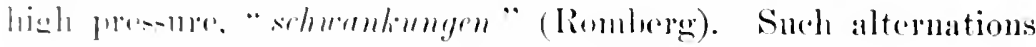
suljeret the artery 10 molue strain and probally aceount for the

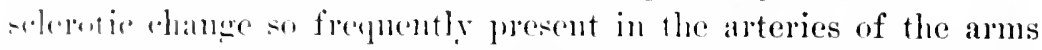
of wokingmen. Arording to Romberg, they also explain the fict that sufficers from migraine sometimes manifest selerosis of the arteries of the side of the head affected by the pain.

It is on this hyputhesis likrwise that we may explain the preInonderane of arterioselemsis in the cerebral vessels of persons who

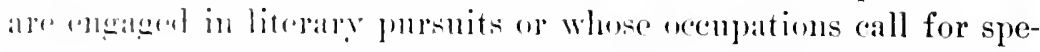
rial aletivity on the fart of the brain during a certain number of

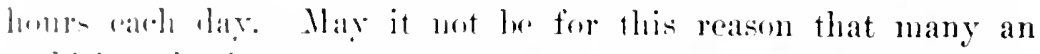
amblitinns buriness man succumbs to the stress of modern com-

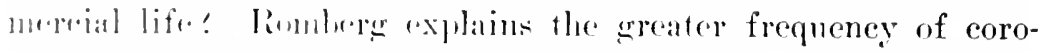

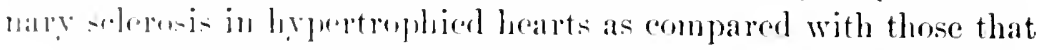

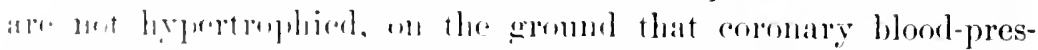
$-11 \mathrm{w}$ is lisher in the former on acemut of their more forcible

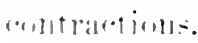

If hi- view is armeret, then one is temptrenl to query if the car-

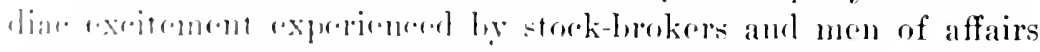
molep the influesuere of rapirl fluetuations of the stock or grain marken may not have mork to do, with the relatively great fre-

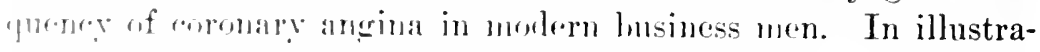
tirn of the infortant eriological influence exerted by variations 
of blood-pressure in circumscribed areas, Romberg cites the remarkable case reported by Erb of an ardent angler who developed a high degree of arteriosclerosis in the lower extremities, in consequence, it is thought, of his standing and walking for hours together in the cold water of the streams where he tished.

Additional instances of the injurions effect of long-continned high blood-pressure are seen in the degenerative changes found in the pulmonary artery of mitral patients and in chronic phthisis as well as the general arterioselerosis of diabetic patients (Romberg). In short, upon the basis of Thoma's conclusions we are now able to understand many a case of arteriosclerosis the development of which was previously almost mintelligible.

Symptoms.-Arteriosclerosis is latent so long as it is of minor degree and not very wide-spread. When at length symptoms are produced, they depend upon the degree and distribution of the process and the organs affreted. In some cases the clinical pieture is that of renal inadequacy, in others of cardio-rascular disorder, in others again of disturled cereloral eirculation, and in still others of interference with the blood-supply to the extremities, digestive organs, or heart-muscle, as the case may be.

Selerosis of the renal arteries may be secondary to already existing interstitial nephritis in consequence of diminished supply of blood to the renal capillaries, but in most cases it precedes or accompanies the development of the nephritis. The angmented blood-pressure occasioned, first declares itself clinically by increased secretion of urine, particularly at night. Examination of the urine in this early stage generally shows nothing moie than a lowered specific gravity. When at length the selerosis has become so extreme as to materially interfere with flow of blood in the renal capillaries, the mine grows scanty, and is apt to present characters like those of genume contracting kidney.

In these eases there is apt to be more or less selerosis of the arteries of other parts, particularly the lieart, or general pulse tension becomes too high to be successfully combated by the hypertrophied left ventricle, and symptoms of cardiac incompetence are added to those of renal disease. Thus I recall the case of a middleaged physician who, aside from cardiac hreathlessness, developed symptoms of serious renal inadequace. Trine grew persistently seanty, contained an oceasional trace of albumin, but rarely casts. 
Il, nltimately died with semptems that were mante rather than

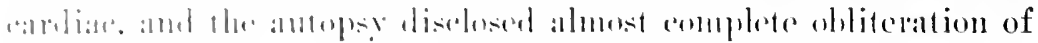
Hhe renal artertice.

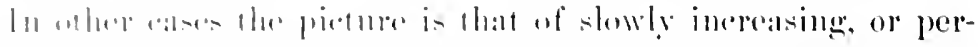

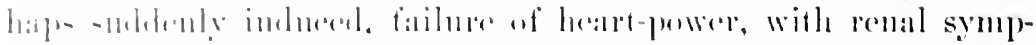

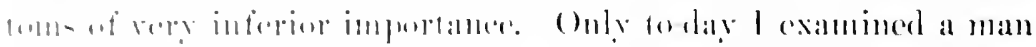

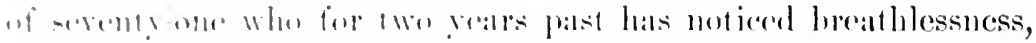

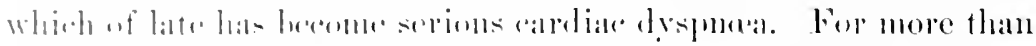

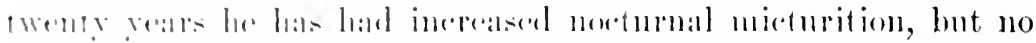

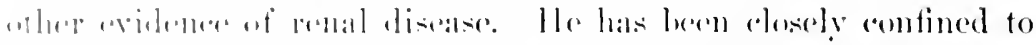

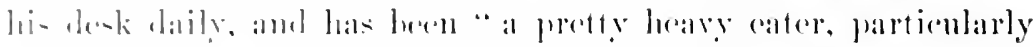

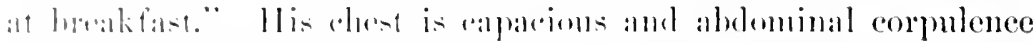

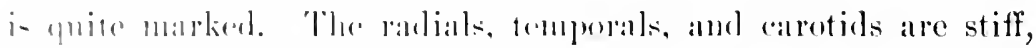

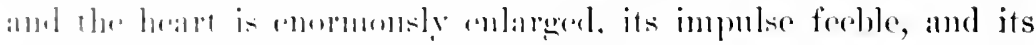

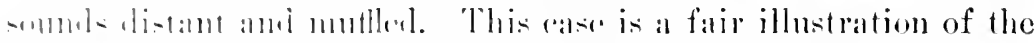

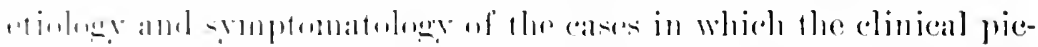

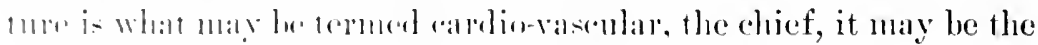
(n)

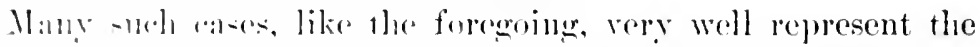

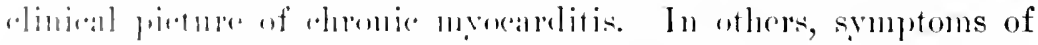

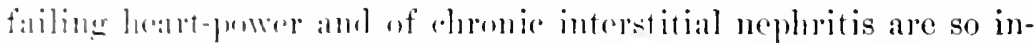

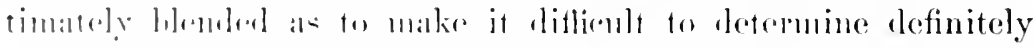

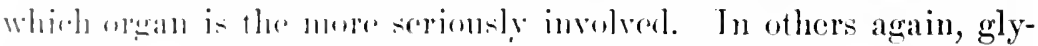

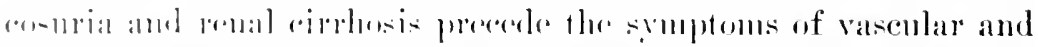

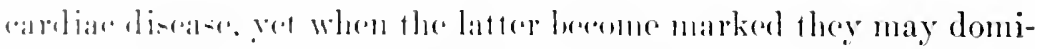

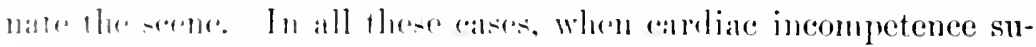

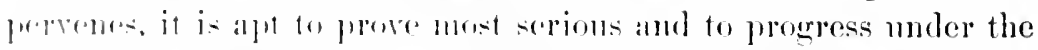

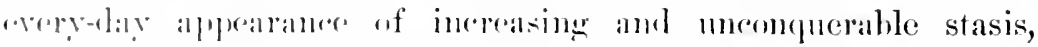

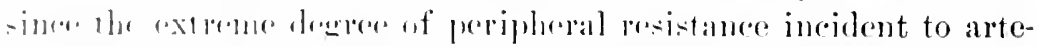

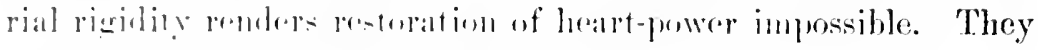

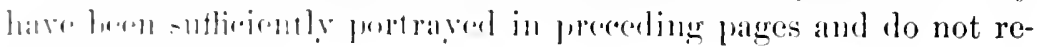
quirm reprition.

In $\cdots$ mplatively fow

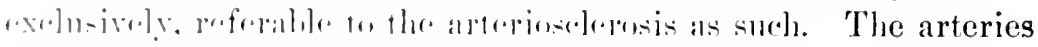

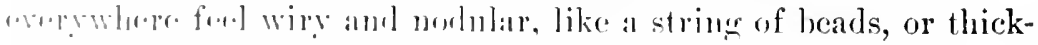

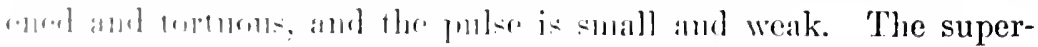

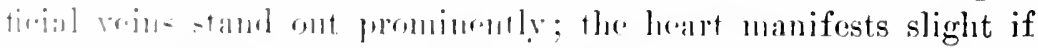
any "hanger. bering in some mererately and in others not at all roplarerel; the wrine is scanty and of poor quality, and if any albu- 
min is present, it is a mero trace, while casts are saluty, being hyaline or granular; the pationt complatins of increasing inability to work or exereise; appetite and digestion tail; slight anlema appears at the ankles; the individual analciates, grows sallow, pale, steadily more feeble, and at length takes to herl and dies from what appears to be general asthenial.

I have notes of snch a typical case in an Englishnin who was a farmer of about sixty-right years of age. I ${ }^{+}$p to a year or so prior to my seeing him he was hale and hearty, and able to perform active work of a not too severe kind.

Examination diselosed $n 10$ distinct evidence of heart or renal disease, but the radials, nhars, temporals, femorals, and tibials all felt hard and empty and most of them contained deposits of lime that gave them a pronounced beady character. Tenons stasis was erident in the turgescent reins, palpable liver, and slight pitting of the ankles and shins. He did not complain especially of dyspnoa, but was much concerned over his growing weakness and loss of weight.

Treatment benefited him for a time, but he nltimately grew too feeble to report at my office, and as he resided in the comntry was lost sight of. It was ultimately learned, howerer, that he died after a few months of what appeared to be general feebleness with failing circulation. In his ease, as in many, the heart seemed to be comparatively unaffected and the difficulty of circulation to be due to the impermeability, so to speak, of the arteries.

The rigidity of the arterial system interferes with proper discharge into the capillaries-neither are the arteries able to receive the full supply of blood sent from the reins, and stasis occurs.

In a considerable proportion of cases the clinical manifestations are not those of disturbed eireulation in general, but of diminished or abolished blood-smpply to a part, as the brain, extremities, heart, ete. The result is perverted fmetion and structural alteration of a more or less serions lind. In some instances such disturbances are plainly apparent, while in others the manifestations of arterial degeneration are obscure and often misinterpreted or overlooked altogether.

Thus sclerosis of the cerebral arteries may be shown by impairment of memory and intellection, headache, transient vertigo, especially upon quickly assuming the erect position, change in disposi- 


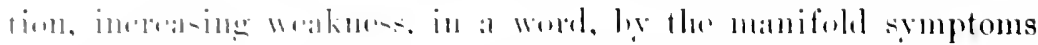

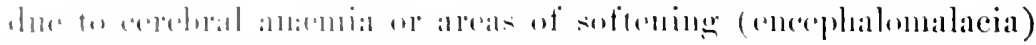

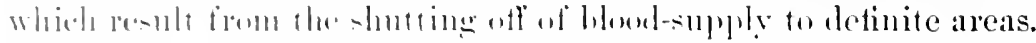

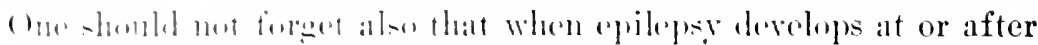

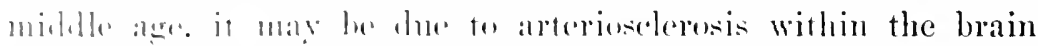

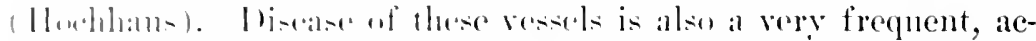

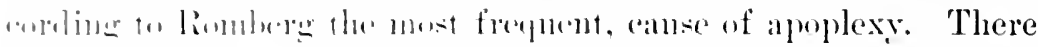

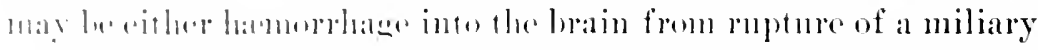

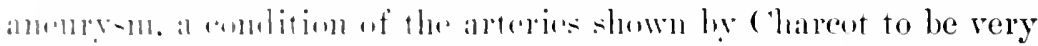

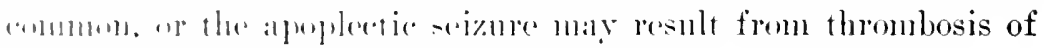

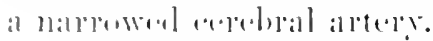

Sulareis of the arteries in the molulla is a reengnised cause nt -lumbers of the pulse anel of renorent bralyeardia known as

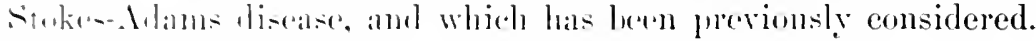

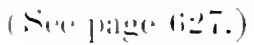

Sulereis nt the arteries of the feet and legs is not uncommon,

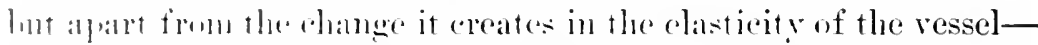

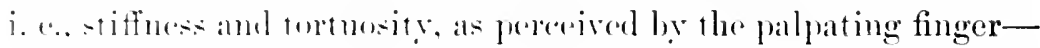

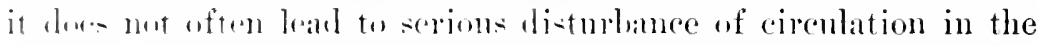

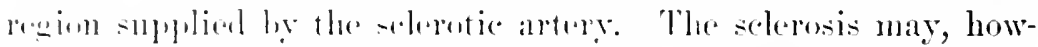

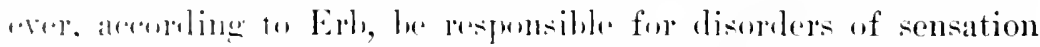

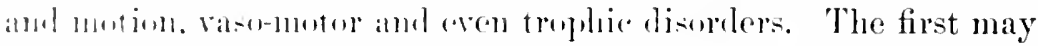

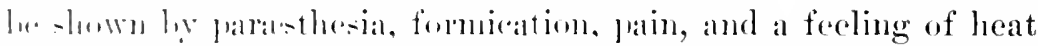

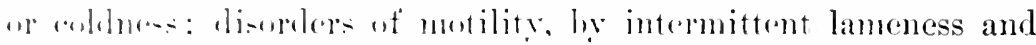

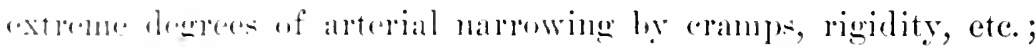

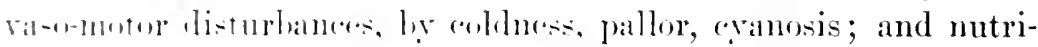

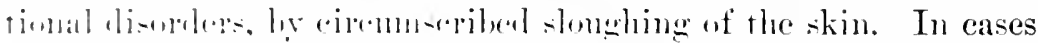
uf ullitration finm solepeis, as is well known, there may be locali

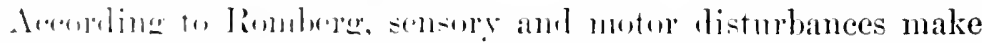

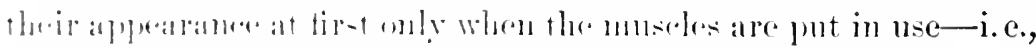

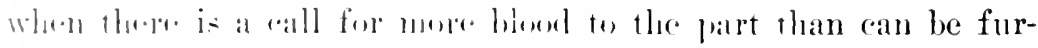

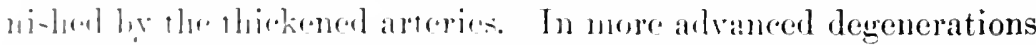

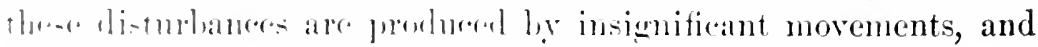

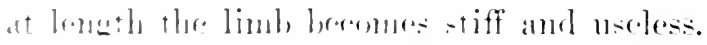

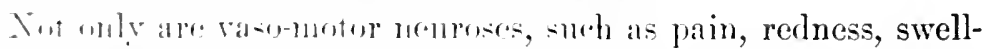

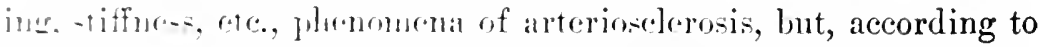

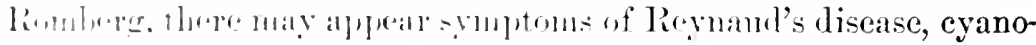
$\therefore i-$ [ballo], and evon gangrene of portions of the skin, such phenom- 
ena being particularly liable to affeet the fingers. Fortunately, however, such serions disturbances are lare, and for the most part only minor degrees of sensory and vaso-motor perversions are present.

The heart may be affected by arteriosclerosis in either or both of two ways: It may be legenerated and feeble in consequence of thickening, narrowing or thrombosis of the coronaries, with angina pectoris and the symptom-complex of nyocardial ineompetence, or the heart may be secondarily hypertrophied in eonseqnence of diffuse selerosis of the arteries supplying the abdominal viscera. Hasenfeld has dwelt on the intimate comnection between selerosis of the mesenteric vessels and general carliac hypertrophy, and Romberg also states that it is degeneration of these arteries which calls forth secondary hypertrophy of the left ventricle. Extensive vasenlar change of the brain and extremities may exist, he states, without appreciable enlargement of the heart. This coincides with my clinical experience, for the largest and most inadequate hearts I have ever seen have been in men whose abdominal corpulence and sedentary lives have furnished the conditions necessary for the development of vascular discase in the splanchinic area. Noreover, their stiffened radials and high-tension pulse have borne out the correctness of that assumption. On the other hand, I have seen old men with emaciated abdomens, peripheral arteries that were like wires strung with tiny beads, and feeble, even flickering pulses, and yet whose hearts conld not be made out as hypertrophied. In some of these cases, to be sure, pulmonary emphysema renders the results of percussion uncertain, but the elinical picture is that of adynamia or of a eachexia, but not of myocardial failure, as in men of the other type.

Lastly, there is still another group of eases which present themselves in guise of chronie bronchitis and emphysema. They are usually at or past middle age, not confined to either sex, yet in my experience more often males of the labouring class. The vaseular system is everywhere stiff, urine is of poor quality or may contain a small amount of albumin, and there is manifest hypertrophy of the right ventricle. This may be due in part to the emphysema, but a contributing factor of importance is the selerosis of the pulmonary arteries. It is not always easy to determine whether this disease of the pulmonary vessels is primary or secondary, but as it 


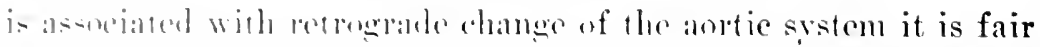

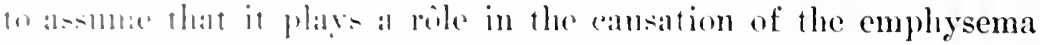
and hromhial witarh.

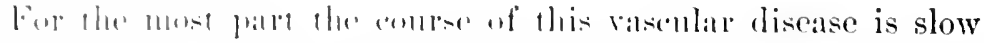

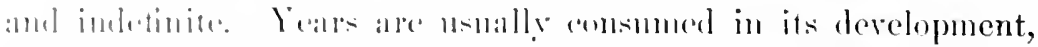

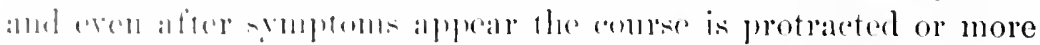

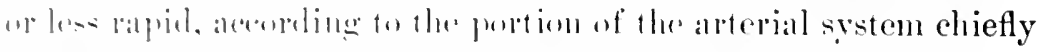

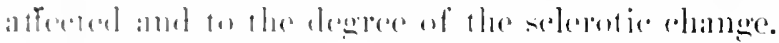

Physical Signs. Inspedion.-There are two main types of

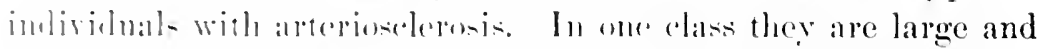

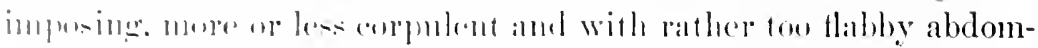

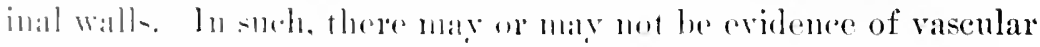
distase in the prepipheral arteries. The other type is quite the rerepese The indivilual is thin, looks ill-nomrished, and the tem-

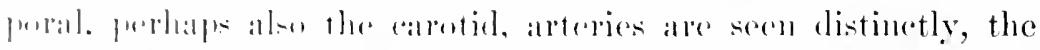
formere lonking like stiff tortnous cords and pulsating visibly.

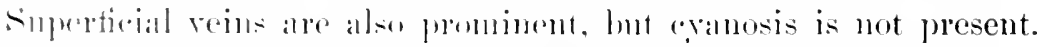
The wly other information obtained be inspection relates to Whanger in the trongthat and location of the apex-beat, and to epi-

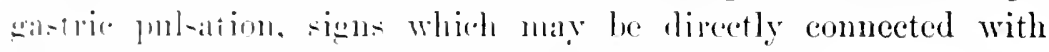

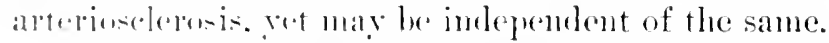

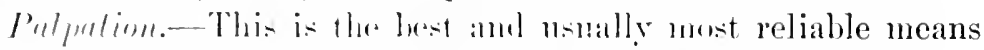
of detentine alderial dewerations. If an artery which rests on a

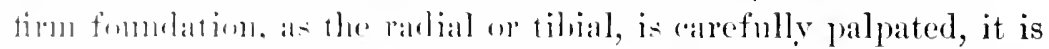

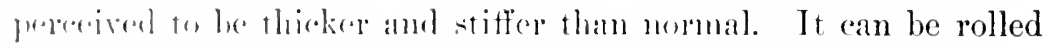

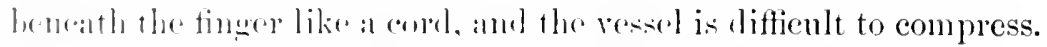

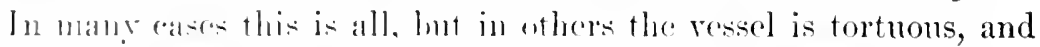

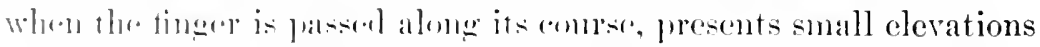

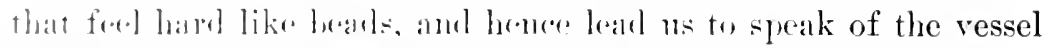

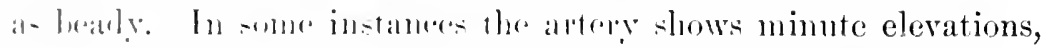
which when arefulle stulied are fombl to be dilatations of the

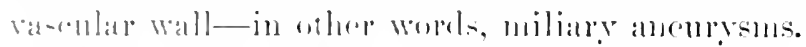

fartionlar attention shombl be paid to the cervical arteries,

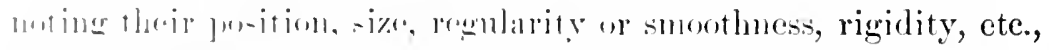
-ince ranger in then may formish valuable hints concerning the Tate of the antala and inferentially of the roronaries. When the

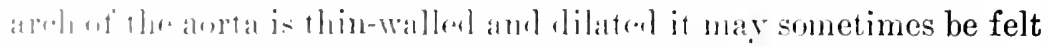

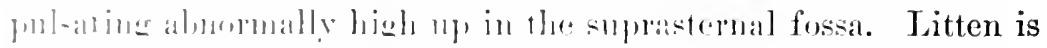
anthority for the statement that when the abdominal aorta is sele- 
rotic and accessible to palpation, thrill is elicited by very much less pressure than is required if the ressel is healthy.

Percussion is of value only in the detection of changes in the size of the heart secomdary to vascular disease. It may, therefore, by demonstrating hypertrophy of the left ventricle, afford a certain anount of corroborative information. Careful and deep pereussion of the areas overlying the ascending portion of the aortic arch may detect a slight degree of duhess due to dilatation of the vessel. In such a case resonance is apt to be impaired in the first and second right interspaces close to the sternum. Dilatation and elongation of the arch may displace the heart downward, the same as does true aneurysm; and hence in cases in which the aorta is suspected of being sclerotic, it is well to pereuss the heart earefully, with view, if possible, to ascertaining its exact location.

Auscultation.- Almost the only value of this means of investigation lies in the study of the second sound in the aortic area. This tone is nomally more intense than is the pulmonic second in persons after thirty years of age, and hence it is the quality of this sound more than its mere intensification that is significant. General arteriosclerosis canses accentuation of the aortic second tene, but so also do other conditions, especially chronic interstitial nephritis. Taken in comnection with left-ventricle hypertrophy, mdue intensification of this sonnd is significant of arterial or renal disease or both. If the sound is not only intensified but is also sharply ringing, even of a netallic quality and is associated with stiff arteries in persons of middle age, it is generally considered to indicate sclerosis of the norta. Should the sound be not quite pure, as well as accented, it is likely that the valve is also involved in the degenerative process. Not infrequently in persons whose vessels are resisting, there is a systolic nmrmur heard along the comse of the ascending arch, and when present is, in the absence of signs and symptoms of anenrym, to be regarded as due to roughening or dilatation or both of the aorta, not of stenosis of the ostimm. Any other modifications of the cardiac sounds are indicative of secondary or associated changes in the heartmuscle and valves.

Diagnosis.-The recognition of sclerotic changes in peripheral vessels that can be reached by the palpating finger, as radial, ulnar, tibial, etc., is a very simple matter, and has been sufficiently 


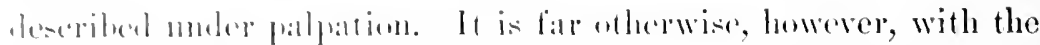
diagnesis of ackeresis of the arteries within the eranial and other alvities. In smeh, diagursis is msually a malter of inference in-

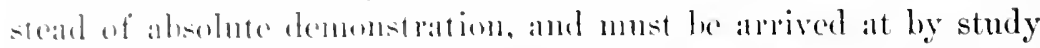

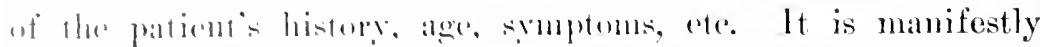

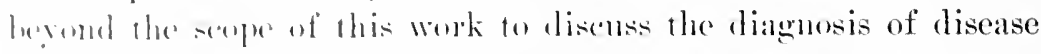

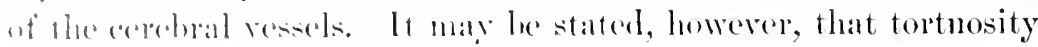
and rigidity of the temporats may, in comeetion with the head

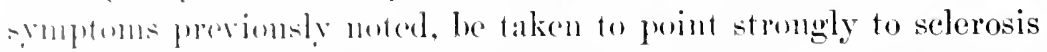
of the corlual arteries. If lombt still rematins, or the external rasels alpe negative, the ophthalmuseope may be appealed to and is sibl an furnish early and relialle information concerning the salte of the erebral arteries (Thoma, Rehluman, Koenig). The

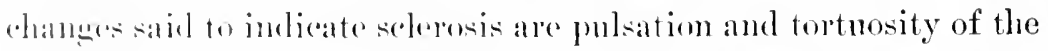
retinal artery (when not dne to chlorosis or anlemia), opacity of its coats, narrowing, and it mat be thrombosis of the artery of the liapillat, and miliary aneurysus and punctate halmorrhages into the retina, the choroid, and the enreloping capsule of the optic nerve (lionig).

The diannesis of sclerosis of the aorta cannot always be definitely makle. Romberge states that the combition of peripheral rescels, ats ratials, affords no criterion of that of the aorta, and henee stiffues of the arm or leg arteries does not warrant a conelusim that the antal is also selerotie. The state of the latter must lwe inferred, therefore, from calreful stuly of the eervical vessel: and of ehanges in the size of the heart or of its somds. If the capotids appear healthy, if the heart is not appreciably enlarend mor displaced, and the antic second tone is not moluly ae centmatcol, then the anda is prebahly liealthy. If, on the contrary, the earotils are myiedding, the sulchavians are sitnated abnormally high and fow stiff, if the left rentriele is hypertrophied, and

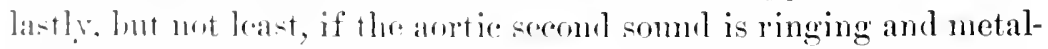
lie, there is probsthly selerosis of the aseenting portion of the arch.

The yuestion of the existenee or not of arterioselerosis within

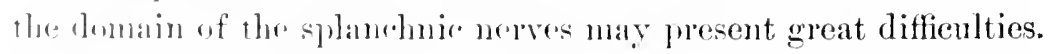
The rengention of stiffener radials in a corpulent individual who complains of lyspmera of effort out of proportion to recognisable chaneres in the heart, renters extremely problable a similar state of the ver.ts dreply situated in the abdominal cavity. If, on the con- 
trary, aceessible arteries are not siff, one must depend for diagnosis on the history, symptoms, degree of blook-pressure, and adequacy. as well as size of the heart. A history of sedentary pursuits and of luxus consumption; gradually developed and increasing shortness of breath; abdominal corpulence; high tension but slow pulse; cardiac hypertrophy without dilatation; these point strongly to arteriosclerosis as the cause of the symptoms.

In suspected cases one should test the officiency of the heartmuscle as well as search carcfully for indications of overstrain of the right ventricle. If the pulse is unduly rapid and feeble during repose, if cardiac dulness is increased transversely and downward with pulsation in the epigastrium, if superficial veins are engorged, there is reason to conclude that the heart is no longer quite adequate and that the dyspnora is cardiac. Then if on the patient's making extra exertion, as by hopping about the room, the action of the heart grows muduly accelerated, perhaps irregular or intermittent, and the sonnds becone feeble, perhaps accompanied by an apex-murmur, but little doubt is to be entertained of myocardial insufficieney.

Even then the state of the internal vaseular system may be a matter of doubt. Prolonged high tension of the pulse, as shown by Gaertner's tonometer, and a ringing metallie quality of the arotic second sound strengthen the assumption that the heart weakness is secondary to arterioselerosis. It is, of course, presupposed that all other etiological lata are wanting.

The differential diagnosis of such cases from the cardiae insufficiency of the obese (the so-called fatty heart), is often impossible, and, as a matter of fact, the two conditions are not infrequently combined. In the obese, however, there is a general distribution of adipose tissue far in excess of what exists where there is only excessive abdominal corpulence with arterioselerosis.

Quite recently I examined a gentleman of fifty-three complaining of breathlessness on more than moderate exertion. His abdomen was very bulging and flabby, while his extremities and ehest were rather thin, his radials were distinctly stiff, but the heart was not appreciabiy enlarged except on the left, and did not grow too rapid or irregular from the effort of hopping up and down my office. In this case I felt no hesitation in attributing his symptoms to arterioselerosis, and not to myocardial inadequacy, 


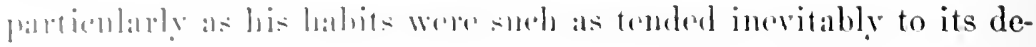

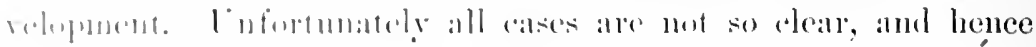

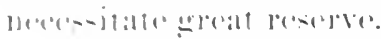

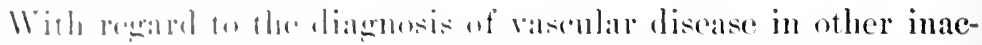

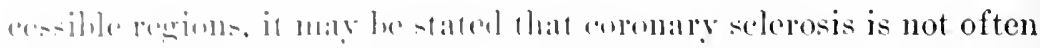

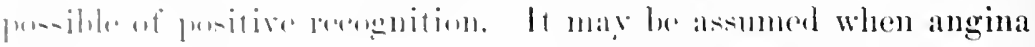

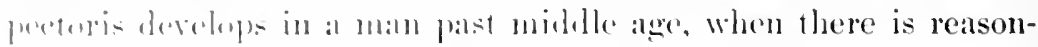

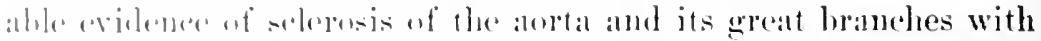

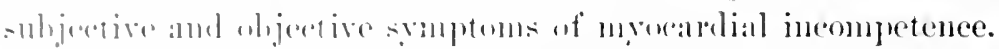

Sclemen of the puhnonary artery eannot be diagnosed with

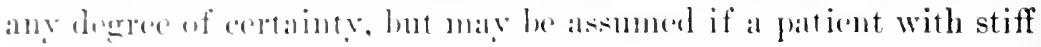

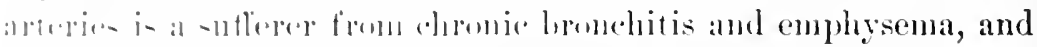

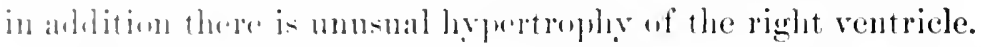

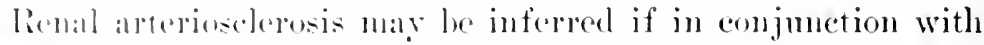
-tiffenel periphesal resels there is nocturnal mictmition, the urine lueng of foren ynality. When in an alvaned stage there is cribence of pustive renal (hange, as shown by albumin and easts, it is priatically impersible to say detinitely how much is due to

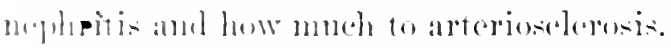

Prognosis. - This defends nprom the degree of the vaseular

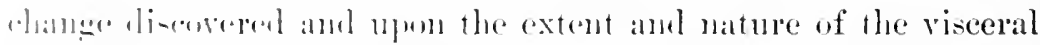

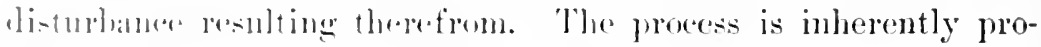
gro-ive, and t believe incurdble. Srmptoms may, however, sometimes le held in eluek lig proper tratment.

(aldir-matcoular simptoms are for the most part subject to the monditins which influenee prognesis in cases of myocarditis, and

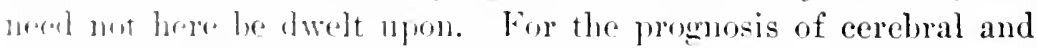

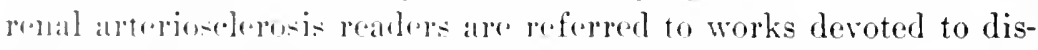
ratere of the repective oreme. The prognesis of selerosis of the

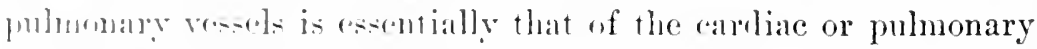
affertims to which it is secondary, while when vascular decay of the arterien of the extromities has onee led to definite disturbance

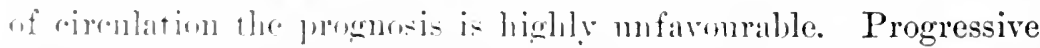
"matriation and les of strongth in general arteriosclerosis indieate (1) seriens an interferenee with mutrition that it may be regarded at 11 ir

Treatment.-This is to be liviled into (1) prophylactic, (2) contive, and (3) symptomatic. The institution of preventive nuct-ures necesitate $(\Lambda)$ the earliest possible recognition of vas- 
cular change and (B) the proper regulation of habits, diet, exercise, and excretion with a view to lessening modne vascular strain and correcting injurious fluctuations of blood-pressure. The disastrous effect of sedentary pursuits must be counteracted by appropriate gymmastic and abdominal exereises, ineluding massage in cases of excessive abdominal eorpulenee. Heary feeding must be restricted and its effects offset by outdoor exercise and sports, as golf, hunting, and fishing. Furthermore, the chatracter of the dietary should be revised so as to exelude or reduce the eating of meats which are tissue-forming foods and are also harmful on account of the extractives they contain.

Theoretically, also, the diet should not consist of foods rieh in lime-salts, and as a matter of fact Rmupf, of Hamburg, ents out such articles from the dietary of his patients. He includes among sueh forbidden articles milk, eggs, cheese, rice, and spinach. For my part, I am of the opinion that quantity euts a far greater figure than does quality, since it is a matter of every-day observation that the individuals who live the longest and are the most active with advancing years are those who eat sparingly and of a dietary relatively rich in regetables, cereals, milk, and fruits. I regard it as a good indieation when a person past middle age tends to lose weight gradnally rather than to gain. Best of all, he should strive to hold his weight about at a standstill until well on in years.

Exereise in the open is a rery important matter, especially for the man who haring been aceustomed to plenty of exereise in eollege suddenly finds himself tied down to his office desk many hours each day. He should endeavour in every way possible to get out for some sort of active physical exertion. If his profession or business duties tax his mental powers severely and keep him keyed up to the highest pitch day after day and month after month, then he should make whatever sacrifice is necessary to secure a yearly raeation, during which he ean obtain perfect relaxation and reereation. Otherwise selerosis of cerebral or other arteries will be his fate after middle age.

If, as is believed, the splanehnie nerves regulate blood-pressure and irritation of these nerves inereases blood-pressure, particularly within the abdominal eavity, then, from a prophylactic standpoint, digestive derangements, including of eourse ehronie constipation, 


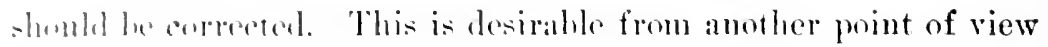

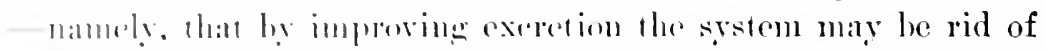
tovime which may he of influenes in angmenting atopial tension,

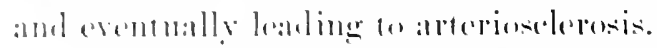

In a word, the prevention of degemerative changes in the blood-

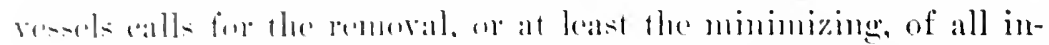

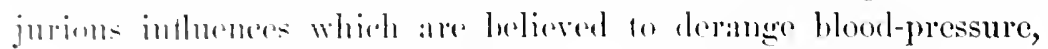

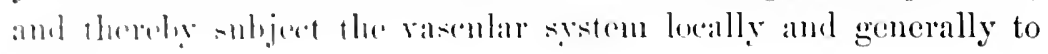
strinin.

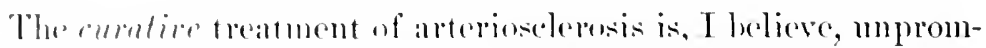

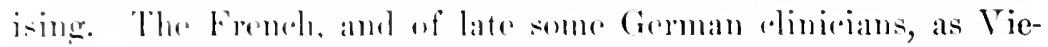
rorlt. "xperes fath in the aliblity of ionline to arrest and even cure ra-enlal deremeration. The remedy is alumintered in the form of indisle of sulimm rather than of potassimm because of its being better tolerated. It is hermom in sulall doses, 2 or 3 grains twice or

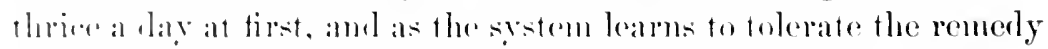
it is eradually incerased mutil 15 grains flure times a day are

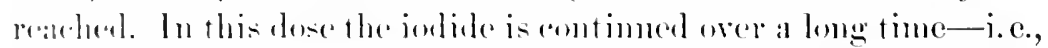

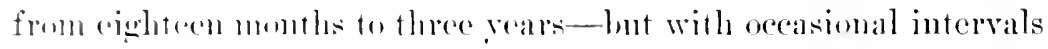

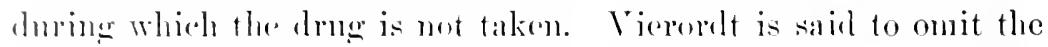
remaly ane week out of five and one month ont of erery five montles. Given in this mammer, and from the start incleased so cautionsly as mot to cams molne irritation, lue has seon very enatifying results. I have malde pegraterl attempts to get me private patients to perserepre in the nse of iodide of sodimm aftor the mamner recommended ly Vierorelt. lont always without suceess. It has invariably disor-

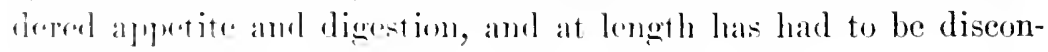
timinel.

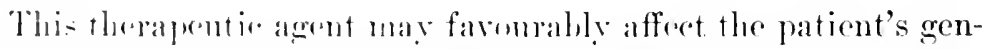

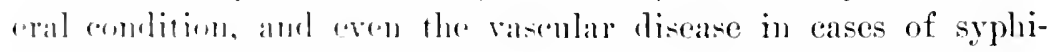

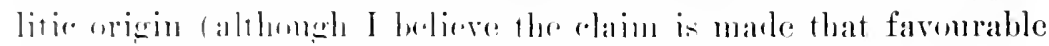

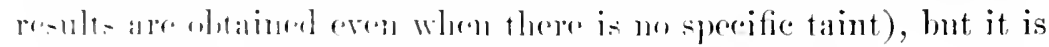

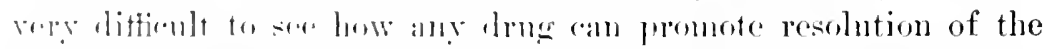

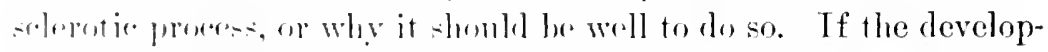
mant of enmoretior tis-nr. in the intima is, as Thoma believes, a

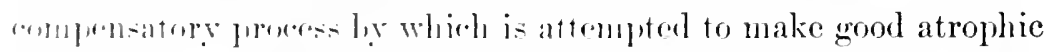

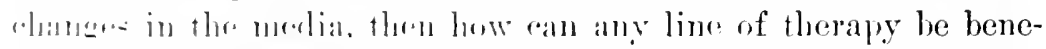

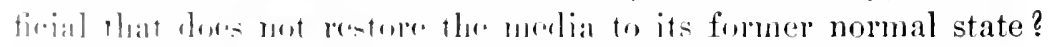
Thr iodile maly in some way prevent or remove deposits of lime 
and the hyaline degeneration that ultimately ocur in the newly formed comnective tissue, but ean it do nore or would it be well to have it do more?

It seems to me, therefore, that when arteriosclerosis has onee becone pronomeed, onr efforts must be limited to the prevention or lessening of srmptoms-in short, numst be symptomatic. To do this we nust endearour to promote better circulation in the arterial system, since it is in this respect that evils arise.

Cardio-rasculatr derangements are to be eombated in the same manner as disorders'due prinarily to cardiac insufficiency, and these do not need to be repeated. I shouid like to urge the necessity, howerer, of freely using raso-dilator's, as the nitrites, that if possille the arterial paths may be somewhat opened up and the labour of the left rentricle thereby lessened. In this class of eases nitroglycerin, ete., should always be given whenerer it is necessary to resort to digitalis. It is heeanse of the constricting action of digitalis on the arterioles that strophanthns onght to be tried instead, and only replaced by digitalis when it has proved inefficient.

Nothing is of greater service in eases of diffuse arterioselerosis with seeondary renons engorgement tham a periodic purge by means of calomel. The catharsis should be brisk to be of benefit, for relief does not follow until several watery stools have been secured. I have seen truly surprising results from such simple treatment. One instance in particular comes to mind as I write, that of an ohl Groman with very stiff ressels who exhausted both my patience and ny resources in a vain endearour to procure relief from formication and coldness of the thighs. At last, in despair, I prescribed 5 grains each of calomel and jalap for the purpose of preventing lis return to my elinie. He did not reappear for two or three months, when one day le returned, and on entering the clinie room exclaimed that he had come back for another powder, as he had never liat anything do him so much good.

I recall also an Irishmam with stiff arteries and an obstinate chronic bronchitis that had defied the efforts of several well-known practitioners, and who obtained greater relief from his dyspnoa and congh by a single dose of 5 grains of calonel than from all the cough mixtures he had previously taken.

Fraenkel reports the highly interesting and instructive ease 


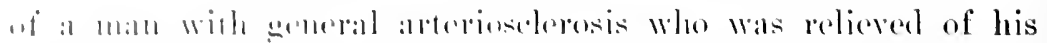

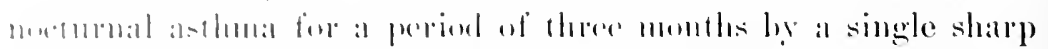

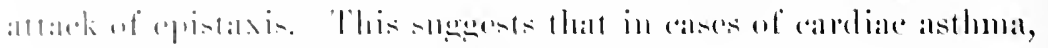

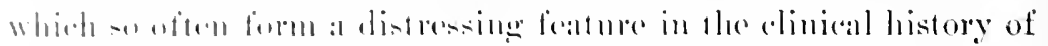

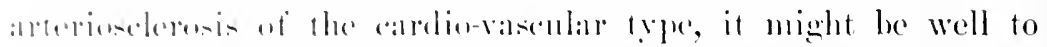

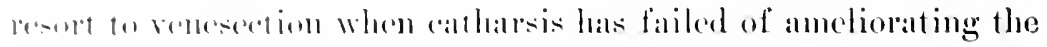
$\because 111016111$.

In corelual arterionelerosis I an of the opinion that stimnlants

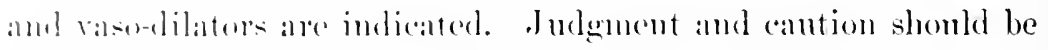

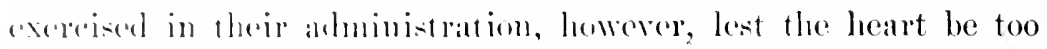
vigurmsly stimulated and rupture of a miliary ancurysm result. 'The safory at such medialtion may be estimated by the state of the

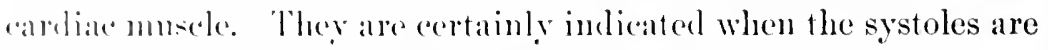

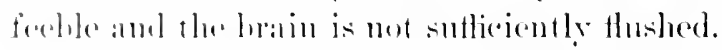

The treatment of colomary seleposis and its resulting angina

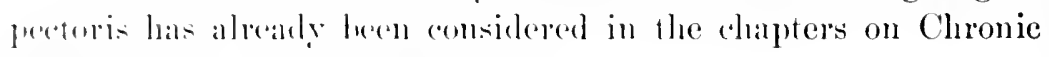
Mroxarrlitis and Angina l'ectoris.

The management of remal selerosis is essentially that of chromic nephritis, since the two conditions are so frequently comhined. When rascular discase in the extremities has led to gamwrone, the treatment is of necessity smereal. Selerosis of the pulmunary artery is practically that of arterioselerosis in general plus that uf bronchitis and emphissoma.

()nly gencial principles can here be haid down. In every ease sureial smptoms must be left to the judgment of the practitioner. 


\section{CHAPTER XXXIII}

\section{ACUTE AORTITIS - ACUTE ARTERITIS - SYPHILITIC ARTERITIS-ENDAKTERITIS OBLITERANS-PERIAR- TERITIS NODOSA-STENOSIS OF THE AORTA AND PULMONARY ARTERY-CONGENITAL SMALLNESS OF THE ARTERIES}

\section{ACUTE AORTITIS}

WIIEN acute inflammation of the aorta is discovered it is in most cases associated with the changes of sclerosis in the same sitution or with an acute endocarditis. French authors, however, have described a form of acute arritis whieh they claim is independent of antecedent sclerotic change and occurs in the course of aente infections diseases. Such statements are received with considerable reserve by the Germans, and von Schroetter in Nothnagel's System secms quite sceptical on the subject, particularly as regards its clinieal recognition.

Morbid Anatomy. - The aorta is found more or less dilated, and the surface of the intima looks rongh from the presence of reddish or grayish translucent more or less thickly scattered patches of a gelatinons consistency. These are minute thrombi, and it is through the detachment of these that cutaneons and other infarets oceur, the same as in acute valvulitis. Indeed, acute aortitis is so similar to acute endocarditis that the description of the latter may answer for the former.

The process may be of a benign type and proceed to the formation of so-called regetations, or it may behave like ulcerative endocarditis and lead to serions destruction of the vessel and rupture. In this manner commmication may be established between the aorta and one of the auricles, a contignous ressel or the perieardinm with fatal hemorrhage (Romberg). The media and even the adventitia becomes infiltrated with round cells, and if the pro- 


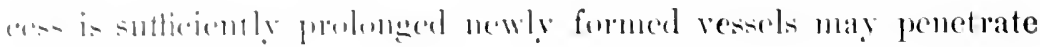
intu tha intima.

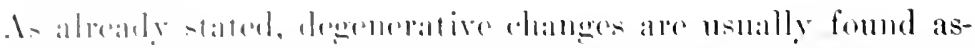

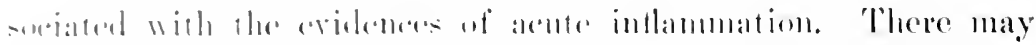

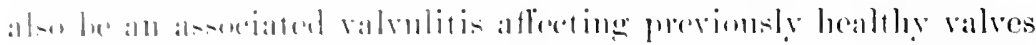

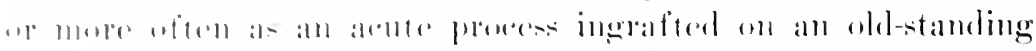

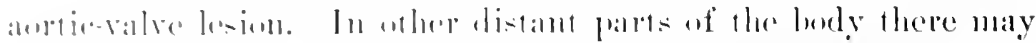

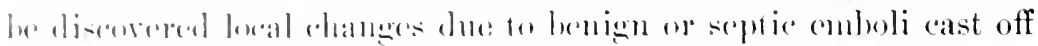
frem the antic intiual.

Etiology. - The anta may liecome aldutely intlaned in conse-

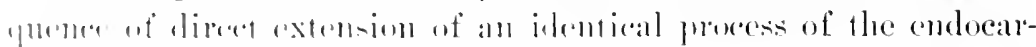

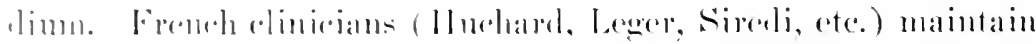

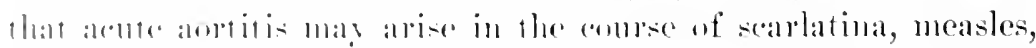

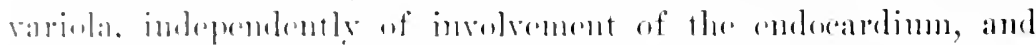

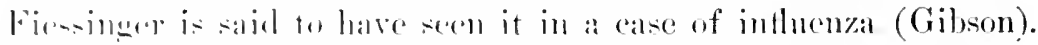

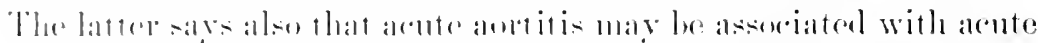

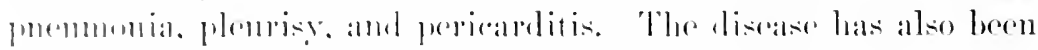

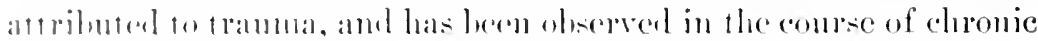
meplupiti-

Symptoms. - Lelle antitis in most instances is latent or is

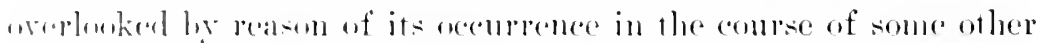
distinctive afferetion. The ase discovered ly Thoma, and whele

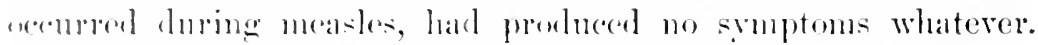

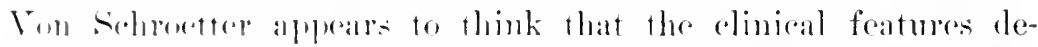

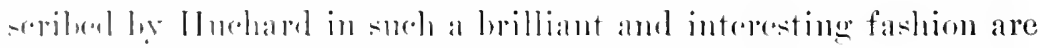

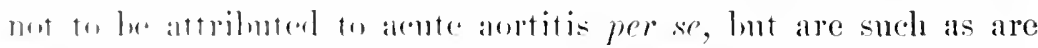

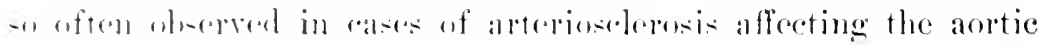

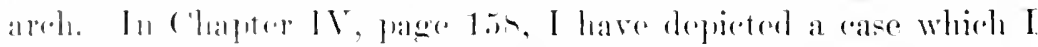

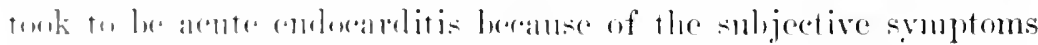

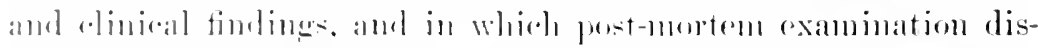

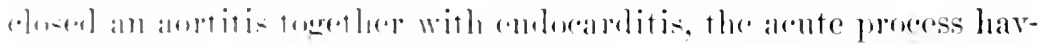

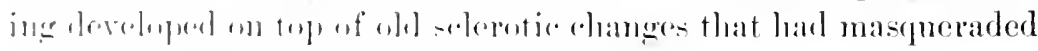

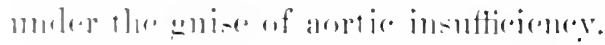

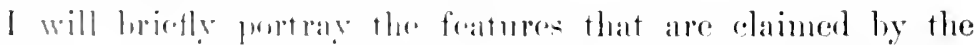

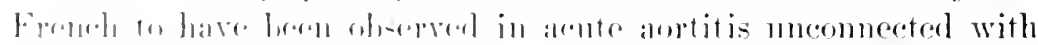

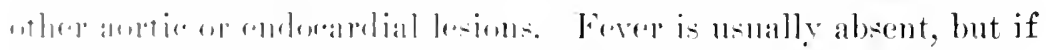

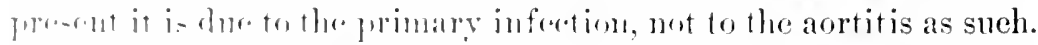

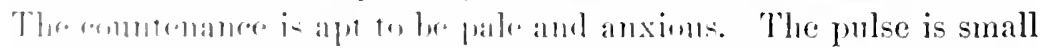
aml wrake reglar or not, as riremutances in each case may dic- 
tate. The patient is likely to eomplain of pain in the npel stepnal region, and sometimes extomling fhomgh the modiastinmm and down the back along the spinal colmme. The pain is described as burning, sticking, smating, (ote., and in some instances is said to ratiate into the left shoukler and down the arn, very like that of angina pectoris. The resemblance to this latter is enhaned by a feeling of oppression and anxiety in some cases.

Peter has observed tenderness on pressure in the intereostal spaces to the left of the manubrimn, and molne thobbing of the right smbelavian has hech noted ly French writers (Laboulhene, Fanre), and by them is attribnted to the greater liability to inflammation of the left subclavian than of the immominate artery. Von Schroetter, howerer, helieves that if snch difference in the pulsation of the two smbelavia exists, it is due to sclerotic changes, an opinion in which Gibson concurs.

Dysphagia, angh with expectoration, and disturbance of the digestive tract shown hy romiting and flatulene distention of the bowels, have heen observed in some cases.

In short, the svmptoms of this affection are often wholly wanting, and when present are not at all distinctive. There is nothing in them which nuay not be observed in other affections involving the heart, and hence Romberg states that even when the malignant form of acute aortitis oceurs, there is nothing in its clinical picture to distingnish it from ulecrative endocarditis.

The comse of acute artitis is often protracted and the termination is usmally in death.

Physical Signs are usually indefinite, or are such as are fonmel in other acnte inflammations involving the cardiac structures, or are those of the infection in the conrse of which acute aortitis oecurs.

Inspection.-The conntenance may be pallid and anxions, the caroids throb strongly, and the right subelarian may pulsate more powerfully than does the left.

Palpation is negative mless pressme elicits sensitiveness in the intercostal spaces to left of the stermum and along the course of the aorta.

Percussion is likely to be negative unless dulness be revealed at right of the manubrium in cases in which the inflammation leads to dilatation of the aortic arch. 
Insultulimo- Phis is not likely to fumish information of a

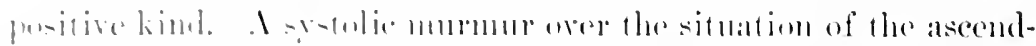

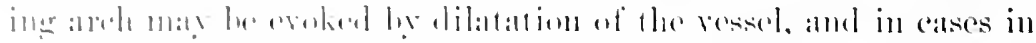

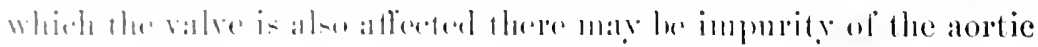
- 2 (4)

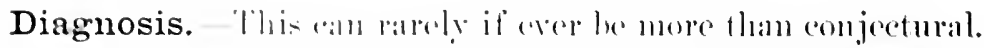

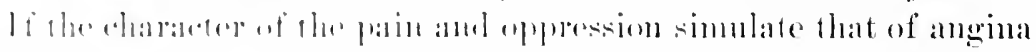

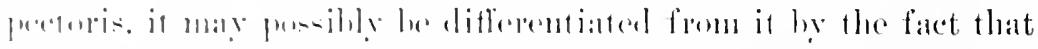

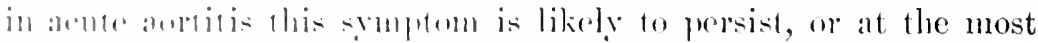

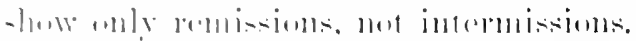

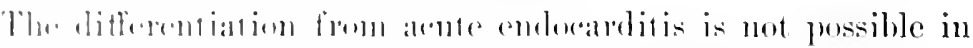

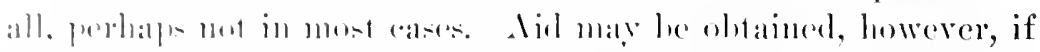

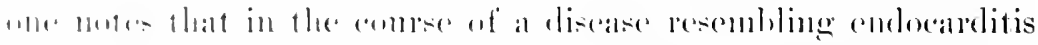

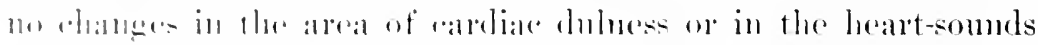

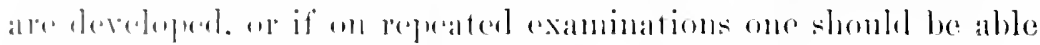

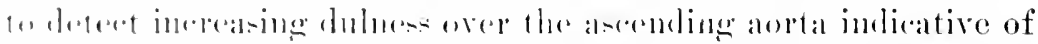

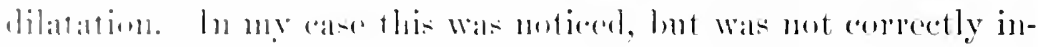

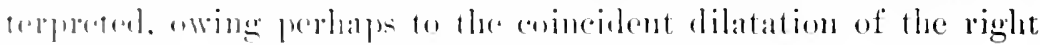
amilicle.

Prognosis.-This may la sald to be very matavomable. The

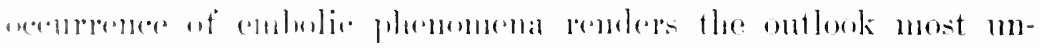

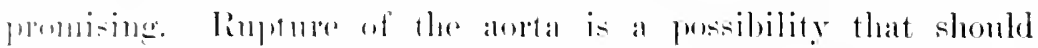

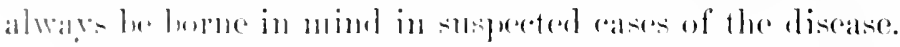

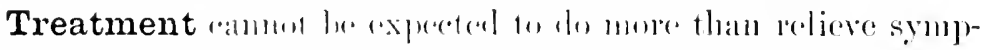

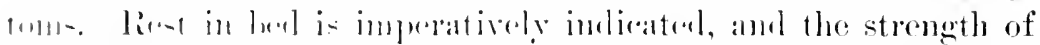

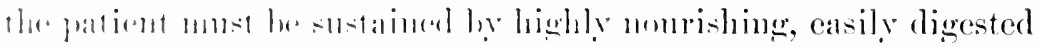

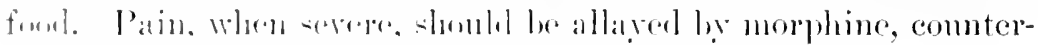

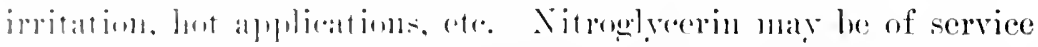

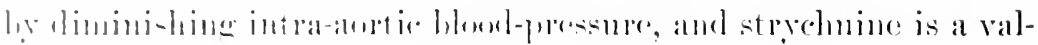

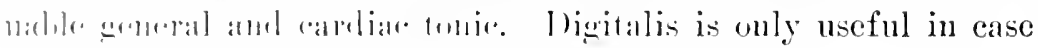

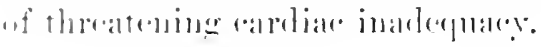

\section{JI. ACTES ARTERTTS}

Morbid Anatomy. - ('im.murrelibed inflammation of the

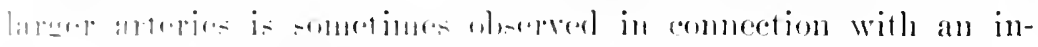

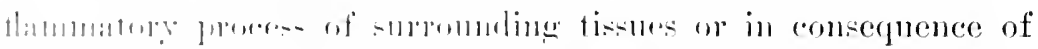

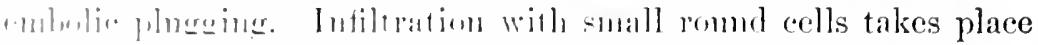
in the ontre and mildla reats, later on also in the intima. The agloplatial lining beromes swollen and of increased thickness, 
while the mulerlying lasers of the intima show the development of newly formed commertive tisme.

In cases in which the intlammation is the result of plugging, throubosis also ocents, and in tine the thrombus undergoes organization. If the embohs is infeetive, the inflammation naly spreal to the parts outside of the resecel and set $n$ p alsecess. When the arteritis results from surommling inflammation, thrombosis and subsequent organization may likewise take pliner.

The etiology has alrealy been stated in the opening sentence. Acute arteritis results either from arljarent inflammation or from embolic ocelusion.

Symptoms are likely to be reeognised only when the arteritis is situated in an extremity or a part aceessible to palpation, and when thereby one can detect either embolism or thrombosis, or when there is phlegmonous inflammation of the tissues surrounding an artery of considerable size.

When loeal inflammation invarles the artery, involvement of the latter is likely to be masked ly the symptoms of associated phlebitis. In the latter event there are circulatory disturbances due to interference with return flow, swelling, and more or less odema, together with pain and great tenderness.

In the case of embolism there are pain and phenomena of obstructed eirenlation, coldness (local syneope), eyanosis, and numbness.

Fhysical Signs consist of such phenomena of loeal inflammation or of the accompanying phlebitis.

Inspection perceires swelling and redness of the affected extremity.

Palpation is of greater service. The limb is lot, painful to touch, usually pits on pressure, and at some point eareful palpation is generally able to deteet resistance due to the embolus or to thrombosis extending for a rariable distance above the seat of the plug.

Diagnosis. - This is to be made by the history, local symptoms, and the result of palpation. The differentiation of acute arteritis from phlebitis is not always easy or possible.

Prognosis depends upon the nature of the eause and the completeness of collateral eirculation. Aente meningitis is a possibility in certain eases, and of course affords a very grave outlook. 


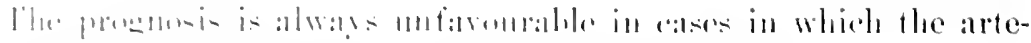

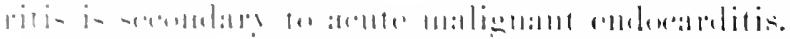

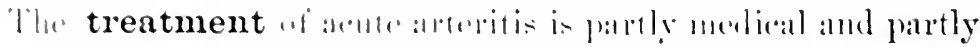

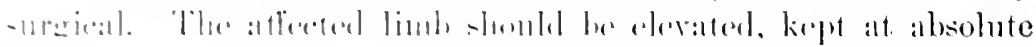

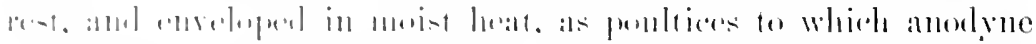

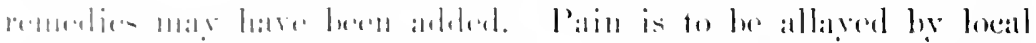

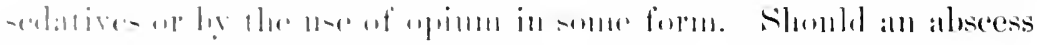

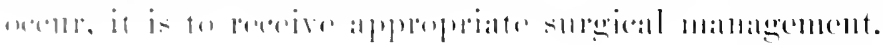

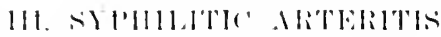

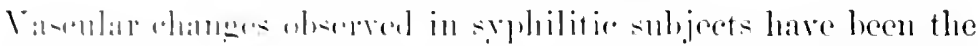

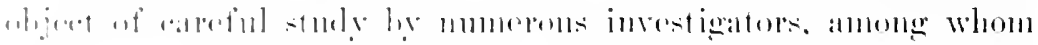

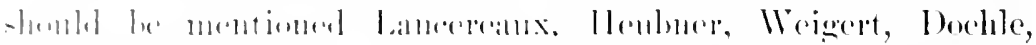

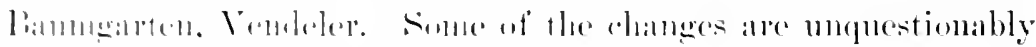

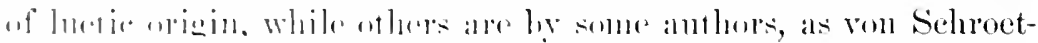

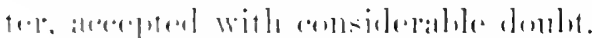

Morbid Anatomy. The inflammatory elanges in the arter-

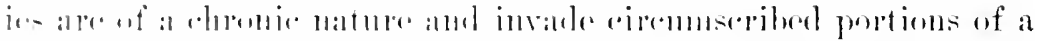

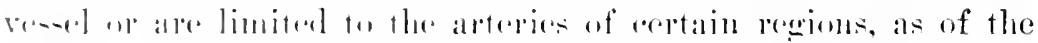

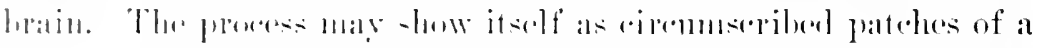

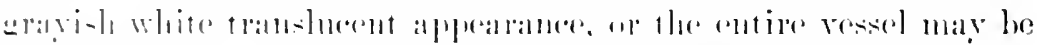

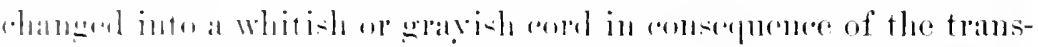
formation of it - ants intu tibuns tisine. In this form the advenjitia.and ultimately the merlial and intima, lecome infiltrated with

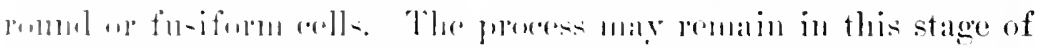

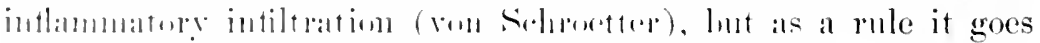

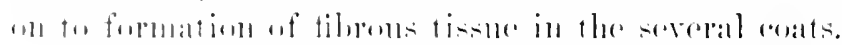

This hyerphlasia of the walls is eftem extrome and leads to

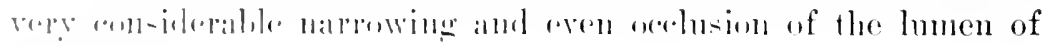

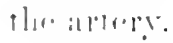

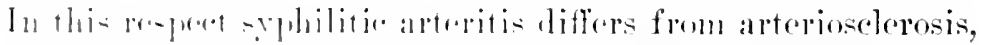

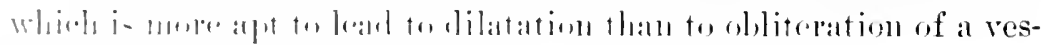

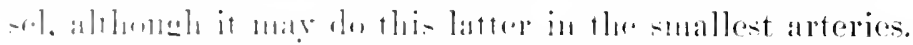

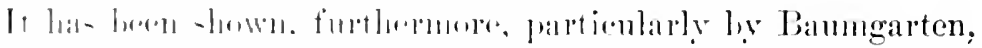

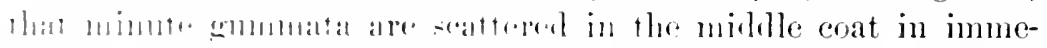

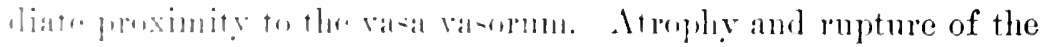

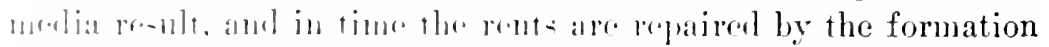

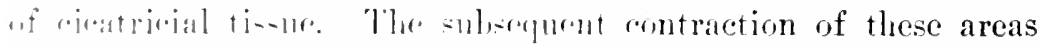
leal- in lwalinge of the intima, which, when they are found in 
the ascending aorta, are alunst pathognostic of syphilis (Romberg). These ponchings of the aortie intinta may prove the starting-place of future aneurysus.

In another form of arterial discase due to syphilis the vessel becomes invaded by a spphilitie proess in its neighbourhorl. The ressel is surrounded by a gummitons mass or by dense cicatricial tissue, and the coats of the artery are more or less thickened and altered (Ziegler). In the early or inflammatory stage the outer and inner coats are rich in cells, but as the process allwances fibrous tissue replaces the cells wholly or in part. The media is not so much invaled hy fibrous tissue as are the adventitia and intima.

The cerebral arteries appear to be the ones most frequently affected. The aorta and coronary arteries may, howerer, be the seat of syphilitic disease, and in a few eases the ressels of the extremities have been affected. C. O. Weber is silul ly von Schroetter to have fomul the right luanch of the puhnonary artery in a syphilitic girl greatly narrowed by reatson of a gumma in its wall. Zeissl is also stated by the same author to have fomm the left brachial artery invaded by a gummatous infiltration, while Langenbeck saw the same sort of process in the right brachial of another case.

Etiology.-Syphilitic arteritis is a late manifestation of lues. The symptoms are determined by the seat of the arteritis. In the case of the brain they are those of disturbed or obstructed eireulation, loss of memory, dizziness, headache, mental confusion, epilepsy, etc--in short, such as arise from areas of acute softening.

When the disease affects the aerta it may lead to aneurysm or to the symptom-complex of selerosis of the areh.

Arteritis of this origin may be a canse of angina pectoris by leading to selerosis and ocelusion of the coronaries, particilarly the left anterior descending branch. In very rare instanees a coronary artery has been said to be invaded and obliterated by a gumma of the myocardium.

In the extremities syphilitic arteritis oceasions elinical manifestations of obstructed circulation the same as may other forms of arterial disease, pallor or eyanosis, coldness, and eventually gangrene. 


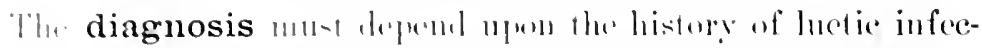

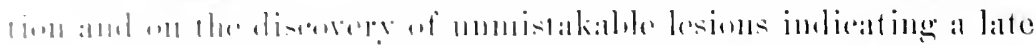

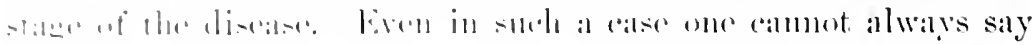

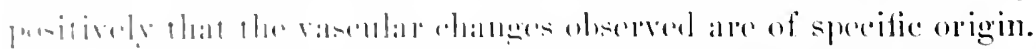

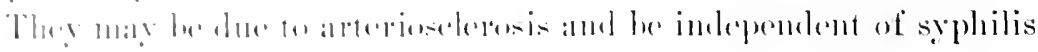

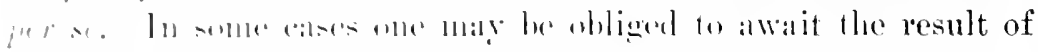

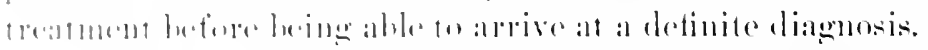

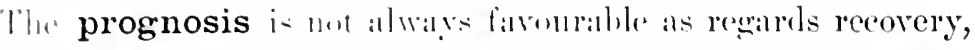

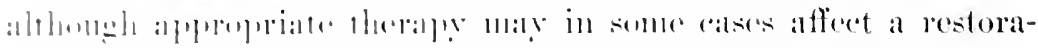

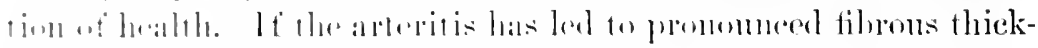

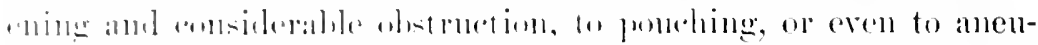

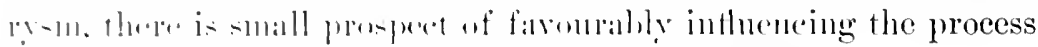

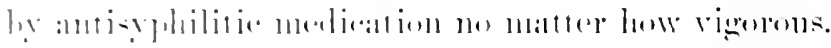

The treatment -homld ansint of the aluminstration of ap-

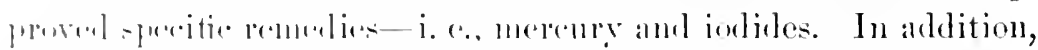

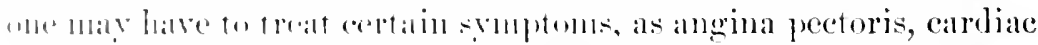

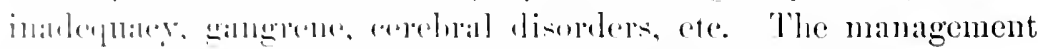

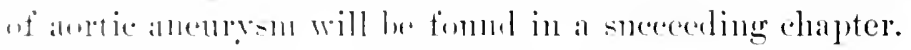

\section{FEDARTEITIS OBLITERANS}

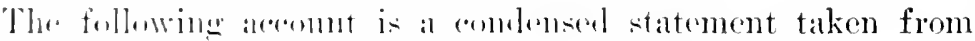

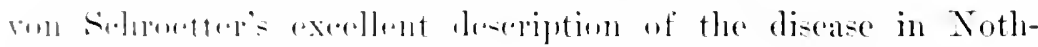

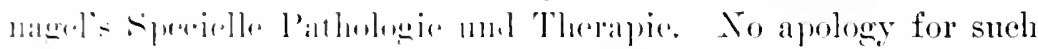

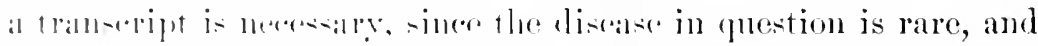

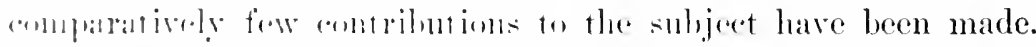

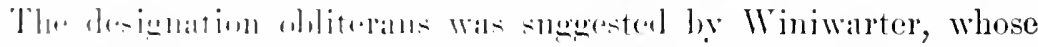

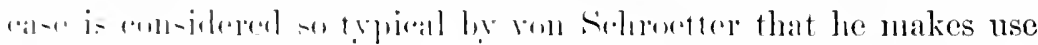

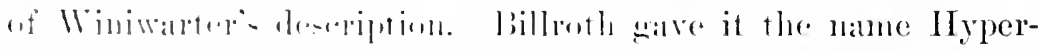

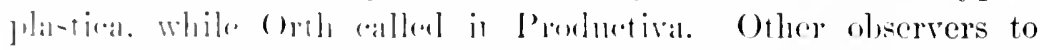

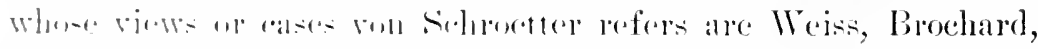

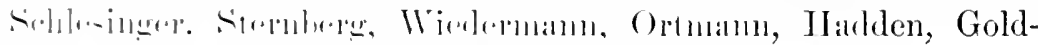

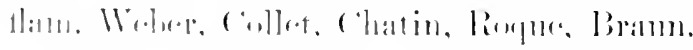

Morbid Anatomy. The liewere oremes most often in the

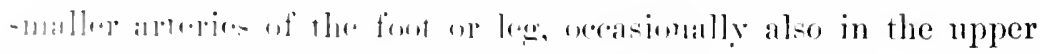

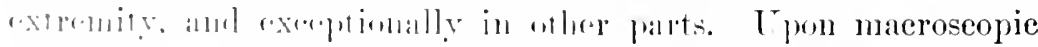
in-

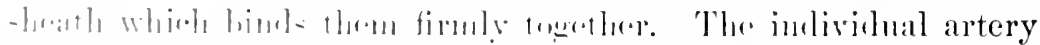

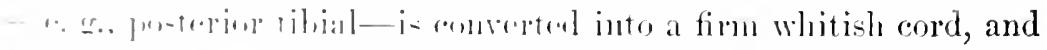

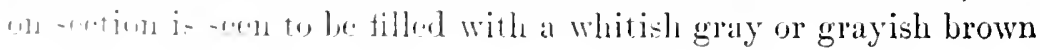


mass, so that a probe ean le passed into the ressel only with difficulty ol not at all.

The artery is nevertheless not miformly so fillerl, yet on the whole is transformed into a rigid cord in conscpucnee of its interior being filled with a somewhat vielding wide-meshed tissue. The proees begins at the periphery and extends upward, reaching from the plantar peroneal and posterior tibial arteries, eren in some instances to the femoral, or in the case of the arm, to the brachial.

Histological examination rereals in different places a somewhat variable condition, ret which is in reality a lyperplasia of the intima which may angment its thickness to even eight times the normal. Tn the larger vessels the newly formed comnective tissue is composed of round, spindle-shaped, or stellate cells, between which can be recognised an intercellular substance made up of delicate threads. Aceording to Winiwarter and others, several strata of elastic fibres may be seen in the onter portion of the intima next to the media. Finally, minute blood-ressels are seen to exist within the comnective tissue of the interior, which Winiwarter regards as an extension or formation of new ehammels by which an attenpt is made to provide a collateral circulation, and not as an organization of a thrombus. The eapillaries thus formed permit a partial injection of the mass filling up the lumen of the artery. In spite of this attempt at a collateral circulation the stump after an amputation does not bleed freely when the Esmarch bandage is remored.

Etiology.-This is practically unknown. It has been observed in men far more frequently than in women, and what is especially strange about it is that it attacks comparatively roung and previously healthy individuals. The process does not necessarily invade all the arteries of a limb, for it has been found in the posterior tibial, while the anterior tilial was free. It has been attributed to oceupation, but in ron Schroetter's opinion without sufficient warrint. The only theory that seems to appeal to ron Schroetter is that the affection is, in some mamner as ret unknown, dependent on some nerrous influence.

Symptoms are made up of prodromata extending through a period of years, as many as twolve, and of such phenomena as depend upon interference with local eireulation. Indiriduals thus 


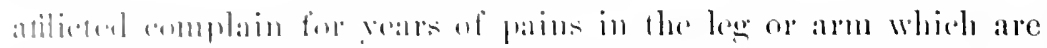

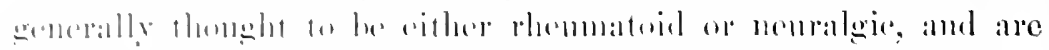

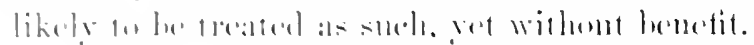

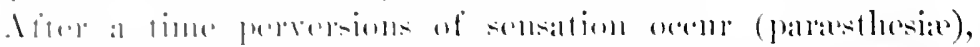

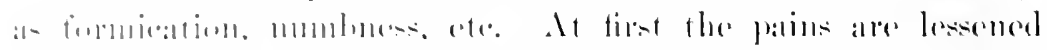

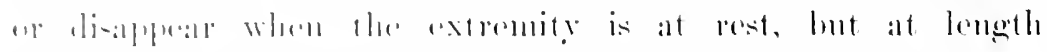

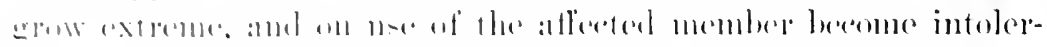

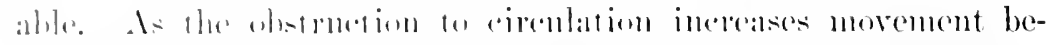

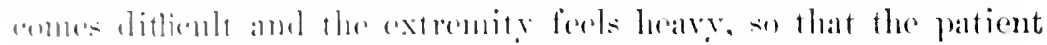

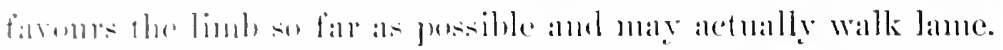

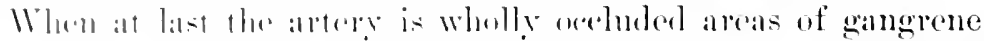

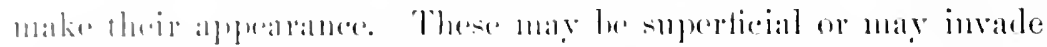

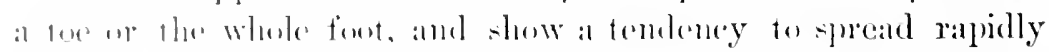

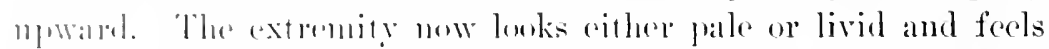

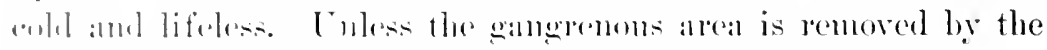

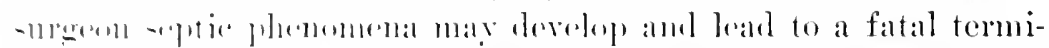

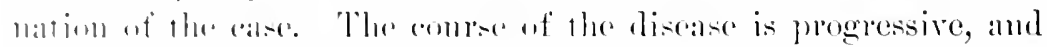

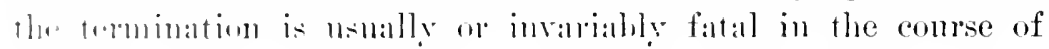
Ya: $11 \%$ -

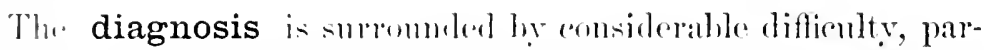

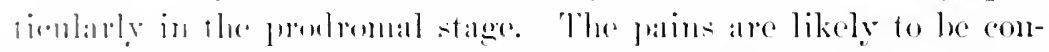

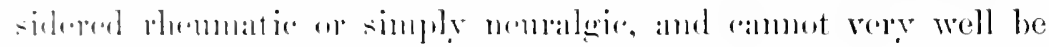

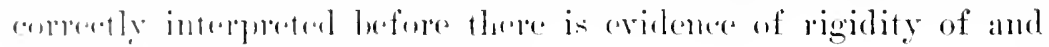
want of pulliation in the arteries.

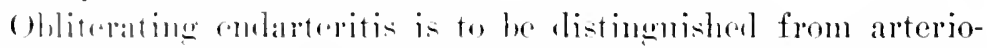
selerenis mainly ly the age of the patient, sinee it has been observed

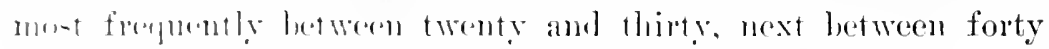

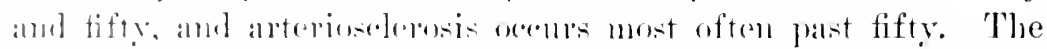

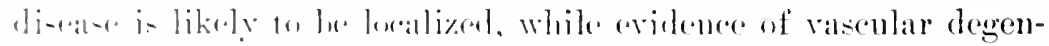

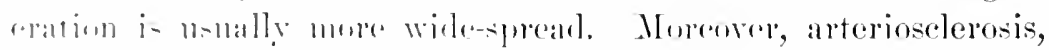

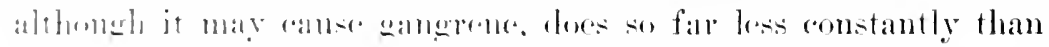

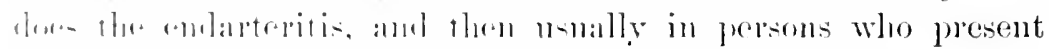

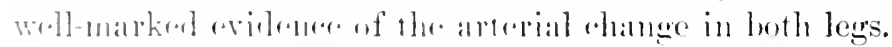

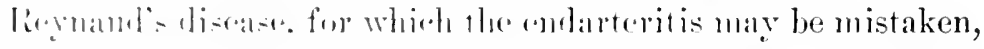

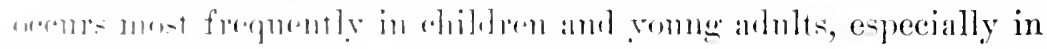

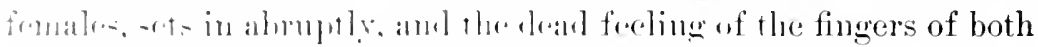

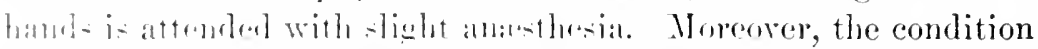

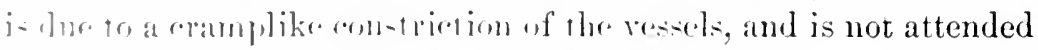

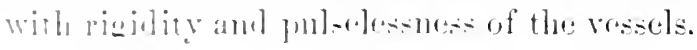


The prognosis is unfirourable, since the affection is progressive.

Treatment is of a necessity symptomatic and restrieted to such measures as may alleviate suffering. The oceurence of gangrene calls for surgical interference.

\section{PERTARTERITIS NODOSA. SYN.: CONGENITAL ANELRTSA}

The very renarkable and rane affection which bears the above titles was first adequately deseribed by Knsinanl and Maier in 1866 , although it apjears that Rokitansky in 1852 , and possibly Pelletan in 1810, observed each a single case (ron Schroetter). The designation Periarteritis Nodosal was bestowed upon it by Kussmatul beeanse of his eonception of the process as an inflanmation originating in the adventitia. The term Congenital Aneuresm is applied to it becanse it has been thought to be dne to eongenital weakness of the arterial coats (Eppinger), leading eventmally to the development of multiphe aneurysus. Accorling o von Schnotter, only thirteen anthentic cases have been report.

Morbid Anatomy. - The affected artery is studded is nodular thickenings of a whitish colour and of variable size, $f_{1}$. that of a pin's head to a jea, which are due to ciremecribed fibrons thickening of the intima with cellular infiltration of the adrentitia and media. The lumen of the ressel may be narrowed or the weakening of its coats may lead to eircumseribed dilatationsi. e., multiple aneuryms. These may reach sneh numbers as to be meomtable. The disease affects arteries of medium calibre, and is found with special frequeney in the arteries of the museles and riseera, as the heart, intestines, spleen, liver, and kidneys, and also of the skin.

Its etiology is entirely unknown, but inasmnch as the clinical picture is very like that of sepsis or an infection it may have some such origin (Romberg). The disease appears to attack both sexes about equally and to oecur between the ages of twenty and fifty-two (Osler).

Symptoms.-The most striking features of the affection are weakness, rapidly progressing antunia, and rapidity of the pulse out of all proportion to the temperature. Ferer may be present in the begimning, but is of moderate height, and tends to ultimately disappear. There is pain in the muscles which may eventually 


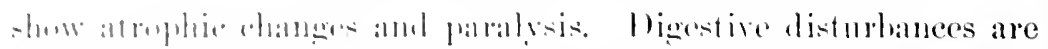

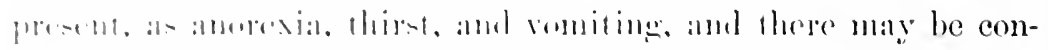

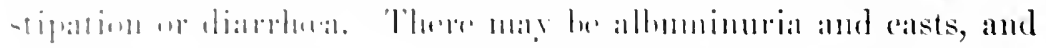

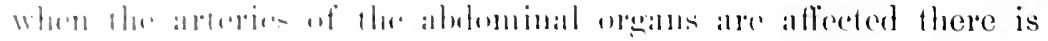

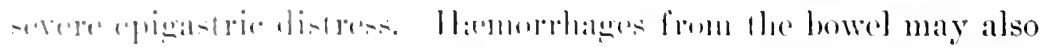

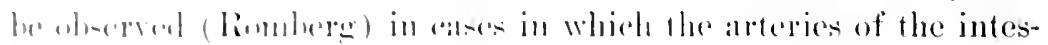

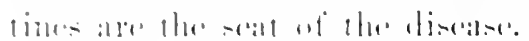

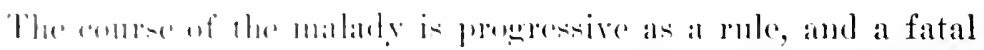

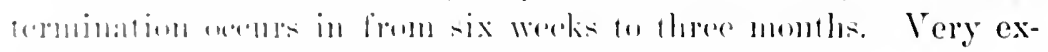

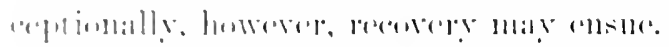

Diagmosis is impeneihle mulare the molular thelienings cam

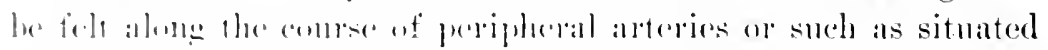

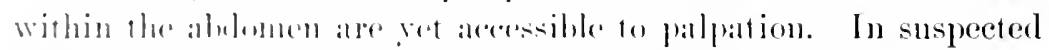

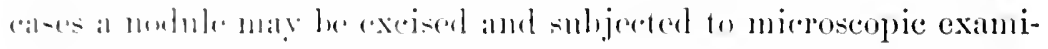
11:11 in11.

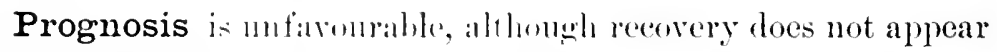
inlı injunible.

Treatment is jurely simptomatic amd is limited to attempts

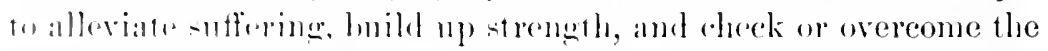
le-truction af the hlornel.

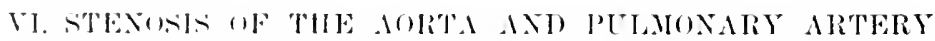

Stenosis of the Aorta may be Congenital or Acquired.-In the

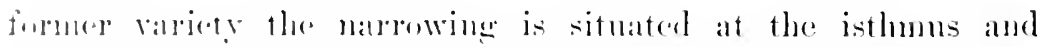

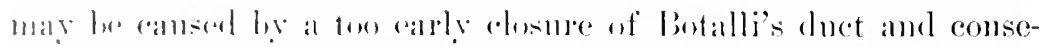

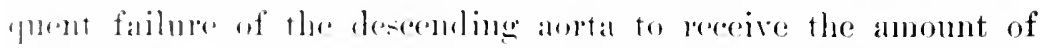

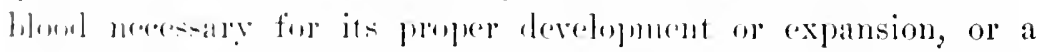

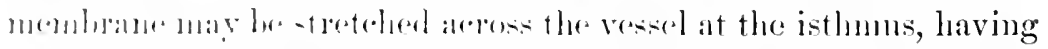

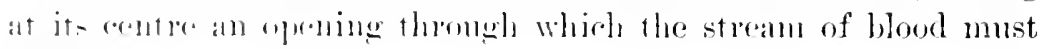
jia.

Acquired stenosis may lor cancerl by a filmons land that con-

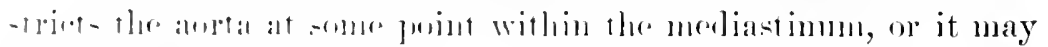
lur (n)

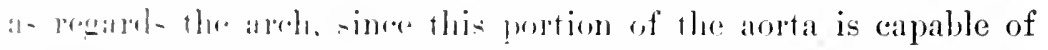

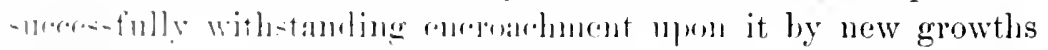
(Iin)

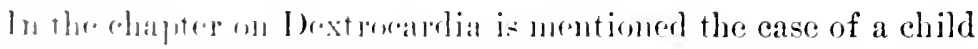
in whem the rotation and displarenent of the heart had cansed

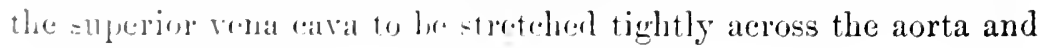


constrict its lumen. I have also in the chapter on Aortic Regurgitation mentioned the calse of a man whose ascending anorta wats greatly narrowed by a ring of fibrous tissue that completely encireled the ressel and hat induced relative insutheiency of the value.

Symptoms depend upon the legree and seat of the stemosis. In the congenital form collateral circulation may becone established throngl the intereostal arteries, the internal manmary, or arteries in the integument and numscles of the back. If such side chamnels are sufficient there may be no obvions hindrance to the bloot-supply of the lower parts of the body, and no mitoward effects are experienced.

Romberg mentions a case observed by him in which the arteries of the back provided a neans of maintaining the circulation below the point of stenosis, and in which he detected a lond rasenlar bruit on the posterior aspect of the trumk between the rertebral colmum and right seapula. The murmur was attributed by him to dilatation of the arteries at that point.

In the acquired form narrowing of the aorta is likely to occasion compensatory hypertrophy of the left ventricle and possibly also incompetence of the artic valve, as in my case. The ultimate effects are those of cardiale inadequacy. In cases in which relative insufficiency does not oceur, but the stenosis leads to leftrentricle hypertroply, the clinical history is likely to be that of narrowing of the ostimn or of the discase which canses the eonstriction of the aorta.

The diagnosis is very difficult as a rule, and may be impossible. One may recognise the signs of obstruetic ow from the ventricle, but may not be able to determine its real nature. The detection of a mediastinal tumour or of chronic fibrous mediastinitis, together with the signs of obstruction-i. e., a systolic bruit over the course of the aortic arch with accentuntion of the aortic secoud tone and left-ventricle hypertrophy-might lead to a correct diagnosis. This would be strengthened if as time went on evidence of regurgitation should appear.

Congenital narrowing of the isthmus might he diagnosed if one were to discover compensatory dilatation of the arteries by whieh collateral flow is established together with hypertrophy of the left rentricle. 


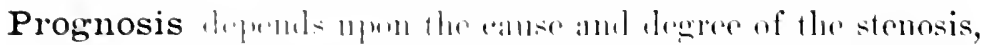

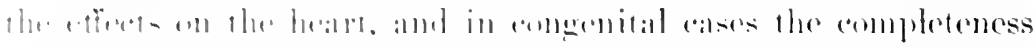

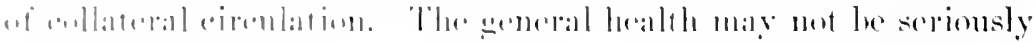

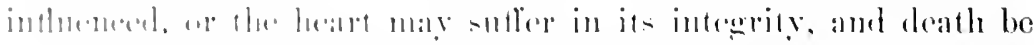

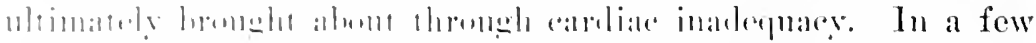

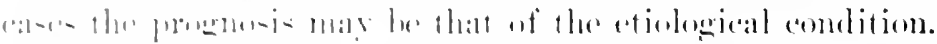

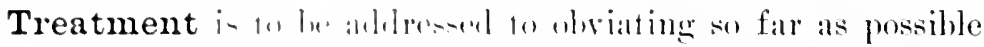

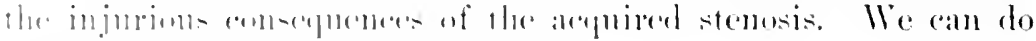

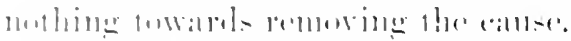

Stenosis of the Pulmonary Artery is alcpuired, and is a relatively

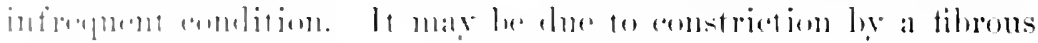

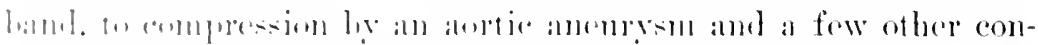

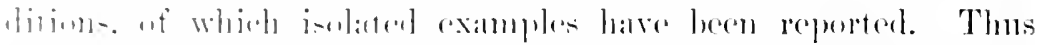

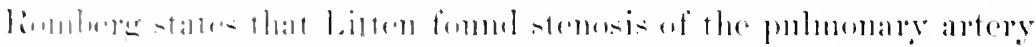

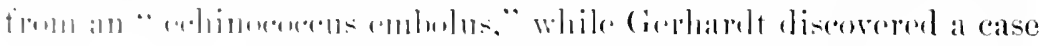

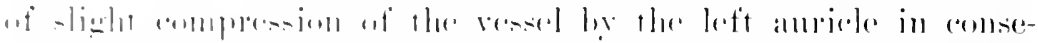

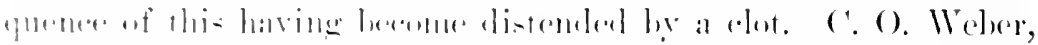

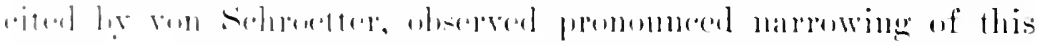

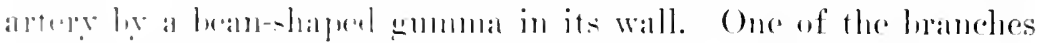

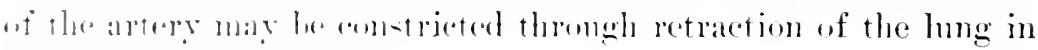
interetitial furellummial.

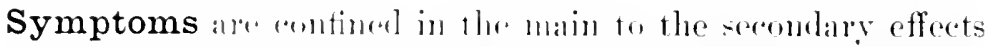

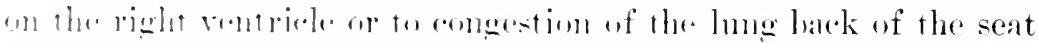
uf -inmeis when this is sitnaled within the lung at a distance from 1he hitimeations.

It the oldetruetion is in the main trunk or in a luaneh suffi-

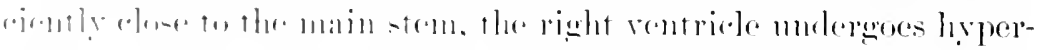

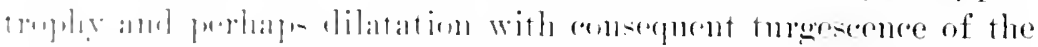

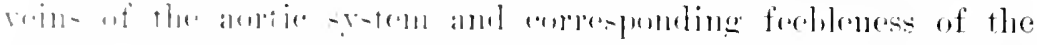

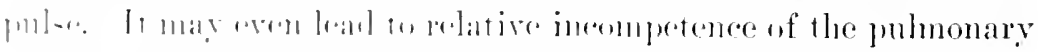

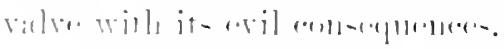

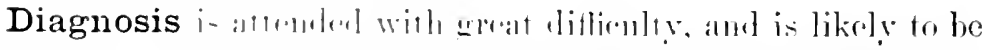

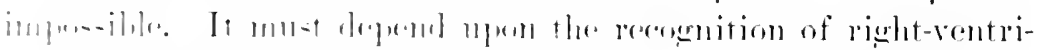

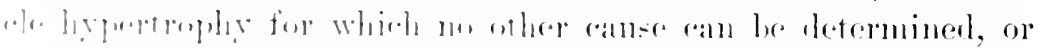

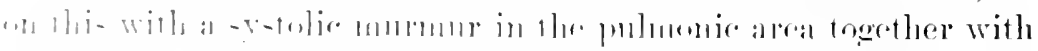

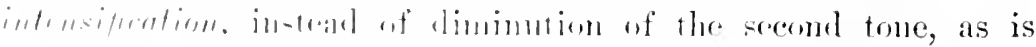

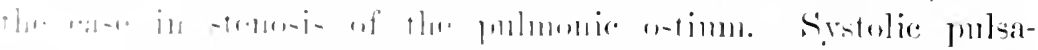

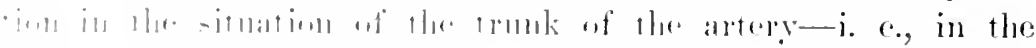

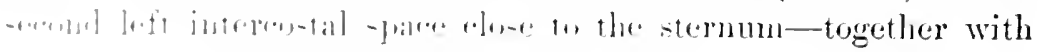


dulness in this area, would greatly strengthen the other signs just mentioned (Romberg).

The prognosis is letermined by the nature and degree of secondary disturbanee. It is of neessity nore or less unfarourable.

Treatment is entirely symptomatie, and, as in stenosis of the aorta, must ain at mantaining cardiac adequacy, since the cause cannot be remored.

\section{CONGFNITAI, SMALLNESS OF TIIF ARTERIES}

This state of the aorta and arterial srsten was studied by Virchow, who pointed ont its association with chlorosis. Not only are the resscls of small ealibre, but their coats are thin and delicate, rendering them partienlarly liable to rupture, and they are abnormally clastic. In extreme cases the lumen of the arteries may be rednced to a third of the nomal (Romberg).

The heart is also abnormally small, the genitalia are likely to remain modereloped, and the individuals are small and delieate in appearance. This is expecially true of those who present the chlorosis spoken of. In other not pronounced cases of arterial hypoplasia there may be nothing in the appearance and no lack of body development to suggest its existence.

Symptoms of this condition as snch camnot he said to exist. The heart, by reason of its smallness, is weakened in its resistance, and is more than usually liable to infeetion (Romberg), and indeed general rigour and resistance may be said to be below par. This is readily comprehensible in cases characterized by chlorosis. The hypoptasia is found more often anong females than males.

Fraentzel was of the opinion that congenital narrowness of the arteries predisposed to hypertrophy and dilatation of the left rentricle, and in support of his riew cited instances of the kind in roung recruits. Romberg, however, thinks the clinical picture drawn by Fraentzel is to be interpreted as the result of prematurely developed arterioselerosis. This is faroured possibly by the smallness of the arterial system; and yet, as a matter of fact, such arterial degencration does not occur with special frequency in the subjects of arterial hypoplasia.

It is worthy of note that rupture of the aorta and dissecting 


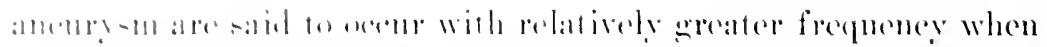

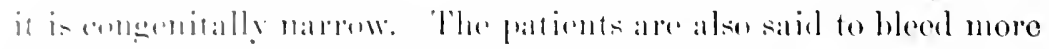

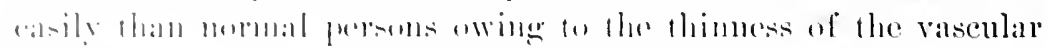
(1):1ts.

Diagnosis af anterial hypoplastia is ditlienlt to make with eer-

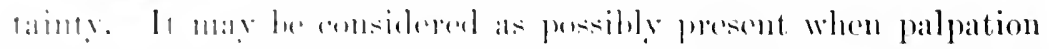

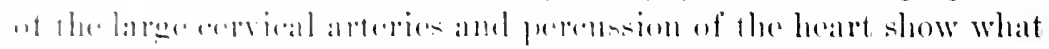

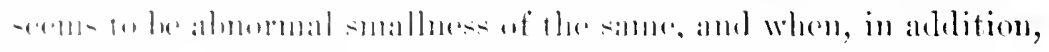

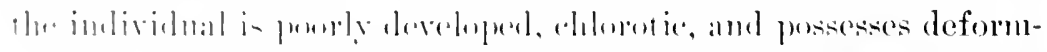

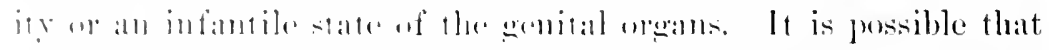

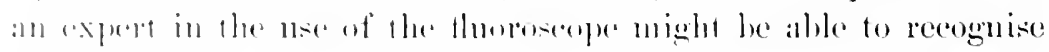

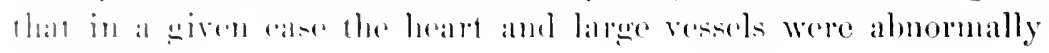
molur.izinl.

Prognosis. - Comgenital narrowness of the arteries affects

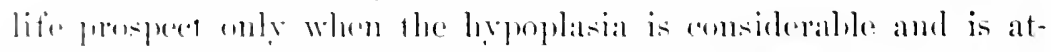

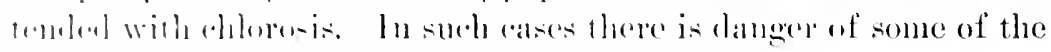

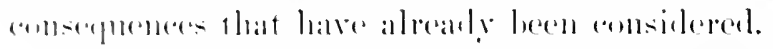

Treatment ammot affere the molerlying condition, and is therefore linited to attempts at relieving or monlifying stech effects ats may result. 


\section{CIIAPTER XXXIV}

\section{ANEURYSM OF THE THORACIC AORTA}

Areckisus have been the ohject of interested study for several centuries both to anatonists and clinicians. The names of many eclebrated men are connected with the history of this arterial disease, and, ats might he expected, they were at first the names of anatomists who studied the subject mainly on the dead body. Methorls of dinguesis were erude and, very naturally, not equal to the discovery of such obsenre affections as intrathoracie ancurysul. Nesertheless it is worthy of record that Vesalins made a diagnosis of artic aneurysu in 15tit. Malpighi and Morgagni wrote on the subject and added to the finets concerning it. There has been scareely an anthor of note since who hats not attempted to add to our knowledge on the sulject, and to seme of then the profession is greatly indebted. Lancisi, Scarpa, (orrisart, Hodgson, Stokes, and in our own time Eppingers and Thoma, are names that are intimately linked with the history of anenrysm.

In this chapter it is proposed to deal exchusively with the diseare ats it affects the antat within the thorax, a condition that possesses peculiar interest for the physician. Aneurysus of peripheral anteries belong to the provines of the surgeon and hence are left to surgical works for consideration.

Morbid Anatomy.- In aneurysu is a cireumseribed dilatation of an artery; and als such must be distingnished from the miform widening of an artery, which results from sclerosis. The three main divisions that are made of aneurysms are, (A) true, (B) dissecting, (C) false. By false ancurysm is meant a circumseribed collection of blood that has resaped from an artery into the surrounding tissues, hence a hirmatoma. The walls of the tumour are not composed of the arterial eoats, and therefore, according to von Schroetter, it should not have the term aneurysm 


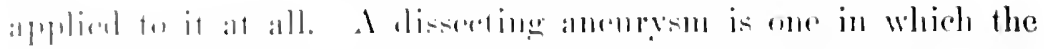

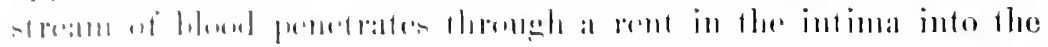

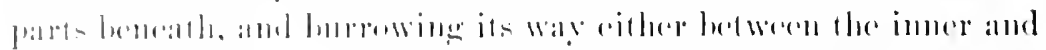

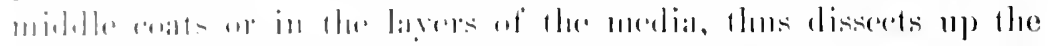

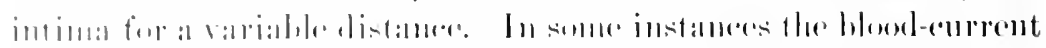

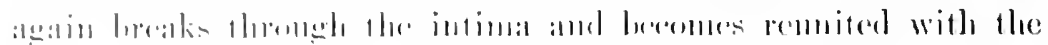

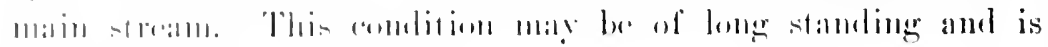
-

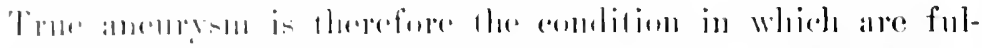

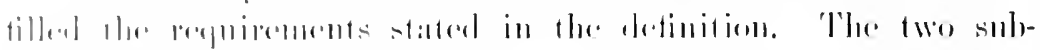

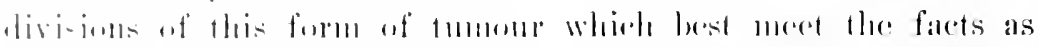

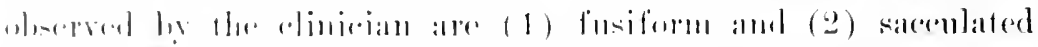

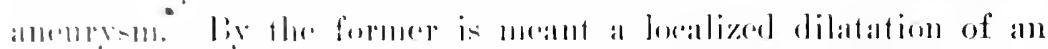

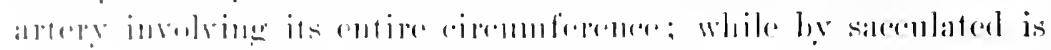

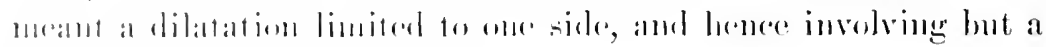

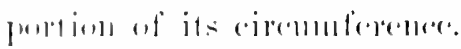

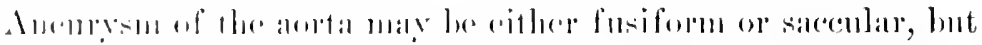

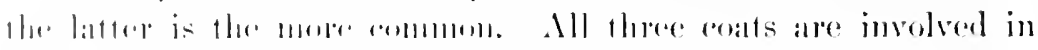

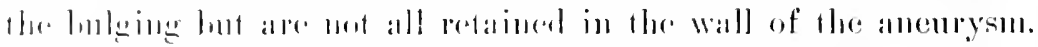

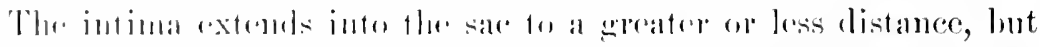

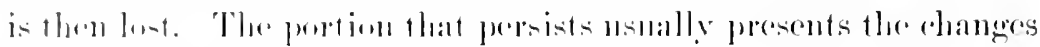

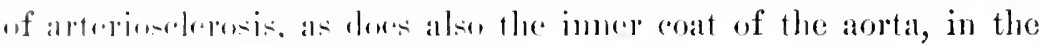

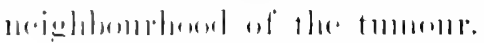

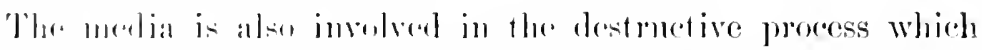

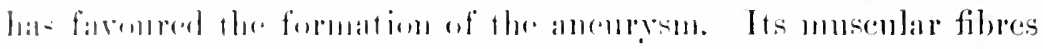

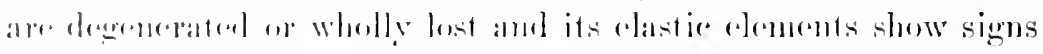

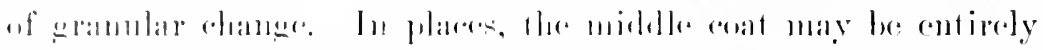

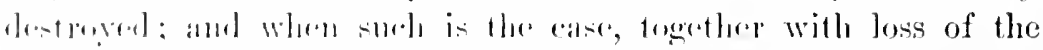

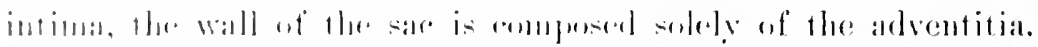

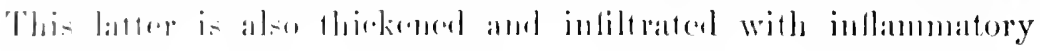
plumlnot

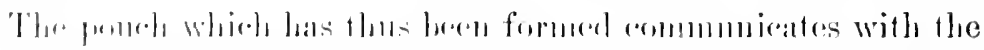

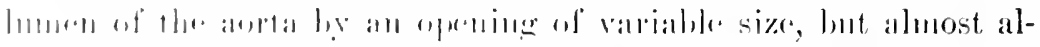

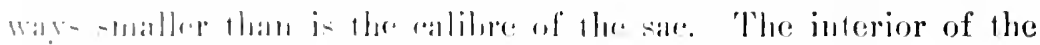

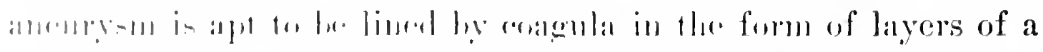

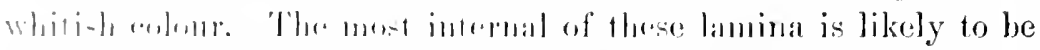

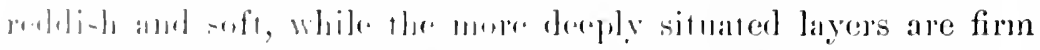
a- woll a whitr. The drewere of thrombus formation within the

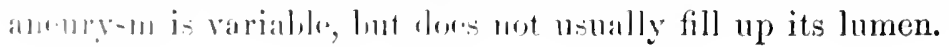


Execptionally, however, when the sale is mot very lange and its opening inte the ehamel of the alorta is small, its carty may be

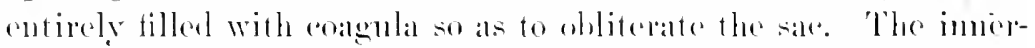
most layer of filmine then forms a firm wall natrly an a level with

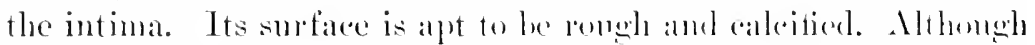

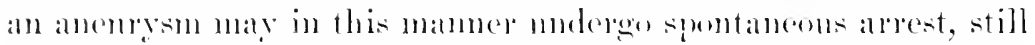
the degeneration of the arterial coats which led originally to the formation of that amenrysu is likely to farour the derelepment of others, so that multiple anenrirms are not al all uneomumom.

Aortic aneurysus differ mueh in shape and size. Thus a sacculated aneuryou may have other sales springing from its walls so that the tmonem presents an irregular ontline. In size the sae may vary from that of a small nut all the way to that of a man's heat. Anemroms may be sitnated at any point aldong the eomrse of the anda from just abere the ling to the termination of the alblominal portiom.

The disastrous effeets of aertie anemrysu alre not confined to the vessel, hut consist of all the rhanges in strueture and position of neighbonring organs produced by preseme of the sale. The nature and extent of these secomblary pressure efferts are determined by the situation as wel] as the size of the anemrym. Aneurysus involving the simeses of Valsalva are not apt to attain much size, ret their influenee on the heart is rery disistroms and they are especially liable to rupture into the pericandimu, alusing suden deatlo.

inemrems of the arels displatee the heart downwarl (Fig. 109) and it may be forwand or to the left. Int they rarely oneasion livpertroply of the left rentriele mules the arotic valves have been rendered inempetent. The latter condition is likely to result when the sate springs from the aseending or transeres alde and hats attained grealt size. I recall a man whom I treated for months for antic regurgitation withont snsperting the existenee of an anempsu until quite sndelenly signs of pressure on the left lomg arose. Fren then other signs of the anemrym wore not at all distinct, ret were of such a kind als to remler its presence certain.

Other effects of anrtic anemrym than these al realy mentioned will be left for consideration under symptoms.

Etiology.-Arteriosclerosis hats long been recognised as predisposing to the derelopment of aneurym. It is objected by Ep- 


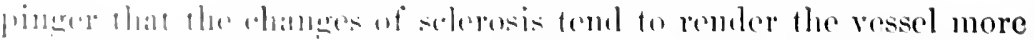

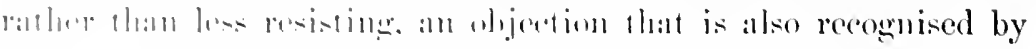

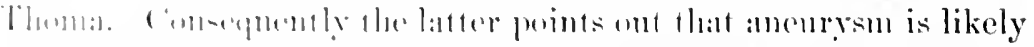

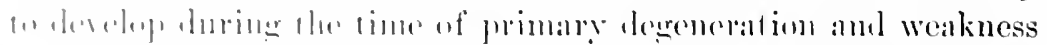

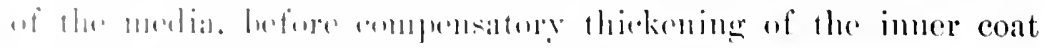

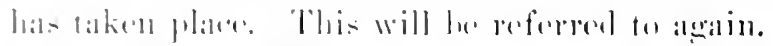

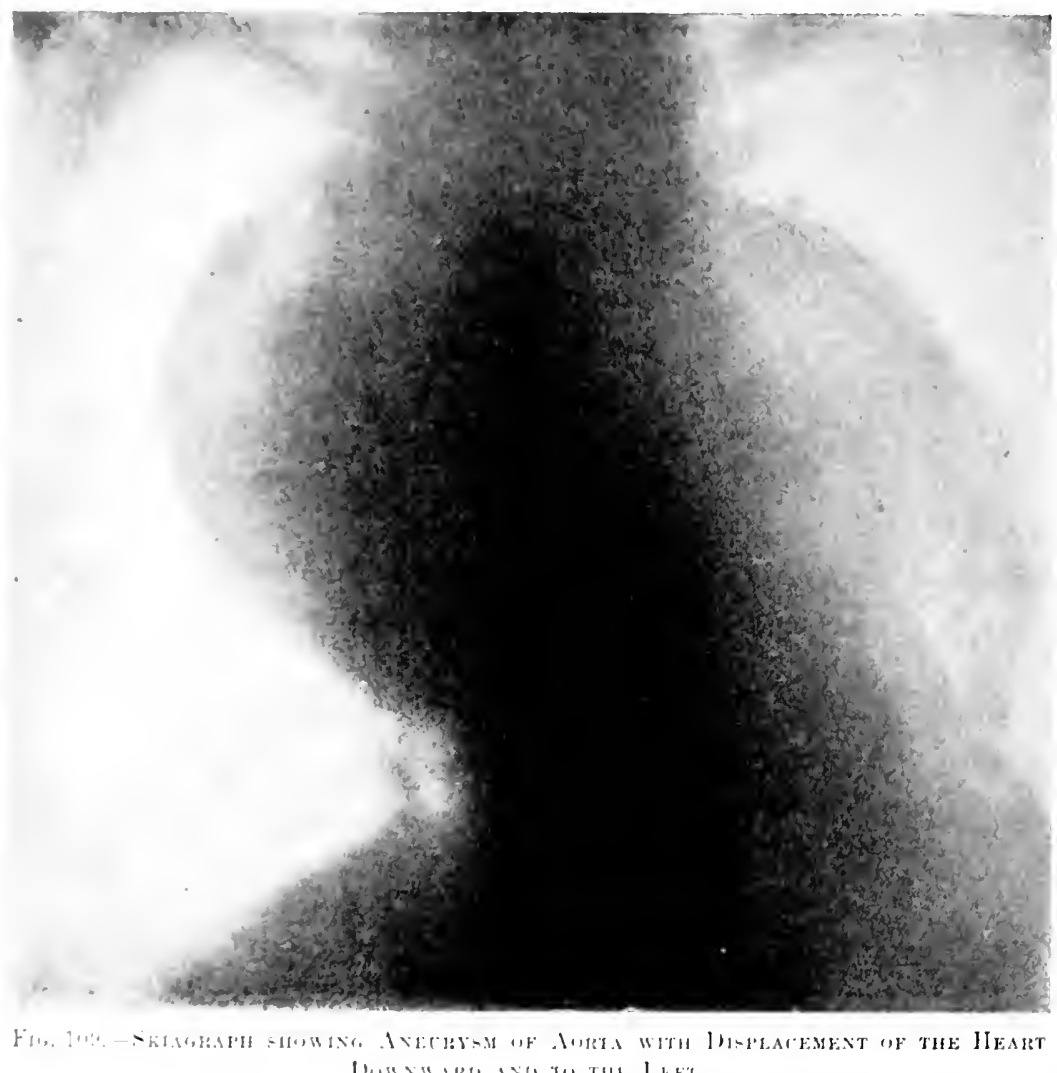

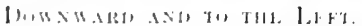

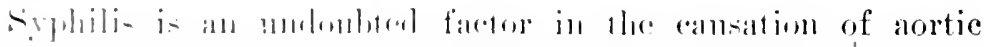

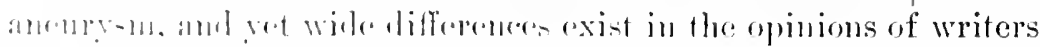

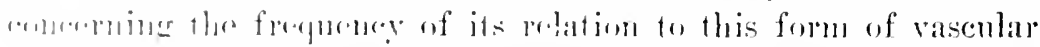

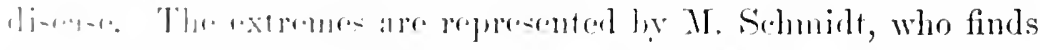

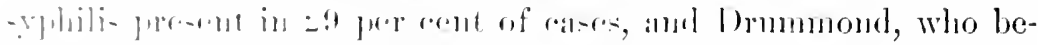

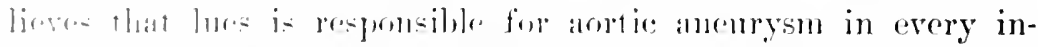

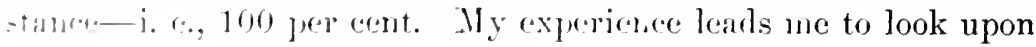


1)rummond's opinion as too extreme, and fo alerept Gerlatrdt's 5:3 pere cent as much nearer the trutl.

Age is a predisposing factor of great importance, since anenresu of the thoracie anta is mudombedly more frequent after than before the fortictli vart. The decaule of life in which it is most common is still unsetted, and figures differ all the way from the fomph decarde (Crisp) to the seventh (Juda, Barsdorff). 'Thoma's notion is that persons are espereially lialsle to the derelopment of aortic anemrsun at or abont the age of forty, in conseguence of diminished resistance of the vascolar eoats at this time. There is, he thinks, a period of about a rear at this age when the weakness of the media has not ret become offset by enowth of commective tissue in the intima, and luring whel tine the conts of the ressel are therefore liable to yield to exeessive blood-pressure at one or more points resulting in future ancurysm.

I have muler olservation at the present writing a muscular man of forty-four who gires no history or signs of previons syphilis, but who has been a more than nsually active, energetic lomsiness manager in a line of work that necessitated much physical exertion. This pationt suffers from symptoms which, together with stiff arteries and sugestive but not onclusive plysical signs, are yet surpicioms of fusiform anemrys of the arch. The age of this person, his oecupation, and the state of his arteries, are all, from an etiologioal standpoint, highly snggestive and strengthen the conclusion to be drawn from the clinical findings.

Sex is likewise a predisposing element in the rlass of cases now uncer consideration. Jen are withunt doult far more liable to aneurysu than are members of the gentler sex. Thus of a total of 425 rases of aortic anemrsm analyzed by Hodgson. Bizot, and Browne, and rited by Gibson, 380 oecmed in males and only 45 in females. This striking prepomlerance of mon is not to be attributed to any quality inherent in sex per se as inferior vascular resistance on the part of men, but to the greater lialility of males to all those factors which farour the development of arterioselerosis as well as their greater exposure to syphilis and conditions of rascular strain which, acting in conjunction with vascular degeneration, are known to predispose to the occurrence of anenrysm. Sex is therefore only incidentally of etiologieal influence. 


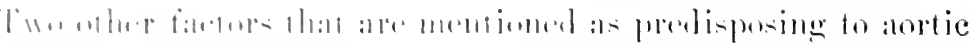

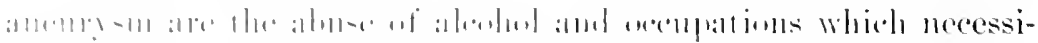

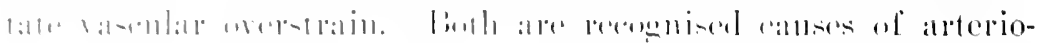

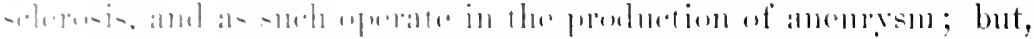

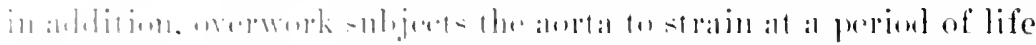

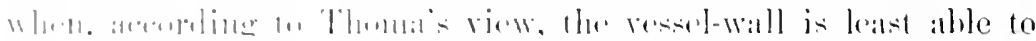

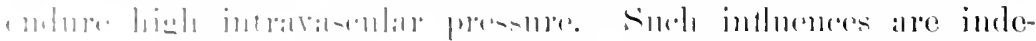

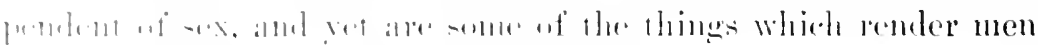

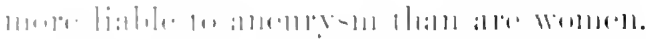

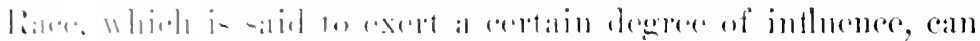

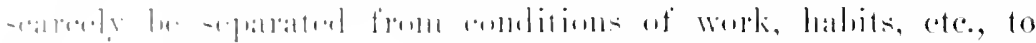

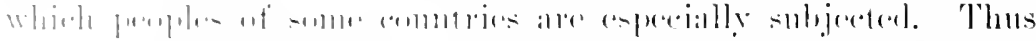

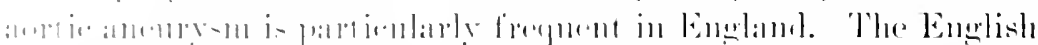

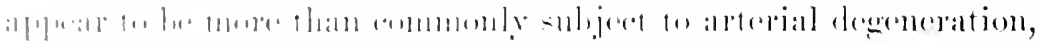

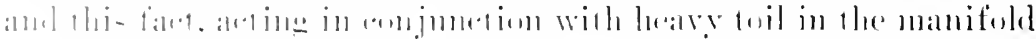

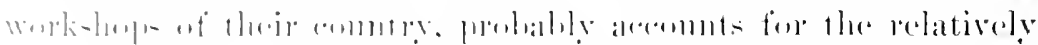

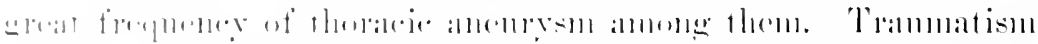

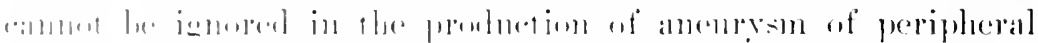

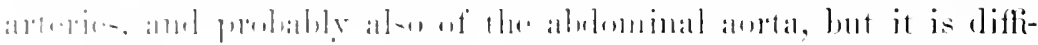

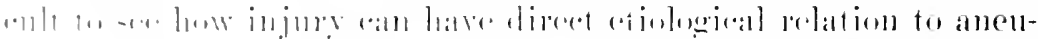

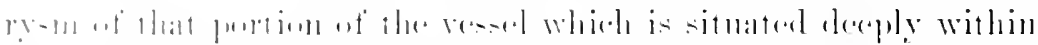

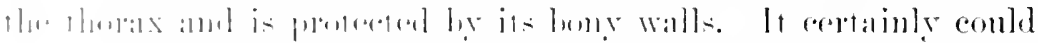

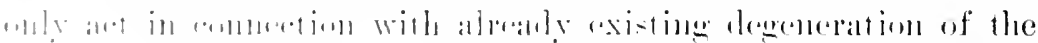

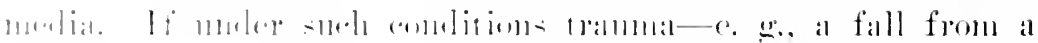

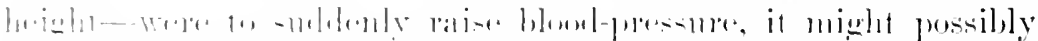

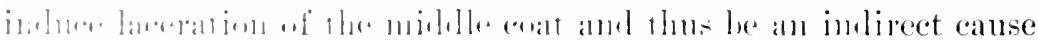
11 $1111,111 \times-111$.

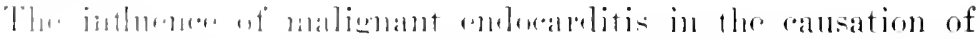

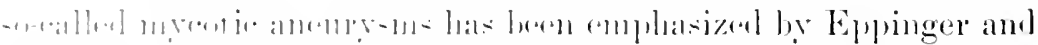

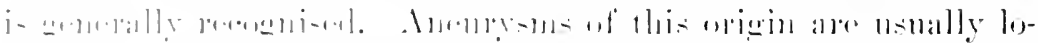

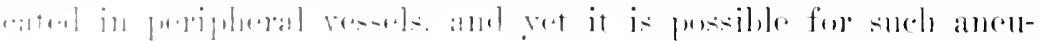

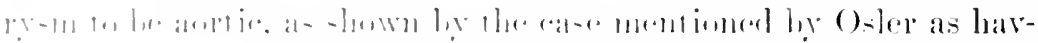

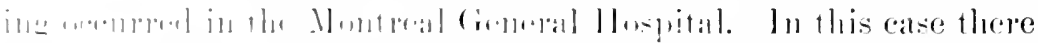

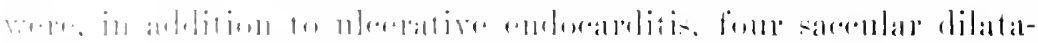

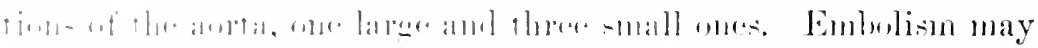

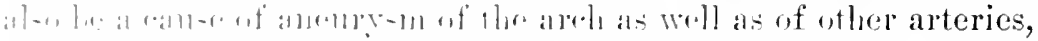

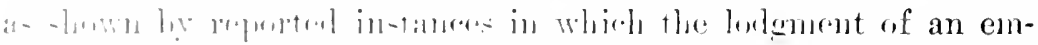

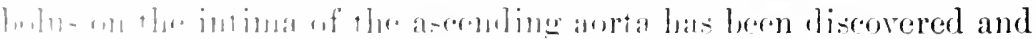

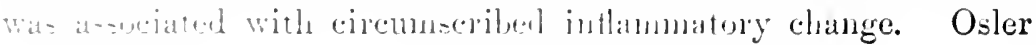


thinks it possible for such an cmbolus, if ansisting of a calcareons plate, to lacerate the intima and thus initiate anemrym.

Lalstly, Osler believes flore maty be an inherent weakness of the vascular coats which predisposes intividuals to anemrym, and cites the instance of Dr. Thomas King ('hamber's, who, alter' having had one of the left popliteal antery, and cleven yours afterward another in the right leg, finally developed "aneurysurs of the carotid arteries."

Symptoms. - Cases of aortic aneurysu may be divided into three groups:

(1) Those in whicl: the tumonr fails to deelatre its presence by either suljective or objective symptoms. Such antemryms are nsually small and are only diseovered at the necropsy, when they may be found associated with some other clinically recognisalle discase or as the cause of moxpected death thromgh rupture. When the sace is situated just aloove the aortic ring, it is very apt to lupture into the pericardiun. This was found to be the catse in 75 out of 289 eases of rupture from a total of 9.59 instances of aortie anewresm analyzed by IIare and IIolder.

(2) Aneurrsus which occasion suljective symptoms as the leading feature of the case. In the majority of cares objective signs are also present, but often of so indefinite a character as to furnish no clear information concerning the nature of the tumonr occasioning pressure. Such cases ledong to Bramwell's second category. They may be sail to correspond also to Broadlont's sulddivision of cases which occasion symptoms but not signs of anemrym.

(3) Aneuryms which produce distinctive physical signs. These are generally nuted with spmptoms of grester or less severity, but the ohjective manifestations of the disease are sufficiently pronomed to warrant their classification in a separate group.

Lortic anemresms may also be classified according to their situation-e. g., of the ascending, of the transverse, and of the descenting portion of the areh, etc. Inderd, one eannot deal with this sulject adegnately and elearly withont describing the features distinctive of ancuresm in the several locations. There are, however, certain general features shared to a yreater or less extent by all anemrsms, whatever their position along the course of the thoracie alorta, and hence these will be considered first.

Such symptoms are the result of pressure, and hence it is plain 


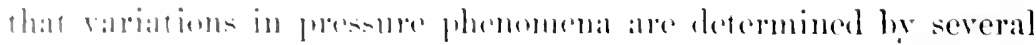

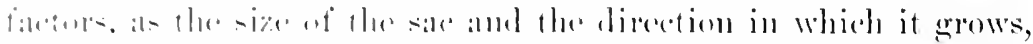

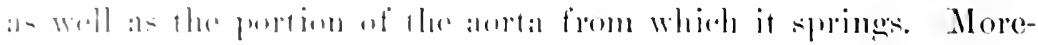

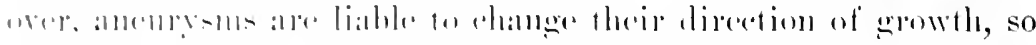

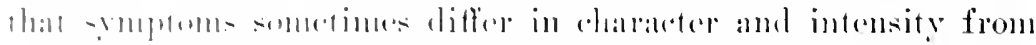

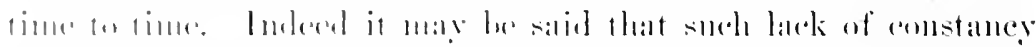
is -

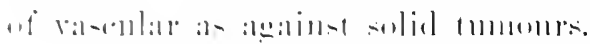

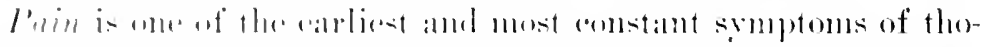

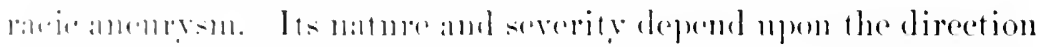
in which the sale develupe. If this is towatres the surface of the

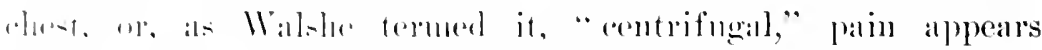

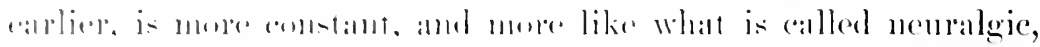

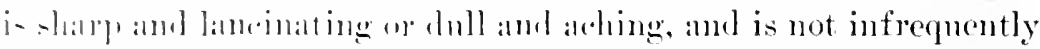

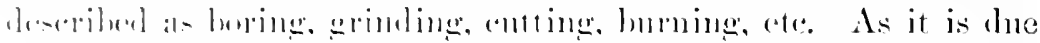

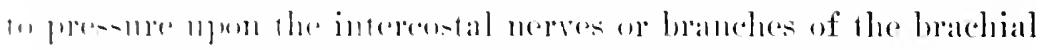

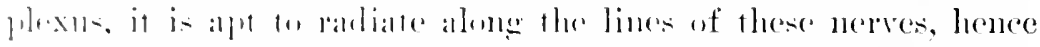

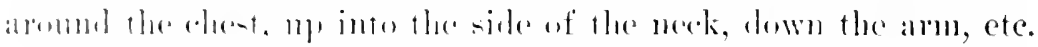

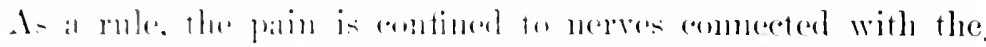

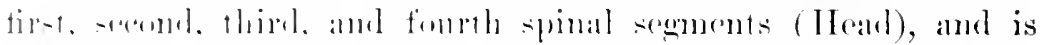

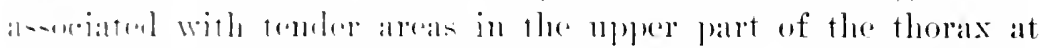

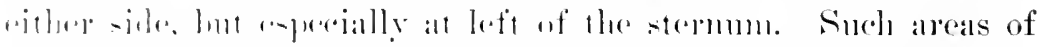

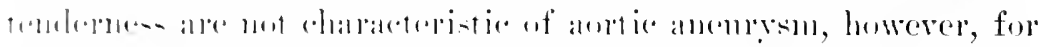

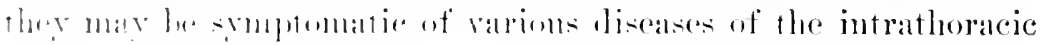

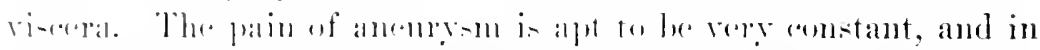

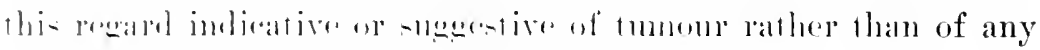

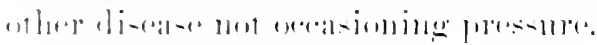

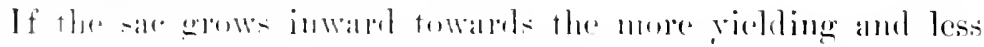

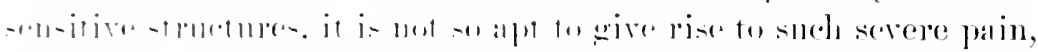

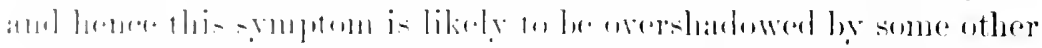

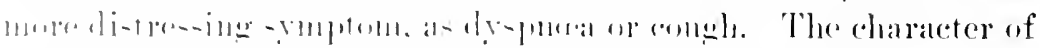

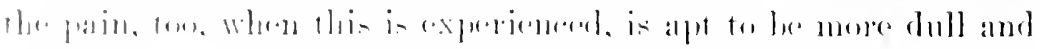

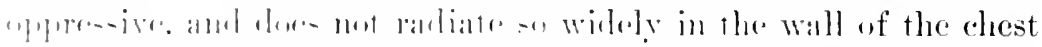

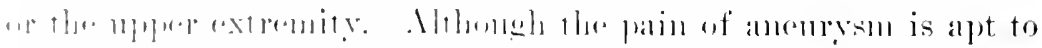

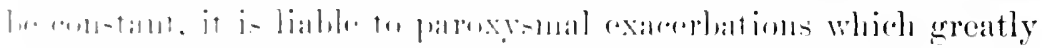

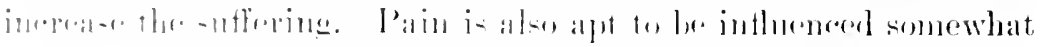

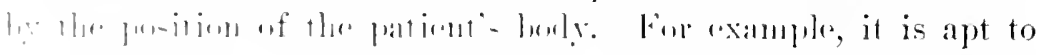

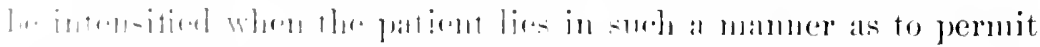

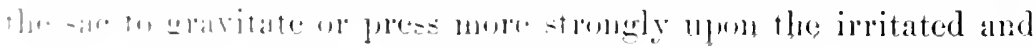


painful nerve. Per conlra, suflering is lessened by attitudes which allow the sac to fall away from the part previonsly pressed upon. Sueh postural variations in the pain are not often narked, but are seen sufficiently often to nerit attention.

It is stated also that in some eases the pain is what is known as intrinsie, by whelh is meant pain experieneed in the sac itself or in the antal either from acute artitis or from internal pressure. Pain of this origin is eroked or aggratrated les increase of bloodpressure, anel is dull or aching in (hatracter and substernal in location. It is likely to be lessened whenever rascular tension is lowered. Extrinsic pain or that dhe to pressure may disappear after the structure subjected to pressure has been destreverl-e. g., after the bony wall has been eroded and the tmmour is permitted to grow without the restrinint of rigid structures. I recall the instance of an enormons aneurym which hat thus penetrated the chest-wall and was covered only ly a thin layer of skin, and in which ease the man made no complaint of pain whaterer.

Dysprea is another very common symptom of aortic aneurysun, bnt varies much in severity. It is of course most pronounced when the growth of the tumour is inward and pressure is exerted on the trachea, large bronchi, or lungs. Very listressing paroxysms of drepnoma are oceasioned by irritation, not paralysis, of one of the recurrent laryengeal nerves, more often the left, and are dne to laryeal spasm. There is apt to be an associated fecling of constriction and perhaps pain in the side of the throat. In a case of the kind eoming under my olservation, the man felt the painful sense of constrietion in the side of the neek corresponding with the recurrent nerve affeeted, and deseribed the sensation as beginning in the left site of the larrnx and rumning thence along the side to the back of the neck.

I have quite reeently seen, in consultation with Dr. Gorgas, a man of fifty with aneur'rsm of the ascending and transverse areh whose drspnoa was extreme, and compelled lim to maintain the right lateral decubitus. Change of position induced a paroxysm of air-humger aceompanied by uneontrollable coughing. It was impossible for him to rest on the left side, or indeed to lie back against the pillows. In this respect his dyspnea corresponded with what appears to he a quite common experience- $i$. e., the inthence of posture orer the intensity of the dyspnoea and of 


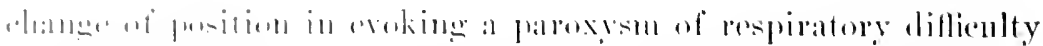

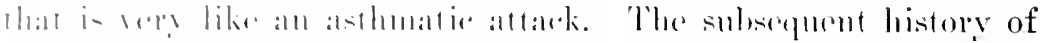

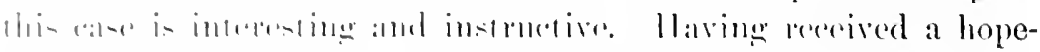

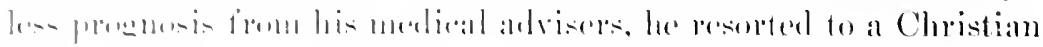

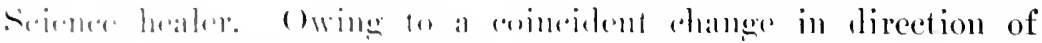

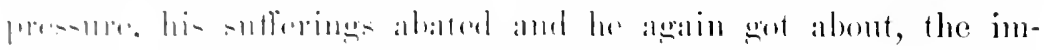

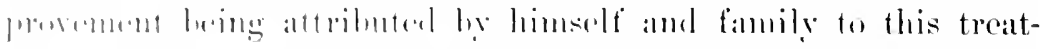

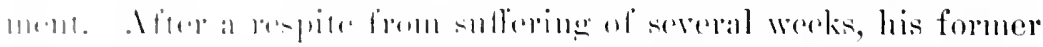

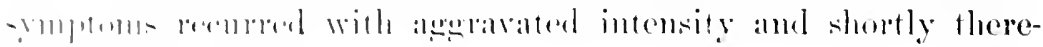
aftere the mall dient.

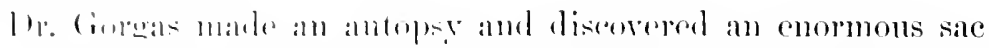

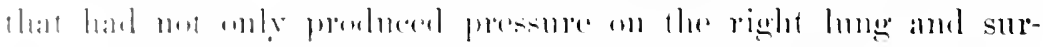

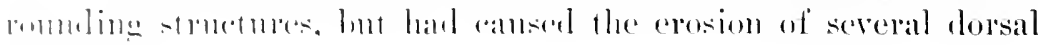
vintilia:

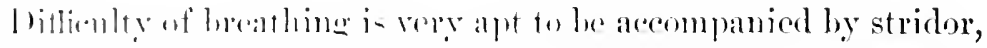

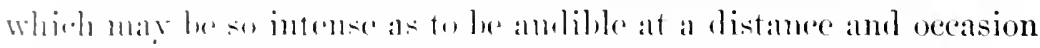

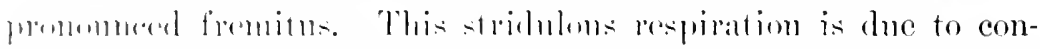

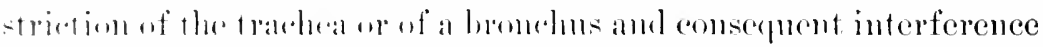

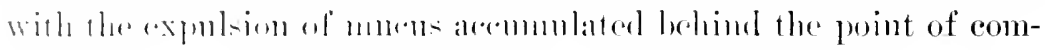
par.inin.

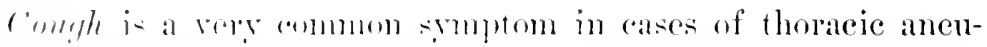

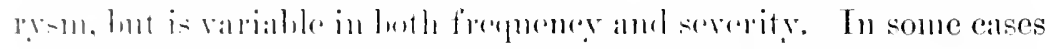

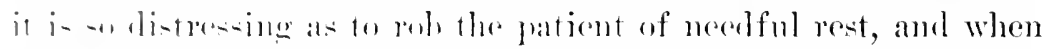

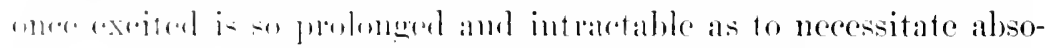

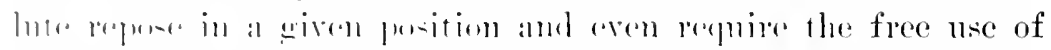

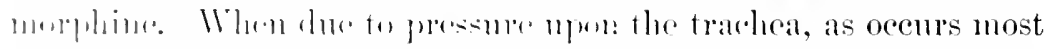

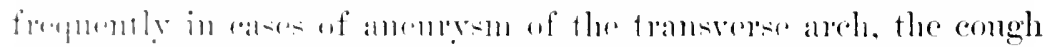

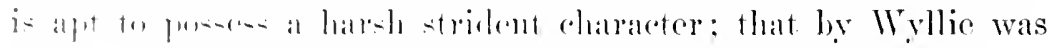

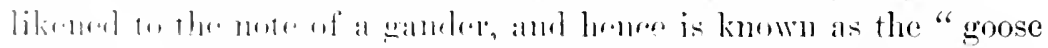

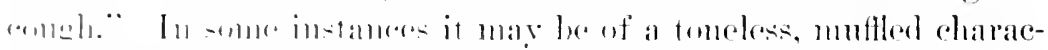

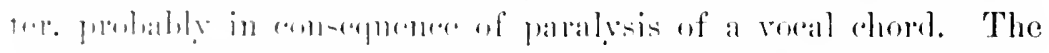

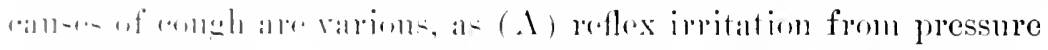

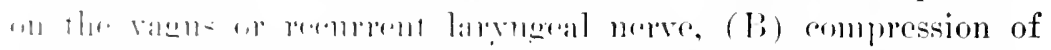

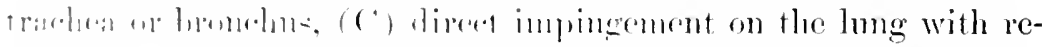

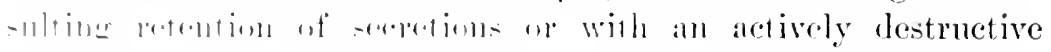
I $110+1+\cdots$

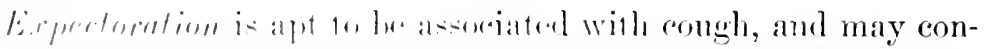

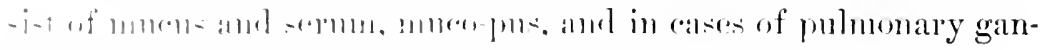

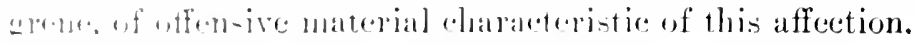


Ilamoptysis is by no means uncounnon in eases of aort ic aneurysm, in which event the blood may come from granulations situated on the tracheal mucosil (Osler), from bronchial congestion, or from destruction of a lung, or from the sale itselt, what is then known as weeping of the anemrys. Such hamoptyses may oceur from time to time orer a protracted period, even for months.

I vividly recall the instance of a man with umnistakable ancurysm of the upper portion of the descending aorta, whose clinieal picture was that of phtinisis. The tumour occasioned destructive pressure on the left lmag, with pronounced dulness, bronchial respiration, and a multitude of coarse and fine bubbling râles, freguent haralssing congh, and copions fululent sputum which was occasionally streaked with blood. In another case of aneurym similarly situated, pressure was whictly exerted upon the left bronchus with consequent dyspnora, congh, and copions râles due to retention, since there was very little expectoration.

Dysphagia is another very frequent subjective symptom, which is oceasioned by aneinresms of the transverse and descending portions of the arch, or when a sac situated on the descending aorta exerts pressure upon the asophagus. The patient not infrequently speaks of the ingesia secming to stick at a certain point in their passage downwal. If the aneurym is sitnated low down near the diaphragm it may canse regurgitation of the food. I)igestive disorders, proper?y speaking, do not form a part of the clinical history of thoracic aneurysms. They may be present nevertheless, and are then the resnlt, in part at least, of the stasis within the portal sustem and its tributaries occasioned hy pressure on the great veins in the thorax.

All aneurrsms of the arch do not ocasion appreciable interference with the flow of blood out of the venous system. When, howerer, an aneurym attains convilerable size it can searcely fail to affect eirculation by mechanical pressure. One or both of the rene carie may be compressed, and to such a degree that the circulation can conly be carried on by means of collateral ressels.

Snch a condition is admirably shown in Fig. 110, which is taken from a photograph kindly furmished me by Dr. Emil Beck. This man, aged thirty-seven, was first seen ly Dr. Feck in October of 1901, at which time his complaint was of congh, dyspmica and in. ability to lie down. He gave a history of syphilis sixteen years 


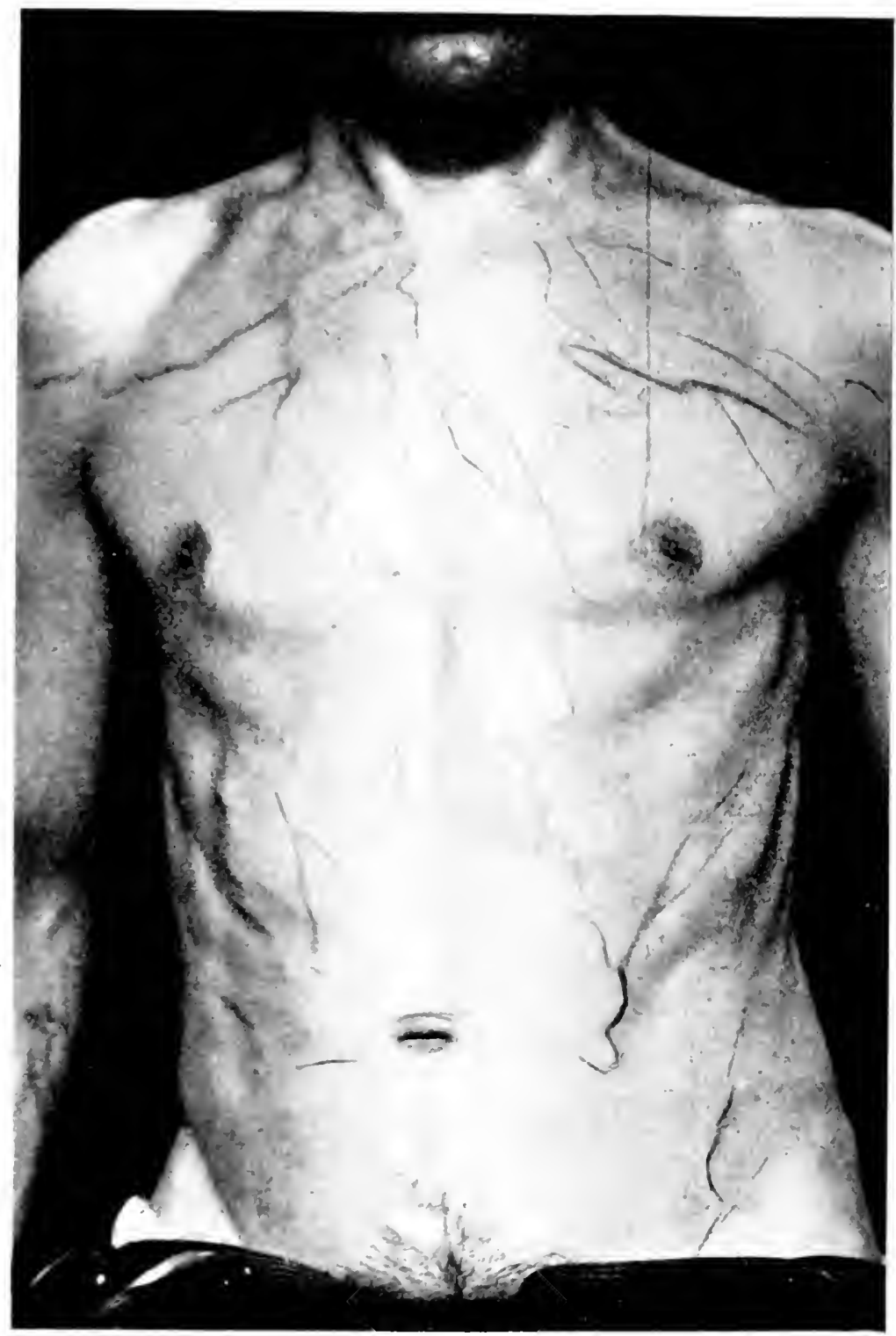

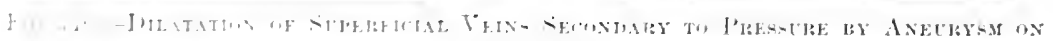

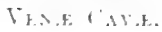

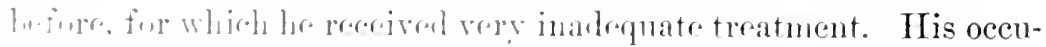

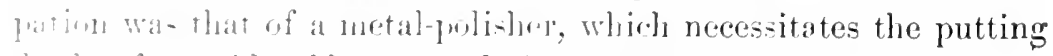
forth of consindrable strength in presing the metal against a 
polishing wheel. Ilere, then, were two factors loth operative in the etiology of aneurysur.

Ilis one initial semptom of hreathlessness on excrtion developed slowly, and did not neecsitate abandomnent of work and the sport of playing basciall until nearly a reall after it wals first notieed. When Inr. Beck examined the patient there was a pereeptible fulness of the neek and bulging in the aortic area. This tmmour pulsated and gave a systolic loruit. The pulses of the right half of the neck and of the corresponding an were distinctly smaller than their fellows on the left side. The diagnosis was aceordingly made of aneurym of the asecending and transrerse aorta.

Cyanosis and turgeseent veins were marked. The was then ardrised to enter St. Joseph's Hospital, in the scrvice of Dr. ('arl Beck, for the purpose of treatment. Rest and iodide of potash clid not seem to ameliorate his endition, and he left the hospital.

An aggravation of simptoms and evident increase in the size of the sac led the pationt to re-niter, in Jamuary, 1902, when he was given hypodermic injections of gelatin (2 per cont in :30) cubie centimetres of normal salt solution ) which were administered once a week, subsequently inereased to tis culsic eentimetros, until he had reeeived ten such injections in all.

Cnder this treatment pressure smptoms nearly disappeared, and the patient felt so well that he again left the hospital. Throngh the eourtesy of Dr. E. Peek, I had the opportunity of examining him a number of weeks later. The distention of the superficial reins was then as shown in Fig. 110, while, viewed from the side, there was the evident bulging of the chest shown in Fig. 111. The arteries of the right arm and corresponding half of the neck were manifestly less filled than those on the opposite side. There was a fecble pulsation in the prominent area, and tracheal tugging could be plainly felt.

Perenssion elicited an area of flatness having a semicircular ontline below and extending from beneath the middle of one elarire across the upper sternal region to abont the sane distanee on the other side. This area is shown by a shaded area in Fig. 112. Over this area could he heard a dull first tone accompanied by a systolic bruit and snceeded by a lond, ringing sceond sound.

The area of relative cardic dulness is also shown in Fig. 112, 


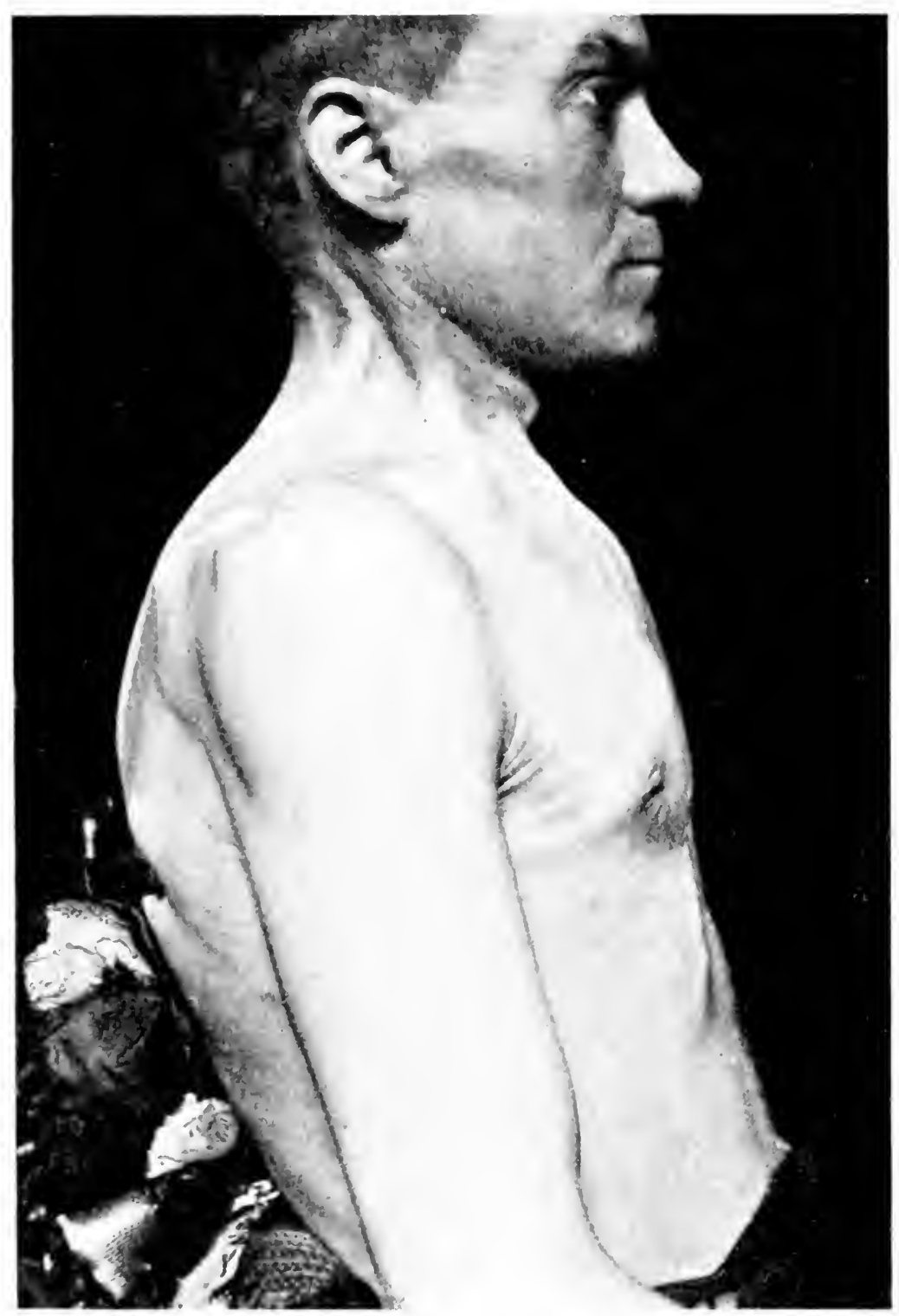

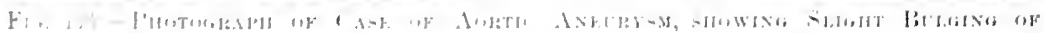

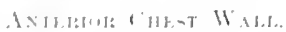

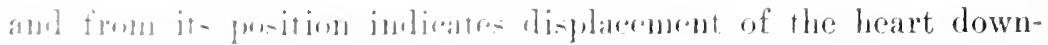

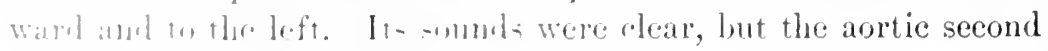

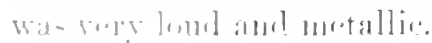


The liver, as indicated by the outline at the bottom of the figme. Was cridently engoreed as woll as probally somewhat depressed. being palpable and having an area of greatly increased flatness.

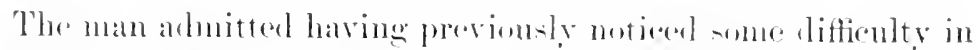
swallowing. He had mot experieneed jain to any extent, but in the last two weeks had begun to notiere some dull pain in the front of the chest at right of the stermun. This, it seemed to me, indicated an increalice of pressure upon the parietes. the sac har ing changed its direetion of growth, and hence its pressure, in the weeks following his abandomment of the getatin injections. It may le stated in ardition that the nature of this case was confirmed by an X-ray examination.

The interferenee with renons eirenlation in these cases may mot only be declatred by turgescence of superficial ressels, but by general or lowalized arlema. Thus the nerk and mpere extremities may be-

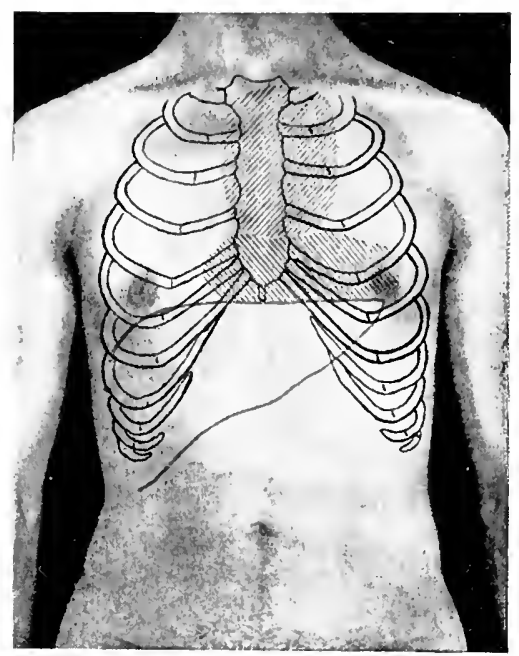

Eit. 112.-Shows Dellanese axi liver OUtLINE IX CANE WF ANETRYSM (1). T85i). come dropsical, or the adema may le limited to one arm and a portion of the thoracie rall. Inequality of the pulses on the two siles is rery common, owing to partial obliteration, displacement, or twisting of the great branches given off from the arch. Displacements of the heart oecur and the function of the valves, especially the aortic, is quite likely to be serionsly interfered with. Pressure effects in detail will be consilered in conneetion with the deseription of aneuryms in the various sitnations.

(1) Aneurysms of the ascending portion of the areh.- These may be sitmated close to the awrtic ling and imolve the sinuses of Valsalva, or they may spring from the convex or concare surface. In the first situation they are apt to be small and to escape deteetion, first declaring their presence by rupture into the perieardium and death. 


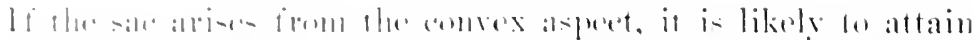

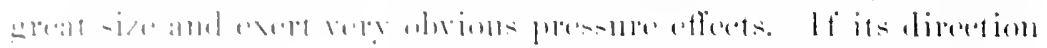

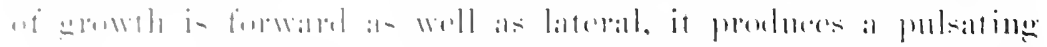

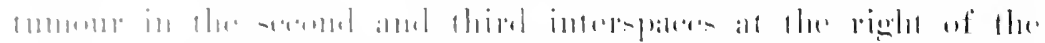

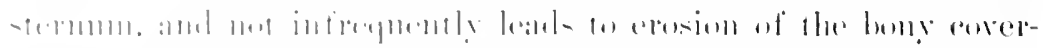

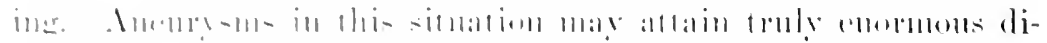

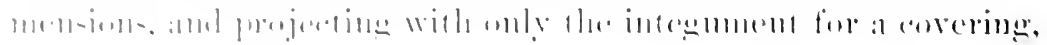
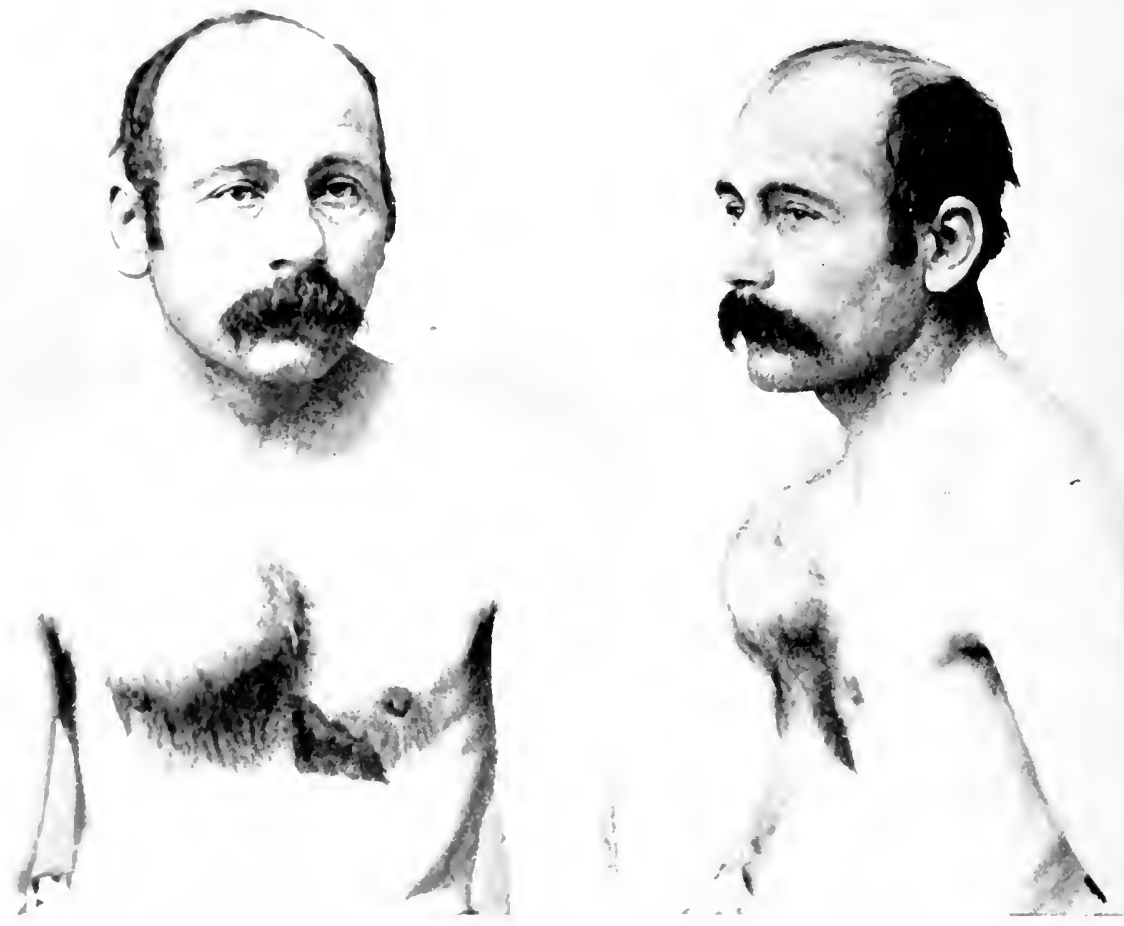

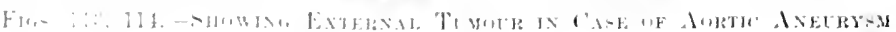

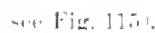

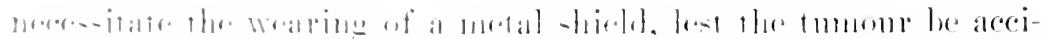

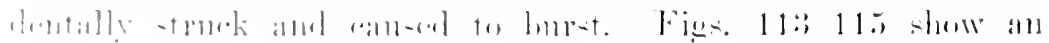

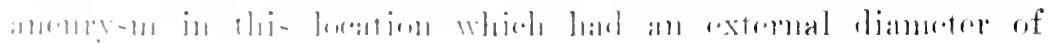

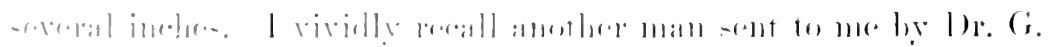

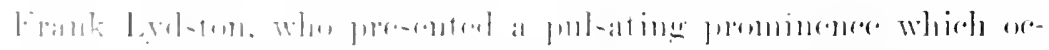

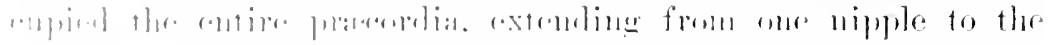

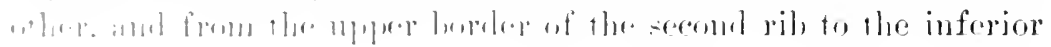




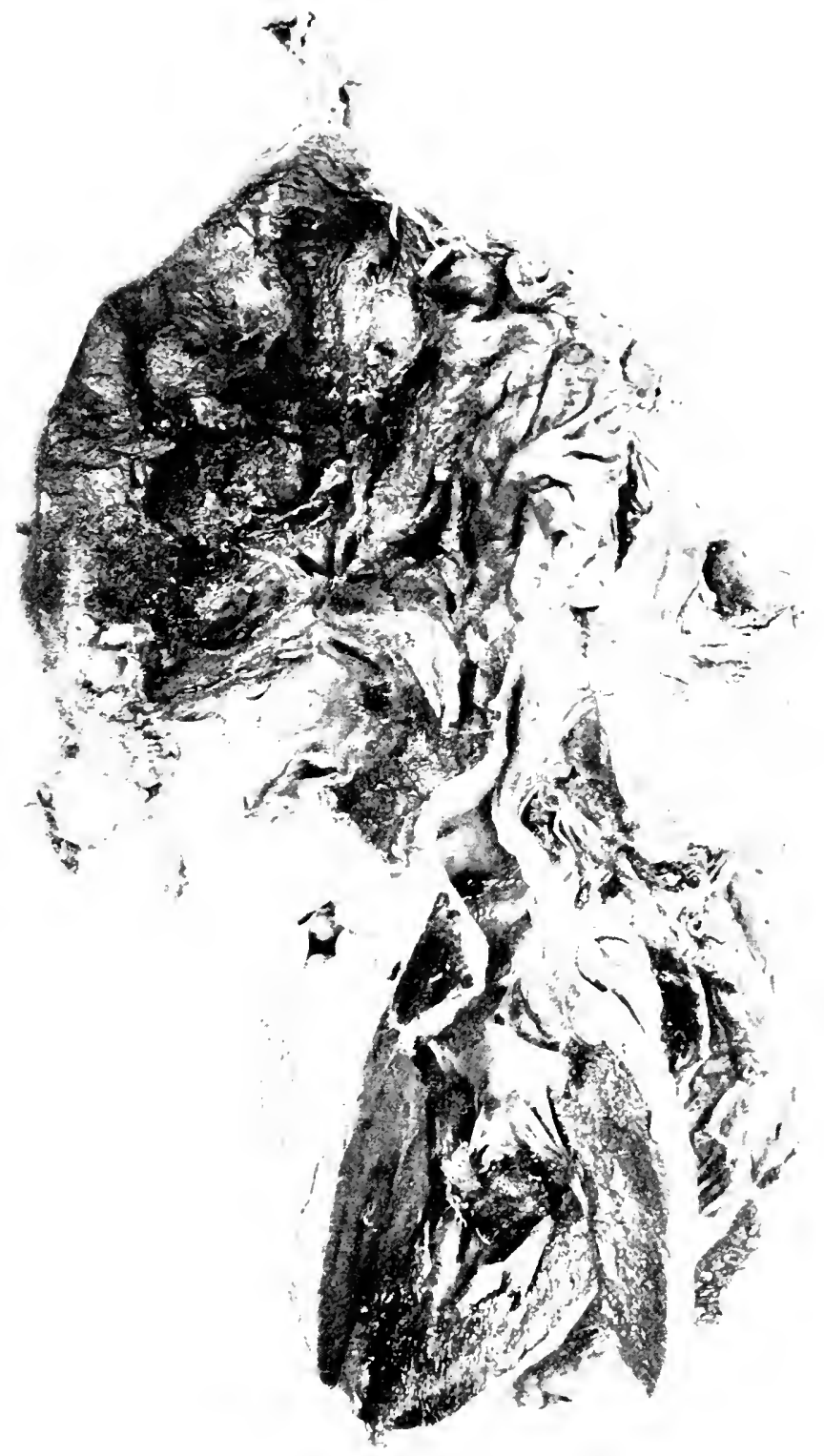

Fig. 115.-Pust-Jluptea spechen of Heapt axis Axerpromal fac from Case figleped Is Figs. 11: ANd 114. 


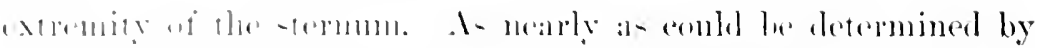

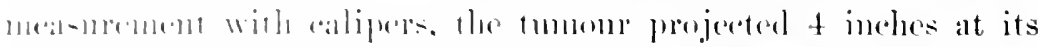

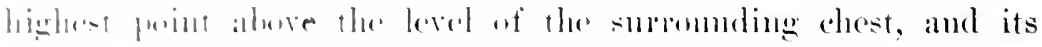

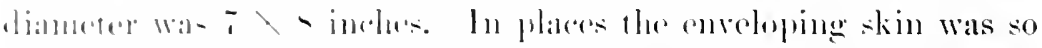
thin and bue that it seremet on the verese of rupture, and made

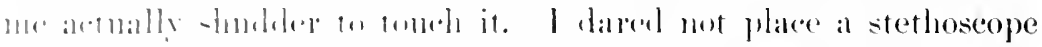

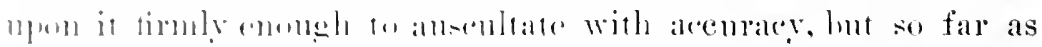

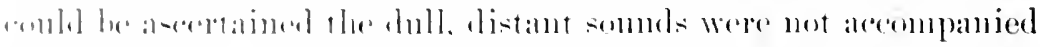

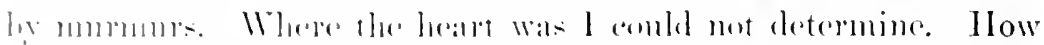

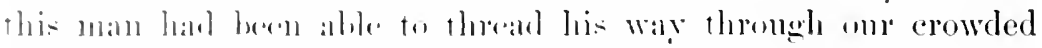

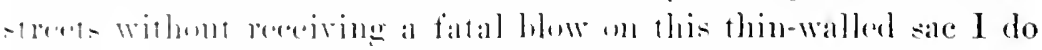

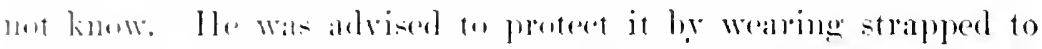

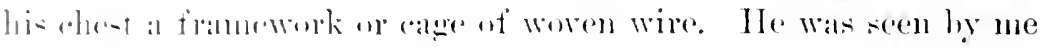
but wire and it is jublable that death from extermal rupture took

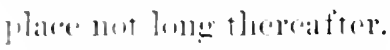

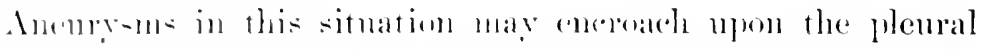

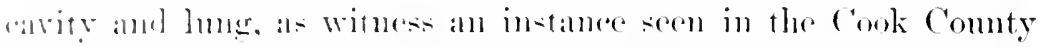

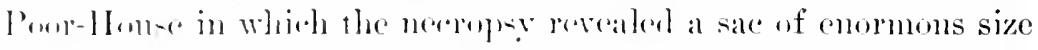
that menly tillol the cutire right half of the thorax and hat caused

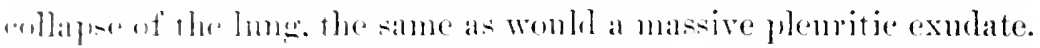

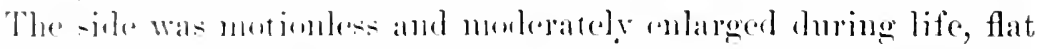
and intensery resting on perension, witl complete absence of

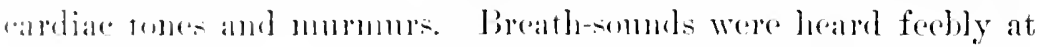

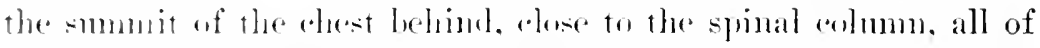

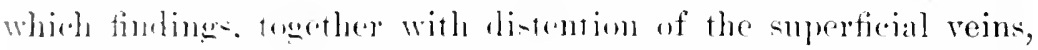

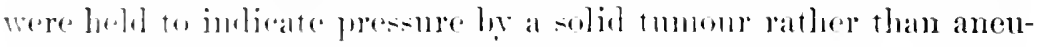
rysill.

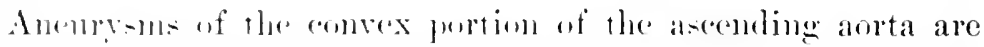

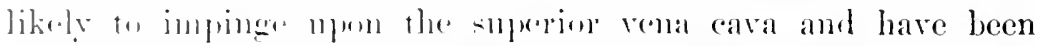

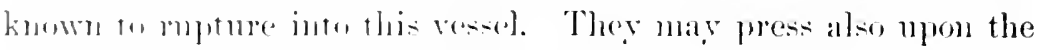

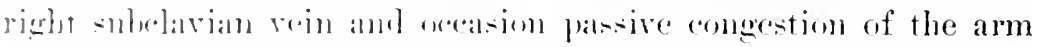

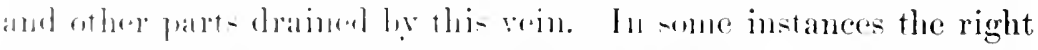

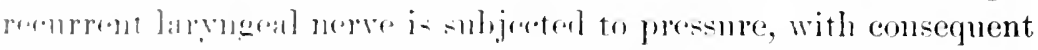

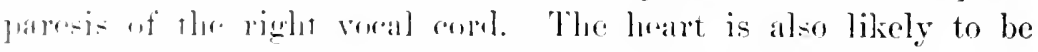

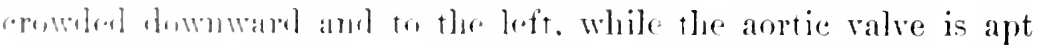

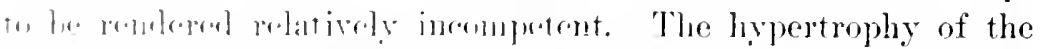

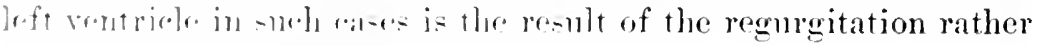

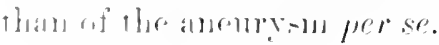

Anenryme suringing from the eoneave portion of the ascend- 
ing aorta may, according to Osler, ocosionally give rise to a

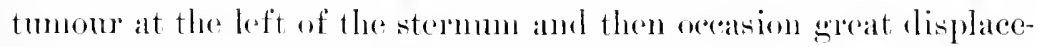
ment of the heart. There is at the present time in Ward 10 of Cook County llospital a man who presents such a tmmomr. It lies in the situation normaly ocempied by the borly of the heart-i. e., between the second and sixth costal cartilages, the left border of the sternum, and 1 incin ontside of manillary line-luas a slowly heaving expansile pulsation and gives forth a distinct, harsh double bruit that has replaced the normal cardiac somels. The heart, as shown by percussion and the location of what appears to be the apex-beat in the serenth interspace midaxillary line, is greatly displaced clownward and to the left. Its tones are rather feebly andible in this situation and are accompanied by the same to-andfro murmur, though less distinctly than on the body of the tumour. Yascular signs of aortic regurgitation are present, and there is an indefinite tracheal tug. There are no signs of pressure on the left recurrent laryugeal nerve, and pressure effects on reins are not present. Without wishing to affim that this sac arises from the concave aspect of the ascending aorta, I yet incline to the opinion that such is the location, since the incompetence of the artic valve is not so likely in cases of aneurysu developed from the descending portion of the arch, and were the transverse arch the portion affected, the tumour would be likely to have a different location. This patient has been an immate of the hospital at various times for the past fom years. Oceasional dull pain over the seat of the growth and drepnua of effort are the only symptoms of which he complains.

(2) Anerrysms of the transverse arch, in the same manner as those just considered, produce a variety of effects according to their size and direction of growth. They most frequently develop in a backward dircetion, and then, when even of small size, oceasion pronomneed symptoms in consequence of pressure on the trachea and cesophagus, interfering with respiration and deghtition. Paroxysmal congh is a very common sympten and inspiration is attended with strictor.

Growth of the sac forward proulues a tumour at the upper part of the sternum and to the right, with absorption of the bony structures. The tmmour may occasionally present at the left of the breastbone, but does so so much less commonly than at the right of 


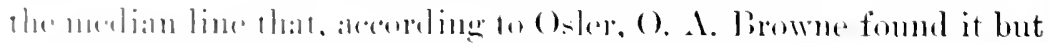

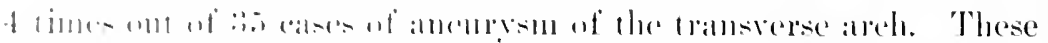

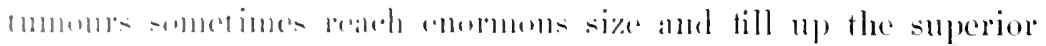

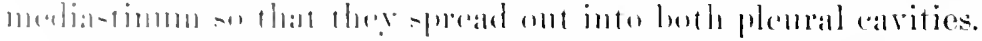

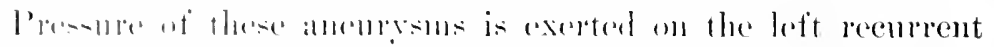

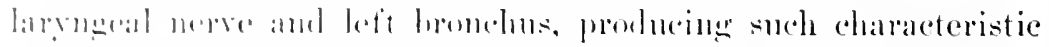

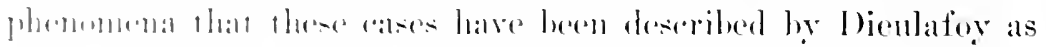

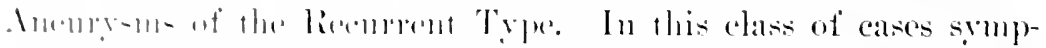

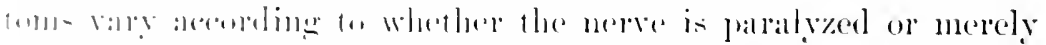

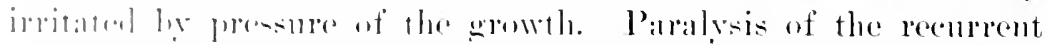

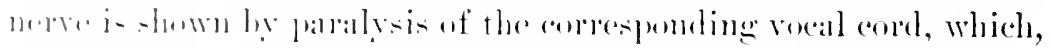

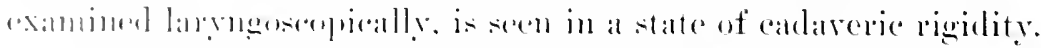

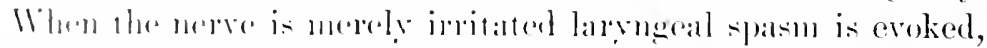

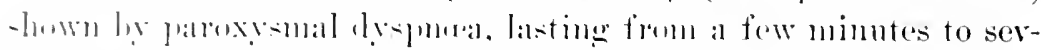

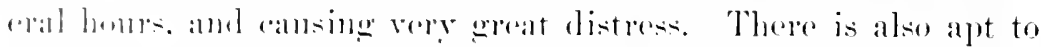

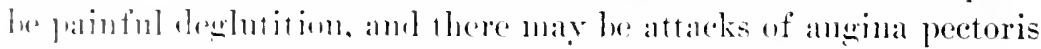

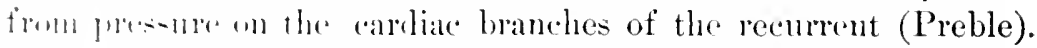
l'ain in -walluwing is due to spasm of the muscles of deglutition in the pharyos and endlet. Variations in the guality and power

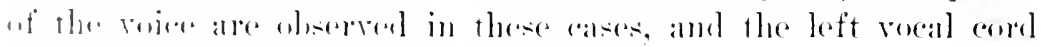

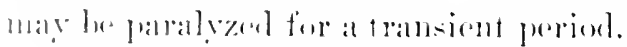

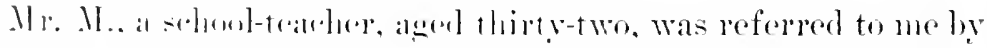

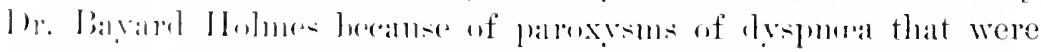
themeht ly the patient to he attalks of asthma. The history was,

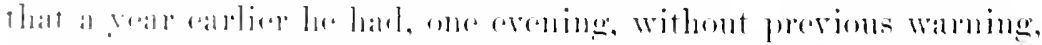

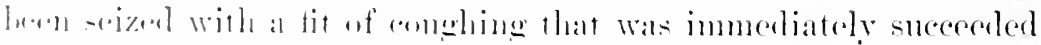

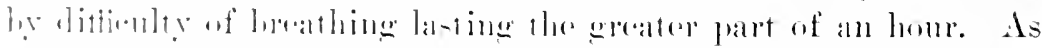

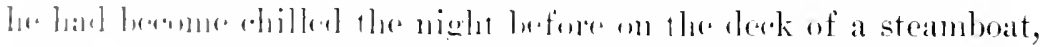

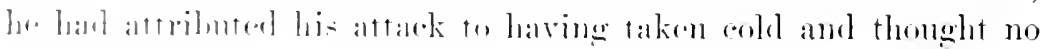
nuture almont it.

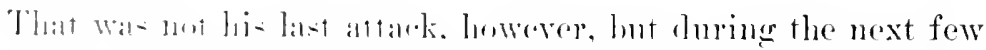

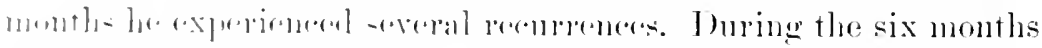

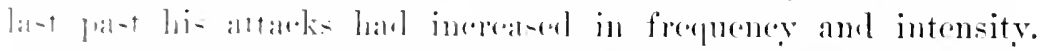

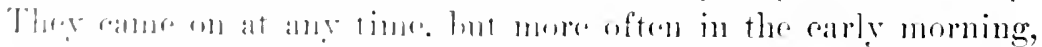

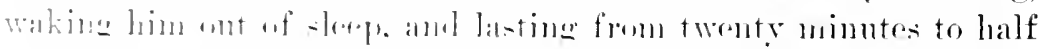

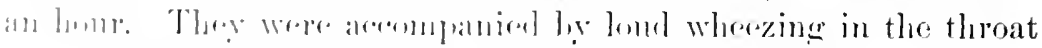

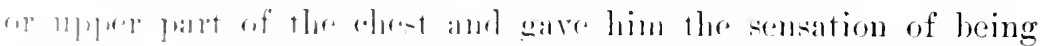

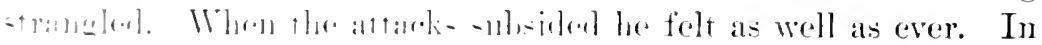

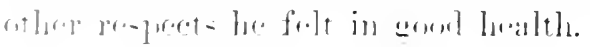


It was apparent that this was not the clinical history of bronchial asthma, but was highly snggestive of some organic disease; especially of intermittent messure. I therefore inpuired eneerning syphilitic infection and learned that he hand hat a chancere twelve vears before. This fact in connection with his spmptoms snggested thoralcic anemrysu as the possible eamse of pressure on the recurrent larrngeal, and led to minute incuiry regarding pain and congh. With exception of a trifling dry cough to which he paid no attention, he declared he was free from all symptoms exeept the spasmodic dyspmea alreaty described.

The results of examination may be briefly stater as follows: The left radial and carotid pulses seemed not quite so full and strong as the right, but the lifference was so trifling that I hesitated to accredit my senses lest I might be deceived hy my suslicion of anemysu into recognising an asymmetry that diet not actually exist. Likewise I was not able to positively identify any abmormal finding in the investigation of the leart and cervical ressels, but I thomght I recognised a slight difference in the intensity of the second tone on the two sides of the neck, that above the left waricle being somewhat houler and more ringing than at the right. There was certainly no abnormal pulsation or incequality in the ressels to the palpating finger. The heart appeared in its normal position.

Cpon examination of the lungs, however, eertain abuormalities were at once detected. Over the upper portion of the eliest there was a single inspiratory sibilns with each act, the rîle seeming to be more pronomed on the left. But the change that was most noteworthy wats duhess of the left apex above the clavicle and in the first interspace close to the left edge of the sternum. This impaiment of resminee was not intense and yet was distinct. Over this area the breatli-somds were obscured by subcrepitant râles. Ifter severil forced inspirations the dulness became less promomed and the rîles partially disappeared.

These findings convinced me that the loss of resonance was diue to atelectasis, and that from the history of spasmodic drspuca the collape of this portion of the left upper lobe was probably cansed by pressure. From the history of spphilis twelve rears before and from the alsence of positive signs on the part of the cirenlatory apparatus, I was led to make an inferential diagnosis of aneurysm 


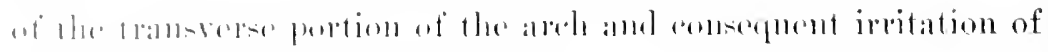

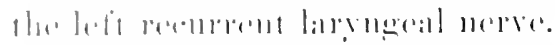

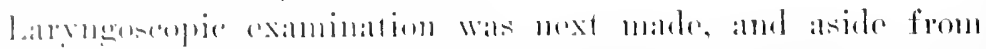

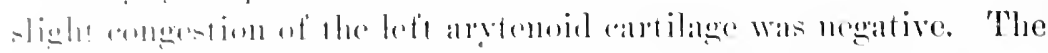

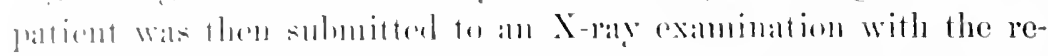

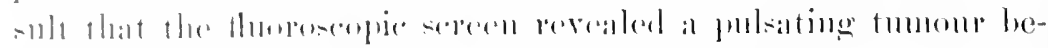

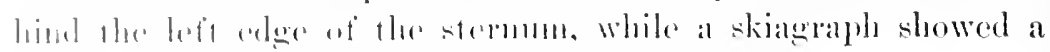

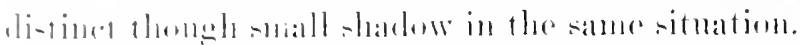

The dialgureis was thus contimed and the case was shown to be

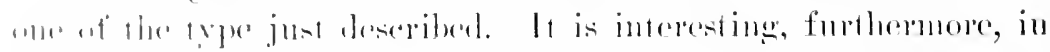

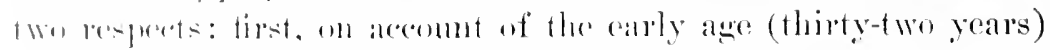

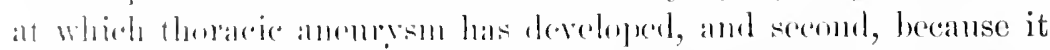

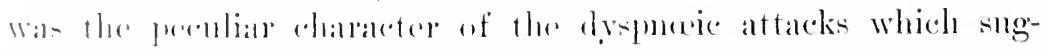

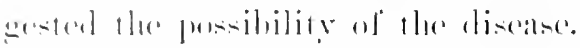

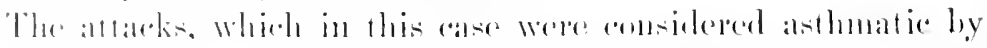

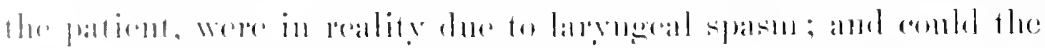

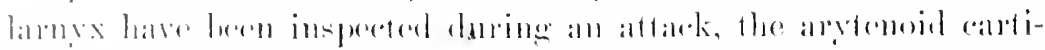

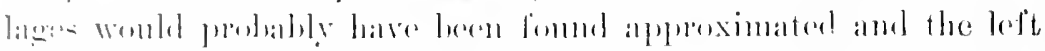

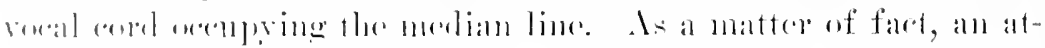

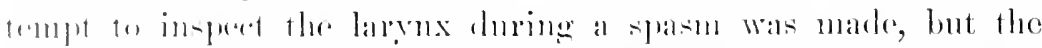

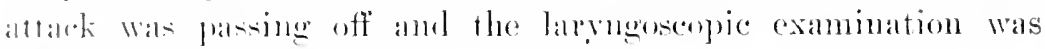
numitive.

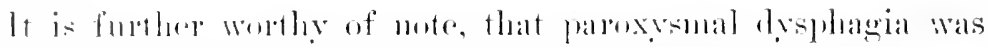

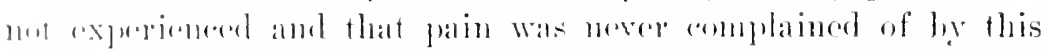

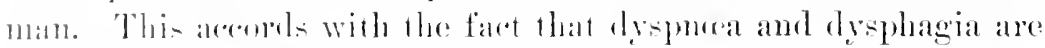

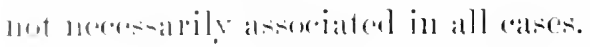

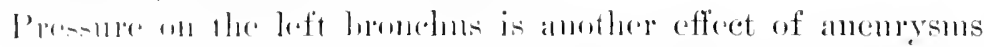

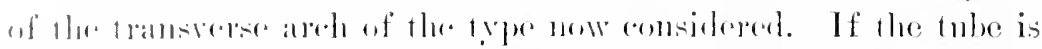

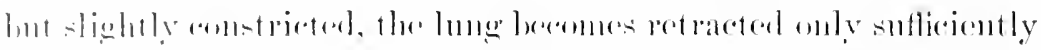

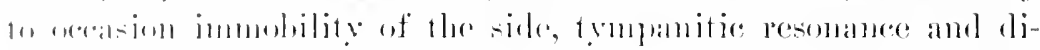

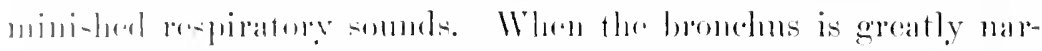

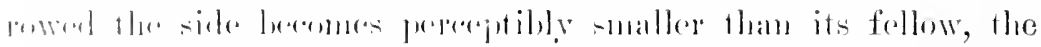

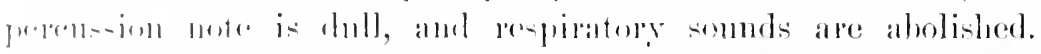

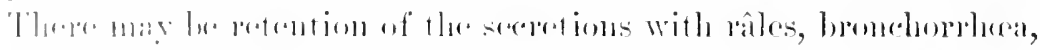

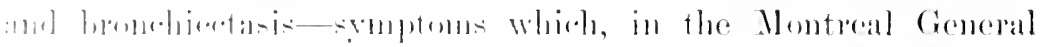

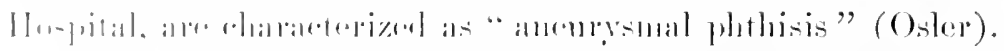

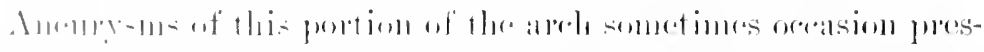

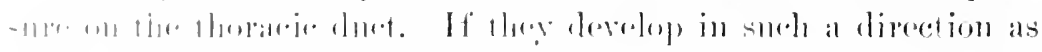

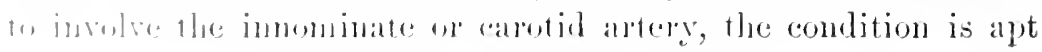


to he shown by a sommotry ow delay of the pulses on that side.

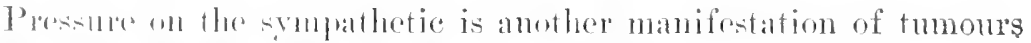
in this situation, ame is shown by dilatation and immobility of the

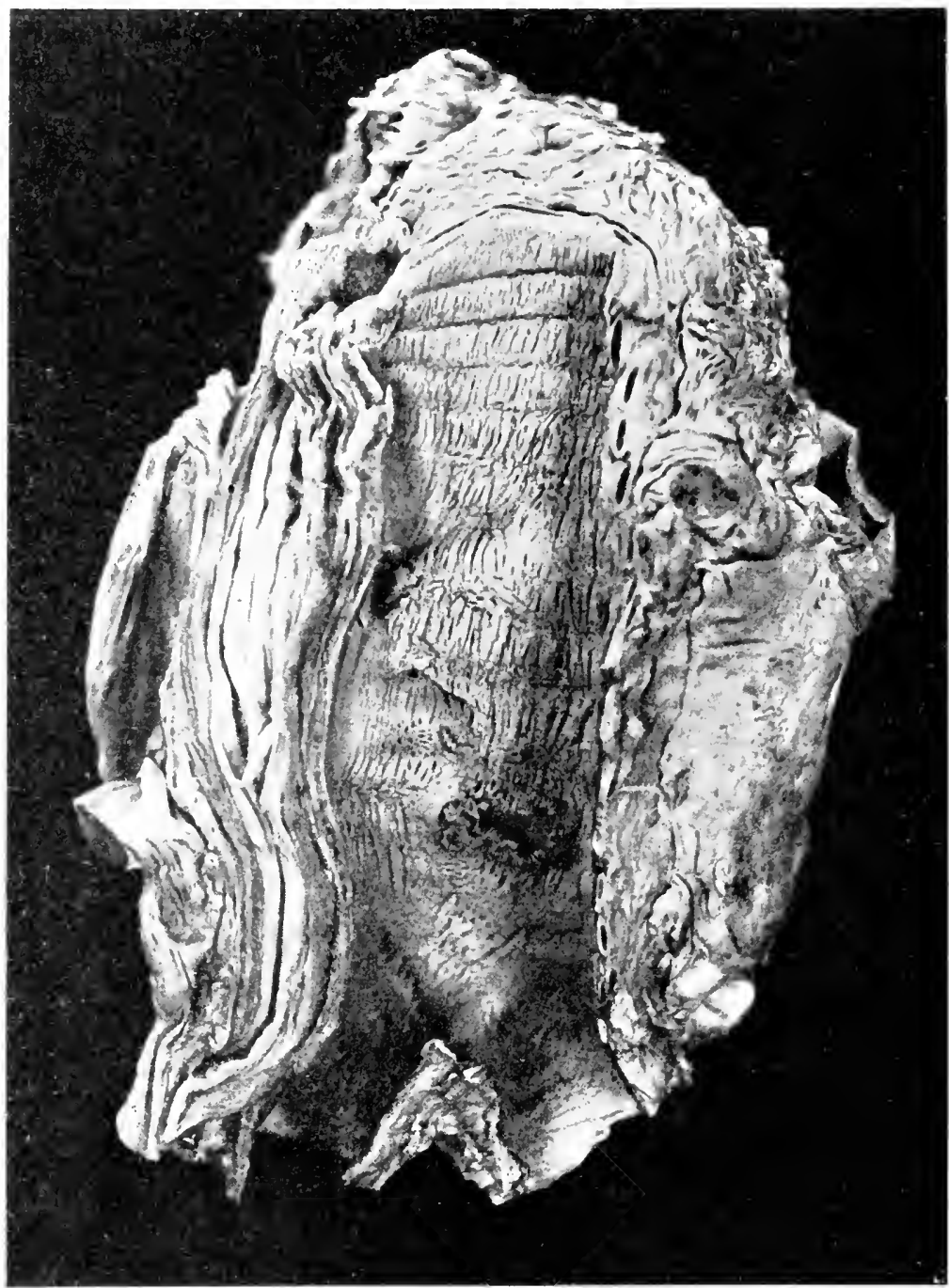

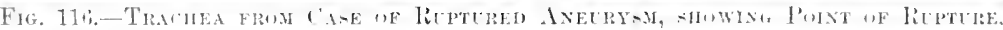

pupil when the nerve is irritated, and by contraction when the stupathetic is paralyzed. Tracheal tugering is another result of anemrym of the transwerse arch, as was first shown by Oliver. It 


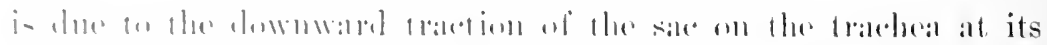

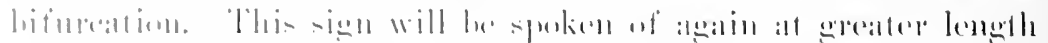

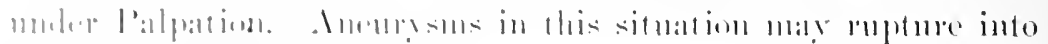

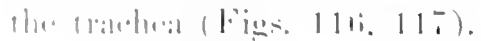

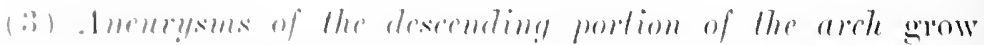

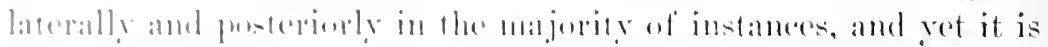

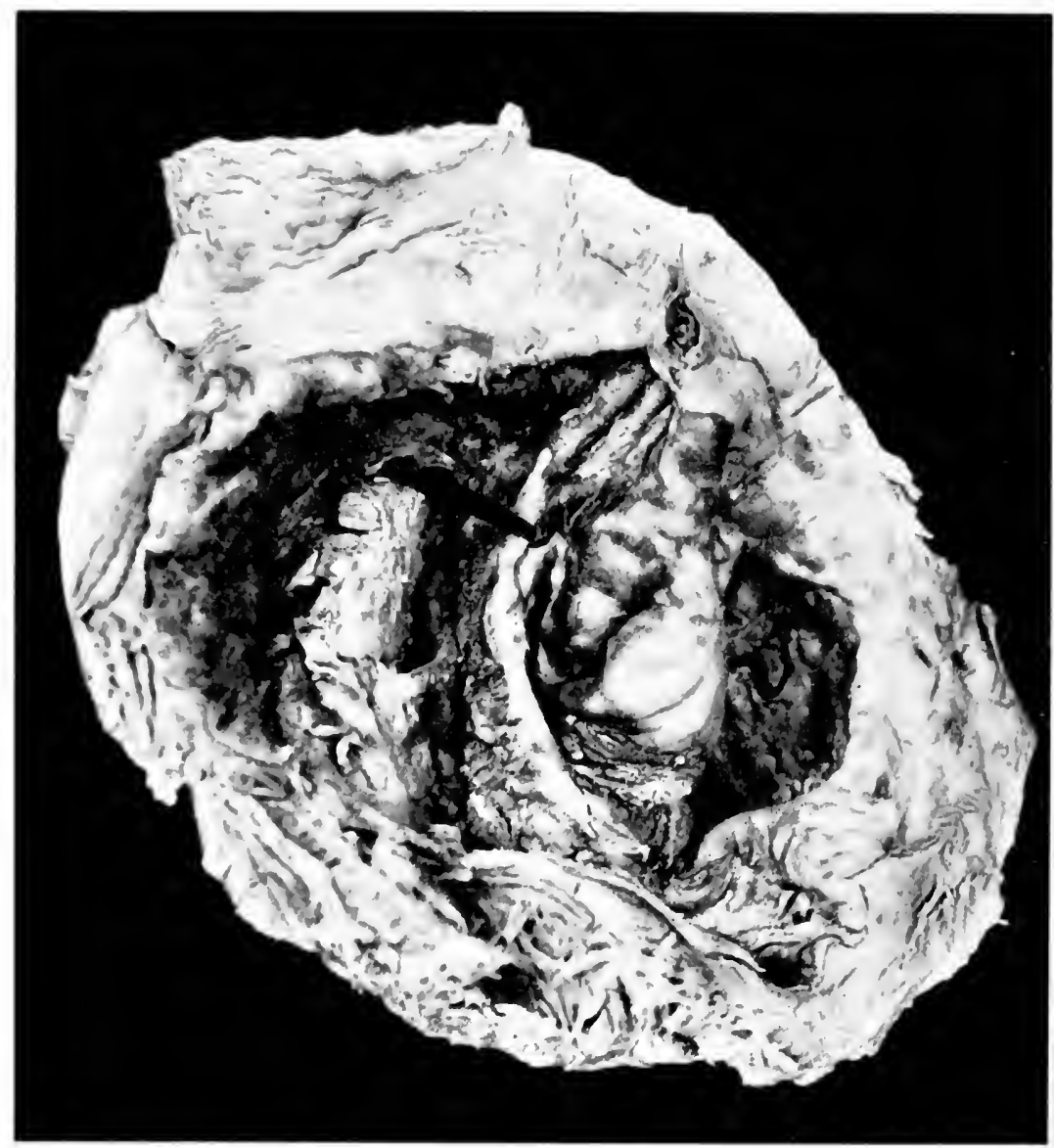

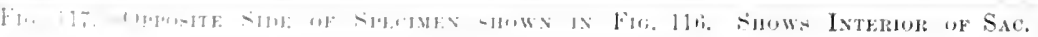

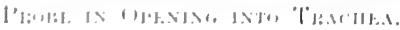

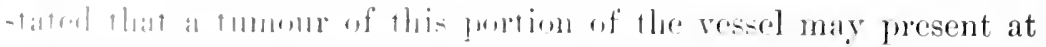

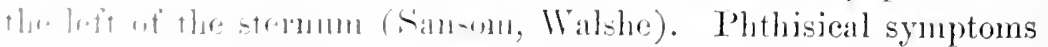

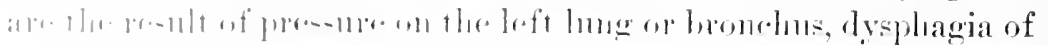
(n) 
(third to sixth), and a tunour in this situation may be the result of backward pressure. Compression of the spinal cord may occasion characteristic effects-e. g., paraplegial.

(4) Aneurysms of the descending thoracic aorta are usually located low down near the diaphragm and produce oftentimes very obscure symptoms. In an instance of the kind which I saw with Dr. Bayard Holmes, and which was not reeognised as aneurysm, the only complaint was dull pain raguely felt in the lower zone of the thorax and upper abdominal region. The only thing that could be discovered on exammation was an area of impaired resonance and feeble broncho-resicular breath-sounds in the left infrascapular region, close to the spinal colmmn. From the history of previous ilness, that seemed to have been plenritic, and from the physieal findings, this area was erroneonsly thought to indicate old arlhesions. The antopsy, months subsequently, revealed a sac filled with deuse coagula pressing on the base of the left lung just above the diaphragm.

Aneurysus in this situation may, as previonsly stated, cause dysphagia and regurgitation of solid ingesta, but they rarely oceasion respiratory embarrassment. Aside from deep-seated pain they are not likely to prodnee subjective synptoms, and unless, by reason of their size, they give rise to lateral dulness and other signs of pressure on the limg, they are likely to escape recognition.

It shonld be borne in mind that an ancurysm which in the beginning is confined to one portion of the areh may as time progresses so increase in dinensions as to eventually invade other divisions of the vessel. Thus, a sae at first limited to the transverse arch may in time spread to the aseending portion, or one in this latter situation may at length involve the entire areh; so that both subjective and objective srmptoms are very liable to exhibit changes corresponding to the extension of the ancurysm.

I recall the case of a locomotive engineer who was for many months an immate of the Cook County Hospital in whom such a change took place. His aneurysm at first presented in such a situation that it was believed to implicate the descending portion of the areh. As months went on, however, the tumour grew enormonsly towards the front, and at the necropsy was found to have involved the entire arch, which had consequently lost all semblance to an arch, being, in fact, but a huge sac from heart to descending aorta. 
Physical Signs. Insperliom.-In some mates this is wholly

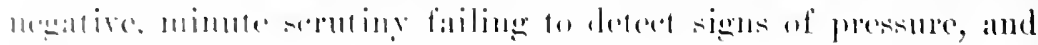

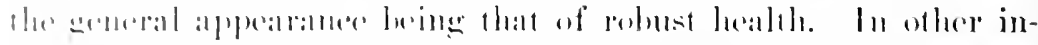

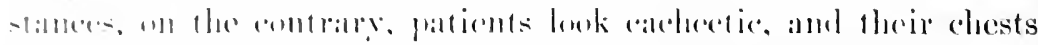

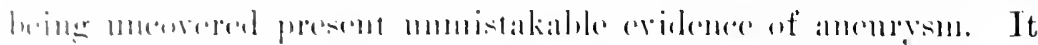

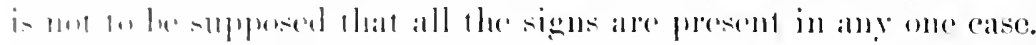
cimangunty the following are the pwints to be earefully linkind fort:

(1) (irementeribed holging of the dhest-wall in the following

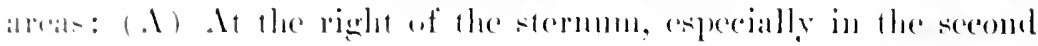

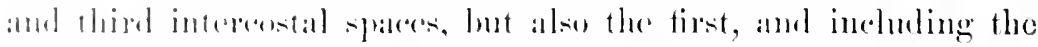

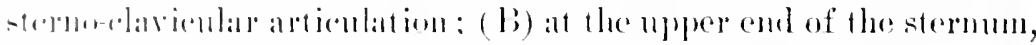

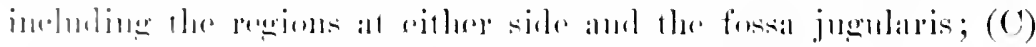
in the interenstal sparess at left of the hreastlone, from claviele

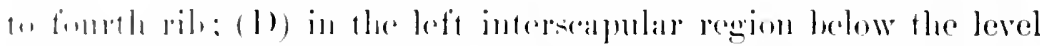

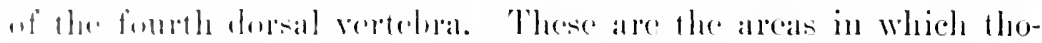

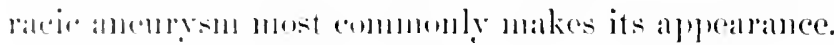

The integument at these prints may alpear smooth and shining, the pouninence being slight, or a tumour of such size may projeet and have so creded the overlying structures that the skin is of a dark red or bhish lue, or may lave disappeared in spots, leaving the wall of the anemrism visille.

(2) Signs of interforence with the circulation: (A) visible

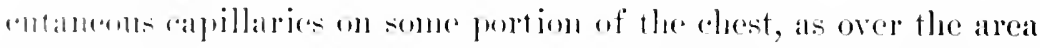
of bulging: (1) distemderl, tortums weins denoting the establishment of collateral cirenlation in conserpuenee of pressure on some

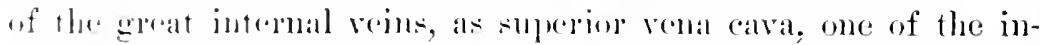

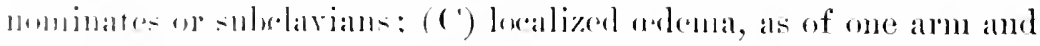

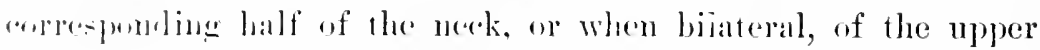
balrt of the lunly, lint not of the lowere extremities. Walshe speaks of the nuek leding in some instanees so distemded and spongy from

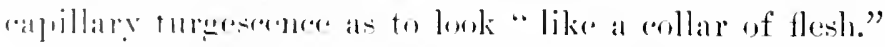

(a) Pulation in some abuomal situation-e. g., one of the

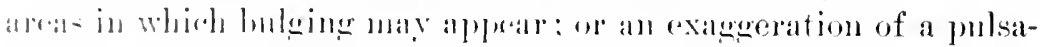
tim in a mornal stuation-e. ge, of the corviral arteries, particularly an one and not the other side or in the episternal notel.

(4) I)isturation of the ardiac impulse, in most instances downwarl and to the loft. The regan may, however, be pushed stronely forwarl against the anterior chest-wall. 
(5) Diminution or absence of respiratory movenent of one half of the thorax, more often the left, with, in some catses of marked bronchial compression, also petraten of the side. 'This' sign in conjunction with presstire-symptoms is highly suggestive.

(6) Inmobility of one pupil, which may be langer than its fellow, but is more often contracted.

(7) Sweating of the lieal, sometimes milateral, and by Walshe said to be very profuse in some instances. This is another sign of pressure on the sympatletic, and taken in conjunction with other pressure-symptoms may be of value, lut foumd alone possesses no significance as respects artic aneurysm.

Palpation is of value chicfly as a means of detecting almormal pulsation, its extent and clanacter. It is especially likely to give information when employed as bimanual palpation, one hand being pressed firmly against the clest in front and the of her behind. In this way, deeply sitmated pulsation may sometimes be appreciated that otherwise would escape reeognition. If a bulging area is perceived to pulsate, one should endeavour to feel the extent, force, and direction of the pulsation. If the tumour is due to aneurysm, it is likely that the pulsation includes the whole area. If this is forcible, so forcible in fact as to equal in this regard the beat of the heart, it is lighly suggestive of anemysur (Balfour). Finally, the pulsation of aneurysm may be slowly heaving and is expansile, and when by palpation this character can be deternined, there is no donbt of the nature of the tmuour. Pulsation imparted to a soidd tmmour by a ressel beneath is a simple forward thrust or shock.

In some cases the liand laid 1 pon a tumour due to aneurysun perceives a distinct diastolie shock which snceeds the systolic impulse. This is very characteristic, being due to elastic recoil in the wall of the sac. In some instances a thrill is detected in the bulging area, but in my experience is not at all common, and is of diagnostic aid only in connection with other signs.

Palpation is of value also in the sturly of the pulse with a view to ascertaining whether or not it is equal and synchunous in corresponding arteries, since when the immominate or the left common carotid and subclavian arteries are implicated, smallness and perhaps retardation or obliteration of the pulse in the arteries of the corresponding half of the neck or arm are likely to be occasioned. 


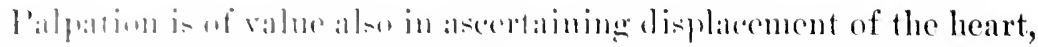

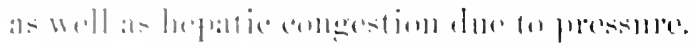

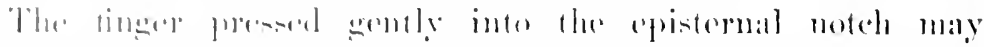

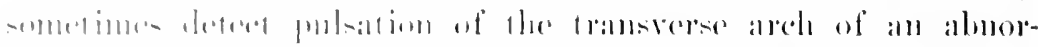

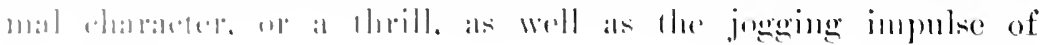

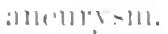

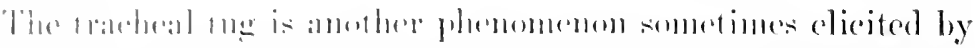

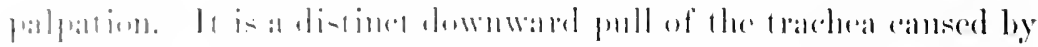

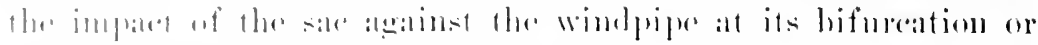

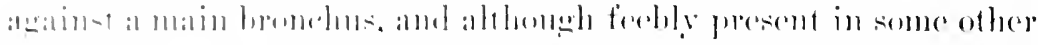

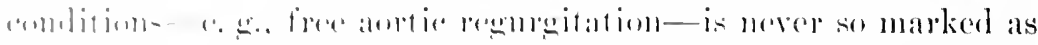

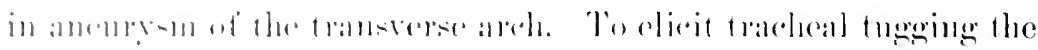

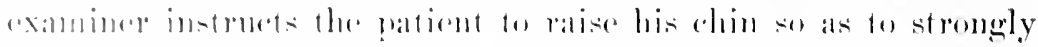

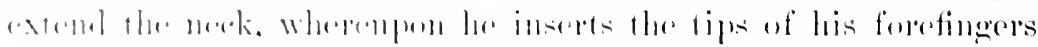

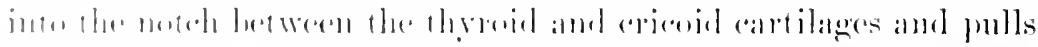

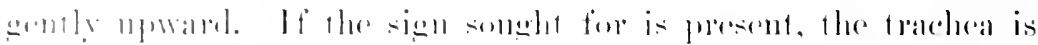

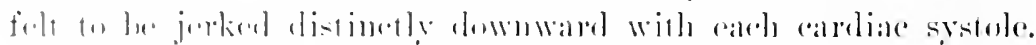

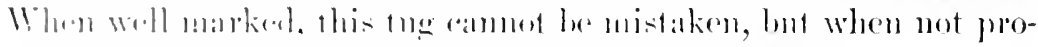

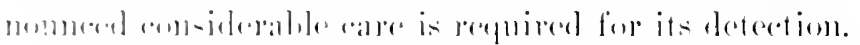

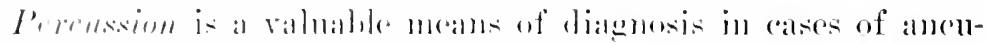

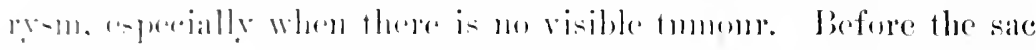

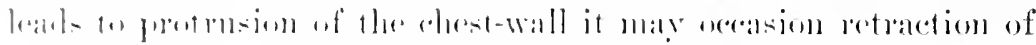

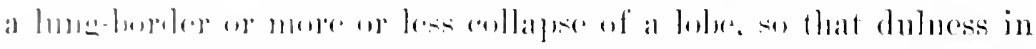

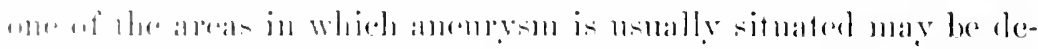

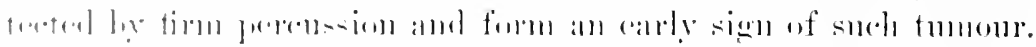

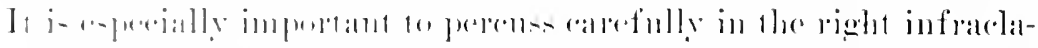

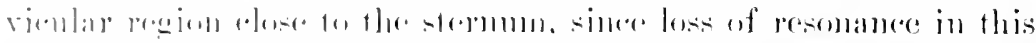

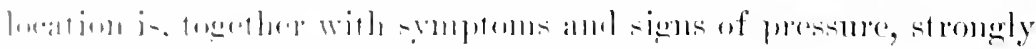

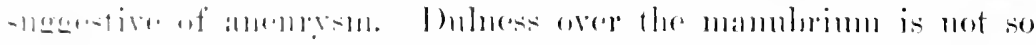

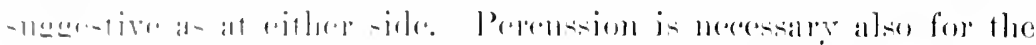

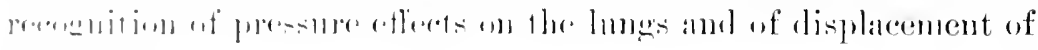
$1]_{11} \cdot 11, \ldots 1 \%$.

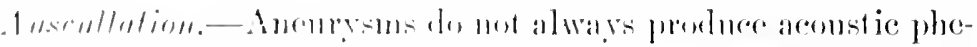

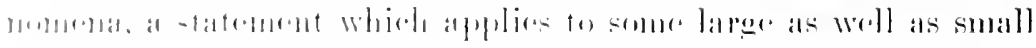

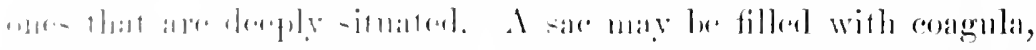

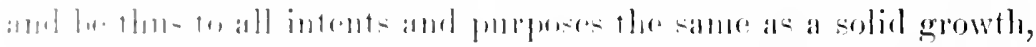

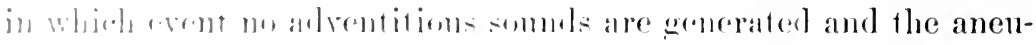
r-m rmanin=-ilrut.

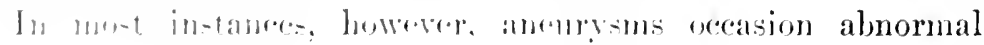


sounds or bruits which are andille wrer the sale or in some neighbouring vessel or part to which they are propagated.

There is no anscultatory phemomenon pathognomonic of ancirysm, but certain somuls are more sngegestive than alre others. 'The two tones nomblnally lueard orer one of the gleat resseds at the base of the neck and in the aortic area are usually alteresl by the development of aneurysm. Either the sistolic ar the diastolic may be modified-i. e., intensified, dininished, or innpure.

Perhaps the most frequent and striking change is a lomel peculjarly ringing quality of the second tone heard orer the growth or in one of the cervical arteries but not the others. In some instances such a sound is impure or split, in other's it is clear and clanging, while the first is not pure or has been replaced by a murmur of harsh quality. In other cases again the systolic tone is pure and aceentuated and the diantolic is acempanied or obsened by a distinct bruit, while in still others there is a donble to-and-fro murmur of wide propagation.

Intensification or modification of the nomal raseular somets oceurring in immediate proximity to the heart-e. g., in the aortic area, are not so suggestive as are such changes in regions in which they do not nomally exist-e. g., the left interseapular region or one side of the neek. Another very valuable ansentatory sign is the propagation of the heart-tones to a much greater distance than normal-e.g., to the onter limit of an infraclavicular region or into an axilla, the lung tissue not being indurated. This condition is essential, for solidifieation of lmog from tuberenlosis may lead to wide tranemission of the cardiar somels without aneurysur.

We do not ret understand the conditions which determine changes of one kind and another in the tones heart over an anenrysm. These sounds are probably not generated de noco in the wall of the sac, but are merely condured thither from the heart and are there intensified, reduplicated, or otherwise modified by vibrations set up in the sac-wall or by some other comdition that eseapes our ken. It may well be that bruits are generated in some cases in the sac itself in consequence of the blood-strean swirling into or out of the sac, but probably the nurmur is due in other instances to atheromatous roughening of the arorta between the heart and sac or to insufficiency of the aortic leaflets. This is believed to be the explanation of the double aortic bruit not infrequently heard in 


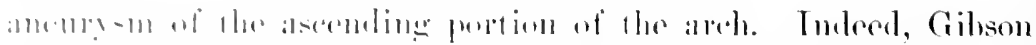

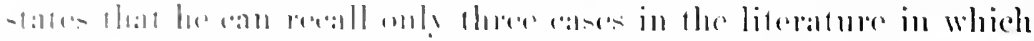

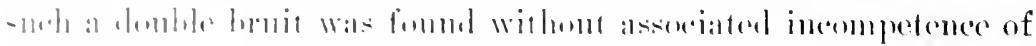

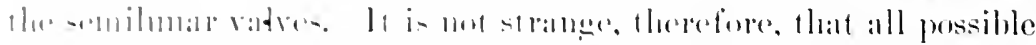

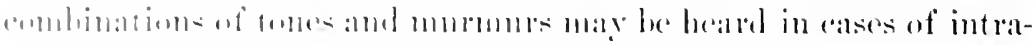

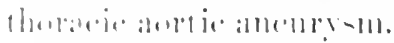

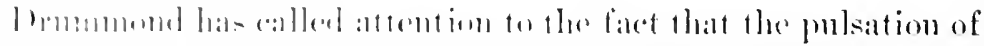

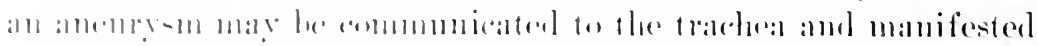

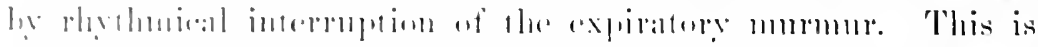

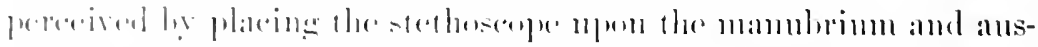

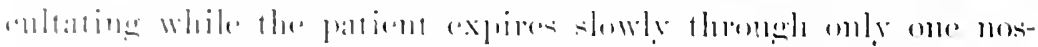

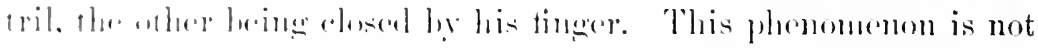

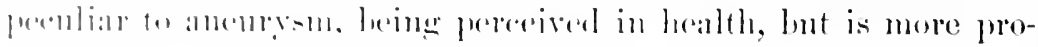
11+1]110.1.

ln

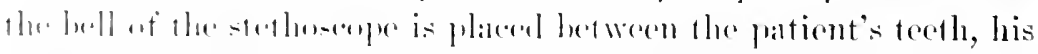

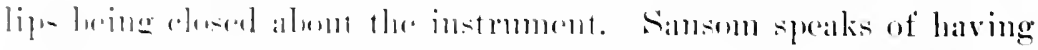

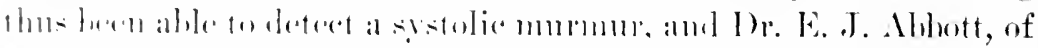

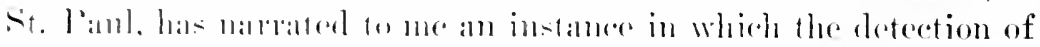

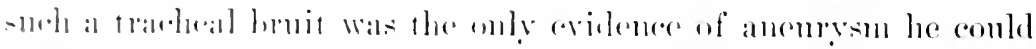
disomere. In rimk ('mmty Inspital at present writing is a man

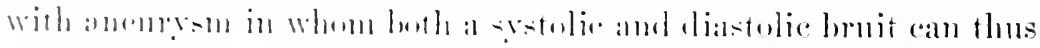

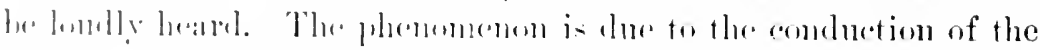

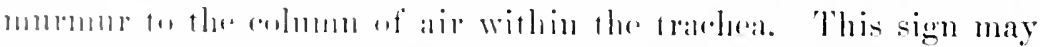

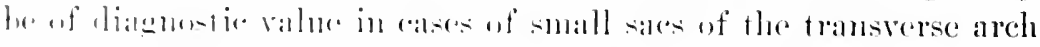

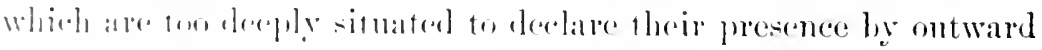

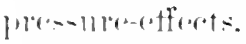

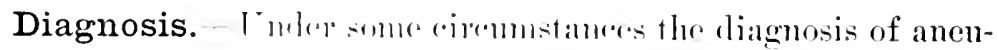

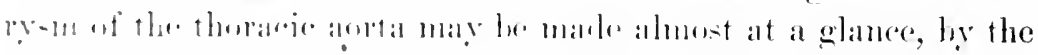

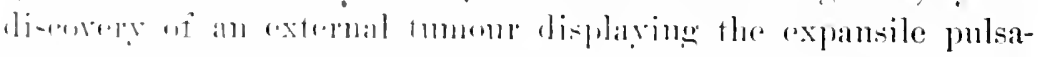

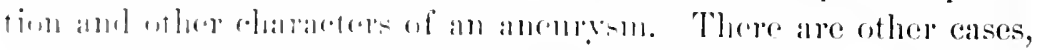

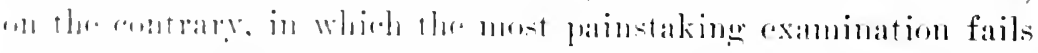

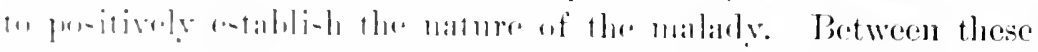

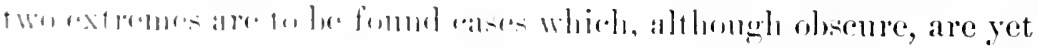

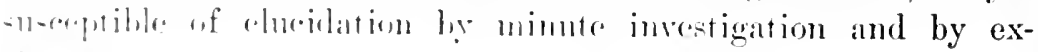
(1)-inn.

In a sllepreterl rase the following points may be considered of diacmetir impertanere: (1) A history of syphilis years before or

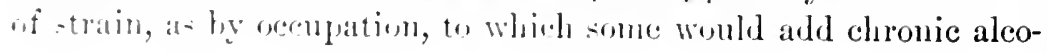


holic exeess. (2) Age, the patient being at w after the middle period of life. (3) The male sex, sinee men are rastly more liable to aneurysm. (4) Sxruptoms indicative of intrithoralcic pressure;

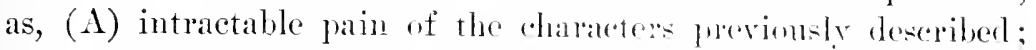
(B) dyspnoa, especially if influenced ly posture; (C) congh of a brazen elang, also evoled on intensitied by pesture; (D) dysphagia or regurgitation of food. These four simptoms, if all present, form a very strong chain of eridence in farour of an existing aneurysm.

If to the foregoing history and stmptoms the following phrsieal signs are added, reasomable doubt can scarcely be entertained: (5) Bulging, even if slight, in some one of the areals in which aneurysm is likely to be present. (6) Juhness in one of these areas even withont pereeptible bulging. (i) Displacenent of the heart, most often downwarl and to the left. (o) Sonne of the

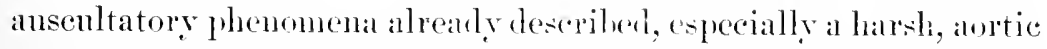
systolic bouit with a clanging sceoml somel. If such second tone is split or doulled and is heard most plainly or solely over a dull area or in the cervical arteries, especially if on one side and not on the other, and is accompanied by al diastolic shock, the evidence, taken in connection witis pressure-symptoms, may be considered almost conclusive.

Aside from an external tmour haring a distinctly expansile pulsation or a diastolic shock, there may be sain to be no signs so distinetive as to be pathognomonic. I)iagnosis is to be found in the association of several important wigns rather than in any one alone. Tevertheless attention may be expecially dinected to what Balfour considers repry trustworthy evidence-namely, a pulsation in an ancurysmal area equal in intensity to the apex-beat, so that there may be said to be two areas of maximm impulse. Even this is not absolute, howerer; for a kyphoscoliosis has been known to push the convex portion of the antic arch so strongly against the anterior chest-wall at right of the stermum as to simulate, with respect to the force of its pulsation, a thoracic ancurysm.

Tracheal tugging is a very strong sign of aneurym of the transverse arch, especially in conjumetion witl other signs; but as it may be produced by other comditions, it is not infallible.

Differential Dingnoxis.-.-This encerns especially the three following diseases, which taken in order of frequener and importance 


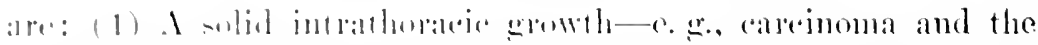

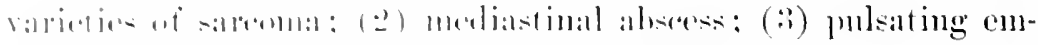

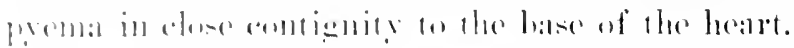

(1) Vulimmut Tummur. This disesse when situated within

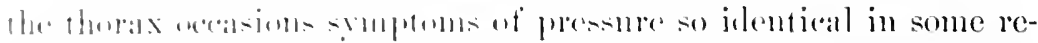

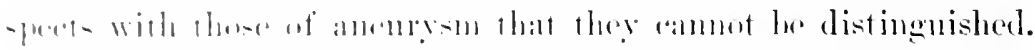

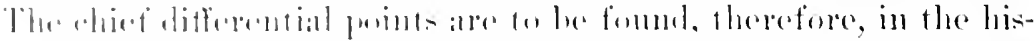

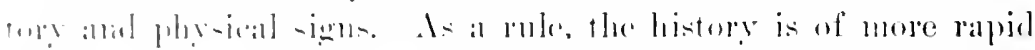

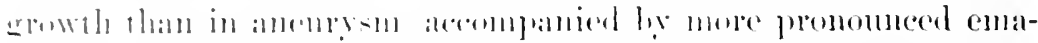

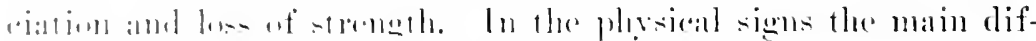

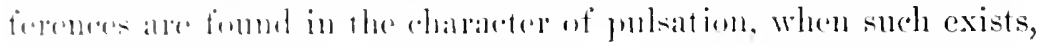
and in the an-r.ultatory jhenomenas.

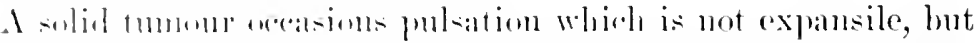

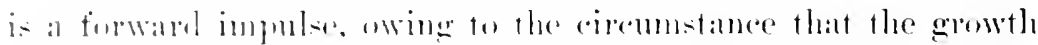

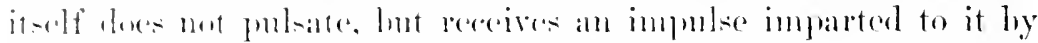

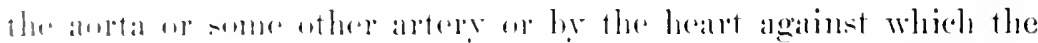

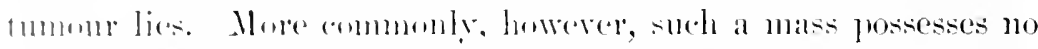

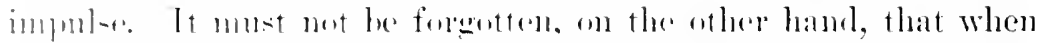

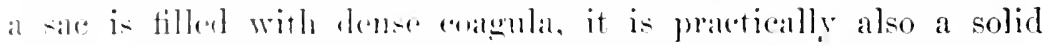

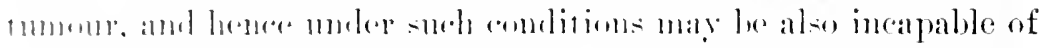

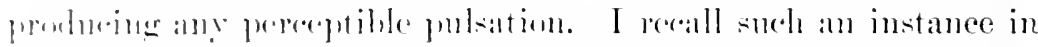

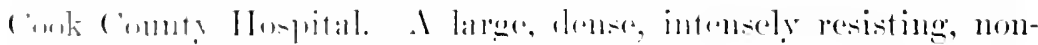

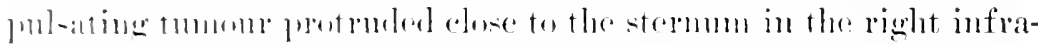

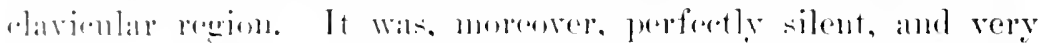
nammlally was for a long time mistaken for a malignant growtl.

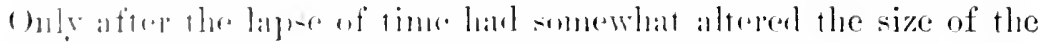

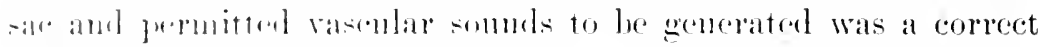

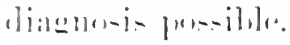

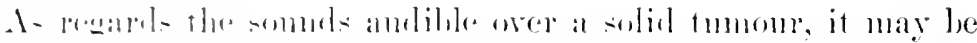

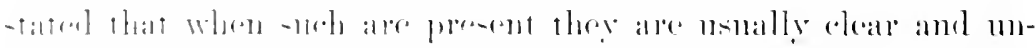

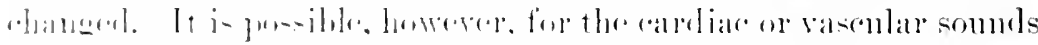

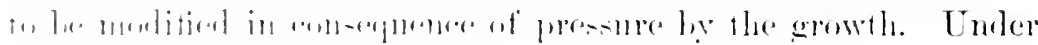

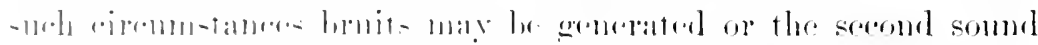

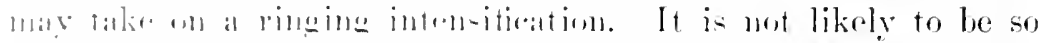

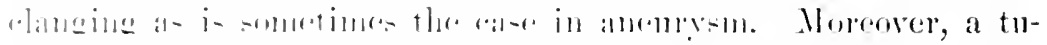

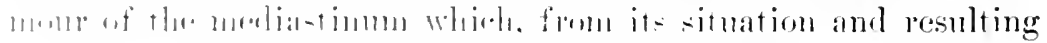

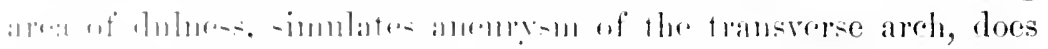

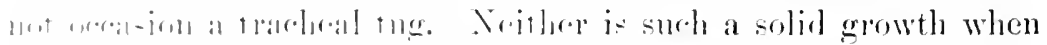
situatul in the area at right of stermun, and licnce simulating 
aneurysm of the ascending antia, likely to lead to signs of insufficiency of the semilmua valves. It does not elange its dircetion of growth and canse sudden modifications of symptoms, nor is it apt to ereate asymmetry of the pulses. Finally, in cases of malignant growths there nay be history or smmptoms of an antecedent tmmour elsewhere, or there may be indmation of some of the lymph-nodes in axilla or neek which may aid in the correct interpretation of the case.

(2) Mediastinal Abscess. - In this infrequent affection there is history of more sudden invasion, and pain is an early srmpton, even before pressure has become sufleient to oecasion drspmexil. Ferer is likely to be present, and is an cally symptom, whereas when it exists in anemrsm it is apt to be late, after the sale hats begum to exert pressure on the bronchus or lumg with phthisical symptoms. In abscess, moreorer, there is not likely to be the change in the rascular somds or the production of new ones as occurs in aneurysm. The disease may arise at any age and in either sex, showing no predilection for the male sex.

(3) Pulsating empyema may simulate an ancurym when an empyema necessitatis forms in elose proximity to the lase of the heart. It is, howerer, exceedingly rare, and may oecur in ehildren as well as in adults. The history and eximnination of the lungs ought to elear up the nature of the case. Shomld a circumseribed empyema in immediate contignity to the heart display bulging and pulsation as well ats dulness, it may oceasion considerable difficulty of correct diagnosis, but onght at length to be diagnosed by exclusion, if not ly history and phesical signs indicative of its real nature.

Other diseases producing signs in the antic area-i. e., dilatation of the aseenrling areh associated with artic regurgitation, stenosis of the aortic ostimu, and selerosis of the ascending arehmay and have been mistaken for anenrym. In the case of the first mentioned a positive differential diagnosis is sometimes extremely diftienlt, when the regurgitation acenrs in the male past middle age, but as a rule pressure-effects are absent. Thrill and systolic mummr may in cases of stenosis give rise to suspicion of aneurysm, but error may orlinarily be avoided by study of the history, age, the second somul. the position and size of the heart, and the characters of the pulse. Sclerosis of the aorta may occa- 


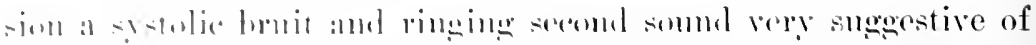

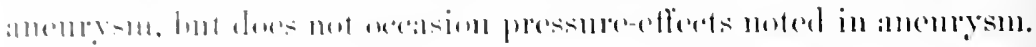

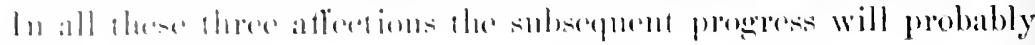

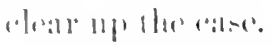

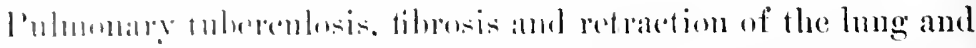

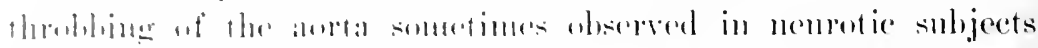

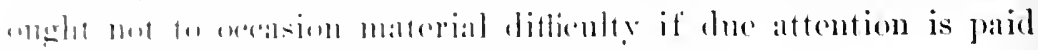

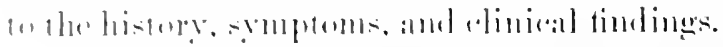

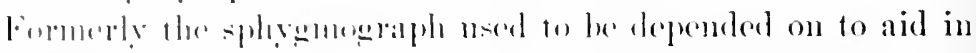

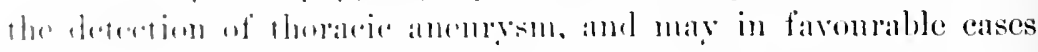

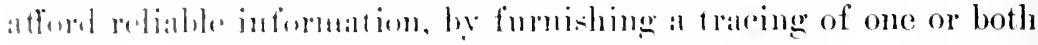

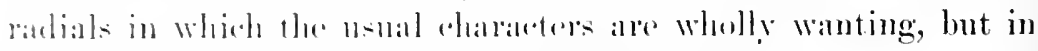

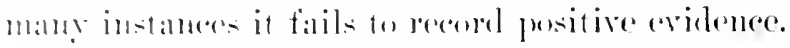

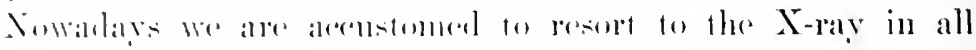

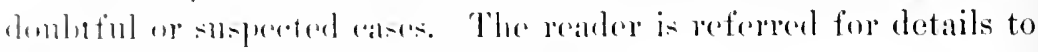
the ilperentiate article in the Apendix.

Prognosis may he said to be extremcly unfavourable, for

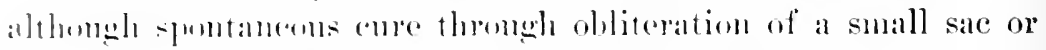
sme with a marme perdiele sometimes takes places, it is mulikely for

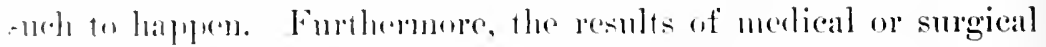

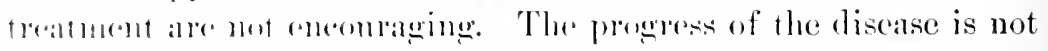

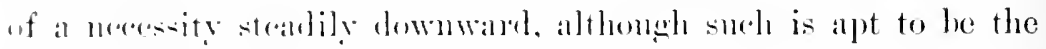

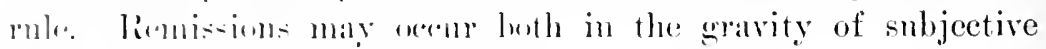

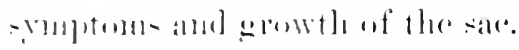

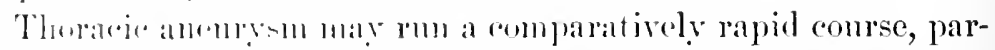

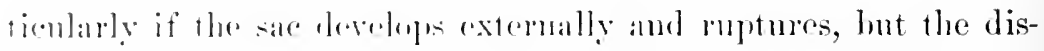

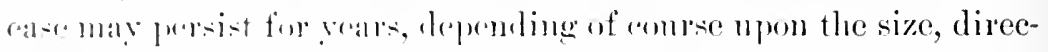

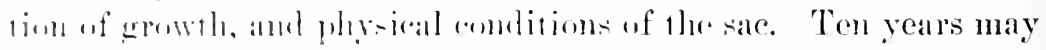

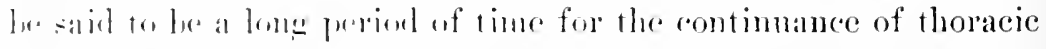

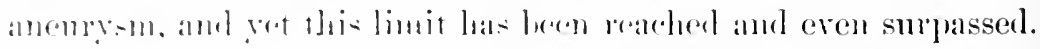

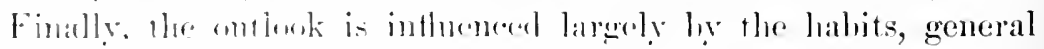

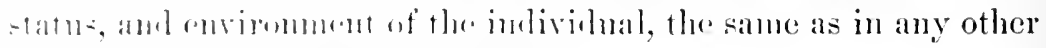

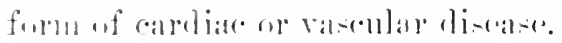

Modes and Causes of Death. - Thr fatal termination may

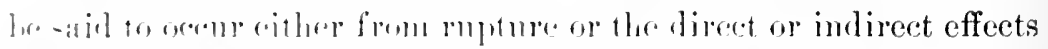

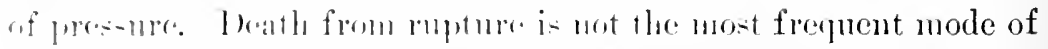

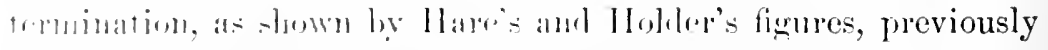

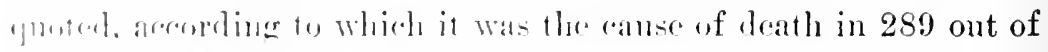
$95 \%$ cates. linpture may lake plate externally or into any one of 
the contiguous structures, propardimn, heat, phemal cavity, bronchus, trachea, wsophagus, vena rava, molmonary artery. In such an event death may be inmediate or protractod weer a period of hours.

More commonly, life is terminated in conserpuenee of mechanical interference with respiration or circulation and abliace inadequacy, or the patient suecumbs to "aneurymal phthisis" or general exhanstion and cachexia. Cnder such rireumstances the ent may come slowly or suddenly after weeks of slowly progessing loss of strength. The last hours are in many cases fratught with extreme suffering and death is hailed as a blessed deliverer.

Treatment.-The not infrequent post-mortem disorery of the spontancons eure of thoracic aneurysu by coagulation of the blood within the sac has furnished the hint upon which all therapeutic measures are based that aim at anything more than palliation of symptoms. The alecomplishment of this object presupposes certain favouring conditions in the sac itself. In the first place the aneurysm must le of the sacenlar variety, and in the second it must commnnicate with the anrta by a narrow opening. Given these essentials, it is possible for clotting within the sale to take place.

If these conditions are not present, there is little or no prospeet of cure, and medical skill is powerless to do more than mitigate suffering or furnish advice, which if carried out may retard progress. In the majority of eases, unfortunately, we are compelled to content onrselves with palliative measures and watching the course of the disease.

Our aim should be, howerer, to effect a cure in erery case in which there seems to be such a possibility. Conserpently, the first measure to be advised is rest in the recumbent position. The olject of this plan of nanagement is the reduction in the number and force of cardiac contractions that thereby the flow of blood within the aneurysu may be less swift. Erer since its introduction by Talsalva the value and importance of this measure has been recognised. To be effective the rest must be absolute and must include rest of mind as well as of body. Whaterer excites the heart to more rapid and powerful systoles must be avoided, and to attain as complete rest as is necessary, the patient shonld be clearly instructed concerning its adrantages and necessity. 


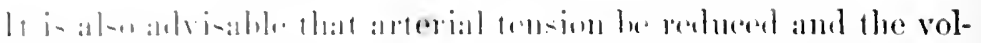

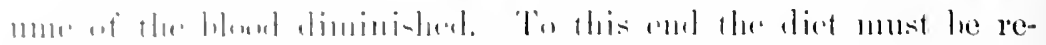

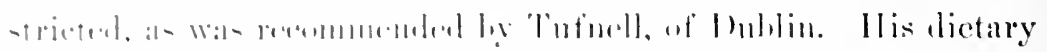

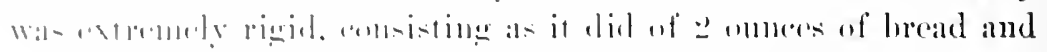
Jutter with $\varrho$ -

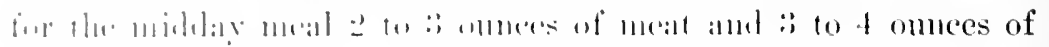

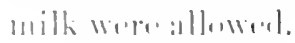

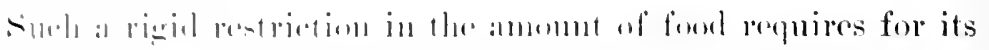

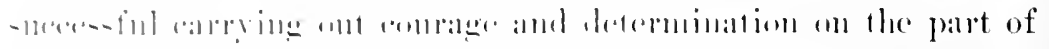

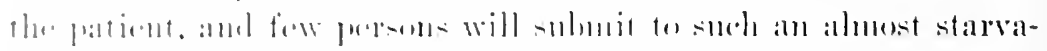

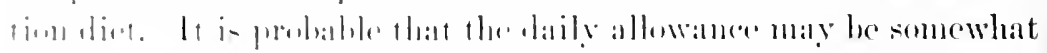

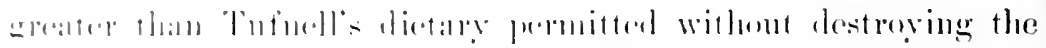

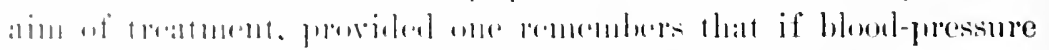

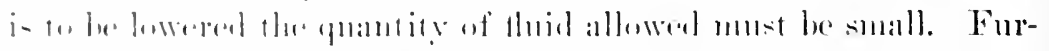

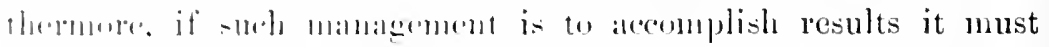

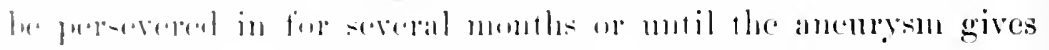

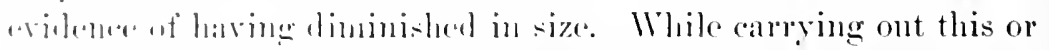

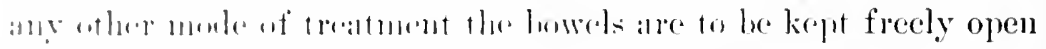

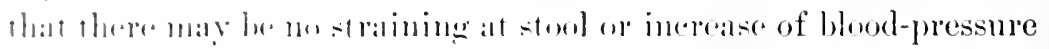

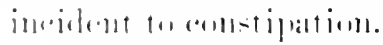

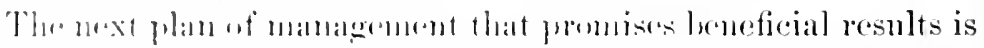
the andmini-trat ion of ind inle of putasimm. This molle of treatment

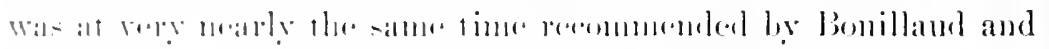

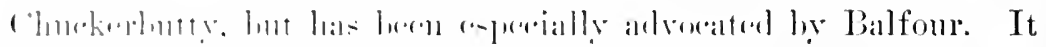

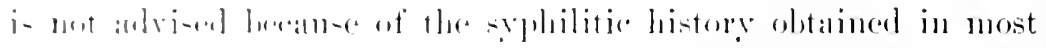

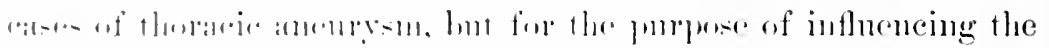

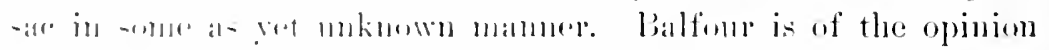

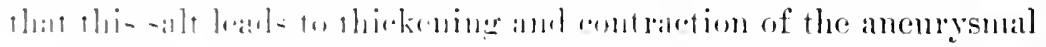

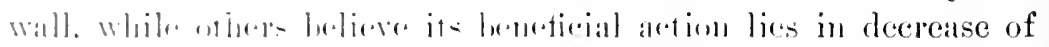

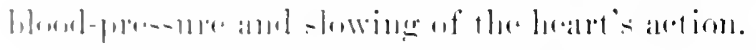

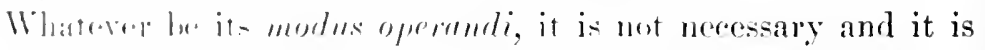

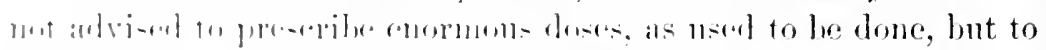

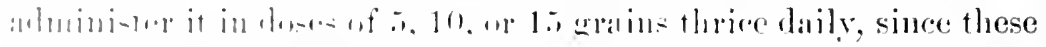

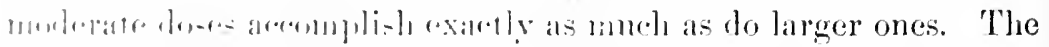

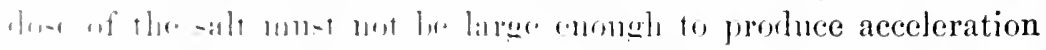

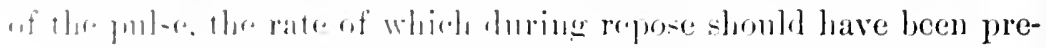

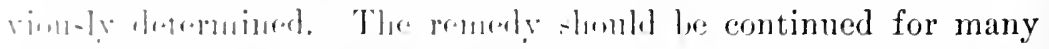

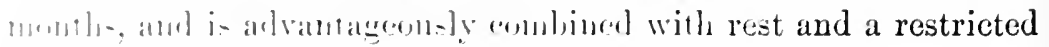
livet. 
Testimony is miversal that the first and pronomned effeet is relief or very consiglerable anclionation of pain due to the ancurysm. Why this is camot be said, lint there and be no doubt of the empirical fact. 'This plan of management shomld he instituted in all cases, yet to promote a cure of the discase firemlable conditions of the sort explained above must he presut in the tumomr.

The foregoing are the simplest meatures, and in most instances are likely to aceomplish as much as any other of the varions plans of management that have been recommended and will now be mentioned.

The surgical procedures sometimes employol in the treatment of this formidable complaint are five in mmber, as follows:

(1) The introduction into the interior of the sate of many feet of fine iron or steel wire, horschair, catent, or silk thrarl. The object of such treatuent is the coagulation of the blood in the meshes of this foreign material, wire being prefurable to the others. This operation, known as the Moore or lopeta method, has been done a number of times, lut not with sufticiently brilliant results to make it a popular mode of treatment. Of the 16 cases collected by White and Gould (Gibson), only ze were sucessful, while of the 8 eases of thoracic anemrom so treated and collected by Humner prior to 1900 (Osler), all died. The great objection to this method of management is the resulting inflammation and aggravation of the condition.

(2) Electrolysis, which consists in passing a galvanic current throngh the contents of the anemrsm by noans of two insulated needles introduced throwgh the wall of the sac. The points of the needles are to be left nncovered hy the insulating material. They must not be in contact when inside the tmmonr. The electrical current thus applied canses coagulation of the sac contents, and in Gibson's opinion promises well, althomgh the results as rot have not been very satisfactory. It is worthy of trial in suitable instances.

(3) The Moore-Corradi method, which comsists in the combination of the two procedures just mentioned. A fine gold, silver, or steel wire is passed into the sac, and then a walvanic current is sent through the wire. This method is sairl to hare riolded satisfactory results in a few instances. It has been performed by Burresi and Ilershey. Of 17 cases of thoracic amemrysm thus treated prior to 1900 only 3 were suecesstul. Accurding to Hun- 
mor. this molhol is mot deroid of the following dangers: (1) ambuli-m: (z) the formation of a seromlary hulging of the wall

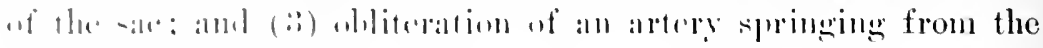

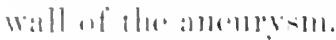

(1) The solituhing of the immes sulfare of the sac-wall with

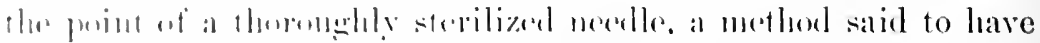

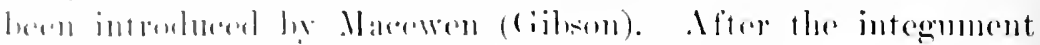

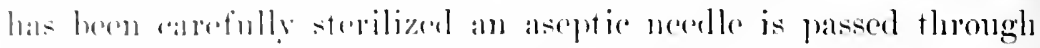

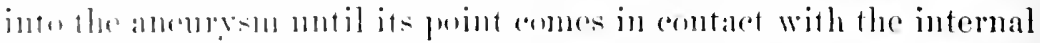
surfare at the epposite sitle. The needle may then be left in situ

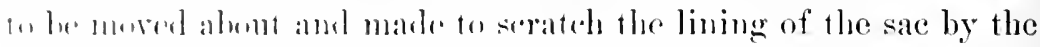

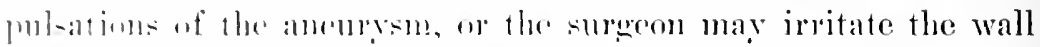
ly moving the point of the neodle about first in one place and linen in another. hut without removing the instrument. If the

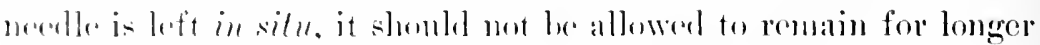
than twent?-four to thipty-six lours. This method is simple, said

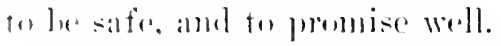

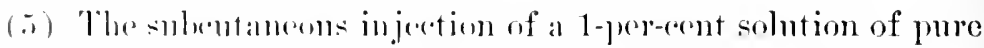
white welatin in nomal salt solntion. This mothod was introduced

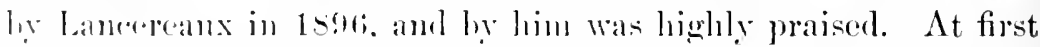

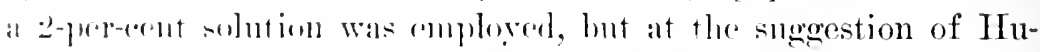

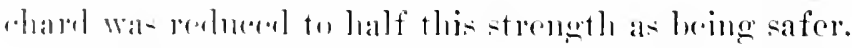

The erelatin selution slomlel be carefully filtered and sterilized meler preseme at the temperature of $120^{\circ} \mathrm{C}$. Two lumbled or zon collice centiunetres of this 1-perecent solution at a temperature

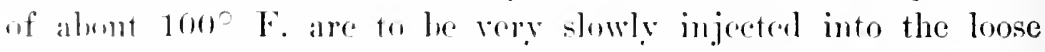
mbentancoms tissue of the thigh or aldomen, after which the

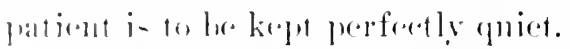

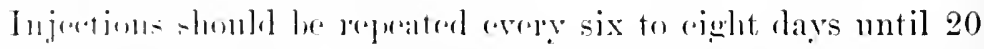

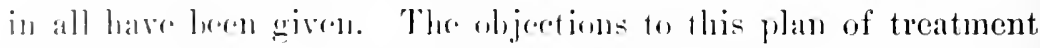

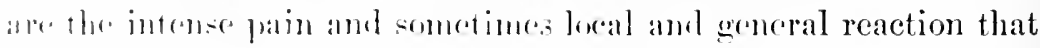
folluw. In the rase of the paticent treated in this manner by Dr.

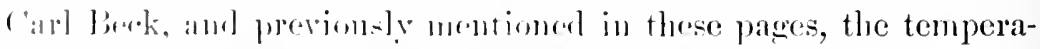

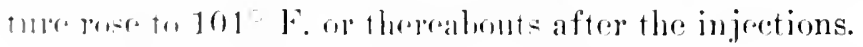

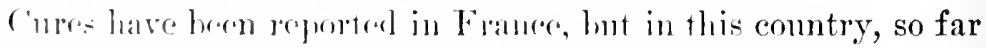
a: I kuow, the results lase lece mustisfactory. It may be tried

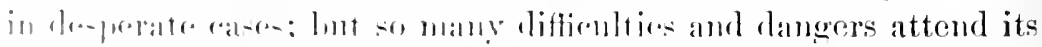
11-e. that it is mot likely to berenne widely employed. Among the langers is the risk of sepsis or tetaums, since 10 per cent of 
commercial gelatin is said to contain gems, apperially the trotamus bacillus. Moreover, not many pationts will be fomml willing to bear the pain from the injections and the suberpment fobrile reaction. Finally, of the eases in which this treatument hals heen tried, but a small pereentage has showa really enconraging results. The use of gelatin in this mamer does not alphall to increase the coagulability of the blood, and sinee the aretion is as yot not murepstood, it has been snggested that the remedy be given by the month as food, 15 grammes being consumed daily.

When one considers the pathology of thoracie ancurym, the great internal pressure to which the wall of the sate may be sultjected in eases in which the montl of the anemrym is a wille one, and usually the advaneed stage of the process when the individual applies to the surgeon for relief, it is not strange that failure, or at best only amelioration, of symptoms follows any attroupt at a cure.

The most that can be done in the great majority of eases is to mitigate the patient's listress. If the iodicle of potath does not relieve the pain, recomse must he had to opimm in some form. Subentaneons injections of morphine are the best, sinee they not only rid the sufferer of his pain for a time, lut they also lessen his sense of dyspnea and promote sleep. I have not yet prescribed heroin in a case of anemysum, hut think it onglit in the dose of one-twelfth grain not only to prove efticient against the cough, but should diminish the sense of dyspnora.

Venesection is highly reconmented for relicf of renons congestion and to decrease blood-pressure for a time, and thereloy the dull pain arising from pressure within the sac. Only a few omees, 3 to 5 , should be taken at a time, since it may have to be frecunently repeated, and the abstraction of too much wonld only serve to weaken the patient without doing more good than do the few recommended.

When the sac is external and large, it is said to minister to the patient's eomfort to have him wear an elastic bandage over the tumour (Osler). It certainly onght to lessen the tension to which the integument and thoracic parietes may be subjected, and thereby mitigate pain. In some cases it may be necessary to protect the tumour against violence from external blows by having the patient wear a shield of thin metal or woven wire strapped to his chest. 


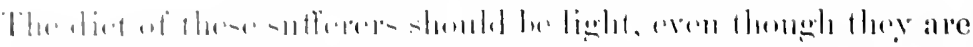

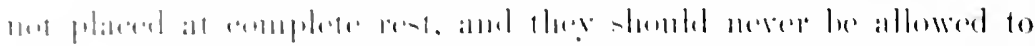

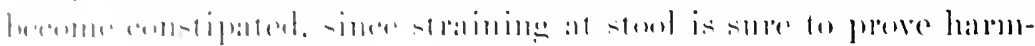

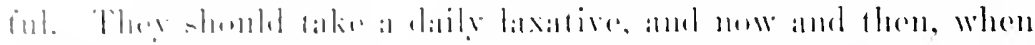

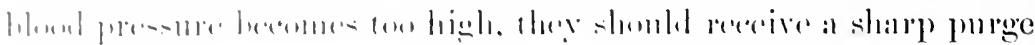

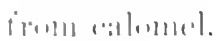

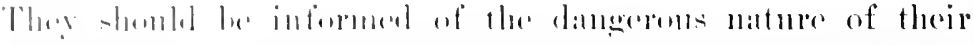

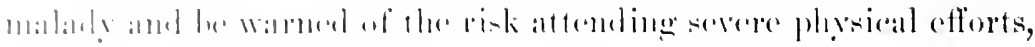

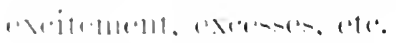

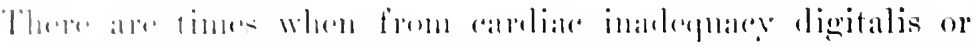

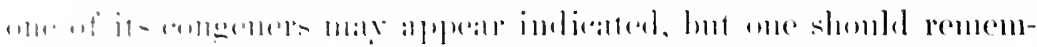

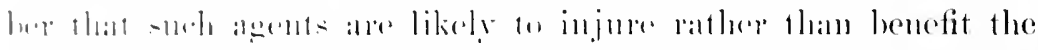

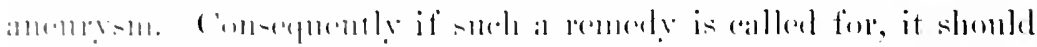

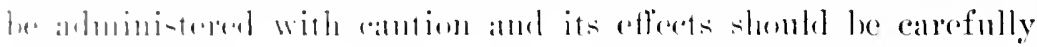
II:IIPlinel.

When at lemente it is plain that lhe amel is near, and, as it

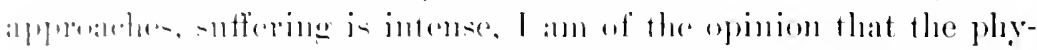

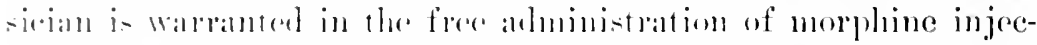

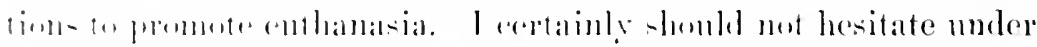

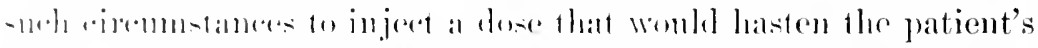

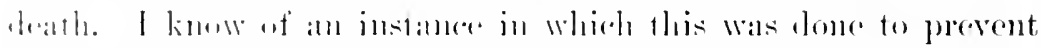

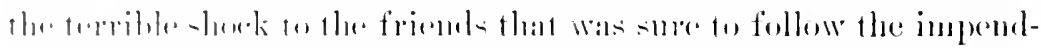

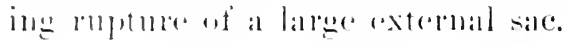




\section{$\triangle$ P P E N D I X}

\section{MECHANICAL DEVICES AS AIDS TO DETERMINING CARDIAC DISEASE}

THE X-RAT

Percussion and anscultation are not rutirely satisfactory methods of examining the heart, for the reason that thick, rigid parietes, pulmonary emphysema, or other conditions may prove sourees of error. Thuch depends also on the skill of the exanniner or on his delicacy of hearing, so that it is anite common for two or more examiners to obtain results that do not wholly agree. When, therefore, the Roentgen-ray came into ne it was quite naturally hoped it would furnish a reliable means of detecting diseased conditions in the heart.

Aceordingly, consideralle work along this line has been done both in Europe and this country. As a result of such investigations we now know that the X-ray is in many cases a valuable aid to the diagnosis of internal diseases, but camnot altogether replace other and older means of investigation. This is pre-eninently true of cardiae disease.

Franeis P. Williams, of Boston, is a particularly diligent inrestigator with the $\mathrm{X}$-ray, and it is to his elahorate paper in the Philadelphia Medical Journal of Jannary 6, 1900, that I am indebted for much of what is here stated. Percussion of the cardiac area was made by Williams and his friends in a large series of eases both healthy and diseased, and after the limits of deep-seated dulness had been carefully marked ont on the bare skin the results thus obtained were enmpared with those of the X-ray by means of the fluorescent screen. The conchnsion Williams arrived at was that the fluoroseope is a much more trustworthy means of judging of the size of the heart. Tle found that in normal hearts the dis- 


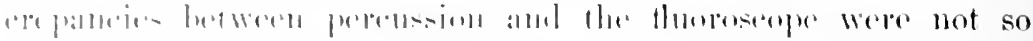

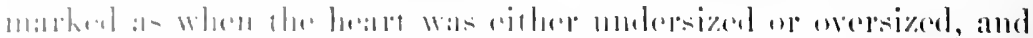

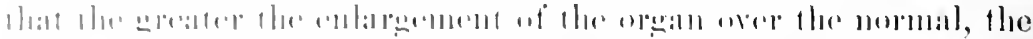

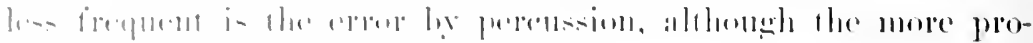

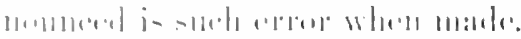

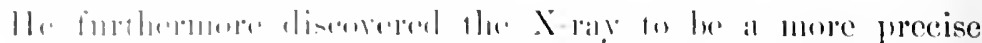

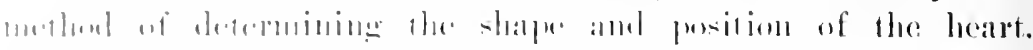

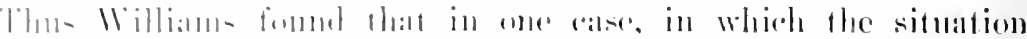

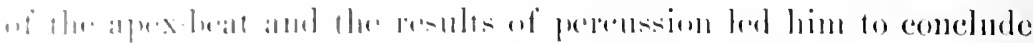

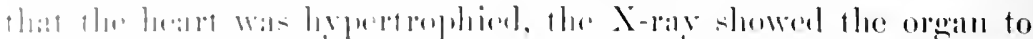

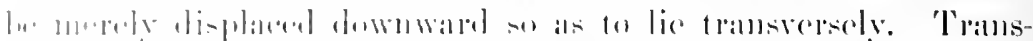
peritions

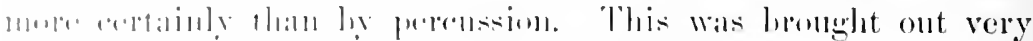

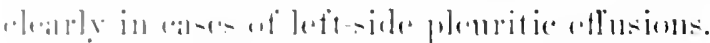

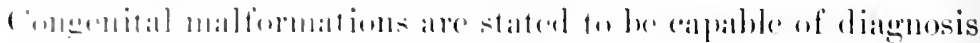

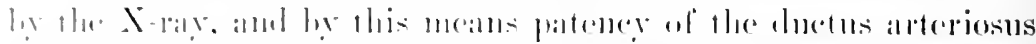

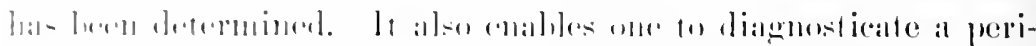

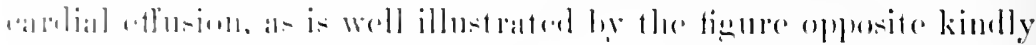

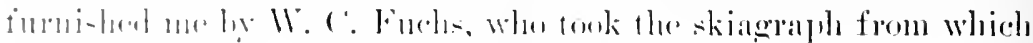

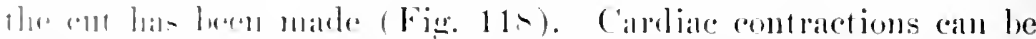

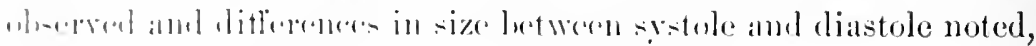

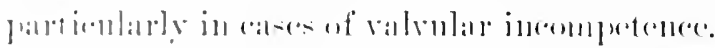

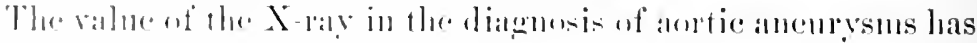

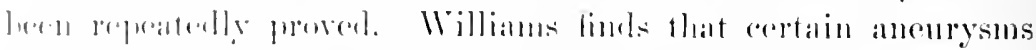

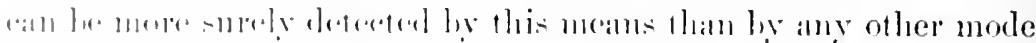

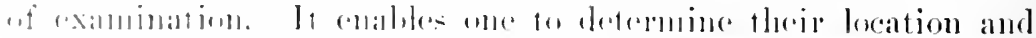

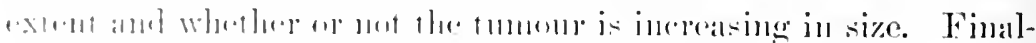

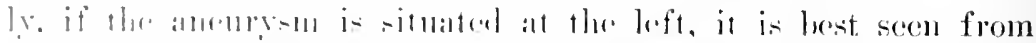

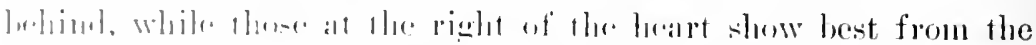

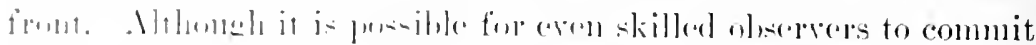

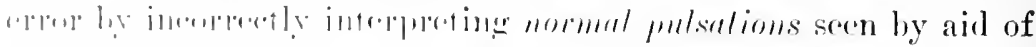

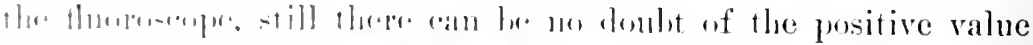

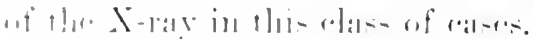

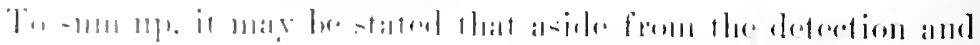

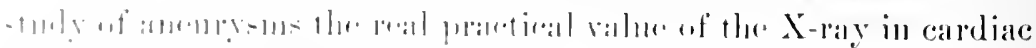

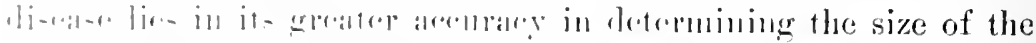

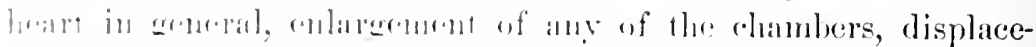

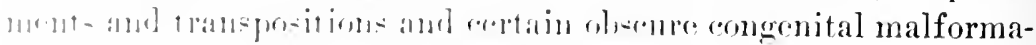

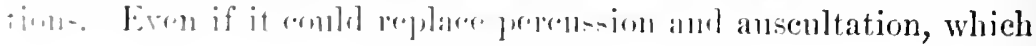




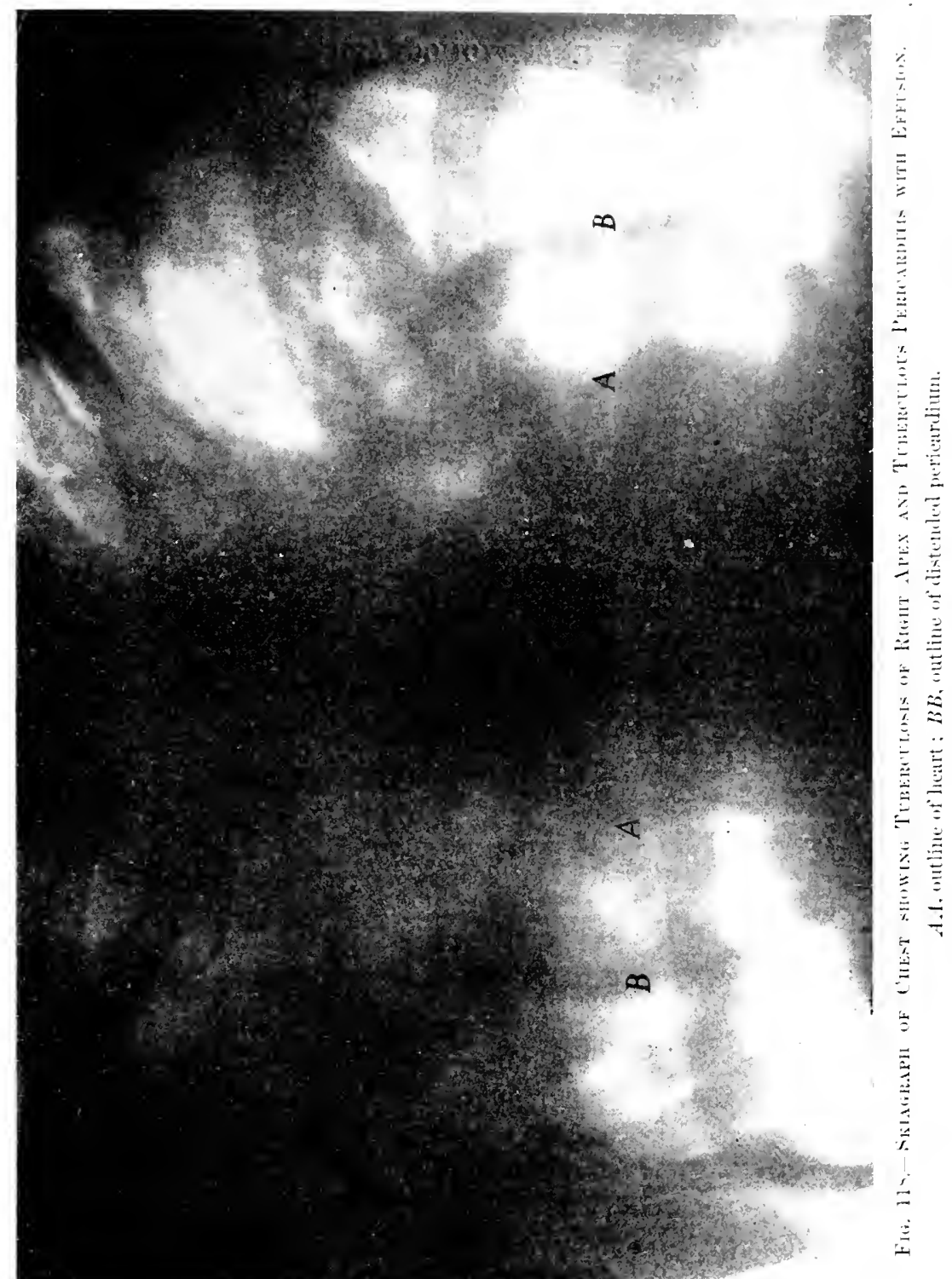




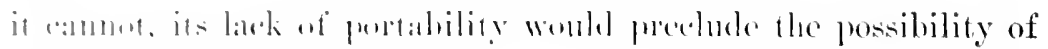
its - mpplantinge oldere motheds.

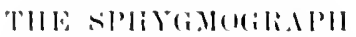

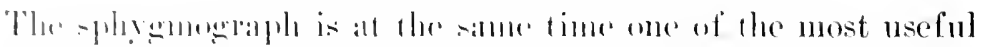

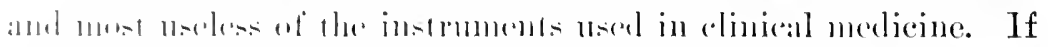

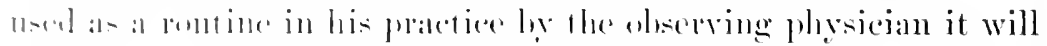

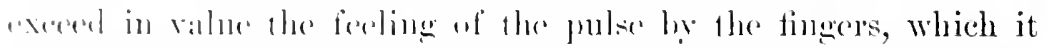
-lomlil -

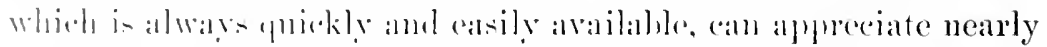

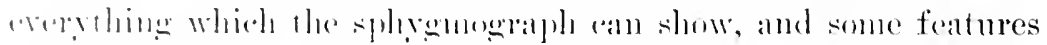

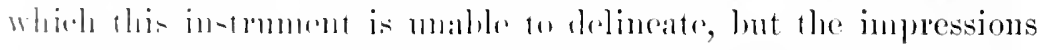

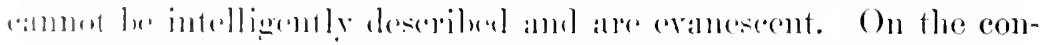

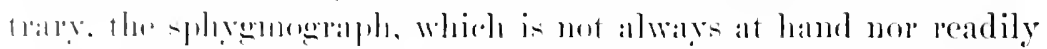

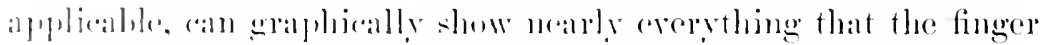

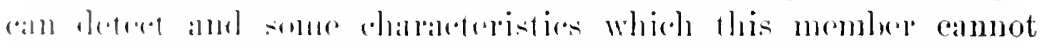

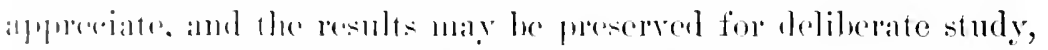

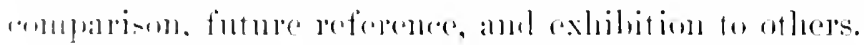

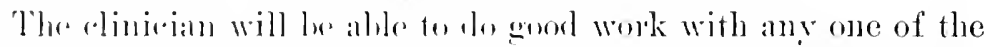

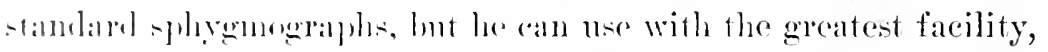
amd ran intrejeret most radily and acemately the tracings made hy the in-loument with which he is mos tamilian. My own pref-

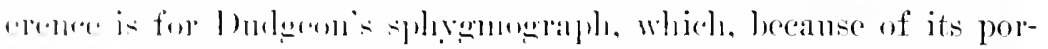
tability amb alaptability, dealily louls itself to the exigencies of all kimbral poration.

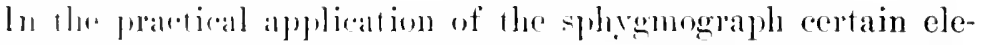

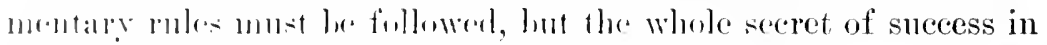
manipulatim the instrument lies in plabug and maintaining the

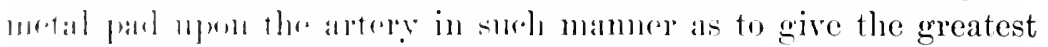

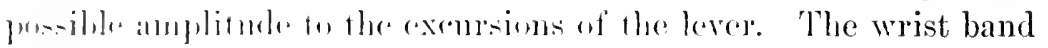

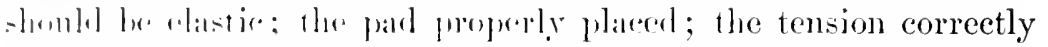

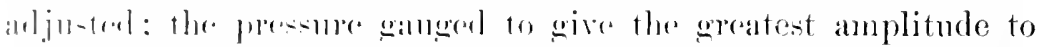

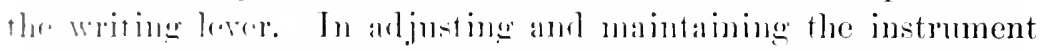

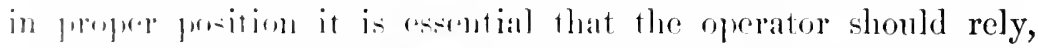

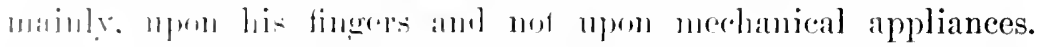

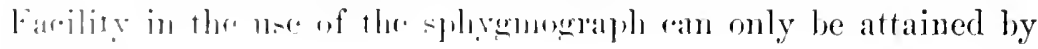
jeatrotion.

It maty be noted that the most ronserniont strips of paper which can be wat are: inarle from ordinary heary writing faper, cut thirty-one thirty-seconds 
of an inch wide, and blackened with smoke from burning camphor. The best varnish for preserving the tracings is the ordinary sandarac varnish used by dentists, suitably thinned by the addition of absolute alcohol.

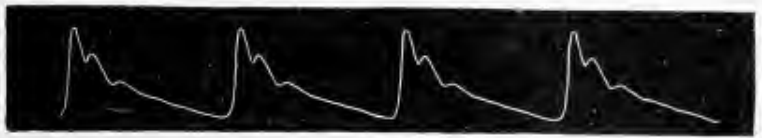

Fig. 119.-From a Healtily Max, Forty-five Years of Age.

Tracings of the normal pulse in health vary infinitely in their characteristies, and no two are ever exactly alike. The above sphygmogram (Fig. 119) may be considered fairly typical of the pulse in the healthy middle-aged adult.

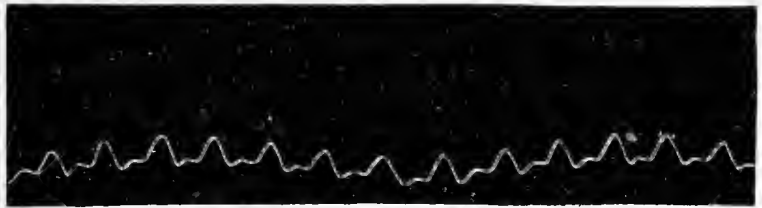

Fig. 120.-From a Woman, Aged Forty-fotr, Dering ax Attack of P'aroxymat Taciscatoda. Pulse, 196 peir Mintte.

Between the extreme frequeney of the pulse in paroxysmal tachyeardia and the remarkable slowness of bradycardia lies a wide gap which is filled by the rapid pulses of infeetious fevers, the varying pulses of health and the slow pulses of age, some of the intoxieations, ete. (Figs. 120 and 121).

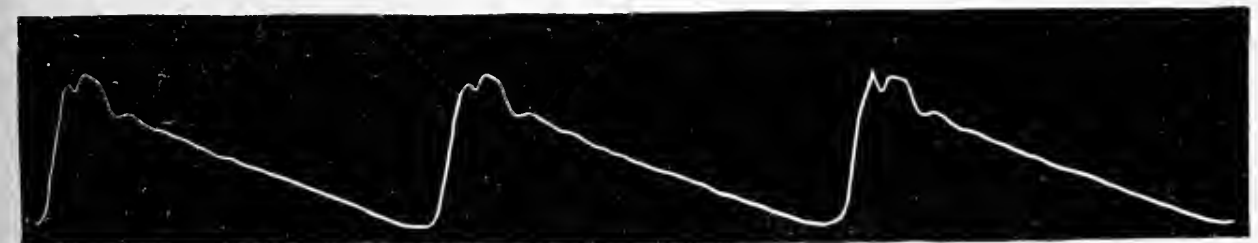

Fig, 121.-From a Man, Aged Twentr-eight, with Recurient Bradychina. P'lles, 25 Peir Minute.

The sustained arterial tension as shown in the pulse varies within wide limits. The lowest tension is fond in some of the acute infections-e.g., general gonorrhual or pneumococcal, in which there oceurs, very early, profound capillary paresis. In many of these cases the powerful left ventricle throws the blood 


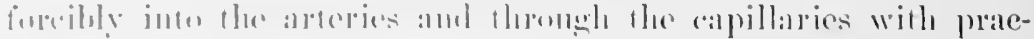

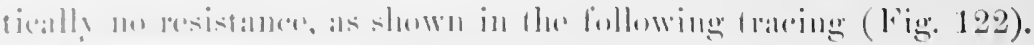

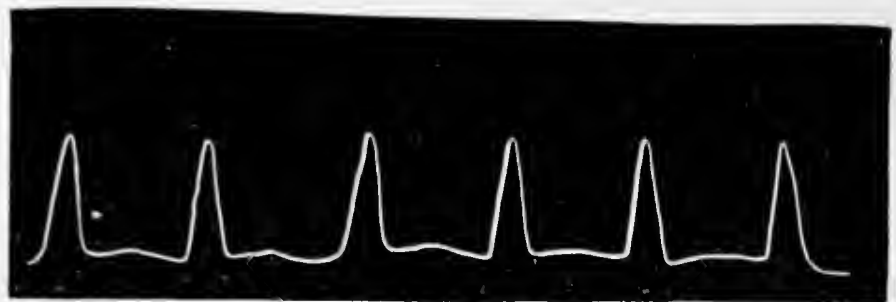

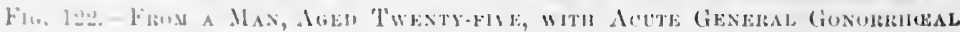
PNFETTON.

In some of threse eases the capillany and arteriole vaso-motor

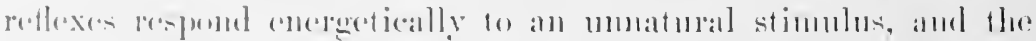
dicrolie julse of every srade is the result, an example of which is

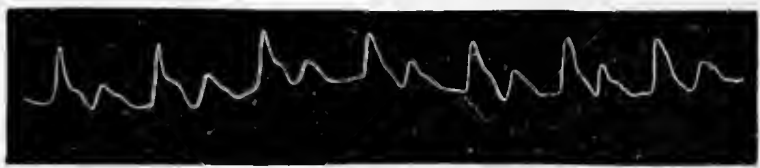

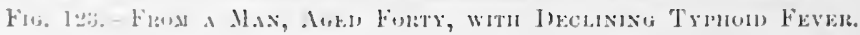

griven in Fig. 129. The hyperticrotic pulse, as slown in Fig. 124,

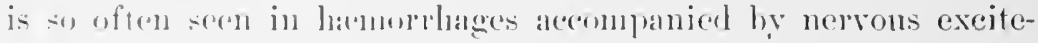
ment-r. e., in hirmontreis- hlat it may be considered somewhat distinctive.

In and ic regurgitation the powerful left rentricle rigoronsly propuls a large volune of blood into nearly collapsed arteries,

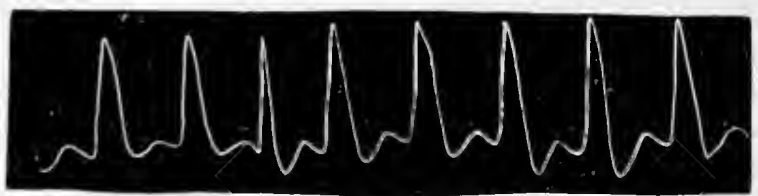

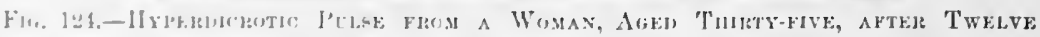

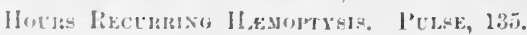

quick]y and widely distrudling then, but the flow of blood through the capillaries, during and immediately following the systole, and the retlux of blood through the open valve, the instant ventricu- 
lar action eeases, as quickly reduce the arterial tension, and the typieal pulse of this condition is the result, as shown in Fig. 125.

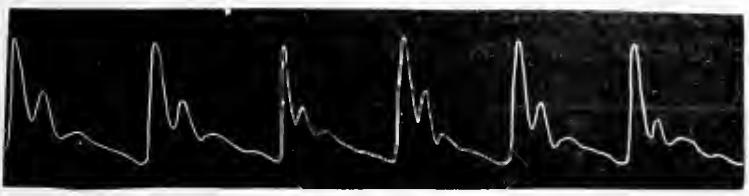

Fig. 125.-From a Woman, Aged Twenty-five, witu Modfrate dohte liscficiency, Weli Compensated.

In this connection it should be remembered that, other conditions being equal, the pulse will be less frequent and approximate the normal in character, or more frequent and with exaggeration of the distinctive characteristies, according to the degree of valvular incompetency. With failing compensation, the secondary curves in the line of descent may disappear.

At the other end of the seale we have the initial and sustained high-tension pulses, which are so often the accompaniment of early

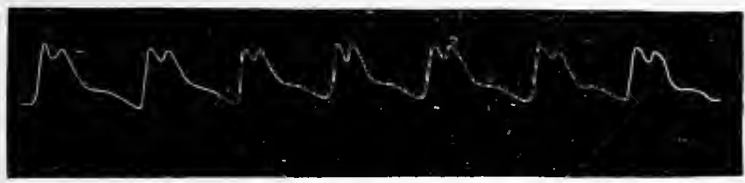

Fig. 126.-Initial High-Tension Pulse, from a Man, Aged Forty-eight, witil Arteriosclerogis and a Sirall Anecrysi of tife Aieni of the Aorta.

arterioselerosis, anemrsms of the aorta, and chlonic interstitial nephritis, typical tracings of which are given (Figs. 126 and 127).

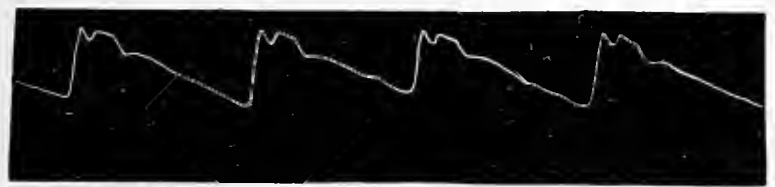

Fig. 127.-Sustained High-Tension Pulse from a Woman, Aged Sixty-turee, witi Cingone Interstitial Nephritis.

The following sphygmogram (Fig. 128) may be considered as fairly representing the average in elnonie interstitial nephritis, and is typical of those oftenest encomntered in this affection.

In this connection it is fair for me to state that, highly as I value the sphygmograph, it is my opinion that its tracings in chronic interstitial nephritis have been accorded, in some quarters, a diagnostic value altogether beyond their merits. This is not to the discredit of the instrument, for it affords the 


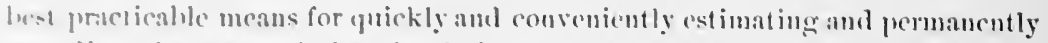
recording the state of the cirmlation, carblate cherger, peripheral resistmee, arterial resilichese and arterial tension. On the contary, this tictitions value 11-4ally depends upon a fauly appreciation of the infinite ruriations of the pulse in healeh and disease, and in the sane persen an diflerent times.

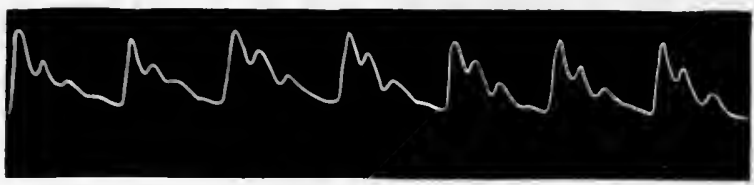

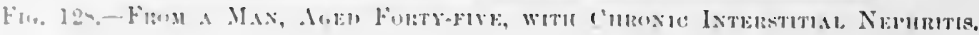

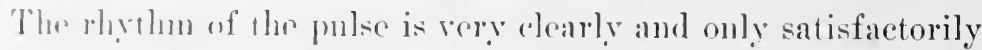
shom lig the sphregungraph. In health, the rhythm, in every partivular. is farly but not absolutely regular. A monent's reflec-

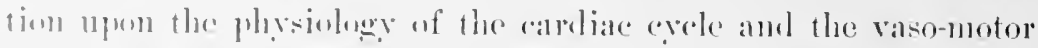
mechandsul shombl loarl ns to expect this, and an inspection of any

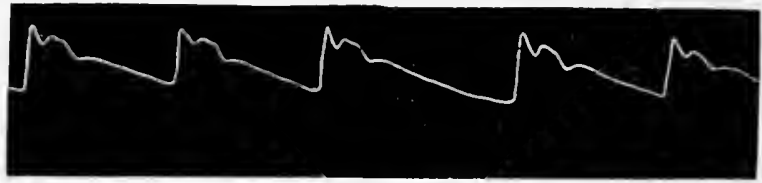

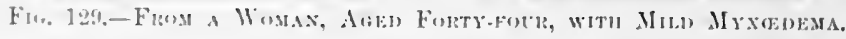

larese eollection of spluyemograms will confirm the inference. Nopertholess, in ordinary health, the points of difference between the individual julsations are minute and well within the limits of plysulngical identity. Howerer, in certain conditions, some of which are molerstrom whils others ale not, the pulse becomes

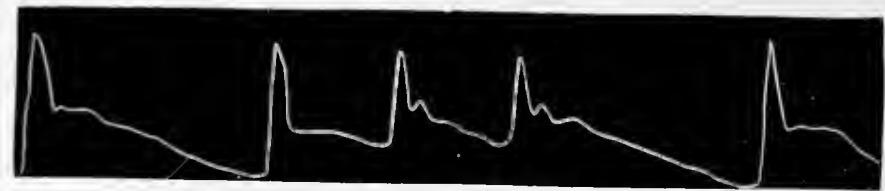

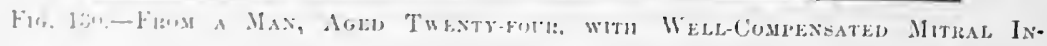
AFFICIFATI.

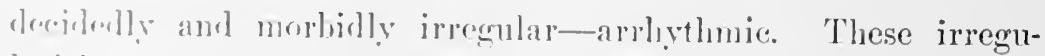
balitire may be of almost every comecivalibe degree and character, somore of whireli arrestrikingly jurouliar.

Thuns throe may lice a marked inropuality in the interval beweene sone of the pulsations, as shown in Fig. 129, or beats may 
be entirely lost, as seen in Fig. 130. It will he found that under these cireumstances the line of rescent reaches a lower level than it does in the regular pulsations, because the artery has had a longer time in which to empty itself through its distributing channels. In some cases the pulsation is not entirely lost, one or more abortive beats showing in the line of descent, as illustrated in Figs. 131 and 132. Such pulses are denominated bigeminal, trigeminal, ete. It is to be noted that the elevation that marks the alon-

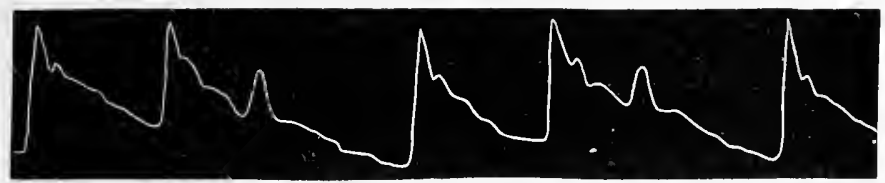

Fig. 131.-Frod a Woman, Aged Sixtr-seven, With Arteriosclerosis and fairey Well-Compensated Mitral Ingompetence.

tive pulsation in the bigeminal pulse is located nearer the preceding than the following full beat, and that the second alourtive pulsation in the trigeminal pulse lies nearer the first abortive beat than does the latter to the preceding full stroke.

The arrhythmias thus far mentioned nay be irregular in their occurrence, or the prolonged, missed, or abortive pulsations may be repeated at regular intervals. The irregularities of this group may be found rarely in apparent health, and frequently in patients

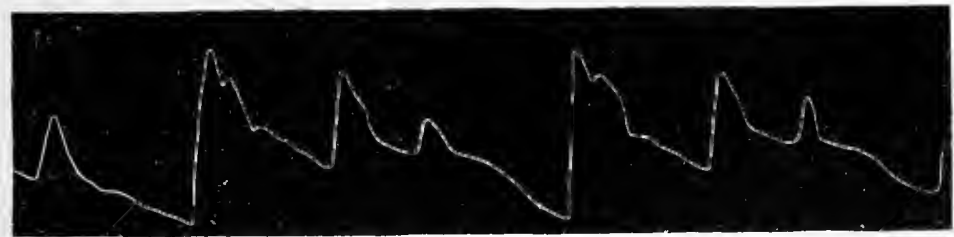

Fig. 132.-From a Woman, Aged Seventr-tiree, with Arteriosclerosis, and Mitral Insufficiency, Fallixg Compeneation.

suffering from digestive disturbances, rarions intoxications-as, e. g., tobaceo, renal insufficiency, organic disease of the central nervous system, the vagus and the cardiae ganghia, arteriosclerosis of the coronary arteries, myocardial changes, etc. They occur, therefore, in conditions of no, or varying degrees of danger. They often lead to the discovery of conditions which without such warning might be orerlooked. They may, by the strain thrown upon the ventricular walls, lead to dilatation, and relative valvular in- 
competence and thus lweome an oloment of danger. As a matter

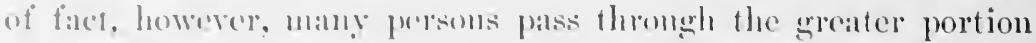

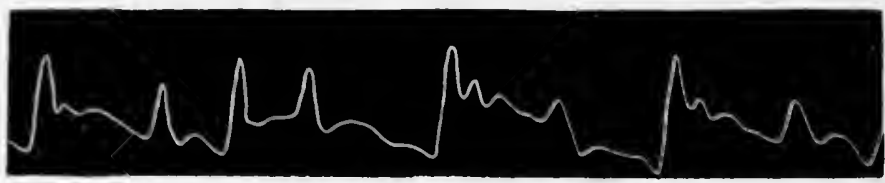

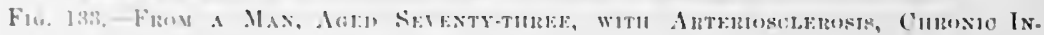

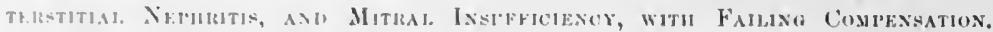

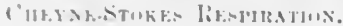

of a long life with such irrogularities and without any juconveniencer whilever.

In addition to the above arlyythmias we have another group

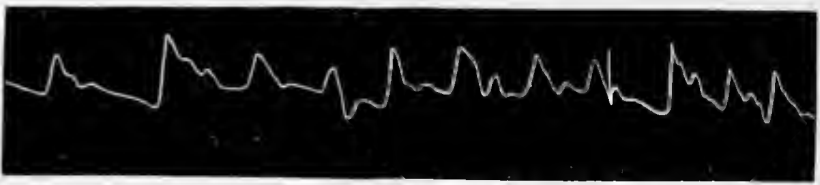

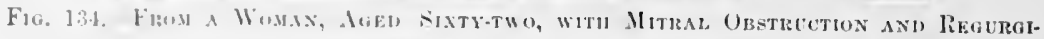

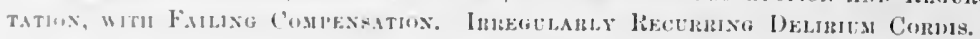

in whide the irregularities of the pulse, as shown by tracings, absolutely defy either analysis or description. Such pulses are simply

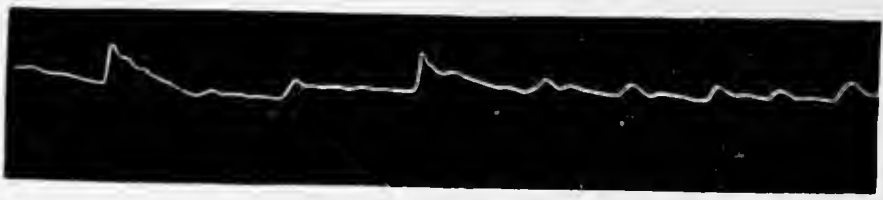

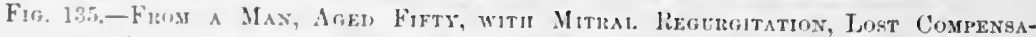

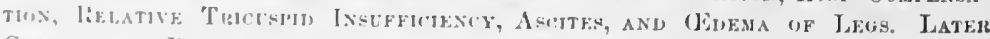
Comishativf. Reroveny with Goot, Conpensation,

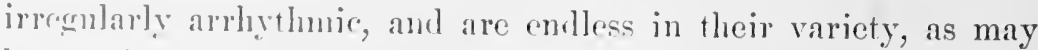
he secoll in the few examples shown (Figs. 13.9, 194, 135, and 136).

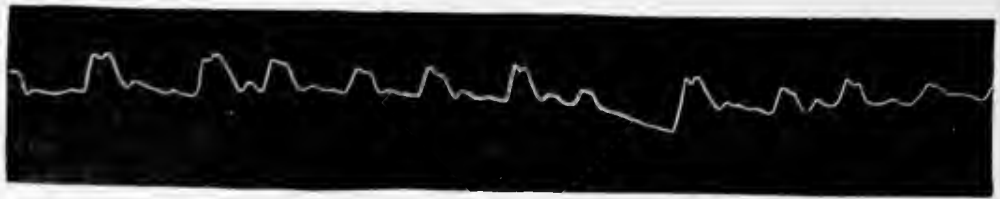

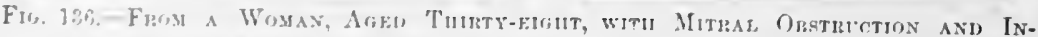

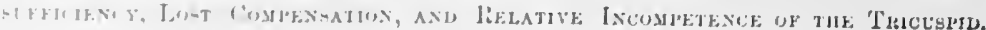

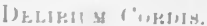


This form of armythmia is met with, piltionlally, in millal

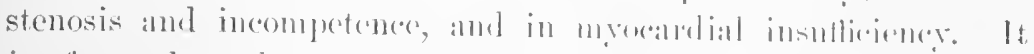

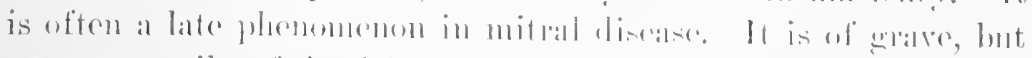

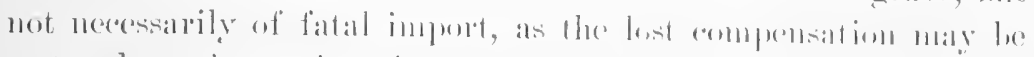

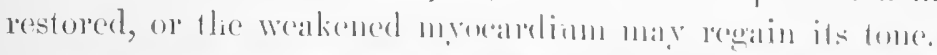

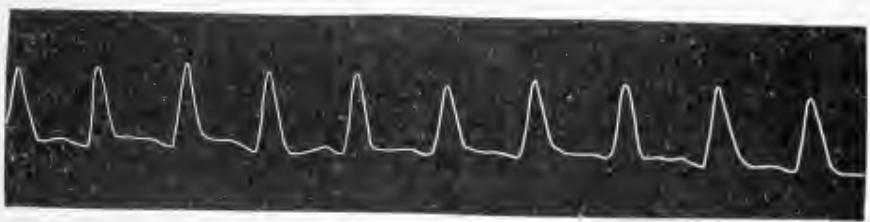

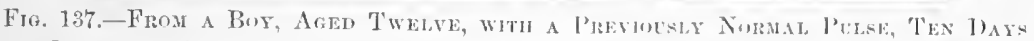

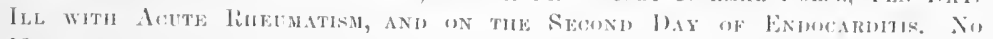
MrRnitr.

In endocarditis the splyemograph minally furnishes us with diagnostic evidence of valvular involvement soveral hours or dars before murmurs can be heard with the stethuseope. 'This evidence

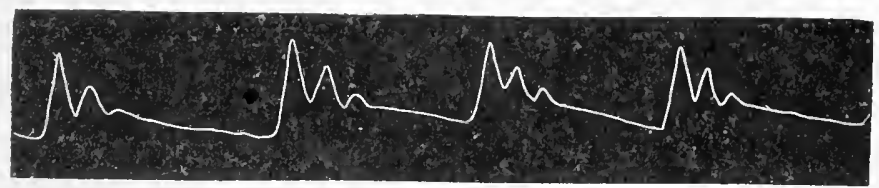

Fio. 138.-From time Sime: Patient, Two Yeare later, with I)evelomen dolete STENOSHS. (CONWHESE'ENT FHM HI'MPS.)

is shown in a more or hess radical change in the chatrieter of the

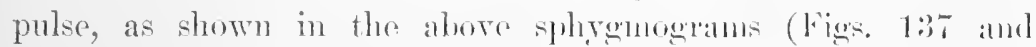
$138)$.

In introducing the above tracings it is proper for me to saly that, during the past five years, I have had under observation for one, three, and tive years respectively, three cases of aortic stenosis in young persons, from cach of whom tracings of a similar character were obtainet. In the slighter alses of aortic stenosis the character of the pulse appreximates the normal. In this connection a word of caution is due. In using the sphygmograph in eases of considerable or great aortic obstruetion the most delicate adjustnent of the instrument is required to obtain satisfactory results. It may be saicl, howerer, that the greater the eare bestowed upon this point the more difficult it will ha to produce tracings corresponding to some which bave been mate classie by more than a generation's text-book currency.

In early pulnonary tuberenlosis the pulse is ofien of a peculiar character, approaching, moro or less asoly, the infantile type, and the tracings, at this time, posicess a distinct diagnostic ralue. 


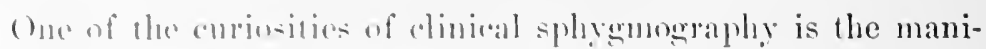

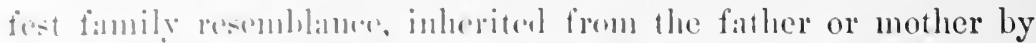

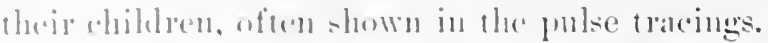

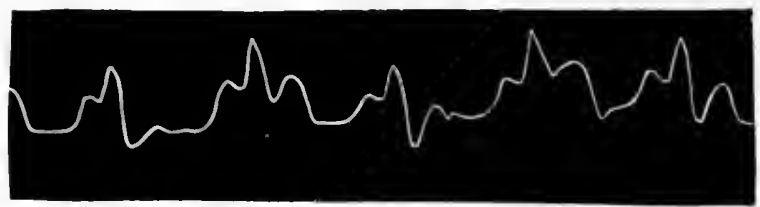

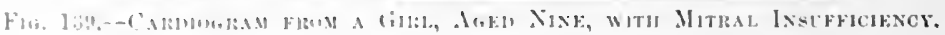

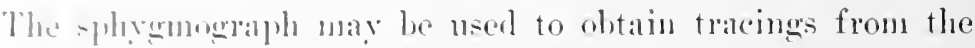
heat (an cximple of which is griven in Fig. 139), ancurysms, pulsating veins, pulsuting tumours, cte., but the information to be derived froun stuch tracings is not very great.

\section{GARTTERS TONOMETER}

The cxanination of the circulation includes the observation of the pulse for what is terumed the arterial or hlood pressure. 'This is dotrimined ly hoart contraction, the peripheral resistance in the alderies and tis-mes, and the quantity of blood contained in the rescels. Anomg silled phrsicians there is often a difference of npinim in legard to the degree of the artorial pressure, even in acural tropus, surh as hard and soft, while subtile differenees are contipely beroul rexistration, and, to most pluysicians, beyond

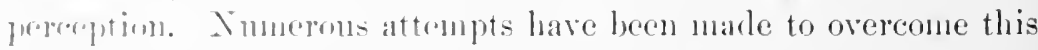
diftionlty in julso canduntions l,y neans of instrments; if sne-

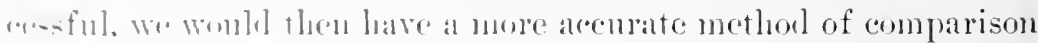

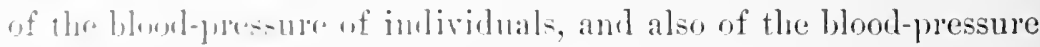
of thro -ande indiridnal muler different conditions. The inrention

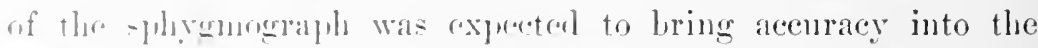

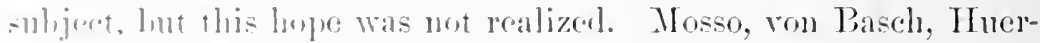
thle, Frere ()limer, Riva-Rored, and Hill and Barnard may be uncotirume as iuventrit of such instruments. Of these, the ron Jia-ch instrunent was thr nost used up to 1899 , since when the

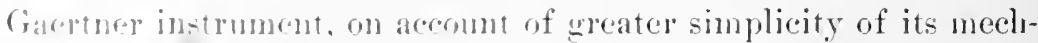
andi-n, has -npluanted it in the hand of many, and has also introduced the praretice of takiug the arterial pressure to a greater extrent than had hepetofore leen customary. Opinions still vary as to the preferable instrument. James Mackenzie (1902) com- 
pares the aetion of the IIill and Bamam instrmment to that of the sphremograph and regalds it moreliable for bloot-pressure registration. So also with the Oliver instrument. Jarotzyy be-

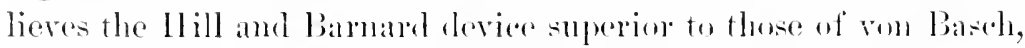
Gatertner, ete. llirsch consiters the Gatertner less reliable tham the ron Basch instrument.

As the latter is at present the chief rival of the Gacerner instrment it may be well to state the principte on which it works.

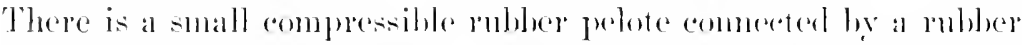
tube to a metallic nianometer. By pressure with the rubler eylinder (pelote) a suitable artery may be ampresiod and the anoment of neessaly pressure at the point of disilplearance or reappeatrance of the pulke on the peripheral side of the instrument is registered on the manometer. The rallial artery may be used,

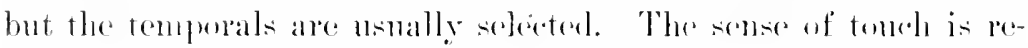
quires for this instrmment, while in the Gatertner method, som

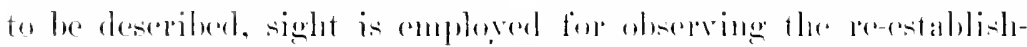
ment of the ritenlation; and beramse in most propte the senere of sight is more acute than the semse of tonch, the Garertner instmment requires less practice for its nee, amd also is believer by many to be more acenrate.

Ton Baisch ealls his instrument a sphygmomanometer. Gaertner's tonometer consists of a mereury manometer, a rubber bull, a "Y" puber tulbing, and a small ring consisting of a metal framework and encased in a rubler envelope, which on inflation stretches inwardly only, and thus compresses the finger that is introduced into the ring. These rings are of different sizes to fit large and small fingers smoly. One end of the "Y" thbe is attached to the manometer. another end to the rubber bulb, and the third end to the rubber finger ring: thus pressure nate on the bulb transfors itself to the manometer and the rubber ring, and the elastic rubler on the insile of the ring unfolds itself and makes inward pressme in propertion to the pressure put on the lnill. The manometer, being on the same elowed tubing, registers the increase or derease of the pressure. A small clanup is servicallile for compressing the bulb firmly and steadily. The rubber ring is pressed over the first or second phalanx of any finger or the thamb. It is to fit loosely,

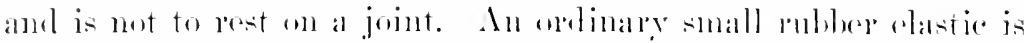
now rolled from the tip of finger to the rubber ring. This produces 


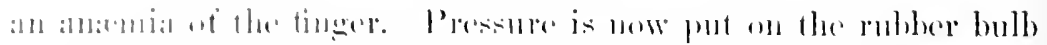

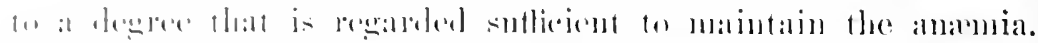

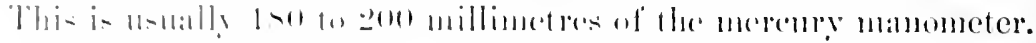

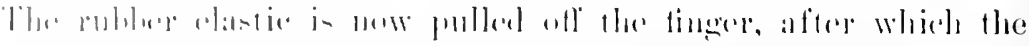

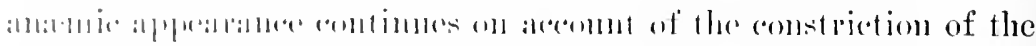

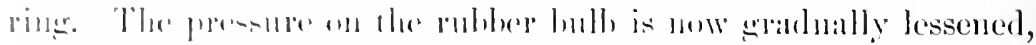

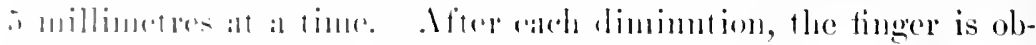

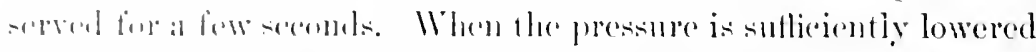

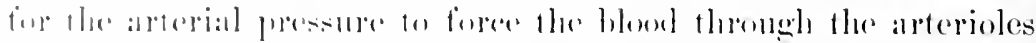
"1

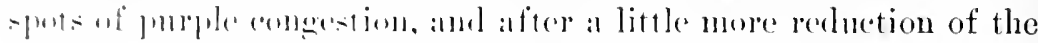

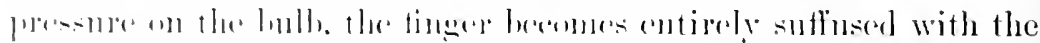

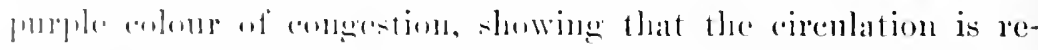

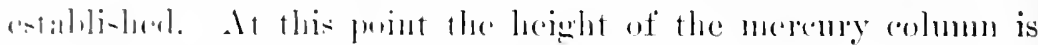

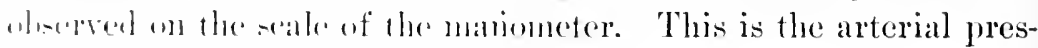

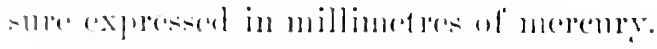

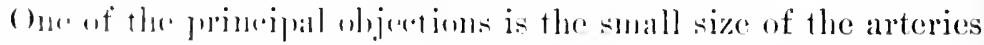

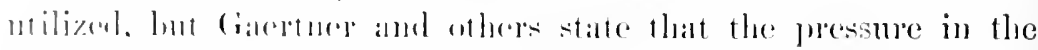

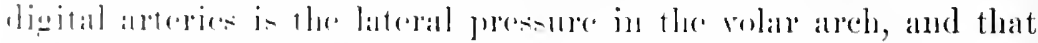

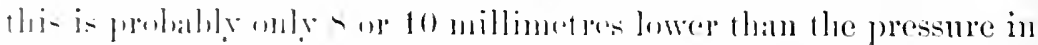

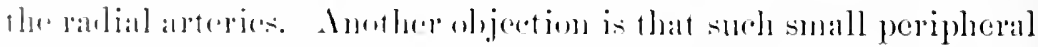

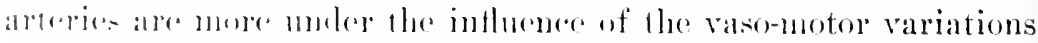

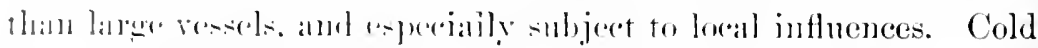

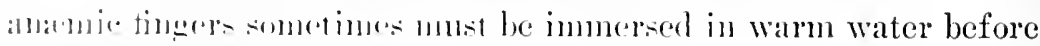
the trot ran le matr.

It is woll to follow his instructions for the nse of the instrument

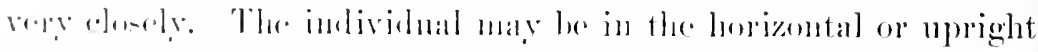

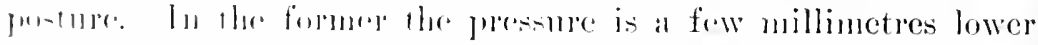

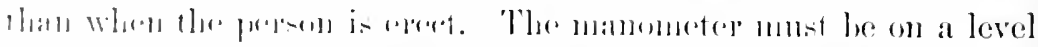

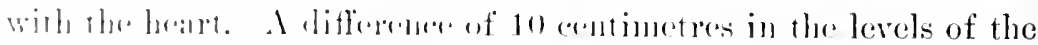

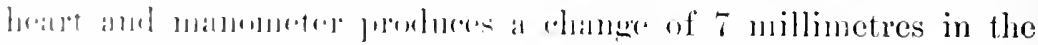

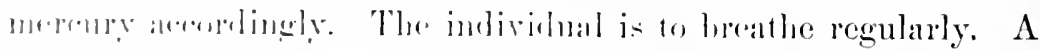

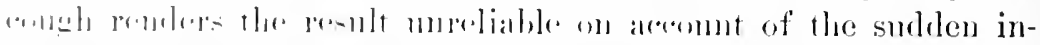

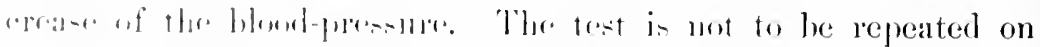

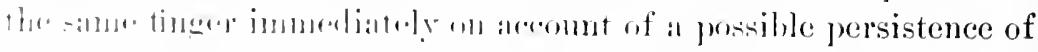

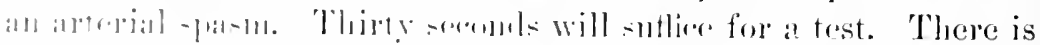

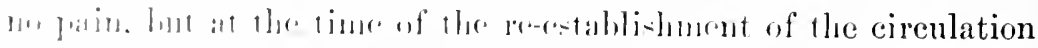

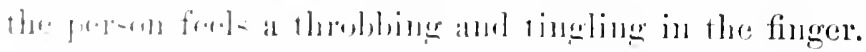

For Jertability a metallic manometer may be used, but it is not 


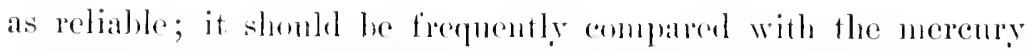

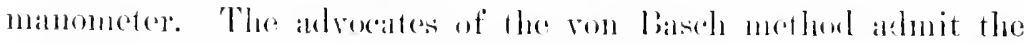
requinement of much more experience and calleful manipmation in its use than in that of the Garemere The ralues obtained by both instruments aglee fairly, those of the vou basch instrument are probably 8 to 10 millimetes higher; the range of mormal blowl-pressure meler ordinary conditions is fon 100 to 160 millimetres of merempy. These limits may be malpowed down to 110 to $1: 35$ for the ereater number of fereons. Constant pressure of 150 to 160 shombl be reagaded smspicionsly high. It is probable lhat aach organism has a mean arlerial pressure tomards whose maintemanee the eregmlalory mechanism lenarionsly slrives as soon

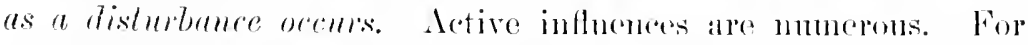
instance: Postme, fool, sleop, pluysical and nental work, porehieal

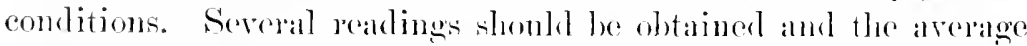
taken; aceorling to some anthorities the lowest realing is the correct blood-pressure, as more callses are arotive in increasing than lowering the blombressure. Aroording to Tellinek the arterial pressure in the fingers of the right side is msmally slightly higher than on the left, lont Eekart and Hirsch, nsing von Baseh's sphygmonanometer, fomm the pressure usually higher in the left temporal arteries, and ascribed this to the diucet origin of the left carotid artery from the aorta. Hirsel, who profers von Basch's splyemomanometer, maintains that the Gacetner instrmuent registers the blood-puressure 10 to 20 millimetres higher than the von Basch instrument, but admits that in general the values obtained by both instrmments agree as to being high, merimm, or low.

The high pressures are of special interest on accomnt of being associated with diseases in which many of the threatrning symptoms are thought to be due to the high pressure; thus in mramia and arterioselerosis pressmes of 170 to 240 or more millimetres are the drule. All observers slate that high pressures are frequendly found in spile of an apparenlly soft pulse by palpalion: here, then, as the general acenracy of these instruments cammot be donbted, their value is moleniable. In many illy dofined conditions of middle age an unnsmally high pressure is fomnd, which returns within the normal limits in the comrse of treatment. Such cases are often described as dne to arteriosclerosis or to some intoxication producing increased arterial pressme. In the troatment of nephritis a 


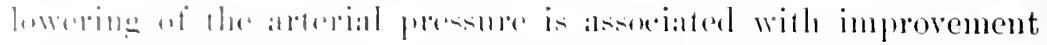

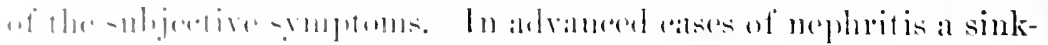

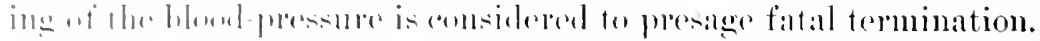

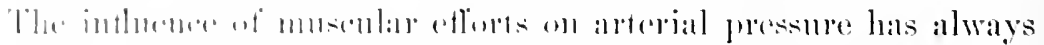

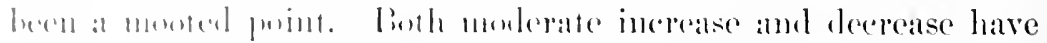

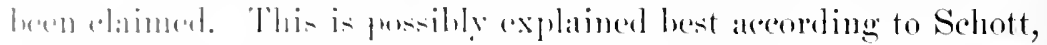

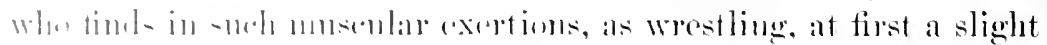

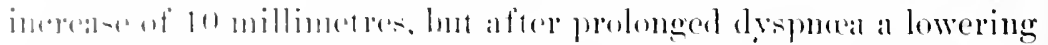

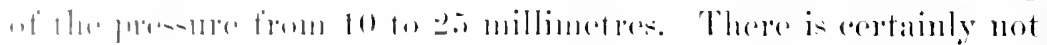

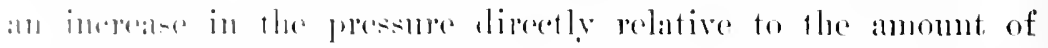

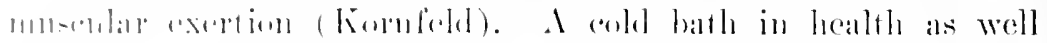

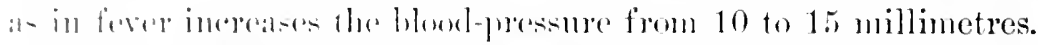

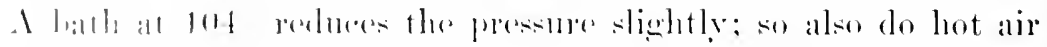

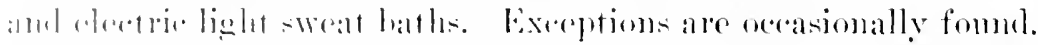

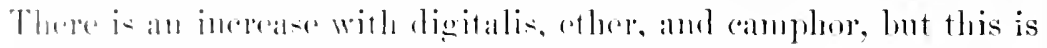

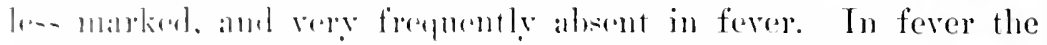

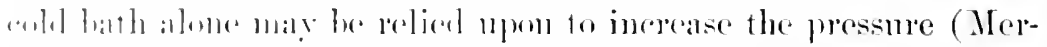

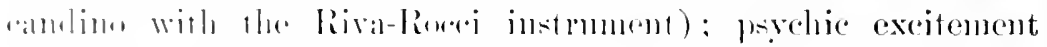

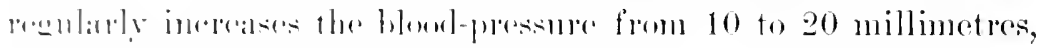

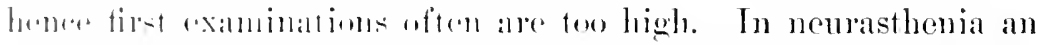

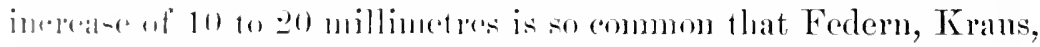
alul Iloin reand it at sign of diagnostic value, especially in chil-

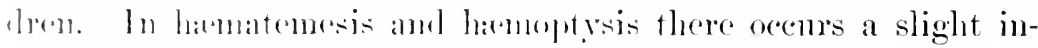

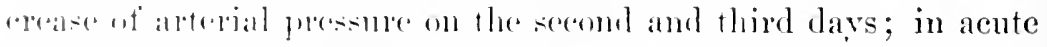
forre there is smonetimes a sight rise, sometimes a slight sinking

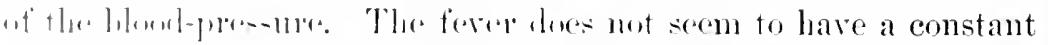

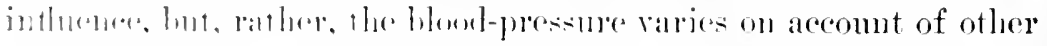

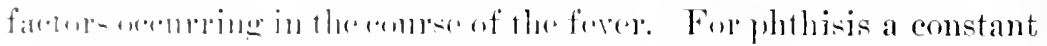

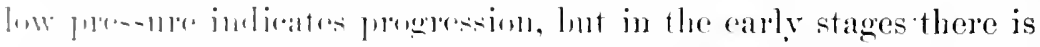

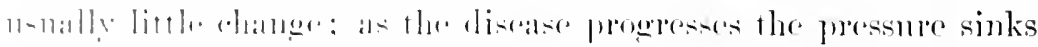

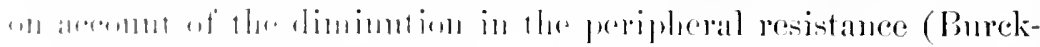

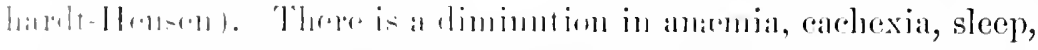

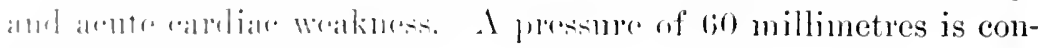

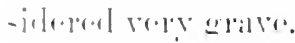

(ialleture thates that his instrmunt registers mean and not maximal pursiner. This is not areepted by all. Tlowever this

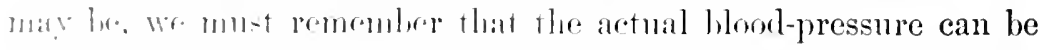

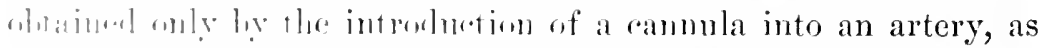
hat been lone in the eomrse of operations ly . Albert, who found the 


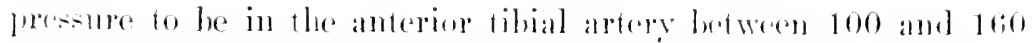

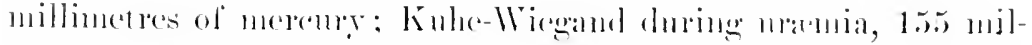

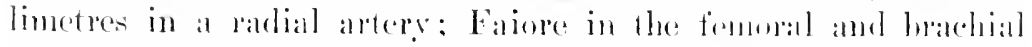

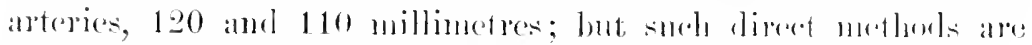
ont of the question for ordinary elinical purposes. The Garertuere instrmment, as well as all the other instrmusents, ale influcuecerl by the resistance of the tissure of the artery and the surmomeling

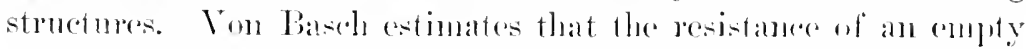

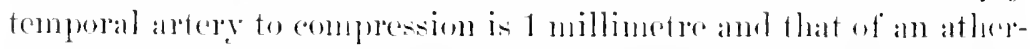
omatoms artery 5 millingetres. The resistanes of the soft tissues orer the temporal artery is abont 6 to s millimetres. So after all we are not dealing with figmes of the aldual puesinde wiflin the artery, but with relatiwe tigures. If all procantions are olsorved,

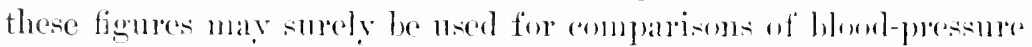
changes in the sande individual with a gloat degere of roliability :

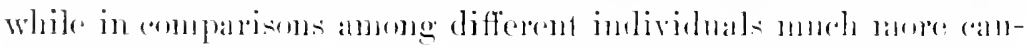

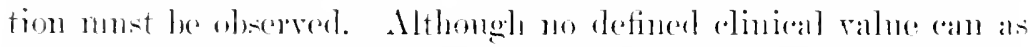

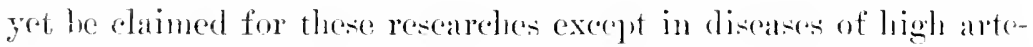
rial pressule, the necessity for more attention to arterial presine las beeome very aplanent within the last ten yours, as sluwn by numepons articles appearing on this subject, especially in (iopmany; and since there are now several instruments wiving pracetical besults, we may lope that soon a clearer minlerstanding of the

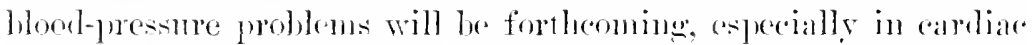
diseases and aroute ferers, so that both diagnosis and therapentio indieations will lecenne more acemate thall hals thus falr been possible, eren with the acmen of the most experienced.

\section{THE SPHYGMOMANOMETER}

Since the forregoing execllent presentation of the arlvantages to be gained fom the elinieal nse of sphyoumomamometry and of the applieation to this and of the Gacetere tomometer was witter by Dr. Otto Schmirit, the employment of some form of hlood-

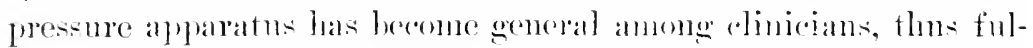
filling the prediction expresed in his alosing paraglaph. Moreover, in 1904 appeared an excellent work on " The ('linieal Sturly of Blood-pressure" by Theodore ('. Janeway which gave iunpetus to the adoption by phrsicians of this inclispensable aid to diag- 


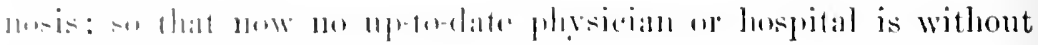

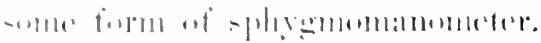

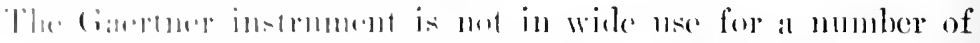

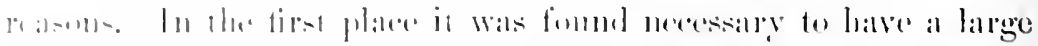

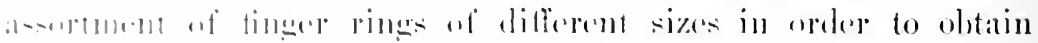

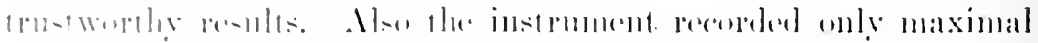

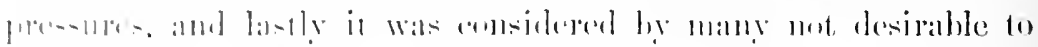

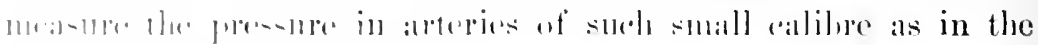

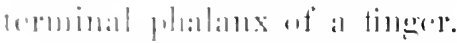

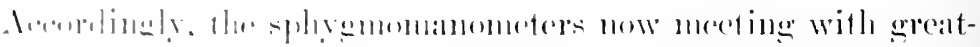

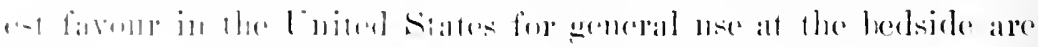

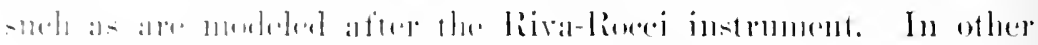

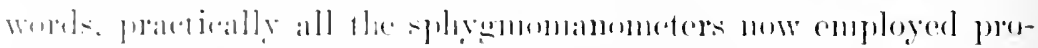

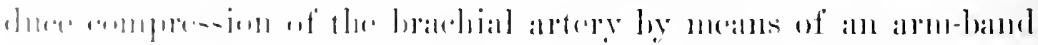

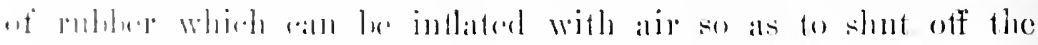

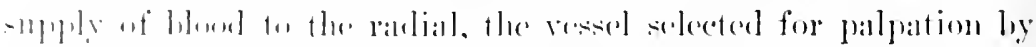

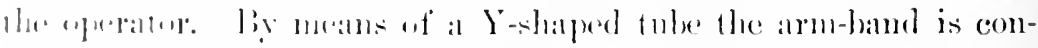

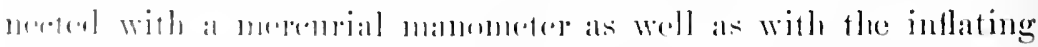
lulb.

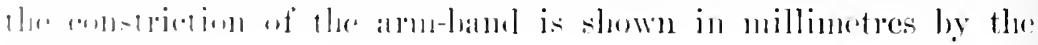
$111: 113+1111 \cdot 91 \cdot 19$

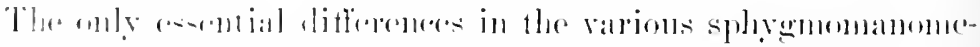

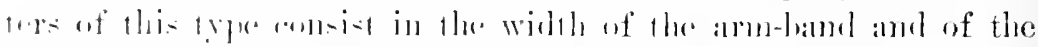

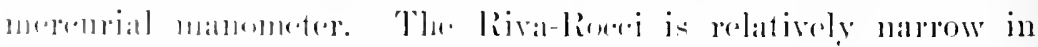

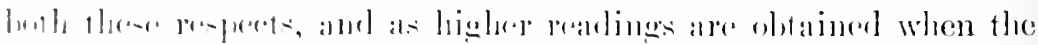

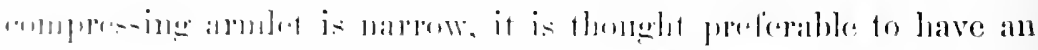

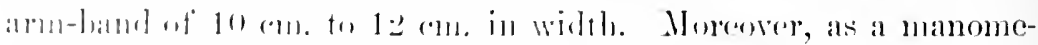

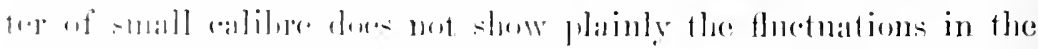

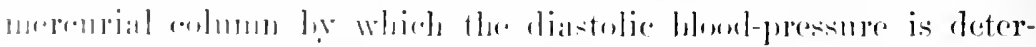

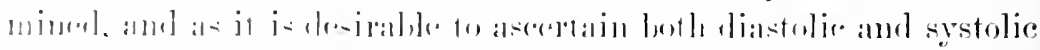

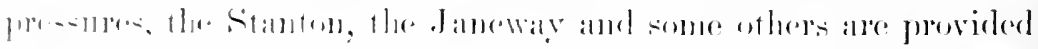

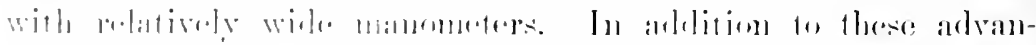

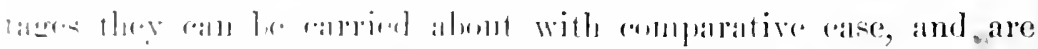

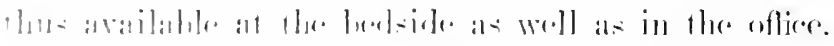

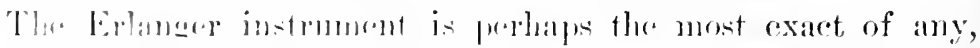

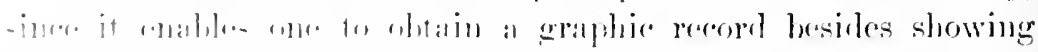

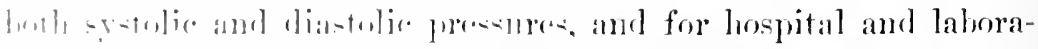

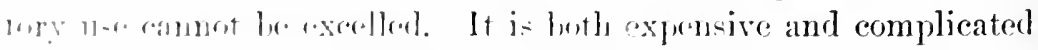

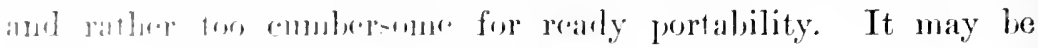




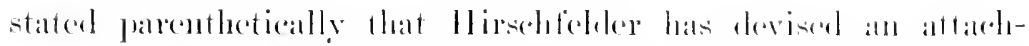

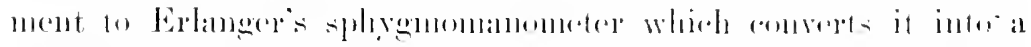

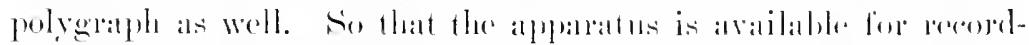

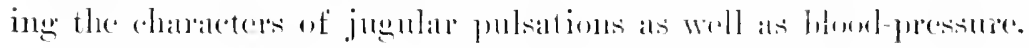

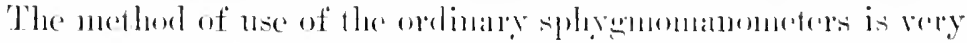

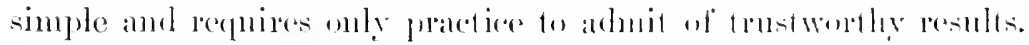
For the sake of raldels who may not he familial with these instruments, the mode of application will be hielly deserilxd. The

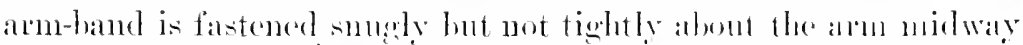

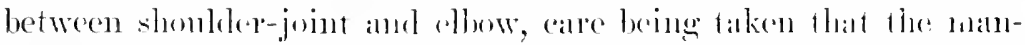
ometer be on a level will the least, whether the patient he sitting

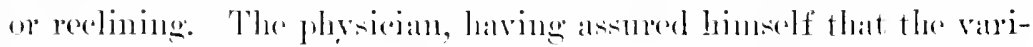

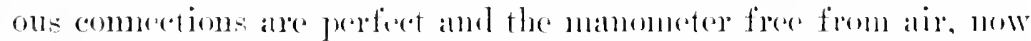
inllates the armber motil his finger, resting on the radial aldery, ferceives that the pulse is totally obliterated. Then allowing the air to escalpe gradually from the alm-bamel or enff so that the mereurial columm falls a fow mme at a time, he watehes atterltively for the instant when lis palpating finger appreciates the first ting flickering of the returning pulstwase. With his ree

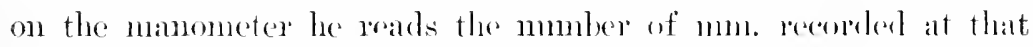
instant. This done, he may again obliterate the pulse and repeat in order to verify his first reading. This gives him the systolie blood-pressure. Thereugem le permits the columu of meremer to sink 5 mme at a time mil al length the lowest point is reatehed at which the medemery still oseillates the most willely. This socalled maximal pulsation gives the diastolic forsine, and the point midway hetween the systolic and diastolic pressite is the nucan pulse pressme for that palticular casce.

According to daneway and oflers the npper limit of nomal

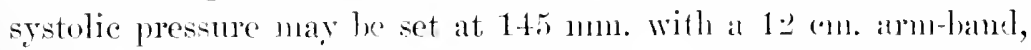
with a Riva-Rocei 10 to $15 \mathrm{~mm}$. higher. The minimmm normal pressure for an arlult is $100 \mathrm{~mm}$., or posibly :10 mom., with a

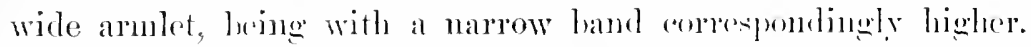

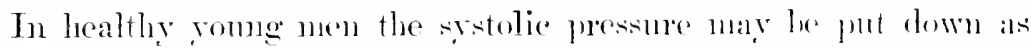
from 100 to 130 mmus, while in females it is perlugps $10 \mathrm{~mm}$. lower.

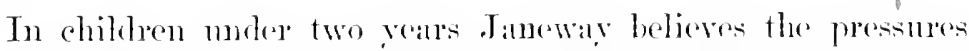

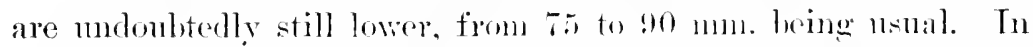
older ehibdren the figures anderspond to the lower values in ardults 


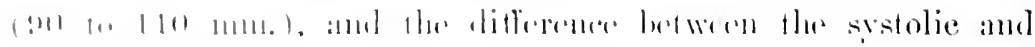

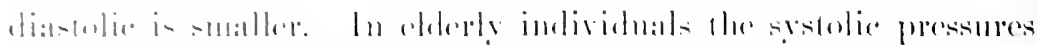

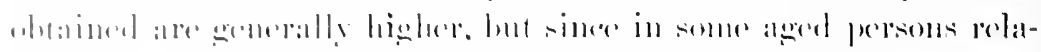

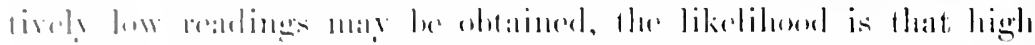

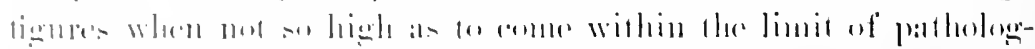

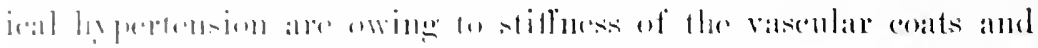

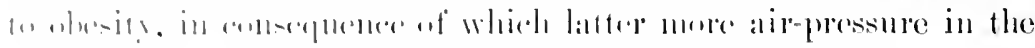

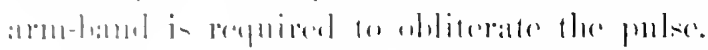

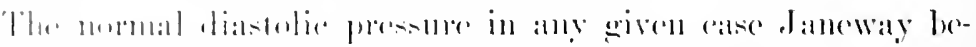

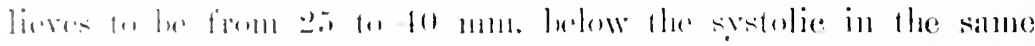

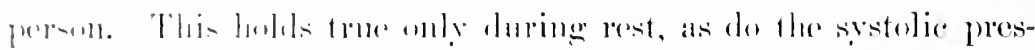

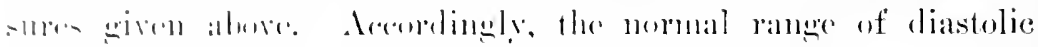

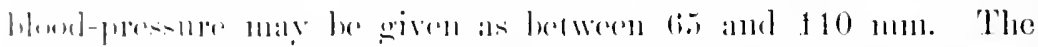

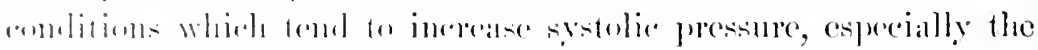

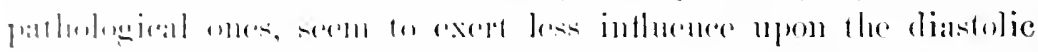

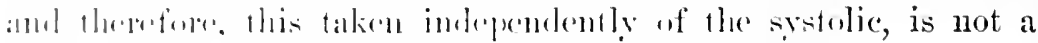

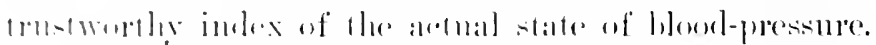

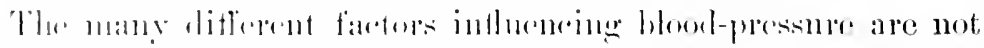

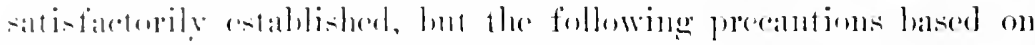

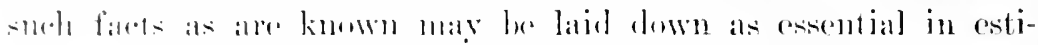
mating the signitieanue of elinical readinges. Mental and cmo-

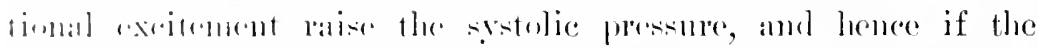

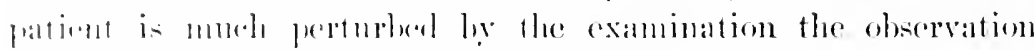

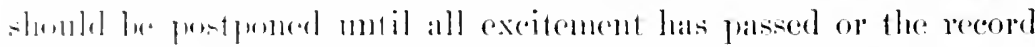

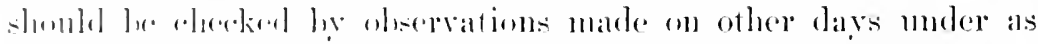

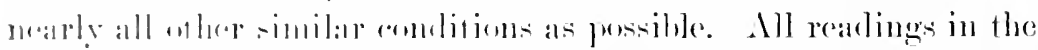
rase of any one individnal slomld be taken in the same posture,

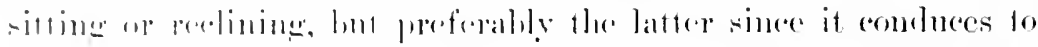

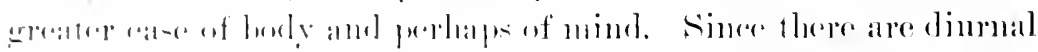

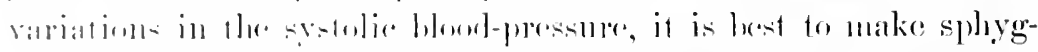

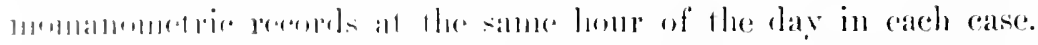

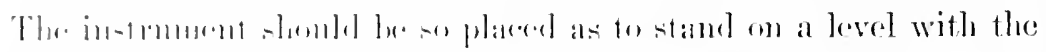

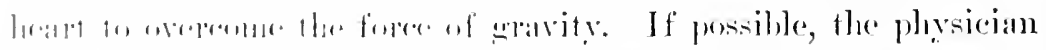

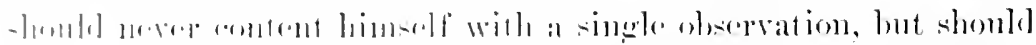

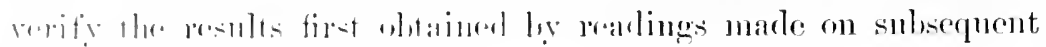

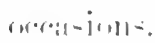

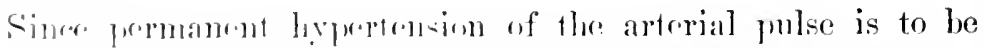

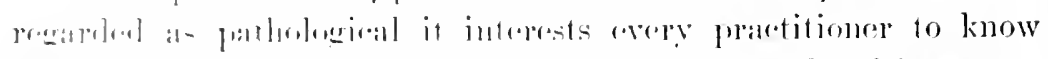

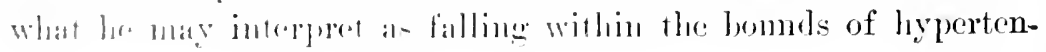




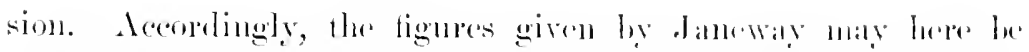

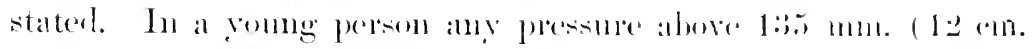

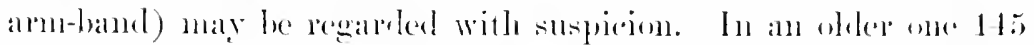
mon. (broad armlet) and alowe 145 mon. in an individual before:

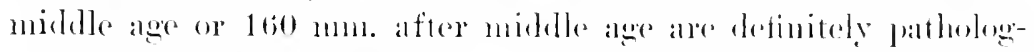

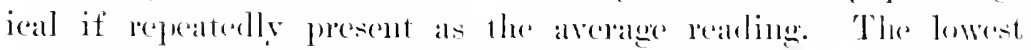

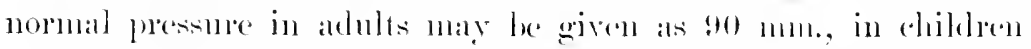

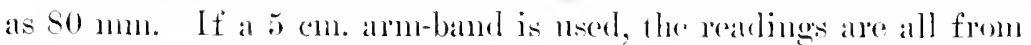
15 to 20 num. higlier:

Finally, the query of practieal importance is in what elats af cases is one to look for abmormally high blowel-pressure. ('oncisely it may be stated that persistent bleod-presime above normal limits should put the phrsician on his guand and anduse him to lowk with suspicion mpon the state of the kidneys, the valsenlan sistem and the leart muscle. It is the detection of arterial hevertension which many times enahles one to estimalte correcoly changes in urine and leart findings which otherwise might be thomght insignificant. Strangely anemele, lowever, it is to be remembered that the blowedpressme is not invariably too high in persons whose hearts, ressels and even kidneys are found on clinical investigation to exhibit signs of degeneration. Such sems to be the ase particulary in pronomeed arterio-sclesosis. In anses planly of ehonic nephritis the blood-pressure is with but few exceptions far alwo the normal so long as the heart is adequate. As the myocardimu fails in its sufficiency blood-pressure falls, and hence a malked and persistent sinking of the pulse tension is an omen of gave danger. The same is true of a promonneed amel persistent increalse, since it may portend apoplexy, miemia or overpower the functional integrity of the myocardimm.

In valvolar diseases the splyemomamometer is not of as ereat value, and ret as emplatsized ly Janeway the systolic blondpressure may give us aid in arriving at a differential diagnosis. Inasmuch as stenosis of an ostimm lestems the anomint of hlood discharged into the aorta with each systole and also tends to canse slowing of the pulse-rate, it may be stated that a persistently low blood-pressure makes in faror of narrowing as against regurgitation.

For instance, in aortic insuffieinery it is rxcestingly common to hear both a systolic and a diastolic murmmr, and the physician 


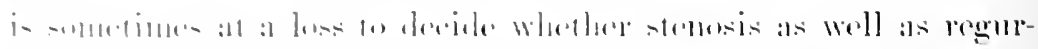

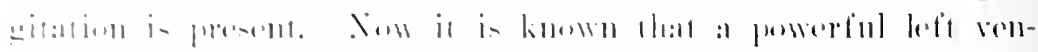

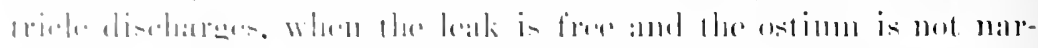

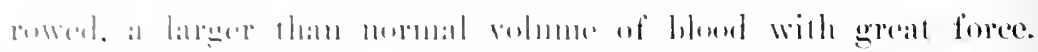

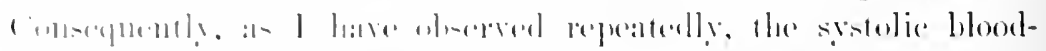

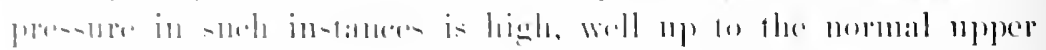

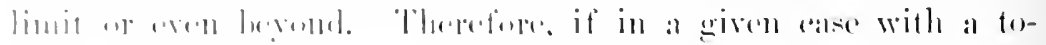

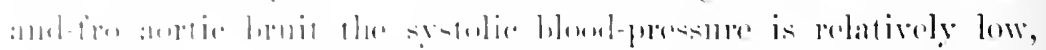

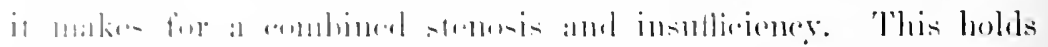

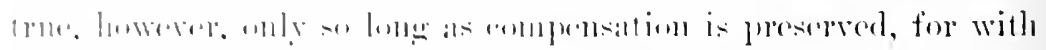

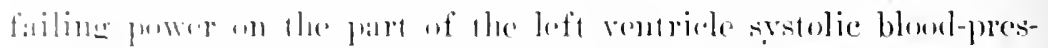

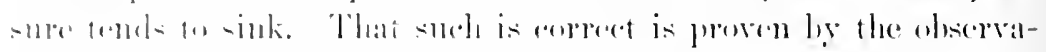

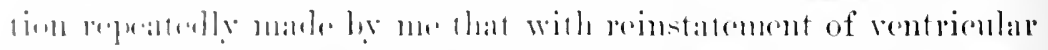

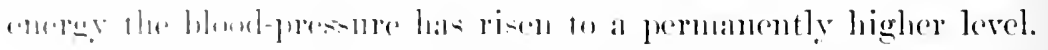

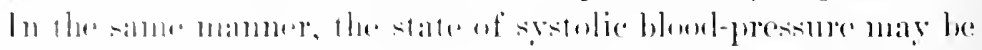
milimel withe artain limis in the detremination of the dregee

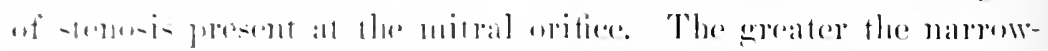

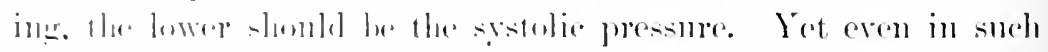

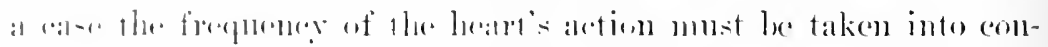

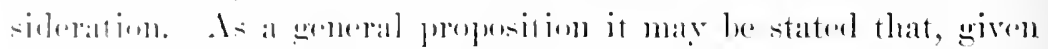

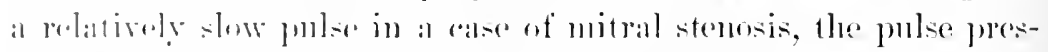
- $13 \%$ -

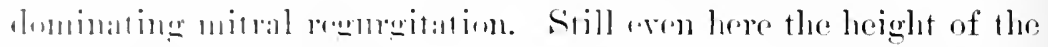

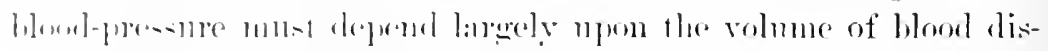

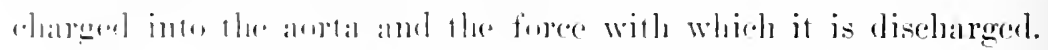

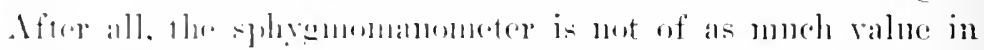

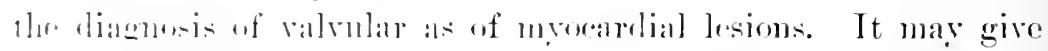

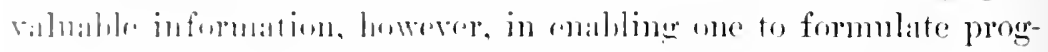

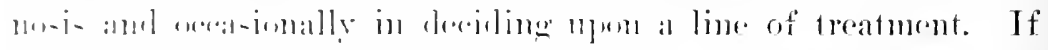

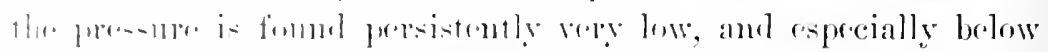

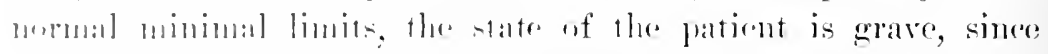

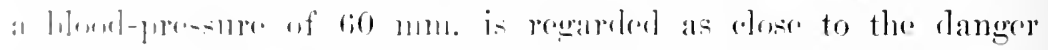

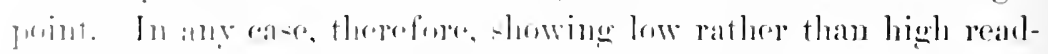

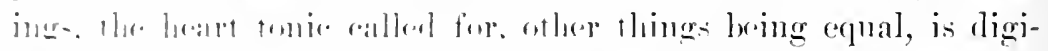

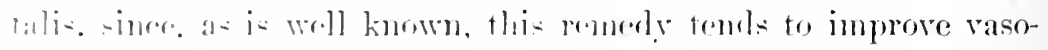

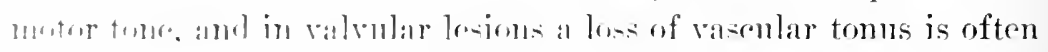

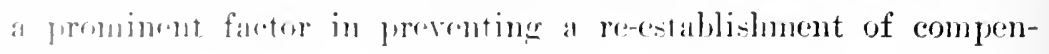
$-i 1 i, 1$, 


\section{NDEX}

Aberrant cords. 30 .

Abortion, cansing acute enlocarditis, 180.

Adherent pericardium, !)! :

Broadbent's sign in, 119;

Frielrei(hs sign in, l-20);

Knssmant's sign in, l:00.

Adhesions, chronic mediastinoprerearolial, lo:

formation of, in elmonie pericalditis, 103.

Age, influcnce of, in mitral stemosis, 2.54 ;

in valvular losions, $40 \%$.

Air lnumger, list.

Alcoholime in arute emlonalitis, 5 : in aortic regurgitation, 2sol).

Amyl, nitrite of, in angina precturis, 658.

Anemrsur, congenital, 769 : eases of. (i], 7 ti.

Anewrsm, of thoracie aorta, 575 ; associated with expectoration and comgh. 7st:

auscultation in, sile;

cases of, 7.!), 7!1, 7!9!, s04;

diagnosic of. $\mathrm{s}(\mathrm{H})$;

drepnoxal in, 7sis;

eleetrolysis in, sll;

atioluger of , 7\%:

injertion of welatin in, 797 :

of gelatin ane! salt solution, sle;

inspection in, 800 ;

morbid anatomy of, 675 ;

morpluine in, sis;

pain in, 7s:

palpation in, sol:

perension in, 80?:

phrsical signs in. 800 ;

prognosis in, sok:

symptoms of, 781;

syphilis in, 7Ts:

treatnent of. 509 :

tuber(ulosis iu, sos.
Angina pertoris, (i3); acomite, net llsed in, 1960 ; anyl nitlite in, liss; anolyoles in, dibio; brandy in, litio:

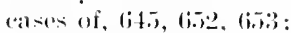
chloroform and other in, 65s; liagmonis of, li.it; digitalis in, ditiz; (tiologe of, (i.to) niturelinerin in, tiss; oprimm in, (i.s), (i.)? ; batholoury of, (itl); frognosis in, bi.j: strophanthus in, diaz; sylulis ine lifli: treatment of, (i.r).

Angina perulo-peretoris, 719.

"Angrina-sclero-tabagrique," (its.

Anomlynes, ss.

Antistreptorocentis sermm. (Ser Ser.11m.)

Intitoxin, in acnte endocilditis, 193; in acute myocarlitis, 515.

Aorta. stemusis of (see Stomosis): tholareie, anemeysur of, 75 .

Aortic renmitation (see Regurgitatioll) :

stemosis (ser stomosis).

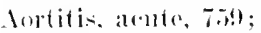
etiology of, itio: inspertion in, 76]: in mea-les. F(in): morlisl an:otomy of, 159; nitroglyerin in. 7li2; palpation in. 761: peralusion in, 761 : plysical signs in. 762 ; in pmenmonia, 760; bronnosis in. 7R2: in soarktina, T(60) strylunine in, 76: symptoms of, 760; ireatment of, 762. 


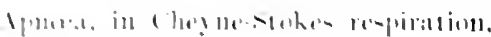
lilit.

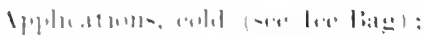

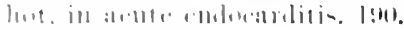

11, : $111111,: 3$ :

1.11,lian, :-1:

mi11.1. : $\because 1$ :

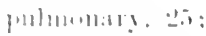

tiin-11-pinl. :20.

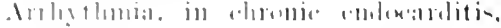
$\because 14$

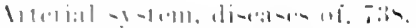

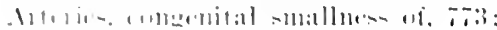

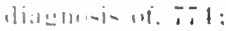

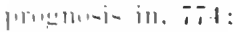

-1mplum- -1i. 7\%:3:

110:11mment uf. 77.

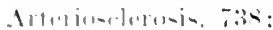

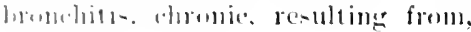
$7+4 !:$

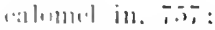

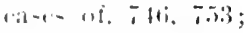

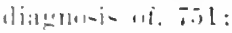

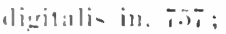

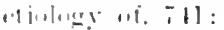

j:1.1p ill. $7.5 \%$ :

mulitil alliltmoly of. $: 39$;

nitrentrerein in. 7.T:

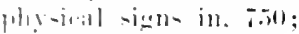

prongus in, 7.st:

-lliplatnthus in. 7ar;

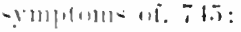

spluilis in. 7.4.

Artaritis. atutr. Tliz:

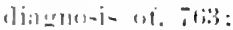

dieitilli- in, 7(i2):

in-perefirn in. Tfis:

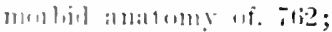

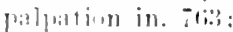

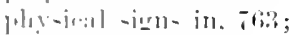

Froternte-in, Tlias:

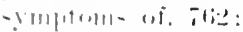

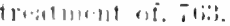

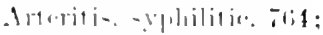

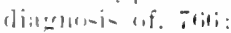

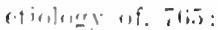

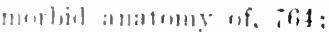

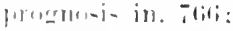

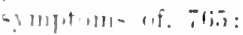

irraturnt rit. Friri.

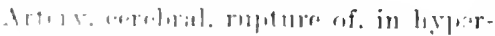

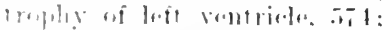

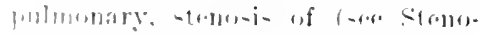
$-i=1$.

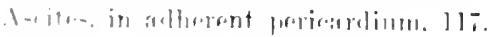

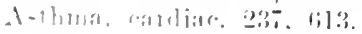

I-1 1,m:1, lommides in, inis:

in mitral stemosis, :-70.

Mheromal. (Nen .Mreriuselerosis.)

Aropley of the heart. litis:

liatplumin of, ticis:

rlinlug! of, ditit:

monloil antilom! of, bitit;

prongumis in, licis:

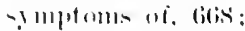

trittment of, litis.

Mropine, in cheyomestokes respira (ioil, tie:3:

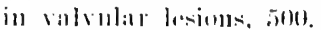

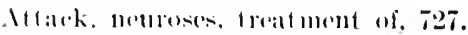

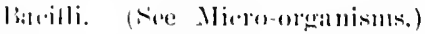

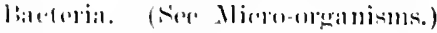

liatlis, hut, evil efluet of, in valvular laimlts. 4.27.

in Valvulat lisions, 427, 4(ili, 503;

Nimlerim, 110, 115, 4lit, iol3, 592;

siline, in valumlat lesions 460 ;

lurki-h, s.i.

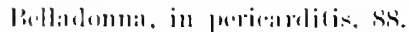

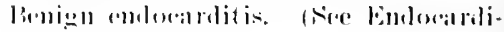
(i.s.)

liluenllotimer, in dilatation of loast, 591.

Hhe hally, of congenital heart discase, (i) $32,701$.

lorallearlial. lows:

discases associatrel with. 625;

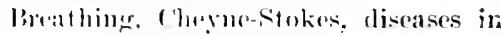
whirh, obsirved. 675.

Briglt is discase. in poricarlitis, acute, 4.):

olumie. in cheyne-stokes respiration, tili:

in myoralitis. rluonie, 539;

in revergratition, mitral. 2:37.

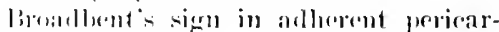
dimm. 119.

linomelial disonders. in valvular lesions, 447.

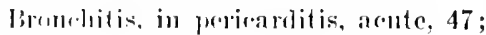
in prerenolitis, rlonnir, 102.

Caffrinc, in tarleyearlia. 736;

in valumar losoms, 432.

('alrification in proriarlitis, ehronic, ]ol.

('Alomel, in artorioselerosis, 757;

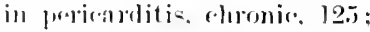

with reffu-iun, s!?:

in va!rmatr lroinm- 4.22, 449, 491, 493.

r'ancere. wi the myorardim, 666. 
Cardiac asthma (see Asthma); nemosis, 71):; :

jail, 7 Is.

Catarh, bronchial, in mitral lesions, 407 .

(athaties, in dilatation, 5!): in endocarditis, (horonic, 202 ; in valvular lexions, 4 !) 2 .

Cherocotokes respiration, dit:; (iisce of, (i2):

ill diphtheria, 617 ; morpline in, 6:2:); in phemontal (ili; progmosis in, (i2.):

treatment of, (is:).

Chills and forer, in suppurative periarditis, 72.

Cliloralamile, in rhronic myocarditis, 563.

C'hloral hydrate, in valvulal lesions, 501.

Chloralose, in valvular lesions, 501.

Chlorosis, in mitral insullirioncy, 597.

Chorea, in acute endocarditis, 1.5. 154 , 15.5.

Cirrhosis, atrophic Jepatic, differenfiated from allierent periondium, l:2:2:

remal, loading to trienspid regurgitation, 34is.

climate change of, in valvolar' lesions, 432.

Clothing, in valvula! lesions, $425,476$.

Colleine, in perionditis. š. 9l.

Compensation, imperfert, in ralvular lesions, 43.5.

lost, 47s:

perfect. 413. 414:

prevental, in chromir perionditis, 10.5.

Congenital menrysu. (See Amonrysin.)

Congenital discases of the heart, 6S6; case of, 695 :

diagnosis of, 701 :

etiology of, gs?:

inspection in. (i9):

morloil anatomy of, 6S6:

morpline in, 69:3:

palpation in, 696 .

Congenital smallness of arteries. (See Arteries.)

Congestion, abdominal viscer:t, in aortie and mitral regurgitation, 397: cerebral, in nitral regurgitation, $23 \pi$. (ompestion, (lumic pulmonary, 231 ; nonolls, 347 .

(iods, alberrant, 30.

corpulent, cardiac inalequary of the, 5!!!.

Congh, in anenrysm of thoracic aorta, $7 s 4$.

('usp, rupture of, in arotic regurgitation, $2-2 \mathrm{~s}$.

Cynosis, in aroute endocarditis, 17l; in antir stenosis, 335;

in dilatation, 5sit;

in trieuspid regurgitation, $34 \bar{T}$.

bath, mole and causes of, in aneuryom of thoracic acola, sos;

in regurgitation, aortic, 307 ;

mitral, 247;

pulmomiry, 374

tricuspirl. 354;

in stemosis, aortic. 340 ;

mitral, 270 ;

pulmonary, 38s;

trienspicl, 364;

sulden, in svphilis of the myocardium. 66.5.

Deglntition, painful, in ay perioarlitis, 49

Delirium, in mitm] stenosis, 270.

Devices, mechaniral. as aids to determining diseases, slin.

Dextrocardia, acepuired, 682;

diagnosis of, 684;

etiology of, 683:

inspection in, 685:

morbiel anatomy of, 682 ;

palpation in, 6st:

perrusion in, 6s4:

prognosis in, 6s.5;

srimptoms of, fist;

tratment of, 695 ;

tubaremlosis in, 681 .

Dextrocardia, congenital, 681;

rase of, 691 :

symptoms of, $6 \mathrm{~s} 1$.

Diathesis, rhemmatic, in ralvular lesions, 406.

Digitalis in arterioselerosis, 757;

in arteritis, $760^{2}$;

in angina pertoris, $66^{2}$ :

in dilatation. $59 \mathrm{I}$;

in endocarditis, acute. 189 ;

in emlocardits, roronir 202;

in fatty Jeart, 611:

in functional disordurs, 709 ;

in hypertrophy, 575 . 


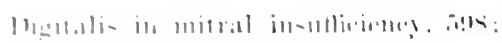
in $11111,111111-$ and111, illi:

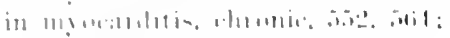

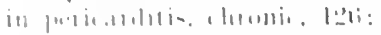

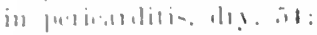

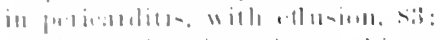

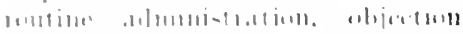
.1 liv,,$! !$ :

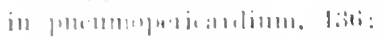

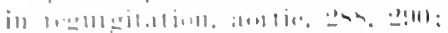

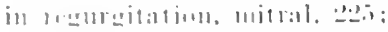

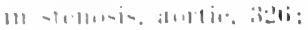

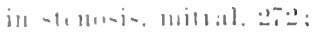

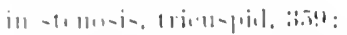

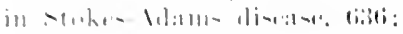

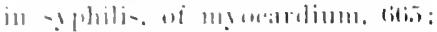

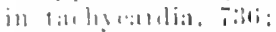

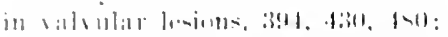

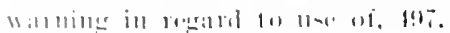

lila1latiull. Sti:

l1:1\}1, in. in:

lolull,11119 in. in!ll:

lil11, 111.1 - in. .1!1 :

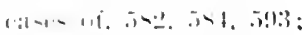

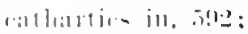

1 1:1311-i-in, inl:

ditlum-i- uf. inti:

digcilali- ill. ontl:

(1juleng uf, 37 :

inllunllz: in, .7?:

in-puratinl in, ins:

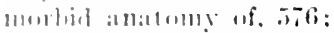

monplinu in. in:?:

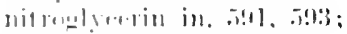

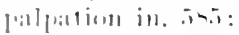

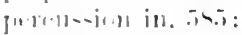

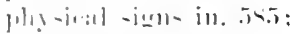

proneme- in, is: :

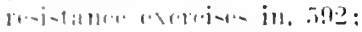

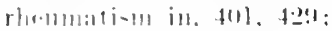

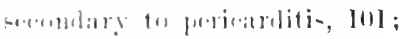

-1ryerhing in. ind:

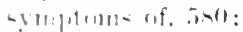

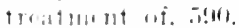

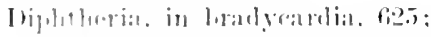

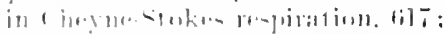

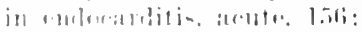

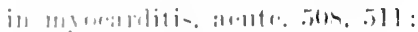

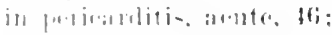

irl lially-arlin. 7as.

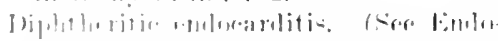
sidiliti-.

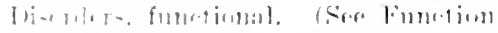
al $1 \mathrm{i}-11 \mathrm{ll} \cdot \mathrm{r}=\mathrm{s}$

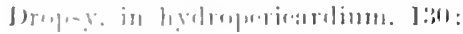

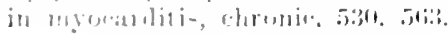

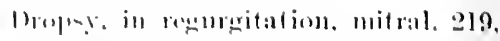

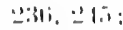

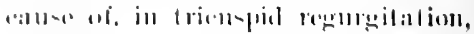
ils:

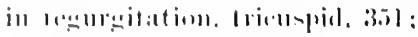

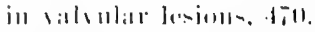

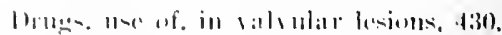

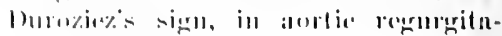
1ioll, :3i.

1

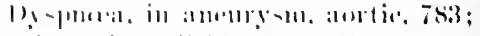

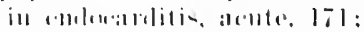

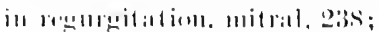

in slumsin, millal, :35.

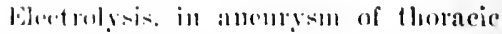
alut:i, sill.

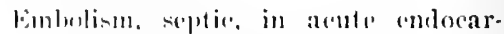
ditis, Jis, ] ]2. Ist.

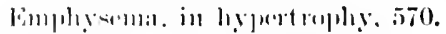

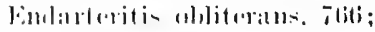

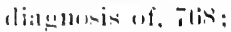

wiolong of, otis:

morlici anatomy of. Ttiti;

pungusis in. This:

symptomes of, Tlit:

116iflusul ut, 769.

Comlenalitio, aleute, 143:

alingere in, listi, lsil:

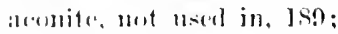

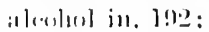

alkalius in, lsi:

applinalions in. hot, 190:

a

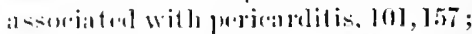

latrillus uf diphtlurial in, lis, log;

of inlluen\%a in, ].il. Jist:

of lyplorid fores in. 15l:

larcteria, lyogrenic, in, 149, 156;

hisler in, Iss:

ln:แmly in, l!)] ;

lumbillus in, 18!;

("illulur in, 19) ;

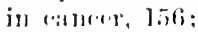

14ses of, 15s, 16.4, 170;

(homel in, 153, 154, 155;

rontro of, 11i.):

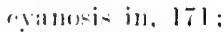

diatrmo-i of. lis.?;

liagrur-in. dilfromtial, from typhoid forrer, lis:

dieritali- in. Is!?:

ly-pun:a in. 17l;

rmbli in, 172;

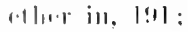

atiolung of, ldis. 
Endoenrditis, acnte, lemiplegia in, 158,$184 ;$

ice-bila in, lsin:

indicated lor rhemmatic fever, $15 \pi$;

infaction in, liss:

in fortal life, 143;

inspertion in, 17ti;

leucoryomis in, lsil;

in moistes, 15.

mombid analomy of, 143 ;

morpline in, dis:

opinm in, 1!m:

oxygen in, 19l:

palpation in. 176;.

in pelvie discate, 1.5.);

perensilum in, 17\%:

plysical signe in, 176;

in phemmonia, 1sti:

in pramia, liti;

prexia in, 171;

resulting from anteric ferer, list:

resulling from gall-stones, 156 ;

resulting from seariet forer. 154;

rhemmatism in, $14 t i, 1.5,153,15 \%$, 181. 1Sti, lsi:

sepsis in, 170, 1!3:

sermm, antistreptococus in, 193 ;

in small-gox, 15t:

strophanthus in, 169 ;

strychnine in, 169, 191;

symptoms of, 157 ;

in tomsillitis, loti;

treatment of. $18 \%$.

Fndocarditis, henign, 143.

Endocarditis. chronic, 199;

arvhythmia in. 2lt:

eaves of, $201,206,210$ :

eathartic; in, 200.

digitalis in, 2(t):

etiologr of, sol :

morlid anatomy of, In!:

nitroglyerin in. 20.3 ;

vhemmatis!n in, 204:

stryolnine in, 202:

symploms of, 2015;

syplitis in, 204:

trealment of, 202.

Endocarditis, diphtheritice, 143.

Endocarditis, malignant, 143.

Endocarditis, myeotic, 143.

Endocarditis, simple, 14:3, 150. 157.

Endocaditis, ulerentive, 143, 154, lo3; comre of, 172 :

diagnosis of. 179:

mophine in, 196 ;

treatment of, 191. lindocarditis, vegelative, 143.

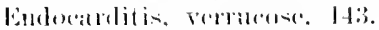

Euloe:arlium, distases of, 143.

linterie forers. (Nere linver.)

lipileper, in mitral stemosis, :2lo.

lwart s sign, in periourditio with etrusion, so, sl.

lixtereare, in dilatation, 59:2;

resistance. 45.5, it!)

in valrular lesions, 414, 451, 502.

lexpertoration, in anemyin of thoracir. alota, Tst.

latty hoalt, ing?);

aperiouts in, (ila;

('ilnulır in, (i)l;

(a)se of, (it) :

diaguesis of, (30);

diret in, (iols:

digitalis in, 61l ;

etiology of, 600?;

gentian in, gin:

glutlony, predisposing to, 601;

hypophosphiles in, 610:

inspectim in, 604 ;

innll in, (i)0;

mostid anatomy of, 599;

nitroglycorin in, (ill;

nux romica in, 610 ;

orthopmera in, 603:

palpation in, 604 :

pathology of, 599:

perenssion in, 604;

physieal signs in, 604;

prognosis in, 606 ;

strophanthus in, till;

strehnine in, 611;

symptoms of, $60 \mathrm{z}$;

tieatument of (io)i.

Fever, in periouditis, dry, 5l:

in previnalitis, with eflusion, 89;

entelic. in emelocimlitis, 1.51:

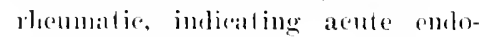
(a) alitis. 1\%7:

scarlet, cheynestokes respiration in, (il):

in myoratritis. iz.2:

leading to alente mulawaditis, l.t.l:

lealing to poricarlitio with ellusion, 72.

Fever, typhode, Cheynestokes respiration in, (ili:

diagnoxis of. dillerential, from acoute endocarditis, 18: :

in lonalyearelial, lias:

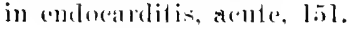




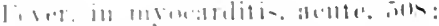

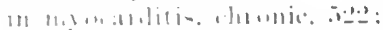

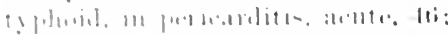

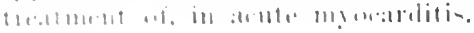
i]li.

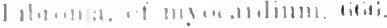

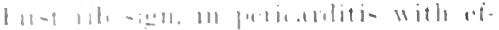
i1) $-i, 11, \quad ; i$

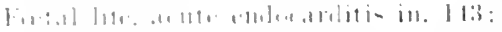

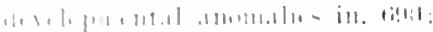

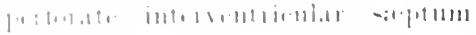
111,110

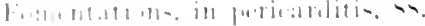

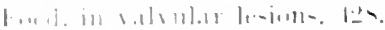

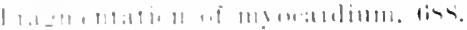

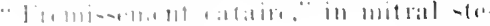
$11,-i-2 ! 1 !$.

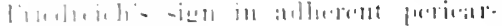
li11111, 1:11.

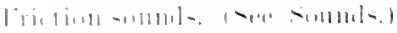

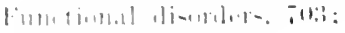

$1,1-1-1,7.71,711$ :

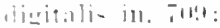

$11,1111-1, i 11.7113:$

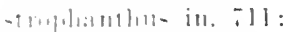

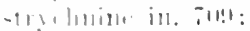

[11], [1, 11],-i-in. i]ti

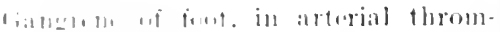
lin-i-. 1i,iti:

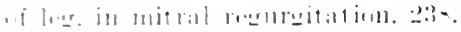

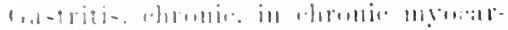
litin..,$-i l$.

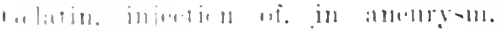
is

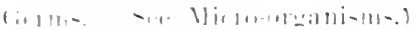

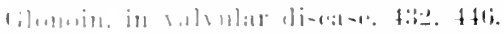

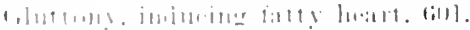

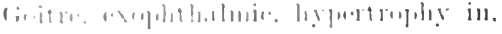
$\therefore, 11$ :

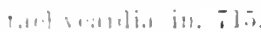

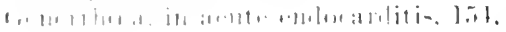
$1-1$ :

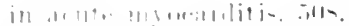

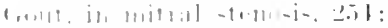

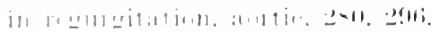

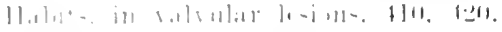
$+i i$.

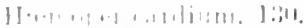

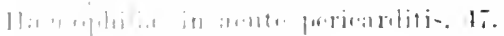

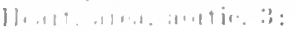

$18 \mathrm{j}+1,11.1$ :

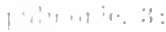

$112,-1-1,1,1,: 3$.

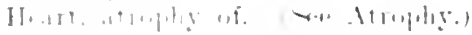

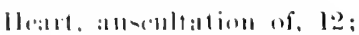

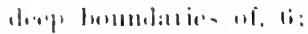

dila1:a1 iun of (-19. l)ilat:ation);

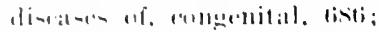

limelel- of. fonctionst. 703:

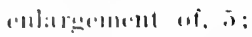

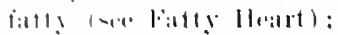

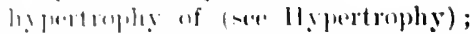

lowat1 ion wi. 1:

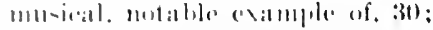

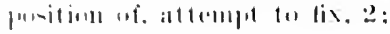

mation of. to antorior flomace $11: 1]$. I:

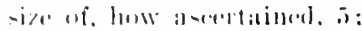

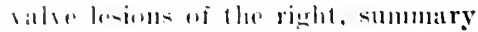
uा ply-iral signs of, 3s!?:

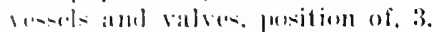

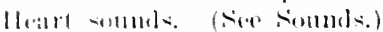

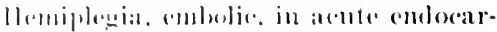
liti- list 1st.

llumin, in pricaralitis with ellusion, sis.

Homne -monomlings, in valvmlar le-iolls. 1111.

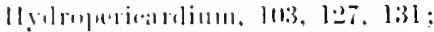

di:1!nu-i- wi. l:3!!:

dropery ins lizo:

a.tiuleng (if. l:2s:

in-prelinin in, les:

morloil allatomly of. 127 ;

pal jallion in, l:zs:

prerrominn in. 1:2!:

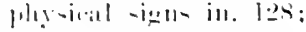

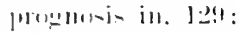

l'ureia in, lest:

Hullutati-n ill. 129:

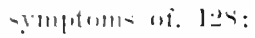

trathument ui, lest.

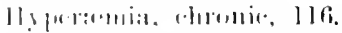

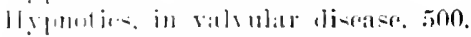

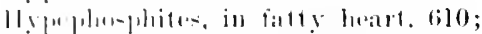

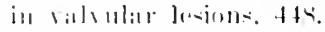

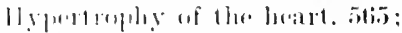

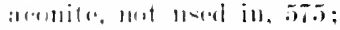

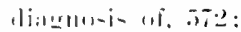

sleritali= in. 5it:

niolouts of. olis:

followiller rolly hermat 570 ;

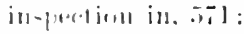

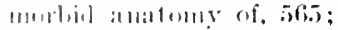

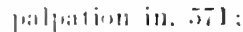

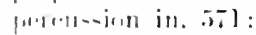

phy-ianl -iglle in, 571 ;

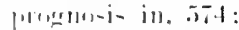

-ymphom- of. .7);

t1maturnt of, $5 \pi 5$. 
Iee, in paroxysmal tadruardia, 730. lev-hage, in acute enducarolitis, ls!); in pericalitis. $\$ T$, s!!

Hllnesoes in ralrular lesions, 4.29.

Inadequacy, cardiae, of the corpulent, 5ig!).

Incompretener, aadiar, 5is.s.

Individual tendencies, in chromice endo(a)ditis, 206 i.

moretion, in acoute enderarditis, 15s; in acute myourditis, 5lt.

Infoction, aflecting valves, tsis.

Inthenza, in dilatation, 5it: in arute endocarditis, 15l, 15ti; in fatty leatet. $(i 0)$ :

in mycorolitis, eloromic, 52.2, 551; in paroxysmal tarhyoulla, 7:3:.

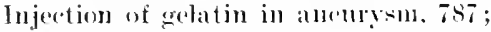
of geratin and salt solution. sla.

moomnia, in mital regurgitation, $23 \%$ :

in mitral stenusis, 256 ;

Insufficioncr, mitral. (Sec Milral In-ntticieney.)

lnsuranee, life. (Sere life Insmanne.)

Iron, in falty heart, 610 :

in instuliciency, mitral, .597;

in mrearditis, acute, 517 ;

in valvular lesions. 448.

Kidneys, in arterioselerosis, 741:

in endocaditis, acute, 1.50, 1.5s, 185;

in endoearditis, chronic. 203 ;

in myocarlitis, alcute, 514;

in pericarditis. acute, 45;

in pericarditic, chronic, 112 :

in regurgitation. mitral. .23s;

in valrular disease, 4!).

Knowledge of lesion, eflect on patient, 411.

lissmanl's sign, in alherent perioule dimm, 120.

Kyphoscoliosis, resulting in hypertrophy of right ventricle, 570 .

Lesions, valrulat. (See Valvolar Iesions.)

Leneoretusis, in aente encorarlitis, 1 isl.

Life insurance, relation to, of prownosis in valvular dionese, 4l:

Lipoma, of myocaldium, biti.

Liver, arrhosis of, 102,150 :

in dilatation, 584:

in endocarditis, acute, 156, 171, IS5.
Liver, in periearditis, chronic, 100 , $102,110.5,10 ! 3,117,1: 2.2$;

in pericatrolitis, dry, tis;

in pericarditis, with eflusion, ligh position of, 70 ;

in recruroitatim, arrtic, בst:

in rogrurgitat ion, mitral, 221!), 23:3, 238;

in legurgitation, tricuspirl. 345. 3.50;

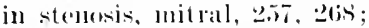

in valvulat discase, fo.j, 4tit;

pseulo-, rick's pericarlitic, 1:23.

Macoular tendiniar, Jot.

Magnesia, sulphate of, in valvular discase, 447, 4!2.

Malignant endocarditis. fsee Endocarditis.)

Marriage, in valvular lisuase, 4.2.

Massage, in cluronic myocalditis, 5.59.

Neasles, resulting in acute arotitis, 760 ;

resulting in aroute endorarditis, list; resulting in aleute periogrlitis, 46.

Mechanioal dovices as aids to determining disease, 815.

Indiastinitis, associated with pericarlitis, lol.

Mediastinoporicarclitis, 103, 104, 105; Perez's sign in. l'st.

Medieinal agents, in valvular disease, 444.

Micro-oreanisus, in abscess, 50s:

in blond. 1si:

in dilatation, 5i:

of diphtheria. 1.3l. 1.sti:

in endocarditis, acute, 144, 149, 150;

gatis foruning, 1:3:;

of influenzal, 1.il:

in mpocarditis, arute, 50s:

in pericatitis, acule, 40, 4.3;

in permmopericadiun, 133;

progenie, 149

of tubereulosis. 4.2. $3: 3: 2$ :

of typhoist ferer, list.

Mitual insutlicioney, relativa, s!) l

Chloresis in. nit:

dianumis of, sith;

digitalis in, inst:

etiology of, 59t:

i)(In) in. 59\%:

nitroglycerin in. 59.1 ;

pathology of , int:

physical signs in. ing6;

prognosis in, 5ir:

in rhemmatism, 5!) ;

symptoms of, 596 . 


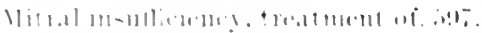

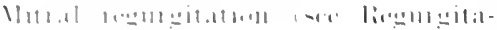
t1, t) :

$-1,1161-i=-11-1,1101-i=1$.

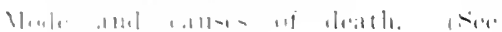
(1)..11h,

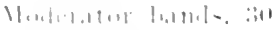

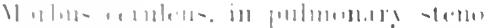
-1, , : i i i

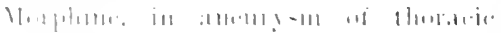
$-1+11: 1 .-1: 3$

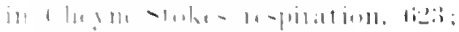

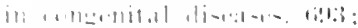

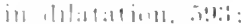

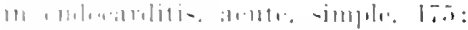

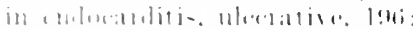

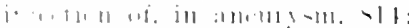

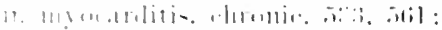

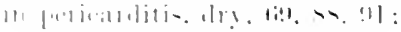

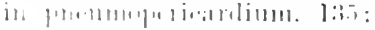

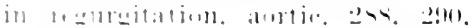

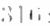

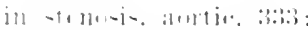

in -1,1]n-i-. mit1:11. 2-20:

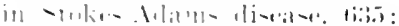

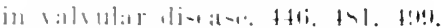

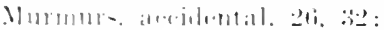

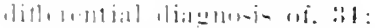

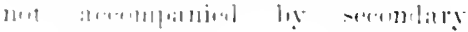

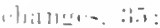

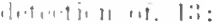

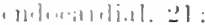

- \willilial. :ati:

$1,111-i+11.291:$

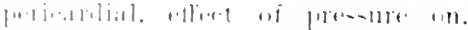
i!r:

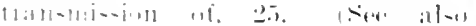
-

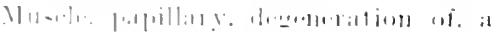

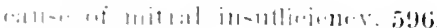

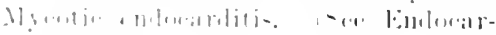
lisio.

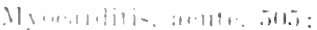

atill vill ir. ils:

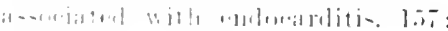

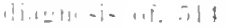

ilizitall- in. illi:

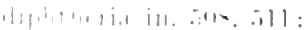

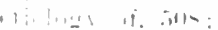

initistill 11 ill. lis :

irall in. 51 ;

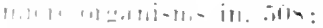

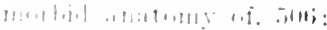

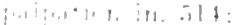

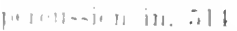

in $|+| y-i n\}-i a n-i n .51$.

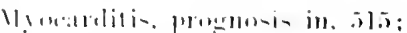
|ull- in. הl], 5l:3:

llandllation in, ills. il:i, ils;

-a1lillinal in, ints, illi:

-mall- for in. ins:

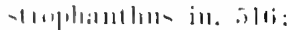

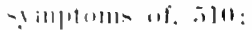

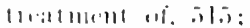

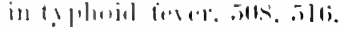

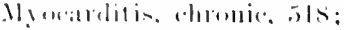

atringe in. inie:

hillhs in. Tulkish, 5.jo:

linimly in. itil:

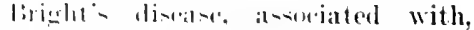
i:i!! :

lormidro in, inis:

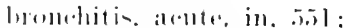

(amploll in. Elil:

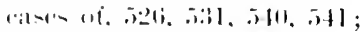

llenalamille in, ili3:

di:1_mu-i in. 1:2.). 51 :

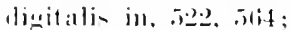

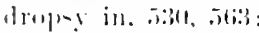

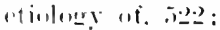

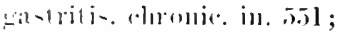

influen/al in. 5i2. . .i. :

in-pution in. in:3:

malmane in. .is! :

molinil allatomy of. 5l!

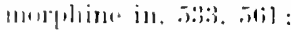

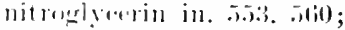

pillpation in, it:3:

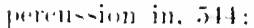

llls-iral -imll-in. its;

[mellmumia in. 5is] ;

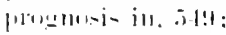

[11]-4 in, .i2!?:

Hormutti-m in, i2.2, is? :

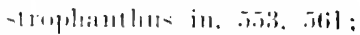

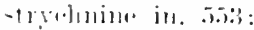

-rmp14rm- ni. 5201 :

11,attment 11, .5.1 :

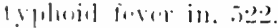

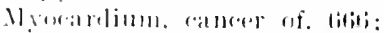

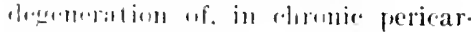

1iti-. 111 :

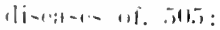

filirumat of. lititi:

Iratenlentallion of. Gilis;

lipenthir of. bitil:

-renturdutation of, bits.

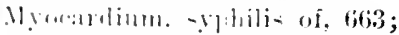

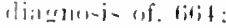

lieritali- in. litiot:

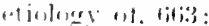

indide... in. (iti.j. 


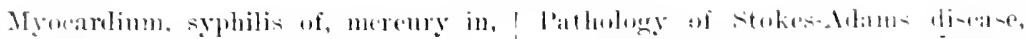
litis: :

mulbil anatumy of, titis;

prognosis in, titi.i:

symptums of , citit;

tratment of titis.

Nephritis, in acute perienalitis, 44.

Nemuses, 70:3, 717, 7:31;

diagnosis of, T21:

etiologry of, 720;

pain in, Tas:

patloology of, 703;

prognosis in, i2t; ;

struptoms of. 704 ;

treatment of, ït.

Nitroglyerin, in ancina pectoris, 6.s, in aortitis, acute. Fti⿱丷);

in arteriosderosis. 7 is:

in flilatation, 5!1, 593:

in emblotalitis. rononic, 2012.2;

in fatty heart. 6ill:

in mitral insutliedency, sol4:

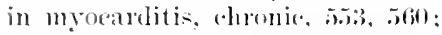

in psendo-angina peetoris.

in regurgitation, aortic, 2sis, 314,316;

in stenosis. antic, 33:2, 33:3:

in stenosis. mitral, 220 :

in Stokes-delams dised e. 633.5:

in tachucatia. $7 \mathrm{~s}$ :

in valvular dicases, 4t2, 44, 446 , 4 s. 498.

Occupation. effect of. in valvular dis(atses, t1)9. 11!), t7i.

Gdema, in mitral tenosis, 256;

in valuular disca-es, 195;

digitales in. 49.

Orthopmax, in fatty hart, (it): : in perioarditis with eflusion, tis.

Oxyen, in aroute endoratritis, 191; in Stokes-tdams diseasce, (iis.).

Iain. in anemysm of thoracic aorta,

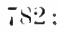

attark of, in nomoses, T.2s:

"ardiare, 75 :

in perianditis. 1ry, 4!.

Palpitation. in earilias menoses, 727 .

Paroxysual tachycaldia, T:30:

fortions of 732 .

l'athogenesic, of thrombi, titt.

Pathologe of aneina peretoris, 6.10 ; of fatty lusart. 5!3!): of mitral insutlieiency, 594; of nemo:acs. 703 . tis.

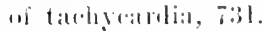

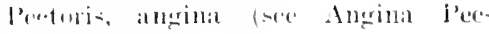
(uris):

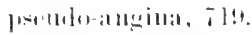

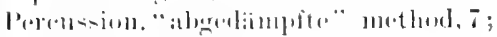

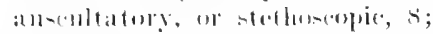
pialpatury, 10 .

Perers sinn in chronic meriastinopricallitis, l:2l.

Pericaulitis. alentu, 37 ;

alsecess in, 4i;

al oblolism in, 4is;

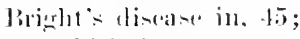

hronchitio in, 47 ;

aincere in, 17 :

aries of rib in, ti;

cholera in, tti;

dipletherial in. 4ti;

eryipelas in. Hi;

atiolugy af, +1 ;

measles ill, thi:

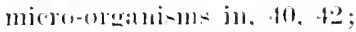

morlicl allatmoy of, :3:

nepluritis in, 14;

perifonatum, discases of, in, 47;

plemritis ine ti;

puemomia in, 46 ;

purulent form, to:

pmpoual hamorrlateriea in, 47:

rheumatism ju, 42, 46;

siallatila in, th;

serury in, ti;

scrotibrinom: form. 40, 42;

sinsplat form. 37;

small-fox in, fli:

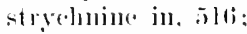

sllppllative form, le:

tom-illitio in, 14, 45 :

typhoid ferer in, 46:

ulier in, ti:

valvular dhefereto dembling from, 49.

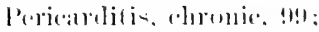

batlls in, 111, 115:

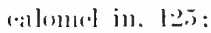

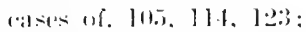

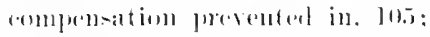

(0)11-8 and termination of. 115;

lialomomis of. 1:2.):

diammo-in, dillorential. from rimboSis of livrr, lez:;

thiritalio in, leli:

diuretin in, 126:

etiolowy of, 10:3:

morbit analum!: of, 100. 


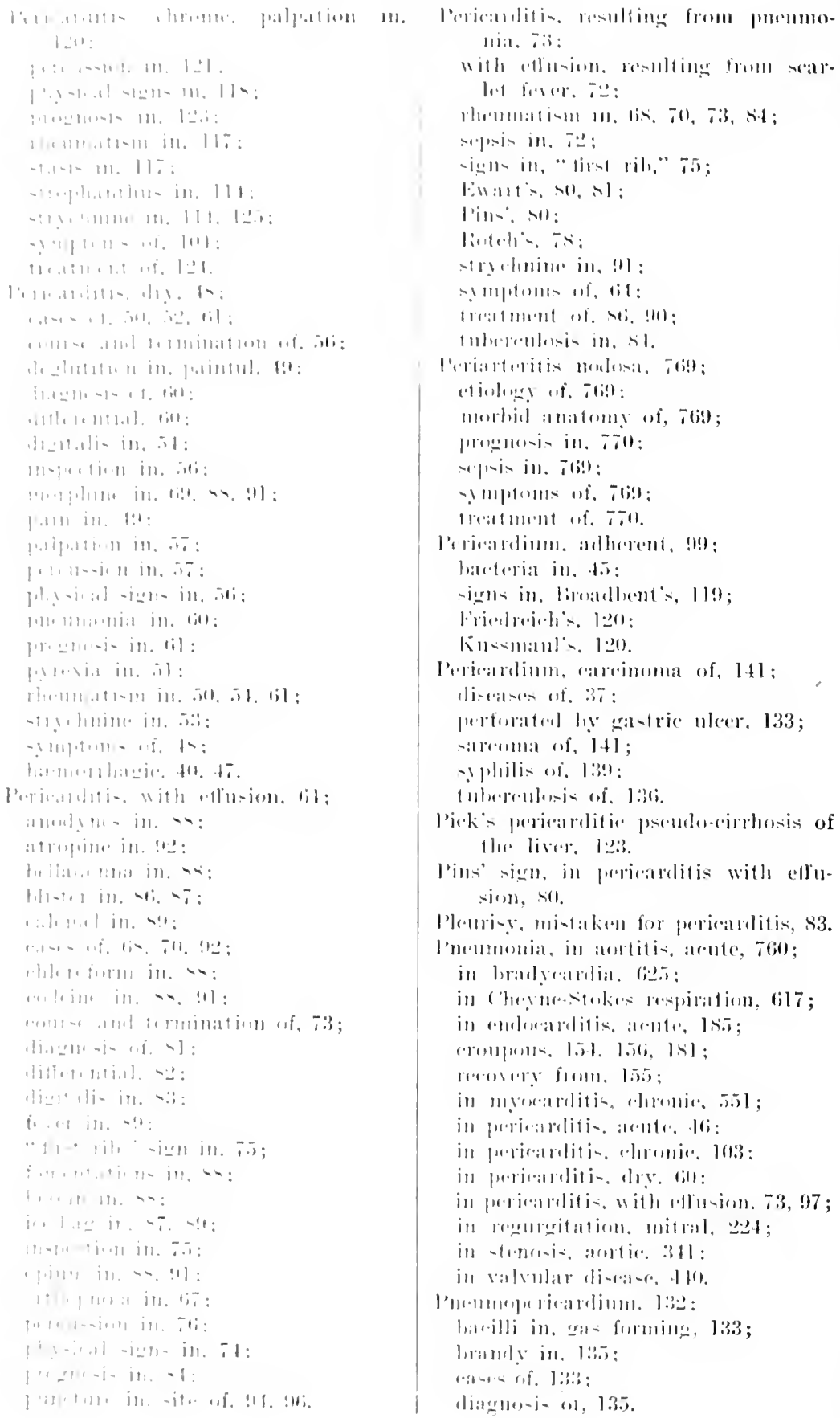




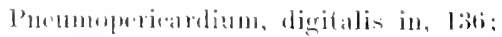
riulowe of, l:3:2:

inspertion in, list;

morbil allatomy of, lise;

mophline in, las;

pounno-is in, 135;

renltime from tratuma, l:3:);

resultiner from uleir, lisi;

stredintilte in, listi;

symptoms oi, l:3:

troiltment of, 13.;.

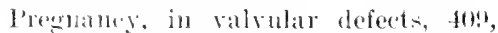
4.3.3.

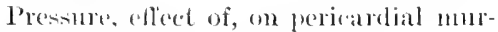
1mu1x. 5)?

Pseudo-ingunat pecoturis, Tl!':

-corhosis of liver, l'ick's pericarditis, le3.

Pulmumity antery stemosis of foe stenomist.

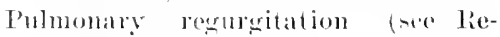
murcitation):

stemosic (an sitemosis).

Pulse, ciplullary, in artic renurgitation, 301 :

inesuality of. in aortic aneurysum, sol :

inequality of, in mitral stemosis, 257.259 .260 :

instability of, in acute myocarditis, 511,513 :

tension of, in elronie myocaraitis, 529

venous, in antio regurgitation, 301;

"water hammer," in aortic regurgitation. 298 .

Fnmeture, site of, in pericarditis with effusion, 9- 96 .

Pyoxia, in mulocarlitis. acute, 17l;

in hyolropericardium, 129:

in pericarlitis. dry, 51;

in reguraitation, tricuspid, $3.1 \%$.

Quincke's sign, in artio regurgitation, ens.

Regurnitation, artice 27s;

a]collolism in, 240:

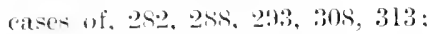

cusp, luptured in, 2-s;

diamosis of. 30.):

digitalis in. 288, 8900:

Duroziezs sign in. 305:

etiology af. 280 :

gont in, 220, 296;

inspection in, 225. 2!n. 316.

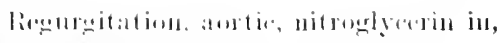
ans, :ilt, : 11 i;

palpration in, 20 !):

[1011->ion in, :301] :

physiolal signo in. 247 ;

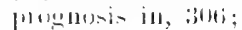

[111-ir in, :2!)s, 301];

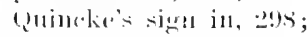

rhemmatism in, 2s:?;

salulatinal in, :36!):

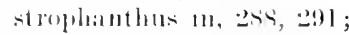

strylluill, in, 2:90, :3ll;

symptoms of, 2as;

syphilis in, est.

lecelurgition, aontic and mitral, comlinerl. :3:1; ;

diagnu-i- of. 391. 395;

prenturis in, 3!s:

-ymploms of 39t.

Regrrentition. antir, and aortie stemonis comblumel, sam.

Regurgitatim. antie, and mitral stemo-is conthined, 3933 ;

inseretion in, :39.;

palliation in, 89.5 ;

perenssion in, 3!95;

progurosis in. 39 t. 396 ;

symptoms of. 8913 .

liegurgitation, nitral, 2lti;

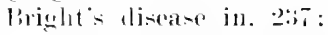

(a) of of. 2.24, 2.29, 2.32, 217 ;

(ongestion in, 237;

diaguosis of, 245 ;

digitalis in. 2.25:

dropser in, 20l!. 2:34. 24.5;

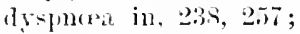

otiolugy of, 2.52:

insurerion in, 23:9:

insommia in, 2335:

morbid anatomy of. 2l6;

palpation in. 2:39:

perension in. 240:

physint signs in, 2:39;

prommunia in, 2.24;

prognosis in, 24ti.

resulting in wangrene, en:3:

rlenuntiom in. 2.2.2. 247:

(rallalinil in, 2.2.2. 2.24, 2.2!)

sta-is in. 2siti:

सryohnine in, 2.25;

symprome of. 223:

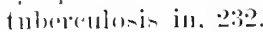

Romernitation, mitral. and aortie ste

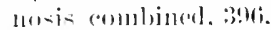

Romurgitution. mitral. and mitral ste110:is combined, 392.2 . 


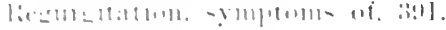

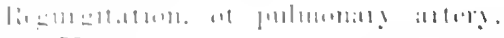
唡:

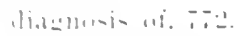

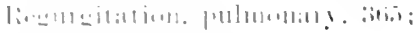

1.1-1 wi. Bis:

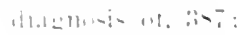

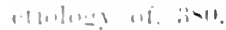

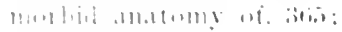

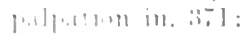

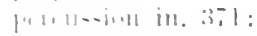

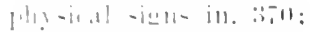

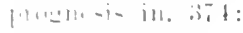

$-1: 1-1-111$. 216, :

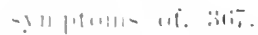

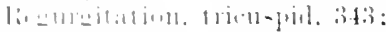

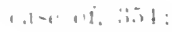

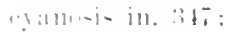

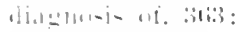

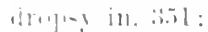

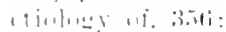

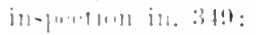

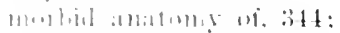

[1:1 [ pattion in, 3.in:

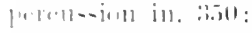

Inty-inal -iern- ill. 34!1:

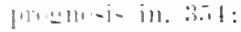

lystial in. $: 3+11$ :

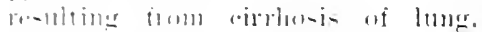
$3+11$ :

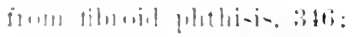

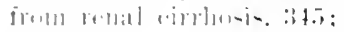

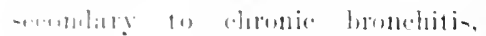
But:

$-1: 1-i-i n .83 i$ :

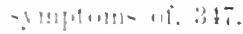

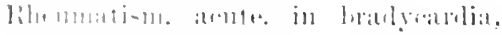
ti-i: :

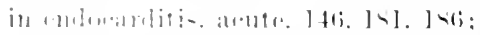

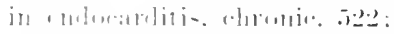

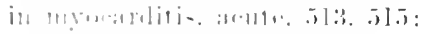

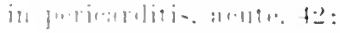

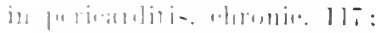

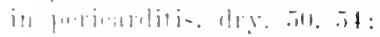

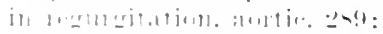

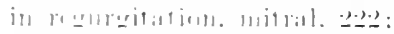

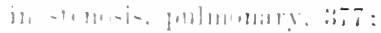

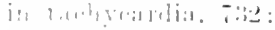

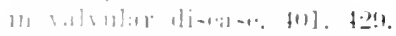

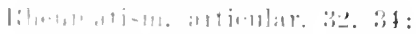

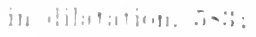

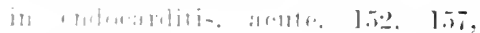
$1-$;

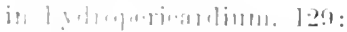

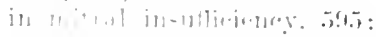

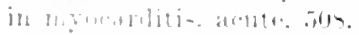

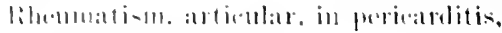
alcutr, 1:2:

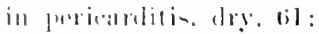

in prequalitis, witl atlu-ium, 70;

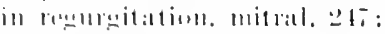

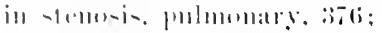

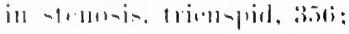

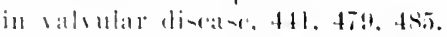

lihromati-m. intlammatory, in entoalmlitia, aloute, l.i3:

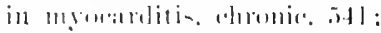

in prinalitis, with athuson, 6s, 73, 4 :

in -lammis, mitral. $2-7$ :

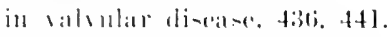

lihythm. \#allup ar ranter, ls;

a -i:-n af 1 he eml, "2ll.

lintelis sign, in pricalditis with effu-ion, is.

Siarlatiol. in aurtitis. aldute, 760 ;

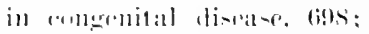

in amlanalulitis, andute, 1.5t;

in myenalitis, anente, 5ns, 516;

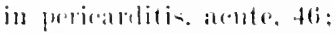

in renturnitalioms. antic, 30!):

in renurgitation, mitral, 22.20, 2.24, $2 \cdot 2 ! !:$

in -lemosi- mitral. 274:

in -temo-is, trien-pide, 3.58.

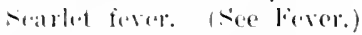

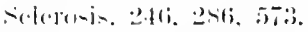

siary, in porialditis, acute, 47.

sinemel sommo, simmatad domblimg of, ].

Singremtatim of the myocardium, bitis.

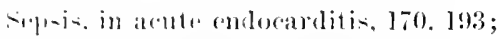

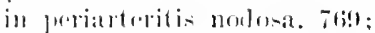

in prevalutis with etlusion, 72.

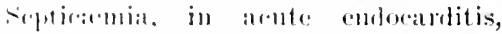
1.1.i. 1.j6\%.

Fremul, anti-streptrococedts, in arate en-

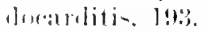

sinn- Brobdlunts. in adherent periarilium. 11!;

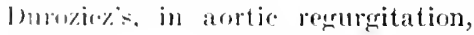
:31.5:

linat - in prearditis with offu-in11. 4). 41;

"fir-1 ril," in preicarlitis with effu-imil. 75:

linelreintis in alleernt pericarlimin. 120:

Kir-smanl's. in arberent pericarrlime, l:30. 
Signs, Perez's, in chronic mediastinopericarditis, 121 ;

Pins, in pericarlitis with ellusion, so;

Quinckes, in artic regurgitation. 298 ;

Rotehs, in periearditis with eflusion, is.

Simple endocarditis. (Sce Endorariitis.)

Smallues of arteries, comgenital. 7 in.

small-pox, in aeute endocarditis. l.jt; in acute mrocarditis, 500;

in acute perionditis, 46.

Somu-friction. intensity of, 59: location of the pericardial, 58 ; quality of, 59 : rhythm of, 58 .

Sounds, heart, normal, 13; rerluplication of, 16, 1s: second, simulated doubling of, 17 .

Splem, abseess of, in acute endorariti. fis. $150,15.5$.

Stasis in pericarditis, ehronic. 117: in resurgitation. aortic. $2 ! 1$ : in regurgitation, mitral, 23t; in regurgitation, puhnomary, 367 ; in regurgitation. tricuspid, 347 ; in stenosis. mitral, 257: in stemosis, trieuspid, 358.

Steucis, of aorta. To: symptomis of, $7 \mathrm{I}$ : treatment of. 7.2 .

Stenosis, aortie. 319 : cases of, $323.330,339$; cyanowis in. 335: diamosis of. 338 ; ligitalis in. 326 ; in-pertion in, 335 ; morlic anatomy of, 319 ; nitroglycerin in. 332,333 ; palpation in, $33 \bar{s}$ : perension in. 336 : physical signs in, 33.5; prenmonia in. 338: froglosis in. 339: strolinine in, 3is: symptoms of, 323 .

Stenosis, aortic and mitral combined, 392 :

dianmosis of, 392 :

prognosis in, 393: symptoms of, 392.

Stenosis, mitral. 249;

womchitis in, 250;

calses of, 253, 263. 270, 2-3.
Stemosis, mitral, delinium in, 2-11 diagllosis of, 光tis; digitalis ill, 2,-2); epilepsy in, 2l:2:

"fremisoment cataire" ill, 259 ; encll in, ..54:

insommial in, 2siti: inspertion in, :.5s; numbial atmalomy af, 2.49; morphne in, 27:2:

nitroglyerin in, 2-27;

(xelenta in, 2.)6;

palpation in. 2.t?; perension in, 260: plycinal signs in. 2.ss; prognosi- in. 269!): pulse in, 257, 2.5!. 2060; flemation in, eztit; scarlatina in. 25t; stasis in, 2.ji: struphanthus in. 272 ; strychnine in. 2-2: symptoms of. 2.5.); syplislis in. 254.

Stenosis, mitral, and pulanonary ste nosis combined. 35 .

stenosis, pulnonary, 376 ; (alses of. 37. 380 ; diagnosis of, 373: inspertion in. 35.5: morbirl anatomy of, 376 ; percussion in, $3 \mathrm{sit}$; plycical signs in, 385 ; prognosis in, 374 : rhemmation in, 37ti, 375; srmitome of. 34(1: tuluerolusing in, Bstl.

Stenomis of pulmonary arters, 772.

Stenosis, trieu-pid. :35; (ases of. $37 ! 1,341$; diagnowis of, :3:3: digitalis in. 35!! : incpertion in. :stil: noubic anatume of. 355; pereusoim in. itie: phy-iral sign- in. 30il; jorgnosic in, 3lit: rhemmati-m in. scallatinal in. 3.s : stasis in, 3.5: smotoms of. 35.

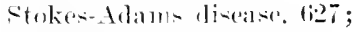

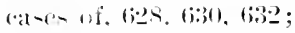

ligitalio in. tinti: etioloey of, (i-2): morphine in. (i3.5. 


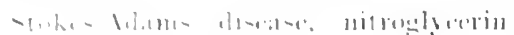
in. lii,i:

, $1111111,112:$

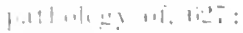

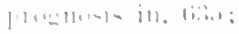

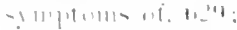

-1 Hhlli- in, 112-

$111,+1111+111,11,13,5$.

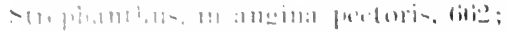

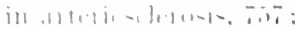

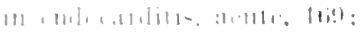

in lit11 |11,11t. 1ill:

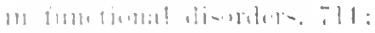

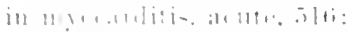

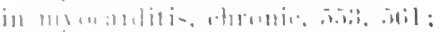

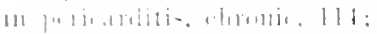

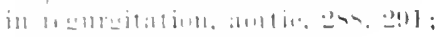

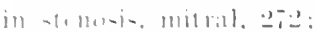

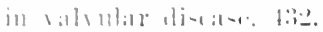

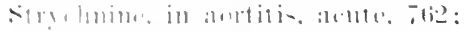

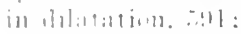

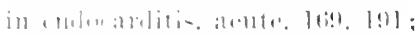

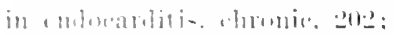

in-lillty lacklt. 1ill:

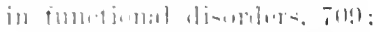

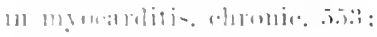

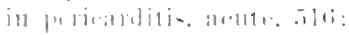

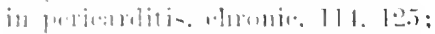

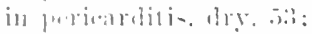

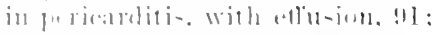

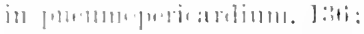

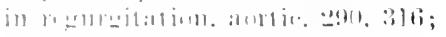

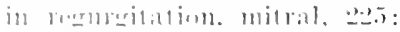

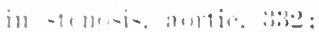

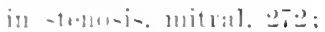

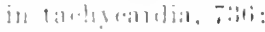

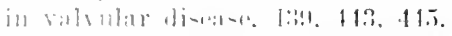

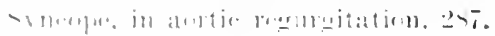

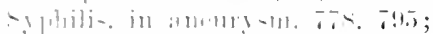

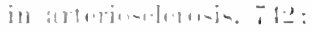

in anderinal Jerfolin tilli:

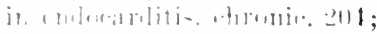

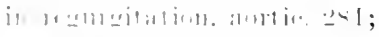

i) $-1+111-i-11191,1]$.

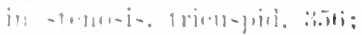

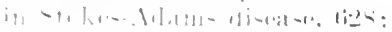

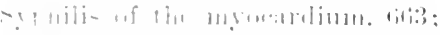

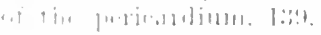

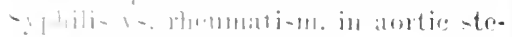
m11-i-. : :

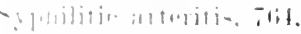

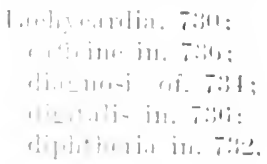

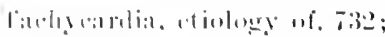

ine in. Fiti:

iullu 11/: iu, 7:32:

111:1 laria in, 7:3:2:

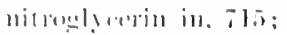

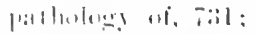

promolic ill. 735:

rhenlllati-nl in. 7:3:;

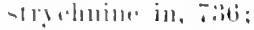

$1611111+111$ wi. 7is.

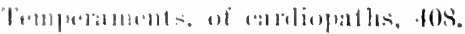

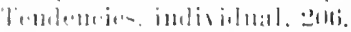

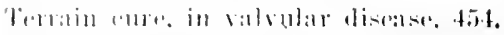

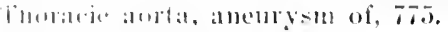

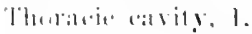

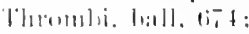

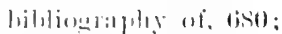

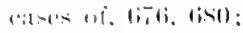

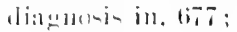

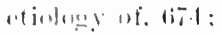

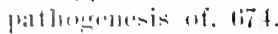

'Thombli. puhmenlatod, 6its;

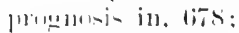

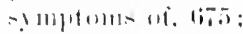

treatment of. lits.

Thromlusis, anterial, ramsing wanElone, ditci;

velume, in ratrulatr diseatere, 208.

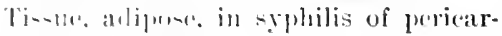
dimin. 1:3!).

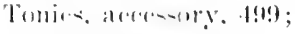

(a) dial1. 111:

1101\%, ilt.

Tom-illitis. in ruloralitis, acute, 150;

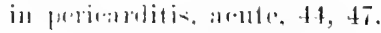

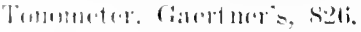

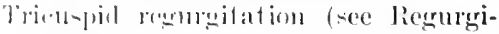
titti(n):

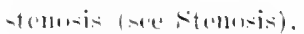

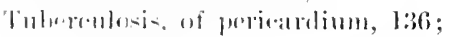
of lune- 10\%.

Tulueloulu-ix. funlnomary, in anenm-lil. Sis:

in ilustronartiat. list :

in fometional listratase, 7 ]6:

in frerinalitis, wilh reflusion, 84 ;

in resturgitation. milral, az:

in -10mosis, pulnomary, 3so;

in valumlat discolse. doli.

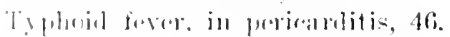

ly phus, in aroute myeramlitis, sos.

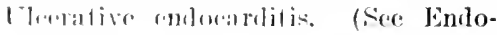
(alditi-.)

Valvular l1-ims = (n) atrugum in, 50). 
balular la-ions. Iaths in, Nanhrim, t.i. Hit, illi;:

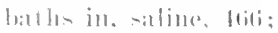

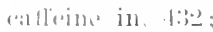

("illomel in, 43:3, 415, 19)1, 19:3:

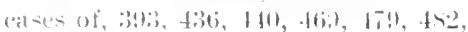
thi:

[atlontian in, for: ;

aldoral hidlate in, itol:

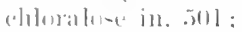

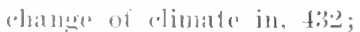

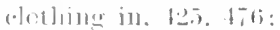

(20m)

eompensation lost in. 47s;

(9)111)

rompliated with atarrh, boumehial, $41 \%$ :

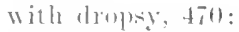

with pmemmonis, 440;

with rhemulti-n. 400;

(o)

diet in, 42\%, 470;

digitalis in. $8344,430,450$;

druen in, 430):

exerio in, 4lt, 4it. 502:

exeroice, resistance, in, 4.55 ;

glomoin in, $432,4+6$ :

habits in, 410, 421). 476;

hatmati $(\cdot s$ in, 44 :

lone snroundiugs in, 410 :

hrpuotics in, 500:

ilnesses in, 429 .

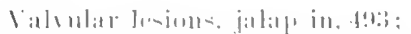

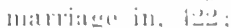

mulirainal at:ult in. 111:

merrelly in, fiz:

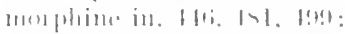

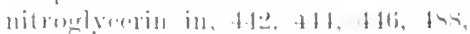
tib:

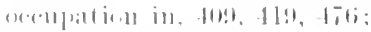

ardentar in, t:1, :

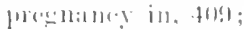

[rongunis in, f11]:

loit in, H1s, ing:

rhembation in, foll, ly?, H36, 411, 1,!1, 14.5:

s[mplatntlits in, 43:2:

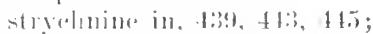

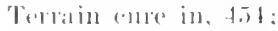

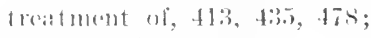

toluerelulosis ins, fori.

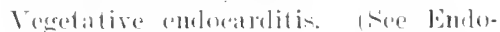
almlitis.)

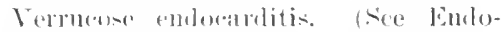
('allitis.)

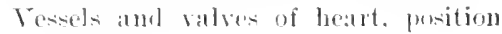
of. 3 .

Whisky, in ande endoralitis, $1 ! 12$ :

in alleina furetoris, titio;

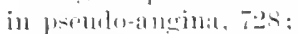

in myoualitis, (l) lonice. 5til ;

in valvular disialse, flis. 



\section{ADDENDUM}

\section{Recent Important Discoveries Concerning the Mechanical Effects of Aortic Regurgitation upon the Cardio-vascular System.}

Cuder the eaption of Experinemtal and ('linical Invertigation of the Pulse and Blood Pressure Chamges in Aortic hosutheiency, there appeared in The Archies of Internal Medicine, Vol. I, No. 1, Jamuary 15, 190s, a contribution to the knowledge of this valvular lesion of such wide-reaching signitieance that, if eonfirmed by other physiologists, it is destined to canse a rewriting of the chapters devoted to this mbliject in medical text-books. On this aceoment I eamot permit this third edition to be given to the publie withont a brief statement of the facts disorered by Dr. Hngh 1. Stewart in the pluysological lahoratory of .Tolms IIophins IIospital. Inasmuch as this present edition has alreally eome from the press and only awaits binding, it has been decided to ineorporate these novel facts in an addendum rather than to leave them monoticed. There is the additional advantage that by so doing I shall leave for the reader the original and, ats it were, historical conception of the disease which has dominited medical thought since the time of Corrigan, that he may contrist the differences between Corrigan's and Stewart's explannation of the phenomena olwerved.

By a reference to chapter VIII it will be seen that the patlologe of aortic regurgitation is, briefly, als follows: Insufticieney of the aostic semilumar values camses a portion of the blood discharged into the artery during systole to leak back into the ventricle with the next ensuing diatolde. The quantity of blood thus regurgitating depends npon the degree of damage sustained by the valve, but whether small or great produces collapse of the pulse and a proportionate dilatation of the ventricle, since the regurgitating strean enters the eavity of the ventricle during its period of diastole. This primary dilatation is soon counter- 


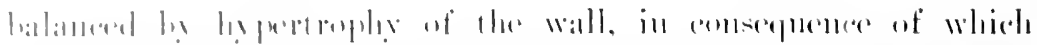

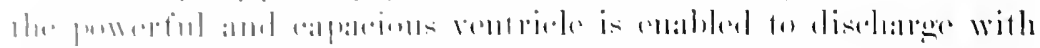

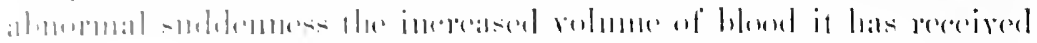

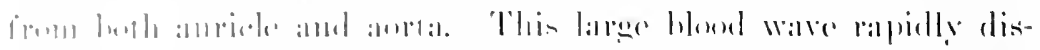
$111,1-1$ the

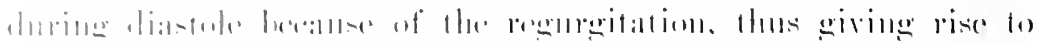

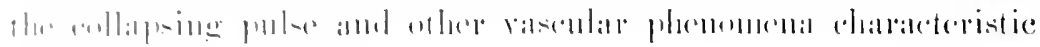

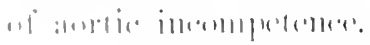

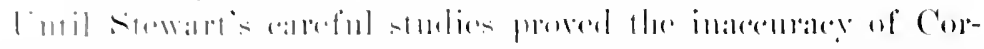

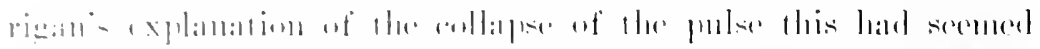

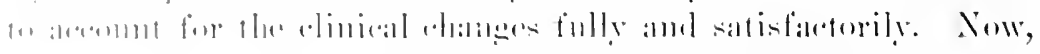

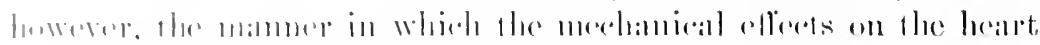

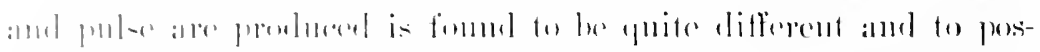

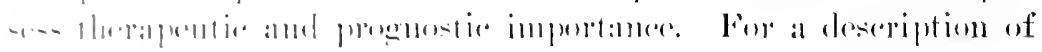

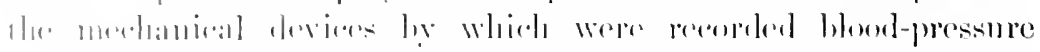

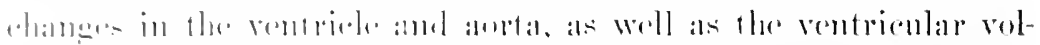

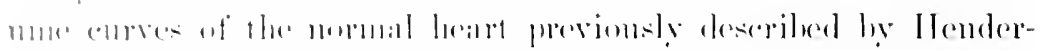

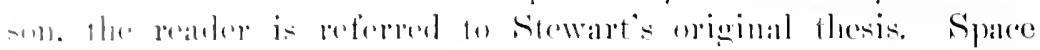

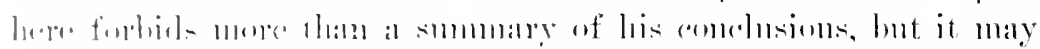

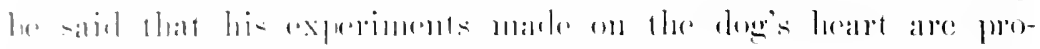

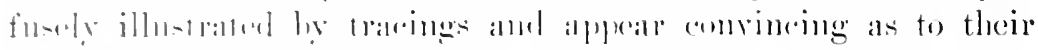

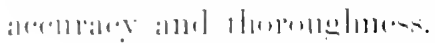

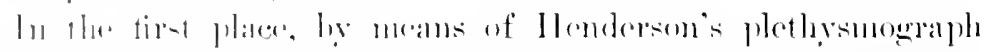

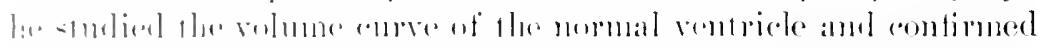

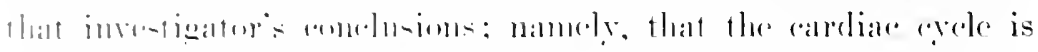

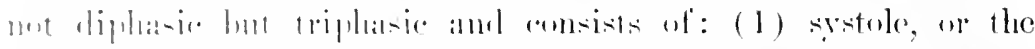

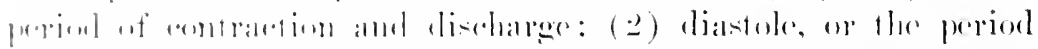

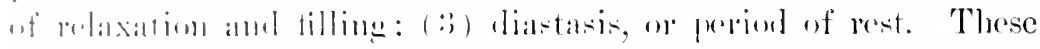

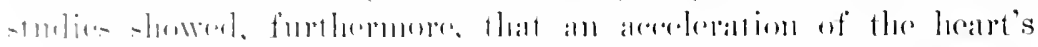

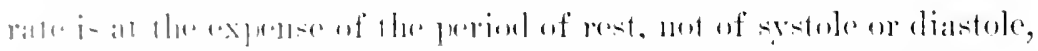

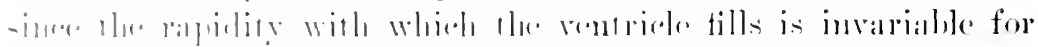

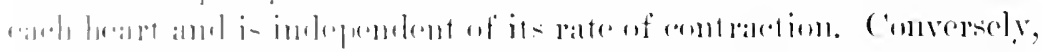

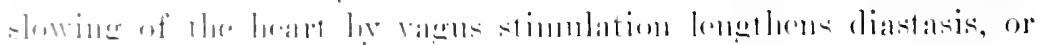

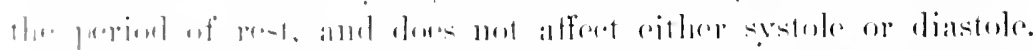

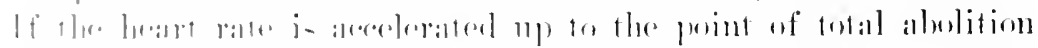

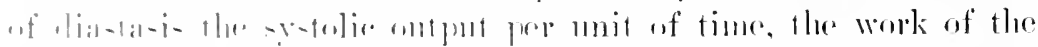
laral.

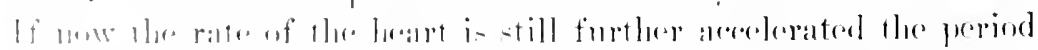

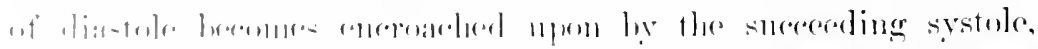

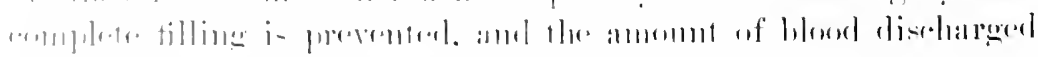

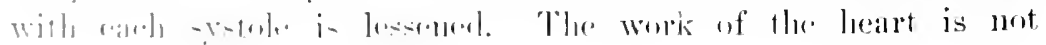


greater, for, notwithstanding the inerease in rate, the amomnt of blood hischanged in a given mit of time remalins as hefore.

Stewal next obtained a reored of the volume enre after the aortie valves had been ruptured by means of McCallumis ralvilotome. These tracings (the heart's rate in the two instances remaining the same) were then laid one npon the other and connpared. It was then found that the systole of the ventricke after

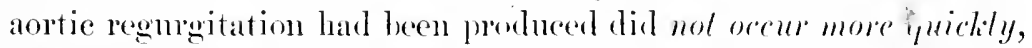
but more slowly, requiring for its completion .2.2 of a second instead of .18 of a seconc, as when the heart was nolunal. It was also ascertained that the amomt of blood discharged with each systole was increased orer the normal by omly .5 ce.

This, as pointed ont ly Stewat, is at valuance with the teachings concerning the immediate effect on the ventricle of aortic regurgitation, for in the animal experimentation it was shom that even with the most extensive incompetence only a fractional part of the blood regurgitated and that the ventricle did not contract more suddenly and rapidly but more slowly than in health. Moreover, it was ascertained that the lengthening of the systole was made up by a more rapid rate of filling during the first part of diastole, until in fact the ventricle lad received about one fifth of its supply.

But still other surprises were diselosed. It is known that there is a certain anomnt of residual blood left in a rentrive when in a state of dilatation, and hence if aortic incompetence causes left ventricular dilatation this shonld lead to retention of blood in the rentricle. It was fomnd, however, that despite a slightly increased filling the ventricle emptied itself more completely than normally. There was then no distention, and this was taken as a proof of increased tomus of the ventricular muscle. This increased tomus conld only be hue to the fact that instead of the regurgitating stream acting as a dilating foree, the incompetence of the valve permitted a transference of pressure from the aorta to the interior of the ventriele, and it was this transfer of pressure from aorta to rentricle which oceasioned the increased rentricular tomus. Moreover, this tension, which results from inereased rentricular pressure, produces hypertrophy as the primary effect of aortic regurgitation and not dilatation, as is nsually tanght.

Finally, in his experiments Stewart discovered that simple irritation of the depressor nerves of the ventricle without destrue- 


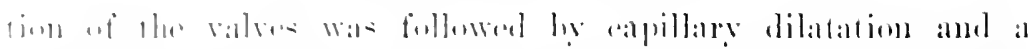

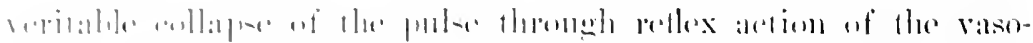

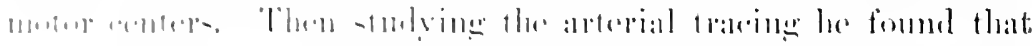

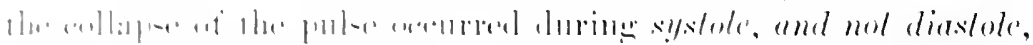

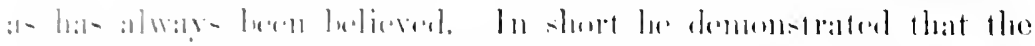

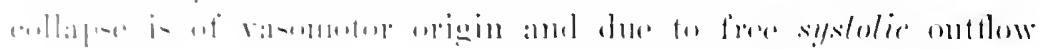

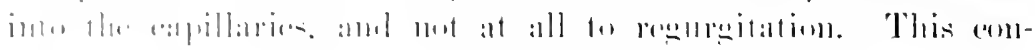

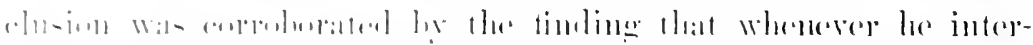

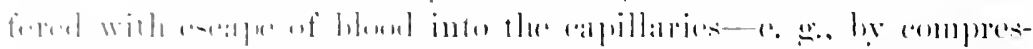

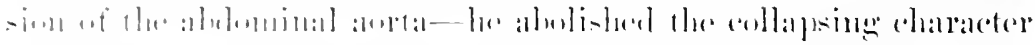

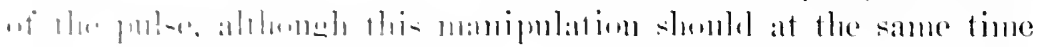

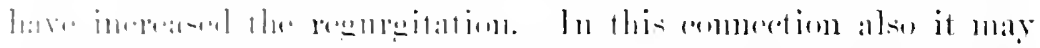

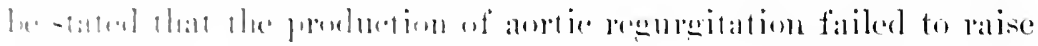

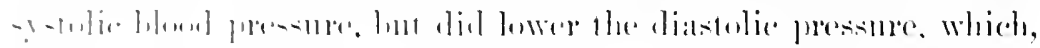

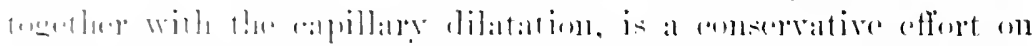

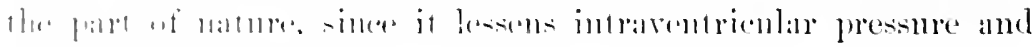

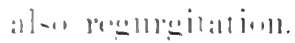

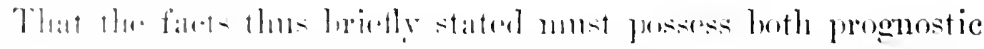

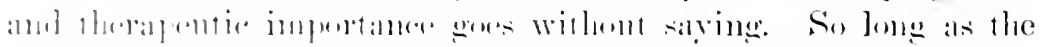

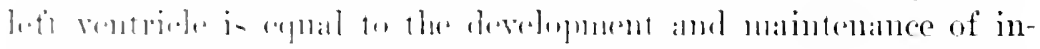

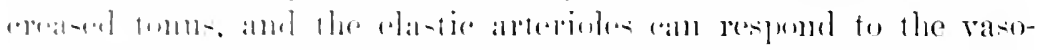

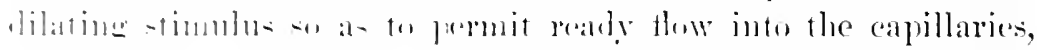

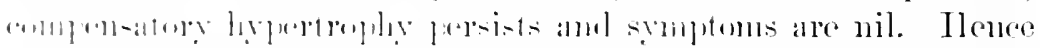

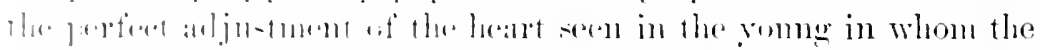

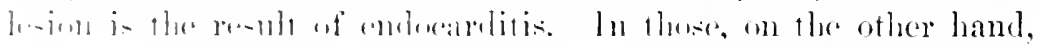

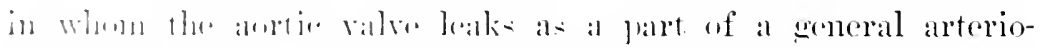

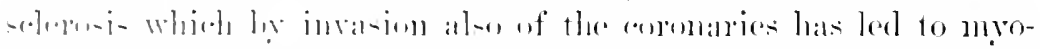

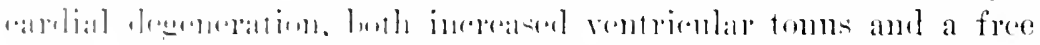

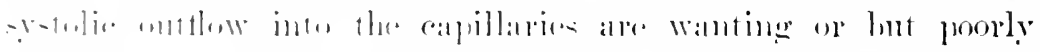

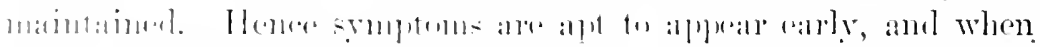

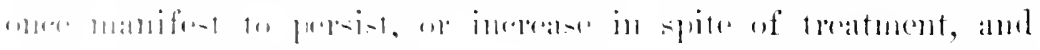

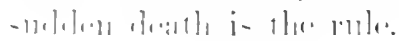

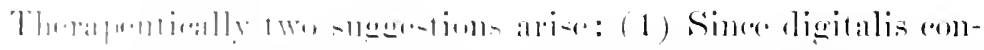

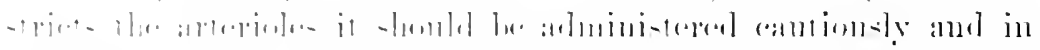

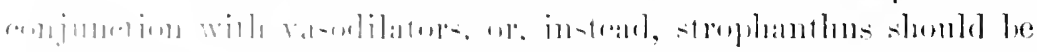

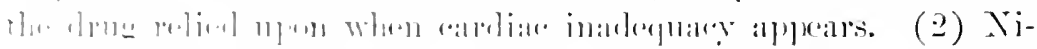

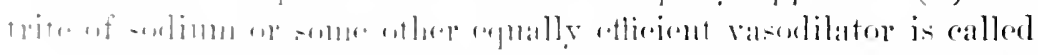

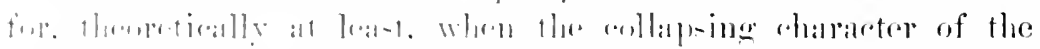

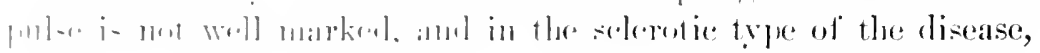

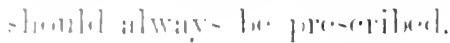






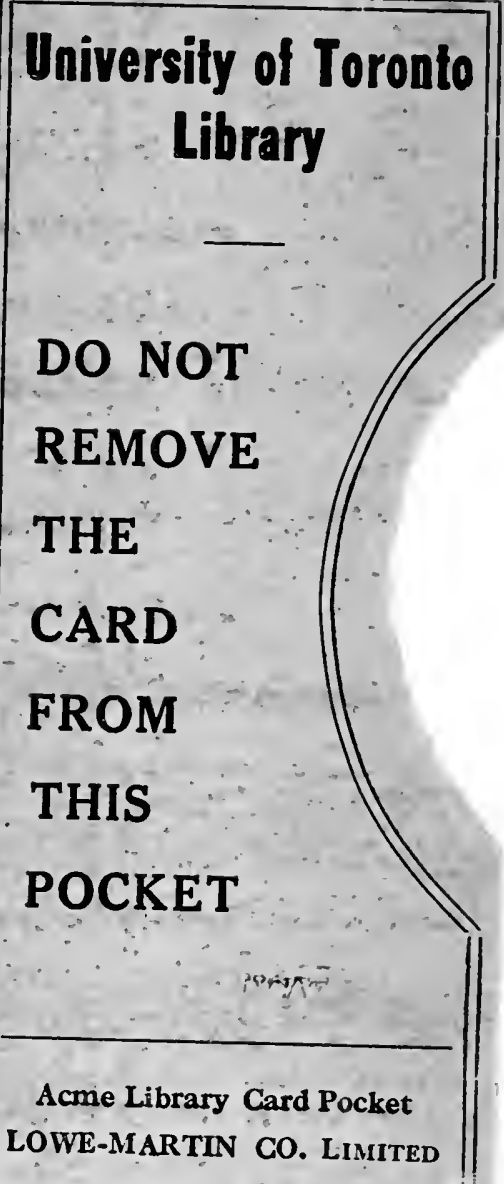


